\title{
RESIDENCIAS UNIVERSITARIAS: HISTORIA, AROUITECTURA Y CIUDAD
}

Autor

MIGUEL ÁNGEL GIL CAMPUZANO

Directoras CARMEN JORDÁ SUCH MARÍA TERESA PALOMARES FIGUERES

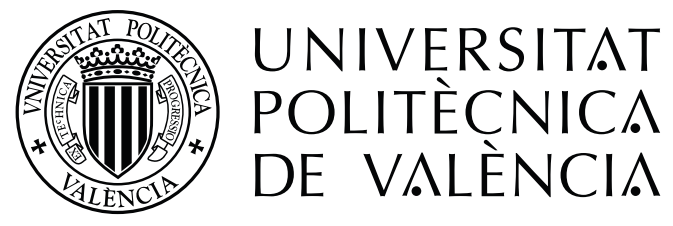

Universidad Politécnica de Valencia Departamento de Composición Arquitectónica Escuela Técnica Superior de Arquitectura Valencia, julio de 2015 


\section{RESIDENCIAS UNIVERSITARIAS: HISTORIA, ARQUITECTURA Y CIUDAD}

MIGUEL ÁNGEL GIL CAMPUZANO

Directoras CARMEN JORDÁ SUCH MARÍATERESA PALOMARES FIGUERES

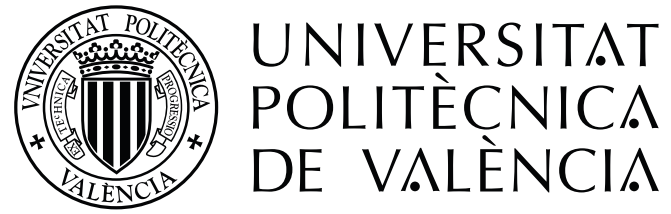

Programa de Doctorado: Patrimonio Arquitectónico: Historia Composición y Estudios Gráficos 



\section{ÍNDICE}

RESUMEN / ABSTRACT

AGRADECIMIENTOS

\section{INTRODUCCIÓN}

O.1 CONTENIDO, ESTRUCTURA Y OBJETIVOS DE LA TESIS

O.2 METODOLOGÍA

0.3 ANTECEDENTES (ESTADO DE LA CUESTIÓN)

\section{PRECEDENTES AROUITECTÓNICOS}

\section{BLOQUE}

\section{I.1 A MODO DE PREHISTORIA UNIVERSITARIA}

"Modelos" universitarios previos: China, India, Marruecos y Grecia.

I.2 LA UNIVERSIDAD MEDIEVAL Y EL MONASTERIO

Espacios configuradores del tipo universitario

I.3 ORIGEN DE LA RESIDENCIA UNIVERSITARIA

De las principales ciudades europeas a la Península Ibérica.

Notas y referencias bibliográficas

\section{LA RESIDENCIA UNIVERSITARIA EN LA HISTORIA}

\section{BLOQUE II}

II.1 BOLONIA. Primera definición de un tipo europeo en la arquitectura residencial universitaria La Universidad de Bolonia, programa y ciudad

El Colegio Mayor San Clemente de los Españoles, una dilatada influencia. (1369)

II.2 DE BOLONIA A ESPAÑA. Repercusión en los primeros colegios españoles

El Colegio Mayor de San Bartolomé o de Anaya. Aparición de la huella italiana. (1401).

Consolidación de los claustros:

Valladolid

El Colegio Mayor Santa Cruz (1486)

El Colegio Mayor San Gregorio (1489)

Alcalá de Henares

El Colegio Mayor San Ildefonso (1499)

Salamanca

El Colegio Mayor de Fonseca (1519)

El Colegio Mayor de Cuenca (1521)

El Colegio Mayor de Oviedo (1522) 
II.3 PARÍS, la adaptación de hospederías a colegios universitarios.

Historia y contexto.

El Colegio de Sorbon y La Sorbona (1252)

El Colegio de Navarra. Espacios y funciones (1309)

La Cité Universitaire, un apéndice contemporáneo

El inicio de las obras en 1925

El Pabellón Suizo de Le Corbusier (1935)

El Colegio de España. Exportando historicismo (1935)

II.4 OXFORD Y CAMBRIDGE. El College como arquetipo

El modelo inglés de residencia universitaria.

Oxford

Merton College. Evolución tipológica entorno al quadrangle (1274)

New College. Primera distribución proyectual con patios (1386)

John's College. Crecimiento espacial jerarquizado (1437)

Christ Church College. La magnificiencia en el conjunto urbano (1524)

Cambridge

Peterhouse College. Asentando el modelo (1284)

King's College. El reflejo de la memoria (1441)

Trinity College. La fusión colegial (1540)

\section{Apéndice contemporáneo:}

Fen Court en Peterhouse College. Adoptando nuevos planteamientos (1939)

Saint Cazt College de Arne Jacobsen. La traducción moderna de la tradición (1962)

Florey Building en Queen 's College de James Stirling. Mirando hacia Estados Unidos (1971)

II.5 ESTADOS UNIDOS. Fragmentación edilicia del modelo inglés

Cambridge-Universidad de Harvard

Old College y posteriores Harvard Hall's. Germen del tipo estadounidense (1637-1642-1682)

Casa de William Peyntree. Conformando el quadranle (1638)

Goffe College. Cerrando el quadrangle (1651)

Colegio Indio. Acotando el campus (1661)

Massachusetts Hall. Restauración y permanencia (1718)

Hollis Hall. Una singular simplicidad (1763)

Stoughton College. Permanencia del estilo colonial (1805)

Charlottesville-Universidad de Virginia

Colegio de William \& Mary (1700)

Pabellones residenciales de la Universidad de Virginia, una intención de heterogeneidad (1819)

Nueva York-Universidad de Columbia y la irrupción de la gran altura.

Hartley Hall (1902)

Livingston, la complementariedad (1905)

Apéndice contemporáneo:

Baker House de Alvar Aalto (1948)

Peabody Terrace, residencia para estudiantes casados de Josep Lluís Sert (1949)

II. 6 LA RESIDENCIA DE LA BAUHAUS: Autonomía y funcionalidad moderna.

La sede universitaria Universitaria en Dessau (1925)

Notas y referencias bibliográficas 


\section{LA RESIDENCIA UNIVERSITARIA EN ESPAÑA, GENERADORA DE CIUDAD \\ BLOQUE III}

III.1 TRANSFORMACIÓN DELOS MODELOS HISTÓRICOS Y APORTACIONES DE LOS NUEVOS PLANTEAMIENTOS EN EL SIGLO XX

III.2 LAS TRES FASES DE LA RESIDENCIA DE ESTUDIANTES DE MADRID.

En la calle Fortuny (1910)

En "La Colina de los Chopos" (1915)

En la Ciudad Universitaria (1942)

III.3 RESIDENCIAS UNIVERSITARIAS EN LAS UNIVERSIDADES LABORALES

La Universidad Laboral de Gijón (1956)

La Universidad laboral de Culleredo (1962)

La Universidad Laboral de Cheste. (1969)

Notas y referencias bibliográficas

\section{COLEGIOS MAYORES DE LA CIUDAD UNIVERSITARIA DE MADRID Y LA ARQUITECTURA} MODERNA

BLOQUE IV

IV.1 DIMENSIÓN URBANÍSTICA

El emplazamiento colegial en la primera Ciudad Universitaria de Europa

El Colegio Mayor Ximenez Cisneros. Luis Lacasa y Javier Barroso. Hacia la segregación funcional especializada

IV.2 DIMENSIÓN URBANO-EDILICIA

Colegio Mayor Nuestra Señora de Guadalupe. Luis Feduchi. Entre el historicismo y la modernidad (1947)

Colegio Mayor Jorge Juan. Alberto López de Asiaín S. y Alberto López de Asiaín M. Rasgos nórdicos. (1958)

Colegio Mayor Aquinas. José María García Paredes y Rafael de la Hoz. Premio de Arquitectura al desglose espacial en plataformas (1957)

Colegio Mayor San Agustín. Francisco de Asís Cabrero. La tradición retomada (1962)

Colegio Mayor Chaminade. Luis Moya Blanco. Un ensayo racionalista (1965)

Colegio Mayor Jaime del Amo. Luis Blanco-Soler Pérez. Rompiendo la ortogonalidad (1967)

Colegio Mayor Nuestra Señora de Luján. Carmen Córdoba y Horacio Baliero . Arquitectura y paisaje (1969)

IV.2 DIMENSIÓN SOCIAL

Colegio Mayor César Carlos. Alejandro de la Sota. Experimentando con el tipo (1970)

Colegio Mayor Casa Do Brasil. Alfonso d'Escragnolle. Un bloque atemporal (1962)

Notas y referencias bibliográficas

\section{EPÍLOGO -CONCLUSIONES}

¿FIN DE UNA ÉPOCA?

Notas y referencias bibliográficas 


\section{BIBLIOGRAFÍA}

BIBLIOGRÁFIA BLOQUE I

BIBLIOGRAFÍA BLOQUE II

BIBLIOGRAFÍA BLOQUE III

BIBLIOGRAFÍA BLOQUE IV 


En la tesis se estudia la evolución tipológica de la residencia universitaria, planteando su función como elemento activo de la configuración urbana, además de relacionarla con la arquitectura en sí misma, a través de la observación de los avances técnicos, cambios formales, estructurales y funcionales, cambios en el programa y también respecto a los recursos expresivos.

El marco cronológico abarca un periodo desde la edad media hasta la segunda mitad del siglo $X X$, aunque con un énfasis especial en la última etapa. Se organiza una estructuración en cuatro bloques diferentes, a su vez susceptibles de dividirse según geografías, apareciendo, en cada uno de ellos, la residencia universitaria como fiel reflejo arquitectónico del tiempo en el que se desarrolla. El índice recoge: Precedentes Arquitectónicos, (Bloque I); La Residencia Universitaria en la Historia, (Bloque II); La Residencia Universitaria en España, (Bloque III); Colegios Mayores de la Ciudad Universitaria de Madrid y la Arquitectura Moderna, (Bloque IV).

La investigación se realiza, en cada uno de los bloques, estableciendo las tipologías que van a ser objeto de estudio. Éstas son las que determinan un modelo que sea perdurable en el tiempo y también transmisor de valores para el desarrollo de los siguientes modelos. El proceso va desde una óptica general amplia y situada en los orígenes de dichos modelos, hasta un rango más acotado donde se particulariza y concreta el final del proceso evolutivo.

Por tanto, se observan unos modelos pioneros en su tipo, estudiando posteriormente su evolución a través de distintas innovaciones que se van desarrollando a lo largo de los periodos estudiados, estableciéndose como punto más destacable los inicios del siglo XX.

Para obtener las conclusiones evolutivas de los citados modelos históricos de residencia universitaria, el análisis se lleva a cabo a partir de tres escalas diferentes. En la primera, de alcance urbano, se reflexiona sobre el modo de implantación de los colegios mayores como elemento residencial único dentro del conjunto universitario. En la muestra de obras seleccionadas se pone de manifiesto un trasvase de las tipologías urbano-arquitectónicas que caracterizan el escenario internacional del periodo que coincide con la última etapa de la materia investigada. Asimismo se reflexiona, en una segunda escala, ésta edilicia, la posible influencia de distintas corrientes europeas y americanas que habían sido transmitidas de forma directa por los arquitectos más destacados durante sus visitas a España y, especialmente a la Residencia de Estudiantes de Madrid en las primeras décadas del siglo XX. Una tercera escala enfocada hacia la dimensión social, contempla como los espacios residenciales de las Universidades Laborales y el nuevo concepto de Colegio Mayor evolucionan hacia una doble dualidad. De un lado, la persona se desarrolla tanto individual como colectivamente y del otro lado, el Colegio Mayor se desdobla en sus aspectos tanto formativos como residenciales.

En síntesis, los ejemplos seleccionados nos muestran un proceso evolutivo que, desde la sinergia inicial (histórica) entre universidad y ciudad, se pasa por una fase intermedia de creación de recinto universitario, para llegar a una última etapa marcada por lo social, donde se observa que el edificio constituyente de la residencia universitaria se ha convertido en una pieza arquitectónica integrada en la ciudad universitaria y vinculada a los principios programáticos del Movimiento Moderno. 
En la tesi s'estudia l'evolució tipològica de la residència universitària, plantejant la seua funció com a element actiu de la configuració urbana, a més de relacionar-la amb l'arquitectura en si mateixa, a través de l'observació dels avanços tècnics, canvis formals, estructurals i funcionals, canvis en el programa i també respecte als recursos expressius.

El marc cronològic comprén un període des de l'edat mitjana fins a la segona mitat del segle $X X$, encara que amb un èmfasi especial en l'última etapa. S'organitza una estructuració en quatre blocs diferents, al seu torn susceptibles de dividir-se segons geografies, apareixent, en cada un d'ells, la residència universitària com a fidel reflectisc arquitectònic del temps en què es desenrotlla. L'índex arreplega: Precedents Arquitectònics, (Bloc I) ; La Residència Universitària en la Història, (Bloc II) ; La Residència Universitària a Espanya, (Bloc III) ; Col-legis Majors de la Ciutat Universitària de Madrid i l'Arquitectura Moderna, (Bloc IV).

La investigació es realitza, en cada un dels blocs, establint les tipologies que seran objecte d'estudi. Estes són les que determinen un model que siga perdurable en el temps i també transmissor de valors per al desenrotllament dels següents models. El procés va des d'una òptica general àmplia i situada en els orígens dels dits models, fins a un rang més tancat on es particularitza i concreta el final del procés evolutiu.

Per tant, s'observen uns models pioners en el seu tipus, estudiant posteriorment la seua evolució a través de distintes innovacions que es van desenrotllant al llarg dels períodes estudiats, establint-se com a punt més destacable els inicis del segle XX.

Per a obtindre les conclusions evolutives dels esmentats models històrics de residència universitària, l'anàlisi es du a terme a partir de tres escales diferents. En la primera, d'abast urbà, es reflexiona sobre el mode d'implantació dels col-legis majors com a element residencial únic dins del conjunt universitari. En la mostra d'obres seleccionades es posa de manifest un transvasament de les tipologies urbà- arquitectòniques que caracteritzen l'escenari internacional del període que coincidix amb l'última etapa de la matèria investigada. Així mateix es reflexiona, en una segona escala, esta edilícia, la possible influència de distints corrents europees $\mathrm{i}$ americanes que havien sigut transmeses de forma directa pels arquitectes més destacats durant les seues visites a Espanya $i$, especialment a la Residència d'Estudiants de Madrid en les primeres dècades del segle XX. Una tercera escala enfocada cap a la dimensió social, contempla com els espais residencials de les Universitats Laborals i el nou concepte de Col-legi Major evolucionen cap a una doble dualitat. D'un costat, la persona es desenrotlla tant individualment com collectivament i de l'altre costat, el Col-legi Major es desplega en els seus aspectes tant formatius com residencials.

En síntesi, els exemples seleccionats ens mostren un procés evolutiu que, des de la sinergia inicial (històrica) entre universitat i ciutat, es passa per una fase intermèdia de creació de recinte universitari, per a arribar a una última etapa marcada pel social, on s'observa que l'edifici constituent de la residència universitària s'ha convertit en una peça arquitectònica integrada en la ciutat universitària i vinculada als principis programàtics del Moviment Modern. 
The present thesis studies the typological evolution of the university residence hall, considering its function as an active element of urban configuration, furthermore relating it with the Architecture itself, through the observation of technical progresses, formal, structural and functional changes in the programme and also about the expressive resources.

Time frame covers a period from the Middle Ages until the second half of the twentieth century, but with special emphasis on the last stage. A four-section structuring is organized, side by side likely to be divided in a location-based way, in each appearing the university residence as a loyal reflection of the contemporary architecture to date. Its index collects: Architectural Precedents (Block I) ; The University Residence Hall in History (Block II); The University Residence in Spain (Block III); Halls of the "Ciudad Universitaria de Madrid" and Modern Architecture, (Block IV).

Research is carried out in each block, setting the typologies under study. These so called types are what determine a model to be maintained over time, what is more being valuetransmitter for the development of these models. The process sees through a general insight, located in the origins of these models, to a more limited range where it is particularized, and materializes the end of the developmental process.

And so, pioneering models in their category are beheld, pondering their trend through multiple innovations that are evolved over the study period, establishing early twentieth century as the most remarkable.

To obtain the evolutionary upshots of these foregoing historical case studies of University Residence Hall, the analysis is carried out in three different scales. In the first one, -from urban-wide scope-, it is reflected on how to implement the site of residence halls as residential elements within the university complex masterplanning. The mosaic of selected works reveals a transfer of urban-architectural styles that beset the international scene of this period co-occuring with the last time stage of the current investigated subject. As well, it deepens, in a second level -this time building-layoutbased-, the plausible influence of several European and American streams that had been transmitted directly by the most prominent architects during their tours to Spain and especially the "Residencia de Estudiantes" in Madrid by the first decades of 2oth Century. A third level, -aimed on the social focus-, addresses how the residential spaces in "UniversidadesLaborales" case-studies, and the new concept of Residence Hall named "Colegio Mayor" develops into a double duality. On the one hand, the individual achieves both individually and collectively upbringing and on the other hand, the "Colegio Mayor" unfolds in both its educational and residential areas.

As a conclusion, the selected examples show an evolutionary process that, from the (historical) germinal synergy between university and city, passes through an intermediate stage of campus master planning and developing, to reach a final phase marked by social affairs, in where the constituent University Residence Hall building has turned into an architectural piece integrated in such Campus/University Town, and linked to the programmatic principles of the Architectural Modern Movement. 
4| RESUMEN 


\section{INTRODUCCIÓN}

BLOQUE o

O.I CONTENIDO, ESTRUCTURA Y OBJETIVOS DE LA TESIS 
8| INTRODUCCIÓN 


\section{CONTENIDO, una primera aproximación.}

El espacio físico de la Universidad ha ido cambiando a lo largo de la historia. El conjunto de elementos configuradores de la trama arquitectónica de dicho espacio, ha sufrido transformaciones desde su génesis hasta nuestros días, adaptándose a la sociedad en la cual se inscribe y colaborando en la mejora de la capacidad de renovación de ésta, además de dar forma al lugar destinado para la transmisión del conocimiento y la investigación. La función universitaria ha ido encontrando, a lo largo del tiempo, su "ecosistema" perfecto en edificios de nueva planta, singulares o reutilizados. Su gran capacidad polarizadora sobre el territorio aglutina una pluralidad de actividades complementarias de distinta índole, como culturales, residenciales, comerciales, deportivas, etc... que impregnan tanto su estructura como su entorno.

De las piezas que conforman la dimensión universitaria, las contenedoras de la función residencial son las que cobran protagonismo como tema único del presente trabajo. La línea de investigación adoptada recorre el proceso de transformación de elementos residenciales universitarios españoles, pero abarcando una óptica internacional, donde se establecen las conexiones, influencias, paralelismos o divergencias que sobretodo Europa y Estados Unidos transmiten en éstos, abarcando un periodo desde la Edad Media hasta la segunda mitad del siglo XX.

Este tipo de edificaciones han trabado su ligazón con la Universidad en base a distintas formas, modos y situaciones de distinta índole, dando lugar a una amalgama de diferentes posturas que atienden a cada época correspondiente. Dado que el periodo abarcado es muy amplio, se hace necesaria una estructuración en bloques. Atendiendo al criterio de lo general a lo particular, se trata en cada uno de ellos un tramo concreto diferente, se enmarca el ámbito territorial de actuación y se analizan ciertas obras seleccionadas vinculadas al camino evolutivo que engloba este estudio.

Hospicios, colegios, residencias de estudiantes, colegios mayores y menores han sido nombres que han adoptado las construcciones objeto de análisis en esta Tesis, la relación urbana de éstas con la Universidad en primer término y con la ciudad en segundo, establecen una serie de patrones que a través de la observación de su arquitectura se argumenta cómo la residencia de estudiantes pasa de ser mero equipamiento a generar ciudad. 
Después de establecer unos precedentes arquitectónicos que delimitan lo que podría llamarse la "prehistoria de la Universidad", se definen los primeros moldes que albergan a residencias universitarias. Las ciudades donde se establecen estos primeros modelos históricos, germen de gran parte de la arquitectura residencial universitaria española, son Bolonia, París y Oxford.

Ante todo, el modelo boloñés, con su disposición claustral en cuanto a forma y las características innovadoras de su época en cuanto al programa, tienen una gran influencia en los primeros colegios que se crean en España, estableciendo unos rasgos definidos que adoptarán formal y constructivamente manteniéndose hasta el final de la edad media.

La importada línea se refleja en los primeros colegios españoles, siendo el primero de ellos el San Bartolomé de Salamanca y, a través de este, llega la influencia a elementos residenciales universitarios con la misma disposición, como, los Colegios Mayores de Santa Cruz y San Gregorio en Valladolid; El Colegio Mayor de San Ildefonso en Alcalá de Henares; y los Colegios Mayores de Cuenca, Oviedo y Fonseca en Salamanca.

Todos éstos se sitúan en los cascos históricos de las respectivas ciudades donde se encuentran ubicados. Es importante señalar el carácter residencial que tienen las primeras instituciones universitarias de España, definiendo el modelo claustral como un primer arquetipo, siendo éste un pequeño bastión autosuficiente en la ciudad.

La disposición claustral, anteriormente mencionada, alberga muchos ejemplos de distinta índole y en su propia génesis alberga unos criterios autónomos que, a medida que avanza el tiempo, van sufriendo transformaciones, también una apertura formal, aunque manteniendo la identidad autosuficiente de esta tipología.

Este proceso de cambio, no se entendería bien sin hacer una parada en los tipos establecidos tanto en París, como en Oxford y Cambridge.

En la capital francesa, se centra la mirada en los primeros casos de adaptación de hospederías a colegios universitarios, cuyos ejemplos son el de Sorbon y el de Navarra.

Los modelos ingleses aportan la primera diferenciación zonal de espacios en torno al claustro. El sector residencial aparece de integrado de manera centralizada en los denominados colleges, para 
después ir situándose en zonas más periféricas del conjunto. El recorrido británico se efectúa a través del Merton College, New College, John's College y Christ Church College en Oxford; después Peterhouse College, King's College y Trinity College en Cambridge.

Tanto en París como en Oxford y Cambridge se tratan posteriormente obras contemporáneas, que por la relevancia de las mismas no pueden pasar desapercibidas en este recorrido. Se trata, en el caso francés, de La Cité Universitaire y, dentro de la misma, el Colegio de España de López Otero y el Pabellón Suizo de Le Corbusier. En el caso inglés, el Fen Court dentro del Peterhouse College de Bricknell y Hugens, en Cambridge; el Saint Cazt College de Arne Jacobsen y el Florey Building perteneciente al Queen's College de James Stirling, en Oxford.

Si bien la primera mirada, a modo de referente o modelo a seguir, recae en las ciudades europeas anteriormente descritas, la segunda visión se dirige, abriendo el espectro, cronológicamente al siglo XIX, a Estados Unidos, y en segundo lugar, sin salir del marco de referencia europeo, a Alemania.

El concepto de campus estadounidense y las corrientes racionalistas como la Bauhaus alemana, son la referencia de la que viene una primera transformación de los modelos históricos citados anteriormente.

De los tipos trasatlánticos se establece una relación entre el primero de ellos, siendo perteneciente a la Universidad de Harvard, donde aparece el sistema cuadrangular británico pero con ciertos matices formales. El germen del tipo estadounidense se presenta formado por un sistema de edificios que, aun dispuestos en forma del cuadrángulo británico, hay un cierto grado de aislamiento en las edificaciones. La forma claustral de modelos anteriores, aquí se abre por medio de la desaparición de uno de los lados conformantes. Esta idea hace abandonar el carácter de" isla" que se advertía en el tipo anterior.

Tanto en la Universidad de Harvard, donde los colegios son edificios totalmente aislados, como en la de Virginia, donde Thomas Jefferson establece la conexión entre edificios docentes y residenciales, se erige el pabellón como tipo albergante de la función residencial universitaria.

El tipo pabellón, dará paso a la edificación en altura, donde entra en escena el campus de Columbia en Nueva York. Esta nueva concepción edificatoria modifica la distribución general del espacio residencial y aparecen nuevos elementos adheridos al programa que 
serán reflejados en la arquitectura española donde José Luis Sert actúa de primera referencia.

Las obras estadounidenses estudiadas se aglutinan en tres espacios temporales diferentes, cada uno correspondiente a un siglo diferente. Del siglo XVII al XIX las obras seleccionadas son, el Old College, la Casa de William Peyntree, el Goffe College, el Colegio Indio, el Massahussets Hall, el Hollis Hall y el Stoughton College por parte del campus de Harvard. El Colegio de William \& Mary y Pabellones Residenciales, ambos de la Universidad de Virginia. El Hartley Hall y el Livignston Hall del campus neoyorquino de Morningside Heights, en la Universidad de Columbia.

Como referencia contemporánea se estudian las obras de Baker House de Alvar Aalto en el campus de Harvard y Peabody Terrace, la residencia para estudiantes casados que Jose Luis Sert, junto a Jacson y Gourley proyectaron entre el campus de Boston y el de Harvard. Estos dos modelos sirven de importanción de valores que ayudan en España a que se consolide la modernidad.

A principios del siglo $X X$, se empieza a ver como nuevos conceptos empiezan a chispear en la arquitectura española, un nuevo estilo empieza a verse reflejado en ciertas obras, y estos caracteres, paulatinamente, se van sumando al panorama residencial universitario.

El concepto de sedes urbanas, con espacios dedicados exclusivamente a la cultura, parques tecnológicos y de investigación, todo ello vinculado a la idea de ciudad saludable, va estableciendo el concepto de ciudad universitaria como la ciudad ideal de la modernidad, en la cual se interpretan los postulados del movimiento moderno.

Junto a estos nuevos cambios de estilo en la arquitectura, surgen otros movimiento socio-políticos en España, y de forma concreta en Madrid, como la creación de la Institución Libre de Enseñanza, la cual juega un papel muy importante, sobre todo por su influencia en la recién creada Residencia de Estudiantes de Madrid en 1910, que se inspira en las ideas de Francisco Giner de los Ríos y ésta, tiene por finalidad, no sólo dar acogida, sino ofrecer una alternativa cultural libre, es decir, sin estar vinculada a instituciones de índole política o religiosa.

La Residencia de Estudiantes de Madrid sirve como plataforma renovadora de la arquitectura española como parte de un proyecto global de modernización que engloba a la ciencia y cultura. Por 
primera vez en España, existe un organismo que sirve de impulso hacia una construcción racional.

Dentro del marco de ciudad universitaria, se hace un repaso por las Universidades Laborales. Algunas guardan en su estructura el carácter de ciudad universitaria y constituyen un modelo representativo de la incorporación de la modernidad a la arquitectura residencial universitaria. Un claro ejemplo de evolutivo que se refleja desde la primera diseñada por Luis Moya Blanco en Gijón; posteriormente en la de La Coruña, proyectada por Luis Laorga Gutiérrez y José López Zanón; y por último la Universidad Laboral de Cheste en Valencia, cuyo autor es Fernando Moreno Barberá.

Acotando el marco de actuación, el último bloque se centra geográficamente en la Ciudad Universitaria de Madrid. Donde miembros de la Residencia de Estudiantes, como Luis Lacasa o García Mercadal, importadores directos de la nueva tendencia, disponen a Walter Gropius y Le Corbusier, entre otros, como embajadores de la doctrina que se empieza a implantar en las nuevas construcciones. El ejemplo donde repercuten de forma paulatina pero espectacular los aires modernos es en la creación de la Ciudad Universitaria de Madrid, donde a través de Modesto López Otero y su equipo se crea, junto a la anteriormente mencionada Residencia de Estudiantes, una de las principales puertas de entrada del Movimiento Moderno europeo.

López Otero designa como redactores de los proyectos de colegios mayores a arquitectos jóvenes que beben directamente de las fuentes de la tendencia internacional.

El estudio de los colegios mayores se hace en base a tres dimensiones, siendo la primera la urbanística, la segunda urbanoedilicia y, por último la social.

Ya en el modo de prever una localización específica dentro de la ciudad universitaria, relacionando distintos servicios adyacentes y la inclusión de la naturaleza como espacios de relación, la primera dimensión queda definida mediante el concepto de ciudad abierta.

En 1932-35 se construyen los primeros Colegios Mayores de la Ciudad Universitaria, los arquitectos implicados en esta primera fase son Luis Blanco Soler y Rafael Bergamín con el proyecto de La Residencia de la Fundación del Amo; y Luis Lacasa con el proyecto de la nueva sede de La Residencia de Estudiantes de Madrid. 
La Guerra Civil española marcará un punto de inflexión en las construcciones universitarias. El papel jugado por los Colegios alcanzará el punto más importante durante la década de los años 60, conocido como el periodo desarrollista, donde se construyen 33 nuevos colegios, de los que cabe destacar los siguientes Colegios Mayores dentro de la dimensión urbano-edilicia el Nuestra Señora de Guadalupe, de Luis Martínez-Feduchi Ruiz ; el Jorge Juan, de Alberto López de Asiaín Selva; el Aquinas, de José María García de Paredes y Rafael de la Hoz Arderius; el San Agustín, de Francisco de Asís Cabrero; el Chaminade de Luis Moya Blanco; el Jaime del Amo, de Luis Blanco Soler Pérez; y el Nuestra Señora de Luján, de Carmen Córdoba y Horacio Baliero.

El último ámbito establecido corresponde a la dimesión social, donde aparecen los colegios mayores César Carlos de Alejandro de la Sota y José Antonio López Candeira, y el Casa do Brasil, de Alfonso d'Escragnolle y Fernando Moreno Barberá.

Con estas dos últimas obras se pone fin a este recorrido histórico en donde se pretende elaborar una visión evolutiva de los modelos arquitectónicos más representativos de residencias universitarias.

Este trabajo se suma, por un lado, a los que tienen carácter historicista que catalogan, dentro del ámbito arquitectónico, a los edificios docentes y residenciales universitarios. De otra parte, se incorpora a publicaciones que nos muestran estudios, catálogos y congresos de edificaciones del Movimiento Moderno, como los recogidos en las publicaciones de DOCOMOMO IBÉRICO, en concreto de edificaciones del ámbito de equipamientos públicos y docencia. 


\section{ESTRUCTURA}

El periodo de tiempo en el que se desarrolla la línea de investigación de esta tesis comienza en la edad media y finaliza en la segunda mitad del siglo XX.

Dada la gran amplitud que abarca, se hace necesario dividir este tramo en subapartados que faciliten el establecimiento de unos objetivos concisos en cada uno de los mismos. Asimismo, facilitarán una lectura más fluida, clara y detallada de este trabajo.

De los criterios elegidos que marcan las piezas de división en capítulos, el primero es el orden cronológico y el segundo la localización geográfica. Atendiendo siempre al criterio de lo general a lo particular, estas pautas delimitan el inicio y final de cada uno de los apartados. Esta acotación subyace también por el establecimiento de patrones, urbanísticos y edilicios que constituyen a ciertas residencias universitarias como un modelo arquitectónico diferente del resto. Posteriormente se atiende a la permanencia, repercusión y posterior proyección en siguientes casos.

El contenido de esta tesis, por tanto, se constituye en cuatro bloques claramente diferenciados. Cada uno de ellos contiene un periodo cronológico y una localización geográfica diferente, donde los modelos representados en cada uno de ellos gozan de unas tipologías urbanísticas, constructivas, formales, estructurales y funcionales diferentes.

El criterio elegido en que estructura cada uno de los bloques es el siguiente:

\section{Bloque I, Precedentes Arquitectónicos.}

Comienza con una primera alusión al periodo anterior al nacimiento de las universidades, donde se observa, alrededor del panorama mundial, en qué lugares aparecen los primeros núcleos dedicados a la docencia superior y qué tipos de arquitectura había relacionada a ellos. Es obvio que sin universidad, no hay residencia universitaria. Por lo que se realiza un barrido en busca de los primeros asentamientos universitarios y residenciales. Emplazamientos en ciudades de China, Grecia, Marruecos o la India, entre otras, donde se producen los primeros tipos universitarios o preuniversitarios, se investiga la existencia de alguna posible estructura dedicada al alojamiento de estudiantes.

Este tramo, sirve de base para sentar el criterio de punto de partida de esta tesis. Se denomina a modo de prehistoria universitaria, y se 
caracteriza por la ausencia de modelos que perduren o se repitan en posteriores etapas.

\section{Bloque II. Residencia universitaria en la historia}

Se inicia con el nacimiento de las universidades, hecho que concurre en la edad media. Abarca un periodo desde siglo XIII hasta el siglo XIX, y las localizaciones se centran en Europa y Estados Unidos.

Cronológicamente, por orden de aparición de modelos residenciales universitarios, se estudian los primeros modelos que sirvieron de molde o ejemplo a los demás. Se definen y se catalogan los arquetipos que forman un precedente en primera instancia, para posteriormente poder identificar a los sucesores, presentando éstos últimos características similares en cuanto a forma, a estructura, a materiales y a programa. Esto hace posible que se establezca un hilo conductor de influencias y se empiecen a relacionar los distintos arquetipos, llamados "modelos históricos" y sus "sucesores".

El nacimiento de la Universidad en Bolonia, produce que se establezca esta ciudad como primera referencia de este bloque, donde el tipo arquitectónico, de nueva planta, corresponde al colegio-universidad y el concepto de forma claustral y programa son las principales referencias. Por las influencias de este modelo en España, se dedica un capítulo al estudio de la repercusión del modelo boloñés en la formación de los colegios españoles.

Cronológicamente poco después, aparece la Universidad en París, donde el modelo de residencia se enfoca desde la adaptación de hospederías a colegios universitarios.

En Inglaterra se establece, siguiendo cronológicamente en la edad media, el college como arquetipo. Este modelo supone una variación dentro del modelo claustral. Por la disposición urbana de los mismos, establecen una unidad de crecimiento residencial que se basa en una trama modular.

La evolución del modelo británico se hace fehaciente en Estados Unidos, donde criterios formales y funcionales hacen elegir tres tipos de edificación: la primera, disposición urbanística y rotura parcial del esquema claustral; la segunda, nacimiento del pabellón como elemento residencial universitario; la tercera la irrupción de la gran altura.

El capítulo de París y el de Estados Unidos, se complementan con dos apéndices contemporáneos. En ellos se vulnera el orden cronológico que sigue la tesis para poner de manifiesto criterios 
relevantes a través obras de autores como Le Corbusier, Alvar Aalto, Arne Jacobsen y James Stirling.

Volviendo de nuevo a Europa, y cronológicamente ya en el siglo XX, el inicio del racionalismo en la arquitectura y las nuevas vanguardias, centran el capítulo destinado a la Bauhaus. Esta parte se caracteriza por la autonomía y funcionalidad moderna dentro del equipamiento residencial universitario.

\section{Bloque III. Residencia universitaria en España. Generadora de ciudad.}

Aquí empiezan a aparecer las tendencias que fructificarán en el Movimiento Moderno y que dan paso a un fructífero siglo XX.

Geográficemente se acota el panorama a un ámbito español.

Las nuevas tendencias generan la transformación de los modelos históricos, anteriormente descritos, y se muestran las aportaciones de los nuevos planteamientos del siglo XX.

En panorama español de comienzos de siglo, el ambiente sociopolítico, en el que nace La Institución Libre de enseñanza, tendrá su reflejo en la construcción del continente de esta nueva forma de entender la docencia. Las nuevas aportaciones vanguardistas, con el racionalismo "aterrizando" a través de los arquitectos que importan sus principios como Garcia Mercadal, Lacasa, López Zanón, Laorga Gutierrez y Moreno Barberá, hace que sus obras describan un subcapítulo de esta tesis, mereciendo especial atención las tres fases, que corresponden con tres ubicaciones diferentes de la Residencia de Estudiantes de Madrid.

Un nuevo urbanismo supone una nueva idea de entender la ciudad, y a través del concepto de ciudad universitaria, se crea el sihuiente subapartado, donde se centra el estudio en la Ciudad Universitaria de Madrid y en Universidades Laborales donde se configura este nuevo planteamiento. Por la repercusión de la Ciudad Universitaria de Madrid, el estudio de detalle de colegios mayores de la misma, se plantea su estudio en un bloque separado de éste que da lugar al cuarto bloque, donde se practica un estudio de detalle de los citados colegios. 
La función residencial en la universidades laborales de Gijón, como precedente y ligado a modelo históricos y de arquitectura clásica; la Universidad laboral de A Coruña, donde se reflejan los criterios modernos más ortodoxos en cuanto a funcionalidad, crecimiento en base a trama y la no existencia de elementos sobresalientes reguladores; y la Universidad Laboral de Cheste, donde se aglutinan tres conceptos fundamentales modernos, influencias corbusierianas, funcionalismo racional y conexión espacial mediante la ciudad abierta.

\section{Bloque VI. Colegios Mayores de la Ciudad Universitaria de Madrid} y la Arquitectura Moderna.

El final del proceso evolutivo de los edificios residenciales universitarios se muestra en este bloque.

Se estudia la evolución tipológica del Colegio Mayor entre 1932 y 1970, planteando su función como elemento activo de la configuración urbana, además de relacionarlo con la arquitectura en sí misma, a través de la observación de los avances técnicos, cambios en el programa y también respecto a los recursos expresivos.

Se centra en la Ciudad Universitaria de Madrid, ventana por la cual entra la modernidad en España $y$, se establecen tres escalas diferentes para poder clasificar los Colegios Mayores elegidos como representativos de los objetivos a cumplir en esta tesis.

Las tres dimensiones son la urbanística, la urbano-edilicia y la social.

En la primera se reflexiona sobre el modo de implantación de los colegios mayores como un elemento residencial único dentro del conjunto universitario, cuyo modelo fue importado por López Otero y su equipo, como consecuencia de sus visitas a los campus de Estados Unidos y Canadá. En nuestra muestra de obras seleccionadas se pone de manifiesto un trasvase de las tipologías urbano-arquitectónicas que caracterizaban el escenario internacional en este periodo.

En la segunda dimensión se estudia en una nueva fase, ésta edilicia, la posible influencia de distintas corrientes europeas que habían sido transmitidas de forma directa por los arquitectos más destacados durante sus visitas a España y, especialmente a la Residencia de Estudiantes. 
Por último la dimensión social, donde las características de la escala humana, a través de conceptos como el modulor de LeCorbiser, establecen nuevas aportaciones en la arquitectura residencial y en el modo de interacción de la arquitectura con el usuario.

Concluyendo, se plantea el proceso evolutivo que en primer lugar partía de la sinergia entre universidad y ciudad, pasando después a una fase de recinto universitario unitario, y por último se observa el edificio constituyente del Colegio Mayor como una pieza arquitectónica integrada en el campus, ya vinculada inequívocamente a los principios del Movimiento Moderno. 


\section{OBJETIVOS DE LA TESIS}

El cumplimiento de los objetivos que se describen a continuación se espera alcanzar a lo largo de todo el trabajo, aunque al final del mismo, en el apartado de conclusiones se hace una síntesis de ellos junto a comprobaciones de hipótesis de partida.

El primer objetivo es datar y ordenar la función residencial universitaria, tanto de forma cronológica como tipológica. Para lo cual se establecen unos modelos o precedentes, urbanístios, tipológicos y constructivos, para posteriormente estudiar una posible herencia arquitectónica en los posteriores casos, además de identificar los criterios en los que residencias de estudiantes han estado vinculadas a la universidad.

Identificar los estadios temporales donde se produce un hito en la relación universidad-ciudad y comprobar el papel que juega la residencia de estudiantes.

Una vez identificados los modelos que sirven de base del estudio, se pretende establecer qué principios o partes han influido en la transformación de los mismos para poder establecer una línea de investigación que marque un proceso evolutivo.

Durante los periodos que conforman esta Tesis, se suceden una serie de objetivos diferentes a cada parte, creando una relación de los arquitectos vinculados, a lo largo de la historia de la Universidad, a la función residencial en cada uno de los periodos establecidos.

Por tanto, en el primer Bloque los objetivos son:

- Datar los posibles antecedentes o precedentes arquitectónicos que determinen el inicio de una época.

- Determinar los nacimientos urbanos de ciudades susceptibles de contener estudios superiores.

- Relación arquitectónica de los estudios superiores, la ciudad y el alojamiento, pudiendo identificar la existencia de función residencial.

En el segundo Bloque:

- Datar el nacimiento de las universidades relacionado con el nacimiento de la función residencial vinculada a las mismas.

- Organizar la función residencial por cronología, tipología urbanística y constructiva. En qué ciudades se produjeron los primeros establecimientos y seleccionar los que tuvieron repercusión en España. 
- Especificar qué hitos dentro de la función residencial universitaria marcaban un periodo arquitectónico, qué

repercusiones se establecen con los inmediatamente posteriores y sucesivos modelos. Identificación de los primeros arquetipos, denominados Modelos Históricos.

- Relacionar unos modelos con otros, para aportar nueva documentación y establecer nuevas pautas y categorías.

- Determinar qué modelos son los que han influido más en la arquitectura universitaria residencial española.

\section{Tercer Bloque:}

- Que elementos han influido en la transformación de los Modelos Históricos, comprobando la influencia de los europeos y estadounidenses en la creación de los nuevos colegios españoles.

- Evaluar cómo se introducen las corrientes del Movimiento Moderno en España a través de residencias de estudiantes.

- Identificar qué arquitectos españoles son los pioneros en adaptarse a las nuevas tendencias internacionales.

- La importancia de la residencia de estudiantes en la creación del concepto moderno de ciudad universitaria.

- Que influencia ha tenido la Institución Libre de Enseñanza en los elementos residenciales universitarios de Madrid.

- Que han aportado los colegios mayores de la Ciudad Universitaria de Madrid a la arquitectura moderna española.

- Determinar el papel jugado por la función residencial en las universidades laborales españolas en general $y$, de forma particular en la Universidad Laboral de Cheste.

- Documentar que hechos arquitectónicos pueden determinar el fin de una época.

\section{Cuarto Bloque:}

-Identificar los colegios mayores que pertenecen a los tres ámbitos anteriormente descritos.

-Establecer, por ser portadores de los nuevos planteamientos, una línea que haga posible establecer criterios evolutivos dentro de los colegios mayores.

-Establecer conexiones e influencias entre los arquitectos españoles de los colegios y los maestros de la arquitectura del Movimiento Moderno euopeos. 
-Establecer criterios que potencien la sinergia histórica entre universidad y ciudad, pasando por una fase intermedia de cración de recinto universitario y establecer el papel del colegio Mayor.

- Observar cuales son las pautas y acciones que constituyen al colegio mayor como pieza integrada en un campus (en este caso la Ciudad Universitaria de Madrid)

-Criterios, impresiones y postulados que vinculen a los colegios mayores de la Ciudad Universitaria con los principios progrmáticos del movimiento moderno. 


\section{INTRODUCCIÓN}

BLOQUE o

0.2 METODOLOGÍA 
24| INTRODUCCIÓN 
Como metodología, se ha seguido un esquema organizado en cuatro fases que van dese lo genérico a lo concreto. En cada una de las fases estudiadas se recopila primero la información para, a través de la misma, organizar y reinterpretar la bibliografía existente con el fin de construir un nuevo tema, centrado en la residencia universitaria, y que no se encuentra como tal, de forma explícita, en la citada bibliografía.

Es necesario construir esta plataforma inicial, donde se analizan y se reformulan tipologías docentes, espaciales y funcionales de interacción entre universidad y ciudad, apareciendo comunidades de aprendizaje vivenciales, funcionalmente integrales en donde la residencia universitaria aparece, de forma explícita, como elemento decisivo.

El desarrollo del trabajo a través de cuatro fases permite elaborar un hilo conductor que posibilita una lectura escalonada desde los rasgos más generales del panorama arquitectónico europeo y americano hasta, posteriormente, pasar a un ámbito nacional donde se profundiza en aspectos más detallados. Por tanto estas fases serían:

1. Aproximación al contexto arquitectónico de la residencia universitaria.

2. Identificación de tipos y modelos arquitectónicos residenciales universitarios.

3. Análisis de los modelos residenciales universitarios.

4. Síntesis del proceso evolutivo y obtención de conclusiones.

1. Aproximación al contexto arquitectónico:

Para poder realizar esta aproximación, primero se consulta bibliografía de tipo general para conocer cuando se implantan las primeras universidades y conocer si existe algún tipo de elemento residencial vinculado a las mismas. Las fuentes consultadas revelan cuáles son las primeras ciudades donde aparece la universidad, comprobando la existencia de equipamiento universitario vinculado a las mismas.

El vaciado se realiza, no sólo por publicaciones de arquitectura, sino también por publicaciones de historia que ayudan a consolidar y ordenar la búsqueda de los primeros modelos. 


\section{Identificación de tipos y modelos}

Estableciendo cuales actúan de pioneros o precursores, para posteriormente detectar aquellas vías o referencias que propician sus cualidades o características a los modelos sucesores. En este apartado aparecen fuentes directas e indirectas. Las indirectas se relacionan con la consulta de los archivos de los primeros colegios, como son los casos de Bolonia, Oxford y Cambridge. Se elabora una bibliografía específica, pasando de la óptica de la evolución de los edificios continentes de la universidad, a una óptica donde se centra la evolución de la residencia dentro del marco universitario; y ambas vistas, desde la perspectiva de la transformación en la ciudad.

\section{Análisis de los modelos residenciales universitarios}

Una vez determinados los modelos residenciales universitarios, se elabora una bibliografía específica desde el punto de vista arquitectónico. Se realizan consultas de archivos personales de los arquitectos implicados en las obras estudiadas. Se realizan tres viajes, el primero a Salamanca, el segundo a Valladolid y el tercero a la Ciudad Universitaria de Madrid. Por el estado en el que se encuentran las obras, se hace más fructífero el de Madrid, donde los edificios mantienen sus características originales, dada la menor diferencia de época respecto a la construcción. De este modo se completa mejor el análisis debido a las visitas in situ, donde se realizan reportajes fotográficos y trabajo de campo. Las impresiones personales intervienen en las posteriores reflexiones.

El análisis de las obras se lleva acabo, primeramente, con el apoyo de la consulta de archivos personales de los arquitectos autores. A su vez, se consultan las publicaciones donde aparecen obras seleccionadas susceptibles de observación y posterior interpretación. Debido a la localización de algunas de ellas, se hace necesaria, por la distancia geográfica, la consulta a través de la petición previa de archivos originales a instituciones extranjeras, tales como la Universidad de Virginia y la Biblioteca del Congreso, ambas de Estados Unidos. También se ha solicitado información, vía correo electrónico, a distintas bibliotecas históricas de "colleges" de Oxford y de Cambridge. Esta es una de las etapas que mayor tiempo requiere pues, la cantidad de archivos a consultar resulta muy elevada.

Supone una gran satisfacción comprobar como desde la distancia se obtienen réplicas de los archivos originales, donde se aprecia el tipo de trazado, grafismo y composición de planos de distintas épocas. Es interesante apreciar el cambio que se produce en las técnicas y representaciones de expresión gráfica.

En el caso de archivos de arquitectos españoles, incluidos en el último bloque de esta tesis, el vaciado ha permitido el estudio de bocetos inéditos y propuestas preliminares que clarifican la génesis de sus proyectos. 
También, se realiza una exhaustiva labor de búsqueda en revistas de arquitectura para localizar artículos publicados. Asimismo se elabora un listado específico relativo a publicaciones en prensa pertenecientes al principio del siglo $X X$ y centrados en los colegios mayores madrileños dentro del entorno de la Ciudad Universitaria de Madrid.

4. Síntesis del proceso evolutivo y obtención de conclusiones.

Una vez realizado el estudio exploratorio de las obras más relevantes, se aborda el estudio detallado de aquellos aspectos más relevantes dentro de las mismas. Siempre intentando fijar un camino cuya meta se encuentra en la modernidad y, una vez alcanzada, intentar responder a los objetivos preestablecidos.

Posteriormente se organiza el trabajo mediante el análisis de la producción arquitectónica de la residencia universitaria como tipología funcional y también urbana y social.

Una parte indispensable en las aportaciones de índole personal de esta tesis, sobre todo en las correspondientes al cuarto y último bloque, se han debido en gran parte, a la asistencia a congresos donde la temática era de índole similar al tema propuesto en este trabajo. El poder escuchar y entablar debate, de primera mano, aunque de forma informal, con expertos como William Curtis o Salvador Guerrero (especialista en la Institución Libre de Enseñanza), de los que ya se han incluido y estudiado sus publicaciones acerca de la materia, aportan un punto más de enriquecimiento a las obras analizadas.

A continuación se detalla una relación de fuentes, donde se explicitan los principales archivos y bibliotecas. La principal fuente de documentación para la investigación ha girado en torno a las fuentes indirectas, donde, como se ha explicado anteriormente, la organización, clasificación y reinterpretación de las mismas ha hecho posible la redacción de esta tesis.

BLOQUE I: Al tratarse de precedentes arquitectónicos, los archivos a los que se hace referencia en la bibliografía se extraen a través de la solicitud digital de documentos al Archivo Histórico Medieval de la Universidad de California y al Archivo Histórico Universitario de la Universidad de Sevilla. Las demás fuentes se obtienen de forma indirecta de la bibliografía general correspondiente a este bloque.

\section{BLOQUE II: Se consultan los siguientes archivos:}

- El Archivo Histórico del Real Colegio de los Españoles en Bolonia conserva los documentos producidos y adquiridos por el Colegio en el desarrollo de su propia actividad desde su fundación. Entre los documentos más antiguos se encuentran las actas notariales de compraventa relativas a la formación de patrimonio inmobiliario, los 
libros de cuentas de la fábrica $(1365-1368)$ y los registros de admisión de los colegiales a partir de 1392 con una relación que se remonta al año 1369.

El Archivo custodia también el fondo albornociano constituido por documentos personales del Cardenal Albornoz (1353-1387). Entre ellos se encuentra el original del testamento del Cardenal Gil de Albornoz (Castillo Papal de San Cataldo, Ancona, 29 de septiembre de 1364), acto de fundación del Colegio de España.

Inventarios:

Primo Bertán Roigè, Catalogo del Archivo del Colegio de España, Publicaciones del Real Colegio de España, Bolonia 1981 (Studia Albornotiana ; 40); Antonio Pérez Martín, Proles Aegidiana, Publicaciones del Real Colegio de España, Bolonia 1979, 4 v. (Studia Albornotiana; 31/1-4); José Trenchs y Carlos Saez, Catálogo de los fondos del Archivo albornociano (Bolonia), Publicaciones del real Colegio de España, Bolonia 1979 (Studia Albornotiana ; 35)

-Archivo Histórico de la Universidad de Salamanca, donde se recopila información, sobre todo gráfica, acerca de los primeros colegios mayores españoles. Se pueden observar también, los testamentos originales de algunos de sus fundadores, donde se aprecia el objetivo que tenían al construir este tipo de instituciones.

-Archivo Histórico de la Universidad de Alcalá de Henares. Se obtienen dibujos originales de las primeras disposiciones del Colegio de San Ildefonso.

-Archivo Histórico del Colegio de Santa Cruz de Valladolid. Se consulta la documentación gráfica de los planos originales del citado Colegio.

Con respecto a Oxford y Cambridge, la principal fuente consultada la proporciona la British Library, donde se consigue documentación gráfica de los "colleges" y, también, a través de sus propios archivos históricos. A través de los mismos se puede consultar documentación gráfica de los planos del proyecto original y los de posteriores reformas.

En los archivos norteamericanos de la Universidad de Harvard y en el Colegio William and Mary en Virginia se ha podido establecer una fuente de información original sobre los mismos, donde, por ejemplo, se han podido recopilar bocetos de Thomas Jefferson sobre la ampliación del citado Colegio William and Mary.

BLOQUE III: Las principales fuentes consultadas para este apartado se producen de forma directa e indirecta. La forma directa afecta al Archivo Histórico de La Residencia de Estudiantes de Madrid, donde se recaba una gran documentación histórica para poder establecer sus tres sucesivas ubicaciones. En la Fundación COAM del Colegio Oficial de Arquitectos de Madrid se consultan de los archivos de 
Luis Lacasa, Antonio Flórez Urdapilleta y Javier de Luque.

De las fuentes indirectas cabe destacar el completo, detallado y exhaustivo estudio que realiza Carmen Jordá sobre la Universidad Laboral de Cheste, con su correspondiente publicación.

BLOQUE IV: Las fuentes directas consultadas se concretan en los archivos personales de Alejandro de la Sota, de José María García de Paredes y de Francisco de Asís Cabrero.

Así se obtiene la mayor parte de documentación gráfica inédita, interesante, pues se trata de ya obras bastante conocidas. La búsqueda en estos archivos se centra en los bocetos previos y detalles constructivos de los colegios mayores que proyectan en la Ciudad Universitaria.

Las fuentes indirectas se detallan en el Estado de la Cuestión en el próximo capítulo, ya que no es recomendable la reiteración de argumentos siendo que parece más pertinente incluir este apartado por su vínculo con la publicación de antecedentes. 
30| INTRODUCCIÓN 
INTRODUCCIÓN

BLOQUE o

0.3 ANTECEDENTES (ESTADO DE LA CUESTIÓN) 
32| INTRODUCCIÓN 
El análisis del espacio residencial universitario realizado de forma histórica es un tema novedoso, pues respecto al origen y transformaciones de estos equipamientos, no existen publicaciones específicas que aborden la materia desde la óptica urbana y evolutiva que se ha desarrollado en la presente tesis.

Las publicaciones consultadas, como se ha comentado en el apartado anterior relativo a la metodología constituyen fuentes indirectas que se ordenan y se reinterpretan para posteriormente redactar el contenido de la tesis. En ellas, aparece alguna temática acerca de la evolución de los recintos universitarios, de los campus y de las ciudades, pero no se hace mención expresa al elemento residencial, quedando por tanto, gran cantidad de aspectos por investigar sobre las residencias universitarias.

Cabe destacar, que en la bibliografía consultada, aparecen estudios y publicaciones sobre algunas de las residencias tratadas en esta tesis, pero de forma puntual sobre cada una de ellas $y$, salvo en los primeros casos medievales españoles, no se concretan relaciones entre unas y otras.

En consecuencia, se hizo necesaria la consulta de muchas publicaciones donde aparecían los datos de los primeros establecimientos arquitectónicos, ya que en muchas de las mismas se incluían datos contradictorios según el dispar parecer de los diferentes autores que las firmaban.

Sobre las primeras instituciones universitarias más antiguas, cabe destacar los siguientes trabajos, que sirven para situar el marco de inicio de la tesis y poder concretar los términos del contenido de la misma:

- Toby E. Huff, "The Rise of universities". Editada por Cornell Paperback, Dartmouth, Massachusetts, 1965.

- Jaime Castrejón Diez, "El concepto de Universidad". Editorial Trillas, Mexico DF, 1990.

- Hilda Ridder-Simoens, "Las Universidades en La Edad Media" Dentro de la Historia en la Universidad de Europa. Ediciones de la Universidad del País Vasco. Bilbao, 1994.

- Santiago Aguadé Nieto, "Universidad, Cultura y Sociedad en la Edad Media". Ediciones de la Universidad de Alcalá. Alcalá de Henares, 1994 .

- Giolano Arnaldi, "Le origi dell'Universitá, de la Editorial Muliono II, Bolonia, 1974. 
- Pablo Campos Calvo-Sotelo, "La Evolución histórica del Espacio Físico de la Universidad". Ed Universidad Carlos III de Madrid, 2011. En esta publicación aparece de forma explícita los criterios arquitectónicos y el "corpus" de las primeras universidades. Además se hace un recorrido por los modelos universitarios ofreciendo una evolución de las estructuras de campus universitarios. Esta fuente ha servido para contextualizar la parte correspondiente a París, Oxford y Cambridge y Estados Unidos. Sin embargo, hay que insistir en que esta investigación en ningún caso se extiende al estudio de la tipología residencial universitaria.

El que más ha ayudado a organizar y clasificar el espacio universitario ha sido la publicación, en inglés, de M. A. Hastings Rashdall, "'The Universities in the Middle Ages", editada por Clarendom Press, Oxford, 1895 y reeditada y anotada por F,M, Powicke y A.B. Emden en 1958. Es la obra clásica para conocer el origen de las universidades de Bolonia y París durante la Edad Media.

De autores varios se destaca el siguiente tomo que comprende contenidos importantes sobre los primeros casos españoles:

- Miscelánea Alfonso IX, Centro de Historia Universitaria (CEHU). Universidad de Salamanca. "Universidades Clásicas de la Europa mediterránea: Bolonia, Coimbra y Alcalá. De esta publicación se extraen las características del modelo boloñés de Universidad dentro del apartado cuyo autor es Javier García Martín. Del pripo Colegio en cuestión aparecen características de su funcionamiento en el apartado que firma Baltasar Cuart Moner "El Colegio de san Clemente de los españoles de Bolonia en la edad Moderna. Historiografía". También, se esta misma publicación, se recaban aspectos generales de la formación de la Universidad de Alcalá de Henares en dos artículos diferentes, el primero del autor José Luis Peset, "La Universidad Clásica de Alcalá de Henares. Estudio y estado de la cuestión"; y del autor Manuel Casado Arboniés, "Los colegios menores seculares de patronato eclesiástico de la Universidad de Alcalá. Líneas de investigación".

Sobre el Colegio de Bolonia y las conexiones con los primeros colegios españoles está publicado el trabajo de Antonio Pérez Martín en la editorial Studia Albornociana, que es una colección propia de los estudios del Colegio de los Españoles en Bolonia, los cuatro tomos de su Proles Aegidiana. En la misma editorial se encuentran las publicaciones, a partir de 1980, sobre el citado colegio los trabajos de: 
- Dámaso de Lario, "La Universidad de Bolonia y el Colegio de España en el tránsito de los siglos XVI al XVII", en la Revista de Historia Moderna 2000. Editado por el Servicio de Publicaciones de la Universidad de Valencia.

- Primo Beltrán Roigé, "Catálogo del Archivo del Colegio de San Clemente de Bolonia", Bolonia, Studia Albornociana, 1981.

- Amadeo Serra Desfilis. "Bolonia y la definición de un tipo en la arquitectura universitaria europea". Editado por Miscelánea Alfonso IX, 2012. Del mismo autor, "Matteo Gattapone, arquitecto del Colegio de España". Correspondiente a la Colección de Estudios del Real Colegio de España Albornociano de San Clemente de los Españoles en Bolonia. Editado por Cometa S.A. 1992.

Sobre los primeros colegios españoles de forma particular, las publicaciones que han ayudado a conocer más características arquitectónicas de los mismos han sido:

- Esteban Madruga Jiménez, "Crónicas del Colegio Mayor Arzobispo Fonseca de Salamanca" Historia de La Universidad de Salamanca, Volumen II, Estructuras y flujos. Ed. Universidad de Salamanca, 1953.

- Pedro Navascués Palacio, "El Colegio Mayor Fonseca y su arquitectura". Ed. Departamento Composición Arquitectónica, ETS Arquitectura Madrid, 1993.

- Águeda Rodríguez Cruz, "Historia de la Universidad de Salamanca", Ed. Fundación Areces y Congregación de Santo Domingo, Salamanca, 1990.

- Luis E. Rodriguez-Sanpesdro Bezares, y Juan Luis Polo Rodríguez, "Universidades Hispánicas: Colegios y Conventos Universitarios en la Edad Moderna", Ed. Universidad de Salamanca. Colección Aquilafuente.2011.

- Nieves Ruipérez Almajano, "Urbanismo de Salamanca en el siglo XVIII", Ed. Salamanca delegación del Colegio Oficial de Arquitectos de León, 1992.; y de la misma autora El Colegio de San Bartolomé o de Anaya", Ed. Universidad de Salamanca, 2003.

- Margarita Torremocha Hernández, "Los estudiantes, los estudios y los grados", Historia de la Universidad de valladolid. Ed. Valladolid 1990., "Las noches y los días de los estudiantes universitarios(posadas, mesones y hospederías) en Valladolid, en "Aspectos de la vida cotidiana en la España Moderna (i). Revista de Historia Moderna. Anales de la Universidad de Alicante, 10, 1995. 
- Ed. Universidad de Alicante, Departamento de Historia Medieval, Historia Moderna y Ciencias y Técnicas Historiográficas, 1991.

Sobre la arquitectura residencial universitaria tanto de París como de Oxford y Cambridge, se ha pedido información directamente a los Archivos históricos de los "colleges" como se ha dicho en el apartado anterior. Cabe destacar, en este apartado también, los trabajos pertenecientes al siglo $X X$ que han servido para incluir en la estructura de la tesis los apéndices contemporáneos:

- Rodney Hilton, "Las ciudades en la sociedad feudal inglesa", Conflicto de clases y crisis del feudalismo. Ed. Oxford University Press. Barcelona,1988. Esta publicación describe muy bien el entornode la ciudad y describe, aunque desde una órbita po arquitectónica, como estaban implantadas las ciudades inglesas desde el punto de vista urbano.

El libro monográfico sobre la Cité Universitaire de Paris: "La Cité Universitaire de París: Pour La Jeunesse De Nos Écoles". Paris: Imprimèrie Chaix, 1925. Microfilmed 1994: The University Libraries of Notre Dame. Es esclarecedor en la inserción urbana de los equipamientos residenciales en el París del siglo XX.

- José Ramón Alonso Pereira, "El Colegio de los Españoles en París como punto de inserción arquitectónico entre las ciudades universitarias de París y Madrid". Liño 19. Revista anual de Historia del Arte. Universidad de Oviedo, 2013. Dentro de la Cité, este artículo pone en valor las etapas de construcción, datando las fechas desde la fase de concurso, como de adjudicación hasta el fin de los procesos constructivos.

De la parte estadounidense, existen varias publicaciones que han sido reveladoras en la comprensión de la nueva forma del "lawn" como modelo de campus. Hay que indicar que la peculiaridad se refiere a una arquitectura diseminada en la naturaleza y a partir de este concepto se ha podido establecer el papel de los pabellones residenciales y sus relaciones funcionales. Las publicaciones más importantes son:

- Oscar Celador Angón, "La América de Thomas Jefferson dentro del Anuario Residencia de Estudiantes "Fernando de los Ríos" : [1995-1996], 1997. 
- Xosé Fernández Fernández, Catedrático de Composición arquitectónica de la Universidad de La Coruña, tiene dos publicaciones fundamentales, en la primera se establece el hilo conductor de la construcción por fases de la Universidad de Virginia:" La Universidad de Virginia de Thomas Jefferson. Un modelo de tipología arquitectónica" ; y en la segunda, se muestran las relaciones que tuvo Jefferson como arquitecto en sus viajes por Europa, "El arquitecto Thomas Jefferson y su relación con España, editada por la Universidad de La Coruña en 2003.

Entrando ya en la parte correspondiente a la arquitectura universitaria española del siglo XX:

Dentro del marco correspondiente a la Residencia de Estudiantes de Madrid, los trabajos de Salvador Guerrero en sus publicaciones y exposiciones, han valido para conocer los entresijos de este organismo, muy vinculado a su vez con la Institución Libre de Enseñanza", y la óptica con que muestra sus argumentos es similar al tratamiento que se le da en esta tesis a dicho establecimiento residencial. Aporta datos sobre las técnicas constructivas $y$, también, sobre los inicios de la arquitectura racional, tanto española como, de forma particular, madrileña. La temática se centra en las dos primeras ubicaciones de la Residencia de Estudiantes, tanto en la calle Fortuny como en la "Colina de los Chopos". Uno de los aspectos de mayor importancia son sus contribuciones sobre los arquitectos que visitaron La Residencia, como las de Walter Gropius y Le Corbusier.

El campus universitario español, se ha enmarcado en el entorno de las Ciudades Laborales estudiadas y la Ciudad Universitaria de Madrid. Con respecto a las primeras, la publicación de Carmen Jordá Such, "La Universidad Laboral de Cheste 1967-1969", aporta, desde un tratamiento global de este gran conjunto, un riguroso análisis de las residencias en esta Laboral. Ha servido para conocer en profudidad la arquitectura de Fernando Moreno Barberá, del que se estudia de forma específica su aportación en el Colegio Mayor Casa do Brasil de la Ciudad Universitaria de Madrid. También demuestra, concretando, las influencias de Le Corbusier en la arquitectura del citado autor, desde las soluciones estructurales, formales, y funcionales, hasta llegar al plano de detalle. 
Varias publicaciones dedicadas a la Ciudad Universitaria d Madrid, las contribuyen a conocer la cronología y desarrollo de la misma, desde un punto de vista urbanístico, en primer lugar, como en el libro de Pilar Chías Navarro "La Ciudad Universitaria de Madrid. Génesis y Realización". Editada por la Universidad Complutense de Madrid en1986. Asimismo cabe resaltar, en la misma índole la publicación de AAVV, "La Ciudad Universitaria de Madrid" volúmenes I y II, editado por El Colegio Oficial de Arquitectos de Madrid y La Universidad Complutense de Madrid. El volumen I se ha utilizado para enmarcar la escala urbanística de este trabajo, mientras que en el segundo aparece información específica sobre función y estructura urbana de algunos de los Colegios Mayores estudiados.

Se puede deducir, por todo lo anterior que la carencia principal, para enfrentarse a la investigación propuesta en la tesis, afecta al estudio comparado entre contextos, países y tipologías, incluyendo lógicamente la que protagoniza la investigación, la residencia universitaria, además de constatar las influencias recíprocas de los modelos históricos consolidados. 


\section{PRECEDENTES ARQUITECTÓNICOS}

\section{BLOQUE I}

A MODO DE PREHISTORIA UNIVERSITARIA

"Modelos" universitarios previos: China, India, Marruecos y Grecia

LA UNIVERSIDAD MEDIEVAL Y EL MONASTERIO

Espacios configuradores del tipo universitario

ORIGEN DE LA RESIDENCIA UNIVERSITARIA

De las principales ciudades europeas a la Península Ibérica 
40| PRECEDENTES ARQUITECTÓNICOS 


\section{A MODO DE PREHISTORIA UNIVERSITARIA}

"Modelos" universitarios previos: China, India, Marruecos y Grecia

El entorno residencial universitario ha ido evolucionando a lo largo de la historia, desde su comienzo en la Edad Media hasta nuestros días. En un primer enfoque, se encuentran las residencias universitarias en el conjunto de edificaciones que rodean al mundo universitario. Las relaciones que puede haber, siendo éstas de distinta naturaleza y atendiendo a distintos criterios, son muchas.

Anterior al término de universidad, el cual se toma como punto de arranque de la presente Tesis Doctoral, se pueden establecer unos precedentes arquitectónicos, ejemplos que, aunque no cumplían todos los requisitos para poder ser considerados universidad, pueden ser la "antesala" del modelo medieval, casos pioneros que conviene observar antes de entrar en la materia objeto de este trabajo.

Acotar temporalmente la prehistoria universitaria es una tarea un tanto compleja, pues previos al modelo medieval existían unas cuasi-universidades que transmitían conocimiento y emitían títulos, pero no estaban ligadas a un modelo arquitectónico concreto definido ${ }^{1}$.

A continuación se detalla una relación de este tipo de centros:

En China se encuentra la "universidad" o cuasi-universidad, registrada como tal, más antigua, la Escuela Superior Hang Shiang, data del periodo $\mathrm{YU}, 2257-2208$ a C $^{2}$. Al igual que la universidad de Nankín en el año 258 d.C, que actualmente sigue en activo, en su origen fue más bien una academia de oposiciones que no emitía títulos superiores de validez universal, sino que preparaba a sus estudiantes para las durísimas pruebas de acceso al funcionariado imperial. Estos modelos empezaron como academias y a lo largo de los años acabarían convirtiéndose en universidades, adaptándose al modelo que nace en la Edad Media.

Otra institución que se sugiere como el precedente universitario más antiguo en existencia es la de Atenas, refiriéndose a la Academia Platónica fundada por el conocido filósofo en el 368 a.C. Cabría entender que la primera realidad espacial "universitaria" fue la polis griega. Este primitivo modelo dibujó en su estructura urbana lugares tan relevantes como el Ágora, la Academia o el Gimnasio, en los que tenía lugar la transferencia y difusión de conocimientos a través del diálogo y convivencia entre maestros y discípulos ${ }^{3}$.

En un primer acercamiento al caso español, un salto cronológico permite situarse en la época de las Universidades musulmanas, las madrasas, antecesoras de las cristianas que surgieron posteriormente. Una de las más notables fue la de Granada: la Ma- 
drasa de Yusuf I en el año 1349, junto a la Capilla Real, espacio donde hoy se continúa ejerciendo una labor cultural valiosa dentro del corazón urbano granadino. La cultura islámica propició la creación de las Escuelas de Traductores, cuya misión fundamental fue la de adaptar y canalizar los conocimientos árabes desde tierras españolas hacia el Norte europeo. La conquista de Toledo en el 1085 trajo como consecuencia la entrada de esa cultura a la civilización occidental.

Sin embargo, ni la Academia de Platón era una universidad, sino una escuela de filósofos, ni la Universidad de Atenas puede trazar lícitamente sus orígenes.

Los modelos de Nalanda (India, siglo $\mathrm{V}$ d.C.) y Constantinopla (Bizancio, 425 d.C.) pueden ser más sugerentes, pero ambas desaparecieron en un periodo de tiempo muy lejano y eran muy distintas de lo que hoy entendemos como universidad.

Así que podemos decir que las academias persas y árabes, anteriores a la edad media, son las antecesoras inmediatas de la universidad medieval. Son establecimientos a modo de escuela.

Según el criterio de varios autores, las más famosas son las de Edesa y Nisibis (siglo V) que fueron fundadas por sirios cristianos. Algunas, al igual que se acaba de ver con el ejemplo de Nankín, fueron transformándose o emulando al modelo medieval, como son la Escuela y posterior Universidad de Bagdad (siglo VIII), la Escuela de Samarcanda (siglo VIII), la Escuela-Universidad de Al-Karamine en Fez, Marruecos (siglo IX), la universidad de Damasco (siglo X) y la universidad de El Cairo(siglo X) 4 .

También sería adecuado destacar el papel de los hospitales universitarios persas como facultades de medicina durante el siglo IX. 


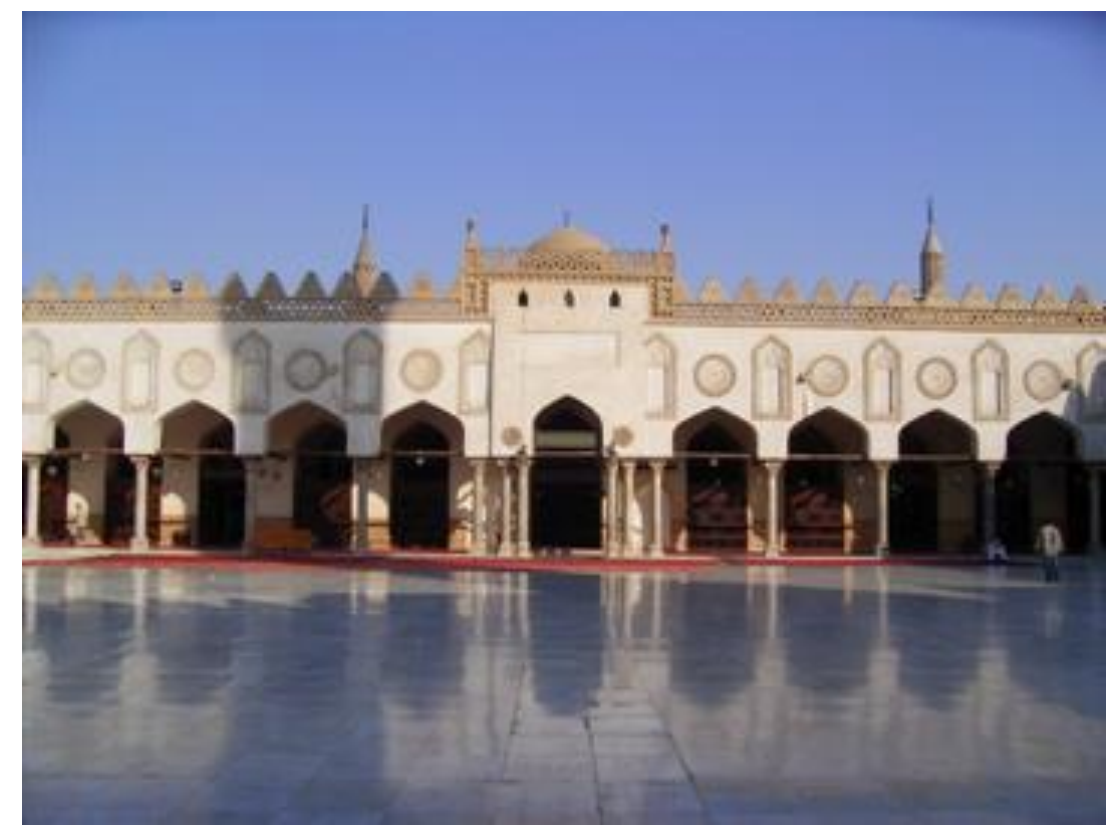

Imagen 1: Universidad de El Cairo.

Imagen 2: Madrasa que

originó la Universidad de

Fez, Marruecos.

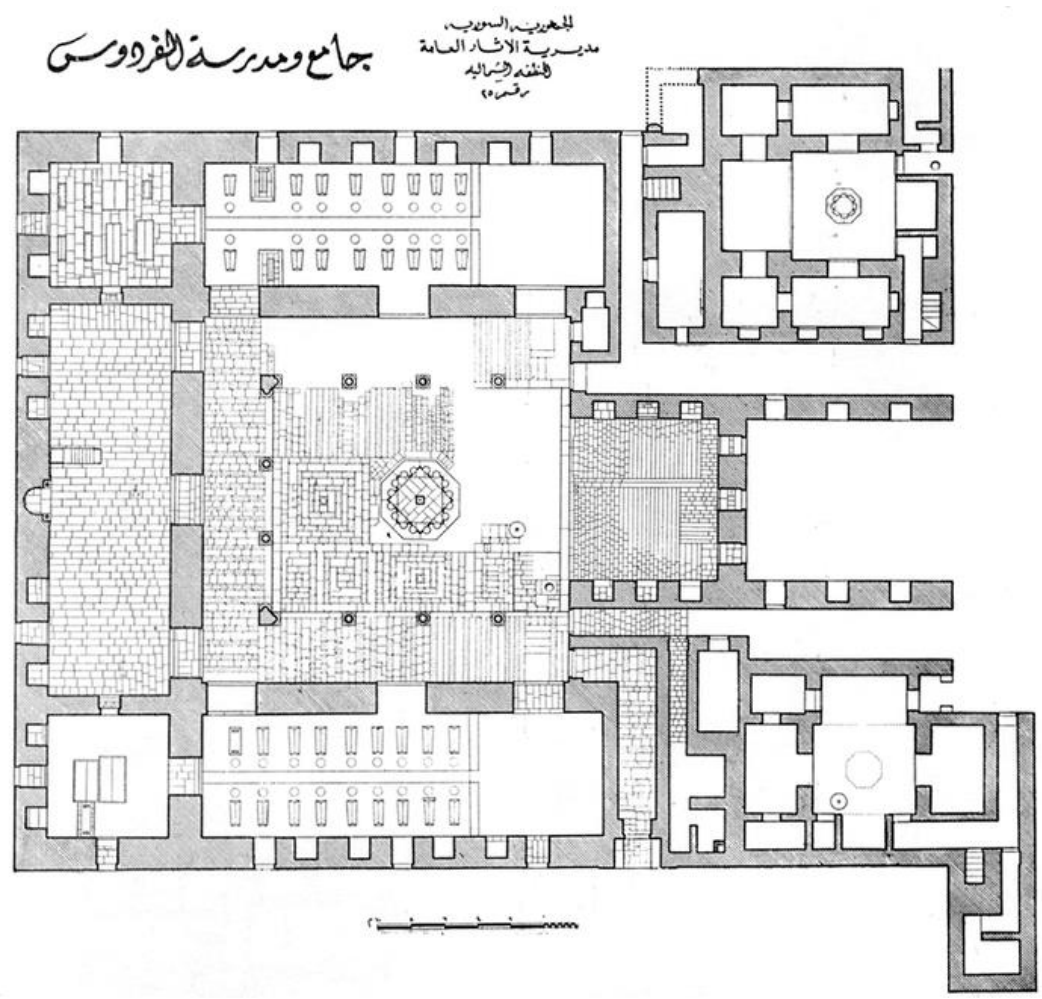


Otra de las universidades más antiguas que se mantiene abierta hasta la actualidad es la Universidad Al-Azhar en el Cairo (Egipto), titulando a sus estudiantes desde el año 972. En este caso, hablar de regresión es más complicado pues siempre fue fundamentalmente un centro de enseñanzas teológicas, considerado en la actualidad como el corazón de la literatura árabe. La colección de manuscritos que se conservan en su gigantesca biblioteca, con más de siete millones de páginas, está considerada como una de las más importantes del mundo. Pese a su clara vocación teológica, dispuso desde su origen de facultades de filosofía, astronomía, medicina, gramática y lógica y en la actualidad, también de ingeniería y agricultura 5 .

Les siguen, a mediados del siglo XI, las nizzamiya ${ }^{6}$ de Isfahán (Irán) y Bagdad (Irak) que fueron las primeras en generalizar el principio de enseñanza superior gratuita a los estudiantes que lo merecían, mediante lo que hoy día llamaríamos becas. En Al-Karaouine y AlAzhar éste había sido un privilegio especial concedido por los sultanes que les hacían de mecenas.

A lo largo del tiempo, estas cuasi-universidades se irán transformando en un modelo que se estudia a continuación y que surge durante la edad media. 


\section{LA UNIVERSIDAD MEDIEVAL Y EL MONASTERIO Espacios configuradores del tipo universitario}

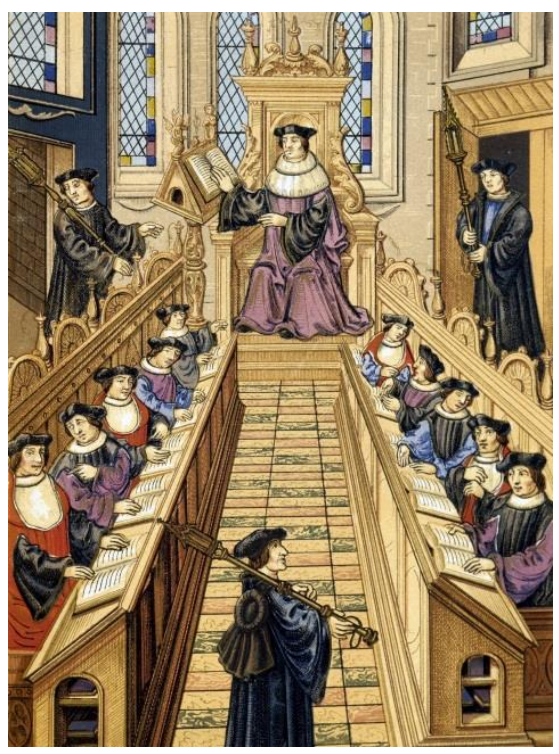

Imagen 3: Maestro en su Cátedra impartiendo una clase magistral. Grabado de la Biblioteca de Artes Decorativas de París.
El mundo artístico e intelectual de la Alta Edad Media fue una época de estupenda vitalidad artística e intelectual. El periodo fue testigo del crecimiento de las instituciones educativas, un renacimiento del interés por la cultura antigua, un despertar del pensamiento teológico, el resurgimiento de la ley, el desarrollo de una literatura vernácula y una explosión de actividad en el arte y la arquitectura.

Si bien los monjes continuaron desempeñando un importante papel en la vida intelectual, cada vez más el clérigo secular, las ciudades y las cortes (fueran de reyes, príncipes o altos funcionarios eclesiásticos) comenzaron a ejercer una nueva influencia. De importancia especial, son las nuevas expresiones que surgen en los pueblos y ciudades.

La educación en la Alta Edad Media descansaba, sobre todo, en el clero, es decir, en los monjes. Aunque las escuelas monásticas fueron centros de aprendizaje desde el siglo IX, estuvieron rebasadas en el curso del siglo XI por las escuelas catedralicias, organizadas por el clero secular. Las escuelas catedralicias se extendieron con rapidez en el siglo XI. Había veinte en el año goo pero, para el año 1000, sU número había crecido cuando menos hasta doscientas ya que cada ciudad catedralicia se sentía obligada a establecer una. Las más famosas fueron las de Chartres, Reims, París, Laon y Soissons, todas ubicadas en Francia que era, realmente, el centro intelectual de Europa en el siglo XII. Aunque el propósito principal de la escuela catedralicia era educar a los sacerdotes para ser hombres de Dios más letrados, también atrajeron a otras personas que deseaban contar con alguna educación pero no querían ordenarse sacerdotes. Muchos administradores universitarios tuvieron títulos como los de canciller, preboste y decano, originalmente utilizados para los funcionarios de los capítulos de la catedral

El término universitas se utilizó a partir del siglo XII en el sentido jurídico de corporación o comunidad-un gremio, una hermandad- en un momento en que empezaron a proliferar todo tipo de corporaciones. De ahí que se hablara de universitas scholarium- o universitas magistrorum et scholarium, es decir, de universidad de estudiantes o universidad de maestros y estudiantes, esto es, comunidades de maestros y estudiantes que se ocupaban de la educación superior en tal o cual ciudad. Estas corporaciones fueron poco a poco teniendo entidad jurídica y creando sus estatutos. Las universidades fueron una aportación medieval que con el tiempo se extendería como forma de educación superior por toda Europa y, más tarde, por todo el mundo. El nombre de "universidad" no se empezó a utilizar de forma usual hasta finales de la Edad Media, mientras que en los primeros tiempos se utilizaba la denominación usual de "studium generale"7. 
Para poder establecer una clasificación de los modelos arquitectónicos, es preciso dedicar una atención especial a los monasterios y a las catedrales, ya que constituyeron los inicios de las estructuras físicas en las que se implantó la universidad y que han sido transportadas, con todas sus mutaciones tipológicas y conceptuales, prácticamente hasta la actualidad.

El origen de la universidad se produce pues, en las instituciones monacales. Los monasterios se definen como bastiones de civilización y ciudadelas ideales ${ }^{8}$. Su multiplicación a lo largo y ancho de la geografía medieval generó un inmerso "abanico" de centros transmisores de conocimiento. La autonomía funcional que preconizaban quedaba resuelta internamente en la organización de sus diversos rectores. El referente de la citada organización puede ser el plan de la Abadía de San Gall9 (siglo IX), en dicho plan se destaca, el claustro como elemento organizador de la transmisión del conocimiento.

El primer modelo arquitectónico, es por tanto, el que concierne al sistema claustral, que es el denominador común en las primeras edificaciones universitarias y del cual partirán los demás arquetipos.

El modelo arquitectónico de los primeros monasterios se remonta al de Montecassino (Italia), fundado por San Benito hacia el año 529. Relativamente pronto se estableció un modelo ideal, que se considera fue debatido en un Concilio ${ }^{10}$ propiciado por Carlomagno y reunido en Inden y Aquisgrán en los años 816 y 817 . Uno de los asistentes, el abad Haito de Reichenan, envió un plano con este modelo ideal a su amigo el abad Gozberto, del monasterio suizo de Sankt-Gallen ${ }^{11}$ (San Galo), entonces en la provincia carolingia de Alemanni, en cuya biblioteca fue archivado.

El plano del monasterio recoge una pequeña ciudad religiosa y autosuficiente, organizada en torno a la iglesia abacial y su claustro, que constituyen el centro de la misma. Está orientada según un eje longitudinal este-oeste que señala la dirección de Tierra Santa, con el acceso principal al monasterio situado en el lado oeste de la iglesia. Al sur de ésta se encuentra el claustro, constituido por un gran patio cuadrado porticado, en el que las arcadas se indican por abatimiento ${ }^{12}$. Al este del claustro se encuentra el dormitorio de los monjes, situado sobre el calefactorio o sala caliente de trabajo, directamente conectado con la iglesia para facilitar los rezos de maitines, y con el baño y letrinas situados en el ángulo sudeste. Al sur del claustro, abierto directamente al mismo, se encuentra el refectorio de los monjes, en conexión con la cocina, situada en el ángulo sudoeste. Por último, cerrando el lado occidental del claustro, se encuentra la bodega, con la despensa encima. Alrededor de este gran núcleo central se sitúan las numerosas dependencias complementarias del monasterio, destinadas a los conversos, viajeros y a otras actividades. En el lado de la entrada principal, en la esquina sudoeste del conjunto, se sitúan los establos destinados al 
ganado, y en la esquina nordeste la posada, reservada a los acompañantes de los señores que acudían al monasterio. Junto a la posada, ocupando el lado norte del conjunto, se sitúan la cervecería, la tahona y la cocina para los huéspedes, la residencia de los visitantes, la escuela exterior y la abadía. Al este se encuentra toda la zona hospitalaria, que incluye en la esquina nordeste un pequeño jardín de plantas medicinales, así como el noviciado y dos capillas, situadas simétricamente. Una está conectada con el hospital, que se organiza alrededor de un claustro, y la otra con el noviciado, también organizado alrededor de otro claustro, simétrico con el anterior. 

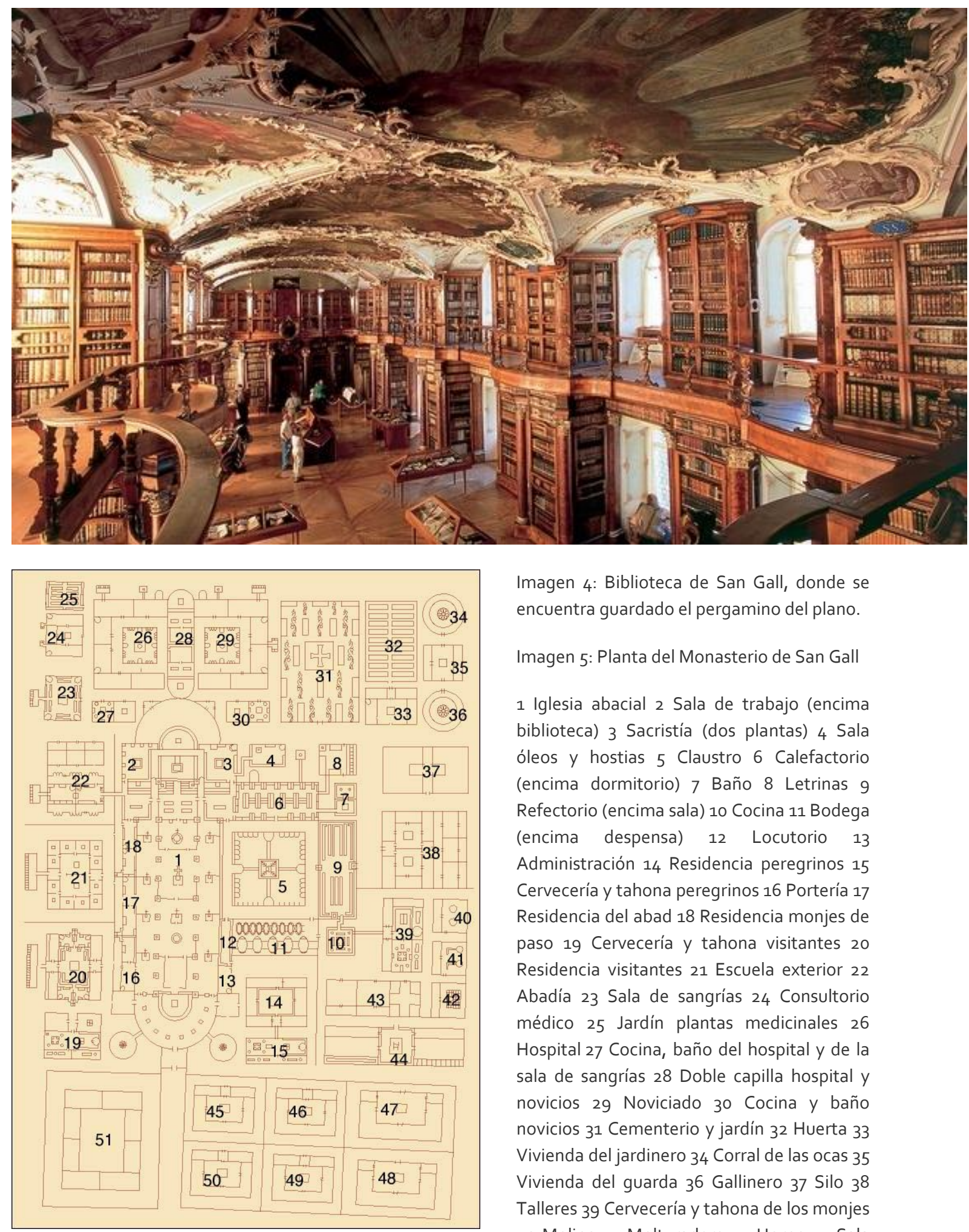

Imagen 4: Biblioteca de San Gall, donde se encuentra guardado el pergamino del plano.

Imagen 5: Planta del Monasterio de San Gall

1 Iglesia abacial 2 Sala de trabajo (encima biblioteca) 3 Sacristía (dos plantas) 4 Sala óleos y hostias 5 Claustro 6 Calefactorio (encima dormitorio) 7 Baño 8 Letrinas 9 Refectorio (encima sala) 10 Cocina 11 Bodega (encima despensa) 12 Locutorio 13 Administración 14 Residencia peregrinos 15 Cervecería y tahona peregrinos 16 Portería 17 Residencia del abad 18 Residencia monjes de paso 19 Cervecería y tahona visitantes 20 Residencia visitantes 21 Escuela exterior 22 Abadía 23 Sala de sangrías 24 Consultorio médico 25 Jardín plantas medicinales 26 Hospital 27 Cocina, baño del hospital y de la sala de sangrías 28 Doble capilla hospital y novicios 29 Noviciado 30 Cocina y baño novicios 31 Cementerio y jardín 32 Huerta 33 Vivienda del jardinero 34 Corral de las ocas 35 Vivienda del guarda 36 Gallinero 37 Silo 38 Talleres 39 Cervecería y tahona de los monjes 40 Molino 41 Molturadero 42 Horno 43 Sala de grano y tonelería 44 Establo bueyes y caballos 45 Aprisco ovejas 46 Aprisco cabras 47 Vaquería 48 Sementales 49 Cochiqueras 50 Alojamiento criados 51 Alojamiento compañeros de viaje de los señores 


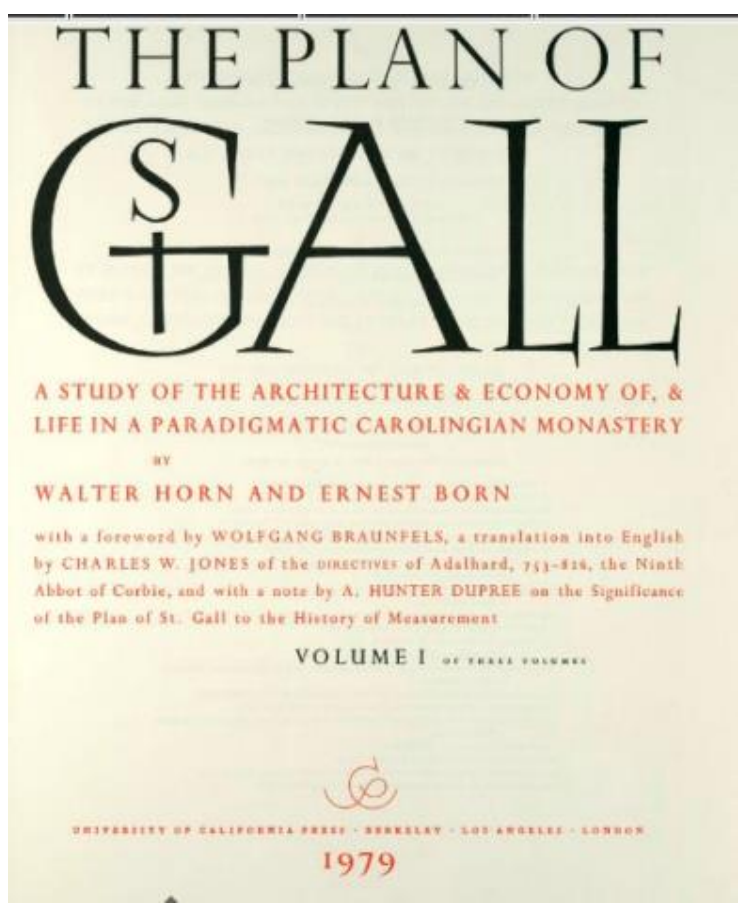

Imagen 6: Contraportada del libro sobre San Gall de Walter Horn y Ernst Borm

Imagen 7: Pergamino de la Abadía de san Gall.

Actualmente se encuantra en la Biblioteca de San Gall Orientación Norte-Sur

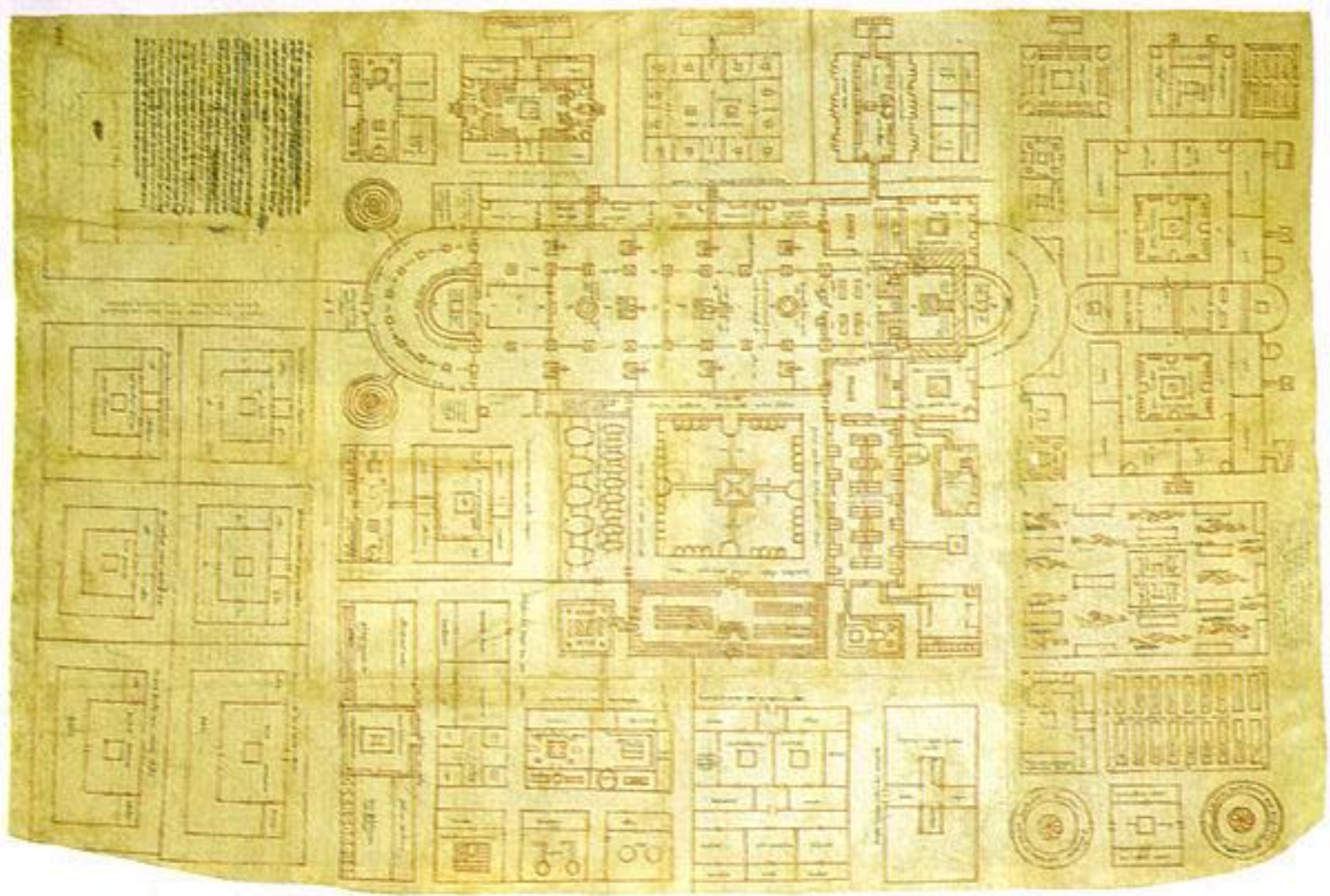


Este plano se conserva en un pergamino en la biblioteca de la Abadía de esta localidad suiza y cuenta con unas medidas de $77 \times 112 \mathrm{~cm}^{13}$. Se considera parte de los documentos primordiales para el estudio del que es uno de los ejemplos más relevantes de la arquitectura carolingia. Su constitución como documento se cree que es de esta época, es atribuido a Eginaldo ${ }^{14}$, el famoso biógrafo del Emperador Carlomagno, y fechado en torno al año 830. El plano constituye un documento extraordinario, no sólo por ser el primer dibujo que se conserva de un monasterio, sino también por ser el plano de arquitectura más antiguo que se conoce de la Alta Edad Media. A partir de este monasterio, su organización interna y la transmisión de conocimiento en él llevada se crea un caldo de cultivo y con el tiempo se irían asentando a su alrededor construcciones hasta llegar a formar una pequeña ciudad.

La cronología de San Gall se detalla como sigue: fue fundada como una ermita por San Gall el año 613 a orillas del río Steinach, a muy poca distancia de Zúrich; tras su muerte en 646 , donde estaba la ermita del santo se levantó una capilla. Carlos Martel (mayordomo del rey de Francia) nombró a un sacerdote, San Otmaro, custodio de las reliquias, quien edificará en 719 una abadía en el mismo lugar siendo su primer abad. En el siglo VIII se creó la escuela de San Gall en su seno, que le daría notoriedad al desarrollarse en ella las artes, las letras y las ciencias, creándose una importante biblioteca con el abad Waldo de Reichenau, considerada la más importante del medievo. Desde el siglo $X$ se encontró rodeada de una ciudad, del mismo nombre, San Gallo. En el siglo XIII los abades regían la abadía y la ciudad como soberanos de un principado independiente, la Abadía Imperial de San Gall , y adoptaron el título de príncipes del Sacro Imperio Romano, será Ulrico VI, en 1204, el primero en ostentar esa dignidad. Se tiene aquí el primer ejemplo de ciudad creada a partir de un monasterio "transmisor de conocimiento", en el cual residían los estudiantes. En este modelo monacal se puede decir que universidad y residencia comparten un mismo espacio.

De la lectura de la planta de este monasterio se deduce que una de sus piezas más sobresalientes es el cuerpo localizado junto a la cabecera de la iglesia, el cual alberga a la biblioteca en planta alta y, la zona de escritorio en planta baja ${ }^{9}$. La consecuencia de esta estructuración es que la citada biblioteca pasa desde entonces a ser parte intrínsecamente vinculada a los monasterios. Desde el punto de vista espacial habitable, el componente más importante del monasterio fue de forma indiscutida el claustro, posiblemente el espacio-tipo más prolífico que ha aportado la historia de la universidad. ${ }^{16}$

El claustro puede ser considerado el espacio de conexión que uniría los establecimientos monacales con la futura universidad. A lo largo de los años, las instituciones monacales fueron multiplicándose en el territorio. Su naturaleza funcional y arquitectónica sentaría las bases 
de las estructuras físicas que sirvieron como cuerpo edificado a las nacientes Universidades.

Las construcciones se organizaban alrededor de la gran iglesia abacial, diseñada con planta basilical, dos ábsides y dos torres a los pies. En el lado sur se ubicaba el claustro, centro de la vida religiosa.

El espacio donde dormían los monjes residentes era una larga sala, en la parte superior de la nave (torre del crucero), en un primer piso con el fin de evitar humedades. Normalmente, tenía en un extremo el acceso al transepto de la iglesia por la escalera de maitines y en el extremo opuesto el acceso a las letrinas, en el suelo, y por un sencillo hueco se accedía a la escalera del claustro.

Así pues, el espacio de estudio y de residencia están fundidos en uno solo en este modelo monacal, con el paso del tiempo evolucionarán por separado hacia universidad y residencia de estudiantes.

Antes de que se constituyeran los Estados europeos modernos, los estudiantes migraban por Europa en busca de la universidad de su interés. Allí empezaron a ser acogidos en hospicios llamados colegios, creados para dar albergue a los estudiantes. Ya en el siglo XIII había becas para estudiantes. Esos colegios estaban tutelados por maestros. En este movimiento migratorio por las ciudades europeas medievales es donde se encuentra el origen de la residencia universitaria.

Los centros universitarios se sucedieron en las principales ciudades europeas de la época. En cada una de ellas fue dando fruto en forma de universidad a medida que el conocimiento salía de las escuelas monacales a su encuentro con la sociedad.

La primera universidad europea apareció en el año 1088 en Bolonia, Italia. La fundación de la Universidad de Bolonia coincidió con la renovación del interés por el derecho romano, sobre todo por el redescubrimiento del Código de Derecho Civil de Justiniano. En el siglo XII un gran maestro como Irnerio ${ }^{17}$ (1088-1125) podía atraer a estudiantes de toda Europa. La mayoría de ellos eran seglares, a menudo individuos de edad que desempeñaban funciones de administradores de los reyes y príncipes, y estaban deseosos de aprender más sobre derecho para aplicar sus conocimientos en sus profesiones. Para protegerse, los estudiantes de Bolonia formaron un gremio, o universitas, que el emperador Federico Barbarroja reconoció y al cual le dio una cédula en 1158. Aunque el cuerpo docente también se organizó como grupo, la universitas de estudiantes de Bolonia tuvo mayor influencia. Obtuvo, por parte de las autoridades locales, una promesa de libertad para los estudiantes, reguló el precio de los libros y del hospedaje y, además, determinó los estudios, las cuotas y el profesionalismo de los maestros. Se multaba a los profesores si faltaban a una clase o comenzaban tarde sus lecciones. La Universidad de Bolonia siguió siendo la mejor escuela de leyes de Europa durante la Edad Media. 


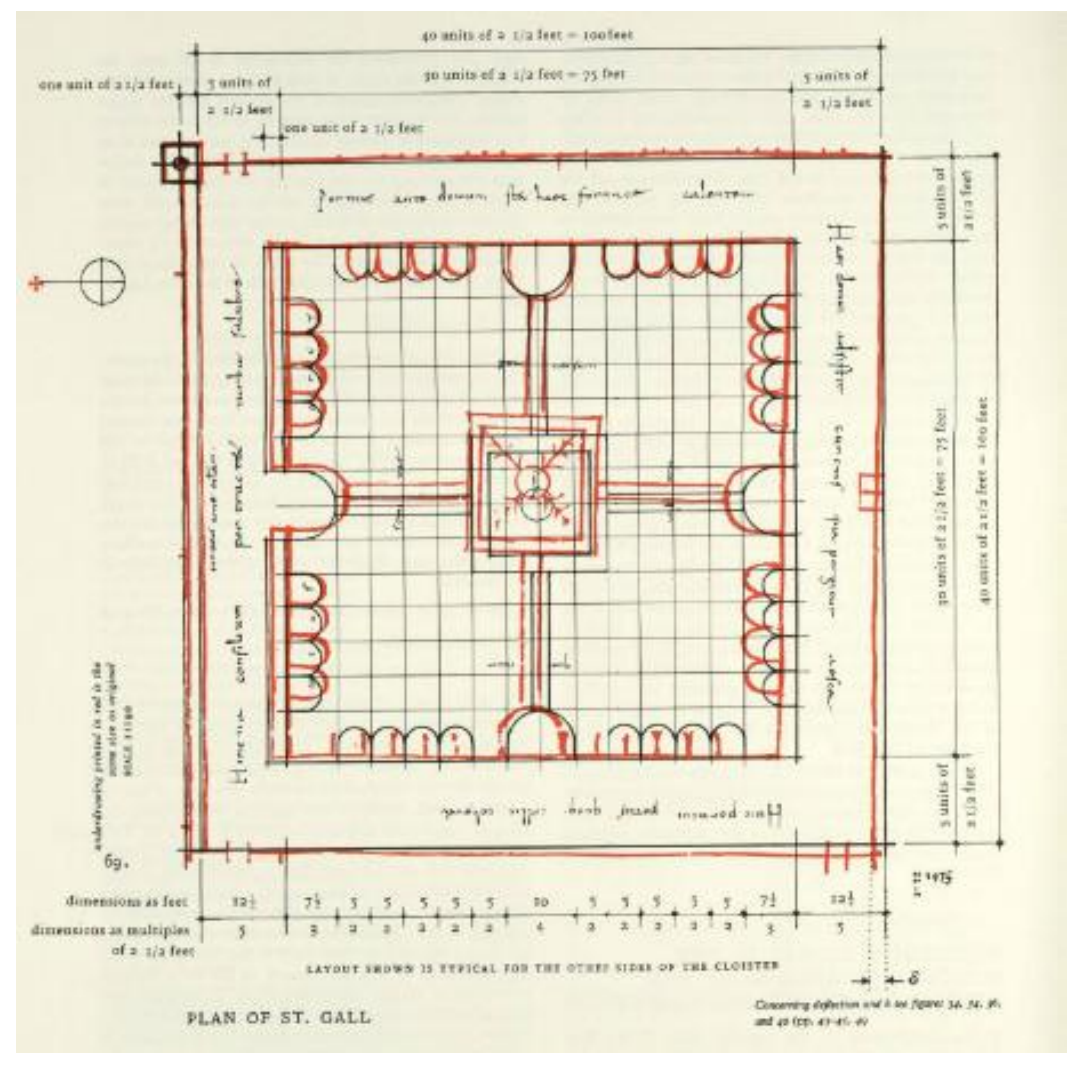

Imagen 8: Croquis del claustro de la Abadía de Saint Gall. Libro de Walter Horn y Ernst Born.

Imagen 9: Vista ideal del Monasterio de San Gall

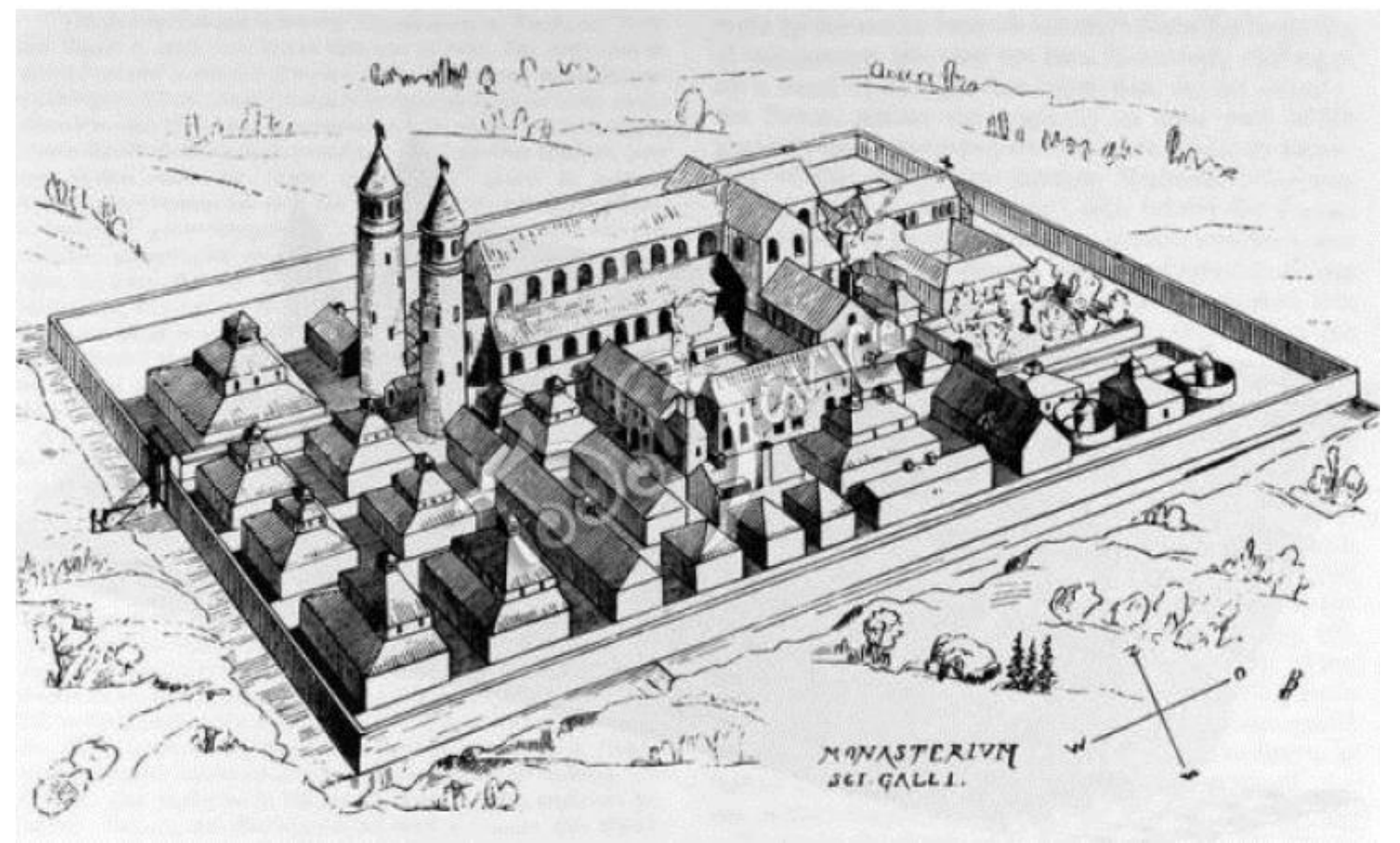


En el norte de Europa, la Universidad de París se convirtió en la primera universidad de prestigio. Varios maestros que habían recibido su licencia para enseñar de la escuela catedralicia de Notre Dame, de París comenzaron a aceptar estudiantes extra por una paga. A finales del siglo XII estos maestros formaron una universitas, o gremio de maestros. En 1200, el rey de Francia Felipe Augusto reconoció de manera oficial la existencia de la Universidad de París. La Universidad de Oxford, en Inglaterra, se organizó según el modelo de Paris, y apareció por primera vez en 1208. Una migración de académicos de Oxford, ocurrida en 1209, condujo a la fundación de la Universidad de Cambridge. En la Alta Edad Media, siglos XIII y XIV, los reyes, papas y príncipes rivalizaron en la fundación de nuevas universidades. A finales de la Edad Media había ochenta universidades en Europa, la mayoría de ellas localizadas en Inglaterra, Francia, Italia y Alemania. Fuera de estas se desarrollaron rápidamente otras, por emigración, o por establecimiento formal.

Como las universidades al principio no poseían edificios con las características que puedan tener los actuales, era bastante frecuente para estudiantes y profesores, que si no les satisfacía un sitio, encontraron acomodo en otro. Los conflictos con el municipio a menudo llevaron a migraciones, especialmente donde alguna ciudad rival ofrecía incentivos: de ahí las secesiones de Bolonia a Vicenza (1204), a Arezzo (1217), a Padua (1222), la "gran dispersión" de París (1229), y la emigración (1209) de Oxford a Cambridge. Aunque también actuaron causas de naturaleza menos tumultuosa.

Siguiendo esta línea de investigación, cronológica y de clasificación, se irá describiendo el surgir de los edificios residenciales ligados a la Universidad para posteriormente estudiar sus tipologías y facetas.

En términos generales se puede hablar de la aparición y desarrollo de las universidades medievales, del siguiente modo:

El acontecimiento crucial fue la creación de Bolonia y París, como se acaba de comentar, las más famosas hasta finales de la Edad Media, y que sirvieron de modelo, cada una con su peculiar organización, a las demás universidades. La universidad de Bolonia, reivindicada como la más antigua de Europa -últimos años del siglo XII, hacia 1180- seguía una larga tradición de escuelas privadas de leyes que al menos se remontaba a la segunda mitad del siglo XI. Su nacimiento está ligado a la temprana renovación de la vida urbana en la Italia del norte junto con el renacer del derecho escrito en un contexto de confrontación política entre el papado y el imperio.

La universidad de París, como también se acaba de citar, originada poco después de la de Bolonia, nació en otras circunstancias bastante diferentes. Su origen se remonta a escuelas previas que funcionaban en la ciudad desde finales del siglo XI. Por un lado estaban las escuelas eclesiásticas tradicionales, la principal fue la catedralicia de Notre-Dame, sobre todo de teología. Estuvo regida 
en la segunda mitad del siglo XII por famosos maestros como Pedro Lombardo o Pedro Comestor, que también compusieron famosos manuales de teología que se estudiarían hasta finales de la Edad Media. Pero, por otro lado, estaban una serie de escuelas privadas abiertas desde el 1150 por maestros independientes aunque necesitaban una "licencia para enseñar" del canciller de Notre Dame, y en las que se impartía sobre todo dialéctica, pero también gramática, derecho y medicina.

Estas escuelas proliferaron a finales del siglo y atraían estudiantes de lugares muy distintos, creando muchos problemas de alojamiento y de orden público, pero también institucionales (pugnas con el canciller y el obispo) intelectuales (desarrollo de disciplinas lucrativas como el derecho o proliferación de traducciones de Aristóteles).

Otras universidades tempranas fueron, por ejemplo, la universidad de Medicina de Montpellier, fundada hacia el 1220 (algo que no llegó a ser Salermo), que estaba bajo la autoridad de la Iglesia y, la mencionada en el párrafo anterior, Oxford, que sólo tendría como precedentes establecimientos eclesiásticos diferentes en la ciudad junto con escuelas en funcionamiento desde mediados del siglo XII; aparte de la importante influencia que tuvo de la universidad de París. Ya en 1200 había en Oxford una embrionaria organización universitaria, aunque hasta 1214 no se conceden los primeros estatutos papales, complementados con cédulas reales (con sus instituciones de canciller, procuradores de las naciones, "congregaciones" de maestros, etc.), independizándose, por tanto, de las autoridades locales tanto civiles como eclesiásticas.

Las dos principales maneras de fundar una universidad en la Edad Media, además de las ya vistas (Bolonia y París) era el llamado "enjambrado" o bien el establecimiento de tal institución por la decisión de un autoridad eclesiástica o civil. El enjambrado consistía en que un grupo de maestros y estudiantes dejaban su universidad de origen, normalmente a causa de una disputa con las autoridades locales, estableciéndose en una nueva ciudad donde creaban una nueva universidad. Por regla general, estas migraciones de maestros y estudiantes e incluso la creación de la universidad era algo provisional, hasta que se resolvía la disputa que había provocado su marcha. Lo normal era que al cabo de un tiempo, más o menos largo, volvieran a la universidad de origen. Pero en ocasiones esto no sucedía y el grupo de estudiantes y maestros se instalaba definitivamente en su nueva universidad, sobre todo si las condiciones resultaban ser favorables.

El ejemplo eminente es aquí el de Cambridge. Un grupo de maestros y estudiantes de Oxford huyeron de esta ciudad entre 1209 y 1214 a raíz del arresto y ejecución de algunos estudiantes por orden del mayor y del rey, y fundó allí la nueva universidad. En el norte de Italia fue donde hubo más ejemplos en esta época la primera mitad del siglo XII, migraciones de estudiantes entre ciudades-estado rivales, 
como las fundaciones de Vicenza (1204), Arezzo (1215), Vercelli (1228), Siena (1246), aunque en muchos casos ninguna deestas nuevas fundaciones universitarias subsistió largo tiempo. Sin embargo, una secesión de la universidad de Bolonia dio lugar a una universidad importante y duradera, la de Padua en 1222.

Como ya se ha comentado, otra forma de fundar una universidad provenía de decisiones directas de las autoridades civiles o eclesiásticas. Por ejemplo, la universidad de Nápoles de 1224, por el Emperador Federico II para competir con la de Bolonia y para preparar a los jueces y juristas que necesitaba en su administración imperial. Es el caso también en Francia de la universidad de Toulouse (1229) que, en principio, pretendió ser una universidad religiosa y proselitista para luchar contra las herejías del sur de Francia, como la de los cátaros, aunque luego siguió más por el camino jurídico. Y habría que citar también la universidad que el Papa Inocencio IV creó en la propia curia romana en 1245 . No obstante, fue sin duda en la Península Ibérica donde, en el siglo XIII, las autoridades políticas interfirieron más directamente en el desarrollo de las universidades. La primera universidad española, Palencia, fue creada en 1208 por Alfonso VIII de Castilla a partir de la escuela catedralicia de esta ciudad, y confirmada por una bula papal en 1220. Pero su existencia fue efímera, el studium donde se enseñaban artes liberales y teología dejó de existir hacia 1250. Entretanto, en el invierno de 1218-1219, Alfonso IX de León había fundado una universidad en Salamanca, que tuvo privilegios reales en 1254, ratificados por una bula papal en 1255 y reiterados en Las Siete Partidas de Alfonso X el Sabio, en tomo a 126o. Otros casos de este tipo son el de Valladolid o el de la universidad de Lisboa, fundada por Denis rey de Portugal y ciertos dignatarios eclesiásticos; ambos casos en la segunda mitad del siglo XIII. Hubo otros ejemplos malogrados como Sevilla, fundada en 1254 por Alfonso X el Sabio y Alcalá de Henares, fundada por Sancho IV en 1293; pero no salieron adelante en esa época.

Antes de 1300 había dieciocho studia generalia repartidos por Europa, de los cuales unos quince estaban funcionando activamente en esta fecha. Algunos de ellos habían atraído a miles de estudiantes de muy variado origen y continuarían siendo las grandes universidades hasta el fin de la Edad Media.

Bolonia, París, Oxford, Cambridge, Salamanca, Valladolid y Alcalá de Henares marcan el camino inicial de la presente investigación. 
56| PRECEDENTES ARQUITECTÓNICOS 


\section{EL ORIGEN DE LAS RESIDENCIAS UNIVERSITARIAS \\ De las principales ciudades europeas a la Península Ibérica}

Con el ya mencionado despertar del mundo urbano durante el siglo XIII, algunos de los lugares que crecían debieron su expansión al desarrollo de una actividad o causa determinada que les llevó a denominarlos y adjetivarlos. Mayoritariamente hablamos de ciudades conventuales, ciudades mercantiles o portuarias, pero también se originaron las primeras ciudades con Universidad, que progresaron y se articularon en su desarrollo urbanístico en torno a un Estudio General o Particular, cuyos maestros, alumnos y sus necesidades, dieron su configuración al núcleo urbano. El rey Alfonso $X$ "El Sabio" definía estos Estudios como "ayuntamiento de maestros et de escolares, que es fecho en algunt logar, con voluntad e con entendimiento de aprender los saberes ${ }^{\prime \prime 18}$.

Ese lugar debía tener unas características determinadas que, como se sabe, no siempre se cumplían. Debía ser saludable, con buen clima, buen aire y buen agua, barato y además reunir las condiciones necesarias para favorecer y no distraer del estudio.

La creación de universidades generó el movimiento de estudiantes hacia sus emplazamientos. Estos estudiantes que venían de lejos se agrupaban según su nacionalidad de origen, y solían hospedarse en las mismas casas llamadas "hospitia" que luego dieron lugar a los colegios universitarios. Los hospitia o residencias de estudiantes fueron promovidas por entidades privadas (mecenas, órdenes religiosas, etc.) para facilitar los estudios a los alumnos con bajos recursos. Con el tiempo, muchos de ellos se desviaron de las intenciones fundacionales y fueron dando cabida a grupos privilegiados y oligarquías de letrados. En algunos casos, en los hospitia convivían maestros y estudiantes.

Estos centros, además de prestar servicio de alojamiento y comida, se convirtieron en el complemento ideal de la Universidad con numerosas actividades académicas y sociales.

Los privilegios disfrutados por los primeros universitarios condujeron a otras ciudades a buscar similares ventajas para mantener en ellas a sus propios estudiantes, y atraer posiblemente a forasteros, aumentando de ese modo la prosperidad y el prestigio locales. Bolonia y París sirvieron como modelos de la nueva organización, y los deseados privilegios se buscaban ante el Papa o el gobernante civil. Se hizo, de hecho, habitual en las cartas papales incluir una fórmula prefijada concediendo a la nueva universidad "los mismos privilegios, inmunidades, y libertades que se disfrutaban por los maestros y escolares de París" o Bolonia; así Oxford, Cambridge, St. Andrews, y Aberdeen fueron en gran medida modeladas sobre París y Glasgow sobre Bolonia. El modelo parisino fue también reproducido en las primeras universidades de la actual República Checa en Praga; de Austria en Viena y de las ciudades alemanas 
Erfurt, y Heidelberg; pero éstas pronto comenzaron a separarse del original; también el modelo parisino tuvo una gran repercusión en Sudamérica. Los colegios estaban bajo control de la universidad, que mantenía la enseñanza en sus manos.

Aunque las primeras universidades surgen en la península de forma más concreta en la Edad Media, como es el caso de Palencia ${ }^{18}$, la mayor parte aparecieron en el siglo XVI, su época de esplendor, y con ellas las ciudades universitarias. Estas supusieron el destino de numerosos varones jóvenes, que tarde o temprano abandonaban sus casas y pueblos y se dirigían a los lugares donde podían seguir estudios de gramática latina y sobre todo "oir Facultad", expresión al uso en la época Moderna. Para entender mejor el peso que una Universidad tuvo en estas ciudades se van a analizar los rasgos característicos que muestren el nexo de unión entre ambas. Durante este periodo emergieron dos sistemas residenciales básicos (fruto de lo anteriormente descrito) que tendrán un gran impacto en los futuros modelos de América, Inglaterra y Alemania.

Un sistema es la construcción de colegio de nueva planta, y el otro la adaptación de edificio existente a usos residenciales universitarios.

La impronta de la universidad en el ámbito urbano tuvo una relación directa entre el número de escolares que poblaban sus aulas y en consecuencia la ciudad, y el censo que ésta tenía regularmente. Quiénes y cuántos poblaban estos lugares en los que se fundaba y funcionaba un Estudio General ${ }^{19}$ son preguntas que hemos de contestar si queremos valorar su peso en la vida urbana. Si por lo general tomamos como referencia la plétora estudiantil para dar realce a las universidades, ellas mismas se medían y se miden por su demanda es decir por su número de matriculados, igualmente hemos de proceder para valorar su peso en la villa o ciudad en la que se instalan. Las más altas cifras de matriculados las encontramos en las tres Universidades Mayores de Castilla, con estimaciones muy superiores a las del resto de la península, por lo que se consideran las ciudades universitarias por excelencia. Alcalá tenía ya 2.056 matriculados en el curso de 1548-49, llegó a los 3.887 en el 1589-90, e inició un agudizado descenso, pues terminó el siglo con $1.846^{14}$. Salamanca se movió entre los 5.000 y los 7.000 en el siglo XVI, pero tras la Guerra de Sucesión (1714-15) contaba solo con 1.547. Valladolid, que en el curso 1588-89 tenía 931 estudiantes, alcanzó en torno a la segunda década del siglo XVII su máximo número, contando en el curso 1616 con 1610 alumnos. Estas cifras fueron en descenso. En 1695 solo hay 980 matriculados, y el siglo XVIII comienza con 430. A partir de entonces, la Guerra de Sucesión, llevó a una crisis mayor de la que no supo salir hasta la Reforma Carolina, momento en el que el mayor celo en el sistema de registros permite volver a alcanzar los valores de comienzos de la centuria anterior ${ }^{20}$. 
En Valladolid, a finales de la Edad Moderna, de una población de 20.000 unos 2.000 eran universitarios, lo que nos coloca en cifras en torno a un $10 \%$ de los habitantes de población flotante estudiantil, que suponía una dinamización suficiente para remover los intereses económicos de la ciudad y generar un determinado sector servicios, que en estas localidades crecía significativamente. Bien es verdad que esta ciudad no fue solo universitaria, como lo fueron Salamanca y Alcalá, pues contaba también con la Real Chancillería y de ella vivían en 1519 entre 2.000 y 3.000 personas contando no sólo con los hombres de leyes, los subalternos y los pleiteantes, sino con los comerciantes, artesanos de industrias ligeras, y posaderos, mesoneros, alojeros y criados $^{21}$.

La mayor parte de los escolares matriculados en una ciudad no eran originarios ni residentes en ella. Son muchos los que se desplazan demandando un Estudio donde cursar y graduarse para convertirse en hombres de letras y gracias a ello, procurarse no solo un sustento sino un esperado ascenso social. Con anterioridad, éste sólo podía llegar de la mano de las armas pero a partir del Renacimiento y la aparición de las Monarquías Modernas, también lo permitían las letras. En esta búsqueda priman distintos criterios tales como la cercanía de sus residencias a la localidad universitaria o el coste de las matrículas pero, sobre todo, el de los grados que constituían el mayor desembolso, principalmente si hablamos de los mayores de licenciado y doctor. Todo ello generaba por lo común un desplazamiento que a veces se iniciaba hacia colegios o conventos de distintas órdenes religiosas, donde también se impartía docencia, al menos en las Facultades de Artes o Teología, para después culminar en una universidad con capacidad de graduar. En otras ocasiones se empezaba la vida académica en la universidad cercana 0 en una de las Mayores ${ }^{22}$ y, finalmente, se buscaba otra donde conseguir un grado que no fuera muy costoso. Esto explica que los grados mayores fueran más restringidos, proporcionalmente, en Alcalá, Salamanca y Valladolid que en otras menores. Estas prácticas implican una "peregrinación académica", que sin embargo no siempre representa una residencia en la ciudad universitaria correspondiente. Graduarse podía suponer solo un desplazamiento. Cursar en una Facultad una permanencia, eran estancias más o menos largas y los escolares se tenían que buscar un aposento para no sólo pernoctar sino estudiar en sus cuartos. Estas necesidades son tenidas en cuenta por las universidades por el deseo de que sean favorecedoras del estudio al que se deben dedicar. Por ello con frecuencia recogen en sus Constituciones características de este tipo de hospedaje, o al menos, las limitaciones que en este sentido se debían tener. En otras ocasiones, disposiciones rectorales o acuerdos claustrales son las vías por las que se van definiendo las posibilidades para un escolar. Así, muchos de estos recintos que acogían a escolares estuvieron sujetos a revisión y vigilancia por parte de las universidades $^{23}$, incluso se elaboraban unos libros de Visitas de Posadas que reflejan la existencia de esa práctica como algo regular. 
En torno a las universidades se desarrollaron tipos de alojamiento universitario específico como fueron los colegios. De hecho, en algunas universidades estos fueron el verdadero origen y sustento de los Estudios. Alcalá es el paradigma de los colegios-universidad, pero no es la única. A su sombra proliferaron otras, a lo largo del siglo XVI, como fueron Oviedo, Sevilla, Osma, etc.

Seis colegios Mayores (cuatro en Salamanca, uno en Alcalá y otro en Valladolid) tuvo la monarquía hispánica donde se alojaron un número escaso de universitarios que, entre todos, no siempre alcanzaba las dos centenas. Aunque estos centros no son conocidos ni reconocidos por sus estancias y condiciones de alojamiento, que sin duda fueron buenas, sino por constituirse en centros de poder. Otros muchos colegios menores ${ }^{24}$ surgieron en torno a todo tipo de universidades. Nada menos que 28 se abrieron para los escolares salmantinos ${ }^{25}$. Éstos siguieron el modelo de los mayores en cuanto a formas de hospedaje se refiere, proporcionando alojamiento, abastecimiento, asistencia espiritual y académica. Algunos de ellos disponían de completas e interesantes bibliotecas que no tenían sus universidades, como es el caso del Mayor de Santa Cruz con respecto a la Universidad de Valladolid ${ }^{26}$.

Pero los colegios - de todo tipo- fueron una parte minoritaria del hospedaje estudiantil. Como se señala en El Estudiante instruido, del jesuita Juan de Paz, "La liviandad de costumbres de la mayor parte de nuestros estudiantes que no viven en seminarios bien reglados, viene de su libertad en las casas de posada" ${ }^{27}$. Porque no todo estudiante disponía de una beca colegial. Los colegios tenían un número variable de plazas que recibían el nombre de becas. El manteísta, se debía procurar un acomodo según sus posibilidades y sus gustos. Unos pocos tenían rentas suficientes para buscarse una casa propia con personal de servicio. Otros conseguían también casa, pero compartida; otros con una dependencia, en solitario o acompañados tenían suficiente; y no pocos servían para tener casa y cama $^{28}$.

Si nos fijamos en el ámbito académico, los pupilajes supusieron el seguimiento del estudio por un graduado (llamado también "maestro de pupilos" o "mayordomo de estudiantes") y, en el caso salmantino, además la concentración en cada casa de matriculados solo en la misma Facultad ${ }^{29}$. En esta ciudad, entre 1560 y 1630 , raramente el número de pupilajes que visitó la Universidad superó los quince $y$, entre todos ellos, acogerían únicamente un centenar de pupilos, pues era normal que el número de integrantes oscilara entre dos y veinte, de quince a veintitrés años ${ }^{30}$. En la visita que efectuó Obando $^{31}(1564-66)$ a la Universidad de Alcalá se pregunta por quiénes tienen en sus casas "pupilos o porcionistas" y resultan ser bastante numerosos, unos treinta y tres, entre los que curiosamente figuran catedráticos de Gramática latina, Griego y Retórica. 
Cuando la elección para pasar el curso escolar o al menos unos cuantos meses necesarios para "ganar curso", eran las posadas abiertas a los escolares, no mesones ni ventas, sabemos que, en teoría, estas debían tener especiales condiciones, siempre pensando en que facilitasen el estudio a sus huéspedes. Por ello, al menos en Valladolid, el rector exigía que las que acogiesen a estudiantes debían cerrar sus puertas a otro tipo de residentes fueran litigantes, soldados, etc. Tal limitación no siempre fue del agrado de los posaderos y por tanto no siempre se respetó, pero como al comienzo del curso se elaboraba una lista con las posadas universitarias, el dueño del establecimiento sabía que en cualquier momento podía verse sorprendido por una visita rectoral de inspección. Si no la superaba satisfactoriamente se le impediría alojar matriculados. Este era el requisito fundamental, no entrando la Universidad pinciana ${ }^{32}$ en este caso a controlar otro tipo de condiciones del alojamiento, salvo la cuestión de los horarios. Durante la noche, de diez de la noche a seis de la mañana los jóvenes debían permanecer en sus aposentos, sin acoger mujeres, sin hacer bailes, sin jugar a los naipes ni demasiado tiempo ni demasiado dinero, con tranquilidad, pues en esas horas era cuando el rector acostumbraba a hacer su ronda con otros ministros de la universidad y podía hacerle responsable al posadero de las ausencias de sus huéspedes. Es más, se les pedía incluso que no dieran llaves a los jóvenes para que pudiera franquear la puerta al regreso de las salidas nocturnas.

Esta es la cédula que se daba a firmar a los posaderos de la ciudad del Pisuerga:

"Por la presente damos licencia a ..., para que pueda tener en su posada estudiantes, graduados, académicos, cursantes y matriculados en esta real Universidad por espacio de, contado desde el día de San Lucas de este presente año con las condiciones siguientes: ...

Que el día primero de noviembre haya de entregar al Sr. Rector que fuese una memoria o nómina de los estudiantes que tiene en su posada, su nombre, patria y Facultad donde estudia, dando aviso en caso de que alguno se vaya a otra posada o se ausente de esta ciudad.

En cuya conformidad damos dicha licencia bajo de el apercibimiento de que si se tuviese noticia que en la referida posada se cometen alguno de los presupuestos excesos, según va expresado, sin más justificación que la de no haber dado cuenta el dueño de la posada, se le privará absolutamente de esta licencia que ahora se le concede, y se le sacarán veinte ducados aplicados a disposición del Sr. Rector que fuese" 3 .

Aunque el reglamento sobre las posadas tuviese unas peculiaridades según la universidad, en general fue una transposición de lo dispuesto para la Universidad de Salamanca ${ }^{34}$, que como en tantas 
otras materias de la vida académica y universitaria proyectó su legislación y costumbres al resto de las universidades de la monarquía hispánica durante la edad moderna.

En general, los posaderos debían ser posaderos y no posaderas, tener buena fama y estar dispuestos a someterse a los dictámenes de la autoridad académica. Sin embargo, al margen de las disposiciones, las posadas fueron abiertas muchas veces por mujeres que no podían hacer el papel de maestro de pupilos, pues eran generalmente analfabetas. Además, su trato con ellas, si era bueno, pudo ir de la relación casi materno-filial, a la personal, sentimental e incluso sexual. Si se producía un trato que llegaba a causar escándalo público la posadera podía perder su negocio, se le cerraba la casa y con ello frecuentemente su único modo de vida; mientras que el escolar recibía una sanción leve que no le impediría seguir con sus estudios.

También era posible que se les exigiese que solo admitiesen en su casa a universitarios, puesto que así, sin ser un colegio todos estaban dedicados al estudio. A cambio, en Valladolid sí por alojar estudiantes se vinculaban a la universidad podían contar con una serie de privilegios como verse exentos de alojar soldados, o en caso de necesidad, por no molestar a sus inquilinos en su trabajo, tener prioridad a la hora de alquilar frente a otro que no fuera a hospedar escolares o incluso aunque sirviese para vivir él mismo. Y, por el contrario, en Salamanca la universidad temía los alquileres estudiantiles en sus propiedades, pues decía hacían tantos destrozos como el temido gremio de los impresores.

Las gobernaciones, las repúblicas de estudiantes y los camaristas son otras fórmulas de hospedaje estudiantil, muchas veces con imprecisos límites a la hora de su definición. Las repúblicas eran "la aristocracia del hambre... quien solos o en grupo montaban casa y a su frente ponían una mujer"127. Aunque se estima que las gobernaciones son sistemas similares, pues son casas que alquilaba uno solo o en grupo, buscando entre ellos la manera de organizar la intendencia, limpieza, etc. a través de la contratación de personas. En el siglo XVII se había constituido ya en la tipología ideal de alojamiento ${ }^{35}$. Por su parte el camarista es visto como "el que no tiene casa por sí, ni tiene compañía con otro, sino tan sólo alquilada una cámara en alguna posada donde tiene su cama y se encierra en ella, sin tener trato con los demás de la casa" ${ }^{136}$. Estos últimos ni siquiera comían en la vivienda sino que salían a tabernas y mesones para cubrir estas necesidades.

En esta variada tipología de alojamientos el huésped no solía contar con dependencias privadas, compartiendo habitación e incluso cama con otros inquilinos, con frecuencia también estudiantes, pero no siempre. El concepto de intimidad es burgués, posterior, y por tanto 
hemos de imaginar una vida compartida con colegas, que no siempre estuvo exenta de problemas.

El número de estas instituciones continuaría aumentando a lo largo de los siguientes siglos. Los estudiantes y sus profesores necesitaban alojamiento y un lugar donde impartir las lecciones, pues la mayoría tenían sus hogares de procedencia lejos y el lugar de reunión del docente con sus alumnos era imprescindible para la enseñanza.

En esta época, no existía una arquitectura universitaria, ya que los docentes y los estudiantes cubrían sus necesidades de espacio en edificios que no habían sido construidos con tal propósito, como albergues, casas, conventos u otras instalaciones. Más tarde, cuando las instituciones adquirieran rango $y$ prestigio $o$ quisieran aparentarlo, surgirán afanes de representación para las sedes universitarias que afianzarían su posición en el paisaje urbano con edificios de aspiración monumental y ubicación escogida. La ciudad es, en todo caso, el ámbito de la enseñanza universitaria pues estudiantes y profesores se desplazan desde una sede a otra ya fuera un convento, una vivienda, o un edificio público o privado y la arquitectura para la docencia y el hospedaje se introdujo en el tejido urbano, poco a poco, adaptando o creando los distintos modelos, objeto de esta Tesis.

Desde el siglo XIII se advertía la necesidad de un espacio y un ambiente adecuado para la formación universitaria. Boncompagno da Signa en su Rethorica Novissima (1235) propuso un centro de enseñanza universitaria que debía superar el incómodo entorno familiar. Tras años de enseñanza en el ars dictandi, en el Estudio Bolonés, Boncopagno reclamaba un lugar salubre, apartado de la asiduidad de las mujeres, del alboroto del mercado y de cualquier otro ruido; con proporciones equilibradas en longitud $y$ envergadura, con ventanas suficientes para iluminar las estancias $y$ contemplar una vista amena; en suma, una arquitectura tan austera como práctica, sin ningún tipo de imagen que pueda distraer a los estudiantes salvo aquellas que sirven a la memoria y puedan, de alguna manera, ejercitar el intelecto. Tales exigencias no eran muy distintas de las que expuso Alfonso $\mathrm{X}$ el Sabio en las Partidas, unas décadas después, aunque seguramente no preveía la construcción de una sede propia para las universidades de sus reinos. El lugar debía ser salubre y grato para maestros y alumnos, abundante en pan, vino y buenas posadas "en que puedan morar et pasar su tiempo sin gran costa", con establecimientos de estacionarios que proporcionaran los libros a profesores y estudiantes. Convenía que las escuelas estuvieran fuera de las villas. Las posadas de los 
estudiantes debían alquilarse y convenía que estuvieran próximas a la universidad $^{37}$.

Las necesidades, pues, estaban claras a los ojos de quienes enseñaban en las universidades y de las autoridades que podían fundarlas pero todavía tardaron en hallar una solución específica arquitectónica. A pesar de que en Europa, durante este siglo XIII, transcurría un periodo de experimentación en todos los órdenes y también en la arquitectura, los esfuerzos de innovación se concentraban entonces en otros frentes como la construcción de las grandes iglesias, las fortificaciones y los conventos de las nuevas órdenes.

La aparición de los colegios resultó el marco institucional adecuado para que, tomara forma arquitectónica, la idea de un edificio concebido ex profeso para el hospedaje y la enseñanza de universitarios. Su origen está ligado al de las propias universidades pues, desde finales del siglo XII aparecen las primeras fundaciones destinadas a alojar y mantener a un número pequeño de estudiantes escogidos según ciertos criterios $^{31}$. Al regular un estilo de vida, orientado hacia la residencia comunitaria y la formación, el colegio propició la aparición de un modelo arquitectónico más formal que los albergues (hospitia, halls, hostels, paedagogiae) donde se hospedaban los estudiantes en muchas ciudades europeas. Sin embargo, al principio la mayoría de los colegios se instalaron en edificios preexistentes hasta que, a mediados del siglo XIV, surgieron las primeras construcciones específicas para la vida universitaria en los, ya nombrados, centros europeos como París, Toulouse, Bolonia y Oxford.

Sin embargo, las ventajas de la fundación de un colegio en un centro universitario convencieron a muchos para llevar a cabo su iniciativa, aun a costa de una gran inversión en adquirir propiedades y construir los edificios necesarios o reformar otros anteriores para una nueva función. Los fundadores mantenían su memoria pública viva en estas instituciones que podían modelar a su antojo, en un acto que combinaba el altruismo con el ejercicio del poder en un centro intelectual, pues aspiraban a obtener beneficios pro anima a la vez que favorecían a un círculo de prójimos o paisanos. Además de hospedar a un número reducido de estudiantes sin medios propios, los colegios contribuirían así a formar una élite de universitarios. 


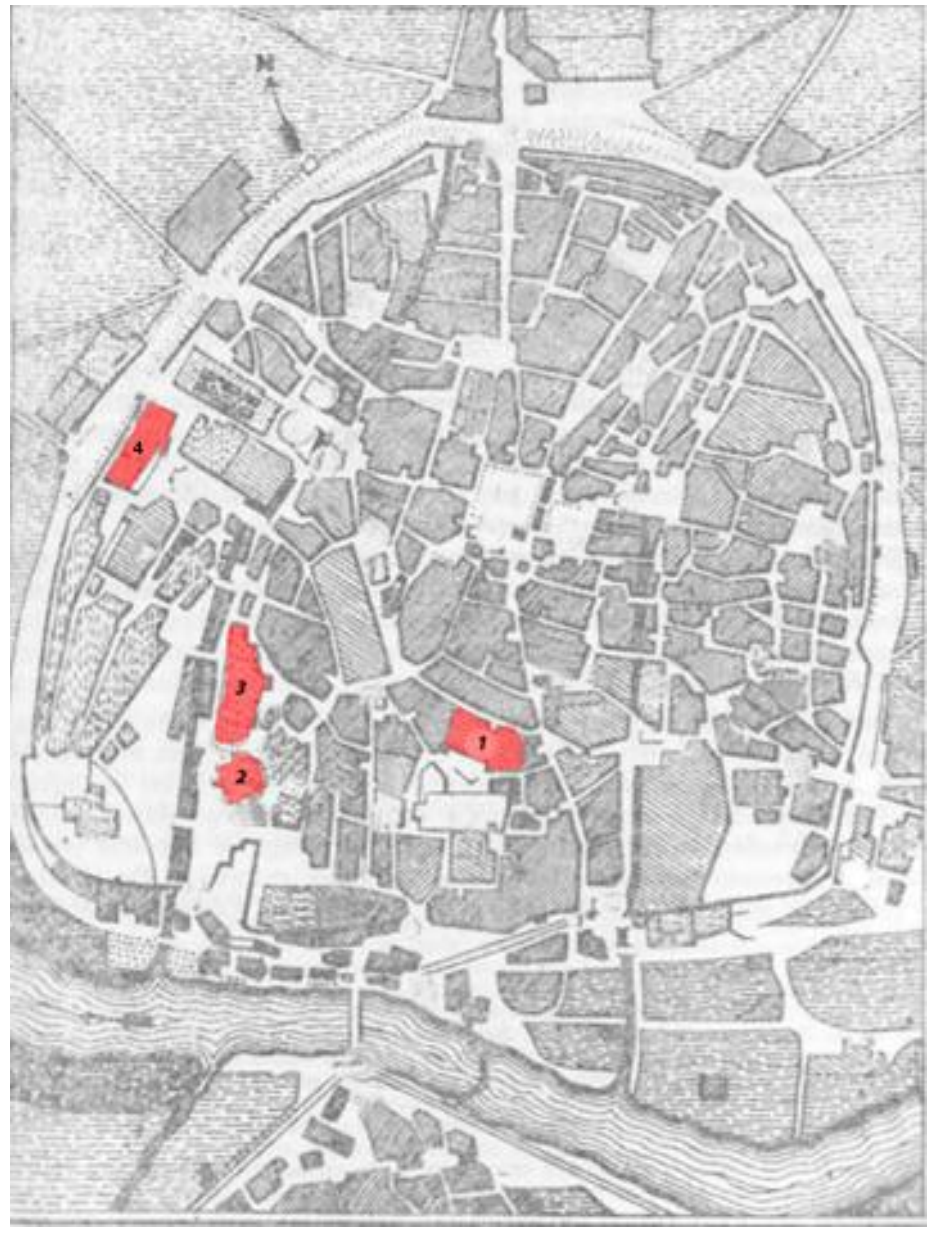

Imagen 10: Primeros

Colegios salmantinos.
1. Colegio de Anaya
2. Colegio Arzobispo
Fonseca
3. Colegio de Cuenca
4. Colegio de oviedo 
66| PRECEDENTES ARQUITECTÓNICOS 


\section{NOTAS Y REFERENCIAS BIBLIOGRÁFICAS (PRECEDENTES ARQUITECTÓNICOS)}

1. Pablo Campos Calvo-Sotelo: Arquitectura y Universidad en la sociedad contemporánea: innovación abierta y aprendizaje activo en las cuatro escalas espaciales. Universidad CEU San Pablo Madrid. 2011. (pp 150-151)

2. Toby E. Huff: "The Rise of Early Modern Science: Islam, China and the West". Ed: Cambridge University Press. p. 56.

3. Arquitectura y Universidad en la sociedad contemporánea: innovación abierta y aprendizaje activo en las cuatro escalas espaciales $O p$ cit $p .3$

4. Andrew Petersen: Dictionary of Islamic Architecture, Routledge. 1996. p.87.

5. GODDARD, Hugh, "A History of Christian-Muslim Relations". Edinburgh University Press. Edinburgh, 2000. P. 14-15.

6. Son instituciones educativas islámicas tradicionales. Incluyen importantes entidades religiosas y sociales, tales como mezquitas, centros de enseñanza teológicos, bibliotecas y hospitales.

7. Alberto Relancio: "Las Universidades medievales". Actas seminario Orotava de Historia de la Ciencia. Años VIII y X. Fundación Orotava Canaria Orotava de Historia de la Ciencia. 2007. P.4-5.

8. Arquitectura y Universidad en la sociedad contemporánea. Op cit 1

9. Plano de Saint Gall siglo IX. Biblioteca de Saint Gall. Proyecto de digitalización y estudio de los monasterios contenidos en las bibliotecas de Reichenau y San Gallen. Se trata en realidad de un palimpsesto compuesto por cinco pieles de oveja o pergaminos formando un gran plano de aproximadamente $112 \times 77 \mathrm{~cm}$, trazado con tinta roja y leyendas en negro, que fue conservado gracias a que, ya a finales del siglo XII, un monje escribió en su dorso la "Vida de San Martín", plegándolo en formato libro y archivado seguidamente. (Cod.Sang.1092)

10. En la formación de las Escuelas Carolingias, Carlomagno emitió en el año 787 d.C. una carta a todos los obispos y abades del Imperio para la generalización del modelo de su Escuela Palatina en catedrales (escuela catedralicia) y monasterios (escuela monástica o monacal); asunto en el que insistió en el Concilio de Aquisgrán del año 789 y en posteriores como el que se cita en este caso.

11. Ver CHAFLÓN OLMOS, Carlos, "El Plano de Sankt Gallen", en Anales del Instituto de Investigaciones Estéticas, num. 78. Ed. Universidad de Navarra, 2001, pp. 53-54.

12. Ibid, p. 56

13. Pablo Campos Cavo Sotelo: Urbanismo y Arquitectura en las universidades de la Comunidad de Canarias. Capítulo 1.2: Educación, Universidad y Ciudad, p. 32.

14. Walter Horn and Ernst Burn. "The Plan of saint Gall: A study of the Architecture, economy and life in a paradigmatic Carolingian monastery". Pp. 14-15. 
15. Ibid, p. 20.

16. Arquitectura y Universidad en la sociedad contemporánea: innovación abierta y aprendizaje activo en las cuatro escalas espaciales Op. cit. p.3

17. Irnerio o Irnerius (Bolonia, 1050-1130). Fue un jurista italiano incorporado a la llamada Escuela de Bolonia, de donde extrae buena parte de la base de conocimientos jurídicos que le permitirán desarrollar su obra. Trabó conocimiento de los gramáticos y retóricos de la época y siguió la línea del movimiento medieval de renovación de las artes que removió los cimientos del conocimiento tradicional del sistema jurídico y del derecho.

18. RODRÍGUEZ -SAN PEDRO BEZARES, LUis E. "HISTORIA DE LA UNIVERSIDAD DE SALAMANCA vol. II". Estructuras y flujos". Ediciones Universidad de Salamanca, 2004. P. 754 .

19. Con este nombre se conocía el término Universidad en la edad media.

20. BELTRÁN DE HEREDIA, Vicente. "Los orígenes de la Universidad de salamanca", Miscelánea Beltrán de Heredia, vol. I. 1972. pp. 6o-64.

21. GONZÁLEZ NAVARRO, Ramón. "Vida cotidiana estudiantil en Alcalá durante la Edad Moderna", en Miscelánea Alfonso IX. Ed. Salamanca, 2001. P. 143.

22. RODRÍGUEZ -SAN PEDRO BEZARES, Luis E. "HISTORIA DE LA UNIVERSIDAD DE SALAMANCA vol. II"Op. Cit. p. 762.

23. TORREMOCHA HERNÁNDEZ, Margarita, "La matriculación estudantil durante el siglo XVIII en la Universidad de Valladolid", en Investigaciones Históricas. Valladolid, 1986. Pp. 39-73.

24. BENASSAR, B. "Valladolid en el reinado de Felipe II", en Valladolid corazón del mundo hispánico. Historia de Valladolid T. III, Valladolid, 1981.

25. BARCALA MUÑOZ, Andrés: "Las Universidades españolas durante la Edad Media", Anuario de Estudios Medievales, 15, Barcelona, 1895, p.83-126.

26. Entre los siglos XV y XIX se denominaron colegios menores a los que impartían enseñanza mediante la cual podía obtenerse una titulación no universitaria.

27. MARTÍN HERNÁNDEZ, Francisco, "Los colegios menores", en FERNÁNDEZ ALVAREZ, Manuel; ROBLES, Laureano; RODRIGUEZ SAN PEDRO, Luis E. Revista de historia moderna (eds.), La Universidad de Salamanca. Historia y Proyectos, Salamanca, 1989, p. 358.

28. TORREMOCHA HERNÁNDEZ, Margarita, "El proceso de creación de la Biblioteca en la Universidad de Valladolid". Otro capítulo de la reforma ilustrada. Homenaje al profesor Mariano Peset, Valencia, 2007, pp. 741-750.

29. El sistema más conocido, aunque probablemente no el más extendido, fue el de pupilaje, que nos relata con tanta ironía y frescura la literatura áurea (tomemos 
como ejemplo el capítulo III en el Buscón de Francisco de Quevedo). Éste, en ocasiones ha sido interpretado como una versión atemperada de un colegio, pues exis-tía en ellos, teóricamente, un control de sus integrantes por parte de un adulto con autoridad y grado. J. García Mercadal introducía nuevos matices al describirlos como los "acomodados en casa de un maestro de pupilos o pupilero, que les daba dos veces al día olla y pan duro, para que comiesen menos, y sólo los sábados poníales mondongo y fruta...".

30. GARCÍA MERCADAL, José. "Estudiantes, sopistas y picaros. Madrid, 1954. pp. 99.

31. Juan de Obando, Reformador que diseño y dibujó los planos del recinto universitario de Alcalá de Henares durante sus visitas en el siglo XVI.

32. RODRÍGUEZ- SAN PEDRO BEZARES, Luis E. "HISTORIA DE LA UNIVERSIDAD DE SALAMANCA", Vol. II. Op. Cit p. p. 786.

33. RODRIGUEZ-SAN PEDRO BEZARES, Luis Enrique, "Estudiantes en Salamanca (1590-1625): el hospedaje(bachilleres de pupilos)" en Primer Congreso de Historia de Castilla y León, Valladolid, 1982; "Pupilajes, gobernaciones y casas de estudiantes en Salamanca(1590-1630)", en Studia Histórica, vol I, nº 3, Salamanca, 1983, pp185-210.

34. RODRIGUEZ-SAN PEDRO BEZARES, Luis Enrique, "Vida estudiantil cotidiana en la Salamanca de la Edad Moderna". Miscelánea Alfonso IX, Salamanca, 2001, p. 78.

35. Archivo Histórico Nacional (A.H.N.), Consejos, leg. $N^{\circ} 5483-25$, sin fecha.

36. El 4-II-1772 se dictaron para Salamanca dos reales órdenes sobre el "arreglo de posadas" y el 16-11-1772 se hicieron extensivas a Valladolid, en cuyo Claustro se presentaron el 16-11-1773. Archivo Universitario de Valladolid, Libro de claustros no 18, pp. 9-16.

37. Op cit, GARCÍA MERCADAL, José.

38. Op. Cit. RODRIGUEZ SAN PEDRO BEZARES, Luis Enrique, "Pupilajes...

39. CORTÉS VAZQUEZ, Luis, "La vida estudiantil en la Salamanca clásica, Salamanca $1985 \cdot$. . 83 .

40. Alfonso X el Sabio, "Las Siete Partidas", Partida $2^{a}$, Título XXXI, Leyes II y V; Ed. De la real Academia de La Historia, vol. II. Madrid 1807, pp.340-342.

41. VERGER, Jaques, "Paterns", en Walter RÜEGG Y Hilde DE RYDDER-SIMOENS (EDS), "A History of the University in Europe, ed. Cambridge, University Press, 1992, pp. 6o-62. 
70| PRECEDENTES ARQUITECTÓNICOS 
RESIDENCIAS UNIVERSITARIAS EN LA HISTORIA

\section{BLOQUE II}

BOLONIA. Primera definición de un tipo europeo en la arquitectura DE BOLONIA A ESPAÑA. Repercusión en los primeros colegios españoles PARÍS. La adaptación de hospederías a colegios universitarios OXFORD Y CAMBRIDGE. El College como arquetipo ESTADOS UNIDOS. Fragmentación edilicia del modelo inglés LA RESIDENCIA DE LA BAUHAUS. Autonomía y funcionalidad moderna 
72| RESIDENCIAS UNIVERSITARIAS EN LA HISTORIA 


\section{RESIDENCIAS UNIVERSITARIAS EN LA HISTORIA}

\section{BLOQUE II}

BOLONIA. Primera definición de un tipo europeo en la arquitectura La Universidad de Bolonia, programa y ciudad

El Colegio Mayor San Clemente de los Españoles, una dilatada influencia. (1369)

DE BOLONIA A ESPAÑA. Repercusión en los primeros colegios españoles

El Colegio Mayor de San Bartolomé o de Anaya. Aparición de la huella italiana. (1401).

Consolidación de los claustros:

Valladolid

El Colegio Mayor Santa Cruz (1486)

El Colegio Mayor San Gregorio (1489)

Alcalá de Henares

El Colegio Mayor San Ildefonso (1499)

Salamanca

El Colegio Mayor de Fonseca (1519)

El Colegio Mayor de Cuenca (1521)

El Colegio Mayor de Oviedo (1522) 
74| RESIDENCIAS UNIVERSITARIAS EN LA HISTORIA 


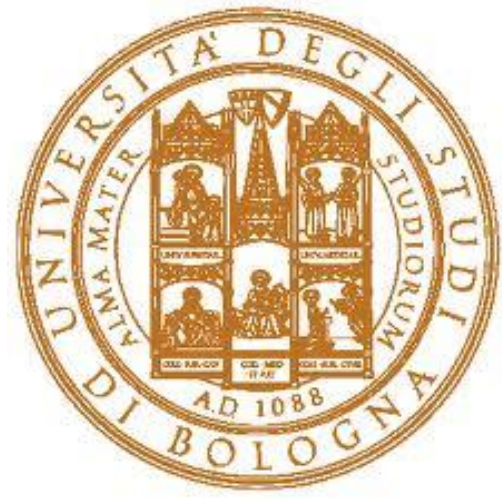

Imagen 1: Escudo de la Universidad de Bolonia.

\section{LA UNIVERSIDAD DE BOLONIA, PROGRAMA Y CIUDAD}

Bolonia había sido famosa como Escuela de Artes, mientras que respecto a ciencia legal era superada de lejos por otras ciudades, por ejemplo, Roma, Pavía y Rávena. La fama de algunos de sus profesores la convirtió, relativamente en poco tiempo, en el principal centro de enseñanza del derecho, no sólo en Italia sino en toda Europa, fueron Irnerius y Graciano ${ }^{1}$. El primero introdujo el estudio sistemático del Corpus juriscivilis en su conjunto, y diferenció la carrera de Derecho de Artes Liberales; el segundo, en su "Decretum", aplicó el método escolástico al derecho canónico, y aseguró para su ciencia un espacio aparte, distinto del de la teología. En consecuencia, Bolonia, mucho antes de convertirse en universidad, atrajo un gran número de estudiantesy sus maestros de todas las partes del Imperio que a la vez que se hacían más numerosos, alcanzaban un prestigio indiscutido.

Ésta afluencia de gente a la ciudad hizo que se necesitaran sitios de alojamiento. Aquí es donde empieza a cobrar importancia el tema residencialy dependiendo de la condición social, sexo, profesión o mero conocimiento,suponía el criterio de la agrupación en colectivos para asentarse en la ciudad.Hacia finales del Siglo XII, se establecieron asociaciones voluntarias por los estudiantes extranjeros, esto es, por los no boloñeses, con fines de mutuo apoyo y protección. Dentro de este apoyo estaba por supuesto el garantizar la morada. Estos estudiantes no eran muchachos sino hombres maduros, muchos de ellos eran clérigos beneficiados.

En su organización copiaron a las cofradías de comerciantes viajeros, en donde cada asociación comprendía un número de naciones, promulgaba sus propios estatutos y elegía un rector que estaba asistido por un cuerpo llamadoconsiliari. Estas cofradías de estudiantes fueron conocidas como universitates, corporaciones en el sentido legal aceptado pero no órganos de enseñanza en sí. Ni los estudiantes ni los doctores boloñeses, al ser ciudadanos de Bolonia, pertenecían a este primer esbozo de universidad, sólo estudiantes de fuera de la ciudad.

Con el desarrollo de la monarquía pontifical en la baja Edad Media y el consiguiente crecimiento de la maquinaria administrativa aumentó la necesidad de personal cualificado en todos los niveles de la administración eclesiástica. Los papas, en consecuencia, desplegaron una política universitaria de triple acción: desarrollo de las facultades de derecho, creación de las universidades y estímulo para la creación de colegios universitarios. La tercera de las vías surgió como solución para proporcionar alojamiento y manutención 
a estudiantes pobres, proveyendo de una educación a quienes tuvieran una disposición intelectual buena pero careciesen de medios económicos². 


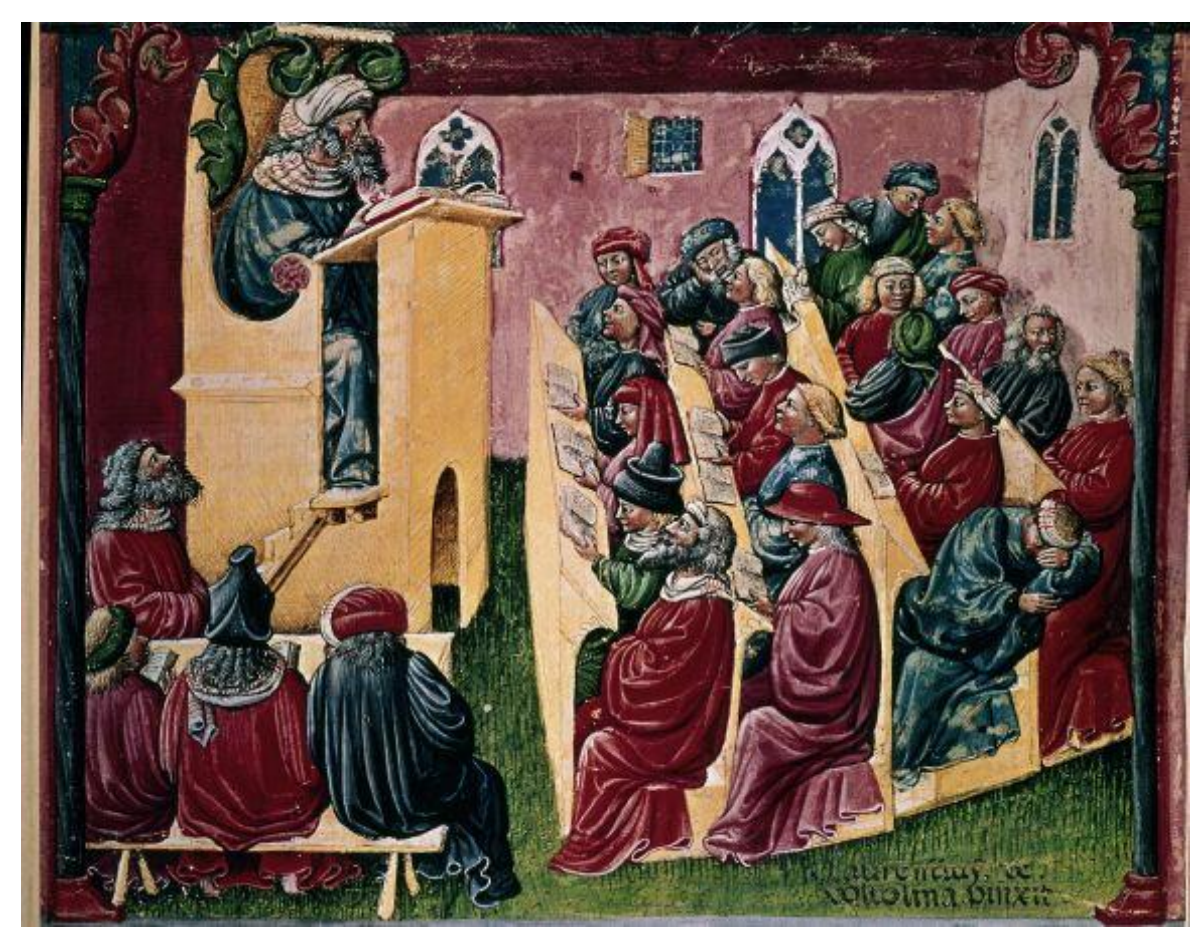

Imagen 2: Lección en la Universidad de Bolonia. Ilustración que se conserva en el StaatlicheMuseum de Berlín.

Las clases en las aulas castellanas tienen la misma disposición.

Imagen 3: Emplazamiento del Colegio de los españoles en Bolonia

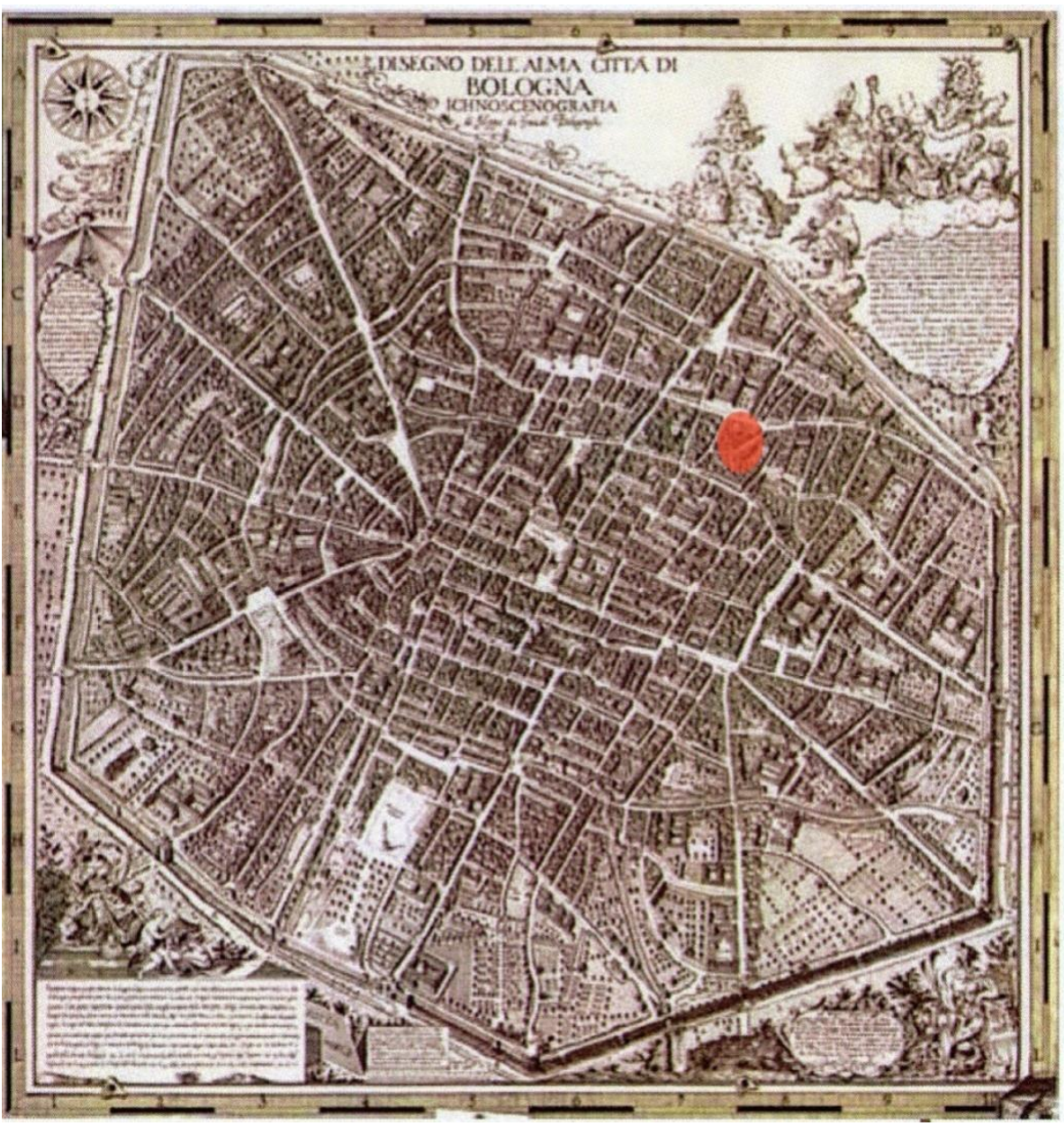


Fruto de esta situación, apareció el que es considerado el primer Colegio Mayor, donde se podían cursar estudios de "grado superior" y también residir en él, es el Colegio Mayor de los Españoles. El colegio fue voluntad del cardenal Gil Álvarez de Albornoz ${ }^{3}$ (13101367), siendo construido entre 1365 y 1367 gracias a su legado testamentario (29 de septiembre de 1364 . El colegio fue tomado como modelo por los colegios de la Universidad de Salamanca, por ejemplo, el Colegio Viejo de 1401, y de otras universidades españolas de los siglos $\mathrm{XV}$ y $\mathrm{XVI}{ }^{4}$. Entre los estudiantes de más renombre que se han hospedado, a lo largo de la historia, en el colegio boloñés están Antonio de Nebrija, Ignacio de Loyola y Miguel de Cervantes. En 1530 se hospedó Carlos V durante cuatro meses, con ocasión de su coronación como emperador.

A partir del siglo XIII los colegios se multiplicaron en Europa sobre la base de rentas perpetuas que prelados o señores laicos donaban para que fuesen mantenidos en estudios superiores estudiantes pobres provenientes de su diócesis o su país de origen de Europa: Calahorra, Vic, Urgel o Zaragoza eran algunas de ellas 5 . Uno de los principales destinos para los estudiantes hispanos fuera de las fronteras castellanas y aragonesas era precisamente esta ciudad. Muchos de los estudiantes europeos, ya en el año 1171, obtuvieron permisos para ausentarse de los principales centros superiores de estudio del país para ir a Bolonia a aumentar sus conocimientos.

A finales del siglo XII había bastantes maestros juristas castellanos y aragoneses en Bolonia que marcaron la presencia española en Italia desde la aparición de la universidad en $1088^{6}$.

Ante esta afluencia de docentes y alumnos a la ciudad empiezan a proliferar una serie de colegiosuniversitarios en la misma. El primero de ellos fue el colegio Avignonense, cuyo fundador fueZoene, obispo de Avignon. Guillermo de Brescia fundó años después el colegio Bresciano, y por último, en 1362 comienza funcionar el colegio Reggiano, para jóvenes de la diócesis de la Reggio-Emilia que fueran a estudiar a Bolonia.Pero estos no conciernen ningún interés arquitectónico que haga profundizar en su estudio.

Teniendo en cuenta estas premisas, el cardenal Gil de Albornoz,que había renunciado a la mitra de Toledo y se encontraba al servicio del Papa en Avignon, otorgó testamento público y solemne en el que disponía que con la mayor parte de sus bienes se construyese en Bolonia un Colegio de estudiantes con huerta, patios, habitaciones y una capilla dedicada al Papa San Clemente Mártir, con rentas para la manutención de veinticuatro colegiales y dos capellanes, que debería llamarse "Casa española". Cuando el cardenal Albornoz fundó su Colegio no era ajeno a las instituciones que de manera similar habían surgido en el resto de Europa, de hecho es muy
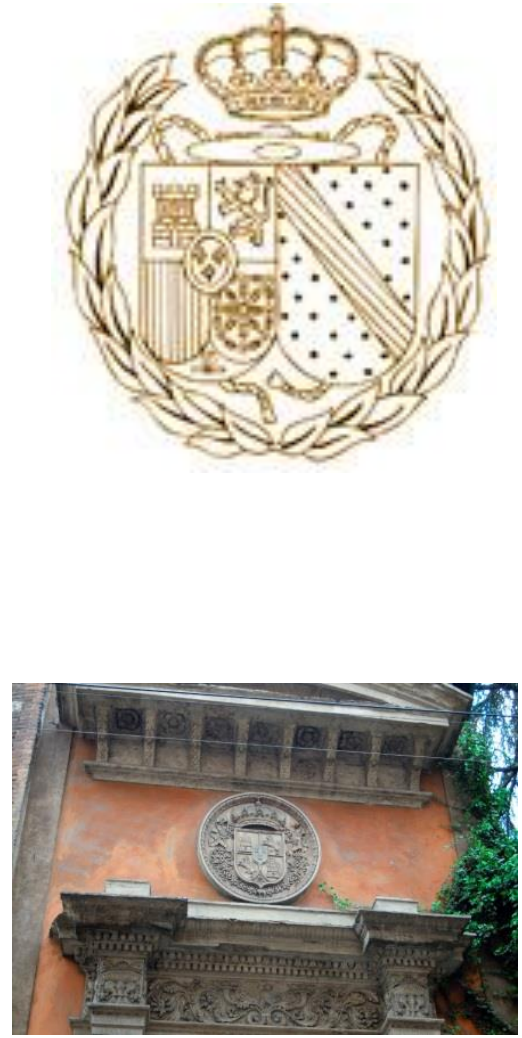

Imagen 4: Escudo del Real Colegio de España en Bolonia.

Imagen 5: Escudo situado en la fachada principal del Colegio de los españoles. 
probable que en su época de estudiante o durante su estancia en la Corte avignonense conociera el colegio de San Marcial, fundado en Toulouse por el Papa Inocencio VI. ${ }^{7}$

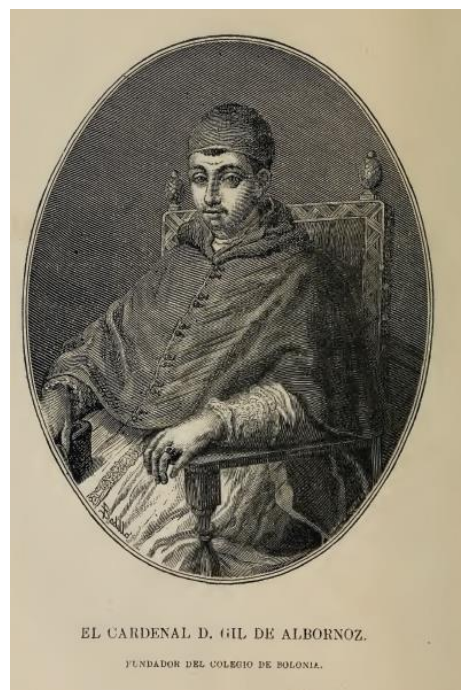

Imagen 6: El Cardenal Don Gil de Albornoz.
La fundación del prelado hispano en Bolonia tenía como fin "remediar la ignorancia de los españoles, entre los que, a causa de las crisis de las guerras y otras calamidades sin fin que ocurrieron en aquella provincia en su momento, el saber de las letras y el número de hombres expertos se ha reducido mucho". ${ }^{8}$ El antiguo colegial Salvador Silvestre de Velasco y Herrera afirma en su obra Compendio de la fundación y privilegios del Colegio mayor de San Clemente de los españoles de Bolonia, fundado por el Cardenal Carrillo de Albornoz que lo que movió al arzobispo a fundar el Colegio en Italia y no en otro lugar fue "...el florecer en ella más que en ninguna parte de la Europa los estudios y carecer España de ellos a causa de las grandes guerras que continuamente se movían entre Christianos y Moros, y otras calamidades que en ellos se padecía, y las causas que tuvo para fundarlo en Bolonia, no pudieron ser otras si no el buen temperamento del Cielo, la amenidad de los campos, la sanidad, la fertilidad de la tierra, y frutos de ella, el amor de los Ciudadanos y la mucha nobleza que en ella se ilustra, y ser aquella la primera universidad". ${ }^{9}$ El Colegio, por el testamento del cardenal otorgado en Ancona el 29 de septiembre de 1364, sería el heredero universal, especialmente, de su biblioteca de derecho canónico y civi $^{10}$, una vez se hubieran cumplido todos los legados y las demás cargas de la sucesión. Según Cánovas del Castillo, uno de los biógrafos del cardenal, al que llama "teólogo, canonista y prelado insigne, primer consejero del primer rey de España en la Edad Media, sacerdote ascético, persuasivo orador, general invicto y profundísimo político, todo a un tiempo", al conquistar Bolonia y crear el Colegio e instituirlo como su heredero universal "coronó brillantemente la vida". ${ }^{11}$

\section{EL COLEGIO MAYOR DE SAN CLEMENTE DE LOS ESPAÑOLES, una dilatada influencia (1369)}

El Cardenal de Albornoz concibió un proyecto para fundar un colegio que sirviera de residencia y lugar de estudio destinado a alumnos hispanos que acudian a la Universidad de Bolonia hacía más de un siglo ${ }^{12}$. La necesidad de un edificio pensado para acoger a profesores y alumnos, destinado al alojamiento de todo aquel que estuviera lejos de casa, era percibida agudamente por quienes conocían el estilo de vida de los Estudios Generales, abocados a la movilidad desde sus lugares de origen $y$, una vez en la ciudad, de una sede a otra, ya fuera de un convento, una vivienda u otro edificio público o privado, tal cual se ha comentado en el capítulo anterior. 
Con el propósito de reunir a los estudiantes ibéricos en un colegio, no sólo se les acogía en una institución que procurase su manutención y formación intelectual, también aspiraba el cardenal fundador adotarles de cohesión frente a otras "naciones" de alumnos y a afirmar una identidad que agrupase a los distintos reinos peninsulares: Portugal, La Corona de Castilla, Navarra y La Corona de Aragón. La fundación se debió, en todo caso, a la voluntad personal del cardenal expresada en su testamento de 29 de septiembre de 1364. Gil de Albornoz dispuso que la institución llamada "Casa o Colegio de España" tuviese su sede cercana a las escuelas universitarias, y que contase con salas y habitaciones para veinticuatro estudiantes, un jardín y una capilla dedicada a San Clemente.

La nueva fundación quedaba como heredera universal de la mayoría de bienes del cardenal, en tanto que la adquisición de propiedades y rentas, así como de la supervisión de las obras debían correr a cargo de Fernando Álvarez de Albornoz, sobrino del fundador, y Alfonso Fernández, camarero del mismo. Mientras se configuraba el solar, se redactaron los primeros Estatutos de la institución, que esbozaban un programa constructivo para el edificio al regular su vida interna ${ }^{13}$. Este es el primer momento en el que se redacta un proyecto con un programa de necesidades para un edificio universitario, y la función residencial es el motivo principal organizador de dicho programa. El proyecto del Colegio estaba ya elaborado el 5 de abril de 1365 cuando se firmó el contrato con los maestros constructores Andrea di Pietro, Mino di Pánfilo y Zanone di Tura, pues éstos debían sujetarse a una traza discutida porel Cardenal Albornoz, sus representantes(Fernando Alvarez y Alfonso Fernández) y el arquitectoMatteoGattapone da Gubio ${ }^{14}$.

Pese a posteriores y notables intervenciones a lo largo de su historia, la planta y el modelo funcional del Colegio de España son todavía inteligibles en la fábrica conservada y en la documentación de su primera etapa de vida. El edificio se articula en torno a un patio cuadrangular, con un eje de simetría que marcan la nave y el ábside orientado de la Capilla de San Clemente, sita en el frente opuesto del acceso principal. En torno al patio se elevan en dos plantas cuatro cuerpos de fábrica, con galerías que suman un total de veinte arcadas de medio punto. En loslados septentrional y meridional la crujía situada tras el pórtico se articula en seis habitaciones de planta cuadrada en dos alturas, mientras que loslados este y oeste estánocupados por ambientes rectangulares de mayor tamaño, y la capilla, con su hastial y su espadaña pujando por encima de la galería oriental. Cabe destacar la posición del reloj, que marca las horas de estudio como novedad, ya que anteriormente, en los conventos, lo 
marcaban las horas de rezo. En su redacción más antigua conocida, los estatutos del Colegio detallan minuciosamente el uso de los espacios que se construyeron según lo establecido en el contrato de la fábrica: cuatro cuerpos alrededor del patio porticado, la capilla opuesta a la entrada, estancias de uso común (refectorio, sala grande y biblioteca), dos escaleras para acceder a la planta superior, veinticuatro habitaciones para los estudiantes, las cámaras del rector y los dos capellanes. A estás se le añaden dependencias del servicio tales como un almacén, la cocina, las letrinas y las piezas para el alojamiento de la servidumbre. Todos estos ambientes, con el jardín previsto por Albornoz en su testamento, se distribuyen con una regularidad impecable a partir de un trazado ad cuadratum y del eje de simetría definido por la capilla y la entrada del patio, todo ello atendiendo a la organización práctica del edificio. 

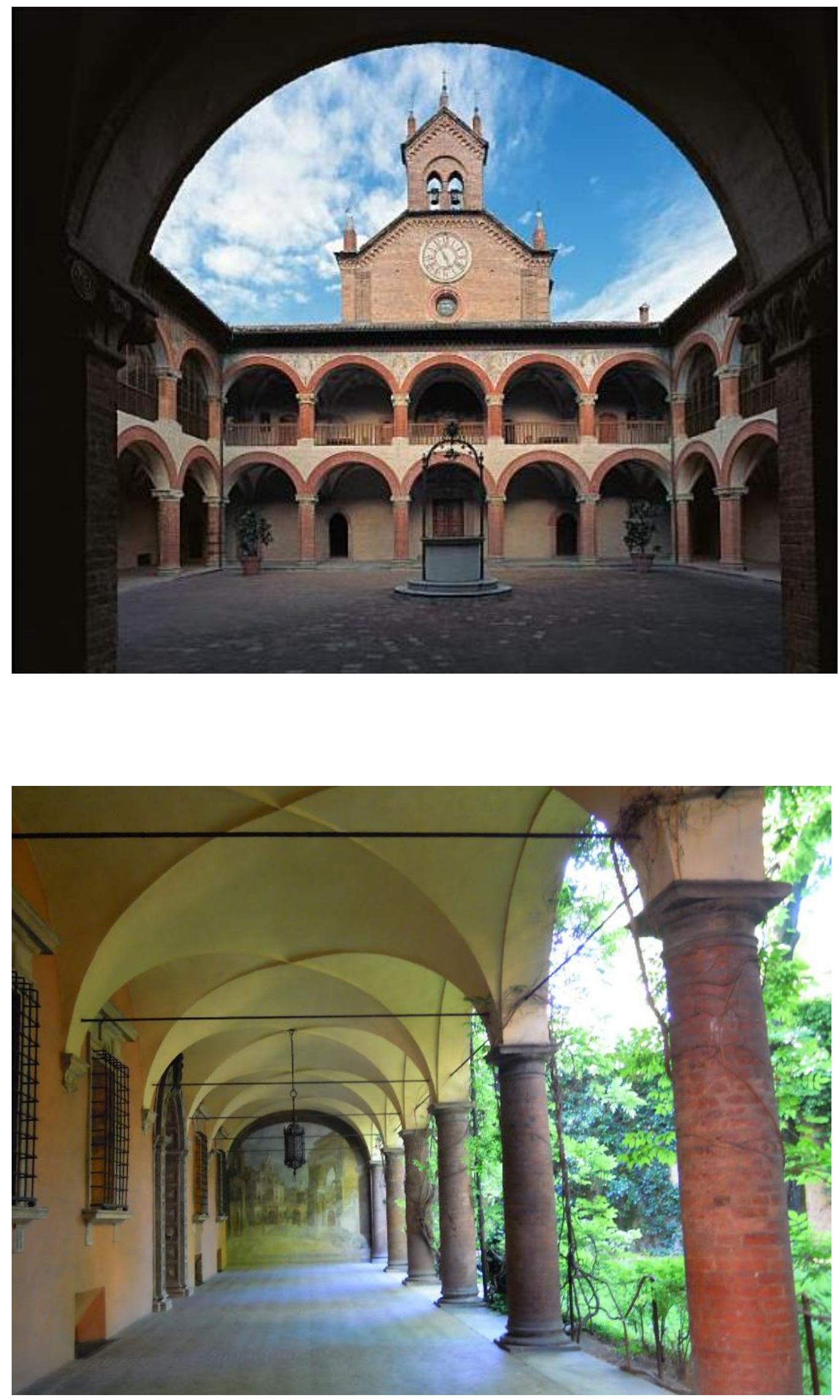

Imagen 7:

Claustro

organizador de

las

dependencias del Colegio.

Imagen 8:

En la página

anterior,

posición del

Colegio

integrado en el

paisaje urbano

de la ciudad. 
En resumen la distribución del edificio es:

Planta baja:

- Recibidor conectado con el claustro.

- Habitaciones de los colegiales y el rector (tanto las habitaciones de los colegiales como las del rector se componen de dos espacios completamente iguales, incluso poseenidéntico mobiliario).

- Salones de estar y para actos oficiales

- Archivo.

- Salas de desahogo estudiantil

Planta primera:

- Comedor

- Cámara de café

- Sala de esgrima y gimnasia

- Coro de la capilla de la iglesia (sirve de tribuna alos colegiales para actos representativos).

La capilla es de estilo Gótico y la sacristía de la capilla guarda obras de arte tales como una Virgen de Filippo Dalmacio, cuadros de Caracci y un incensario y la "navicella" de plata, atribuida a BenvenutoCellini.

En la biblioteca del Colegio se conservan un centenar de códices en pergamino, entre ellos un incunable denominado "Clementinas", impreso en Maguncia y una "Divina Comedia", posiblemente salida de la imprenta de los hermanos Gutemberg.

Este plan constructivo y funcional constituye una novedad en la arquitectura universitaria europea de mediados del siglo XIV. En este momento, se está tomando conciencia, no sólo en Italia, sino en Inglaterra y Francia, de la idea de un edificio de nueva planta destinado al alojamiento y estudio de profesores y alumnos, en vez del acostumbrado recurso a locales alquilados o reformados que sirvieran a tal fin. No obstante, rara vez se logró durante este periodo un proyecto tan definido.

La estructura claustral" cerrada al exterior"del conjunto evidencia el objetivo del colegio de gozar de una relativa autosuficiencia respecto a la ciudad. 
La conjugación del uso residencial del edificio y la distribución de sus ambientes hacen de este colegio un hito en la arquitectura residencial universitaria. Lo específico del Colegio de España consiste, pues, en la configuración de un modelo sui generis llamado a tener fortuna en la historia arquitectónica hispánica posterior, que se desarrolla en los siguientes capítulos.

Las dependencias interiores se proyectan con la idea de que reciban gran iluminación y ventilación, buscando unos principios de salubridad pioneros en los criterios proyectuales de esta época.

Este colegio es el primer ejemplo del éxodo de la cultura y el saber desde los claustros monacales y catedralicios a su encuentro con la sociedad.

Antes de terminar con este capítulo, cabe destacar actuaciones en Italia sobre edificios para hospedar estudiantes, casos como el del anteriormente mencionado Colegio Gregoriano de Bolonia, fundado en 1371 con sede en el antiguo palacio Pepoli. Otros casos que merecen mención son edificios construidos o ampliamente remodelados para adecuarlos a su función residencial universitaria: El Colegio Pratense de Padua, fundado en 1390 pero construido con capacidad para veinte estudiantes entre 1408 y1420, y el Colegio Castiglione de Pavia, establecido en 1429 en una antigua casa que fue a su vez integrada en nuevas edificaciones para servir de sede a la institución.

A lo largo del tiempo, este Colegio destacó y aún hoy destaca por poseer la protección de los reyes de España. Algunos autores señalan que la protección comenzó con los Reyes Católicos bajo la autorización del pontífice Inocencio VIII en 1488. La llamada «regia protección» invocaba la protección de los reyes de España y estaba destinada a ennoblecer aún más las constituciones originales del colegio. No obstante, la protección regia debe situarse en 1530 gracias a Carlos I, como así consta en la inscripción de la capilla del colegio. Esa protección se mantuvo por otros reyes Felipe Il y demás monarcas españoles. 


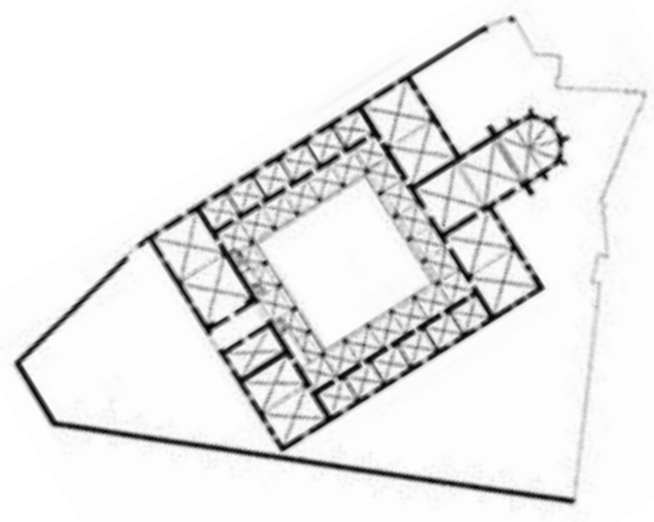

Imagen 9: Plata baja

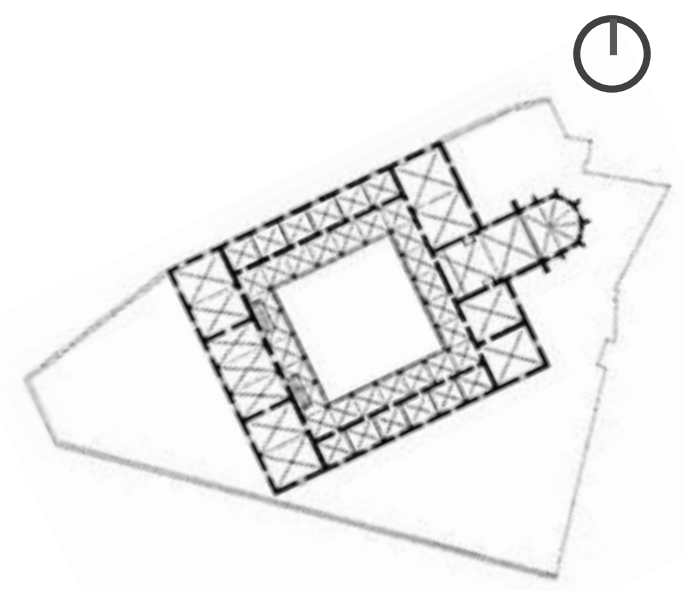

Imagen 10: Plata primera

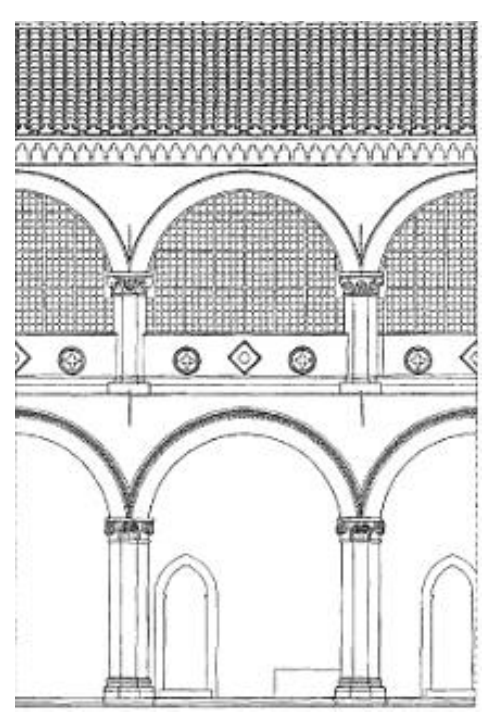

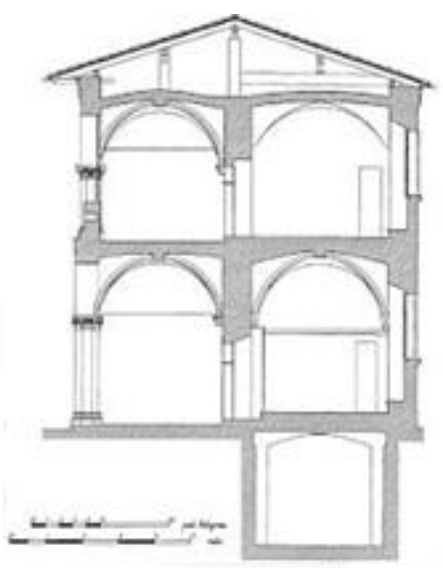

Imagen 11: Sección transversal galeria norte.

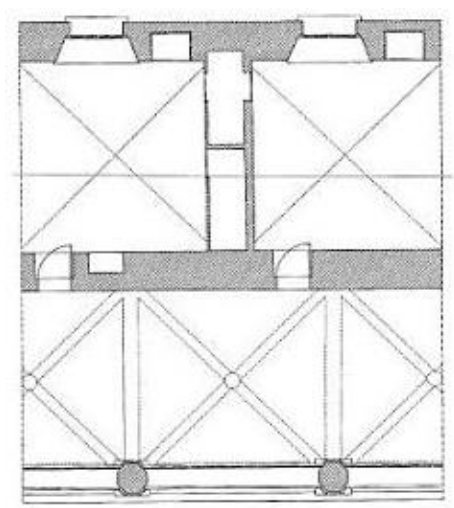

Imagen 12: Detalle galería patio norte $y$ sur (planta baja)

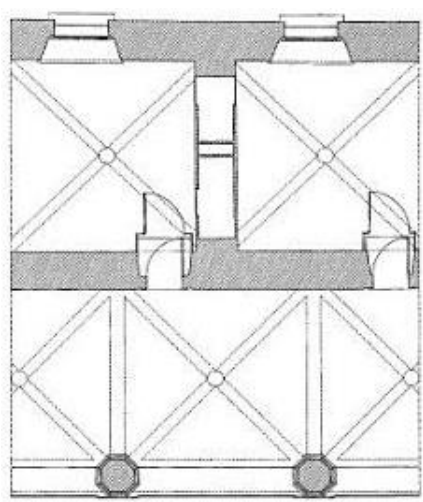

Imagen 14: Detalle galería patio norte $y$ sur (planta primera)
Imagen 13: Detalle galería patio norte y sur (alzado) 

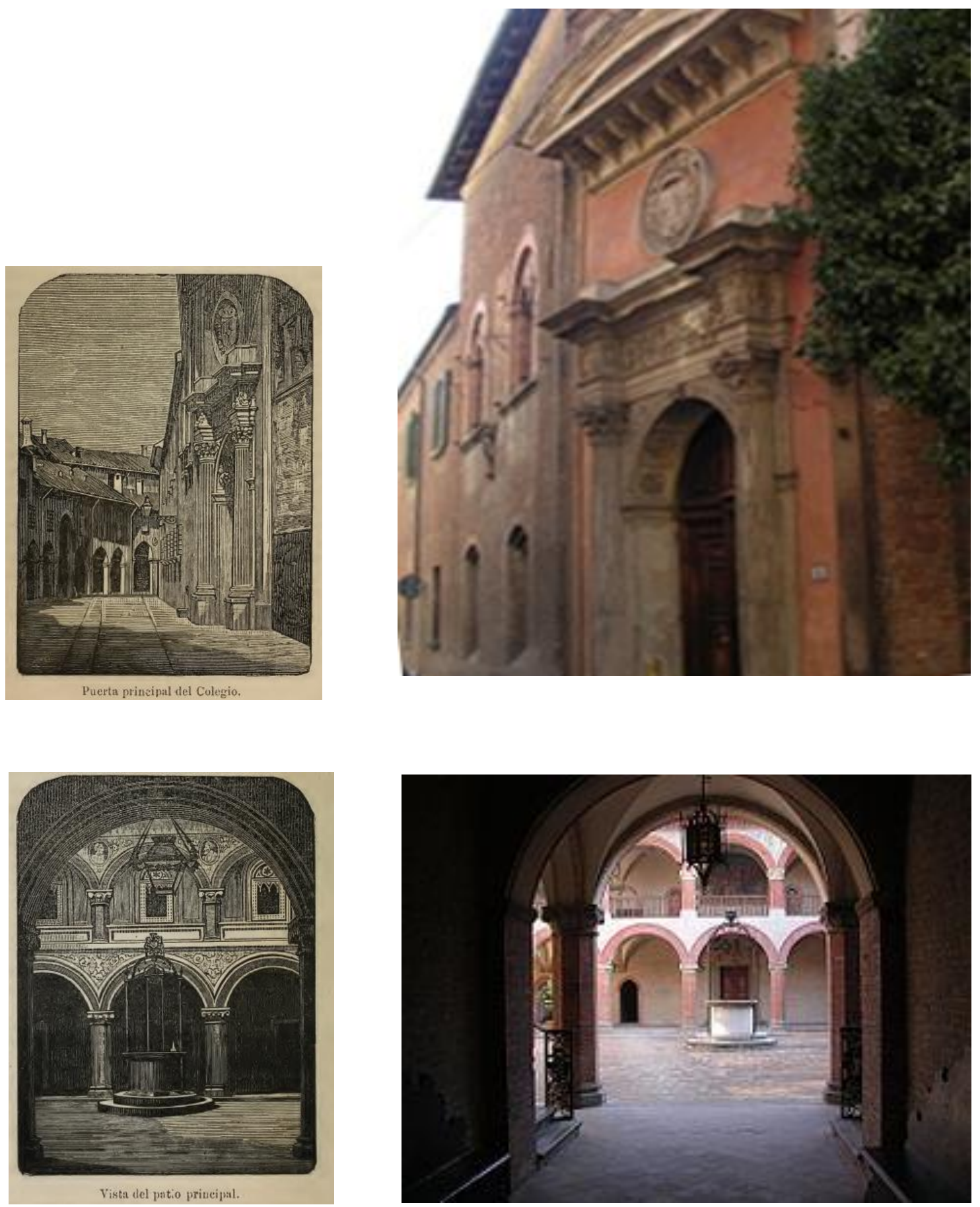

Imágenes 15 y 17: Imágenes pertenecientes a "El Colegio de Bolonia" cuyos autores son Pedro Borrajo y Heredia y Hemergildo Giner de Los Ríos. Son la puerta de entrada principal del colegio y un detalle del alzado este.

Imagen 16: Fotografía actual de la puerta principal del colegio, cuya calle recibe el mismo nombre. Al fondo, patio interior, lado norte.

Imagen 18: Fotografía actual de la entrada al colegio, viendo el alzado este al fondo. 
En 2012 el Real Colegio de España en Bolonia recibió el Premio Europa Nostra en su primera categoría, conservación del patrimonio. El jurado se refirió al Colegio en los siguientes términos: "Podría ser el mejor ejemplo de nuestra herencia común europea: una universidad medieval para los estudiantes de español en una universidad italiana - la universidad más antigua en el mundo - con el motivo italiano de una logia en torno a un patio. El jurado admiró la belleza y el detalle de esta restauración meticulosa, sobre todo de los frescos, y el coraje y la determinación mostrada en el mantenimiento tanto impulso y financiación durante un período tan largo." Asimismo, se destacó el esfuerzo llevado a cabo por el Colegio en sus obras de restauración y consolidación, especialmente durante el periodo 1978-2010, uno de cuyos principales resultados fue el descubrimiento y puesta en valor de importantes frescos en varias salas del edificio. 

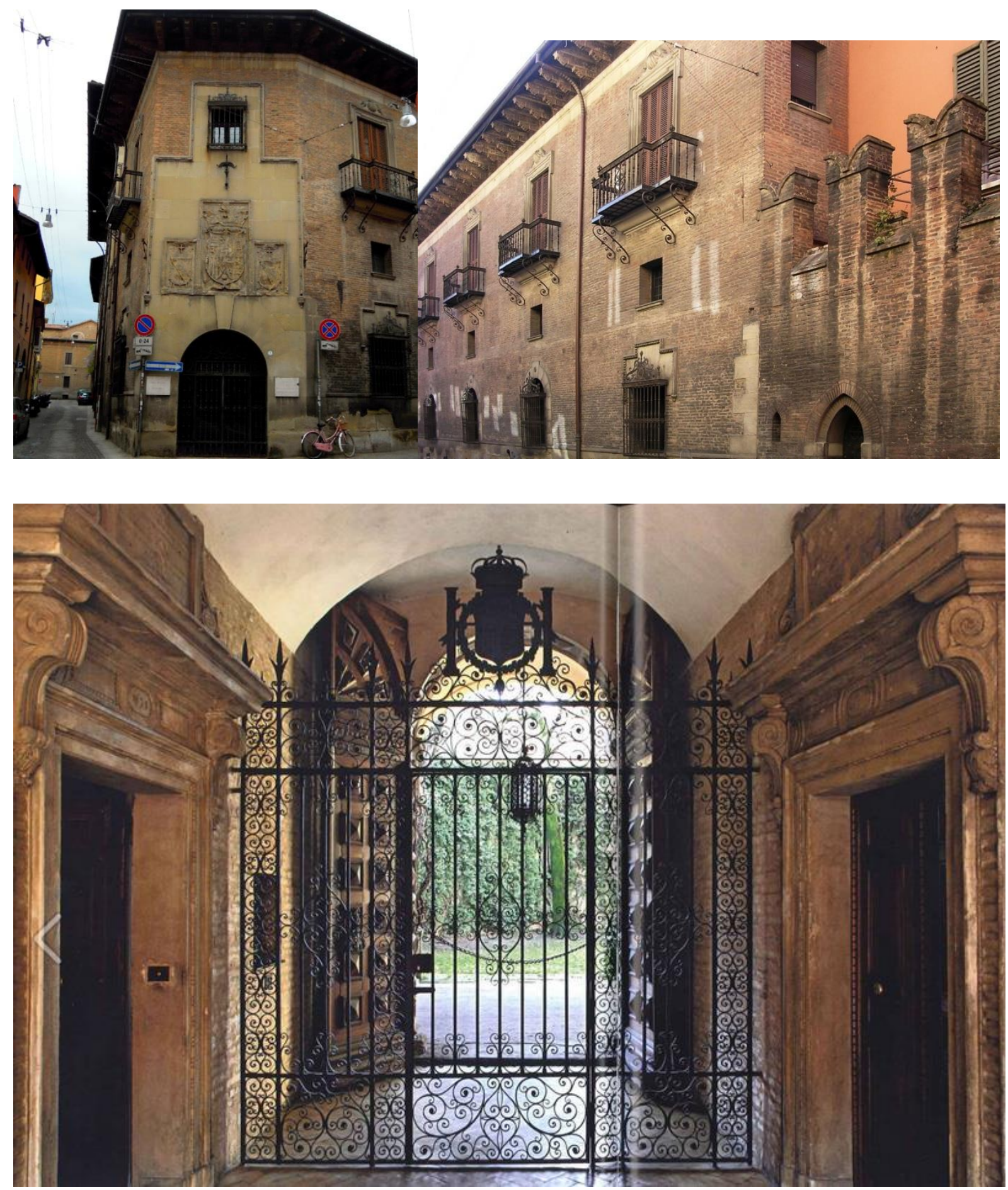

Imágenes 19 y 20: Exteriores del colegio, la dimensión de las ventanas es reducida, ya que el colegio está pensado para "volcar" al interior. Las ventanas tienen la dimesión justa para iluminar y ventilar. Las de los profesores suelen tener un pequeño balcón al exterior.

Imagen 21: Vista de la puerta del colegio desde el claustro hacia afuera. 

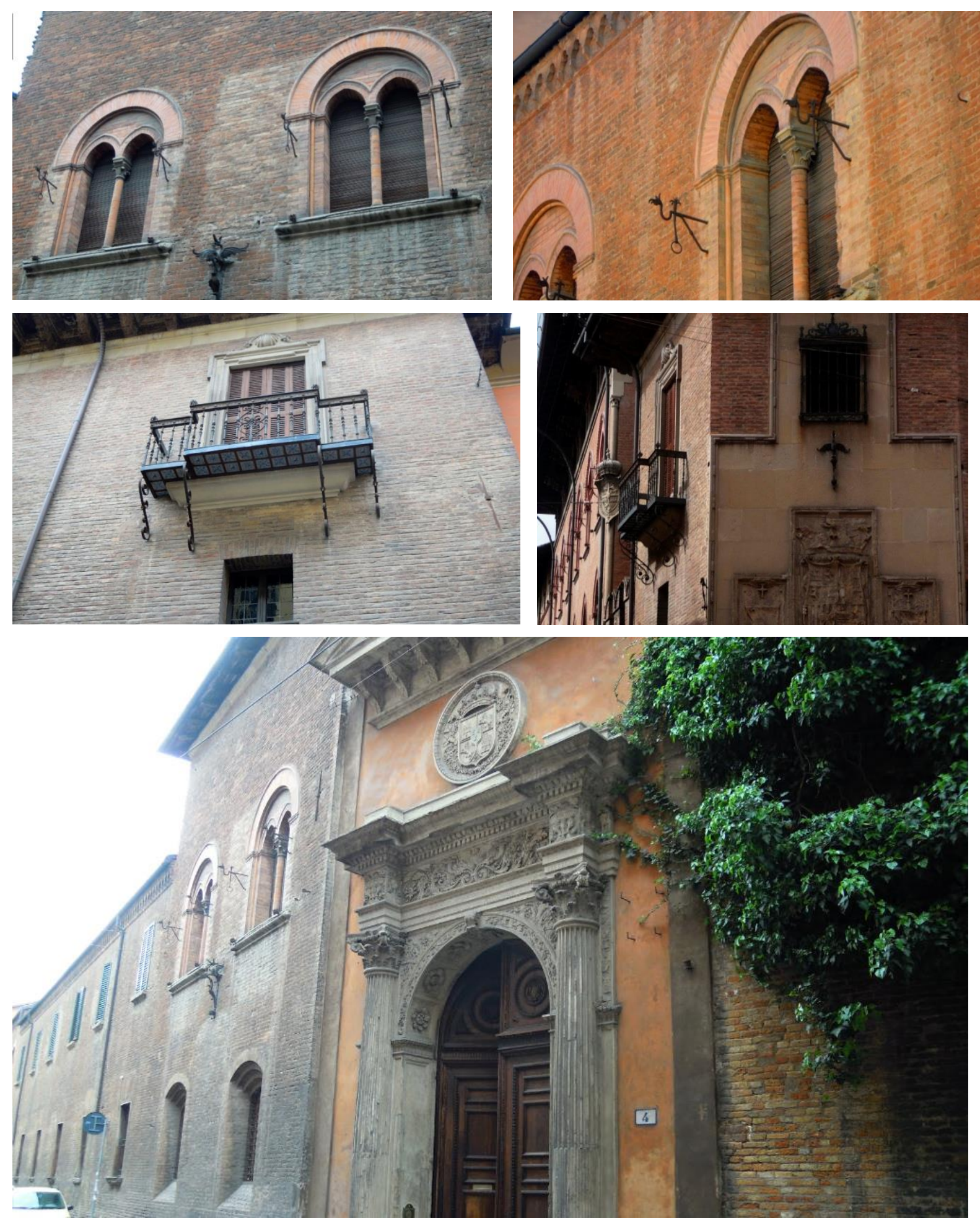

Imagen 22, 23, 24 y 25: Ventanas exteriores. Las pertenecientes a las zonas comunes tienen formas circulares en su perímetro mientras que las de las zonas privadas tienen formas rectangulares.

Imagen 26: Puerta principal del colegio. 

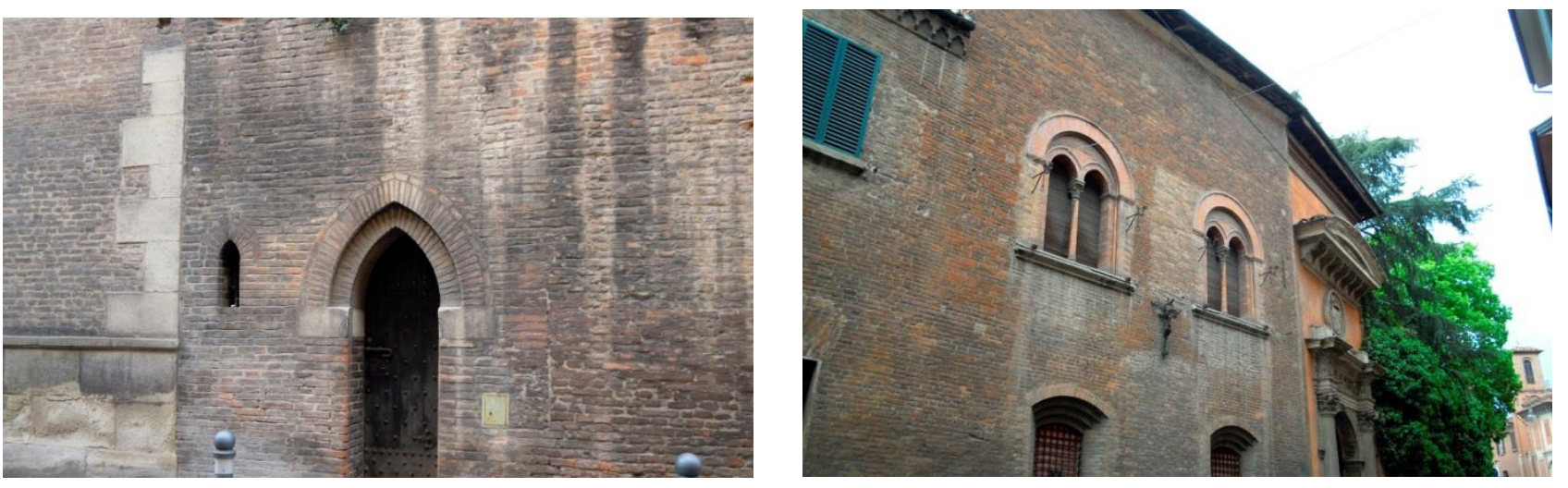

Imagen 27, 28 y 29: Fachadas exteriores del colegio. Conformada por fábrica

de ladrillo y mampostería.

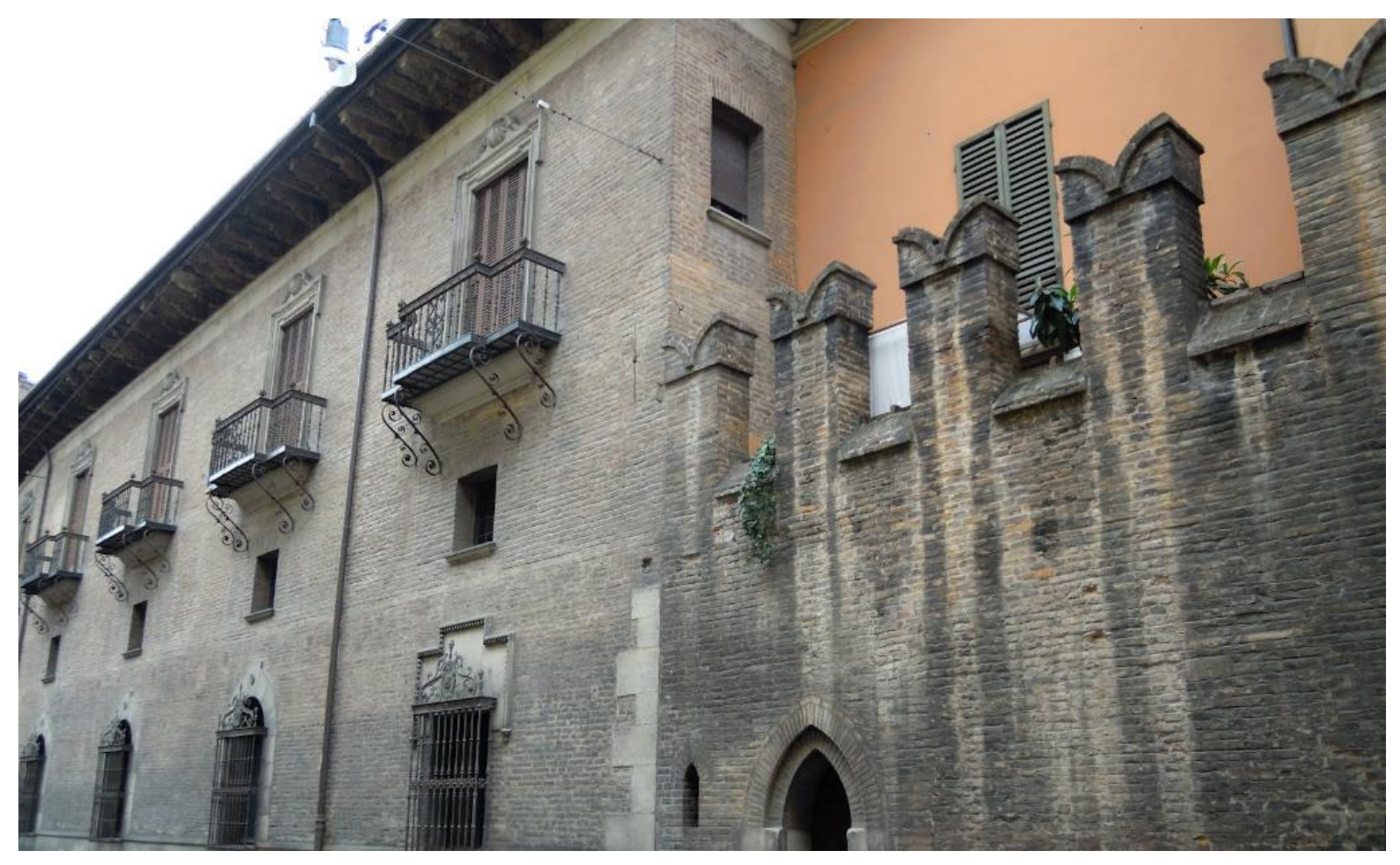




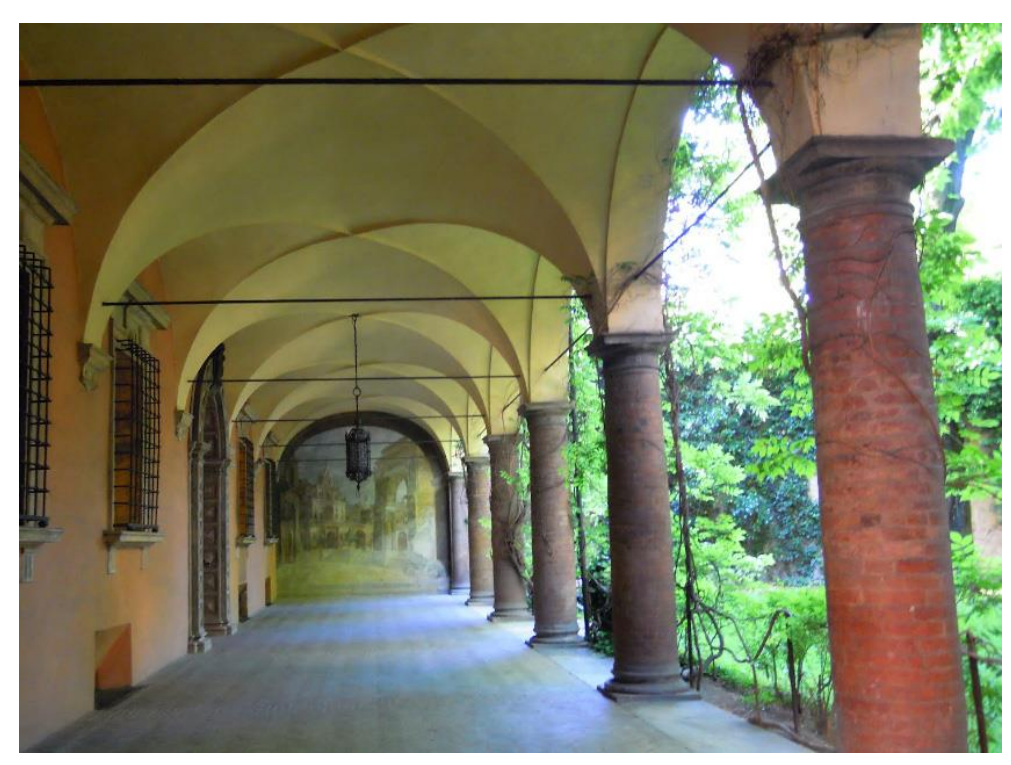

Imágenes 30 y 31: Vistas de las logias de planta baja. Donde se puede apreciar la decoración con frescos en algunas paredes.

Imagen 32: Vista de la logia de planta primera, también con decoración de fresco.
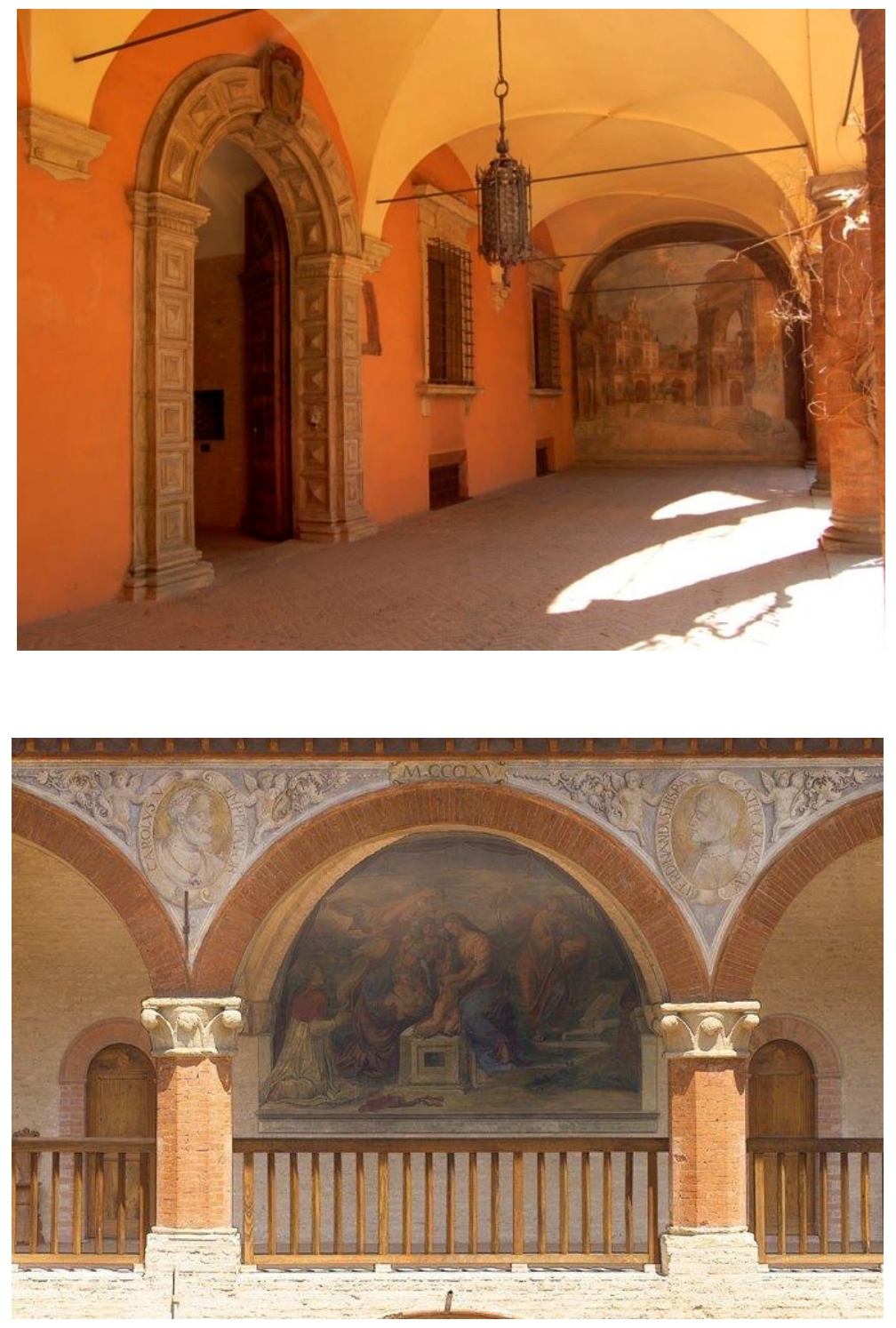


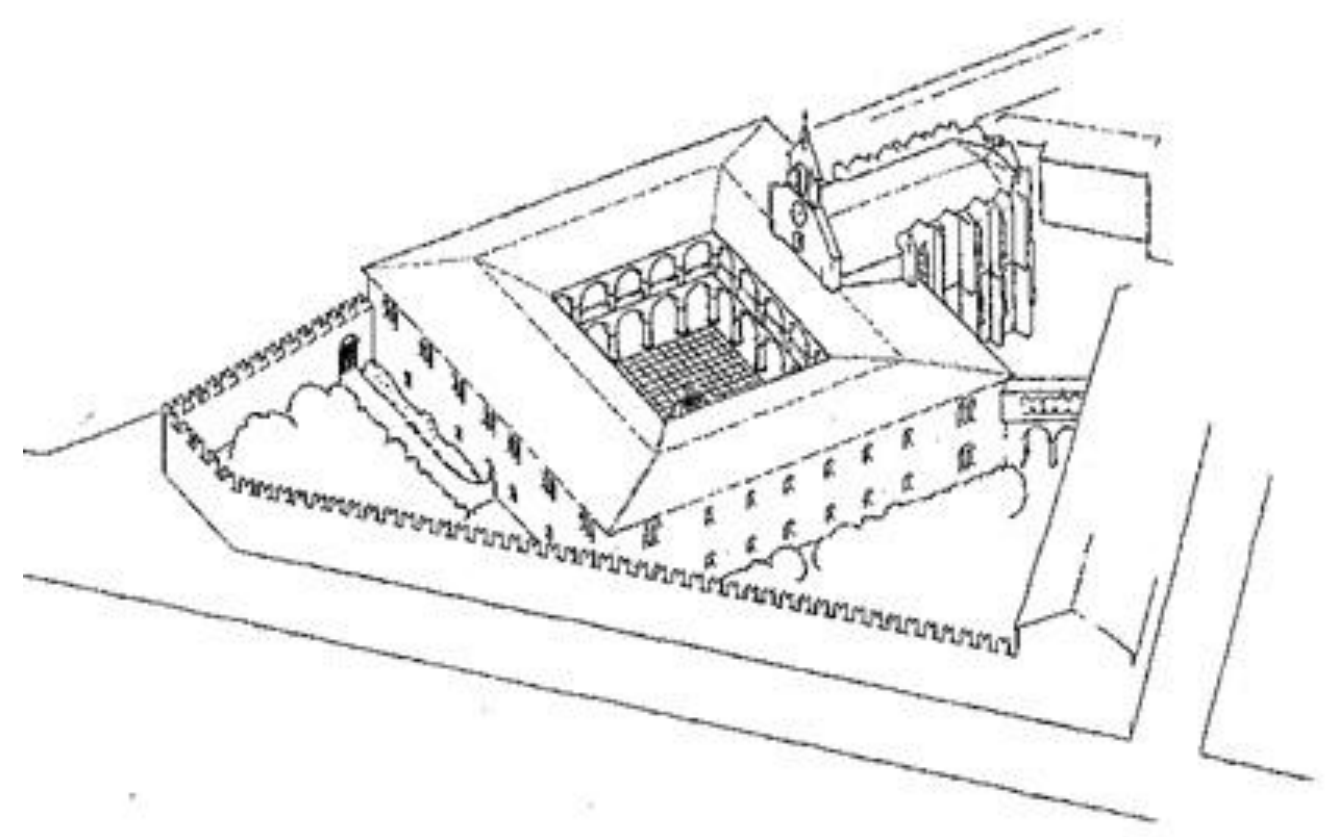

Imagen 33: Perspectiva del Colegio de España, El hastial de la capilla "muerde" la nave.

Imagen 34: Vista del claustro.

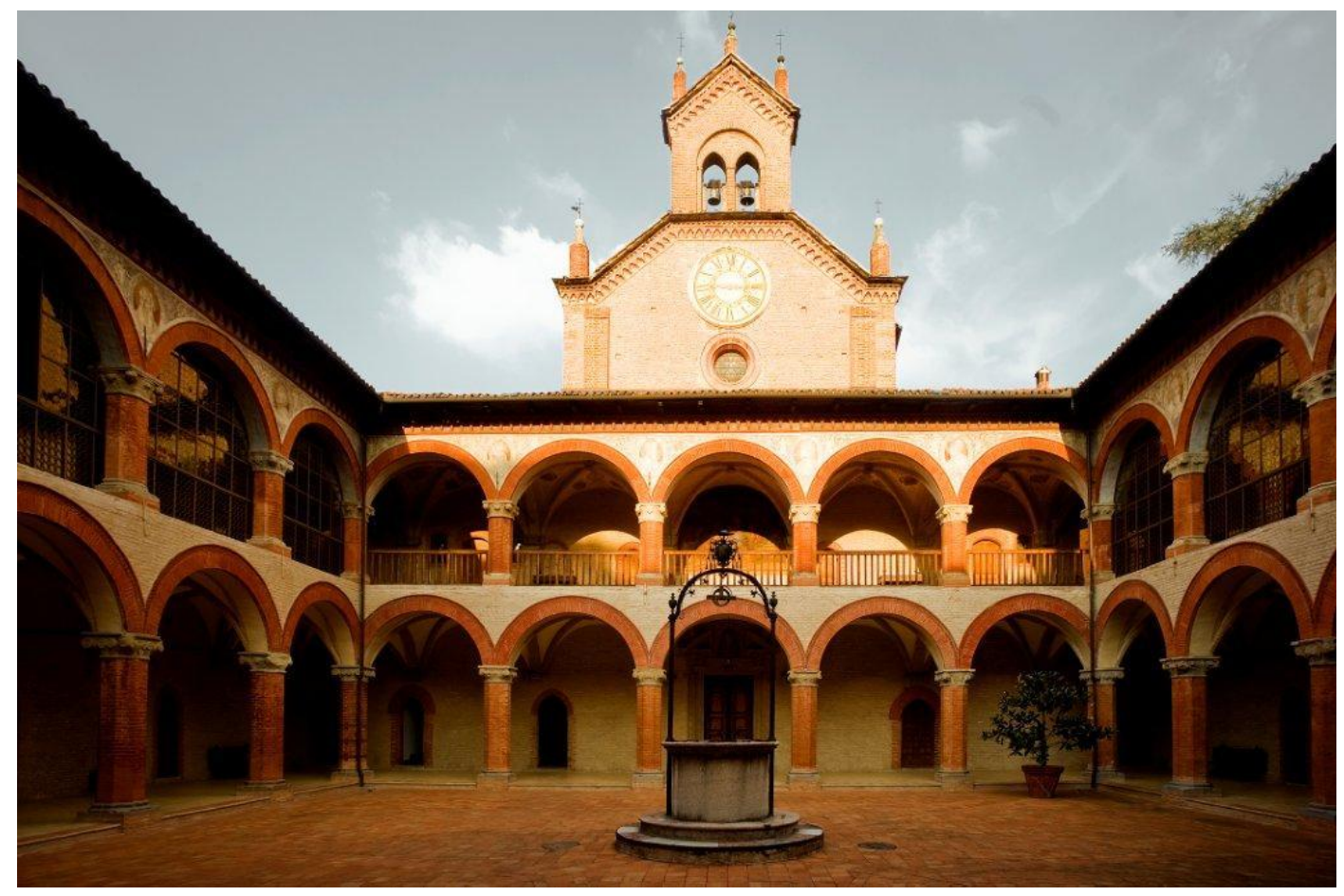



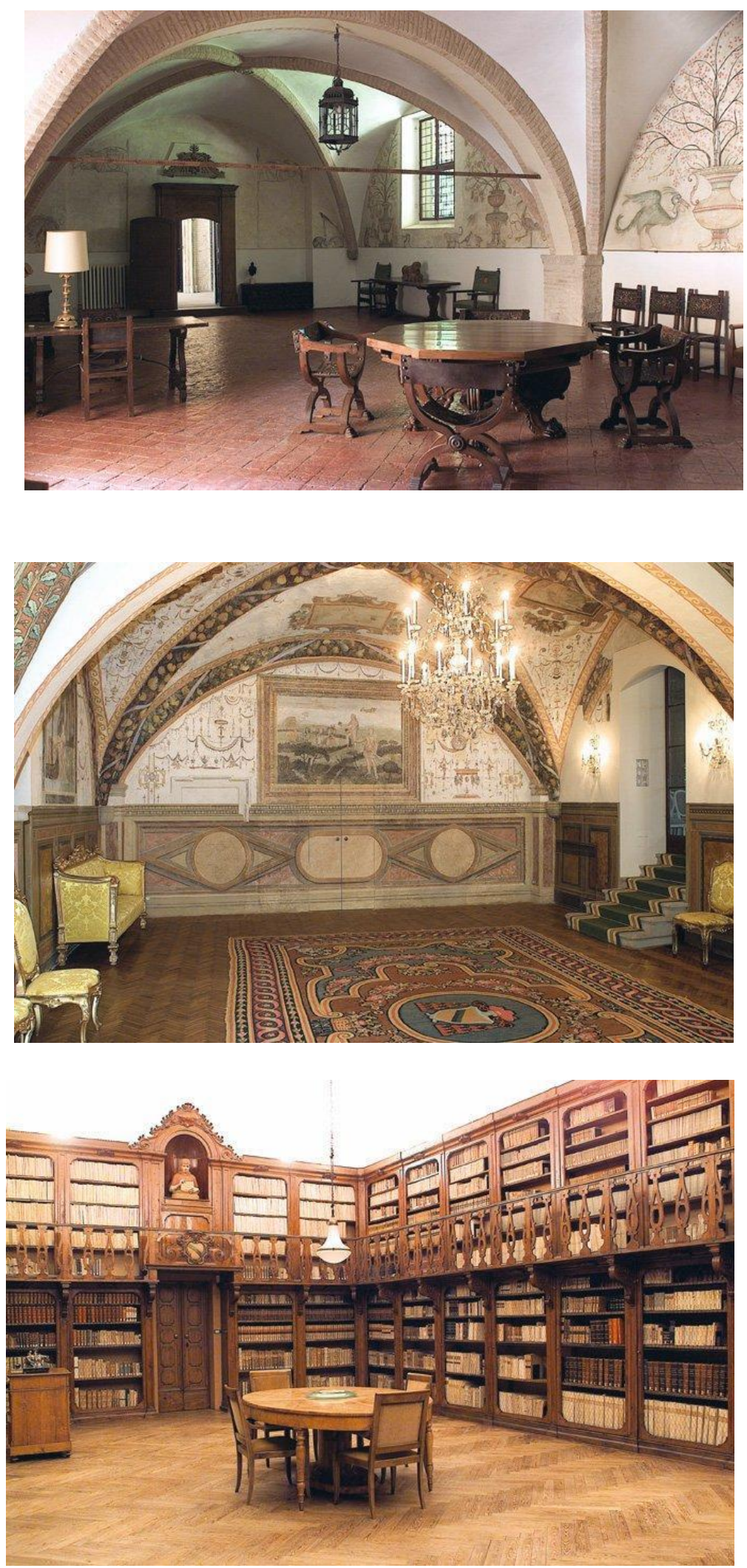

Imagen 35: Vista de sala común d planta baja, se utiliza como comedor.

Imagen 36: Vista de la entrada a la capilla

Imagen 37: Vista de la biblioteca 


\section{De Bolonia a España: La repercusión de este modelo en colegios peninsulares}

En los reinos hispánicos, la construcción de edificios de nueva planta para acoger a los colegiales y servir a la enseñanza universitaria no tuvo consecuencias apreciables hasta bien entrado el siglo $\mathrm{XV}^{16}$, por más que se hubieran fundado instituciones comparables a las del resto de Europa. En el siglo XIII, cuando los primeros Estudios Generales habían surgido en la península, Alfonso X el Sabio trazó las directrices para elegir el emplazamiento y las condiciones más adecuadas para estas instituciones pero, seguramente, no previó la construcción de una sede ex profeso ${ }^{17}$. Un siglo más tarde, el canónigo Doménec Pons estableció en la Universidad de Lérida el Colegio de la Assumpta para doce estudiantes pobres en una casa de su propiedad en la plaza de la Zuda, en 1376, pero no será hasta la fundación del Colegio de San Bartolomé en Salamanca cuando se puede empezar a hablar de una arquitectura genuina universitaria que fuera más allá de la adaptación y el uso de edificios preexistentes $^{18}$.

La línea de investigación se centra en las ciudades de Salamanca, Valladolid y Alcalá de Henares porque recogen la construcción, en el siglo $\mathrm{XV}$, de edificios destinados a acoger de una manera permanente las funciones docentes, a través de las cuales la Universidad crea su propio espacio físico de influencia en la ciudad y su imagen arquitectónica.

Estas ciudades representan los ejemplos donde se producen unas transformaciones arquitectónicas y urbanísticas en unas dimensiones y trascendencia difíciles de encontrar en otras ciudades medievales españolasdonde también se habían fundado universidades.

\section{El Colegio Mayor de San Bartolomé o de Anaya. Aparición de la huella italiana (1401).}

Diego de Anaya, siendo Obispo de Salamanca, tuvo la idea, en 1401, de fundar un colegio universitario en un edificio de nueva planta ${ }^{15}$. Al principio el promotor acogió y mantuvo al primer grupo de estudiantes en una vivienda anexa al palacio episcopal. A su regreso del Concilio de Constanza en 1417, por tierras italianas visitó el Colegio Mayor de los Españoles en Bolonia, cuyos estatutos inspiraron directamente las constituciones del Colegio de San Bartolomé ${ }^{19}$. Puesto que la sede del colegio salmantino empezó a tomar forma después de este viaje de su fundador, se puede afirmar o suponer que el edificio boloñés pudo servirle de modelo

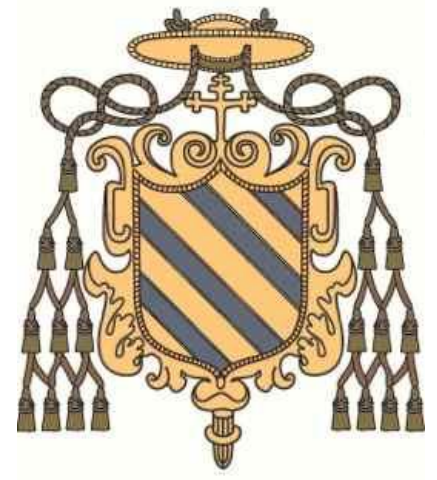

Imagen 38: Escudo del Colegio de san Bartolomé 
arquitectónico, tanto más plausible resulta esta elección cuanto que por aquellas fechas en los reinos hispánicos no existía nada semejante. Esta idea procede cuanto menos de autores del siglo $\mathrm{XVIII} \mathrm{que} \mathrm{pudieron} \mathrm{recoger} \mathrm{una} \mathrm{tradición} \mathrm{poco} \mathrm{documentada}{ }^{20}$.

En este caso, el emplazamiento en el casco urbano de Salamanca, dando directamente a una amplia plaza. En la elección del mismo, antes que la tranquilidad y economía que podía reportar un lugar apartado y libre, Diego de Anaya optó por darle visibilidad dentro de la ciudad ${ }^{21}$. A diferencia del colegio boloñés, todas las fachadas lindan directamente con las calles, no hay un recinto delimitado por murallas en el interior.Toda la organización del conjunto se va a disponer de manera análoga a la del Colegio de San Clemente, partiendo del claustro, que en este caso también consta de dos plantas de altura. 


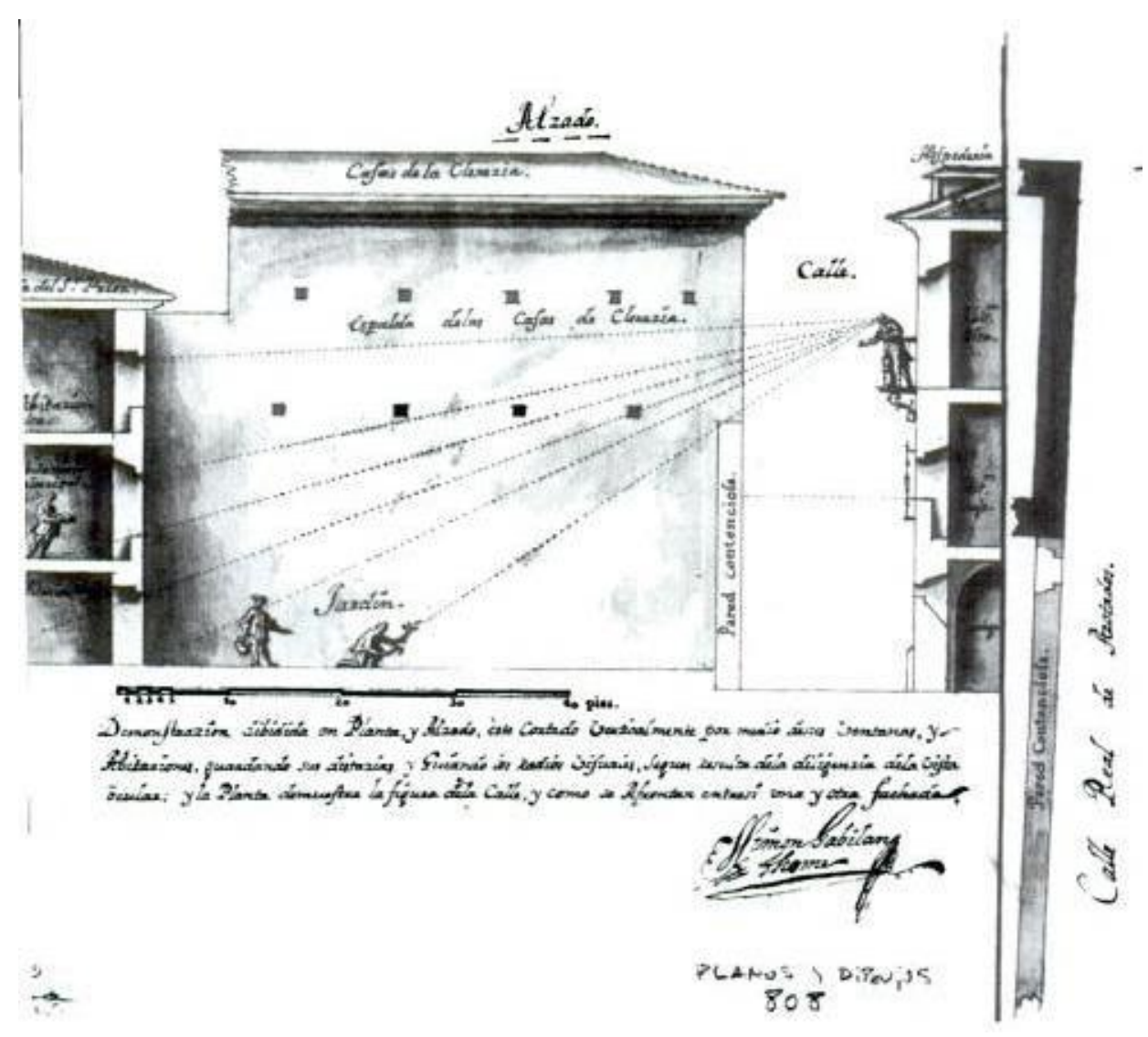

Imagen 39: Planos que se utilizaron para la construcción del colegio

Imagen 40: Planta claustral del colegio. Se accede a las logias por esquinas. Tanto las habitaciones como las zonas comunes tienen entrada a través de las logias.

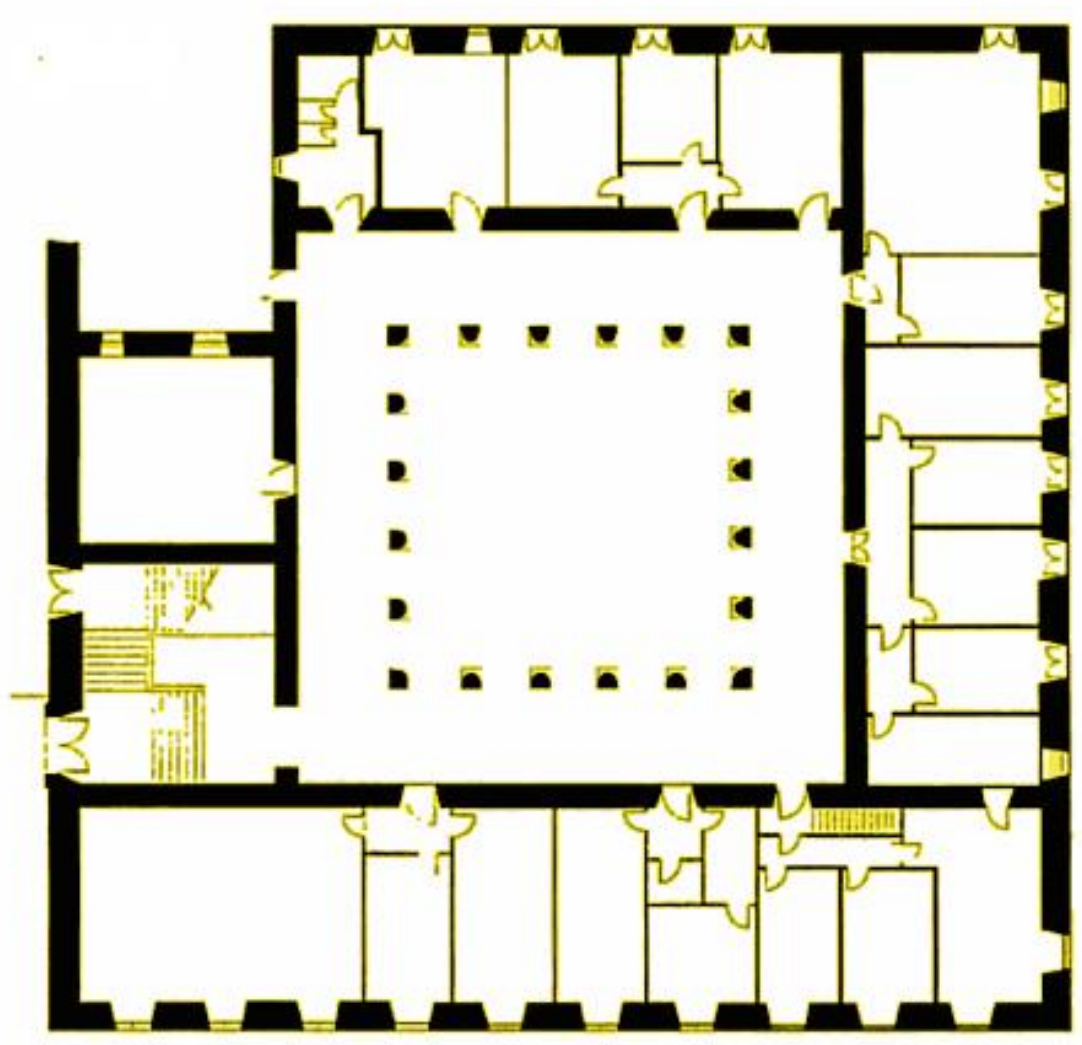


En la dependencia arquitectónica entre el Colegio de España y el de San Bartolomé puede surgir una objeción que atañe a la duración de las obras. Éstas empezaron en Salamanca en 1413 y estaban lo bastante avanzadas el 27 de diciembre de 1418 como para que Diego de Anaya, a la sazón arzobispo de Sevilla, pudiera inaugurar la nueva sede colegial, aunque prosiguieron las compras de solares y casas junto a la fachada y el jardín para completar el edificio a lo largo del siglo XV. Tal circunstancia sugiere que el colegio salmantino fue configurándose poco a poco en lo arquitectónico como había sucedido en lo institucional, sin que hubiera un proyecto unitario, coherente y de rápida ejecución como el que caracterizaba al de la fundación albornozianatomado como modelo. El fundador del colegio, Diego de Anaya, tenía una gran cultura bibliográfica ${ }^{22}$, lo más probable es que la inspiración en la arquitectura del Colegio de España fuera genérica. Desde luego, la fidelidad con la que se adoptaron los estatutos boloñeses para las constituciones del Colegio de Anayarepercute directamente en la organización funcional del edificio, pues el régimen de vida colegial y la distribución de ambientes estaban totalmente enlazados en el Colegio de España desde el principio, y en Salamanca como en Bolonia, se trataba de integrar el alojamiento de los colegiales y los servicios de la comunidad con los espacios dedicados al estudio y al culto divino ${ }^{23}$.

La monumentalidad de este edificio se potencia con la elección de la piedra como material en la fachada.

Este modelo va a influir de forma directa, con la introducción de algunos matices, en la formación de los siguientes colegios, tanto de la propia ciudad de Salamanca, como de Valladolid y Alcalá de Henares. En cada uno de ellos se interpretará las directrices arquitectónicas del Colegio de los Españoles, cuyo estudio se desarrolla en los siguientes capítulos, así como algunos matices de la trama de colegios de París, Oxford y Cambridge, donde, al igual que aquí, el programa se desarrolla volcado y jerarquizado por el patio. 

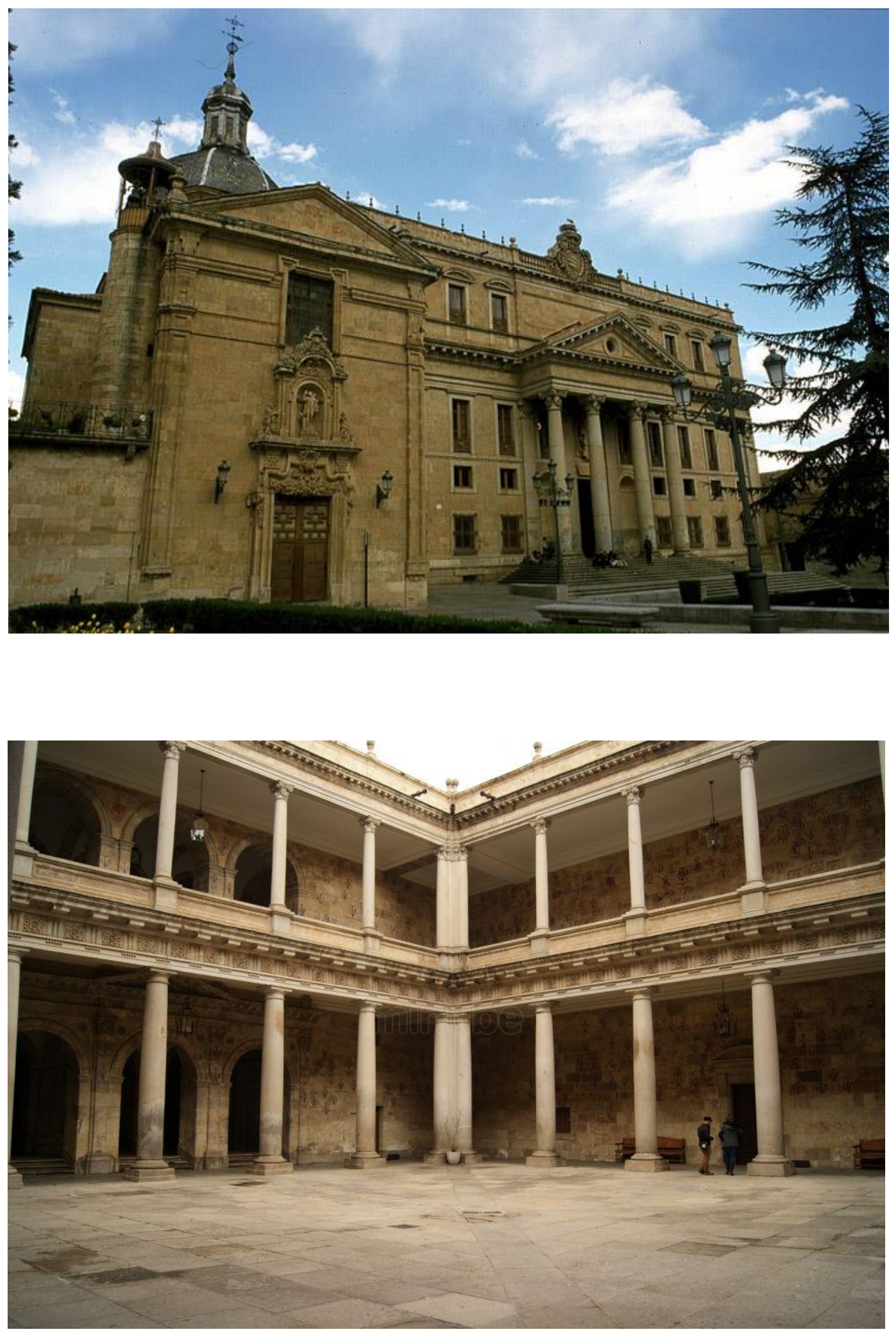

Imagen 41: Fachada principal del colegio.

Imagen 42: Claustro interior, donde se observan las logias en planta baja y planta primera. A través de ellas se acceden a las habitaciones y a las zonas comunes. 
El Colegio de San Bartolomé sirvió tanto de cabeza como de puente para la penetración en la arquitectura universitaria hispana de un tipo de edificio de nueva planta con patio porticado destinado expresamente al hospedaje de los colegiales y a su formación intelectual.

El patio cuadrangular rodeado de galerías en dos alturas y la posición destacada que tienen en el conjunto la capilla y la biblioteca, las dos piezas llamadas a convertirse en los elementos comunes de mayor solemnidad, junto con la fachada, son las coincidencias que se va a probar que existen en sedes universitarias españolas de este periodo.

Con su riqueza y el carácter arquitectónico del edificio, el Colegio de San Bartolomé estaba en condiciones de convertirse en un modelo próximo y prestigioso que inspirara la construcción de otros colegios mayores de la península ibérica y tuviera también cierta resonancia en las sedes de los Estudios Generales dedicados a la docencia, aunque no participasen del albergue de los becarios propio de los colegios.

El colegio dejó de funcionar a finales del siglo XVIII y el edificio se dedicó a ampliar las aulas de la Universidad y actualmente es laFacultad de Filología de la Universidad de Salamanca. Fue refundado hacia 1940 y está en otro edificio.Junto al colegio se encuentra la Hospedería(1715) de Joaquín Churriguera, que alojaba a estudiantes que se pagaban los estudios sirviendo a otros estudiantes nobles y ricos que ocupaban el Colegio. Hoy en día se utiliza para aulas y despachos y sus antiguas caballerizas albergan la cafetería de la Facultad.También se encuentra anexa la barroca iglesia de San Sebastián, antigua capilla del colegio y actualmente Parroquia de la Catedral.

\section{VALLADOLID}

\section{El Colegio Mayor Santa Cruz (1486)}

Salamanca y Valladolid construyeron nuevas sedes para sus universidades durante el siglo XV. En el Estudio Salmantino las obras comenzaron en 1415 , como se acaba de exponer, y se dilataron hasta finales de siglo.

El Cardenal Pedro González de Mendoza fundó en 1486 el Colegio de Santa Cruz con un propósito que tiene tanto que ver con la idea de magnificencia como con la intención benéfica de este tipo de instituciones universitarias

El edificio se configura en torno a un patio porticado con triple galería, una capilla en el lado opuesto del acceso principal y una biblioteca, similar al modelo boloñés. La Universidad de Valladolid 
tuvo el mecenazgo del almirante de Castilla, Alfonso Enríquez, entre 1479 y 1492 aproximadamente. Como en Salamanca, el núcleo es un patio interior cuadrangular con triple galería de arcadas, la capilla en la planta baja y una escalera claustral para acceder a la planta superior.

Con pocos meses de diferencia, se establecen en esta Universidad Castellana los colegios de Santa Cruz y San Gregorio ${ }^{24}$.

La obra estaba casi terminada en $1491^{25}$ y consta de un patio cuadrado, con tres galerías de arcadas que tienen reminiscencias del modelo boloñés en su relación de alturas, en la combinación de arcos rebajados y de medio punto y en detalles como las columnas con basas cuadradas en la planta baja y de ocho lados en las superiores ${ }^{26}$. Sin embargo, será la colocación de la capilla con su sacristía en el lado sudoeste, junto al zaguán, y ajena por tanto a la pauta que se había marcado en el Colegio de España, una de las soluciones más influyentes del edificio en la posterior arquitectura colegial hispánica. Al otro lado del zaguán se situaba el aula de grados y ocupaba toda la planta alta oeste con una amplia biblioteca. La presencia de estos espacios abovedados determina la aparición de los contrafuertes en la fachada principal y es uno de los rasgos singulares de este edificio vallisoletano. En esta obra, se pueden establecer vinculaciones con el Renacimiento temprano italiano, patentes en las portadas de la biblioteca y en el cuerpo central de la fachada principal, deben atribuirse a la influencia de uno de los sobrinos del cardenal, Íñigo López de Mendoza conde de Tendilla, que sirvió a los reyes católicos como embajador en Florencia y en Roma $^{27}$.

En los documentos consultados, algunos autores atribuyen el diseño al arquitecto Enrique Egas, mientras que en otros se defiende que se desconoce el arquitecto autor del edificio ${ }^{28}$. Se sabe con seguridad que en su construcción participaron los canteros Pedro Polido y Juan de la Riba, que levantaron la fachada principal abriendo en sus paños unas ventanas góticas ${ }^{29}$. El edifico al final no se derribó, sino que se adaptó y se finalizó siguiendo los criterios del nuevo estilo. Esta actuación se produjo a partir del año 1490 recayendo bajo la responsabilidad sobre el arquitecto Lorenzo Vázquez de Segovia, al que el cardenal contrató como maestro de obras, siendo el artífice de la arquitectura renacentista del proyecto ${ }^{30}$.

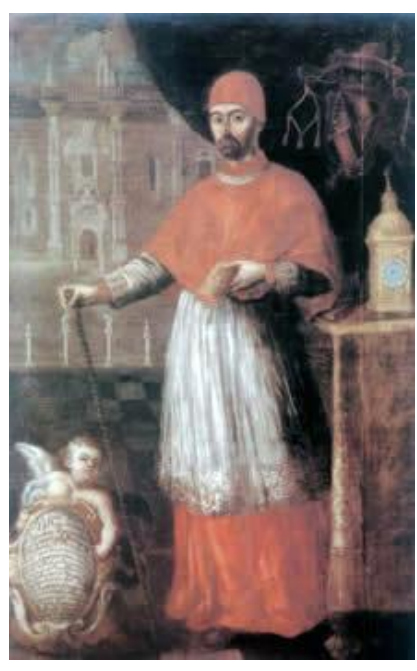

Imagen 43: El cardenal D. Pedro González de Mendoza, fundador del Colegio.

Imagen 44: Placa situada en las pilastras de acceso con la insignia del colegio.

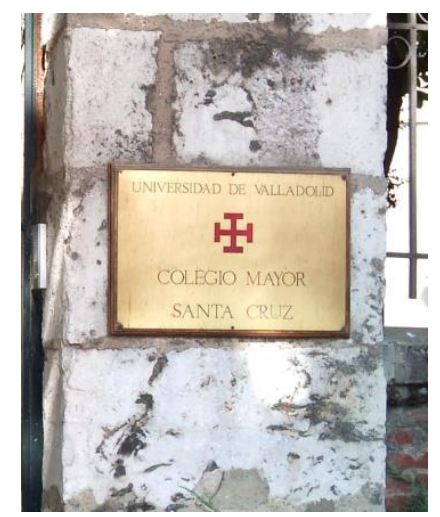




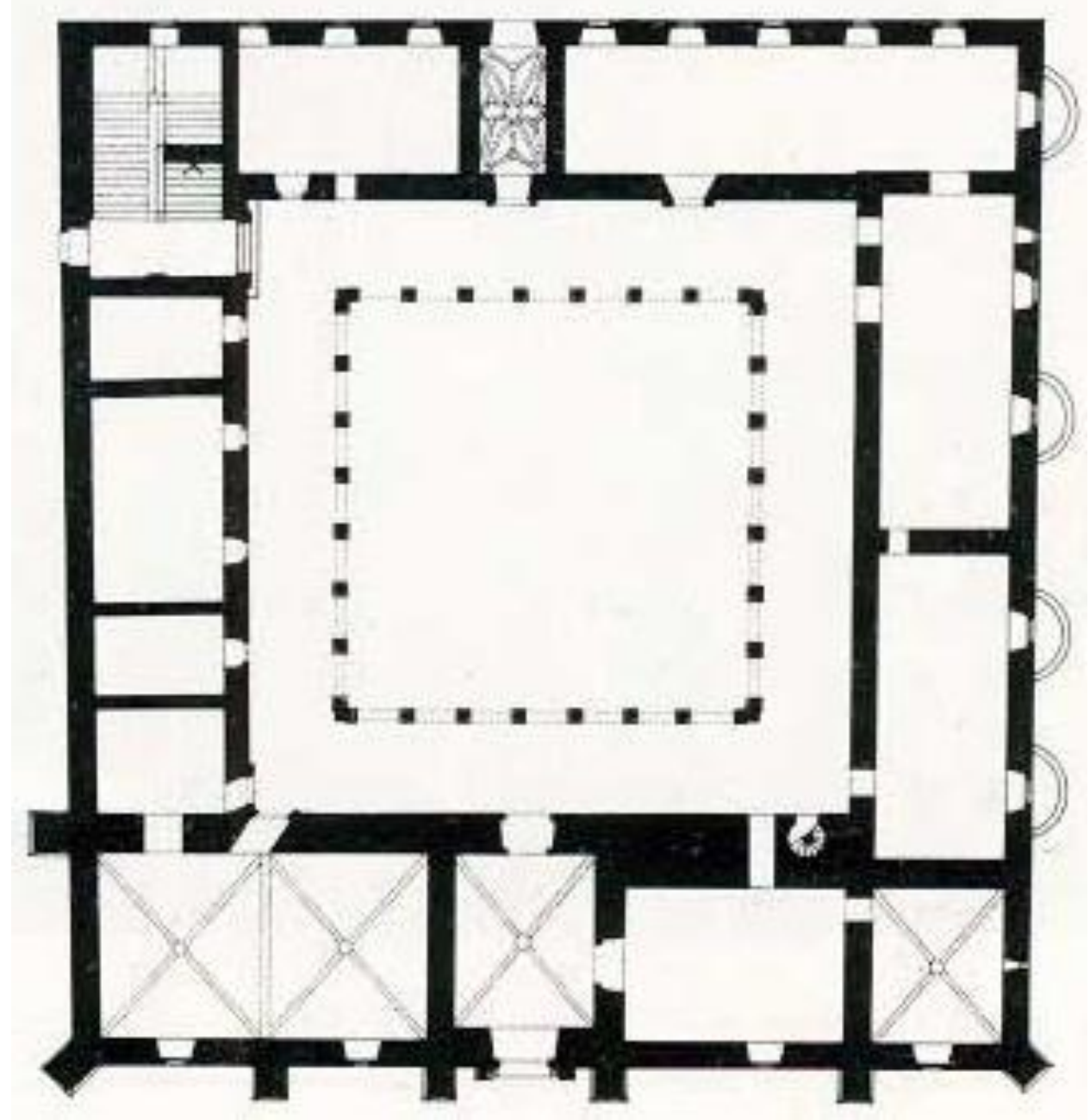

Imagen 45: Planta baja del colegio Santa Cruz.

Imagen 46: El colegio tiene la entrada principal vinculada a jardines.

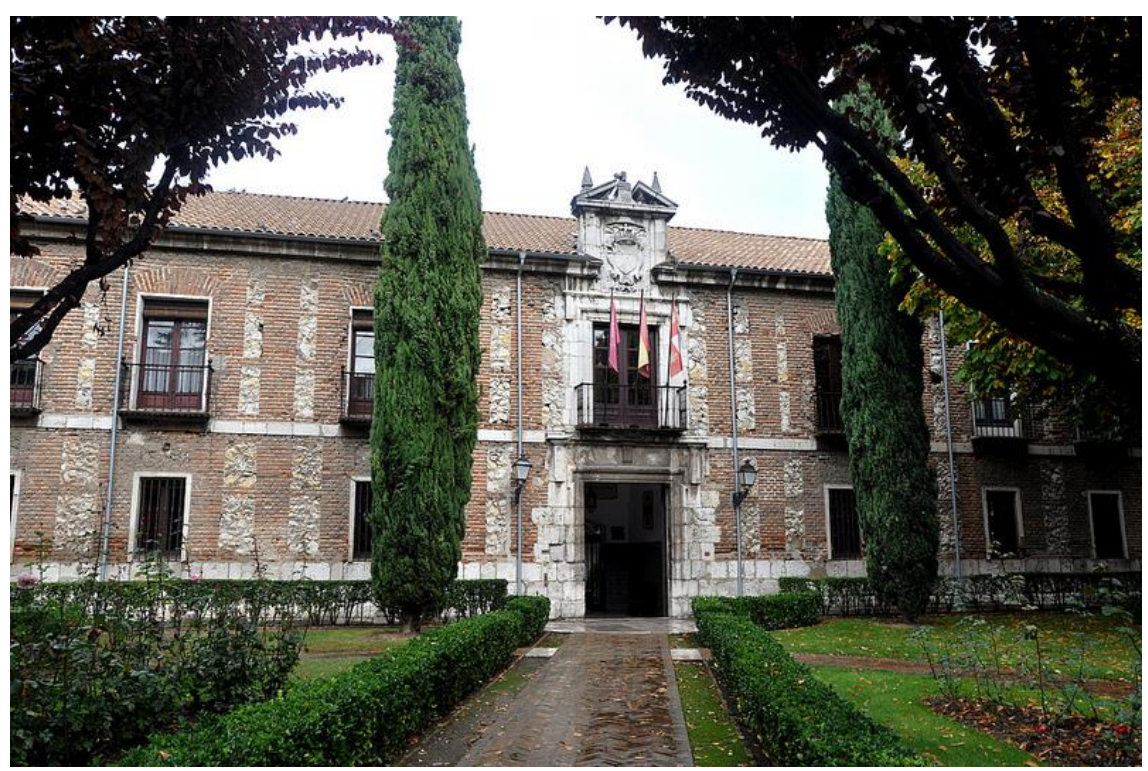



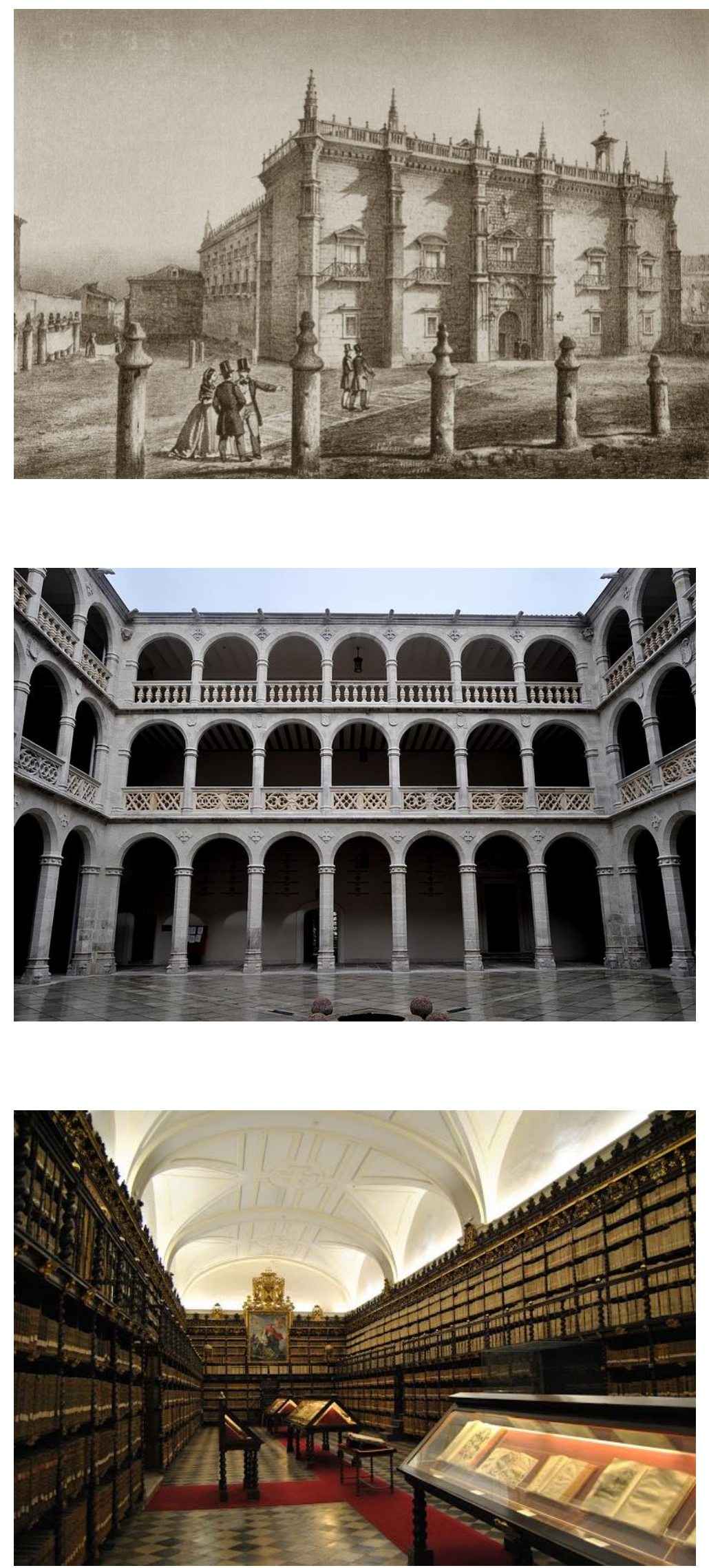

Imagen 47: Dibujo de la

fachada principal (siglo XVII)
Imagen 48: Claustro con triple galería de arcadas.

Imagen 49: La librería ocupa los cuatro lados de un amplio salón que da en su primer piso a la fachada principal. Su misma localización en la crujía de la planta noble, sobre la Capilla y el Aula General expresanelevada consideración.

Imagen 50: Detalle de entrada a la biblioteca.

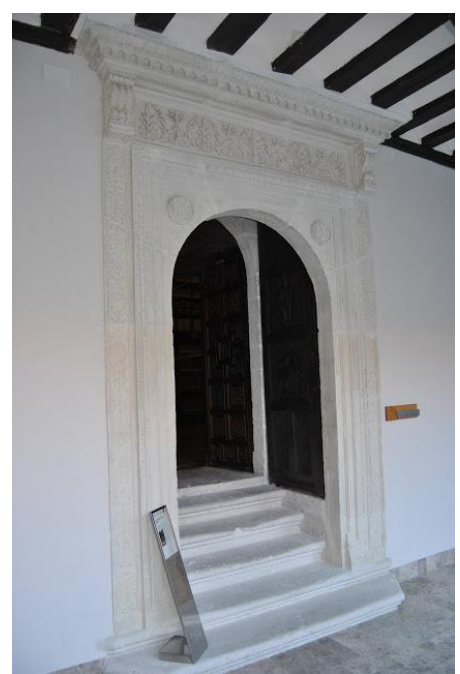


El claustro continúa en este Colegiocomo el elemento organizador de los espacios. La complementariedad de los distintos ambientes, transmite la función de autosuficiencia como en los monasterios vistos anteriormente.

La construcción fue finalizada en lo esencial en el año 1491, como lo indica una inscripción situada en el zaguán del mismo, inaugurándose al año siguiente, en el que se trasladaron los colegiales.

\section{El Colegio Mayor San Gregorio (1486)}

El Colegio de San Gregorio se construye en esta misma ciudad entre 1486 y 1489 por voluntad del dominico y confesor de los Reyes Católicos, fray Alonso de Burgos ${ }^{31}$. La fundación debía hospedar dieciséis colegiales, frente a la veintena prevista para Santa Cruz, y mantiene una relación funcional con el vecino convento dominico de San Pablo ${ }^{32}$. Por ello, a través de la fastuosa fachada esculpida se accede a un modesto patio que comunica, por un lado con la capilla, discurriendo por un corredor construido en 1499 por Simón de Colonia33, y por otro, en eje quebrado, desemboca en el consabido patio cuadrado del colegio. Las salas de planta baja servían de aulas de artes y teología, con una de ellas reservada, probablemente, para la colocación de grados. En la planta alta, la pieza mayor y más suntuosa es la biblioteca y da al mismo muro que la portada principal, recargado tapiz de piedra suspendido delante del pequeño patio de estudios que abrocha el colegio y el convento. En el patio mayor, las proporciones recuerdan al de Santa Cruz, pero en las arcadas de las dos plantas hay un punto entre fantástico y orgánico ${ }^{34}$ en la combinación de fustes sogueados, festones y antepechos de ajustada ornamentación que torna en austera la imagen del patio del Cardenal Mendoza35. Se alcanza la galería superior por una escalera de dos tramos paralelos, con densa decoración en almohadillado, balaustres y tracería gótica bajo techumbre de madera, que ignora la simétrica y sencilla solución boloñesa de la escalera doble ${ }^{36}$.

A modo de conclusión, los dos colegios vallisoletanos, con los precedentes salmantinos, precisan el programa constructivo de este tipo de instituciones y ofrecen una gama de soluciones que serán retomadas o adaptadas en casos venideros españoles, en un periodo de experimentación que abarca desde mediados del siglo XV hasta el siguiente siglo. De éstos derivan, con ciertas modificaciones evidentes y comprensibles debidas a la personalidad de cada uno de sus promotores, su dotación económica y su emplazamiento, obras que se describen sucintamente a continuación como el Colegio del 
Arzobispo Fonseca, el Colegio de Cuenca y el de Oviedo en Salamanca, y cabe resaltar, a modo de nota, al Colegio Fonseca de Santiago de Compostela, de Juan de Álava; y el Colegio de Sancti Spiritu de Oñate, que busca intencionadamente el parecido con el de Santa Cruz en la planta y en la distribución de ambientes ${ }^{37}$. 


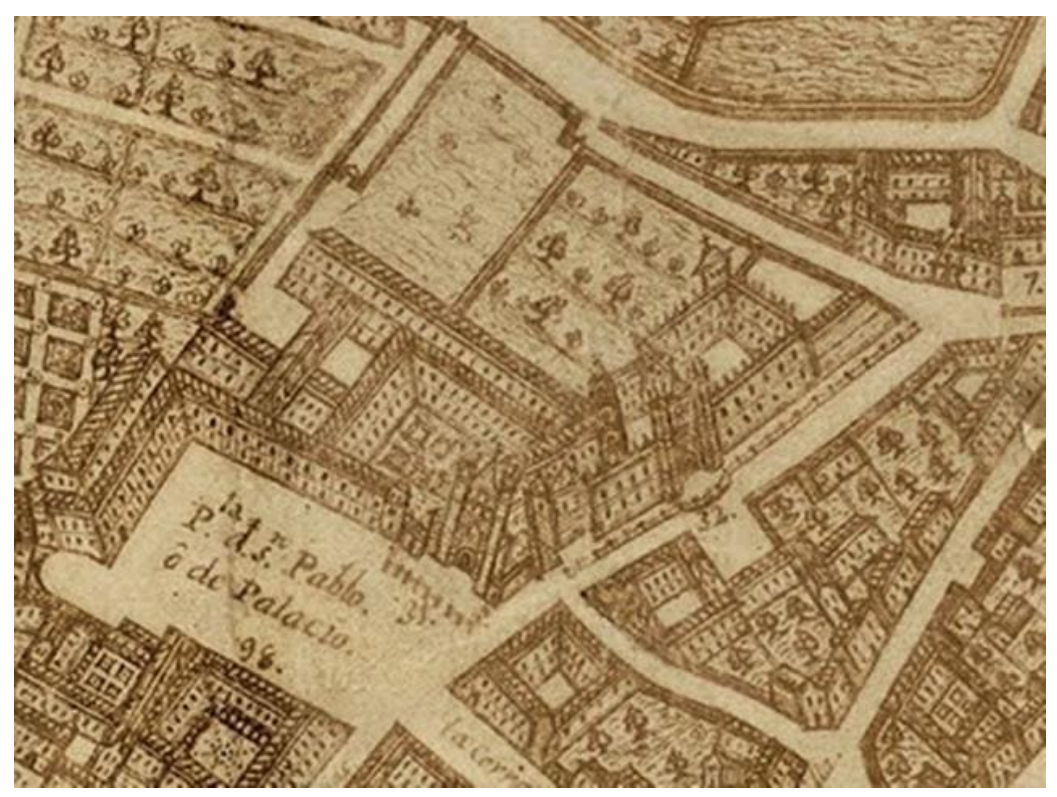

Imagen 51:

Emplazamiento del colegio de San

Gregorio

Imagen 52: Planta del colegio, donde se puede ver el claustro cuadrangular, la escalera se sitúa en la galería este y el acceso principal está vinculado a un patio previo.

Imagen 53:
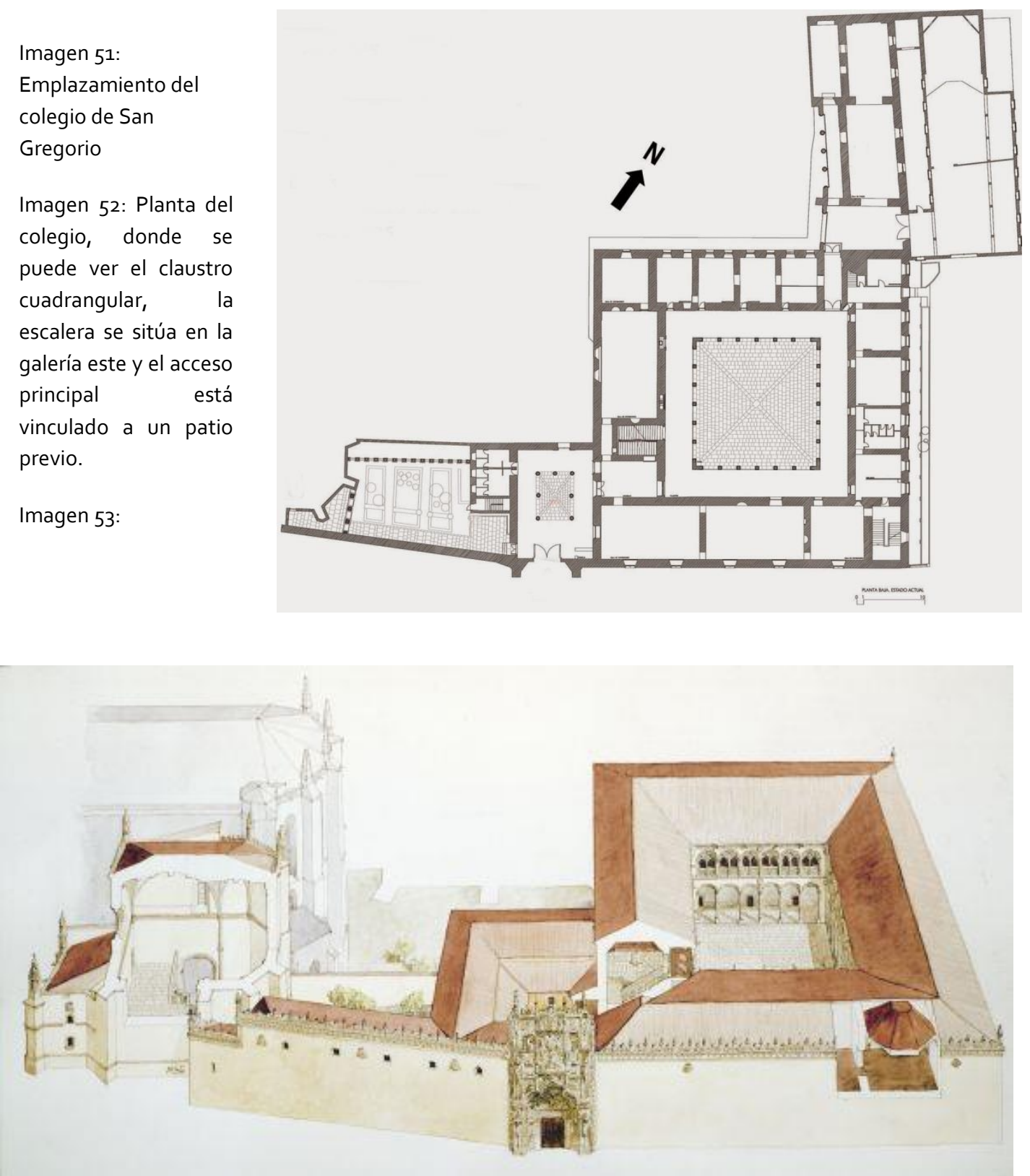


\section{ALCALÁ DE HENARES}

\section{El Colegio Mayor San Ildefonso (1486)}

La voluntad del cardenal Francisco Jiménez de Cisneros de fundar el Colegio de San Ildefonso, inaugura una nueva etapa al tiempo que culmina experiencias anteriores de Valladolid. En Alcalá de Henares se forja el paradigma de Universidad-Colegio, relativamente fácil de dotar y fundar, aunque de mayor ambición que los colegios de siglos anteriores y capaz de responder a las nuevas necesidades de la Monarquía Hispánica a principios de la Edad Moderna ${ }^{38}$.

La obra Alcalaina, larga y compleja, interesa también por el ambiente intelectual en torno a su construcción y la particular inclinación por la arquitectura de quienes allí se formaron o ejercieron su magisterio como Diego de Sagredo, autor de las Medidas del romano (1526)39, el bachiller Francisco de Carabaña y Bartolomé de Bustamante, no menos que por ser quizá la primera universidad hispana que reservó un título para el maestro mayor de la construcción ${ }^{40}$.

De las obras promovidas por el Cardenal Cisneros poco ha llegado hasta nuestros días. La documentación transluce tanto un sentido práctico en el empleo de los artífices y las técnicas: yeserías, azulejos, muros de ladrillo y tapial y armaduras de madera; como una voluntad de contención en el gasto y la ostentación, la cual llama más la atención a la vista de los precentes inmediatos ${ }^{41}$. Cabe atribuir al franciscanismo del fundador y a los medios limitados con los que contó, este espíritu modesto y pragmático de la primera fase de las obras, inauguradas en 1495.

El Colegio Mayor (1499-1513), la Capilla de San Ildefonso (1508-1515) y el primer patio del Colegio Nuevo (1516-1518), más tarde llamado Trilingüe, se levantan bajo la dirección de Pedro Gumiel ${ }^{42}$, pero salvo el Teatro o Paraninfo (1518-1526) y la capilla, las dependencias colegiales fueron sustituidas tempranamente por nuevos patios. Los patios antiguos de los colegios de San Ildefonso y Nuevo eran de planta cuadrangular, porticados, con arcos escarzanos sobre pilares octogonales de ladrillo. El Teatro, seguramente, es la aportación más notable de cara a que configura un espacio de representación académica para actos públicos y comedias antiguas, que se convertirá en parte del programa constructivo de colegios y universidades futuras ${ }^{43}$. 
Lo que se echa de menos, es un plan de conjunto que ensamblara todas las piezas de la arquitectura universitaria más allá de servirse de los patios como núcleo de cada colegio. Prueba de ello es que la Capilla de San Ildefonso con la sepultura de Cisneros tiene acceso propio y queda separada por un pequeño patio intermedio. La biblioteca quedaría instalada en la primera planta tras la tardía fachada de la Universidad (1537-1553), obra de Luis de Vega y Rodrigo Gil de Hontañón. En un plano de 1564 el núcleo del Colegio de San Ildefonso integraba los de San Pedro y San Pablo, el de Teología y el Trilingue de San Jerónimo con el patio más grande de Escuelas, el de Continuos y el del Teatro rodeados por las aulas universitarias ${ }^{44}$

En tiempos de Cisneros, el Colegio de San Ildefonso recuperaba a su manera el espíritu de la fundación boloñesa de Albornoz en cuanto que se regía por principios de austeridad y funcionalidad, aunque esta última se quedó atrás en la Universidad de Alcalá. Así lo considera una opinión autorizada, como la de Elio Antonio de Nebrija colegial de San Clemente y profesor en Salamanca. Establecido en Alcalá desde 1513, manifestó al Cardenal Cisneros que tenía una nueva fundación magnífica y amplísima, pero puso reparos al sitio escogido y sobre todo a la influencia, a su juicio excesiva, de ala mitra toledana en la institución, al no disponer de mucho patrimonio propio 45 .

Es difícil saber si Nebrija pensaba entonces en Bolonia o tenía más presentes los recuerdos de su estancia salmantina, donde el autoritarismo de la monarquía ya se había dejado sentir, pues su testimonio llega a través del también humanista Alvar Gómez de Castro. Sea como fuere, Nebrija parece que ha considerado más las condiciones de autonomía y prosperidad de la fundación que lo acertado de una arquitectura que para entonces ya se había contrastado en otros colegios y Estudios Generales y definía un tipo bien conocido para él en su modelo. 


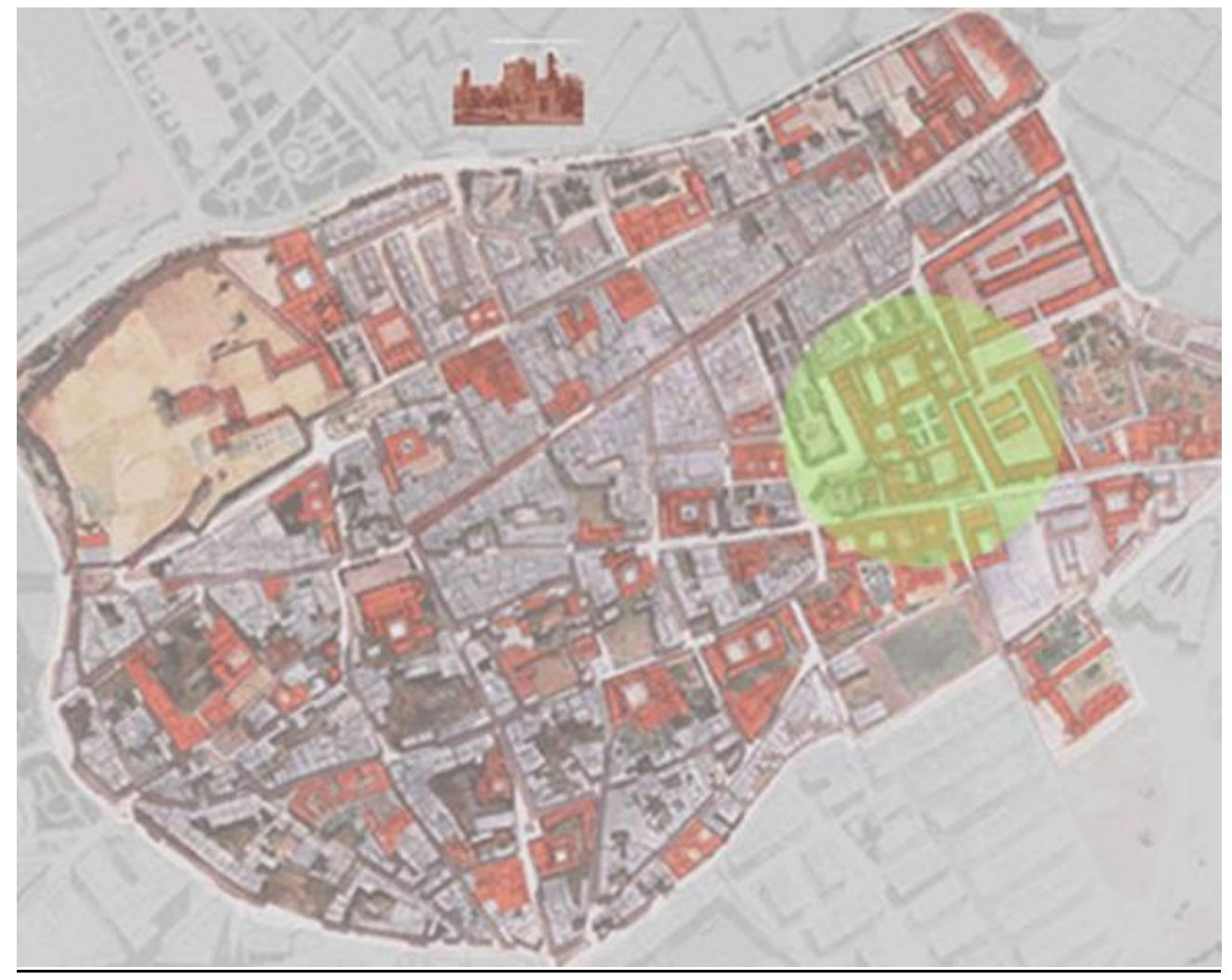

Imagen 54:

Emplazamiento

urbano del colegio de

San Ildefonso

Imagen 55: Vista aérea del claustro principal con acceso a por la entrada principal a través de la plaza de la Universidad. $\mathrm{Se}$ aprecia la vinculación de jardines en los exteriores como en los casos anteriores.

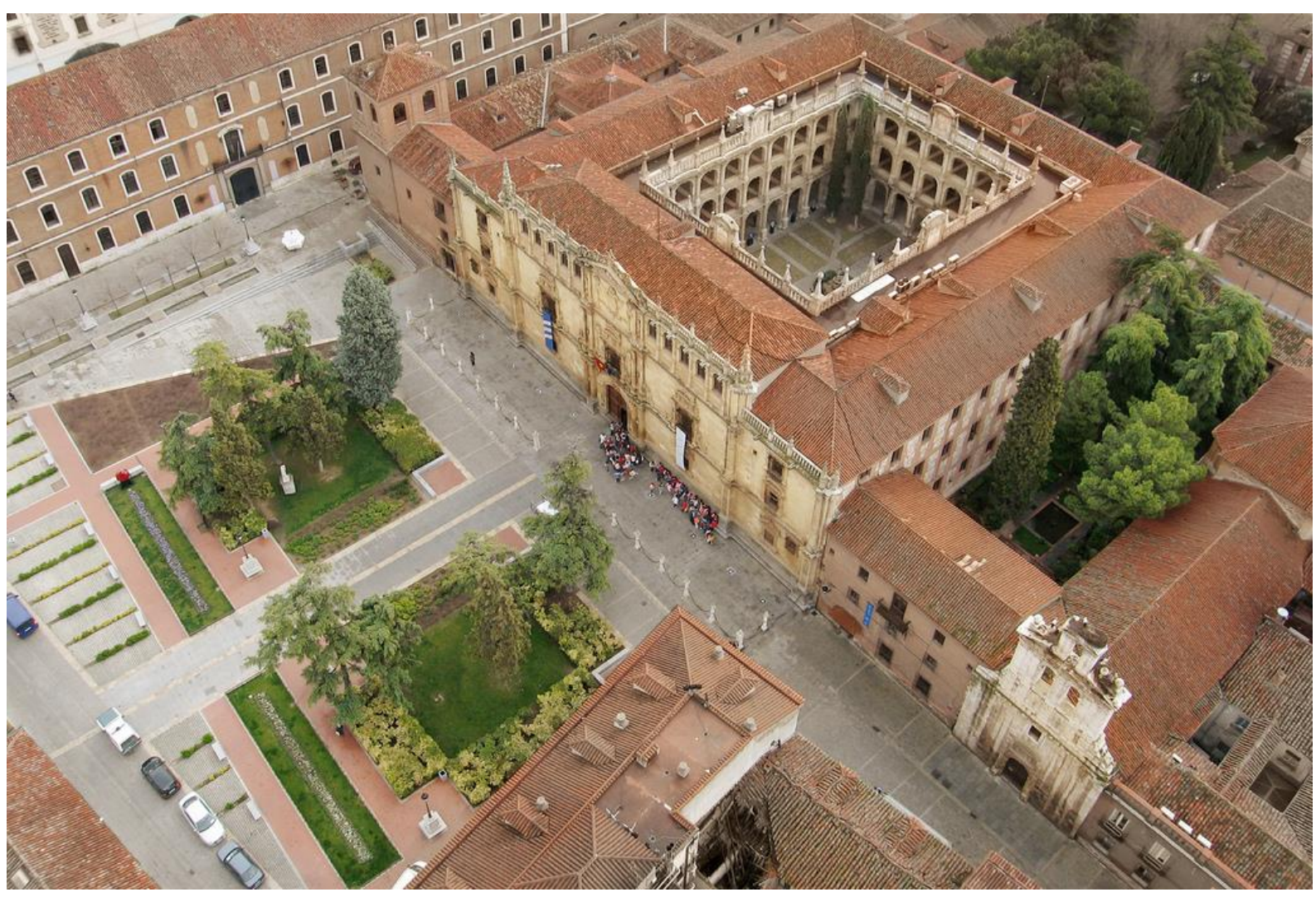




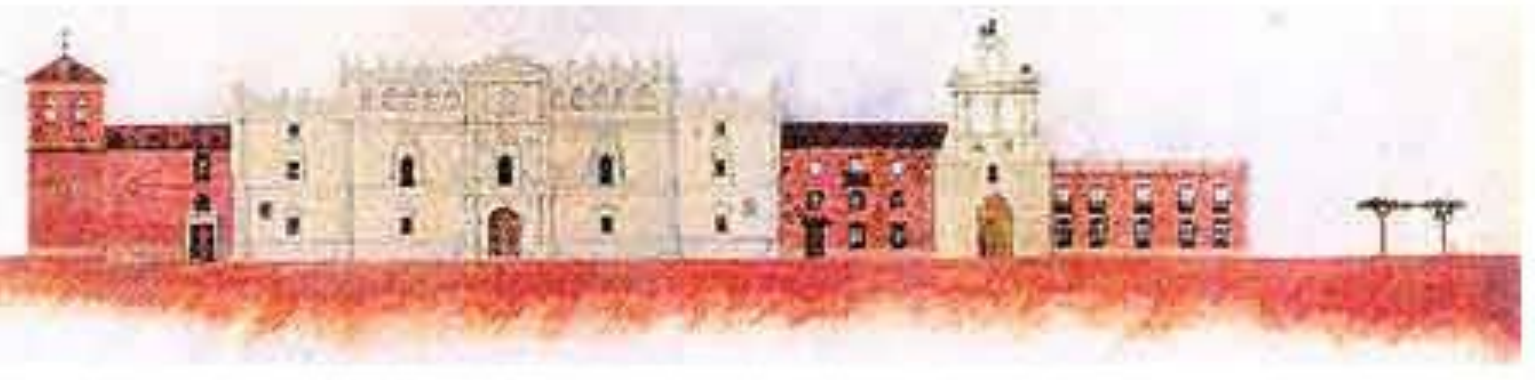

Imagen 56: Alzado principal del colegio desde la Plaza de la Universidad.

Imagen 57: Planta general, con el claustro principal y los adyacentes.

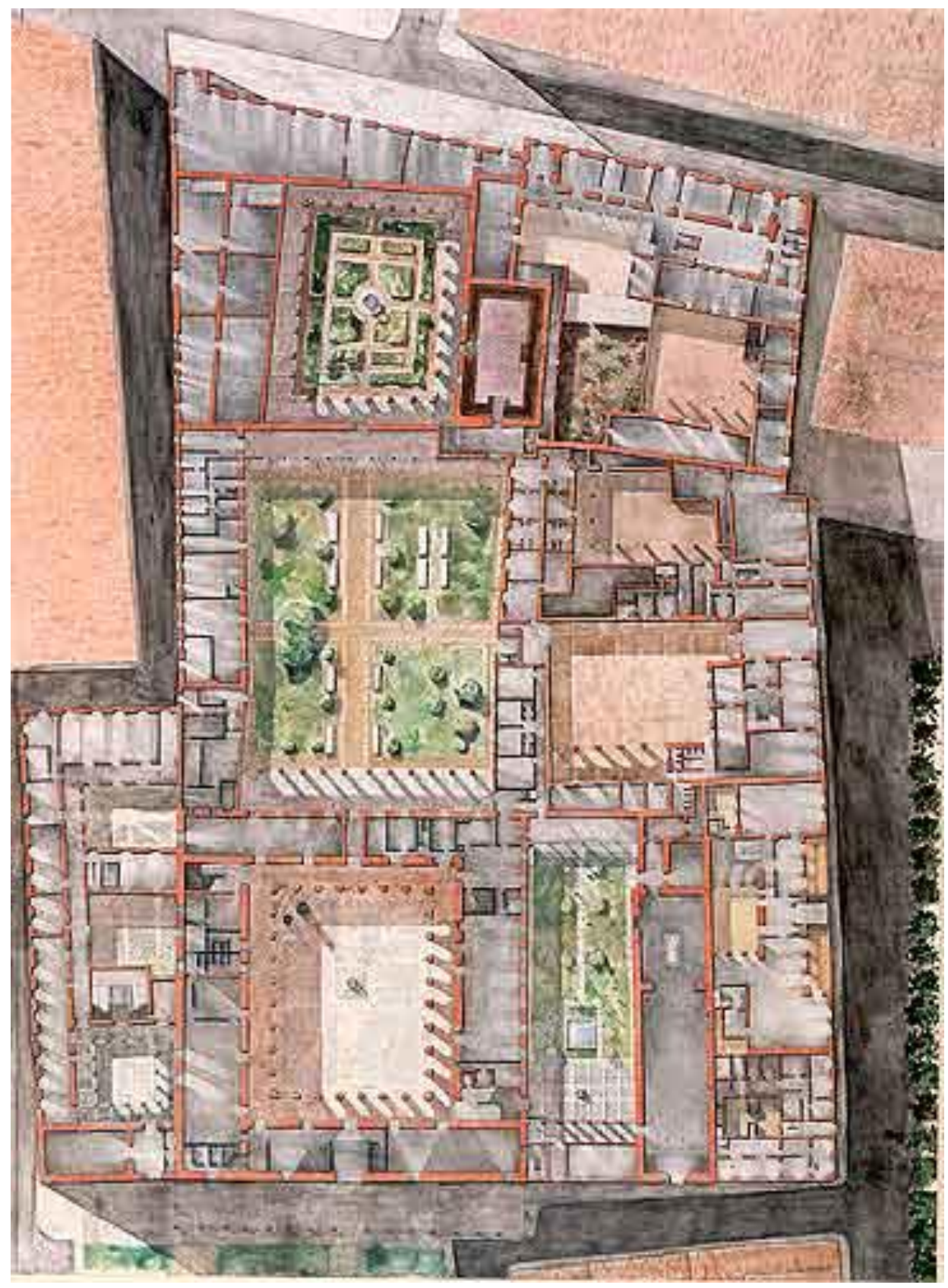




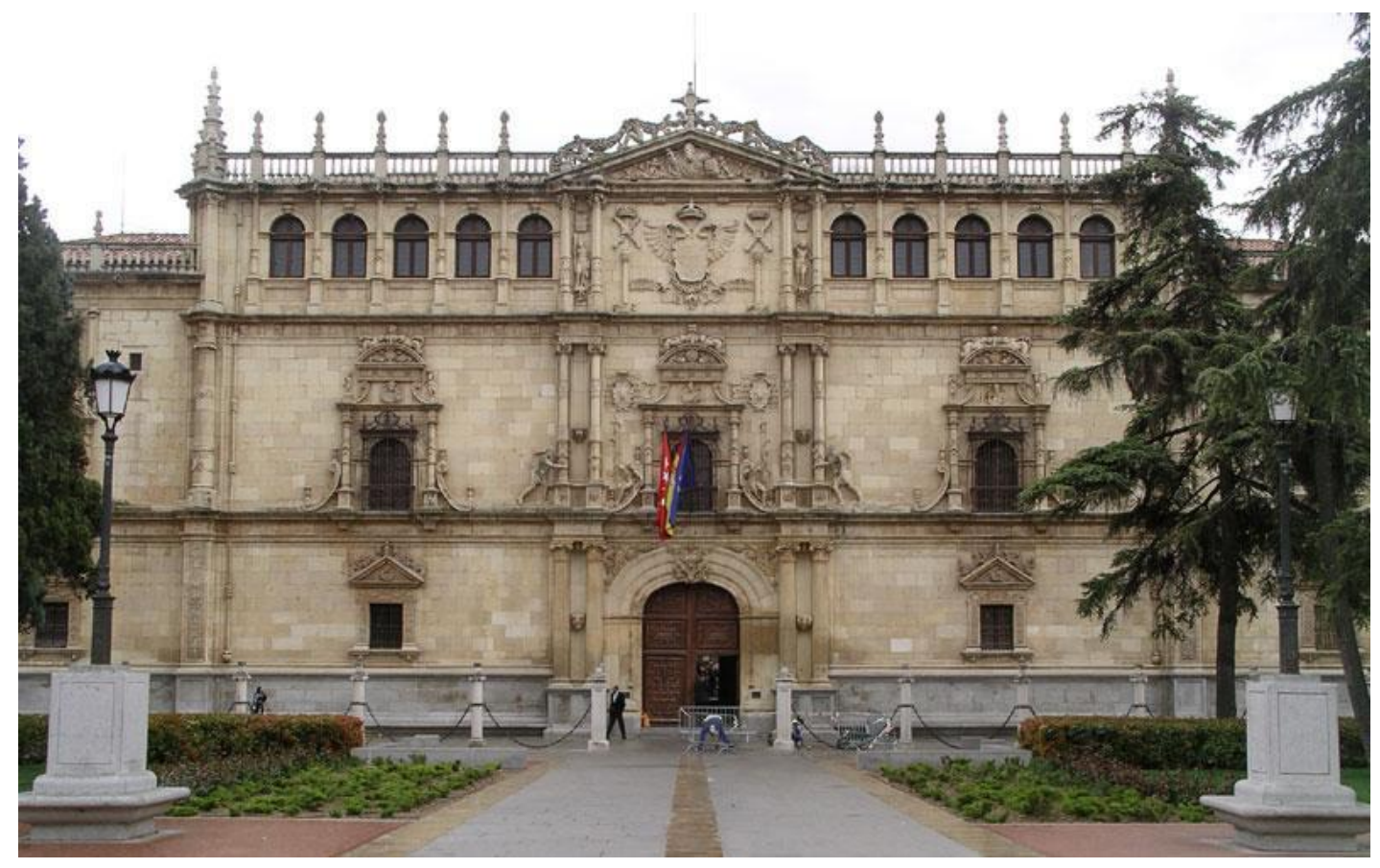

Imagen 58:

Fachada principal

Imagen 59: Claustro principal,

cuadrangular con

tres galerías de altura

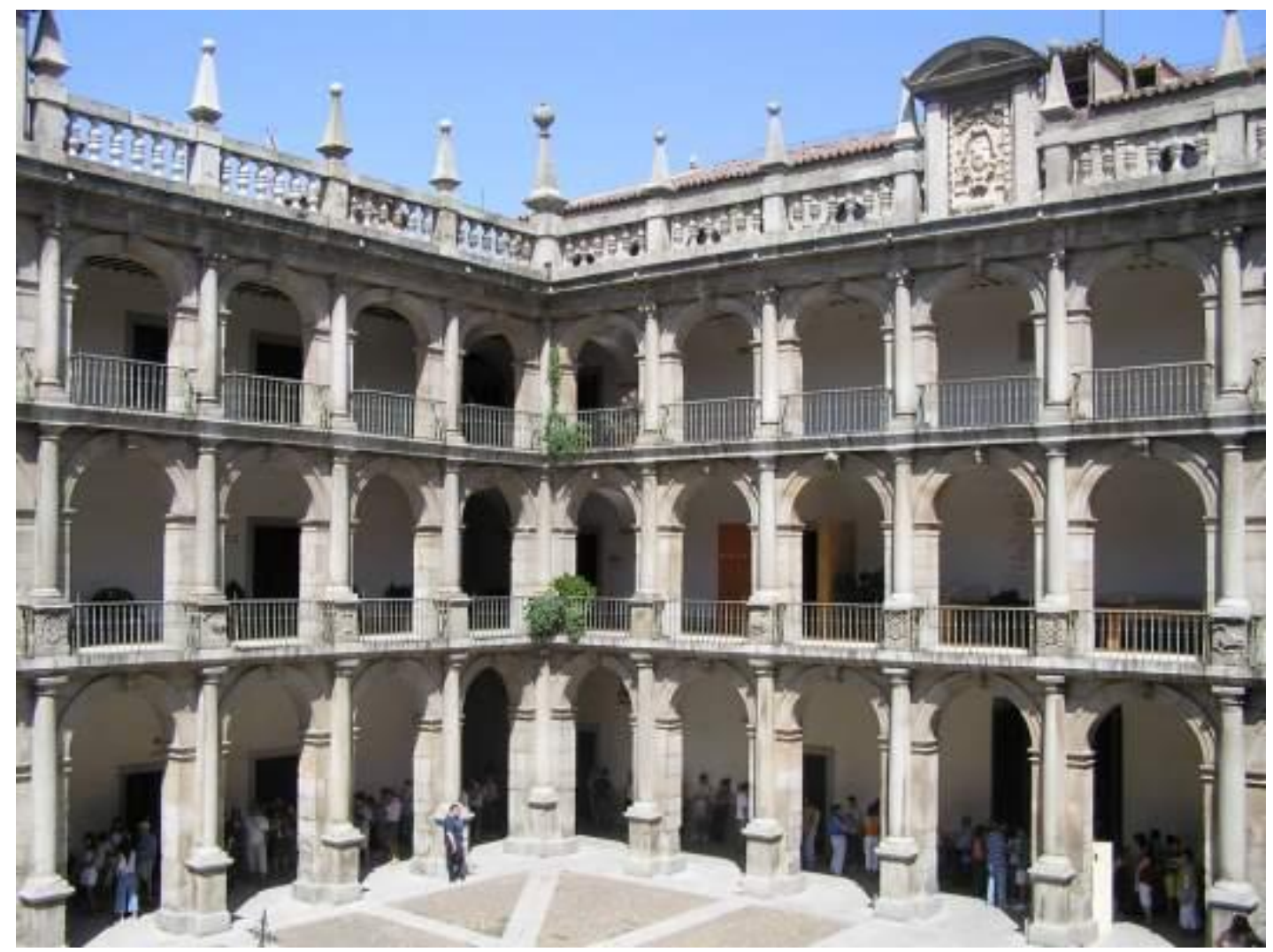




\section{SALAMANCA}

\section{El Colegio Mayor de Fonseca (1519)}

Más conocido como Colegio del Arzobispo y más tarde como Colegio de los Irlandeses, es uno de los cuatro Colegios Mayores de Salamanca. Fue fundado en 1519 por Alonso de Fonseca, arzobispo de Santiago de Compostela, para que los estudiantes gallegos tuvieran un Colegio para estudiar en la Universidad ${ }^{46}$.

El nombre popular de Colegio de los Irlandeses es debido, mucho después de su fundación, a que en tiempos de Felipe II, se hizo el Colegio de San Patricio, o de los Irlandeses, para albergar a los estudiantes de ese país que venían a Salamanca por la persecución inglesa a los católicos de Irlanda. En 1838, cuando los irlandeses volvieron a su colegio tras la Guerra de Independencia lo encontraron destruido (los franceses destruyeron muchos edificios universitarios y religiosos para hacer fortificaciones) y se les permitió instalarse en este colegio 47 .

Antes de estudiar a fondo el edificio, conviene exponer algo de su fundador quien, a través de esta obra plantea el anhelo humanista de alcanzar la fama. Sólo así, se explica tal generosidad que rebasa lo simplemente útil y funcional, como lo sería el de una fundación para acoger a un reducido grupo de jóvenes sin recursos económicos, de entre quince y veintitrés años, debidamente tutelados hasta alcanzar los grados de bachiller $y$, en el mejor de los casos, de licenciado y doctor por la Universidad de Salamanca. En 1523 fue nombrado arzobispo de Toledo, por lo tanto Primado de la Iglesia en nuestro país, desde donde apoyó el movimiento erasmista en España ${ }^{48}$. En esta ciudad conoce al nutrido grupo de artistas que hicieron de Toledo uno de los focos más importantes de nuestro renacimiento. Encargó obra a pintores, escultores y arquitectos de la época. En fin, todo refleja en la vida de don Alonso de Fonseca un cumplido perfil humanista ${ }^{49}$.

Es el único de los edificios de los viejos Colegios Mayores salmantinos que se conserva ${ }^{50}$.

Participaron como arquitectos Diego de Siloé, Rodrigo Gil de Hontañón y Juan de Álava. Los trabajos terminaron en 1578. Es un edificio plateresco, de tipo conventual, organizado alrededor de un claustro. Tiene una fachada relativamente sencilla, en la que la única decoración está en la portada. Destaca, además del claustro, la capilla con una curiosa bóveda de planta cuadrada sobre el crucero y un retablo de Alonso Berruguete ${ }^{51}$.

Importa del Colegio de San Bartolomé la disposición tanto de la capilla a la derecha del zaguán como la de la biblioteca a la izquierda de la entrada, en el piso superior. 
El perfil urbano de este Colegio evidencia la vitalidad de la ciudad universitaria y clerical, que en estos momentos está aumentando su caserío dentro y fuera de sus murallas. Dentro del paisaje urbano, destaca el cimborrio de la capilla del "Colegio del Arzobispo". Este edificio se presenta como uno de los más espectaculares de la Salamanca de este siglo, cuando todavía estaba sin concluir la catedral o la extraordinaria iglesia del convento dominico de San Esteban, todos estos obras de Juan de Álava ${ }^{52}$. En este momento, Salamanca está viviendo su particular siglo de oro, que desde el punto de vista arquitectónico, se hace muy interesante a través del amplio repertorio ornamental, que bajo el nombre de plateresco, enriquece superficies, trepa por columnas y pilastras, aflora en medallones y se encarna sobre cornisas y aleros.

Todo este pujante decorativismo, se muestra en los motivos ornamentales de este colegio. El material constructivo principal de este colegio es la piedra de Villamayor, donde la fantasía de sus formas y la maestría de su ejecución evidencian el cambio que se está produciendo en la arquitectura española en general y en la salmantina en particular, entre el viejo sistema gótico y las novedades renacentistas ${ }^{53}$. Una de las razones que hacen a este colegio singular es que ha llegado hasta hoy tal cual y como físicamente lo concibió su fundador, es "el único de los grandes colegios que ha salvado su edificio de renovaciones, de estragos del sitio contra los franceses y de las bárbaras demoliciones susbsiguientes" 54 .

Las dimensiones de las estancias, se repiten de manera proporcional en los colegios salmantinos objeto de estudio, también, como se ha visto en Valladolid, y a diferencia de la forma organizativa de Alcalá de Henares, se puede apreciar que el espacio de conexión entre estancias no atiende a la dualidad interior-exterior.

La vinculación con Santiago hizo que el propio don Alonso de Fonseca III fundara otro Colegio en la capital compostelana al poco tiempo de erigir el Colegio salmantino, de tal modo que el mismo papa Clemente VII, que había dado la bula para el de Salamanca en 1525 , al año siguiente la expide para el de Santiago ${ }^{55}$. Uno y otro permanecerán hermanados en el nombre, pues quedarían bajo la advocación de Santiago Zebedeo el primero y de Santiago Alfeo el segundo. Por otro lado, la fundación del Colegio Mayor de Salamanca, como iniciativa de un prelado, coincide y rivaliza con el gesto de otros obispos y príncipes de la Iglesia que, a lo largo de los siglos $\mathrm{XV}$ y $\mathrm{XVI}$, levantaron a sus expensas estos monumentales edificios que hablaban de la magnificencia de sus mentores ${ }^{56}$. Como el del cardenal don Pedro González de Mendoza y el Colegio de Santa Cruz de Valladolid, como se acaba de exponer, o el del cardenal Cisneros, Colegio de San Ildefonso en Alcalá de Henares. 


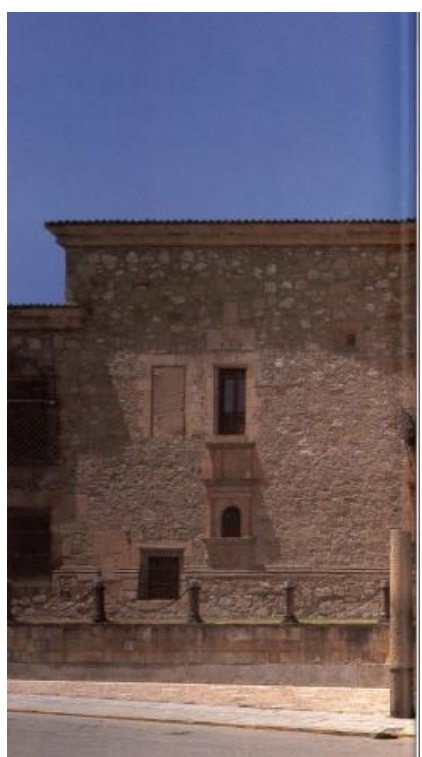

Imagen 6o: Detalle de la fachada. Compuesta de mampostería. Los huecos al exterior son de reducidas dimensiones. El espacio "vuelca al interior" como en todas estas disposiciones claustrales.
El proceso constructivo del Colegio, comienza con parte de un solar cedido por el inmediato convento de San Francisco sobre $1519^{57}$. Cuatro años más tarde, en 1523, se alojaban los primeros cuatro colegiales a falta todavía de mucha obra importante $5^{58}$. Por entonces se iniciaba el gran patio y la portada que se acabarían en $1534^{59}$. Faltaría por rematar la iglesia que pasó de ser capilla del Colegio a templo funerario, donde reposarían los restos mortales de su fundador según había señalado éste expresamente en su testamento, pues de ser enterrado en la catedral de Toledo apenas se le recordaría entre otros muchos y muy importantes prelados ${ }^{60}$. Por ello, y siguiendo el ejemplo de Cisneros que saliendo de Toledo fue enterrado en Alcalá de Henares, don Alonso de Fonseca prefirió volver a su ciudad natal.

Si se ha insistido en los problemas de autoría y trazas es porque la primera impresión que ofrece el edificio desde su fachada es de desconcierto, lo cual evidencia varias cosas. Por una parte los distintos episodios constructivos con sus cambios de criterios y, de otro lado, el relativo desinterés por una fachada unitaria como cabría esperar de una obra renacentista. Frente a la ejemplar concepción de la planta del edificio, donde todo indica claridad compositiva, funcionalismo, geometría y proporción, la fachada del Colegio del Arzobispo resulta descompensada como resultante de un proceso proyectual que atiende a la organización interna del edificio y arrojaal exterior las luces y huecos que necesita pero sin darles la más mínima unidad ni articulación. Es una fachada invertebrada, pintoresca, lo cual no supone un juicio negativo sino más bien cualitativo y muy frecuente en nuestro primer renacimiento. Masque la fachada de un arquitecto parece el muestrario de la habilidad de los entalladores que allí trabajaron, pues son los escultores quienes hicieron fragmentariamente atractiva la fachada que, pese a su carácter renaciente, no resulta a pesar de los esfuerzos del comitente y maestros nada italiana, como cabría esperar de un Diego de Siloé venido de aquellas tierras y esforzado arquitecto a lo romano en tierras del sur $^{61}$. De forma afortunada, intervino Rodrigo Gil de Hontañón en la cabecera y crucero de la iglesia proporcionándole un fuerte volumen coronado por el cimborrio, en la que apoyarse y ganar la nobleza que no tenía ${ }^{62}$.

Cuando se analiza el número, situación y tamaño de los huecos abiertos en el primitivo paño de la fachada no puede por menos que causar perplejidad, sobre todo cuando sabemos del orden y buena arquitectura que se esconden tras ellos. El paño central no es sino una decoración adherida y mal trabada entre sí, posiblemente por una deficiente interpretación de la traza original y de la presencia del granito, menos dúctil que la blanda piedra de Villamayor. De cualquier modo es donde mejor se percibe el espíritu siloesco a pesar de lo ingrato de la proporción de los órdenes y de su indefinición estilística. A la derecha de la portada se ven los dos arcos rasgados de la capilla, de claro perfil gótico, contradichos por los de la izquierda, marcados por una variedad de tipos, unos con bellísima 
embocadura de arquitectura renacentista y otros sólo a medio labrar.

La planta del edificio, al margen ahora de su autor, se inscribe no sólo en la tradición monástica, sino que tiene antecedentes y modelos en los que apoyarse, tanto el desaparecido Colegio Mayor de San Bartolomé en Salamanca como el de Santa Cruz en Valladolid ${ }^{31}$ el siglo XV ofrecía lo que parece perfilarse como modelo para los colegios del siglo $\mathrm{XVI}$, como bien detectó Vicente Lampérez ${ }^{32}$. Es decir, un gran patio o claustro al que se accede desde la calle a través de un zaguán. A un lado de éste se encuentra la capilla y al otro el llamado "general", a modo de aula magna, como sucede en el Colegio del Arzobispo, de tal modo que estos tres elementos dan contenido a la crujía de la fachada. Las demás piezas que no deben faltar como biblioteca, dormitorios o celdas, el refectorio, cocinas y otros servicios se disponen en torno al patio con leves diferencias entre unos y otros colegios dependiendo de que cuenten con una o más plantas, en cuyo caso la escalera claustral en un ángulo del patio será lo más común.

En el caso del Colegio Fonseca de Salamanca, se produce una distribución ejemplar de las que podamos encontrar de un Colegio Mayor, de tal índole que otros lo tomarían como punto de partida33, las celdas se distribuyen en las crujías norte y occidental, formando una escuadra, mientras que el refectorio y cocinas se sitúan a saliente.

Desde el punto de vista de la composición la novedad mayor estriba en el carácter doble de las crujías de los lados este y oeste, encerrando una suerte de corredor cada una. Ello permite situar las escaleras en el centro de cada una de las pandas, de un modo distinto al habitual en otros Colegios Mayores que suele ser en rincón de claustro, posibilitándoles además un desarrollo palaciego. Cada una tiene tres tiros, alma hueca y una formidable caja abierta en sus dos niveles, asegurando luminosidad y vista, siendo las dos escaleras gemelas dos de los puntos fuertes del formidable patio. Ambas están compuestas de modo que su arranque y desembarco en el piso alto coincida con los correspondientes vanos de las galerías bajas y altas. En este sentido, los ejes principales del claustro están muy cuidados en su correspondencia con los pasos más importantes, de tal modo que el de la entrada principal y zaguán correspondecon uno de los ocho arcos del claustro bajo y no, como sucede en Santa Cruz de Valladolid o en el Colegio de Oñate, donde el eje de la entrada viene a tropezar con uno de los apoyos de las arquerías.

De la planta alta debemos destacar la biblioteca que, situada encima del "general", recibe luz desde la fachada principal. La sala rectoral, piezas para criados, etc., irían completando el programa de necesidades propuesto por el rector Pérez de Oliva a Diego de Siloé.

El claustro, pasa por ser una de las joyas del renacimiento español. La elegancia de las proporciones tanto de una como de otra planta es exquisita, siendo posible la esbeltez de sus apoyos por el hecho de 
llevar un forjado de madera sus crujías, de tal modo que no ejerciendo empujes no necesitan estribos exteriores. En lugar de éstos encontramos un orden casi corintio adosado a los pilares de los corredores bajos y otra serie de columnas abalaustradas en el piso alto $^{63}$. La solución abalaustrada es un hallazgo feliz para acompañar la difícil y poco clásica proporción de los mencionados arcos carpaneles $^{64}$. Por encima de la cornisa vemos los flamero sque resaltan los ejes de apoyos de todo el claustro, contribuyendo así a resaltar el ritmo de los alzados en una sólida articulación. El patio tiene, en resumen, la sólida estructura compositiva de la que carece la fachada del Colegio. No es necesario insistir que el detalle escultórico tanto de los elementos arquitectónicos como de los relieves y medallones es absolutamente extraordinario, y en ello debió de tener bastante responsabilidad Pedro de Ibarra,. Lo mejor que le ha podido suceder a este claustro es la reciente intervención que le ha devuelto la alegría perdida en la anterior restauración, cubriendo la ingrata parte de sus muros de mampostería con una piel blanca, comola tuvo siempre. Ello hace que las partes vivas del claustro destaquen con fuerza, recobrando protagonismo los perfiles y molduras, a la par que gana luminosidad y belleza.

A la capilla se accede desde el zaguán o vestíbulo cubierto con una bóveda nervada muy plana bajo la que se alza la portada de la capilla propiamente dicha. Está concebida como un arco de triunfo romano, con los característicos motivos de "candelieri" de tradición cuatrocentista ${ }^{65}$. En el interior se percibe pronto la obra de Álava en sus dos primeros tramos, con los soportes fasciculados que tanto le gustaban y donde ningún elemento interrumpe esta molduración vertical que encuentra su desarrollo continuo en las ricas nervaduras de las bóvedas ${ }^{66}$. Por el contrario, llegando al crucero nos sale al paso el peculiar estilo de Rodrigo Gil de Hontañón en el que los soportes, ménsulas, nervaduras, ventanales, proporción, luz, todo muestra que pese a la solución estrellada de sus bóvedas, nos encontramos ya lejos de la Edad Media ${ }^{67}$. Bajo el gran cimborrio descansaron, en el centro, los restos del fundador hasta que a finales del siglo XVIII se trasladaron a una suerte de arcosolio que hoy los cobija ${ }^{68}$.

Uno de los apuntes más importantes que se puede resaltar de este colegio es la similitud que tiene con el esquema de los colleges de Oxford y Cambridge, donde los espacios vuelcan hacia el patio.

Fue declarado Bien de Interés Cultural en 1931.

Actualmente se utiliza como residencia de postgraduados y para actos culturales. Anexo se encuentra el edifico de la antigua Hospedería, edificio barroco dedicado a Centro de Posgrado de la Universidad de Salamanca. 
Imagen 61: Puerta principal del colegio.

Imagen 62: Fachada principal del colegio. Acceso principal con la capilla situada a la derecha y espacios de uso común a la izquierda.
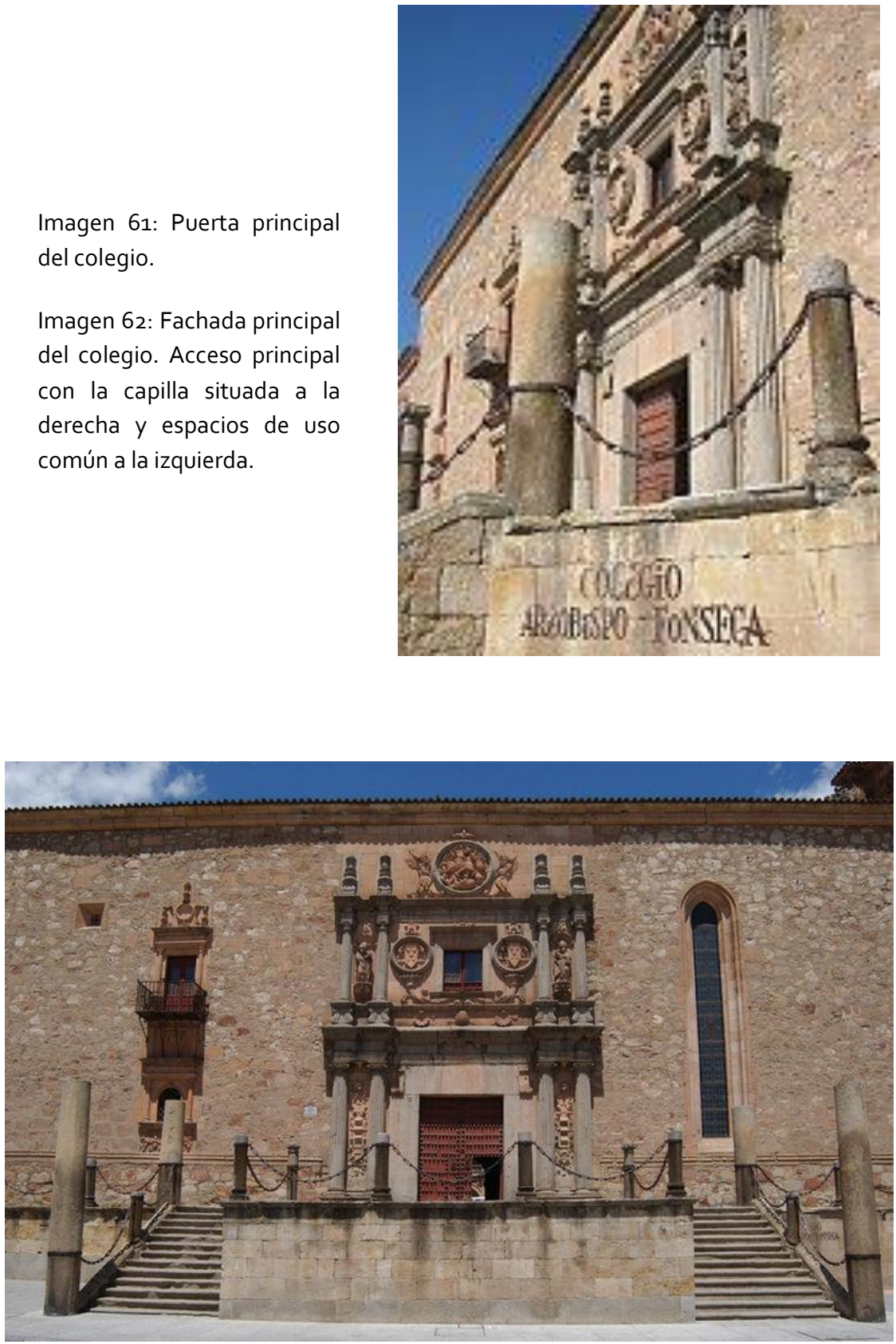


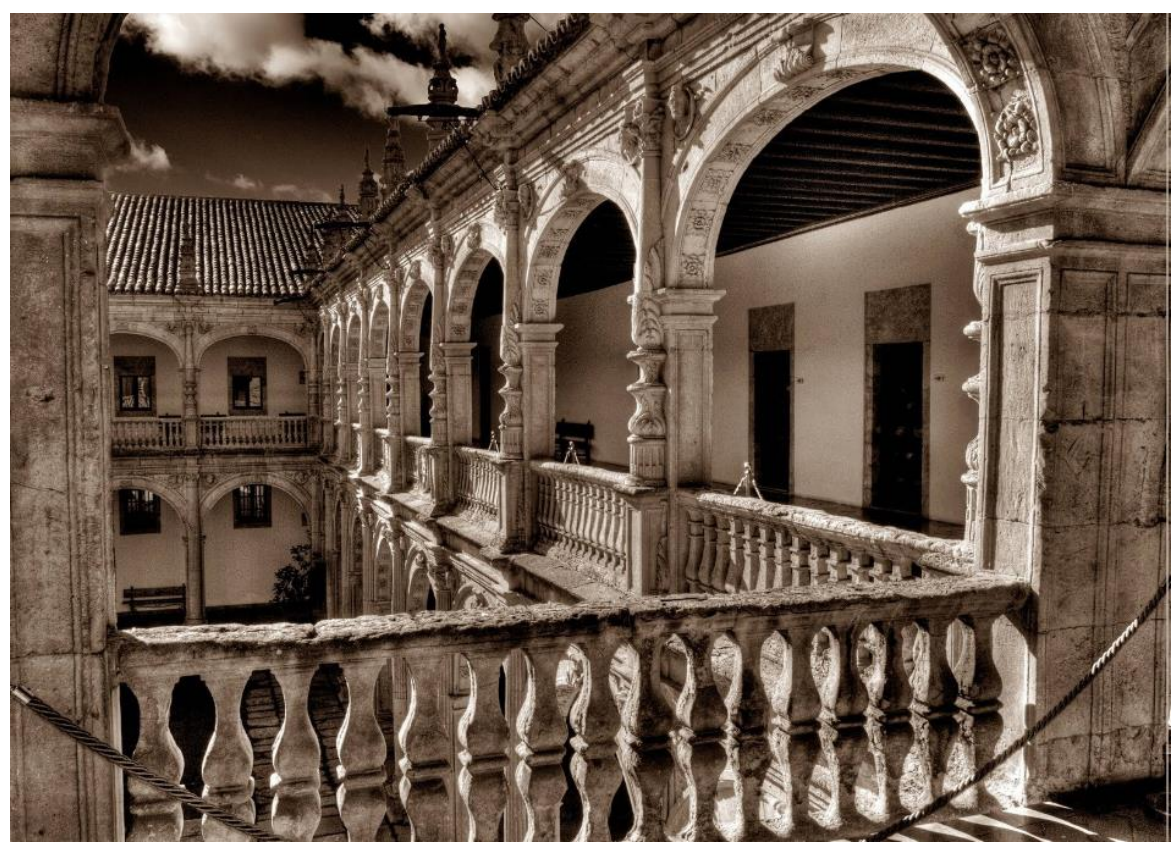

Imagen 63: Galerías del claustro. Corredores de acceso tanto a las zonas privadas (habitaciones) como a las zonas comunes.

Imagen 64: Escalera con el tramo de inicio encuadrado a una de las puertas "dobles" de la logia del claustro.

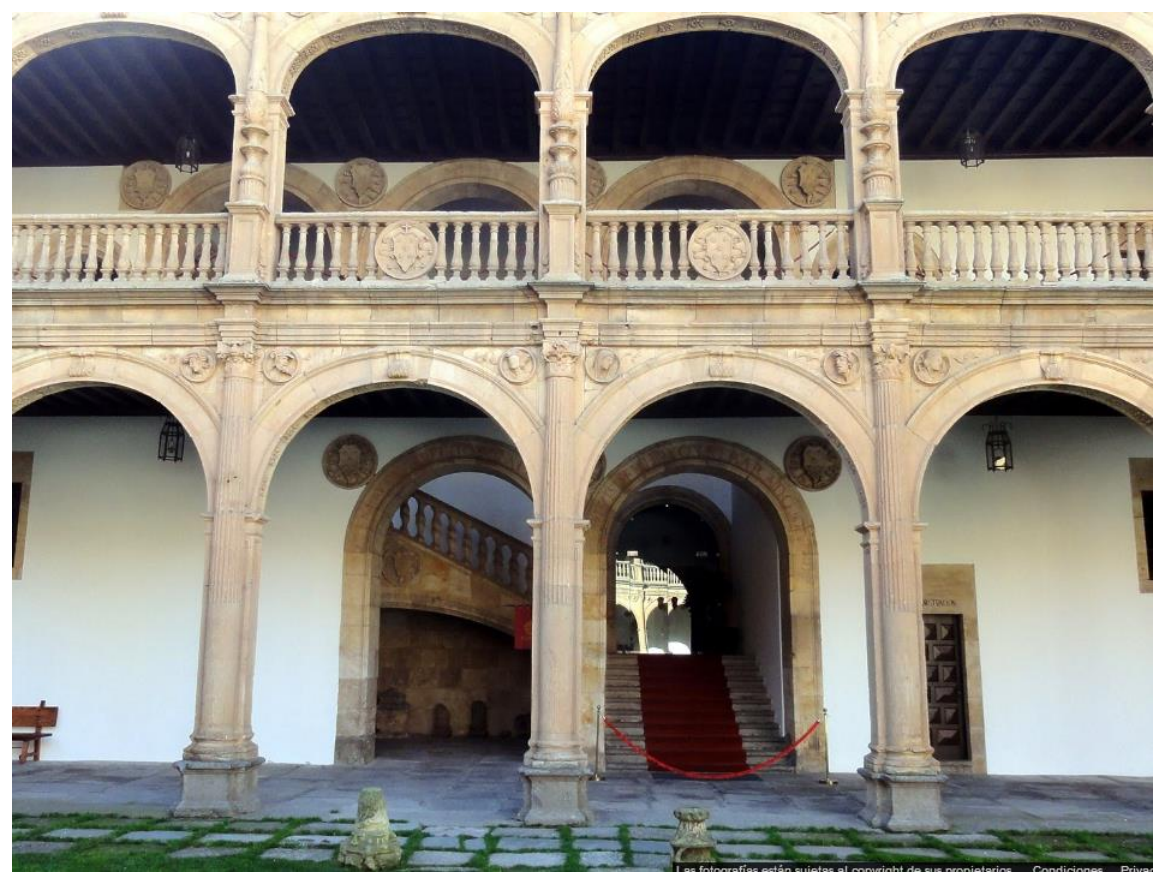


El Colegio es, en sus dos plantas, un conjunto de gran unidad.

Imagen 65: Planta primera.

Imagen 66: Planta baja. La entrada se produce por la zona central de una de las galería como en el Colegio de los Españoles de Bolonia. La capilla se dispone a la derecha de la entrada como el en Colegio de Anaya.

Las alas laterales constan, cada una de ellas, de dos naves que dejan un corredor en medio; en la parte del ala izquierda, que tiene fachada exterior, se disponen las habitaciones de los colegiales, así como en la crujía opuesta a la principal, y en la nave construida entre el patio y el corredor una de las escaleras y los cuartos pertenecientes a los criados. En el ala derecha, el comedor, cocina y el almacén ocupan la zona situada entre el corredor y la fachada exterior de ese lado.

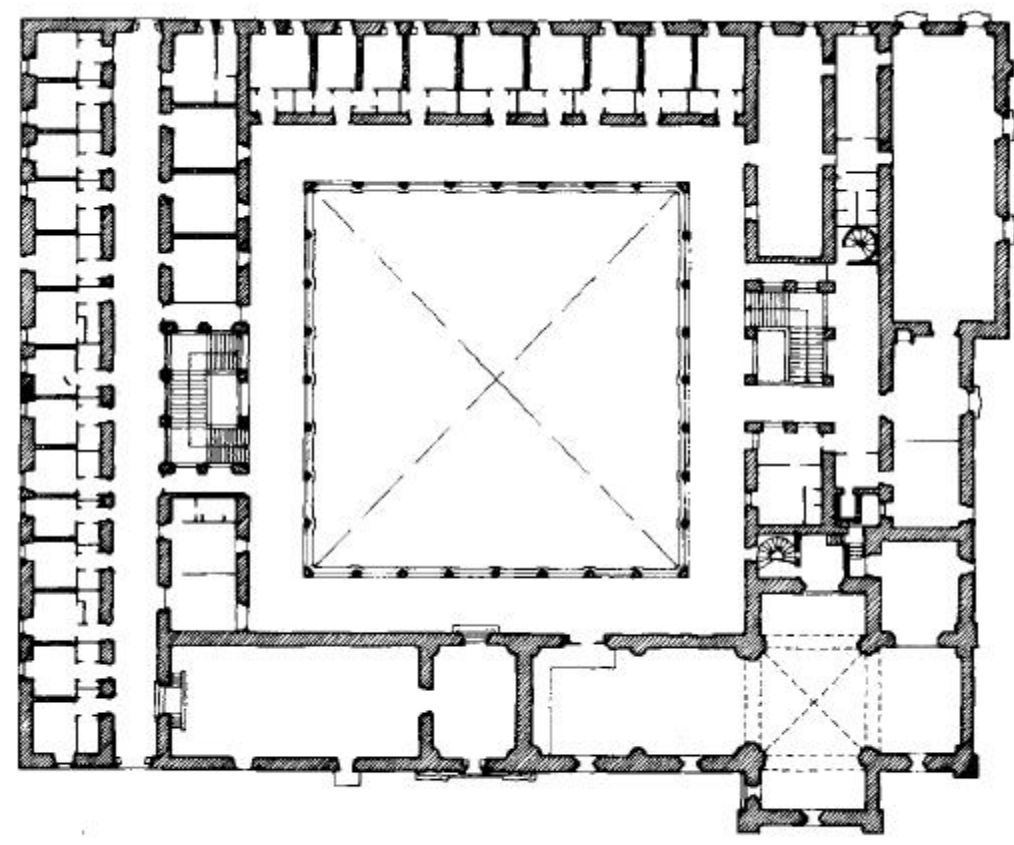

(7) nata nema

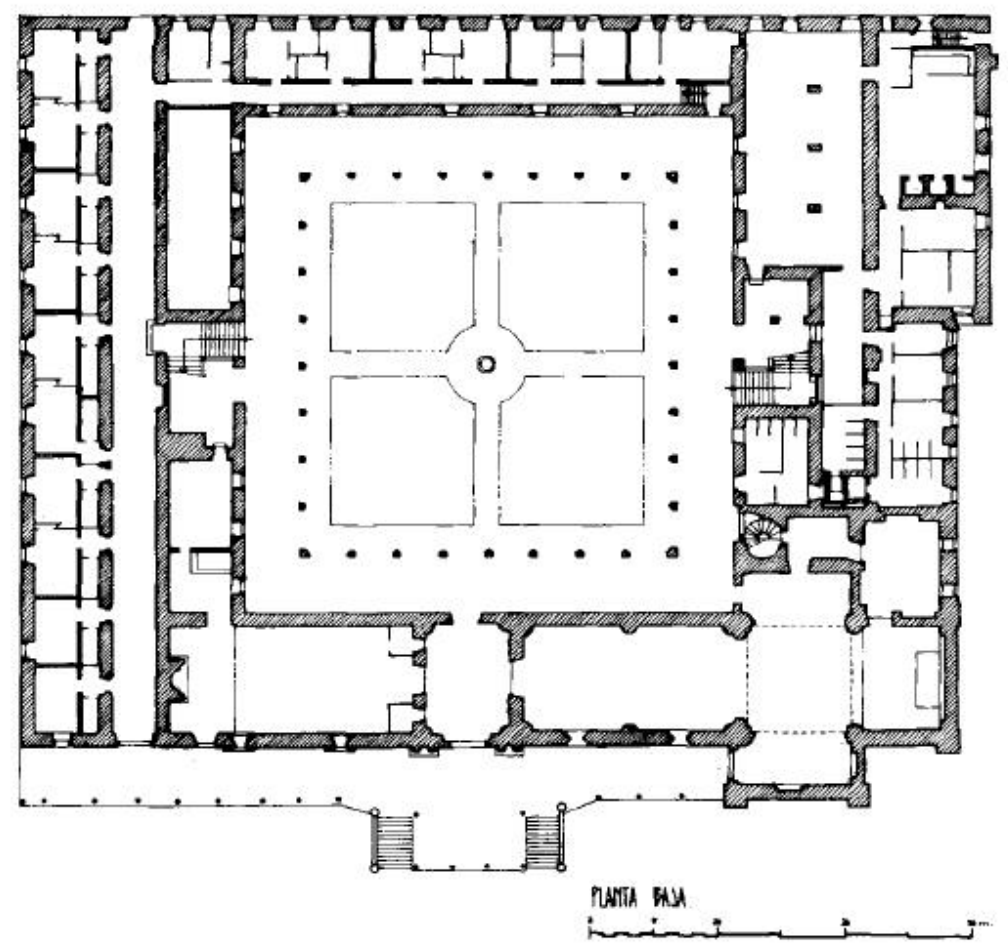




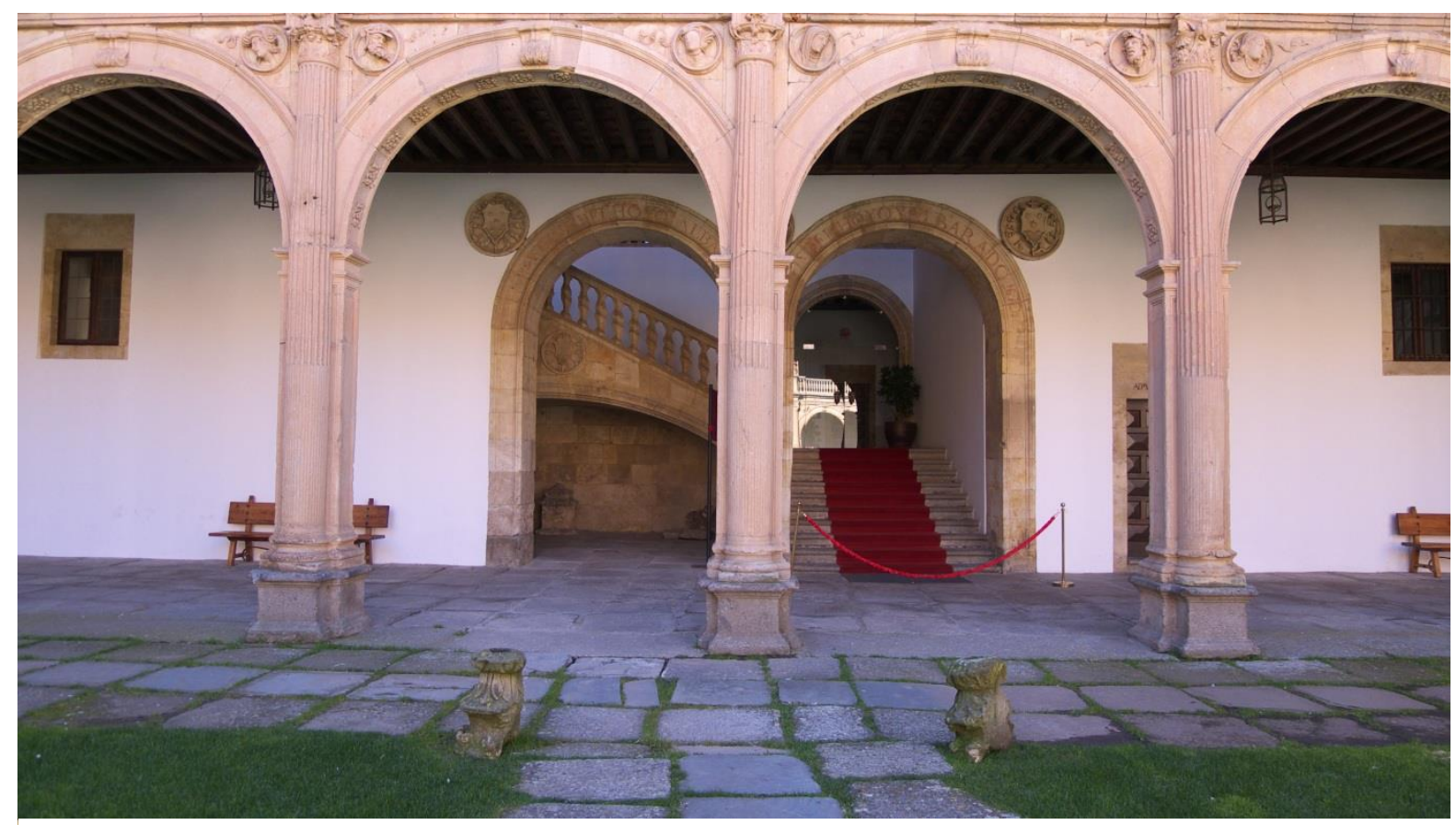

Imagen 67: Escalera con el tramo de inicio encuadrado a una de las entradas dobles de la logia del claustro

Imagen 68:Galerías del claustro. Corredores de acceso tanto a las zonas privadas (habitaciones) como a las zonas comues.

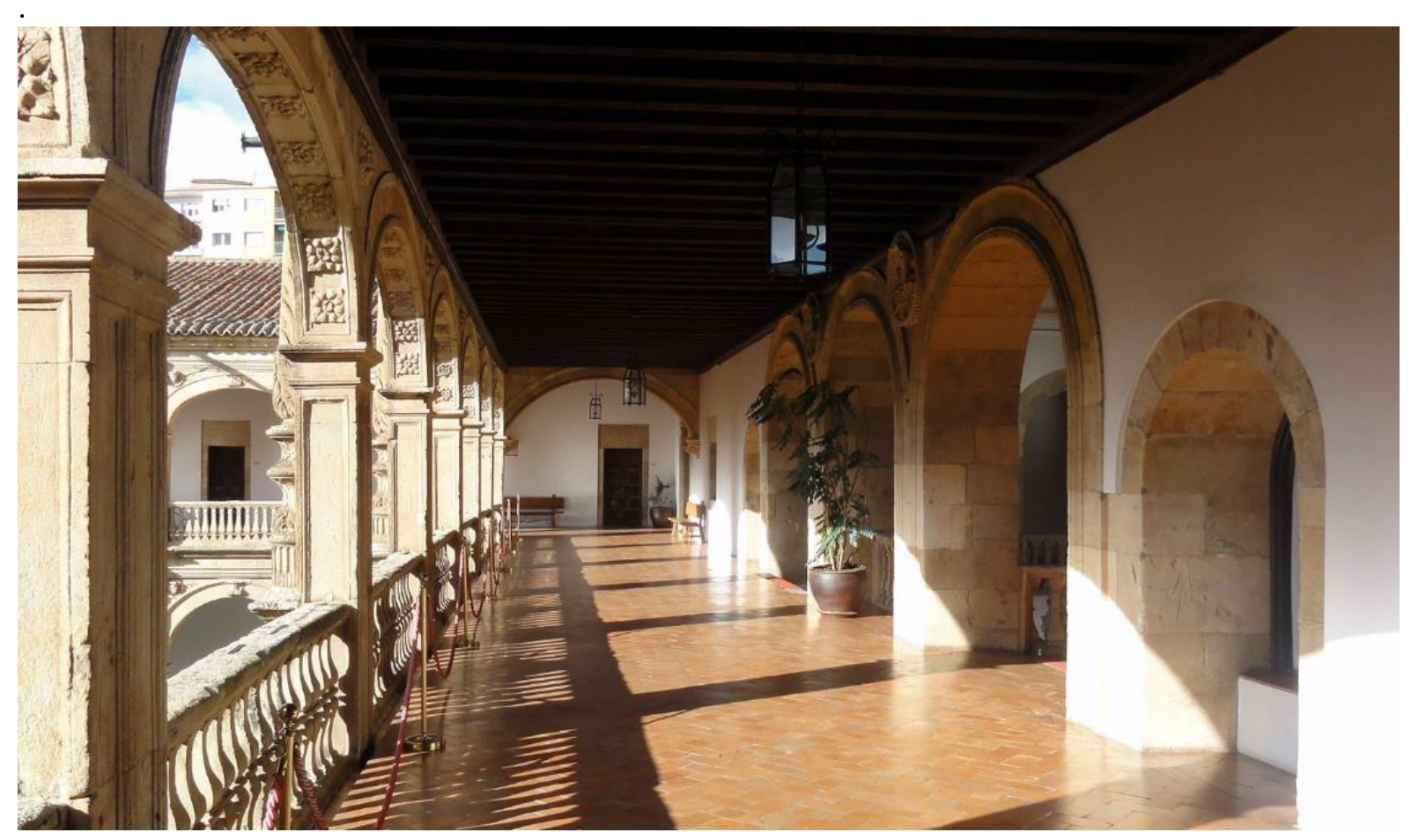




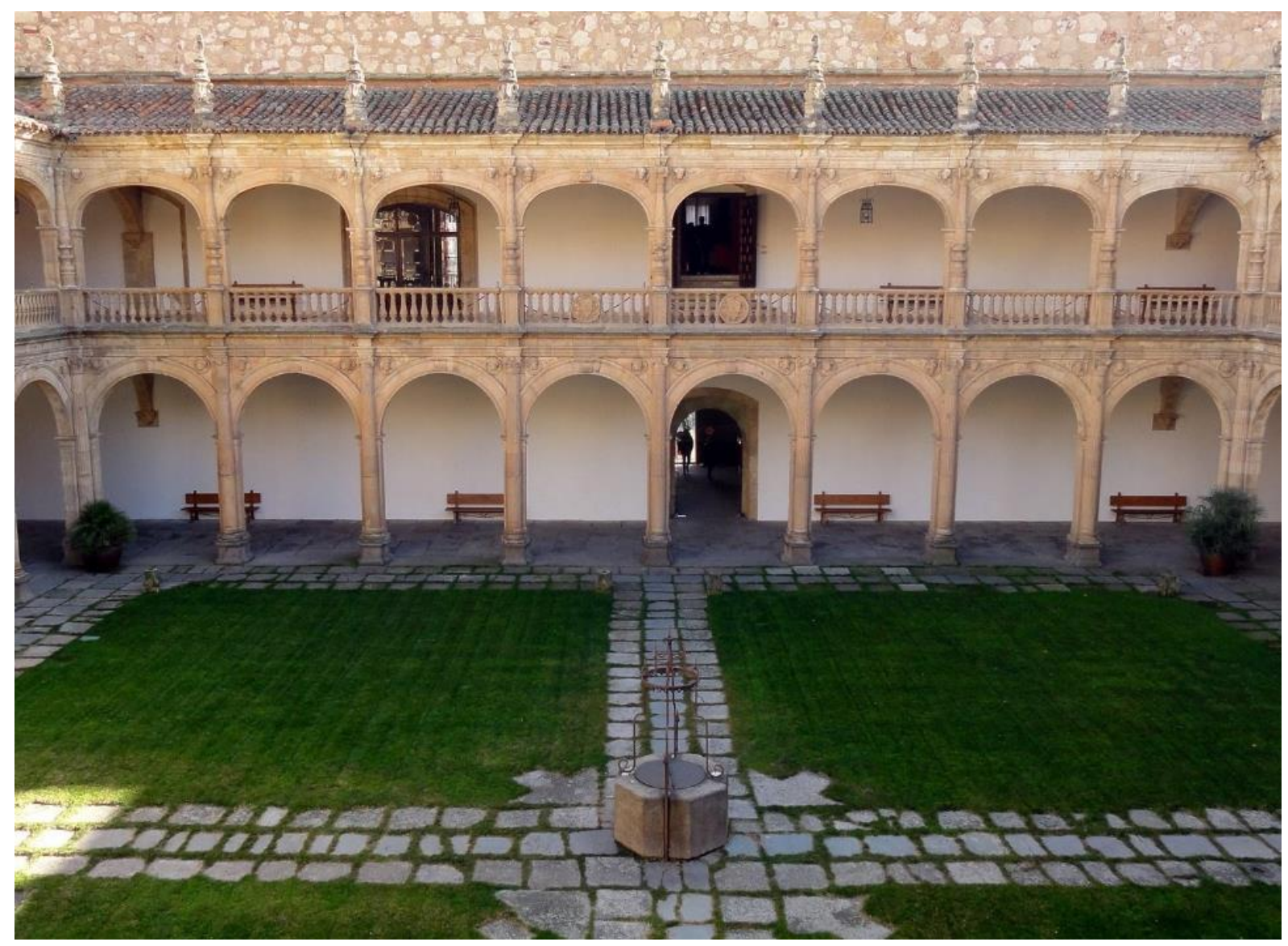

Imagen 69: Claustro interior. Logia de acceso.

Imagen 70: Capilla, con la altura del cimborrio tres veces mayor que la altura de las galerías del claustro. Se enfatiza el acceso principal, ya que está situada justo a derecha de la puerta principal.

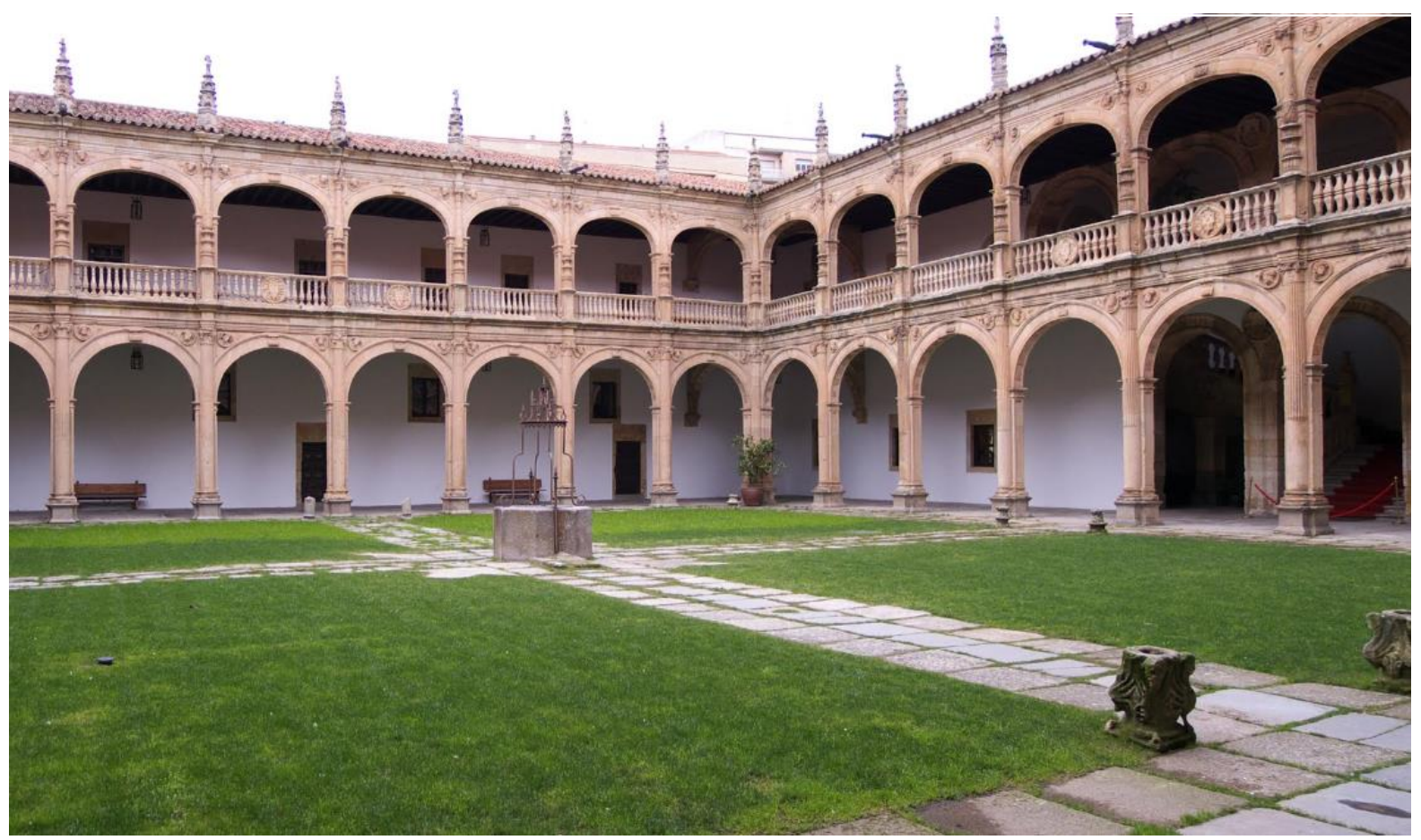




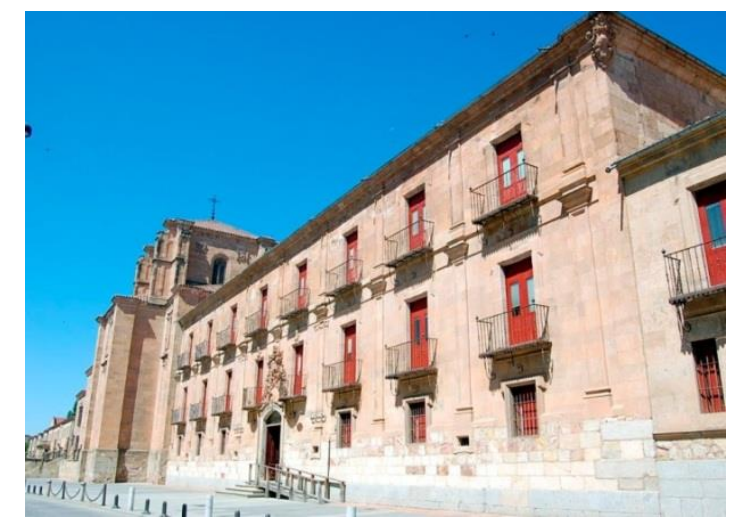

Imagen 71: Hospedería, este edificio barroco sele añadió al colegio debido a la falta de alojamiento en el año 1740.

Imagen 72: Patio interior de la hospedería.

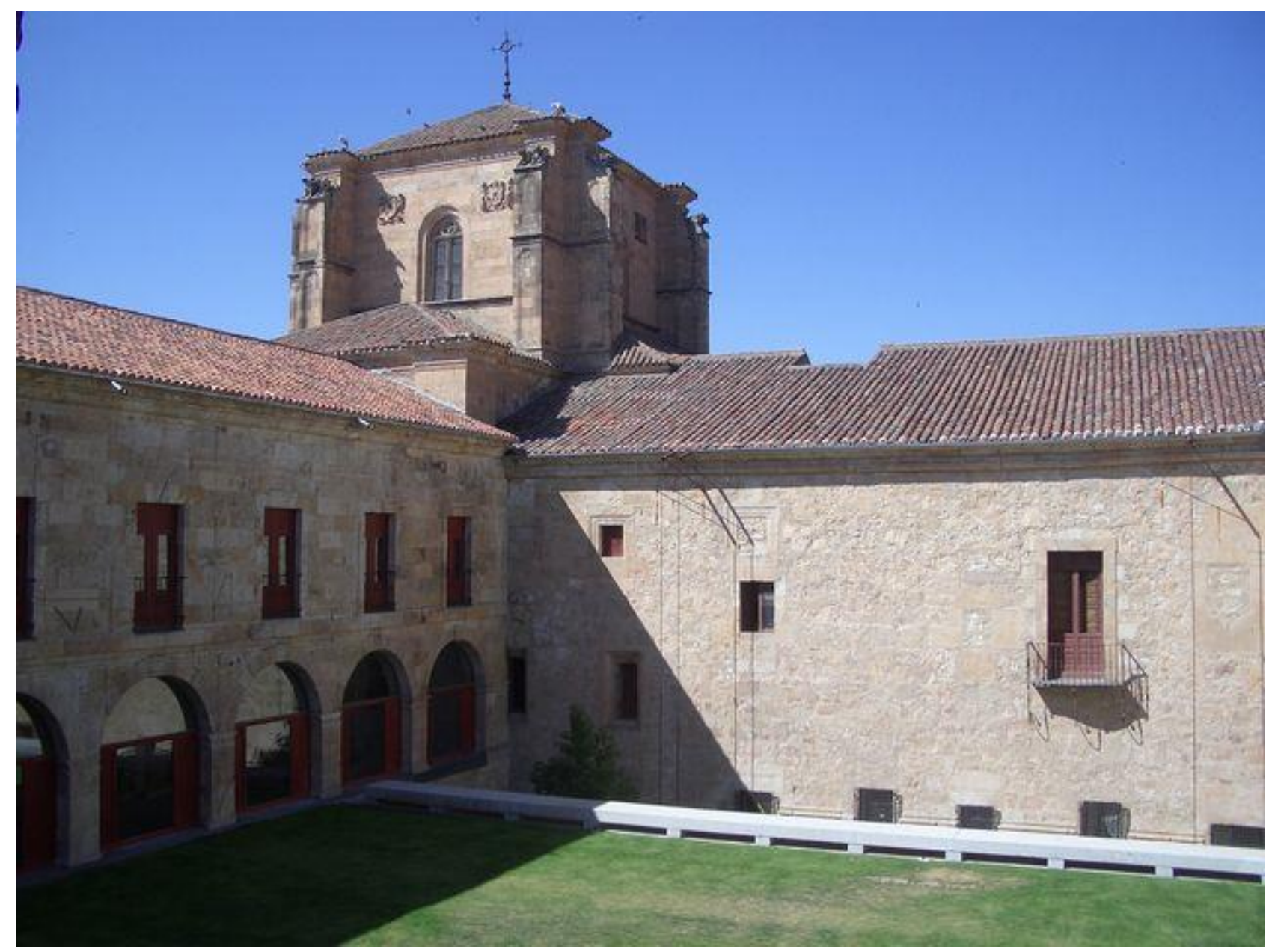




\section{El Colegio Mayor de Cuenca (1521)}

Es fundado por D. Diego Ramírez Villaescusa, que había sido colegial de San Bartolomé ${ }^{9}$. Precisamente en Cuenca, su tierra natal, había tenido la intención de crear una Universidad, pero renunció al proyecto al saber que el Cardenal Cisneros iba a desarrollar una en Alcalá de Henares. Una vez cambiados sus planes, ideó en Salamanca el colegio bajo la advocación y patronato del colegio de Santiago el Zebedeo para el que obtuvo la debida aprobación, confirmación y concesión de todas las gracias y privilegios que gozaban los otros Colegios Mayores ${ }^{70}$. Aunque la historia de los inicios de esta institución es muy confusa, se acepta la fecha de 1517 como el arranque de la construcción ${ }^{71}$. Parece que los colegiales habitaban ya en casas alquiladas frente a la Parroquia de San Adrián. Aunque en El libro de "La Cadena"72 comienza en 1518 con la inauguración del nuevo edificio. Es muy probable que continuara con la compra de solares y materiales de construcción con el objeto de engrandecer la obra.

El edificio original siguió las trazas de Juan de Álava que intervino en su construcción a partir de $1527^{73}$, mientras participaba a su vez en la construcción de la Catedral Nueva. Él mismo utilizó las mismas trazas que en el Colegio de Fonseca74, y el resultado es que la disposición en planta es la misma que en el Colegio de Fonseca. Se organiza en torno a un claustro cuadrado central.

Constaba de 3 pisos, el inferior de cinco arcos por crujía, con capiteles agrutescados y medallones en las enjutas, mientras que el superior iba adintelado con zapatas y decorado con medallones 75 .

Este Colegio, al igual que los anteriores, sigue la tónica general del claustro como elemento configurador, sin ninguna particularidad importante que resaltar diferente a los ya citados. Entre las fases constructivas en periodos posteriores a su creación, cabe destacar que entre 1725 a 1738 se construyó, con el proyecto de Alberto de Churriguera, la fachada principal y la escalera en el lado noroeste en la misma situación que en la traza original. Entre 1756 y 1764 se construyó la fachada frente a la calle Gloria, en la plazuela, junto a la hospedería del Colegio de Oviedo. Aquí se hallan el zaguán, la librería, la sacristía y la nueva capilla. En 1778 se construye la nueva capilla del Colegio, la obra fue adjudicada a Jerónimo García de Quiñones por Licitación de la provisión solicitada a varios arquitectos ${ }^{76}$. 


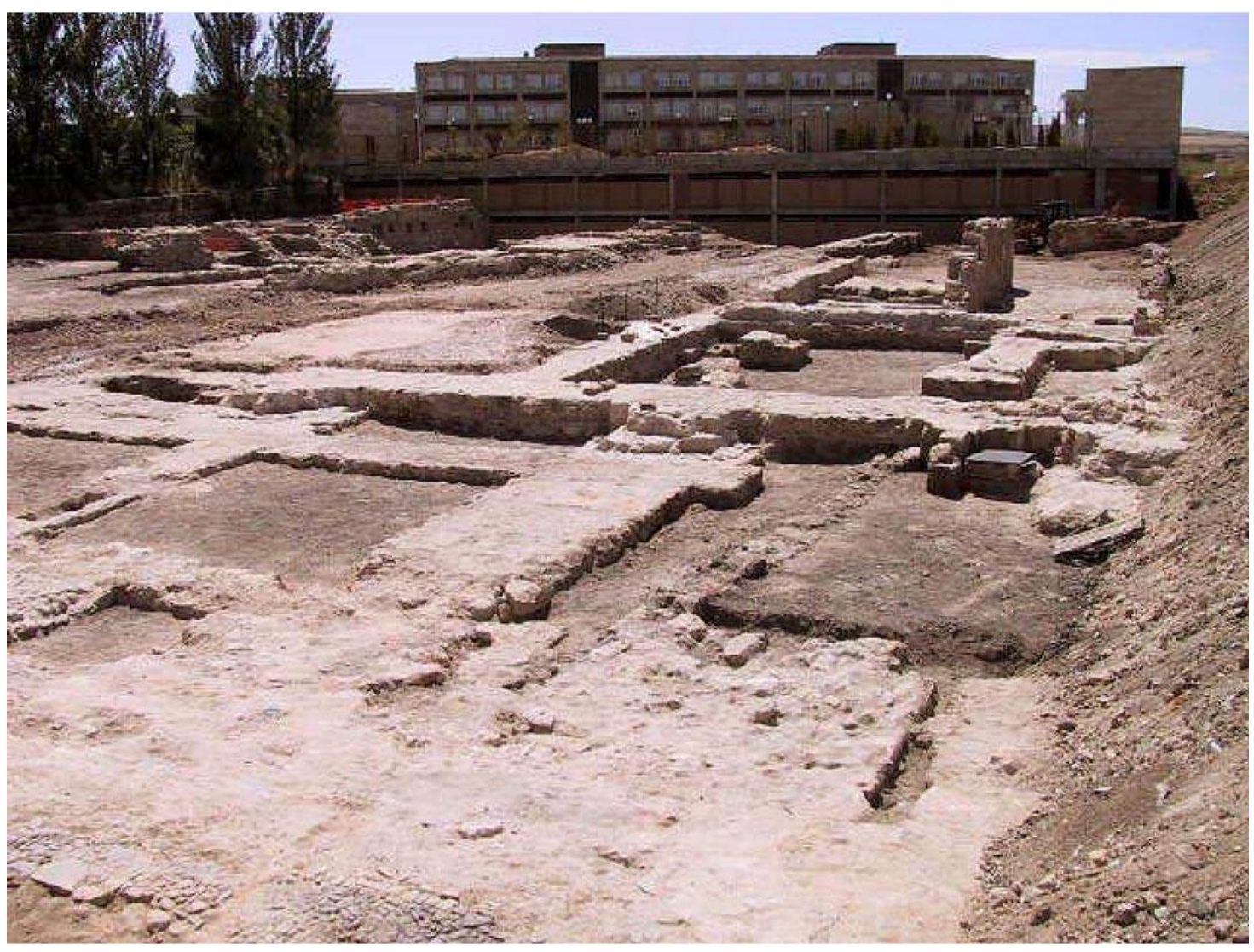

Imagen 74: Restos del colegio original, donde se puede apreciar la

traza de sus muros. 


\section{El Colegio Mayor de Oviedo (1522)}

Diego de Muros fundó esta institución hacia septiembre de $1522^{77}$. Ya que había sido obispo de Oviedo se adoptó el nombre para el colegio. De las estancias que lo conforman, cabe destacar la presencia de biblioteca y de forma muy especial, la capilla de estilo barroco, obra de Joaquín y José Churriguera ${ }^{78}$.

De este colegio se conocen rasgos limitados pero significativos. El edificio se puede describir como sólido, elegante y cómodo ${ }^{79}$. Se levantó sobre el solar de la casa del primer Duque de Alba ${ }^{80}$. La construcción se inició en torno a 1524 y en ella participó Machín de Sarasola, Martín del Luno y Pedro Nieto, que trabajaron también en el de Cuenca ${ }^{81}$

La edificación se organiza, como es de esperar, en torno a un patio cuadrangular y en la fachada destaca como primordial adorno "los hermosos balcones de la rectoral". Ya en 1675, Juan de SetiénGüenes, dio trazas para las obras en los lienzos de poniente y mediodía, que incluían la hospedería. Pero sin duda, lo más destacado es la capilla de nueva planta, construida en honor de un antiguo colegial, Santo Toribio de Mogrovejo. Con ella se pretendía que el colegio mostrara una este colegio pretendía, aun siendo religioso, dar una imagen al exterior de "Palacio de las Ciencias" ${ }^{12}$.

Este contenido, claramente propagandístico, se expresaba fundamentalmente a través del programa iconográfico que completaba la arquitectura del edificio, pero no era el único. La iniciativa de construir a fines del seiscientos, en un momento general de crisis, una capilla con toda la magnificencia posible y elevado coste económico, constituye en sí misma una clara manifestación del poder social de los Colegios Mayores y de su prepotencia frente a la propia Universidad, que la iconografía no hace más que reafirmar ${ }^{82}$. Indirectamente este proyecto puede servir también para mostrar la difusión que va alcanzando la concepción científica de la arquitectura $^{83}$. La vertiente intelectual de ésta no sólo se destaca mediante la exaltación del tracista, sino especialmente a través de algunas de las alegorías materializadas en sus esculturas, mucho más eficaces para la transmisión de las ideas a nivel popular que las imágenes grabadas o los textos teóricos.

La soberbia torre constituye el símbolo de identidad de este Colegio Mayor en el espacio público de la ciudad. José de Churriguera trazó una capilla de arquitectura limpia, toda bien labrada de cantería, con presbiterio semicircular, articulada en los ángulos con Pilastras 
cajeadas provistas de capiteles compuestos. En el exterior estaba adornada por dos "corredores" de piedra, uno en el arranque del mismo ochavo y el otro dispuesto "al quadrado", lo que podría inducir que la forma era de planta central. "los corredores" se coronaban por doce estatuas de las ciencias de cuerpos naturales sobre sus pedestales. Cada una llevaba un distintivo que permitía identificarlas sin error. Cada una de las ciencias quedaba representada en base a unas características ${ }^{84}$.

La intervención de José de Churriguera en la elección concreta de las alegorías explicaría la presencia de la Arquitectura entre las disciplinas liberales y la aparente arbitrariedad de las imágenes simbólicas, que en lo esencial ilustran las facultades primordiales de esta época salmantina. 
126| RESIDENCIAS UNIVERSITARIAS EN LA HISTORIA 


\section{RESIDENCIAS UNIVERSITARIAS EN LA HISTORIA}

\section{BLOQUE II}

PARÍS, La adaptación de hospederías a colegios universitarios Historia y contexto

EL Colegio de Sorbon y la Sornona. (1252)

El Colegio de Navarra. Espacios y funciones (1309)

La Cité Universitaire, un apéndice contemporaneo

El inicio de las obras en 1925

El pabellón suizo de Le Corbusier (1935)

El Colegio de España. Exportando historicismo (1935) 


\section{HISTORIA Y CONTEXTO}

Los primeros Colegios son de finales del siglo XII y en un principio no eran más que unas pensiones, la mayor de las veces creación caritativa de distintos personajes para ayudar a los estudiantes que venían de fuera de París ${ }^{85}$. La condición dispersa de los eruditos en París a menudo dificultaba alojamiento. Algunos estudiantes alquilan habitaciones de gente del pueblo, que a menudo exigía altas tasas, mientras que los estudiantes necesitaban establecerse en espacios de tarifa inferior ${ }^{86}$. Esta tensión entre los académicos y los ciudadanos se convertían a menudo en una especie de guerra civil. Los colegios nacen como respuesta a esta presión de tirantez entre habitantes estudiantes y los que no lo eran. Cada uno de los colegios contaba con la premisa de conseguir un objetivo especial, que cada uno de ellos recogiera a los estudiantes de la misma nacionalidad o de la misma ciencia. Los fundadores dotaban a los colegios de una renta que cubriera el funcionamiento del Colegio con la asignación de unas becas o bolsas ${ }^{87}$. Los estudiantes becados (boursiers) podían ser "cameristas" (con habitación particular) o "porcionistes" (con habitación compartida) después se añadieron los "martinets" que eran externos al colegio, es decir, no pernoctaban en él pero tenían algún tipo de vinculación ${ }^{87}$. Las clases se dieron fuera del Colegio y en general al aire libre, en la plaza Maubert, en la calle Fuarre, llamada así por las pacas de heno ${ }^{88}$, que llevaban los estudiantes para no sentarse directamente sobre el suelo de la calle. Al final del siglo XIV se abandonaron las clases al aire libre y comenzaron a darse en algunos Colegios, eran los llamados "Grandes Colegios" gracias a los cuales la universidad parisina alcanzó su alto prestigio. Estas instituciones fueron: el d'Harcourt (1280), el Cardinal Lemoine (1303), el de Navarra (1304), el Montaigu (1314), el Plessis-Sorbonne (1322), el Lisieux(1336), el La Marche (1422), el Grassins (1559), el Clermont (1562) y por último, el Manzarino $(1688)^{89}$.

Siendo el Colegio de Sorbon y el de Navarra los más importantes dentro de los "precursores de la universidad". Merece especial atención éste último por ser ejemplo de la antesala de los colegios por naciones, como por la futura Ciudad Universitaria de París que será tratada en capítulos siguientes. 

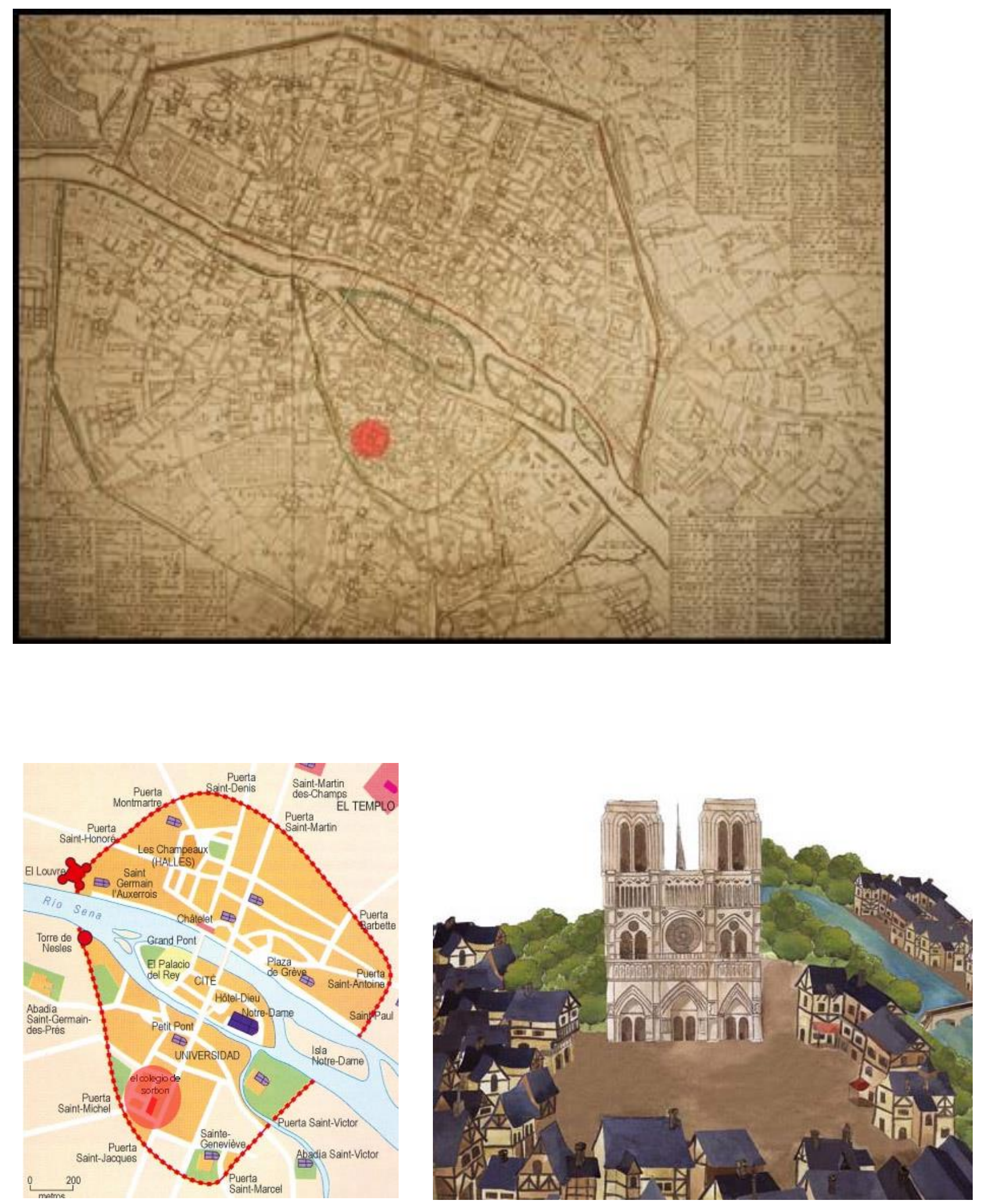

Imagen 75: Plano de París siglo XIII. Zonificación del Colegio de Sorbon.

Imagen 76: Emplazamiento del Colegio de Sorbon en la Rue Coupe-Maw, donde Robert du Sorbon adquirió el inmueble debido a su influencia como capellán.

Imagen 77: Edificaciones típicas parisinas, aledañas a Notre Damme, en siglo XIII. 

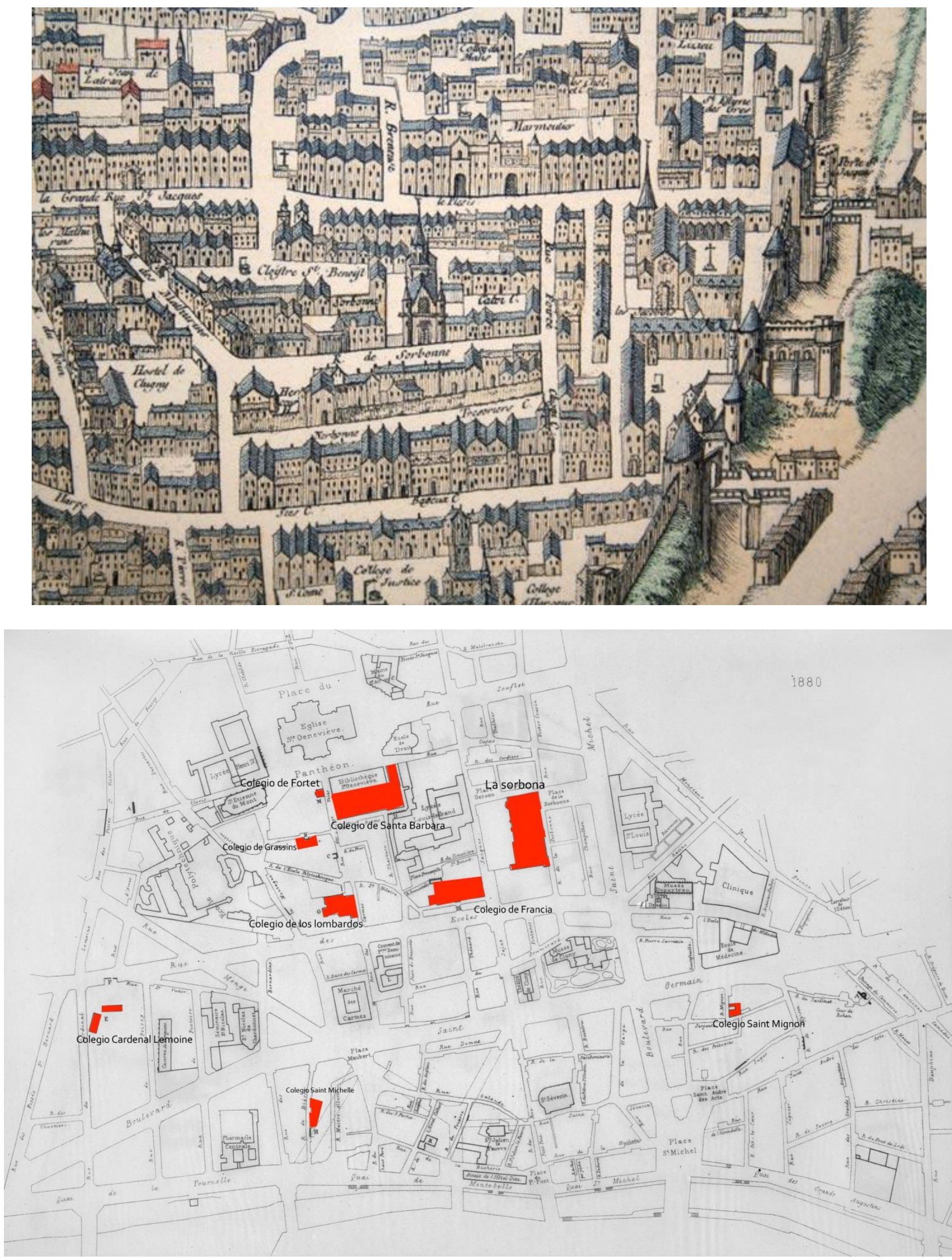

Imagen 78: Perspectiva del Colegio de la Sorbona hacia el año 1314

Imagen 79: Disposición de colegios universitarios de París en el año 1800 . 


\section{EL COLEGIO DE SORBON Y LA SORBONA}

Con problemas similares de alojamiento a los acontecidos en Bolonia, la dificultad de reunir, alojar y sustentar a los estudiantes también fueron resueltos con el modelo de colegio, pero en este caso se adoptó una modalidad o modalidades con ciertas diferencias con respecto a Bolonia ${ }^{9}$. La implantación se hace en edificios existentes, normalmente hospederías o de otro uso, y se van transformando según los criterios del fundador en colegios universitarios $^{91}$.

El primero se establece en 1180, el Collège des Dix-Huit (Colegio de los 18), cuyo fundador, el mercader José de Londres, lo creó a favor de 18 estudiantes pobres, de ahí su nombre ${ }^{92}$. Lo instaló cerca de las escuelas de Notre-Dame, en un bajo que adquirió para tal efecto ${ }^{93}$. Cabe destacar que, en la actualidad, sigue cumpliendo una función educativa situada en el Hôtel Dieu, con ánimo de favorecer a los enfermos proporcionándoles la asistencia anteriormente daría a los colegiales. A éste siguieron otros más y para mediados del siglo XIII París contaba ya con varios colegios. Este modelo inspiró a otros ricos benefactores, como el Conde Robert de Dreux que fundó en 1186 el Colegio Santo Tomás, el eclesiático Robert d'Hancourt, arcediano de Roven, que para veinticuatro estudiantes normandos fundó en 1280 el Colegio d'Hancourt, o el cardenal Cholet que fundó el Colegio Cholet para acoger a estudiantes de Amiens y de Roubaix ${ }^{94}$. A ellos vinieron a sumarse los Estudios Generales, que así se llamaba a los centros que emitían títulos universitarios en la edad media (universidades o centros universitarios), dedicados exclusivamente a la enseñanza, es decir, sin procurar alojamiento a los alumnos, y propiedad de dominicos, franciscanos y otras órdenes religiosas, como bernardinos, carmelitas y cistercienses ${ }^{95}$.

En este contexto, especial atención merece la fundación de un canónigo de Cambray llamado Roberto de Sorbon ${ }^{96}$. Propuso fundar una sociedad de eclesiásticos seglares dedicados al estudio y a la enseñanza gratuita97. La sociedad obtuvo en 1252 la autorización de la reina (regente por la ausencia de Luis IX que se encontraba defendiendo la fe cristiana del poderío musulmán en las cruzadas) y quedó legalmente constituida con el nombre de "Congregación de los muy pobres maestros" por carta del rey en 1255 y del Papa Alejandro IV en 1259 que la declaró útil para la religión ${ }^{98}$. Los inmuebles en el centro urbano de la ciudad eran mucho más caros que los del extrarradio, pero debido a su posición como capellán y confesor del rey le permitió obtener una casa en la calle CoupeMaw99.

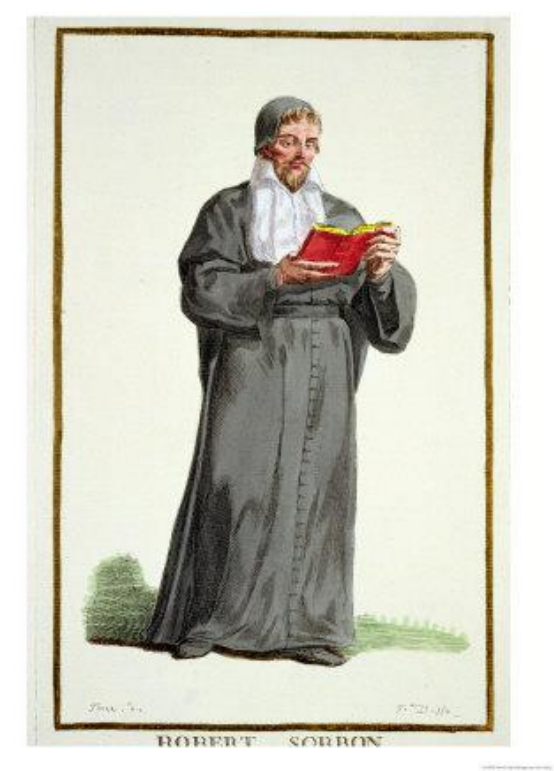

Imagen 8o: Roberto de Sorbon, fundador del Colegio de Sorbon 
Si los Colegios eran instituciones destinadas a dar alojamiento y formación religiosa y espiritual a estudiantes pobres, fundación de Robert de Sorbon aspiró desde un primer momento a algo más. Sin embargo no era propiamente una universidad, ni se puede decir que París llevara la delantera a otros países, puesto que Italia, Inglaterra y España ya tenían las suyas establecidas en Bolonia, Oxford y Salamanca, respectivamente. El colegio de Sorbon se implantó en el corazón medieval de París como la institución de enseñanza teológica por definición. Esta institución constaba de veinte estudiantes, que eran sometidos a una férrea disciplina para mantenerlos en óptimas condiciones y para así realizar los estudios de forma satisfactoria. Estaban obligados a comer en común (desayuno, almuerzo, comida, merienda y cena), asistir diariamente a los oficios divinos y a llevar una vida extremadamente austera. En este colegio se impartía una enseñanza que estaba inspirada en la universitas magistrorum et scholarium de Bolonia (1088). Robert de Sorbón dotó a su institución de algo que carecían los demás colegios, un espacio con una gran librería y biblioteca. Fue el germen del espacio físico de la universidad de París. La universidad como tal, es alrededor de un siglo, más antigua que el colegio, y otras escuelas menores ya habían sido fundados a finales del siglo XII. La Sorbona acabará tomando su nombre de este Collège de Sorbonne, tan altamente reconocido por la calidad de su enseñanza. Este término (Sorbona, la Sorbonne) ha sido después comúnmente usado de manera genérica para referirse a la histórica universidad.

Este tipo de colegios pertenecen a los que están integrados en el casco urbano de la ciudad y guardan estrechamente una relación directa entre ubicación y universidad.

Cabe destacar que, a diferencia de Bolonia y España, aquí la mayor parte de los colegios no son construcciones de nueva planta, sino que se implantan en edificaciones existentes y se adaptan al nuevo uso.

A lo largo de los siglos XIV y XV se multiplicó su implantación, en 1400 el número de colegios existentes era superior a cuarenta y se sabe que dos de ellos acogían a un número de casi cien estudiantes autóctonos o extranjeros. A lo largo de la Edad Media el mayor número de colegios se produjo en Francia, ya que a lo largo del siglo XIV los reyes se fueron interesando cada vez más en este tipo de instituciones. En 1353 Juan II "el Bueno" tuteló el Colegio Mignon ${ }^{100}$, tomando bajo su autoridad las directrices de la administración y la gestión del colegio. Carlos V, hijo del anterior, reafirmó la protección real de ese y otros colegios más al implantar una política que tenía por objetivo poner a todos los colegios bajo el control real. De 1328 a 1350 fue cuando se crearon el mayor número de colegios en París. 

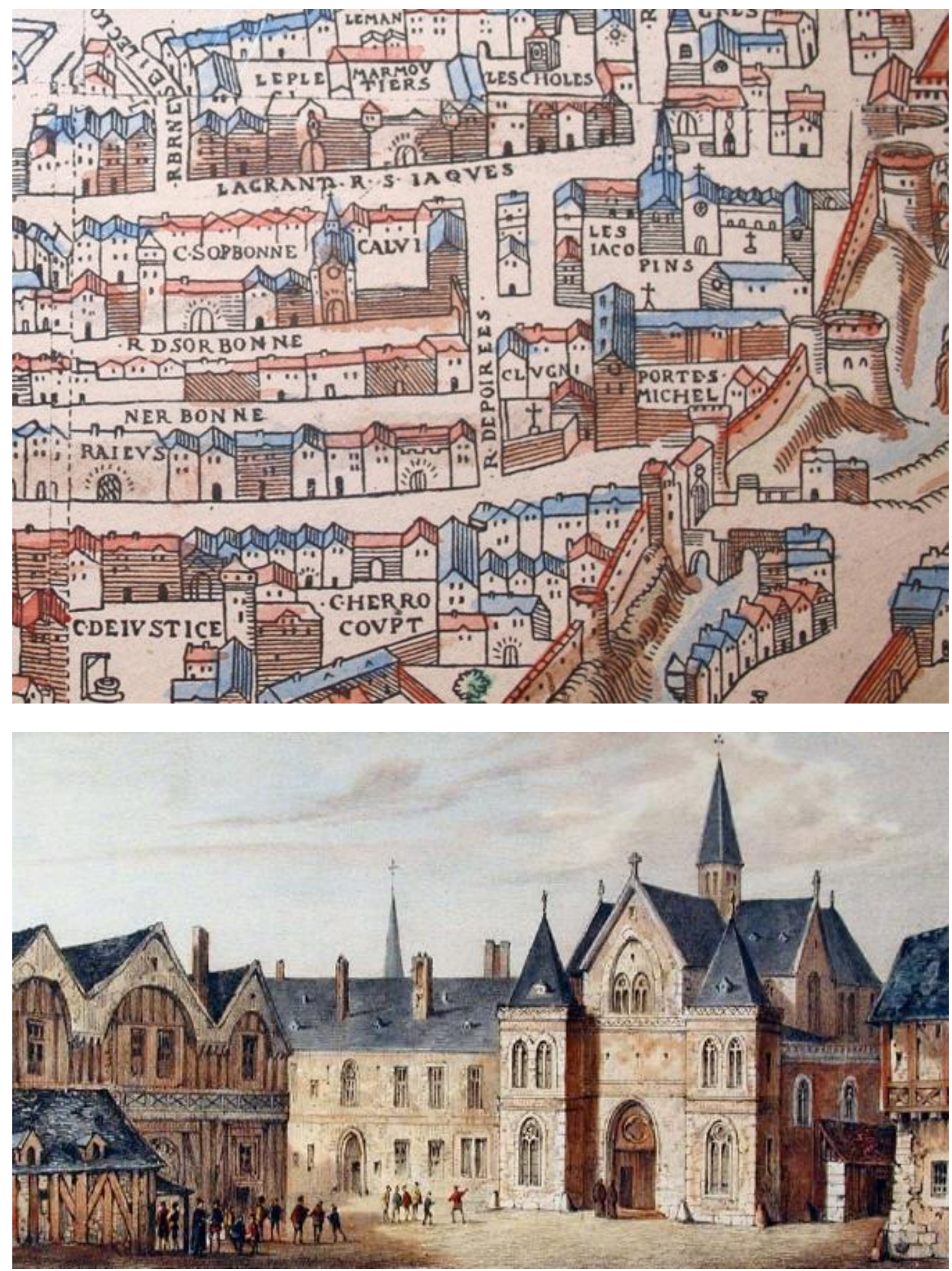

Imagen 81: Localización en el espacio urbano del Colegio de Sorbon.

Dibujo Año 1327.

Imagen 82: El Colegio de Sorbon en 1550. 


\section{EL COLEGIO DE NAVARRA}

Este es un caso especial porque a diferencia de los anteriores, sí es de nueva planta.

El "Collège de Navarre" fué fundado en París el año 1309 gracias a un legado testamentario (de fecha 25 marzo 1304) de la reina Juana I de Navarra Champagne (1273-1305) ${ }^{101}$. La reina Juana legó una parte de su "hôtel de Navarre", una de las más bellas mansiones aristocráticas de París en su época, sito en la calle Saint André des Arts (cerca de la puertas de Bucy y de Saint Germain des Près) para fundar allí el Colegio, juntamente con un fondo de 2.000 libras de renta anual a perpetuidad, generado con la asignación de propiedades en los condados de Champagne y de Brie. Sin embargo los ejecutores testamentarios, que disponían de amplios poderes otorgados en el propio testamento, decidieron vender el "hôtel" y con los fondos obtenidos adquirir un amplio terreno en la "montagne Sainte Geneviève" (rue de la Montagne-Sainte-Geneviève / rue Descartes), en pleno barrio latino ("quartier des écoles"), donde construir el Colegio, siendo éste un lugar mejor adaptado a las necesidades de enseñanza pues allí se encontraba precisamente la Universidad. El punto de partida de la nueva localización es una casa propiedad de uno de los ejecutores testamentarios (Simon Festu, el hombre de confianza de la Reina Juana), casa que es vendida al rey Felipe IV. Alrededor de esta casa se expropian varios edificios mediando indemnizaciones financiadas por el Rey. Los edificios del Colegio se construyeron entre 1309 (el 12 de abril se coloca la primera piedra de la capilla) y 1314, año éste en que fallece el rey y es encerrada en prisión la reina de Navarra, Margarita de Borgoña. Los edificios estuvieron dispuestos para cumplir su cometido en 1315 , fecha en la que comenzó a funcionar el Colegio cuando se recibe a la primera promoción de becarios y se publican los nuevos estatutos reformulados por los ejecutores testamentarios.

Según las disposiciones testamentarias de la reina Juana I de Navarra, el Colegio debía acoger 70 becarios, 20 en gramática, 30 en artes (lógica y filosofía) y 20 en teología. A modo de comparación, el Colegio de Sorbon acogía en ese tiempo solamente 20 becarios. A tal efecto, dispuso la reina Juana que se destinasen de sus bienes 2.000 libras tornesas - una suma importante para la época - como renta anual del Colegio, que quedaba así dotado en mejores condiciones que el vecino Colegio de la Sorbona. 

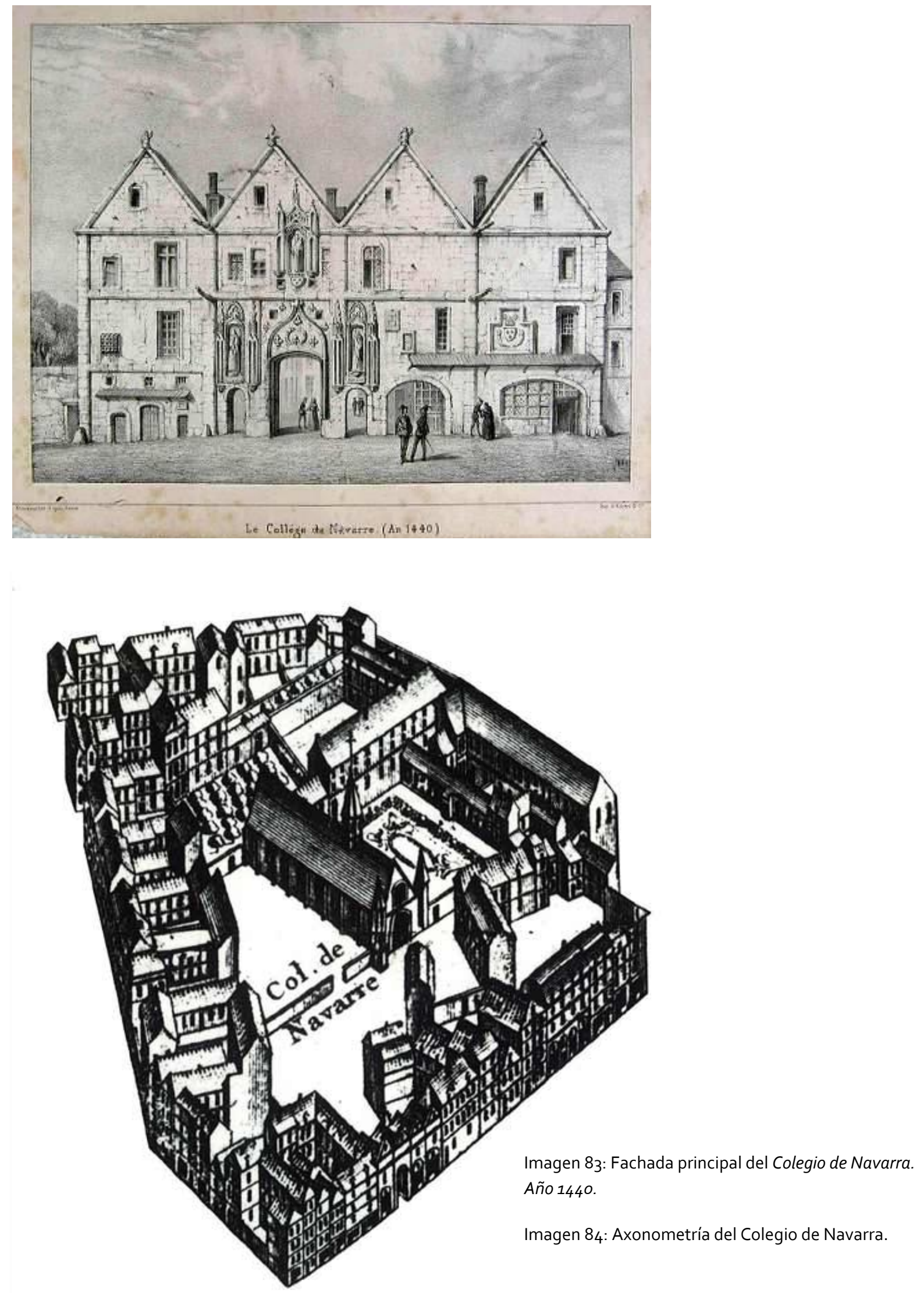


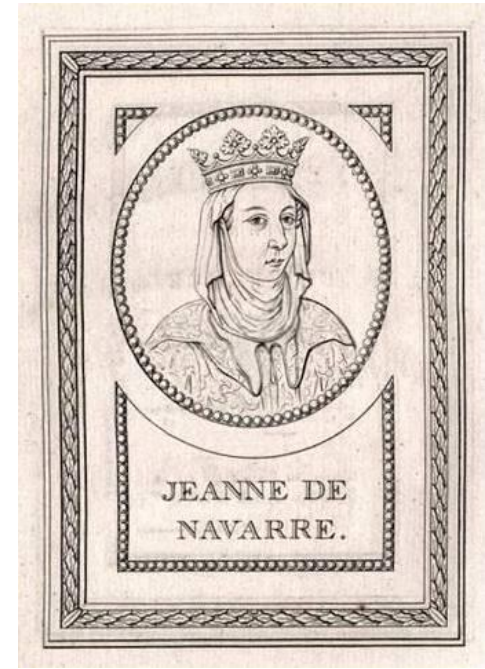

Imagen 85: Juana I. Reina de Navarra
Los estudiantes recibían un estipendio semanal: los gramáticos 4 sueldos parisinos, los artistas 6 , y los teólogos 8 . No se destinaba ninguna plaza a estudiantes de leyes y medicina, ya que se trataba de profesiones lucrativas que no necesitaban estímulos o ayudas especiales. Cada grupo estaba presidido por un Maestro de la Facultad respectiva, que recibía un estipendio doble del de sus propios estudiantes. El Maestro de los teólogos era al mismo tiempo el Gran Maestre del Colegio, y debía ser nombrado por el Decano y doctores de la Facultad de Teología de Paris. Los Maestros debían vivir en el Colegio y les competía cuidar de la educación completa de los estudiantes, tanto en el aspecto intelectual como en el moral.

El Colegio de Navarra pronto se convertiría en uno de los más notables e influyentes de la Universidad de París. Fue acumulando una buena biblioteca, puesto que estaba establecido estatutariamente que si sobraba dinero se dedicase a la adquisición de libros. Apenas unas décadas después de su fundación, dos rasgos lo convertían en una institución de gran calidad. Por una parte, era un núcleo intelectual de excepcional calidad, como lo muestra suficientemente la presencia de Nicolás Oresme. Por otra, el Colegio de Navarra, al ser de fundación real era un lugar de particular devoción hacia la monarquía. Era precisamente el confesor del rey quien escogía a los becarios de este Colegio. Cada 25 de agosto, día de San Luis, se celebraba la fiesta del Colegio a la cual, con frecuencia, asistía el propio rey. Fue el 18 de octubre de 1369 cuando una decisión unánime de toda la Universidad de París - respondiendo a una petición del Rey - atribuyó al Colegio de Navarra ser el centro del culto universitario a San Luis. A partir de septiembre de 1373 la capilla del Colegio se pondrá bajo el patronato del rey San Luis, oficialmente dedicada (16 octubre 1373) a la SantÍsima Trinidad, San Luis y Santa Catalina.

La fundación del Colegio de Navarra tuvo un carácter innovador en la enseñanza en Francia:

Reúne bajo el mismo techo a estudiantes de Teología y otros más jóvenes de Artes. Añade además otros estudiantes becarios de Gramática ("enfants grammairiens") que constituye una de las 7 artes liberales definidas desde el siglo V. La Gramática, juntamente con la Retórica y la Dialéctica, pertenecía al trivium, mientras que el quadrivium comprendía la Aritmética, la Geometría, la Astronomía y la Música. Este colegio es así el primero que introduce una neta distinción entre la enseñanza de la Gramática y las restantes Artes. Acoge los estudiantes, no solamente por razón de proporcionarles alojamiento y comida encontrándose lejos de sus familias, sino también -y ésto puede ser considerado como una gran innovaciónpara ofrecerles al mismo tiempo enseñanza dentro del propio Colegio $^{102}$. 
La Reina planifica la vida cotidiana en el futuro Colegio con detalles mucho más numerosos y precisos que los conocidos en los anteriores colegios fundados en París. Describe, ella misma, a este fin la arquitectura que será necesaria en el futuro establecimiento de albergue y enseñanza.

EL colegio se situó en lo alto de la colina de Santa Genoveva, en el barrio de los teólogos, cerca de la muralla de la ciudad, y su puerta principal se abría a la calle Montaigne ${ }^{103}$.

La forma del colegio estaba estructurada en tantas zonas diferenciadas como enseñanzas proveía, siendo solamente la capilla y el comedor áreas de uso común. Esto era posible gracias a los distintos elementos o bloques de que constaba, pues para dar cumplimiento a la voluntad de su fundadora los dos albaceas encargados del proyecto construyeron un edificio adecuadamente distribuido en distintos módulos, de los cuales, unos eran para residencia y alojamiento, y otros destinados a la enseñanza, como el colegio y el seminario. La apropiada distribución, el color del uniforme de los estudiantes, las comidas comunitarias, la regularidad en la celebración de ejercicios religiosos y la prohibición de llevar armas, tanto en el interior como en el exterior, confirieron a esta institución la etiqueta de ser un colegio novedoso, importante y de calidad.

El colegio estaba provisto de dormitorios, una sala, una enfermería y una cocina, todo ello acondicionado para llevar a cabo una vida colectiva, de la que solamente se dispensaba al maestro gobernador. La Reina quiso que los estudiantes vivieran juntos en permanencia, excepción hecha de los enfermos que quedarían en la enfermería. El corazón del Colegio sería la capilla que debía poder acoger los 70 becarios, quienes diariamente elevarían oraciones por el alma de su fundadora. La capilla del Colegio de Navarra podía en efecto acoger unas 1.000 personas pues medía 47 metros de larga por 12 metros de ancha.

Siguiendo el modelo de la Sorbona el Colegio tenía sus propios estatutos: la regencia del colegio estaba confiada a tres cargos, principalmente: un maestro, un capellán y un procurador. Parte de las habitaciones de la casa eran ocupadas por los estudiantes y las demás eran alquiladas para obtener algunas ganancias. Los escolares recibían semanalmente una beca, entre dos y ocho sueldos, procedente del cofre de la comunidad y destinada a su alimentación. A las lecciones que recibían los becarios internos del centro podían asistir también alumnos externos de toda Francia. Para que la educación de los alumnos fuera completa, sus maestros debían vivir con ellos en el colegio, atendiendo a su formación moral tanto como a la intelectual. 


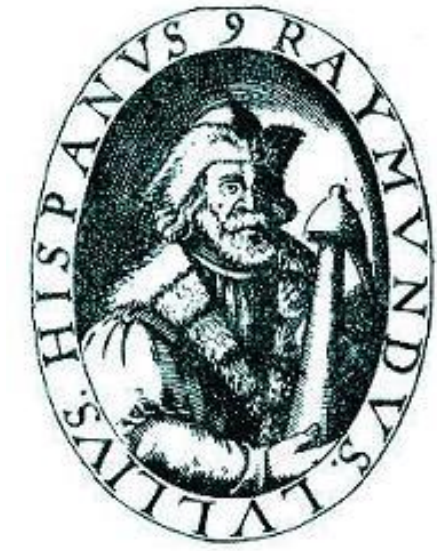

Imagen 86: Ramón LLull.
"Cada clase de estudiantes tenía su propia zona y sólo se reunían todos para las funciones religiosas en la capilla. Una vez obtenido el grado respectivo, expiraba la beca del alumno»"104

Las originales e innovadoras ideas de la reina Juana de Navarra sobre la función y organización de los colegios universitarios de enseñanza y educación pudieron haberse inspirado en las ideas del filósofo místico mallorquín Ramón Llull ${ }^{105}$ quien había estado tres veces en la corte de Francia entre los años 1287 y 1311 y había participado en el Concilio de la catedral de Vienne (1311-1312), convocado mediante la bula "Vox in excelso" por el pontífice Clemente $\mathrm{V}$, en el cual se suprimía la Orden de los Templarios. En su tratado "Doctrina Pueril" expone los principios y elementos de la educación que muchos estudiosos han visto la coincidencia con los proyectos educativos de la reina de Navarra. Para Llull, los niños y jóvenes pobres muestran superioridad física y sobre todo intelectual sobre otros niños menos aplicados al trabajo ya que son más orgullosos. Piensa por ello Llull que es necesario ayudar a los pobres a estudiar y valorar su trabajo que les permitirá elevarse en la sociedad. 

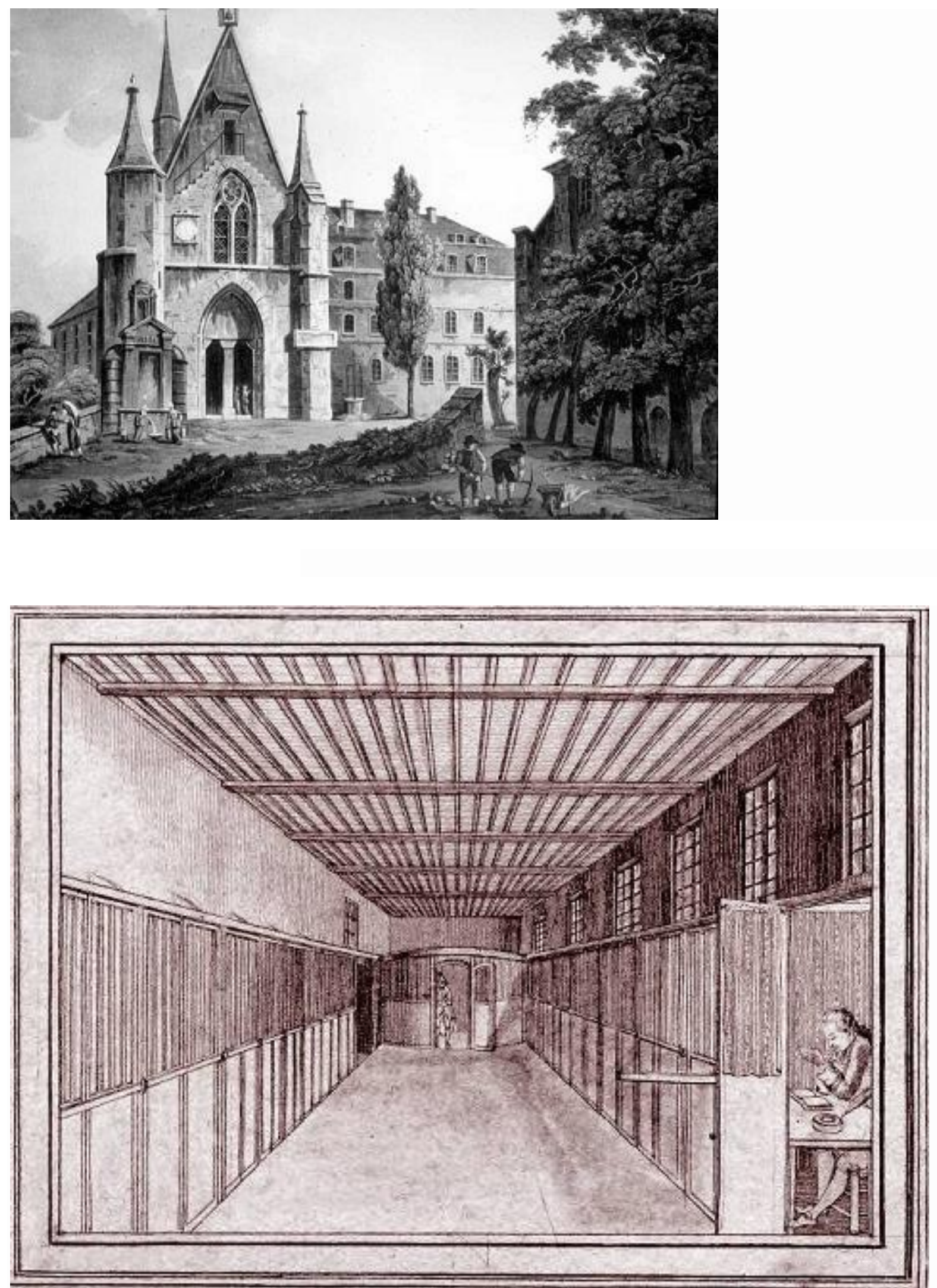

Imagen 87: Capilla del Colegio de Navarra. Se distingue el emplazamiento en lo alto de la colina de Santa Genoveva.

Imagen 88: Pasillo al cual dan las albaceas de los estudiantes. Se repartían según estudios. Se pretendía que los estudiantes de distinta índole sólo coincidiesen en la capilla. 

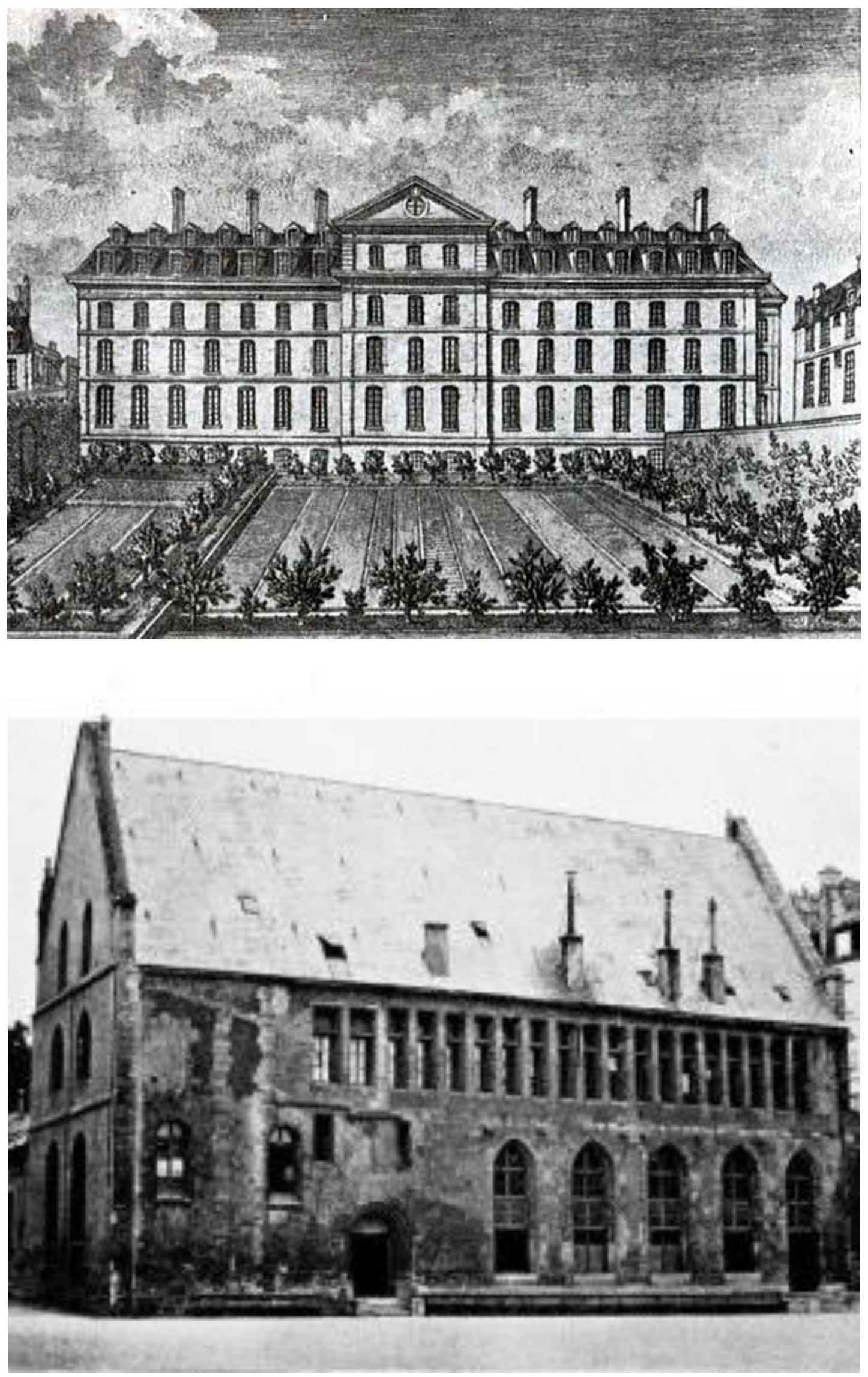

Imagen 89: Alzado posterior del colegio. El espacio posterior se

configura formando un patio cuadrangular con el jardín en el centro.

Imagen 90: Restos de la biblioteca. Año 1750. 
Desde finales del siglo XVI, siguiendo la impulsión de los jesuítas, algunos Colegios se distancian de la Universidad para convertirse en establecimientos de enseñanza secundaria. En vísperas de la revolución francesa el Colegio de Navarra es sin embargo uno de los centros más avanzados de París en la enseñanza de la ciencia moderna, tal como la había concebido Newton. A partir de julio de 1752 Luis XV había creado en el Colegio de Navarra una cátedra de física experimental.. Esta vocación científica y técnica del Colegio debió de ser una de las razones por las que Napoleón Bonaparte decidiera trasladar la recientemente creada Escuela Politécnica a los edificios e instalaciones del antiguo Colegio de Navarra, que conservaba todavía un importante inventario de equipos técnicos para ensayos y desarrollos científicos.

En 1763, se reorganiza la Universidad reuniendo 28 colegios en el Colegio Louis-le-Grand que se convierte en el principal colegio de la Universidad. En ese momento quedan en la facultad de artes de París solamente 9, además del de Louis-le-Grand, impartiendo enseñanza: Cardenal Lemoine, de Navarra, de Grassins, de Harcourt, de la Marche, de Lisieux, de Montaigu, de la Sorbona, Royale y de las Cuatro Naciones. La Escuela Politécnica (inicialmente llamada "Ecole Centrale des Travaux Publiques") es creada en 1794 por Lazare Carnot y Gaspard Monge. Será en 1805 cuando Napoleón establezca la sede de la Escuela en la "Montagne Sainte Genevieve", en pleno centro de París, en el antiguo Colegio de Navarra (juntamente con las instalaciones del vecino Colegio de Boncourt que había sido reunido con el Colegio de Navarra, como hemos visto anteriormente). El gran claustro fue demolido en 1811 y asimismo en 1836 el edificio construído por Pierre d'Ailly, para poder crear un espacio para las nuevas construcciones de la entrada principal de la Escuela Politécnica. La capilla fue demolida en 1845 . El edificio medieval de la biblioteca, el salón de actos y el pabellón de Teología fueron derruidos en la segunda mitad del siglo XIX. Como resultado de todas estas destrucciones, los archivos del Colegio de Navarra se dispersaron, desapareciendo en gran parte.

En esa ocasión, Napoleón transformó la joven Escuela Politécnica en una academia militar guiada por el lema « Por la patria, la ciencia y la gloria ». Los estudiantes pasan entonces a ser alumnos internos con estatuto militar, hasta el año 1970 en que la Escuela se transforma en una institución pública civil, aunque dependiente siempre del Ministerio de Defensa. El Colegio de Navarra supone la antesala a los colegios que agruparán colegiales según naciones para dar respuesta al problema de alojamiento. Un ejemplo claro, lo tenemos en el Colegio de las Cuatro naciones que actúa como nexo de unión entre la los colegios medievales y los del siglo $\mathrm{xx}^{106}$. 

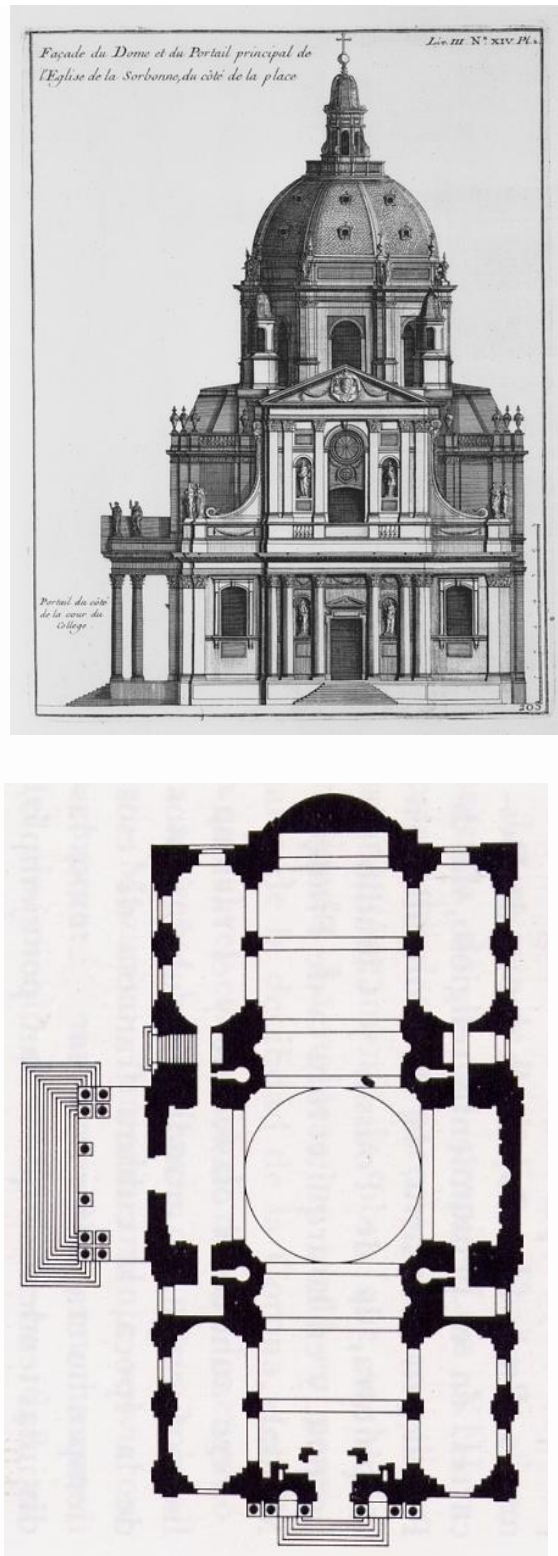

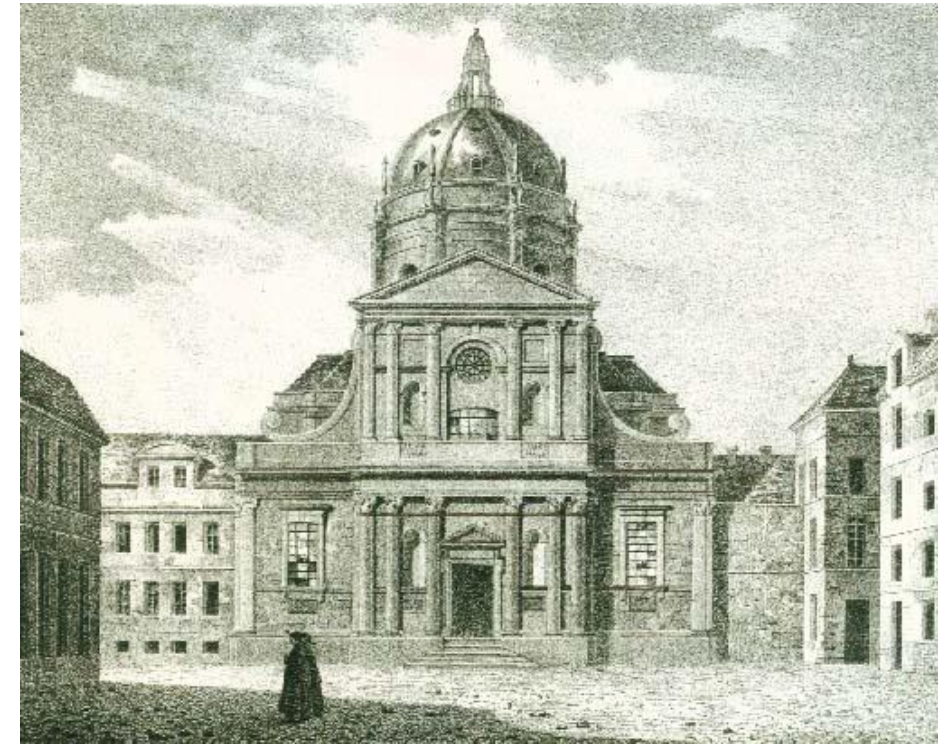

Imágenes 91 y 92: Actual capilla de la Sorbona.

Entorno de la Rue de la Sorbona.

Imagen 93: El espacio ha evolucionado, configurándose en forma claustral con nuevas partes como la capilla.
Imagen 94: planta de la Capilla de La Sorbona

Imagen 95: Facultades distribuidas en torno al patio. Actualmente ha perdido la función residencial.

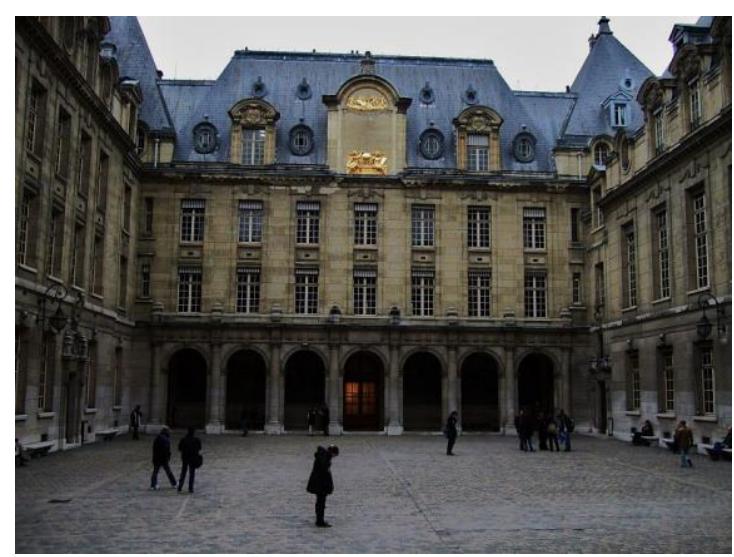

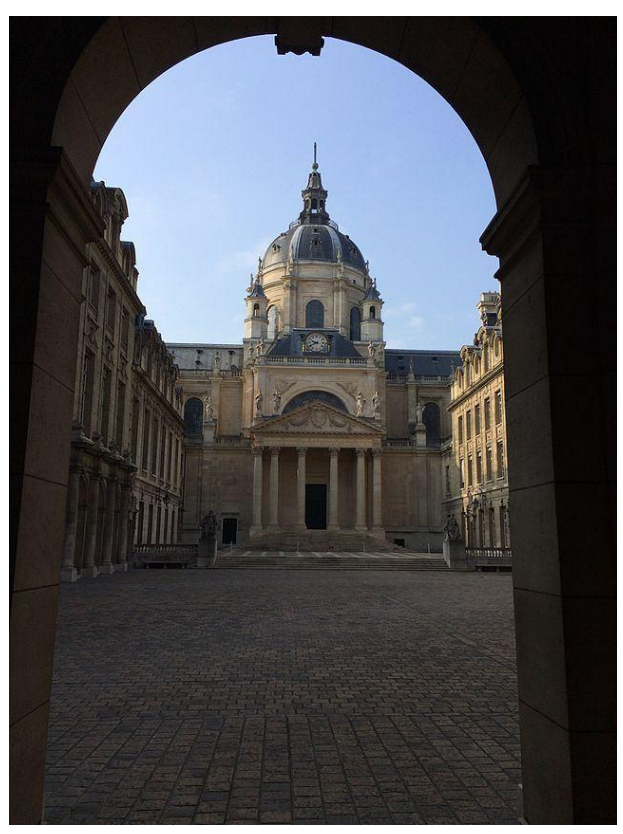



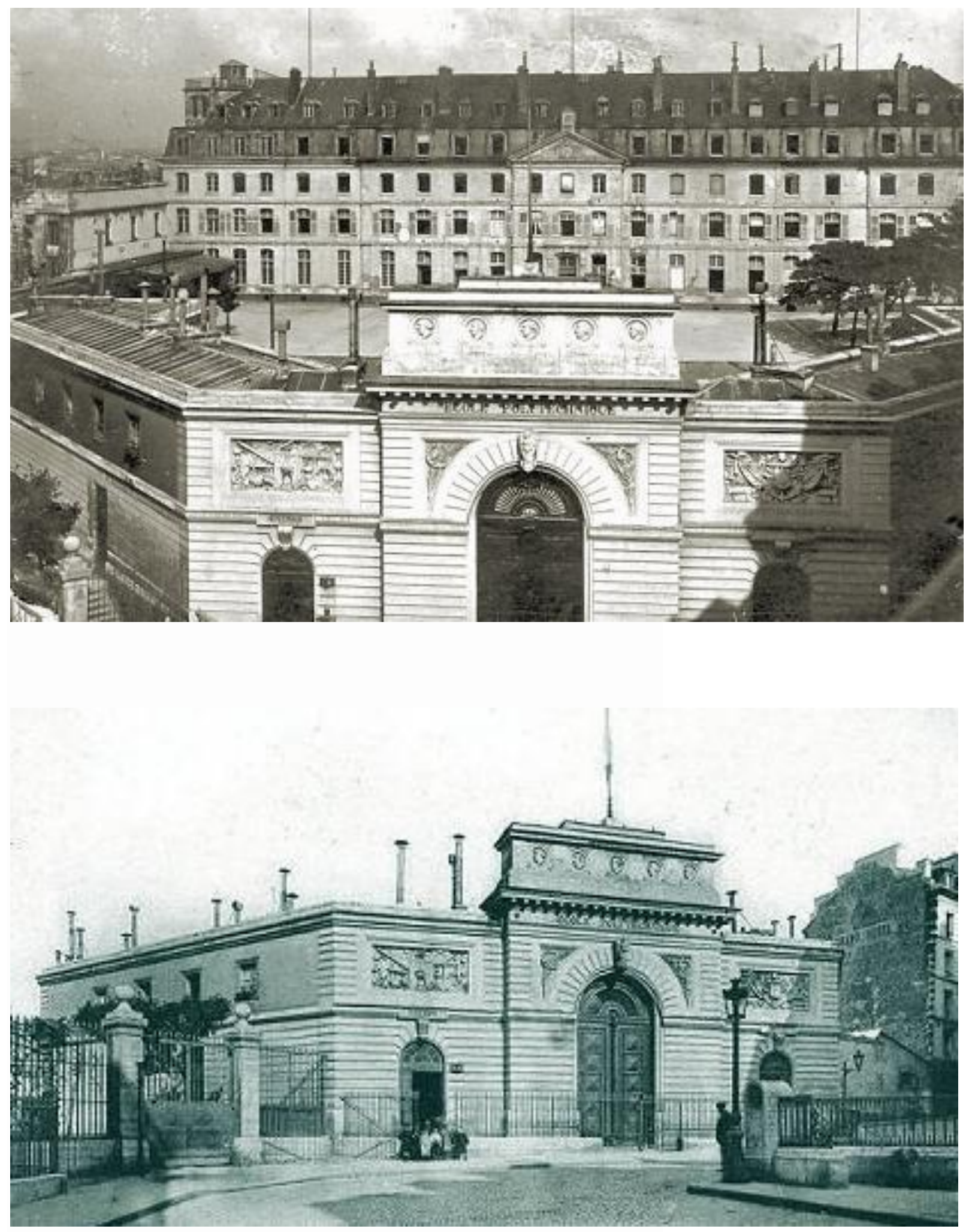

Imagen 96 y 97: Escuela Politénica, su situación es la del antiguo Colegio de Navarra. Se puede pareciar que la fachada posterior es la fachada posterior del antiguo colegio, se ha mantenido hasta la actualidad. 


\section{LA CITÉ UNIVERSITAIRE, UN APÉNDICE CONTEMPORANEO. El inicio de las obras en 1925}

Hasta ahora, los distintos edificios que albergan los colegios se han ido distribuyendo por el tejido urbano, muy cerca de los centros de enseñanza del barrio latino, situado en el umbral de la ciudad. Pero lo hacen sin un orden claro, sin ninguna estructura que los defina. La creación de la Ciudad Universitaria supone un punto de inflexión en cuanto a organización urbana se refiere, aunando todas las residencias universitarias en una misma zona. Aparecen espacios donde la naturaleza, a modo de espacios verdes, zonas de deportes y zonas de paso peatonales ajardinadas, fomenta la relación entre los universitarios.

En París podríamos hablar de las residencias que han aparecido en las zonas universitarias pero cabe resaltar el modelo que bien podría ser tratado como "conjunto de residencias", que queda perfectamente definido en esta ciudad. El proyecto de una residencia para estudiantes del mundo entero se inicia en 1920, en el contexto pacifista del periodo entreguerras, por André Honnorat, ministro de Instrucción Pública y Educación, que tras la guerra deseaba reconstruir el diálogo entre los pueblos, lo materializó en un lugar destinado a residencia de estudiantes para promover una nueva comunidad internacional, donde los miembros de muchos países aprendieran a conocerse y a vivir juntos ${ }^{107}$. El objetivo era convertir Francia en un centro cosmopolita: reconstruir alrededor de la Universidad de París los Colegios de las naciones que, como se ha visto en el capítulo anterior, le confirieron desde la Edad Media su carácter de universalidad. El ministro le dedicaría treinta años de su vida a este proyecto, durante los cuales recibe el apoyo de Émile Deutsch de la Meurthe, un mecenas e industrial alsaciano. Asimismo, la iniciativa de Honnorat contó con el apoyo del matemático Paul Appell, rector de la Universidad de París y presidente de la Academia de Ciencias y del Instituto de Francia; de Bernand Brunot, en su doble calidad de decano de la Facultad de letras y Alcalde del distrito XIV, también recibió la ayuda de Davis Weil, coleccionista de arte, presidente del Consejo Nacional de Museos. Estos fueron los padres de la Cité, trabajando unidos fueron capaces de dotar al proyecto de una dimensión internacional ${ }^{108}$. El proyecto general se encargaría a Lucien Bechmann y el estudio del parque a Jean-Luc Forestier 
La primera residencia para estudiantes, hoy bautizada Fundación Deutsch de la Meurthe, se levantó gracias Émile Deuch y abre sus puertas al comienzo del curso 1925-1926.

La ubicación designada fue la antigua zona de fortificaciones de París, desmilitarizada tras la $1^{\text {a }}$ Guerra Mundial y cedida al municipio, que extendió su límite hasta ella. Entre 1920 y 1924 se suprimieron muros, se nivelaron fosos y comienzan los acondicionamientos de la zona. Poco a poco, se fue vaciando de ocupantes. Las fortificaciones fueron reemplazadas por un gran anillo verde, autorizándose la construcción de viviendas y obras sociales. Se cedió a la Universidad la zona comprendida entre los bastiones 81,82 y 83 que estaban situados entre las puertas de Gentilly y Arcueil, sobre un sitio organizado por la cobertura del acueducto del Vanne y del ferrocarril de Sceaux. Más tarde, el área fue ampliada con una parte de terreno que no llegó a liberarse hasta 1934, conservándose la vía que en prolongación del parque Montsouris y sobre la traza del antiguo acueducto, atravesaba el bulevar, marcando en diagonal el paso entre la entrada y el pabellón Suizo. Frente a la Cité, sobre el lado opuesto, se instaló el estadio universitario. ${ }^{109}$

Esta zona territorial se halla al sur de París, era una de las más despobladas y desurbanizadas, lo que hace pensar que seguramente por eso, discurrieron los fundadores de la Ciudad Universitaria que convenía regalar los terrenos para que las naciones extranjeras se apresuraran a construir suntuosos edificios y aportaran a los alrededores un valor del que urbanísticamente carece, porque el valor paisajístico, era bastante atractivo ${ }^{110}$.

La universidad cedía gratuitamente superficies proporcionales al número de estudiantes a alojar, a condición de observar ciertas obligaciones sobre la organización y construcción de los edificios cuyos proyectos, antes de presentarse al Municipio, se sometían a la Cité para velar por las bases generales urbanísticas. Más tarde, los edificios se entregaban a la Universidad por medio de una donación. En Junio de 1920 se encargó el proyecto general a Lucien Bechmann ${ }^{111}$, y el estudio del parque a Jean-Luc Forestier. Se aprecia en los croquis de este autor la conjugación de alineaciones rectilíneas de árboles, espacios verdes abiertos a modo debosques, lo cual daba un aire pintoresco, también incluía en sus dibujos campos de juego. Los alojamientos de estudiantes, proyectados inicialmente por Bechmann, se agrupaban en pequeñas maisons articuladas según la composición de las ciudades-jardín británicas ${ }^{112}$. 

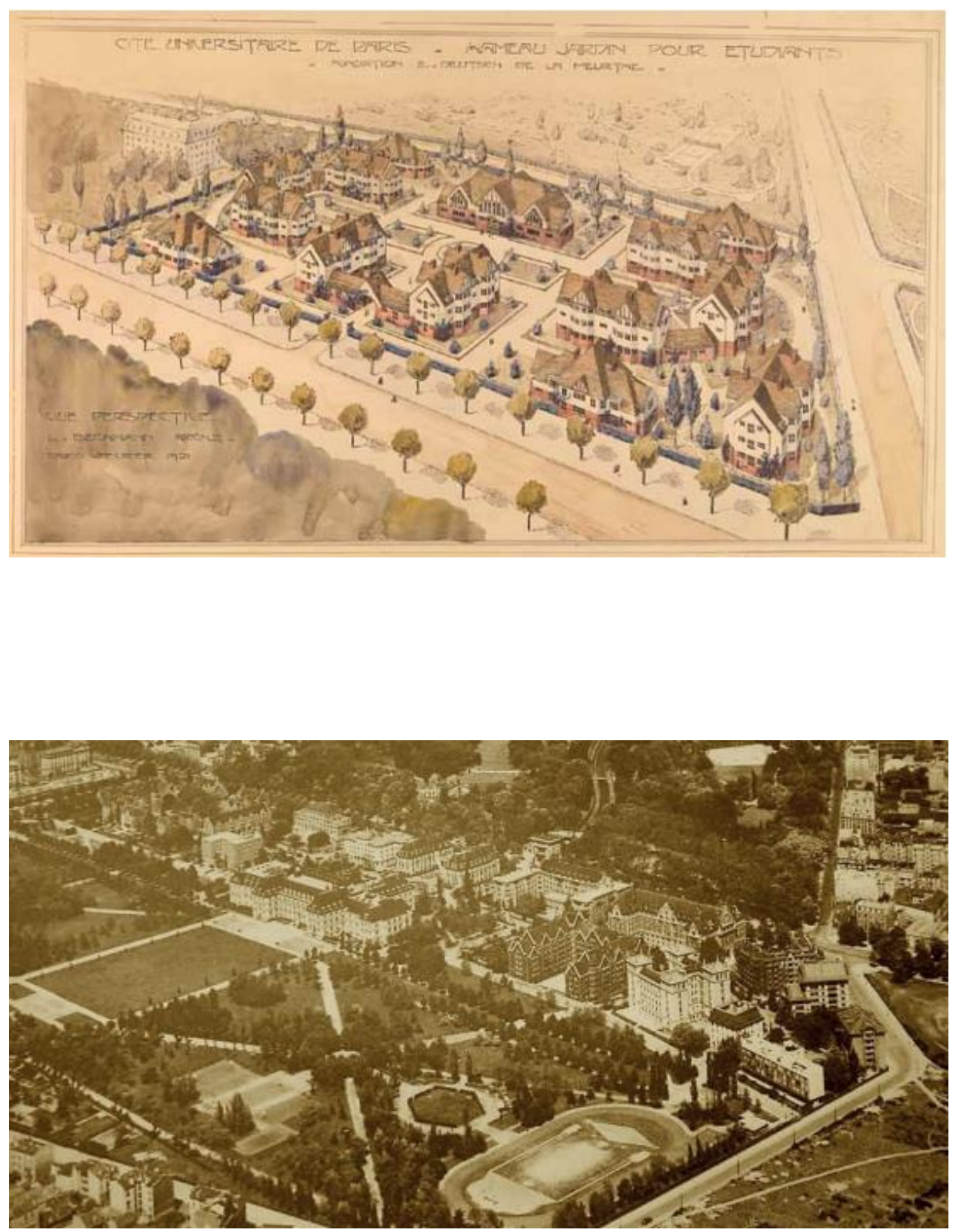

Imagen 98 : Entorno urbano de la Cité Universitaaire, las edificaciones se disponen en torno a la "franja verde" del Boulevard Jordan. Las residencias, de forma general, se configuran albergando a estudiantes de la misma nación, y por lo tanto son financiadas por cada uno de sus países representantes. Poseen espacios intermedios de relación a base de zonas ajardinadas.

Imagen 99: Foto aérea de conjunto. 
Una delegación de la Cité, invitada por Rockefeller, viajó a Estados unidos $^{113}$ entre noviembre de 1927 y enero de 1928, visitando Berkeley, Stanford, Duke, Princeton, Yale, Northwestwern, Chicago, Michigan, Ann-Harbor, Cornell, Toronto, Harvard y Columbia. En el barco de vuelta, Honnorat y Bechmann elaboraron el programa completo de los edificios que debían formar el centro de la Cité, el mayor de los cuales, financiado por Rockefeller, es el de la Maison Internacional. En París su aportación de la Maison Internacionale, fue consecuencia del viaje ${ }^{114}$. Una y otra dejan constancia edificada de la importancia de los viajes y del impulso universitario de Rockefeller en Madrid y París.

La trama urbana queda establecida por residencias de estudiantes asociadas a cada nación. Los creadores de la ciudad tuvieron la idea de que los estudiantes se establecieran según naciones, como se ha visto en el capítulo anterior, tradición desde el inicio de la Universidad, como el Colegio de los Españoles en Bolonia o el Colegio de las Cuatro Naciones.

Un primer rasgo moderno se muestra en la extensión destinada a lo largo del boulevard Jordan, todo un paisaje natural, rodeado de naturaleza. Este concepto influirá en la relación del edificio con la naturaleza, tanto en los recintos docentes universitarios como en los edificios destinados a alojamiento. Se promueven los puntos de encuentro entre estudiantes, así que la "Cité" es creada como punto de encuentro de estudiantes internacionales, esta iniciativa será muy del gusto del gobierno español de la época. El propio rey Alfonso XIII, junto con otros personajes importantes como el Duque de Alba, y José María Quiñones de León, embajador de España en París se interesarán por el proyecto. El rey quedará impresionado y conseguirá que Modesto López Otero proyecte en esta Ciudad el Colegio de España. El hecho de que haya una representación española en la Cité no será un hecho aislado, sino que será un punto clave para los edificios de residencias de estudiantes de la Ciudad Universitaria de Madrid, ya que los arquitectos españoles estarán unidos a las corrientes europeas y uno de los muchos brazos de unión será este recinto. 
Imagen 100 : Fundación de la Meurthe

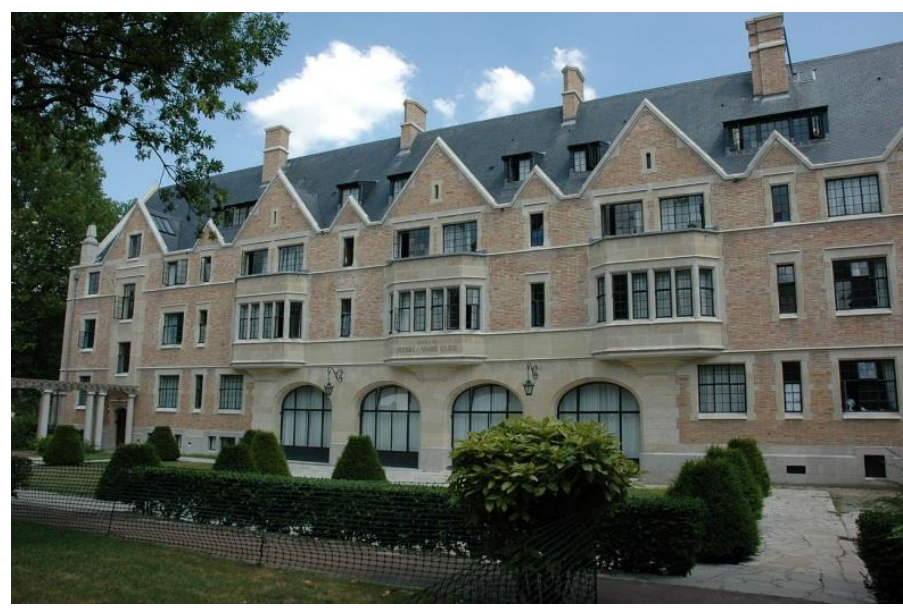

Imagen 101 : Colegio Norteamericano

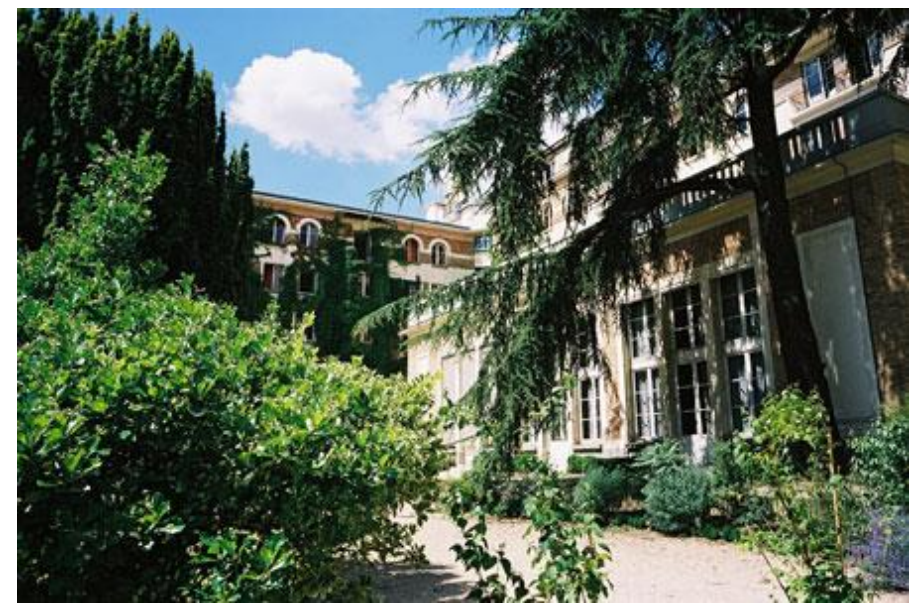

Imagen 102 : Colegio Franco-británico

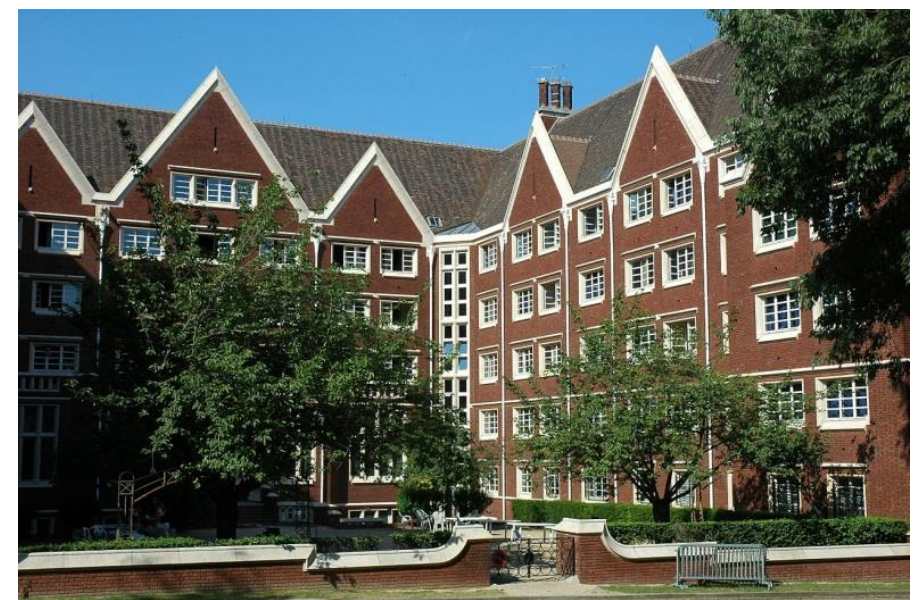

Estos tres colegios se encuentran situados en las inmediaciones del Colegio de España. Muestran un estilo tradicional. López otero en su obra respetó este carácter y exportó historicismo español. 
A lo largo de los años, la Cité atrajo y suscitó el interés de inversores de diversos países en el proyecto. A raíz de esto, se organizaban conferencias y viajes para obtener un amplio soporte humano. Como resultado, Jean-Hubert Biermans Lapôtre, financió la creación de la Casa Belga en 1926; el senador Joseph Marcellin Wilson respaldó la fundación de la Casa del Canadá; Edward Nathan la del Colegio Franco-Británico (1927); Otto Bemberg, la del Argentino (1928); Jikei y Jirochatchi Satsuma la casa del Japón (1929); al mismo tiempo, Benny Dessau y Helge Wanbert, consejeros de la embajada de París, lanzaron una colecta de fondos privados para construir la Fundación Danesa en 1932. Un año antes, el Comité Franco-americano acometía la Fundación de Estados Unidos. Muchos países y sus gobiernos contribuían a la construcción de los pabellones de sus naciones respectivas, como es el caso de la Casa de Suecia (1931), erigida con fondos privados y completada por el gobierno sueco; o la de Grecia (1932) para cuya construcción se reunieron por supcripción fondos completados por el gobierno de este país. El mayor mecenazgo recibido fue por parte del millonario norteamericano John D. Rockefeller, ya citado anteriormente, que financió la Maison Internacionale(1930-1936), situada en el centro de la Cité y provista de restaurante, biblioteca, piscina y muchos otros servicios. Este hecho, tuvo su antecedente unos años antes, cuando Rockefeller invitó a una delegación de la Ciudad Universitaria a Estados Unidos. Añadir que, el poeta Edmond Haraucourt le deja en herencia también una residencia en la Isla de Bréhat, en las costas de Bretaña, donde los estudiantes podrían acudir en periodo vacacional.

Tras la guerra, las obras se reemprenden y una nueva serie de construcciones se empieza. De 1948 a 1969, diecisiete nuevas casas abren sus puertas. A comienzos del siglo XXI su oferta se completa con dos residencias extramuros, en el XIX Distrito de París.

Las residencias universitarias de la Cité mostraron una amplia gama arquitectónica, pasando de los estilos historicistas a la modernidad y haciendo que esta Ciudad Universitaria fuese una verdadera exposición de la arquitectura del siglo $\mathrm{XX}$, en la que se muestra su pluralidad.

Por su repercusión en la posterior arquitectura residencial universitaria española, merecen un estudio particular el Colegio de los Españoles y el Pabellón Suizo.

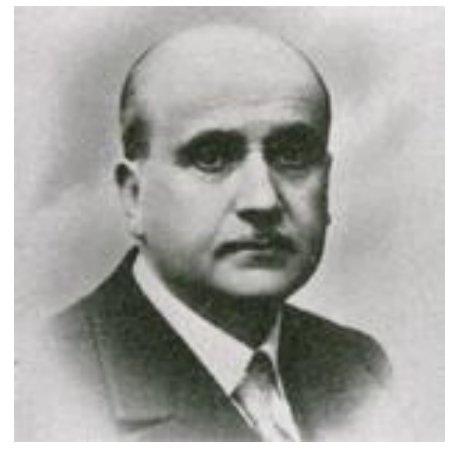

Imagen 103: Modesto López Otero

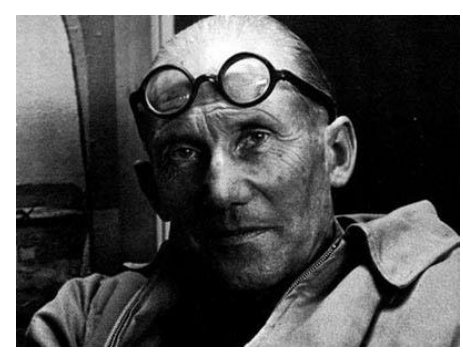

Imagen 104: Le Corbusier 


\section{EL COLEGIO DE LOS ESPAÑOLES EN PARÍS}

Como se acaba de expresar en el apartado anterior, la idea de su construcción surgió en el periodo de entreguerras, cuando la representación diplomática y los estamentos universitarios hicieron gestiones ante el Gobierno para lograr la participación española en la Cité Universitaire, solicitándose en julio de 1924 información pertinente para fundar una institución española en París. Dos años después, en mayo de 1926, el Gobierno anunció su intención de alzar una "Maison de l'étudiant espagnol"115 en la Cité Universitaire, "donde los países más importantes están ya representados"116. El propósito era que la Casa del Español fuese capaz de albergar a unas 80 personas, de las cuales 60 podrían ser de las que cursaran allí sus estudios y 20 para las que ya habían obtenido su carrera y cuyo objetivo fuese ampliar sus conocimientos. Este propósito se encarriló en 1927, coincidiendo también con el 25 aniversario del reinado de Alfonso XIII. En un viaje privado del monarca a París, tras visitar la Cité, escogió el emplazamiento para la construcción del Colegio. A continuación, enterado de que otros países como Bélgica alojaban 225 estudiantes, Estados Unidos 260 e Inglaterra 150, pidió ampliar los terrenos hasta la correspondencia reglamentaria con un edificio que consiguiese albergar a 150 estudiantes ${ }^{117}$. Su decisión fue ratificada por el Gobierno, creando el Colegio por Real Orden el 15 de julio y encomendando al Ministerio de Instrucción las medidas necesarias para construir, instalar y dotar sus servicios. Dos meses antes había tenido lugar la creación de la Ciudad Universitaria de Madrid, cuyo paralelismo en aspecto residencial y contemporaneidad son significativos. Estos conceptos se desarrollan en los bloques tres y cuatro de este trabajo.

La concreción de las negociaciones para la creación del Colegio, dio su fruto el 8 de noviembre, cuando, tras la concesión del suelo para este pabellón, se firmó el Acta de Donación a la Universidad de París, fijándose en dos años el plazo de construcción. La prensa francesa hizo eco de ello, resaltando cómo esta fundación era la primera hecha por un gobierno, cobrando por ello una gran importancia particular. Por su parte, la prensa española informó de los detalles de la fundación y del anuncio ministerial de un concurso entre arquitectos españoles para elegir a quien sería el autor del proyecto. En España se vivía un proceso de transformación social sin precedentes, donde la noticia fue muy bien recibida ya que se creía firmemente en la gran capacidad de modernización de la sociedad de la mano de la educación y la cultura, por lo que el proyecto de construir el Colegio vence todas las dificultades. Casi simultáneamente, el 27 de octubre tenía lugar la creación del 
patronato o Comisión del Ministerio de Instrucción para el Colegio, integrada por el Duque de Alba como presidente de la Junta de Relaciones Culturales, el embajador en París, Quiñones de León, y el Director de Enseñanza Superior, González Oliveiros.

Ante la envergadura del proyecto, se intentó reducir sus dimensiones, hacer el edificio con 50 habitaciones, siendo éste susceptible de ampliación a 150 a medida que las" necesidades lo requieran y las circunstancias lo permitan", como explicó la propia Comisión del Colegio. La Cité se opuso rotundamente a tal reducción, en razón del compromiso firmado, abriendo un contencioso que se prolongó hasta mayo, cuando el presidente del Gobierno telegrafía: "Orden definitiva, construcción Colegio 150 habitaciones", proponiéndose conceder 50 de ellas a estudiantes iberoamericanos. Al mismo tiempo, se nombraba a Luis Doreste representante en París encargado de los asuntos relacionados con la construcción del Colegio de España. Resueltos los contenciosos que paralizaban el tema, el Duque de Alba, en nombre del Rey y como presidente de la Comisión, encargó a López Otero la elaboración y ejecución del proyecto, olvidando el concurso anteriormente citado. Para el mes de junio, el Duque de Alba puso en conocimiento de Quiñones que le había encargado el proyecto a López Otero y que éste ya lo estaba desarrollando, esperando tener el anteproyecto en un periodo breve de tiempo para llevarlo a París y en pocos meses, él aseguraba que para otoño, el proyecto definitivo estaría listo y se podría empezar con las obras de construcción del edificio. Realizado con celeridad y en paralelo con los trabajos de la Ciudad Universitaria de Madrid, de la que también a López Otero el rey había nombrado jefe de la Junta Constructora de La Ciudad Universitaria de Madrid, el 30 de junio se remitió a París el anteproyecto, aprobado por la junta de Relaciones Culturales, que causaría en París grata impresión por el "depurado arte y estilo español de suma elegancia con que está

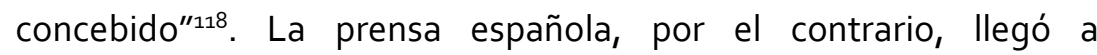
cuestionar la razón de ser del Colegio y su lugar en La Cité, expresando que existían obras en España de carácter más "necesario" que esa. El proyecto se concretó en diciembre, aprobándose definitivamente en 1929. Resulta curioso que el estilo arquitectónico escogido fuera la arquitectura castellana, con cierto aire al modelo del Palacio de Monterrey en Salamanca, evocando los colegios libres e internacionales de la vieja escuela de Salamanca, como la raíz europea de la cultura española. Dejando a un lado las atribuciones de modelos históricos como los de Salamanca, Valladolid o Alcalá, está más próximo, arquitectónicamente, a obras como la Fundación del $\mathrm{Amo}^{119}$ para 160 estudiantes americanos y españoles en la Ciudad Universitaria madrileña, La residencia de 
Estudiantes de Madrid en la Colina de los Chopos u obras en la Cité como la Fundación Deutsch de la Meurthe.

Como se acaba de apuntar, dicha fundación fue proyectada por Lucien Bechmann, se organiza en 6 edificios de apartamentos en torno a un jardín rectangular, con un pabellón central coronado por un campanario. Su estilo tradicional evoca la arquitectura de los colleges ingleses "había dos modos de abordar las fachadas" dijo Bechmann: adoptar el espíritu moderno o aparentar arquitecturas del pasado ${ }^{120}$. El arquitecto expuso estas cuestiones a su cliente y la decisión fue clara. No quería que su Fundación hiciese tabla rasa del pasado. La Universidad tiene orígenes y tradiciones seculares; sus enseñanzas se basan en la experiencia y el saber de generaciones que nos han precedido. ¿Por qué no inspirar sus edificios en estilos del pasado? Así el proyecto de la Fundación está impregnado de soluciones arquitectónicas de los colleges de Oxford y Cambridge, detalladas éstas en el próximo capítulo de este trabajo. Los otros referentes son las grandes fundaciones nacionales ${ }^{121}$ que, vecinas inmediatas al Colegio de España, contrastan con él su tipología organizativa y sus formas.

Proyectada por Armand Gueritte, la belga busca una expresión unitaria, y un tanto monumental, mezclando caracteres flamencos y valones, mientras en la norteamericana Pierre Leprince-Ringuet busca el habitual modo "composicionalist" de los grandes edificios americanos del momento. Por su parte, Pierre Martin y Maurice Vieu quieren evocar en el franco británico la obra de las universidades inglesas, fragmentando su apariencia volumétrica y formal.

En cuanto a sus organizaciones planimétricas también difieren, siendo una $U$ abierta al sur y al parque, la franco-británica, mientras que las otras dos plantean un esquema en doble $T$, si bien con acceso central la estadounidense y acceso frontal por el lado menor la belga.

López Otero se plantea si el edificio debe ser de carácter o estilo formal, sobre si inspirarse en la arquitectura áulica o vernácula, religiosa o laica, antigua o reciente, cada uno presenta una respuesta diferente. Los tejados volados, la madera y el empanelado identifican el pabellón del Japón. La columnata jónica, la fundación helénica. La Fundación Argentina pretende evocar las viejas estancias de la Pampa. No se escapa de esta intencionalidad, entendida en esta ciudad universitaria como permanencia estilística francesa, la Maison internacionale, proyectada por Bechmann y Frèdèric Larson ${ }^{122}$, que auna los edificios sociales, administrativos y residenciales, y define la entrada principal a la Cité por un porche de 
arcadas, con una figuración que evoca la arquitectura de Fontainebleau.

Retomando el caso español, en ese mismo otoño, se redactó el proyecto definitivo, que se desarrolló para su ejecución material con los medios franceses $y$, adaptado a ellos, se sometió a subasta para la contratación, dando comienzo las obras en septiembre de 1929. La proclamación de la República en abril de 1931 abrió una primera etapa de incertidumbre, pasará un tiempo hasta que se reconduzca y redirija el proyecto de construcción. Tras estos momentos iniciales de duda, en los cuales se llegó a contemplar la cesión del edificio a la Universidad de París, el apoyo de Alberto Jiménez Fraud y del nuevo embajador, Salvador Madariaga, imprimió un fuerte avance a los trabajos. En 1932 parecía que iban a darse por finalizadas e iba a procederse a habitar e inaugurar el Colegio. Así lo recogió la prensa de la época. Las cosas, sin embargo, se demorarían un poco más. Aunque finalmente en otoño de 1933 ya se incorporaron algunos estudiantes y en 1934 se constituyó su Consejo de Administración, la inauguración oficial no tuvo lugar hasta abril de 1935.

En el proceso de proyecto del Colegio de España se plantearon varios problemas. Los más importantes fueron el estilo y la imagen, ligados al problema del carácter y a la ordenación tipológica. En cuanto a las bases formales o estilísticas del Colegio de España, debe resaltarse la continuidad formal con sus obras coetáneas en Salamanca o en Sevilla, dándose una coincidencia en la estructura de los alzados, elementos y detalles que, con pequeñas variaciones de tamaño, ritmo y proporción de huecos, son similares. Debe resaltarse el deseo de sus promotores de que el edificio fuera eminentemente español, es decir, que su arquitectura reflejara la historia española. La respuesta fue un proyecto austero, cuyas formas y volúmenes ofrecen un conjunto unitario, quizá el más clásico de los concebidos entonces por López Otero, conformando una imagen sobria y rotunda. Así, López Otero debió insistir en el carácter español del Colegio, de acuerdo tanto de los deseos tanto de Madrid como de París. El problema era identificar arquitectónicamente España en un lenguaje comprensible a los residentes de la Cité, originarios de todo el mundo. 
López Otero quiso rendir homenaje a la tradición universitaria, como el mismo decía: "Al recuerdo de nuestras universidades de Alcalá y de Salamanca, tan prestigiosas", con un diseño nacional, aunque abstrayendo y simplificando los modelos en el proyecto, dando tono severo al edificio y austeridad en su decoración. La personalidad del edificio reside en sus torres, versión moderna de las de Monterrey. El "Colegio de España, se escribión ${ }^{123}$, se refiere en su concepción a la tradición universitaria española de los siglos XVI y XVII. La coronación de sus cuatro torres ilustra dicha referencia". El Colegio es un edifico exento, que consta de una planta semisótano y cinco sobre rasante. La tipología de organización está considerada en tres esquemas posibles de distribución del edificio, como reflejó López Otero tiempo más tarde, en una nota manuscrita, donde los posibles esquemas eran: $\mathrm{C}$, E y $\mathrm{H}$, decidiéndose finalmente por este último.

Al igual que en la Fundación del Amo, la forma en $\mathrm{H}$ puede deberse a la necesidad de dar solución funcional a los problemas de recorridos e independencia de las zonas habitacionales. Desechada la distribución con patios de otros proyectos coetáneos, esta planta permitía un acceso en el eje de simetría que independizaba los espacios a ambos lados disminuyendo de esta manera las circulaciones. En esa $\mathrm{H}$ las alas albergan la residencia y las distintas dependencias, situando en el eje transversal las circulaciones verticales y las estancias comunes de cada planta. Se reserva el sótano a servicios generales, la planta baja contaba con una escalera central, que arrancaba de un amplio vestíbulo, y dos cuerpos laterales con la sala de conferencias y la dirección a un lado, y el comedor y la sala de lectura y la biblioteca al otro. Los pisos que se ocupaban de los dormitorios y una pequeña sala de estar por cada planta. La similitud de la composición en planta se refuerza en los alzados, totalmente revestidos con piedra que actúa como material perenne y ayuda a reforzar la claridad volumétrica y arquitectónica ${ }^{124}$ 

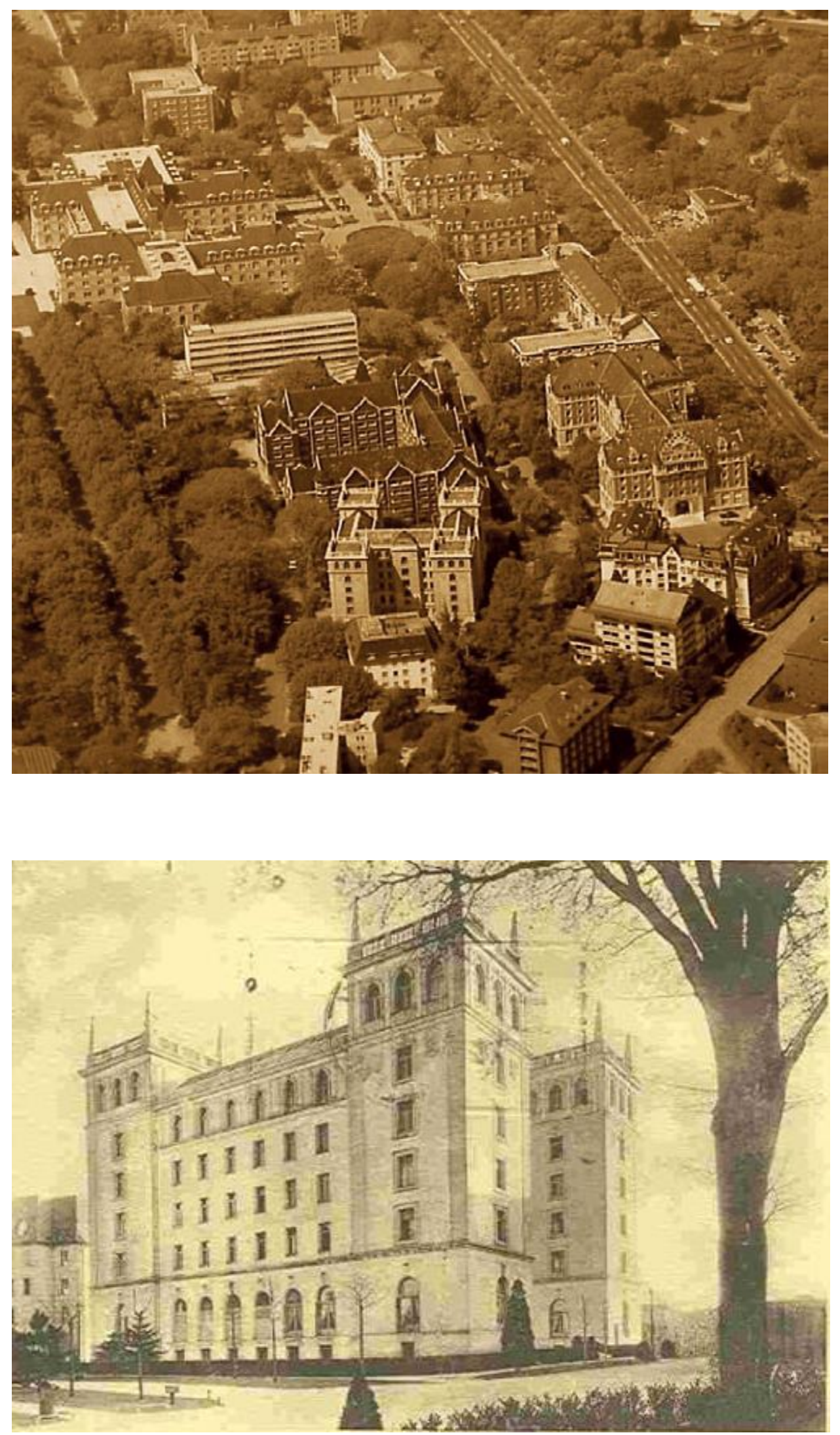

Imagen 105: Inserción en la Cité del Colegio de España.

Imagen 106: Perspectiva del Colegio ( 1935) 
Imagen 107: Existencia de continuidad formal con las obras del Hotel de Sevilla y el Gran Hotel de Salamanca, donde se puede apreciar la estructura de los alzados, elementos y detalles que son similares.

Imagen 108: Hotel Cristina de Sevilla de López Oteo

Imagen 109: Gran Hotel de Salamanca de López Otero.

Imagen 110: detalle de la puerta principal de entrada
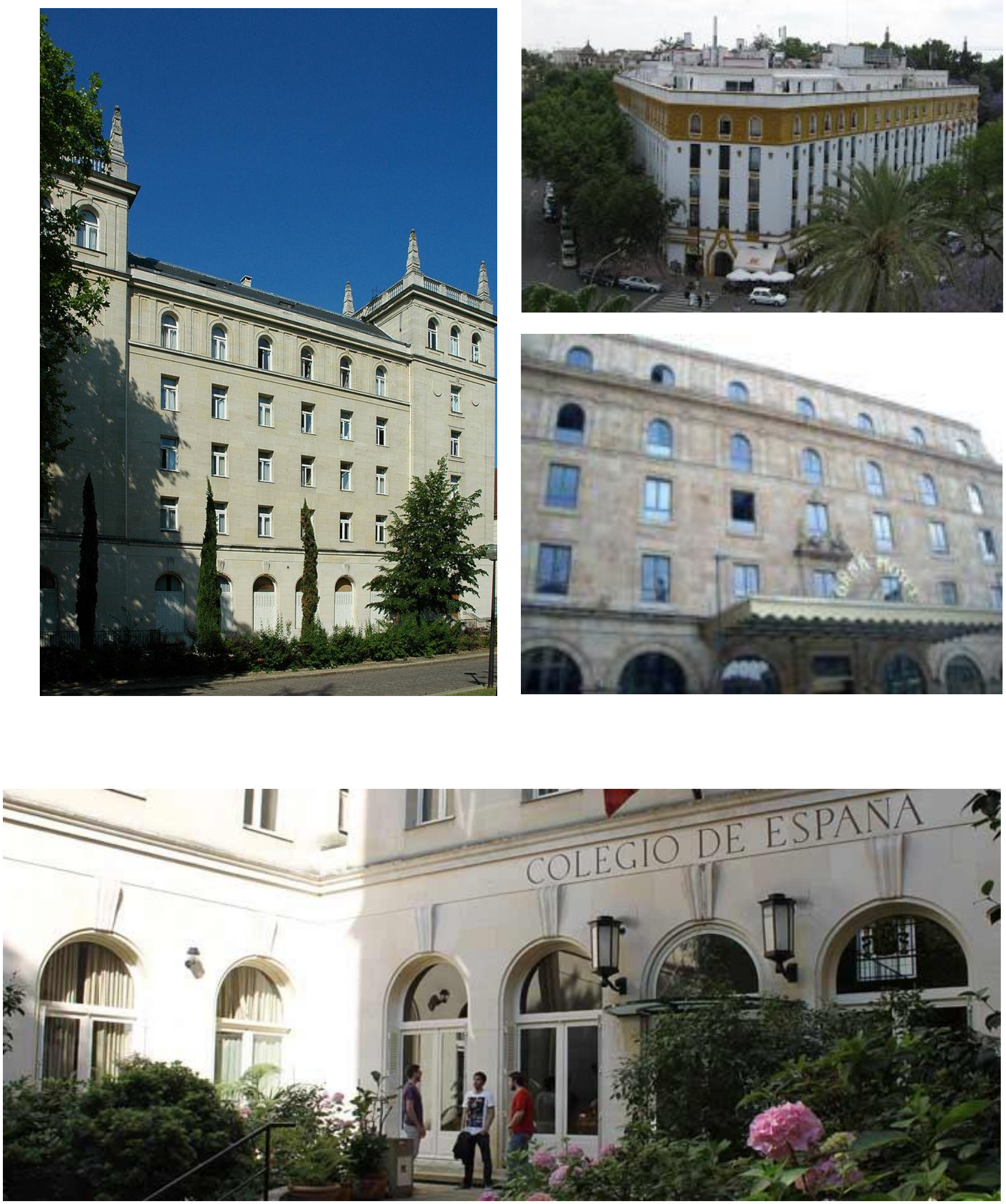


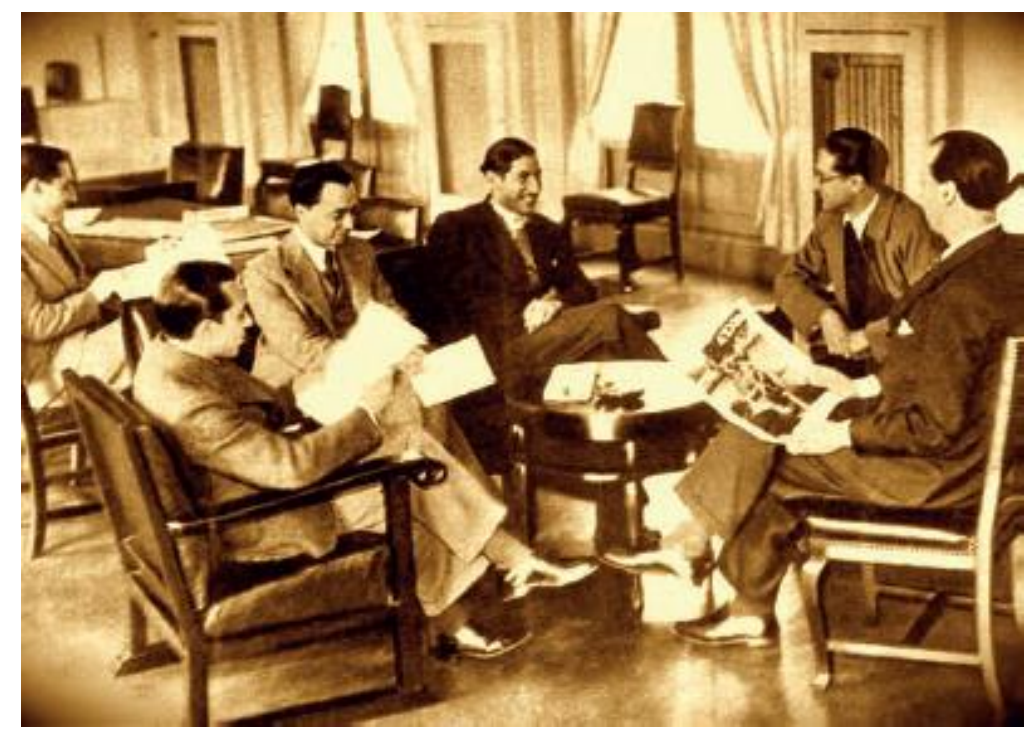

Imagen 111: Estudiantes en una de las salas comunes de planta baja.

Imagen 112: Planta del Colegio d España. Se aprecia la elección de López Otero por el esquema en " $\mathrm{H}$ " en detrimento de los esquemas de patios interiores empleados en proyectos

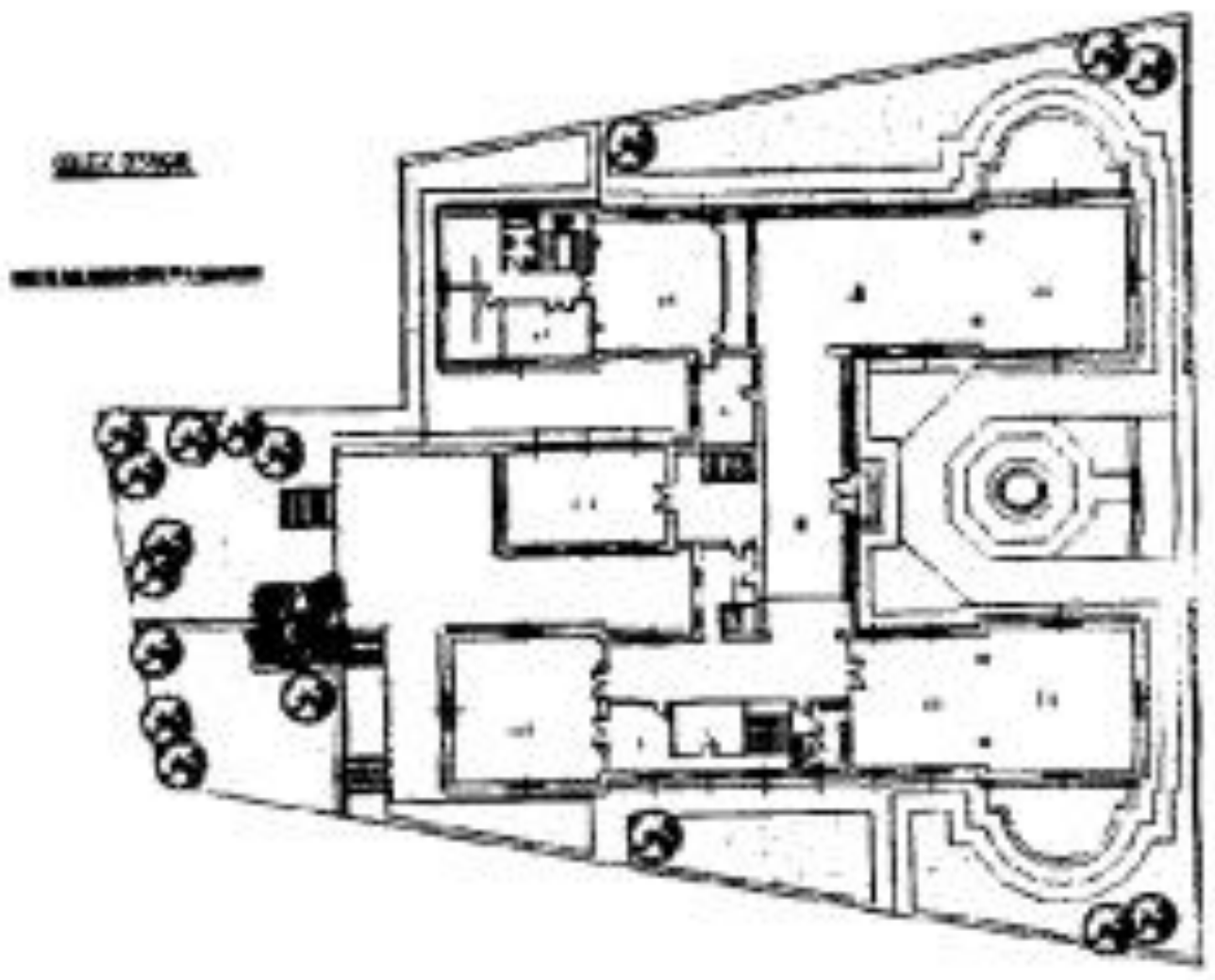




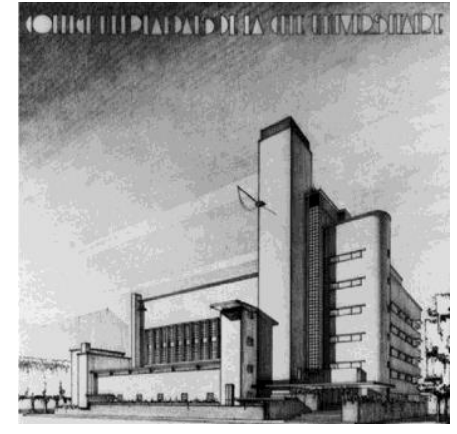

Imagen 113: El Colegio Holandés de Willem Dudok

\section{EL PABELLÓN SUIZO}

Carácter excepcional y contrastante tienen el Pabellón Suizo, construido en 1933, el Colegio Holandés de 1938 y la Casa del Brasil, un tanto posterior, construida en 1958. Estos ejemplos buscaron su expresión en las bases de la modernidad y supondrán un claro punto de referencia de la arquitectura moderna. En los próximos capítulos se hace especial hincapié en las repercusiones que éstos tienen en la Ciudad Universitaria de Madrid.

El Colegio Holandés, proyectado por Willem Dudok, muestra su personal concepción de rasgos racionalistas y refleja la arquitectura holandesa de su tiempo. El Pabellón Suizo es un excelente ejemplo de la obra de Le Corbusier que, como es conocido, en 1925 había formulado sus célebres cinco puntos que, a modo de axiomas, se convirtieron en sintagma de la modernidad y que se ejemplificaron en este Pabellón Suizo, entre otros.

Se trata de un edificio estudiado desde diversos aspectos, sin embargo, en este caso es relevante su posición y emplazamiento dentro del trazado de la Cité.

El edificio se coloca al fondo del recinto, de espaldas a la Ciudad Universitaria de París. El recorrido de acceso ofrece en primer lugar el zócalo del cuerpo bajo de piedra, de forma cóncava y totalmente cerrado. Sobre él, la fachada neutra con huecos cuadrados de ritmo monótono y el núcleo de comunicación vertical, también cerrado y repitiendo curvatura cóncava; esto al norte. Hacia el sur, el edificio aparece totalmente acristalado abriendo los dormitorios al entorno, y ningún elemento compositivo marca la entrada. Se puede deducir que el arquitecto quería mostrarla al futuro parque deportivo que se construiría detrás del recinto universitario ${ }^{125}$. Este hecho es relacionable con la solución que se adopta en campus modernos americanos al vincular los espacios residenciales con los deportivos.

En la configuración volumétrica y formal, el pabellón queda configurado tras varios bocetos previos. El volumen se define con tres cuerpos: el contenedor de dormitorios, el núcleo de comunicación vertical y el bloque de servicios el de servicios. Le Corbusier resuelve el bloque de servicios como antítesis del bloque de dormitorios, en forma, volumen y materiales. Esta organización recuerda o parece ser influencia, de la estancia años antes del autor en Rusia, donde conoció el edificio Narkomfin, en Moscú, de los arquitectos Ginzburg y Milinis, donde aparecen también los servicios comunes en un pabellón aparte del destinado a vivienda. 
Le Corbusier concibe la solución organizando los cuartos para estudiantes en un paralelepípedo de cuatro plantas de $49 \mathrm{~m}$ por $9 \mathrm{~m}$, apoyado sobre pilotis y extendiéndose en su eje longitudinal al esteoeste. En cada una de las tres primeras plantas se disponen, en una solución de corredor, quince cuartos de veinticuatro metros cuadrados de superficie perpendiculares a un corredor de distribución, solución a la cual el arquitecto se enfrenta por primera vez y se repetirá en el desarrollo de la célula mínima de habitación desde los proyectos para las Unités d'Habitation, hasta la Casa de Brasil o la Tourette. De esta manera el cuerpo de habitaciones queda abierto al sur hacia el sol y las vistas de los campos deportivos mediante un muro de vidrio (pan de verre) y se cierra al norte dejando sólo pequeñas aberturas que iluminan los corredores. El volumen vertical central que contiene los servicios funciona como nexo con el cuerpo bajo que contiene los ámbitos comunes. En esencia es un gran espacio tratado con libertad formal, cuyas poéticas curvas contrastan con la austeridad de líneas del primer volumen.

En el espacio interior en planta baja, el cuerpo de la escalera está iluminado a través de un paramento continuo de pavés. Cabe destacar que la escalera va intercalando distintos tipos de barandilla, el lado de la escalera que da al vestíbulo posee una barandilla metálica mientras que el lado que da al comedor es de fábrica de ladrillo, con este gesto, el autor también está cuidando las vistas en función de lo más y menos privado. La separación entre vestíbulo y comedor está constituida por un murete bajo sobre el que se cierra una pared de vidrio. Este muro bajo se transforma, en el lado que da al comedor, en un mueble de obra. Le Corbusier transforma un elemento de cerramiento en uno de mobiliario, consiguiendo efecto de transparencia y, a su vez, volver a difuminar límites.

Las fachadas se configuran atendiendo a la orientación solar, con un lenguaje moderno. La mayor parte de los huecos está ejecutada con muro cortina. La fachada sur es acristalada y en ella se sitúa el acceso, de espaldas al recorrido de aproximación al edificio pues a la entrada principal se accede bajo el bloque donde se encuentran situadas las habitaciones. La fachada norte es cerrada y cóncava, no existe en ella acceso, ni siquiera secundario, sin embargo es la imagen con la que se muestra el pabellón al recorrer la Ciudad Universitaria. Estos dos alzados son antagónicos pero poseen rasgos que los hacen frontales y traseros al mismo tiempo, en un juego novedoso que pone fin a la antigua relación de recorrido de aproximación-alzado frontal-acceso. El mismo sistema había sido utilizado en la Villa Saboya, forzando rodear el edifico antes de 
producirse el acceso. De esta manera, traslada un recurso utilizado en vivienda a un bloque en altura de residencia universitaria.

En esta solución, lo público toca el suelo mientras que lo privado flota sobre la naturaleza. La importancia del "elemento verde" en los campus modernos, como espacio de relación exterior, toma mucho sentido en este proyecto, sobre todo con la elevación de planta sobre pilotis, difuminando la frontera entre lo común y lo reservado.

El pabellón posee un número reducido de apoyos para no "molestar "al jardín donde se encuentra ubicado. Le Corbusier forma un esquema de caja ligera y homogénea sobre una bandeja de robustas patas.

En la relación Interior -Exterior existe una frontera difusa. Al recorrer el perímetro del Pabellón, y desde su interior, se puede apreciar el alcance de la ambigua relación dentro-fuera que ofrece este edificio. La zona de acceso es donde ésta relación es más rica o, lo que es lo mismo, más equívoca.

La puerta central se encuentra descentrada con respecto a los soportes, esto da la sensación de que esconde su función, además de que es opaca estando rodeada de muros de vidrio. Esta puerta desdibuja la frontera exterior-interior.

La forma del edificio, su composición, estructura, elementos singulares o relaciones internas están llenas de significados sensibles y sutiles, que añadidos a una idea potente de planteamiento compositivo y funcional, dan como resultado una obra llena de contrastes, que tendrá repercusión en el edificio que Le Corbusier realizará junto a Lucio Costa en la Cité. Se trata del Colegio Casa de Brasil, que anteriormente se ha nombrado, donde también se trabajará la separación de los espacios privados y los públicos mediante la volumetría y la utilización de distintos materiales.

Asimismo, y atendiendo a estos criterios, este edificio tendrá una clara influencia en el Colegio Mayor Casa do Brasil de la Ciudad Universitaria de Madrid. 


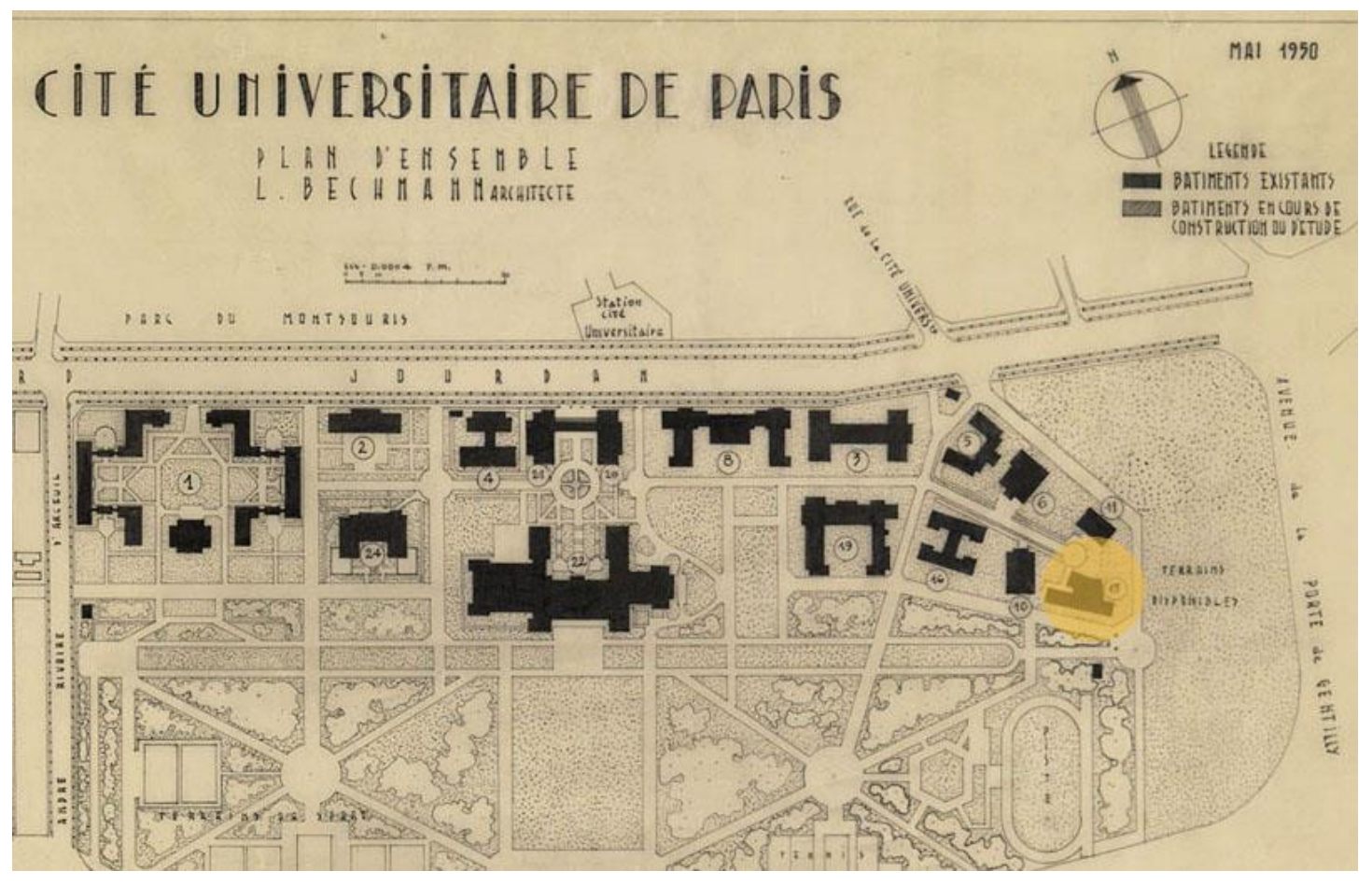

Imagen 114: Zonificación del edificio en la Cité, donde se aprecia que el acceso no se encuentra inmediato vinculado a la fachada frontal principal.

Imagen 115: Planta baja libre y sustentada mediante pilotis.

Imagen 116: Esquema del nucleo de comunicación vertical y la planta de dormitorios, donde se ven los quince cuartos de $24 \mathrm{~m}^{2}$ perpendiculares al corredor de distribución. Las vistas de las habitaciones se proyectan a los

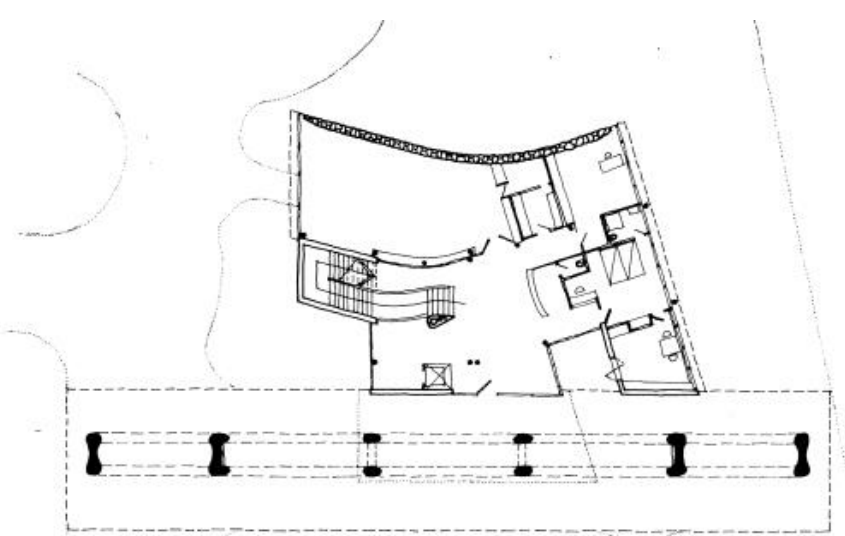
campos deportivos.

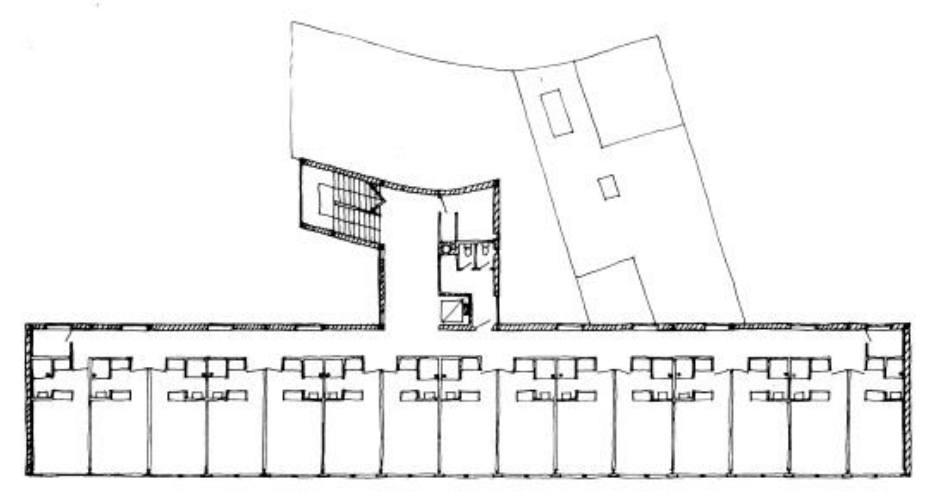



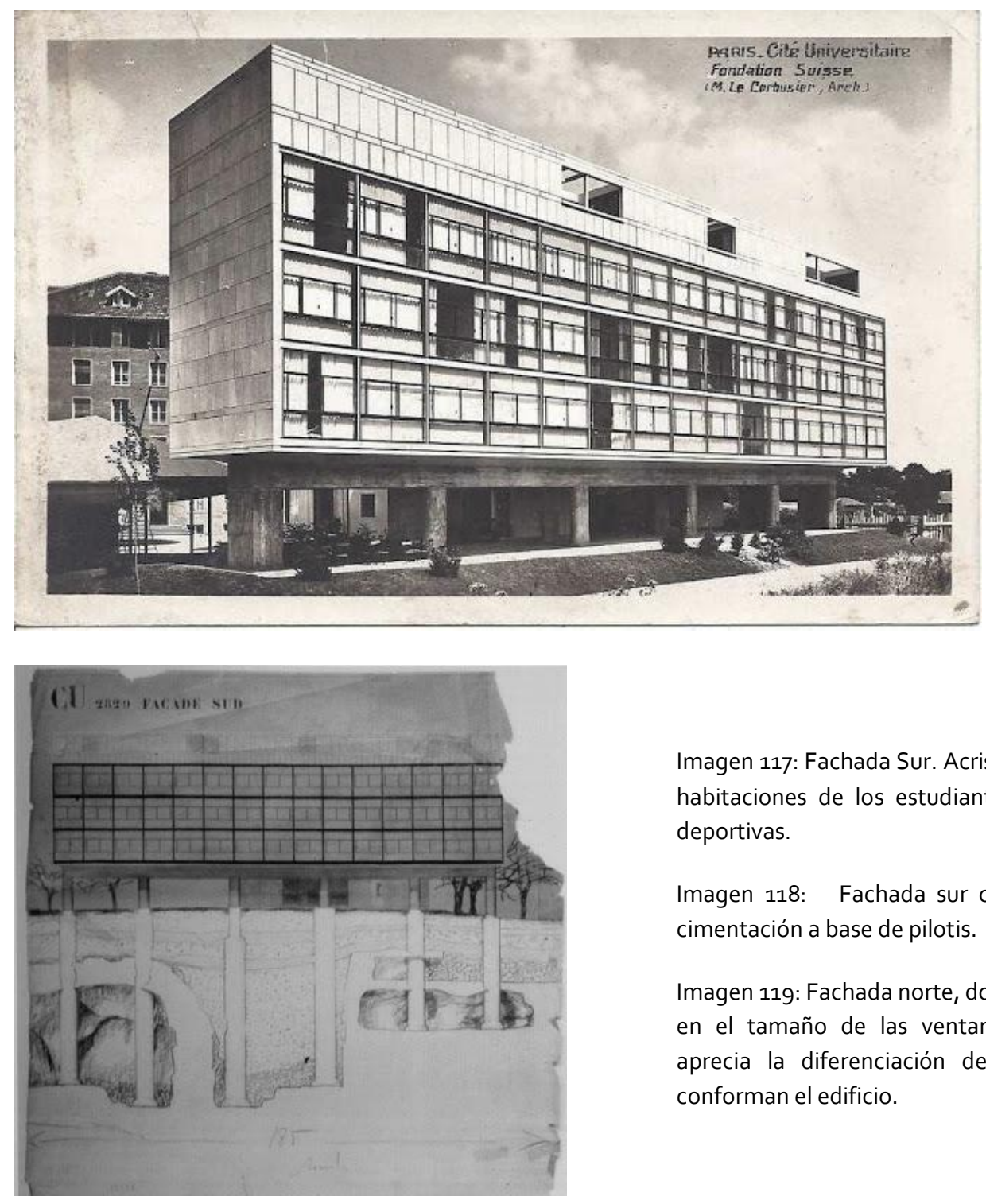

Imagen 117: Fachada Sur. Acristalamiento continuo de las habitaciones de los estudiantes con vistas a las zonas deportivas.

Imagen 118: Fachada sur con esquema detalle de la cimentación a base de pilotis.

Imagen 119: Fachada norte, donde se aprecia la reducción en el tamaño de las ventanas de los corredores. Se aprecia la diferenciación de los dos volúmenes que conforman el edificio.

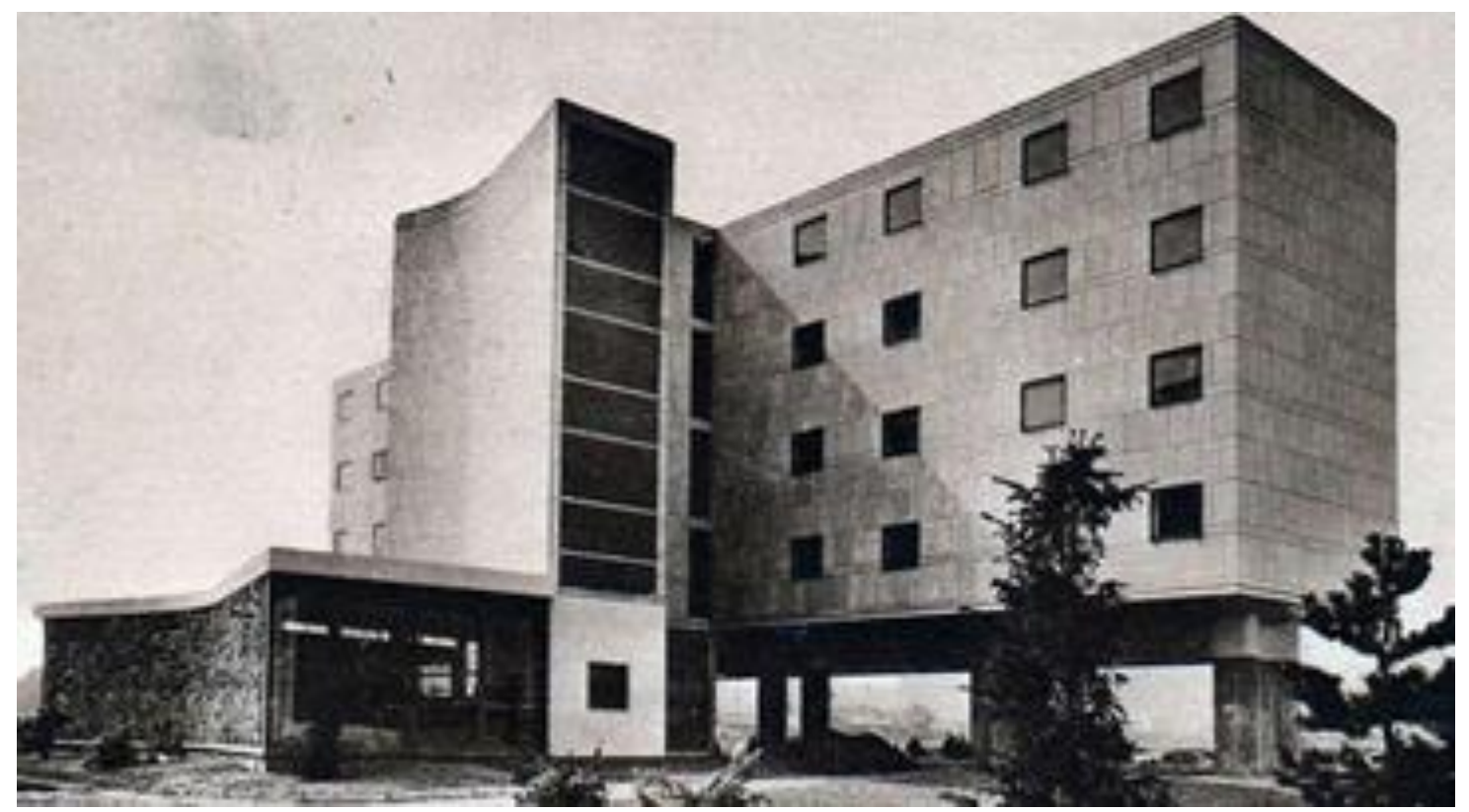




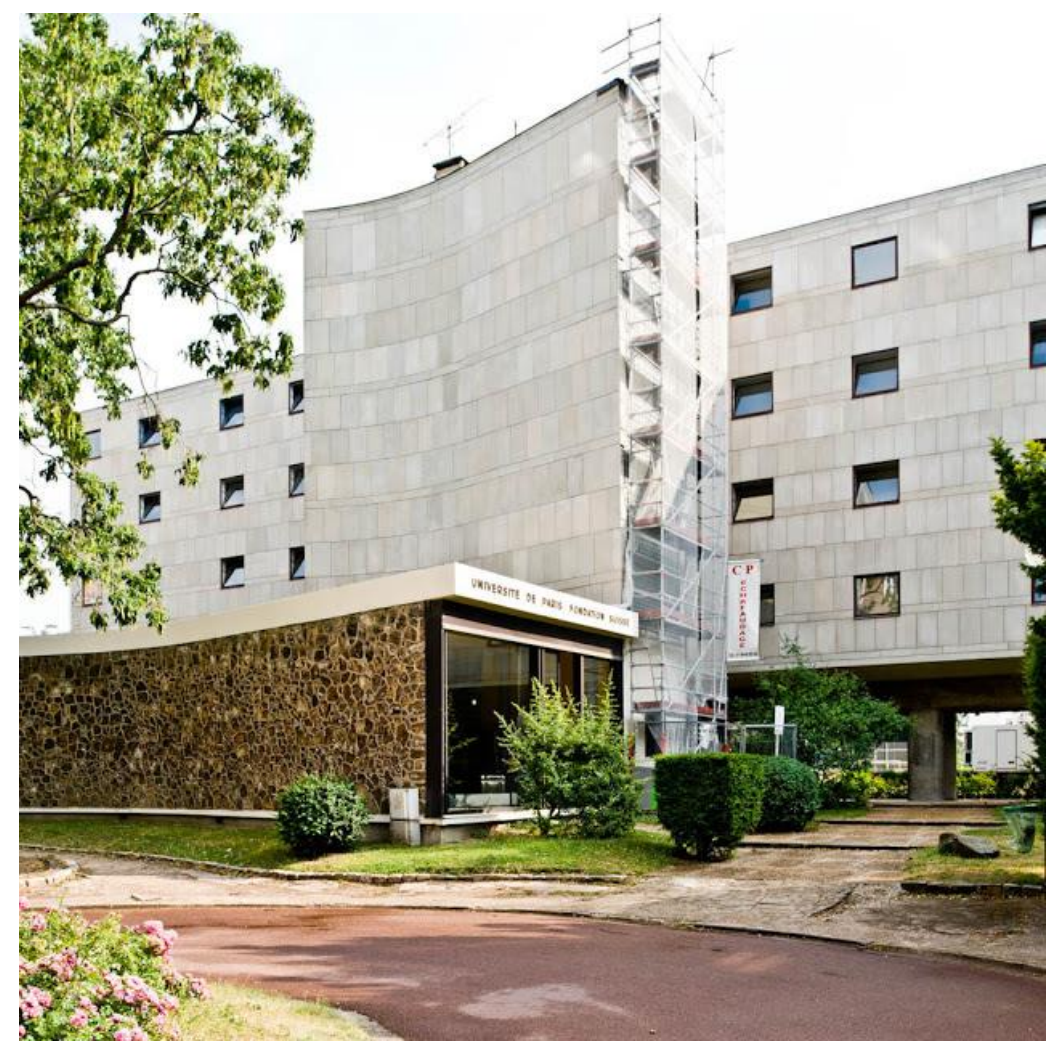

Imagen 120: Caracterización de materiales de los dos volúmenes

Imagen 121: Detalle de la planta sobre pilotis

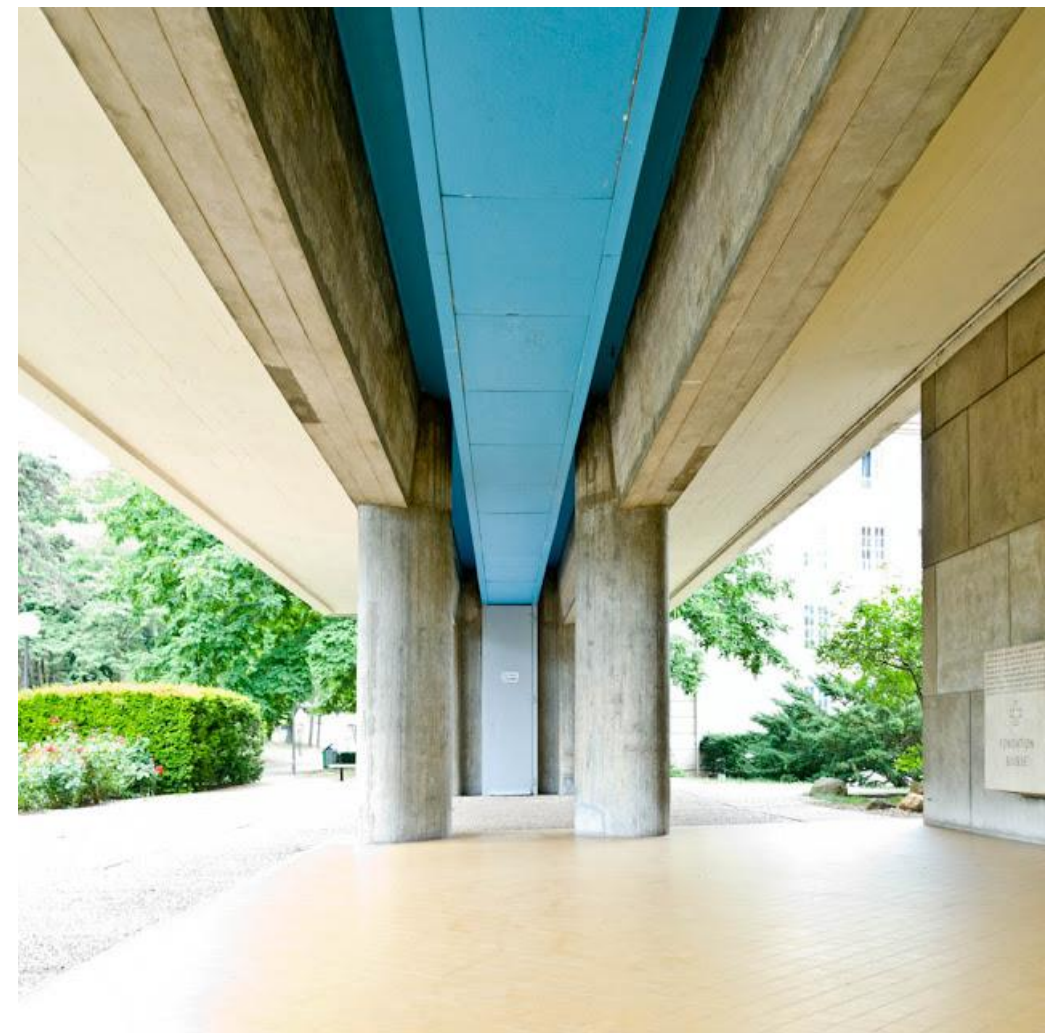




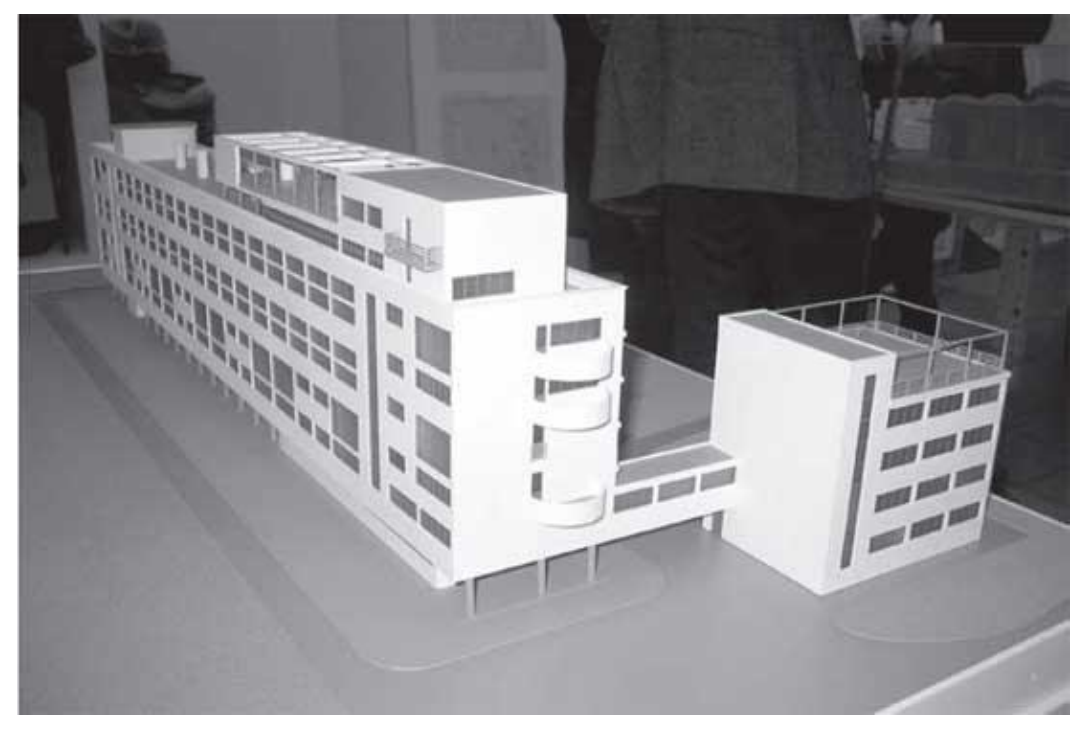

Imagen 122: Maqueta del edificio Narkomfin, donde se aprecia la diferenciación, en distintos bloques, de las viviendas con respecto a los servicios.

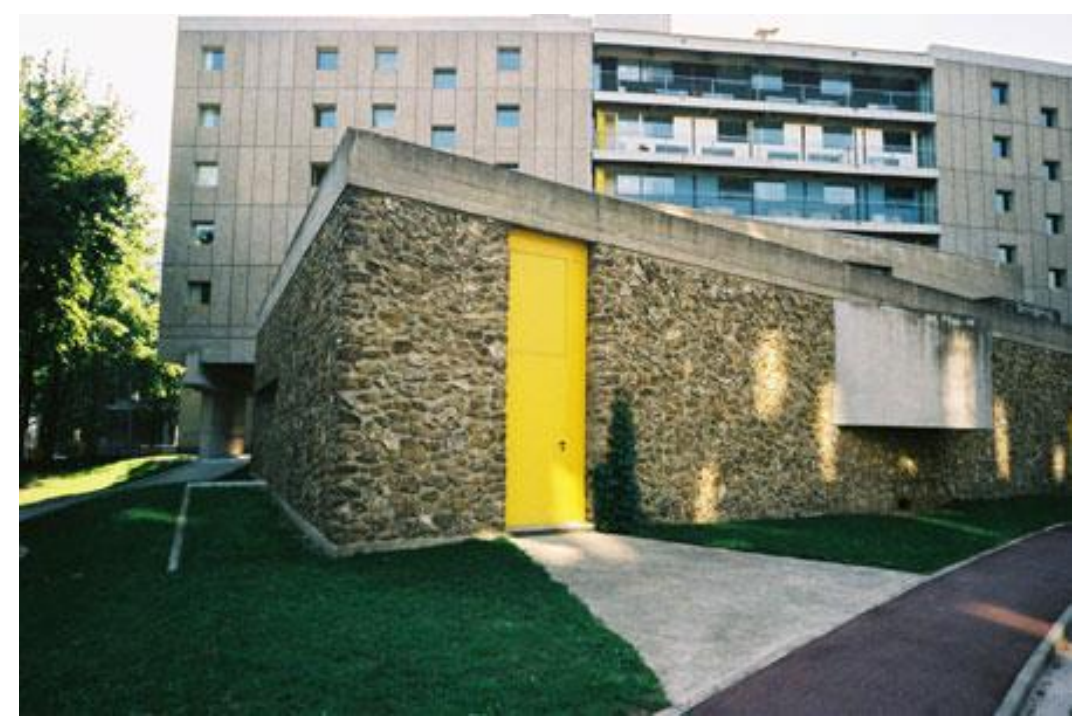

Imagen 123: Detalle del colegio Casa de Brasil (1954) de Lucio Costa y Le Corbusier en la Cité Universitaire, donde también aplica materiales distintos en función de lo público y lo privado. 


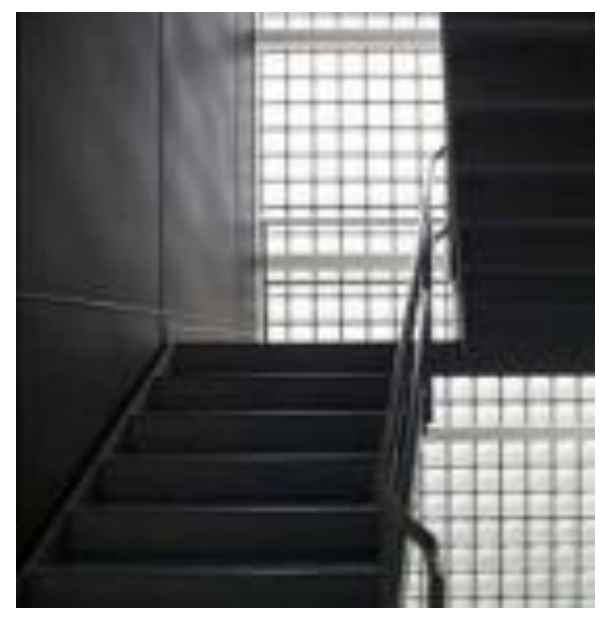

Imagen 124: Detalle de la iluminación del núcleo vertical de comunicación a través del pavés.

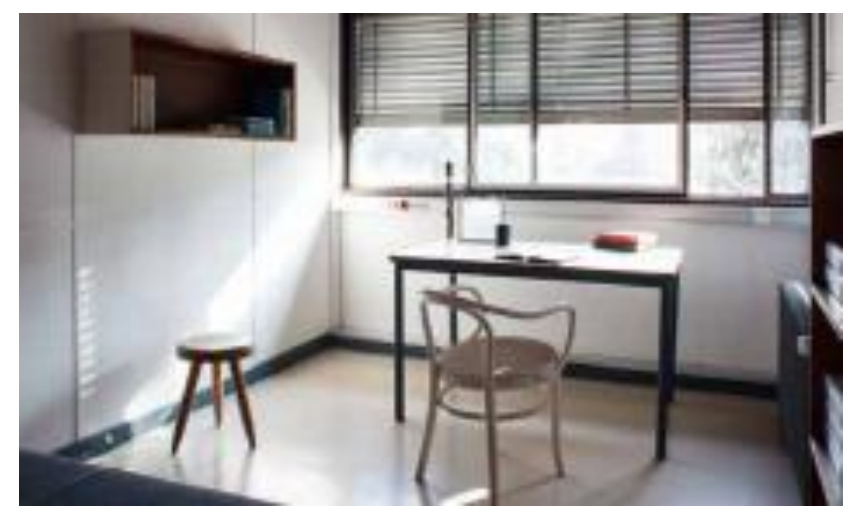

Imagen 125: Habitación de estudiantes 


\section{RESIDENCIAS UNIVERSITARIAS EN LA HISTORIA}

\section{BLOQUE II}

OXFORD Y CAMBRIDGE. El College como arquetipo

El modelo inglés de residencia universitaria.

Oxford

Merton College. Evolución tipológica entorno al quadrangle (1274)

New College. Primera distribución proyectual con patios (1386)

John's College. Crecimiento espacial jerarquizado (1437)

Christ Church College. La magnificiencia en el conjunto urbano (1524)

Cambridge

Peterhouse College. Asentando el modelo (1284)

King's College. El reflejo de la memoria (1441)

Trinity College. La fusión colegial (1540)

Apéndice contemporáneo:

Fen Court en Peterhouse College. Adoptando nuevos planteamientos (1939)

Saint Cazt College de Arne Jacobsen. La traducción moderna de la tradición (1962)

Florey Building en Queen 's College de James Stirling. Mirando hacia Estados Unidos (1971) 
168| RESIDENCIAS UNIVERSITARIAS EN LA HISTORIA 


\section{EL MODELO INGLÉS DE RESIDENCIA. EL COLLEGE COMO ARQUETIPO.}

Se desconoce la fecha de fundación de la universidad, y tal vez no existió como un suceso en concreto, pero hay evidencia de actividades de enseñanza desde el año $1096^{127}$. Cuando Enrique II de Inglaterra prohibió a los estudiantes ingleses la asistencia a la Universidad de París, en el año $1167^{128}$, Oxford empezó a crecer con rapidez. La fundación de las primeras residencias estudiantiles, que luego devinieron en los colleges, data desde esta época en adelante. Se puede considerar el comienzo de la función residencial estudiantil en Inglaterra a partir de estos hechos.

La salida del "conocimiento" desde los claustros catedralicios y monacales a su encuentro con la sociedad formuló, aquí en Gran Bretaña, un modelo arquitectónico del cual tomó cuerpo la propia Universidad. La implantación física de este modelo se va a realizar en torno a un espacio central, de forma cuadrangular o rectangular, alrededor del cual se van a disponer las distintas estancias que conforman los colegios. La herencia del claustro viene reflejada en los patios de este modelo arquitectónico de colegio: el college. Estos patios, además, supondrán una unidad de crecimiento de los propios colleges.

El college parece presentar una autonomía más acusada que sus homónimos continentales tanto con respecto al Estado como a la propia Universidad. En la configuración en planta que se acaba de describir, esencialmente cuadrada o rectangular, lo que se conoce con el nombre de quadrangle, se puede leer la huella de la arquitectura monástica en tanto que el claustro constituye, como se ha visto en el capítulo Precedentes Arquitectónicos de esta Tesis, un espacio de marcado orden formal dentro del cual el control de la vida estudiantil es más directo. Además de esta cuestión, mediante esta geometrización, se logra constituir una ciudad con su propia geometría, o al menos con un patrón o módulo de crecimiento.

El college posee una composición cerrada pero múltiple en su interior, que va densificando y estructurando un ente urbano de carácter homogéneo, en el cual cristaliza la plena identificación Ciudad-Universidad $^{129}$. Dentro de las funciones albergadas en este geométrico modelo, la función residencial es uno de los pilares constituyentes de este sistema, y se pretende una formación integral del individuo a través de conseguir espacios de relación entre ellos, y también con el profesorado, pues ambas residen en el college.

Un concepto originado en esta época y que se mantendrá hasta la modernidad.

El esquema organizativo se desarrolla entorno a patio o patios, éstos son los núcleos a los que vuelcan las distintas zonas del programa, y 
tienen el cometido de ser las zonas comunes exteriores necesarias para el encuentro entre residentes, dicho esquema produce un ambiente que será "buscado" en centros residenciales universitarios en la futura modernidad, donde se crucen estudiantes de distintas facultades, propiciando a que la variedad de opiniones circule libremente dando pie a polémicas y debates. Esta forma desembarazada y no reglamentada de formación y educación que este tipo de residencia universitaria ofrece, al margen de los auditorios y laboratorios, llena el vacío que el estudio formativo, deja sentir respecto de conocimientos culturales e ideológicos. Así pues estas residencias universitarias asumen una parte importante en la formación integral del individuo, como se ha apuntado anteriormente.

A continuación se muestra una selección de obras. Se han tomado dos criterios para su elección, en primer lugar el orden cronológico y, en segundo lugar, la repercusión tipológica que han proyectado en otros colleges posteriores, haciendo a los primeros distintivos de conformar un arquetipo.

\section{MERTON COLLEGE.}

\section{Evolución tipológica entorno al quadrangle (1274)}

La "Casa de los estudiantes de Merton" tuvo originalmente propiedades en Surrey, hoy llamadas Old Malden, así como en Oxford, pero no fue hasta mediados de la década de 1260 cuando Walter de Merton adquirió los terrenos del emplazamiento actual en Oxford, a lo largo del lado sur de la que fue Saint John Street, hoy Merton Street. El college se consolidó en este lugar en 1274, cuando De Merton realizó la revisión final de sus estatutos.

La adquisición inicial incluía la iglesia parroquial de Saint John, que fue incorporada a la capilla, y tres casas al este de la iglesia (que ahora forman parte del lado norte del patio principal). De Merton también obtuvo permiso del rey para extenderse desde esas propiedades hacia el sur, hasta la muralla de la ciudad, para formar un cuadrado. El college continuó adquiriendo otras propiedades cuando estas estaban disponibles a ambos lados de Merton Street. Hubo un tiempo en que el college era propietario de toda la tierra que había desde el actual emplazamiento del Christ Church College hasta la esquina suroeste de la ciudad. Los terrenos que había al este se convirtieron en los jardines actuales, mientras que los terrenos orientales fueron alquilados por el entonces director Rawlins en 1515 para la fundación del Corpus Christi College, por una renta de cuatro libras al año. 

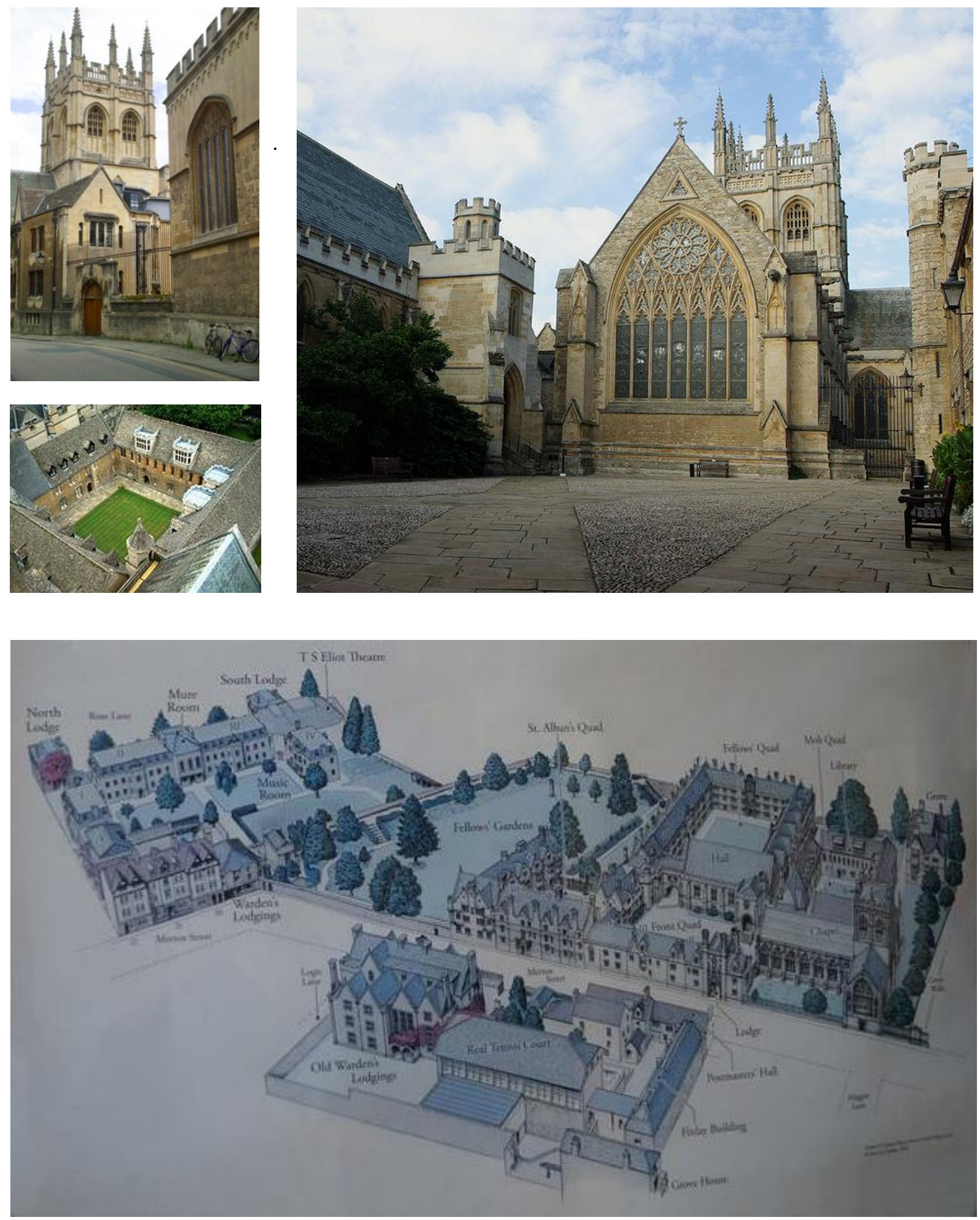

Imagen 120: Entrada principal del Merton College

Imagen 121: Vista de la capilla desde el el Front Quad

Imagen 122: Vista de la capilla desde el el Mob Quad

Imagen 123: Perspectiva de las dependencias que conforman el college, donde se aprecian los distintos estilos de las construcciones que lo conforman. Este primer college, se formó a partir de edificaciones preexistentes. 
Este sistema, como se aprecia de manera fehaciente en este colegio, se agrupa o crece por la adhesión de "quads", elementos de cuatro lados que delimitan un patio central, éste entendido como un jardín. Este rasgo "natural" es importante, ya que se da en todo este tipo de colegios. Las habitaciones están en los lados largos del quadrangle mientras que los otros albergan zonas comunes como la biblioteca, comedor y hall. La capilla forma parte importante del programa y se sitúa de forma adyacente a este sistema.

A lo largo del tiempo el college se va haciendo cada vez mayor, va adquiriendo terreno y construyendo más módulos a su alrededor. Debido al crecimiento geométrico que presentan, el recorrido a lo largo de los distintos quadrangles muestra tanto huellas del pasado como edificios de nueva planta, pero todos "cosidos" formando parte de un mismo patrón.

Este es uno de los colegios de mayor magnificiencia en Oxford, los espacios interiores tienen unas proporciones bastante amplias, sobre todo los espacios comunes. Las habitaciones de los estudiantes tienen unas dimensiones más reducidas.

En Fellows' Quadrangle es donde se sitúan la mayoría de habitaciones. Las dependencias están compuestas por la capilla, la sala y las habitaciones para los colegiales, dispuestas, dispuestas en torno a un patio, el Mob Quadrangle, que fue terminado en $1379^{130}$.

Es importante reseñar que en estos espacios herederos de los claustros monacales, aparece, tanto en los colegios españoles, como aquí en los colleges la presencia del reloj, las horas de estudio ya no son determinadas por los tiempos de oración y rezo.

St. Alban'sQuad., en su origen fue una residencia de estudiantes medieval $y$, que el propio college aglutinó en su sistema de crecimiento geométrico por adhesión de elementos configuradores del espacio entorno a patios ajardinados.

Alrededor de 1905 los edificios fueron restaurados por Basil Champneys. 

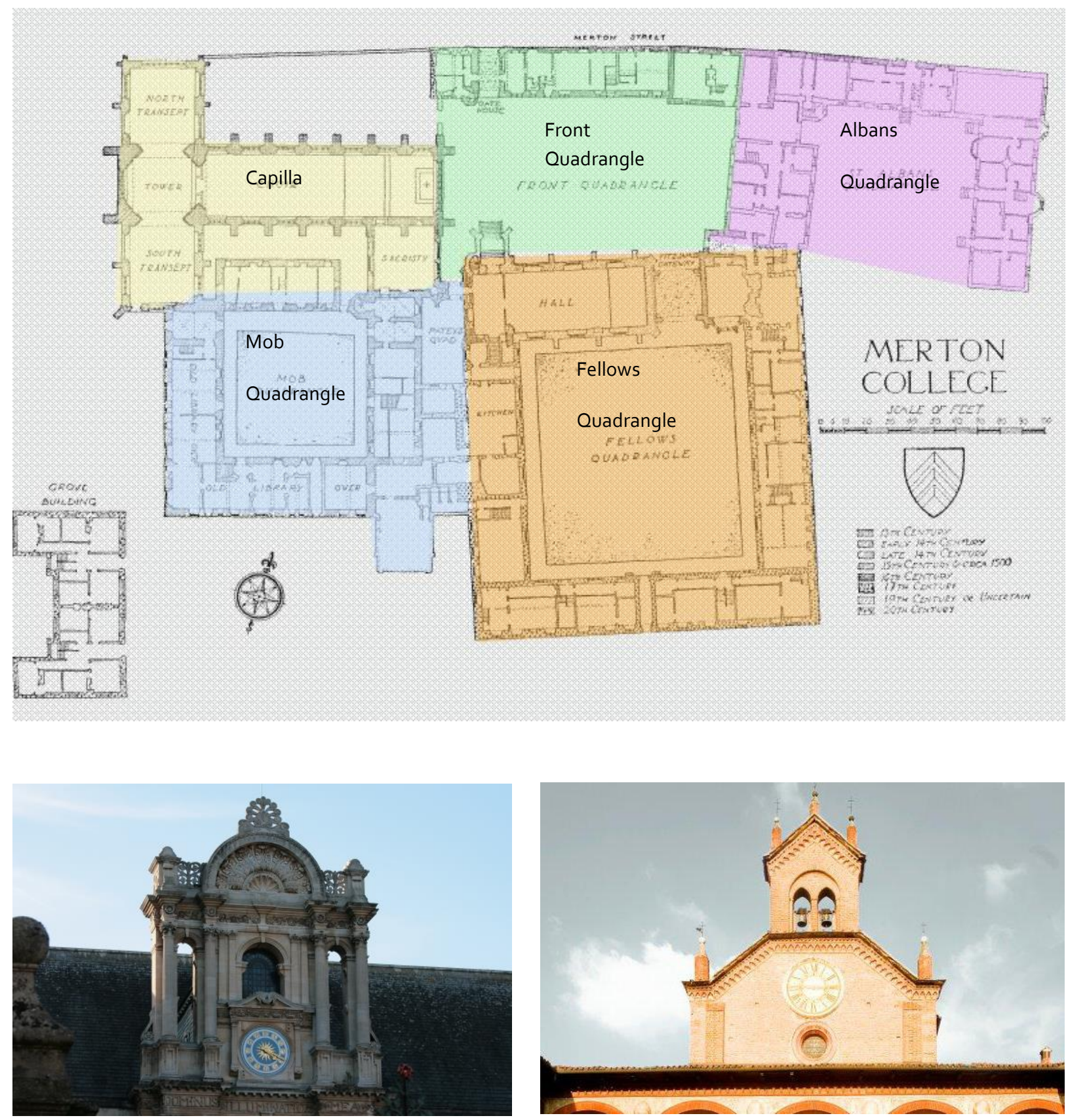

Imagen 124: Planta del Merton College. Zonificación de quadrangles.

Imagen 125: reloj en el Fellows quadrangle. Característica también se da Bolonia y aparecerá como rasgo común en espacios claustrales de residencia universitaria.

Imagen 126: Reloj en el hastial del Colegio de los Españoles de Bolonia. 

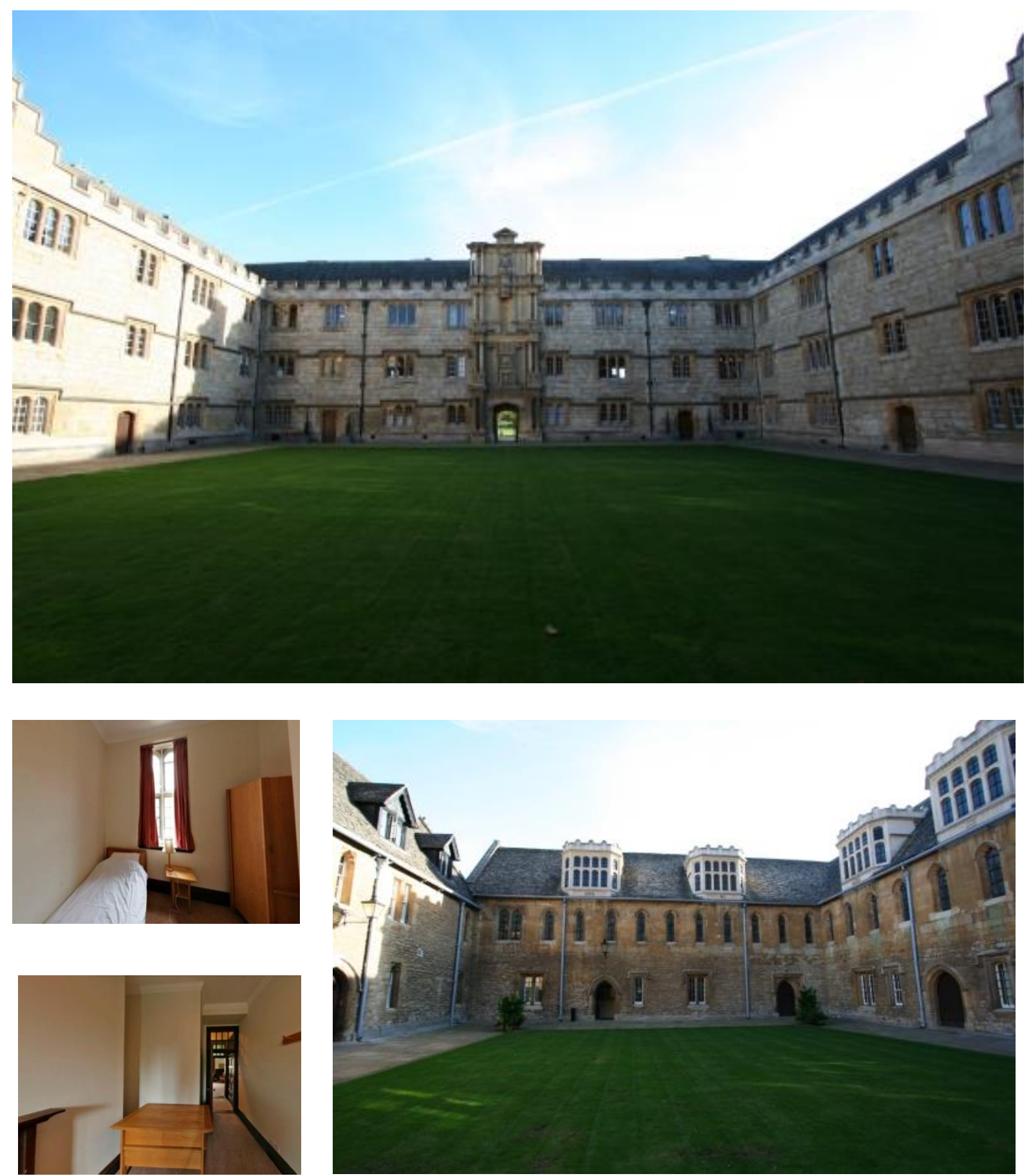

Imagen 127: Vista del Fellow's quadrangle.

Imágenes 128 y 129: Fotos de una habitación estudiantil (2001). Se aprecia la pequeña dimensión de las mismas. Cada ventana en alzado corresponde a un ahabitación. Se accede a ellas mediante un corredor.

Imagen 130: Vista del Mob quagrangle. Zona de las habitaciones de estudiantes que vuelcan al patio. 

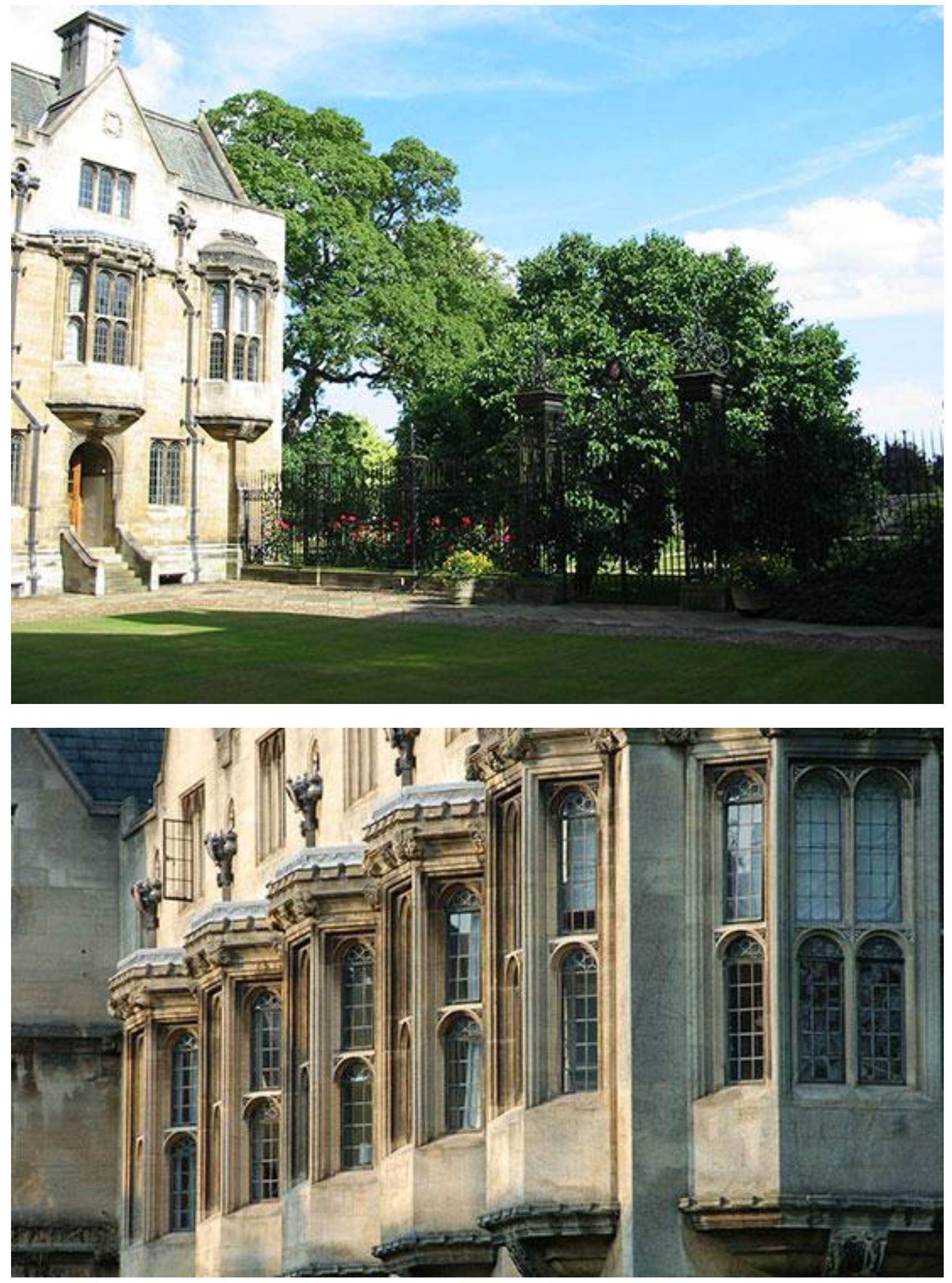

Imagen 131: Vista de San Alban's quadrabgle.

Imagen 132: Vista de San Alban's quadrangle. 


\section{NEW COLLEGE. Primera organización proyectual con patios (1386)}

Su fundador fue William de Wykeham, Obispo de Winchester.

Se puede considerar el primer colegio universitario, de nueva planta con la configuración cuadrangular, construido en Gran Bretaña. De hecho, cronológicamente sólo el Merton es anterior. Como la mayoría de los colleges en esta época, sus piezas principales son: la sala, que sirve tanto de refectorio como de aula; la capilla; el patio y las habitaciones para 70 colegiales. Estas dependencias se reparten formando un quadrangle con patio rectangular, (1380-1386) en cuyo lado norte están concentrados los espacios de uso común. Alredor de este se crean otros patios de menor tamaño. La capilla tenía Estatuto parroquial y mantenía una actividad litúrgica que convertía al patio grande en un atrio de la iglesia, con uso procesional, mientras que el otro patio de menor tamaño, está rodeado por las habitaciones de los colegiales. La organización en torno a un patio pronto se exportaría a otras ciudades, tal es el caso de Cambridge, donde también la organización en torno a un patio se convirtió en el rasgo común de todos los colleges. En este modelo, los dormitorios compartidos se alternan con estudios de uso individual, jalonando las crujías en torno al patio con el ritmo binario de las bíforas y los vanos más pequeños de los estudios ${ }^{131}$.

En los jardines existe una sección del muro medieval de la ciudad, la antigua Oxford City Wall, cuando Guillermo de Wykeham fundó el colegio, acordó con las autoridades el hacerse cargo de su mantenimiento. A la hora del crecimiento del college_se respetará esta muralla, por lo que como se puede apreciar en la planta crece en línea horizontal en la orientación este-oeste.

Este centro se encuentra ubicado en una parcela llena de robles, particularidad por la que los techos de la galería del claustro están compuestos por vigas de madera de roble, en ocasiones, ha sido susceptible de varios tratamientos y de reformas ya que presentaban problemas de pudrición., con lo que fue fácil la recolección del material autóctono. 
Imagen 133: Alzado sur.

Imagen 134 : Dibujo del siglo XVII de los alrededores del college.

Imagen 135 : Perspectiva general del New College. El estilo y la altura de la capilla junto con la torre, que marca la entrada principal, jerarquizan los espacios.
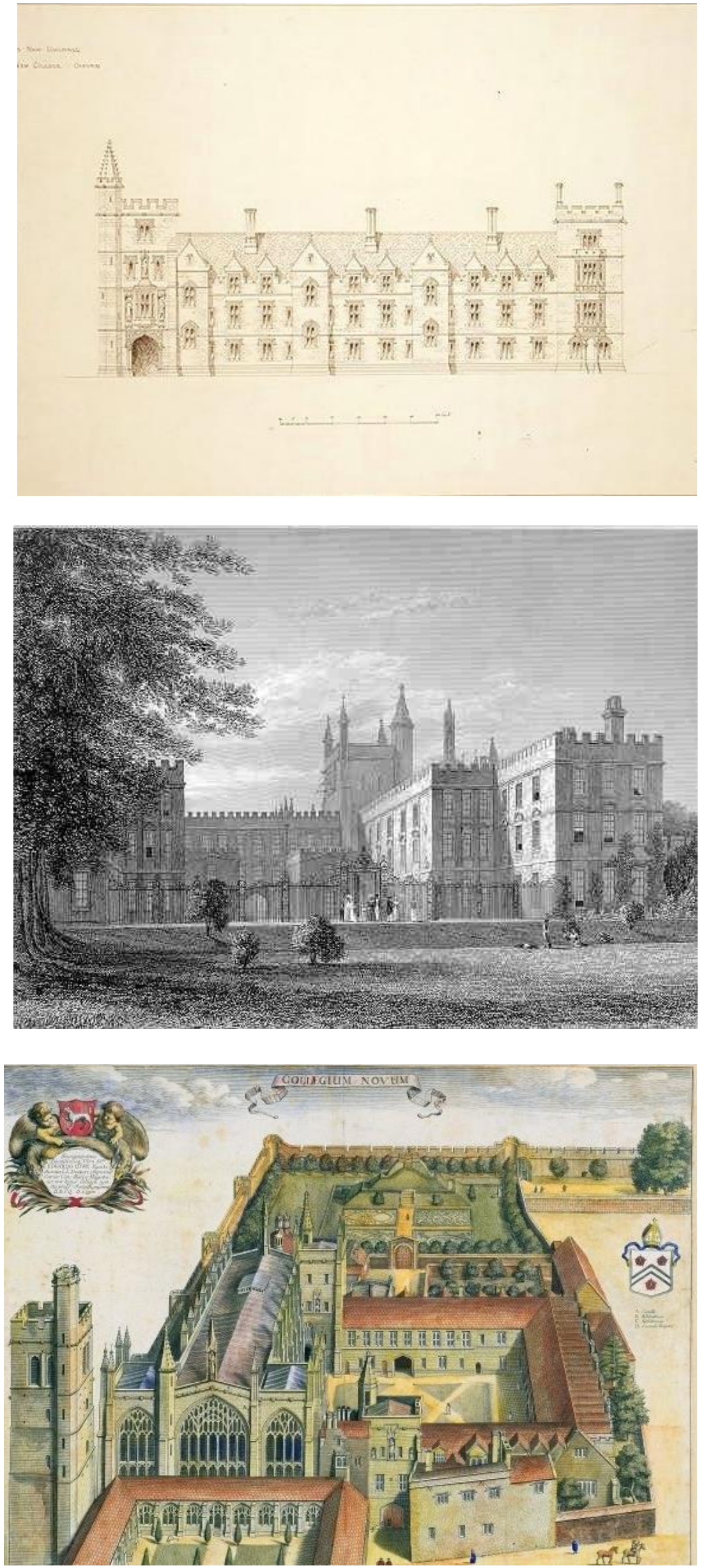


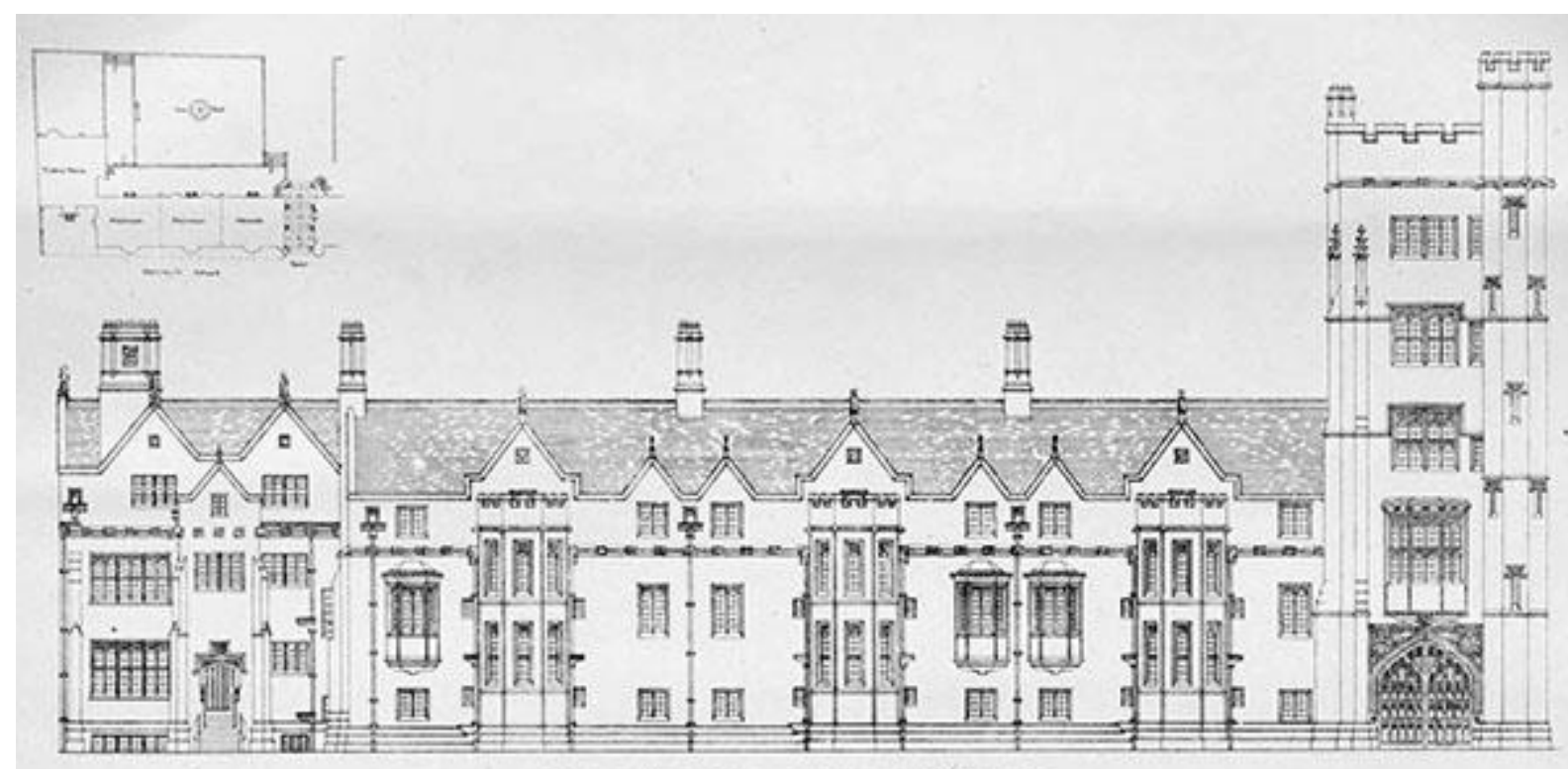

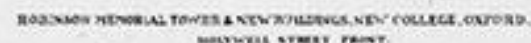

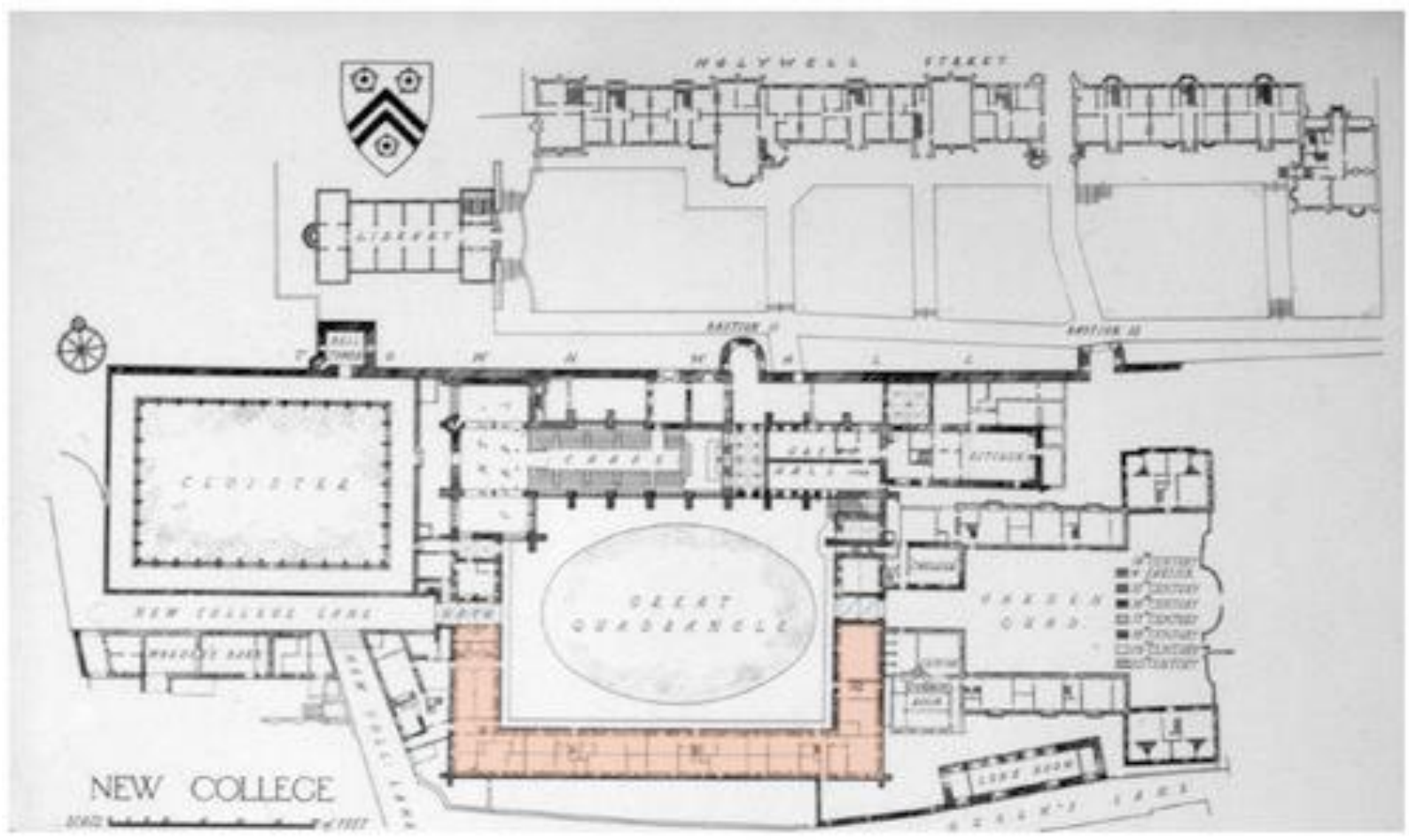

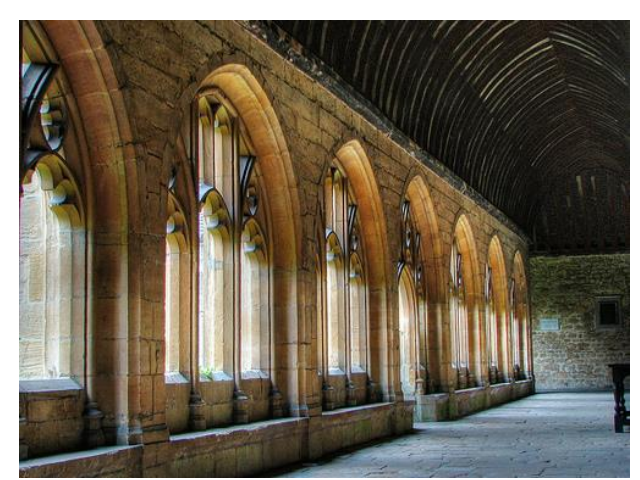

Imagen 136: Alzado del Great Quadrangle.

Imagen 137 : Zonificación de New College.

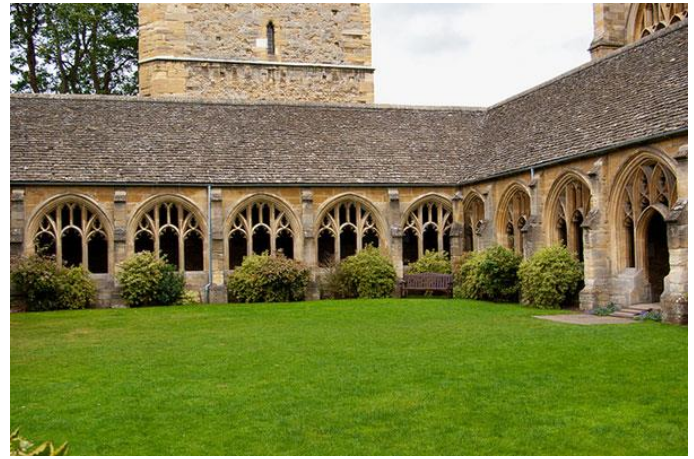

Imagen 138: Vista del Cloister Quadrangle Interior. Las vigas de madera de roble han sido restauradas varias veces a lo largo de su historia

Imagen 139 : Vista del Cloister Quadrangle exterior. 
La disposición de este colegio proporciona el primer ejemplo en Oxford de un "quadrangle" destinado a contener todos los edificios necesarios para satisfacer las necesidades previstas para la sociedad. El plan combina ingeniosamente planeamiento arquitectónico con conveniencia práctica. Los dos edificios principales, la capilla y el salón, ocupan el lado norte del patio, éstos dominan la volumetría del conjunto con una altura superior. La disposición de la capilla es original sirve de modelo para muchos otros colleges posteriores como el Christ Church college. Se compone de un largo coro de cinco tramos y una nave corta de dos tramos o bahías, llamada navis capelle en numerosos documentos medievales y antecapilla desde el siglo XVIII. La planta de la misma es así diseñada por motivos prácticos, pues se necesitaba albergar un gran coro para alojar un órgano de gran tamaño. La nave no tenía que ser muy grande ya que la capilla no era parroquial.

Al oeste de la capilla y separado de ella, se sitúa el claustro que se utiliza para cementerio y procesiones ${ }^{132}$. La entrada principal se encuentra en la torre, justo en el centro de la parte oeste. En ella y en las habitaciones entre ella y la "antecapilla" se sitúa el Garden Quad, donde se localiza también la cocina y el granero. Apartada de los ruidos de la calle se encuentra la biblioteca, salas de estudio y lo que podría considerarse como oficinas. Fuera ya de este quadrangle y separado de él, se encuentra la Long House en la cual están situadas las letrinas.

Los edificios parecen haber sido planteados con cierto carácter defensivo. El fundador puso la capilla y el salón a norte, donde estaban protegidos por las murallas y el foso.

El claustro, con su pared exterior en blanco, formó un parapeto para las ventanas al oeste de la capilla. El frente sur del quadrangle está únicamente atravesado por las estrechas ventanas de la zona de estudio y está protegido por un gran muro de piedra. Este muro se une a la pared del pasaje de la Longhouse en la parte este y por el oeste se une a la cocina del Garden Quad. El claustro no tiene una forma cuadrada exactamente, es oblongo. Tiene ocho ventanas en sus lados este y oeste y doce en los lados norte y sur. Se entra por un breve pasillo, a modo de pasaje, directo desde el vestíbulo de la capilla.

A la capilla se accede por un vestíbulo abovedado al sur de la antecapilla En las restauraciones que ha ido sufriendo este colegio a lo largo del tiempo, cabe remarcar la que recayó sobre las vigas de roble del techo del comedor. Son vigas de unos seis metros de largo y veinte centímetros de ancho que sufren con frecuencia ataques de polillas que para restaurarlas se necesitaba madera del mismo roble que el original y, a lo largo de los siglos se iba repoblando un robledo plantado en las afueras del colegio para tal uso. 


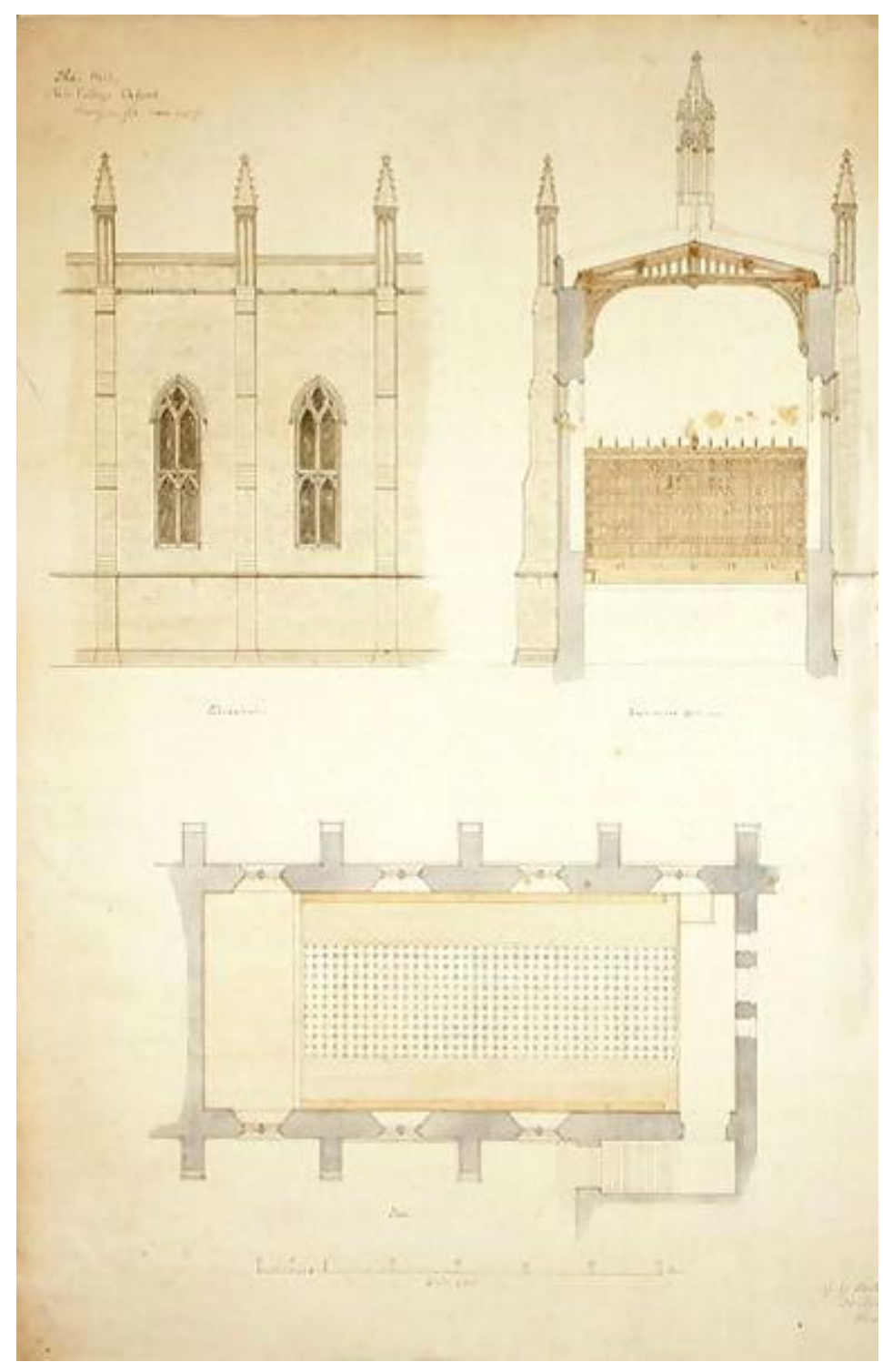

Imagen 140: Plano correspondiente al proyecto de restauración del techo de la capilla.

Imagen 141: Detalle de las puertas de entrada a las habitaciones de los estudiantes, donde se apreciasólo en algunas, que la puerta no sigue el plano del corredor, se retranquea. 


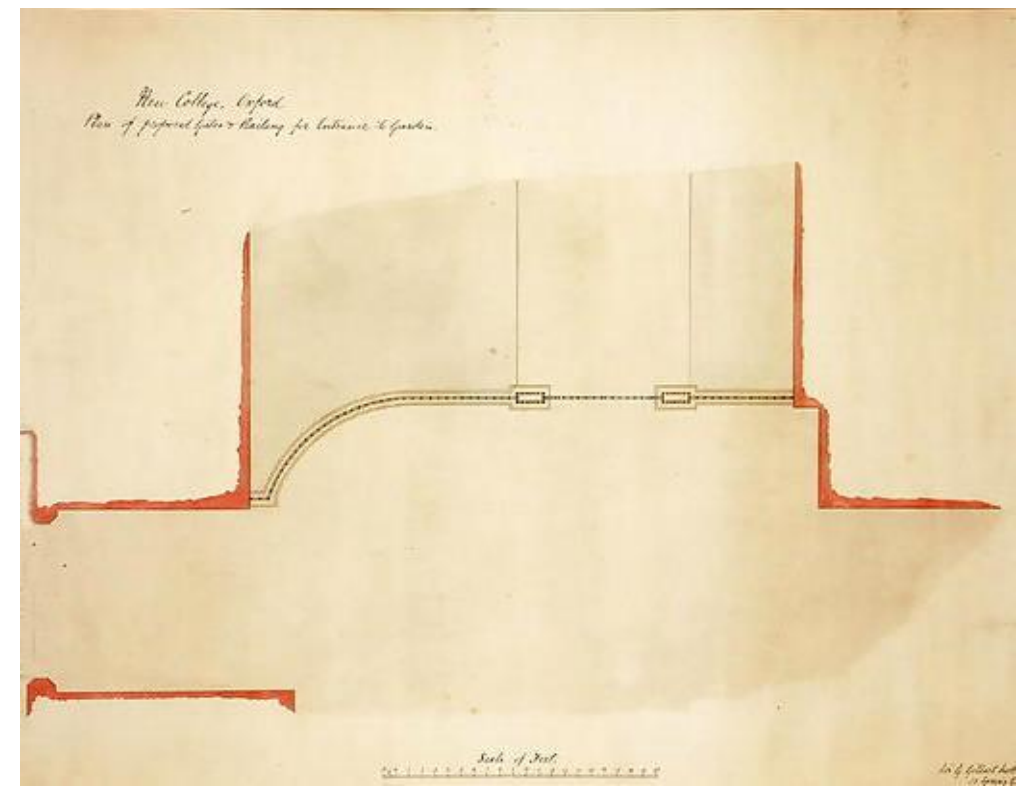

Imagen 142: Plano correspondiente al proyecto de de restauración del techo de la capilla.

Imagen 143 : Detalle de las vigas de madera que hubo que sustituir por ataque de insectos.
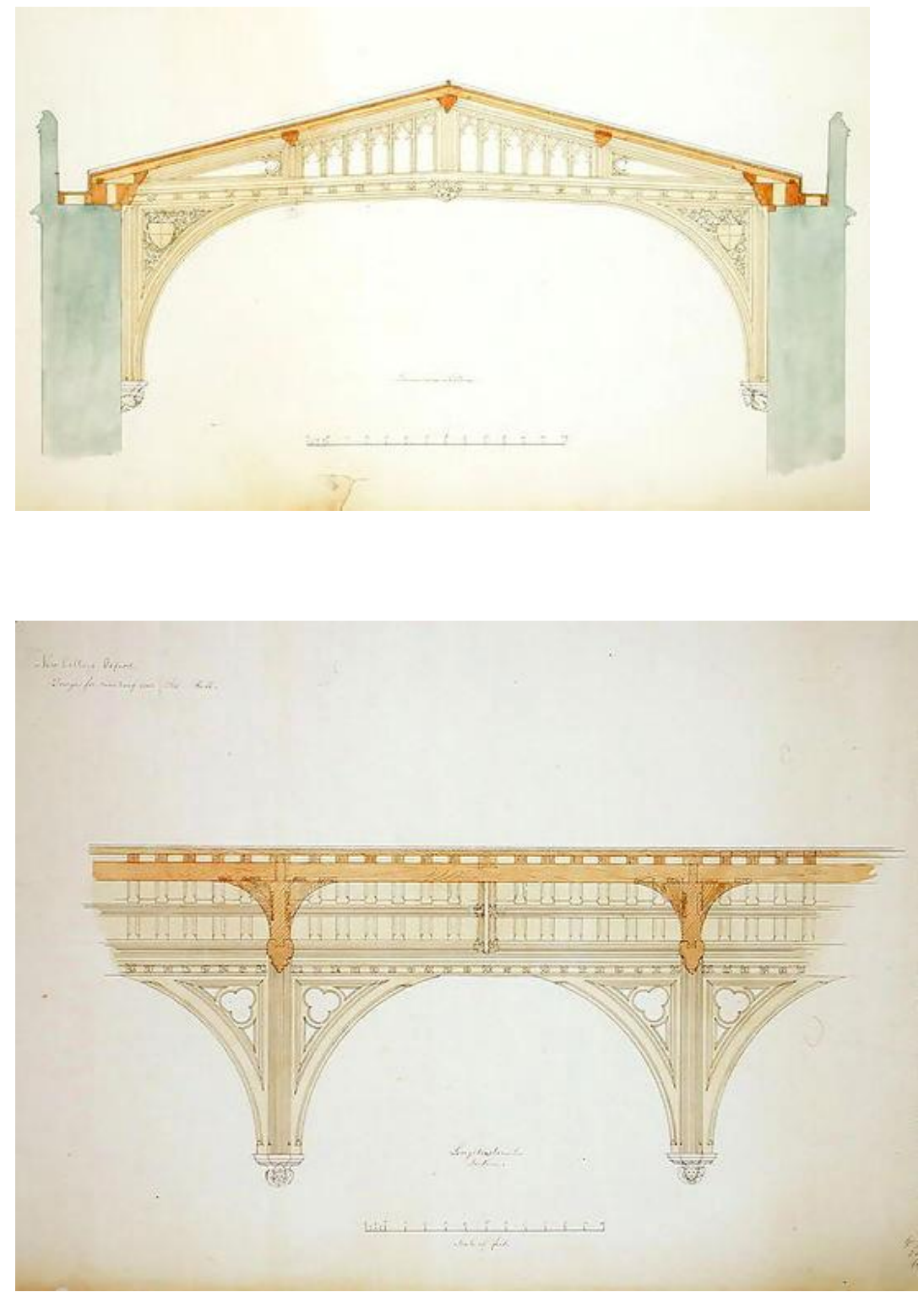


\section{JOHN'S COLLEGE.}

\section{Crecimiento espacial y jerarquizado (1437)}

Al igual que el ejemplo anterior, la configuración espacial se desarrolla en torno a los quadrangles. Los patios que configuran estos quadrangles se llaman respectivamente: North, Front, Dolphin y Canterbury. El Patio Principal lo constituyen los edificios del siglo XV correspondientes al antiguo monasterio de St Bernardo. En 1437, el arzobispo Henry Chichele fue el que fundo el colegio de San Bernardo para estudiantes de la orden cisterciense y fueron, eventualmente, añadiendo edificaciones en forma de patio frente al edificio existente. La zona más antigua del conjunto es la noroeste. La parte destinada a la residencia estudiantil, conocida como Gatehouse es de la misma fecha.

En 1555, Sir Thomas White renombra el colegio como St. John, adquiere los edificios completando la gama este del quad. En su reforma, añadió una gran cocina, alojamientos para los colegiales y la biblioteca.

El Patio de Canterbury es el primer ejemplo de arquitectura renacentista italiana en Oxford, datan del año 1674. La mayor parte de la biblioteca del college se encuentra allí, incluyendo la Antigua Biblioteca en el lado sur, y la Biblioteca Laudiana sobre la columnata este, con vistas al jardín.El Patio del Delfín es la construcción más tardía, construido a principios del siglo XX en el lugar que ocupaba el antiguo Dolphin Inn. El Patio del Jardín, es de estilo neo italiano, incluye el auditorio y edificios destinados a conferencias. El Patio Norte es una mezcla irregular de edificios de los siglos XVIII, XIX y XX. Estos incluyen la escalera de caracol, de la despensa adjunta al salón, el bloque que contiene la Habitación SeniorCommon, el edificio del siglo XIX situado a lo largo de St Giles', y la "Beehive" con habitaciones hexagonales no regulares. Los frescos de la Habitación SeniorCommon, completados en 1742, cuentan con la artesanía de Thomas Roberts quien también trabajó en la Cámara Radcliffe y la Biblioteca Codrington. Las paredes son de sillería y los techos en su mayoría son de pizarra cubierta.

La residencia de los profesores se encuentra en el edificio que vuelca al patio de Canterbury, donde se encuentra también el Midleton Hall, un bloque residencial con una fachada de piedra de principios del siglo XIX, aunque la parte trasera, de estilo victoriano, está constituida por ladrillo y contiene una escalera jacobina. Este college, a día de hoy, sigue aumentando sus dependencias, como seguramente sucede en todos los colleges que sean susceptibles de comprar terrenos o edificios anexos 
para crecer. Este crecimiento es producido por la demanda de residencia colegial a medida que se va necesitando más hospedaje. 

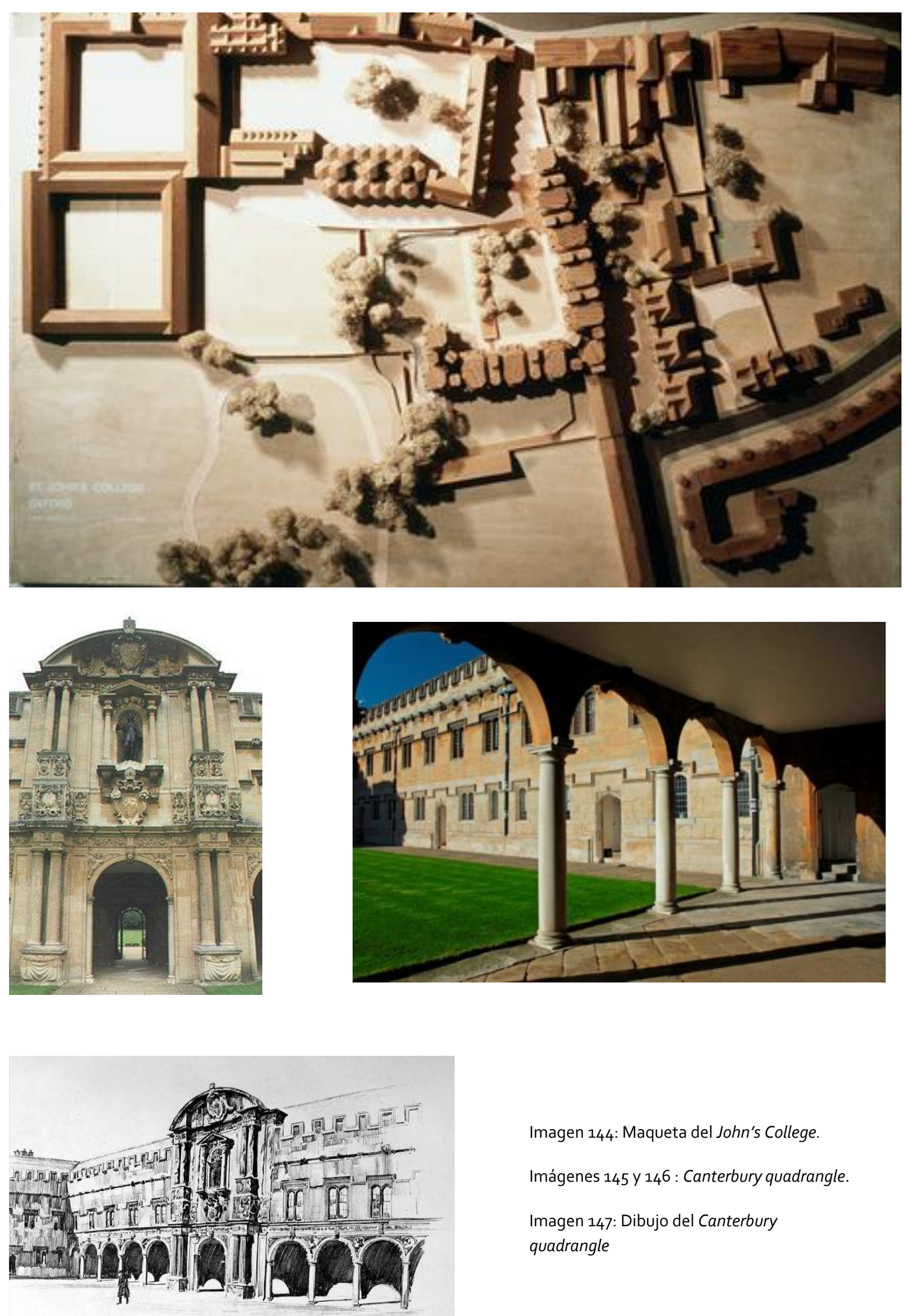

Imagen 144: Maqueta del John's College.

Imágenes 145 y 146 : Canterbury quadrangle.

Imagen 147: Dibujo del Canterbury

quadrangle 

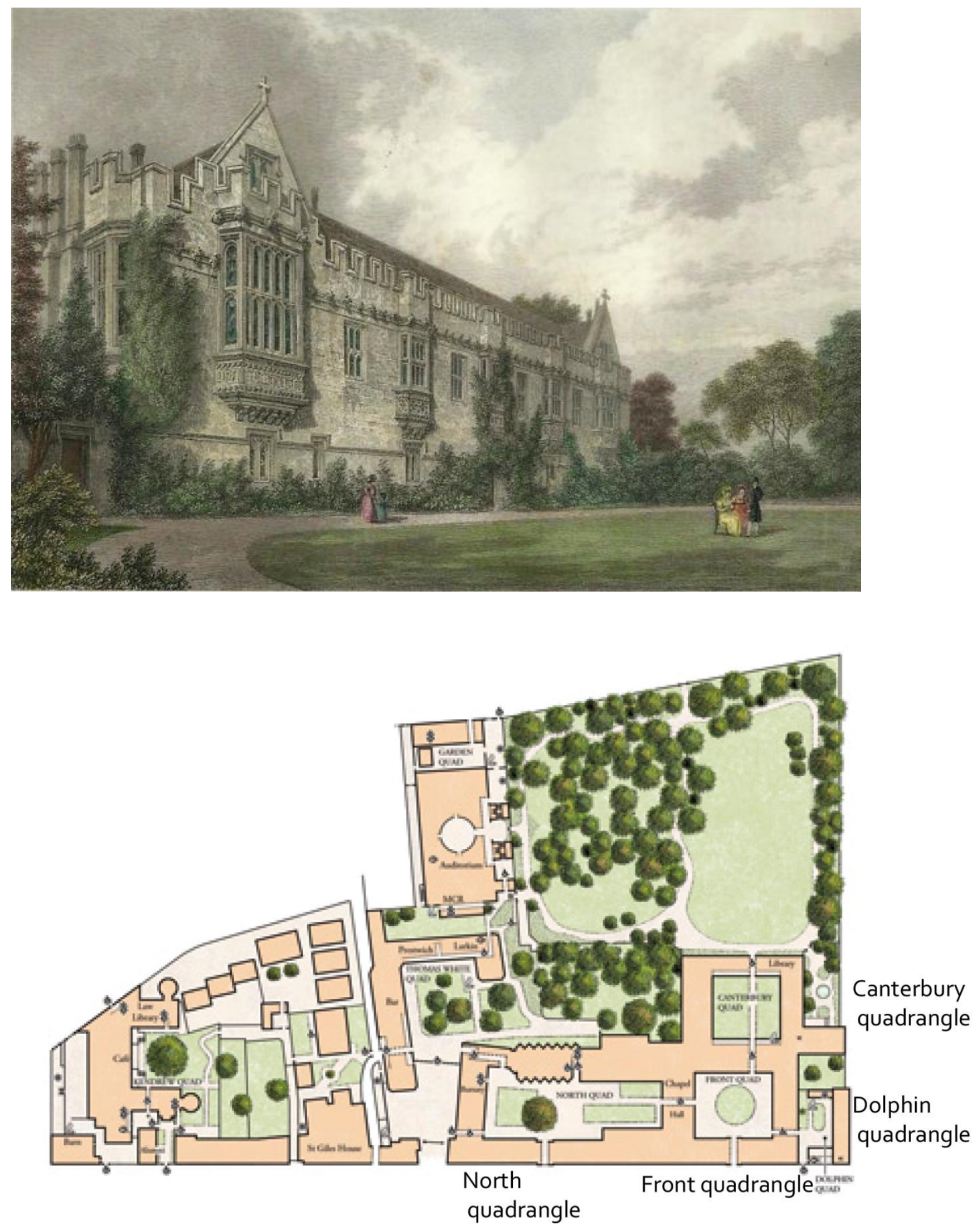

Imagen 148: Vista del John College desde los jardines posteriores

Imagen 149 : Zonificación de los quads 

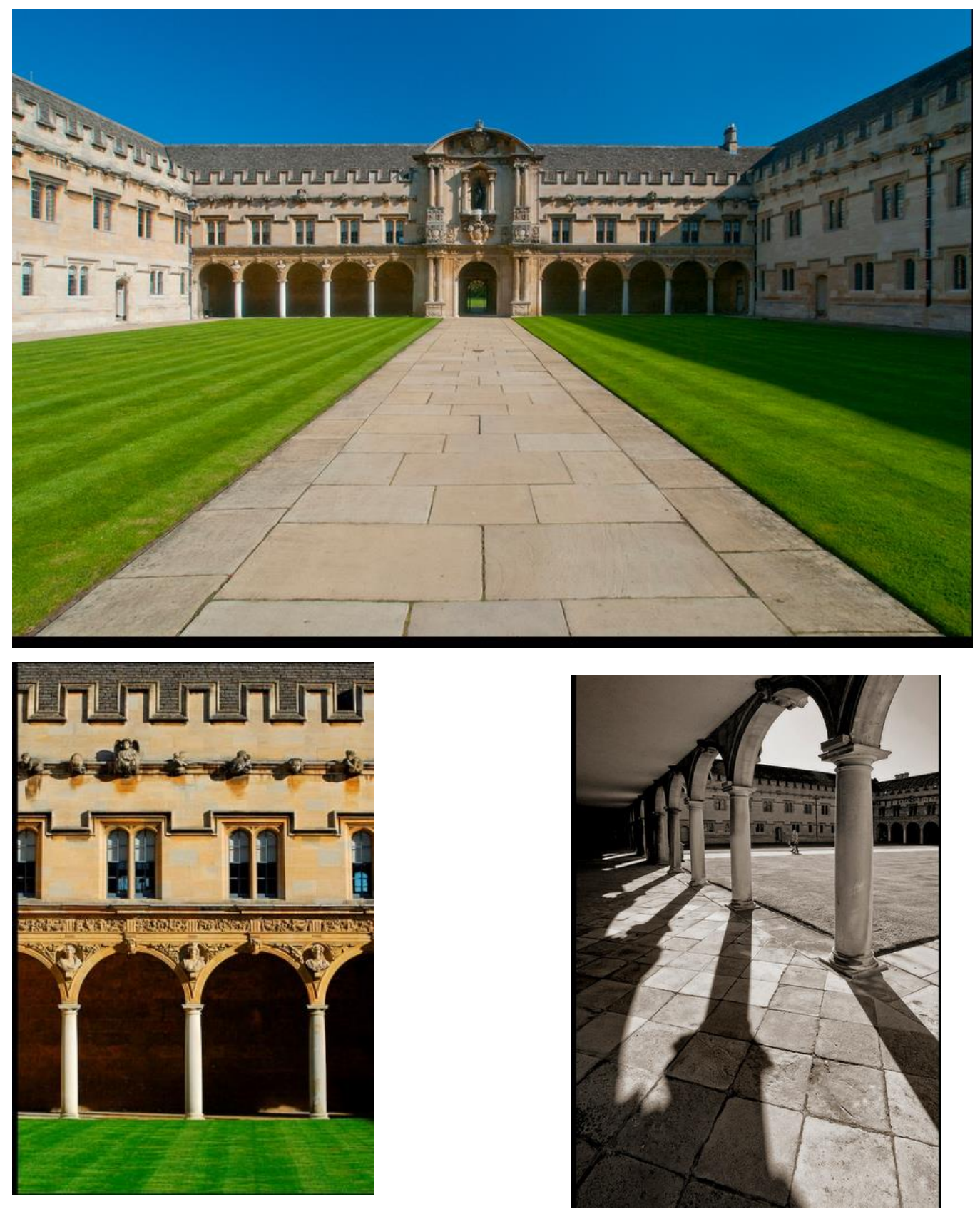

Imagen 150: Vista Canterbury quad.

Imágenes 151 y 152 : Columnas de la logia norte del Canterbury quad.

Imagen 153: Detalle del capitel de las columnas.

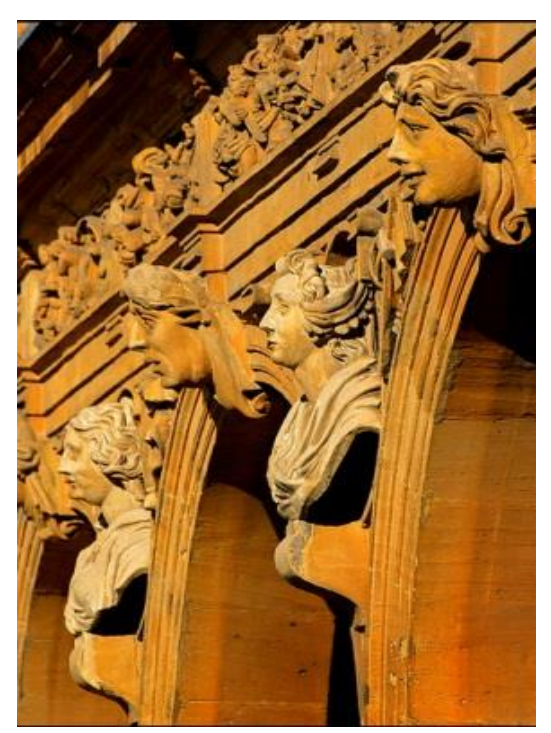




\section{CHRIST CHURCH COLLEGE.}

\section{La magnificencia del conjunto urbano (1524)}

Las distintas partes que conforman este college hacen que sea uno de los de mayor tamaño de Oxford. De entre los elementos constituyentes cabe destacar que donde en los demás colleges hay una capilla, éste alberga la Iglesia Catedral de la Diócesis de Oxford, la llamada Christ Church Catedral. Debido a su imponente volumetría se ha visto tradicionalmente como el college más aristocrático de Oxford.

Los rasgos arquitectónicos de este edificio han sido imitados por muchos otros, entre los que destaca el edificio de la Universidad Nacional de Irlanda, Galway, que reproduce el patio principal que a continuación se describe, denominado Tom Quad.

Éste college ha ido transformándose desde sus inicios. En su origen comenzó siendo el Monasterio de St. Frideswide, donde se encontraban monjes agustinos, pero se disolvió en la época de Enrique VIII durante el cierre de los monasterios. Su fundador fue el cardenal Wolsey, y su denominación original fue Colegio del Cardenal. Se ha ido consolidadndo mediante la construcción de edificios, que aunque son cada uno de siglos diferentes, no pierden su identidad y conviven de manera unitaria dando lugar a este elegante college.

El primero de los edificios es la Catedral, construida en el siglo XII y dónde de la cual se han ido situando los restantes edificios creciendo según la trama cuadrangular típica de este modelo.

Imagen 155: Cardenal Wolsey.

La torre fue construida a lo largo de dos periodos de tiempo distintos. Está ubicada en la zona sur del Tom Quad. La parte inferior fue diseñada por el fundador, define la entrada principal de este colegio, mientras que el ámbito superior corresponde al arquitecto Sir Christopher Wren ${ }^{133}$ en torno a 1681-1682. El tramo inferior de la torre se inició con dos "medias torres" a modo de pilastras que flanqueaban el arco. Poseen entrantes y salientes en su superficie. La superior, ya diseñada por Wren es mucho más ordenada, y de planta octogonal, adornada con tapas ojivales. Así pues, pasa de cuadrada en su base, a lo largo de su longitud a octogonal, situándose en las caras de dicho octógono las ventanas.

El hall de entrada es otro elemento icónico de este edificio por su escalera y su techo. 
El Tom Quad mide 264m x 261 m, es el más grande de Oxford. En el diseño original, se pretendía que estuviese rodeado por espacios claustrales de índole menor. En el lado sur se encuentra el hall, anteriormente descrito.

En el comedor, también nos encontramos uno de los espacios más emblemáticos en el comedor del college, con gran presencia debido a su triple altura, una más que el resto de dependencias. El techo está conformado a base de pequeñas vigas de madera talladas, característica muy típica de los colleges en general. Estás vigas apoyan normalmente o sobre el muro que actúa como muro de carga o sobre el extremo de un arco.

En la configuración de este college destaca el quad llamado Peckwater. El edificio principal de este "subquad" es el que alberga el uso residencial en los tres lados principales, conteniendo a la biblioteca en su lado este. Está situado donde antiguamente había una posada medieval, ésta estaba dirigida por la familia Peckwater, de ahí el nombre. Las habitaciones de los estudiantes se encuentran distribuidas alrededor de la primera planta del edificio principal que fue diseñado por Henry Alrich ${ }^{134}$, un decano de este college. Este edificio produce un gran contraste con el resto por su aspecto eminentemente clásico. Cada lado a su vez está estructurado en quince partes que en el alzado quedan representados por las pilastras de doble altura rematando la.

La relación directa con la naturaleza se produce a través del Meadows building, actúa de charnela hacia el exterior aunque, en los demás espacios también pretende conseguir esta sensación a través del verdes central donde vuelcan todas las habitacionales interiores.

Debido al crecimiento lineal de este tipo de edificaciones, se puede ver reflejada la huella del tiempo en las ampliaciones que sufren. Se pretende dejar constancia de ello en el Apéndice contemporáneo al final de este capítulo. 

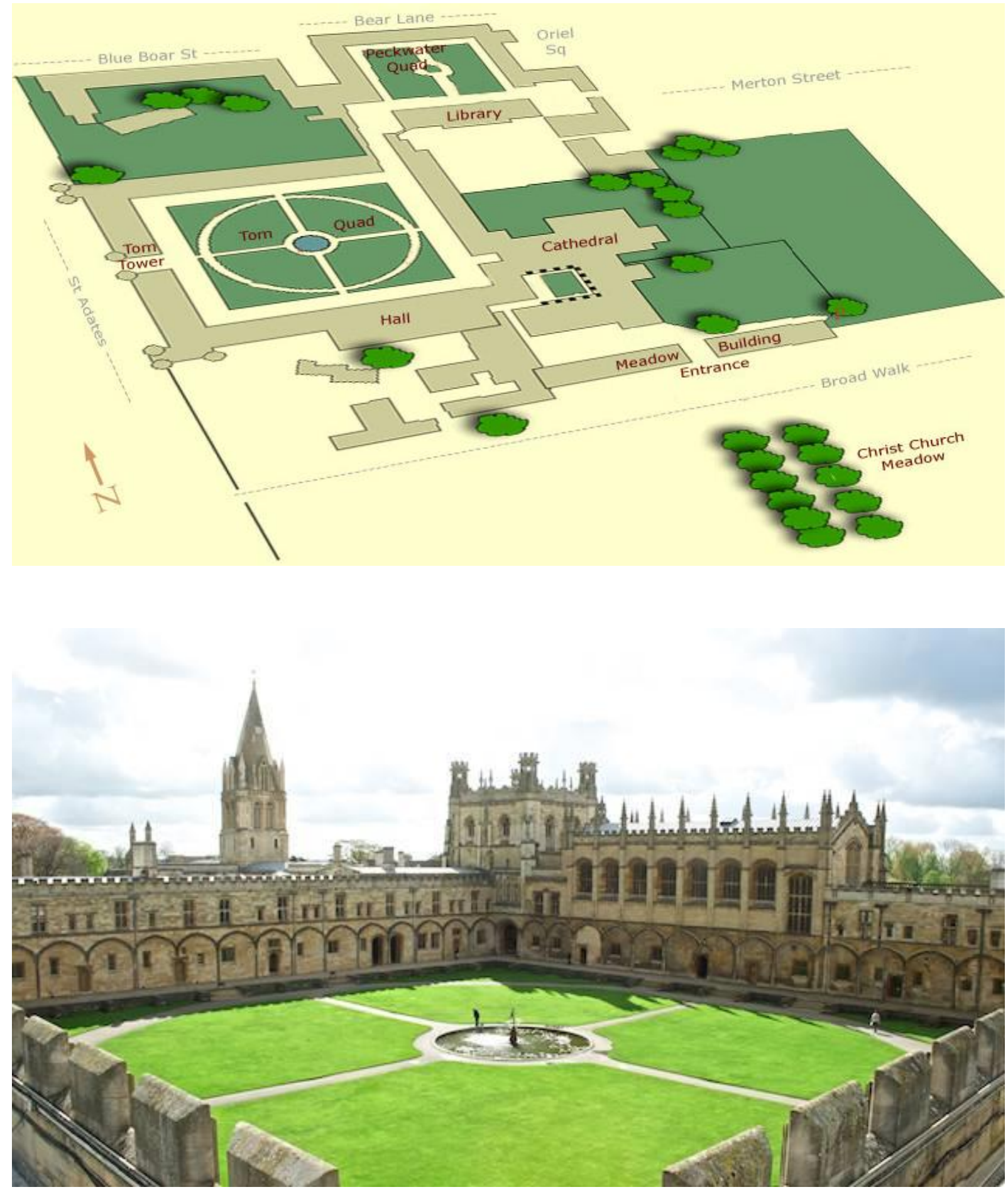

Imagen 156: Zonificación del college.

Imagen 157: Vista general del Tom Quad. 

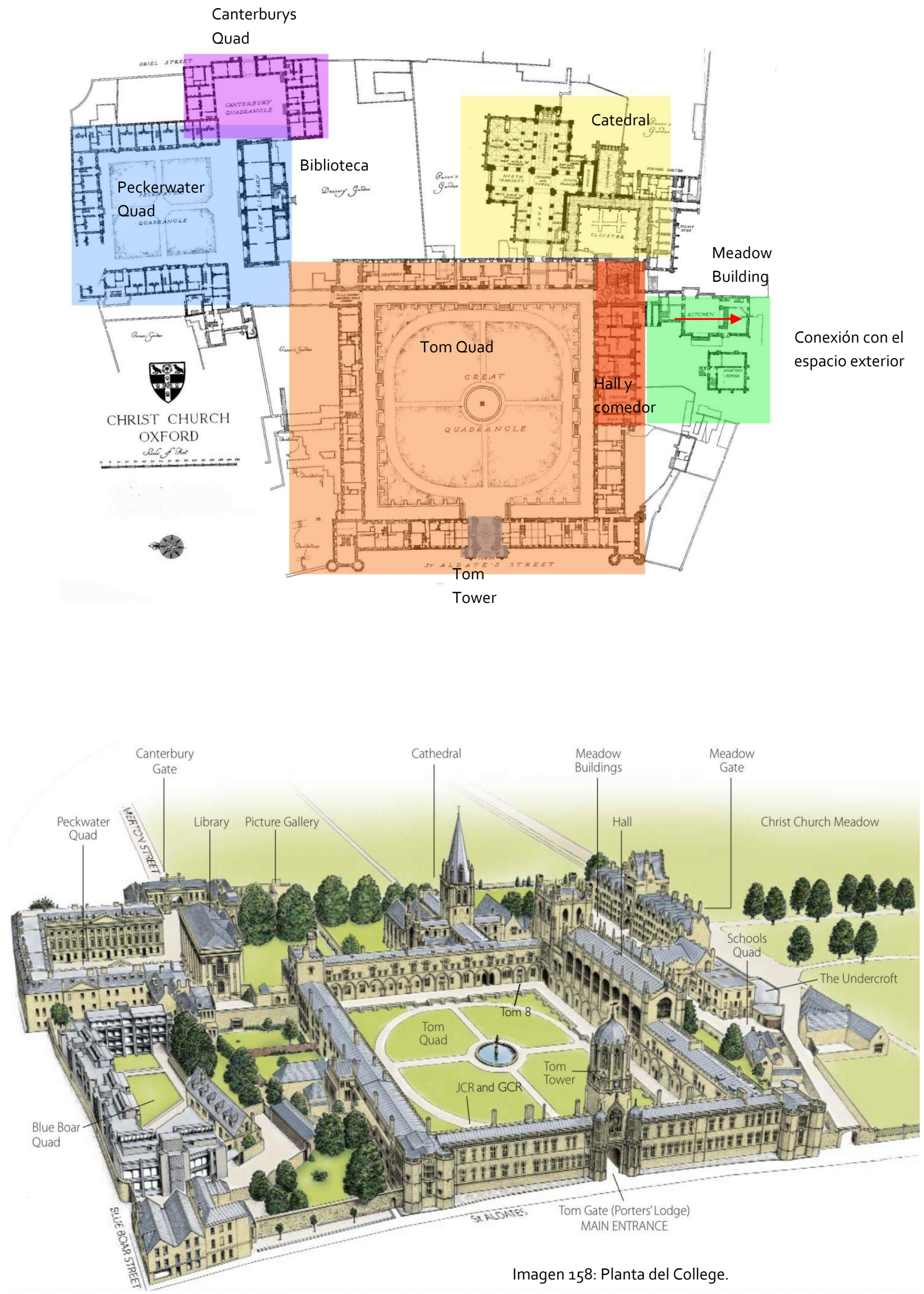

Imagen 159 : Vista axonométrica del college 

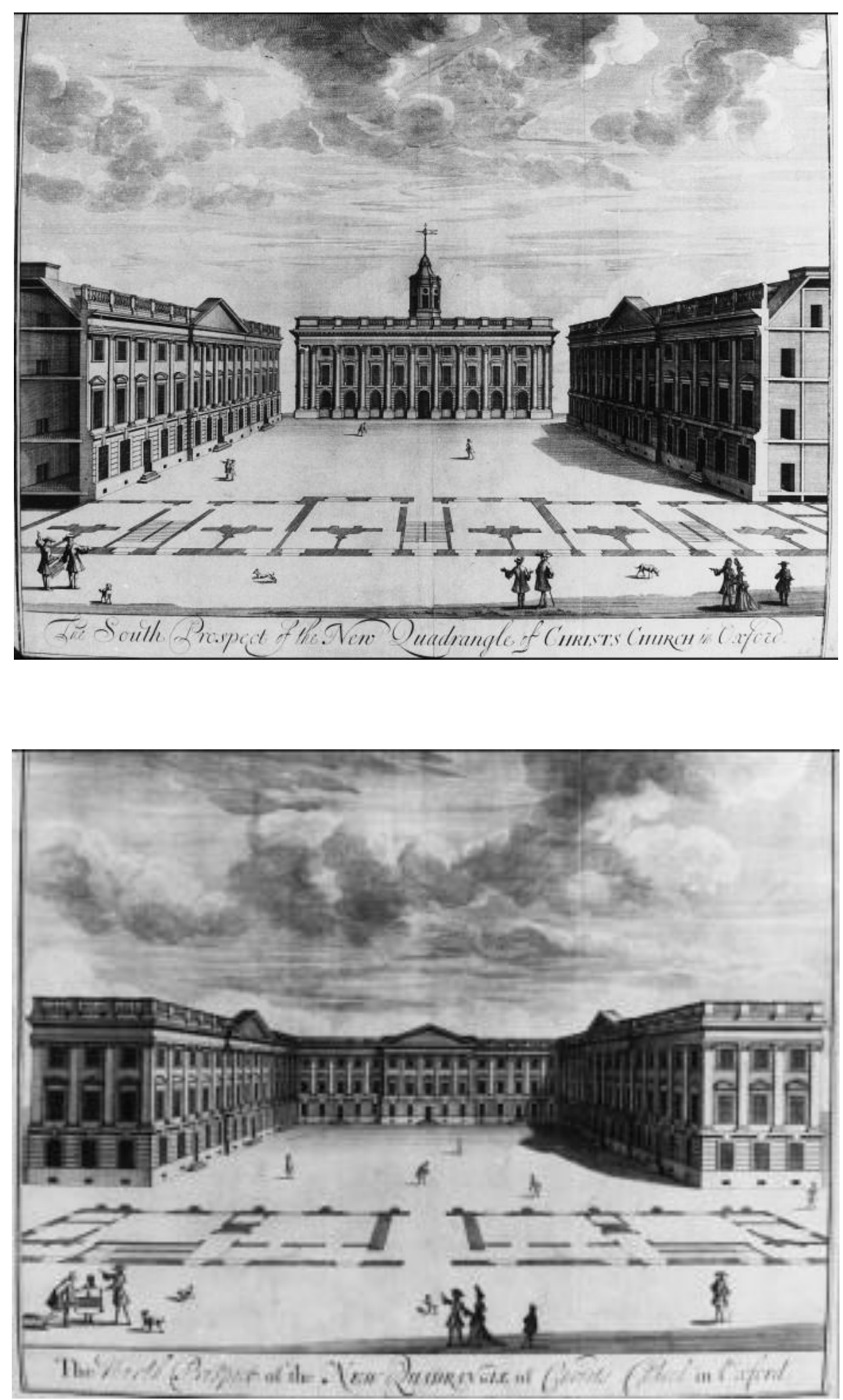

Imagen 160: Vista del Peckwater quad hacia la biblioteca. Se ve en planta la distibución tipo de habitaciones.

Imagen 161 : Vista del Peckwater quad desde la biblioteca, se ve en planta la distribución de planta baja d ela biblioteca 

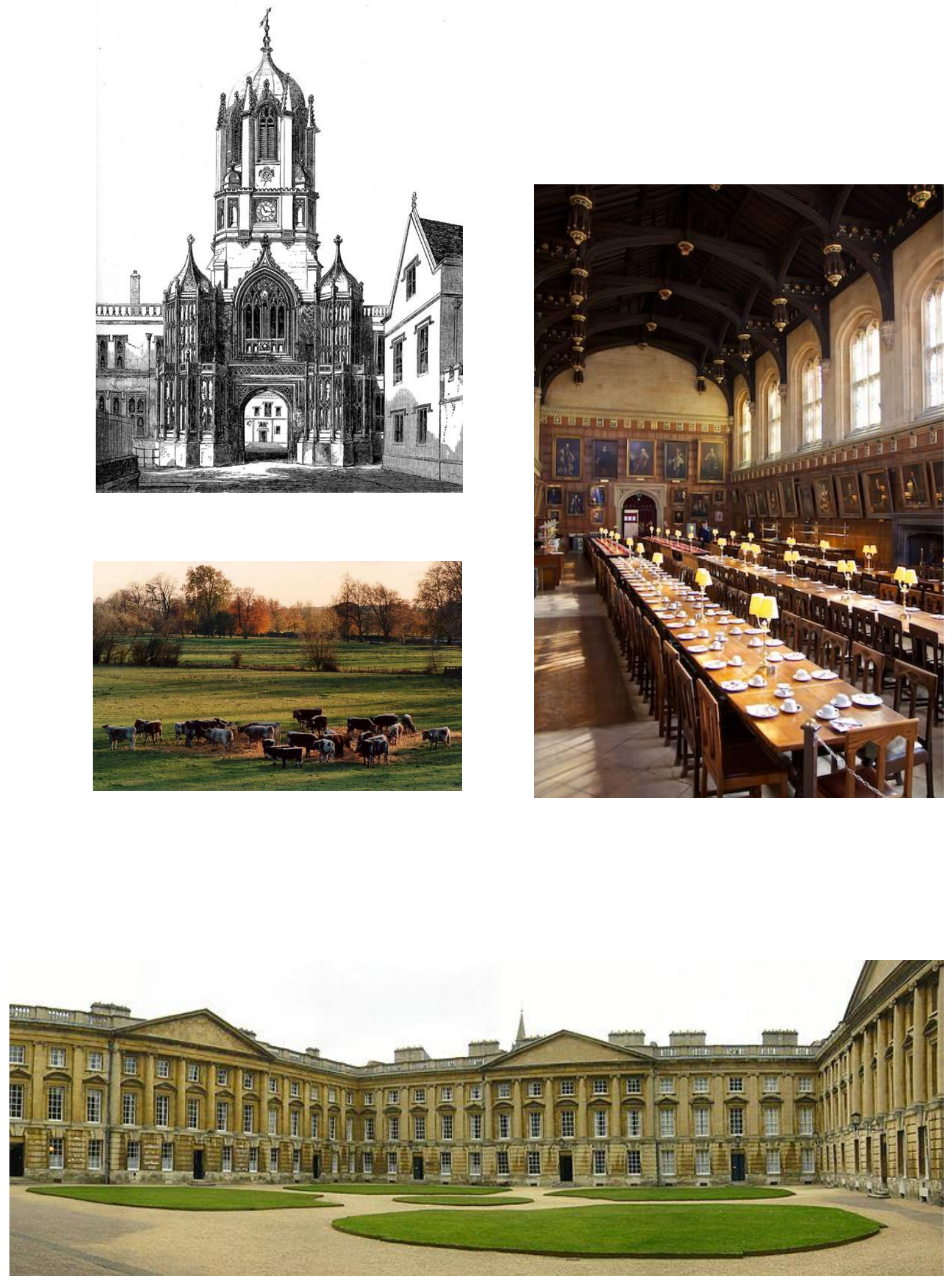

Imagen 162: Tom Tower

Imagen 163 : Comedor del college.

Imagen 164: Pastos alrededor del Meadows building

Imagem 165: Peckwater quadrangle 
A continuación se muestra una selección de los modelos estudiados de Cambridge, los criterios de selección son los mismos que en Oxford.

\section{PETER HOUSE COLLEGE.}

\section{Asentando el modelo (1284)}

Es el más antiguo de los colleges que conforman la Universidad de Cambridge. Fue fundado en 1284 por Hugh Balsham, obispo de Ely ${ }^{135}$, el cual planeó fundar un college en las tierras en que hoy forman parte del Saint John College de Cambridge.

El prelado se trasladó al lugar actual comprando dos casas para alojar a un maestro y a catorce "dignos pero empobrecidos profesores", y así es como queda establecido el Peterhouse. Dos años después se construyó un salón; que actualmente es el edificio más antiguo de los colleges de Cambridge. Balsham murió en 1286, legando una suma de dinero que se usó para la compra de más tierras.

La distribución de este college es:

Old Court._Al sur de este patio se encuentra el comedor, es el único edificio del siglo XIII que sobrevive. Fue restaurada en 1870, se le atribuyó un aire medieval a través de finos paneles, una impresionante ventana mirador y un nuevo tejado de madera, todo ello realizado por el arquitecto George Gilbert Scott. Las vidrieras son obra de William Morris, Ford Madox Brown y Edward Burne Jones, son un ejemplo de vidireras prerrafaelitas.

La capilla: Si se mira el college desde la entrada principal, la parte correspondiente al altar de la capilla es el edificio que primero se ve. Ésta fue construida en 1628 cuando el "Maestro de la época" Matthew Wren, tío de Christopher Wren, demolió los hostales originales del college. Previamente, este colegio había usado la iglesia de santa María la menor como su capilla. El estilo laudiano gótico de la capilla mezcla detalles del Renacimiento y los incorpora al edificio tradicional gótico. En la arquitectura renacentista de esta capilla resalta el techo con soles de oro.

Las partes norte oeste de este patio fueron añadidas en el siglo XV. La capilla es el cuarto lado del patio. Las habitaciones están ocupadas por una mezcla de profesores y estudiantes.

EL Master Lodge: Edificio destinado a la residencia de profesores y visitas de realeza o altas personalidades. Se unió al college, y no se 
construyó expresamente para formar parte de él, sino que fue una antigua vivienda que se donó por parte de su último dueño en 1727.

Su construcción data de 1702, y el cerramiento exterior está conformado de ladrillo rojo con apósitos de piedra, cuenta con tres plantas y un sótano.

El Gisborne Court es el otro patio. Se puede acceder a través de una arcada desde I lado oeste del Old Court. Éste fue construido en 1825. Su coste se cubrió gracias a la donación en 1817 del Reverendo Francis Gisborne, un antiguo profesor. El patio está construido en ladrillo blanco con apósitos de piedra en un sencillo estilo gótico diseñado por William Mcintosh Bookes. Solo se construyeron dos de los tres lados. Las habitaciones de este patio están ocupadas sólo por estudiantes.

Detrás de Gisborne Court aparece Fen Court y el edificio Birwood. Este edificio del siglo XX. Construido entre 1939 y 1941 con diseño de HC. Hughens y Meter Bicknell ${ }^{136}$. Es uno de los primeros edificios de Cambridge ideados según la arquitectura del Movimiento Moderno. La casa de baños adyacente, conocida como edificio Birdwood, conforma el lado oeste del Gisborne Court , también fue diseñado por Hughes y Bicknell y construido entre 1932 y 1934. Hoy, entre otros usos, se utiliza como gimnasio.

La biblioteca. Siguiendo el patrón de todos los colleges, es elemento principal en el plan del conjunto. A diferencia de otros colegios está diferenciada en dos usos, la bilioteca para profesores y becarios y la del resto de estudiantes. La primera se denomina Perne Library y la segunda Old Library.

El edificio William Stone, se encuentra al sur del parque de los ciervos, fue financiado gracias a un legado de Willian Stone (18571958), un antiguo estudioso del college. Construido en 1963 , es una torre de ladrillo de ocho plantas. Aloja tanto a profesores como a alumnos del college.

El edificio Burroughs, está situado en la parte delantera del college, en paralelo a la capilla. Se le llamó así en honor a su arquitecto, Sir James Burroughs, presidente de Caius College. Fue construido en 1736. Es uno de los muchos edificios de Cambridge de estilo neopalladiano diseñados por este arquitecto. 

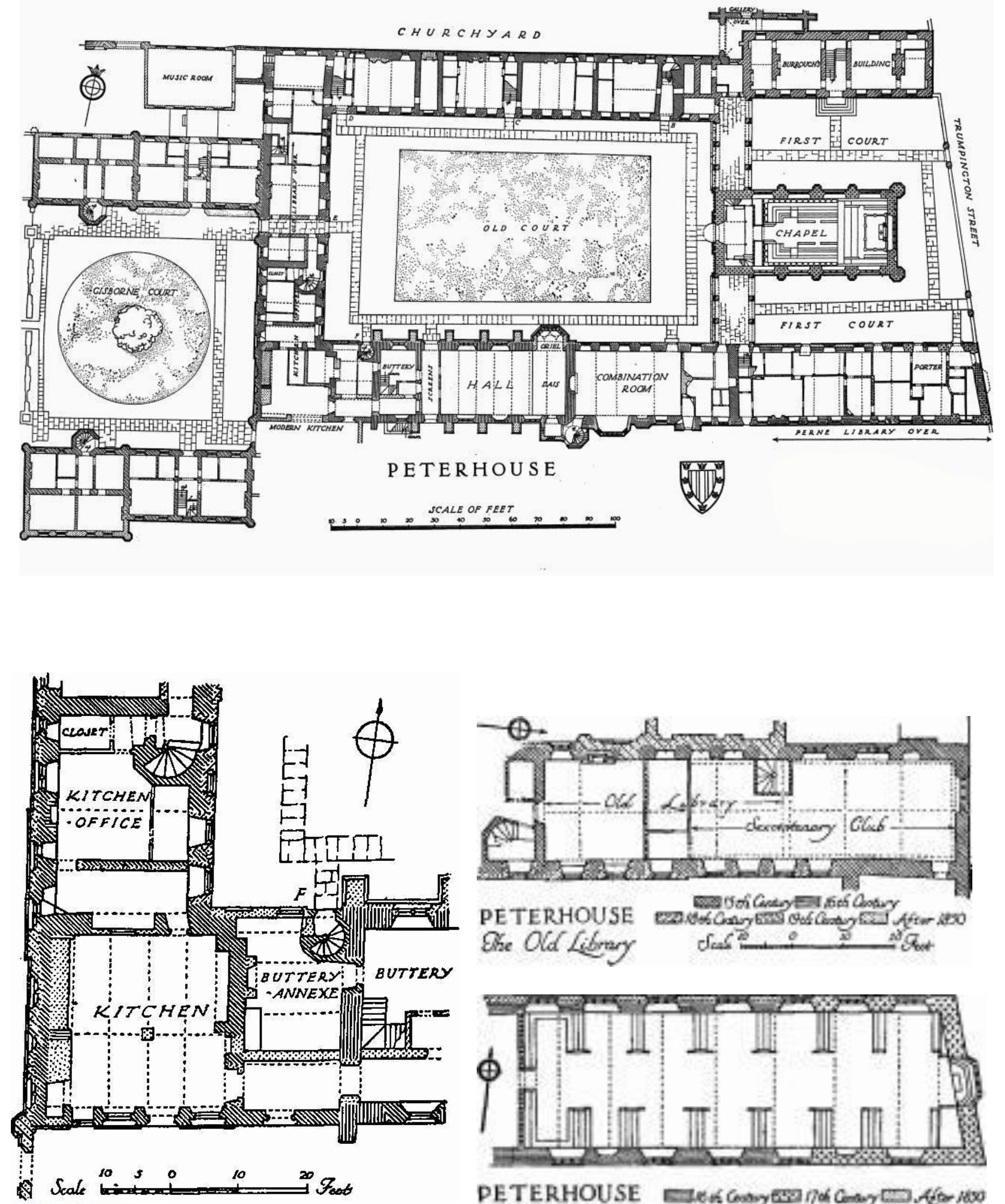

Imagen 166: Plan de conjunto

Imagen 167: Zona de cocina, despensa y servicios
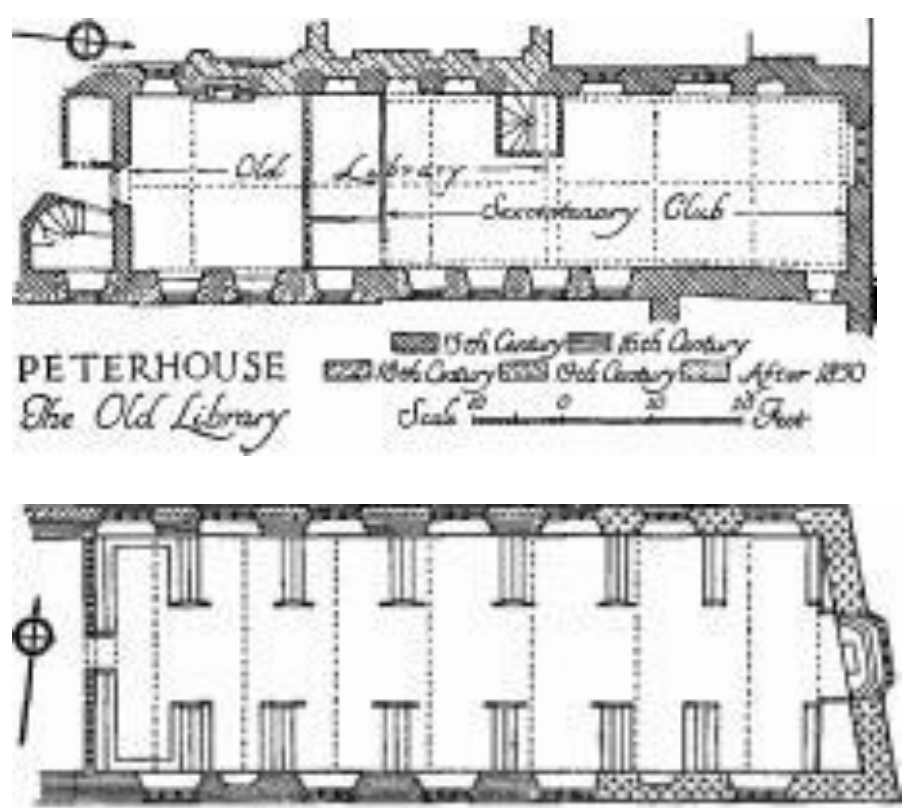

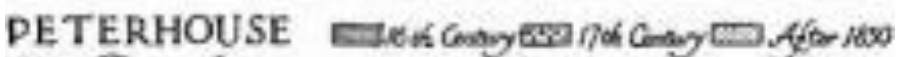

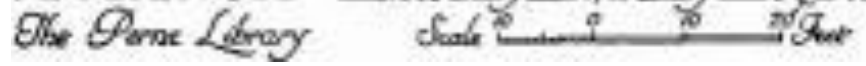

Imagen 168: Old Library

Imagen 169: Perne Library 

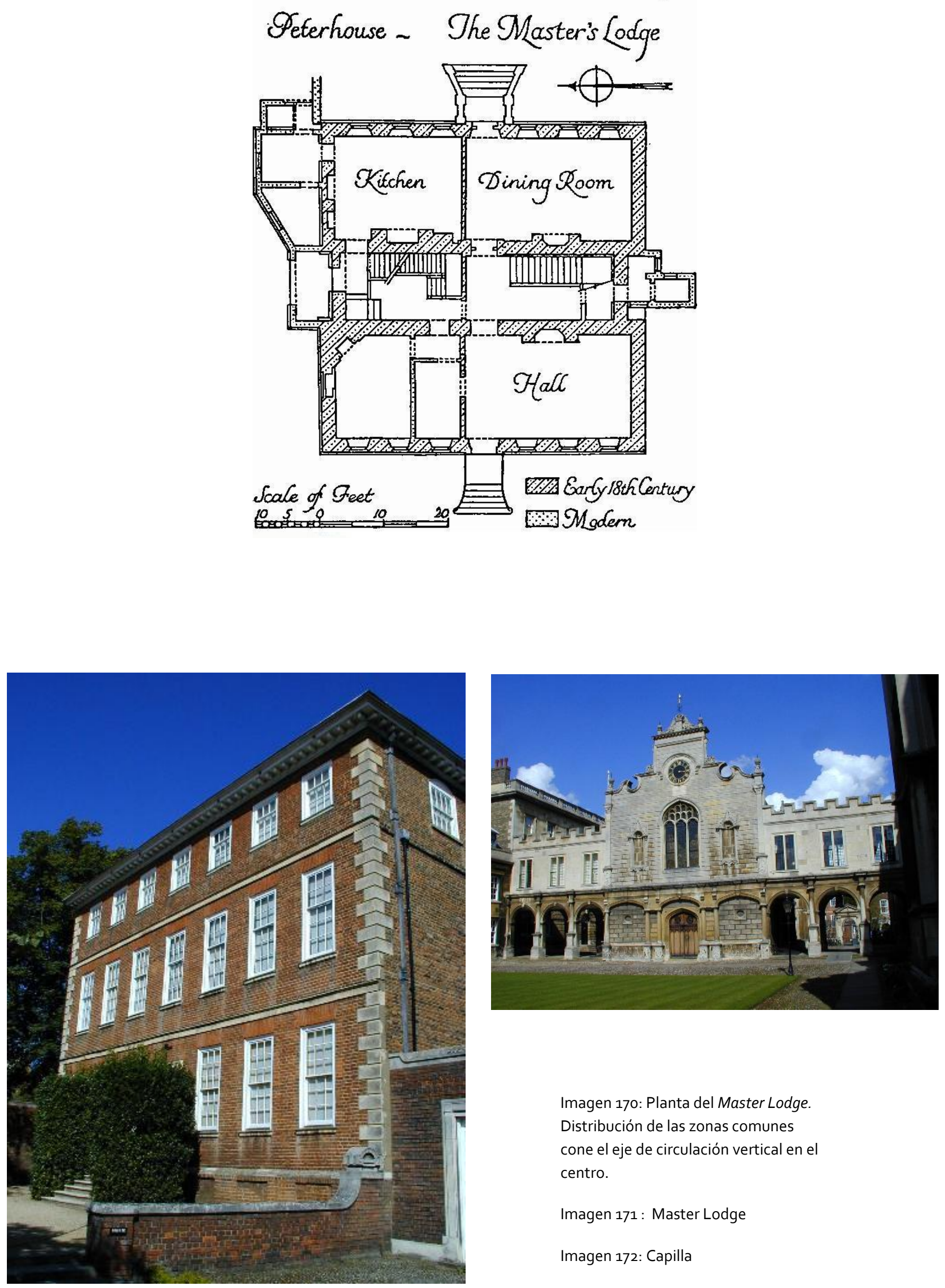

\author{
Imagen 170: Planta del Master Lodge. \\ Distribución de las zonas comunes \\ cone el eje de circulación vertical en el \\ centro. \\ Imagen 171: Master Lodge \\ Imagen 172: Capilla
}




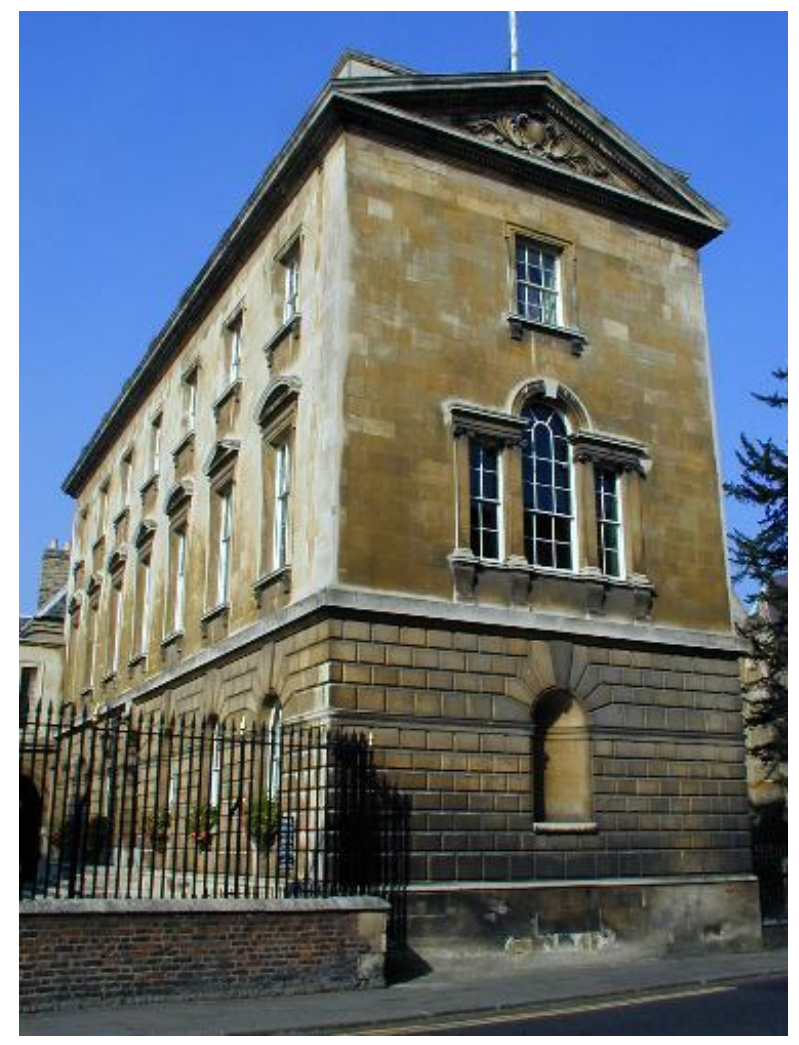

Imagen 173: First Court, Buroughs Building

Imagen 174 : Gisborne Building

Imagen 175: Dinning Hall (comedor)
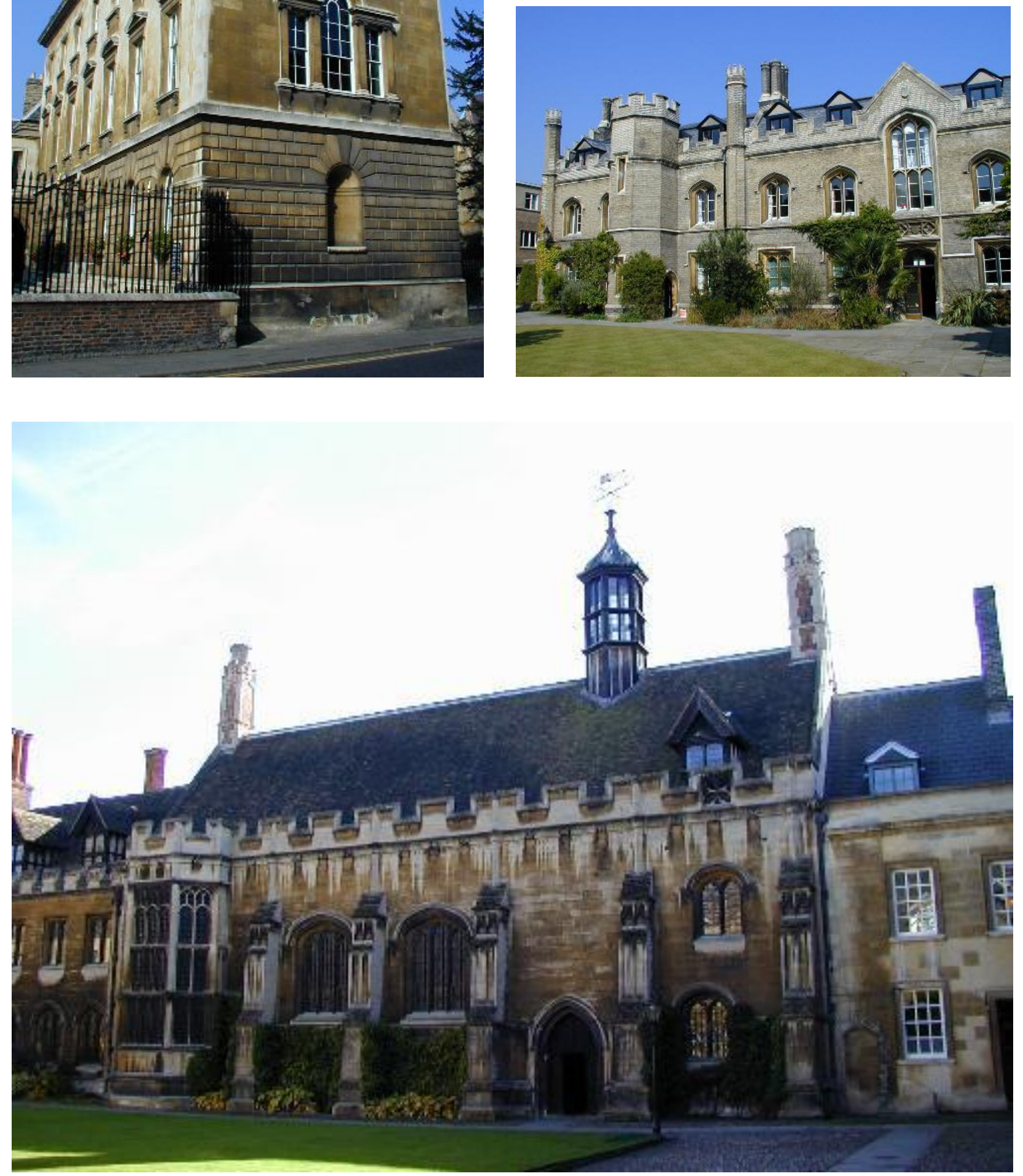


\section{KING'S COLLEGE.}

\section{El reflejo de memoria (1441)}

Fue fundado por el rey de Inglaterra Enrique VI (1421-1471) en 1441. En aquel momento, esta ciudad ubicada en tierras pantanosas y anegadas contaba con un puerto, y no podía dar cabida a este college universitario, por lo que el monarca decidió comprar y expropiar terrenos en el centro del Cambridge medieval. Posteriormente se produjo un proceso de nivelado y allanado de tierras en una labor que se dilató durante tres años. El primer diseño del complejo fue modesto, aunque en 1445 ya estaba destinado a ser un magnífico ejemplo del patrocinio real. Inicialmente, Enrique VI planeó una organización académica para acoger a doce alumnos, el mismo número que los apóstoles de Cristo, aunque durante el transcurso de los trabajos decidió mudar su plan a otro mucho más ambicioso, optando por seleccionar a setenta eruditos que representasen a los setenta primeros evangelistas escogidos por Jesús, quienes a su vez serían seleccionados entre los estudiantes del colegio Eton, fundado en el año 1440 por el propio rey Enrique VI de Inglaterra. Un designio real que perduró durante más de cuatro siglos en los que este college admitió únicamente a estos privilegiados estudiantes. El rey impartió detalladas instrucciones acerca de este college, aunque sus mayores esfuerzos se centraron en la capilla.

Desde un primer momento los edificios conformantes tienen la intención de ser una magnífica muestra del poder del patrocinio real, además el propio monarca hizo grandes esfuerzos para asegurar que la capilla del colegio fuese inigualable en tamaño y belleza. Con el tiempo se puede comprobar que los no todos los planes del rey fueron llevados a cabo. La composición de las construcciones es similar a la de Oxford, la trama va a ser dirigida en torno al modelo de quadrangle. La composición inicial consiste en un espacio central rodeado por edificios adyacentes: una capilla al norte; el alojamiento de los estudiantes y la puerta de entrada al este; más alojamiento, donde se encontraba la habitación del decano, al sur; la biblioteca, el salón y zonas de almacenamiento al oeste. Detrás de la biblioteca se sitúa un cementerio en forma claustral que contiene un gran campanario.

Cada bloque es un reflejo de la época en la que fue construido. Las características pasan de ser de corte clásico a corte gótico o neogótico. A continuación se realiza por orden cronológico una breve descripción de cada uno de ellos.

La capilla. Es uno de los edificios medievales más famosos de Inglaterra. Se construyó en 1446 y tardó más de un siglo en finalizarse su construcción por completo, siendo esta fecha en 1547. 
Anterior a esta capilla existía otra en la zona norte del conjunto, construida cuando se fundó el college y destruida hacia el año 1536. Durante la construcción de la capilla actual, Enrique VI fue depuesto. Al llegar la noticia a este colegio se paralizaron las obras por miedo a no ser pagados por el nuevo monarca.

Cada contrafuerte tiene una línea bien definida donde la piedra inferior es más clara que la superior. La piedra más blanca estaba suministrada por una cantera que proveía de piedra al college en tiempos de Enrique VI, después la piedra posterior era extraída de otra cantera diferente, siendo ésta de color más oscuro.

La capilla cuenta con una gran bóveda de abanico y algunas de las vidrieras más representativas de su época. Su nave, como se acaba de comentar, se alza verticalmente sustentada por contrafuertes, tan ligeros y elegantes que parecen no tener otra función que la de enmarcar las 25 vidrieras, obteniendo así un espacio de gran luminosidad. Al interior, transmite una gran fuerte impresión visual, sobre todo al levantar la vista hacia su majestuosa bóveda que parece flotar en el espacio.

El edificio Gibbs. Después de la capilla, Gibbs es el segundo edificio más antiguo del college, iniciándose su construcción en 1724. Del conjunto que en su día diseñó el arquitecto Gibbs $^{137}$, sólo permanece este edificio. El plan de Gibbs era bastante extenso, incluía edificios similares en el lado sur y este del actual quadrangle.

Está constituido de piedra portland blanca, dicha piedra es la misma que la de los contrafuertes de la capilla. En el interior contiene habitaciones de estudiantes y de becarios. El esquema en planta es similar a la disposición de las habitaciones de otros colleges, núcleos verticales de escaleras colocados cerca de las uniones entre bloques que sirven a la disposición de las estancias que se abren al patio central, relacionándose con el "espacio verde" y la naturaleza. 


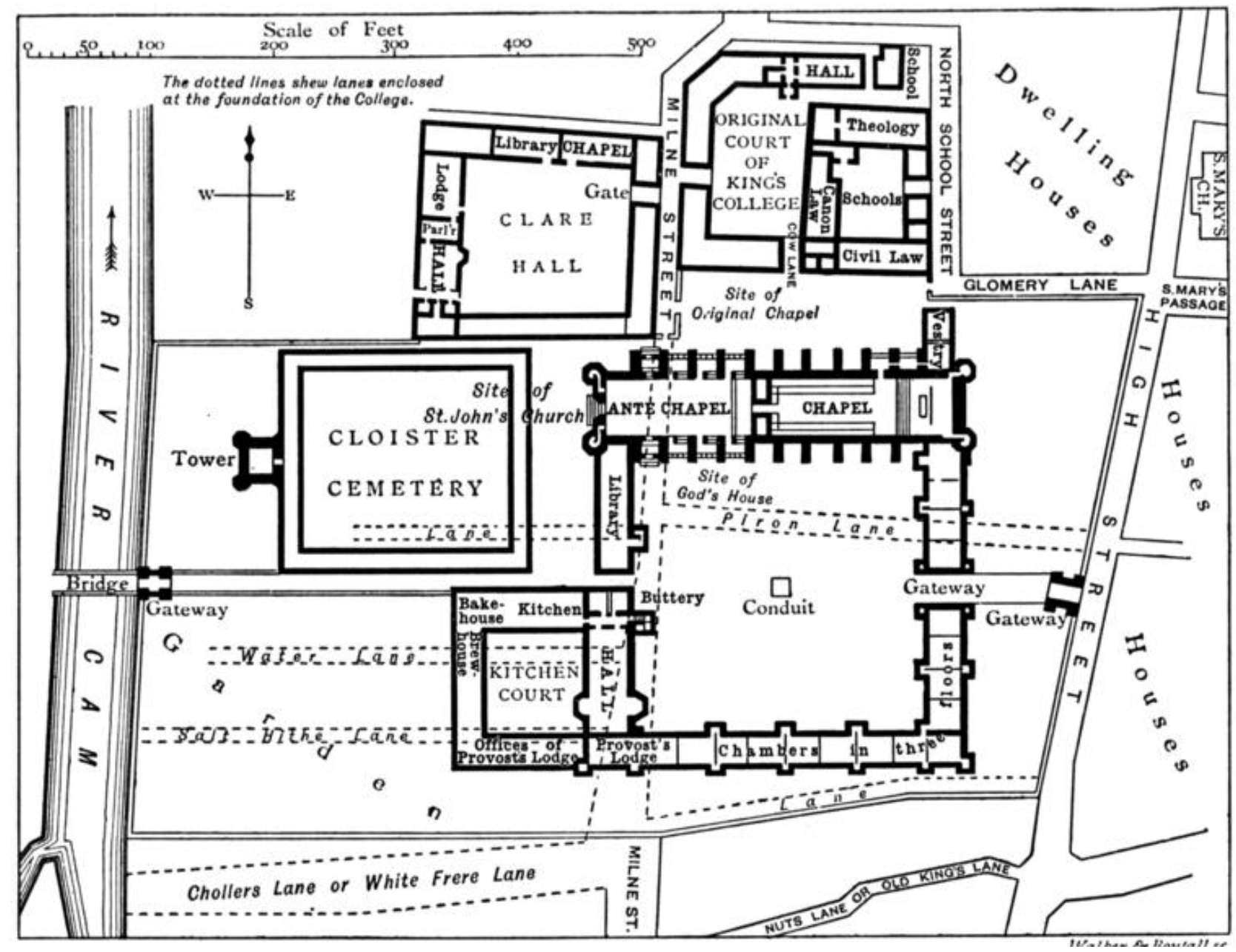

Imagen 176: Plan de 1440. 

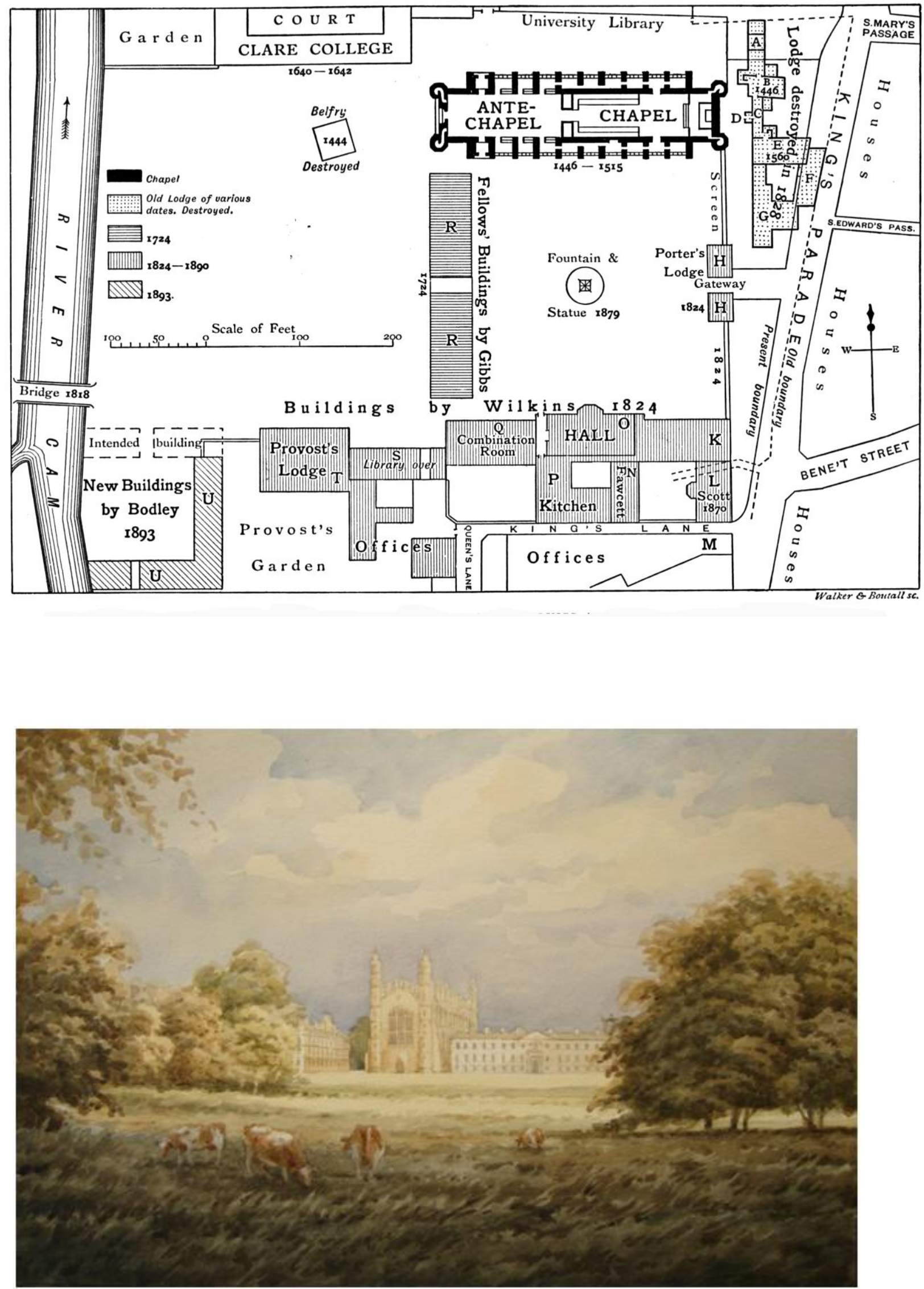

Imagen 177: Plan de 1897.

Imagen 178: Acuarela autor desconocido. 

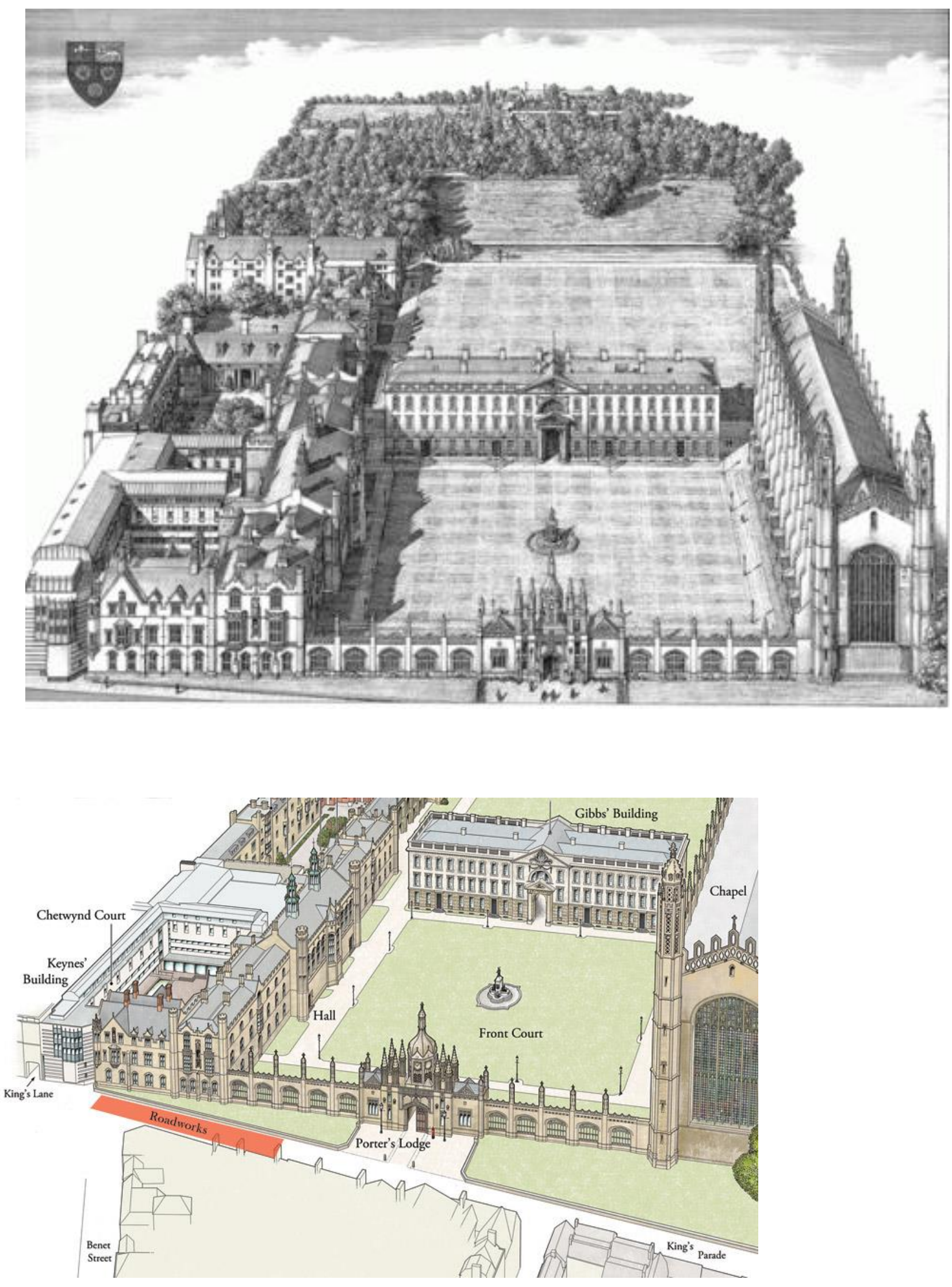

Imagen 179: Plan de 1897.

Imagen 180: Axonometría que

muestra el acceso orientación este 
TRINITY COLLEGE.

\section{La fusión colegial (1540)}

Fue fundado en 1540 por Enrique VIII. Este rey era prudente a la hora de dar uso a las arcas reales, así que decidió no comprar nuevos terrenos y edificios para fundar el college, y en su lugar ordenó a dos colegios que se fusionaran en uno. Los colegios eran el Michaelhouse y el King's Hall.

Estos dos colegios poseían antes de su fusión grandes extensiones de tierra y una serie de edificios, de los que forman parte los albergues Ilamados Physwich, Gregorio, Ovyng, Catalina, Garrat, Margaret y Tyler $^{138}$.

Las dos edificaciones, Michaelhouse y King's Hall, eran muy diferentes. King's Hall era una gran institución fundada por Eduardo II como un lugar de estudio de sus empleados. Los residentes eran gente acomodada, súbditos directos del rey y el número estaba entre veinte y treinta y cinco personas. Por el contrario, Michaelhouse fundado por clérigos pobres, estaría conformado por seis o siete becarios y el maestro ${ }^{139}$.

Michaelhouse se estableció en el día de San Miguel de 1324 como un colegio para Órdenes Sagradas. Fue fundado por Hervey de Stanton, Ministro de Hacienda de Eduardo II y Presidente del Tribunal Supremo. El colegio se construyó entre la primavera de 1323 y el otoño de 1324.

El 11 de noviembre de 1324 Hervey de Stanton obtiene las propiedades para la creación del nuevo college. Ordenó la reconstrucción de la Iglesia Parroquial para que tuviese el uso de capilla, o sea, que pasara a ser la capilla del colegio. Cuando Stanton murió fue enterrado en la capilla, estando ésta aún sin terminar.

La construcción del colegio (Michaelhouse) siguió a cargo de John de Illegh y Alexander Valsham. Compraron propiedades para la ampliación del college, en concreto dos albergues al sur del carril de San Miguel y Milne Street, lo que actualmente está denominado como Trinity Hall Carril. Los albergues se llamaban Ovyng y Garret, éste último dio su nombre a la vía que conduce al río.

En 1337, Illegh compró otro salón de un albergue próximo llamado Newmarket Hostel, junto a esta adquisición obtuvo dos propiedades ubicadas en el Carril de San Miguel que completaban la temparana expansión. La primera de ellas es el legado de Joan de Refham, en 1549, de su vivienda y tiendas, y la segunda es el hotel de San Gregorio, antigua vivienda del Arcediano de Norfolk ${ }^{140}$. 
Hacia la mitad del siglo XIV Michelhouse ocupaba la mayor parte de la actual esquina sur-oeste del college.

Atendiendo a planes históricos se puede determinar la forma del Michaelhouse y si ha quedado algún vestigio en el actual Trinity College. En el plan de Richard Lyne de 1574 Michaelhouse estaba formado por sala, con la función de comedor, cónclave y biblioteca. Las habitaciones de los estudiantes se encontraban en los albergues adheridos. Según el plan de Hammonds de 1592, Michaelhouse es un edificio de tres pisos sin contafuertes y un mirador provisto de cuatro ventanas a norte y tres al sur. Sin embargo, en un plan de la biblioteca del college del que se desconoce el autor, se define este mirador con número diferente de ventanas. Hay otro plan reseñable de David Loggan de 1688 , en el que se distingue un nuevo comedor y una nueva cocina, construidos de nueva planta anexionados a la edificación existente.

El King's Hall se encontraba al noroeste de la actual capilla. Se fundó en 1317, segundo en orden cronológico tras el Peterhouse. Como se acaba de exponer fue establecido por el rey y colocó a secretarios de su administración al frente de la docencia. Al contrario que Michelhouse, éste se encontraba en la parte norte del actual quadrangle principal, donde queda en pie una parte, es el Fellows Bowling Green, conectado con la capilla. En este edificio actualmente están algunas de las habitaciones más codiciadas, sólo accesibles a colegiales de muchos años de antigüedad. Están situadas en la primera planta $y$, junto a ellas se encuentra la habitación del profesor. Esta zona habitacional tiene lucernarios que dotan de luz natural los espacios. En la planta baja estaban las zonas comunes junto con la cocina y las zonas de almacenamiento. El acristalamiento es de vidrio oscuro, a diferencia de la primera planta. Hacia 1400 se añadieron las letrinas y un porche perimetral. Se construyeron nuevos espacios de almacenamiento de víveres.

El King's Hall está construido a base de muros de piedra de Barrington ${ }^{141}$. Las cubiertas son de pizarra natural de Stanford. Todas las ventanas están realizadas en madera. Los pavimentos están conformados a base de baldosa cerámica.

EL edificio Bowling se revistió totalmente de ladrillo hacia 1791, tapando los muros de mampostería. Actualmente el college tiene una "piel" en todos los edificios que lo conforman de combinación de mampostería y ladrillo.

Michaelhouse y King's Hall se fusionaron cuando el rey Enrique VIII estaba cerrando iglesias y apoderándose de las tierras pertenecientes a monasterios y abadías. Los miembros de estas dos entidades convencieron a la reina Catalina para que no cerrara el college. No lo cerró 
y creó uno nuevo a partir de la unión de éstos, el Trinity College.

Los edificios actuales, sobre todo los de mayor tamaño datan de los siglos XVI y XVII. Thomas Neville, quien se convirtiera en director en 1593 rediseñó y reconstruyó la mayor parte del college. En estas obras se incluía la ampliación y terminación del Great Court, de obra nueva se realizó el Neville's Court, justo entre el río Cam y Great Court. Se completó este último cuando Christopher Wren diseño la biblioteca, conocida como la biblioteca de Wren.

Descripción de los edificios que conforman el conjunto actual:

El Fellows Bowling Geen, se encuentra al norte del Great Court, detrás de la Torre del reloj, es, junto con la Gran Puerta los únicos restos del desaparecido King's Hall.

La Gran Puerta es la entrada principal del College, a través de ella se accede al Great Court que es el patio principal del quadrangle que conforma este college.

El Great Court, se consolido a través de construcciones realizadas por varios arquitectos entre 1599 y 1608 . Fue la idea maestra de Thomas Neville, que demolió muchos de los edificios existentes, incluyendo el antiguo Michaelhouse. El único vestigio que quedó sin reemplazo son los que hoy ocupan las cocinas, dentro del diseño que realizó James Essex entre 1770 y 1775.

Master Lodge, Congrega una zona de reunión y la estancia de profesores y rector del college. Está situado para mantener el control de forma directa de las zonas comunes.

El Salón (Hall), se encuentra al lado del Master Lodge. Construido durante la época de Neville, es el más grande de todos los pasillos de Cambridge. Las escaleras son de tramos curvos y están revestidas de piedra. Antes de acceder al Hall hay puertas a la izquierda para las cocinas y habitaciones privadas y la entrada al Salón a la derecha. En el interior, hay retratos de ex alumnos de la universidad, incluyendo Thomas Neville, Francis Bacon, Sir Isaac Newton, John Dryden y Lord Tennyson. Otras características del Hall son el un magnífico techo de vigas, unos muros tallados en la entrada, carpintería isabelina en la Galería de los trovadores "y un retrato de cuerpo entero de Enrique VIII al final sobre la tarima.

En la actualidad, el Salón se utiliza a diario para las comidas, tanto formales como informales. 
Neville's Court, se construyó en 1612 y el arquitecto es desconocido. Este patio fue creado a partir de un legado del director del college y se encuentra entre el Great Court y el rio Cam. Esta parte fue construida por personal de Thomas Neville y comprendía inicialmente sólo tres lados. El cuarto, ahora la Biblioteca de Wren, fue originalmente una pared cerrada, con una puerta central que posteriormente se eliminó. Esta puerta ahora se erige como una entrada a la zonade Trinity Lane. Actualmente ocupa una superficie menor dentro del conjunto de lo que lo hizo en un principio.

El Hostal del Obispo es un edificio aislado al suroeste del Great Court y llamado así en honor de John Hacket, Obispo de Lichfield y Coventry. El arquitecto de este edificio es Robert Minchin ${ }^{142}$, y se construyeron edificaciones adosadas a éste en 1878 diseñadas por Arthur Blomfield.

Biblioteca de Wren ${ }_{L}$ diseñada en 1676 y terminada su construcción en 1695. Se encuentra en la parte oeste del Neville's Court. Se completó en 1695 bajo el Maestrazgo de Isaac Barrow, quien convenció a su amigo Sir Christopher Wren para diseñarla. El trabajo de construcción se llevó a cabo bajo la supervisión del maestro local albañil, Robert Grumbold, que eligió la piedra exterior con un tinte rosado de una cantera de Rutland. La Biblioteca dispone de proporciones clásicas exquisitas y maximiza el espacio y la luz que tienen las estanterías debajo del nivel de las ventanas. El primer piso está decorado con talla madera de tilo por Grinling Gibbons y amueblado con una serie de bustos de mármol de ex alumnos de la universidad, incluyendo el naturalista John Ray y su amigo Francis Willoughby, Richard Bentley, Francis Bacon y Sir Isaac Newton. En el otro extremo de la biblioteca hay una estatua Lord Byron. La biblioteca es una de las más famosas y mejor dotadas de Cambridge. Entre sus posesiones más notables se encuentran dos de los primeros manuscritos de Shakespeare, un manuscrito del siglo XIV de las visiones de "Pedro el labrador"1/43 y cartas manuscritas por Isaac Newton. En la planta baja de esta biblioteca se encuentran los tranquilos claustros donde los estudiantes tienen vistas al rio Cam.

La capilla fue terminada en 1567 . Se comenzó en el reinado de la reina María, hija del rey Enrique VIII, pero no se terminó hasta 1567, durante el reinado de la reina Isabel. Como con muchas otras capillas universitarias, se divide en dos partes por la pantalla de órganos, éstas son: la ante-capilla y la capilla. 
En la ante-capilla. Las paredes y el techo son de origen Tudor, mientras que la madera de la pantalla de órganos, puestos, paneles y baldaquino sobre el altar son de la época de los reinados de la reina Ana I y el rey Jorge I y II. Las ventanas de cristal de colores son de estilo victoriano.

New Court o King's Court ${ }_{L}$ diseñado en 1825 por Williams Wilkins, donde utilizó predominantemente el estilo neogótico, muy característico de la época Tudor.

Whewell's Court, se encuentra cruzando la calle desde el Great Court, estos dos patios fueron sufragados completamente por William Whewell entre 1860 y 1868 , que era director del college en esta época. El arquitecto fue Anthony Salvin ${ }^{144}$.

Angel Court es el patio situado entre el Great Court y el Trinity Street. Está formado por edificios construidos ya en el siglo veinte. El arquitecto H.C. Husband fue el responsable de su diseño de ellos. 

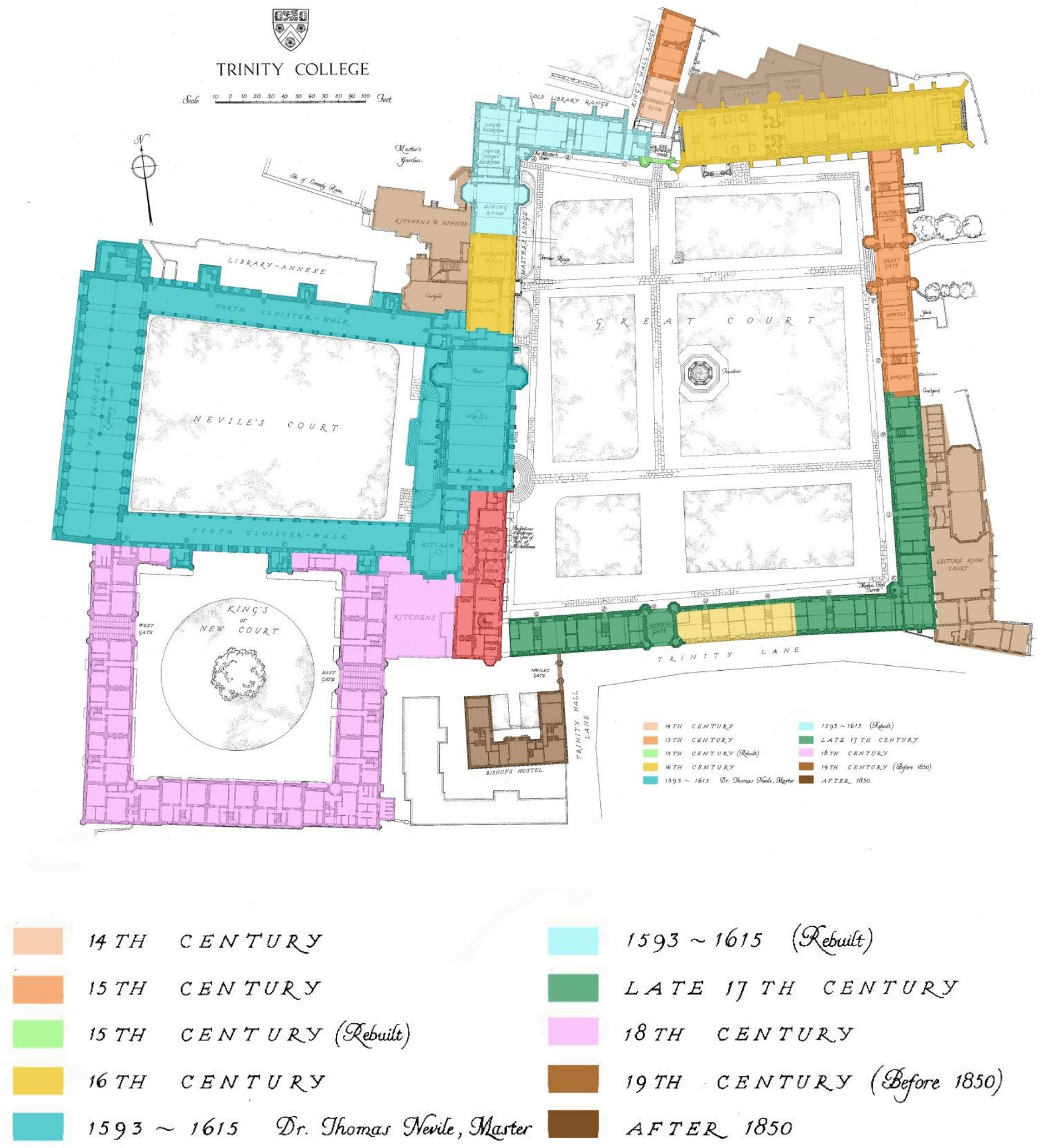
14 TH CENTURY
15 TH CENTURY
15 TH CENTURY (Rebuilt)
16 TH CENTURY

$1593 \sim 1615$ Dr. Thomas Mevile, Master

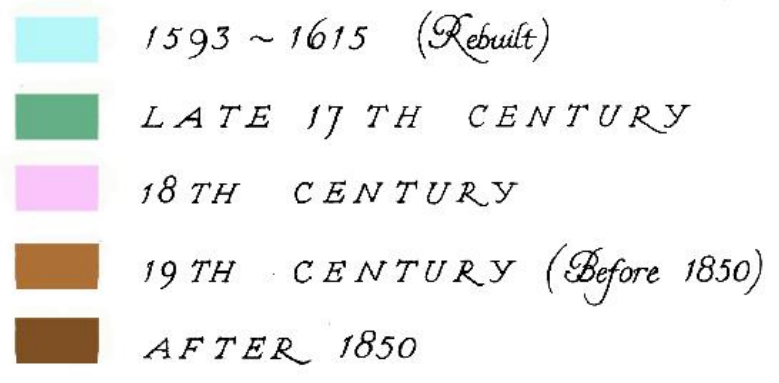

Imagen 181: Esquema de

construcciones ordenado cronológicamente por siglos. 

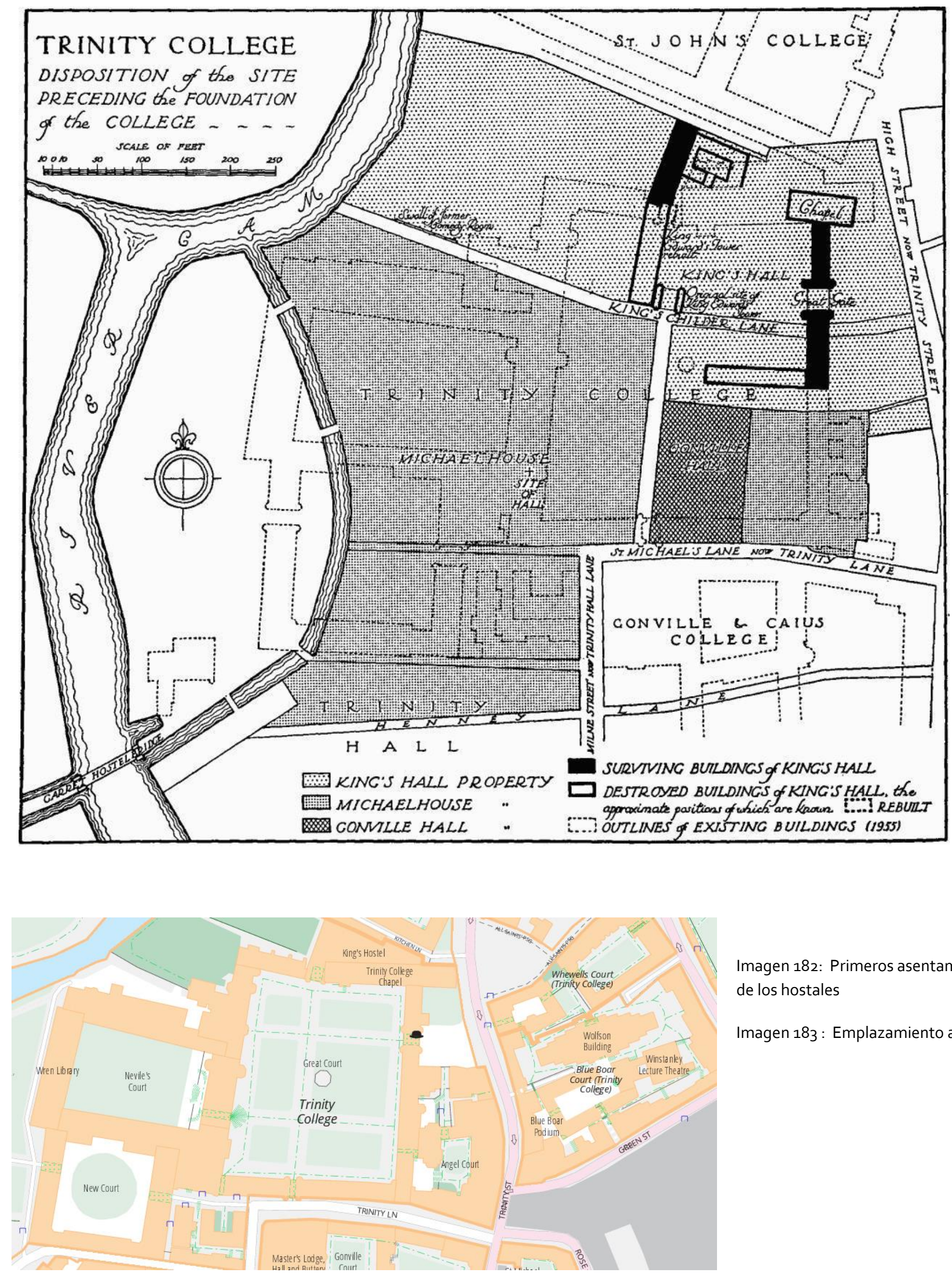

Imagen 182: Primeros asentamientos de los hostales

Imagen 183: Emplazamiento actual 


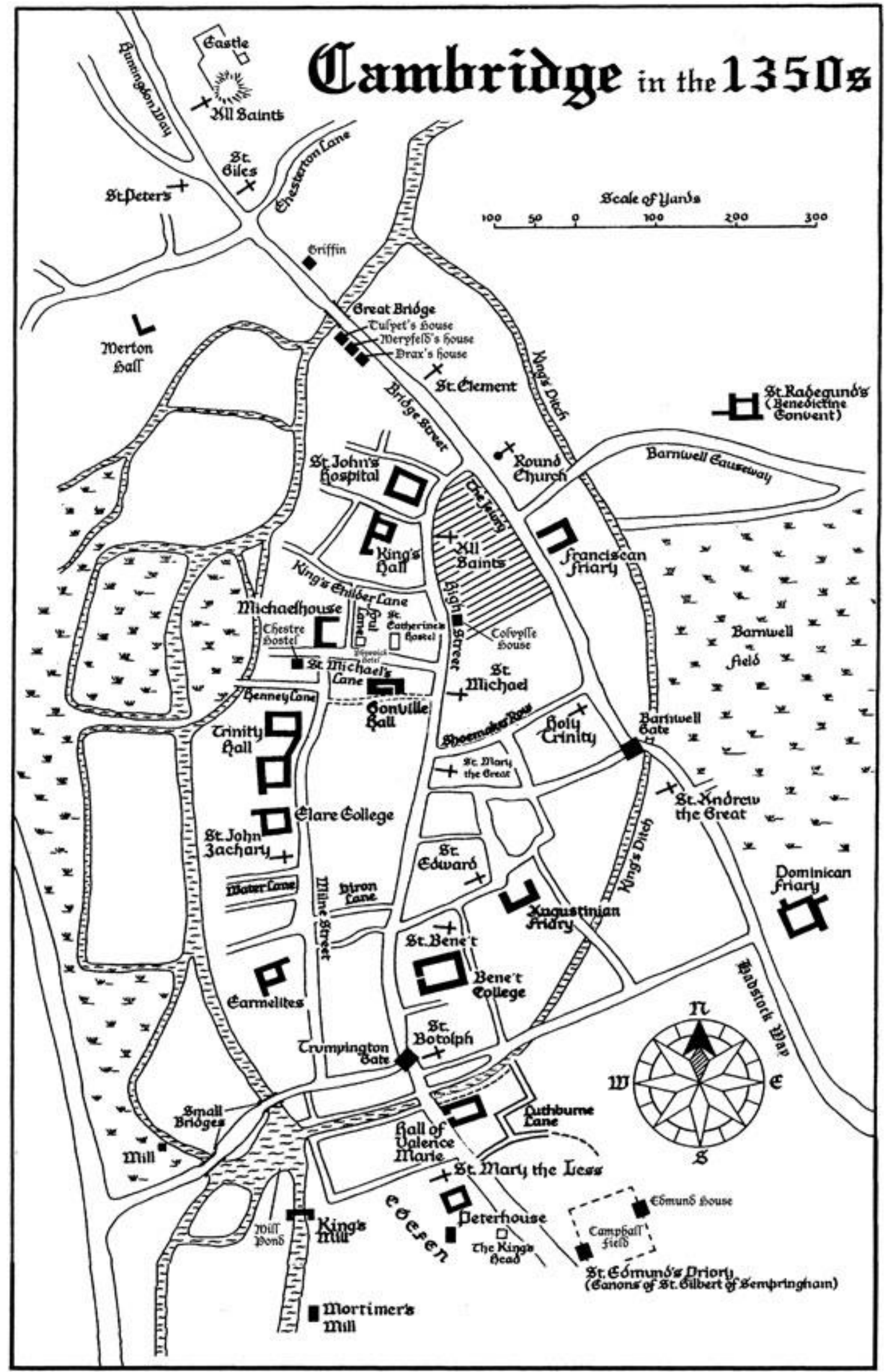

Imagen 184: Primera disposición de

Michaelhouse y King's Hall 

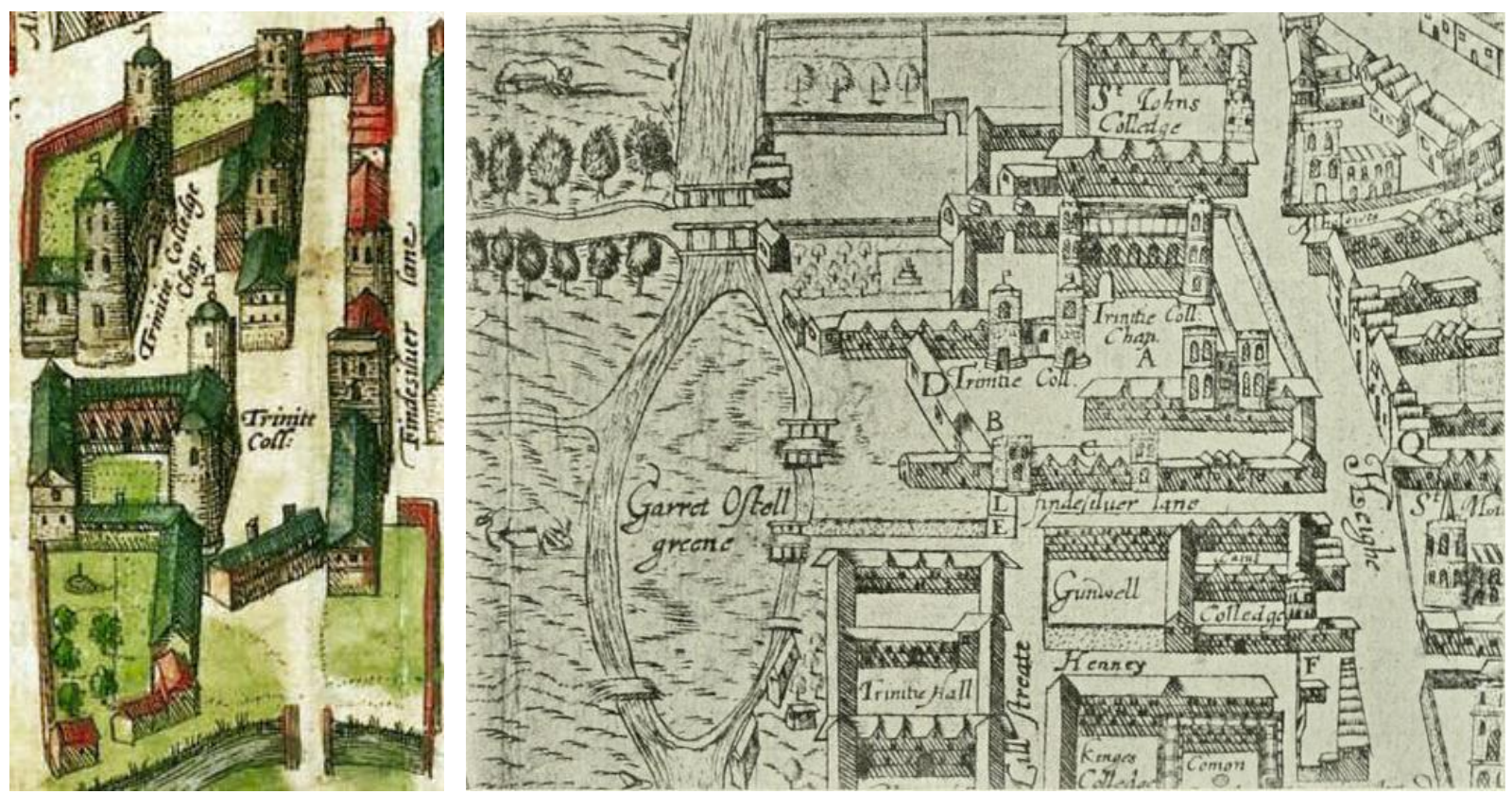

KING'S HOSTEL, TRINITY COLLEGE

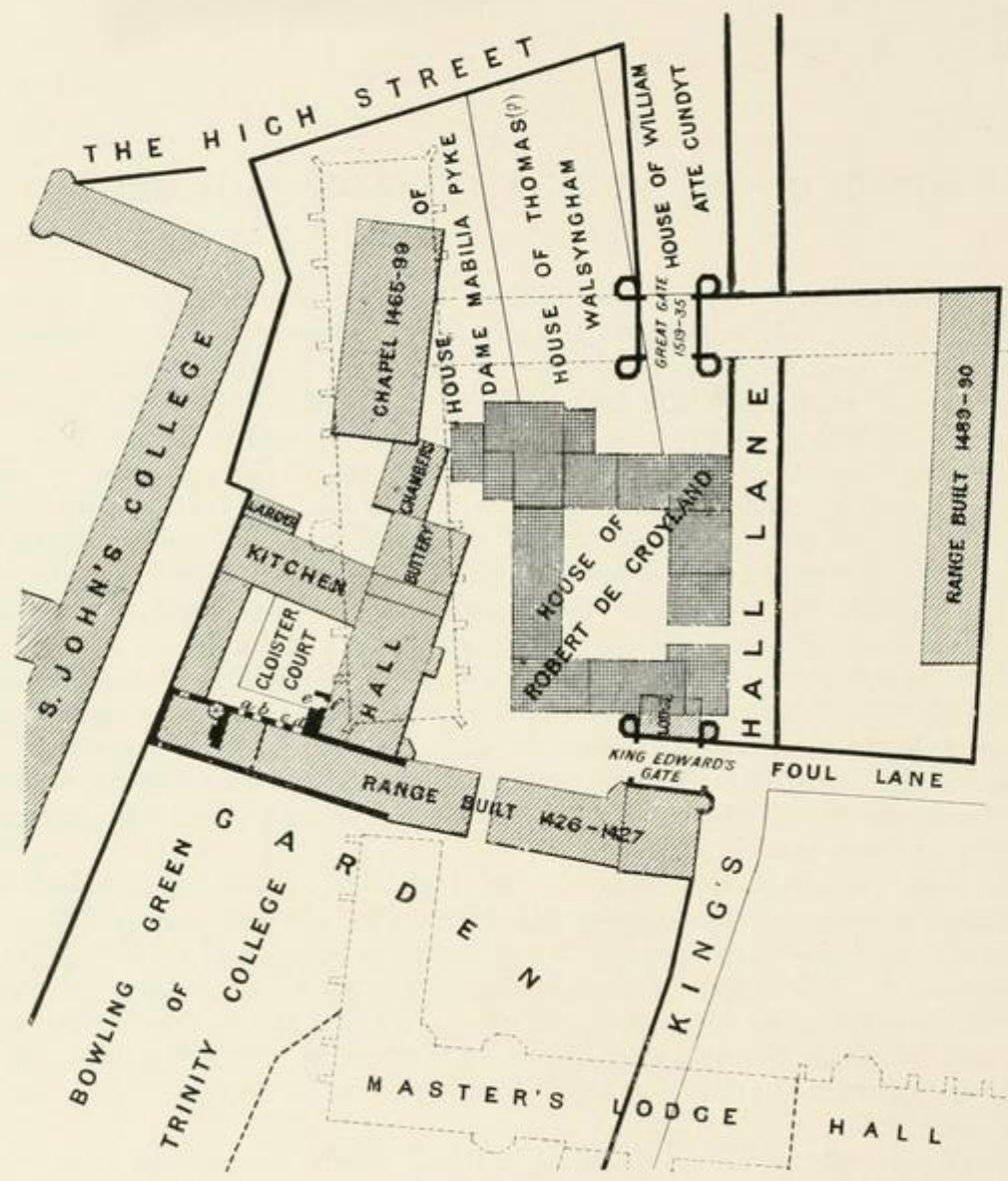

Imagen 185: En la parte norte King's Hall y en la Sur Michaelhouse.

Imagen 186: Plan de Lyn.1574

Imagen 187: Emplazamiento de los primeros asentamientos del College con respecto a su posición actual 


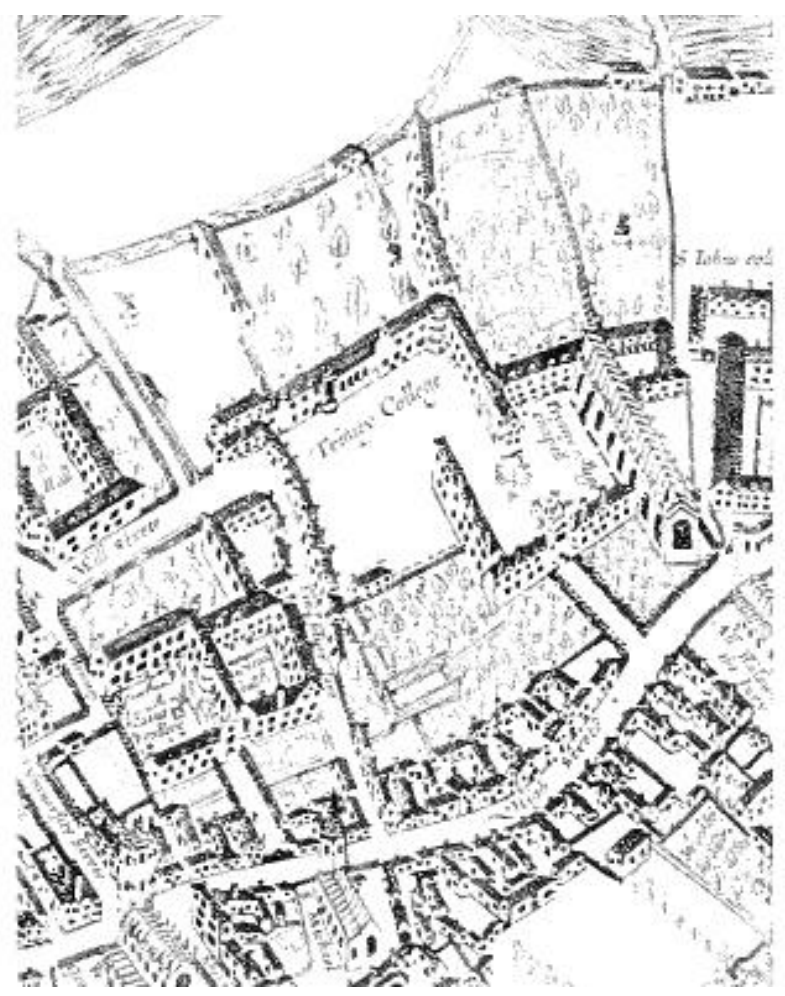

Imagen 188 : Plan de Hammond.

1592.

Imagen 189: Plan de Loggan. 1688.

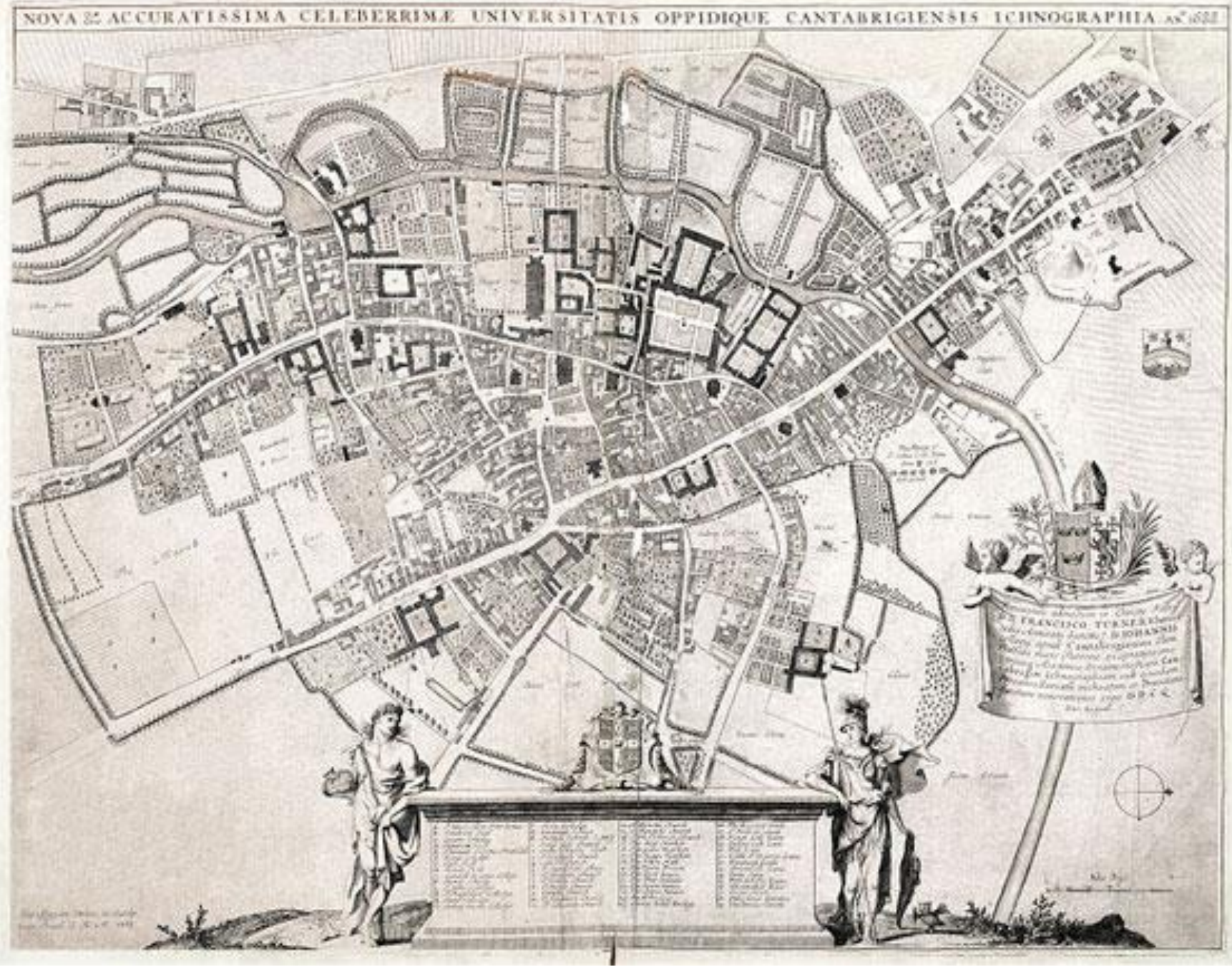




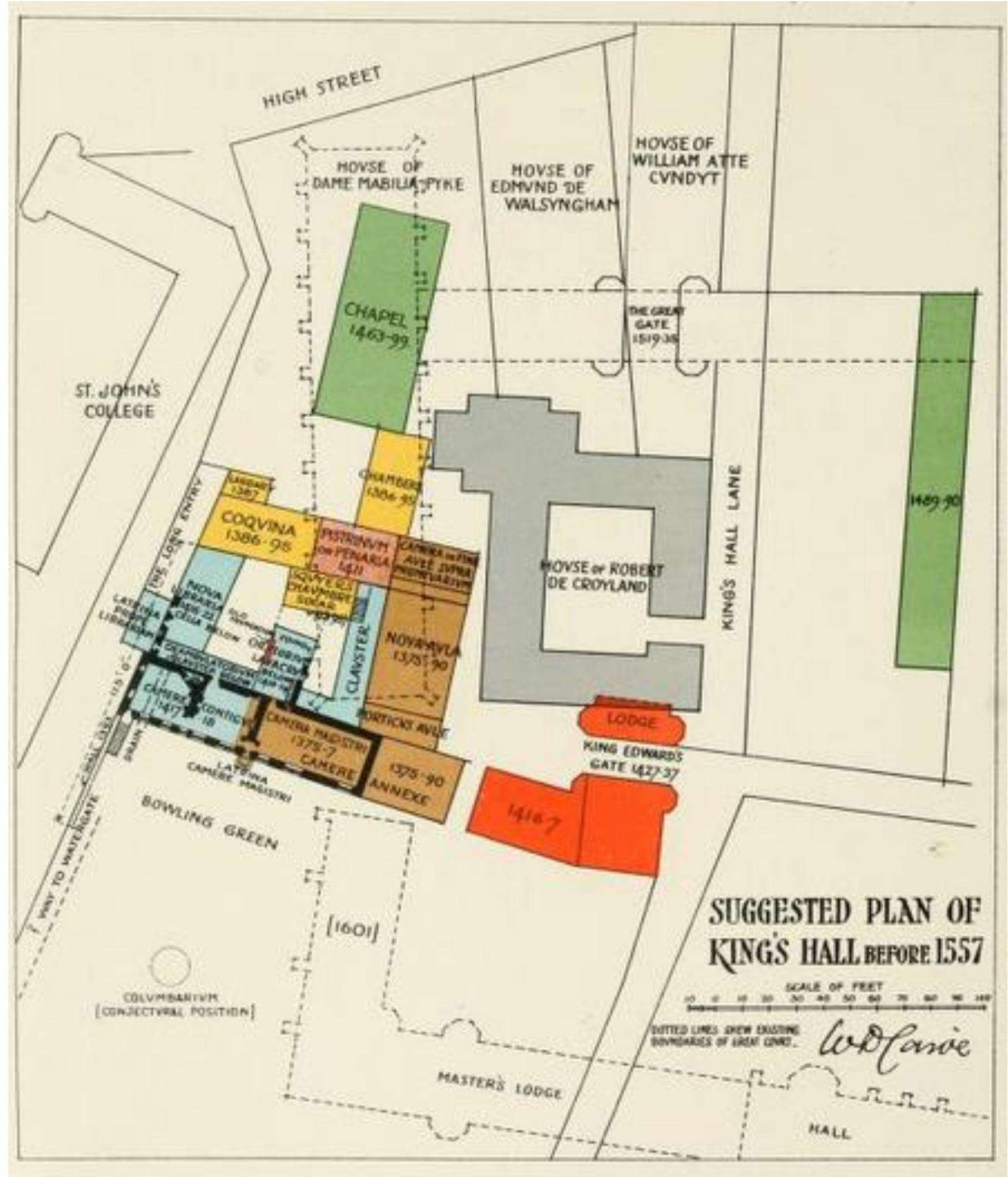

Imagen 190: Situación del conjunto

antes de 1557 . 


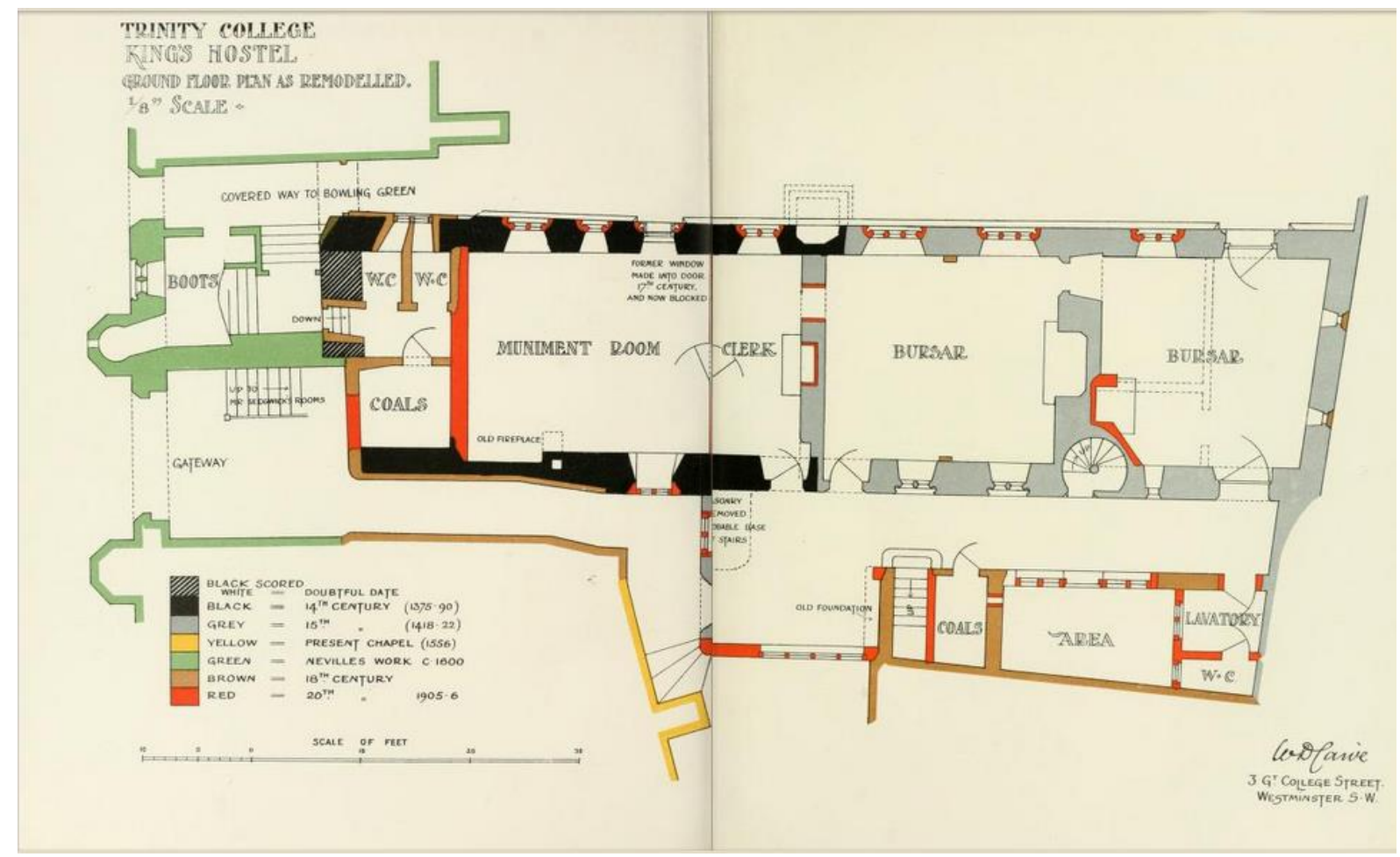

Imagen 191: Planta baja con las restauraciones y modificaciones a lo largo de cuatro siglos.

Imagen 192: Idem anterior planta primera.
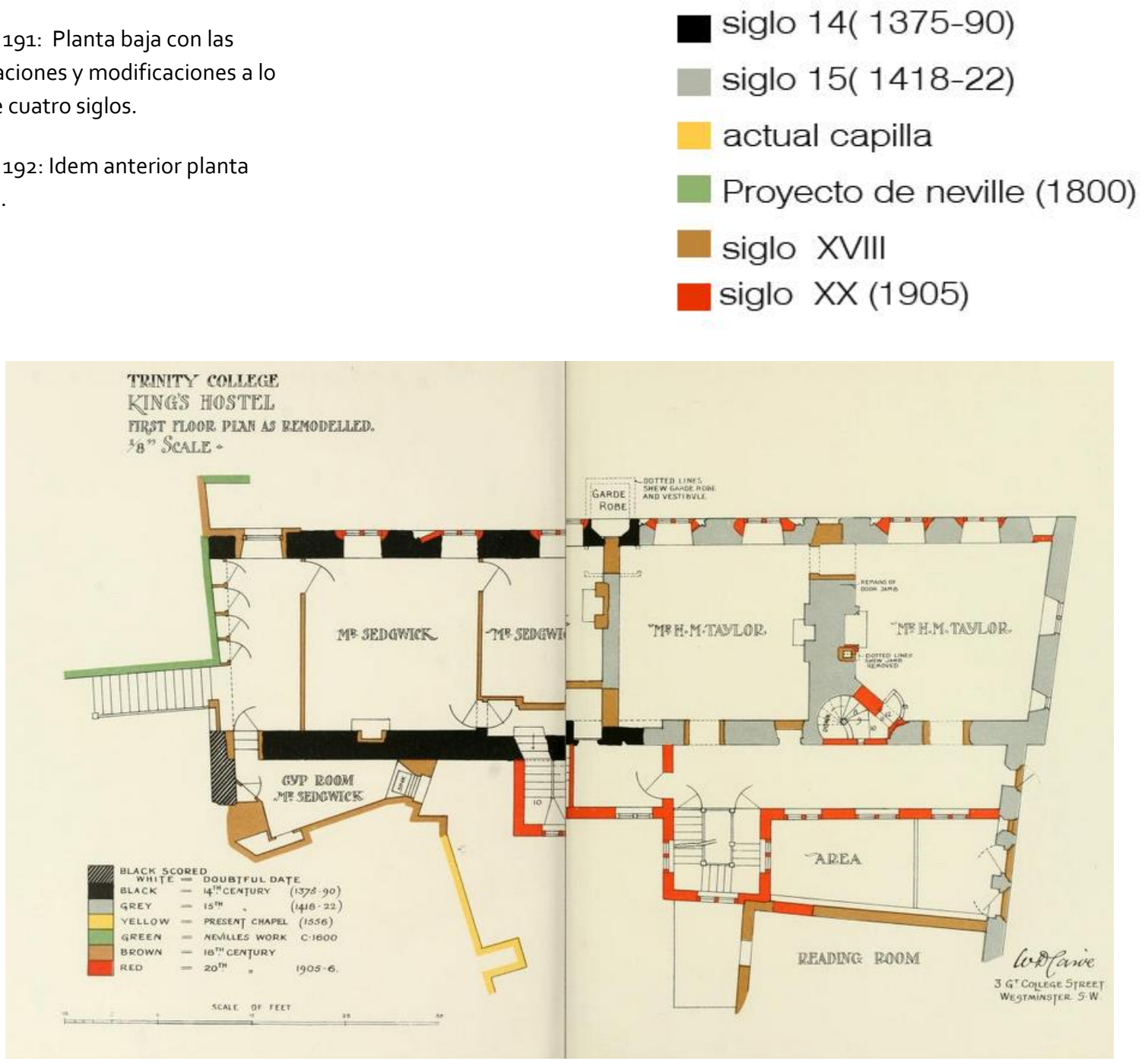
TRINITY COLLEGE

KINCS HOSTEL

SECOND FLOOR, PLAN AS REMODEULEID.

13 " SCALE.

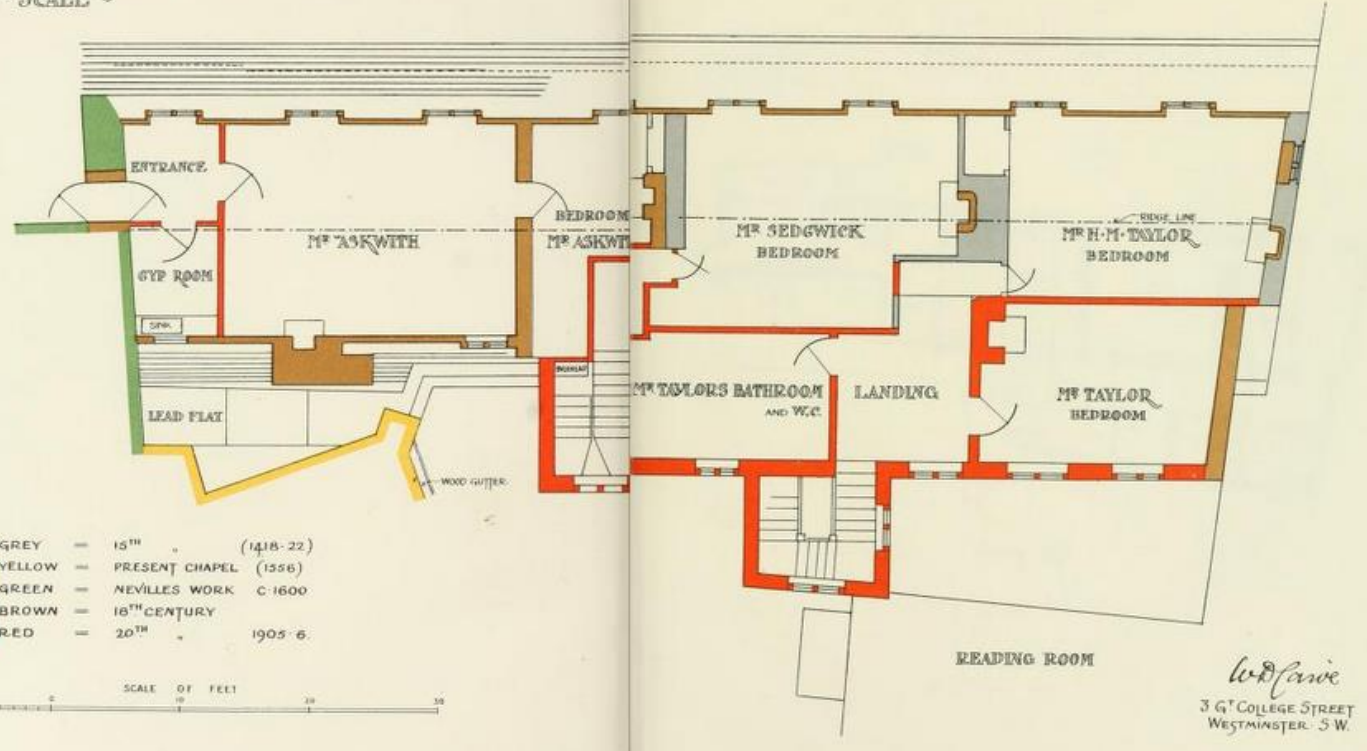
restauraciones a lo largo de cuatro siglos.

siglo 14( 1375-90)

siglo 15(1418-22)

actual capilla

Proyecto de neville (1800)

siglo XVIII

siglo XX (1905) 
TRIVTY COHECE

KNGS HOSTR. BOWING GRPR MONT

excosmen Resmestim
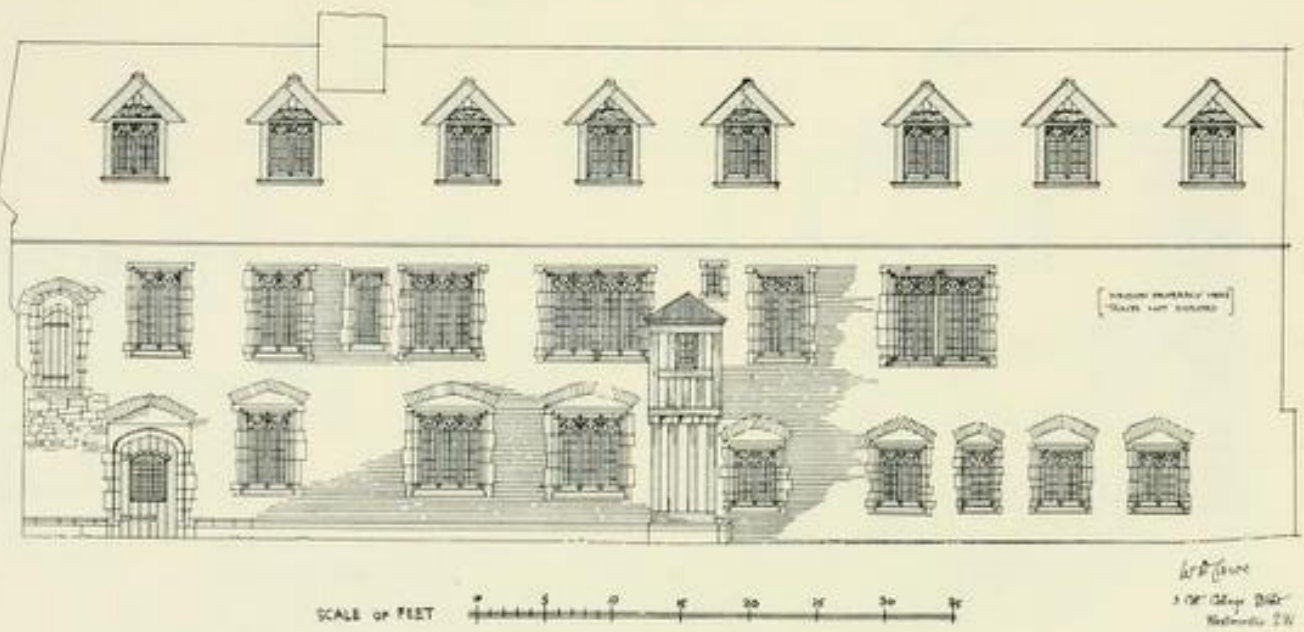

TRETY COLEGE

KINGS HOSTEL.

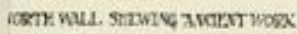
4 ans-
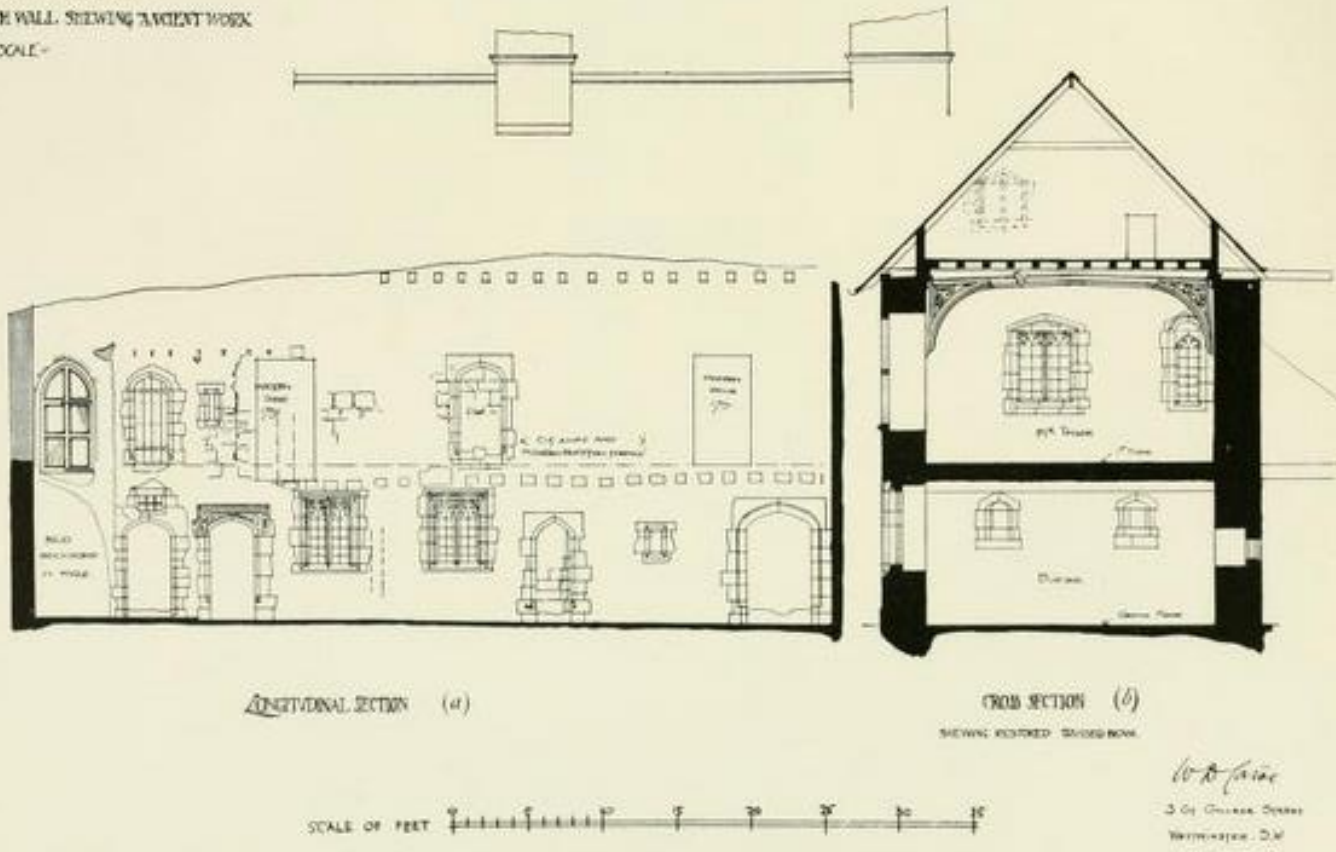

Imagen 194: Alzados del edificio Bowling

remodelación siglo 15

Imagen 195: Sección del edifico Bowling en la misma

remodelación 
TRET COLPA.

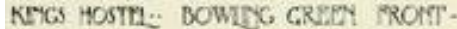

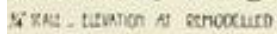

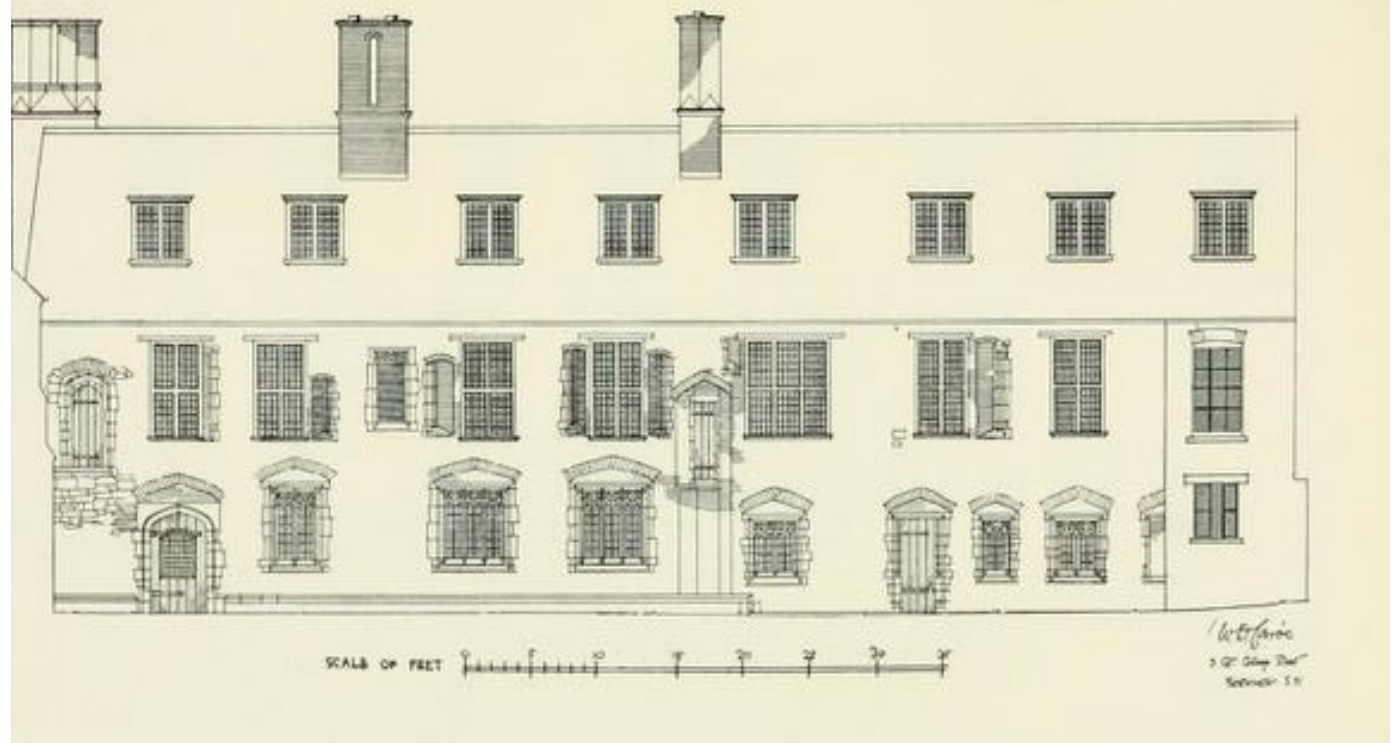

Imagen 196: Alzados del edificio Bowling

remodelación siglo 18 

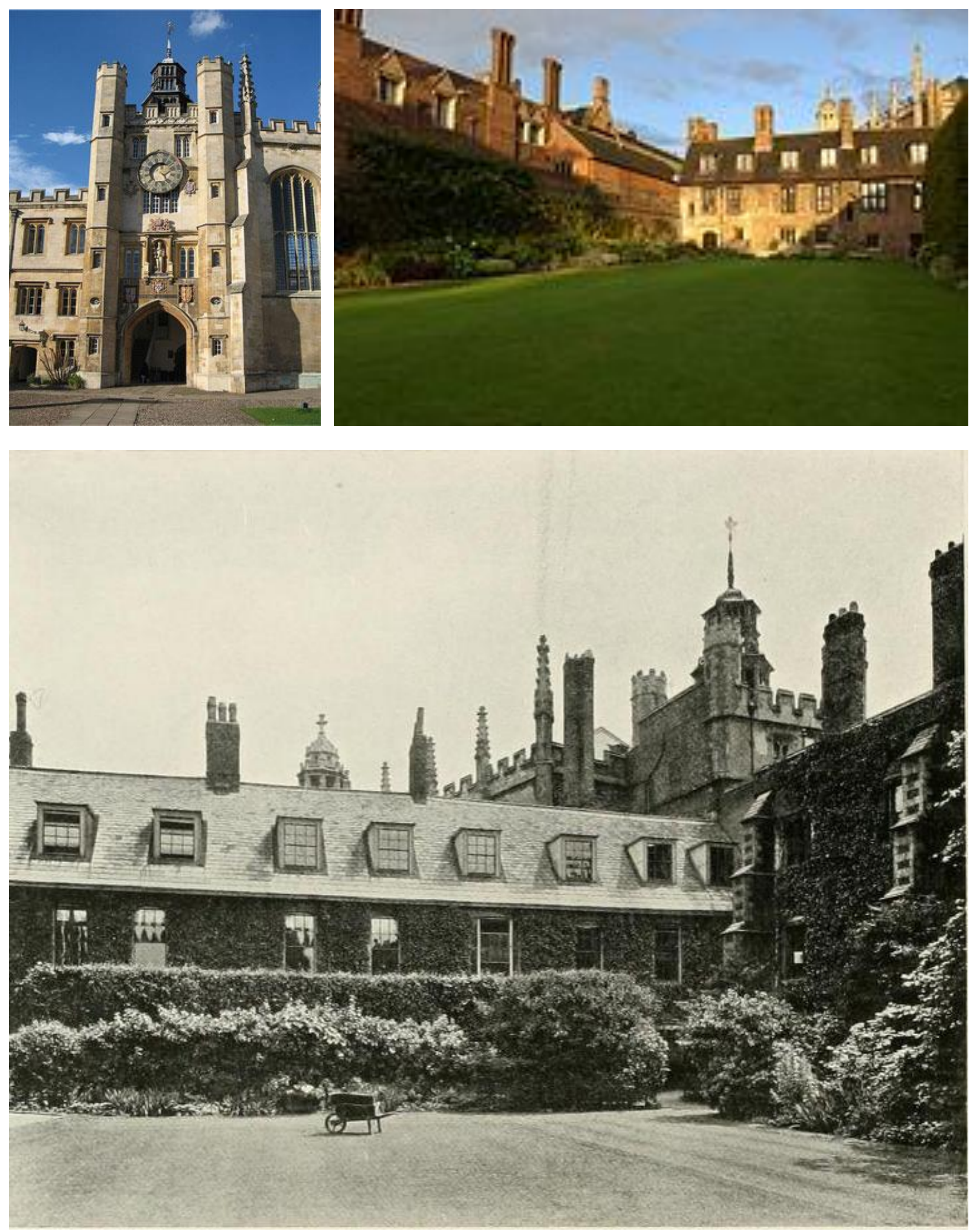

Imagen 197: Torre del reloj, en su

origen formaba parte del King's Hall.

Imágenes 198 y 199: Edificio Bowling

Green Front. Formó parte del King's

Hall. 

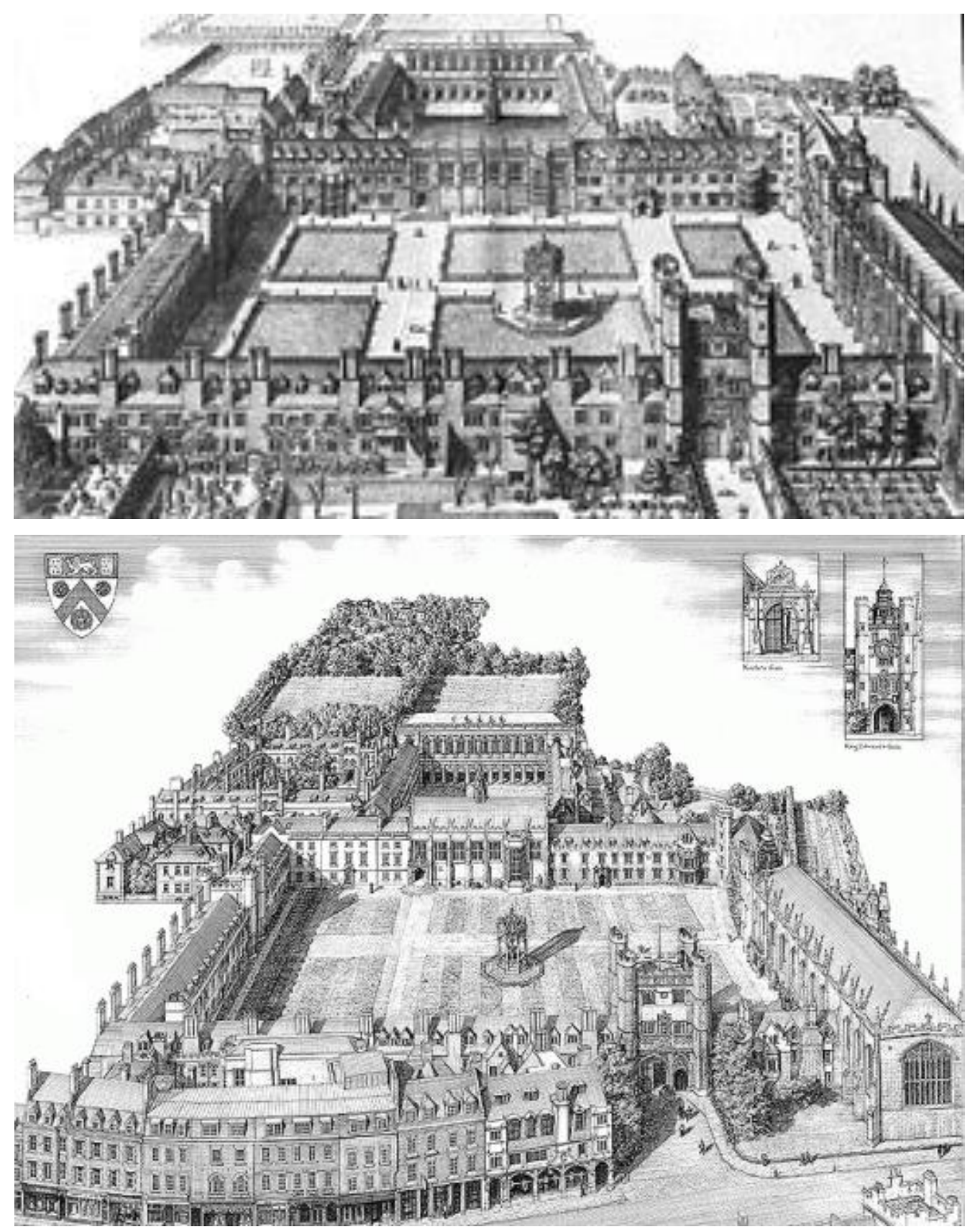

Imagen 200: Plan de David Loggan 1566, Nevile's Court aún no está construido.

Imagen 201: Axonometría del Trinity año 1668

Imagen 203: Alrededores cercanos al

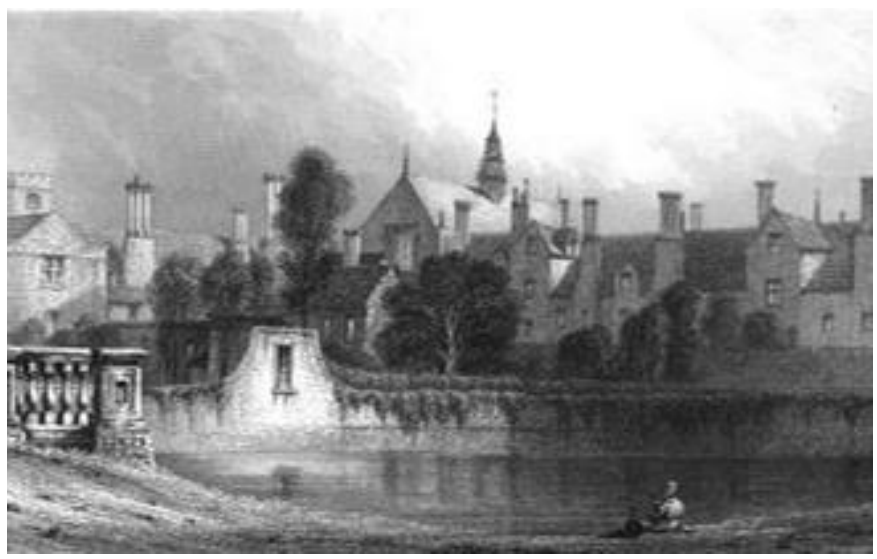


Imagen 204: Great Court

Imagen 205: Great Court
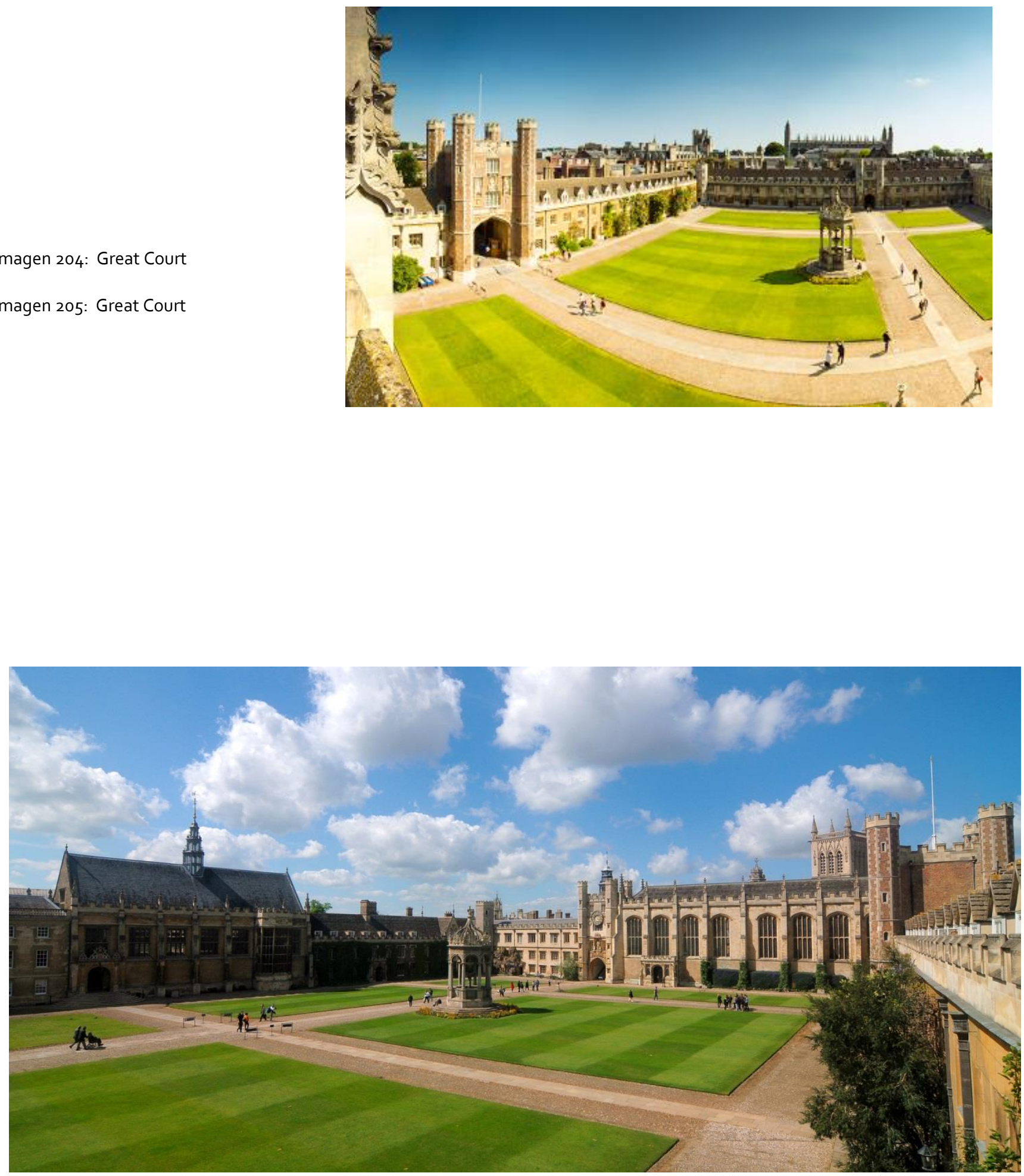

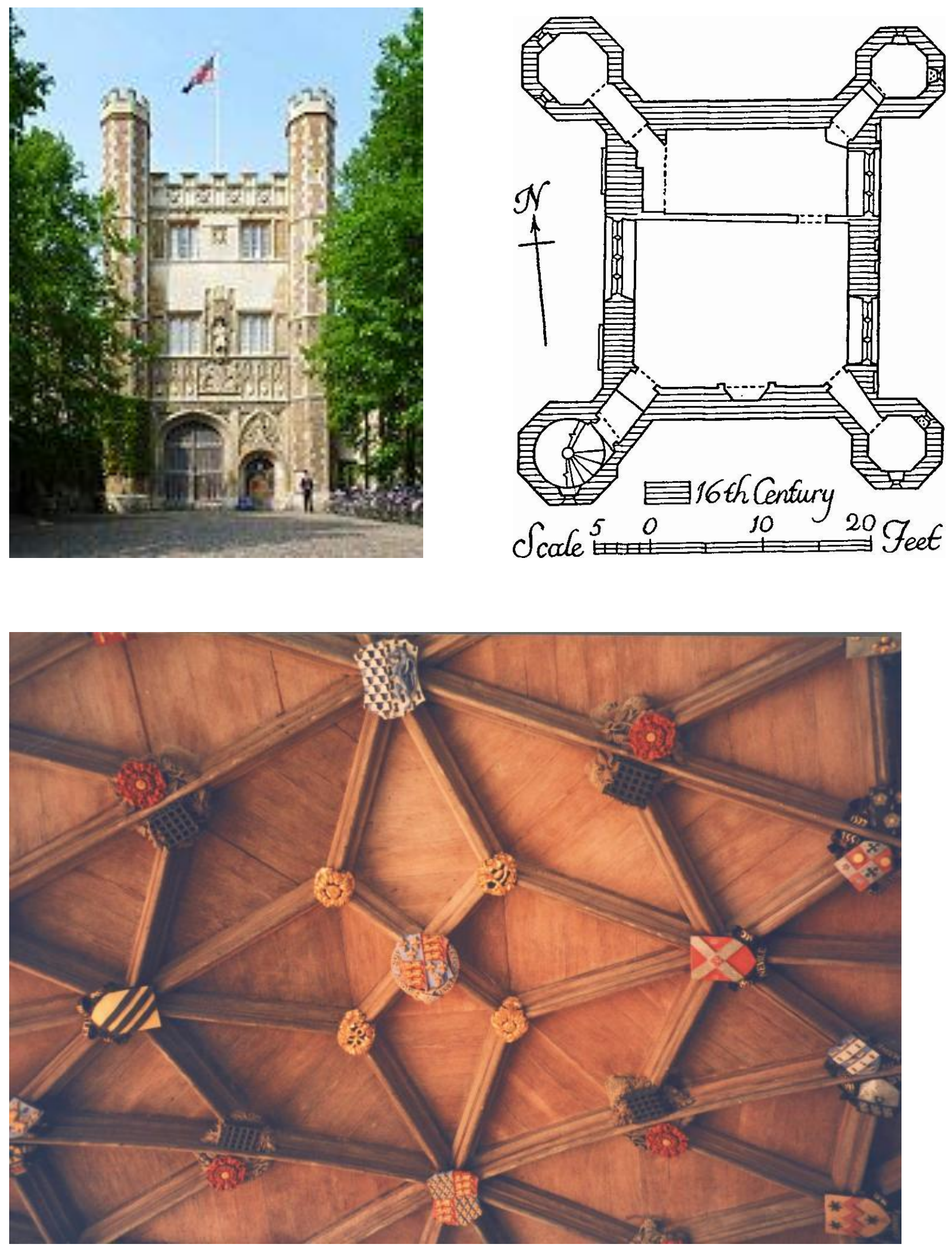

Imagen 206: Great Court

Imagen 207: Planta Great Court, siglo 16.

Imagen 208: Techo de la entrada de la Puerta principal 


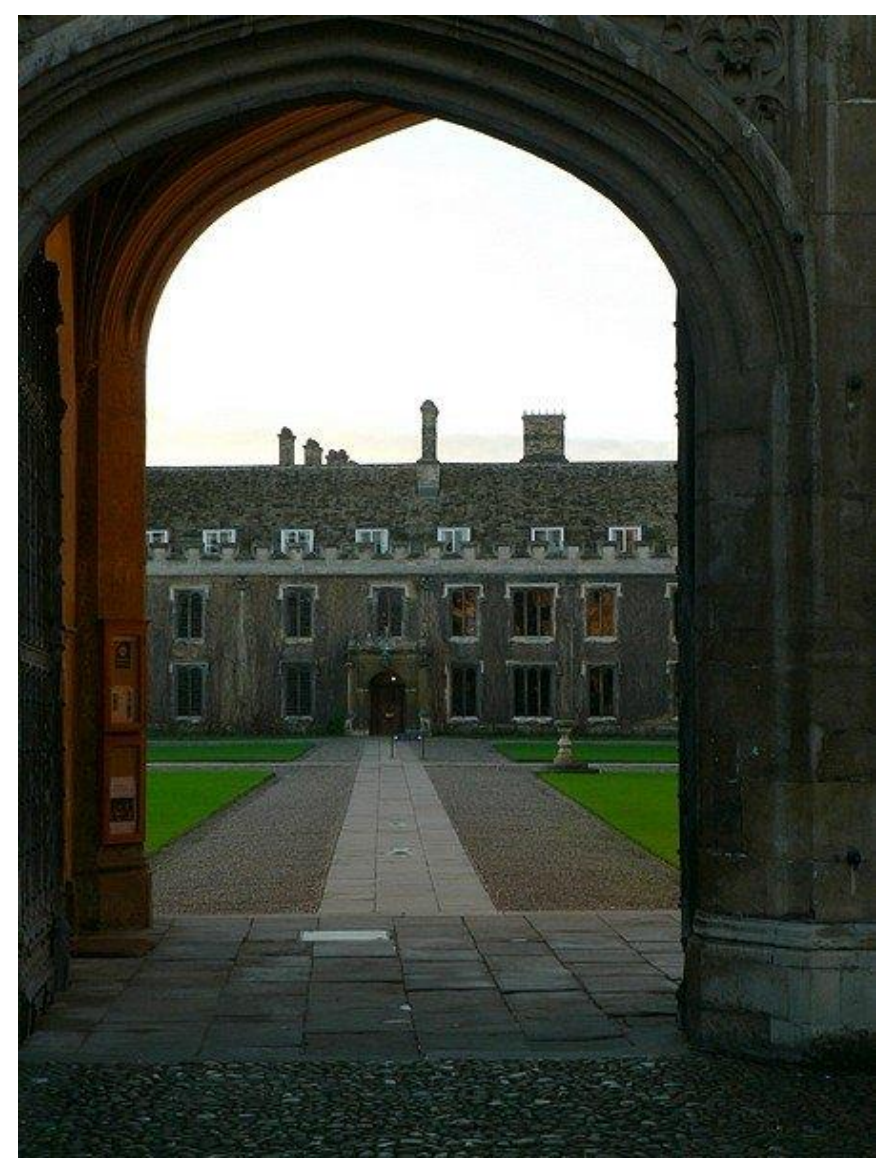

Imagen 209: Master Lodge desde la

Gran Puerta

Imagen 210: Interior del Master Lodge

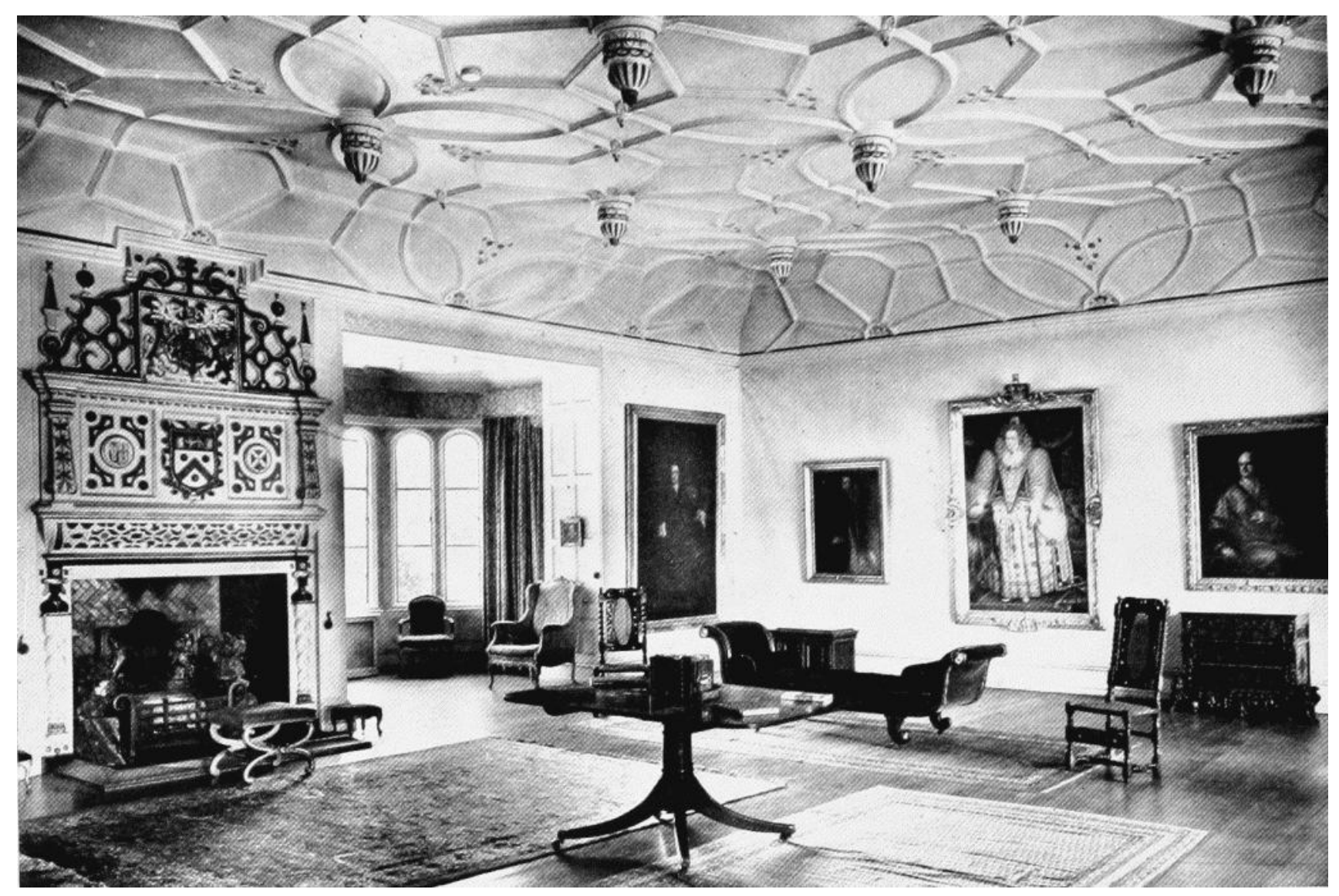




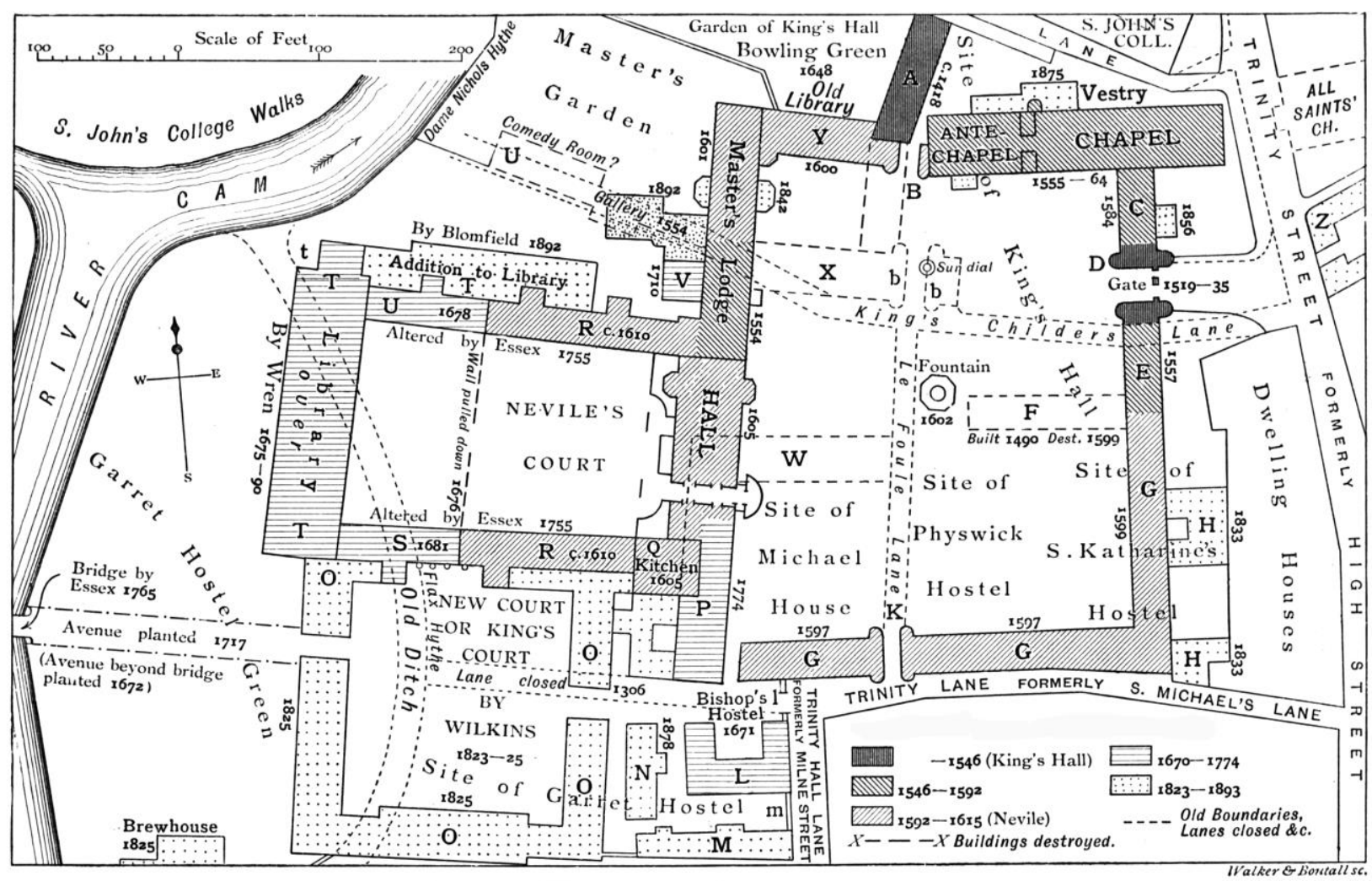

Imagen 211: Plan de conjunto

Imagen 212: Sección del comed

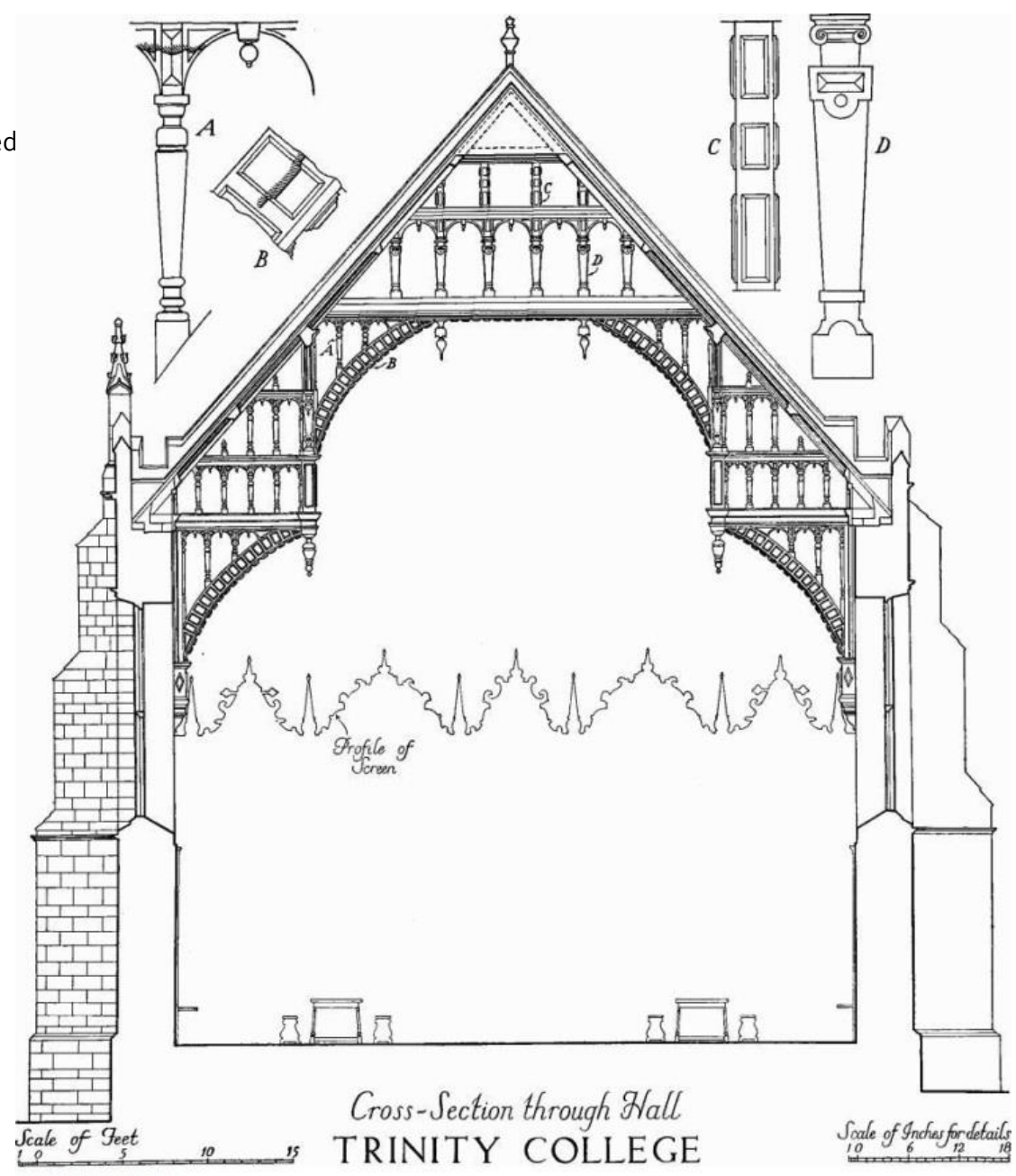



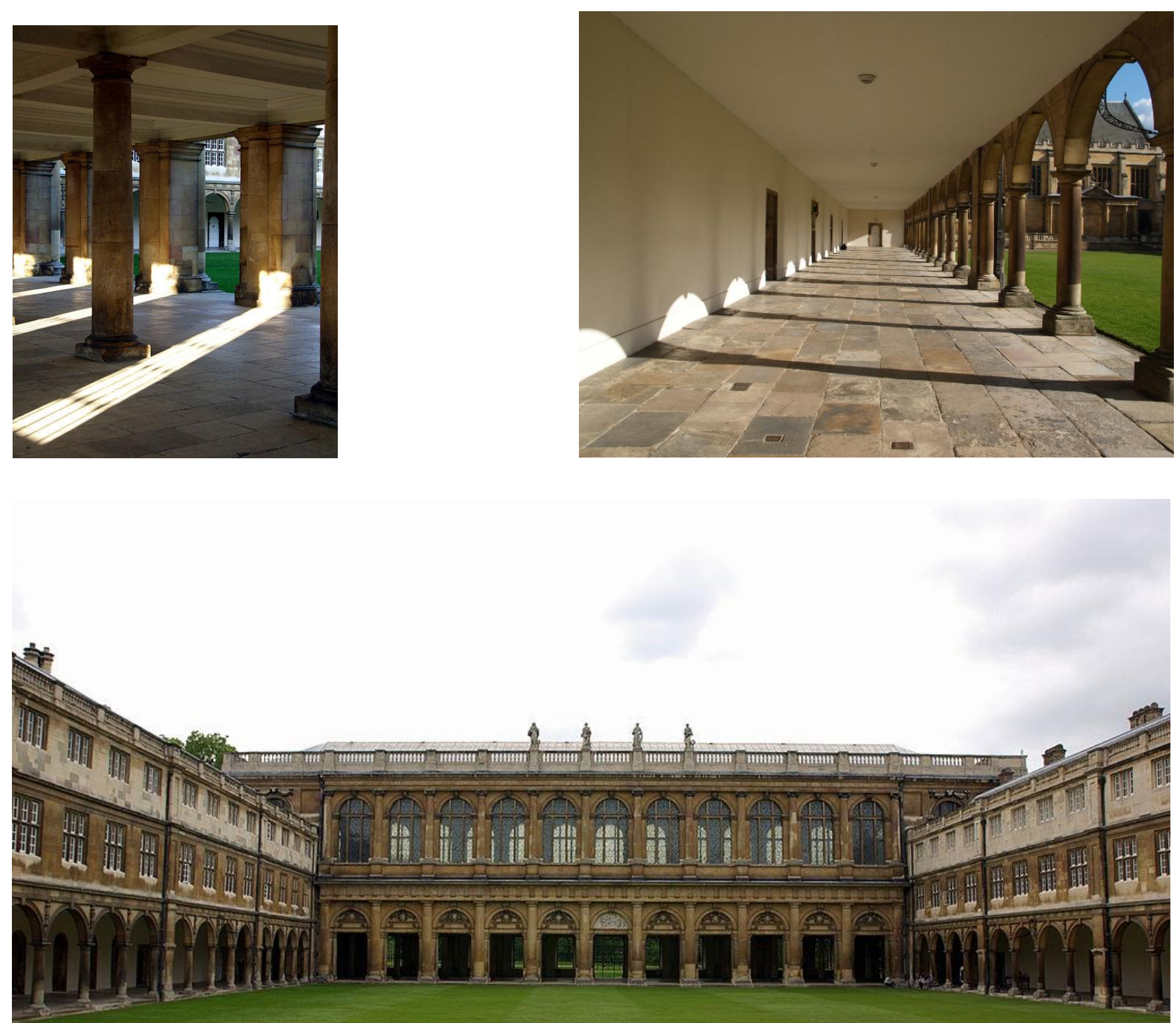

Imágenes 213 y 214: Logias de la Bilioteca de Wren en el Nevile's Court

Imagen 215: Logias de la Bilioteca de Wren en el Nevile's Court

Imagen 216: Biblioteca de Wren desde el Río Cam

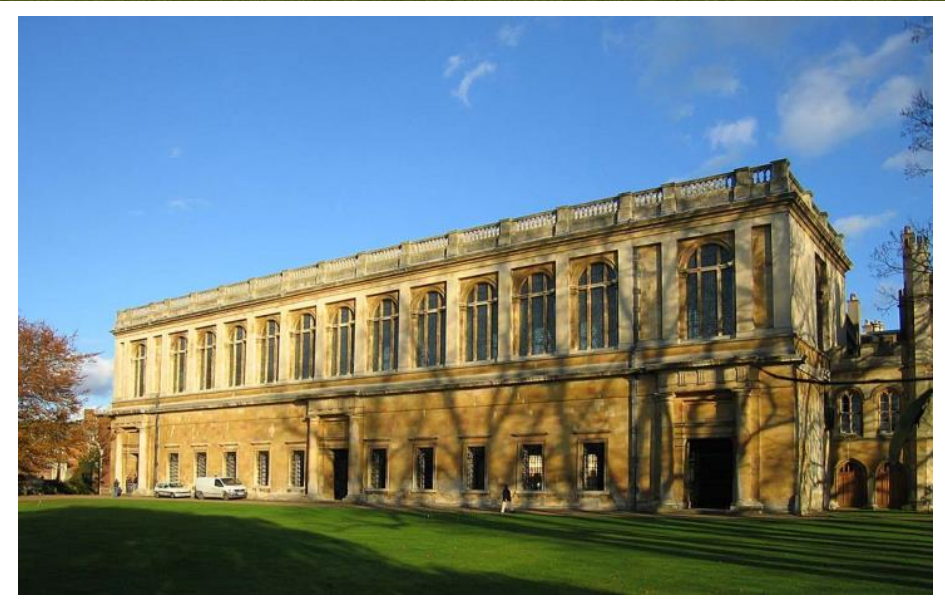




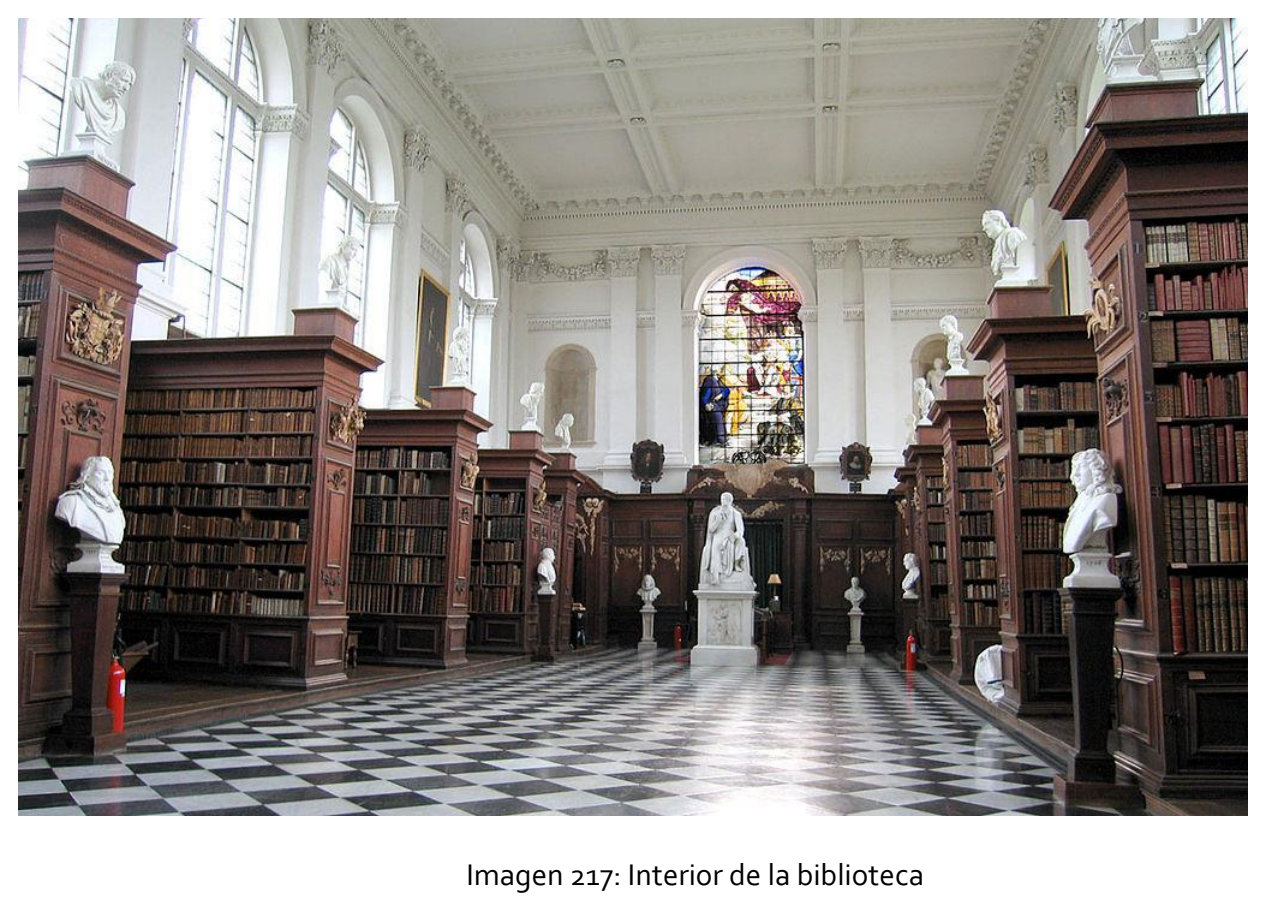


226| RESIDENCIAS UNIVERSITARIAS EN LA HISTORIA 


\section{RESIDENCIAS UNIVERSITARIAS EN LA HISTORIA}

\section{BLOQUE II}

Apéndice contemporáneo:

Fen Court en Peterhouse College. Adoptando nuevos planteamientos (1939)

Saint Cazt College de Arne Jacobsen. La traducción moderna de la tradición (1962)

Florey Building en Queen's College de James Stirling. Mirando hacia Estados Unidos (1971) 
228| RESIDENCIAS UNIVERSITARIAS EN LA HISTORIA 


\section{FEN COURT EN EL PETERHOUSE COLLEGE}

\section{Adoptando nuevos planteamientos (1939)}

Esta intervención se realiza en los años 1939 y 1940 en el Peterhouse College. Es un edificio residencial para albergar a maestros y becarios de este complejo y, surge por la falta de alojamiento estudiantil. Fue diseñado por los arquitectos Hughens y Bicknell, el primero fue becario de este college.

Es la primera estructura de Cambridge desarrollada según los principios del Movimiento Moderno Internacional. Se puede afirmar que este estilo entró a partir de este edificio en la orbe de Oxford y Cambridge.

El edificio en planta tiene forma de "T". Se dispuso así para facilitar las vistas al pantano en la medida en que fuera posible. La planta se encuentra parcialmente elevada sobre pilotis, clara influencia corbusieriana. Los pilotis proporcionan acceso abierto al jardín produciendo vistas que permiten controlar los espacios desde el Gisborne Court. Como novedad, las habitaciones tienen vistas a dos orientaciones, a diferencia de los antiguos colleges donde todas volcaban al interior, herencia de los antiguos claustros monacales.

El revestimiento exterior del edificio corresponde, principalmente, al ladrillo Gault ${ }^{145}$, quedando el hormigón prefabricado como acabado principal en el interior. Al respirarse en el ambiente los prolegómenos de una inminente guerra, tuvo que ser determinante para los autores la decisión de construir el sótano de este edificio con las características de servir como refugio antiaéreo, siendo ejecutado con muros de sótano de hormigón armado de un pie de espesor $y$, a su vez, se dispusieron unas puertas herméticas al gas que conectaban los distintos espacios. Las plantas superiores están resueltas mayormente con elementos prefabricados. La cubierta es plana y hay dispuestos en ella una serie de lucernarios acristalados. Sobre rasante hay tres plantas.

El edificio tiene especial interés arquitectónico, sobretodo en la elección de materiales que, aun siendo austeros, son de gran calidad. Cabe resaltar la jerarquización constructiva a partir de los materiales en su construcción. Posteriormente ha sido varias veces reformado. En la distinción de zonas, por ejemplo, la carpintería es metálica y existen distintos rangos de metal en los marcos de las ventanas. Ocurre algo similar con la madera, que es diferente en cada planta. 
Una operación de proyecto interesante es la elevación de la planta sobre pilotis para permitir vistas abiertas entre antiguas y las nuevas edificaciones.

Es el primer edificio universitario en la preguerra en Cambridge con estilo del Movimiento Moderno Internacional y se le considera el precursor de otros edificios universitarios de posterior construcción. 

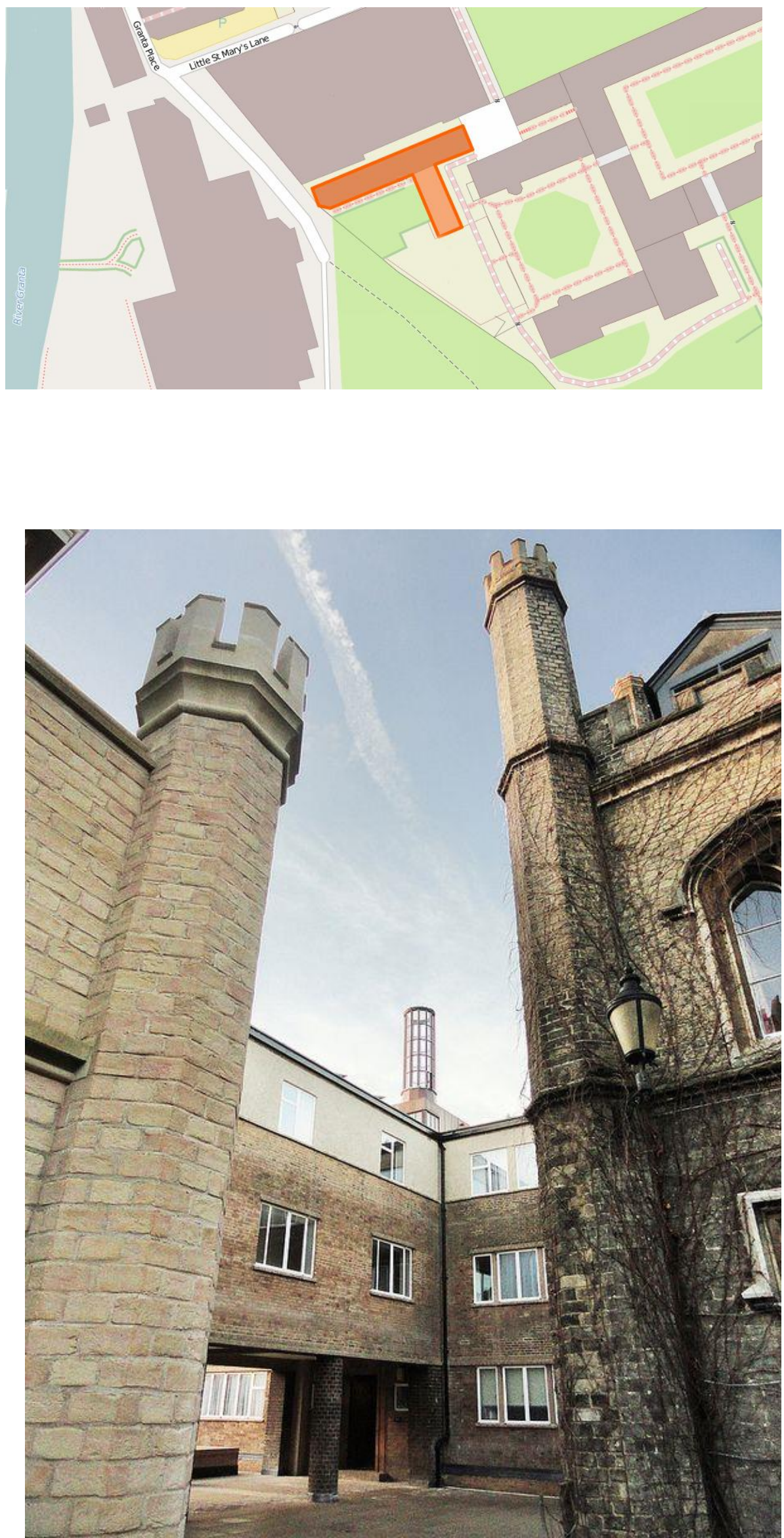

Imagen 218:

Disposición en " $T$ " del Fen Court en el Peterhouse College Imagen 219: Elevación de planta baja sobre pilotis, permitiendo la vista abierta entre las antiguas y nuevas edificaciones. 

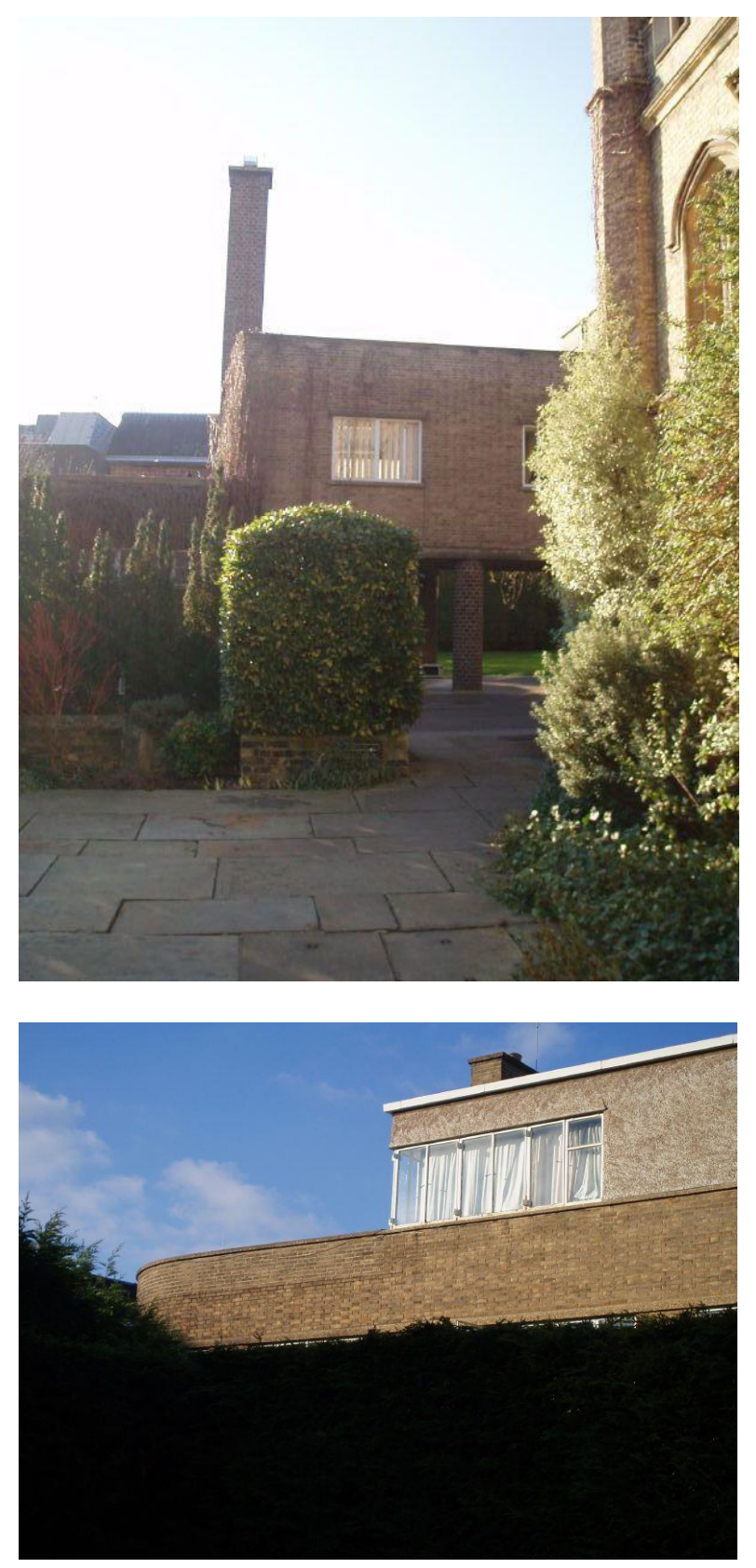

Imagen 220: Planta sobre pilotis vista desde el Gisborne Court

Imagen 221: Patio privado del Fen Court.

Imagen 222: Última planta con antepecho curvo y revestido de ladrillo Gault.

Imagen 223: Relación visual y circulatoria directa entre los distintos patios establecida por la elevación de planta sobre pilotis.

Imagen 224: Lucernario cenital iluminando el núcleo de comunicación vertical que da acceso a las habitaciones.
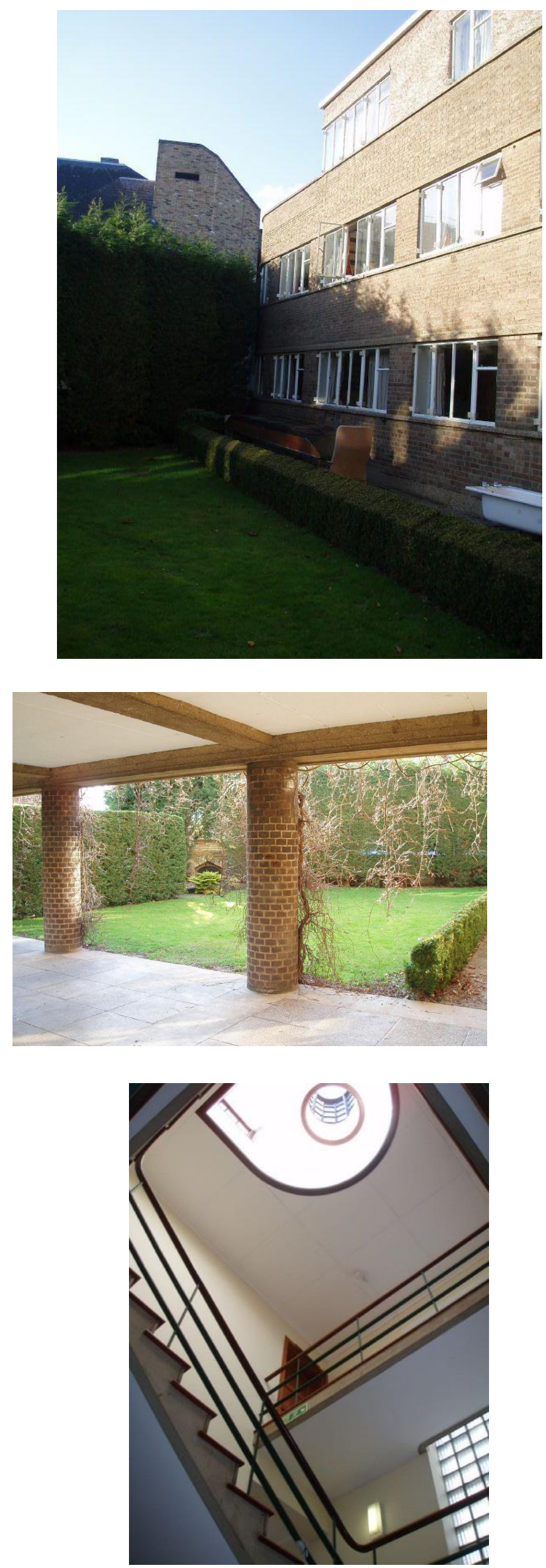
SAINT CATHERINE COLLEGE DE ARNE JACOBSEN

\section{La traducción moderna de la tradición (1962)}

En el diseño de este college, Arne Jacobsen refleja los elementos tradicionales de los colleges de Oxford, que se transmiten a través de soluciones modernas integradas perfectamente en el entorno.

El college está flanqueado por el río Cherwell a un lado y por los campos de juego de la Escuela de Merton al otro, lo que dota al complejo de un entorno rural a pesar de encontrarse a poca distancia del centro de Oxford.

El jardín se considera la parte fundamental del diseño. A partir de este elemento se posicionan las demás edificaciones.

El esquema generado se configura a partir de una trama de 3 metros que unifica todo el conjunto. Los edificios se conectan a través de aceras cubiertas que enlazan las líneas de circulación existentes entre los edificios. Las circulaciones se apoyan en la vegetación dispuesta y elegida, convenientemente por el autor, con una gran variedad de árboles, arbustos y flores que configuran las distintas áreas.

Se puede leer la importancia que tienen los patios para Jacobsen a través de la búsqueda de equilibrio entre las zonas pavimentadas, y las no pavimentadas con hierba. Estos espacios propician elementos de relación entre los usuarios, leit motiv de los colleges desde su creación.

Jacobsen analiza en el plan director del New College a la hora de trazar su diseño, el cual guarda una relación directa con este modelo de seiscientos años de antigüedad que se acaba de analizar.

La disposición inicial de las edificaciones es similar entre ambos. Aquí, el quadrangle formado no está totalmente cerrado en su perímetro lo que produce una permeabilidad en los recorridos. Las circulaciones se apoyan en la vegetación dispuesta creando, junto con los voladizos translúcidos que las protegen un entorno exterior de legibles tránsitos.

Las circulaciones se conforman a través de paredes de ladrillo y las citadas aceras cubiertas que conectan las líneas de los edificios. Es fehaciente la búsqueda de equilibrio entre la parte "natural", los patios, representada por la hierba y la parte de actuación, representada por la pavimentación. 
El arquitecto danés hace una composición muy ordenada y clara, dos pabellones alargados de habitaciones de estudiantes enmarcan los edificios comunes del colegio, y a su vez organizan por un lado la biblioteca y el salón de actos y por otro el comedor.

La disposición general de las edificaciones es la siguiente:

Dos bloques alargados y paralelos de tres plantas de altura destinados a residencia de los estudiantes formalizan las fachadas este-oeste. Comprenden cincuenta y cuatro habitaciones de estudio, cada una de ellas con baño. Cada bloque conforma un pabellón con núcleos verticales de tres escaleras cada uno. Las partes no acristaladas poseen un muro-zócalo de ladrillo que se alinea con el rio. Las habitaciones de orientación oeste tienen su intimad al agua del rio, mientras que las que dan a este, la privacidad viene propiciada por la vegetación.

La jerarquía de zonificación por orientación es exactamente la misma del New College. Junto al río, en la zona de entrada, se sitúa la vivienda del rector conteniendo la misma un jardín privado, extraída esta tradición de los master lodge anteriormente descritos.

Aparecen como elementos aislados la sala de música y dos pistas de squash.

Los porches cubiertos situados bajo los bloques residenciales conectan residencial con la biblioteca y el salón de actos. Son circulaciones producidas en la dirección norte-sur al igual que ocurre en el New College.

Entre ellos, en la zona media del conjunto, otros cuatro bloques contienen el resto del programa: salas comunes, cocina y oficinas, el comedor, la biblioteca y la sala de actos. Estas zonas se sitúan en la zona norte. Estas zonas de carácter común tienen una envolvente diferente a las zonas privadas. Están conformadas a base de estructura de hormigón y muros de ladrillo y mampostería, contrastando con el vidrio y acero de las zonas habitacionales.

La cocina está ubicada junto a las zonas de ocio de los estudiantes, posee un acceso rodado desde el exterior. En este mismo bloque, en la parte oeste se encuentran las oficinas.

Las áreas de ocio de los estudiantes junior y senior se encuentran separadas. Cada una dispone de un jardín privado, salas de reuniones y un área de debate que, en el caso de la junior, está hundida respecto al nivel del suelo y está presidida por una chimenea.

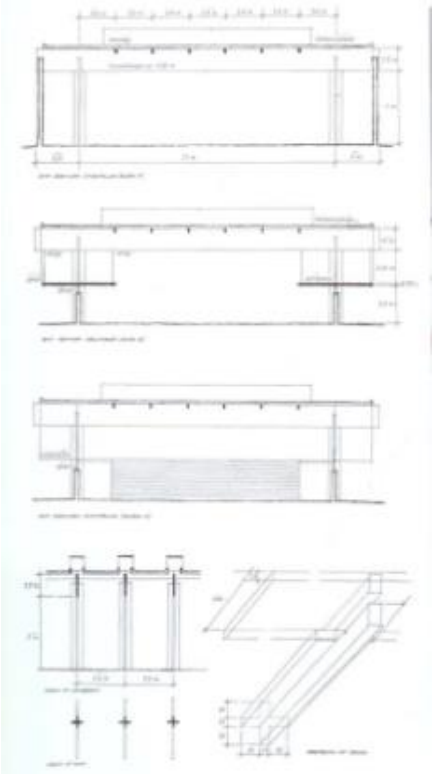

Imagen 225: Bocetos estructurales del comedor 

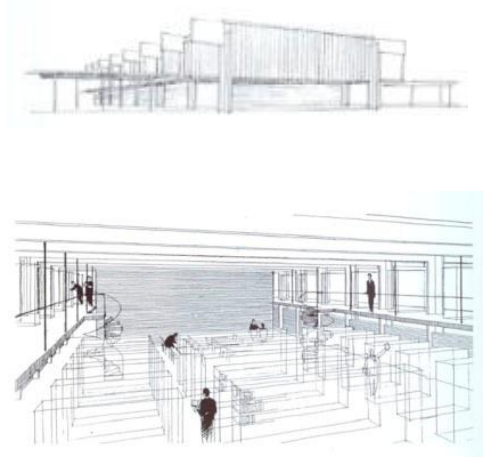

Imagen 226: Boceto del comedor

Imagen 227: Boceto de la biblioteca
De estas estancias se accede directamente al comedor. Entre el volumen del comedor y el de la biblioteca se encuentra la plaza central descubierta.

El comedor crea un espacio, conseguido a través la iluminación y la altura de la estancia. La pericia del autor en este espacio, se muestra en la resolución mediante parámetros arquitectónicos, que reflejan el movimiento moderno, los siglos de tradición que se perciben y se dejan leer con muy pocos elementos. Esta estancia está terminada con tapices de Tom Phillips ${ }^{146}$, que están grafiados con temas de Santa Catalina de Alejandría. Todos los espacios poseen muebles diseñados por Jacobsen, la mayoría fueron exclusivamente para este college y son de madera. Uno de los ejemplos más significativos son las mesas y los bancos del comedor de los estudiantes y las sillas del comedor de los profesores. Estaban realizadas en contrachapado moldeado, con un respaldo muy alto, tal vez, Jacobsen quería identificar la gran altura del salón con el respaldo. Como se ha visto en los ejemplos de colleges anteriores, a estas estancias se les dotaba de una mayor altura para resaltar su magnificencia.

En otra plaza adyacente se encuentra la biblioteca y la sala de actos. En ella se erige la torre del campanario.

La biblioteca tiene claras señas de identidad de su autor, creando un ambiente de estudio a través de la conjugación de luz, materiales y mobiliario.

En 1964, Jacobsen recibe el encargo de unos equipamientos deportivos en la zona norte del college. El proyecto, que no llegó a construirse, contaba con un área de deportes, un aparcamiento, un pabellón de deportes cubierto, un edificio para maquinaria de mantenimiento de las zonas ajardinadas, otra construcción para almacenaje de embarcaciones, una zona para basuras y dos viviendas para uso del personal.

A los edificios originales se les ha ido sumando añadidos. El colegio cuenta ahora con tres bloques de alojamiento para los estudiantes a parte de los dos bloques lineales.

Saint Catherine sintetiza muchos aspectos de la obra de Jacobsen y marca un punto álgido en lo que se refiere a la integración del edificio con el jardín formando un conjunto unificado.

Este icono moderno, "una pieza perfecta de arquitectura" en palabras de Nikolaus Pevsner, es una síntesis perfecta de neoclasicismo nórdico y el más estricto estilo moderno. 
Este college refleja el don de saber condensar la esencia de arquitecturas pasadas y volver a expresar las mismas emociones con lenguajes de su tiempo. 

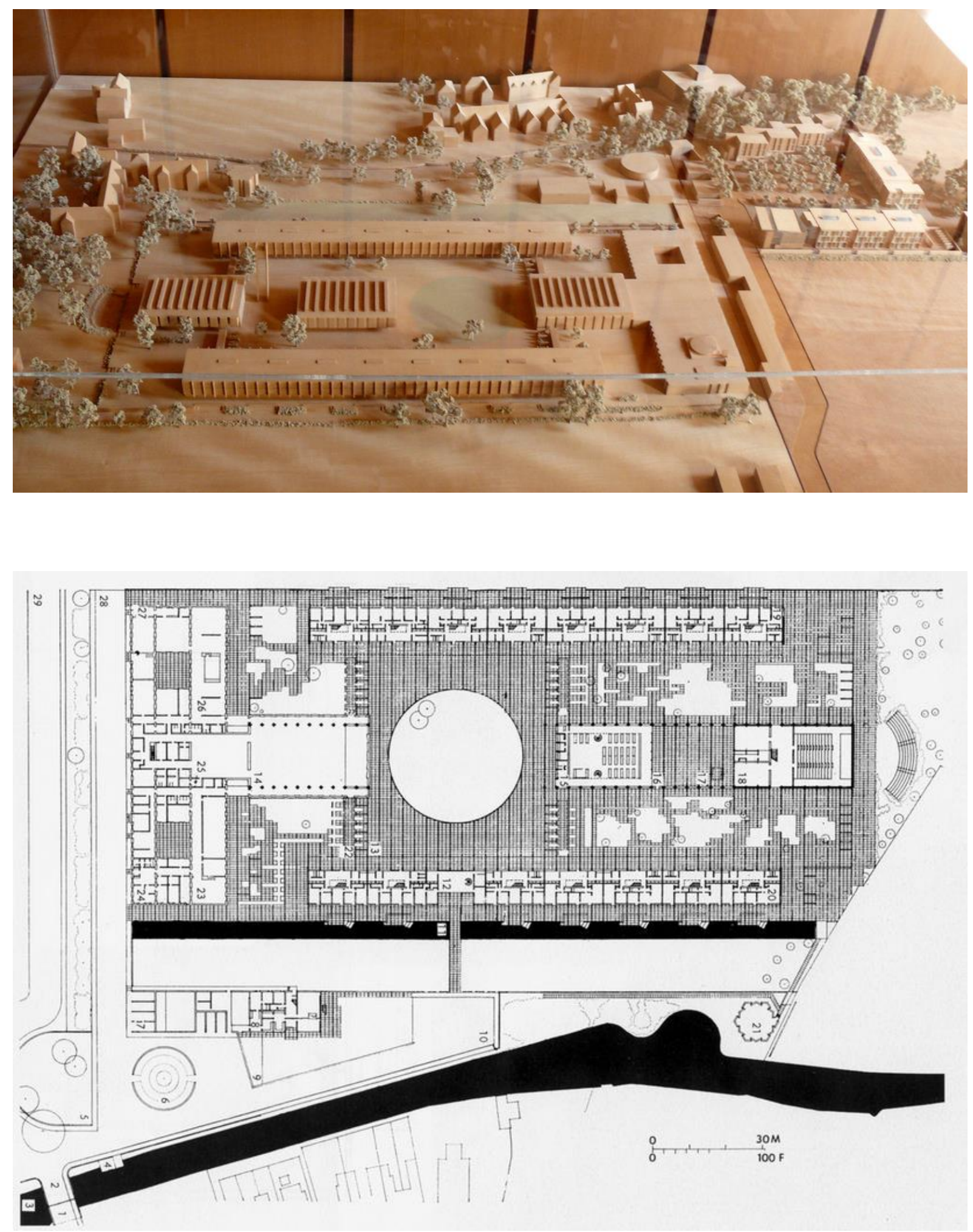

Imagen 228: Maqueta del Saint Catherine College

Imagen 229: Planta de conjunto. 

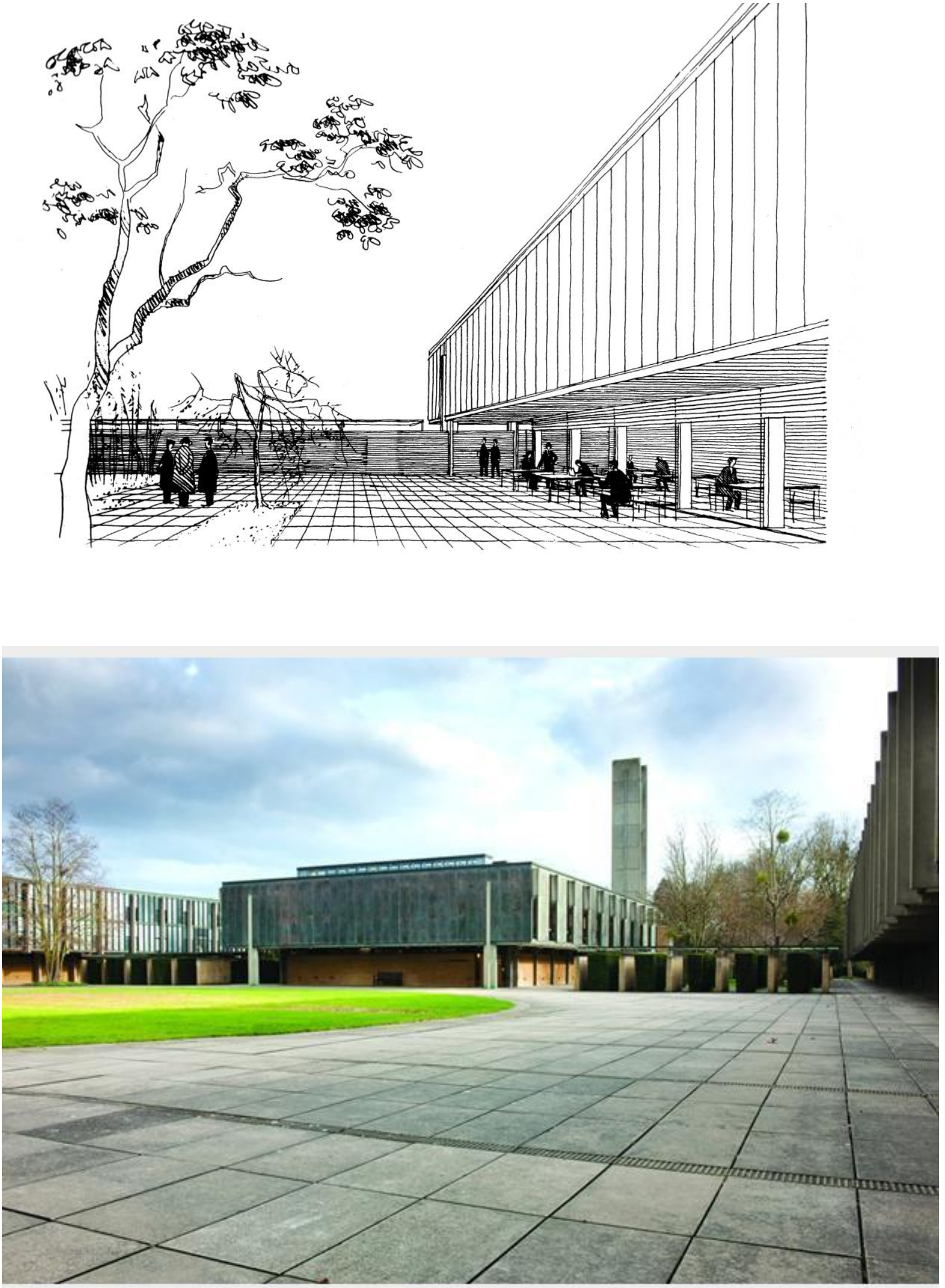

Imagen 230: Boceto del AJ Building volcando a la parte interior del recinto.

Imagen 231: Vista de la biblioteca desde el patio principal, de la zona norte a la sur. 


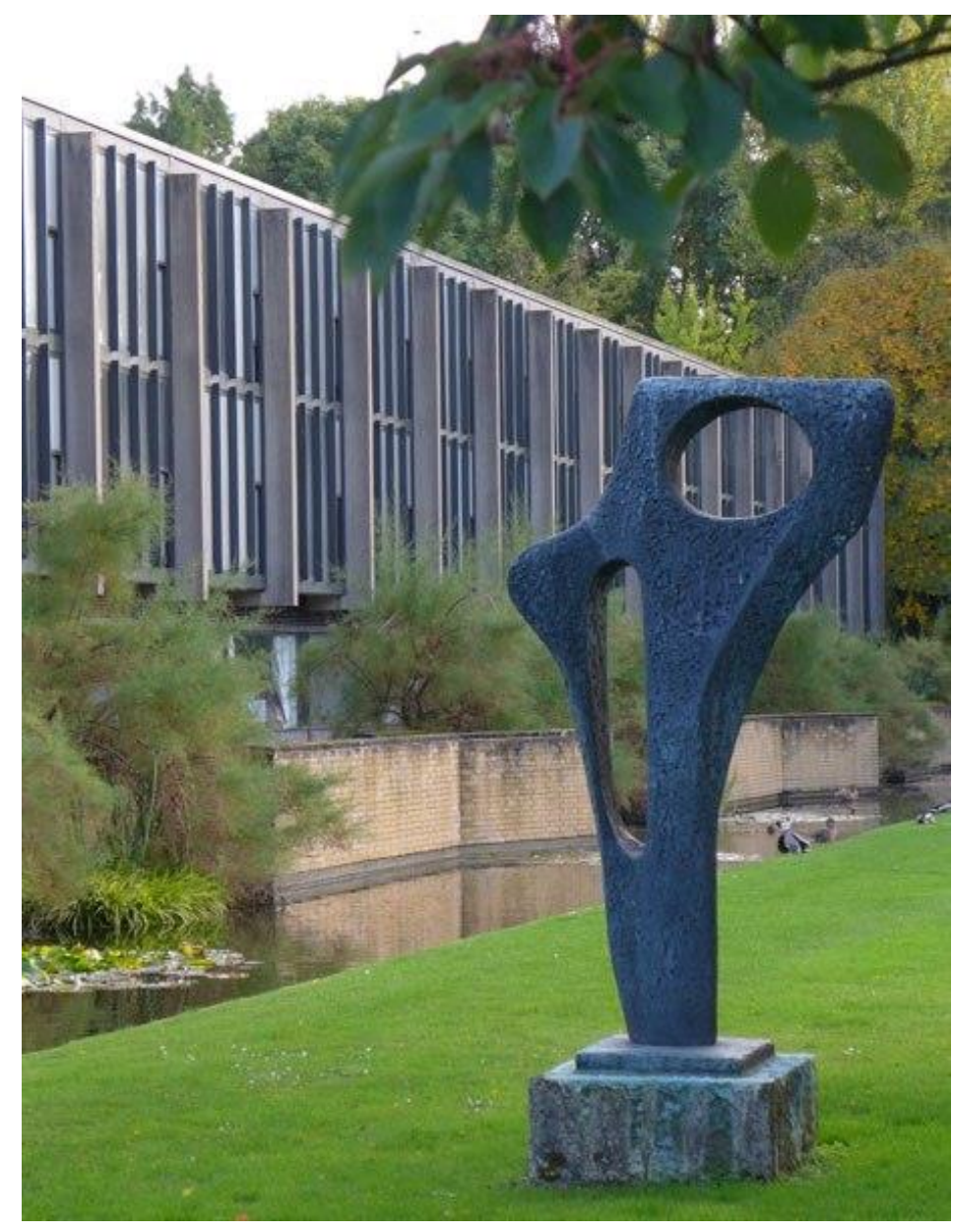

Imagen 232: Escultura de Barbara Hepworth situada a la entrada del college, simboliza la incorporación de la mujer a los estudios superiores.

Imagen 233: Vista de la biblioteca desde las

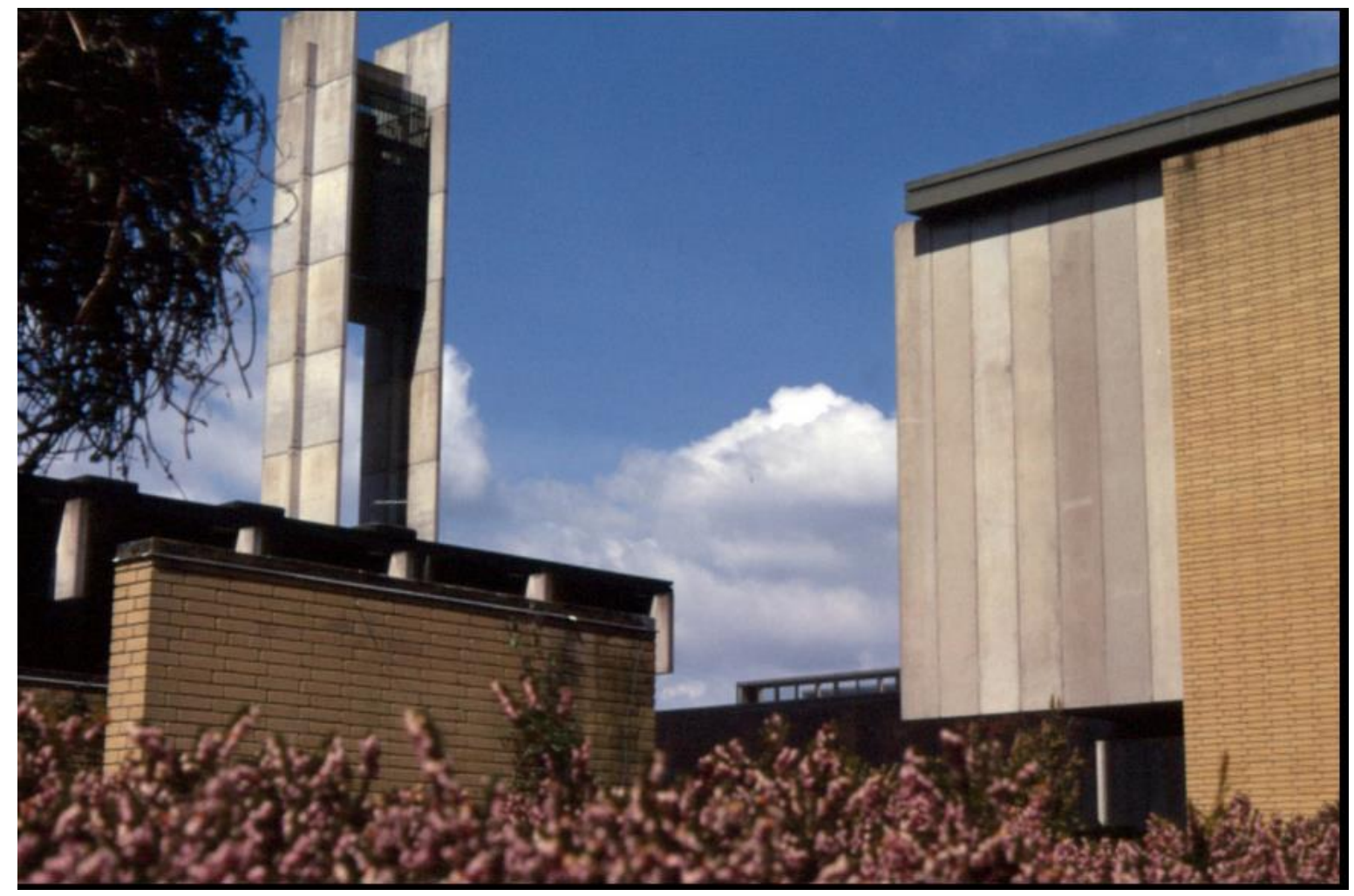



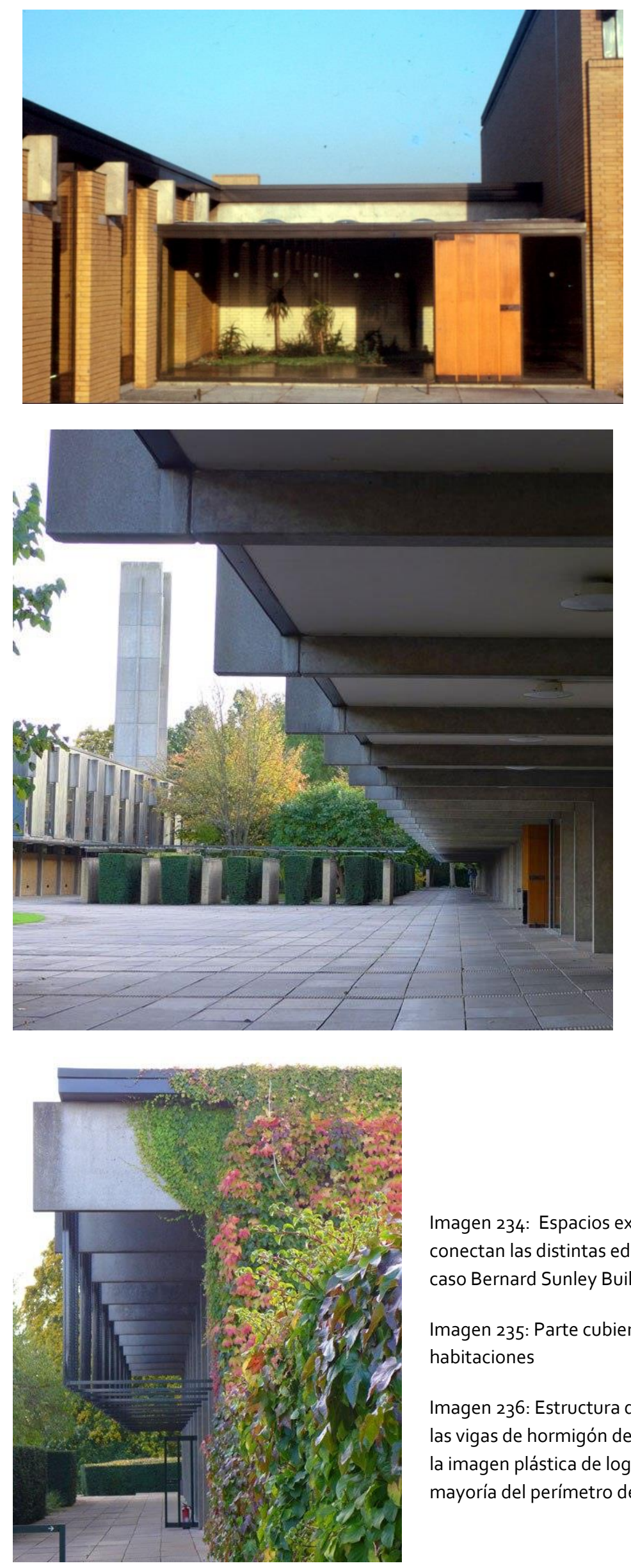

Imagen 234: Espacios exteriores cubiertos que conectan las distintas edificaciones, en este caso Bernard Sunley Building y biblioteca.

Imagen 235: Parte cubierta del bloque de habitaciones

Imagen 236: Estructura de acero colgada de de las vigas de hormigón del comedor, se consigue la imagen plástica de logia, presente en la mayoría del perímetro del college. 

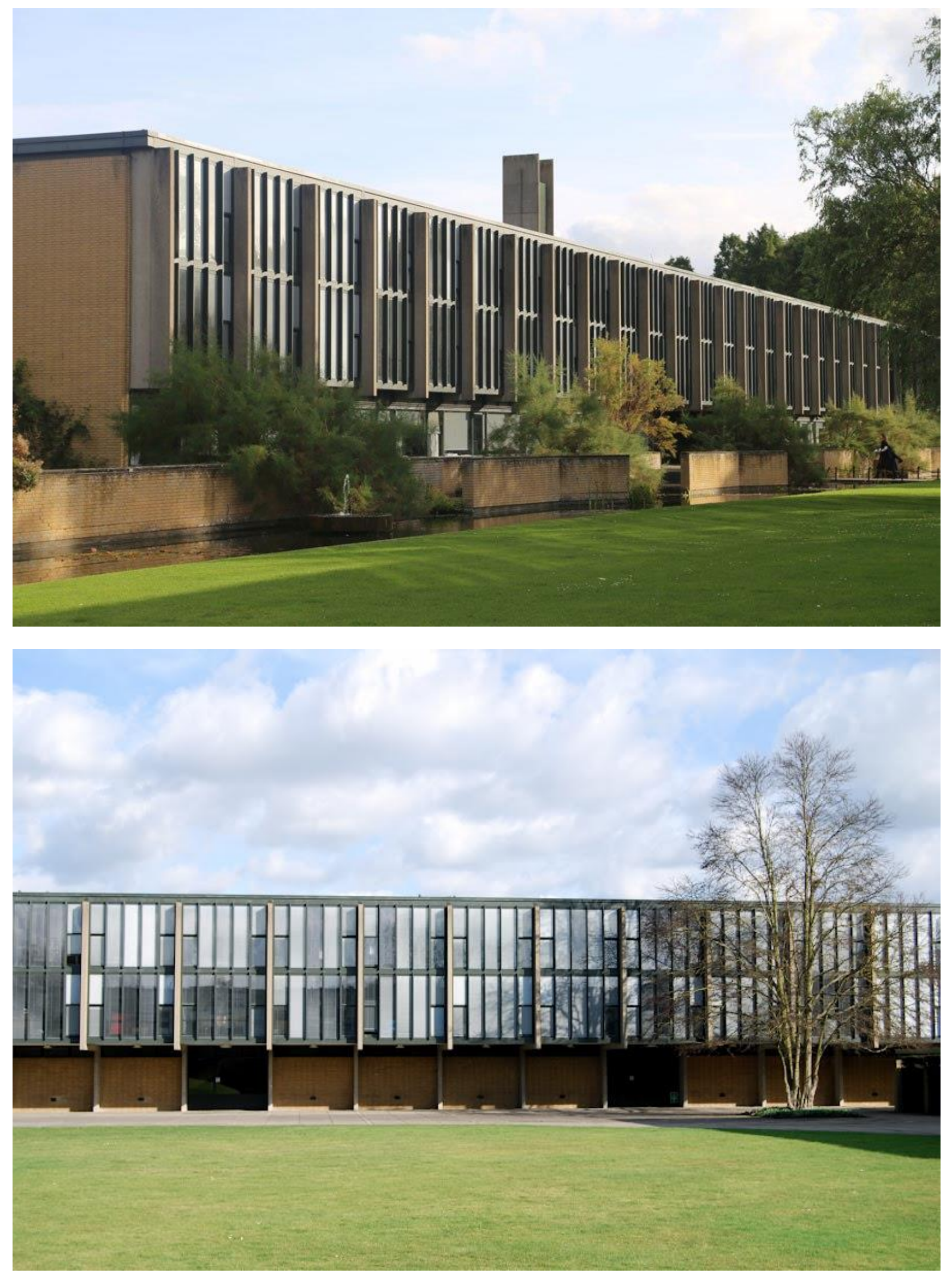

Imágenes 237 y 238: Vista Exterior del bloque de habitaciones. 

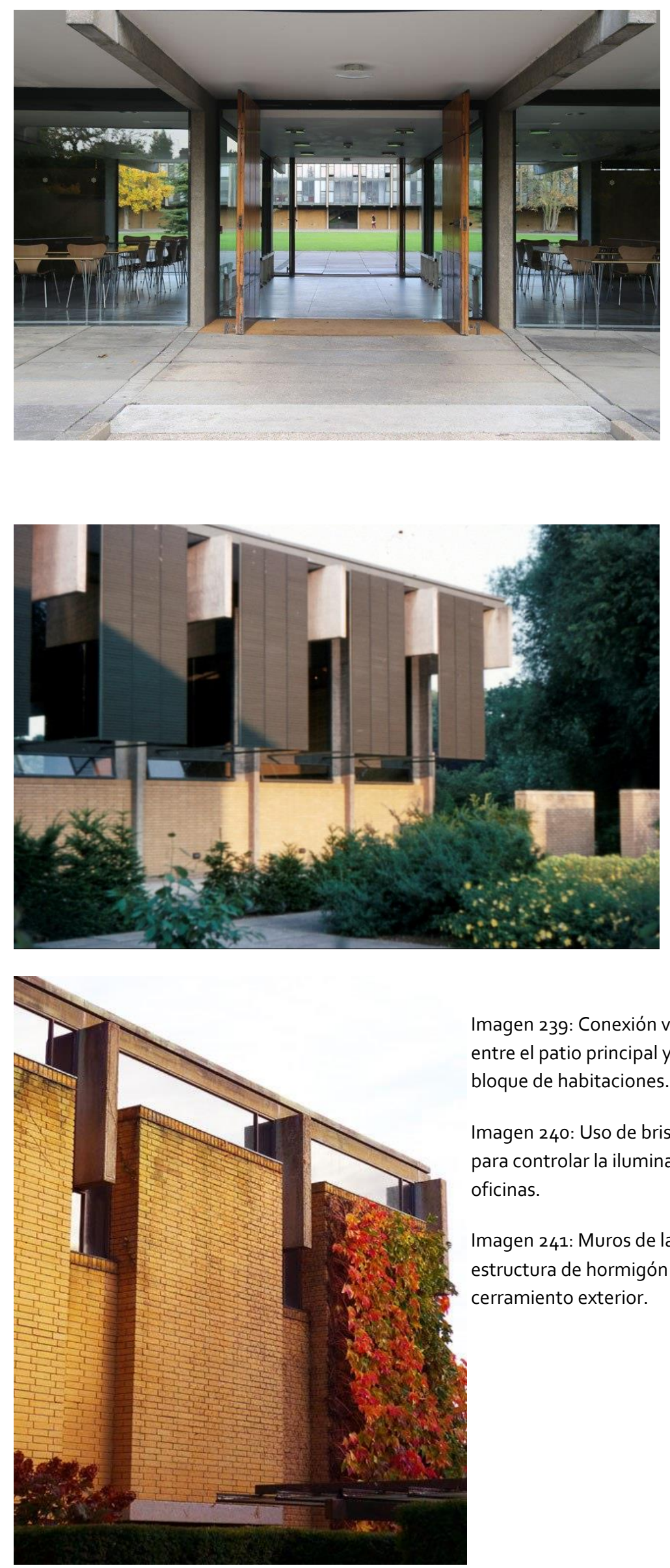

Imagen 239: Conexión visual y de circulaciones entre el patio principal y los exteriores, entrada al bloque de habitaciones.

Imagen 240: Uso de brise-soleil como elemento para controlar la iluminación en el edificio de oficinas.

Imagen 241: Muros de ladrillo, combinados con la estructura de hormigón visto y el crista, l en el cerramiento exterior. 

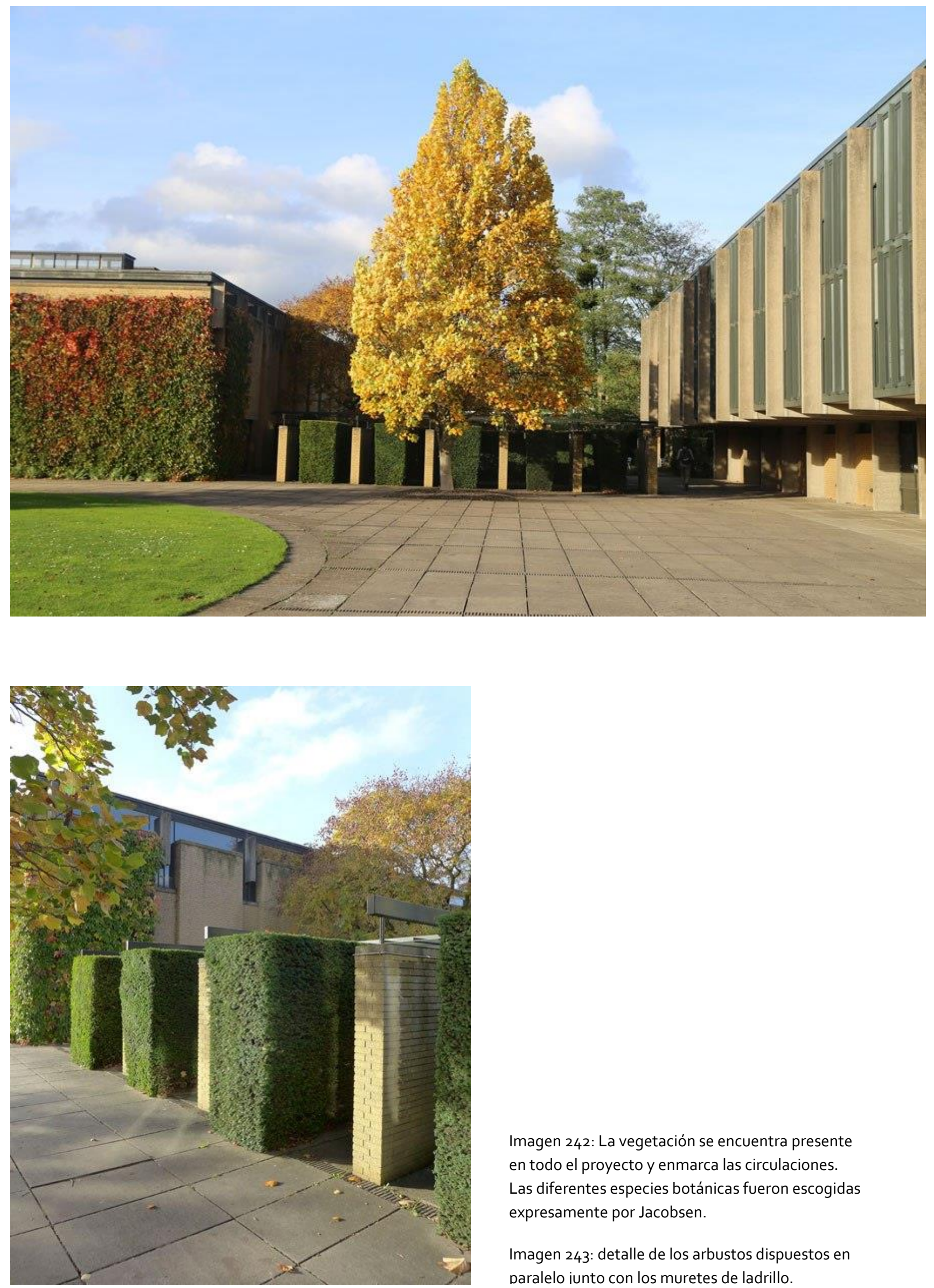

Imagen 242: La vegetación se encuentra presente en todo el proyecto y enmarca las circulaciones.

Las diferentes especies botánicas fueron escogidas expresamente por Jacobsen.

Imagen 243: detalle de los arbustos dispuestos en paralelo iunto con los muretes de ladrillo. 


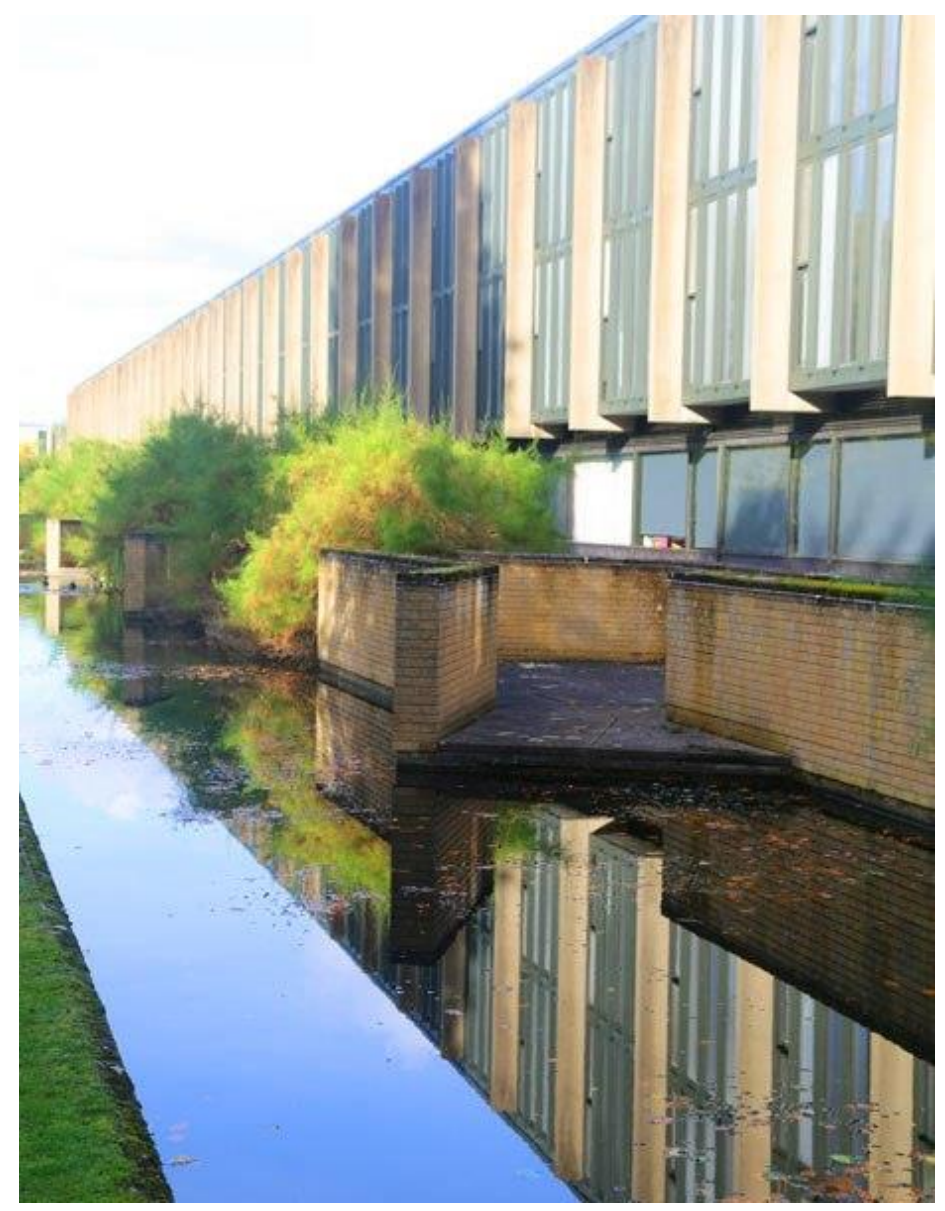

Imagen 244: Espacios exteriores del bloque oeste de habitaciones que vuelca a este "río artificial".

Imagen 245: Vista exterior de la biblioteca, donde se aprecia el recurso moderno de elevar la planta sobre pilotis.

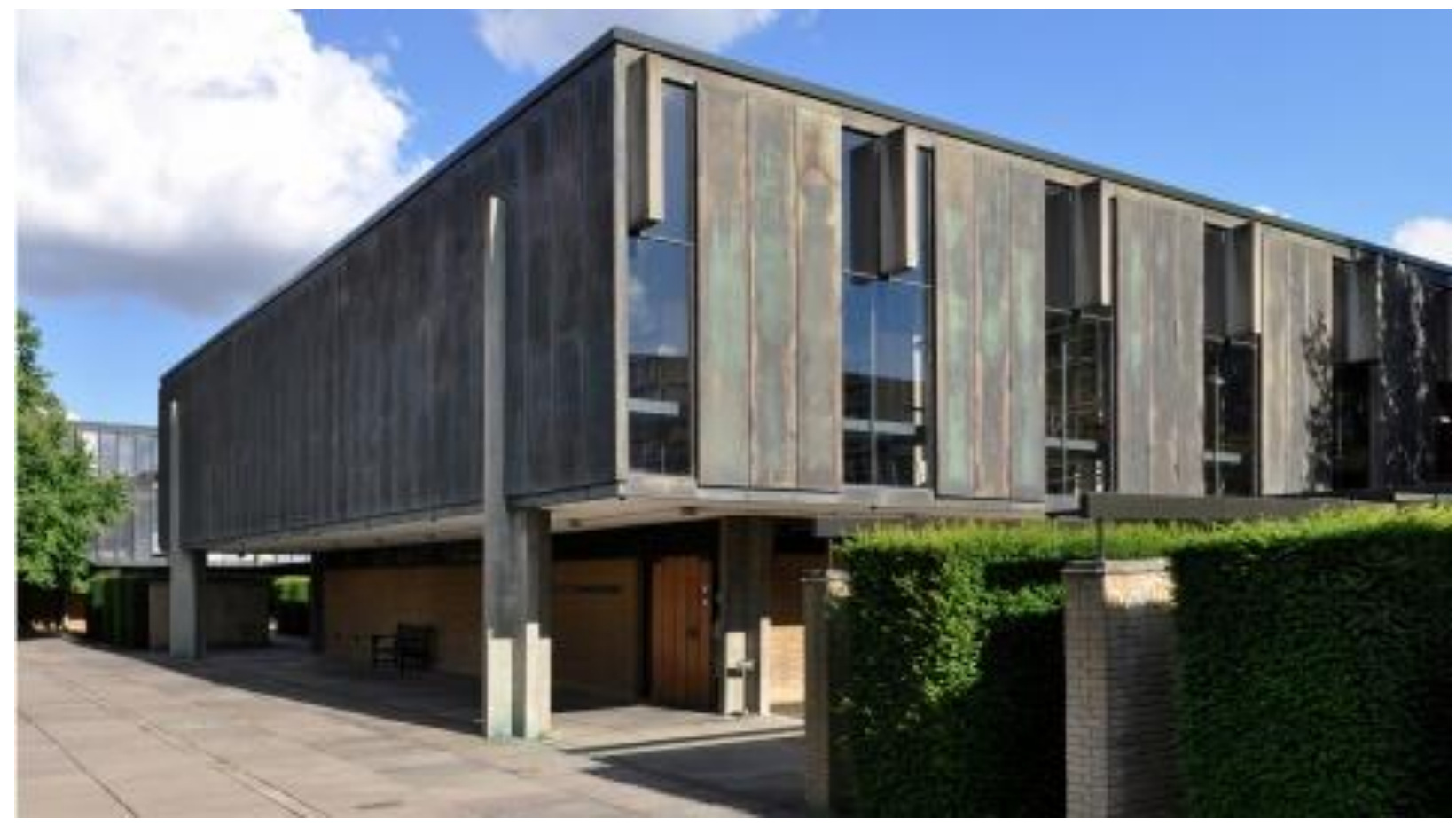



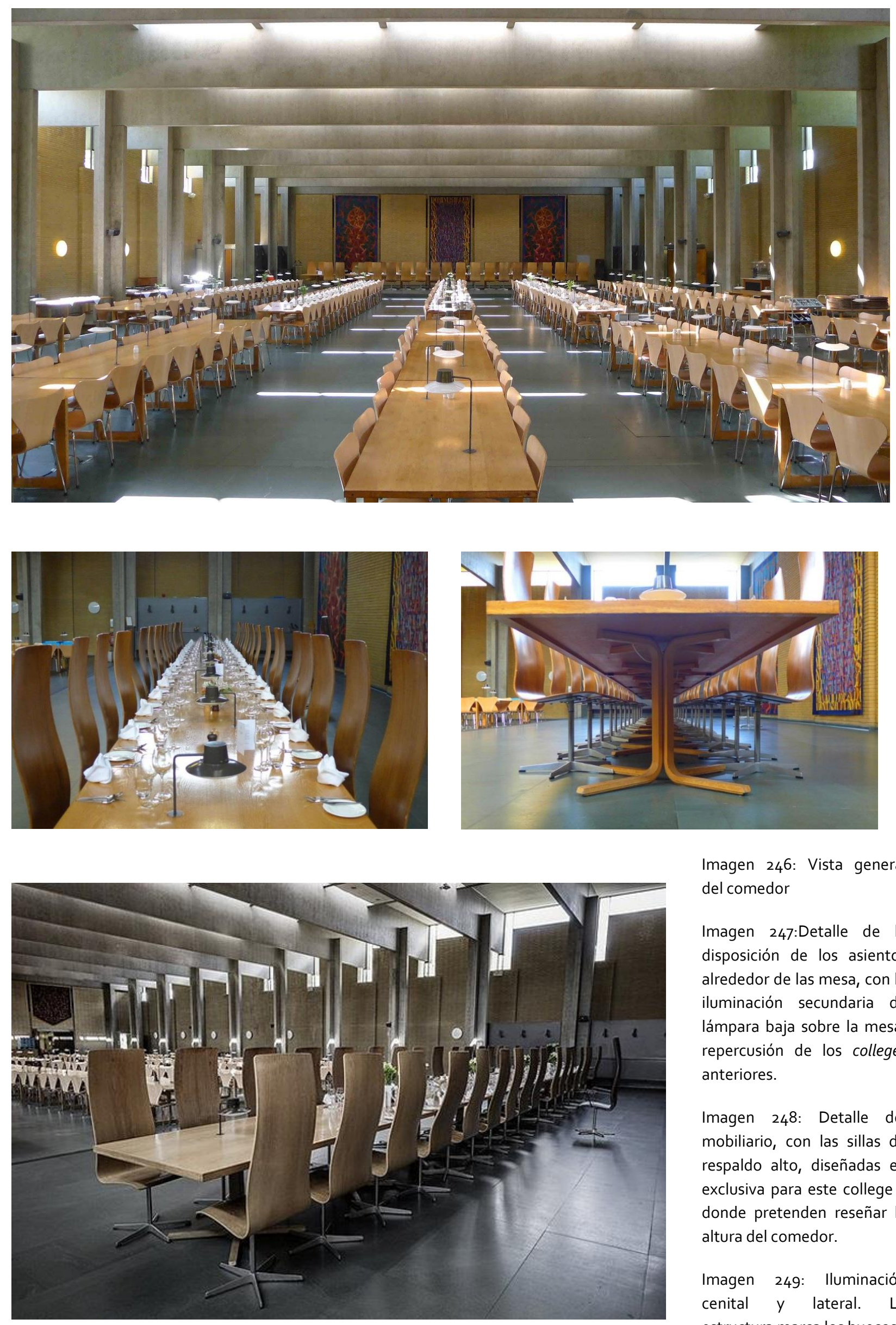

Imagen 246: Vista general del comedor

Imagen 247:Detalle de la disposición de los asientos alrededor de las mesa, con la iluminación secundaria de lámpara baja sobre la mesa, repercusión de los colleges anteriores.

Imagen 248: Detalle del mobiliario, con las sillas de respaldo alto, diseñadas en exclusiva para este college y donde pretenden reseñar la altura del comedor.

Imagen 249: Iluminación cenital y lateral. La estructura marca los huecos. 


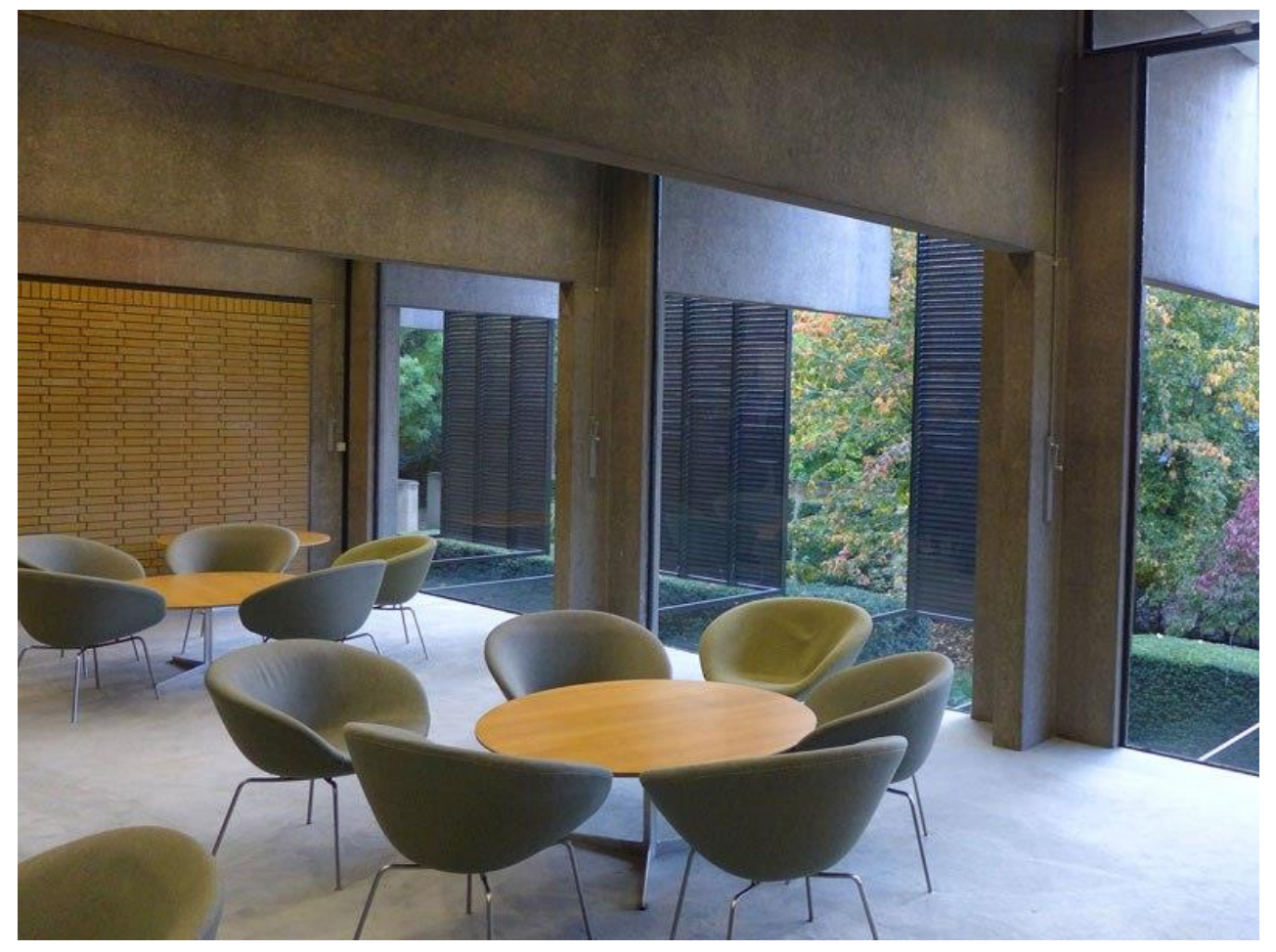

Imagen 250: Salas de reuniones en espacios comunes.

Imagen 251: Sala principal del bloque de oficinas.

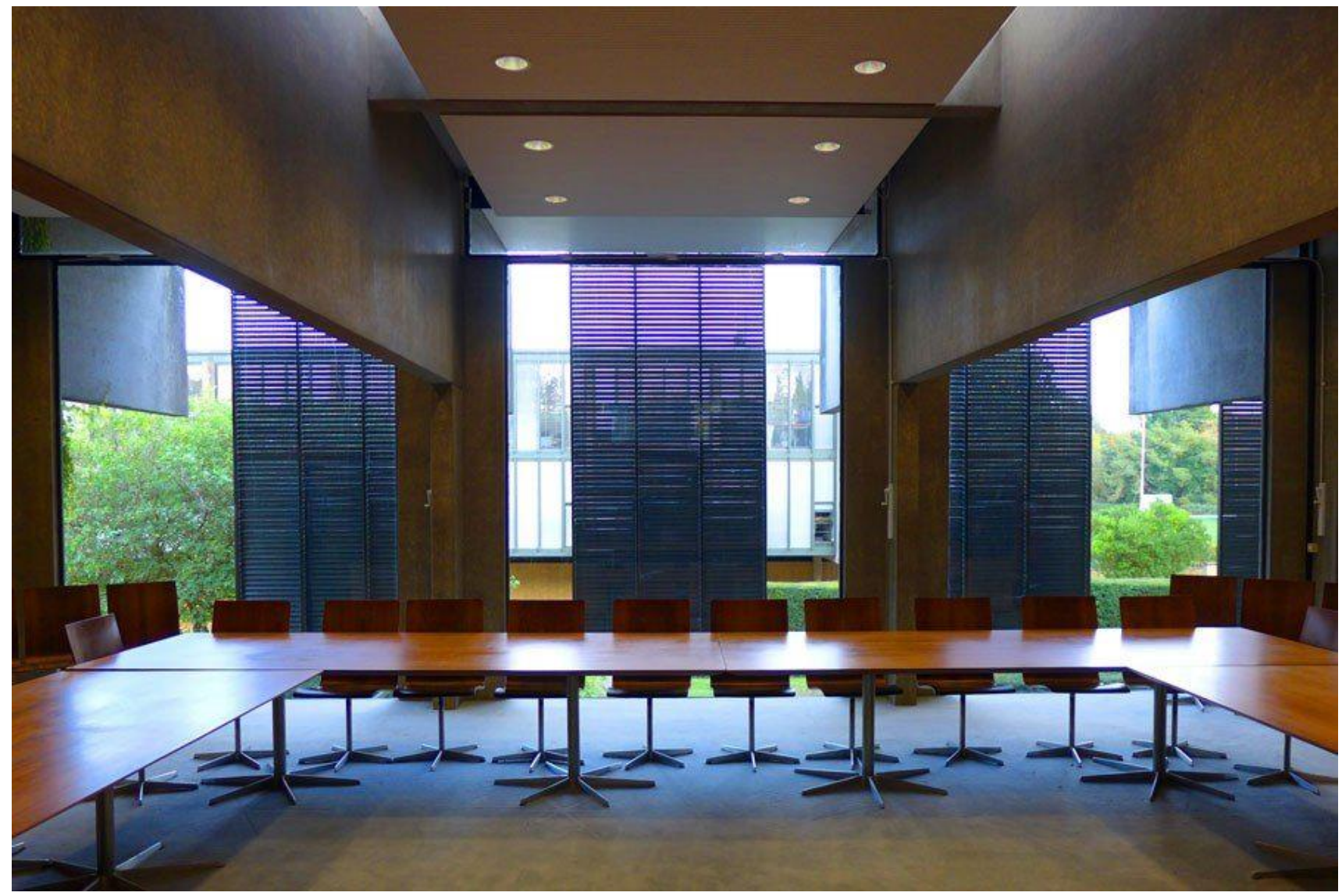



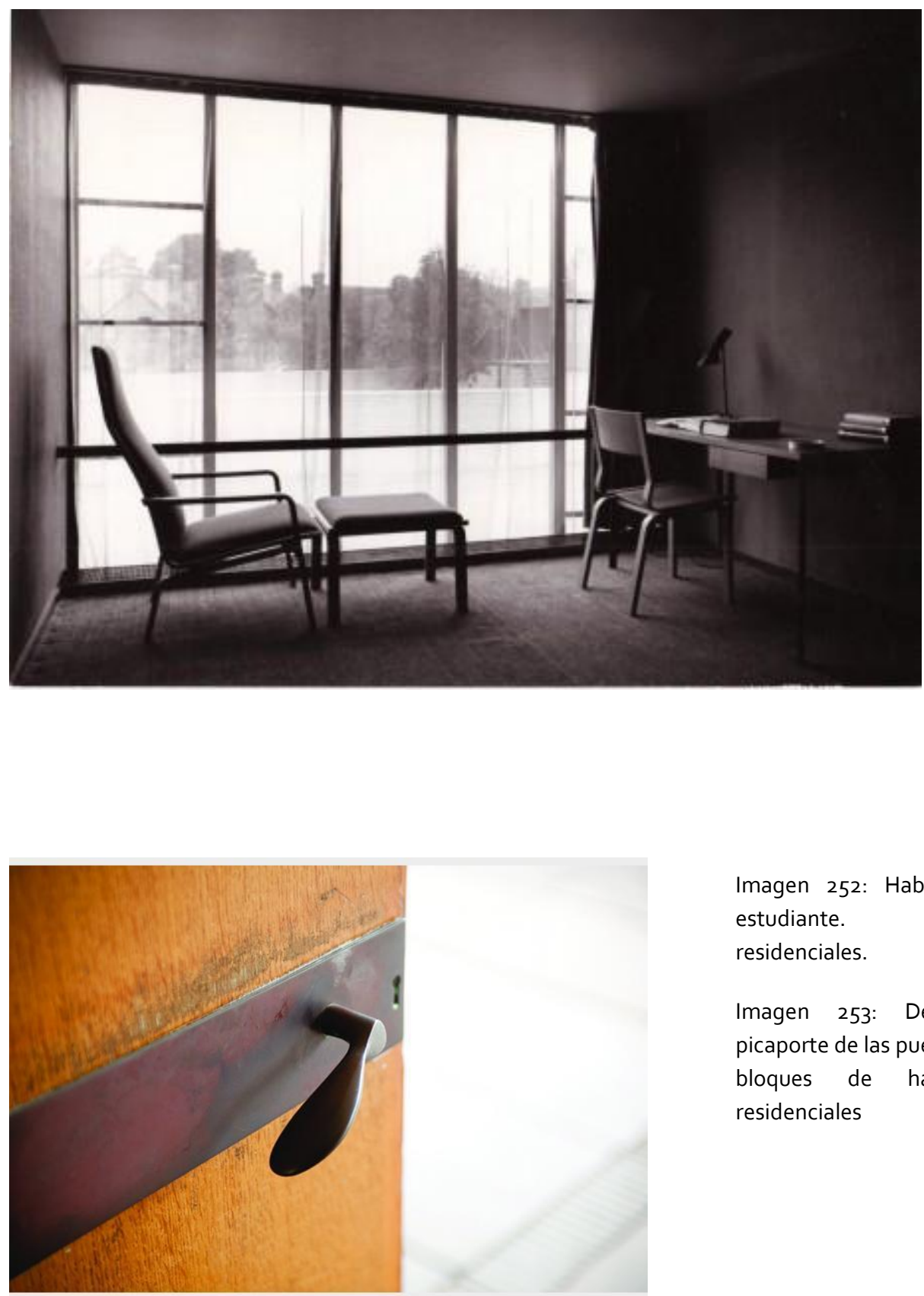

Imagen 252: Habitación de estudiante. Bloques residenciales.

Imagen 253: Detalle del picaporte de las puertas de los bloques de habitaciones residenciales 


\section{FLOREY BUILDING DE JAMES STIRLING}

\section{Mirando hacia Estados Unidos (1971)}

Terminado en 1971, este edificio se puede considerar como una de las construcciones modernas de la posguerra, junto con los dos anteriormente estudiados. Además sus instalaciones están dotadas de un diseño energético ejemplar.

Como el propio Stirling explica, es una nueva residencia universitaria "planeada alrededor de un patio", cuyas dimensiones son treinta y siete metros de ancho por 26 de profundidad. A este espacio vuelcan a través de una gran superficie acristalada las habitaciones, teniendo vistas al rio. Se abre a la naturaleza, esta herencia estadounidense se trata con profundidad en el próximo capítulo.

La construcción se concibe como una " $\mathrm{U}$ " compuesta por cinco cuerpos rectos que se articulan a cuarenta y cinco grados. Uno de ellos se duplica en longitud, generando la entrada principal y núcleo de circulaciones verticales.

Todas las habitaciones residenciales están abiertas al patio, volviendo a la postura de los colleges medievales, con la salvedad de que aquí no se termina de conformar el quad, sino que queda abierto en forma de media luna. En la parte exterior discurre un pasillo a través del cual se accede a las habitaciones y servicios. No hay habitaciones de los estudiantes a nivel de suelo y existe un claustro, o más bien una logia, que se desarrolla alrededor del patio, denominador común de todos los colleges originarios. Un rasgo característico recibido del pasado es que la entrada se encuentra en el lado sur y está enmarcada por dos escaleras-torres.

Los desniveles interiores en torno a este patio retroceden en cada nivel de piso y el espacio dentro del mismo será, quizás, más parecido a un anfiteatro que a un quadrangle de college.

Las hileras de árboles a lo largo de la orilla del rio son de quince a veinte metros de altura, casi tan altas como el propio edificio $y$, en cierto modo harán el papel de cuarta pared dotando al patio de una sensación de recogimiento.

La estructura es de hormigón armado, siendo parte de la misma vista en planta baja, ya que dicha planta se encuentra elevada, al igual que sucede en el Fen Court, sobre pilotis. Se ven unos pies de hormigón, denominados A- frame, que nacen de la entreplanta primera $y$ segunda y mueren en el nivel cero. La parte opaca de las distintas fachadas se encuentra revestida con baldosas de terracota, este envoltorio se conjuga con pequeñas superficies de acristalamiento 
en la parte exterior, mientras que en la parte interior el patio está totalmente formado por un acristalamiento de suelo a techo que se enfrenta a la orientación norte con vistas hacia el rio Cherwell.

El edificio cuenta un total de setenta y seis habitaciones. Siendo dobles las de las primeras tres plantas e individuales las de la cuarta.

Las habitaciones se distribuyen en cinco plantas de las que, las dos más altas fueron proyectadas como un solo nivel de habitacionesestudio, para un total de dieciocho estudiantes. La doble altura de estos estudios permite dormir en el nivel superior. A través de la vidirera del piso alto, situada en la cara externa del edificio, el sol penetrará en ambos niveles de los estudios, y más allá, en el interior del patio.

La pared de la entrada es un armario continuo y compacto conteniendo un lavabo en cada habitación, además de estanterías para libros, etc. La parte acristalada, mirando hacia el patio, tiene persianas enrollables fijadas de suelo a techo, otorgando a los ocupantes total privacidad cuando están completamente desenrolladas y permitiendo todas las posibles posiciones de apertura.

El edificio cuenta un total de setenta y seis habitaciones. Siendo dobles las de las primeras tres plantas e individuales las de la cuarta.

En los pisos primero, segundo, tercero y cuarto las tres escaleras están conectadas a los corredores interiores que dan acceso a todas las habitaciones. En la zona opuesta de estos corredores están situados los servicios, tales como duchas, baños, lavabos y armarios. Existen cuatro aseos, dos baños y dos duchas en cada piso.

En los quiebros aparecen unas zonas pensadas como galerías o descansillos del pasillo. Los extremos de las habitaciones de servicio que flanquean estas zonas proporcionan pequeñas estancias versátiles: existen pequeñas cafeterías y lavanderías. Estas galerías tienen una ventana corrida que se dispone a lo largo de la pared exterior, permitiendo que el sol penetre en el corredor. Las ventanas suministrarán también una vista para los estudiantes que se encuentren en estas áreas de charla-café, sobre la fachada sur y la entrada principal del edificio. La circulación por los corredores promueve la relación de los que se encuentran en ellas. Existen cuatro en cada planta, situadas a intervalos de catorce metros, en los giros. Las líneas visuales están restringidas por la forma que la planta 
impone a los corredores y este hecho impedirá las largas perspectivas sobre ellos.

En la entrada principal, en el lado sur, se encuentra la portería y abre directamente sobre el claustro. Junto a ella están el ascensor y la escalera principal. Estas torres de circulación vertical destacan del edificio y se encuentran separadas de la estructura principal, pudiendo reflejar una clara repercusión de la arquitectura de Le Corbusier y de Oscar Niemeyer,

La forma vertical adoptada para las torres indica y simboliza la entrada al edificio, como de forma similar ocurría en el King's College de Cambridge; en las torres de la entrada principal del Trinity College deCambridge que conducen directamente al Great Court; o en las dos medias torres, situadas también al sur, que marcan el acceso del Christ Church College de Oxford.

En el extremo del ala este, el claustro termina en una rampa dirigiendo a los usuarios que llegan a pie por la orilla del río. A esta entrada-salida se le requiere dar igual importancia que a la entrada principal, especialmente cuando el camino del río se amplíe y existan otros dos nuevos colleges a ambos lados de éste, en la zona de St Clement.

El comedor tiene ventanas altas en las orientaciones noreste y noroeste, permitiendo vistas hacia afuera y sobre los árboles. Junto al comedor existe un mostrador y una pequeña cocina. El techo del comedor es una terraza pavimentada elevada medio metro aproximadamente sobre el nivel del patio, accesible por amplio tramo de escaleras.

Las zonas comunes se sitúan en planta baja, conteniendo el comedor, y una sala común destinada a actos académicos y reuniones.

La primera peculiaridad a tener en cuenta en la arquitectura de Stirling es su interés por el ser humano, tal vez influenciado por Alvar Aalto, le Corbusier y la tradición moderna del norte de Europa. De lo que Aalto llama "factor humano" Stirling organiza los espacios de acuerdo a percepciones visuales y a las circulaciones de los usuarios, para adecuar los detalles en base a su uso. Un ejemplo viene reflejado en la planificación de las zonas de reunión de los pasillos y en el diseño de las barandillas.Es toda una remodelación anglosajona del college tradicional. 

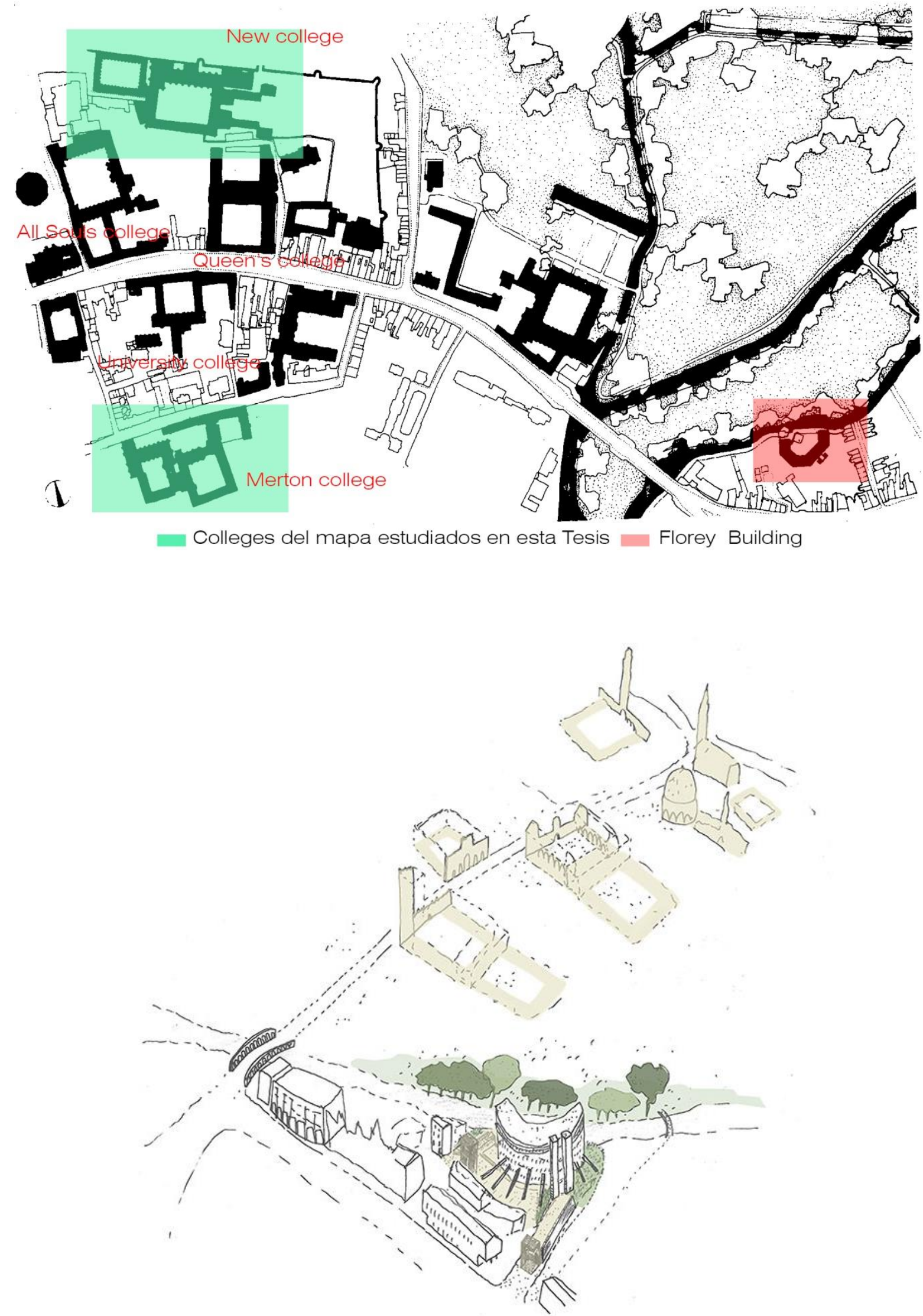

Imagen 2554: Plano de situación del Florey Building.

Imagen 255: Perspectiva del Florey realizada en acuarela por el

despacho de Lynch Arquitectos para un concurso de intervención en el edificio. 

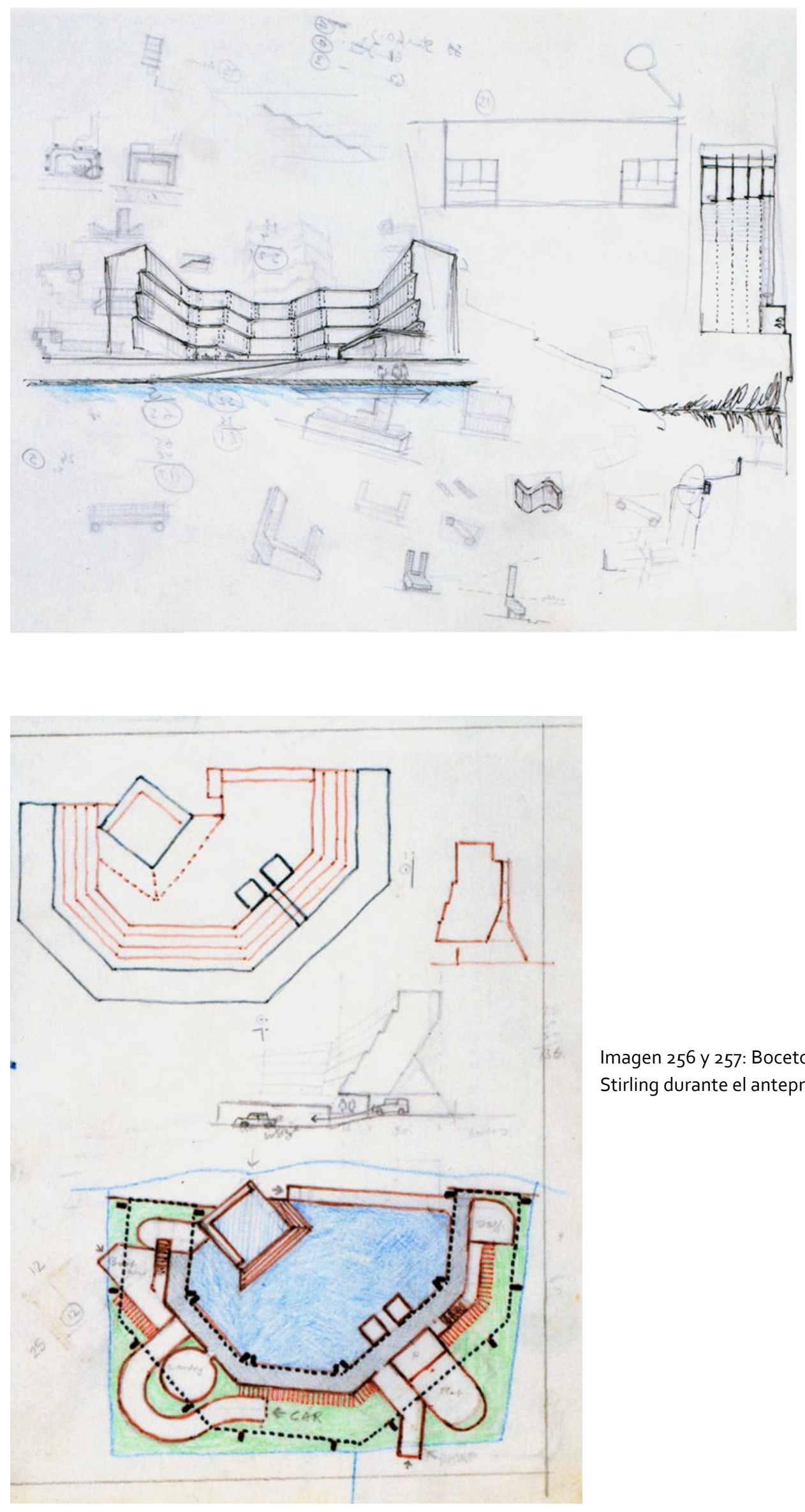

Imagen 256 y 257: Bocetos realizados por Stirling durante el anteproyecto. 

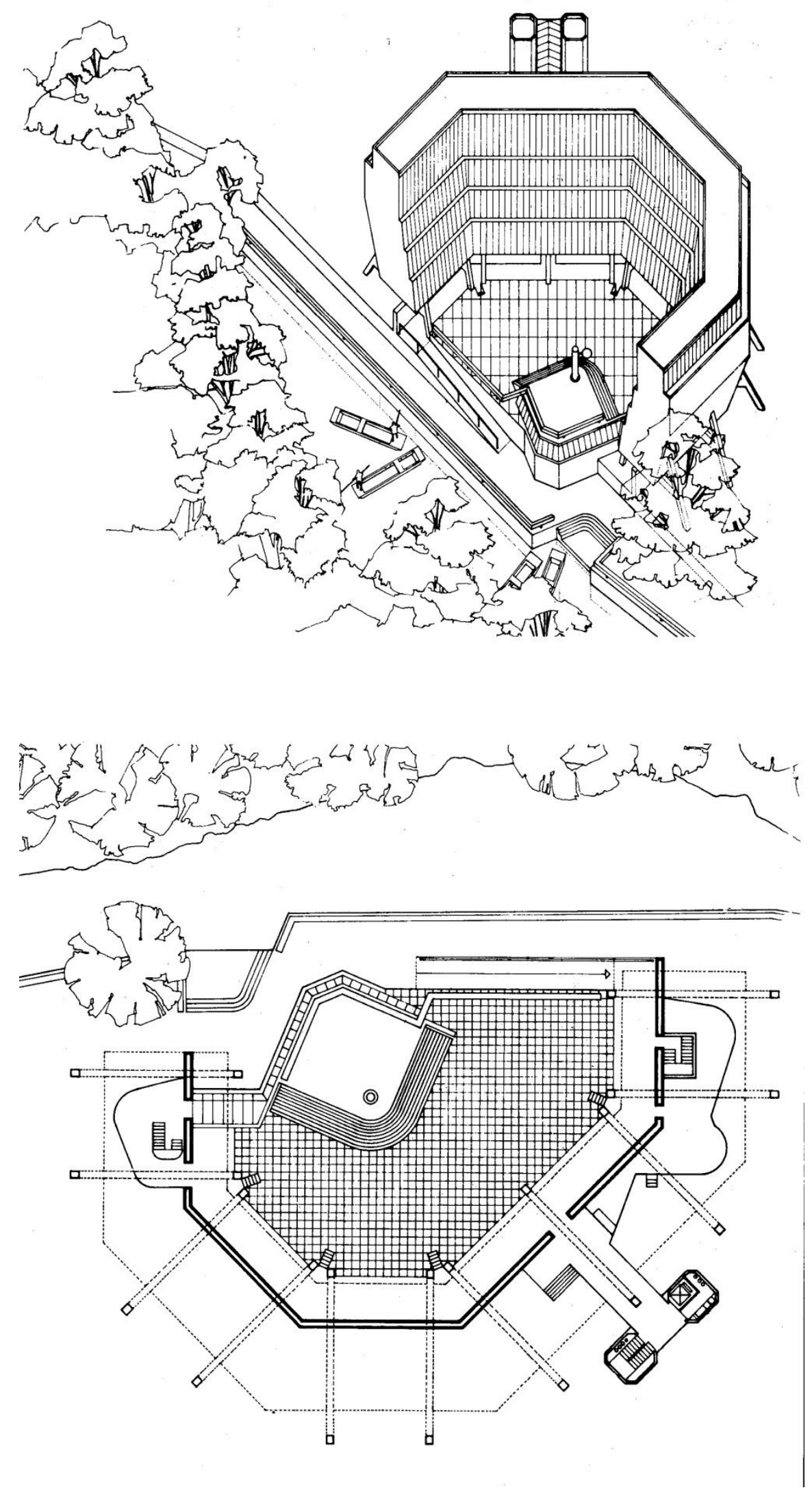

Imagen 258: Bocetos realizados por Stirling durante el anteproyecto.

Imagen 259: Planta de acceso 

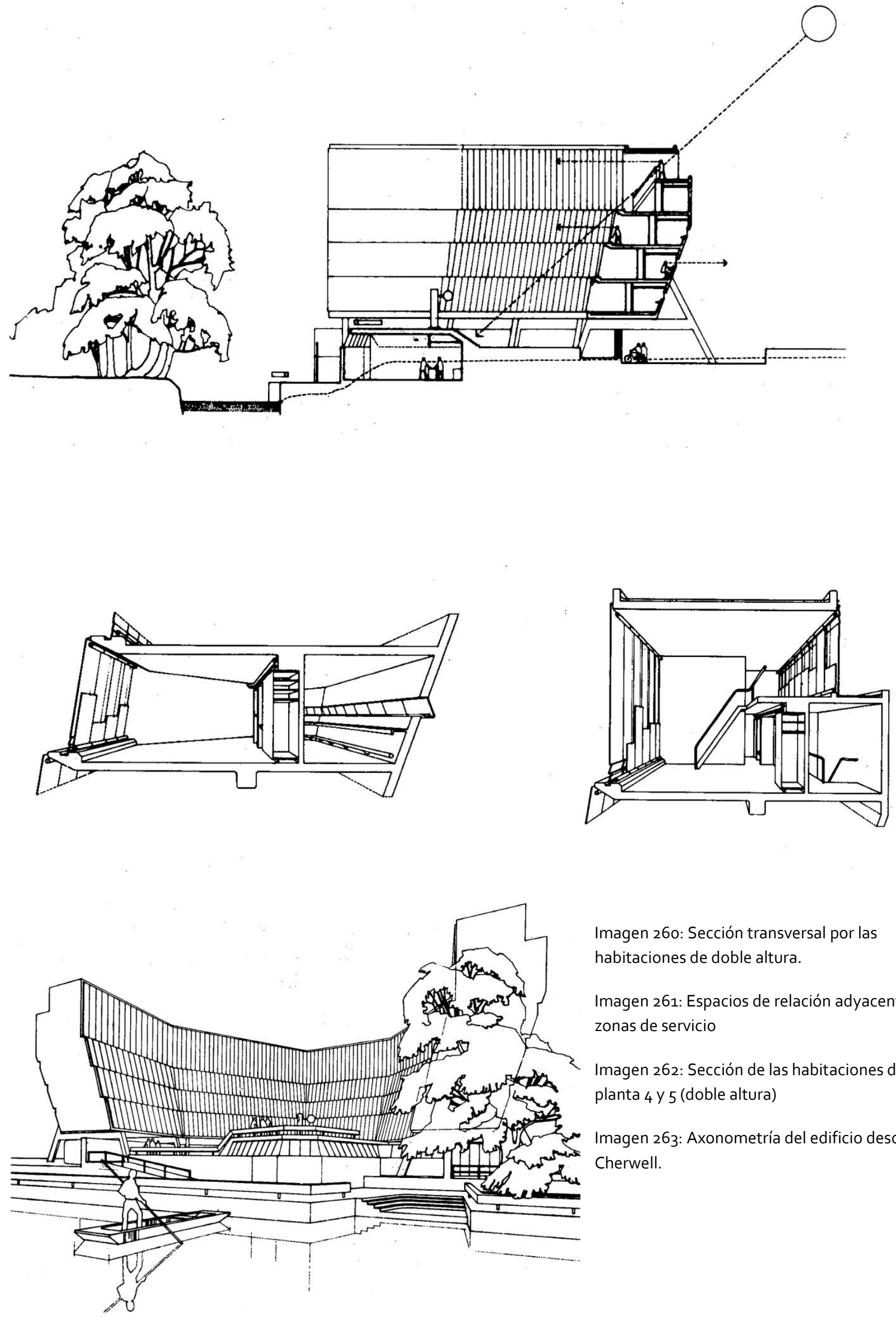

Imagen 260: Sección transversal por las habitaciones de doble altura.

Imagen 261: Espacios de relación adyacentes a las zonas de servicio

Imagen 262: Sección de las habitaciones de la planta 4 y 5 (doble altura)

Imagen 263: Axonometría del edificio desde el Río Cherwell. 


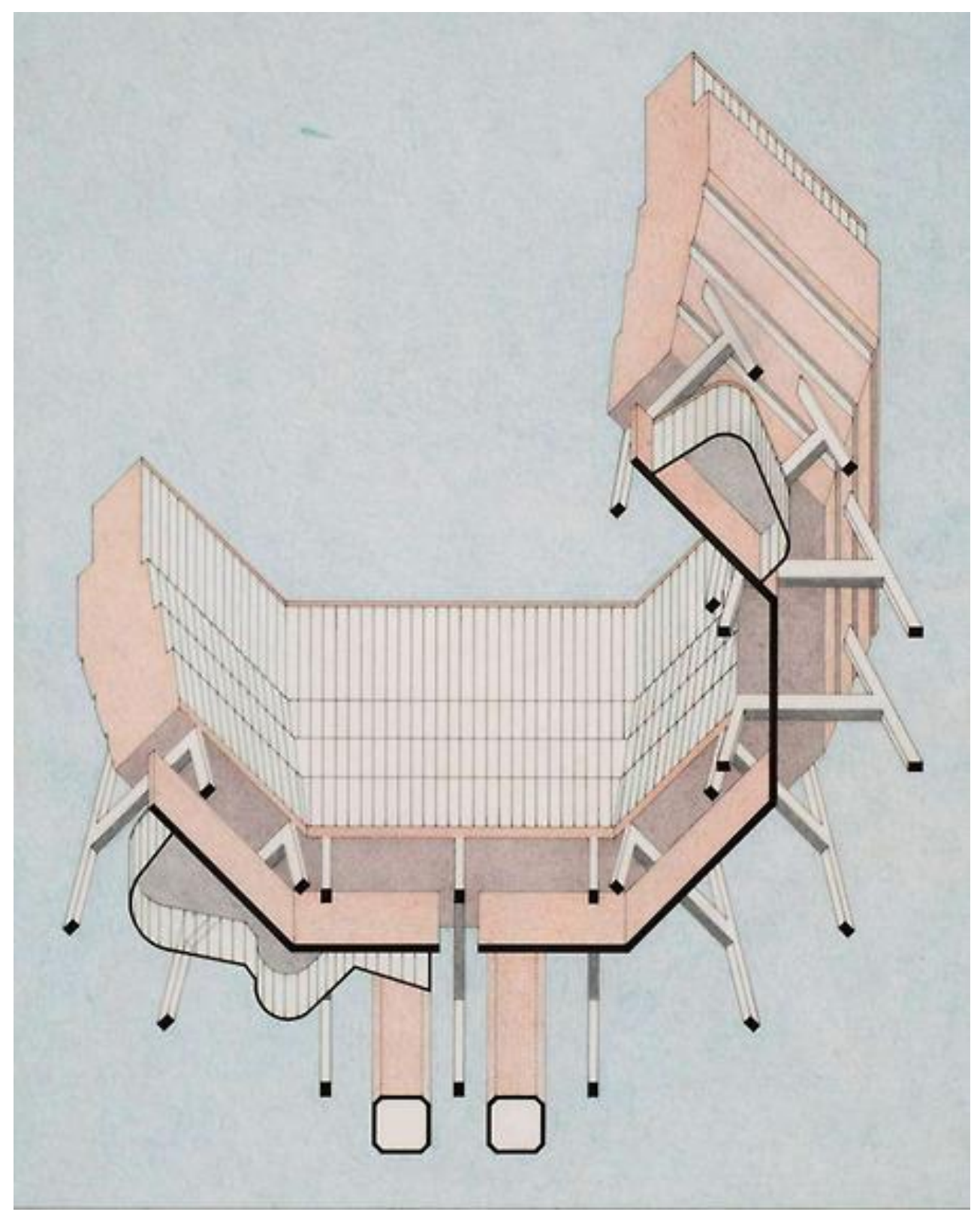

Imagen 264: Perspectiva cenital donde se

muestranla estructura vista de hormigón (A-

Frame) conteniendo a los espacios comunes de planta baja. 


\section{RESIDENCIAS UNIVERSITARIAS EN LA HISTORIA}

\section{BLOQUE II}

ESTADOS UNIDOS. La fragmentación edilicia del modelo inglés.

Cambridge-Universidad de Harvard

Old College y posteriores Harvard Hall's. Germen del tipo estadounidense (16371682-1768)

Casa de William Peyntree. Conformando el quadrangle (1638)

Goffe College. Cerrando el quadrangle (1651)

Colegio Indio. Acotando el campus (1661)

Massachusetts Hall. Restauración y permanencia (1718)

Hollis Hall. Una singular simplicidad (1763)

Stoughton College. Permanencia del estilo colonial (1805)

Charlottesville-Universidad de Virginia

Colegio de William \& Mary (1700)

Pabellones residenciales de la Universidad de Virginia, una intención de heterogeneidad (1819)

Nueva York-Universidad de Columbia y la irrupción de la gran altura.

Hartley Hall (1902)

Livingston, la complementariedad (1905)

Apéndice contemporáneo:

Baker House de Alvar Aalto (1948)

Peabody Terrace, residencia para estudiantes casados de Josep Lluís Sert (1949) 


\section{LA FRAGMENTACIÓN EDILICIA DEL MODELO INGLÉS.}

Inspirado en el college medieval británico, el modelo de residencia universitaria es un aspecto importante en Estados Unidos ya que existe una directriz de destinar a los mismos casi la mitad del total de edificios albergados en los distintos campus.

Aun con este patrón inglés, los primeros promotores no pudieron reproducir los modelos de Oxford y Cambridge, varios colleges agrupados formando una gran universidad. La escasa población, su relativa pobreza, junto con la inmensa extensión de territorio, lo hace imposible. Así, desde un principio se fundaron varias, muchas instituciones a lo largo del territorio, siempre de un tamaño reducido para dar servicio a la población aledaña. El patrón edilicio buscará un sistema cuadrangular, casi siempre dejando abierto uno de sus lados, en la mayoría de los casos.

La línea de investigación de este capítulo comienza con el primer asentamiento universitario para continuar a campus más actuales donde el uso empieza a ampliarse y diversificarse.

La ubicación va a ser determinante, puesto que los asentamientos se van a emplazar en zonas periurbanas, buscando la naturaleza y el entorno tranquilo. El concepto residencial va a adquirir una nueva dimensión en cuanto al posicionamiento con respecto al núcleo urbano de la ciudad donde se asienta.

Las primeras instituciones están en conexión con las iglesias cristianas, por lo que la ubicación se producía en las proximidades de las parroquias. Un punto discordante es el caso de la creación de la Universidad de Virginia en Charlottesville, donde los pabellones "giran" en torno a una biblioteca y no a una capilla, buscando un patrón de laicidad a través de la libertad de culto.

Aunque la habitación compartida va a ser el denominador común de muchos de los modelos estudiados, aparecen casos donde se empiezan a proyectar residencias para parejas, matrimonios, o incluso, personal del mundo laboral. 


\section{CAMBRIDGE: UNIVERSIDAD DE HARVARD}

La Universidad de Harvard se creó en $163^{147}$. Era conocida con el nombre de New College o también llamada The College at New Town. Es la Institución de Educación Superior más antigua de los estados Unidos.

El principal benefactor y artífice de la creación de este organismo fue John Harvard, un joven clérigo que donó a este establecimiento su biblioteca, en la que constaban unos cuatrocientos volúmenes y 779 libras, cantidad significativa, pues correspondía a la mitad de su patrimonio. Harvard era originario de Londres, estudió primeramente en el St. Saviour's Grammar School y posteriormente recibió la Educación Superior en el Emmanuel College de Cambridge (Inglaterra). Conocía de primera mano el sistema educativo inglés. En 1637 emigró con su esposa a Nueva Inglaterra en Estados Unidos y se estableció en la ciudad de Charlestown, que actualmente forma parte de Boston, en la cual fue nombrado ministro de la Iglesia. En este periodo, en un acre y una octava parte de la tierra de Newtown se estaba preparando para albergar la futura universidad. Debido a la ocupación de Nueva Inglaterra por una gran parte de obispos y colonos que habían sido educados en los colleges ingleses, el 2 de mayo de 1638 el nombre de Newtown fue cambiado a Cambridge.

Una vez conseguidos los terrenos, se construyeron los primeros edificios universitarios. Los colonos ingleses estaban asentados en la orilla del rio Charles, en un enclave de similares características a los de Oxford y Cambridge. Éstos adoptaron una disposición similar a los quadrangles ingleses, pero con la particularidad de no cerrar el perímetro, se situaban tres edificaciones y el cuarto "lado" quedaba abierto, fragmentándose así el sistema claustral medieval.

El primer sistema estaba formado por el Colegio Indio, el llamado "Antiguo Colegio" y la Casa del Presidente (President Lodge). El Tribunal General de Massachusetts dio a esta Institución el nombre de Harvard College en 1639.

El primer edificio fue el correspondiente al Antiguo Colegio, básicamente de madera. En el primer piso del ala este estaban situadas las dependencias para oraciones, comidas y actividades de uso común, mientras que el ala oeste contenía la cocina, trateros y despensa. El segundo piso albergaba las habitaciones de estudiantes y la biblioteca.

A diferencia de los colleges ingleses, estaba construido en madera por lo que sufría mayor deterioro debido a las condiciones climáticas 
de Nueva Inglaterra, para el año 1677 el edificio no era habitable debido a humedades en techos, paramentos verticales e incluso desperfectos relativos a la cimentación. 
Is
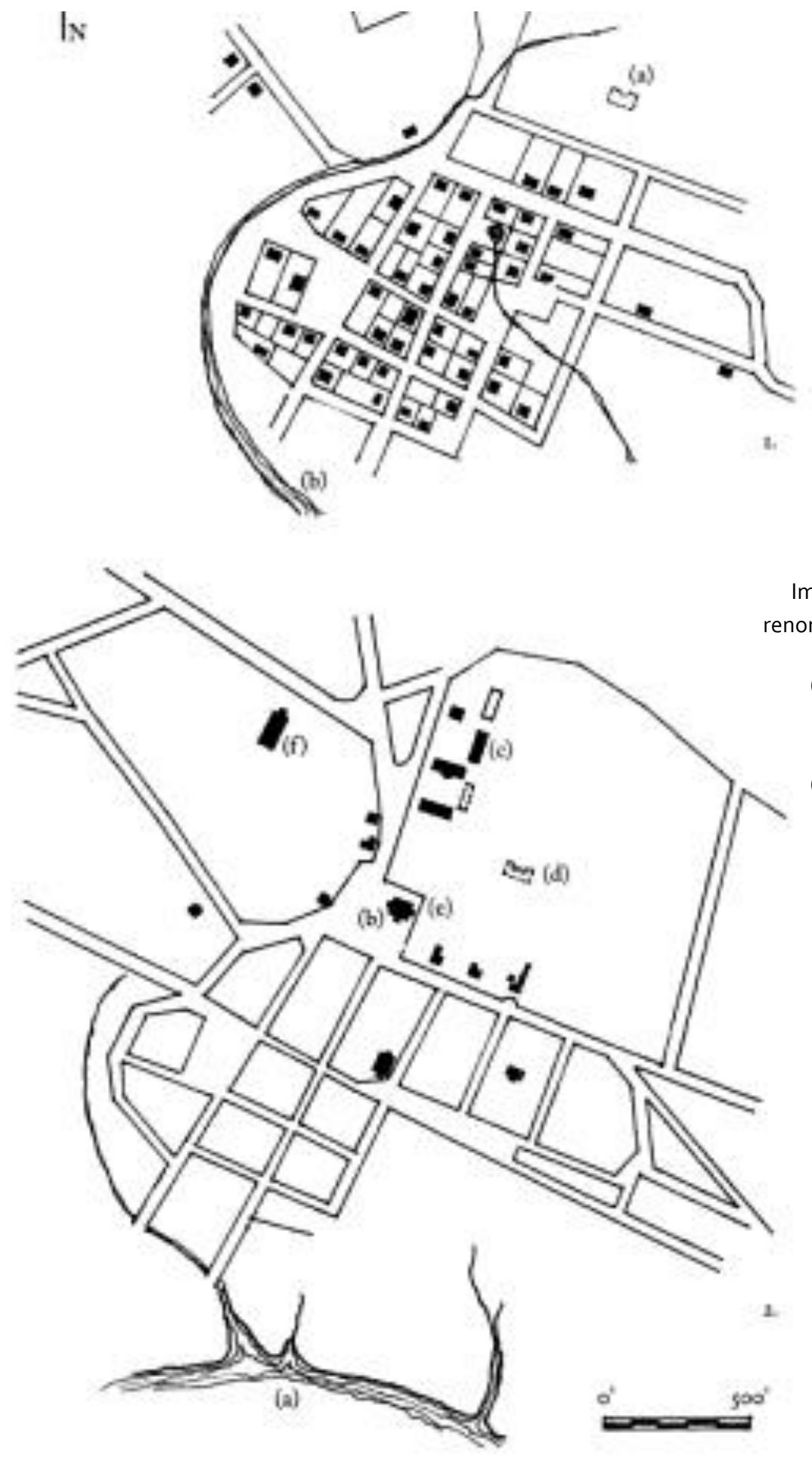

Imagen 264: Plan DE 1635. Newtown, renombrada Cambridge en 1635 .

(a) Futura implantación del primer colegio de la Universidad. La localización es fuera del núcleo urbano del pueblo.

(b) Río Charles

Plan de 1833. Cambridge, Massachusetts.

(a) Río Charles

(b)Harvard Square

(c) Colegios residenciales de la Universidad de Harvard.

(d) Implantación del Old College de Harvard.

(e) Casa de reuniones (Meeting house)

(f) Christ Church 


\section{OLD COLLEGE Y POSTERIORES HARVARD HALL'S.}

\section{Germen del tipo estadounidense (1637-1682-1768)}

The college at Newtowne como era llamado este primer colegio estadounidense, fue fundado a través de un cargo legislativo de la Colonia de Massachusetts el 28 de octubre de 1936. Primeramente, en los años 1637-1638, comenzó como una escuela, la cual adquirió un lote de terreno donde había una vivienda vacía, conocida como Casa de William Peyntree.

El lugar en sí era un campo de pasto de ganado vacuno, más tarde adquiriría el nombre de Harvard Yard, y la edificación del colegio el nombre Harvard Hall. De esta manera, se sustantivaba la primera zona de que albergaría estudios superiores con alojamiento para sus estudiantes y se diferenciaba de los "lotes" de terreno adyacentes donde continuaban pastando las reses.

Como se acaba de exponer en la página anterior, el regalo más importante a este colegio se debe a John Harvard. Con él se impulsó de manera notable el colectivo académico naciente, y con ello, la necesidad de alojamiento entorno a la Institución Académica, con lo que la residencia estudiantil cobra un papel protagonista en la disposición y construcción de los nuevos edificios.

El patio original de la Universidad está formado por cuatro edificios, tenían en conjunto forma de cuadrilátero, pero no estaba cerrado en su perímetro. Los cuatro eran: el Harvard Hall o Antiguo Colegio, Casa del Presidente (Aka Peyntee House), el Goffe College (Olmsead-Goffe House) y el Colegio de la India.

El primer Harvard Hall es el que recibe el nombre de Old College, comenzó su actividad en 1638 , pero el edificio completo no se terminó hasta 1642. La base de su estructura y materiales conformantes era básicamente madera, incluida la cubierta que estaba resuelta a dos aguas. El edificio estaba dotado de una torre en la azotea que un folleto de la época, se describe como: Demasiado idilica para encontrarse en un desierto.

El programa contaba con un salón-hall, comedor, salas de estudio, dormitorios y una biblioteca.

Sólo cinco años después de su finalización, uno de los primeros presidentes de Harvard, Henry Dunster, se lamentaba de las "desintegraciones" de los tejados, paredes y estructura. En 1679 se derrumbó parte del colegio, lo que indujo a demoler las restantes 
zonas. Una nueva construcción se levantaría próxima a ella, hacia el oeste, donde se erigirá el conjunto de colegios que dan forma a la actual Universidad de Harvard. Esta construcción es conocida como el segundo Harvard Hall. El segundo Harvard Hall combina características arquitectónicas medievales con renacentistas. Fue construido a base de ladrillo para intentar paliar, los problemas acaecidos en el anterior edificio por las condiciones meteorológicas de la zona.

Al igual que ocurría con el primero, todas las actividades como oración, biblioteca, comedor y cámaras de estudio fueron agrupadas en un mismo edificio. Se construyó entre 1672 y 1682 . Fue arrasado por el fuego originado durante una tormenta el 24 de enero de 1764 , donde se perdieron además todos los volúmenes de la biblioteca, que eran en torno a unos 5000.

El Tribunal General de Massachusetts se había estado reuniendo en lo que quedaba de colegio tras el incendio, debido a que en Boston existía una fuerte epidemia de viruela, votó y se aprobó a favor de utilizar unos fondos para la que sería la tercera generación del Harvard Hall.

El diseño principal corrió a cargo de Bernard Francis ${ }^{148}$, que era gobernador provincial. El edificio tardó dos años en construirse. El programa constaba de capilla, biblioteca y comedor. No tenía salas de estudio destinadas para estudiantes y profesores tutores, ni tampoco habitaciones-dormitorio. Fue el primer aulario de Estados Unidos dedicado exclusivamente a usos académicos.

Dentro del programa, en la segunda planta, se ubicó un museo, el primero de Harvard. En una descripción del bibliotecario de la época relataba: "contiene reptiles en alcohol, aves y bestias disecadas y otras curiosidades misceláneas". Esto dotaba de un cierto atractivo al colegio y proporcionó innumerables visitas. El gran hall del salón se utilizaba para comedor estudiantil, cenas de graduación y bailes de fin de curso. Las paredes de este hall estaban adornadas con pintura, se intentaba emular los halls de los colleges ingleses de Oxford y Cambridge. La biblioteca estaba completamente revestida de madera y los muebles también realizados todos con el mismo material reflejaban un rico trabajo artesanal.

Los espacios y dependencias colegiales al igual que los de Oxford y Cambridge, tenían distintas dimensiones y estaban estructurados de forma diferente. Existe una escala más doméstica para los espacios de dormitorio y salas de estudio, y otra escala de grandes dimensiones para los usos comunes, como el gran hall, que pronto se 
convertiría en un espacio polivalente para rezar, enseñar e incluso comedor. Esta característica es común a los colleges ingleses.

Los estudiantes se movían por estas dependencias de acuerdo a un horario establecido, el ámbito era de las 5.00 de la mañana a las 23.00 de la noche. Éste variaba según rangos estudiantiles dentro de la residencia, creados en función de una jerarquía y papel social desempeñado por los usuarios.

Aunque el Harvard Hall era un espacio común, dentro de este existen espacios restringidos a un cierto número de alumnos. Los espacios acotados podían ser unas salas de estudio, algún almacén o la propia biblioteca. Incluso para poder salir a pasear libremente por los espacios exteriores sólo un número restringido de alumnos gozaba de permiso.

Como novedad, en 1800 este colegio invirtió en la creación de un baño de madera que se construiría en las orillas del Río Charles para los estudiantes, ya que anteriormente se habían producido varios ahogos mientras se bañaban en el río. El colegio se asoció con la Sociedad Protectora de Animales de Cambridge y a varios particulares para diseñar y financiar el proyecto.

Con el tiempo, las zonas comunes fueron trasladadas a otras dependencias de la Universidad. Fue entonces cuando la primera planta se transformó en aulas y laboratorios y todo el segundo piso se destinó a biblioteca.

En años posteriores, las adiciones de otros edificios contribuyeron a la configuración actual. En 1842 se construyó un pabellón con el objetivo de proporcionar un espacio destinado a conferencias. En los espacios a ambos lados del pabellón se situaron edificaciones de una sola planta cuyos arquitectos fueron Ware y Van Brunt, los mismos que, diseñaron el Memoriall Hall y el Weld Hall.

El Tercer Harvard Hall, de ladrillo rojo, se encuentra en el lado norte del patio original de la Universidad, frente a la construcción más antigua de las que siguen en pie, el Massachusetts Hall. 


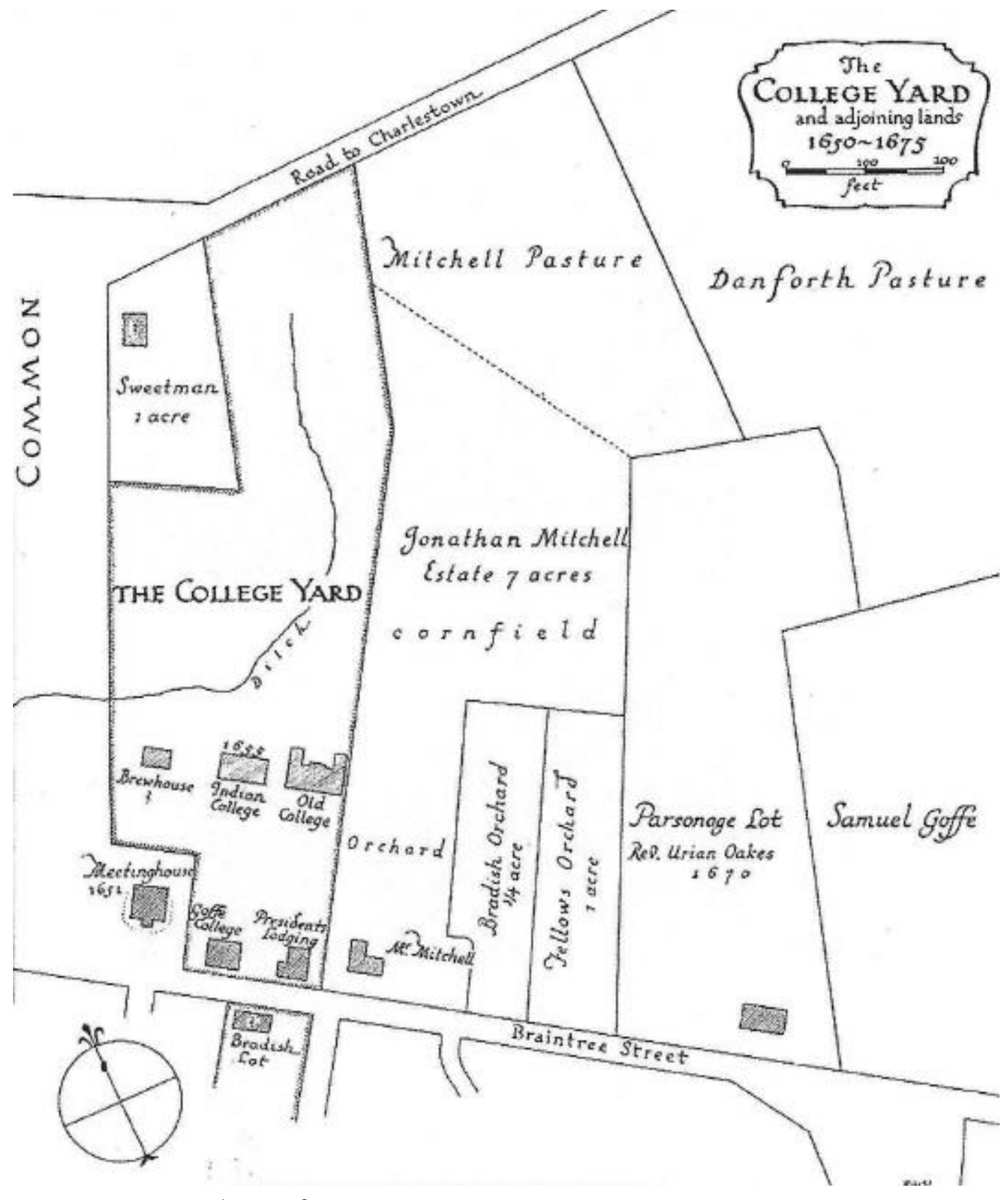

Imagen 267:

Plan DE 1650-1675. Cambridge.

Disposición del primer quadrangle de Harvard.

El patio principal está formado por los cuatro edificios principales: Old College, Indian College, President Lodge y Goffe College. 

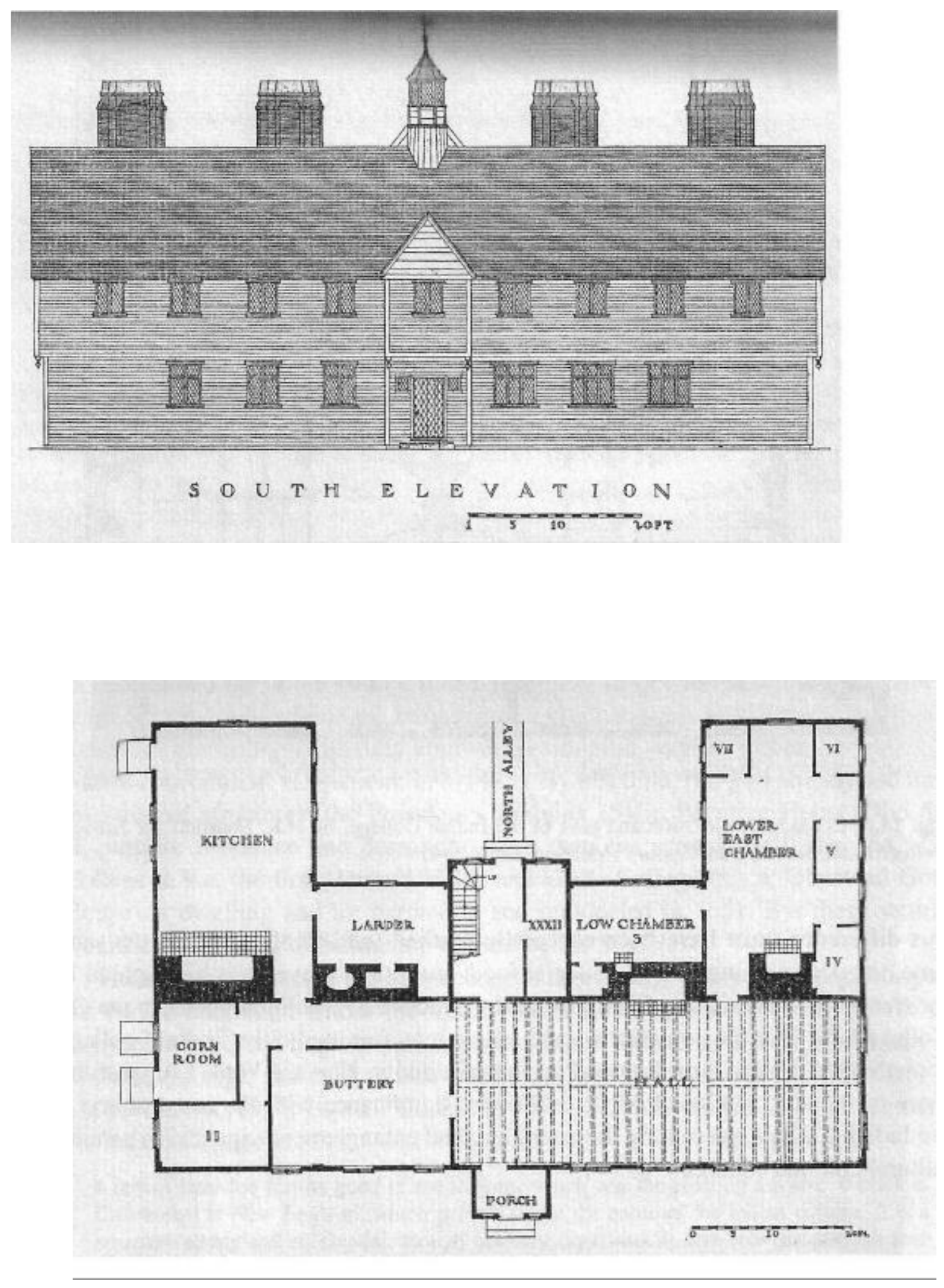

Colegio Antiguo (Old College). Harvard Hall I.

Imagen 268: Alzado principal (sur)

Imagen 269: Planta baja del college. 


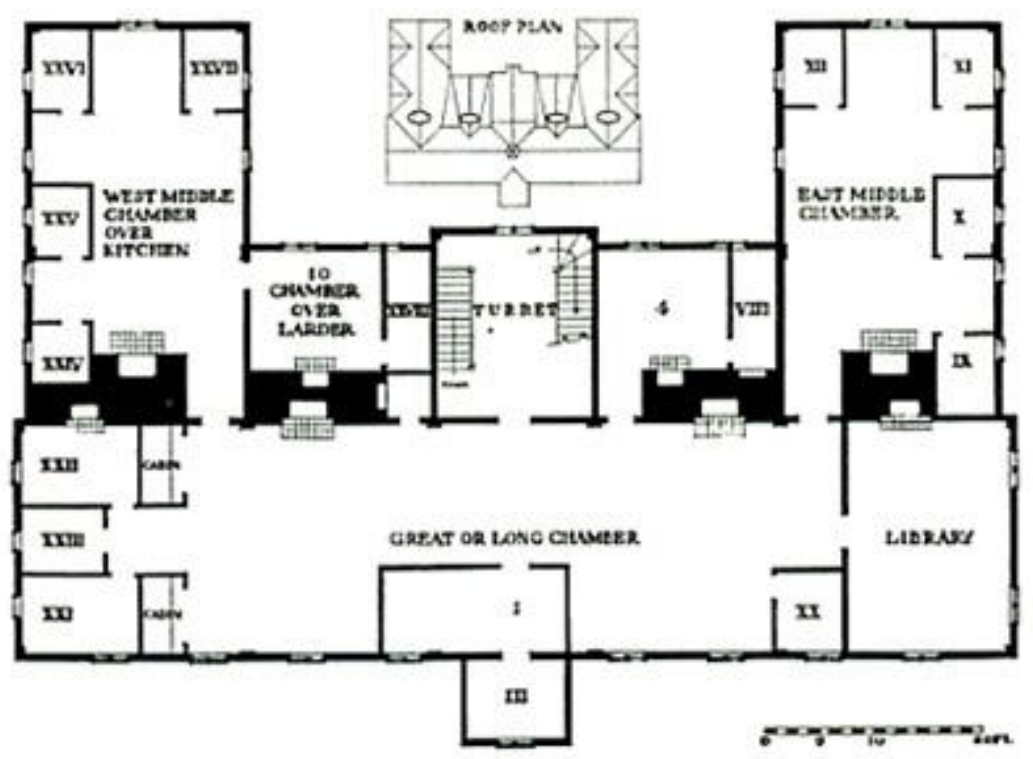

Colegio Antiguo (Old College). Harvard Hall I.

Imagen 270: Planta segunda

Imagen 271: Dibujo axonométrico del college.

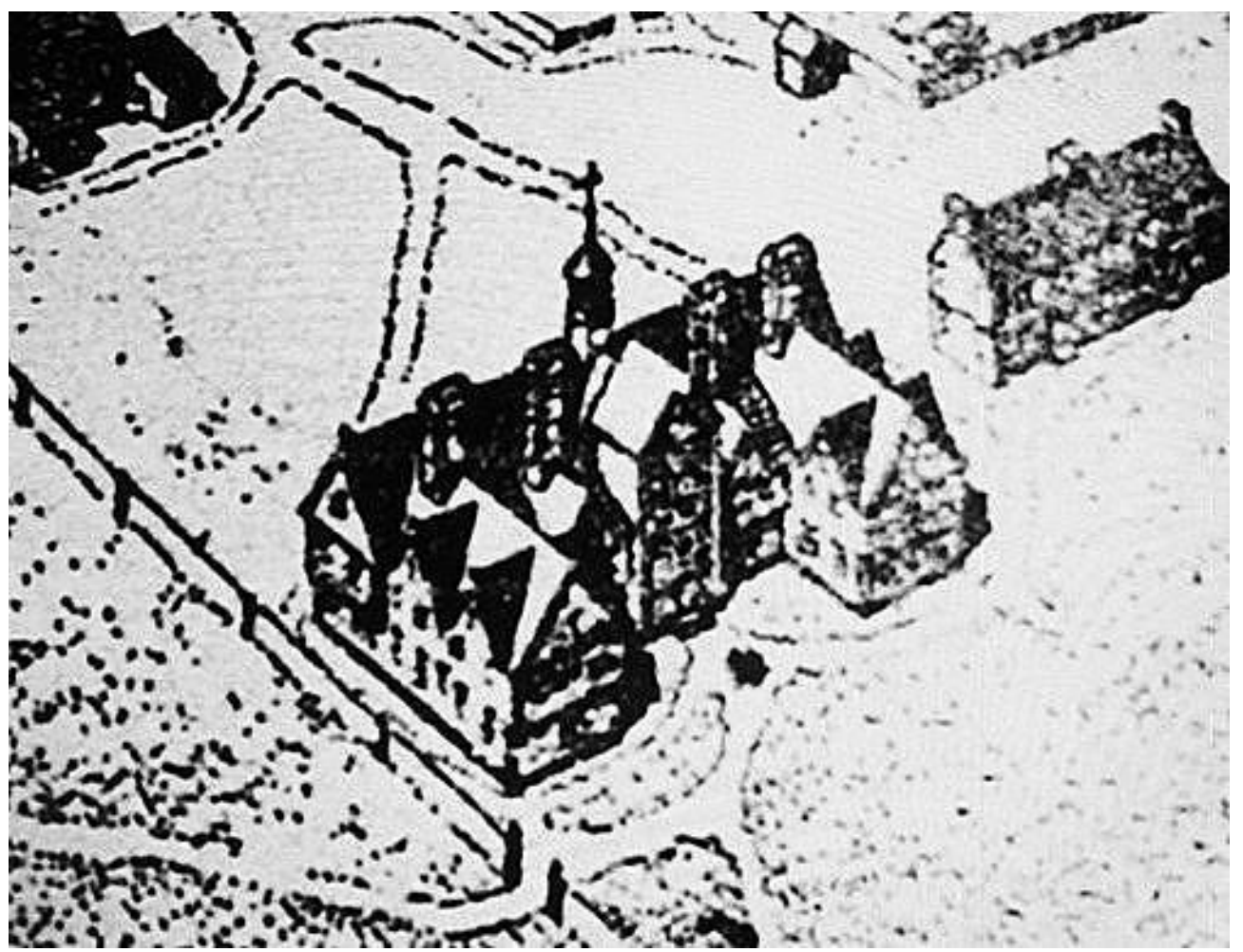



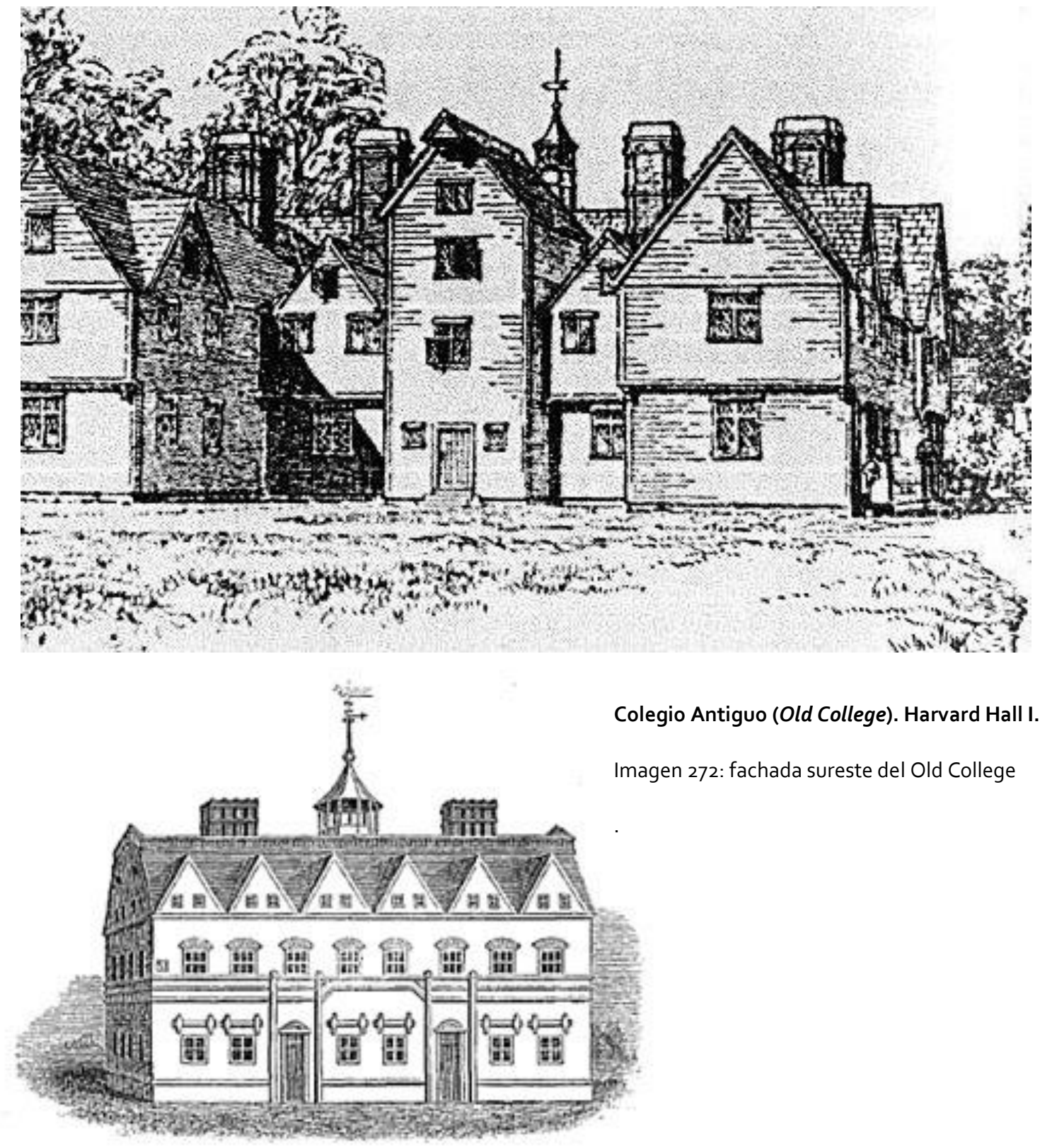

Colegio Antiguo (Old College). Harvard Hall I.

Imagen 272: fachada sureste del Old College

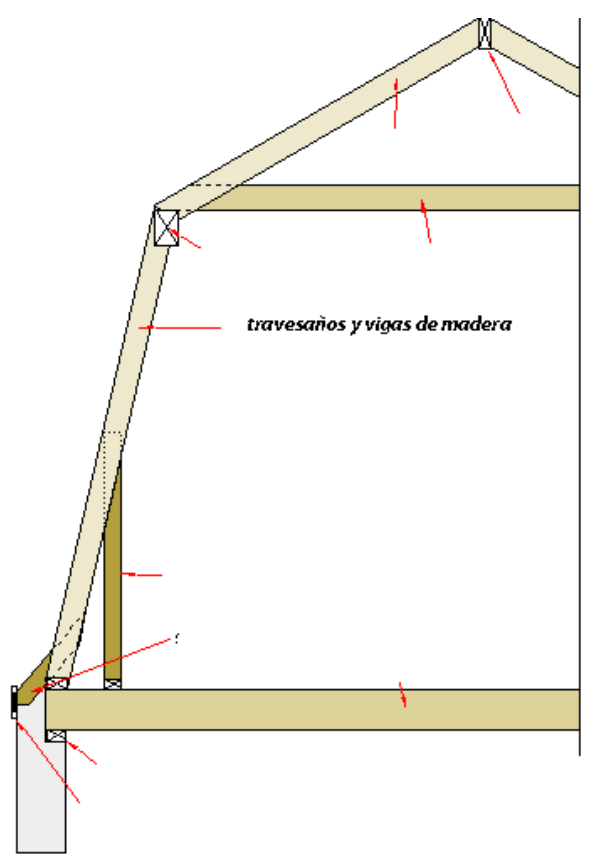

Colegio Antiguo (Old College). Harvard Hall II.

Imagen 273: Cubierta dos aguas y simetría en la fachada. Se

reconstruye sobre la estructura del primero (Harvard Hall I)

Imagen 274: Detalle del tejado mansardo de la cubierta dos aguas. Aunaue la fachada se hace de 


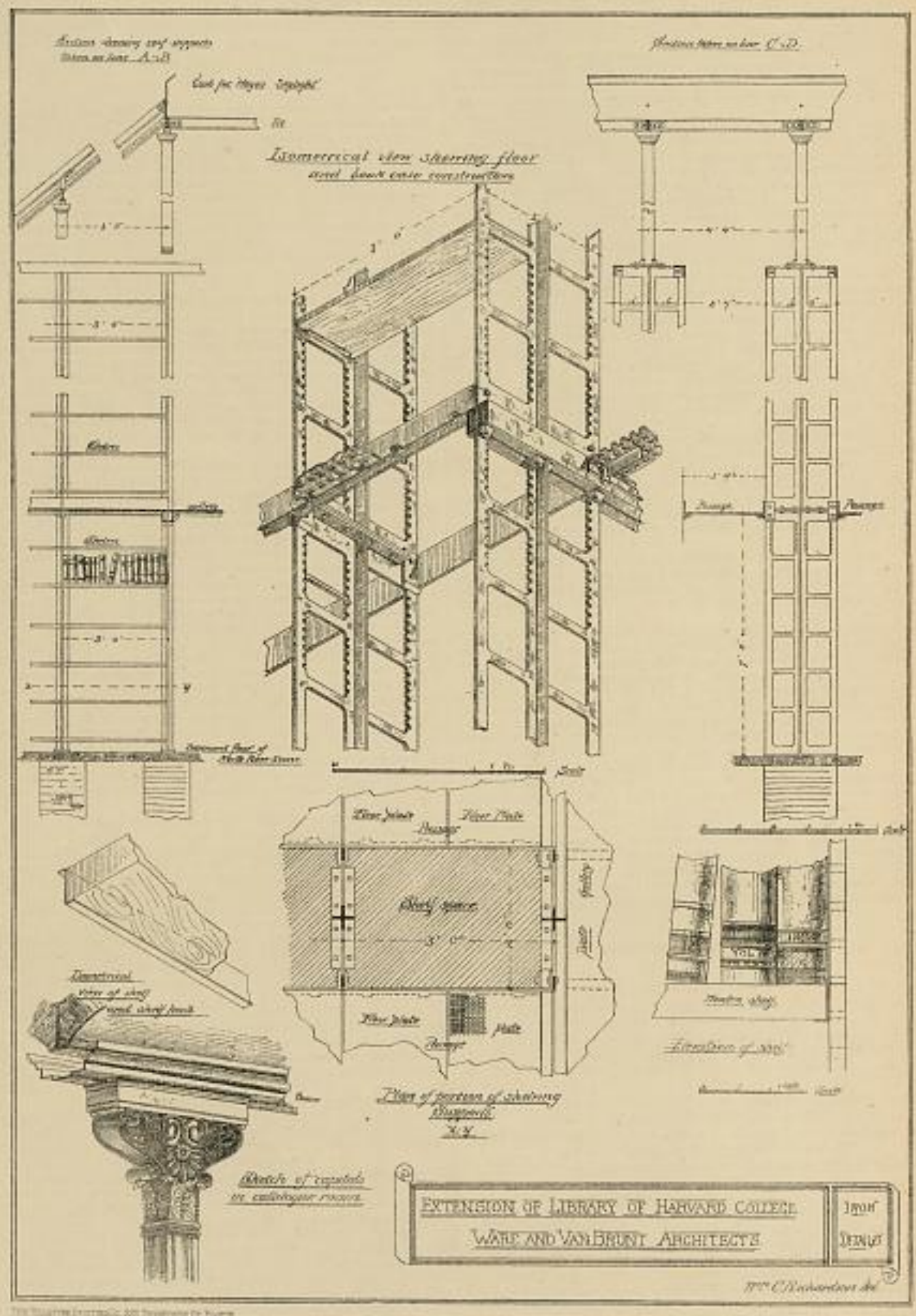

Colegio Antiguo (Old College). Harvard Hall III.

Imagen 275: Detalle de la ampliación de la biblioteca. Ware y

Van Brunt arquitectos. Nudos estructurales de madera. 

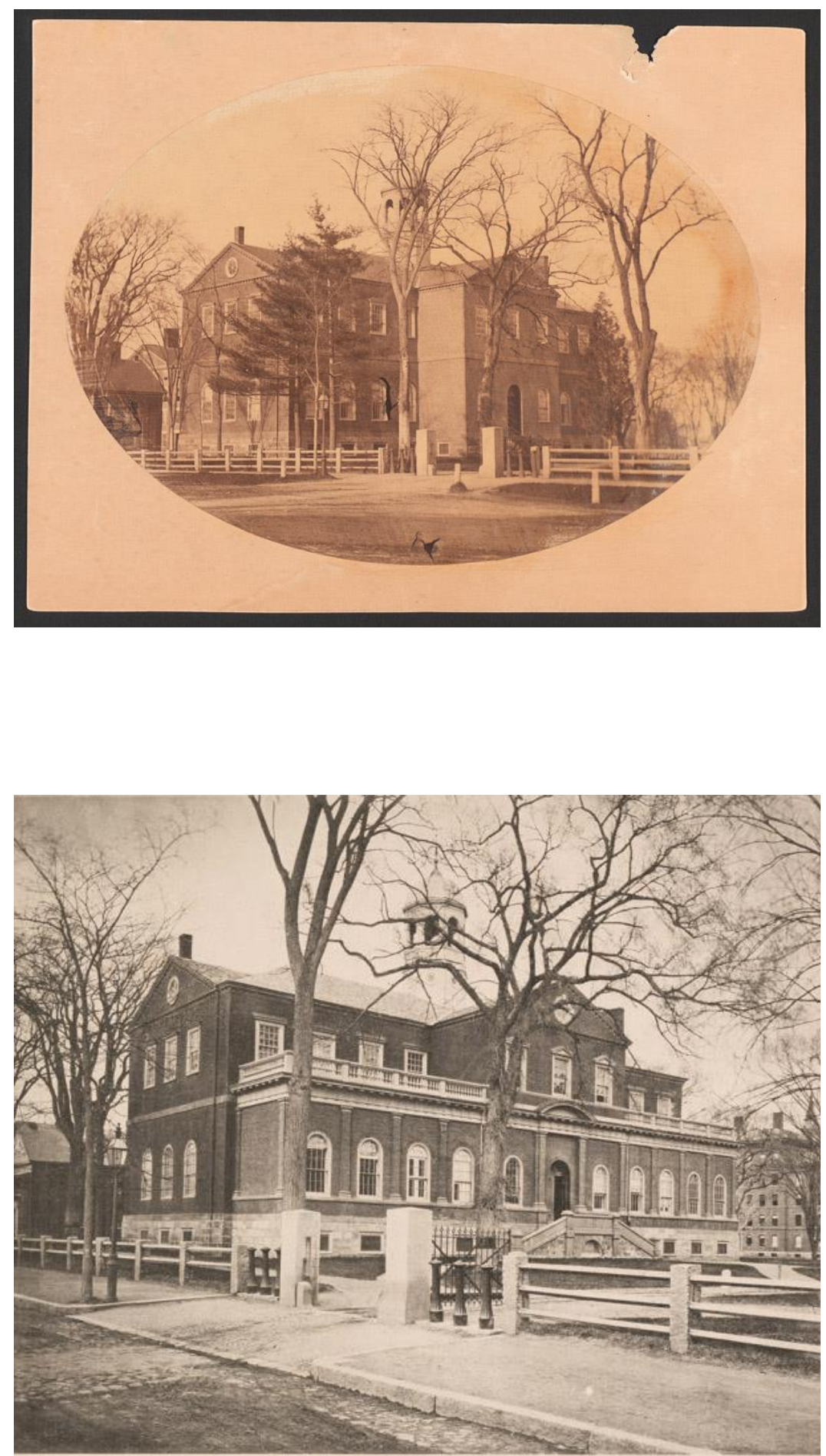

Colegio Antiguo (Old College). Harvard Hall III.

Imágenes 276 y 278: Detalle de la ampliación de la biblioteca. Ware y Van Brunt arquitectos. Se unen al pórtico central dos alas en planta baja y semisótano. 

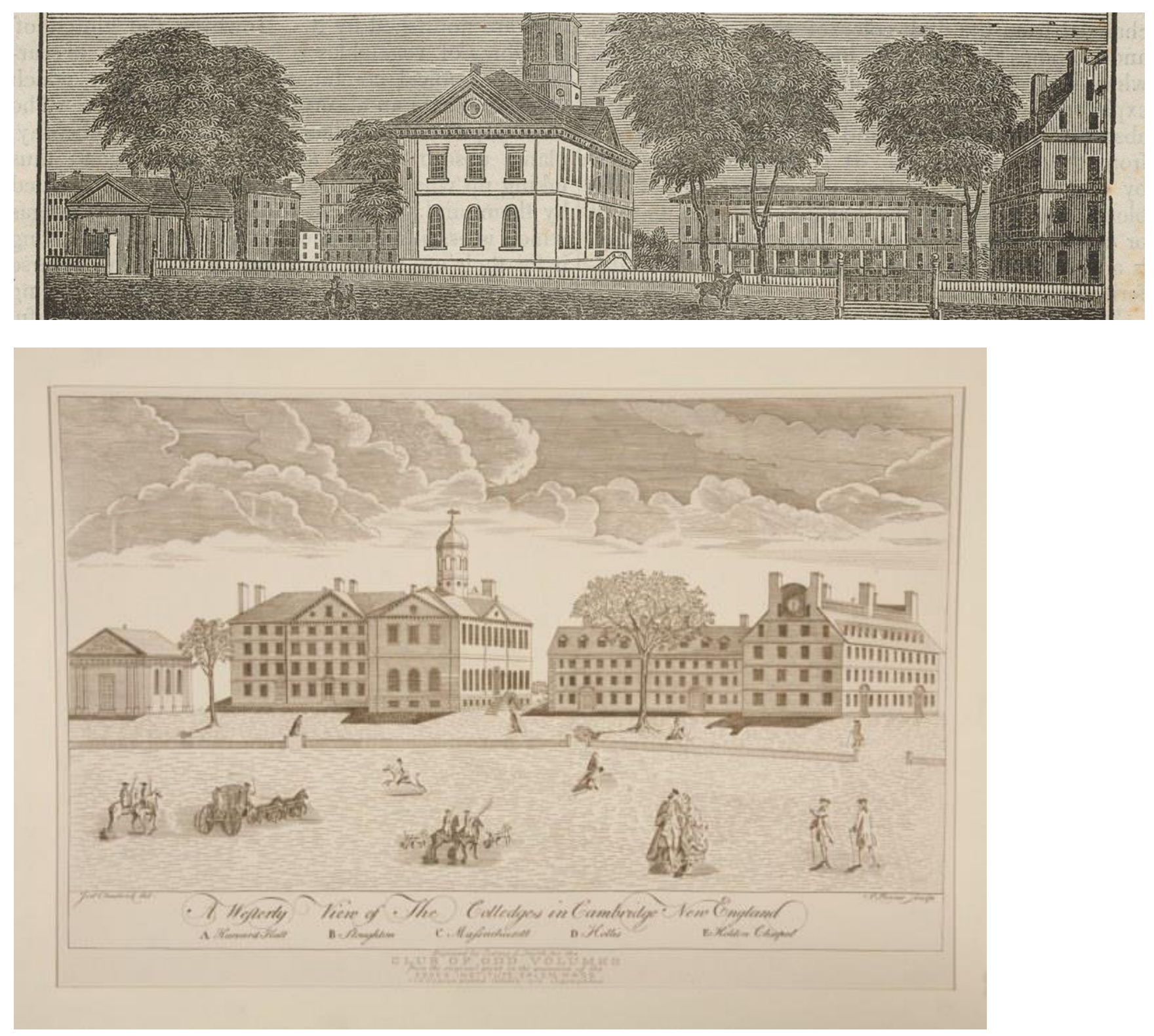

Harvard Yard.

Imagen 278 y 279: Los edificios se disponen dejando espacios libres, donde predomina el patio interior a modo de quadrangle. Aquí en Estados Unidos se suele dejar uno de los lados del cuadrilátero sin cerrar, para que los edificios "miren" al río o a la naturaleza. En la imagen se ven, de izquierda a dercha: La Capilla Holden, Hollis Hall, Harvard Hall III, Stoughton Hall y Masachustts Hall. 


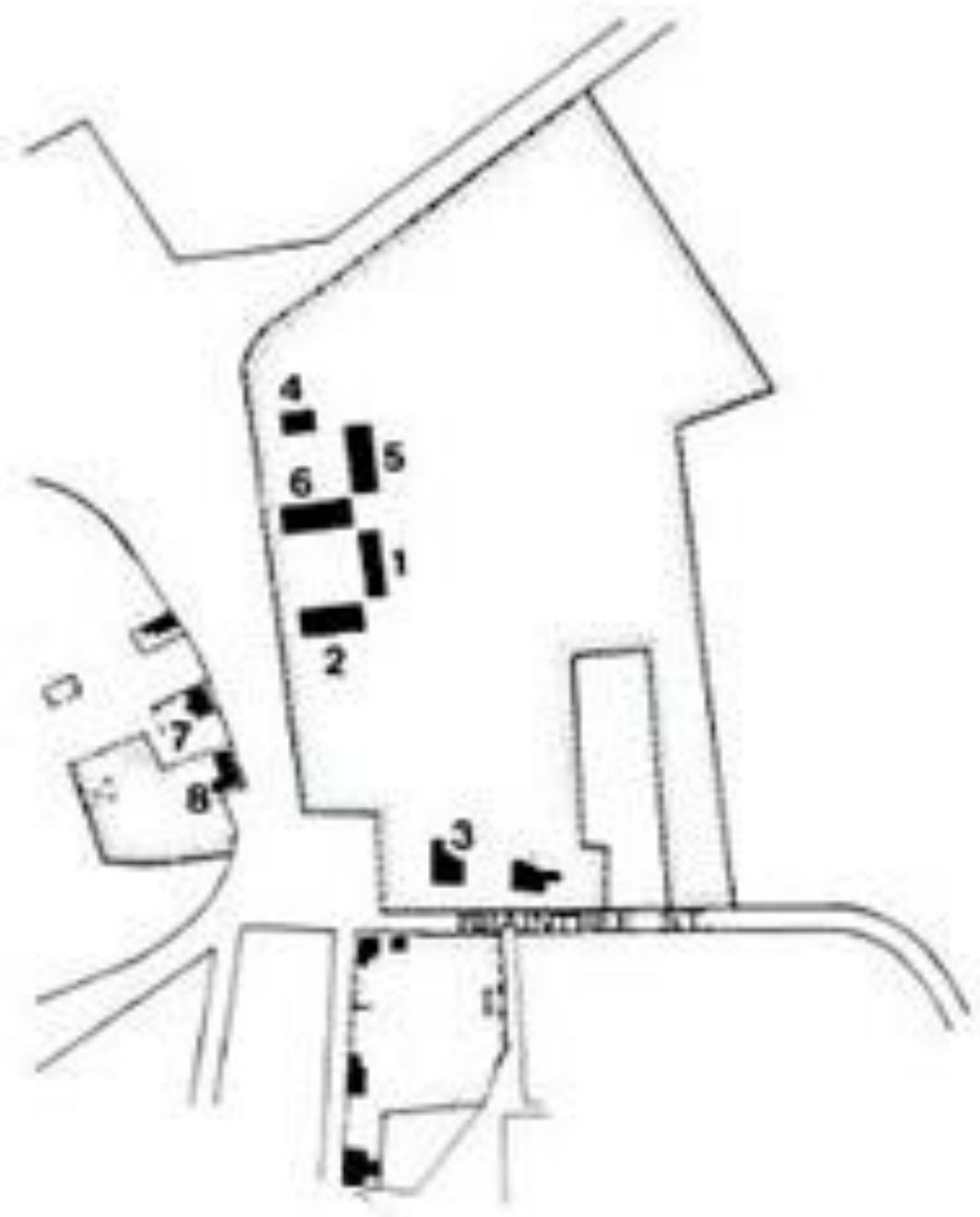

Imagen 280:

Situación de la disposición de las residencies dejando patios en su interior.
1. Old Stoughrton 1699.
2. Massachusetts Hall
3. Wadworth House 1726
4. Holden Chapel 1742 (Capilla)
5. Hollis Hall 1762
6. Harvard Hall III
7. College House I
8. College House II 


\section{COLEGIO INDIO.}

\section{Acotando el campus.}

Se convirtió en la cuarta estructura en el interior del quadrangle de Harvard, situado al oeste del primer Harvard Hall. Con su construcción se cerró el patio como un cuadrilátero, era la pieza que faltaba.

El Colegio Indio no dio la bienvenida a sus primeros estudiantes nativos hasta 1661. Es de los primeros modelos de colegio residencial de Estados Unidos, en él convivían nativos americanos con los colonizadores ingleses. Existía un fuerte componente racial, ya que, en el Old College pernoctaban sólo los estudiantes ingleses o de origen inglés y en el Colegio de la India tanto los nativos como los de origen inglés.

Los hombres nativos abandonaban sus hogares para instalarse en el Colegio de La India y poder recibir educación, al mismo tiempo eran "convertidos" a la religión cristiana. El Colegio no les cobraba matrícula a estos alumnos.

Esta intervención constituía el primer edificio de ladrillo de Harvard y segundo edificio construido con fines edcucativo-residenciales. De hecho, era el único edificio construido en este material de los tres que conformaban el quagrangle.

El colegio era de forma rectangular y estaba conformado a base de ladrillo, tiene dos pisos de altura y unas dimensiones de 20 metros de ancho por $6 \mathrm{~m}$ de ancho. Estaba preparado para albergar a 20 estudiantes. El ladrillo era autóctono, se fabricaba en Medford (Massachusetts)*(Ciudad conocida en el siglo XVII por su producción de ladrillos), y se eligió para que resistiese mejor ante las adversidades meteorológicas, ya que tenían experiencia viendo la respuesta de las estructuras conformadas con madera en el Harvard Hall I. Este componente cerámico era llamado "plinth squint". El Colegio Indio, con sus paredes rojas de ladrillo y el techo de teja rojo, fue sorprendentemente diferente a las otras tres estructuras conformantes del patio.

La imagen que se tiene es conjetural por parte de H.R. Shurtlett*(fue publicada en 1936 por Samuel E. Morison. Esta reconstrucción se basa en documentos consultados del siglo XVII, mapas e ilustraciones, en el Massachustts Hall)

El programa del colegio se desarrolla en dos plantas, las zonas comunes en planta baja que, distribuida de forma simétrica con respecto al eje tranversal, estaba provista de salones, aulas de estu- 
dio y las escaleras para subir a al nivel superior en los hall de entrada. La planta es simétrica respecto a su eje transversal y tiene un acceso desde el exterior a cada una de las partes, y enfrente de los mismos se encuentran las escaleras de acceso al nivel superior. Desde el interior no se comunican.

En estos espacios se generaba un dinamismo compartido con otros ambientes de enseñanza, tales como escuelas, centros de reuniones, iglesias y tribunales. La universidad de Harvard se convirtió se convirtió en un modo de conexión entre distintas comunidades

De las estancias integrantes del programa, cabe destacar la sala de prensa, donde se encontraba una imprenta. Este hecho le otorgaba una identidad propia al colegio y ayudó a la alfabetización de los usuarios. Se imprimieron textos universitarios a la par que biblias y libros de relatos en inglés.

En 1698 fue demolido este colegio y los ladrillos fueron utilizados para construir el Stoughton College en 1699. 

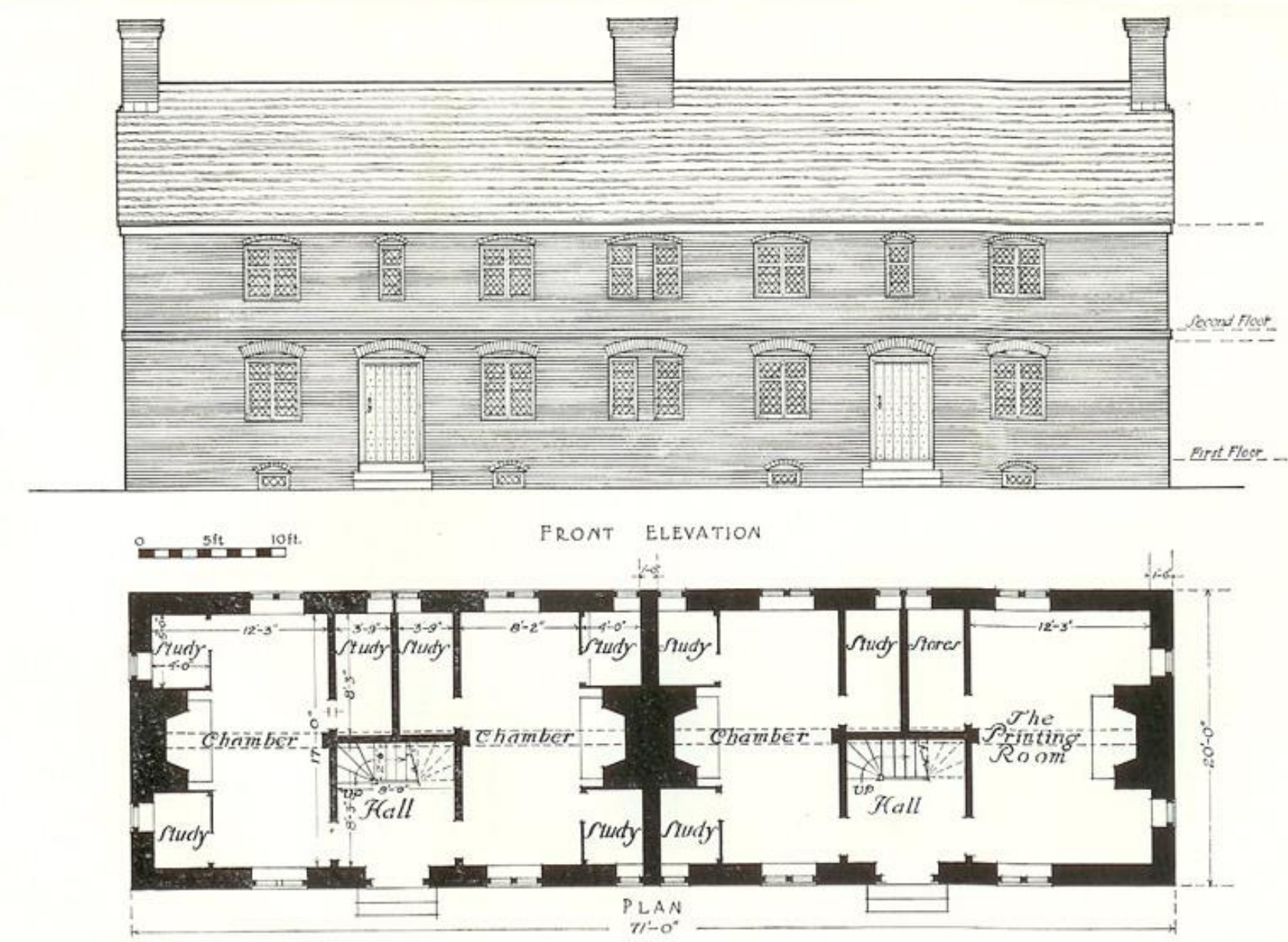

Imagen 281 : Disposición del primer quadrangle de Harvard.

El patio principal está formado por los cuatro edificios principales: Old College, Indian College, President Lodge y Goffe College.

Imagen 282:Alzado lateral y sección transversal
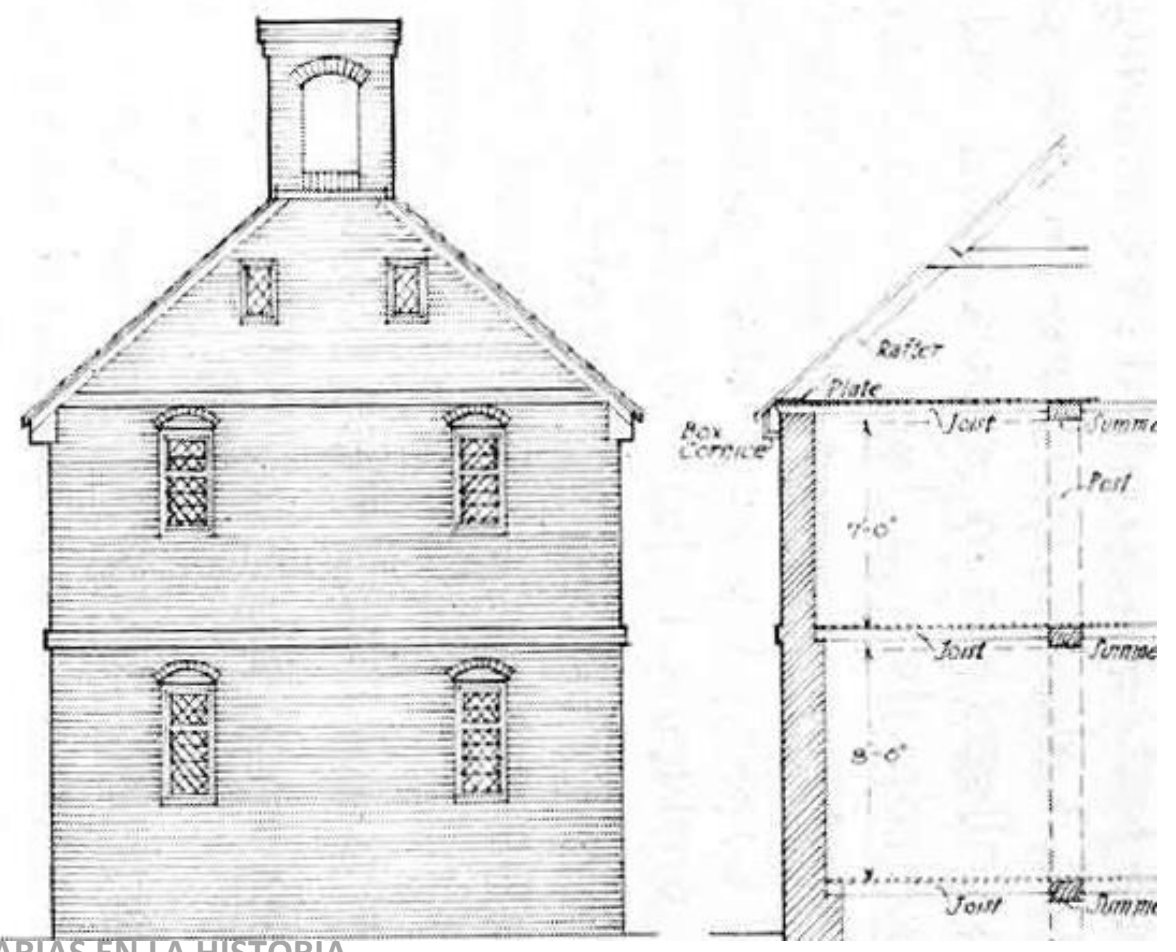
CASA DE WILLIAM PEYNTREE.

\section{Conformando el quadrangle.}

En el plano de zonificación del primer patio universitario de Harvard, está situada al sureste.

Se abrió a los estudiantes en el verano de 1638 y más tarde se convertiría en el hogar del primer presidente de Harvard, Henry Dunster, durante 1640 y 1641.

En 1644, una nueva edificación fue construida sobre los cimientos de la antigua vivienda, ésta es la que albergó a varios presidentes de Harvard incluido el anteriormente mencionado.

Posteriormente, se construiría otra residencia para presidentes a la derecha del Harvard Hall.

\section{GOFFE COLLEGE}

\section{Cerrando el quadrangle.}

Esta vivienda de estilo colonial se incorpora en 1651 al conjunto universitario, el objetivo es poder dar alojamiento al excedente de alumnnos que no podían ser ubicados en el Old College.

Goffe House es de grandes dimensiones y posee holgados espacios, posee dos alturas y el programa se desarrolla con 5 salas, 15 estudios, una cocina, una bodega y tres buhardillas. El tema de la organización de la distribución interior estaba minuciosamente pensado, ya que, cuando la casa fue adquirida tenía os habitaciones por planta y una cocina nueva en planta baja, con tres pequeños estudios fuera de cda una de las habitaciones, además de otros tres estudios que se instalaron en el ático. Con esta compra, se crea el primer quadrangle universitario de los Estados Unidos. Esta residencia fue demolida junto con la Casa del Presidente hacia 1670.

Tanto la Casa del Presidente como la Goffe House diferían poco de las estructuras nacionales ordinarias de la época en Massachustts, excepto quizás en tamaño. Como la mayoría de las viviendas de Nueva Inglaterra de la época, este edificio de dos plantas más buhardilla se enmarca en madera, forrado a base de tablillas y techado con cubierta de teja. Las ventanas son abatibles de hierro y posee una gran chimenea conformada a base de ladrillo. El ladrillo en la parte exterior, estaba revestido de mortero de cal con conchas de ostras molidas. Se puede asumir que, salvo por el tamaño del edificio es muy similar a las viviendas contemporáneas realizadas con tablillas de madera de con tonos degradados oscuros, en esta época 
la pintura no era de uso común. La cubierta estaba resuelta a dos aguas, dejando un pequeño frontón en el alzado principal. En el alzado posterior estaban las ventanas de las buhardillas para proporcionar luz a estas habitaciones. La escalera que une las distintas plantas estaba situada en el patio, donde además se situaba el baño.

\section{MASSACHUSETTS HALL.}

\section{Restauración y permanencia.}

Es el edificio más antiguo que sobrevive, como tal, en Harvard y una de las residencias estudiantiles más antigua del país.

En 1718, la Corte General de Massachusetts autorizó 3.500 Libras para la construcción de esta residencia universitaria.

Está situado en la entrada al Harvard Yard. El edificio fue diseñado por John Leverett y Benjamin Wadsworth, ambos fueron presidentes de Harvard.

Se encuentra cerca de la Avenida Massachusetts en la zona oeste de del Antiguo Harvar Yard (antiguo patio, formado por Harvard Hall, Stoughton $Y$ el Massachusetts Hall), como se acaba de decir anteriormente, es el campus original de la universidad de Harvard. Su fachada principal linda con la fachada principal del Harvard Hall. En su parte posterior y fijado en ángulos rectos a él se disponen los Straus y Mathews Halls (ambos del siglo 19). Cerca del extremo occidental de este edificio está la puerta de Johnson, una estructura imponente diseñado por McKim, Meads y White en 1889.

El estilo del edifico es colonial, quizás con rasgos georgianos tempranos. Massachusetts Hall es un sencillo edificio rectangular que mide aproximadamente 29 por 12 metros; que es de tres pisos de altura con un cuarto bajo el amplio techo abuhardillado. El techo se rompe con buhardillas en su parte frontal inferior y además por seis chimeneas interiores dispuestos en pares en el centro y en los extremos del edificio. Los que están en los extremos están conectados por los parapetos.

Los paramentos exteriores son de ladrillo visto color rojo. Hay dos entradas situadas de forma simétrica en cada una de las fachadas de mayor longitud. Los testeros del edifico siguen la misma composición de fachada que las de mayor longitud, también cuentan con accesos al edificio. Las ventanas se organizan en la fachada de forma simétrica. 
Con este edificio se consolida el modelo pabellón de residencia universitaria. Se está consolidando la fragmentación edilicia del modelo inglés. En un gran espacio contenedor, en 4 plantas, se desarrolla el programa. Tiene 32 habitaciones dobles para albergar a 64 estudiantes, éstas están situadas en las dos últimas plantas. En las otras dos se encuentran los espacios comunes y salas de estudio.

Abrió sus puertas en 1720, contaba con 32 habitaciones, cada una de ellas provista con dos zonas de estudio. Fue restaurado durante el siglo XIX para albergar aulas y oficinas. El techo quedó gravemente dañado durante un incendio en 1924, lo que dio lugar a una renovación a gran escala del edificio completo. Se eliminaron aulas y oficinas y volvió a su uso principal de residencia de estudiantes, siendo un pabellón de estilo colonial de ladrillo rojo dotado con 64 habitaciones.

En 1939 sufrió su última remodelación, que dio como resultado su estado actual, donde las plantas inferiores se volvieron a transformar en oficinas y las superiores continúan siendo habitaciones. 


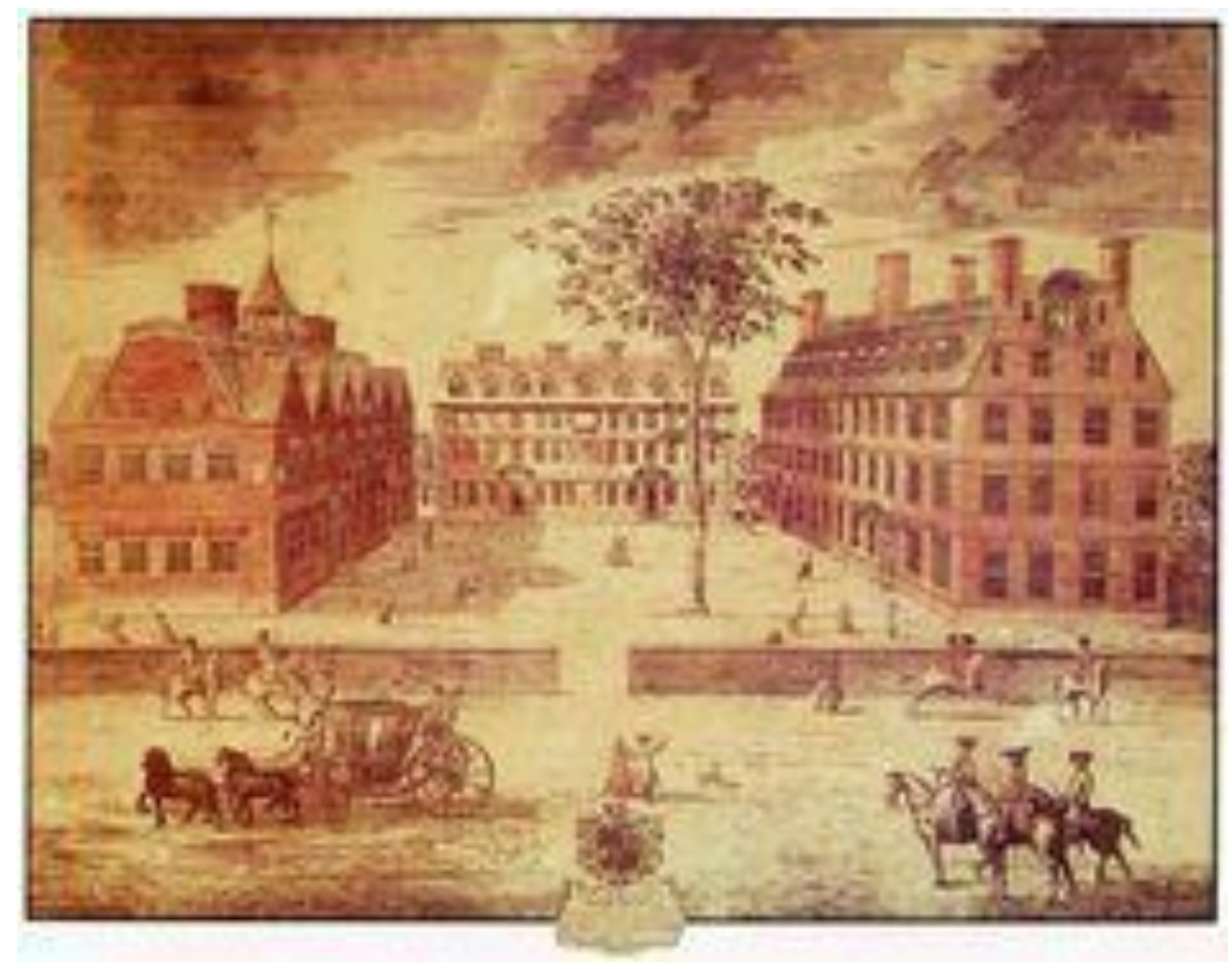

Imagen 283: Al construirse el Massachusetts Hall se cierra en torno a al patio el que se considera el Patio Viejo de Harvard. Es el espacio de relación exterior entre las tres residencias (Harvard Hall, Stoughton Hall y la propia Massachusetts Hall)

Imagen 284: Vista actual del edificio donde se aprecia el espacio bajo cubierta, la simetría de la fachada y las distintas entradas situadas en el

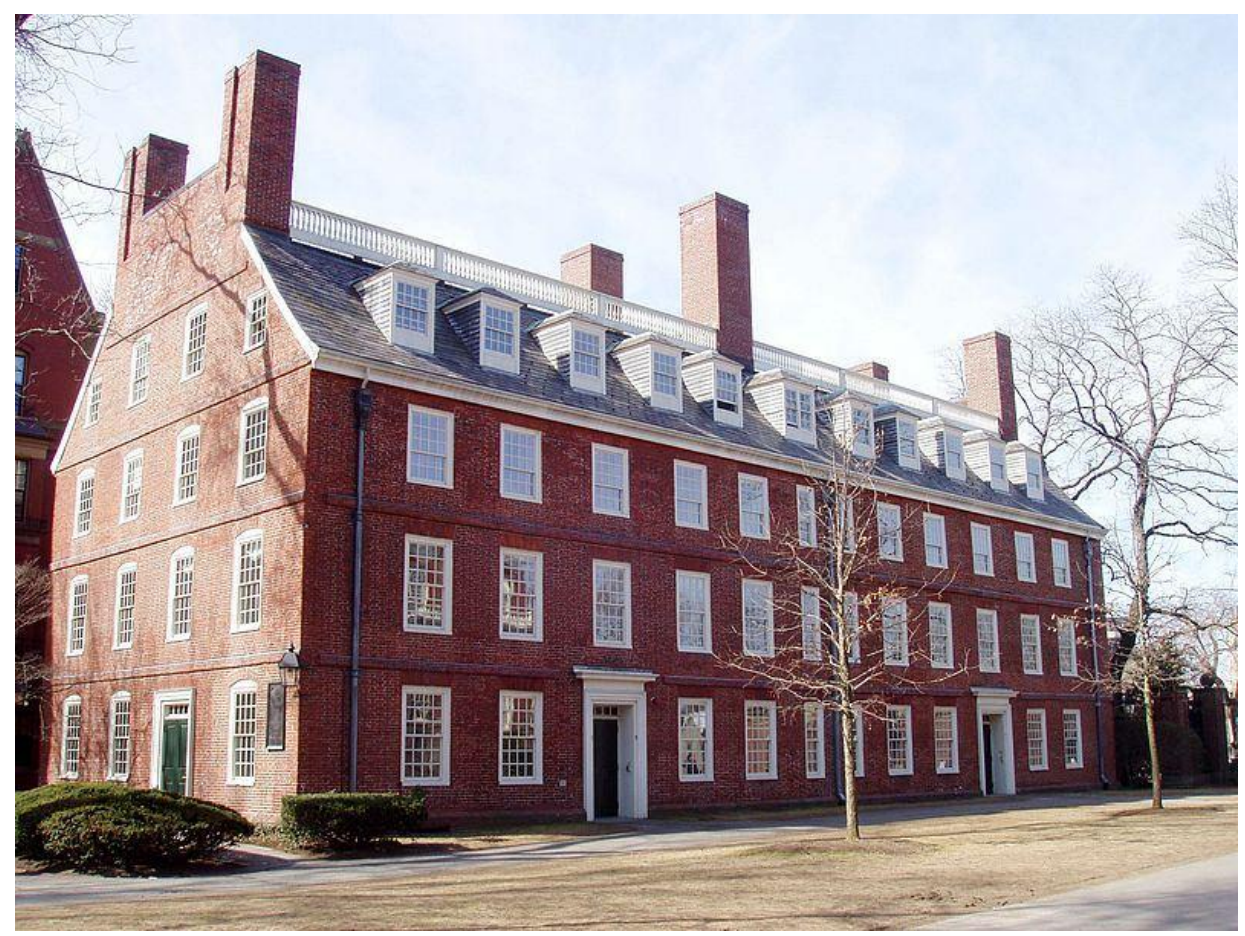


HOLLIS HALL.

\section{Una singular simplicidad (1763)}

Fue construida en 1763. El objetivo de la corporación de crear esta residencia de estudiantes era que los estudiantes saliesen del marco habitual de la familia, puesto que creían que eran menos ordenados y regulados que aquellos que vivían en el campus. Como resultado del hacinamiento en el campus en 1761 , noventa estudiantes de Harvard se alojaban con familias cercanas. La Universidad solicitó entonces los fondos de la provincia para construir esta residencia. El proyecto fue aprobado fue aprobado por el tribunal general de Massachusetts y donó 2500 Libras para su construcción, nombrando también un comité para la supervisión del proyecto.

Cuando el colegio abrió sus puertas en enero de 1764 , fue nombrado Hollis Hall en honor a Thomas Hollis ${ }^{149}$, miembro de la familia benefactora de que hizo posible la construcción.

Un pabellón conforma el segundo patio de la universidad, contiguo al Antiguo Harvard Yard. La estética exterior es similar a Massachusetts Hall y Stougjton Hall, está revestido de ladrillo rojo también. Las fachadas están compuestas por las aberturas de las ventanas situadas de forma simétrica, con dos accesos en la fachada principal. La tipología en planta es similar al resto, una planta simétrica con respecto al eje tranversal en la zona de las habitaciones. Los dos núcleos de comunicación vertical se encuentran enfrentados a los accesos, característica repetida cuyo precursor fue el Colegio Indio como se ha dicho anteriormente. En este caso las escaleras son de un solo tramo. Es original que los vestíbulos estén orientados a ambas fachadas, agrupados en un solo volumen, solución simple y al mismo tiempo elegante Existen 4 habitaciones por planta, estando las dos que se sitúan en las esquinas a doble orientación. Las habitaciones centrales y las de esquina tienen aproximadamente el mismo tamaño. Este sencillo esquema se repite las cuatro plantas de habitaciones. En los testeros no hay accesos, se resuelven proyectando los huecos de las ventanas al exterior de igual manera que la fachada principal. 

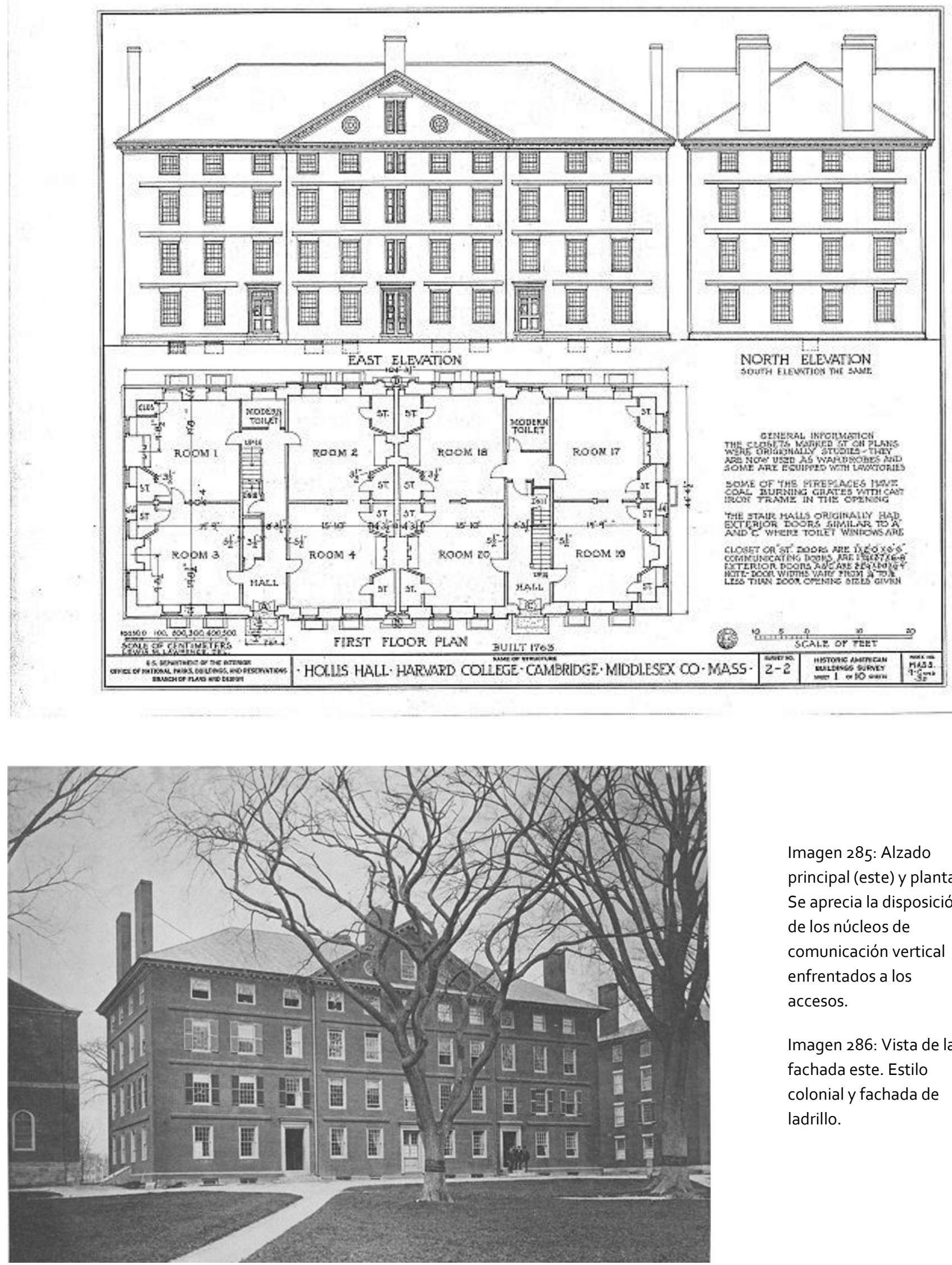

Imagen 285: Alzado principal (este) y planta. Se aprecia la disposición de los núcleos de comunicación vertical enfrentados a los accesos.

Imagen 286: Vista de la fachada este. Estilo colonial y fachada de ladrillo. 
STOUGHTON HALL.

\section{Permanencia del estilo colonial (1805)}

Tercer edificio conformante del Patio de Harvard. Su fachada principal está de frente al lado abierto de quadrangle. Este edificio, que fue designado a principios de los catálogos como New Hall, fue construido en el año 1804, los fondos necesarios fueron obtenidos principalmente por la venta de lotería del estado.

Anterior a éste existió otro que fue demolido debido a su mal estado, fue declarado inseguro debido al mal estado de sus muros de mampostería. Era también de estilo colonial aunque se podría decir que más pintoresco. Constaba de tres pisos de altura con ventanas abuhardilladas. Albergaba a unos 50 estudiantes.

El actual Stoughton ha sufrido pocos cambios desde su construcción, ha mantenido su estilo intacto a lo largo del tiempo. La fachada exterior es de ladrillo rojo, la misma que Massachusetts Hall, salvo pequeños detalles formales estos dos pabellones son muy parecidos en su imagen exterior. Se eliminaron las ventanas abuhardilladas en esta segunda versión.

En el interior si ha sufrido algún cambio. Su planta era una copia del Colegio Indio. Simétrica con respecto al eje transversal, con dos accesos al exterior y las escaleras enfrentadas a éstos. Los accesos. Con el paso del tiempo se hizo la planta baja más diáfana y se comunicaron las dos partes. En las plantas superiores, se ubican las habitaciones de los estudiantes, con el paso del tiempo se reformaron para ganar amplitud quitando parte de los armarios. 


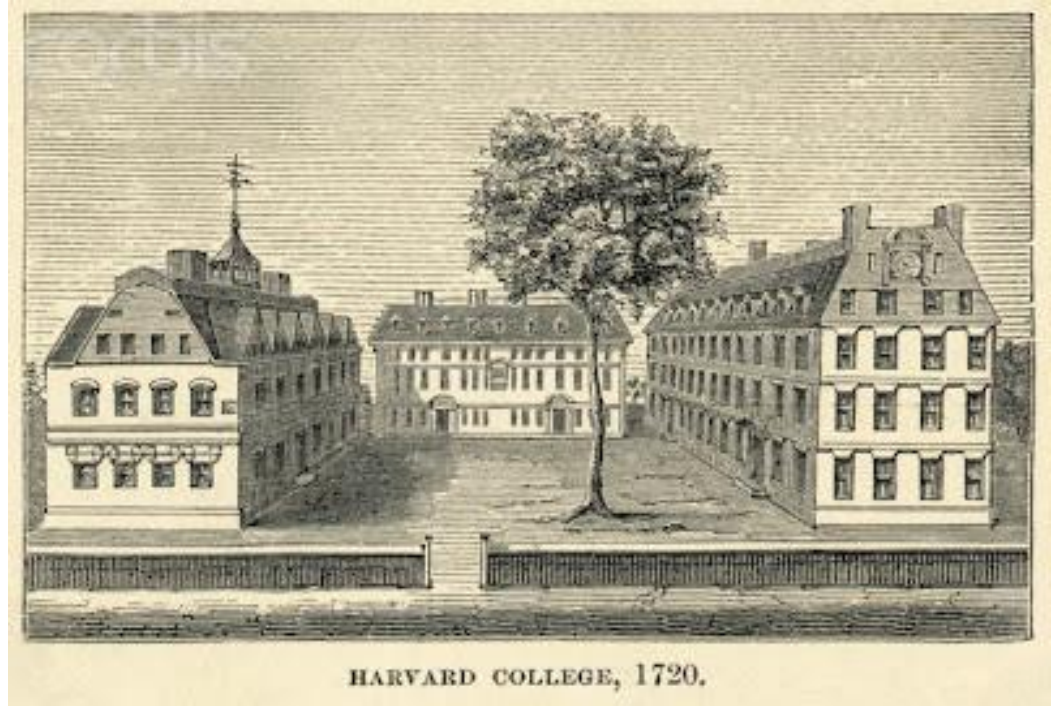

Imagen 287: Antiguo Patio de Harvard, formado, de izquierda a dercha por Harvard Hall II, Stoughton Hall I y Massachusetts Hall.

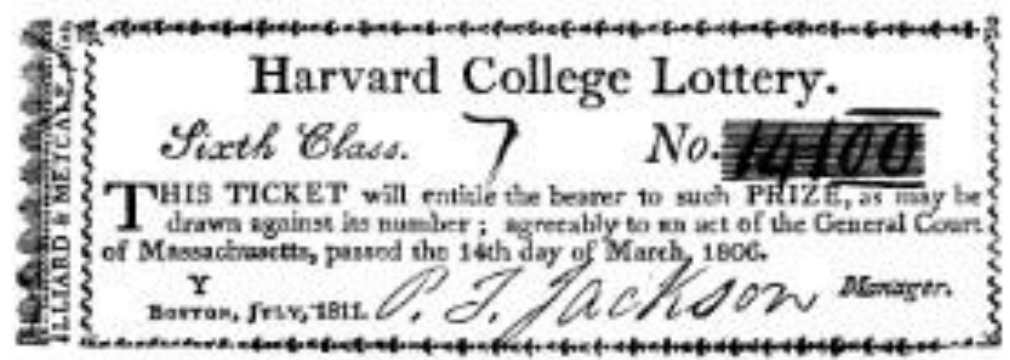

Imagen 288: Boleto de lotería con la que se recaudaron fondos para la construcción de Stoughton Hall y suplir la falta de alojamiento.

Imagen 289: Fachada principal del Stoughton Hall en la actualidad.

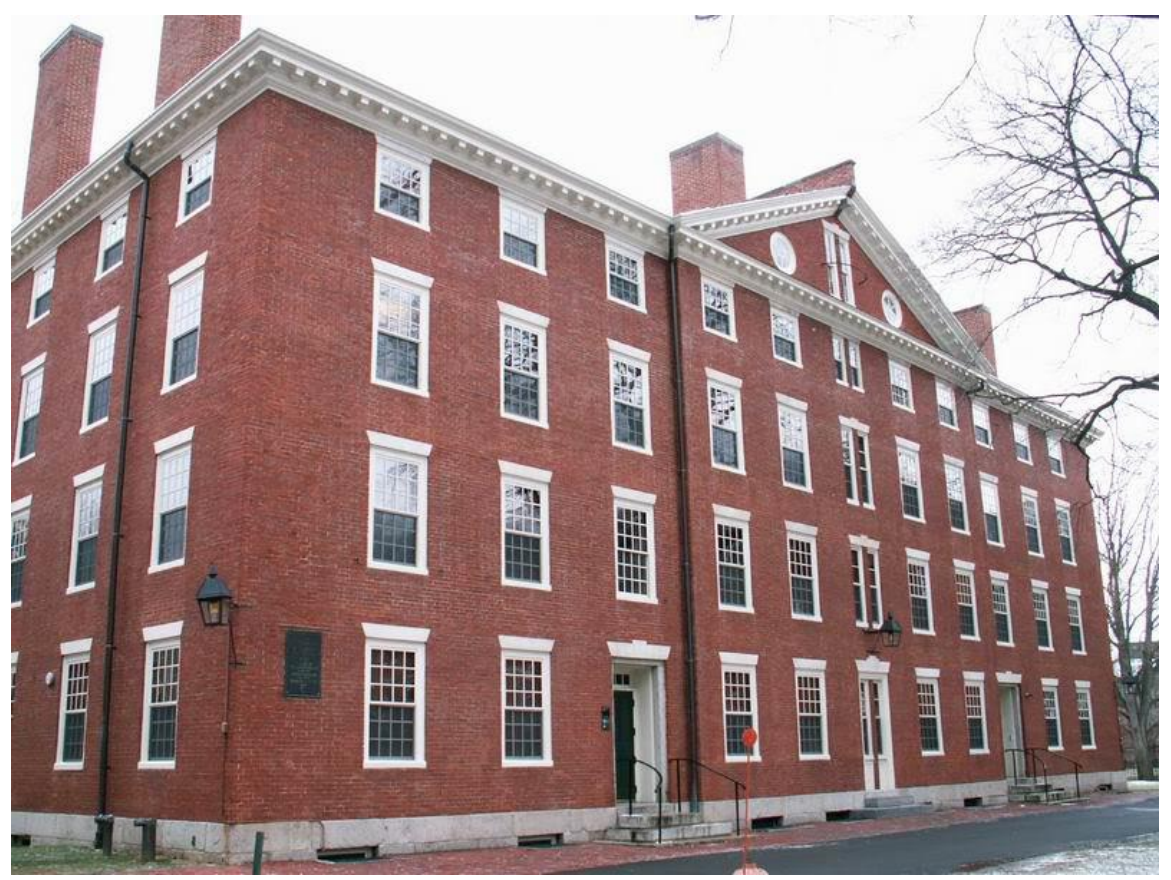




\section{CHARLOTTESVILLE: UNIVERSIDAD DE VIRGINIA}

La Universidad de Virginia se puede considerar el conjunto de los esfuerzos arquitectónicos de Thomas Jefferson ${ }^{150}$ y de sus intereses políticos referentes a la independencia de las masas que conforman una sociedad. Los ideales de Jefferson reflejan que la libertad sólo puede conseguirse plenamente si el pueblo está educado. En 1805, cuando planeaba la creación de la universidad escribió: "considero nuestro estado actual de libertad como una posesión de corta vida a no ser que las masas que conforman nuestro pueblo puedan ser educadas a un cierto nivel ${ }^{\operatorname{m5} 51}$

Las creaciones arquitectónicas de Jefferson han adquirido una resonancia tan importante en la cultura americana que cualquier consideración acerca del diseño y la arquitectura de la Universidad de Virginia supone inevitablemente acercarse a un hito nacional. Cabe resaltar que, en el epitafio de su tumba reza: "Autor de la Declaración de Independencia de América / Autor del Estatuto de Virginia para la libertad de culto / y padre de la Universidad de Virginia"152, lo cual revela su orgullo por haber sido el alma matter de la universidad. Con ella culminó la ambición que tuvo toda su vida de obtener para el pueblo la libertad política e intelectual. Sim embargo, conviene recordar, que el intento educacional de Jefferson, similar a la mayoría de Instituciones de la época, sólo incluye a una parte escogida de la sociedad, excluyendo a las mujeres y a las personas de color. Tan sólo los hombres jóvenes privilegiados de más talento asistían a los cuerpos docentes universitarios. La suya, no es la amplia libertad de oportunidades para todos los ciudadanos propia del siglo XX. Aun así se puede considerar a Jefferson como el primer defensor de la modernización de la educación superior, convirtiéndose en el creador de la universidad centralizada, donde la residencia de estudiantes, en este tipo de nuevo campus universitario, va a jugar un papel más abierto que en los modelos anteriores. 


\section{COLEGIO DE WILLIAN \& MARY.}

\section{Elemento de transición al campus estadounidense.}

El Colegio de William \& Mary es la segunda institución universitaria de Educación Superior más antigua de los Estados Unidos, por detrás de la anteriormente estudiada Harvard. Aunque los planos originales datan de 1618, décadas antes de Harvard, no se llevó a cabo la construcción debido a un levantamiento indígena. El Colegio se fundó en 1693 por una cédula real de Guillermo Il y María II. Se puede considerar la primera Universidad Pública de Estados Unidos.

El primer intento de fundar el colegio fue un 18 de noviembre de 1618, cuando la compañía Londinense de Virginia inicia la creación de la Universidad de Henrico : Henricopolis. El emplazamiento se produce en la orilla norte del río James, a pocos kilómetros de la posición actual de Richmond en Virginia.

No duraría mucho el asentamiento, ya que, debido a un ataque de los indios en 1622, la edificación queda totalmente destruida.

En 1691, el Gobierno de la Colonia de Virginia envía a Londres a James Blair, líder religioso de la Colonia, por una carta real que permite establecer "un lugar para la educación universal". Con carta garantizó en apoyo de las diferentes figuras religiosas como Henry Compton o el arzobispo de Canterbury John Tillotson, finalmente se consigue la meta: el colegio fue findado de nuevo el 8 de febrero de 1693 por cédula y nombrado en honor de los manrcas Guillermo III y Maria II. La carta contempla a Blair como el presidente del Colegio, cargo que asumió hasta su muerte en 1743.

La Cédula Real ordena la creación de un colegio compuesto por tres secciones:

-La Escuela Filosófica, a cargo del estudio de la Filosofía Moral y la Natural.

-La Escuela Religiosa, la preparación de la ordenación de hombres jóvenes como sacerdotes de la Iglesia Anglicana

- El estudio de la Literartura.

Cerca de 330 hectáreas de tierra fueron compradas en diciembre de 1693, y los primeros ladrillos para el edificio principal fueron puestos en 1695 . 
Antes de que el nuevo edificio colegial se construyera, existía una pequeña vivienda en el terreno conocida como La Casa de Blair. Era una casa-escuela, pudiéndose denominar como una escuela con residencia para sus alumnos y profesores. Era una escuela de secundaria pero no estaba ligada a estudios superiores universitarios. Los integrantes fueron dedicados desde 1694 a 1700, junto con el maestro Blair y otros estudiosos que residían en ella hasta el edificio de Wren fuese ejecutado.

En 1699 la capital colonial fue trasladada de Jamestown a Williamsburg. El Edificio de Wren es la construcción más grande de la zona. Debido al nombre de este colegio se le atribuyó a la ciudad el nombre de Williamsburg, el colegio se convertiría en la sede temporal del Gobierno desde 1700 hasta 1704, año en que se completó el Capitolio.

Los trabajadores comenzaron la construcción del Ilamado edificio de Wren, que con bastante probabilidad fue este arquitecto el que lo diseñó, muy anteriormente. El edificio se implantó durante los años 1695 y 1700, justo antes de que existiese como tal la ciudad de Williamsburg.

Junto a este colegio, se añadieron en conjunto y formando en disposición de patio, dos edificaciones más, El edificio Brafferton y la Casa Presidencial (President Lodge). El edificio de Wren es la "cabeza" de este tridente universitario-residencial, el alma de este campus colonial. La implantación se disponía de igual manera que la vista en Harvard en el Old College, posteriormente Harvard Hall, el edificio principal flanqueado por dos edificaciones adyacentes. El edificio Brafferton sirvió como Escuela de la India, gracias al legado de Robert Boyle ${ }^{153}$, como pasara en el Colegio de la India de Harvard, aunque en este caso se obtuvieron peores resultados, a medida que salían los estudiantes nativos regresaban a sus modos y costumbres de vida indígena.

Los tres edificios conformaban un patio central, rodeado de naturaleza a base plantaciones de árboles de hoja perenne, esto hacía del entorno exterior un lugar muy agradable.

Debido a los incendios, el edificio de Wren tuvo dos "reconstrucciones" a lo largo de su historia.

Primer edificio de Wren:

El diseño es atribuido a un inglés ya que, en esta época no había en Jamestown un diseñador capaz de realizar estos planos. Cualquiera 
que sea la derivación del diseño, sustantivamente, gran parte del edificio viene de Inglaterra.

Los obreros fueron llevados a Virginia específicamente para desarrollar la construcción. Un inglés, Thomas Hadley, fue nombrado inspector y supervisor de las obras. Se conoce el nombre de operarios intervinientes como George Cryer y Samuel Baker, que fueron albañiles y Robert Harrison, carpintero. Cuando el edificio se terminó, la mayoría de estos hombres volvieron a su país de origen. No sólo los operarios fueron "importados", también materiales de construcción, como adoquines para pavimentos, vidrio y otros enseres que se trajeron en grandes cantidades. Gran parte del mobiliario colegial fue adquirido de comerciantes ingleses, Micajah y Richard Perry de Londres fueron agentes principales de estas operaciones donde, también existían diseños del propio arquitecto. Si se asume que Wren fue el diseñador del edificio, podía especularse que también diseñó algunos de los muebles del colegio, ya que existe una gran similitus entre los muebles de la Biblioteca del Trinity College y los del William and Mary.

Estaba destinado a ser conformar un patio interior en su concepción inicial, pero finalmente sólo se construyeron dos de sus lados: los denominados bloque este y bloque norte. Déficits financieros y disenciones políticas provocaron que la construcción se prolongara durante 5 años, entre 1695 y 1700.

Desde el principio el trabajo fue elaborado por etapas, más tarde, se sabe mediante un estudio que los ladrillos que conformaban el edificio revelaban el año de su construcción. Dicho examen, durante las posteriores restauraciones, revelaron que la pared del ala norte no se unió a la pared norte del bloque principal. Esta condición da a entender que las partes no se colocaron de forma simultánea o premeditada como una unidad inicial.

Un incendio en 1705 lo dejó impracticable.

Segundo Edificio de Wren:

Pasaron cuatro años antes de que se adoptaran medidas para la reconstrucción del colegio. Los gobernantes deliberaron sobre la importancia de mantener los muros principales para continuar o seguir, de alguna manera, el trazado de la anterior construcción. Esta idea se mantuvo hasta el final y se reconstruyó el colegio sobre los antiguos muros.

Durante el comienzo de las obras, junio de 1710, llegó a Virginia el nuevo Gobernador, Alexander Spotswood. Era arquitecto aficionado 
y mostró un gran interés en dicha reconstrucción aportando ideas e impulsando la reforma. Hugh Jones escribió en 1724 que este segundo edificio "estaba muy bien ideado y reconstruido gracias a la dirección del ingenioso Gobernador Spotswood".

Como ya pasara en el primer edificio, muchos materiales de construcción, muebles e incluso mano de obra fueron traídos de Inglaterra. Finalmente fue terminado entre 1716 y 1718.

Se amplía el programa con salas destinadas a biblioteca, habitaciones más confortables, residencia para profesores y salas destinadas a oficinas.

Tanto en la primera como en esta segunda intervención, los jardines exteriores han estado "adornando" el exterior de ambas edificaciones.

Debido a que los antiguos muros fueron reutilizados, existían pocas alternativas para modificar la distribución en planta, no se alteró apenas nada. La fachada difiere sustancialmente de la del primer edificio, sólo en pequeños detalles.

Las diferencias principales entre la versión primera y la segunda fueron:

1. Altura de los muros. Debido a lo dañados que estaban los muros sobre los que se levantó bloque este, la altura en la parte frontal que en los laterales. En esta parte, el bloque tenía 2 alturas y media en lugar de tres.

2. Cubiertas. La diferencia entre las alturas de los muros frontal y posterior del bloque este causa asimetría en las laderas este y oeste de la cubierta, en consecuencia, se decidió resolver la situación disponiendo dos cubiertas a cuatro aguas.

3. Pabellón. La reducción en altura del bloque este enfatiza la al bloque central, con esto se pierde la extensión horizontal del bloque.

4. Cúpula. Sustitución de la cúpula de dos pisos del primer edificio por otra de forma hexagonal de un piso de altura, rematada con una veleta. El diseño se originaria, seguramente, con Spotswood.

5. Canalones. El primer edificio tenía los canalones de plomo. En este segundo, lo canalones eran de madera y fueron dispuestos en los aleros del techo. Se situaron, también, en las cornisas para proteger a las distintas fachadas de la erosión del agua.

6. Drenaje/saneamiento. El drenaje fue un problema en el primer edificio. El agua discurría por el edificio con el fin de evacuarse y se estancaba en algunas repisas y sobretodo en el sótano. Este detalle fue subsanado en el segundo edificio por un sistema de 
drenaje que evacúa el agua desde la parte frontal por unos canalones hasta la parte posterior donde se evacuan por el sótano. El patio también estaba dotado con desagüe directo al exterior.

7. Entrada. Estaba elevada unos $45 \mathrm{~cm}$ con respecto a la rasante en esta segunda intervención.

8. Escalera. El hueco central de la escalera propició, en el primer edificio, que el fuego se propagara rápidamente. Por esta razón la escalera principal se trasladó de sitio, ubicándose al sur de la entrada principal y separado mediante muros del resto de la distribución.

9. Ventanas. En la reconstrucción se cambiaron las ventanas del estilo Tudor con acristalamiento en forma de diamante por ventanas de hojas correderas.

La disposición interior es muy similar a la del primer caso, salvo la posición de la escalera, como se acaba de apuntar, todo lo demás es prácticamente igual. La habitación del presidente estaba situada en el primer piso, exactamente igual que en anterior caso, más tarde su uso se cambiaría por otro, ya que, a la llegada de James Blair, el presidente del college no se alojaba en el edificio de Wren sino en la President Lodge, casa del presidente, que se construiría en 1733 acompañando al edificio de Wren y la Casa Brafferton para formar el patio principal de la universidad.

Thomas Jefferson llegó a Williamsburg para cursar estudios universitarios en el Colegio de William \& Mary en marzo de 1760. Tenía 16 años cuando comenzó su andadura universitaria. Había recibido educación, a través de unos tutores, en su casa. En el momento en el que llegó a Williamsburg, el joven erudito era experto en obras clásicas, capaz de leer a autores griegos e incluso obras en latín.

Dumas Malone, biógrafo de Jefferson en el siglo XX escribe: "La época de estudiante de Jefferson en Williamsburg es la historia de la primera floración de una mente extraordinaria". Como estudiante de William \& Mary, el joven Jefferson tenía una gran capacidad observativa y receptora para ser enseñado por los líderes de la colonia, poco después, él tomaría un lugar relevante entre ellos.

Estuvo alojado en el edificio de Wren, donde su estancia se prolongaría durante cinco años. Uno de sus profesores fue el distinguido jurista George Wythe, que se convertiría en el primer profesor de derecho del colegio. Cabe destacar que entre sus 
profesores tuvo a William Small, un escocés que había sido educado en el Marischal College en Escocia. Quizá éste documentó a Jefferson acerca del modelo inglés de college.

Desde el principio, el edificio de Wren había sido concebido como un edificio en forma de cuadrilátero, cuyos lados rodean un patio central. En 1732, tres de sus cuatro lados se habían construido. En 1772 John Murray, cuarto Conde de Dunmore y el último gobernador real de Virginia, en su calidad de Rector de la Junta de Visitantes, pidió a Jefferson que diseñara una adición al colegio debido a la necesidad de nuevas dependencias. El plan de Jefferson proponía duplicar la longitud de las alas de la capilla y el gran hall, además de completar el cuadrilátero con una nueva ala oeste. Planteaba que la galería porticada existente se extendiera a lo largo de los cuatro lados del atrio interior.

El programa y distribución se conoce gracias a unos planos de 1772 donde se muestra la distribución interior del colegio, primero supuestamente moldeada por Sir Christopher Wren y posteriormente reconstruida, y muy bien ideada por el Gobernador Alexander Spostwood. Estos planos estaban dibujados, según el propio Spostwood por Thomas Jefferson, alumno durante varios años en este colegio. Se muestra la ubicación de las puertas y ventanas, las dimensiones y denominaciones de las habitaciones. Se puede apreciar también características de los acabados como son los "muros encostrados", el artesonado, el "plegado de las puertas", ventanas de guillotina y persianas interiores.

En el edificio de Wren, segundo edificio, el programa se desarrolla en tres plantas:

Planta semisótano: cocina, almacenes y bodega.

Planta baja: Gran salón, Logias Exteriores, Habitación Azul y Sala de Secundaria y capilla.

- Gran salón: Tiene doble altura y ocupa toda la la planta baja del ala noroeste. La altura del techo es igual a la anchura del bloque. Posteriormente fue dividido en dos plantas, fue alrededor de 1836. Durante el siglo XVIII tuvo varias denominaciones como "gran salón", "gran sala" o simplemente "Hall". Esta ala norte fue diseñada albergar el comedor o refectorio. Antes de que se construyera el ala noroeste en 1732 el salón sirvió como como capilla improvisada, Los exámenes de carácter público se realizaban en esta sala. Tenía aforo 
para 100 personas. Estaba amueblada con largas mesas y bancos fabricados en Virginia a base de madera autóctona.

Al igual que sucedia en los colleges ingleses, se decoraban las paredes con retratos de benefactores o personajes ilustres.

Este salón es de forma muy similar al salón del Hospital de Chelsea, por lo que es otro punto a favor de la autoría del diseño del edificio hacia Wren, que también hay mucha similitud en el revestimiento de madera, versión simplificada de la artesanía de madera del Hospital de Chelsea.

Las ventanas son de arco, y están repartidas a lo largo de los dos muros de mayor longitud. En el muro oeste hay dispuestas varias ventanas de ojo de buey, la más grande está dispuesta encima de lapuerta oeste, que vincula la sala al exterior.

Capilla: Es la construcción de la tercera y última parte del Edificio de Wren, se inició en junio de 1729. Fue destinada principalmente a los servicios de adoración diaria dentro del colegio y para aumentar la educación y preparación de los estudiantes de teología. Los estudiantes tenía asistencia obligatoria una vez al día, normalmente a las 7.00 de la mañana en invierno y a las 6.00 en verano. Tenía una capacidad aproximada para albergar a 100 personas.

Era muy similar al Gran Salón, eran prácticamente iguales, en forma y detalles arquitectónicos. Sólo se diferenciaban en que se desarrollaban actividades de carácter religioso en ésta $y$, estaba provista de un altar, por lo demás, de dimensiones y forma análogas. El altar estaba situado al nivel del resto de la planta del edificio, mientras que el resto del suelo estaba a un nivel medio metro inferior. El pavimento de la zona central es de pizarra de Buckingham mientras que los laterales son de madera de pino.

Los muros exteriores son de ladrillo, cubierto con malla de acero y yeso por encima del friso.

Esta capilla posee una galería típica en iglesias de Virginia del siglo XVIII. Está soportada por cuatro columnas corintias de proporciones clásicas y coronada por un entablamento completo.

El retablo se asemeja mucho al de la Capilla del Hospital de Chelsea, sólo cambia en que en lugar de pilastras son columnas. El zócalo es idéntico también al del citado hospital. El retablo está elaborado con la combinación de pino y de nogal, igual que en la Capilla del Christ Church de Oxford. También la disposición de los bancos está realizada como era costumbre en los colegios ingleses, situados frente al pasillo central. El disño de los bancos es idéntico a los que hay en la Capilla del Trinity College de Oxford. 
- Sala de Secundaria (Grammar School Room): Situada al norte del vestíbulo de entrada. La sala e gamática es una escuela preparatoria para los varones jóvenes entre edades aproximadas de 12 a 16 años. Es de las de mayor tamaño del colegio. Sus dimensiones son comparables a las del gran Salón y la Capilla. Tiene cuatro ventanas en la pared este y dos ventanas en el lado oeste con vistas a la zona posterior donde están las logias y la plaza. La chimenea está ubicada en el centro de la pared norte. Hay dispuesta una puerta de entrada doble en la esquina suroeste.

Planta $1^{\mathrm{a}}$ :

- Corredor/Distribuidor: Tiene las mismas dimensiones que las logias de la plaza de planta baja. Se encuentra en la zona situado a orientación oeste de la planta.

- Habitación azul: está ubicada en el extremo norte. Está superpuesta por encima de la Sala de secundaria, con lo cual tiene las mismas dimensiones. Está amueblada con una gran mesa central en torno a la cual se organizan una serie de sillas revestidas de cuero. A principios del siglo XVIII la habitación fue denominada como la "sala de la convocatoria" o "sala del consejo".

- Sala Común: Se unió a la sala Azul en el siglo XVIII. Esta sala servía de reunión para los altos cargos del colegio, más tarde, pasó a albergar reuniones de carácter más informal. Este tipo de sala viene "importada" de los colleges de Oxford y Cambridge, donde eran muy frecuentes. Estaba situada justo encima del aula de Filosofía Moral.

Biblioteca

Planta $2^{\text {a }}$ y bajo cubierta: Dormitorios de los estudiantes y profesores.

En 1732 se terminó la capilla, situada en el ala sur.

Los planos para completar el quadrangle se hicieron alrededor de 1772. Thomas Jefferson elaboró un plano en el que se mostraba la adición de una planta de piso.

En los interiores cabe resaltar que los suelos estaban revestidos de madera de pino amarillo, a excepción de la capilla, bodega, claustro exterior y la entrada al Gran salón. Los techos estaban revestidos de yeso, el cual contenía en su composición conchas trituradas, arena y agua, lo que le aportaba una textura característica. Todo el revestimiento de yeso está pintado de blanco con un producto que 
simula cal. En muchas de las habitaciones el yeso está tintado para asemejarse al color de la carpintería.

El Edificio de Wren se quemó en mayo de 1859 por segunda vez y la reconstrucción del mismo se elaboró, una vez más, a partir de la antigua trama, siguiendo las trazas de los antiguos muros. Un tercer incendio arrasó el edificio en 1862, cuando soldados de "La Unión" acantonados en Williamsburg le prendieron fuego. Entre 1928 a 1931 el edificio de Wren fue restaurado y devuelto a su aspecto colonial por parte de la fundación Rockefeller, que en la misma época estaría subvencionando edificios, en España, pertenecientes a la Ciudad Universitaria de Madrid.

A finales del siglo XVIII algunas de las habitaciones del segundo piso se dedicaron a aulas y a salas de reuniones de la sociedad estudiantil.

Se hicieron algunos pequeños retoque que no modificaban sustancialmente la forma del edificio, simplemente se reorganizaban usos. Ya en el siglo XIX se hicieron importantes reparaciones. El interior fue renovado en gran medida y la cubierta fue rehabilitada por completo durante 1855 y 1856 . Estas reformas fueron sobre todo interiores, no alterando la imagen exterior del edificio.

En general, el estilo de este edificio sigue siendo una forma principalmente medieval, típica del Renacimiento Inglés. Su planta cuadrangular, aunque abierta, es muy similar a la de los colleges ingleses. Una vez ejecutado, es de los primeros edificios de esta forma en la américa colonial británica, similar a la del Antiguo Colegio (Old College) de Harvard. Esta obra se convierte en el heraldo de un nuevo tipo colegial estadounidense, que con su diseño abierto en forma de $U$, fue junto con el Old College el modelo de transición del patio cerrado, vinculado con el monasterio y época medieval, al modelo abierto que empezará a denominarse campus estadounidense.

De igual manera, el edificio de Wren ejemplifica un nuevo tipo de edificio colonial. Establece un estilo adecuado a su función partiendo de una forma doméstica $y$, termina por convertirse en el modelo de otras edificaciones de instituciones públicas, cuyo primer ejemplo son los colleges de la universidad de Yale. 

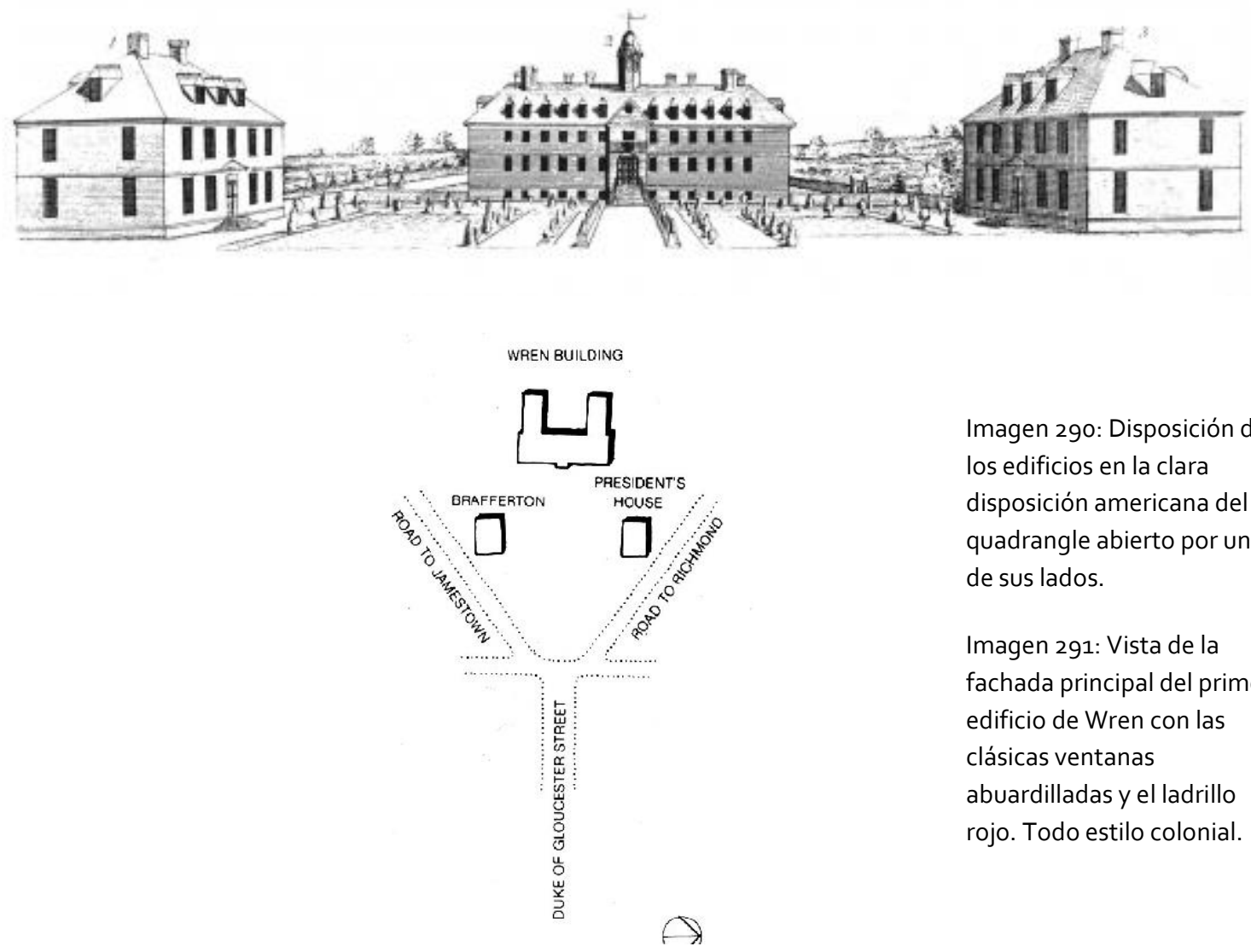

Imagen 290: Disposición de los edificios en la clara disposición americana del quadrangle abierto por uno de sus lados.

Imagen 291: Vista de la fachada principal del primer edificio de Wren con las clásicas ventanas abuardilladas y el ladrillo rojo. Todo estilo colonial.

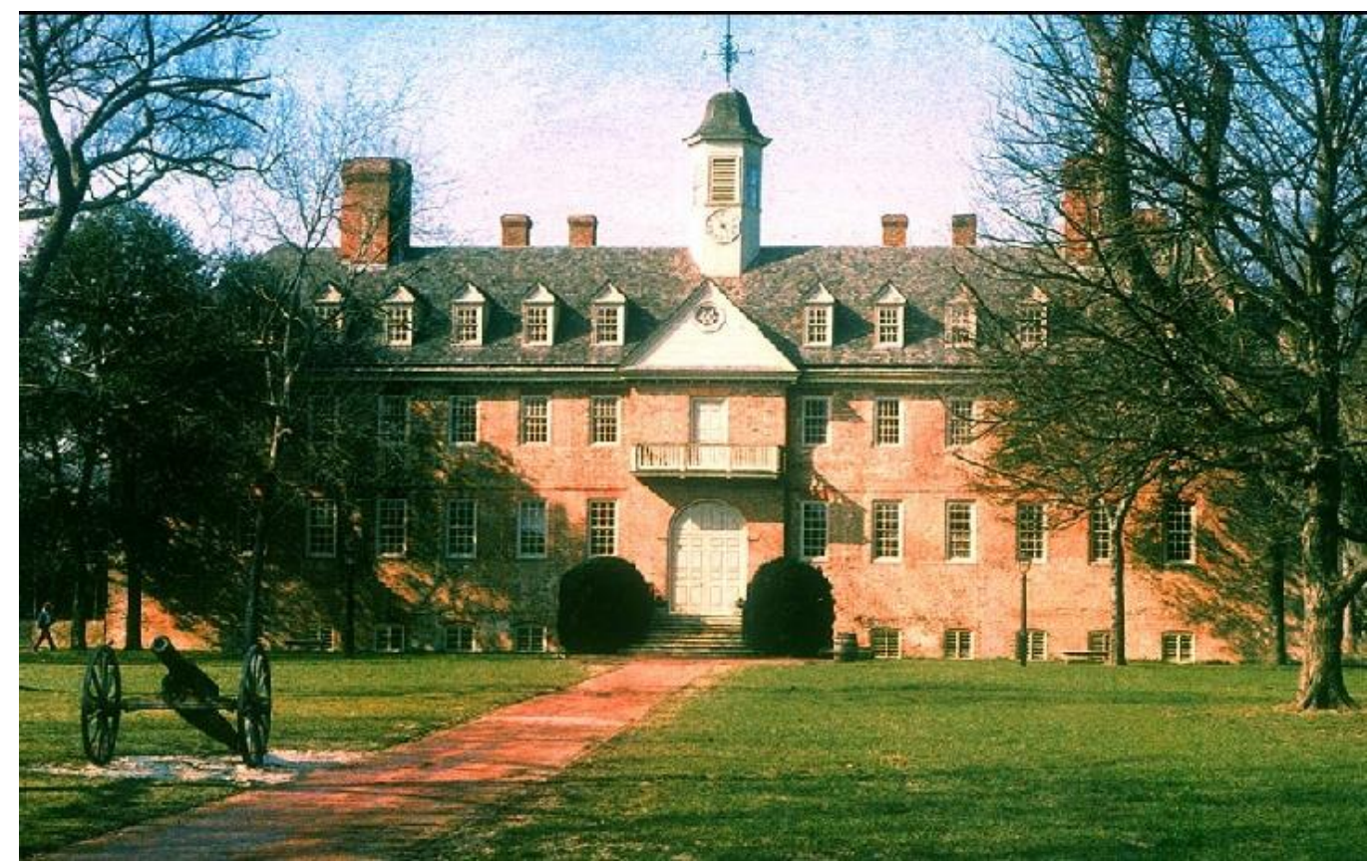




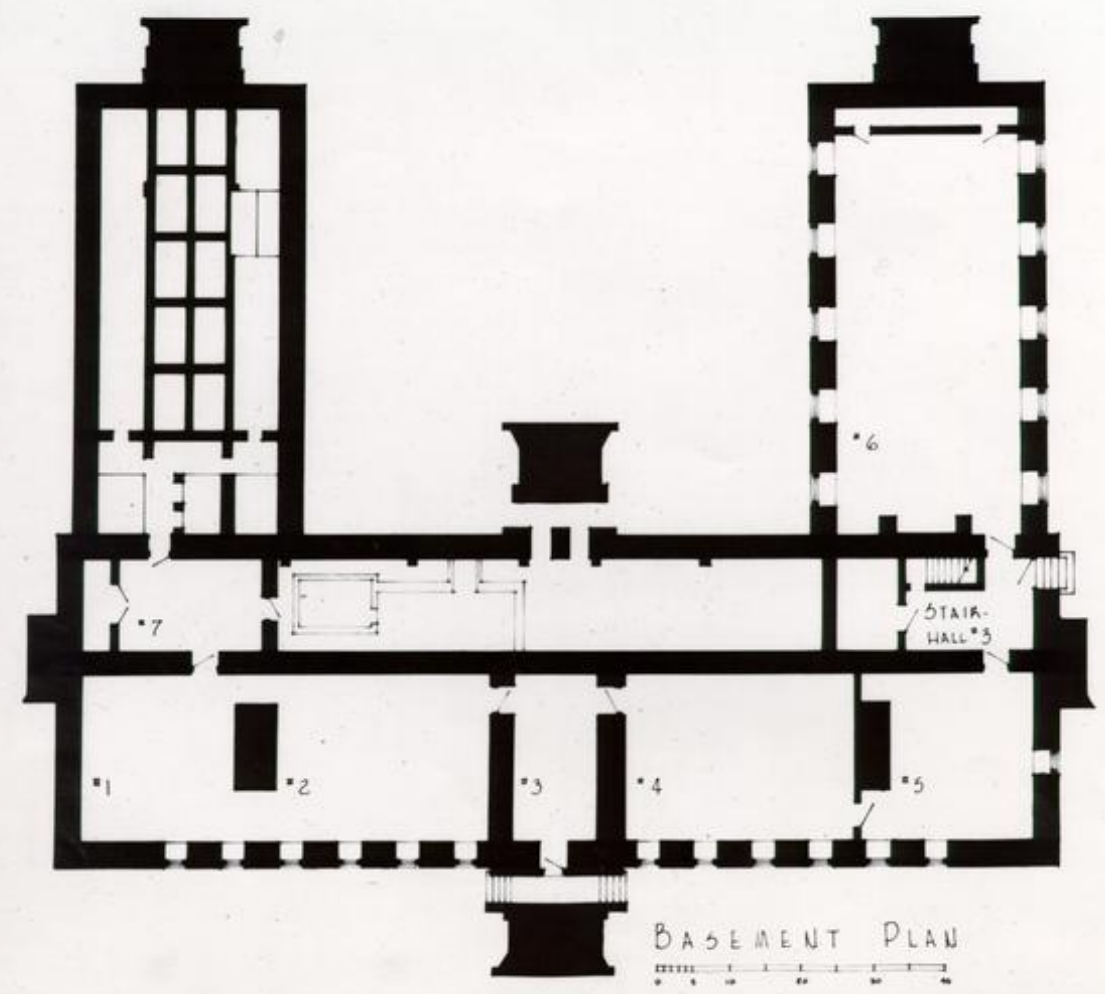

Imagen 292: Planta

semisótano

Imagen 293: Planta baja

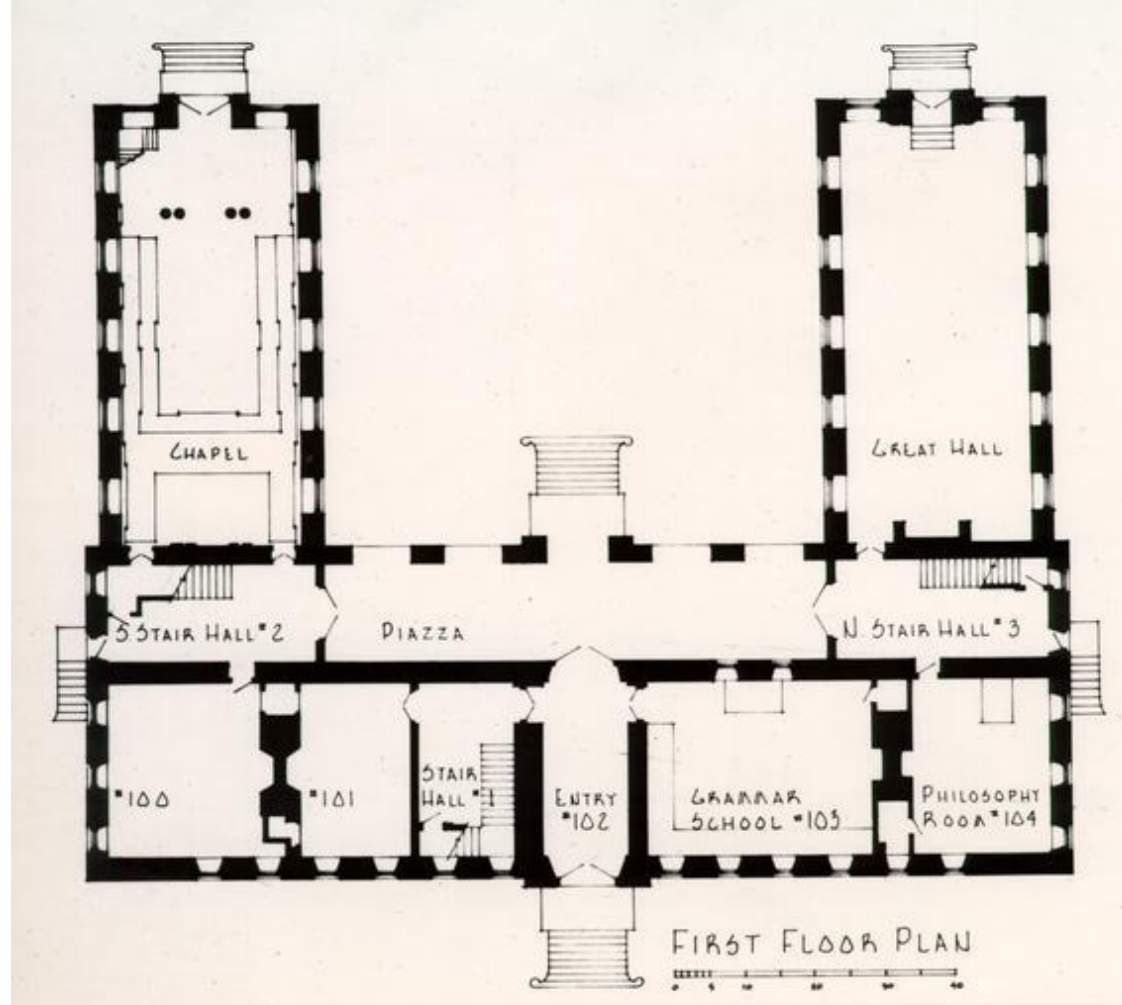



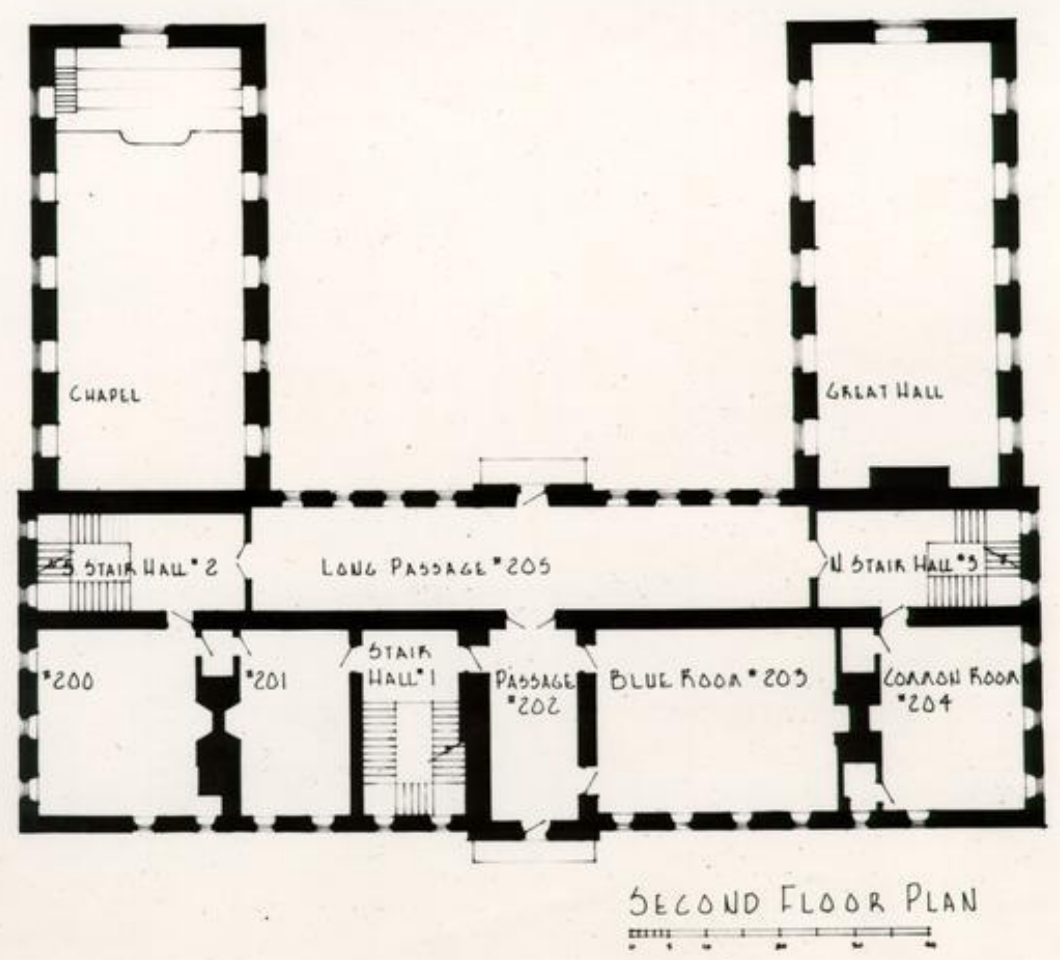

Imagen 294: Planta segunda

Imagen 295: Planta tercera

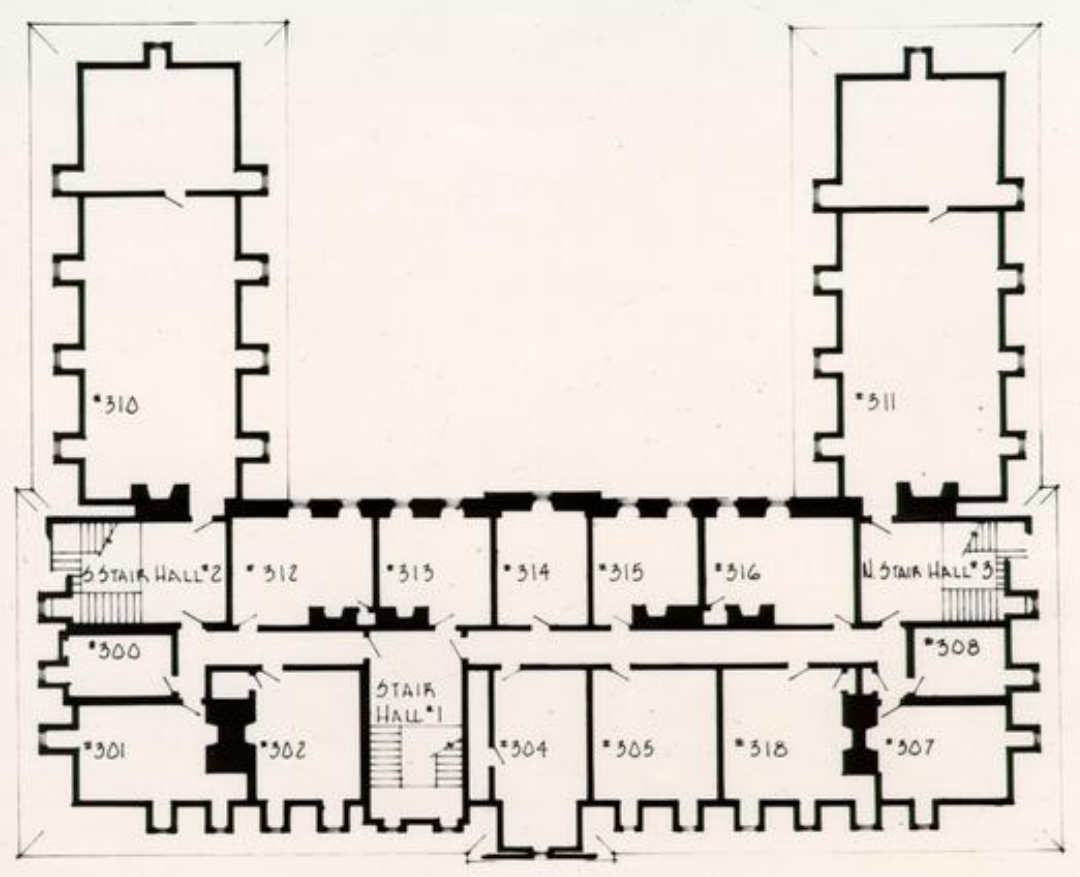

THIRD FLOOR PLAN 

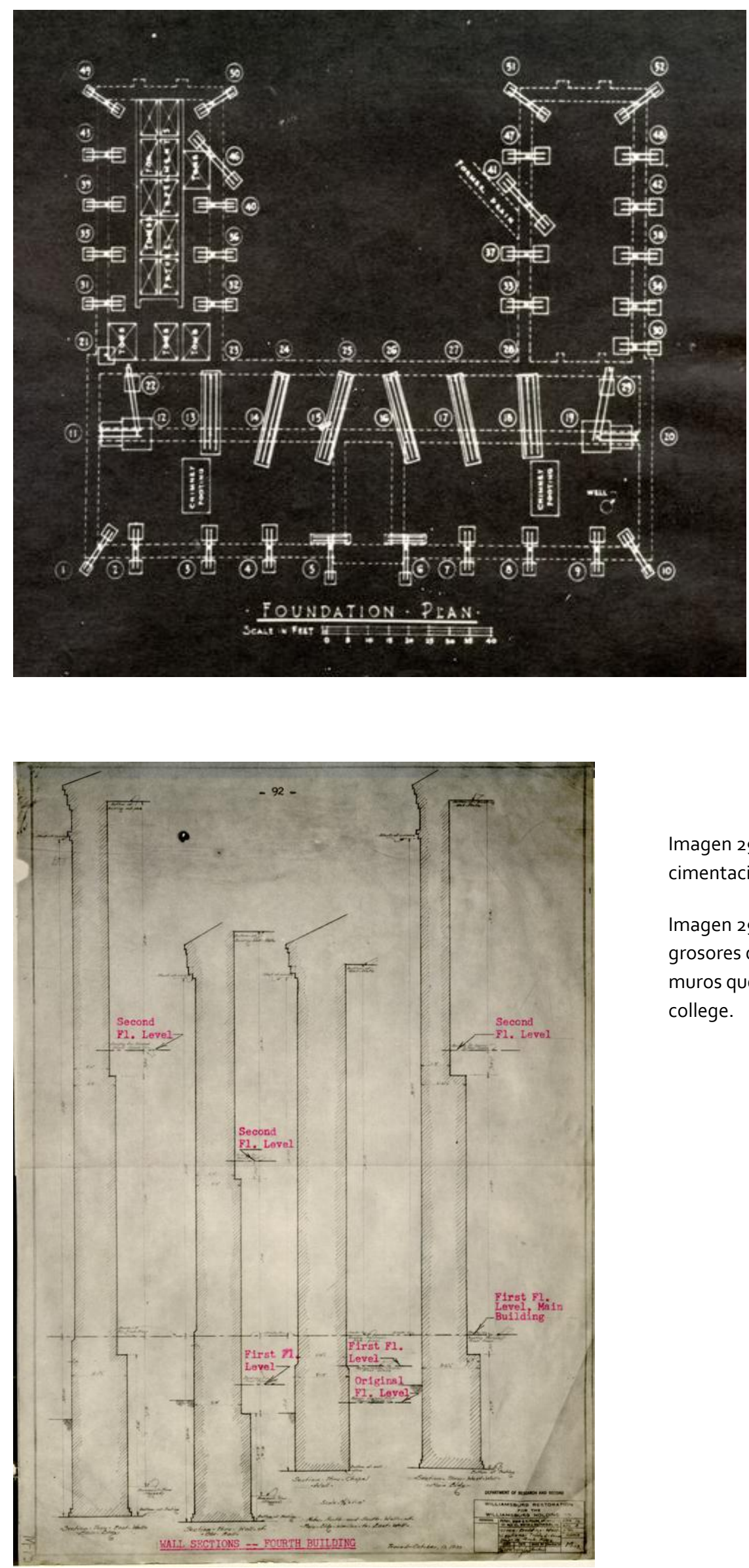

Imagen 296: Detalles de la cimentación del colegio.

Imagen 297: detalles de los grosores de los distintos muros que conforman el college. 


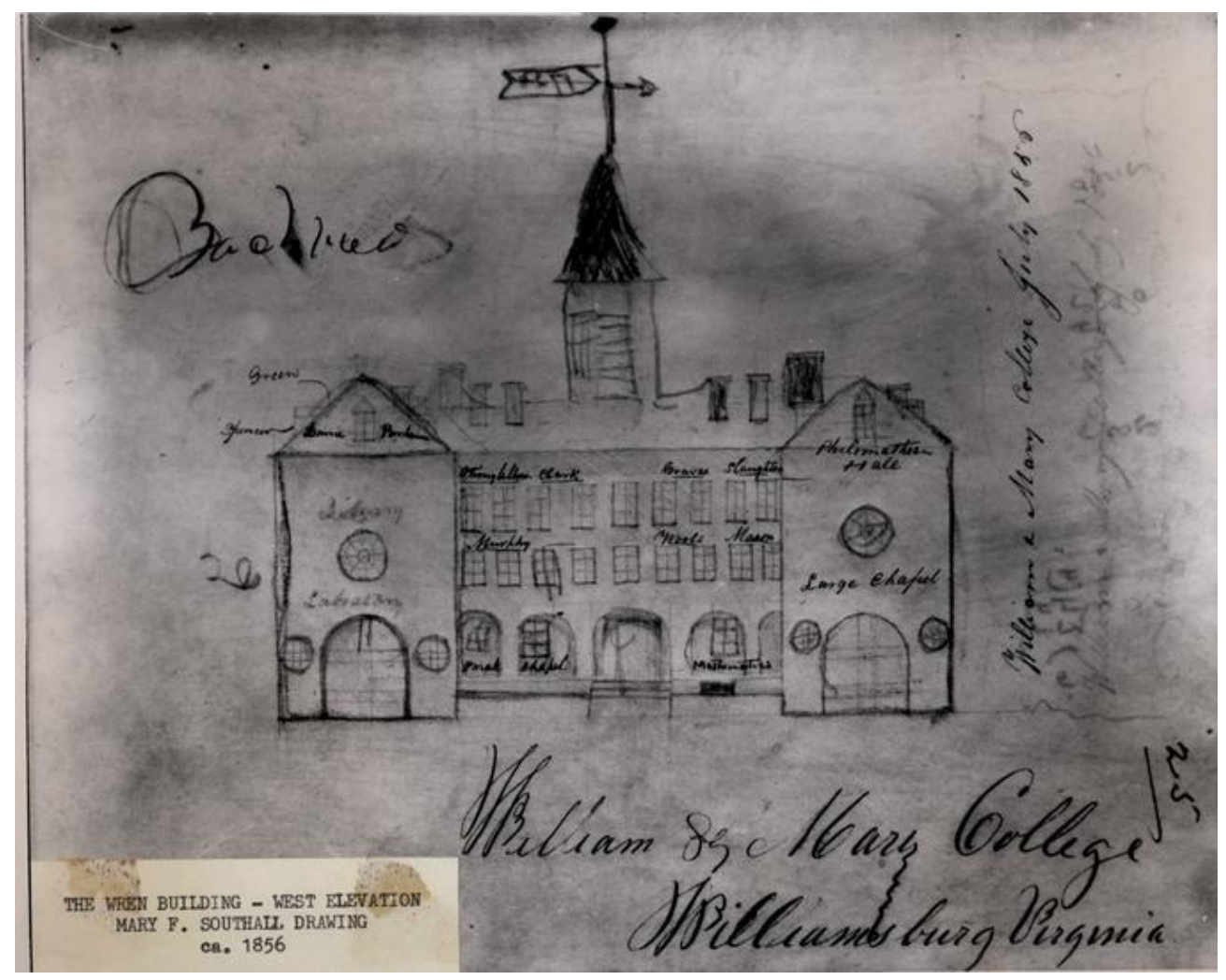

Imagen 298: Alzado oeste (posterior al principal), se aprecia la galería que recorre el perímetro, seguramente como herencia de los modelos claustrales ingleses. En este caso el claustro no llega a cerrarse, aunque Thomas Jeferson ideó un plan para cerrarlo.

Imagen 299: esquema de cubiertas y secciones del oclegio

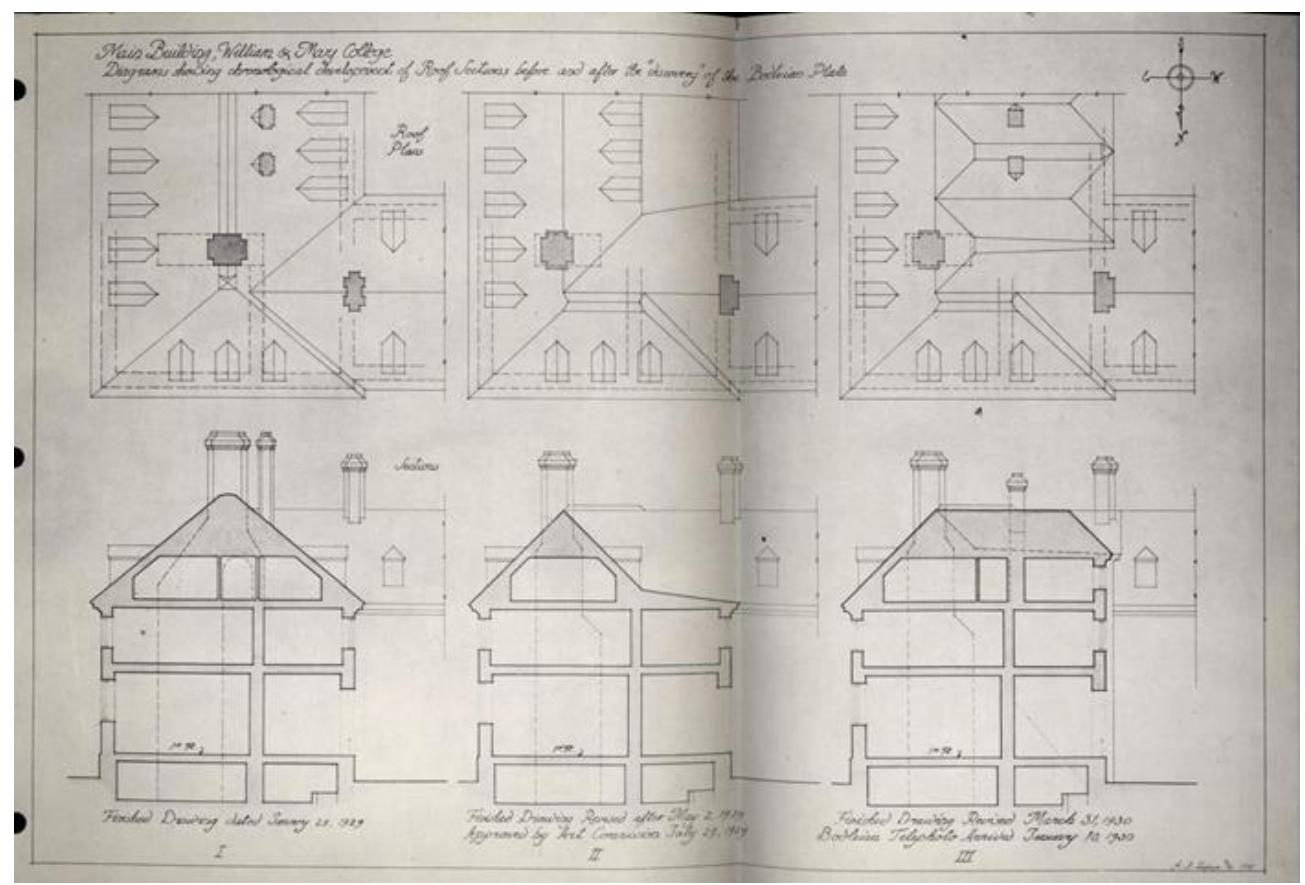




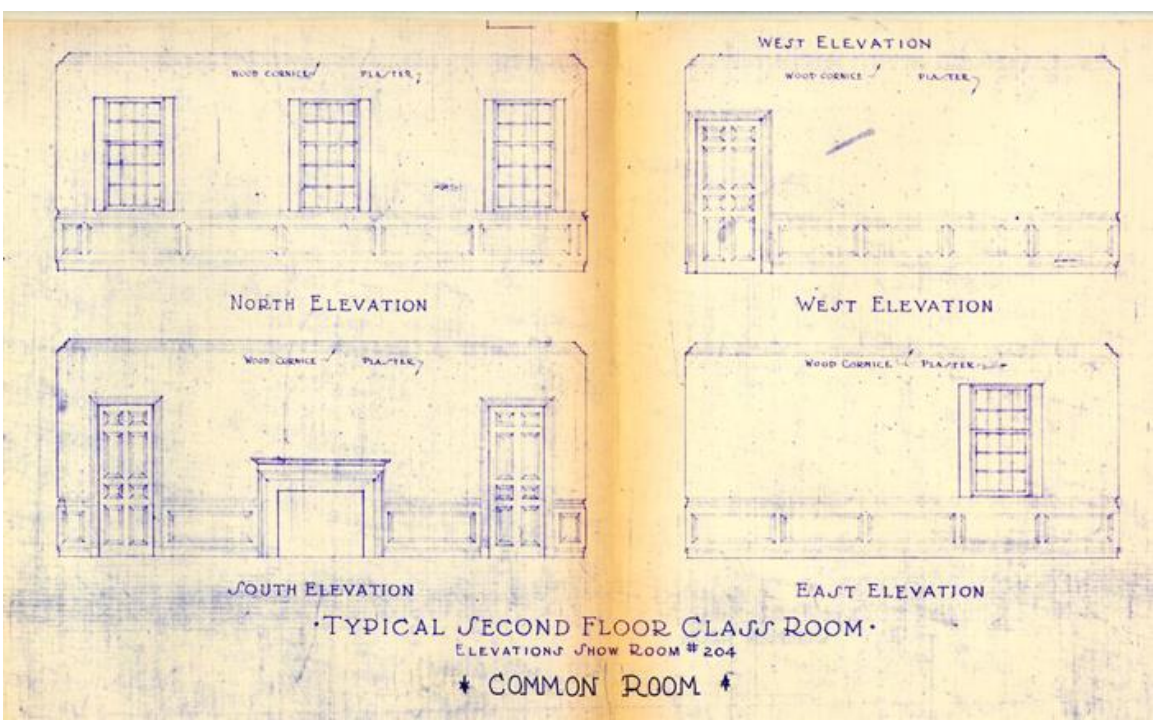

Imágenes 300 y 301 : Detalle sde los alzados interiores de las estancias comunes. Todos los espacios docentes estaban a un nivel exhaustivo de definición desde el proyecto.

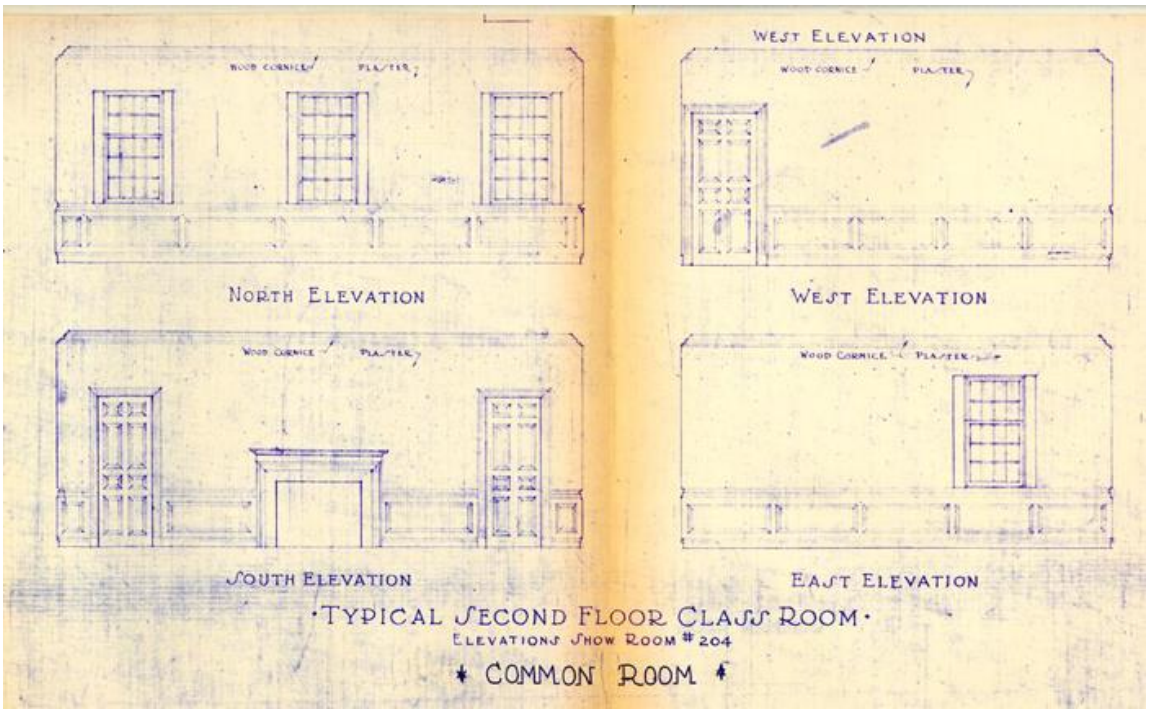




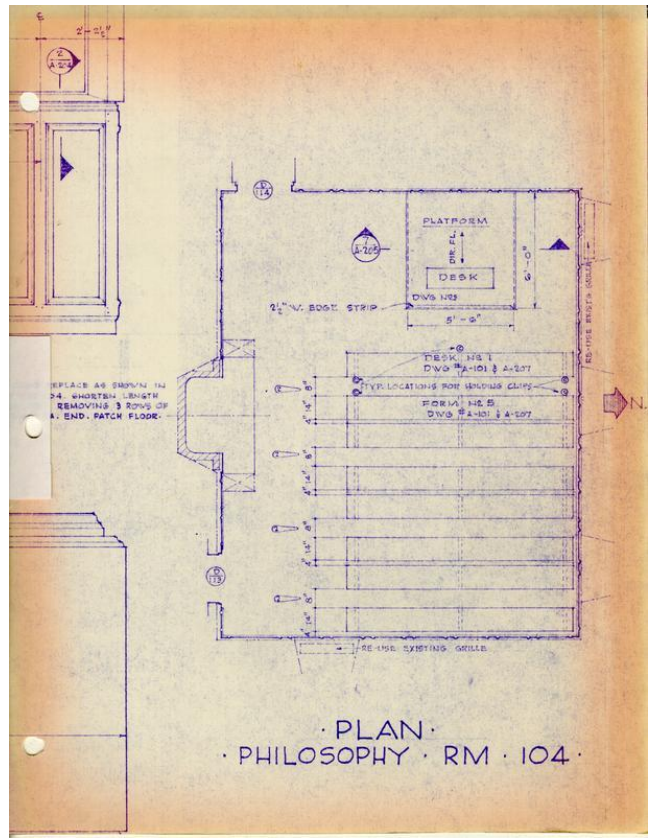

Imagen 302: Alzado oeste

(posterior al principal), se aprecia la galería que recorre el perímetro, seguramente como herencia de los modelos claustrales ingleses. En este caso el claustro no llega a cerrarse, aunque Thomas Jeferson ideó un plan para cerrarlo.

Imagen 303: Vista de la School Room. En las distintas plantas se intercalan las aulas docentes con las habitaciones de los estudiantes.

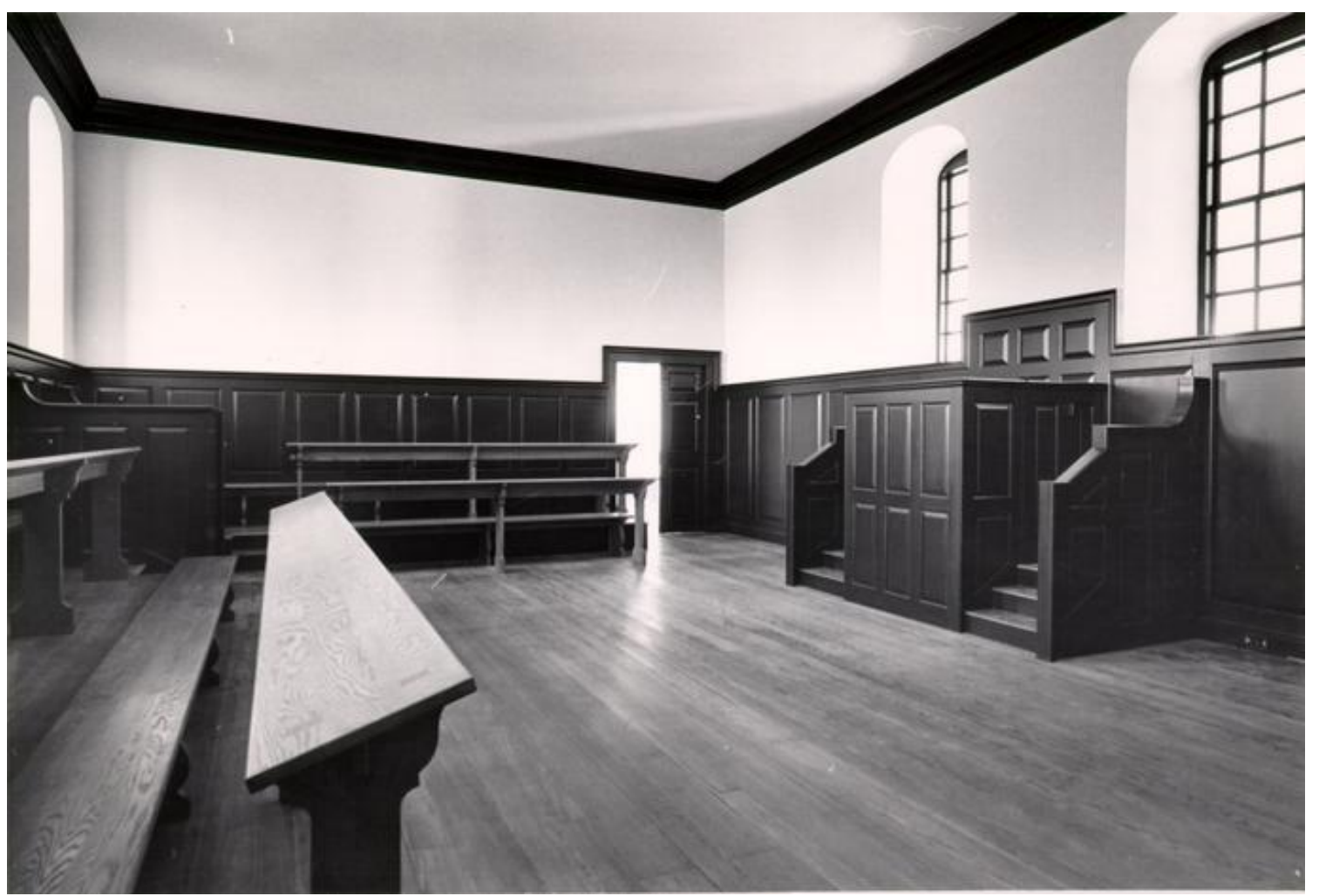




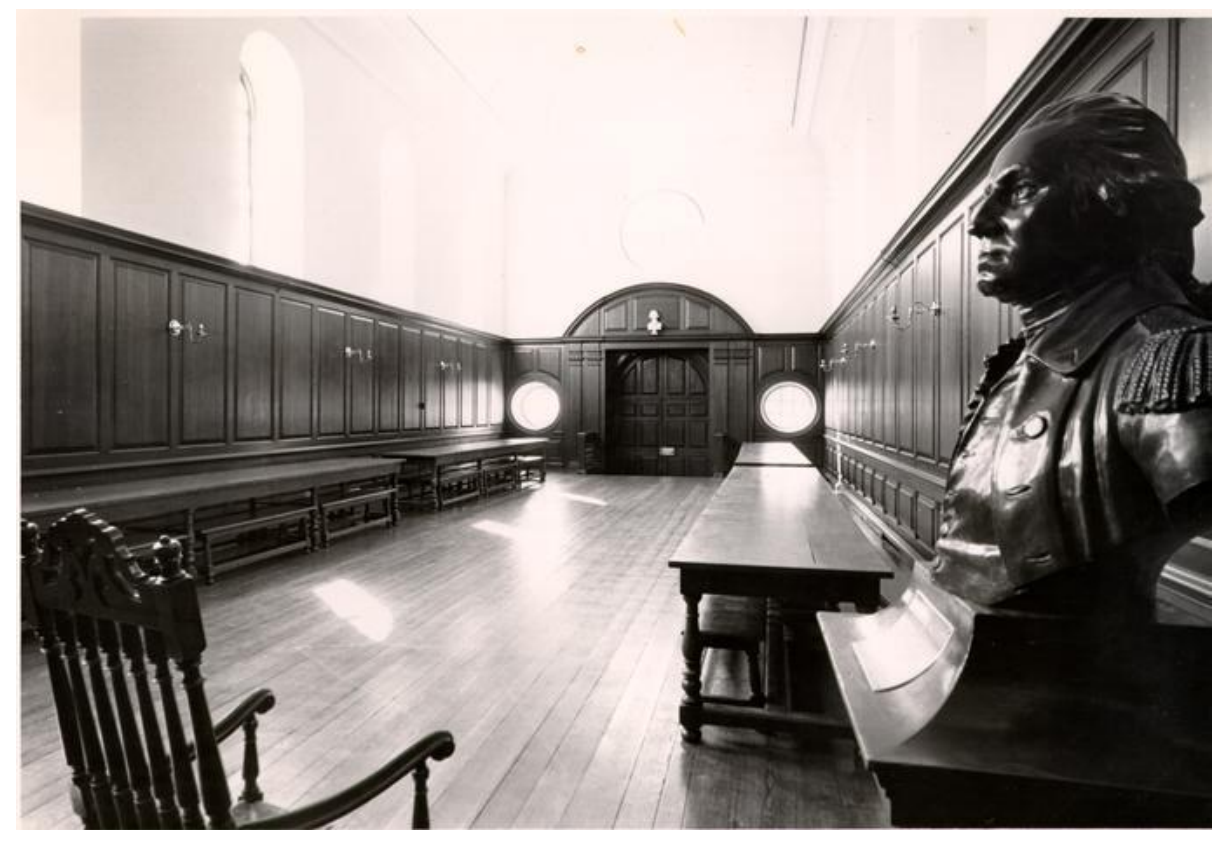

Imagen 304: Vista del Great Hall, esta estancia es, probablemente, herencia de los colleges de Oxford.

Imagen 305: Vista de la School room. En las distintas plantas se intercalan las aulas docentes con las habitaciones de los estudiantes.

Imagen 306: Segundo edificio de Wren.

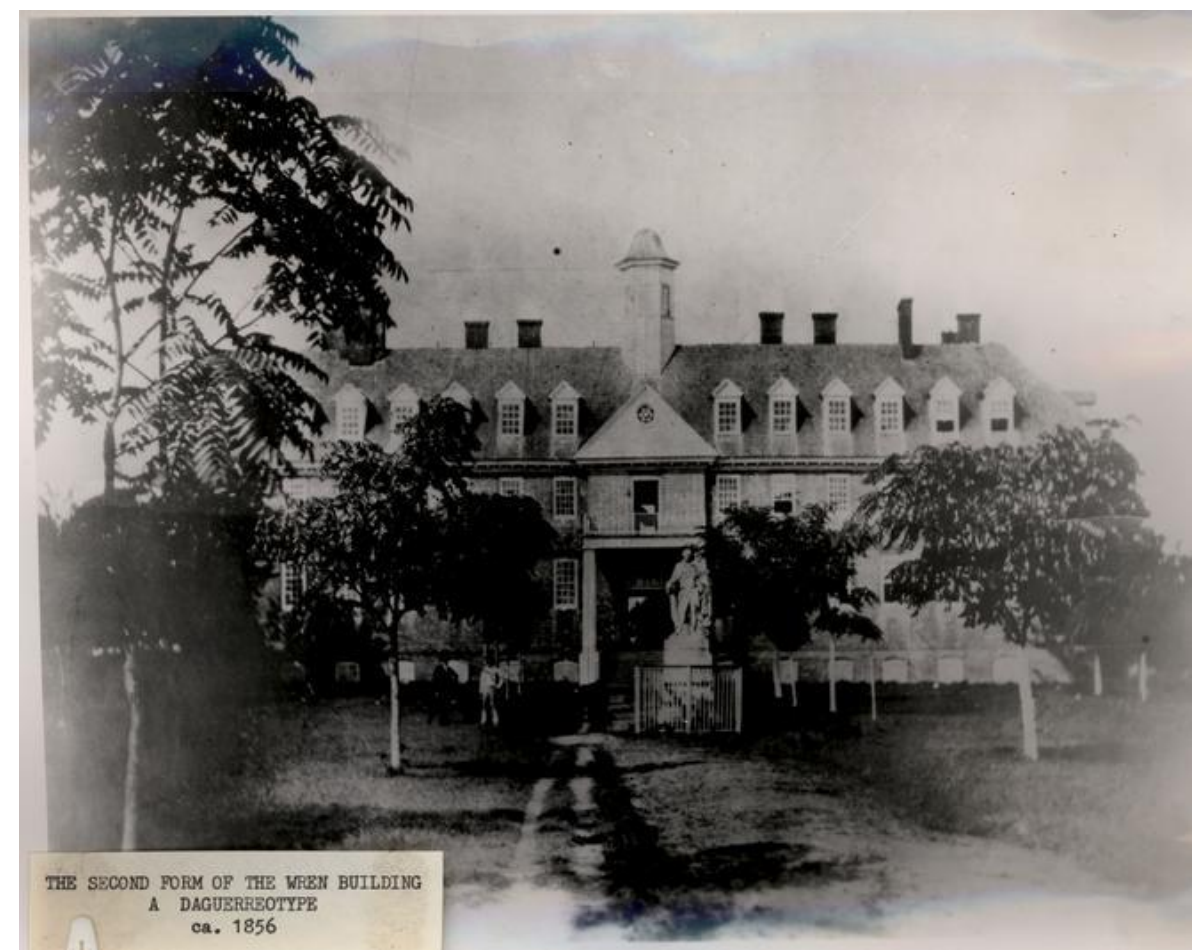




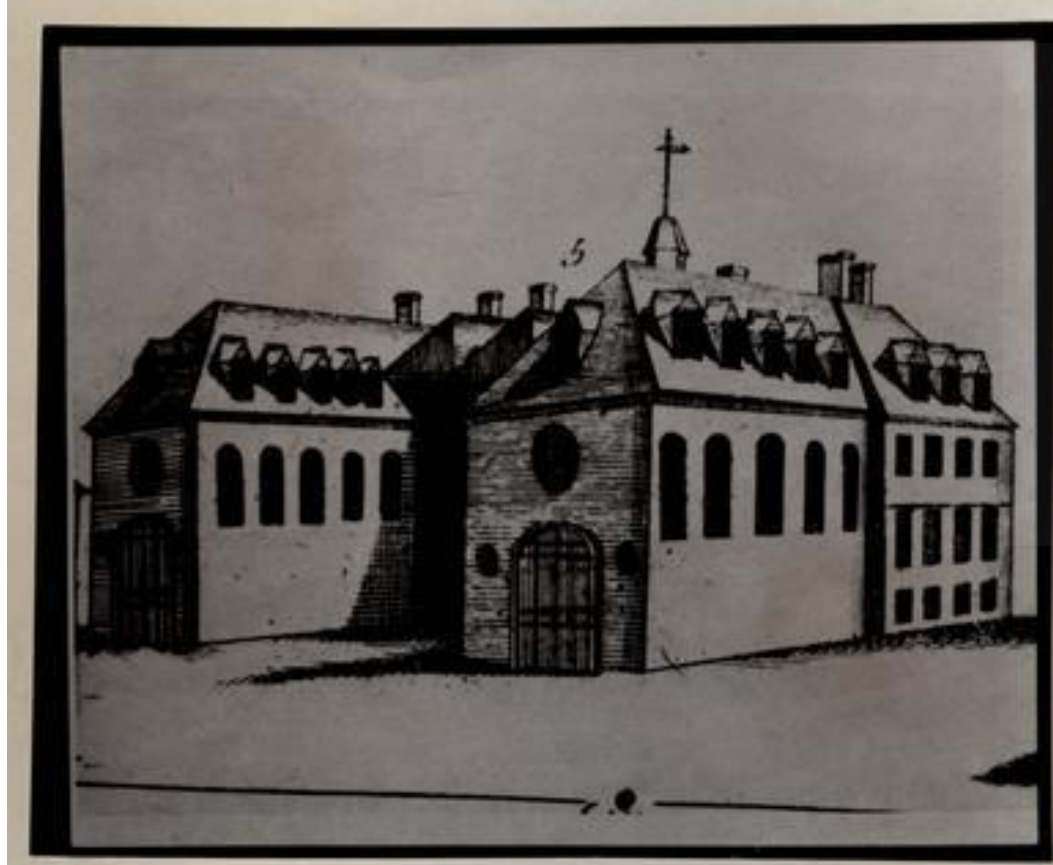

Imagen 307: Alzado posterior del segundo edificio de Wren (1740)

Imagen 308: Propuesta de Jefferson para cerrar el perímetro del colegio en formando un claustro central en 1755 .

THE SECOND BUILDTNG - WEST BLEVATION

ENLARGEMENT FROM THE BODLEIAN COPPBRPLATE ca. 1740

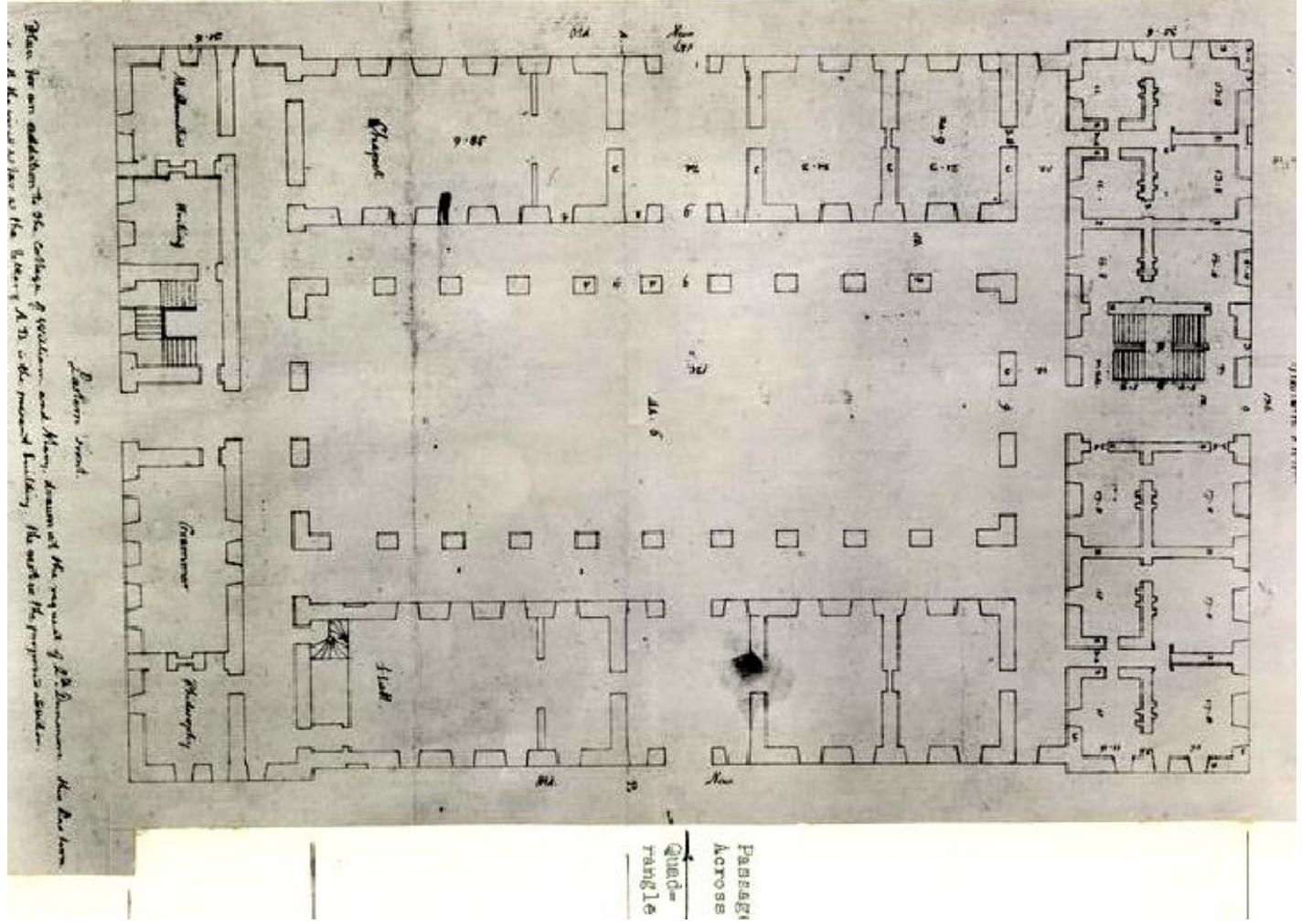




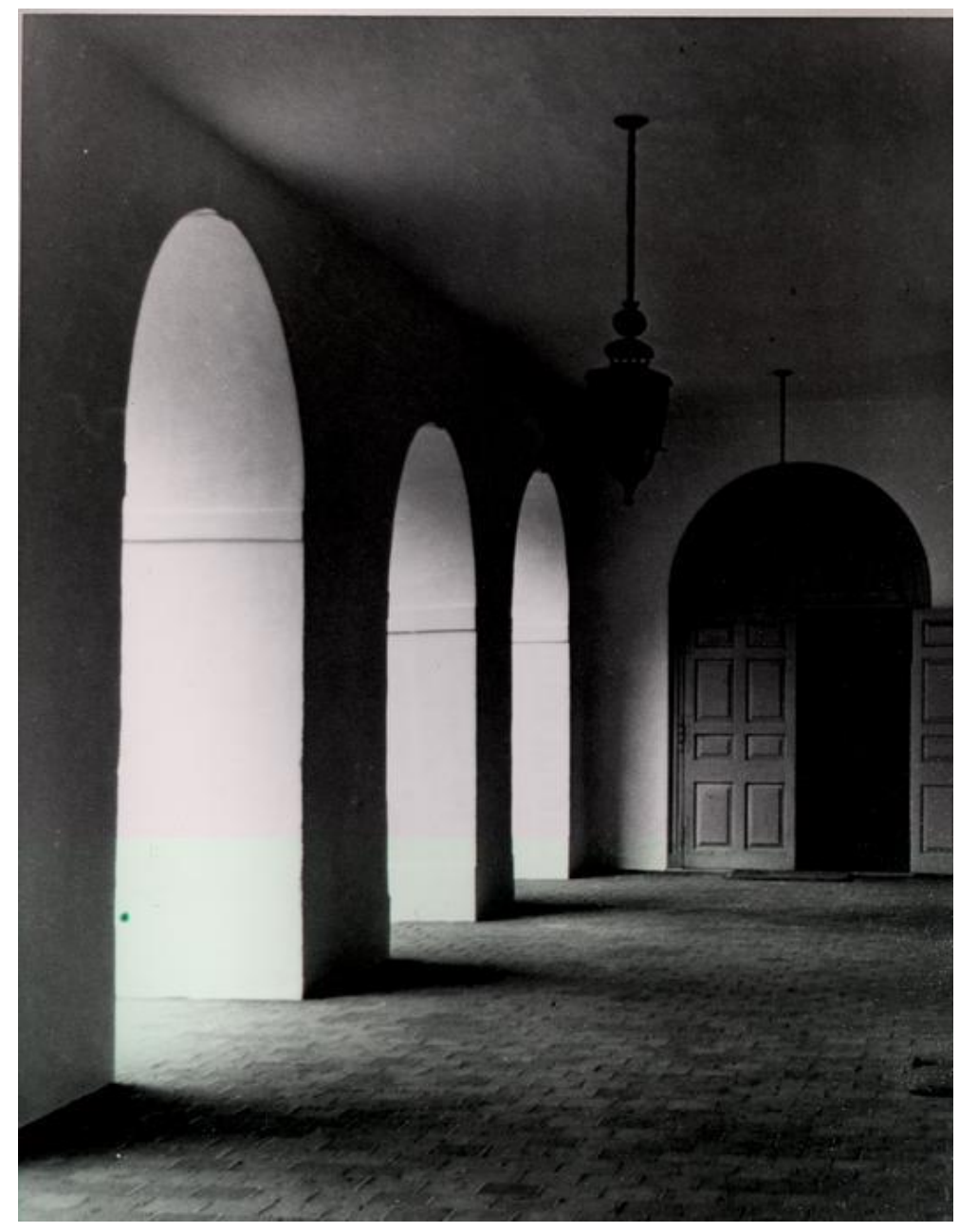

Imagen 309: logias

pertenecientes a la galería de la parte posterior del college. Produce unos recorridos perimetrales de las estancias como en los colegios ingleses. 


\section{PABELLONES RESIDENCIALES DE LA UNIVERSIDAD DE VIRGINIA.}

\section{Una intención de heterogeneidad.}

La educación era un factor clave para Thomas Jefferson, a través de ella se conseguía la supervivencia del Nuevo Mundo. Criterios que dejó reflejados a través de La Carta de Independencia que él mismo había ayudado a consolidar en 1776. Argumentaba que si el pueblo tenía cultura podía discernir y podía distinguir todas las formas de tiranía y, de esta manera, evitar sus caracteres o cualidades destructivas. Con este propósito, defendió un completo sistema de educación pública para Virginia y alcanzó el culmen en su obra con la creación de la Universidad de Virginia y la "Ciudad Universitaria" que diseñó para albergar esta institución.

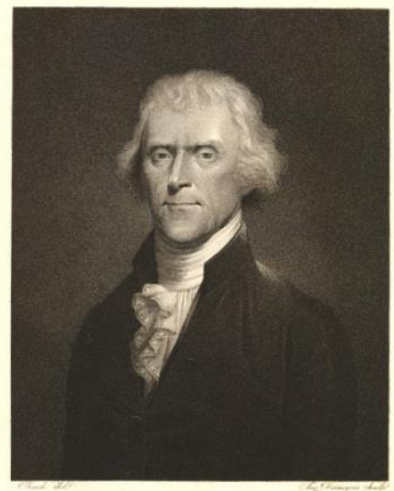

La formación de Jefferson ${ }^{154}$, que siguió el modelo educativo típico de las familias de terratenientes de la Virginia del siglo XVIII, comenzó en su propia vivienda con un profesor que le daba clases particulares. A la edad de nueve años, asistió a una escuela de latín y unos años más tarde adquirió amplios conocimientos sobre los clásicos, en un colegio del Condado de Albemarle. A la edad de 17 años, se matriculó en el College de William \& Mary, donde descubrió la filosofía de la llustración de la mano del profesor William Small155.

La disciplina arquitectónica la comenzó a adquirir Jefferson desde Williamsburg. En sus años aún como estudiante, compró a un ebanista un tratado sobre arquitectura clásica, justo a las puertas del College. De este modo inició su carrera a la que dedicaría sus esfuerzos durante el resto de su vida ${ }^{156}$. Esta afición atrajo la atención de Lord Dunmore, gobernador de la Colonia Británica e Virginia que, en 1771, pidió a Jefferson que diseñase, como se ha apuntado en el capítulo anterior referente a este colegio, un anexo al edificio de Wren. El proyecto de Jefferson se basaba en la tradición europea; de hecho, cuando se inició la construcción en 1695, la intención original era completar la disposición cuadrangular del College. Aunque, como se ha dicho anteriormente, nunca se completaría el patio interior debido a problemas de financiación. Su diseño de un quadrangle con una arcada interior dispuesta alrededor de un patio al aire libre reaparecerá en muchos de sus proyectos posteriores y se va a convertir en un ingrediente primordial en su diseño de la Universidad de Virginia.

El propio Jefferson expresó de manera inmejorable el origen de la idea de educación pública en Virginia cuando recordó las normas enmendadas que Whyte, Edmund Pendleton y él mismo habían preparado para Virginia en 1776-79: "Nadie puede poner en duda mi 
entusiasmo por la instrucción general de la gente. ¿Quién puso en marcha por primera vez esta idea? Puedo decir con certeza que he sido yo mismo. Tengan en cuenta el proyecto de ley del código enmendado que redacté hace más de 40 años, y anterior al cual, por lo general, nunca se había propuesto en este estado la idea de un proyecto para educar al pueblo." 157

La idea a de crear una universidad en Virginia no surgió de forma inmediata. Los administradores locales que dependían directamente de la Asamblea Legislativa de Virginia encargaron a Jefferson un proyecto para una academia en la zona, la cual albergaría una escuela de secundaria. Jefferson tenía redactado un "Proyecto de Ley para una Mayor Difusión del Saber" que lo definía el mismo como su "quijotismo"158. Estaba estructurado en tres niveles educativos: Las escuelas elementales (nivel primario), las escuelas de distrito (nivel secundario) y la universidad. Proponía una educación subvencionada por el Estado en primaria y además, tenía en mente dotarla de un carácter residencial, creando lo que denominaba una casa-escuela.

También dejaba bien definido que las escuelas de secundaria también debían estar provistas de residencia para profesores y alumnos. Dejaba bien claro cuál debía ser su programa, de qué debían estar provistas en cuanto a departamentos y estar construidas a base de ladrillo o piedra. Contendrían una estancia destinada a aula, otra a sala-comedor, cuatro estancias para maestros y un encargado y diez o doce habitaciones para alojar a los alumnos $^{159}$. En cuanto a los niveles universitarios, no tenía una forma constructiva definida y destinaba su función al Colegio de William \& Mary. Jefferson no conseguiría su sueño de ver escuelas públicas ni tampoco que fuese en parte subvencionado en Colegio de William \& Mary.

Volviendo al tema de la propuesta que presentó para la Academia, el diseño constaba de 9 pabellones idénticos flanqueados por 10 dormitorios a cada lado, situados alrededor de las 3 caras de un cuadrado y comunicados por pasillos cubiertos. En cada uno de estos pequeños pabellones Jefferson dispuso una sala en planta baja destinada a instrucción y dos habitaciones superiores para alojamiento de profesores. La parte delantera de los dormitorios los planteó con una serie de estribos de ladrillo cuadrados rematados con una reja que recordaba al tratamiento de las alas de su vivienda de Monticello. Jefferson explicó que su proyecto era susceptible de ampliación, bien en sí mismo o mediante el añadido de anexos, ya que estaba adaptado a las condiciones económicas del momento. 
Teniendo en cuenta su idea sobre un ideal educativo distribuido en tres niveles, puso de manifiesto que la Academia comenzaría impartiendo el nivel general o secundario, y cuando fuese posible se ampliaría al nivel superior universitario. Enumeró 9 cátedras, una por cada nivel, y cada uno de ellos en su pabellón correspondiente. Cabe destacar que en uno de éstos se albergarían estudios de Arquitectura ${ }^{160}$.

Su propuesta fue aceptada y, el mismo fue participe para encontrar cual sería el mejor emplazamiento para ubicarla. Todos sus esfuerzos se centraron en convencer a los administradores de que ese sitio debía ser Charlottesville.

Posteriormente Jefferson solicitó a los Administradores Locales que solicitasen a la Asamblea Legislativa de Virginia un cambio en el nombre de la Institución, fue aceptado y pasó de llamarse Academia Abemarle a Central College.

En el diseño, descartaba hacer una "gran casa" o "grandes casas" estando o no agrupadas como lo que se había venido construyendo hasta ahora en esta zona estadounidense ${ }^{161}$.

Impulsó su diseño en base a la seriación de pabellones y éstos estuviesen interconectados. Defendía que era mejor una casa sencilla y pequeña para la escuela y el alojamiento de cada profesor. Introducía la mejora de que éstas estuviesen conectadas mediante caminos también cubiertos que llevarían a las habitaciones de los estudiantes, y el número de ellas se construiría en función de la necesidad de alojamiento.

Estaba claro que lo que había Jefferson había presentado para la Academia Abemarle era un proyecto de universidad. Al describir los pabellones, sin embargo, mencionó por primera vez una función didáctica: "La exposición de un modelo arquitectónico de las formas más puras de la antigüedad, proporcionará a los estudiantes ejemplos de los preceptos que se les enseñará en ese arte ${ }^{\prime \prime 162}$.

Para entender el deseo de Jefferson de construir modelos de arquitectura antigua, se necesita tan solo saber que lo mismo que había recogido material para ayudarse en la creación del mejor sistema educativo posible para Virginia, también había pasado las tres últimas décadas intentando reformar la arquitectura de Virginia. Creía que la mejor manera de mejorarla era mediante la educación y el ejemplo. Puesto que durante sus primeros años había pocos modelos arquitectónicos singulares en Virginia para servirle de inspiración, Jefferson recurrió a las publicaciones sobre arquitectura con el fin de cultivar sus gustos en diseño. Los libros que adquirió en primer lugar, tales como El Libro de Arquitectura y Reglas para diseñar 
las diferentes partes de la arquitectura de James Gibb, y varias ediciones de los Cuatro Libros de Arquitectura de Palladio, exponían la belleza y la armonía de la arquitectura antigua y los métodos que se debían seguir para recrear proporciones agradables. Para Jefferson, las mejores manifestaciones de estas reglas de gusto intemporales eran los imponentes edificios de la antigüedad clásica que habían sido reunidos y codificados en esos libros. Jefferson aprendió a reconocer y a apreciar la belleza arquitectónica que derivaba de la sencillez, regularidad y proporción, más que de la ornamentación aplicada arbitrariamente, e intentó infundir esta sensibilidad en sus compatriotas proporcionándoles modelos arquitectónicos bellos y funcionales.

Jefferson tenía en mente una idea de "villa" más que de college aislado, con lo que se podría decir que éste posría ser el germen de la primera ciudad universitaria. Hablaba de espacios verdes entre las estancias para conseguir que los espacios fueran más acogedores. Ideó un determinado número de comedores para conseguir grupos reducidos en lugar de un gran salón como lo que conocía de los colleges de Oxford y Cambridge.

\section{DISEÑO CAMPUS:}

El diseño principal lo ideó a partir de un cuadrado de 180 metros, donde se dispondrían a su alrededor pabellones de $7 \times 11 \mathrm{~m}$ cada uno de ellos. Se localizaban en tres de los cuatro lados del cuadrado, creando una zona verde en medio que denominó "lawn". Estos pabellones tendrían albergarían función residencial.

Para el diseño mantuvo contacto con compañeros, William Thornton y Henry Latrobe. Además tenía que ir informando a los Administradores de la Junta para que le fuesen "dando el visto bueno" a sus planteamientos.

Con sus compañeros mantenía el contacto por correspondencia, principalmente $y$, obtuvo tres modelos diferentes. Éstos fueron evolucionando a partir del original a medida que reflejaba los consejos e intervenciones de sus colegas. Al tiempo también era fruto de modificación o repaso algunas características introducidas por la Junta. Aunque Jefferson tampoco era un hombre que se dejase influir demasiado, por norma a la Junta intentaba complacerla para obtener su beneplácito y así conseguiría, con el tiempo, presentar su "modelo de universidad".

El principal problema que se le planteaba era readaptar su proyecto al terreno donde finalmente se ubicase la Academia, ya que su diseño de universidad ya estaba ideado por Jefferson años atrás y lo presentó al ser elegido por la Junta de Administradores. 
Finalmente se decidió que la ubicación donde Jefferson había defendido siempre que era el mejor sitio: Charlotessville, en una zona rural. Una vez decido esto, mantuvo correspondencia con Thornton y Latrobe para que le aconsejaran sobre posibles soluciones para adaptar su proyecto original a las nuevas pendientes y rasantes que presentaba el terreno.

Primera propuesta: El cuadrado tiene unos lados de 213 ó 243 metros, en cuyo perímetro se disponían los pabellones de forma independiente cada uno de ellos. En cada uno de ellos estaba preparado para albergar a un profesor y sus alumnos. Los dormitorios se situarían en una segunda fila paralela a la anterior y se unirían a los pabellones mediante pasillos cubiertos.

Cada pabellón tiene en planta baja un espacio destinado a escuela y en la planta superior se destinan dos habitaciones para la residencia del profesor $y$, entre pabellón y pabellón, hay un conjunto de dormitorios para los alumnos en un espacio de una sola planta.

Todos los pabellones y dormitorios se comunican mediante una columnata de altura similar al piso inferior de los pabellones, a través de la cual ir de escuela a escuela sin mojarse. La columnata es de pilastras de ladrillo y contiene un entablamento toscano.

Jefferson se planteó el que no habría dos pabellones iguales, esta es una de sus principales premisas.

Una de las indicaciones que le hizo Latrobe es que diseñara terrazas en el terreno en pendiente y que situara un pabellón y 20 dormitorios a cada lado de la terraza. Jefferson diseñó las tres terrazas que formalizaban el campus. Ahora se encontraba con una disposición de pabellones y dormitorios mucho más estrecha, todo debido a las irregularidades del terreno, modificó sustancialmente su proyecto, acercando las líneas del cuadrado donde había colocado los pabellones, de manera que se creaba un rectángulo ahora.

La franja de terreno de $61 \mathrm{~m}$ de ancho queda dividida en tres terrazas llanas, cada una de 77,7 metros de largo, que acomodan a 20 dormitorios, cada uno de 3 metros de ancho, y un pabellón de 10,3 metros de ancho, estas medidas no habían sufrido modificación con respecto a su proyecto original de 1814 .

Los pabellones estaban representados, en el proyecto, con una letra cada uno de ellos.

En el diseño arquitectónico Jefferson argumentó que: "La separación de los estudiantes en diferentes habitaciones independientes, de dos en dos, me parece lo esencial en este proyecto"n63. 
En los pabellones pretende construir con el criterio de poner los motivos habituales del orden dórico con un pórtico en la parte superior apoyado en los arcos de la planta inferior y con un frontón que abarque el ancho total del frente. Las columnas son de $40 \mathrm{~cm}$ de diámetro. Los dormitorios presentan cubierta plana, en palabras de Jefferson: "...techo plano como las oficinas de la Casa el Presidente".

En la zona norte del rectángulo se colocaría la Rotonda, también sugerencia de Latrobe, para que fuese la "cabeza" del campus, se pretendía que fuese un edificio representativo del campus.

El primer pabellón que se construyó (el denimonado pabellón 7) seguía los criterios aportados por Thornton, mientras que los demás se veía más la influencia de latrobe.

Segunda propuesta: Se suprime la comunicación por pasillos cubiertos y se incluye residencias para el profesorado y estancias de una sola planta y sin pórticos.

Cada pabellón tiene un pequeño patio vallado, contiguo a la parte trasera del edificio, probablemente destinado a albergar los caballos y el carruaje del profesor. Además todos los profesores y encargados de las residencias pueden tener acceso a parcelas de jardines particulares situadas detrás de las filas externas formadas por las residencias y los dormitorios. En esta segunda propuesta aleja más la línea de separación entre pabellones y residencias -dormitorios.

Para resolver el problema de acceso añade una nueva característica al plano del terreno, pasillos perpendiculares o "calles cruzadas" para la comunicación, que se extendían entre los jardines particulares y conectan la hilera de pabellones con la fila externa de residencias ${ }^{9}$.

Con esta propuesta dotaba al conjunto de un cierto carácter de ciudad, ya que al trasladar las residencias y dormitorios adicionales a una calle es factible una posible ampliación, hasta el punto que pueda ser necesario, en un futuro.

Tercera propuesta: Una tercera versión salió a la luz el 8 de julio de 1819, cuando Jefferson diseñó los famosos muros serpenteantes para los jardines e instaló aseos para los estudiantes. En esta versión, casi definitiva, se trasladan las residencias de estudiantes aún más lejos de los pabellones e incluye un muro divisor para proporcionar espacios ajardinados para cada residencia. En un diagrama de la zona de 1824, Jefferson nombra las calles que se extienden delante de las filas de las residencias como "Calle Este" y "Calle Oeste".

Finalmente, Jefferson decidió reutilizar el proyecto de una sola planta para la zona residencial que había diseñado en su primer estudio de la fila oeste. Sin embargo, la nueva disposición de los jardines y residencias crea problemas, ya que en el extremo norte de la fila externa oeste no hay espacio suficiente para colocar las grandes residencias de 1 metros de ancho que aparecían en sus 
diseños de la fila externa oeste, y todavía dejar espacios para los dormitorios contiguos.

Las residencias estaban denominadas por letras mayúsculas: $A, B$ C... Todas se diseñan y se construyen utilizando el orden toscano, y las 6 residencias, en su totalidad, contienen al menos una pared exterior de 10 metros, que era la que estaba representada en la primera propuesta.

Por temas de ahorro económico a la hora de hacer la excavación de los pabellones, se hicieron los jardines de la fila este más anchos que los de la fila oeste.

Jeferson acabó muy orgulloso de su diseño y de haber tomado las decisiones correctas, lo muestra en el momento que escribe a John Eppes a mediados de la década de 1820: "Nuestra universidad se encuentra en una etapa de construcción tan avanzada que merece la pena venir a verla, ya muestra la apariencia de una preciosa Ciudad Universitaria, con los modelos de edificios de arquitectura clásica más bellos de los Esados Unidos. Está empezando a ser muy visitada y es admirada por todos ellos, por la belleza, originalidd y utilidad de su diseño"

Jefferson puso de manifiesto al comparar las oportunidades presentes en América y Europa que, a la hora de educar a las masas para preservar en el mantenimiento de la libertad:

"Si todos los soberanos de Europa se tuviesen que poner a trabajar para emancipar a sus súbditos de su actual ignorancia y prejuicios... ni mil años bastarían para situarlos en el alto nivel en el que ahora el pueblo americano se encuentra... Creo, con mucho, que el proyecto de ley más importante de nuestra legislaciónes que e l que estipula la difusión del saber sobre todos los individuos. No se puede concebir otro método seguro para la conservación de la libertad y la felicidad" 


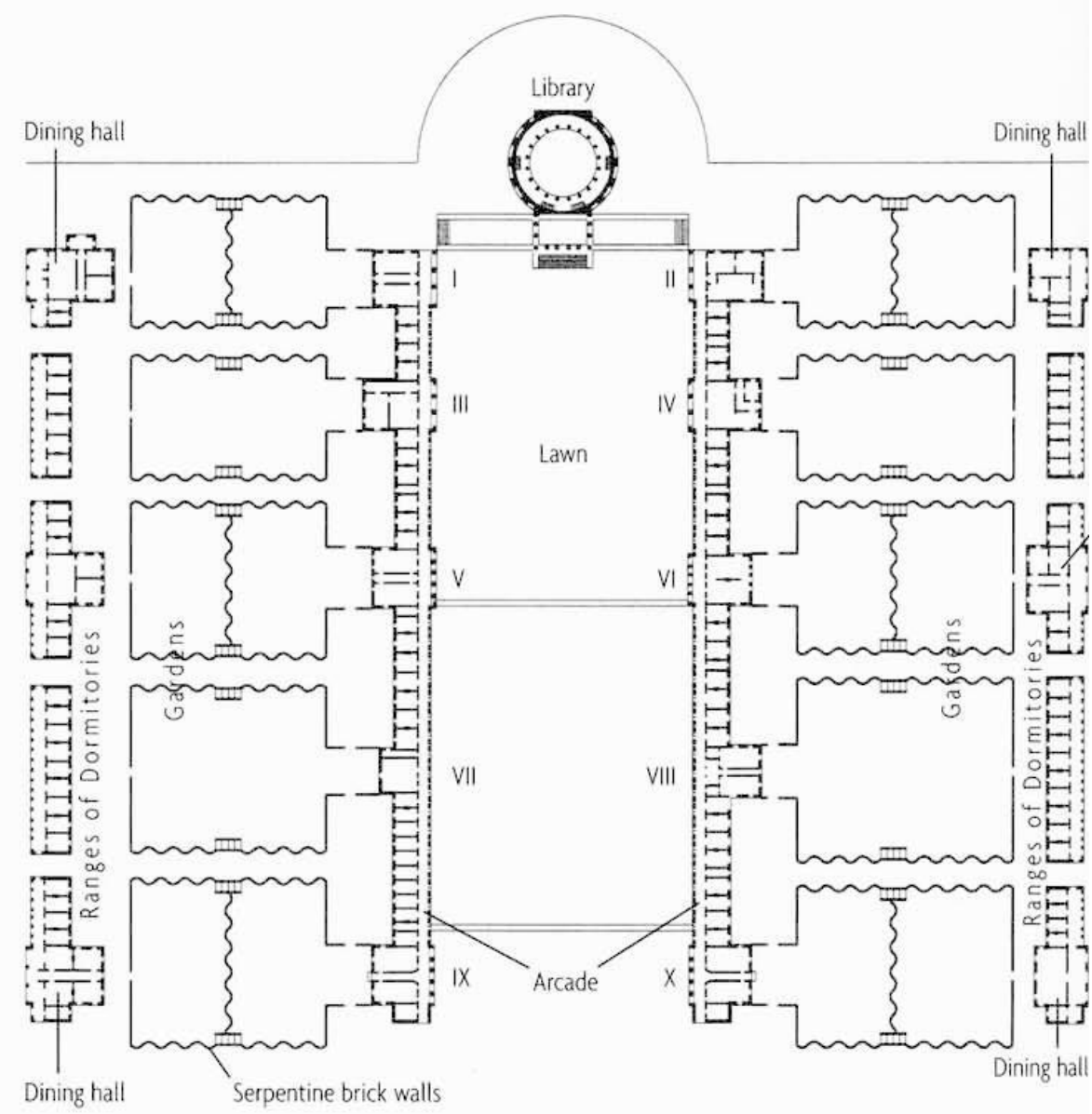

$$
\otimes \quad:-=---=\frac{100 \mathrm{~m}}{300 \mathrm{ft}}
$$

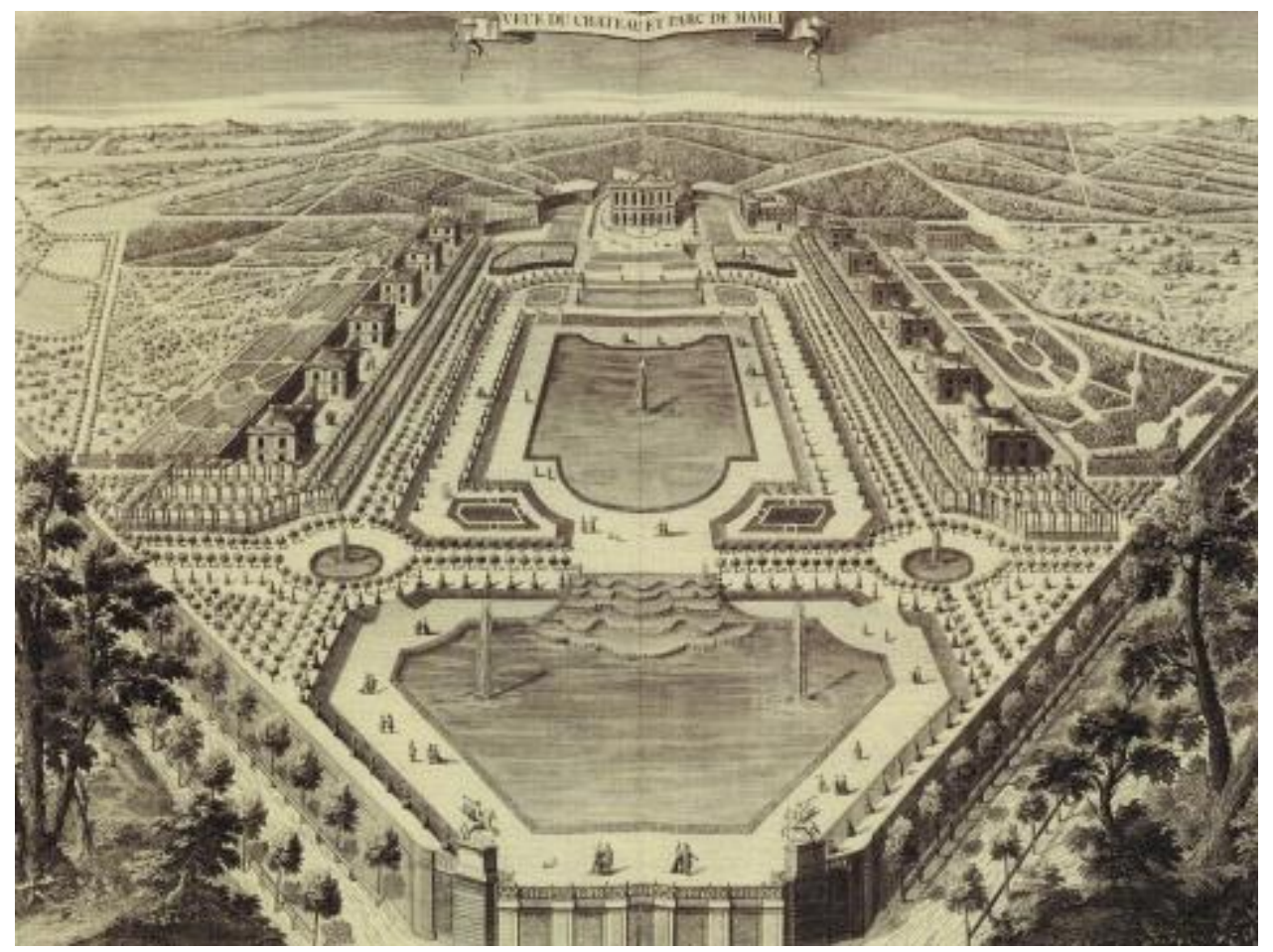

Imagen 311: Ubicación de los pabellones con los bloques residenciales dispuestos en el perímetro de los mismos. La disposición deja un gran espacio central donde se producen los accesos a los bloques docentes.

Imagen 312: Plano de la Mansión de Marly en Francia, visitada por Thomas Jeferson durante su estancia como embajador. La similitud en el esquema, hace pensar que influyeera en el diseño de la Universidad de Virginia. 

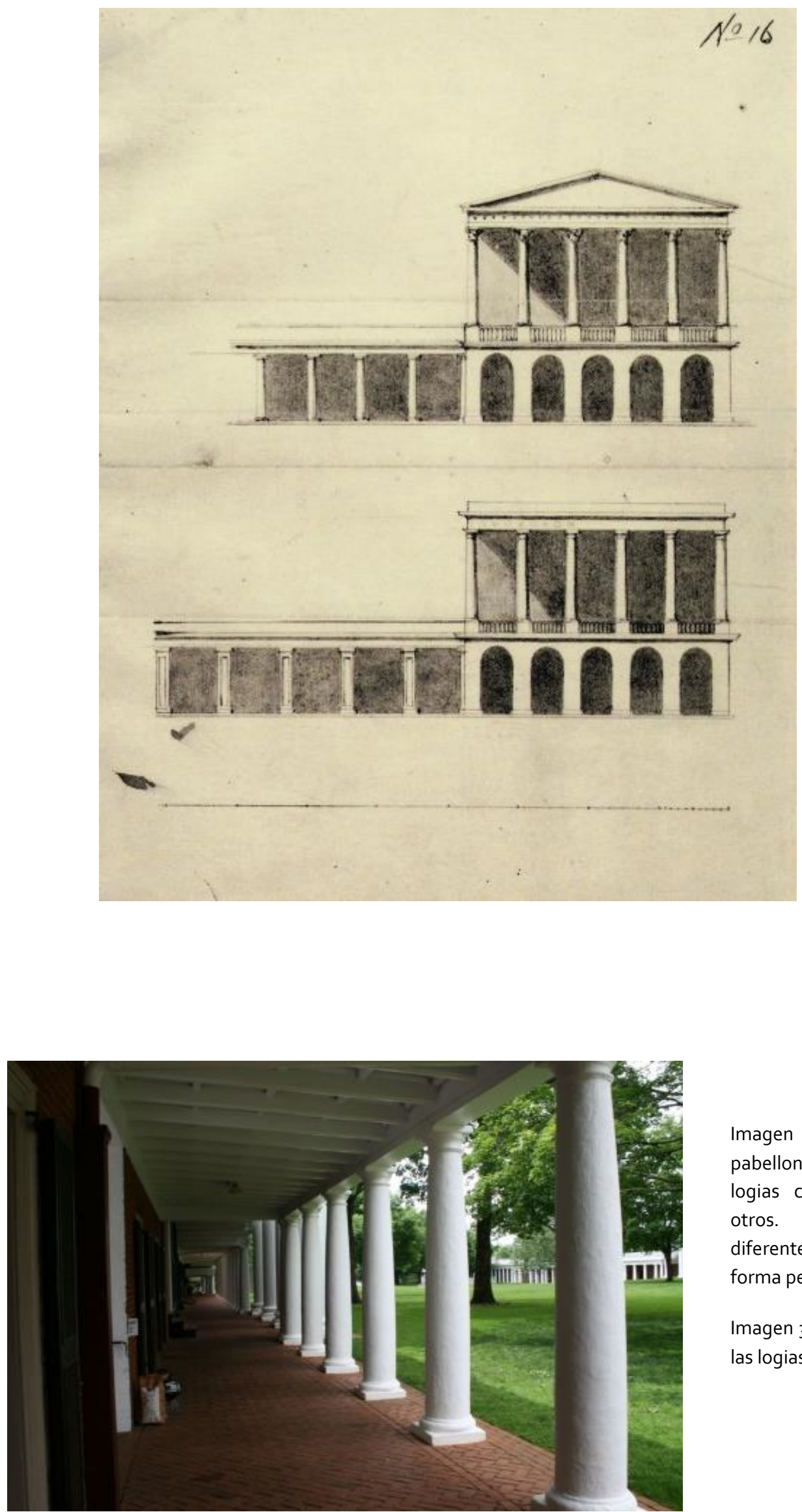

Imagen 313: Alzado de los pabellones docentes. Las logias comunican unos con otros. Cada pabellón es diferente a los demás en forma pero no en estilo.

Imagen 314: Detalle de una de las logias. 


\section{NUEVA YORK-UNIVERSIDAD DE COLUMBIA Y LA IRRUPCIÓN DE LA GRAN ALTURA.}

\section{Hartley Hall (1905).}

El Campus de Morningside Heights de la Universidad de Columbia, necesitaba alojo estudiantil a primeros de siglo. Por lo que se empezó a pensar en la disposición de edificios de residencias a lo largo del complejo universitario cuyo plan director había sido elaborado por la firma estadounidense de arquitectos McKim. Mead y White.

La primera obra residencial fue la del edificio llamado Hartley Hall.

Una donación de 300,000 dólares de Helen Hartley Jenkins y su sobrino Marcelo Hartley de Dodge hizo posible la construcción de esta residencia universitaria. Junto con este regalo, los sindicatos estudiantiles se comprometieron a erigir una segunda residencia. Los arquitectos elegidos para su diseño fueron los mismos, anteriormente mencionados, que redactaron el masterplan de la universidad.

El diseño de la residencia continúa con las características y estilo de lo que se estaba construyendo actualmente en Nueva York: La gran altura.

Del modelo colonial que se ha estudiado hasta ahora en capítulos anteriores, se pasa a una construcción de más de diez plantas de altura donde se va a desarrollar el programa residencial. A diferencia de los anteriores casos, en el programa no hay un espacio destinado a capilla. Lo que si van seguir disponiendo es de residencia para profesores de aulas de estudio, pero ajenas a la universidad, las clases se dan en las distintas facultades y no hay relación directa como podía pasar en Virginia.

En la localización en el campus, por primera vez se relaciona el espacio residencial con el deportes, situándolos juntos, de manera que se puedan proporcionar vistas desde las habitaciones a las dependencias deportivas. Este hecho se verá repetido en muchas ciudades universitarias europeas.

El edificio está compuesto de nueve plantas de altura más un espacio bajo cubierta. En todas las plantas se combinan las estancias de uso común con las privadas. En las planta de acceso hay un gran hall de entrada, a través del mismo se accede a las plantas superiores a través de dos núcleos de comunicación vertical. El edificio está orientado este-oeste, para obtener la mayor iluminación en sus fachadas de mayor longitud, donde se disponen, las habitaciones de 
los estudiantes. Están dispuestas a lo largo de un pasillo central, donde se alberga a unos 231 estudiantes. Las habitaciones tienen distintos tamaños. Adyacentes a las mismas existen distintas áreas comunes dedicadas al ocio, esto también es una novedad en este caso. El edificio está dotado de una gran biblioteca.

El edifico pasa de una planta rectangular en las dos primeras plantas a tener una forma en " $u$ " en las siguientes. Esta forma es fruto de obtener una mayor iluminación en las estancias.

Mientras que Colombia no puede tener los colegios de Harvard o los de Virginia, los estudiantes pueden elegir entre una gran variedad de alojamientos incluyendo individuales, dobles, suites y apartamentos.

La residencia en seguida se quedó con falta de poder alojar a más estudiantes, por lo que se construyó el Livingston Hall justo a la derecha del Hartley. Es su edificio gemelo, comparten la misma planta, forma y características formales. Se unen en planta baja, compartiendo la misma fachada principal. Éste segundo aloja a estudiantes de pregrado mientras que el Hartley sólo tenía a estudiantes de postgrado. 

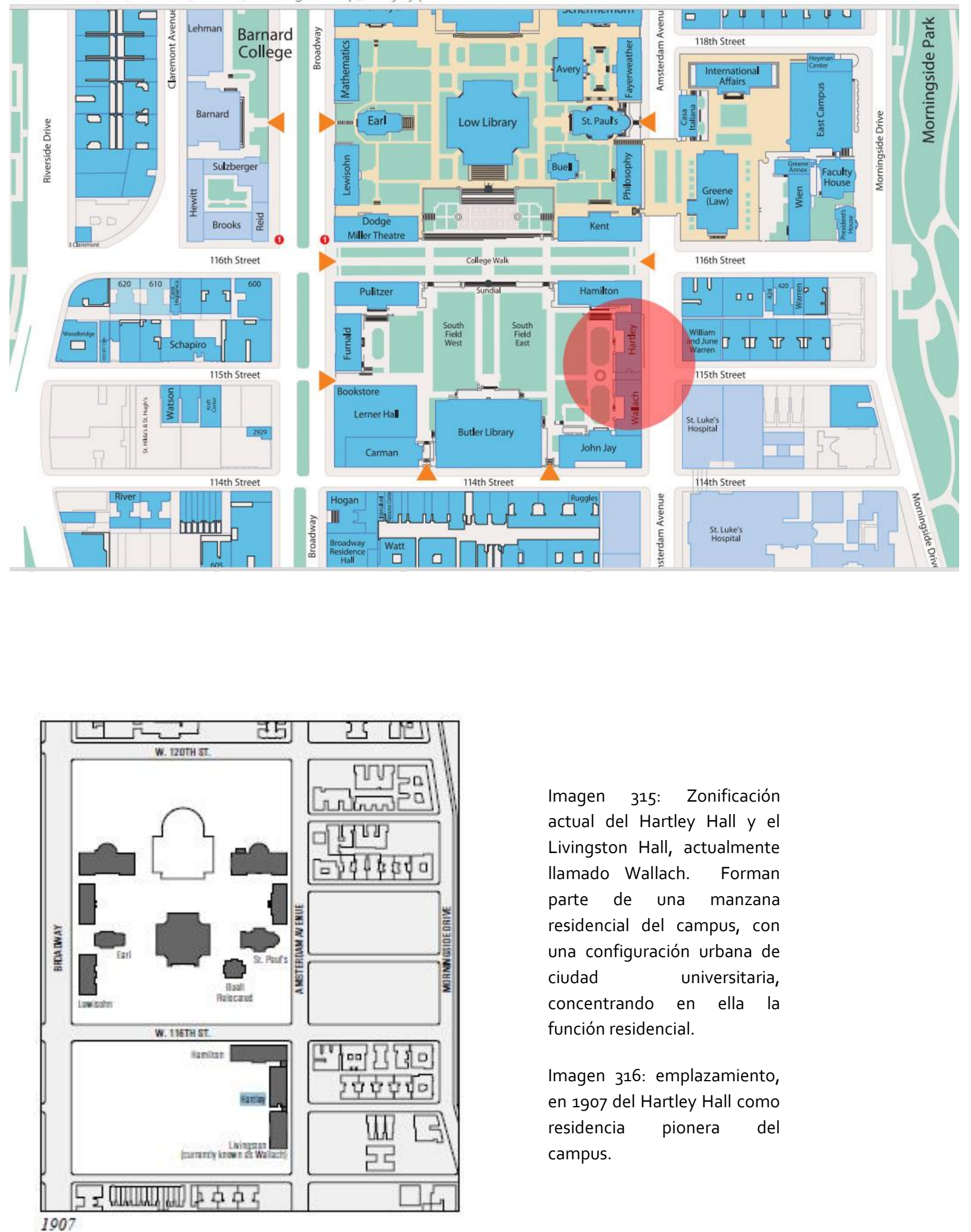

Imagen 315: Zonificación actual del Hartley Hall y el Livingston Hall, actualmente llamado Wallach. Forman parte de una manzana residencial del campus, con una configuración urbana de ciudad universitaria, concentrando en ella la función residencial.

Imagen 316: emplazamiento, en 1907 del Hartley Hall como residencia pionera del campus. 


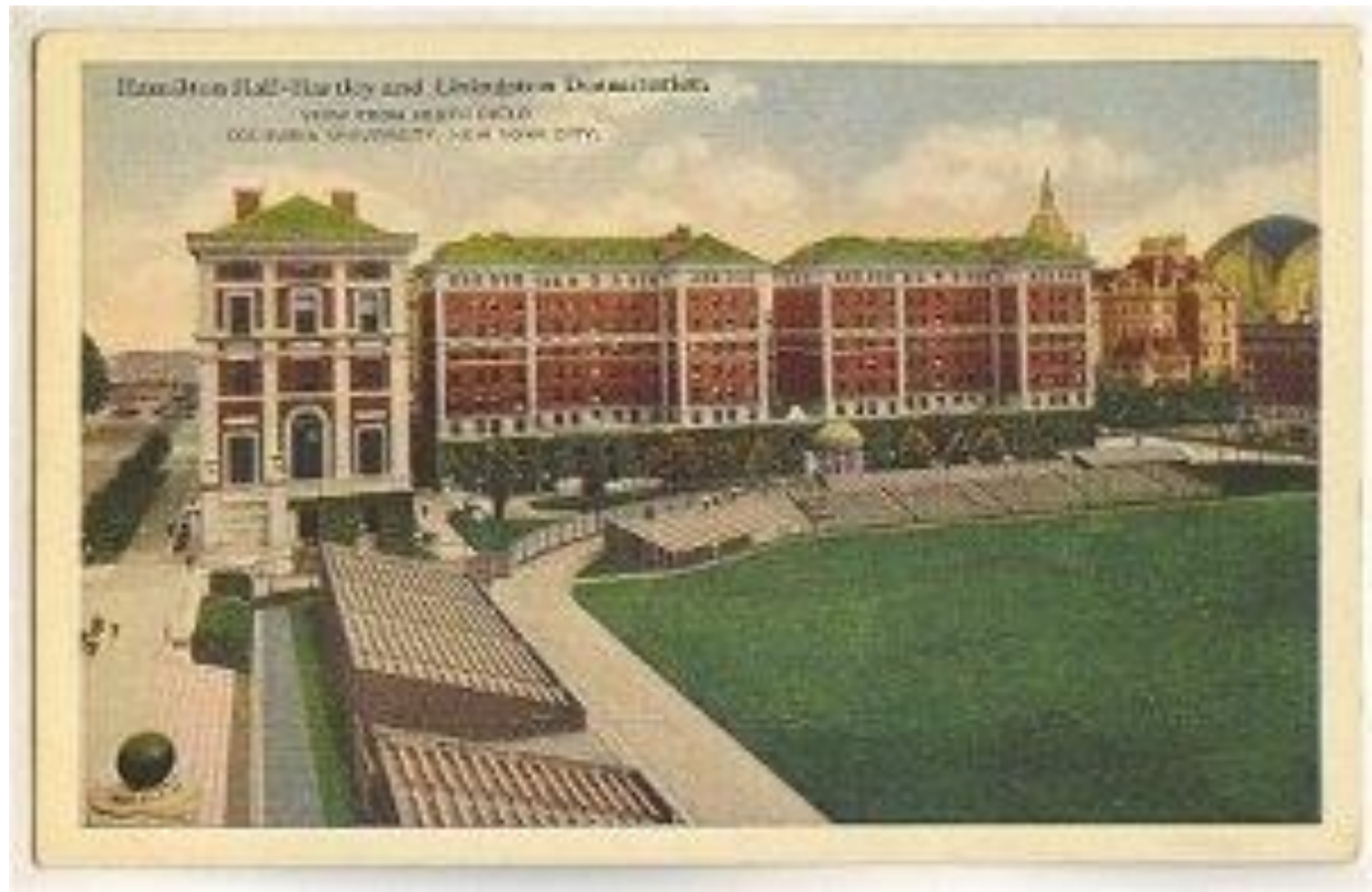

Imagen 317: Hartley Hall y Livingston, dos primeros edificios de gran altura conectados por el basamento

Imagen 318: Una de las novedades con respecto a residencias anteriores fue la de proveer al edificio de salas de ocio y juegos para los estudiantes.

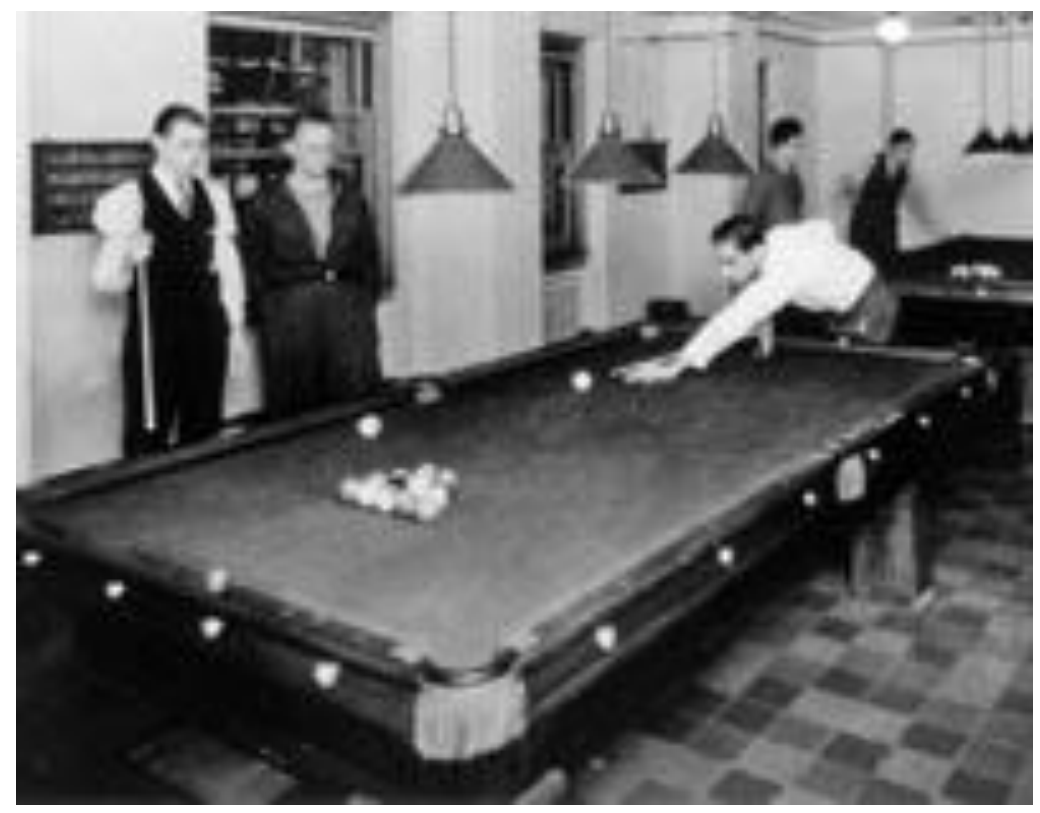



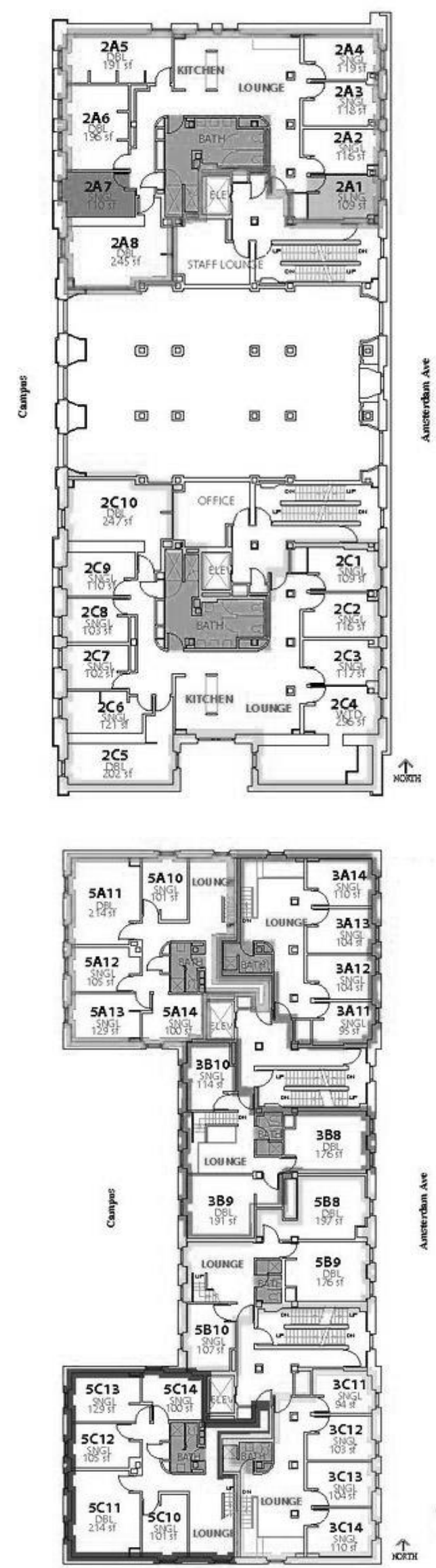

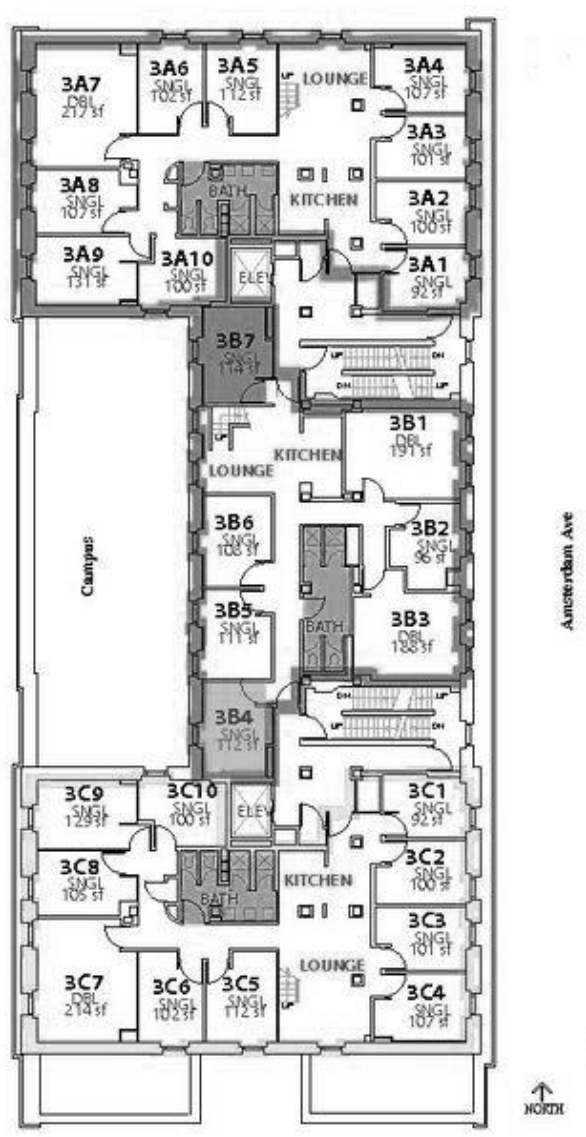

Imagen 319: Planta primera del Hartley Hall. Se aprecia el espacio central a doble espacio, donde a través de él se accede a los núcleos conformantes del edificio. EN esta época se va a seguir esta disposición en el resto de edificaciones residenciales que se van a implantar en esta manzana del campus.

Imágenes 320 y 321: A medida que aumenta en altura, se va transformando la planta rectangular en una "U" para aprovechar mejor el asoleo de las habitaciones. Hay distintos tamaños de habitaciones distribuidas a lo largo de las 10 plantas. 

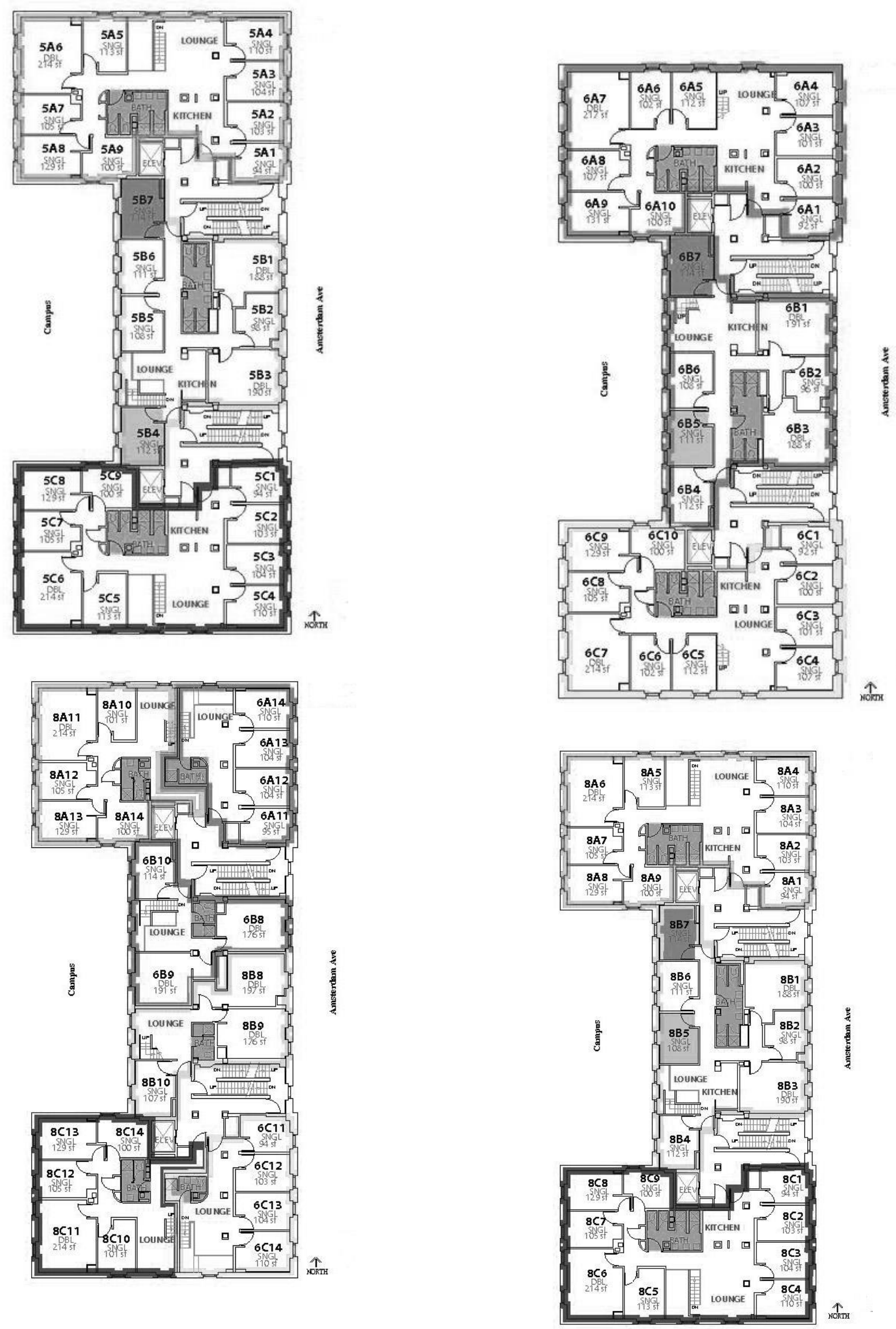

Imagen 322: Plantas de la quinta a la octava. 

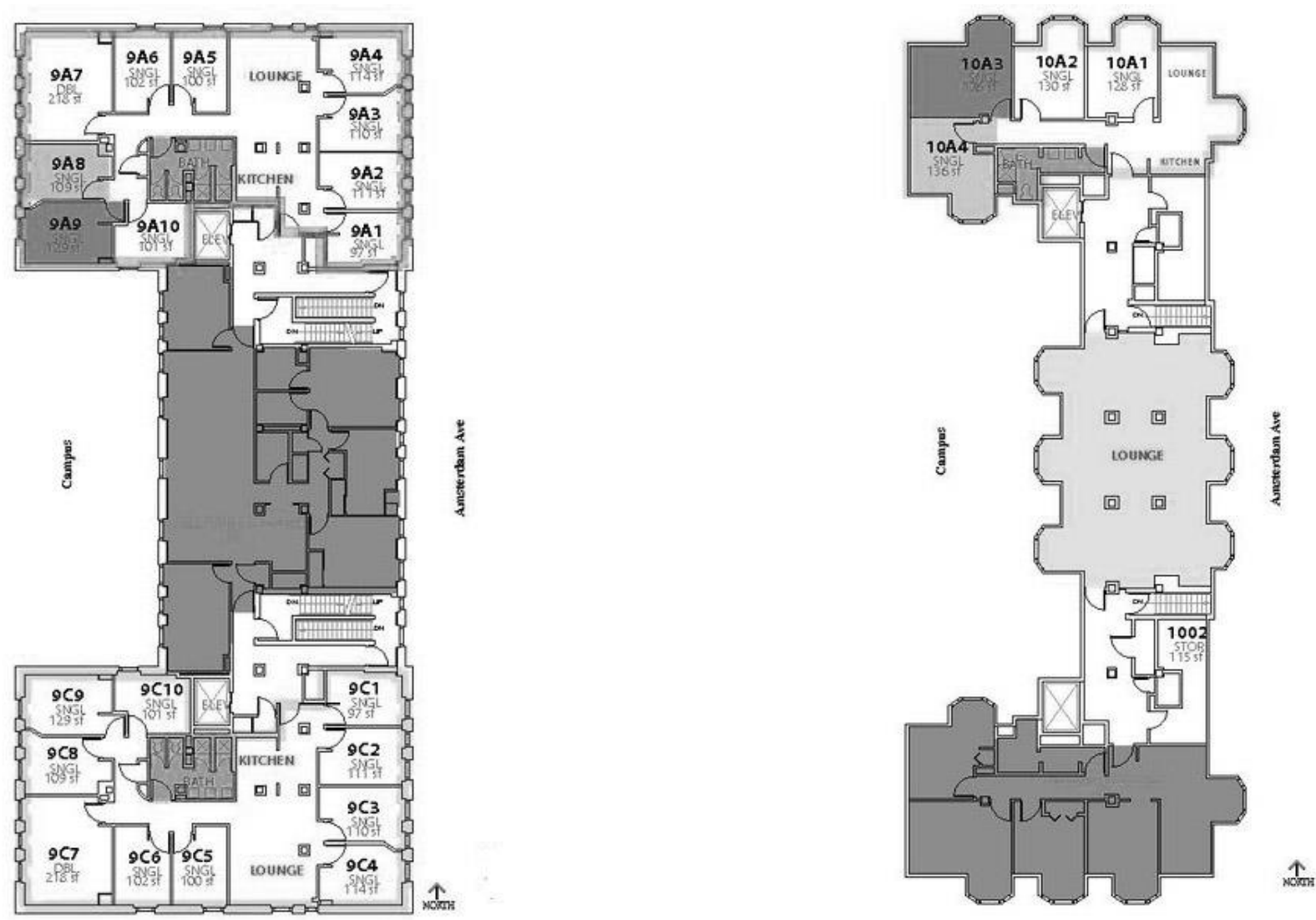

Imagen 323: Planta novena y décima (espacio bajo cubierta) 


\section{RESIDENCIAS UNIVERSITARIAS EN LA HISTORIA}

\section{BLOQUE II}

ESTADOS UNIDOS. La fragmentación edilicia del modelo inglés.

Apéndice Contemporaneo:

Baker House de Alvar Aalto (1948)

Peabody Terrace, residencia para estudiantes casados de Josep Lluís Sert (1949) 
322| RESIDENCIAS UNIVERSITARIAS EN LA HISTORIA 


\section{BAKER HOUSE DE ALVAR AALTO (1948)}

Tras el fin de guerra, Alvar Aalto recibe el encargo de los planos para la nueva residencia de MIT ubicado a orillas del Charles River. Entre la edificación y el rio, se encuentra ubicada la principal arteria de tráfico de la región, el Memorial Drive, situación que resolvería dándole una forma al edificio que aprovechara y protegiera al usuario según la ubicación. El complejo cuenta con siete niveles, seis dedicados a vivienda. Aalto plantea los accesos y las salas comunes en estas plantas en la parte norte del edificio.

Incorpora a su edificio una vía peatonal preexistente que marca una fuerte diagonal, penetrando por la entrada principal en el edificio, continuando por el vestíbulo y escaleras hasta aparecer por el lado sur de la cafetería.

La composición de este autor contrasta con la habitual configuración estática de los edificios institucionales en este mismo contexto. Se utilizaron ladrillos recocidos irregularmente; Aalto insistió en que además la utilización de material de desecho se tapiara de tal manera que las partes deformadas en la superficie plana sobresalieran hacia fuera dando así a la superficie la irregularidad deseada.

El proyecto estuvo sujeto a un presupuesto limitado debido a la situación económica después de la guerra, obligando al arquitecto a maximizar el número de habitaciones en relación con el número de metros cuadrados; la mayoría de estas son individuales, dejando otras con dos o tres camas.

La forma curva de la fachada sur responde a las condiciones de su ubicación, todas las ventanas de las viviendas están orientadas al paisaje del río, quedando en diagonal a la parte de la calle de forma que se puede observar el tráfico que circula de la manera más agradable posible, de una manera oblicua y no perpendicular. La forma curva proporcionaba una mayor capacidad de habitaciones, un recorrido interesante hacia ellas, y una forma única para cada espacio de vivienda. El complejo se equipa con mobiliario ARTEK.

Al edificio principal, se le integra un volumen más bajo y cuadrado en donde se ubica la cantina y el café. Este está recubierto a diferencia del complejo principal, en mármol gris decorado con claraboyas redondas, mobiliario característico de Alvar Aalto.

Las escaleras de un solo tramo, se diseñan como un elemento incrustado en la fachada norte, creando un contraste interesante entre la forma orgánica de la fachada sur y la simétrica de la fachada en donde se sostiene. 
Alto había planeado un enrejado en la fachada principal de forma que la hiedra la cubriera con el tiempo, siendo esta una característica de la visión que tenia de sus construcciones como proyectos que no finalizarían, sino más bien, crecerían y desarrollarían al igual que sus usuarios. Se había proyectado una azotea que no se llegó a construir, idea que probablemente adquirió por influencias europeas y su círculo de amistades que incluían a Le Corbusier (quinta fachada)

Así, con este edificio, Aalto resalta la individualidad, la robustez e independencia de la vida estudiantil en lugar del anonimato institucional. 


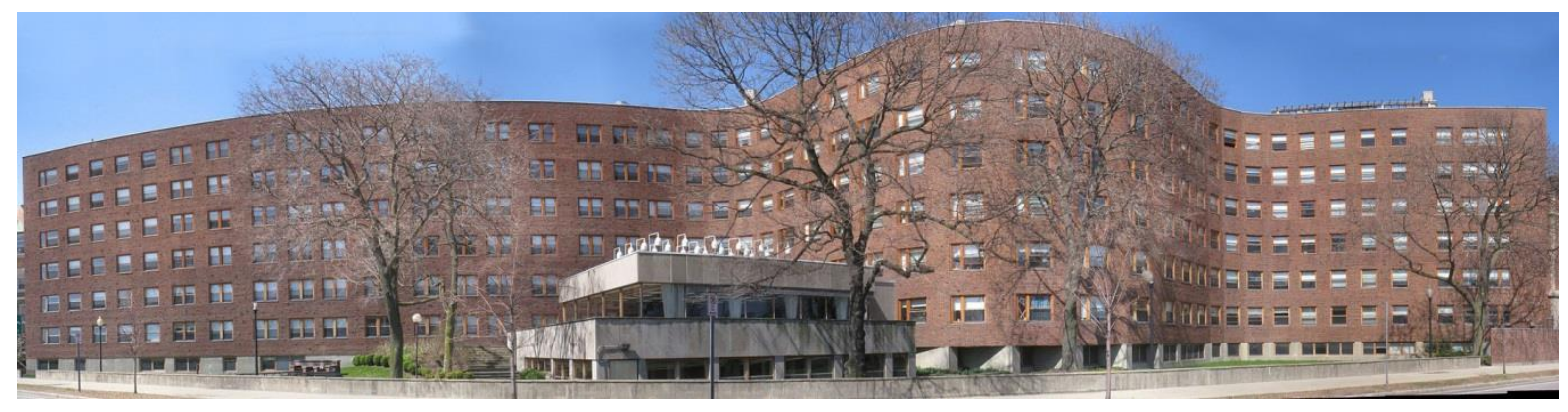

Imágenes 324 y 325: Fachada principal de la residencia. La curvatura responde a la intención que todas las habitaciones gozasen de la misma orientación. Aalto también configura el diseño de su edificio introduciendo una vía peatonal hasta el interior del edificio. El dialogo entre residencia y campus se hace fehaciente con este concepto.

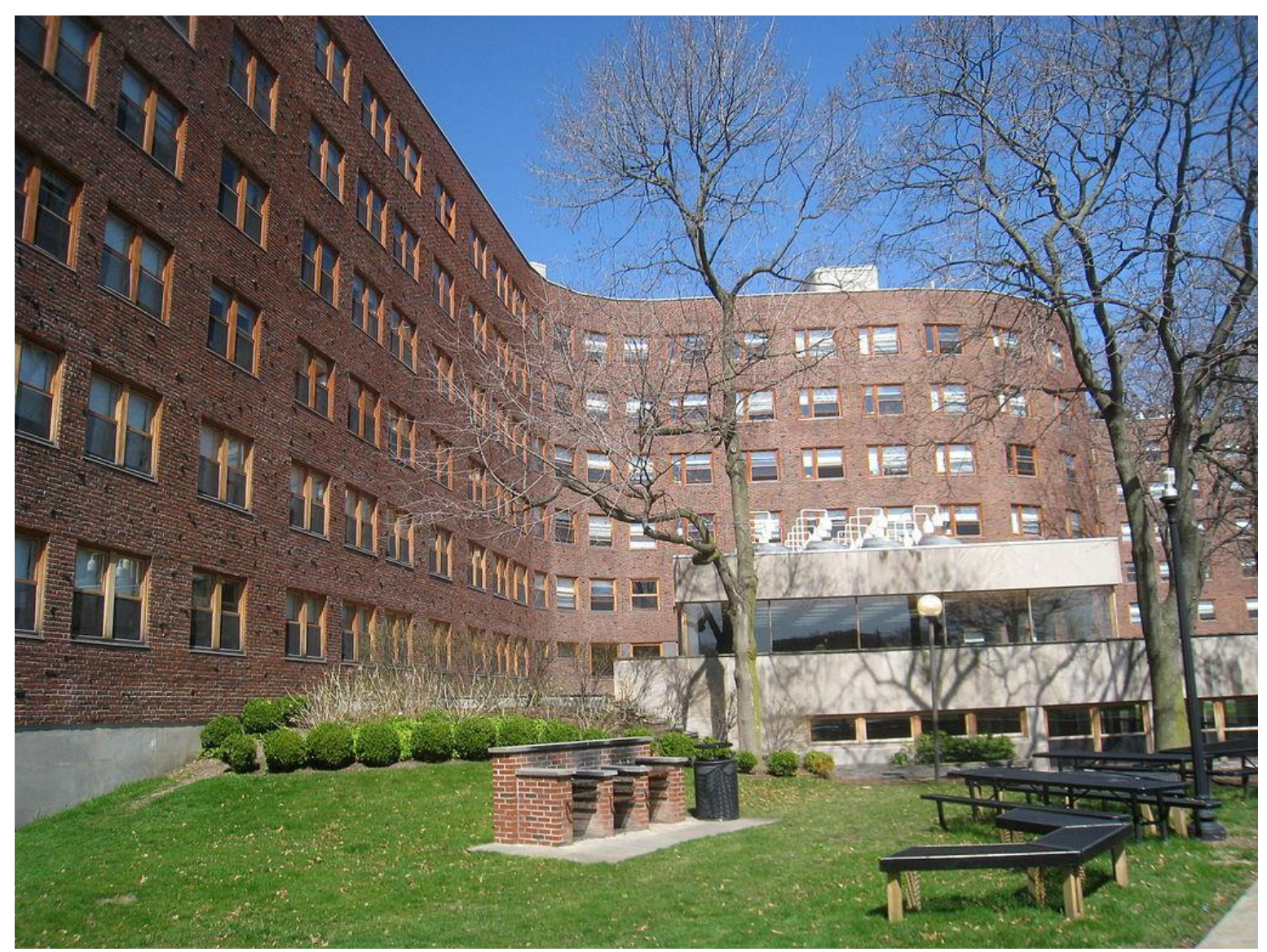




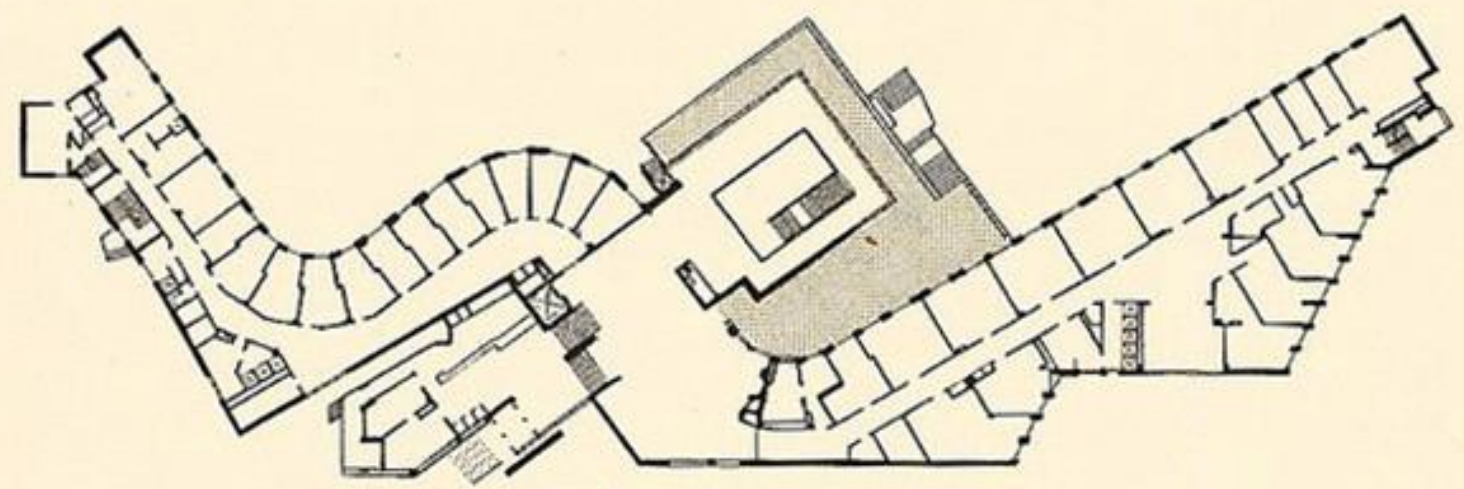

Imagen 326: En la planta del edificio se muestra la sinuosidad con la que Aalto pretende conseguir la equidad lumínica en todas las aulas.

Imagen 327: Se aprecia como sobresalen los núcleos de comunicación vertical con respecto al plano de fachada.

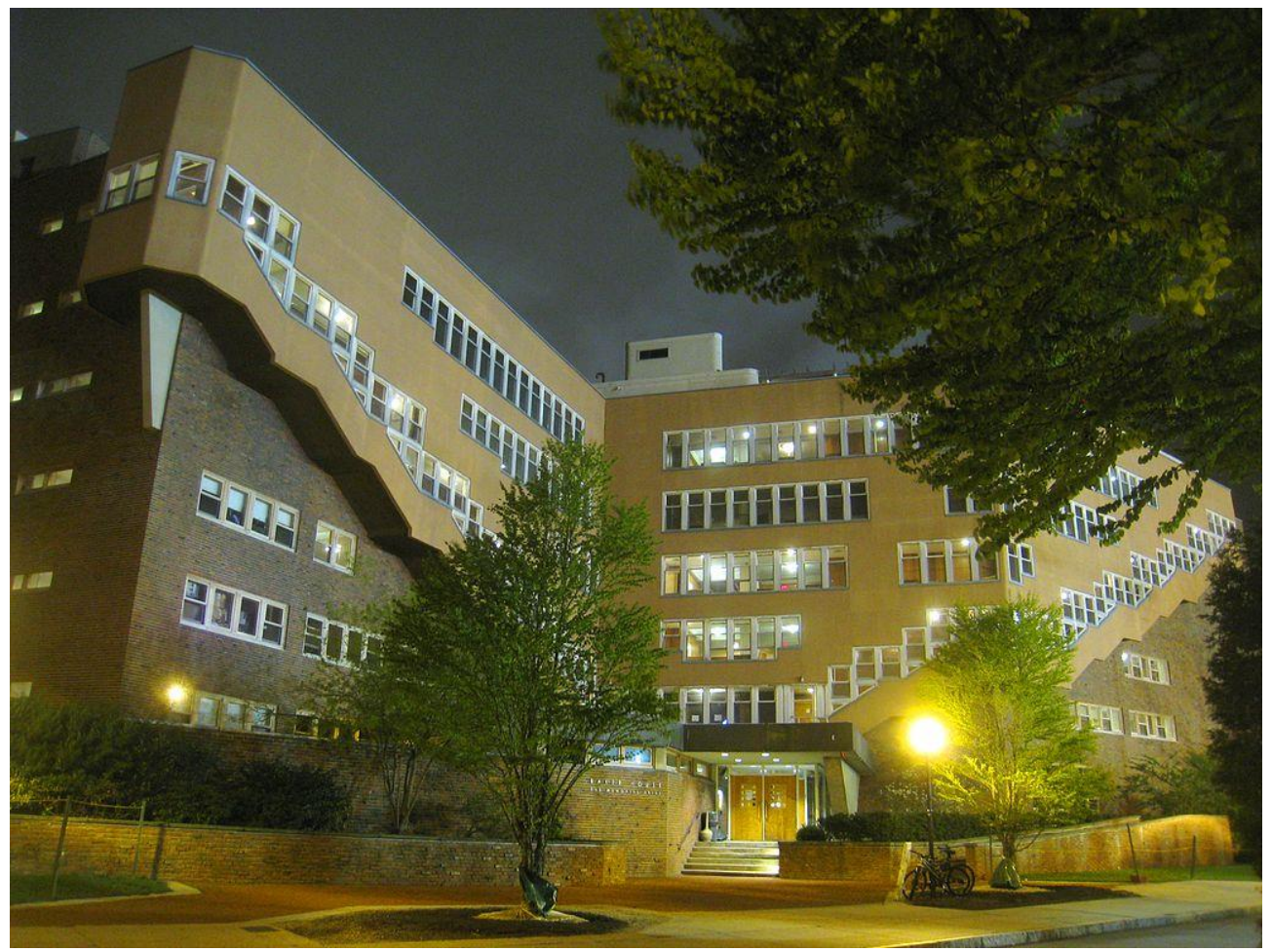




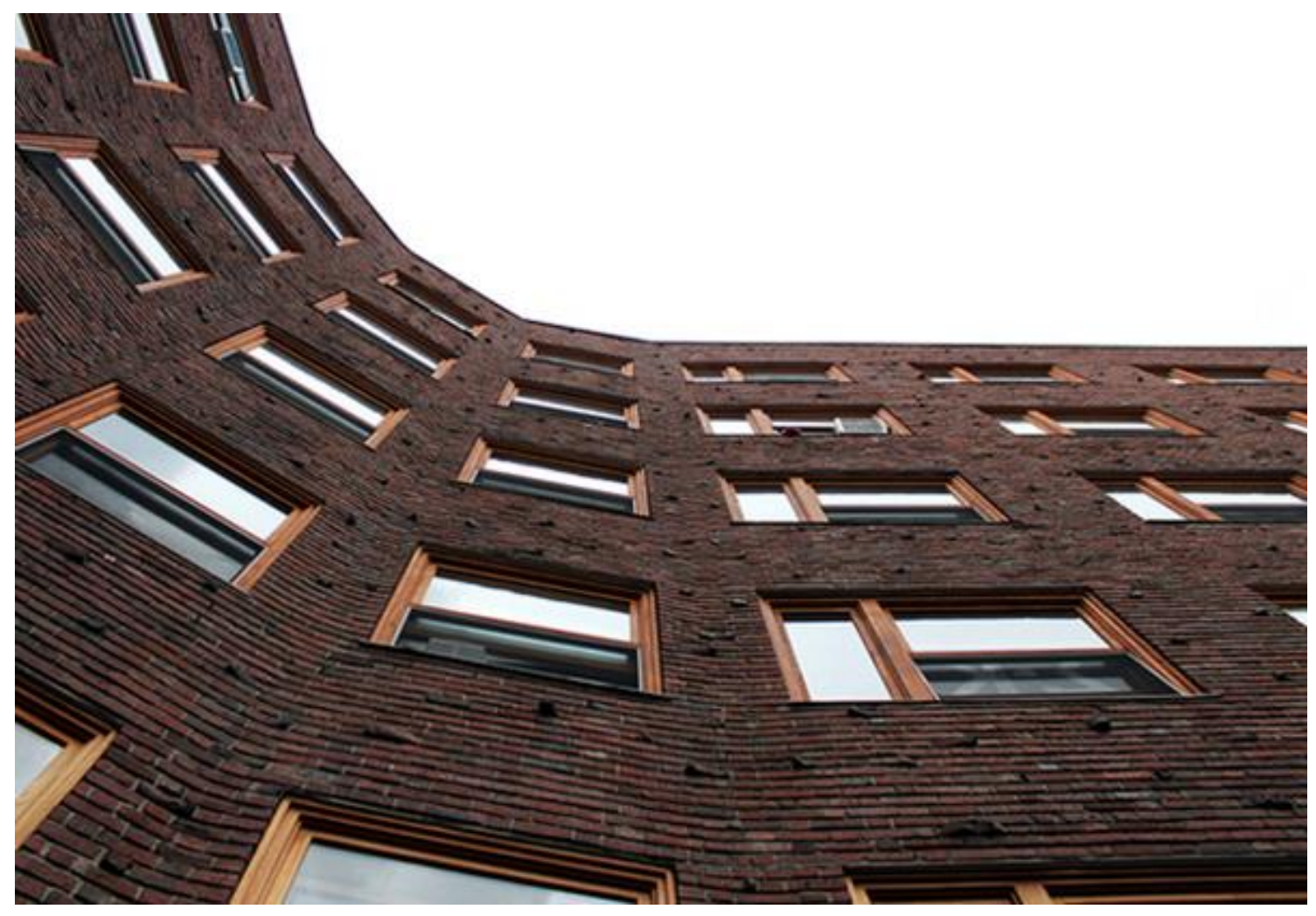

Imagen 328: Para la composición de la fachada que configura el perímetro del edificio, utilizó material de desecho, estipulando que en las superficies planas los ladrillos sobresaliesen del plano de fachada para conseguir la imagen de irregularidad que deseaba.

Imagen 329: en la iluminación interior utiliza formas que dotan al edificio de un marcado carácter nórdico, recordando a los lucernarios que utiliza en otras de sus muchas obras.

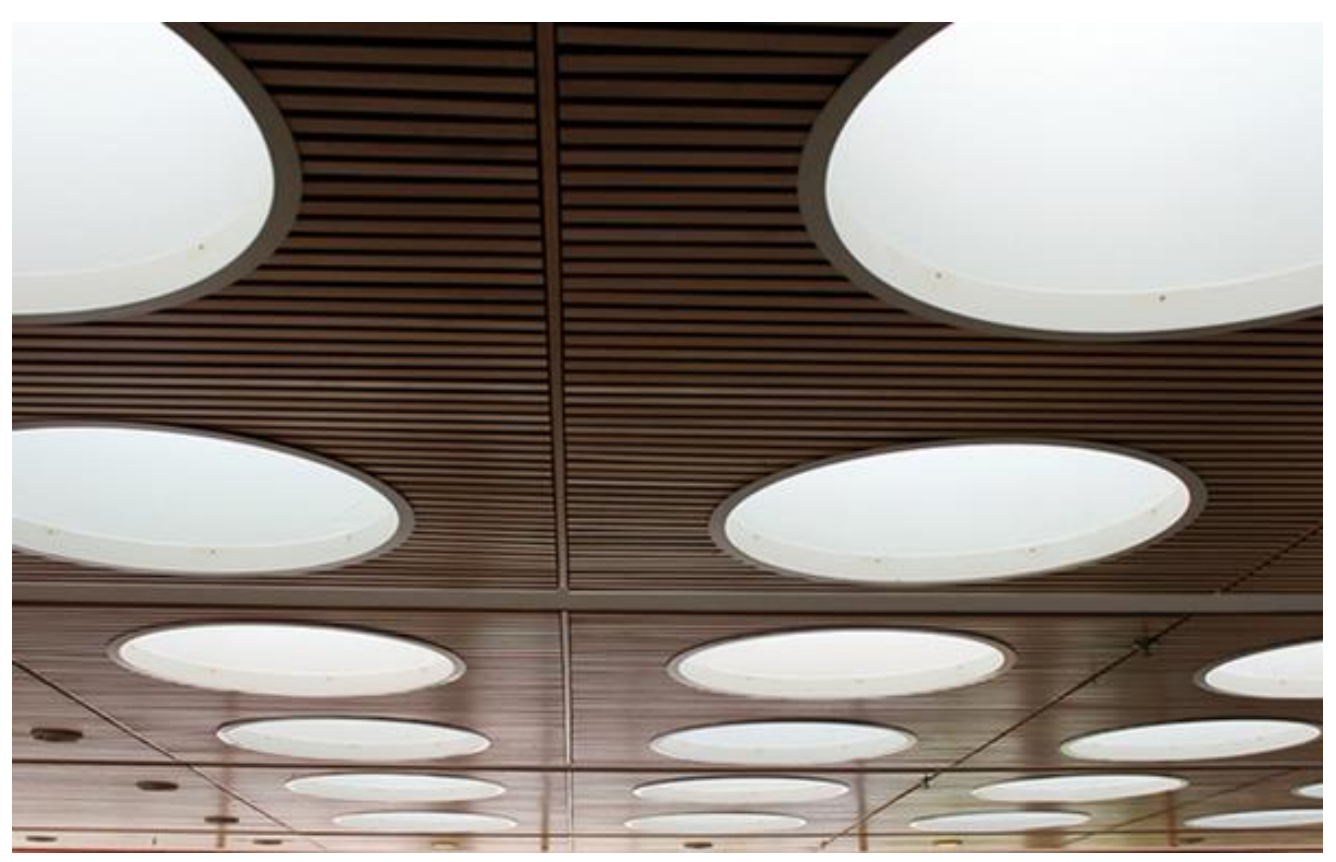




\section{PEABODY TERRACE, residencia para estudiantes casados de Josep Lluís Sert (1948)}

Emplazada en el distrito Memorial Drive, a orillas del río Charles, y marcando el límite sur del campus, el conjunto Peabody Terrace se ha convertido en una referencia urbana para la universidad desde su construcción. Este conjunto de viviendas para estudiantes casados ha cambiado notablemente el paisaje urbano del área. Las torres son uno de los hitos que marcan el paisaje a lo largo del río junto a otros edificios adyacentes, como el Instituto Tecnológico de Massachusetts (MIT) y otros tantos relativos a la Universidad de Boston.

La creación de la unidad mínima residencial, la organización de ésta en bloques compactos y austeros, el despliegue de amplios espacios públicos para reunión y beneficio colectivo, y su propuesta urbana en busca de la proximidad y la integración de la ciudad, lleva a pensar que esta propuesta urbano-arquitectónica no sólo se ha proyectado resolviendo un fin específico, sino que, además, se ha hecho pensando en el ideal de un conjunto de residencia colectiva, que pueda servir de prototipo al desarrollo urbano.

En este momento, empiezan a oírse con fuerza las propuestas teóricas modernas de Ludwing Hilberseimer, Walter Gropius, Martin Wagner y el propio Jose Luis Sert.

A finales de 1940, podemos observar diferentes tendencias respecto a la idea de la ciudad. Por un lado se aprecian las ideas del CIAM apoyadas en la ciudad funcional, por otro lado, y por el otro, los reunidos en torno a Asociación Regional de Planeamiento de América (RPAA) que promueven la descentralización de las ciudades y la completa "suburbanización" del paisaje americano.

Sert presentó entre las propuestas urbanas del CIAM muchas de las experiencias europeas de residencia colectiva que estaban vinculadas con la idea de Ciudad Jardín británica.

Comentario foto1 (Ubicación): Plano de la zona sur del campus. El círculo indica la ubicación de Peabody Terrace en el barrio de Riverside. Sert, Jackson y Gourley architecs.

A mediados de 1950, Harvard Square, la parte exterior del campus, presenta una imagen con un cierto desorden urbano: un paisaje deteriorado por el tráfico rodado y el metro. Esto puede ser debido a la falta de espacios abiertos de relación, como plazas o espacios ajardinados. Este paisaje contrasta notoriamente con el ambiente calmado y bucólico que existe en el interior del campus. En palabras de Sert, en su charla inaugural en las conferencias de Diseño Urbano de Harvard, el interior del campus tenía balance y armonía entre los edificios de las escuelas y los de las residencias universitarias con espacios agradables y correctamente proporcionados, mientras que fuera de éste, no había bajo ningún punto de vista, alguna 
coordinación de elementos de diseño: "...a pocos metros de esta escuela, hay una puerta de entrada que da hacia Harvard Square, que como la puerta de Dante hacia el infierno, podría llevar la inscripción que dice 'jabandona toda esperanza!'164

En esta misma conferencia, Sert señalaba que el problema que sucede en la parte circundante del campus es el problema de casi todas las ciudades americanas, y propone revertir esa situación urbana desde la práctica del diseño, planteando proyectos específicos en oposición a los planes metropolitanos. Dentro de esta lógica, Sert ya había iniciado en el taller de proyectos de último año, varias investigaciones sobre los puntos de intervención para mejorar el campus y sus alrededores. Después de algunos semestres de estudios y proyectos con los estudiantes, Sert articuló un proyecto para la mejora del campus de la universidad. En 1956, propuso al rector Nathan Pusey iniciar una serie de proyectos en el campus que regenerarían las zonas aledañas para así mejorar la ciudad ${ }^{165}$, ya que con la expansión del campus, la fusión con Cambridge es inevitable.

Paralelamente al esfuerzo de convencer al rector de la universidad acerca de la necesidad de intervenir fuera de sus límites originarios, Sert seguía organizando anualmente, junto con Jacqueline Tyrwhitt, las Conferencias de diseño urbano. Después de mucho insistir, Sert recibió el primer encargo de un edificio para la universidad en $195^{166}$. Se trataba de un centro administrativo y de servicio para los estudiantes de todas las escuelas, ubicado en pleno Harvard Square. De esta forma, el Holyoke Center se convertía en la primera intervención de Sert en el campus e iniciaba concretamente la implementación de su estrategia urbana para regenerar la ciudad de Cambridge.

En 1959, siguiendo la propuesta urbana de Sert, que sería publicada al año siguiente ${ }^{167}$, la dirección de la universidad encargó a distintas oficinas de arquitectura nuevos edificios fuera del campus original, convirtiendo las zonas de influencia en parte activa del campus y mejorando notablemente el paisaje urbano. Había varias residencies de estudiantes como Quincy House, Leverette Towers, Cabot House, pero ninguno conseguía lo que la residencia de Sert: Peabody Terrace. Se fueron construyendo paulatinamente, pero no todos lo hicieron con la misma vocación de reconectar la ciudad y revertir la desconexión de los edificios con el paisaje urbano como se planteaba Sert. A pesar de que varios de esos edificios se "encerraron en sí mismos", estas intervenciones lograron mejorar la imagen urbana reemplazando varias casas deterioradas de la zona.

Quincy House está ubicada al sur del campus central, a mitad de camino entre el campus original de la universidad y Peabody Terrace. Tradicional en el uso de los materiales de la fachada, como ladrillo y piedra en todos los edificios, el conjunto presenta edificios nuevos que se articulan con los antiguos para cerrar la manzana. 
Todos ellos guardan proporciones y alturas similares integrándose al entorno. Por otra parte, ese mismo año de 1960, otra residencia de estudiantes fue proyectada, con dos torres sobre pilotis y un pabellón también "flotante" sobre un campo verde. Leverett House está ubicado a tan sólo dos manzanas del lote que ocuparía Peabody Terrace y sobre la misma avenida Memorial Drive. El conjunto que buscaba seguir el ideal lecorbusieriano de la década de 1920, resultó bastante funesto para crear espacios públicos y el sentido de comunidad que se buscaba en el ambiente urbano universitario. Este conjunto, cerrado en su acceso para los peatones, ofrece algunos puntos de encuentro al aire libre, pero el espacio disperso que se genera entre las torres no invita a consumirlo ni apropiarse de éste. En 1961, cuando estos proyectos estaban cerca de su finalización, se iniciaba el desarrollo de otra nueva residencia de estudiantes en el sector extramuros al norte del campus. Cabo House fue construido por esos años copiando todas las características de las residencias de estudiantes tradicionales de esta parte de Norteamérica. Proyectada en versión inglesa de estilo palladiano, la construcción se coronaba con un enorme techo a dos aguas de tejas, y con su presencia, ayudaba a cerrar un jardín central que integraba un grupo de edificios pertenecientes a Harvard.

En medio de este contexto urbano-arquitectónico que estaba directamente relacionado con el crecimiento de la población universitaria y la extensión física de sus instalaciones, se iniciaba las conversaciones entre la Universidad de Harvard y la oficina de Sert, Jackson \& Gourley para la proyección de un nuevo conjunto de residencia para estudiantes casados. José Luis Sert y sus socios recibieron el encargo de proyectar las residencias, incluidas del plan de Harvard de 1960 recientemente nombrado y dirigido por Sert. Proponía construir un complejo de edificios de no más de doce plantas. Pero, el requerimiento no fue seguido al pie de la letra por la oficina del propio Sert, y propusieron un conjunto con torres del doble de altura, triplicando las áreas comunes abiertas a la ciudad y con mayor densidad de la prevista. Sert y sus socios se preocuparon mucho de que la propuesta no superara el costo inicial, pero definitivamente Sert fue más allá de lo pactado inicialmente, ya que vio en este encargo la oportunidad de crear un modelo de vivienda colectiva para el desarrollo urbano. Y efectivamente, este proyecto se convirtió en un proyecto insignia de residencia urbana en los años siguientes.

Entre 1958 y 1959, Sert propuso los talleres de proyectos de vivienda colectiva en la escuela, en donde se realizaron análisis e investigaciones teóricas de proyectos, al igual que propuestas de diseño. En las clases, se estudió todas las tipologías de vivienda colectiva proyectadas que se habían convertido en paradigmas de vivienda para el siglo $X X^{168}$, y se terminó con la publicación de un proyecto de vivienda colectiva para Cambridge en la zona sur del campus y algunos terrenos adyacentes. En este ejercicio, se puede ver el interés de Sert por investigar las posibilidades de la articula 
ción urbana de la residencia y vivienda colectiva entre las unidades de una y dos plantas y las torres de apartamentos, y al mismo tiempo, la especulación sobre el producto de la regeneración y desarrollo de la ciudad moderna en las estructuras urbanas existentes.

Peabody Terrace estaba en el lugar de una fábrica, que era lo más típico a lo largo del río. En esta época, los frentes de ríos eran considerados tierras de desecho y eran proyectadas como lugares de industrias y comercios ${ }^{169}$. En realidad, el área que ocupa el conjunto no solamente era el terreno ocupado por la fábrica, sino que a eso habría que agregarle una manzana y media de casas dispersas cuyo frente daba también al río, y que habían sido curiosamente identificadas como ejemplo de la dispersión de las viviendas en manzanas semivacías en barrios degradados en Cambridge en el plan de 1960. En esa publicación, Sert buscaba erradicar las viviendas en mal estado y construir proyectos de planta nueva. En estos momentos, el barrio de Riverside en Cambridge estaba catalogado como una zona de bajo nivel en su calidad de vida y por tanto, propensa a ser intervenida con proyectos de regeneración urbana por la Cambridge Redevelopment Authority.

Este conjunto, entonces, se convirtió en uno quebraderos de cabeza del proyecto de Sert, del mismo modo que el resto de las viviendas de poca altura del barrio, que significaron una preocupación para ser integradas en el conjunto de Harvard. Así, al iniciar el desarrollo del encargo, la oficina de Sert se vio en la tarea de proveer de residencia a los estudiantes casados de la universidad en un terreno de casi $6000 \mathrm{~m}^{2}$, con una densidad original de $85 \mathrm{hab}$./ha en ese terreno. Sin embargo, el resultado fue un proyecto con una densidad de 250 hab./ha, autosuficiente en servicios y capaz de ofrecer privacidad a sus residentes, al mismo tiempo que integra el conjunto al barrio de Riverside.

Parece evidente que Sert tenía aspiraciones de crear referencias metropolitanas para el campus de Harvard cuando colocaba tres torres, las mismas que iban coronando el perfil bajo de los edificios tradicionales del campus en su propuesta de crecimiento para la universidad unos años antes. Asimismo, se puede ver en los croquis de Sert como éste buscaba la creación de un conjunto que fuera capaz de generar los vínculos con su entorno y crear, a través de las torres, un punto de referencia metropolitano que buscara dialogar con los campus constituyentes tanto del MIT como de la Universidad de Boston. Por esos mismos años, en una conferencia referente a la relación entre el urbanismo y la vida académica, Sert enuncia varias ideas de las que se desprende sus intenciones para el campus de Harvard: "Los edificios bajos deben albergar los espacios de grandes dimensiones y aquellos que requieran tratamiento especial. Éstos pueden continuar formando plazas cuadrangulares como en los modelos británicos"1170. Las torres pueden ser de muchas formas distintas, determinadas por usos diferentes y condiciones que no 
rompan las barreras de altura, o tengan un bloque que oprima los tamaños de los edificios más bajos y las plazas. Así, por un lado, con la creación de las plazas cuadrangulares de edificios bajos de larga tradición en las universidades del noreste americano, se continuaba con la topología en la configuración de espacios urbanos académicos; mientras que, por el otro lado, las torres proveían de densidad suficiente para que tales espacios estén cargados de vida y actividades.

Dentro de las estrategias de integración al entorno, el complejo de Peabody Terrace mantiene bajas alturas en la mayor parte de sus edificios y ofrece amplios espacios urbanos a pesar de tener una alta densidad. Este conjunto de 1500 personas está formado por edificios bajos de tres y cinco plantas con algunas partes de hasta siete niveles que articulan la transición a las torres de veintidós plantas. Las fachadas del conjunto hacia el barrio cuentan con tres niveles de altura ajustándose a la proporción de las casas. Otra estrategia para integrarse a la zona es la apertura de las calles peatonales que conectan directamente los espacios públicos de Peabody Terrace, el barrio de Riverside y el resto del campus. Bajo este objetivo, se clausuró las calles Banks (dirección norte-sur) y Sterling (dirección este-oeste) al tráfico rodado para convertirse en trayectos peatonales con espacios abiertos en forma de alamedas. Esta acción, que no sólo enriquece el espacio urbano, se puede entender como un manifiesto crítico a una sociedad más bien motorizada que ha olvidado el recorrido peatonal. El caso del tramo este-oeste, que comunica el barrio de Riverside con el río, ofrece los servicios de uso diario como kindergarten, tienda/bodega y la lavandería; de la misma forma en que Sert lo había descrito en su ponencia de 1952, como se ha mencionado anteriormente.

Durante las décadas de 1960 y 1970, el conjunto fue premiado en distintas oportunidades por diferentes instituciones oficiales en los Estados Unidos ${ }^{171}$. Entre los motivos de las distinciones, se destacaba sus ideas urbanas, la plasticidad y complejidad de sus volúmenes en su expresión arquitectónica, así como su efectividad constructiva y técnica. De ese modo, el conjunto se convirtió en un modelo de residencia económica y colectiva.

Aparentemente, la sola presencia de un conjunto perteneciente a una universidad tan poderosa en medio de un vecindario de bajos ingresos fue razón suficiente para el rechazo de sus vecinos. Incluso, la construcción de las torres, cuyo objetivo era ofrecer densidad sin hacinar el ambiente del barrio, fue tomada como demostración de poder. Asimismo, la ubicación del volumen del estacionamiento con capacidad para 350 vehículos frente al complejo de vivienda pública existente, también creó malestar entre sus vecinos. Posteriormente, la colocación de unas vallas, por decisión de la administración, que delimitaron claramente el límite de propiedad fue, además de lo mencionado, motivo suficiente para argumentar el rechazo definitivo de sus vecinos al conjunto. Al parecer, todas estas quejas 
expresaron la falta de identificación de los vecinos con la arquitectura moderna austera de carácter colectivo y la poca familiaridad con una estructura abierta y contundente. Sin embargo, si analizamos los objetivos del proyecto y los comparamos con lo que éste ofrece a sus habitantes, se pueden desprender otras reflexiones. Una de las preocupaciones en el diseño del conjunto fue la creación de diversos espacios comunes para actividades colectivas. De los espacios públicos, los más destacables son la plaza central y los jardines laterales. La creación de la plaza central en el cruce de los ejes norte-sur/este-oeste del proyecto no sólo constituye la refundación simbólica del lugar, sino, además, ofrece a la "ciudad" un espacio de reposo. Las proporciones y el escalonamiento de los edificios que circundan la plaza están correctamente tratados, de tal modo, que eliminan el impacto de la torre de veintidós pisos que flanquea uno de sus lados. Igualmente, el juego de las fachadas con los balcones y la diferenciación de la estructura y los cerramientos prefabricados colaboran con la articulación de los volúmenes que configuran la plaza. Por su condición de centralidad, la plaza es usada con mucha frecuencia; sobre todo, cuando el clima lo permite, se observa niños y familias disfrutando la calma del paisaje. Igualmente, los jardines laterales al este y oeste del conjunto se articulan con la misma calidad y ofrecen al habitante sensación de libertad a pesar de que los edificios que los definen tienen alta densidad. Estos jardines son frecuentemente utilizados por los vecinos y el resto de la comunidad universitaria que organiza eventos al aire libre. Otra vez, el factor del clima es determinante para su uso; pero, al menos, a mitad de año se organiza reuniones o simplemente es utilizado por la gran población infantil que acude diariamente a la guardería infantil que ocupa uno de sus lados.

Sin duda, la plaza en Peabody Terrace ocupa el lugar central del proyecto. La voluntad de que la arquitectura promueva el encuentro y desarrollo social se centra en el planteamiento de la plaza., la imagen de la ciudad medieval está presente en la mente de Sert al proyectar Peabody Terrace, con sensibilidad por el espacio público y los trayectos peatonales. En ello, uno de los factores mejor logrado del proyecto es el manejo de escalas para pasar de lo urbano a lo doméstico, es decir, de lo público a lo privado. La forma de lograr esta transición espacial y sensorial es a través del manejo de la escala metropolitana a la vecinal y, finalmente, a la residencial. Desde la ciudad, se accede al conjunto a través de los umbrales que generan los edificios; éstos preparan la llegada a la plaza principal, la cual ofrece al usuario una suave transición a los vestíbulos de los edificios, y éstos a los pasadizos de los departamentos. Finalmente, un pequeño espacio de distribución anuncia la entrada al departamento que generalmente remata en un ventanal y un balcón que dirige la vista al río. 

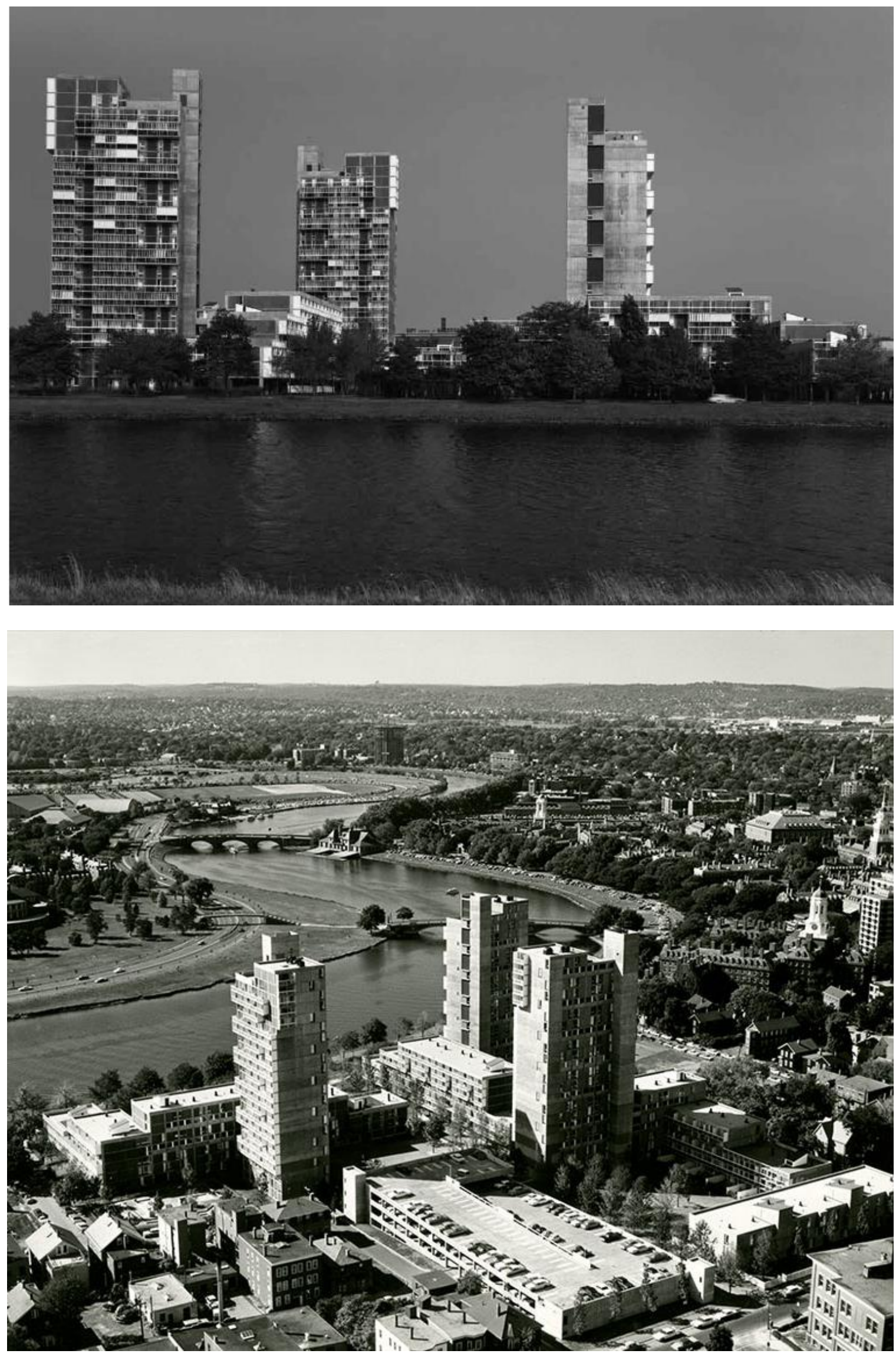

Imagen 330 y 331: Complejo residencial Peabody Terrace, orientado a la orilla del rio Charles. Como en los casos de residencia en altura de Nueva York, la tipología es muy variada, estableciendo hasta 5 tipos diferentes de vivienda. 


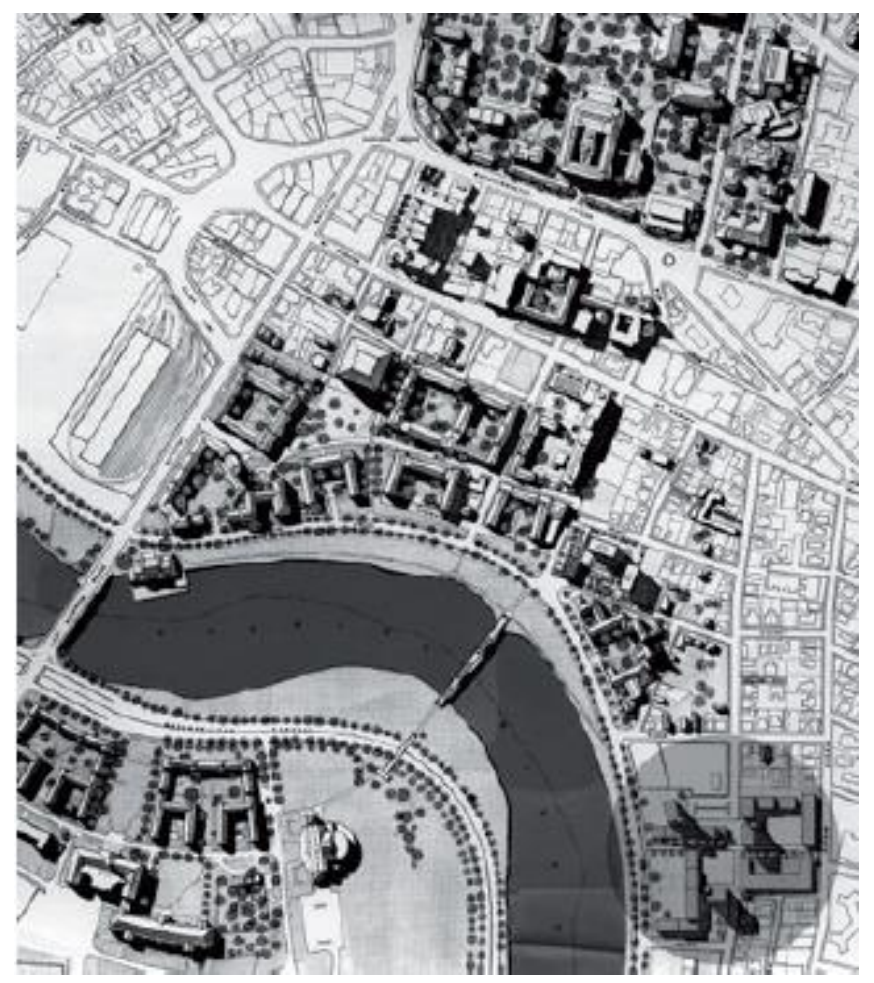

Imagen 332: Ubicación del Peabody Terrace en la orilla del io Charles.

Imagen 334: Boceto de Jose Luis Sert donde configura cada uno de los espacios siendo la interacción entre las distintas partes del conjunto, bloques bajos y bloques en altura, su principal objetivo de proyecto.
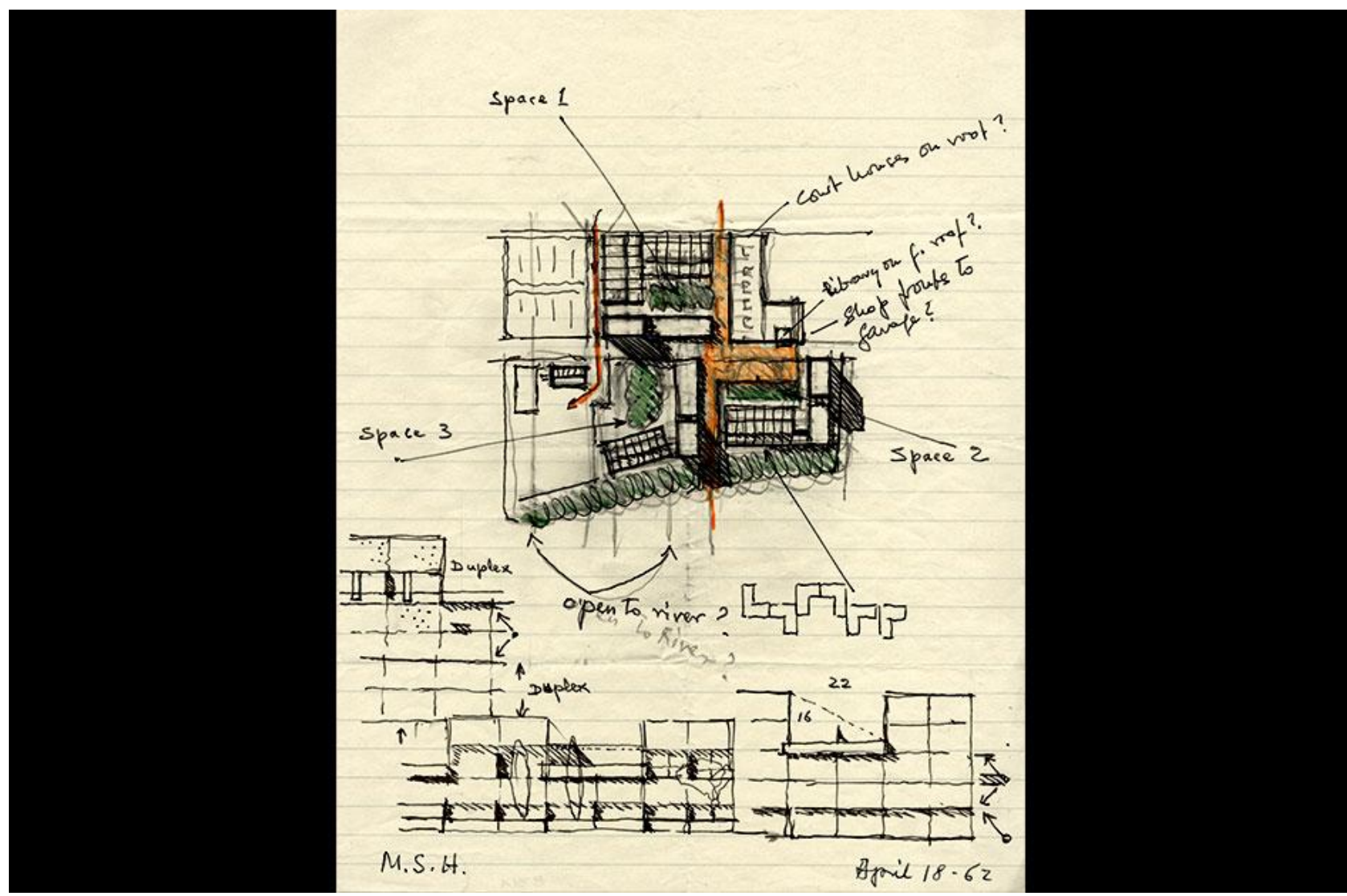
RESIDENCIAS UNIVERSITARIAS EN LA HISTORIA

\section{BLOQUE II}

LA RESIDENCIA DE LA BAUHAUS: Autonomía y funcionalidad moderna.

La sede universitaria Universitaria en Dessau (1925) 


\section{LA SEDE UNIVERSITARIA EN DESSAU (1925)}

En este caso se estudia el edificio de la Bauhaus en Dessau centrando la atención en su bloque destinado a residencia de estudiantes. Aquí no está ligada a una universidad en particular pero se considera al conjunto de categoría universitaria debido al movimiento que generó y la talla de escuela de artistas que aquí se creó.

En primer lugar hay que destacar el control territorial que el edificio ejerce en el desarrollo urbano ${ }^{172}$. El edificio se relaciona con la ciudad y éste hecho se puede apreciar desde el proyecto, el conjunto se posiciona en relación a las principales infraestructuras territoriales, condicionando el posterior desarrollo del mismo y creando un espacio urbano cualificado.

Esta arquitectura empieza a transmitir y demostrar que participa y activa el lugar en el cual se implanta, sin que ello merme la idoneidad de su solución funcional sino por el contrario, la multiplique, porque I estrategia del proyecto aprovecha la interacción y la superposición de todos los objetivos perseguidos en un ensayo interesadísimo por demostrar el potencial de la arquitectura funcional moderna para construir no sólo habitaciones confortables, sino también ciudades funcionales y paisajes urbanos amables.

Dessau se encuentra al sur del río Elba. En esta ciudad, urbanisticamente, las vías principales de circulación (carreteras) se encuentran en sentido norte-sur $u$ este-oeste. La entrada desde el norte se transforma en la avenida principal. El trazado ferroviario atraviesa Dessau en paralelo a esta avenida, y constituye un límite al oeste de la ciudad. En el otro extremo se encuentra el río Mulbe, afluente del Elba, que configura el otro límite. Existen una serie de avenidas y pasos elevados de tren que relacionan al edificio con las arterias principales de transporte. Una de estas vías es la Gropiustrabe, donde la edificación se sitúa en su punto medio y dando frente a Bauhausplatz. La arteria que pasa por el bloque elevado de oficinas es la BauhaustraBe que actualmente es el eje principal del campus universitario. Por tanto funciona como germen del núcleo universitario y como puerta de encuentro de la red de infraestructuras metropolitanas y la red de circulación local de carácter más doméstico y peatonal. Se configura como un edificio único aunque aunque con varios cuerpos reconocibles y claramente diferenciados por su volumen y su materialización. 

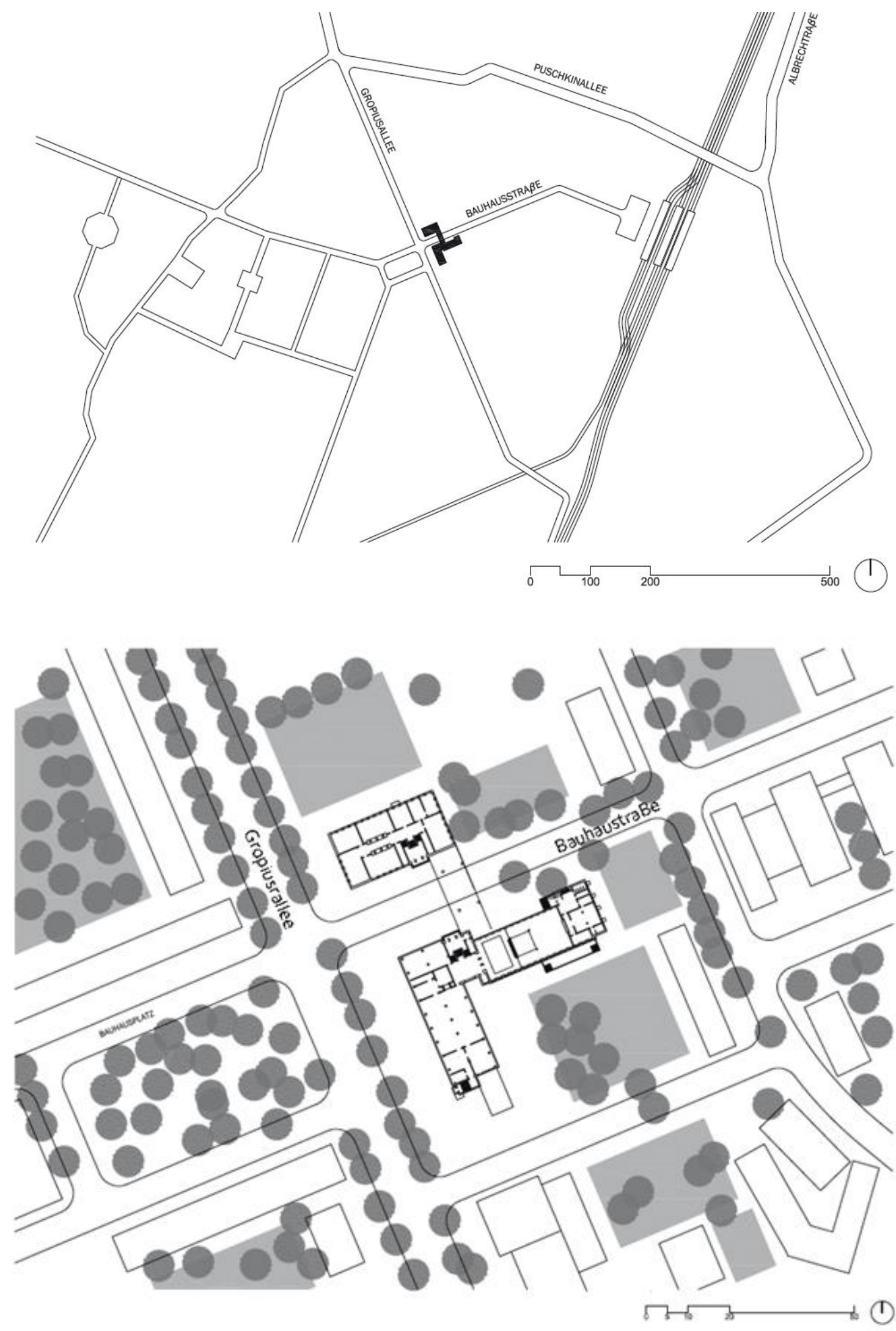

Imagen 335: Lección en la Universidad de Bolonia. Ilustración que se conserva en el Staatliche Museum de Berlín.

Las clases en lasaulas castellanas tienen la misma disposición.

Imagen 336: Emplazamiento del Colegio de los españoles en Bolonia 
Al referirse al edificio, Gropius afirmaba que al rechazar la fachada tradicional simétrica, la estructura del edificio exigía que el espectador caminara bordeándolo para comprender su composición. Los interiores, desde los colores, hasta la señalización, los acabados e incluso el mobiliario, se convirtieron en una expresión de la filosofía Bauhaus.

Un notable carácter funcionalista se observa en esta obra ya que, presenta volúmenes independientes para las diferentes funciones impuestas por un complejo programa. Además de la diferencia de tamaño entre los volúmenes, estos abren diferentes huecos en la fachada dependiendo de la función que albergan

Gropius separó cada función en un volumen prismático individual con entrada independiente: el más espectacular, por su extensa fachada de vidrio, alberga los talleres; otro contiene las aulas de la escuela profesional; y el tercero, de mayor altura, es la residencia de los alumnos. Los dos primeros están unidos por un cuerpo elevado sobre una calzada en el que se encuentran la administración y el despacho del director. A su vez, talleres y residencia se conectan mediante un cuerpo bajo ocupado por el salón de actos, el escenario y la cantina. El edificio forma así un conjunto dinámico. Los diversos volúmenes se distinguen además por la distinta articulación de las fachadas. La del bloque de talleres es un plano continuo de vidrio que deja traslucir los grandes espacios interiores; en el bloque de la escuela, las bandas continuas de amplios ventanales corresponden a las aulas de tamaño intermedio; y la torre de residencia de estudiantes se resuelve mediante huecos individualizados con balcones.

Dentro del programa, que se puede clasificar como experimental y cambiante, centramos la atención en el bloque de residencia estudiantil. Posee dos accesos, uno situado en la parte norte y dos en la sur. El primero desemboca en la zona del vestíbulo y el segundo se encuentra en la terraza que da servicio exterior a la cantina, donde a través de ésta y pasando previamente por el auditorio se llega finalmente al bloque residencial.

El programa es sencillo y se desarrolla en seis niveles. Planta baja y cuatro plantas sobre rasante y un nivel bajo rasante. En la planta baja se encuentra la cocina y la despensa. En planta primera y en las otras tres sucesivas se disponen 7 habitaciones por planta de igual tamaño con orientación este-oeste. En cada planta también hay un aseo de uso común. Para acceder a cada una de las plantas existe una escalera en el extremo oeste que desemboca en los corredores que dan acceso a las habitaciones. Este corredor se 
encuentra iluminado por un gran ventanal en ambos de sus extremos norte-sur.

En el semisótano hay un espacio de lavandería, gimnasio y duchas.

La construcción, en cuanto a materiales se refiere, tiene como protagonistas al hormigón, al vidrio y al hierro. Son los materiales modernos por excelencia. El uso del vidrio en las paredes es fundamental para que la luz invada el espacio de trabajo de las habitaciones para que el aprovechamiento del estudio sea máximo. Gropius no contempla ningún elemento de control de la luz como parasoles o cortinas, lo que acentuará la vista hacia el entorno natural que rodea al bloque residencial. Se potencia la relación interior-exterior con balcones individuales, conformados con una losa de hormigón, interpuestos en cada una de las habitaciones, donde proyecta el espacio interior hacia afuera.

Este bloque es el más másico del conjunto, interrumpido sólo en la fachadas este y oeste como se acaba de mencionar, quizás por el ser el más privado de los espacios.

El conjunto se completó con otros edificios independientes: la casa del director, y tres casas dobles para el profesorado. Sin embargo, la Bauhaus no gozó de larga vida: fue cerrada poco antes del ascenso al poder del nacionalsocialismo, unos años después de que Gropius abandonara la dirección. El edificio fue profundamente transformado durante el régimen nazi y, además, sufrió bombardeos durante la segunda guerra mundial. No le fue mejor tras la guerra: el régimen comunista impidió su reapertura, y sólo comenzó la recuperación del edificio a mediados de los años setenta. 

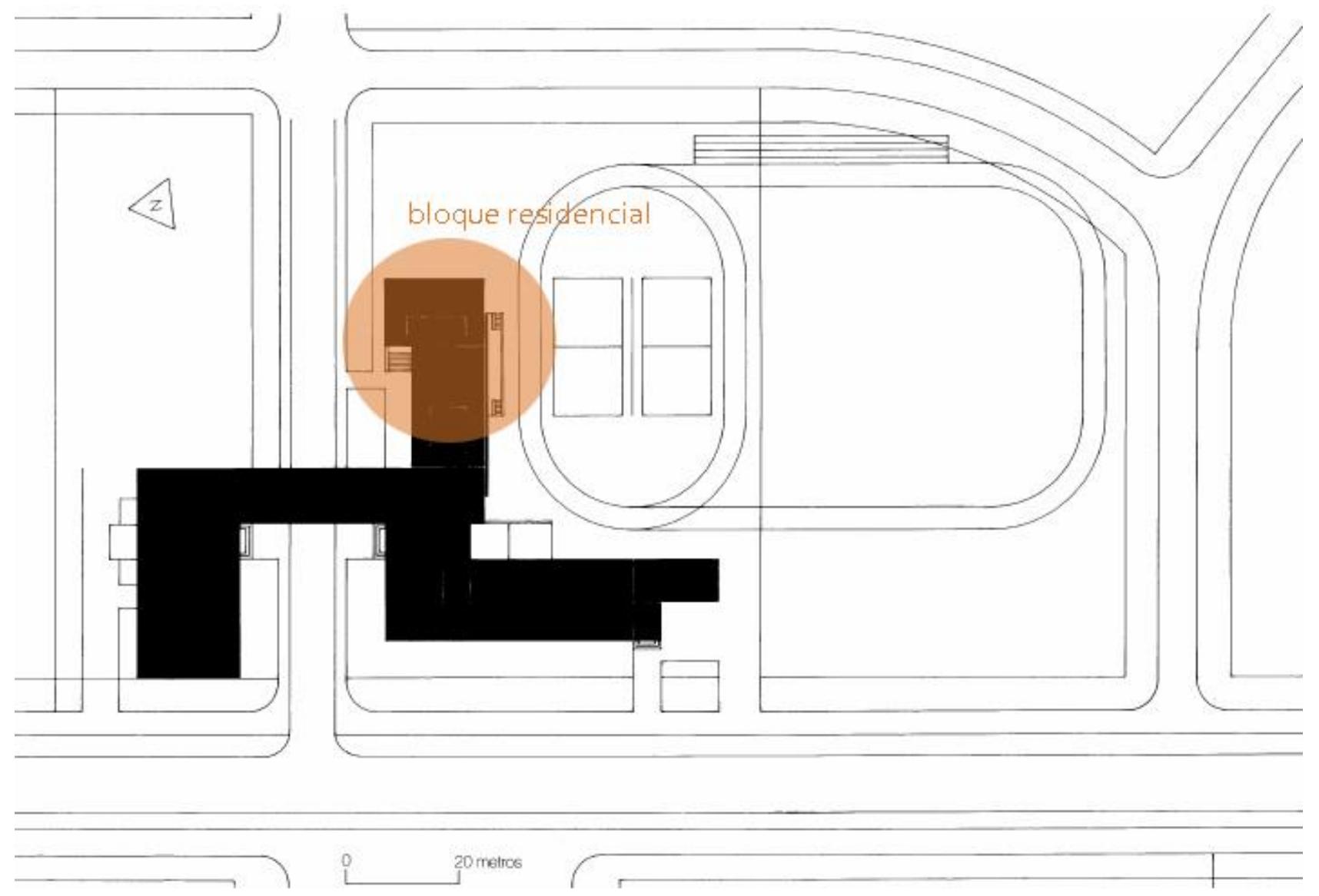

Planta del conjunto

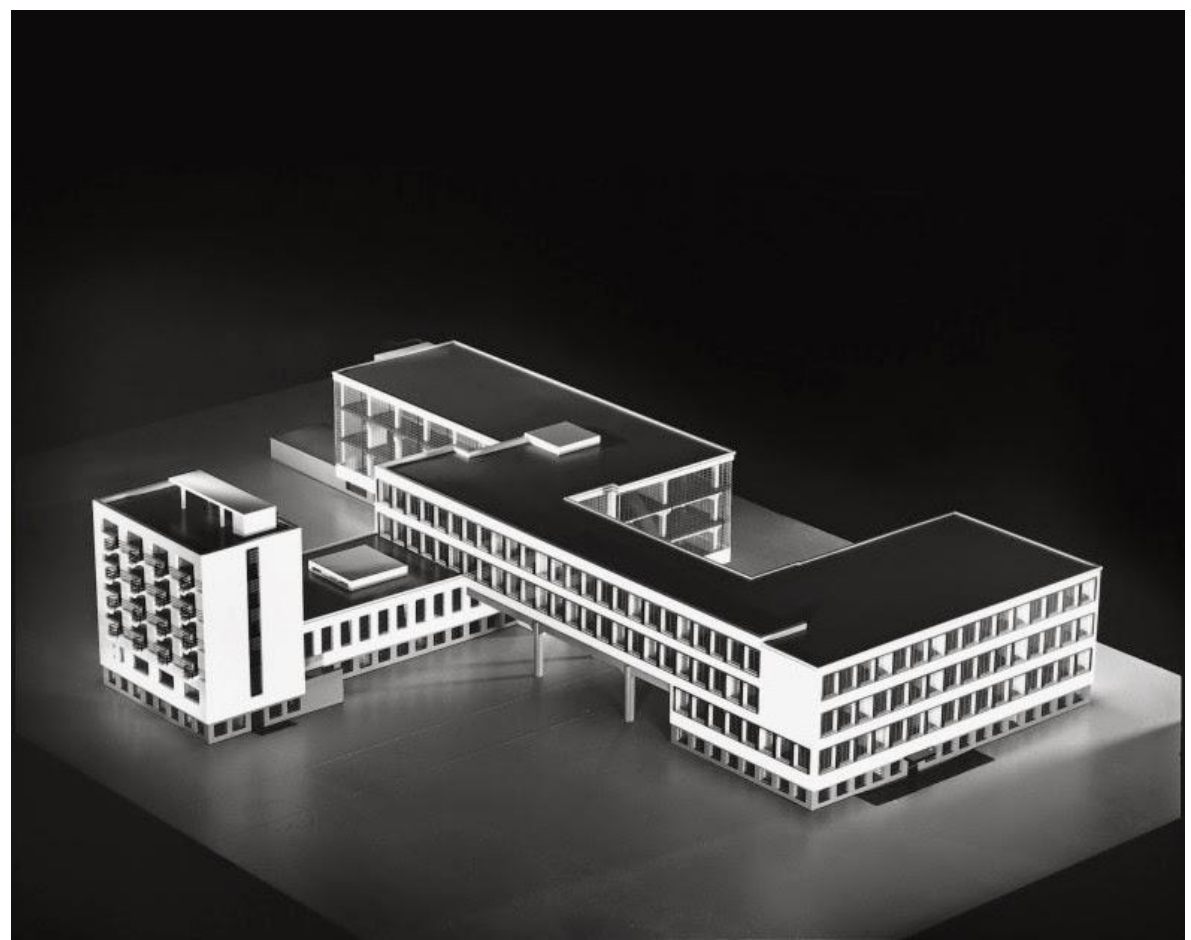

Imagen 337:

Emplazamiento del conjunto

Imagen 338: Maqueta.

En esta se aprecia la

separación de

volúmenes según

funciones y la conexión

entre ellos 
Planta semisótono

1 baños, gimnasio,

vestuarios, lovandería

2 taler de leatro, imprenta

erildo, escultura, empaquetado

y almacenamiento, vivienda

del conserie, coldera, carbonera

3 labaralorios, aulas
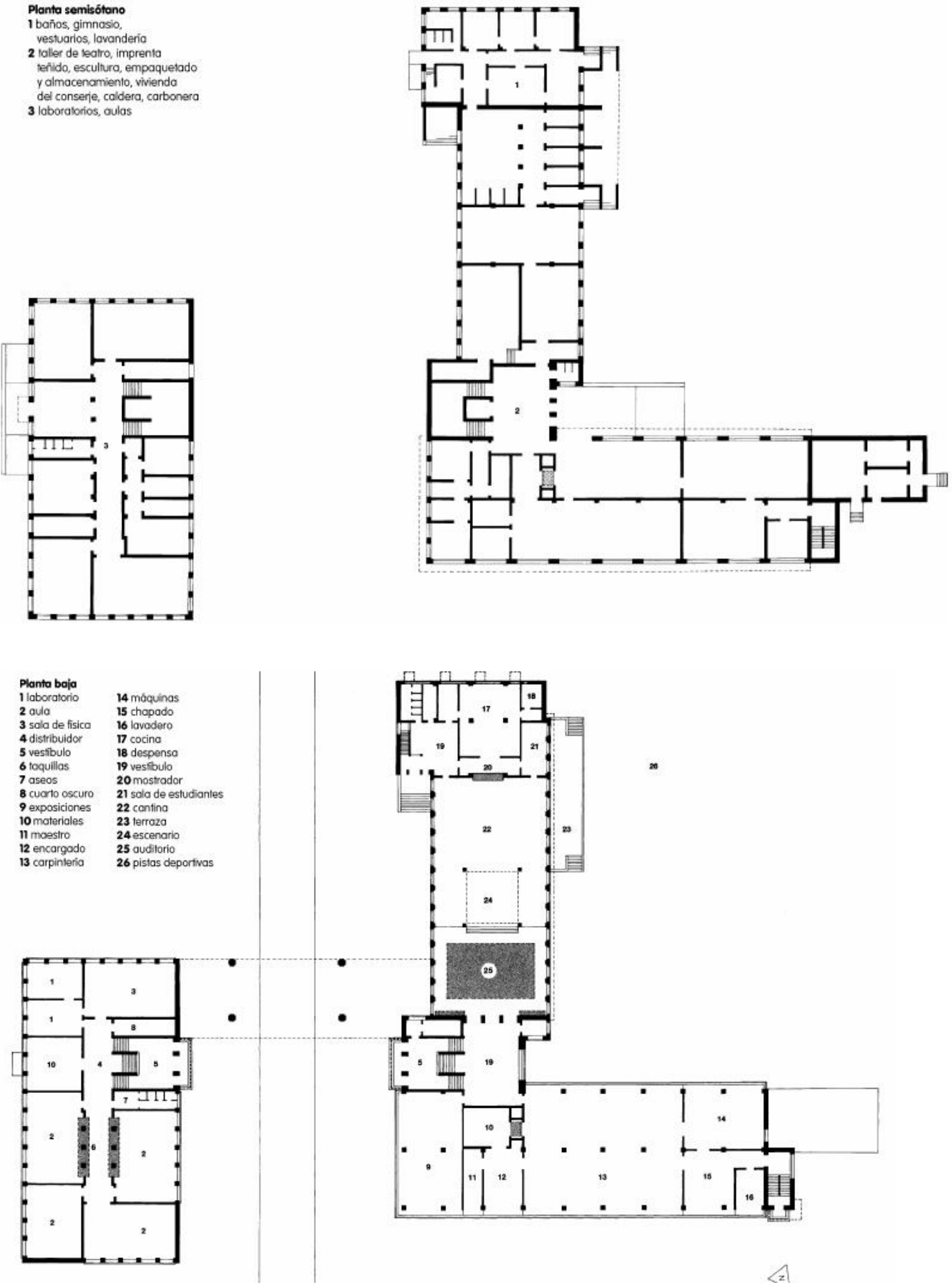

Imagen 339: Planta semisótano del conjunto 
Planto segunda 1 distribuidor 2 corredor

3 materioles

4 aula

5 estanterios

$6 \mathrm{dpto}$. arquisecturo

7 profesor

oficing

9 conferencias

10 vesfibulo

11 estudio

12 allodo

13 galvanización
14 soldadura

15 melales

16 moestro

17 máquinas

18 toria

19

20 guardarropa

21 lovadero

22 ialler

23 pintura mural

24 barnizado

25 aseos

26 estudio

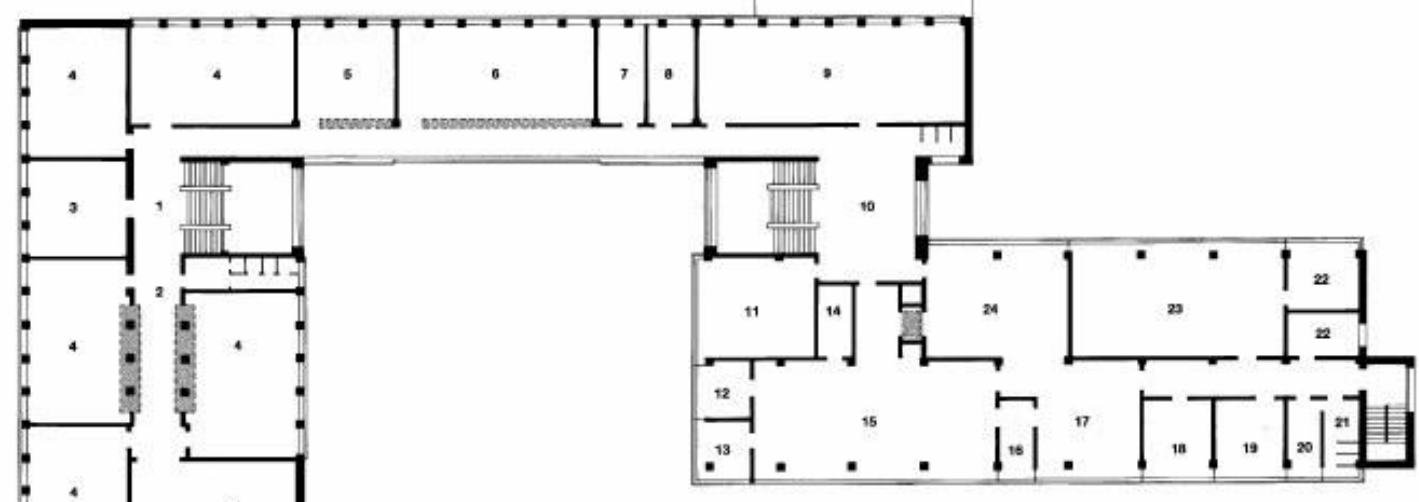

Imagen 340: planta segunda del conjunto

Imagen 341 : Sección por el bloque de habitaciones

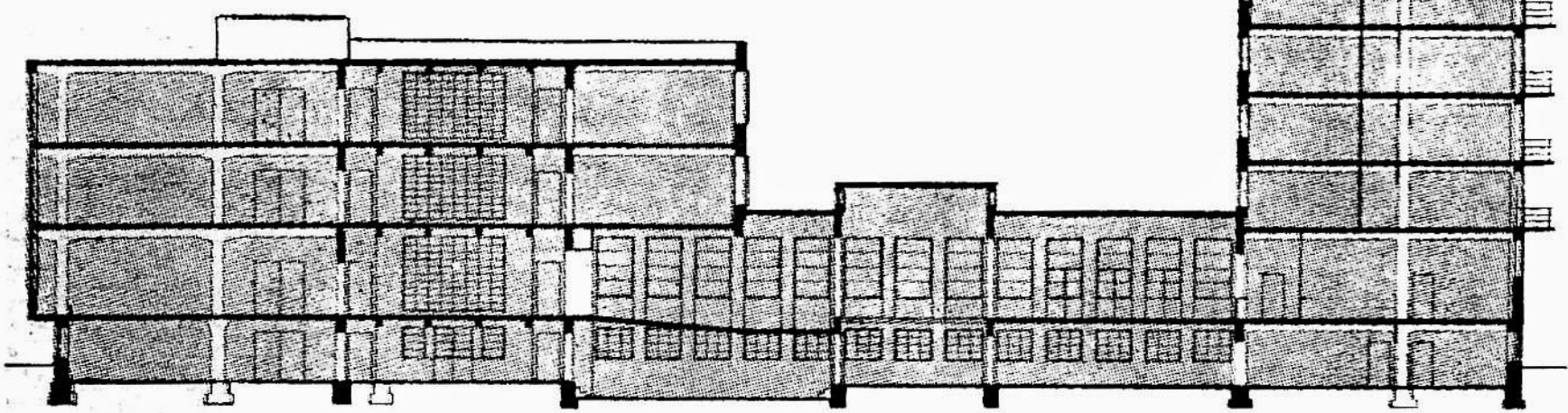



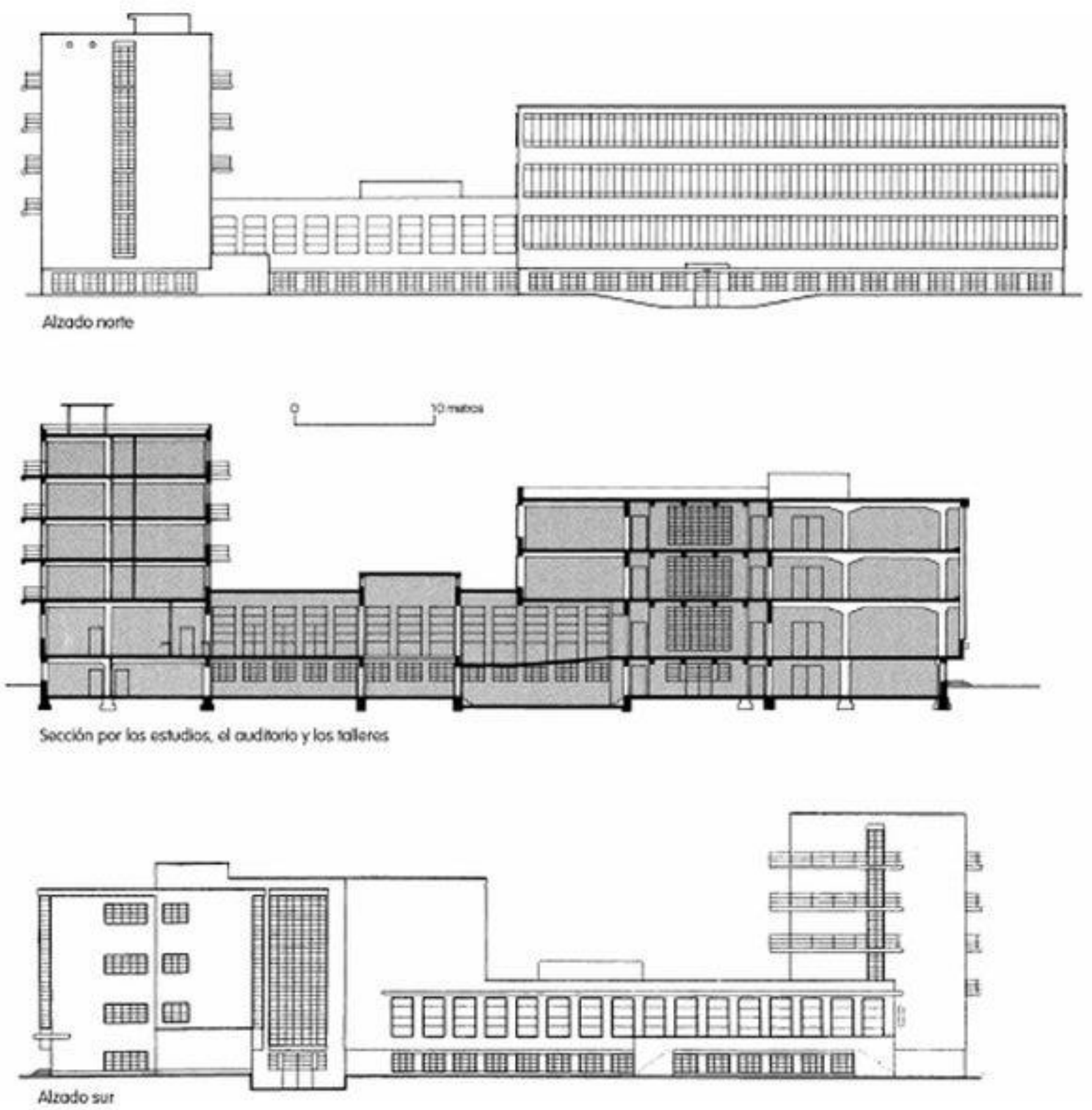


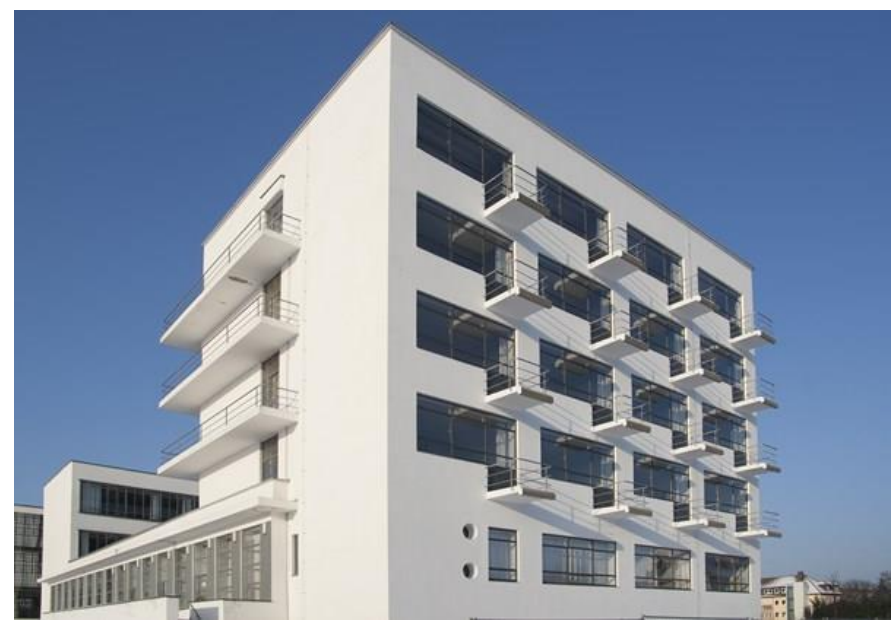

Imágenes 343, 344, 345 y 346 Vistas del bloque de habitaciones residenciales
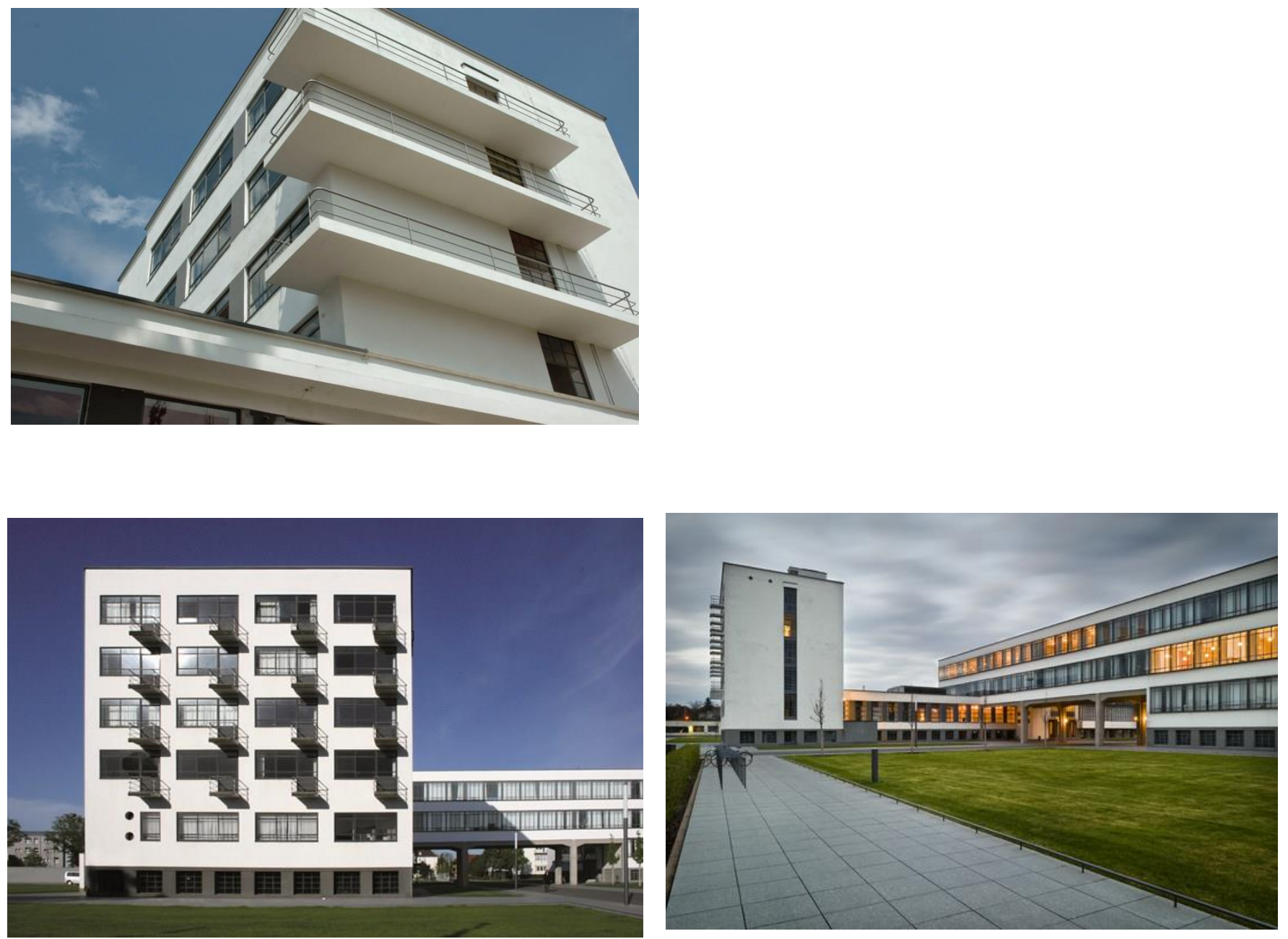


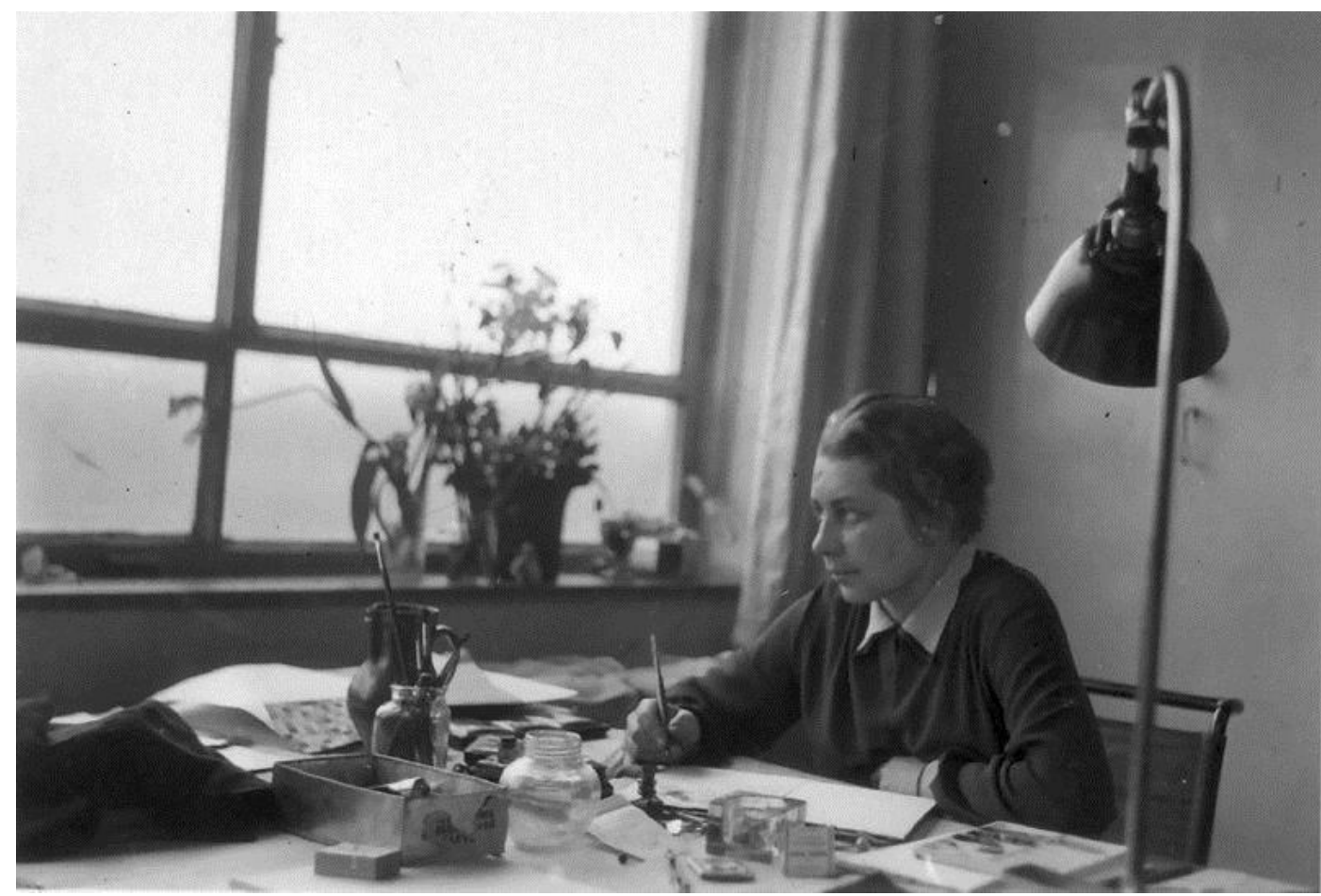

Imagen 347: Gunta Stölzl trabajando en su atelier de la Residencia de estudiantes de Dessau.

Imagen 348: Una de las habitaciones de estudiantes de la Residencia.

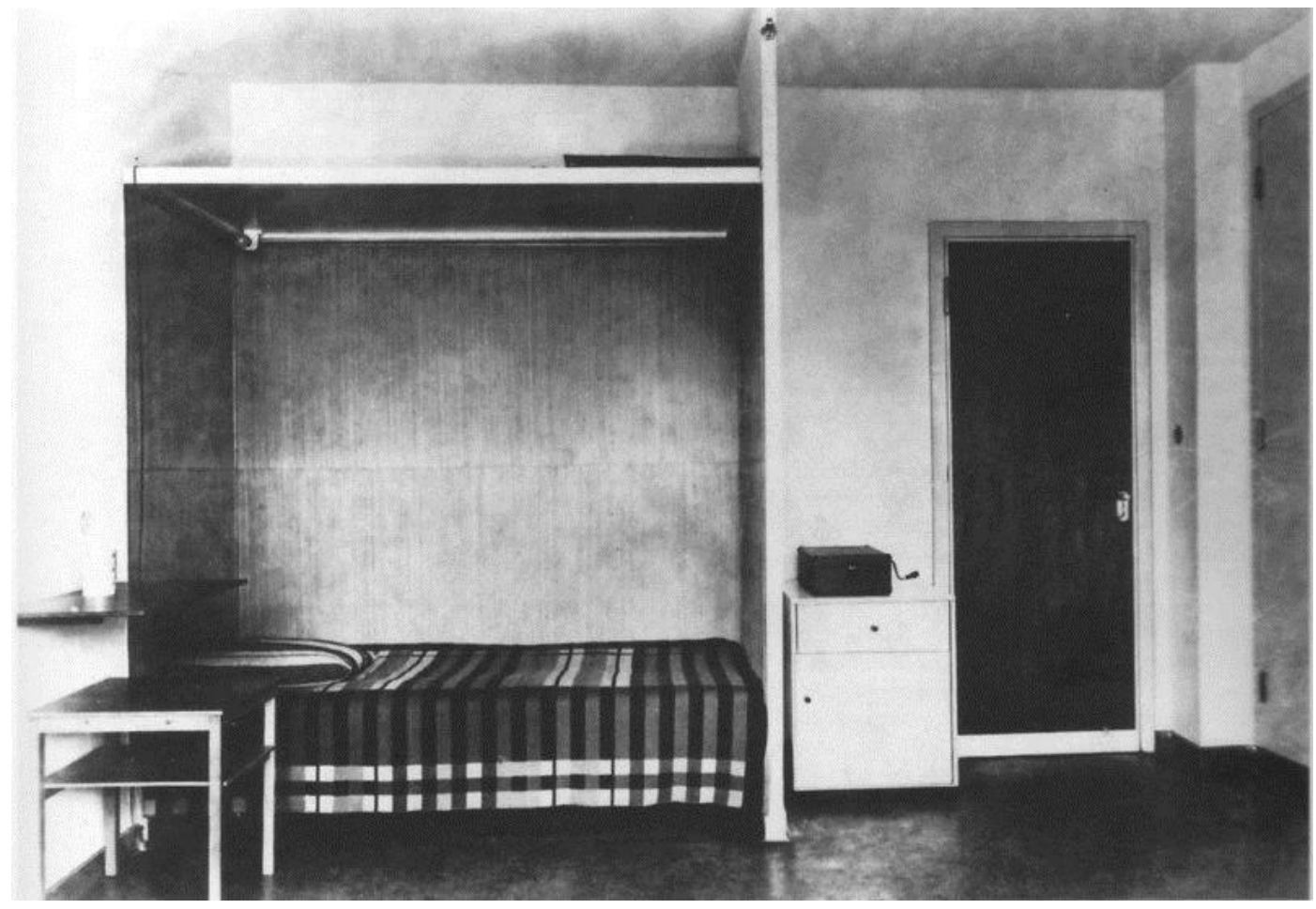




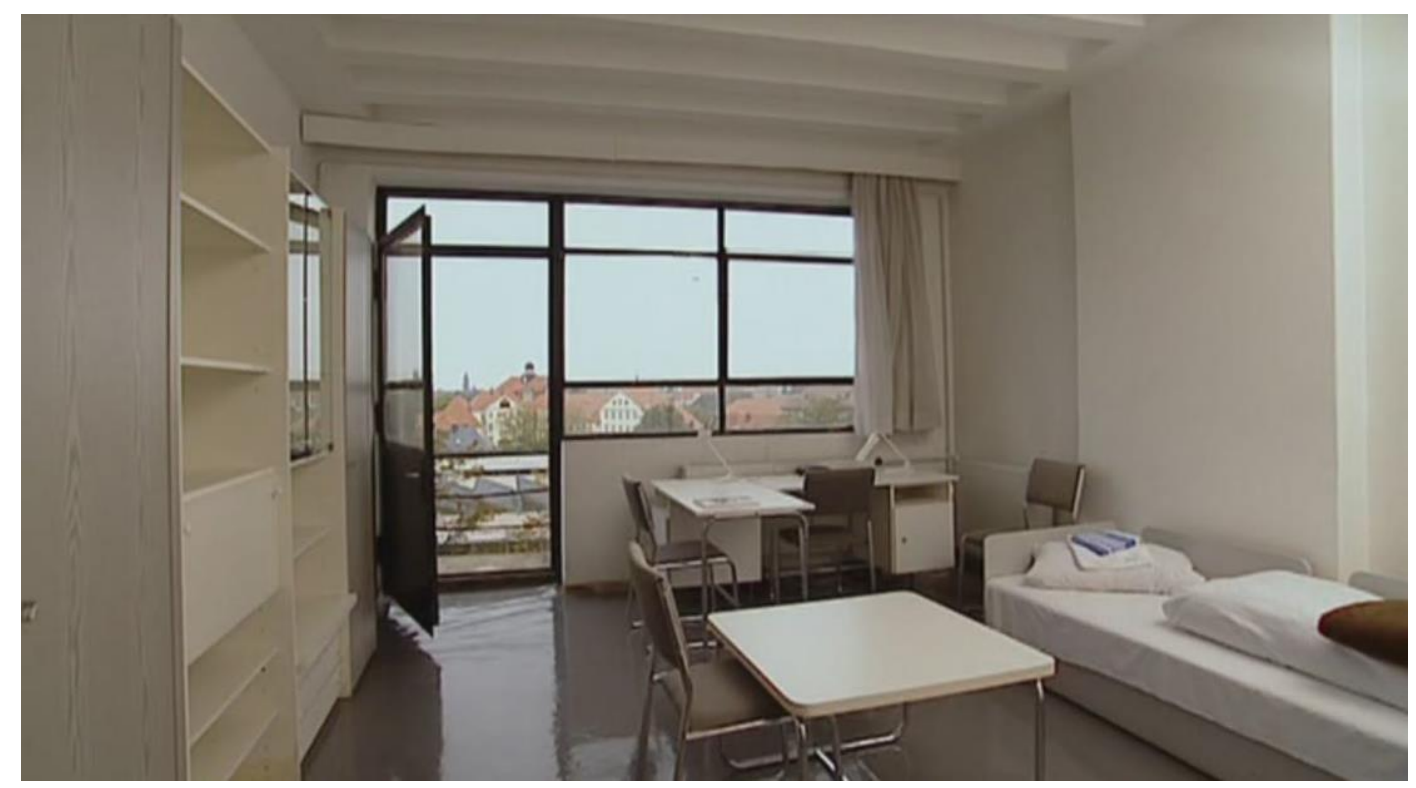

Imagen 349: El espacio de las habitaciones de los estudiantes está totalmente iluminado por una gran cristalera, la cual conecta la estancia con el balcón que es la prolongación del espacio interior con el exterior. Esta relación será llevada a cabo en todos centros residenciales modernos. 


\section{NOTAS $Y$ REFERENCIAS BIBLIOGRÁFICAS (RESIDENCIAS UNIVERSITARIAS EN LA HISTORIA)}

1. MAGALLÓN IBARRA, Jorge Mario, "El Renacimiento Medieval de la Jurisprudencia Romana", Ed. Universidad Nacional Autónoma de México. 2002. pag 155.

2. Tesis Doctoral "El Colegio de Bolonia (1788-1889)", autor: Carlos Nieto Sánchez,dirigida por Raquel Sánchez García. Universidad Complutensede Madrid, 2011. pag 19.

3. PÉREZ MARTíN, A. "Proles Aegidiana". Ed. Publicacionesdel Real Colegio de España, 1979. pag 27.

4. SERRA DESFILIS, Amadeo y COLOMER, Josep Lluis, " España y Bolonia: siete siglos de relaciones artísticas y culturales",Ed Fundación Carolina: Centro de Estudios de Europa Hispánica.pag 20.

5. ROGGERO, Marina, "I collegi universitari in etá moderna", en L'Université in Italia fraetá moderna e contemporanea: aspetti e momenti. Ed CLUEB, Bolonia, 1991.

6. Artículo "Glispagnoli prima dellafondazione del collegio di Egidio d'Albornoz (13641369), en El Cardenal Albornoz y el Colegio de España, vol II, Bolonia, Publicaciones del Real Colegio de España. 1972, pag 43.

7. SERRA DESFILIS, Amadeo y COLOMER, Josep Lluis, " España y Bolonia: siete siglos de relaciones artísticas y culturales",Op cit pag

8. MARTI, B. "The Spanih college at Bolonia in the fourteenth century",Edition and traslation of its statutes with introduction and notes. Filadelfia, 1996.p.132.

9. VELASCO Y HEREDIA, Salvador Silvestre de, "Compendio de la fundación y privilegios del Colegio Mayor de San Clemente de los españoles en Bolonia, fundado por el cardenal Carrillo de albornoz". Sevilla, imprenta de Blae, 1695. p. 16.

10. Dámaso de Lario afirma que el cardenal había creado su fortuna con el patrimonio adquirido durante los años dedicados a reorganizar y conquistar los Estados de la Iglesia. Con este capital Albornoz, y al morir sus albaceas, adquirieron un total de 602 hectareas de tierra rústica por valor de 35.191 libras boloñesas y una serie de fincas urbanas, valoradas en 14.951 libras, en "Al hilo del tiempo. Controles y poderes de una España Imperial, Valencia, Publicaciones de la Universidad de Valencia, p85.

11. CÁNOVAS DEL CASTILLO, Antonio: "El cardenal Albornoz", Sevilla, tipografía de El Universal, 1894, pp. 4 y 26

12. TAMBURRI, P. "NatioHispanica: juristas y estudiantes españoles en Bolonia antes de la fundación del Colegio de Espana", Zaragoza, 1992

13. BELTRÁN DE HEREDIA, V."Primeros estatutos del Colegio Español de San Clemente de Bolonia", ed. Hispania Sacra, XI, 1958, pp.187-224 Y 409-426.

14. ACE , Instrumenta praediorumurbanorum, caja I, doc 35, El texto íntegro del documento en F. FILIPPINT, "Mateo Gattapone da Gubio, architetto del Colegio de di Spagna in Bolonia, BolletinodÁrte, 11 (1922-1923), pp. 91-92. Y nuevamente transcrito y comentado en A. SERRA DESFILIS, MatteoGattapone, arquitecto del Colegio de España, Zaragoza, 1992 pp. 198-199).

15. RUIPÉREZ, M.N., "EL Colegio Mayor de San Bartolomé o de Anaya". Ed. Universidad de Salamanca. Salamanca, 2003. P. 19 
16. SERRA DESFILIS, Amadeo y COLOMER, Josep Lluis, " España y Bolonia: siete siglos de relaciones artísticas y culturales". Op. Cit p. 24.

17. Ibíd, p. 25

18. RUIPÉREZ, M.N., "EL Colegio Mayor de San Bartolomé o de Anaya". Op. cit. P. 21.

19. F.MARTIN, "Influencia del Colegio de San Clemente de Boloniaen los Colegios Mayores españoles", en VERDERA (ed)1972, vol II, pp 239-26o

20. Véase J. DE ROXAS Y CONTRERAS (MARQUÉS DE ALVENTOS), Historia del Colegio Viejo de San Bartolomé, Madrid, 1976, p. 28 y 40. Sopsa esta posibilidad PEREDA, 2000, pp 27-31.

21. PEREDA 2000, pp 29-31; y RUIPÉREZ 2003, pp 19-26

22. SERRA DESFILIS, Amadeo "El Colegio de España en Bolonia y la arquitectura universitaria del primer renacimiento en Italia y España" en España y Bolonia: Siete siglos $S$ de relaciones artísticas y culturales, Ed Fundación Carolina. Centro de estudios de Europa Hispánica. P, 25.

23. Ibid, p.26.

24. J.J. MARTIN GONZÁLEZ, "Valladolid, ciudad universitaria", Boletín del Seminario de Estudios de Arte y Arqueología, LXI, 1995, pp.467-476, y PEREDA 2000, p. 45.

25. CERVERA VERA, L. "Arquitectura del Colegio Mayor de Santa Cruz en Valladolid, 1982, P. 14 .

26. Veáse M.A. ZALAMA, "Arquitectura y estilo en la época de los reyes católicos", en F. CHECA(ed), Isabel la Católica. La magnificiencia de un reinado, Valladolid, 2004 pp. $127-140$

27. El Cardenal Mendoza quiso que la obra del colegio fuera muy "sumptuosa, rica y costosa" según P. DE SALAZAR Y DE MENDOÇA, Crónica del Gran Cardenal de España, don Pedro González de Mendoça, Toledo, 1625.

28. M. GÓMEZ MORENO, Sobre el renacimiento en Castilla, Granada, 1991, pp 37-47(ed. Original 1925); L. CERVERA VERA, "Arquitectura del Colegio Mayor de Santa Cruz de Valladolid, Valladolid, 1982; F. MARIAS, "El largo siglo XVI. Los usos artísticos del Renacimiento Español, Madrid, 1989, pp. 254-256, con una reconsideración del papel de Lorenzo Vázquez y de la importancia atribuida al edificio y a su maestro de obras en la Arquitectura del renacimiento español. El patio tuvo que ser reconstruido en gran medida en 1602-1603 y otra vez en 1744-1745

29. L. CERVERA VERA, "Arquitectura del Colegio Mayor de Santa Cruz de Valladolid, Op. Cit. p 256.

30. MARIAS 1989, pp. 255 y 257-258. F. MARIAS, "Los Mendoza y la introducción del renacimiento en España", en Nobleza, coleccionismo y mecenazgo, Sevilla, 1998, pp. $29-44$

31. OLIVARES MAERTíN, Diana, "Documentos para el estudio de Alonso y el colegio San Gregorio de Valladolid" en "Estudios Medievales Hispánicos". ED. Universidad autónoma de Madrid, Madrid, 2014.

32. AGAPITO Y REVILLA, J. "Del Valladolid Monumental: El Colegio d San Gregorio", Boletín de la Sociedad Castellana de Excursiones, 107 (1911), pp.240-244; 108(1911), pp. 253-26o y 109 (1912), pp.269-279.

33. ARRIAGA, G. de, "Historia del Colegio de san Gregorio d Vallaoolid", Vol I, pp. 29-30. 
34. MARTINELL, C. "Las antiguas universidades y colegios españoles como monumentos arquitectónicos". Cuadernos de arquitectura, 9. (1945), p. 5.

35. Ibíd, p. 12

36. Ibíd, p.13

37. Otros muchos Colegios se han puesto en relación con el del Arzobispo de Salamanca, tales como el de Oñate, aunque en una versión muy simplificada.

38. SERRA DESFILIS, Amadeo,"El Colegio de España en Bolonia y la arquitectura universitaria del primer renacimiento en Italia y España".Op. cit. P.27.

39. SAGREDO, D."Medidas del Romano", Toledo, 1526, fol 1 va. Sobre las emociones y vicisitudes. La edición de Las Medidas del Romano, con introducción de F. Marias y A: Bustamante, Madrid, 1986, en la que reproduce el ejemplar de la Biblioteca Nacional de Madrid de 1549.

40. GARCÍA ORO, J. "La Universidad de Alcalá de Henares en su etapa fundamental 81458-1578)", Santiago de Compostela, 1992. También en el epitafio de Pedro Gumiel lo recuerda como "Academia Architectus", en la que puede ser la primera vez que se emplea el término en España para identificar al maestro de obras.

41. CASTILLO OREJA, M. A., "Colegio Mayor de San Ildefonso de Alcalá de Henares. Génesis y desarrollo de una construcción, siglos XV-XVIII", Alcalá de Henares, 1980. p. 182.

42. GARCÍA ORO, J. "La Universidad de Alcalá de Henares en su etapa fundamental 81458-1578)". Op. Cit. P.126.

43. Ibid. P. 127.

44. CASTILLO OREJA, M. A., "Colegio Mayor de San Ildefonso de Alcalá de Henares. Génesis y desarrollo de una construcción, siglos XV-XVIII", Op. cit. p. 186.

45. SERRA DESFILIS, Amadeo,"El Colegio de España en Bolonia y la arquitectura universitaria del primer renacimiento en Italia y España".Op. cit. P.28.

46. RODRÍGUEZ-SAN PEDRO BEZARES, Luis E. y POLO RODRÍGUEZ, Juan Luis, "Historia de la Universidad d Salamanca, volumen II. Estructuras y flujos". Ed. Universidad de Salamanca, 2004. p.475.

47. RUIPÉREZ ALMAJANO, M. Nieves, "La Universidad y los Colegios Seculares", Capítulo $V$ en "8oo años de Patrimonio de la Universidad de Salamanca". Ed. Universidad de Salamanca, 2013. P. 196.

48. BATAILLON, M. "Erasmo y España". Madrid, 1983. Pp163-164.

49. NAVASCUES PALACIO, Pedro, "El Colegio Mayor Fonseca y su Arquitectura". Ed. Universidad Politécnica de Madrid, 2011. P. 54.

50. Ibid, .p. 53

51. Ibid, p.56.

52. Ibid, p.56

53. Ibid, p.52. 
54. GÓMEZ MORENO, M. "Catálogo fundamental de España". Ed. Provincia de Salamanca, Madrid, 1967. P.271.

55. NAVASCUES PALACIO, Pedro, "El Colegio Mayor Fonseca y su Arquitectura". Op. cit. P. 55 .

56. Ibid, p. 55 .

57. RUIPÉREZ ALMAJANO, M. Nieves, "La Universidad y los Colegios Seculares", Capítulo V en "80o años de Patrimonio de la Universidad de Salamanca". Op. cit. P. 195.

58. Ibid, p. 195

59. NAVASCUES PALACIO, Pedro, "El Colegio Mayor Fonseca y su Arquitectura". Op. cit. P. 56.

6o. SENDín CALABUiG, M. "El Colegio Mayor del Arzobispo Fonseca en Salamanca" Ediciones Universidad de Salamanca, 1977. Este minucioso y completo estudio va acompañado de un interesante apéndice documental y abundante material gráfico, incluyendo también la inmediata hospedería barroca, hoy facultad de Medicina, iniciada por Juan de Setien Güenes y terminada por Alberto Churriguera.

61. NAVASCUES PALACIO, Pedro, "El Colegio Mayor Fonseca y su Arquitectura". Op. cit. P. 61.

62. Ibid, p. 68

63. Ibid, p. 68

64. Ibid. P.69

65. Ibid, p.69

66. Ibid, p. 70

67. Ibid. p. 70

68. SENDÍN CALABUIG, M. "El Colegio Mayor del Arzobispo Fonseca en Salamanca",Op. Cit, p. 167.

69. RUIPÉREZ ALMAJANO, M. Nieves, "La Universidad y los Colegios Seculares", Capítulo V en "8oo años de Patrimonio de la Universidad de Salamanca".Op. cit. P. 197.

70. Ibid, p. 198

71. En los libros de Claustros de la Universidad, pertenecientes al Archivo Histórico de la Universidad de Salamanca, aparece en 1527 una carta de su fundador sobre "el colegio que quiere edificar", donde se muestran las características principales que pretende llevar a cabo en la nueva Fundación.

72. "Libro de la Cadena" llamado así porque se guardaba pendiente de una cadena en el arca del Colegio, donde firmaban las constituciones colegiales y capellanes.

73. RODRÍGUEZ-SAN PEDRO BEZARES, Luis E. y POLO RODRÍGUEZ, Juan Luis, "Historia de la Universidad d Salamanca, volumen II. Op. Cit. p.476. 
74. Ibid, p. 476.

75. Ibid, 477 .

76. Ibid, 477 .

77. RUIPÉREZ ALMAJANO, M. Nieves, "La Universidad y los Colegios Seculares", Capítulo V en "8oo años de Patrimonio de la Universidad de Salamanca".Op. cit. P. 197.

78. RODRÍGUEZ-SAN PEDRO BEZARES, Luis E. y POLO RODRÍGUEZ, Juan Luis, "Historia de la Universidad d Salamanca, volumen II. Op. Cit. p.476.

79. Ibid, p. 476 .

8o. Ibid, p. 477

81. Ibid, p. 477 .

82. En este sentido la arquitectura constituye, junto con las ceremonias, el protocolo, el atuendo o el modo de vida un elemento más, y no el menos importante aunque a veces se olvide, a través del cual los colegiales construyen su imagen pública, su "representación" o modo de "ser percibido". CARABIAS TORRES, Ana María, "Poder y Conocimiento. Universidad contra colegios" en Las Universidades Hispánicas: De la Monarquía de los Austrias al centralismo liberal. Junta de Castilla y León. Universidad de Salamanca, 2000, vol I, pp. 117-118.

83. En este sentido la arquitectura constituye, junto con las ceremonias, el protocolo, el atuendo o el modo de vida un elemento más, y no el menos importante aunque a veces se olvide, a través del cual los colegiales construyen su imagen pública, su "representación" o modo de "ser percibido". CARABIAS TORRES, Ana María, "Poder y Conocimiento. Universidad contra colegios" en Las Universidades Hispánicas: De la Monarquía de los Austrias al centralismo liberal. Junta de Castilla y León. Universidad de Salamanca, 2000, vol I, pp. 117-118.

84. La Gramática con un libro en la mano izquierda y en la diestra una vara; la Gramática con un libro en la mano izquierda y en la diestra una vara, la Lógica con un «libro sin juego, ni manecillas y un clavo que le atraviesa»; la Filosofía con un libro abierto en la mano, la Geometría con un cuerpo geométrico irregular en la diestra. la Astronomía con dos globos en la mano y a los pies; la Retórica con una figura en la mano siniestra apuntándola con el índice la derecha; la Astrología con una esfera en la mano y elevada la vista; la Aritmética con un papel en las manos y en él diversidad de números; la Música con un violón rodeado de cifras, la Metafísica con una culebra en la mano diestra, un sol en el pecho, y en la cabeza una corona; la Arquitectura con un compás en la mano, reclinada sobre una columna jónica, a quien rodean algunas trazas y la Cosmografía con un cuadrante y un papel en la mano.

85. VILLARROYA, Rafael, "París en tiempos de San Vicente Paul" vol II. Ed. Vivencianod, Madrid, 1986, p.17.

86. Ibid, p. 17

87. Ibid, p. 17

88. Empacados de heno seco a modo de fardos.

89. VILLARROYA, Rafael, "París en tiempos de San Vicente Paul" vol II. Op. Cit. P. 17. 
90. CORELA IRÁIZOZ, José María. "El Colegio de Navarra en París" en "Príncipe de Viana" Año LXXV, num 259. Ed. Separata. 2014 p. 66.

91. Ibíd, p.66

92. Ibid, p. 66

93. Ibid, p.66

94. HARLÉ, R. "Les Collèges Médievaux ed. Libraires Autran, París, 1811, p.44.

95. RELANCIO, Alberto, "Las Universidades Medievales". Comunicación en actas seminario Orotava de Historia de la Ciencia. ED. Fundación Canaria de Historia de la Ciencia, Las Palmas de Gran Canaria, 2007. P. 332.

96. CORELA IRÁIZOZ, José María. "El Colegio de Navarra en París". Op cit . 67.

97. Ibid, p.66.

98. Ibid, p.66

99. Ibid, p. 67.

100. El colegio había sido fundado por el pintor Jean Mignon diez alos antes(1343) para los miembros de su familia.

101. Última soberana de la dinastía de la Casa de los Condes de Champagne y Brie, fallecida en 1305 y esposa (1284) del rey de Felipe IV el Hermoso.

102. SÁNCHEZ MARCO, Carlos, "Collége de Navarra en París" en "Historia Medieval del Reyno de Navarra". Ed. Fundación Lebrel blanco. Navarra, 2006.

103. ORCASTEGUI GROS, María del Carmen, "El Colegio de Navarra en la Universidad de París", en Actas del primer Congreso general de Historia, Pamplona, 1986.

104. ARTIGAS, M., Nicolás Oresme, Gran Maestre del Colegio de Navarra, y el origen de la ciencia moderna, enviado a «Príncipe de Viana», cit. pro manuscripto, p. 3.

105. SÁNCHEZ MARCO, Carlos, "Collége de Navarra en París". Op. Cit.

106. Colegio diseñado por Luis Le Vau en 1661. Es un colegio destinado a la preparación gratuita de sesenta gentiles hombres pertenecientes a las cuatro naciones agrupadas y sometidas a la obediencia real después de la firma de los tratados: Paz de Westfalia y Tratado de los Pirineos llevada a cabo en 1648 (de ahí la procedencia del nombre: Colegio de las Cuatro Naciones: Artois, Alsacia, Pignerol y Rosellón y Cerdaña. Su fundador fue el Cardenal Manzarino.

107. ALONSO PEREIRA, José Ramón,"El Colegio de los españoles en París como punto de inserción arquitectónico entre las ciudades universitarias de París y Madrid". Liño 19. Revista anual de Historia del Arte. Universidad de La Coruña, pp 69.

108. Ibidem p. 70 .

109. LEMOINE, Bertrand, "La Citélnternacional Universitaire de Paris", ed. Heervas, París 1990.

110. ALONSO PEREIRA, José Ramón, “El Colegio de los españoles... Op. Cit. P. 70. 
111. arquitecto francés de edificios tan notables como el Hospital Rothchild o la Sinagoga Chasseloup- Laubat.

112. DREYFUSS-SEE, Genevève, "La carriére deLucien Bechmann(1880-1968), Archives d'Architecture du XXe siècle, Fonds Bechmann, París.

113. El concurso fue convocado por la Junta para Ampliación de Estudios e Investigaciones Científicas, costeando el edificio el International Educational Board de la Fundación Rockefeller; a él se presentaron 7 proyectos, publicados posteriormente por la revista Arquitectura, 105/1928.

114. Si la aportación de Rockefeller en Madrid era previa, reflejada en el Instituto de Física y Química, proyectado por Manuel Sánchez Arcas y Luis Lacasa

115. Como Pavillion Espagnol à la Cité Universitaire", fue publicado por la revista LArchitecture, París, en Noviembre de 1938, pp 393-396.

116. ALONSO PEREIRA, José Ramón,"El Colegio de los españoles... Op. Cit. Plano de parcela, con superficies, cotas y servidumbres, modificado el 27 de marzo, donde se indica:"Lot 10, Foundation Espagnole, supf. 3.291,49m². ARCHIVO COLEGIO DE ESPAÑA (ACEP).

117. Ibidem p. 73

118. Ibidem

119. La Fundación del amo fue publicada en la revista Arquitectura en 1931, así como en el libro Arquitectura Contemporánea (Edarba, Madrid 1935), donde se define como residencia de estudiantes hispamoamericanos; Se realiza una mención y breve análisis de forma más exhautiva en el bloque cuarto de esta Tesis.

120. ALONSO PEREIRA, José Ramón, "El Colegio de los españoles... Op. Cit. P 71.

121. LEMOINE, Bertrand, "La Citélnternacional Universitaire de París", Op. Cit.(47)

122. Revista Lárchitecture, 1935 y Archivo ACEP(Archivo colegio de España París)

123. Ibid

124. ALONSO PEREIRA, José Ramón, “El Colegio de los españoles... Op. Cit. P 75.

125. FRAMPTON, Kenneth, "Le Corbusier". Ed. Akal Arquitectura, Madrid, 2000. P. 80.

126. COHEN, Jean Louis, "Le Corbusier". Ed. Taschen, 2009.

127. RELANCIO, Alberto. "Las Universidades Medievales". Actas SeminarioOrotava de Historia de la Ciencia. Años VIII y X. Fundación Canaria Orotava de Historia de la Ciencia. 2007. P. 328-331.

128. Ibíd, p. 329 .

129. SERRA DESFILIS, Amadeo. "Bolonia y la definición de un tipo en la arquitectura universutaria europea". Imagen, contextos morfológicos y universidades. Miscelánea Alfonso IX, ed. Universidad de Salamanca, 2012. P.23.

130. Ibid, p. 23

131. SERRA DESFILIS, Amadeo. "Bolonia y la definición de un tipo en la arquitectura universutaria europea". Op. Cit p. 23. 
133. Christofer Wren, científico y arquitecto del siglo XVII, famoso por realizar el proyecto de reconstrucción de varias iglesias de Londrea tras el gran incendio de 1666. Es también conocido por el diseño de la catedral de san Pablo de Londres.

134. Henry Alrich. Teólogo, arquitecto y músico inglés (1647-1710). Sólo se conocen dos edificios suyos: el college All Saints de Oxford y el quad Peckwater del Christ Church.

135. Ely es una pequeña ciudad situada en el distrito de East Cambridgeshire en Cambridgeshire, en el este de Inglaterra, a 103 kilómetros al noroeste de Charing Cross, en Londres. Cambridge no tiene obispado y pertenece a la Diócesis de Ely.

136. Arquitectos destacados de Cambridge de los años 30 (siglo XX)

137. James Gibbs (Aberdeen, Escocia 1682- Londres 1754). Arquitecto británico muy influyente en su tiempo. Su obra se puede considerar entre la tradición de Sir Christopher Wren, el clasicismo barroco italiano y el palladianismo. Una de sus obras más conocidas en la Biblioteca Radcliffe.

138. Willis y Clark (1988) en WILLIS, R. y CLARK: "La historia de la Arquitectura de la Universidad de Cambridge y de los Colegios de Cambridge e Iton". Ed. Cambridge University Press, Cambridge, 1988. P. 136

139. Ibid, p.137.

140. Funcionario eclesiático de alto nivel perteneciente a la Iglesia de Inglaterra, éste en concreto a la Diócesis de Norwich. En su función recae la supervisión del clero y la responsabilidad de los edificios de la iglesia dentro de la zona geográfica que abarque la Diódesis

141. Piedra caliza de la zona.

142. Arquitecto y constructor inglés que trabajó en Cambridge, donde nació. Diseño "porciones", pequeños edificios dentro de los colleges. Era un admirador de la arquitectura Gótica. Famoso es su diseño del puente sobre el río Cam.

143. Poema alegórico medieval inglés escrito por William Lagland en versos alternativos y sin rima.

144. Anthony Salvin (1799-1881) fue un prolífico arquitecto de gran prestigio. Desde muy pronto trabajó en el estilo Tudor y era un experto en la arquitectura medieval. Se creó buena reputación como restaurador de castillos antiguos.

145. Tipo de ladrillo de color blanco que son conocidos en Inglaterra como "Gault", nombre de la arcilla con la que están compuestos. Estos ladrillos se fabrican principalmente en el sur del país. Obtienen su color blaquecino de la tiza que contiene la arcilla en gran cantidad.

146. Tom Phillips, nacido en 1937, es un artista cuya obra se nutre de varias preocupaciones persistentes, expresada a través de un número aún mayor de formatos. Estos incluyen la pintura (tanto figurativa y abstracta), ópera (compositor, libretista, escenógrafo), la poesía concreta y formas ornamentales de la escritura, la escultura y los diseños específicos del lugar (objetos de mosaico, tapices, marco de alambre). Él también ha asumido varios papeles para-artístico - crítico, curador, el presidente del comité de la Real Academia, traductor - todos los cuales se ha doblado de nuevo en su arte.

147. GUERRERO YOACHAM, Cristián y GUERRERO LIRA, Cristián, "Breve Historia de los Estados Unidos de América". Ed. Universitaria, S. A., Santiago de Chile, 1998. P 44. 
148. Sir Francis Bernard (12 de Julio de 1712-16 de Junio de 1779). Fue un administrador colonial británico que fue gobernador de las provincias de Nueva Jersey y Massachusetts.

149. TOLLES, Briant Jr. "Architecture and Academe" ed. University press for New England, 2010, p. 48.

150. Respecto a la educación más temprana de Jefferson, véase Dumas Malone, "Jefferson the Virginian", vol.1 de Jefferson and his time Boston, Little Brown, 1948, pp 37-112

151. FERNÁNDEZ fernández, Xosé. "La Universidad de Virginia de Thomas Jefferson. Un Modelo de Tipología Arquitectónica. P.72

152. Ibíd. P.72.

153. Cientifico Británico que donó fondos para la creación de esa entidad.

154. Dumas Malone, "Jefferson the Virginian". Op. cit p. 37-112.

155. Ibid, p37-112.

156. William Short a John Hartwell Cocke, 8 de julio de1828, Papeles de Cocke, Caja 55, Departamento de Colecciones Especiales, División de Manuscritos, Biblioteca de la Universidad de Virginia (Las colecciones especiales se citarán en adelante como UVA)

157. Boyd, volumen 2. Pp. 529-531 en De Edmund Pendleton a Jefferson, 11 de mayo de 1779, en The Papers of Thomas jefferson, de. Julian P. Boyd, 23 volúmenes hasta la fecha. Princeton, Servicio de publicaciones de la Universidad de Princeton, 1950, vol 2.

158. De Jefferson a Peter Carr, 7 de septiembre de 1814, DLC.

159. Como él mismo admitió, Jefferson había realizado el plano del terreno de 1814 como un concepto inicial ,y lo había diseñado teniendo en cuento la economía, la comodidad, y la posibilidad de ampliarse en caso necesario. Había incorporado soportes cuadrados en el proyecto inicial por la mismo razón, diciendo que los usaría "en primer lugar". Luego, a medida que crecía la esperanza de que el Central College se convirtiese pronto en una universidad, incorporó su propio idea de asignar una función didáctica los pabellones, y después añadió el concepto de un importante edificio central. Lo adopción de ideas más elaboradas, tales como la propuesta de Thornton de utilizar columnas circulares en vez de cuadradas para la columnata y la sugerencia de Latrobe para que una gran Rotonda se convirtiese en el edificio principal, pasaron o tomar parte de este concepto original así ampliado. Sin embargo, a medida que su proyecto de diseño se amplió con la influencia exterior, se empezó o parecer cada vez más al proyecto de diseño que había utilizado tanto en Monticello como en la Caso Blanco.

160. De Jefferson a Breckenridge, 8 de julio de 1819. Papeles de Jefferson UVA.

161. De Joseph C. Cabell a Cocke, 15 de abril de 1819. "Papeles de la familia Cabell, UVA, el diseño fue definitivamente concluido el 17 de abril, porque cabell le dijo a Jefferson en una carta de esa fecha que: "... estaba extremadamente feliz de ser informado por el General Cocke de que había juntado los jardines con los patios traseros de los pabellones"

162. De Jefferson a John Wayles Eppes. 30 de junio de 1820. Papeles de Jeffferson, UVA.

163. Ibid 
164. "El Diseño urbano". Conferencia inaugural de curso celebrada en la Universidad de Harvard en Abril de 1956.

165. FREIXA, Jaume, "Sert, medio siglo de arquitectura 1928-1979" Ed Fundación Miró. 2005 .

166. ROVIRA, Josep María: "José Luis Sert". Ed. Electa, Milán 2000

167. Propuesta Urbana de Crecimiento de la Universidad de Harvard.1960)

168. Opus cit. Freixa, 2005

169. De esta forma, Huson Jackson, socio de Sert, Jackson \& Associates, se refiere al terreno del proyecto de Peabody Terrace.

170. "El diseño urbano". Conferencia inaugural... Op. Cit. p.

171. Entre los premios más reconocidos que recibió el conjunto Francis Greenwood Peabody Terrace está el Premio de Honor del Instituto de Arquitectos Americanos y la Medalla Harleston Parker de la Sociedad de Arquitectos de Boston. 
LA RESIDENCIA UNIVERSITARIA EN ESPAÑA, GENERADORA DE CIUDAD

\section{BLOQUE III}

III.1 TRANSFORMACIÓN DE LOS MODELOS HISTÓRICOS Y APORTACIÓN DE LOS NUEVOS PLANTEAMIENTOS DEL SIGLO XX. 
358| RESIDENCIAS UNIVERSITARIAS EN ESPAÑA, GENERADORA DE CIUDAD 
Este bloque es una introducción, unas pinceladas de rasgos generales que posteriormente se desarrollarán en cada una de las obras estudiadas.

El cambio producido en la arquitectura a partir de la Revolución Industrial y que cristaliza con el nombre de Movimiento Moderno, se puede decir que hace su irrupción en España en la primera mitad del siglo XX.

En este movimiento se pueden clasificar tres momentos en su búsqueda de un nuevo método arquitectónico ${ }^{1}$ : el reconocimiento de la identidad entre la forma y la función y la necesaria coherencia con el espíritu de los tiempos, la experimentación a pequeña escala para desarrollos que postularán alternativas válidas a los estilos históricos, representado por las vanguardias que operaron entre 1890 y 1918, y la convergencia de todas esas avanzadillas en un movimiento unitario capaz de reestructurar la producción constructiva, modificar el espacio social y hacerlo accesible.

La Modernidad, como en el resto de Europa, entra en España como una ruptura, un comenzar nuevo, olvidando todo lo anterior. Pero no entra totalmente de lleno, sino que lo hace de forma paulatina.

Mediante la función como estrategia, la arquitectura encuentra un nuevo planteamiento que supone el antídoto esperado contra los eclecticismos. Combatir la expresión aplicada mediante el ornamento reduciendo el resultado formal a la condición funcional y constructiva del edificio, constituía, según las voces militantes de la vanguardia, un recorrido deseado y necesario que pronto señalaría las nuevas directrices a seguir por la arquitectura.

Efectivamente, durante los procesos de gestación teórica del funcionalismo hasta el desarrollo universal de la doctrina del racionalismo, en sus diferentes versiones, la arquitectura vive un momento en donde la imagen y la apariencia del proyecto han perdido su impulso formal, emblemático o representacional. El espacio recobraba así, la fuerza y el protagonismo temporalmente perdidos. Su singularidad, por lo tanto, y su organización funcional, distributiva y circulatoria encontraban en el proyecto una nueva plataforma de exploración donde hacerse realidad. Le Corbusier apuntaría: "La calidad de la circulación interior será la virtud biológica de la obra. La buena arquitectura 'se camina' tanto adentro como afuera. Es la arquitectura viva. La mala arquitectura está coagulada alrededor de un punto fijo, irreal, ficticio, extraño a la ley humana". 
Materialidad y expresión de la arquitectura moderna.

Durante el periodo comprendido entre las tres primeras décadas de siglo, la arquitectura moderna mantuvo ese fuerte tono aséptico que había sido empujado desde las esferas más ancestrales de las vanguardias arquitectónicas, principalmente las dirigidas desde el estatuto del racionalismo. El Estilo Internacional divulgó y difundió las bases de un cuerpo de leyes que quiso ser referente universal en todo el mundo, creando una gramática, un lenguaje, que aspiraba a ser el legado común y colectivo -autorreferencial- que diera la imagen igualitaria que la arquitectura perseguía.

Los núcleos nórdicos europeos, con Alvar Aalto a la cabeza, como se ha visto en el apéndice contemporáneo estadounidense, capitanea con sus escritos, reflexiones y práctica arquitectónica, una revuelta necesaria para que la progresión revolucionaria de la modernidad no cediese y se estancara en el fango provocado por el internacionalismo corrosivo arquitectónico de la década de los treinta. Si la arquitectura moderna, desde el protoracionalismo hasta el racionalismo radical de los veinte y treinta, había tenido en la investigación, espacial, circulatoria y de movimiento, su más firme aliado para definir las condiciones de la forma y la imagen arquitectónica, serán ahora otros los que sumen a estos valores un material que, desde la radicalidad moderna inicial, había sido rechazado u olvidado dentro del proyecto. Dos aspectos, sumados a otros, pueden subrayarse dentro de esta evolución: por un lado, la progresiva sensibilización que la arquitectura poco a poco fue mostrando por el lugar y el contexto a la hora de proyectar; y, por otro, la recuperación paulatina de la historia y tradición material y espiritual de esos lugares.

Los arquitectos implicados.

El contrapunto ideológico al clasicismo arquitectónico y al modo de entender la ciudad se empieza a ver en ciertos arquitectos, éstos pueden ser considerados como los introductores de la arquitectura moderna en España.

En los apéndices contemporáneos vistos en los capítulos anteriores, ya se da cuenta de obras relevantes y de los arquitectos que empiezan a aportar nuevos criterios arquitectónicos y que tendrán una repercusión posterior en España, objeto principal de este bloque.

Con respecto al nuevo concepto de entender la ciudad se centra el estudio en la primera Ciudad Universitaria Europea: La Ciudad Universitaria de Madrid. 
En este proceso cabe destacar el que papel juega el concepto de racionalismo arquitectónico, tendencia que centrará sus nuevas bases conceptuales en lo que pueden ser sus tres puntos fundamentales: función, tecnología y sociedad. A través de estos tres conceptos se establecen tres escalas de estudio de las obras de los colegios de la Ciudad Universitaria de Madrid. De estos tres factores la función será el predominante y a través de ella se hace una "interpretación exclusiva"2 .

Como se acaba de ver en el último capítulo del bloque anterior, la experiencia de la Bauhaus es decisiva para el desarrollo de un linaje racionalista. En la Residencia de Estudiantes de Dessau se muestra con claridad la investigación formal y la tendencia del ahorro máximo en la utilización de suelo y en la propia construcción.

Los modelos históricos vistos en los primeros bloques van a ir sufriendo cambios en función tanto de la utilización de nuevos materiales (madera, hierro, cristal, metales) y de la técnica empleada, como de aplicar la idea de que la forma artística proviene de un método o problema previamente definido, lo que conduce a la correspondencia entre forma y función.

Los arquitectos españoles introductorios de estas nuevas tendencias y con repercusión directa en el tema que nos ocupa son: Luis Lacasa, Fernando Garcia Mercadal, Jose Luis Sert, Luis Blanco Soler y Rafael Bergamín.

De los extranjeros se extraen los estudiados en los apéndices contemporáneos como han sido Le Corbusier, Alvar Aalto y James Stirling.

Los viajes de los arquitectos españoles a centro Europa, y más concretamente a Alemania, hacen que se impregnen de las nuevas tendencias y las empleen en sus proyectos desarrollados en su vuelta al país, constituyendo el núcleo madrileño más concienciado culturalmente $^{3}$. La Residencia de Estudiantes de Madrid juega un papel principal en la importación de estas pautas y es un nexo de unión entre los arquitectos autóctonos y los extranjeros, recibiendo las visitas de los precursores de este movimiento como Walter Gropius y Le Corbusier.

Atendiendo a la propia Residencia de estudiantes, cabe destacar la labor de García Mercadal. De la etapa inicial del Movimiento Moderno, entre los años 20 y 30, llega a través de este autor una obra con espacios y formas radicalmente modernas como es el rincón de Goya de Zaragoza, que marca el periodo de inicio de este movimiento en el país. Tanto en escritos como en conferencias hace una labor propagandística de la nueva arquitectura ${ }^{4}$ y juega un papel muy importante en el panorama arquitectónico madrileño. Una trayectoria jalonada por una serie de etapas, la que cabe destacar 
aquí es la centrada en su paso por la Residencia y el propiciar la visita de los arquitectos antes mencionados de los que de Le Corbusier era un defensor a ultranza.

La divulgación de la arquitectura moderna, en cuanto a residencia universitaria se refiere, se produce de forma pionera a través de Rafael Bergamin, Luis Blanco Soler y Luis Lacasa que son los que poseen ejemplos de ello en su producción arquitectónica.

Lacasa, aparte de lo aprendido durante su estancia en Alemania, pone la mirada en el mundo anglosajón y especialmente a Estados Unidos, considerado por él como un ejemplo de modernidad, entendida ésta como racionalidad funcional. En su artúculo titulado "Le Corbusier, o Americo Vespucio" publicado en El Sol 5 Lacasa defiende que, frente al racionalismo abstracto y propagandístico de Le Corbusier, se adscribe a un racionalismo funcional americano ${ }^{6}$ frente a lo que entendía como un racionalismo formal europeo $y_{1}$ más concretamente, de Le Corbusier. Cuestiones como las de la salubridad e higiene, las ordenanzas sobre las colonias de casas baratas, los problemas de la nueva vivienda o la nueva ciudad, la gestión municipal, la alternativa de los bloques multifamiliares frente a la casa obrera de baja densidad son algunos de los temas que preocupan a Lacasa y se verán reflejados en su proyecto de la nueva sede de la Residencia de Estudiantes en la Ciudad Universitaria de Madrid. Lacasa tuvo presencia en varios frentes, por una parte, con los arquitectos que integran el equipo formado por López Otero para la Ciudad Universitaria; por otro lado, colaboró con Sánchez Arcas en varios proyectos y con otros arquitectos como Colás y Esteban de la Mora en la Oficina Urbanística del Ayuntamiento de Madrid bajo la dirección de Luis Bellido. Con José Luis Sert, donde a través de su colaboración en la construcción del Pabellón de España en la Exposición de París de 1937, adquiriría conocimientos de la anteriormente citada modernidad americana.

Hay un párrafo de las "Notas autobiográficas"7 de Lacasa que se refiere precisamente a esta colaboración con Sert que muestra algunas claves sobre el inicio de las nuevas tendencias en Madrid: "Aunque yo había combatido públicamente en España los principios de Le Corbusier y, por lo tanto, no participaba del funcionalismo que en la composición arquitectónica tenia Sert, consideré que no era la ocasión de reñir una batalla por cuestión de tendencias, máxima si se tiene en cuenta que frente a esta tendencia no oponía que la dominaba entonces en Madrid en ciertos círculos de arquitectos jóvenes y que consistía en un racionalismo moderado a base de la utilización, en las fachadas, del ladrillo aparente ${ }^{\prime \prime}$. Apareciendo en estos jóvenes arquitectos madrileños, en relación con sus preocupaciones y políticas sociales, un interés por aspectos como la funcionalidad de la arquitectura, la racionalidad proyectual, los problemas de la vivienda obrera y las cuestiones de urbanización. 
La representación de cambio de las nuevas tendencias la muestra La casa en la nueva sede de la Residencia de Estudiantes en la Ciudad Universitaria, la cual se estudia en profundidad en el próximo capítulo, donde deja entrever el tratamiento de los volúmenes planteado por un predominio de las formas prismáticas, suprimiéndose en lo posible cualquier clase de referencia a los tipos de construcción tradicional y a los elementos del lenguaje clásico. En las soluciones de fachada, de huecos, de acabados, de detalles, tanto interiores como exteriores, el lenguaje procura una aproximación respecto de las obras modernas que van apareciendo en este emplazamiento ${ }^{9}$.

Como conclusión se puede establecer que la visión paralizada, inmóvil, de volúmenes herméticos de los primeros modelos, sobretodo de los organizados en torno al claustro, da paso o evoluciona, a través, entre otros recorridos con la aparición del racionalismo arquitectónico, a una construcción de espacios de carácter más centrífugo, móvil, dinámico y temporal que configura sistemas de estudio incentivados por la arquitectura. Las primeras aportaciones $y$, pudiendo ser las más serias, en relación a estos nuevas tendencias arquitectónicas vienen a producirse en España dentro del entorno de la nueva Ciudad Universitaria de Madrid. Citando el capítulo anterior correspondiente a la Bauhaus, Gropius manifiesta en la Residencia de Estudiantes de Dessau la preocupación por representar el tiempo y su tránsito, lo que se puede denominar como una cuarta dimensión. EN la mayoría de sus proyectos se expresa la preocupación por la ordenación mediante la regularidad y el equilibrio, la total eliminación de la decoración aplicada y el entendimiento de la arquitectura como la suma de un número indefinido de planos, independientes de la estructura, que actúan como catalizadores de movimiento y circulación.

De los antiguos modelos, Bolonia, París, Oxford, Cambridge, Salamanca, Valladolid y Alcalá de Henares, la caja muraria se rompe. Las posibilades de circulación aumentan.

Se eliminan muchas restricciones gracias a la libertad concedida por la planta libre, se desprende la emergencia por la continuidad espacial que suprime la dicotomía interior-exterior, totalmente enfrentada en los ejemplos de colegios de las ciudades que se acaban de citar.

Se va a conseguir, y se muestra en los capítulos siguientes, la continuidad espacial donde se explicita la figura e imagen que la arquitectura ofrece desde un punto de vista exterior.

En los próximos capítulos se expone los ejemplos españoles de la evolución arquitectónica, aproximados ya a la modernidad. 
364| RESIDENCIAS UNIVERSITARIAS EN ESPAÑA, GENERADORA DE CIUDAD 


\section{LA RESIDENCIA UNIVERSITARIA EN ESPAÑA,}

\section{GENERADORA DE CIUDAD}

\section{BLOQUE III}

III.2 LAS TRES FASES DE LA RESIDENCIA DE ESTUDIANTES DE MADRID.

En la calle Fortuny (1910)

En "La Colina de los Chopos" (1915)

En la Ciudad Universitaria (1942) 
366| RESIDENCIAS UNIVERSITARIAS EN ESPAÑA, GENERADORA DE CIUDAD 
La Residencia de Estudiantes de Madrid fue creada en 1910 por el Ministerio de Instrucción Pública, dependiendo de la Junta para Ampliación de Estudios e Investigaciones Científicas (JAE) e inspirada por las ideas de Francisco Giner de los Ríos y la Institución Libre de Enseñanza ${ }^{10}$ (ILE), con la finalidad no sólo de dar acogida sino también de ofrecer una alternativa a una Universidad que se consideraba obsoleta y fomentar la renovación de la enseñanza, como parte de un proyecto global de modernización científica y cultural de la sociedad española. Pocos años después la Residencia de Estudiantes se había convertido en un relevante foro de debate de la modernidad española con residentes como Federico García Lorca, Salvador Dalí, Luis Buñuel, Pepín Bello o Severo Ochoa, y con visitantes como Albert Einstein, Madame Curie, Miguel de Unamuno, Walter Gropius, Manuel de Falla, Le Corbusier, Rafael Alberti, Paul Valéry o Igor Stravinsky.

Como antecedente se puede establecer la situación socio-políticocultural que había en España en estos momentos. Dentro de la estructura centralizada del sistema educativo español, la lucha por el poder político va acompañada del control de la educación. La reforma educativa había sido un proceso muy lento que ha tenido al país anclado en el pasado durante el siglo XIX y buen aparte del XX. El precedente más inmediato tiene lugar en la crisis universitaria de 1875 que donde se concretó la separación de sus cátedras a varios profesores de la Universidad Central de Madrid. En el núcleo principal de los que separan se encuentran Francisco Giner de los Ríos, Gumersindo Azcárate, Nicolás Slamerón, Laureano Figueroa y Eugenio Montori Ríos entre otros. De entre todos ellos, el promotor directo fue Giner de los Ríos.

En 1876, Laureano García Figueroa, primer presidente de la Institución, inaugura la Asociación de la Institución Libre de Enseñanza y junto a un grupo de catedráticos, los anteriormente nombrados, que habían sido separados de la Universidad por defender la libertad de Cátedra y negarse a ajustar las enseñanzas a cualquier dogma oficial en materia religiosa, política o moral, tienen que proseguir su labor educativa al margen del Estado creando un establecimiento educativo privado laico (ILE), que comienza en primer lugar por la enseñanza universitaria para posteriormente extenderse a la educación primaria y secundaria.

La ILE sienta las bases para la futura creación de centros residenciales. Las características generales de estos centros deben de ser acordes con el programa de un organismo que pretende ser "el principal órgano de vanguardia en la renovación educativa del país"11, que se proponía lograr el "encauzamiento e intensificación de la cultura en España"12. 
En la concepción arquitectónica del espacio físico de la residencia se pretendía crear un edificio que contuviera salas de trabajo, de lectura y de conversación, ampliando el programa a los nuevos tiempos y buscar servicios más allá de los únicamente estudiantiles. Se pretende dotar al centro de salas de ocio al igual que ocurría en Hartely Hall de Nueva York, donde los estudiantes puedan disfrutar de sus tiempos de ocio teniendo sus juegos y diversiones ${ }^{13}$ lo que les ayudará a fomentar su vida social.

Los responsables de la Residencia de Estudiantes tenían unas ideas preconcebidas de cómo querían que se fuese este centro. Se basaban en la cultura educativa británica, la cual pretetendían establecer como modelo.

El primer viaje a Inglaterra lo realizaron en en 1884 Francisco Giner delos Ríos y Manuel Bartolomé Cossío. Seguramente tuvieron ocasión de apreciar directamente el funcionamiento de los centros residenciales ingleses, (colleges que se han estudiado en el bloque anterior). Más tarde, realizaron otro viaje en el año 1886, en esta segunda estancia si hay constancia de que visitaron los colleges de Oxford. Estudian el modelo y el funcionamiento de estos colegios en busca de inspiración y de encontrar algo trasladable a España. En sus observaciones encuentras algunas carencias de los colleges visitados, haciendo alusión a que no disponen ni de baños, ni de ascensores ni de otras comodidades modernas ${ }^{14}$.

El proyecto que pretendía esta institución tiene muy presente al college inglés ${ }^{15}$. Así lo confirma también la admirativa minuciosidad con que algunos autores como José Castillejo, que en la crítica que dirige a las universidades españolas de comienzos de siglo detaca de forma expresa la falta de centros residenciales ${ }^{16}$, donde estudia la organización colegial de la educación inglesa en los grados secundario y universitario ${ }^{17}$.

Paralelamente a estos estudios, tienen también en cuenta, el antiguo sistema colegial de la Universidad Española, en general perdido, aunque todavía vigente entonces en el caso singular del anteriormente estudiado Colegio de Los Españoles en Bolonia, elogiado con frecuencia en el círculo institucionalista y donde estuvo becado Manuel Bartolomé Cossío ${ }^{18}$. El Secretario de la Junta para la ampliación de estudios e Intervenciones Científicas, Castillejo, señala, para poner de manifiesto la necesidad de crear la Residencia de Estudiantes, que "los colegios medievales y renacentistas habrán desaparecido de las universidades españolas y éstas no conocían ninguna vida corporativa" ${ }^{\prime \prime}$.

Más explícito es aún Alberto Jiménez Freud, Presidente de la institución residencial, en el capítulo titulado: "Significativamente, un nuevo colegio" de su obra "Ocaso y Restauración", donde cuenta los comienzo de la Residencia de Estudiantes. Cabe destacar que debía ser conocedor de la historia de los colegios parisinos en sus 
comienzos, ya que llamaba a La residencia "colegio de los quince", debido a sus primeros quince estudiantes residentes, en alusión al llamadao "colegio de los 18" que fue el primero de los colegios medievales parisinos (como se indica en el segundo bloque de esta tesis).

Aunando todos estos criterios, la Residencia de Estudiantes como entidad pretende implantar un sistema de educación superior diferente al entonces vigente en España, un sistema tutorial, una universidad de tipo residencial directamente inspirada en la universidad humanista inglesa, la cual se proponía la educación general de los alumnos aunque sin renunciar al carcter científico de la educación alemana, de acuerdo con una tendencia de Giner de los Ríos y sus seguidores percibían en la Europa de su tiempo ${ }^{20}$.

La importante proyección cultural de la Residencia de Estudiantes, una de las más sobresalientes, corresponde también a la concepción de las instituciones universitarias como "centros de vida y progreso cultural", que, actuando como un "foco de síntesis cultural" tienen como misión" el mantenimiento, propagación y transmisión de los valores de la cultura"21.

Este gran proyecto general permite comprender el alcance real, el auténtico sentido de las diversas secciones residenciales que son necesarias. El edificio debe estar dotado en su programa de estancias o servicios que compensen las deficiencias que para la institución tenía la universidad en este momento, que son especialmente tres: falta de conocimiento de lenguas modernas, la insuficiencia de material y la ausencia de atención individual. Para solucionar la primera se ofrecen clases de idiomas gratuitas a los residentes; para la segunda se dispondrán aulas y laboratorios a su disposición; y para la tercera, se dotará a la residencia de espacios de reducidas dimensiones para clases particulares.

La relación de esta actividad confiada por la Junta a la Residencia de Estudiantes con un nuevo modelo universitario ha sido expresamente destacada por Manuel García Morente al calificar a esta institución residencial de "afortunado ensayo" de una universidad planteada como centro autónomo devorador de "toda cultura, no sólo la cientñifica, sino la cultura moral, artística y la técnica" ${ }^{\prime 22}$.

La Institución se pretende servir de la arquitectura para crear una red de centros residenciales.

Una de sus premisas más importantes es que el contacto con la naturaleza es fundamental, para la Institución no hay mejor aula que la que se sitúa en la sombra de un árbol. Este concepto va a ser reflejado en cada una de las tres sedes.

La primera sede se instala en Madrid en la calle Fortuny. 


\section{EN LA CALLE FORTUNY (1910)}

La primera implantación se realiza en un hotel, forma parte de una de las manzanas, con hoteles y jardines, situadas en la parte alta del paseo de la Castellana.

El hotel posee una fachada blanca, tiene unas reducidas proporciones y unas condiciones muy modestas en general. Es un pequeño edificio alquilado y rodeado de un pequeño jardín en una zona tranquila y alejada entonces del bullicio de la gran ciudad, lo que parecía convenir extraordinariamente bien para los fines de la institución naciente.

"El edificio era pequeño y silencioso, pero agradable y limpio, y lo bastante alejado de los ruidos del paseo cercano para que la vida residencial pudiera transcurrir en una especie de remanso discreto y silencioso"23.

Al igual que ocurriera en París con el Colegio de Navarra, se acondiciona la función residencial en un hotel. Antes de la apertura de la Residencia hubo que realizar obras de acondicionamiento para ajustar el edificio a su nuevo uso.

La zona, que dentro del Plan de Ensanche ideado por Carlos María de Castro quedaba incluida en un sector de preferente asentamiento para la burguesía más acomodada y la aristocracia ${ }^{24}$, constituía un área no céntrica, al norte de Madrid, emplazamiento considerado tradicionalmente saludable por su proximidad a la Sierra y por el régimen de vientos imperante, área además tranquila, con predominio de viviendas unifamiliares ajardinadas, y en la que aún proliferaban, a comienzos de siglo, grandes espacios sin edificar ${ }^{25}$.

La ubicación en este mismo ámbito de la sede de la Institución Libre de Enseñanza, la "casa del Obelisco", como familiarmente se la denomina por la calle en que se encuentra, hoy Paseo del General Martínez Campos, "típica quinta de mediados del siglo XIX, de los alrededores de Madrid"26, situada en lo que hacia 1900 era todavía un barrio prácticamente en las afueras de Madrid $^{27}$, singulariza el espacio elegido por la Residencia de Estudiantes. La comunión espiritual, la participación en un mismo proyecto intelectual y vital que reúne a los miembros del núcleo institucionista y a los responsables de la Residencia, se plasma así en un acercamiento, en una proximidad espacial: proyectando el carácter de sociedad particular y diferenciada que indudablemente tiene la Institución Libre de Enseñanza, y la peculiaridad y originalidad de la Residencia de Estudiantes, quizá ello no se deba tan sólo a un deseo vivir de modo conjunto, sino también a la conformidad en gustos $y$ necesidades, lo que lleva a una elección coincidente. Los presupuestos higienistas de la Institución Libre de Enseñanza, su concepción de la ciudad, del habitat, de la casa y del edificio escolar, no son ajenos a la elección de este tipo de ámbito urbano, muy 
valorado, por lo demás, en la Europa de la época y, singularmente, en Inglaterra.

En la misma zona se había instalado ya una modélica institución educativa norteamericana, el International Inslitule for Girls in Spain, que no tardaría en establecer relaciones fructíferas con la Junta y, más concretamente, con el grupo femenino de la Residencia. Su ubicación en la misma calle de Forluny y en la de Miguel Ángel no se había producido de forma espontánea y casual, sino por el influjo de su relación con miembros destacados de la Institución Libre de Enseñanza, con la que compartía no sólo su fe en la educación y un común interés por estimular y acrecentar la formación de la mujer en España, sino las grandes coordenadas de la Pedagogía moderna. Según señala llene Avery, la sugerencia de Nicolás Salmerón a la fundadora, Alice Cordón Gulick, resulló decisiva a la hora de elegir Madrid para el emplazamiento definitivo de la sede del Instituto Internacional en España, determinándose por consejo de Gumersindo de Azcárate su ubicación concreta en esa zona de la ciudad $^{26}$. La corporación norteamericana adquiere, como precisa Carmen de Zulueta, una finca con jardín en la calle de Fortuny $n .^{\circ} 5$, hoy 53 , en noviembre de 1901 , y "un segundo solar en la calle de Miguel Ángel y otro en la de Rafael Calvo" en abril de 1902. Llega así a poseer en propiedad "casi una manzana, limitada al norte por el paseo del Obelisco, al sur por la calle de Rafael Calvo, al este por la de Fortuny y al oeste por la de Miguel Ángel ${ }^{27}$.

La adquisición, años más tarde, por la Junta de la casa con jardín situada en la calle de Fortuny para albergar parte de la Residencia de Señoritas, y la utilización del edificio construido por la entidad norteamericana en el solar de la calle de Miguel Ángel por el Instituto-Escuela y por el grupo lemenino de la Residencia de Estudiantes, en sus secciones de niñas y de señoritas, justifican una breve referencia a estas sedes del Instituto Internacional. La finca de la calle de Fortuny n. ${ }^{\circ}$, comprada por William Hookcr Gulick Thomas en representación del Instituto, según consta en escritura otorgada el 25 de noviembre de 1901 ante el notario Zacarías Alonso Caballero, aparece inscrita en el Registro de la Propiedad, el 6 de diciembre, como "casa-palacio u hotel" que "linda al Norte con el paseo del Obelisco a que hace fachada; al Sur forma medianería con fincas propiedad del Señor Duque de Tarifa y el Marqués de Casa Jiménez, antes este último y Don Felipe González Vallarino; al Este la calle de Fortuny por donde tiene su entrada principal y al Oeste la de Miguel Ángel». Su solar tiene algo más de 3.500 metros cuadrados, y en el, «además del hotel o edificio principal, existen algunos árboles y arbustos, una fuente de fundición, un pequeño canal revestido de cemento hidráulico, una gran estufa de hierro, otra más pequeña de los mismos materiales y una pequeña edilieación en que está la portería». Los vendedores, Cayetano Aliaga Jiménez y Martín González Gomara, recibieron 274.861,44 pesetas13. El hotel tuvo que ser ampliamente restaurado antes de poder ser ocupado por el Instituto Internacional, lo que requirió una fuerte inversión ${ }^{28}$. 
El nuevo edificio de la calle de Miguel Ángel $n .{ }^{\circ}$ 2, hoy $n . "$, realizado por el arquitecto Joaquín Saidaña López, se ajusta, según Avery, a los planos del edificio principal del Mount Holyokc Sewiiutrv, una de las primeras instituciones para la educación superior de la mujer en Estados Unidos, de la que había sido alumna y profesora Alice Gordon Guliek ${ }^{29}$. Muestra en su factura solemne y sólida una indudable impronta del origen

norteamericano de sus propietarios: la fachada culmina en un torreón, inicialmente previsto como observatorio astronómico, y presenta, como elementos destacados, un pórtico de entrada terminado en pequeña galería abalaustrada y gran frontón superior. Las tres plantas centrales que, con la de sótanos y la de cubiertas, componen el edificio, aparecen comunicadas por una doble escalera de mármol en torno a un amplio vano central que singulariza el interior $y$, con su techo acristalado, ilumina el conjunto. Las anchas galerías que recorren estas plantas por tres de sus lados dan entrada a las diversas aulas con ventanas al exterior; en la planta baja ocupa lugar preferente un gran paraninfo. La construcción del edificio, que sufrió algunas modificaciones respecto al planteamiento inicial, se prolongó durante mucho tiempo, ya que el proyecto se presentó el 25 de agosto de 1904 y el certificado de fin de obras no se expide hasta el 15 de abril de $1911^{30}$.

Así, esa zona va definiéndose paulatinamente como un espacio con notorias funciones educativas y culturales, llevadas a cabo por pequeñas unidades autónomas y formalmente independientes, pero que confieren un carácter peculiar y homogéneo al barrio: una disposición que sugiere un cierto paralelismo con el tradicional tipo de «campus» universitario anglosajón, cuyo modelo, por lo demás, está muy presente en los impulsores de la institución residencial. La Junta para Ampliación de Estudios c Investigaciones Científicas hará patente más de una vez esta tendencia al agrupamiento, a la definición de áreas en las que se asientan diversas instituciones de fines complementarios y vinculadas a una misma comunidad de pensamiento: si ello resulta evidente ya en la zona de Obelisco, Forluny, Miguel Ángel y Rafael Calvo, donde en algún momento llegan a convivir, además de la sede de la Institución Libre de Enseñanza y el Instituto Internacional, diversos grupos residenciales y el Instituto- Escuela, instalándose definitivamente muy cerca (en la calle de Almagro $n .^{\circ}{ }^{26}$ ) la propia Junta y el Centro de Estudios Históricos, con más facilidad podrá comprobarse en las diversas construcciones de los Altos del Hipódromo, de marcado carácter unitario y globalizador, conjunto en el que queda excluido el hipotético factor de casualidad que podría invocarse en el caso precedente.

Esta voluntad de cercanía y convivencia, basada seguramente en la búsqueda de un habitat con rasgos vinculados a modelos y formas de vida compartidos, se observa no sólo en el caso de los organismos inspirados en el pensamiento institucionista o que comparten al menos sus presupuestos mayores, sino en la agrupación de las casas 
particulares, a comienzos de los años veinte, de varios intelectuales y profesores, muchos de ellos relacionados con la Junta, entre los que cabe destacar a Ramón Menéndez Pidal y a José Castillejo ${ }^{31}$, en torno al núcleo de Chamartín de la Rosa, zona entonces periférica que llegaría a conformar la ciudad jardín madrileña. Además de la indudable identificación que este acercamiento supone, puede interpretarse también el hecho como expresión de un deseo de establecer ciertos vínculos de vida comunitaria, lo que de nuevo puede evocar hábitos de claustros anglosajones donde los profesores y sus familias se mueven cotidianamente en una estrecha proximidad, dentro de un recinto reducido.

Bajo todo ello subyace, como hilo conductor, el influjo de la Institución Libre de Enseñanza: en efecto, el compartir unos mismos planteamientos que determinan una unidad de pensamiento supone, por el propio sustento krausista, la definición de un tipo de vida caracterizado por inequívocas notas definitorias comunes; en muchos casos ello significa compartir un mismo espacio, si no físicamente, al menos de forma ideal. De hecho, la casa instivicionista del Paseo del Obelisco de Madrid adquiere (y no sólo para sus habitantes fijos y para su asiduos visitantes) un alto valor simbólico como reducto ejemplar, como "sancta sanclorum", donde se realiza el nuevo modelo de vida. Constituye un núcleo que hay que imitar, que hay que reproducir, al que hay que acercarse lo más posible (física y espiritualmente), cuya vecindad ha de resultar, por tanto, beneficiosa y estimulante.

La ubicación de la Residencia cerca de la sede institucionista sugiere, en suma, no sólo que ésta comparte con aquélla, al igual que, en buena medida, el Instituto Internacional, lo que se refiere a sus aspectos organizativos espaciales y a las características ambientales, sino que constituye una prueba más del deseo de seguir el modelo ensayado en la casa del Paseo del Obelisco. La cercanía espacial parece expresar las cercanías de otro signo entre la Institución Libre de Enseñanza y la Residencia de Estudiantes. Y, además, no dejará de ayudar, a lo largo del tiempo, a mantener y reforzar los lazos de unión que tal proximidad entraña.

La primera sede.

Como se ha acaba de decir en párrafos anteriores, Antes de la apertura de la Residencia hubo que realizar en la casa de Fortuny no 14 obras de acondicionamiento para ajustar el hotel a su nueva finalidad. «La Junta para ampliación de estudios( puede leerse en el diario $A B C$ del lunes 20 de febrero de 1911) alquiló un hotel en la calle de Fortuny, transformó las cocheras en comedor, las caballerizas en cocinas, lo decoró y amuebló modestamente y comenzó a recibir en él estudiantes". La misma fuente aporta luego la siguiente 
descripción del interior del edificio ya acondicionado: "La casa tiene, además del comedor y la cocina que ocupan, con las habitaciones de la servidumbre, un pabellón aparte, una sala y un cuarto de trabajo, confortablemente preparados, para ser el lugar de estancia adecuado de los estudiantes. Después, cada uno tiene su habitación independiente, con balcón o ventana a la calle o al jardín" ${ }^{22}$. Alberto Jiménez Fraud precisa, por su parte, que «en los dos cuartos más grandes de la casa se instalaron la biblioteca y un saloncito, y la primitiva cochera del hotel fue convertida en comedor». Por tanto, desde el primer momento, y a pesar de las reducidísimas dimensiones del edificio, se reserva ya, además del comedor, una habitación u la vida en común (la sala), y se constituye un espacio destinado al estudio, un embrión de biblioteca (el cuarto de trabajo); de acuerdo con los datos aportados por el Presidente del nuevo centro, sólo pudieron instalarse quince dormitorios ${ }^{33}$.

Este primer hotel no va a ser más que el embrión de una institución que muy pronto, requerirá una sede mucho más amplia.

Distribución interior (según descripción hecha por Javier de Luque):

- 3 crujías por paredes de traviesa que forman tres rectángulos concéntricos, estando toda la primera crujía destinada a habitaciones, la intermedia a galería y ésta rodeando a la central que constituye la caja de escalera, se concreta, por alturas, de la siguiente manera:

Planta baja: La planta baja está formada por un amplio hall central, comprendido entre la fachada principal y la caja de escalera situada al frente y eje de entrada, con el ancho de esta caja de escalera y galerías laterales, el cual, mediante éstas, da acceso a las habitaciones de planta baja. A la izquierda del hall se encuentra la sala de recibo y a la derecha el gran salón o comedor cuyas dimensiones son las de mayor tamaño que el resto de piezas de esta planta debido a la añadidura del cuerpo rectangular adosado al edificio. El fondo o crujía posterior está ocupado por otra sala, el cuarto de baño y el office, con una escalera tipo caracol a las plantas superiores. Por la galería de fondo y parte posterior de la escalera principal se baja al sótano.

Sótano: crujía de la derecha: cocina formada por dos piezas, baño de servicio en el testero de la crujía izquierda, con la carbonera y la sala donde se halla instalada la caldera de la calefacción, cuya pieza tiene salida al jardín. En la crujía de delante se sitúan el lavadero, despensa y un dormitorio de criados can capacidad para cinco camas. Debajo de la escalera existe un espacio que es utilizado para almacenar leña y carbón. 
Planta Principal: en primer término se encuentra un pieza de paso al amplio mirador de fachada, y con disposición análoga a la planta baja, la galería circunda la caja de escalera y conduce a las ocho habitaciones, principalmente dormitorios de esta planta, al cuarto de baño, al W.C. y a la pieza de servicio.

Planta segunda: Ofrece la misma disposición que la planta anterior pero sin mirador. Consta de 11 piezas y un cuarto de baño. Posee un desván con tres espaciosas espacios abuhardillados.

La comunicación entre plantas se realiza a través de una escalera principal de dos tramos. Existe, como se ha comentado, una escalera de servicio de caracol que relaciona también a todas las plantas, prolongándose en dos tramos rectos hasta el desván, y desde allí, en un solo tramo recto, hasta la cubierta de la escalera principal que remata un lucernario de cristal con armadura de hierro. La bajada al sótano, desde laplanta baja, se realiza mediante una escalera de dos tramos rectos que arranca de la galería del testero. Una escalinata, en la fachada principal, da acceso a la casa y otra en la fachada posterior comunica la parte trasera del hotel con el jardín. Finalmente, una última, en la fachada lateral izquierda, permite descender directamente al sótano.

Se emplean en el acondicionamiento de los Hoteles de la calle Fortuny unos materiales de una cierta calidad que contribuyen a mejorar las sensaciones de los espacios interiores, como el pasamanos de caoba en la barandilla de la escalera principal, molduración en techos y paredes de los espacios más destacados, por ejemplo:" Toda la edificación(dictamina el arquitecto conservador de los edificios residenciales) puede decirse es de las buenas de su época, esmeradamente construída y bastante bien conservada, pues no se nota en ella desperfectos que merezcan mencionarse".

El aspecto exterior del edifico, revocado a la catalana, adquiere una cierta peculiaridad debido al cuerpo saliente que, adosado a la fachada principal en forma de balcón o terraza y sobre elevado un metro con respecto a la rasante general, aparece rodeado por una barandilla de hierro, cubriendo todo el frente de la casa excepto el módulo yuxtapuesto a su lado norte.

El cuerpo rectangular adosado está cubierto con una terraza, rodeada en su perímetro por una barandilla. Por otra parte, cabe destacar, en la fachada posterior del conjunto la existencia de un recinto abierto como preparación de un posible emparrado con el 
que, al parecer, se busca un efecto decorativo, está formado por dieciocho pilastras de sección rectangular de unos $4 \mathrm{~m}$ de altura, son de función y se encuentran ornamentadas en dos de sus caras con relieves de estilo renacentista y unidas entre sí por cartelas chapadas de hierro fundido.

Rápidamente (casi a la vez que se abren las puertas de esta sede a los primeras residentes) se plantean sus responsables la conveniencia de agrandar ese limitado marco inicial: en la sesión celebrada el 10 de noviembre de 1910, la Junta para Ampliación de Estudios e Investigaciones Científicas decide autorizar "al Comité para alquilar otra casa si lo cree prudente", y en la tenida el 20 de diciembre de ese mismo año se encarga a éste "alquilar un nuevo hotel para establecer otro grupo de estudiantes". Por último, en la primavera de ese primer curso de experiencia residencial, acuerda la Junta, en la sesión de 30 de abril de 1911, "que el Comité directivo de la Residencia proceda a alquilar un piso en una casa próxima al Hotel n. ${ }^{\circ} 14$ de la calle de Fortuny y lo amueble" ${ }^{\prime \prime 3}$. A finales del curso inicial, la Residencia ha llevado a cabo, por tanto, una ampliación sensible y cuenta ya con dos hoteles alquilados (Fortuny 14 y Fort uny 10) y un piso situado en "una casa contigua de la calle de Rafael Calvo"35.

En estas primeras ampliaciones de la Residencia no cabe ver simplemente una expansión, un ensanche, sino una consolidación paulatina del centro. Buena prueba de ello lo constituyen las acuerdos adoptados por la Junta en la sesión celebrada el 12 de junio de 19l1, según los cuales no sólo se continúan las pequeñas obras de adaptación y reforma de los inmuebles, similares a las efectuadas en el primer hotel antes de ser ocupado, sino que, con el fin de dar cabida a un mayor número de residentes, se inician ya las primeras construcciones aprovechando parte del jardín de los hoteles alquilados: "Se acordó autorizar a la Comisión ejecutiva (puedeleerse en un resumen del acta correspondiente) para construir dos pabellones en Fortuny 10, un comedor en el 14, y reparaciones en Rafael Calvo, adquirir mobiliario, etc. para poder ser ocupado por unos 50 alumnos" ${ }^{\prime \prime 6}$.

Las últimas ampliaciones que se hacen en esta sede constan de la unión a los hoteles de 1911 de otros dos contiguos, que hace que que se rompan líneas divisorias y que se forme un jardín común que rodea a todos los edificios. Se hace posible establecer una sola entrada, unificar los servicios de cocina, lavado y planchado, y habilitar una espaciosa biblioteca, nuevas salas de reunión y $\mathrm{d}$ estudio y dos laboratorios. Este crecimiento, rápido y continuado, junto a las obras de acondicionamiento anteriormente citadas, supone un importante afianzamiento de esta institución, nacida apenas tres años antes y con dimensiones modestísimas. Con estas últimas ampliaciones se consigue duplicar el número de plazas. 


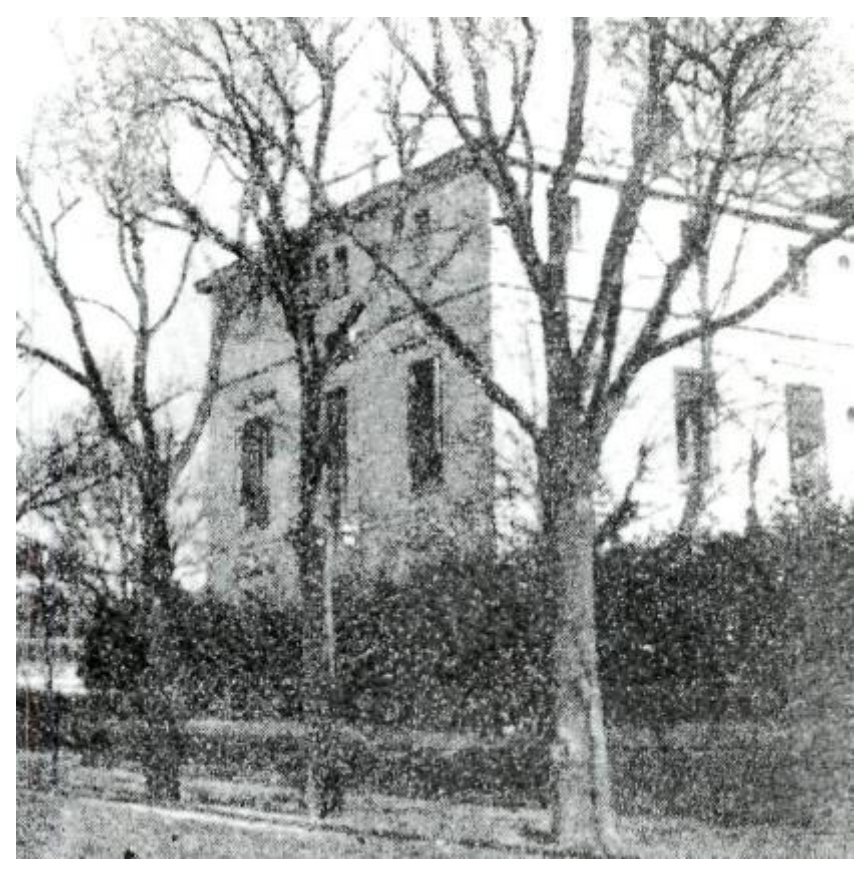

Hotel de la calle Fortuny.

Imagen 1 y 2: Vistas del hotel desde el acceso exterior.

Imagen 3: Vista de los dormitorios desde el jardín.

Imagen 4: Vista de las aulas desde el jardín
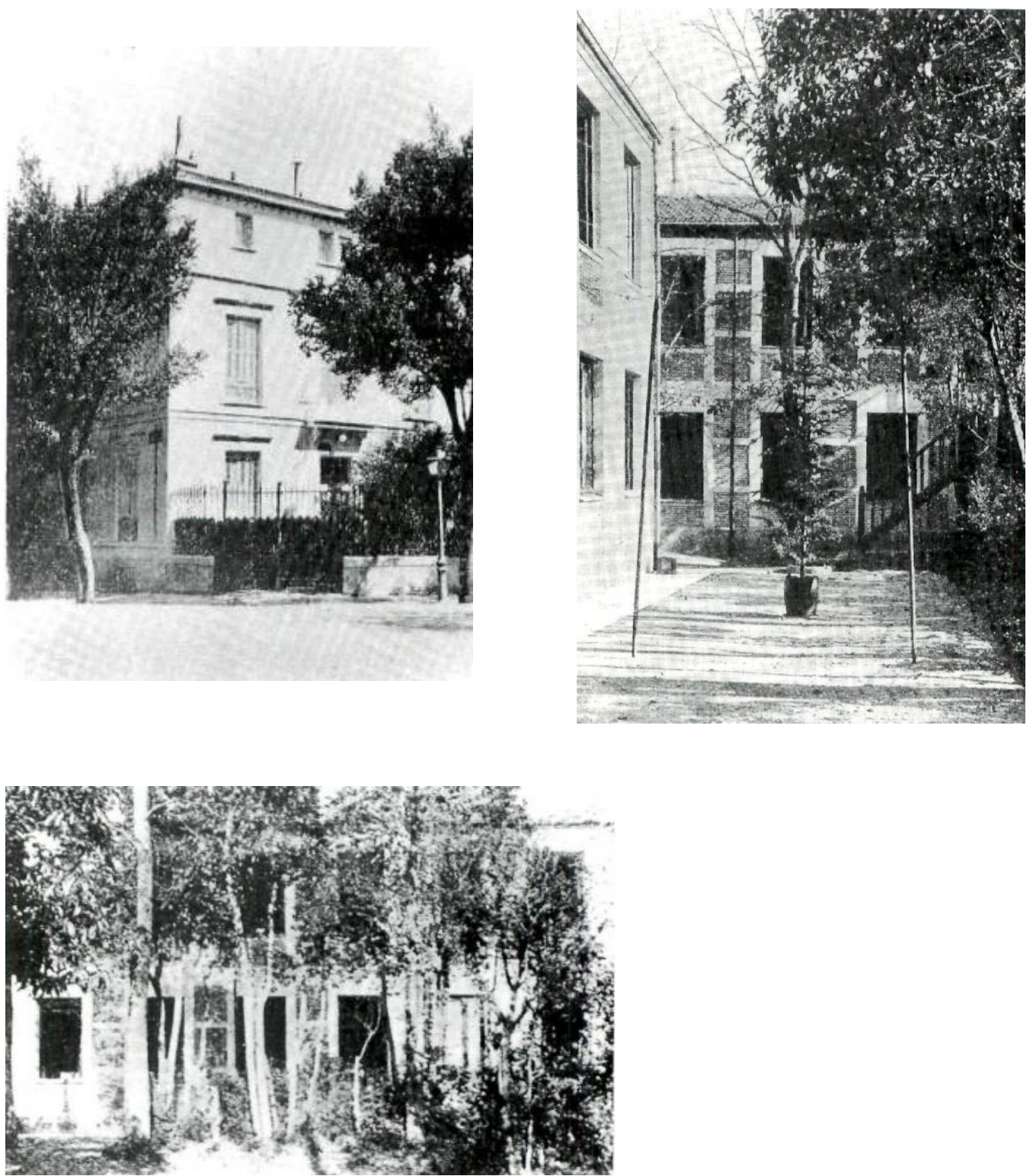


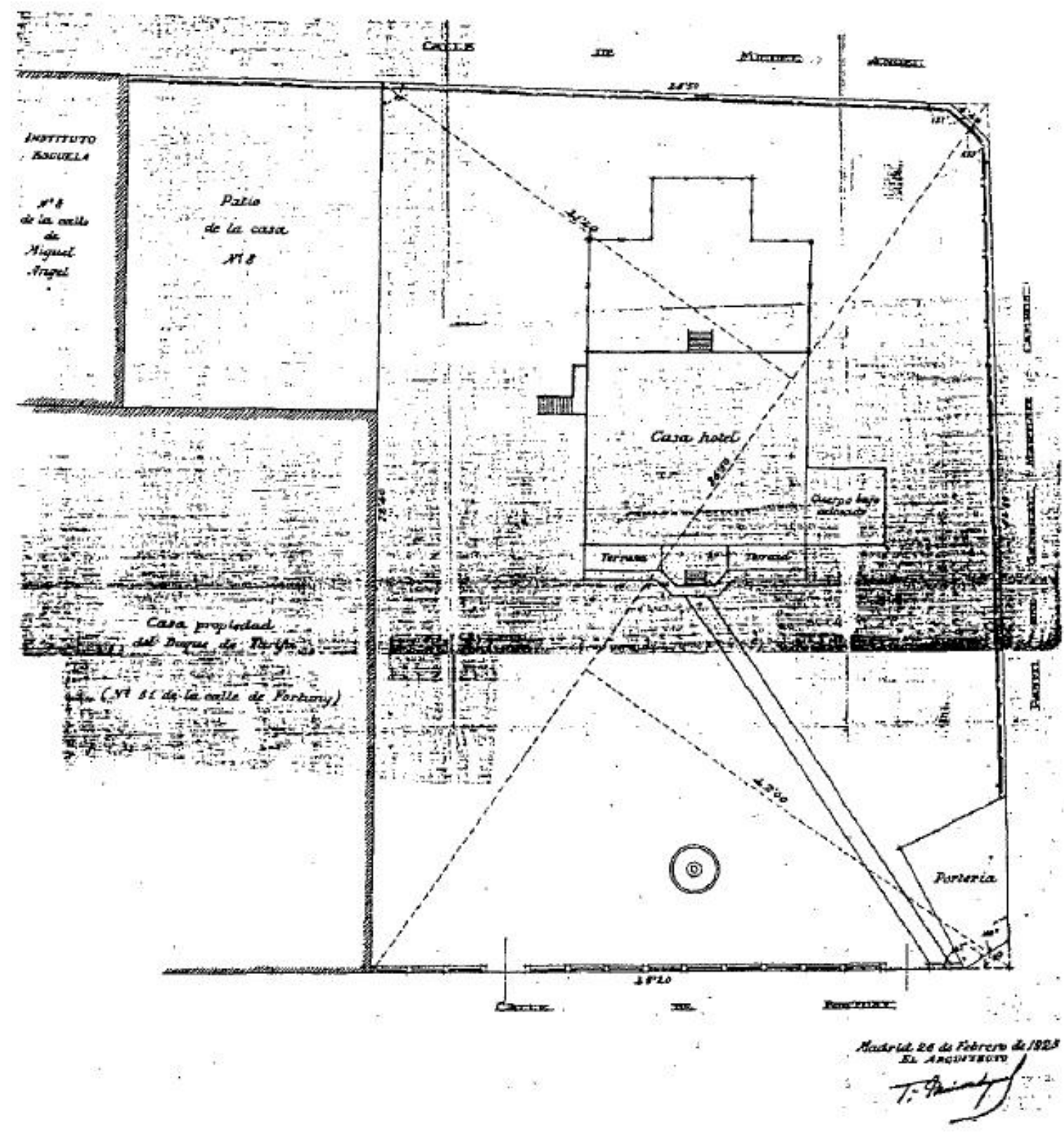

Hotel de la calle Fortuny.

Imagen 5: Finca del hotel Fortuny $n^{\circ} 53$

La Junta tenía la imprescindible premisa de que los bloques debían estar aislados. 
Tate tow

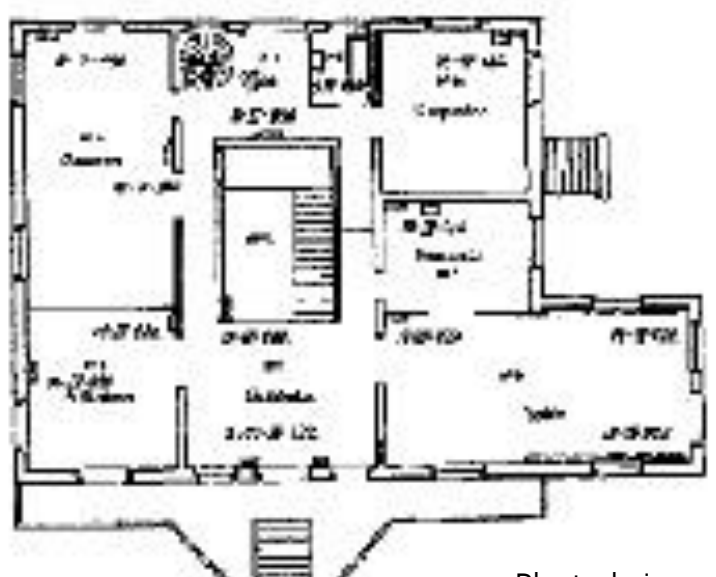

Planta baja

Eereng

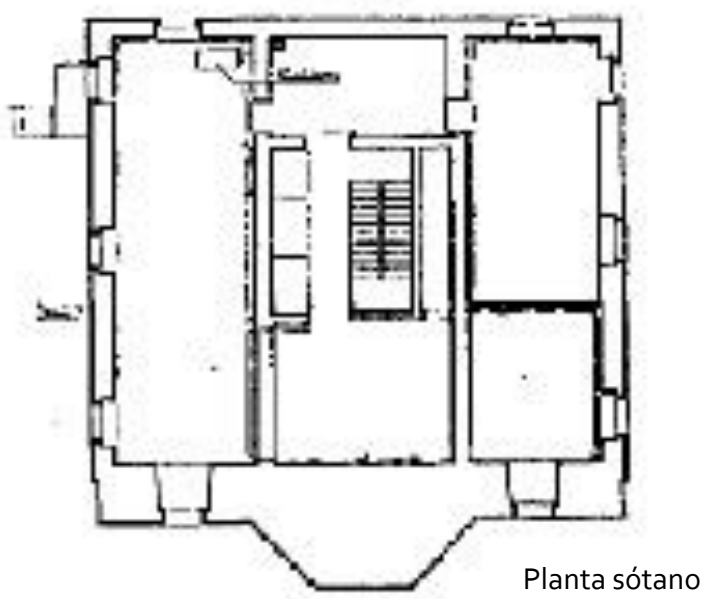

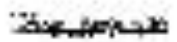

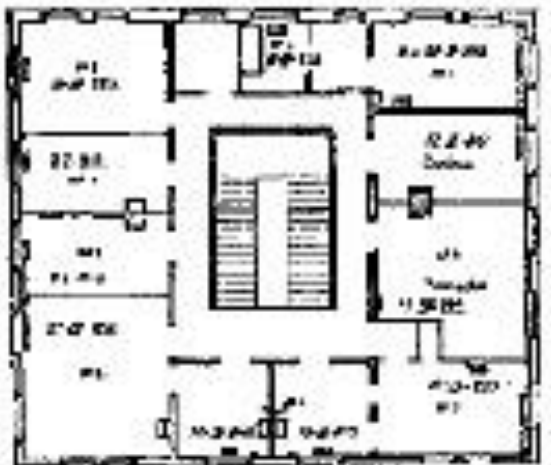

Planta segunda

Trisive:

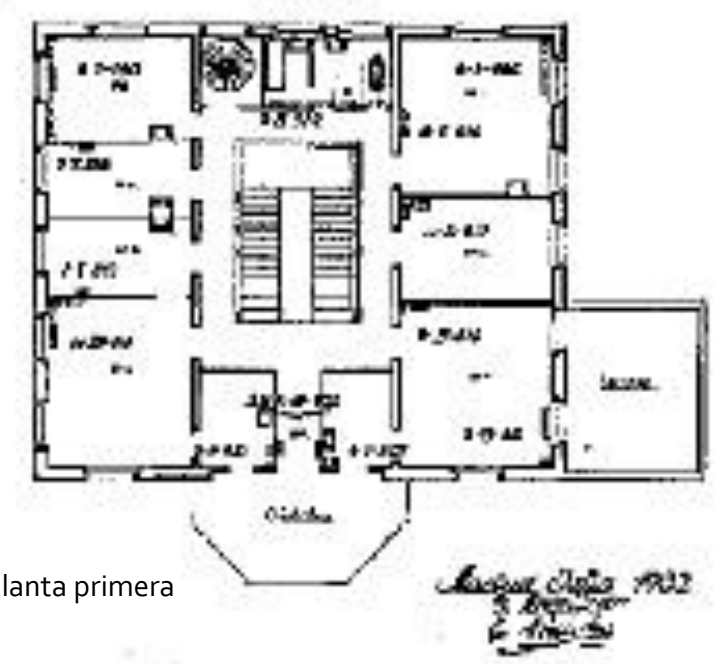

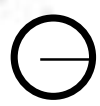

Hotel de la calle Fortuny.

Imagen 6: Plantas de distribución del hotel.

Entorno al núcleo de comunicación vertical se

organizan las dependencias en las distintas

plantas. 


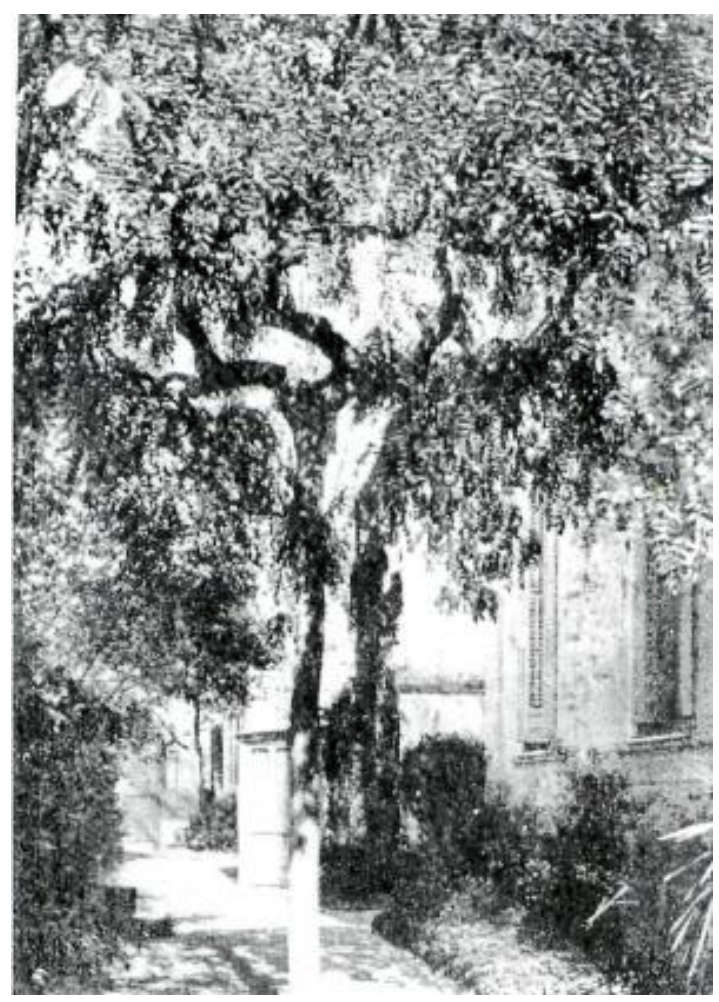

Imagen 7: Los jardines y la naturaleza son el denominador común de los espacios exteriores.

Imagen 8: Conjunto de los hoteles, donde se ve el frente e arboles como "colchón" entre la calle y las edificaciones.

Imagen 9: Rincón de los jardines.
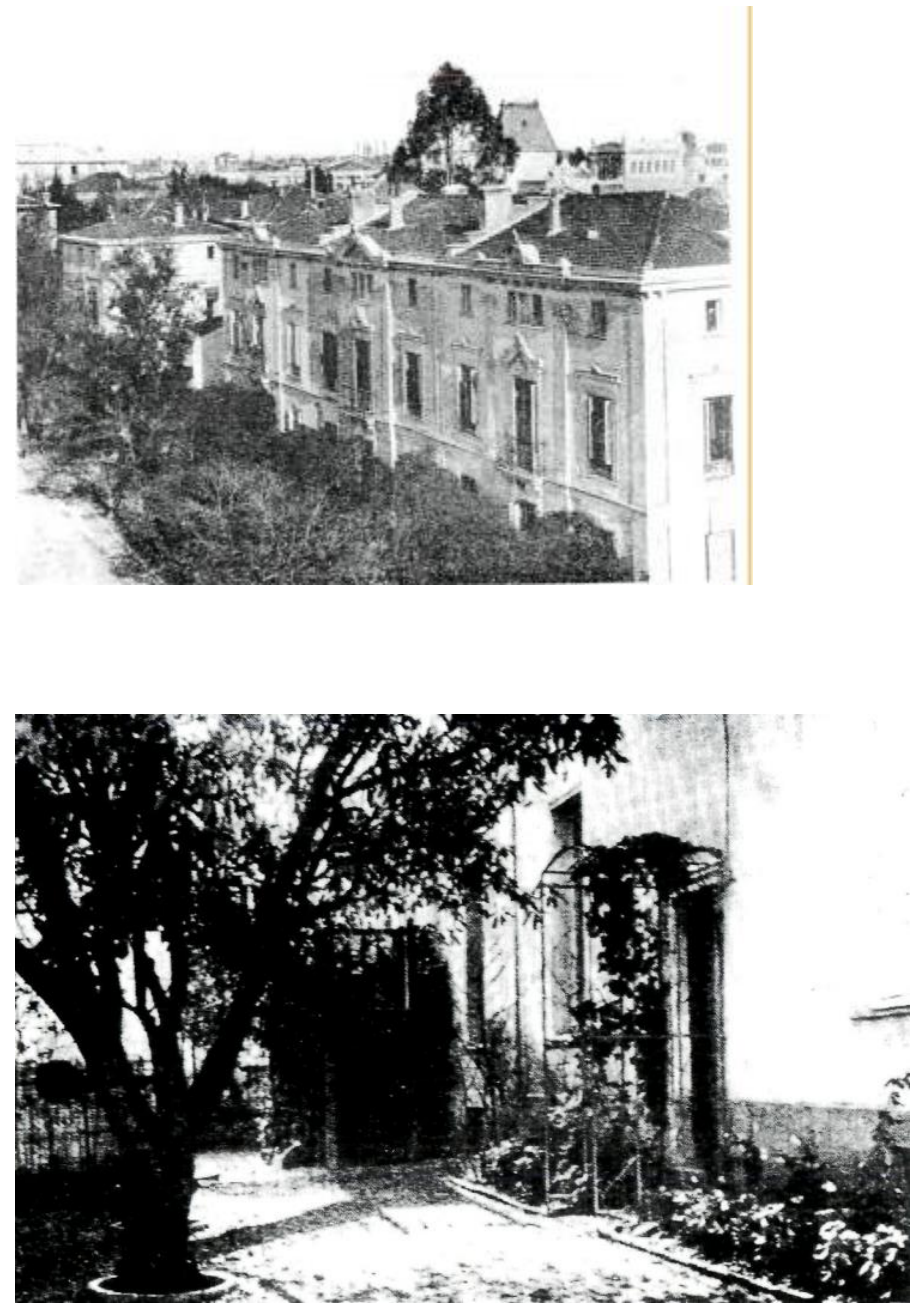
Imagen 10: Vista de las aulas desde el jardín.

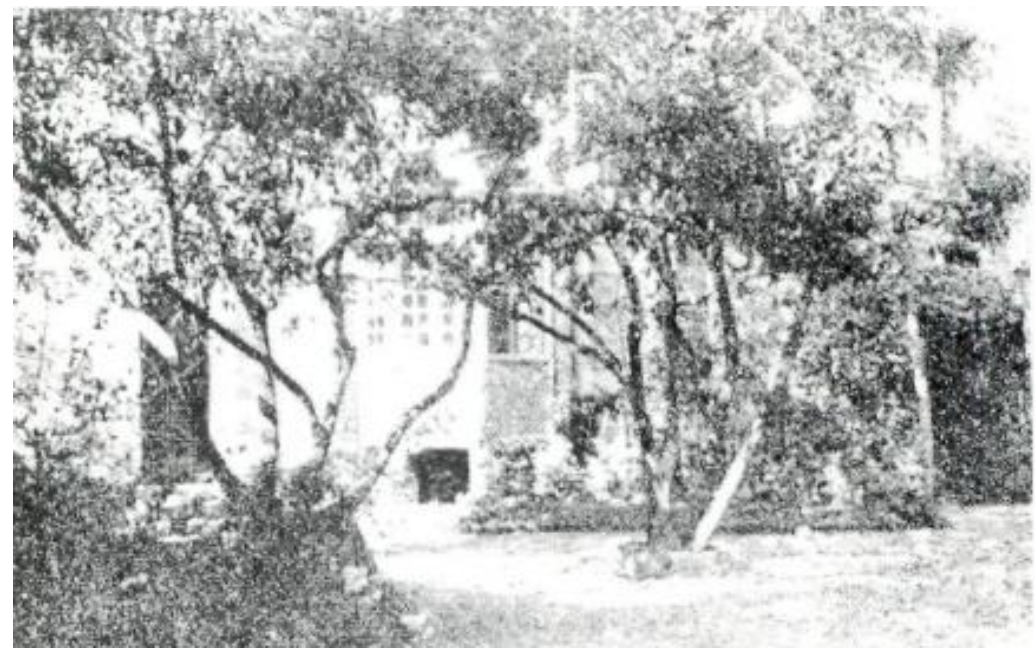

Imagen 11: Visita de Alfonso XIII a la Residencia de Estudiantes. El contacto con la misma y el conocimiento en la forma de plantear las nuevas formas de enseñanza así como sus edificios contenedores, repercitirán en su forma de concebir el que será su gran proyecto de futuro como monarca: La Ciudad Universitaria de Madrid.

Imagen 12: Miguel de Unamuno en su habitación de la sede de Fortuny.
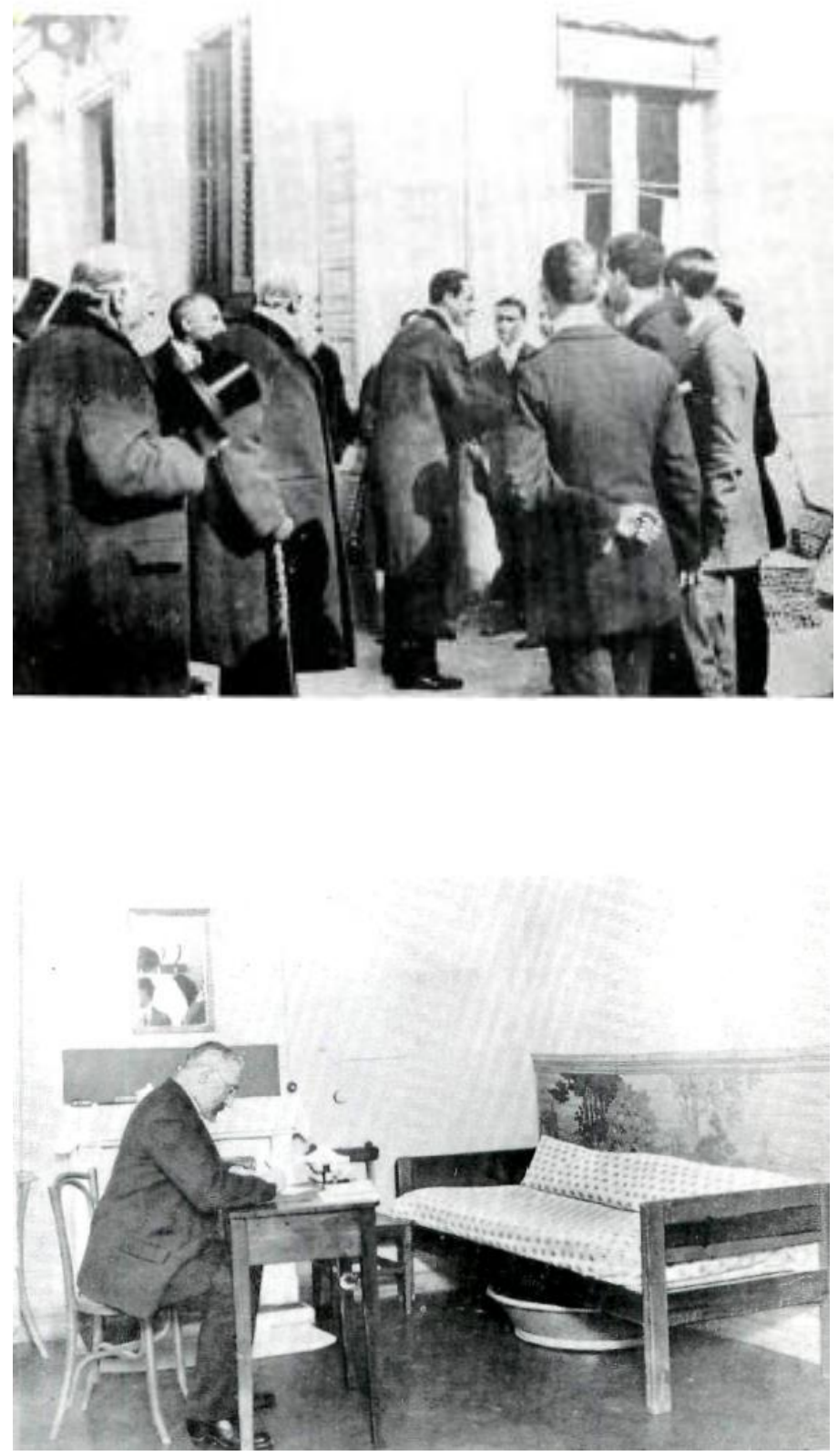


\section{EN LA "COLINA DE LOS CHOPOS" (1910)}

Tras los problemas de falta de alojamiento, que anteriormente se ha hecho referencia, la Junta adopta unos acuerdos por los que aprueba un proyecto de ensanche de la institución. A partir de este momento comienza una exhaustiva búsqueda de solares adecuados para llevar a cabo la función residencial. El 14 de Noviembre de noviembre de $1912 \mathrm{La}$ Junta hace una petición de terrenos para edificar algunos pabellones destinados a la Residencia a lo largo del paseo del Rey en la Moncloa ${ }^{37}$. El lugar era apropiado al proyecto por ser un terreno amplio, en las afueras de la ciudad, en una zona donde se hacían presentes los vientos de la Sierra y estaba dotaba de una importante cantidad de vegetación.

La petición de estos terrenos será denegada por real Orden del 6 de diciembre de 1912. A partir de enero de 1913 se inician nuevas negociaciones con el objetivo de conseguir nuevos solares para la disposición de los edificios residenciales. Finalmente La Real Orden de 11 de agosto de 1913, refrendada por el Ministeriode Instrucción Pública y Bellas Artes, Joaquín Ruiz Giménez, otorga finalmente unos terrenos adyacentes al palacio de la Exposición en el Hipódromo, cedidos por este mismo Ministerio ${ }^{38}$.

Situados en la zona conocida como "Los Altos del Hipódromo" (en los altos de la derecha del Hipódromo detrás del Palacio de la Industria y de las Artes según reflejan las memorias de la Junta ${ }^{39}$ )y extendiéndose desde la calle Pinar hasta casi la hondonada que actualmente ocupa la calle Vitruvio, los solares concedidos para la construcción de los edificios destinados a La residencia de Estudiantes constituían "una larga y estrecha faja de terreno que lindaba a levante con una gran parcela de terreno propiedad del conde de Maudes, y al norte con solares de diversos propietarios; y que a poniente quedaba cortada por la sinuosa línea del Canalillo, para bajar en rápido desmonte a la plataforma ocupada por el Palacio de Industria y los jardines de éste, que en suave declive bajan a la Castellana"40.

La índole periférica de su ubicación respecto a la ciudad, su situación en el límite norte de Madrid, muy cerca del final del Paseo de la Castellana, plasma de nuevo las características ideales de la primera sede residencial. Pero ahora, además, la mayor disponibilidad de terrenos e incluso el hecho de tratarse, como indican el nombre "Cerro del Aire" que recibe popularmente o la denominación "Cerro del Viento" que utiliza Juan Ramón Jiméne ${ }^{41}$, de una zona ligeramente elevada, "el terreno tiene excelentes condiciones por su altura», se señala en una de las Memorias de la Junta, haciéndose en otra referencia a su "salubridad y situación inmejorables" ${ }^{42}$; confieren a la zona una especial idoneidad. "Era un cerrillo, inundado por el sol y batido por los vientos, desde el cual se disfrutaba (rodeado por todas partes del azul del cielo) de una gloriosa vista de la Sierra del Guadarrama", en palabras de Alberto Jiménez Fraud 
Los nuevos edificios.

Reproduciendo también el modelo de la calle de Fortuny, la nueva Residencia se concibe desde el primer momento como un conjunto de edificios independientes $y$ de proporciones reducidas, estructura articulada que se ajusta perfectamente a las características del centro y que explicita el horror sentido por sus responsables hacia la aglomeración de los internados al uso, que se suelen alojar en caserones de proporciones inasequibles. Los principios innovadores, de raíz anglosajona, que sustentan la Residencia de Estudiantes explican sin duda la originalidad, la modernidad de este planteamiento arquitectónico que contrasta fuertemente con el seguido en la mayor parte de los edificios educativos que entonces se construyen en Madrid.

En esta ubicación se van a plasmar las obras de bloques residenciales de dos arquitectos: Antonio Flórez Urdapilleta en primer término, y de Francisco Javier de Luque y López en segundo lugar.

Antonio Flórez había sido alumno de Cossío. Había estudiado un largo tiempo en Roma ${ }^{43}$. Una vez elegido por la Junta para crear los primeros bloques residenciales estudia las condiciones del solar en relación con las necesidades que le ha transmitido la institución.

Flórez diseña un sistema de pequeños edificios separados cuya distribución final en línea viene determinada por la propia forma alargada y estrecha del solar. Esta disposición ofrece la ventaja de poder escalonar la construcción de acuerdo con las disponibilidades económicas. Los dos primeros pabellones edificados son rectangulares y tienen unas dimensiones de $43 \times 7,50 \mathrm{~m}$ y en su programa contienen:

- 24 habitaciones de $4 \times 4 \mathrm{~m}$ cada una de ellas, situadas en tres niveles diferentes a razón de 8 por planta.

- Las ventanas de las habitaciones están orientadas a mediodía.

- Las habitaciones están protegidas por un muro en su orientación norte y se comunican entre ellas mediante un pasillo-corredor de $2 \mathrm{~m}$ de anchura.

- Las cubiertas son amplias terrazas.

- La composición material de estos dos bloques está realizada con fábrica de ladrillo recocho, hierro y madera.

Posteriormente, se construye el edifico destinado a laboratorios, aprobado en la sesión del 13 de diciembre de 1914 de la Junta para la Ampliación de Estudios. Este bloque también es rectangular y tiene unas dimensiones de $57 \times 10 \mathrm{~m}$. Su programa se distribuye en tres pisos:

- Piso $1^{0}$ : laborartorios

- Piso $2^{\circ}$ : dormitorios

- Piso $3^{\circ}$ : cuartos de servicio 
Este bloque se encuentra orientado en dirección norte-sur y, dada su configuración, con unas largas fachadas orientadas a poniente y mediodía. Cuenta con amplios espacios de almacenaje y lavaderos en un semisótano.

La planta baja se distribuye de la siguiente manera:

- 6 laboratorios

Planta primera:

- 38 dormitorios y 9 cuartos de duchas

Planta segunda:

- Dos torres habitables, en los extremos de una terraza que sirve de cubierta.

Los materiales utilizados son, como en el caso de los pabellones gemelos, ladrillo, fábrica de ladrillo recocho y madera. ${ }^{44}$

Una vez visto el resultado de estos primeros tres bloques, la Junta queda muy satisfecha por por la concordancia entre los presupuestos inspiradores del centro y los proyectos realizados por Antonio Flórez Urdapilleta ${ }^{45}$. Consigue una fórmula constructiva sencilla y sobría, tanto por la concepción como por los materiales utilizados, carentes prácticamente de elementos decorativos y resolviendo la situación de no caer en una confusión de estilos, característica de muchos arquitectos de la época. Su preocupación por los aspectos funcionales, pueden permitir inscribirle en una tendencia preracionalista en la que los rasgos historicistas, aún evidentes, aparecen en estos bloques muy depurados.

Este conjunto de edificios, que se pueden perfilar dentro de una tradición popular modernizada, representan un claro avance hacia una arquitectura moderna. En palabras de Adolfo González Amezqueta "constituyen un buen ejemplo de ciertas experiencias transitivas que van acercándose a la desornamentación y a las propuestas racionalistas internacionales". Antón Capitel señala que: "aunque la fuerza de los españolismos, tan extendidos en estas primeras décadas del siglo XX y potenciados por un regeracionismo del que participa Flórez", y tras entroncar la tradición sobria y puritana de este arquitecto con su ideología institucionalista reforzada por la mejor tradición local, considera que en las construcciones de Antonio Flórez "se dan cita la sobriedad, racionalidad constructiva y buen hacer del XIX madrileño tan vinculado a la valoración de la fábrica de ladrillo, al tiempo que, por ello mismo, se anticipan cuestiones, y se establece así un puente, de lo que será nuestra posterior, y mejor, arquitectura moderna de anteguerra ${ }^{47}$

Sin embargo, a pesar de la estrecha armonía existente entre el arquitecto y los responsables del nuevo centro, en el verano de 1915 Antonio Flórez pone fin a su vinculación profesional con la 
Residencia de Estudiantes. En la Memoria de la Junta de este periodo se muestran los detalles de dicho abandono por parte de Flórez, achacando a que sus múltiples obligaciones y la falta de recursos que conllevaban múltiples dudas y cambios de última hora.

Finalmente la Junta tiene que buscar un sucesor, y pone sus ojos en Javier de Luque. En estos momentos es profesor de la Escuela de Madrid y quien, se compromete a mantener, en los edificios por él proyectados, el tono mesurado y sencillo de Antonio Flórez. Actuará además como conservador de los edificios residenciales, incluidos los del núcleo de Fortuny.

Tardará sólo dos meses en tener el proyecto del próximo bloque que se construye. Este cuarto pabellón, con unas dimensiones de $44 \times 14$ $m$, consta de:

-Una planta central de sótanos, con una amplia cocina, almacén, carboneras y otras dependencias.

-Planta baja: galería acristalada, vestíbulo, despacho del director, oficinas y dependencias para el servicio de comedores.

-Piso principal y en el primer piso hay 24 habitaciones y 4 cuartos de duchas. Dos alas laterales de una sola planta, en comunicación con el cuerpo central, donde se ubica el salón y el comedor de $14 \times 13 \mathrm{~m}$ cada una de estas dos estancias.

Este bloque alberga casi todos los servicios comunes y logra aumentar la capacidad residencial de forma notoria. Al mismo tiempo se amplía el tercer pabellón, del que ya se habían construido la planta de laboratorios y la planta principal destinada a 24 dormitorios, con una planta extra con 14 habitaciones, cuartos de baño, escaleras, terraza y dos torreones con secaderos de ropa, la cual era lavada en los lavaderos del sótano como se ha explicado en líneas anteriores.( Oficio enviado el 5 de junio ck1 1915 al Ministerio de Instrucción Pública y Bollas Arlos por José Castillejo en solicitud de autorización para realizar las obras y efectuar el consiguiente gasto do $33.011,29$ pesetas $^{4}$. Asimismo se adecua en este pabellón un espacio para biblioteca que ocupa, de forma provisional, dos de los espacios de planta baja, inicialmente previstos para laboratorios; junto a éste se realizan una serie de obras correspondientes a infraestructuras, como la prolongación del alcantarillado hasta los nuevos edificios. En esta misma fase se lleva a cabo la construcción de un pequeño pabellón de portería y un hangar para bicicletas.

Para conseguir un ambiente y una implantación tipo campus estadounidense, se decide. Por parte de la Junta, cerrar con una valla el terreno donde se encuentran implantados los edificios, también se lleva a cabo el ajardinamiento de los espacios libres dentro del recinto vallado. En esta adecuación de los espacios exteriores se disponen puentes de madera de acceso sobre el "canalillo", la explanación, el empedrado del terreno y la plantación de árboles ${ }^{49}$ 
En el Archivo J.A.E.I.C. (Archivo General de la Administración), legajo 13.609-1, se conserva una solicitud efectuada al Ministerio de Instrucción Pública y Bellas Artes por Santiago Ramón y Cajal del 27 de mayo de 1922 para acotar estos terrenos). El Ministerio de Instrucción Pública y Bellas Artes cede una parcela de terreno, situada al suroeste de la Residencia, que se utilizará para construir pistas de tenis y futbol para los eventos deportivos. Este recinto y las zonas deportivas crean lo que podría denominarse un "mini campus" residencial.

A parte, también empieza a construirse como adhesión al conjunto de la Residencia de Estudiantes un pabellón que albergará la función de biblioteca, en un local exento, con unas dimensiones de $14,25 \mathrm{X}$ $12.20 \mathrm{~m}^{50} \mathrm{con}$ el fin de albergar de forma definitiva los libros. Contará con una sala de lectura de dimensiones suficientes, así se dejar libre la planta baja del pabellón de laboratorios.

El quinto pabellón proyectado por Javier de Luque se erige muy cerca del pabellón de la biblioteca. Es un edificio de unas dimensiones de18,80 × 9,80 m. Tiene semisótano y tres plantas sobre rasante.

El sexto pabellón que se construye hacia 1923, se sitúa la entrada de la calle Pinar, al otro lado del canalillo pero no muy alejado del primer pabellón, es un hotel de tres plantas, de líneas y materiales acordes con los restantes edificios, y está destinado a albergar la vivienda del Presidente de la Residencia. Esta es una analogía más con la zona residencial del campus estadounidense.

Francisco Javier de Luque supo respetar y continuar los rasgos estilísticos y arquitectónicos determinados por la impronta personal de Antonio Flórez. Constituyen un aspecto muy digno de ser tenido en cuenta dentro del marco residencial madrileño.

Walter Gropius, en una de sus visitas afirma en una conferencia en 1930, explicando qué era lo funcional, ponía como el edificio destinado a laboratorios y decía que las nuevas formas nacen de la esencia de la obra arquitectónica, de la función que la misma ha de cumplir, y clamando, como muchos años antes hacía Ruskin contra lo artificial y convencional, añadía que en arquitectura la función del color es esencial y esa solo la dan los mteriales nobles como la piedra y el ladrillo. De esta manera, describe el revestimiento del edifico, "ese color carmin del ladrillo "recocho" al descubierto, con reflejos de oro, que arrancaba el sol poniente de Madrid, es un espectáculo admirable" ${ }^{1}$ 
La Junta para Ampliación de Estudios va comprando los terrenos adyacentes a donde se encuentran situados los pabellones de la Residencia de Estudiantes, con el fin de proveer edificios con funciones que, de algún modo sean complementarios a los residenciales en este "micro campus" que se está creando y además, asegurarse que no van a acercarse al conjunto edificios de otra índole que pudieran perjudicar la armonía del conjunto ${ }^{52}$. Se crea por lo tanto una trama edificatoria generadora de ciudad mediante el conjunto generado por la suma de estos centros, singulares y complementarios. Al final se busca, como en los modelos medievales, ser un pequeño bastión donde el estudio y la convivencia sea lo más agradable posible, pero en este caso, con los recursos de una arquitectura casi moderna.

Dentro de los complementarios cabe destacar al Instituto Nacional de Física y Química de Manuel Sánchez Arcas y Luis Lacasa, que guarda concordancia estética por el parentesco de material, líneas y proporciones. Otro edificio que conviene resaltar es el Institutoescuela (parvulario bachillerato) de Carlos Arniches y Martín Domínguez junto con Eduardo Torroja en la del parvulario.

La última construcción que se añade a este conjunto de la Residencia de Estudiantes en 1934 es el del bloque destinado a Auditorio. Se implantó sobre un solar de $2.394 \mathrm{~m}^{2}$. El arquitecto es Carlos Arniches, arquitecto que había sustituido a Javier de Luque como conservador de las construcciones residenciales desde el otoño de 1927.53

Albergará las funciones de sala de conferencias, biblioteca y clases para cursos especiales. Se presenta como un anejo a la Residencia de Estudantes para potenciar su faceta cultural.

Este edificio se plantea de forma claustral con un patio. Es un volumen macizo de fábrica de ladrillo, rectilíneo con cubiertas planas rematadas con terrazas. Este bloque, cuya planta parece ser que realiza una trasposición del esquema conventual del claustro, responde a una estudiada mediación entre tradición y modernidad, no resultando su apariencia tan avanzada como como la de los edificios que albergan el Instituto-escuela, realizados por estos mismos arquitectos ${ }^{54}$

La carpintería exterior es metálica. Con este pabellón se puede constatar la evolución arquitectónica acaecida desde la construcción de los primeros pabellones residenciales hacia este tipo de soluciones más puramente racionalistas.

Antes de acabar este capítulo, merece una mención especial aunque esté ubicado fuera de la Colina de los Chopos, la obra de Carlos Arniches del Pabellón de la Residencia de Señoritas, situado en la confluencia de la Calle Miguel Ángel y del Paseo General Martínez Campos y ajustándose su planta a esta disposición angular. Éste es un edificio icónico. La planta se organiza en forma de "L", con chaflán y escalera sobresaliente de la línea de fachada por un cuerpo 
semicircular en altura. Posee cuatro plantas de dormitorios, una planta semisótano para salón y servicios generales de calefacción, lavaderos, secadero y plancha, y espacios comunes para propiciar el ambiente adecuado al estudio. Armónico y sencillo en sus materiales, en su hechura, equilibrado y funcional, luminoso, el pabellón construido para la Residencia de señoritas y conocido como "edificio Arniches" representa una valiosa muestra del racionalismo madrileño de los años treinta. 


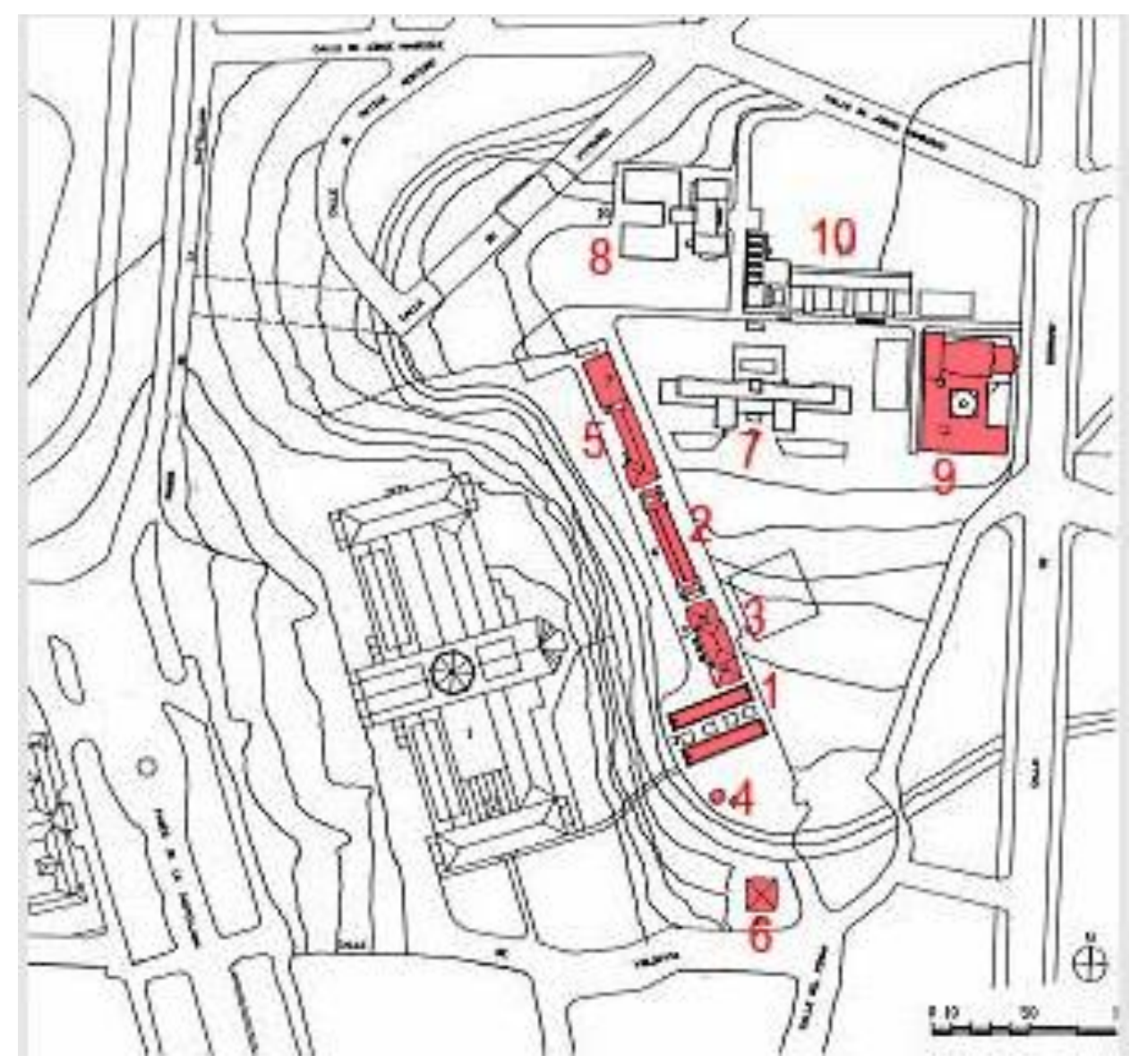

Imagen 13: Ubicación y emplazamiento de los edificios que conforman La Residencia de Estudiantes en la "Colina de Los Chopos". Siendo: (1) Pabellones 1 y 2, Antonio Flórez, 1915-15; (2) Pabellón 3, A. Flórez, 1915; (3) Pabellón 4, F. J. de Luque, 1915i (4) Pabellón de Portería, A. Flórez, 1915; (5) Pabellón 5, F. J. de Luque, 1916-18; (6) Vivienda del Director, 1923. (7) Centro de Investigación, Lacasa y Sánchez Arcas, 1928-32; (8) Instituto Escuela, Arniches y Domínguez, 1931-33; (9) Auditorio y Biblioteca, Arniches y Domínguez, 1931-33; (10) Escuela y Aulas Jardín, Arniches y Domínguez, 1933-35.

Imagen 14: Franja residencial en la "Colina de los Chpos". Disposición lineal de las edificaciones.

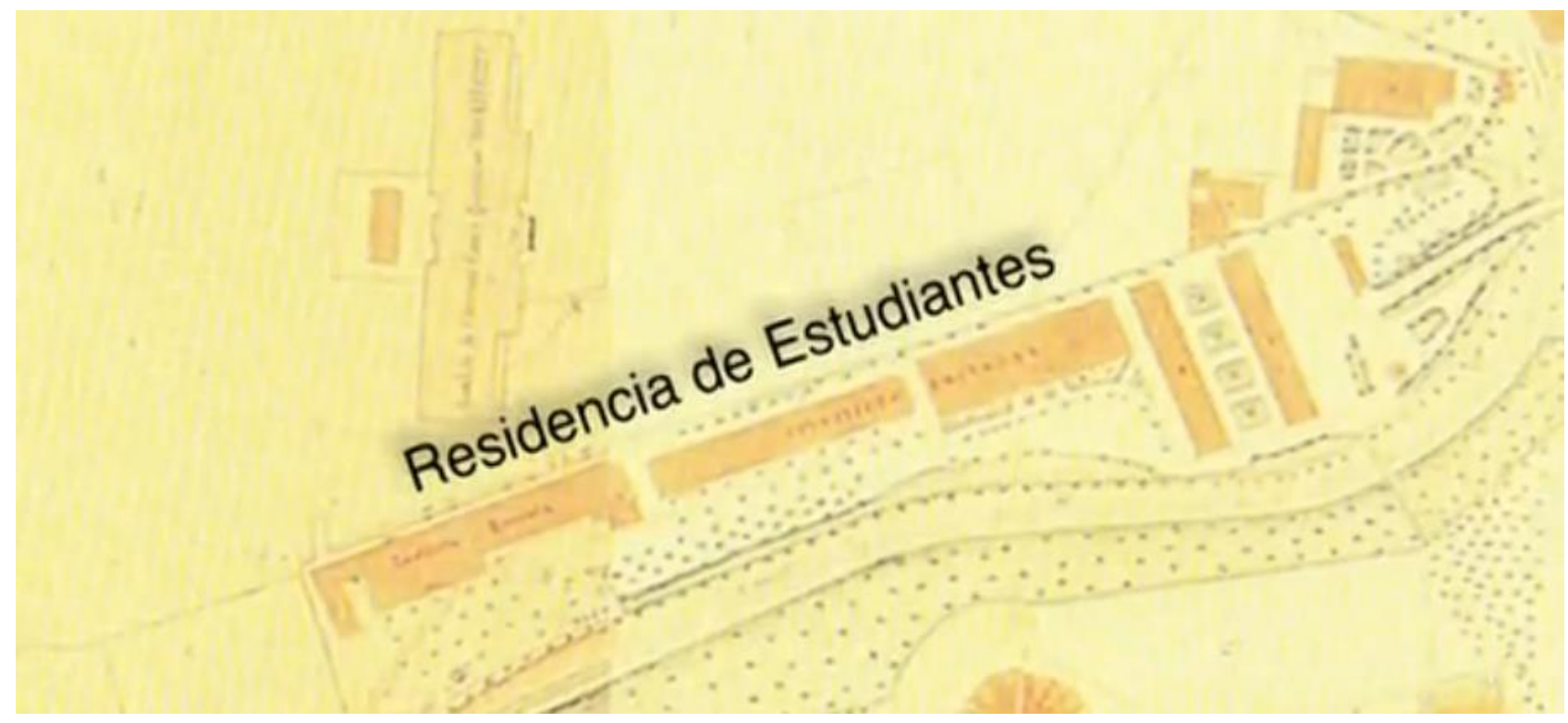



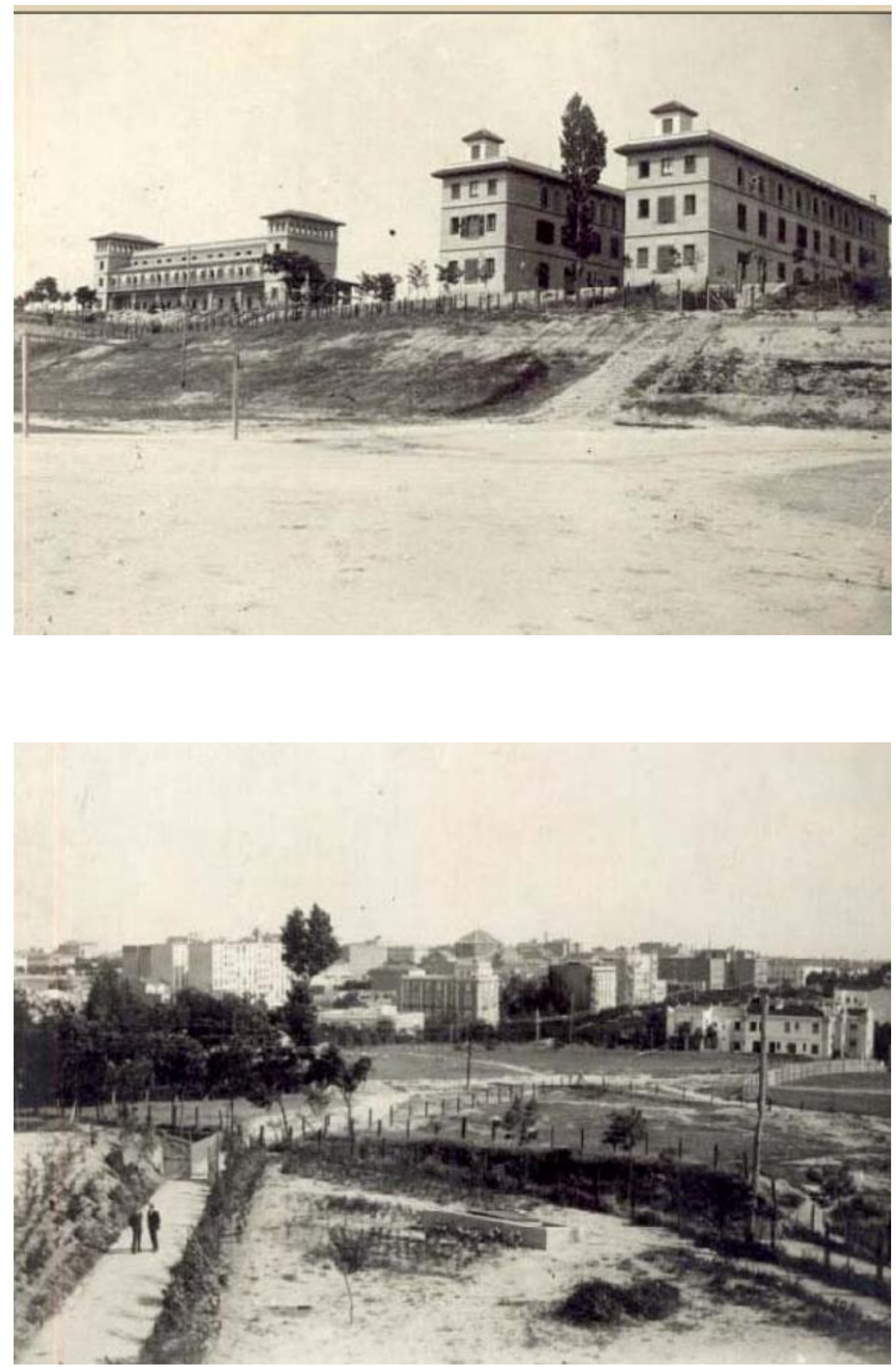

Imagen 15: Vista de los primero bloques que se dispusieron, a la derecha los Pabellones Gemelos, encontrándose en Jardín de las Adelfas entre ambos; a la izquierda, el pabellón Trasanlántico. Estos tres edificios son proyectados por Antonio Flórez Urdapilleta.

Imagen 16: Acceso al conjunto residencial por la calle Pinar. 


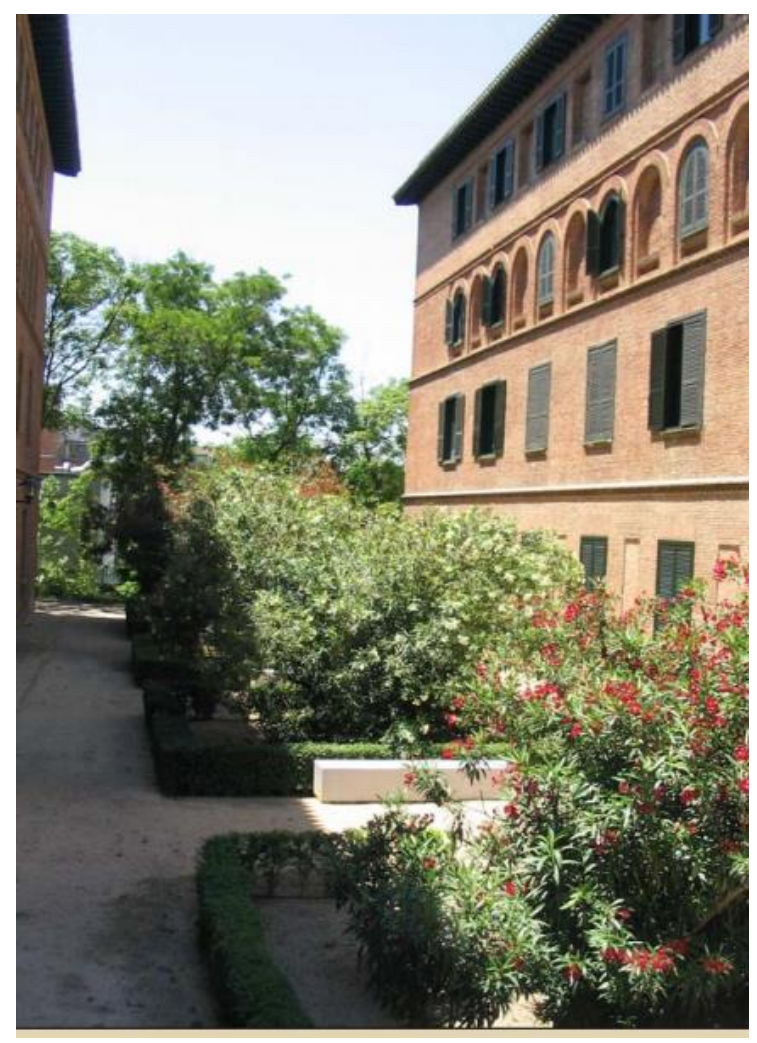

Imagen 17: El Jardín de las Adelfas como espacio de relación exterior entre edificaciones.

Imagen 18: Visita de Le Corbusier a la Residencia Estudiantes. En la foto, en compañía de Garcial Mercadal.

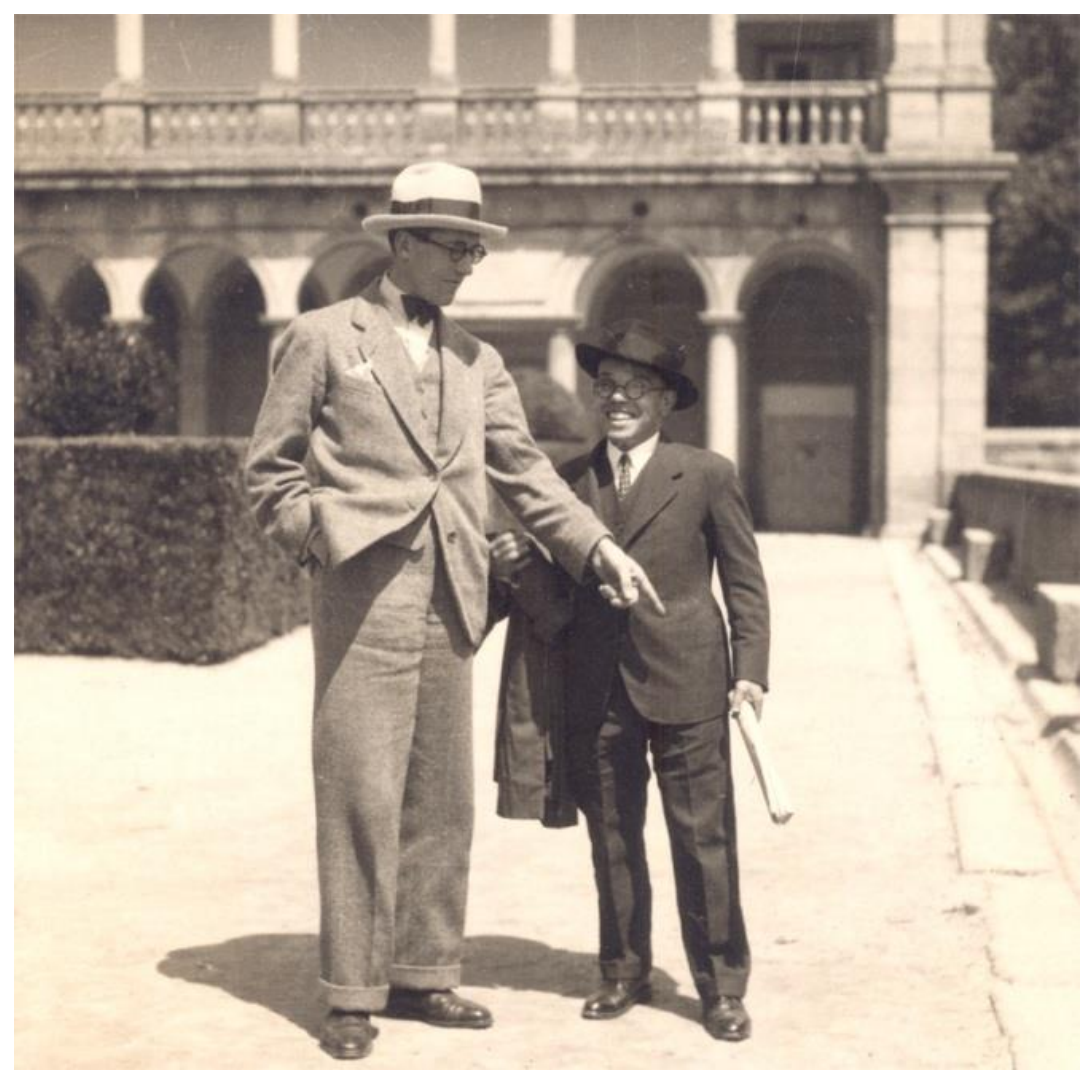



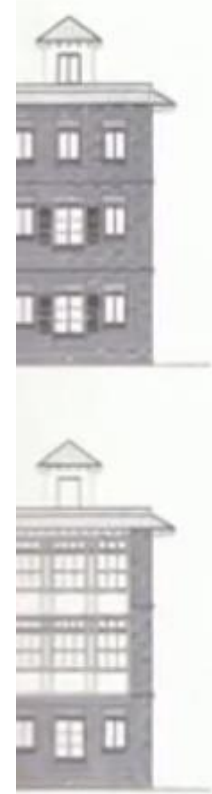
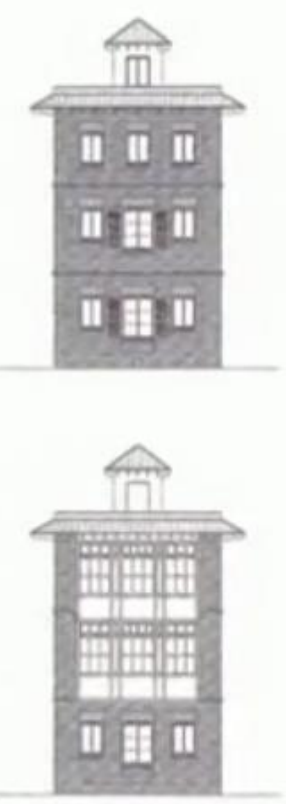
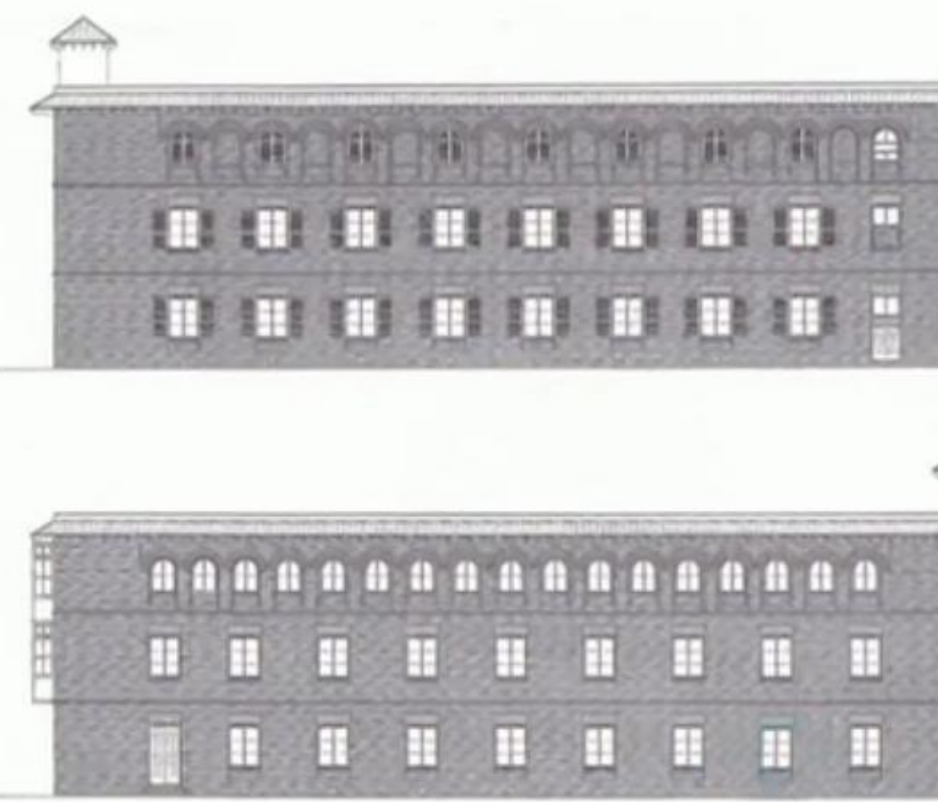
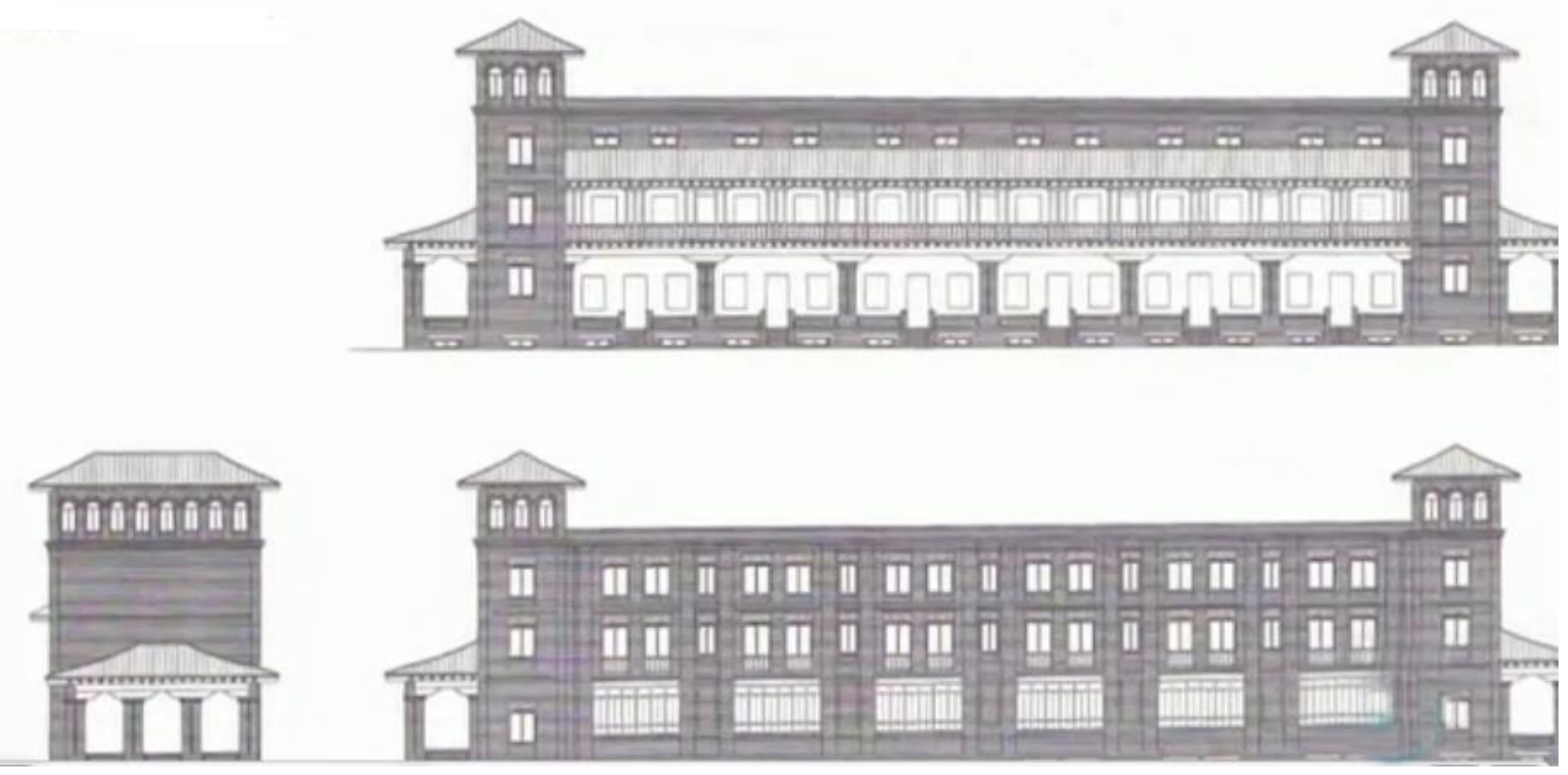

Imagen 19: Alzados y testero de uno de los Pabellones Gemelos de A. Flórez. La fenestración se dispone en la repetición de un módulo de ventana en las distintas plantas.

Imagen 20: Fachada principa, posterior y testero del Pabellón Trasatlántico de A. Flórez. La planta baja busca la mayor iluminación de las zonas comunes a través de grandes cristaleras. 

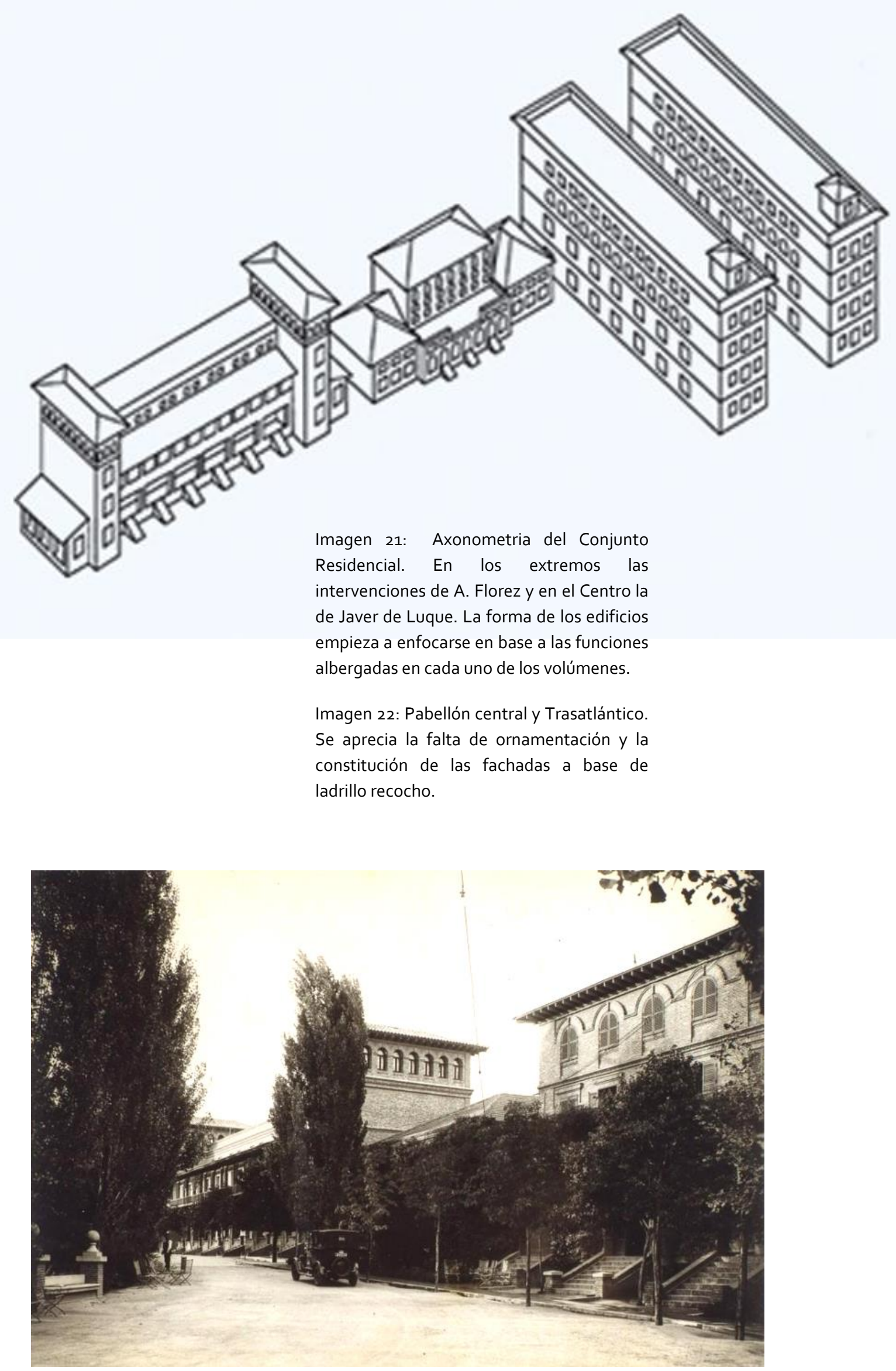


\section{EN LA CIUDAD UNIVERSITARIA (1942)}

El edificio que albergará a la nueva Residencia de Estudiantes es la primera edificación que se implanta, abandonando su antigua ubicación en el centro de Madrid. El proyecto se encarga en 1935 a Luis Lacasa, que debido a su estancia en Dresde y en la propia Residencia, era conocedor del nuevo tipo de urbanismo. El Colegio comprende un complejo de edificios e instalaciones cuyo programa se desarrolla levantando una agrupación de bloques lineales y geométricos, de disposición ortogonal e independiente. Dichos bloques se sitúan en torno a una serie de jardines y espacios libres y deportivos. El conjunto se completa con unos volúmenes transversales en $T$ dedicados a servicios generales y dos pabellones longitudinales donde se sitúan los dormitorios, con pasillos a norte y habitaciones a sur. Esta misma orientación sur es la que corresponde a la residencia del director, la sala de conferencias y otras dependencias complementarias. Como se puede detectar, el proyecto de La Residencia inicia un camino hacia la segregación funcional especializada.

En el aspecto constructivo, Lacasa optó por un sistema modular que, mediante ejes de simetría perpendiculares, le permitía aquella repetición de volúmenes en ladrillo visto dentro de la más pura ortodoxia racionalista, con fachadas perforadas por huecos de inexistentes recercados y cuya horizontalidad quedaba remarcada por las finas impostas que separaban las plantas. Tras la guerra, el conjunto tuvo que reedificarse, introduciéndose en él importantes modificaciones. Se eligió entonces, para los bloques de dormitorios, una organización con habitaciones a ambos lados que se estructura por un pasillo central, a la vez que se introducía un sistema de galerías de enlace con los pabellones de servicios, de forma que, aunque se conservó el espíritu funcionalista original y la volumetría exterior de sencillas líneas, resultó una agrupación más rígida y ahora sujeta a cánones de ordenación clasicista. Esta última parte se llevó a cabo ya a las órdenes del arquitecto Javier Barroso.

En 1943 se inauguró una residencia para estudiantes universitarios con el nombre de Colegio Mayor Ximénez de Cisneros que, poco más tarde, se fraccionó en varios:Colegio Mayor Antonio de Nebrija y Colegio Mayor Covarrubias, además del propio Colegio Cisneros. 

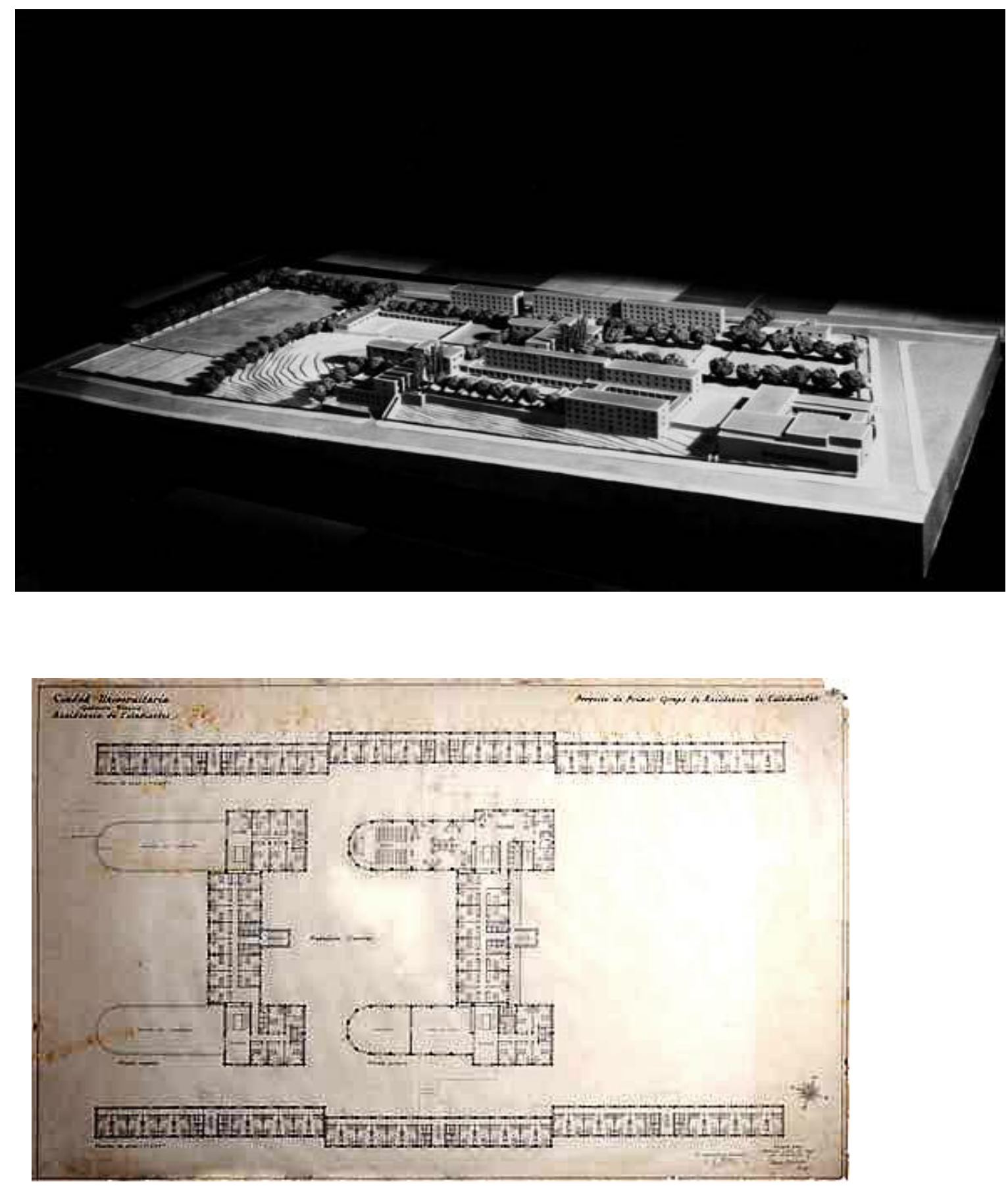

Imagen 23: maqueta de la disposición de la nueva sede de la Residencia de Estudiantes en la Ciudad Universitaria.

Imagen 24: Distribución en planta de los pabellones. Cada volumen del conjunto contine una función diferente. Lacasa Introduce la orientación solar como valor proyectural. El proyecto inicia un camino hacia la segregación funcional especializada. 
396| RESIDENCIAS UNIVERSITARIAS EN ESPAÑA, GENERADORA DE CIUDAD 
LA RESIDENCIA UNIVERSITARIA EN ESPAÑA, GENERADORA DE CIUDAD

\section{BLOQUE III}

III.3 RESIDENCIAS UNIVERSITARIAS EN LAS UNIVERSIDADES LABORALES.

La Universidad Laboral de Gijón (1956)

La Universidad Laboral de Culleredo (1962)

La Universidad Laboral de Cheste (1969) 
398| RESIDENCIAS UNIVERSITARIAS EN ESPAÑA, GENERADORA DE CIUDAD 
Las Universidades Laborales españolas son un conjunto de centros educativos promovidos por el Ministerio de Trabajo a lo largo de la segunda mitad del siglo $\mathrm{XX}$, dentro de un ambicioso proyecto destinado a la triple dimensión humana, técnica y profesional.

Estas instituciones tienen su referente en la Universidad del Trabajo creada por Paul Pastur en Charleroi (Véase la tesis doctoral de Ricardo Zafrilla Tobarra, "Universidades Laborales. Un proyecto educativo falangista para el mundo obrero (1955-1978), Universidad de Castilla la Mancha, Cuenca, 1998, p. 35. Según este investigador y profesor, el modelo de referencia de Charleroi sería directamente tomado para crear la primera institución española de este tipo, La Universidad Laboral de Gijón), provincia de Hainaut (Bélgica) e inaugurada en 1911. Pastur, antes de la fundación de la primera universidad laboral había realizado una intensa labor social, creando orfanatos de trabajo, casas de maternidad, una escuela industrial y otra de adultos, además de la concesión de numerosas becas y bolsas de viaje para los alumnos más aventajados. Este filántropo poco a poco comenzaría a pensar en la conveniencia de una escuela industrial superior, apoyando en el parlamento regional, como diputado, una iniciativa de Alfred Langrois, que era un militar profesor de topografía. Esta nueva institución se impulsaría para mejorar las condiciones de vida de las clases obreras a través de su formación profesional.

Sus objetivos docentes perseguían una formación íntegra en todos los aspectos, intelectual, técnico, físico, moral, social, artístico y estético, para conseguir una integración efectiva de los trabajadores en la vida de la sociedad dentro de un sistema democrático.

Este modelo de enseñanzas técnicas pasaría tempranamente a Francia a través de la Mutualidades de Burdeos, de donde se supone se podría irradiar la influencia hasta nuestro país, del mismo modo que en la década de los años 70 se crearon otra Universidades del trabajo en Teherán, Montevideo y Zaire, lo cual prueba la vigencia teórica del modelo.

El antecedente inmediato nacional de mayor trascendencia a las Universidades Laborales lo constituyó, tras la Guerra Civil, la Escuela de Capacitación Social de Trabajadores, dependiente del Ministerio de Trabajo, y que fue creada en el año 1942. Esta Escuela compartía con lo que serían posteriormente las Universidades Laborales los objetivos de elevar el nivel cultural quienes en terminología de la época, el régimen denominaba "productores". Así, organizaba e impartía cursos de formación para trabajadores. 
Dentro de las construcciones de este tipo de universidades, las residencias de estudiantes tienen un papel de relevante importancia, formando parte como elemento necesario para transformar el conjunto en una ciudad-residencia-universitaria.

De todas las Universidades Laborales que se crean en España, se han elegido tres modelos a estudiar en el presente trabajo, donde en cada una de ellas la parte residencial se expresa en diferentes modelos arquitectónicos y en cada uno de ellos con una escala diferente. La Universidad Laboral de Gijón por ser la primera en entrar en funcionamiento y estar ligada a los modelos históricos presentes en los primeros bloques de esta tesis; La Universidad Laboral de La Coruña, por ser importadora de vanguardias europeas y tratar los principios de la arquitectura del movimiento moderno de una forma ortodoxa, práctica en Industrial; y por último la Universidad Laboral de Cheste, por su resolución del espacio residencial, evitando la sensación de masificación y mostrando, a través de influencias Corbusierianas, una arquitectura moderna de sublimes soluciones tanto constructivas como estéticas. 


\section{LA UNIVERSIDAD LABORAL DE GIJÓN}

La Universidad Laboral de Gijón es una de las construcciones más significativas del siglo XX en España. Se encuentra emplazada al este de la ciudad de Gijón, dista aproximadamente 4 kilómetros del casco urbano.

En 1945, en el marco de una continua sucesión de accidentes mortales en las minas asturianas, surgió la idea de crear en Gijón una Fundación benéfico-docente para huérfanos mineros. Por Decreto de 5 de abril de 1946 fue declarada la construcción del orfelinato minero de Gijón como "obra de urgente ejecución", siendo encargada su realización a la Fundación José Antonio Girón, creada un año antes.

El centro fue concebido como una residencia-escuela, equipada con todo lo necesario para la formación cultural, moral, patriótica y profesional de niños huérfanos de la minería: talleres industriales,

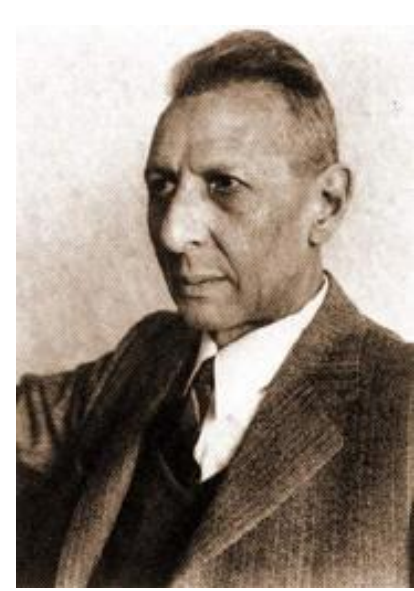

Imagen 26: Luis Moya granja-escuela, instalaciones deportivas, jardines, campos de cultivo, etc. Para la realización del proyecto la fundación eligió al prestigioso arquitecto Luis Moya, que formó equipo eligiendo a los arquitectos Enrique Huidobro Pardo, Pedro Alonso de la Puente y a su hermano Ramiro Moya. Huidobro abandonará poco tiempo después el equipo y se incorporó al mismo el arquitecto José Díez Canteli, quien desempeñó las labores de director de obra.

Además de los autores directos del proyecto, hubo otras colaboraciones destacadas, como es el caso de los arquitectos Juana Ontañón y Manuel López Mateos, que firmaron el proyecto de una de las piezas más singulares del conjunto, el paraninfo. Luis Moya fue quien asumió la dirección efectiva del proyecto, trazando las líneas generales de la composición y del diseño de las piezas arquitectónicas más señaladas. El proyecto general para el orfanato minero se componía de dieciséis proyectos parciales. Las obras se iniciaron en 1948 por la granja agronómica de Somió (actual sede de la universidad nacional a distancia y del instituto de Enseñanza Secundaria "Universidad Laboral"), que era el proyecto más acabado, y finalizaron en 1955.

En 1951 el proyecto dio un cambio sustancial al convertirse el orfanato minero en Universidad Laboral, instituciones auspiciadas por el ministro de trabajo José Girón, cuyo cometido habría de ser "nivelar las clases sociales por medio de la cultura. El 1 de noviembre de 1955 se incorporó la primera promoción con alumnos internos y externos.

Esta Laboral asombra por sus colosales dimensiones, es dos veces y media mayor que el escorial.

Se concibe como un modelo autárquico, como una ciudadela aislada del exterior y configurada entorno a un gran espacio central, que remite a los espacios claustrales porticados de los primeros modelos. 
En torno a este patio central surgen los distintos elementos configuradores del conjunto:

-La Iglesia

-El Teatro

- Edificios de dirección

-Edificios del patronato

\section{- Edificios de residencias}

Destacan, además, otros elementos relevantes como son la torre de $129,25 \mathrm{~m}$ de altura; los talleres, los jardines y el magnífico paraninfo.

Luis Moya concibió el proyecto como una ciudad ideal, partiendo del ideal del clasicismo y de la tradición arquitectónica española. La transformación del proyecto inicial en Universidad Laboral tuvo su reflejo espacial en el aumento del número de aulas, dando origen a un tercer pabellón que servía de cierre al patio central por el este, así como a la ampliación notable de los talleres, y a la edificación de una nueva construcción para alojar a la comunidad de las Clarisas.

Los promotores de este proyecto tienen una doble intención de, materializar un programa funcional, y también la de erigir "un monumento al trabajo", según sus propias palabras.

El modelo de ciudad propuesto se corresponde con una ciudad autónoma, cerrada y tradicional, que surge como alternativa a la ciudad convencional. Además, las formas arquitectónicas reflejarán la tradición, y se adoptará el clasicismo greco-romano como el modelo más idóneo para llevar a cabo la elevada misión simbólica, que deben poseer las edificaciones.

El conjunto de la Universidad Laboral se dispone de espaldas a la ciudad de Gijón, según un eje longitudinal de dirección oeste-este, con acceso por la fachada oriental. Ésta disposición obliga al visitante a un recorrido de aproximación controlada, reforzando el carácter escenográfico y monumental del conjunto. El patio central que articula todo el conjunto es concebido como una plaza mayor de traza rectangular formada por cuatro crujías de fachadas uniformes con bajos con soportales y siete torreones en cada lado de mayor longitud. La uniformidad de las fachadas se rompe con la presencia de los edificios representativos: la iglesia, la dirección, el patronato y el teatro. La iglesia, de planta oval, se sitúa al extremo del eje de la entrada principal, adentrándose en el patio. Está unida al resto del edificio mediante unas galerías de columnas de dos pisos, que, a su vez, sirven de acceso a la zona residencial y a la gran torre, hito arquitectónico que por sus dimensiones, sirve de punto de orientación en el recinto. 
Como ciudad universitaria contempla numerosas instalaciones capaces de hacer frente al plan de estudios previsto y de las actividades adicionales que se recogen en los estatutos, siendo deportes una de las más relevantes. Estas Instalaciones se disponen en cuatro grupos:

-Espacios para la práctica de educación física

-Espacios para las enseñanzas de Formación Profesional.

-Espacios dedicados a la residencia de los alumnos internos y de profesores, estos últimos con la posibilidad de incluir a familiares.

-Servicio médico, con enfermería general y de infecciosos, radiología, quirófanos, análisis clínicos y gabinetes de odontología y oftalmología.

Todos los edificios están proyectados en base a una malla de módulo 2,40 $\mathrm{m}$, que, como se puede apreciar en la planimetría original, fundamenta plantas, alzados y los principales elementos estructurales y compositivos.

El esquema responde de forma diferenciada y específica a los diferentes usos, necesidades representativas y espaciales, adaptándose a los requerimientos en cada caso y a las solicitaciones específicas, con un rico surtido de soluciones, lenguajes y composiciones.

La parte residencial tiene una estructura uniforme en forma de " $L$ ", en la se disponen patios cuadrangulares de diversos tamaños con sus correspondientes crujías circundantes.

En el conjunto hay fachadas caracterizadas por sus elementos compositivos innovadores, o por la composición novedosa de elementos tradicionales, y por el contrario fachadas caracterizadas por el empleo de formas y lenguajes clásicos. En la zona residencial, las fachadas responden al arquetipo de edificios monacales. En éstas prevalece el macizo frente al hueco, enfatizando su opacidad con acabados en sillarejo de bulto toscamente labrado y aparejo irregular de corte rústico y vanos regulares pequeños y austeros, sin concesiones ornamentales.

Las residencias están macladas al conjunto respondiendo al modelo monacal de los primeros colegios en España. Con esta disposición, Moya pretende conseguir iluminación y ventilación en todas las habitaciones, la cuestión higienista es muy importante para él. Los servicios higiénicos están resueltos a base de mamparas de mármol, con sujeción y apoyos de piezas especiales de fundición cromada (que tuvieron que proyectarse al no existir en esos momentos en el 
mercado). Con esta solución se pretende evitar los focos de suciedad.

Dormitorios de los estudiantes. Se ubican en cuatro plantas sobre una planta baja donde se ubican las zonas comunes de comedor, salas de estar $y$, como ocurre en los modelos estadounidenses del siglo XX, salas de juegos y ocio. Se subdividen en forma de " $L$ ", como se acaba de decir, cada módulo, con las escaleras y grupos de seos en la esquina de la "L". Se dispone una ventana para cada habitación, de modo que hay un total de mil ventanas.

Se proyectan dos grupos de dormitorios:

Los de la parte norte, con 600 dormitorios individuales, y los de la parte sur, con dormitorios dobles para 400 alumnos.

La parte residencial se macla al resto del conjunto con edificio de transición que es un pabellón de dos plantas, albergando los servicios de lavandería, enfermería, cocinas y otros servicios. A parte se añade dos aulas para clases. Entre ambos grupos residenciales se encuentra la iglesia.

Al oeste del patio, fuera de la ciudadela pero comunicado con ella mediante una galería de dos plantas, se sitúa el convento de la Clarisas. Su trazado se resolvió con una planta circular para favorecer la clausura y se rodeó de un singular muro de cierre de generatriz ondulada. Situados fuera del recinto, también se situaron los talleres, resueltos en un conjunto de seis naves longitudinales paralelas, orientadas según el eje norte-sur y una transversal. Todas las naves tipo tienen un ancho uniforme de $19,20 \mathrm{~m}$ y están cubiertas con bóvedas cilíndricas de generatriz inclinada, en forma de diente de sierra, en tramos de $9,6 \mathrm{~m}$.

Las partes exteriores se resolvieron mediante espacios ajardinados, posiblemente por influencia del campus estadounidense, y los espacios centrales de las zonas claustrales, como la parte residencial que se acaba de describir, poseen una zona verde, como se disponía en los colleges de Oxford y Cambridge. Todos los jardines están diseñados por Javier de Winthuyssen ${ }^{55}$ y Ramón Ortiz Ferrer ${ }^{56}$.

Esta ciudad bien podía ser considerada como la esencia del clasicismo, a aquella idea de la fórmula clásica que se descubre en la lectura de los grandes tratados del arte de la retórica.

Para Moya, la arquitectura clásica no restringía la libertad creadora, sino que, por el contrario, es el mejor recurso para hacer arquitectura ${ }^{57}$, sólo si existen las normas cabe hablar de libertad ${ }^{58}$. 
Parece evidente, que lo viene a decir Moya es que la arquitectura clásica tiene unas normas y reglas, pero junto con ellas también cabe la posibilidad de modificar, adaptar o transgredir esas normas, tal y como se puede apreciar en la amplia tradición de la arquitectura clásica y, muy especialmente, en los sistemas compositivos de la arquitectura española 59 .

En este caso, la residencia estudiantil está directamente apoyada en los primeros modelos, tan sólo se parecía un ligero cambio en la falta de ornamentación. Los programas son distintos, actuales, conteniendo, como se ha apuntado, espacios con características de los nuevos programas residenciales y educativos. 


\section{Universidad Laboral de Gijón.}

Imagen 27:Vista del espacio claustral principal desde la torre de la capilla

Imagen 28: Boceto original de Luis Moya

Imagen 29: Vista de pájaro del conjunto
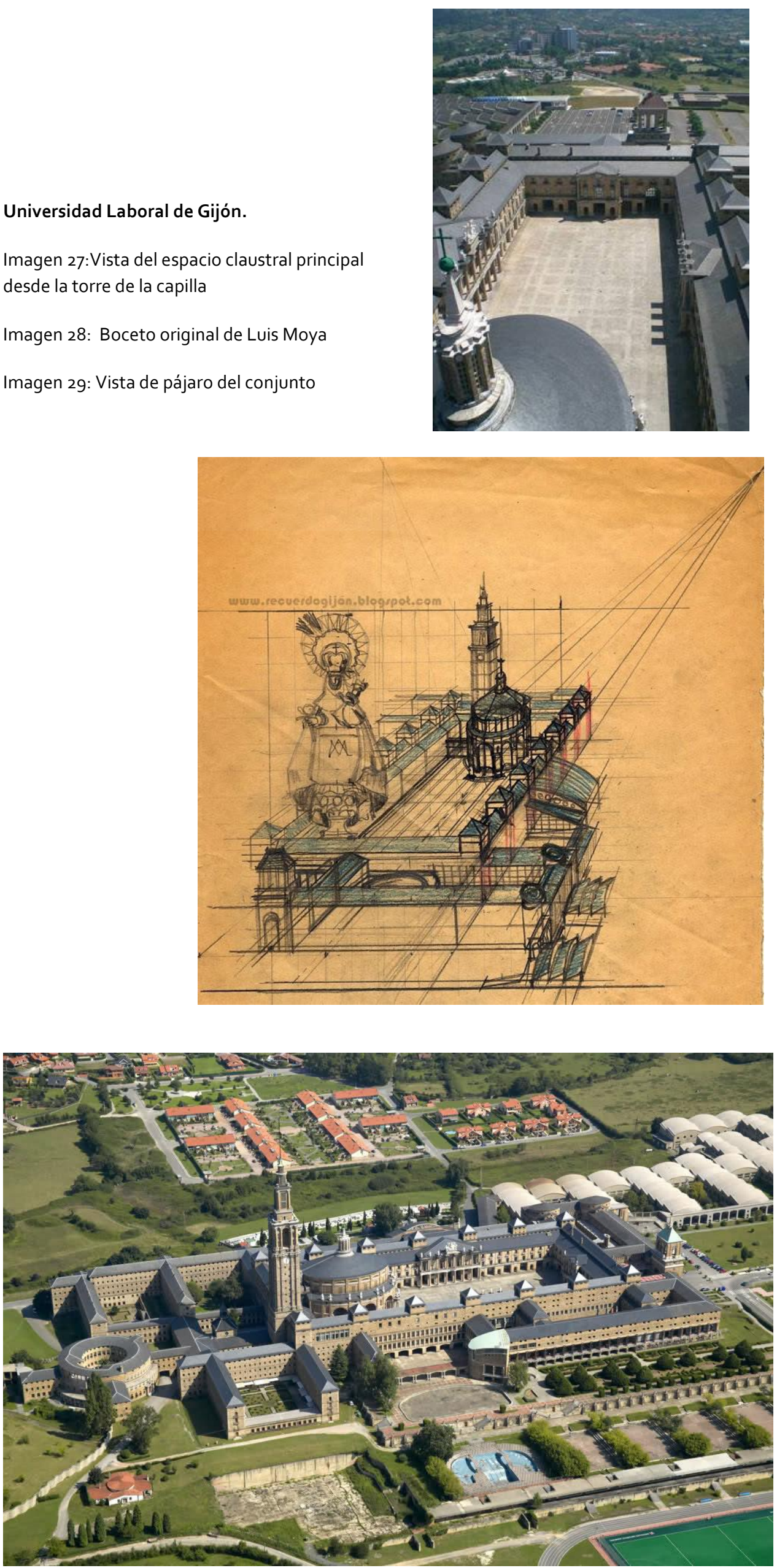

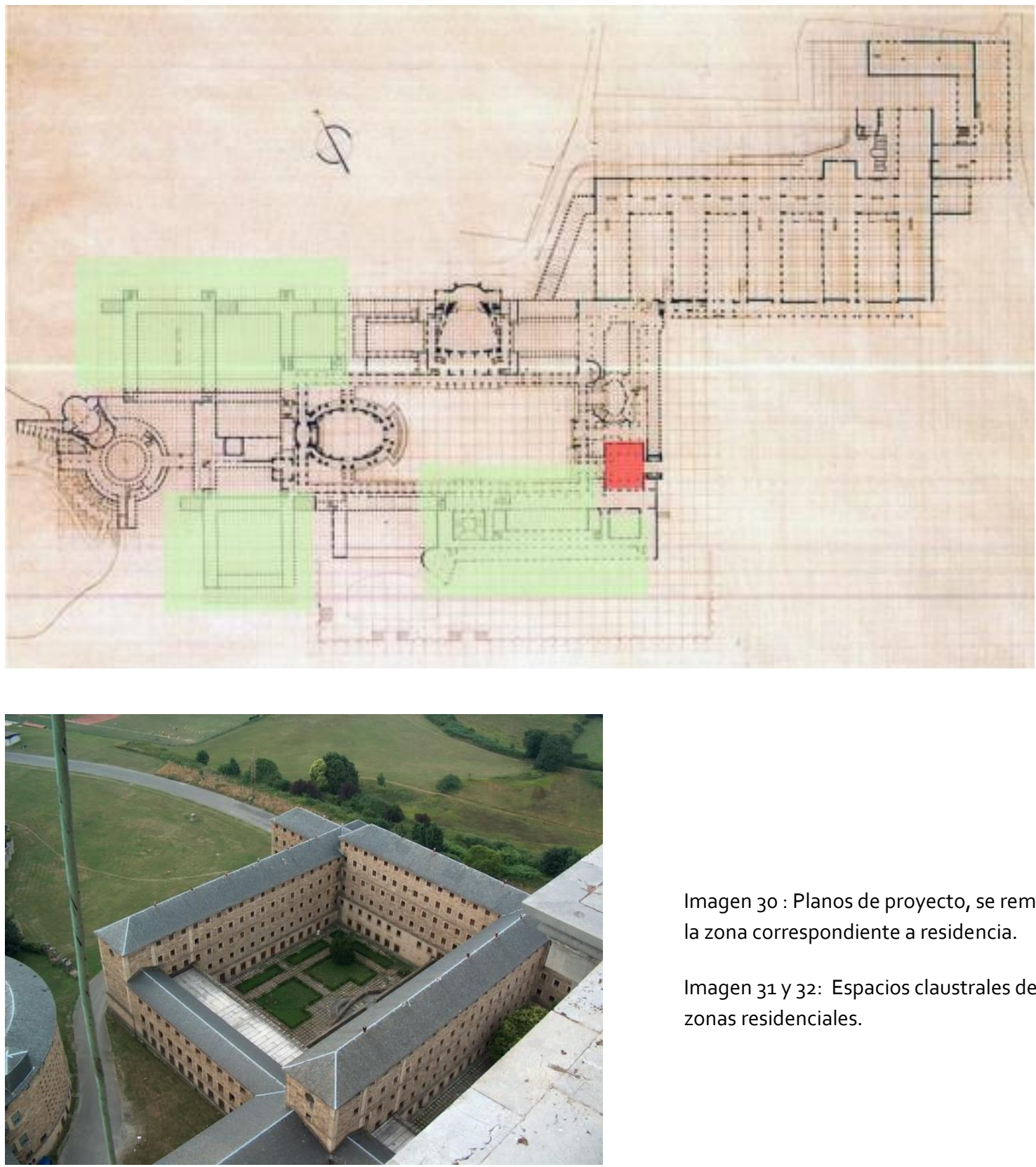

Imagen 30 : Planos de proyecto, se remarca la zona correspondiente a residencia.

Imagen 31 y 32: Espacios claustrales de las zonas residenciales.

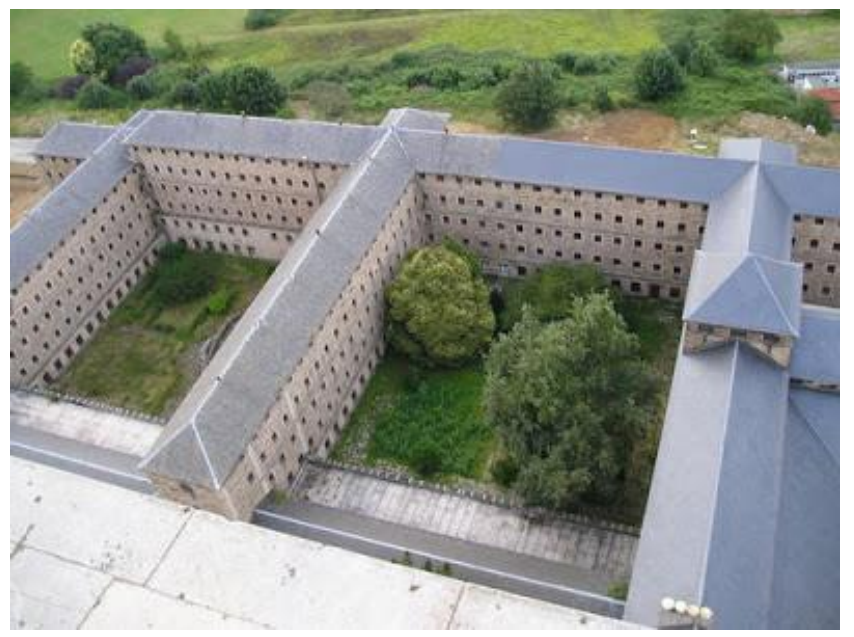


Imagen 33 : Axonométrica del conjunto Imagen 34: Planos de proyecto donde se aprecia la modulación que configura la edificación.

Imagen 35: Planos del calustro principal donde se ve la conexión entre espacios comunes y residencialaes.
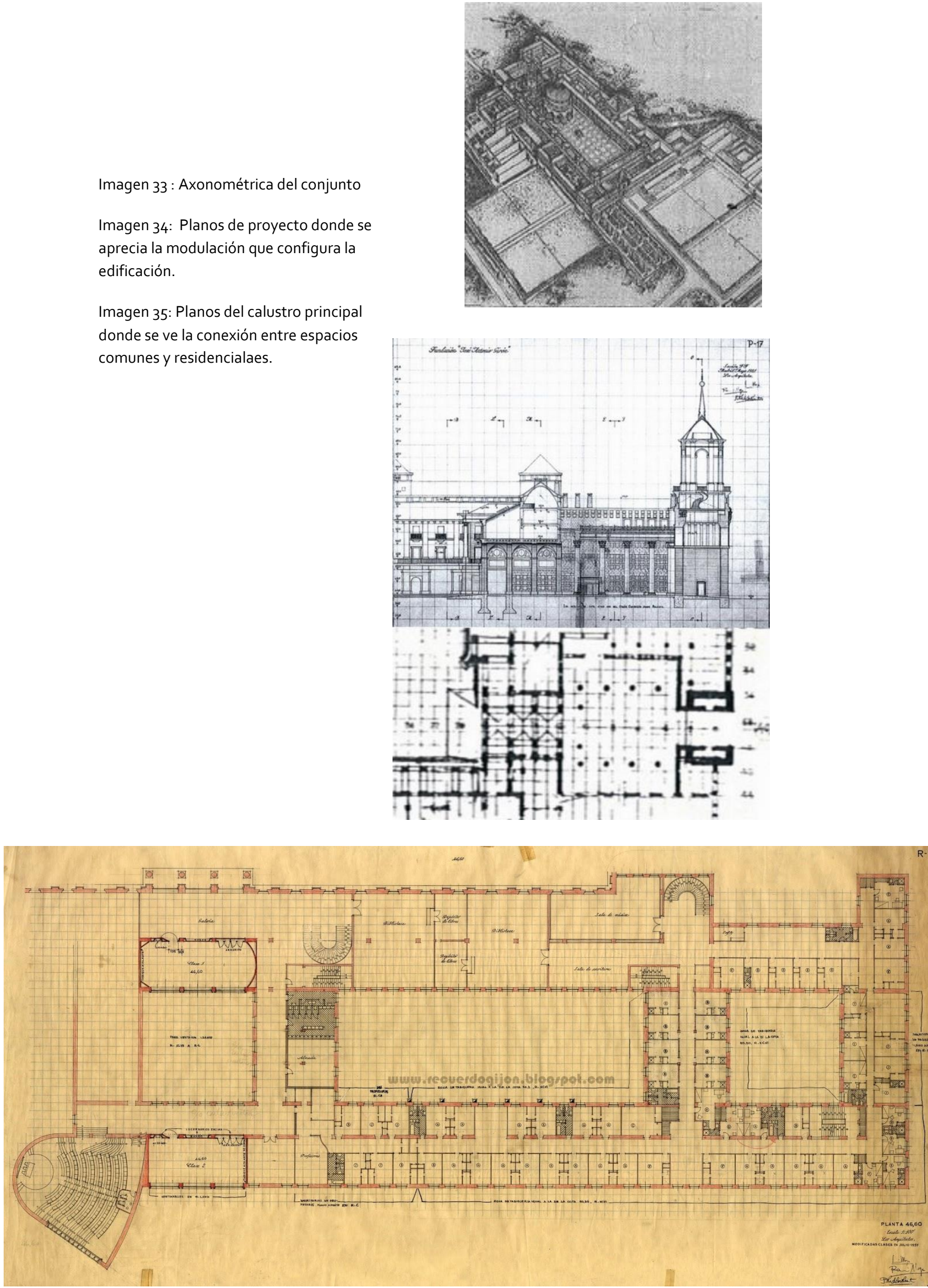
Imágenes: 36: : Maqueta del conjunto

Imagen 37 y 38: Maqueta donde se aprecian los espacios claustrales de correspondientes a zona de residencia.
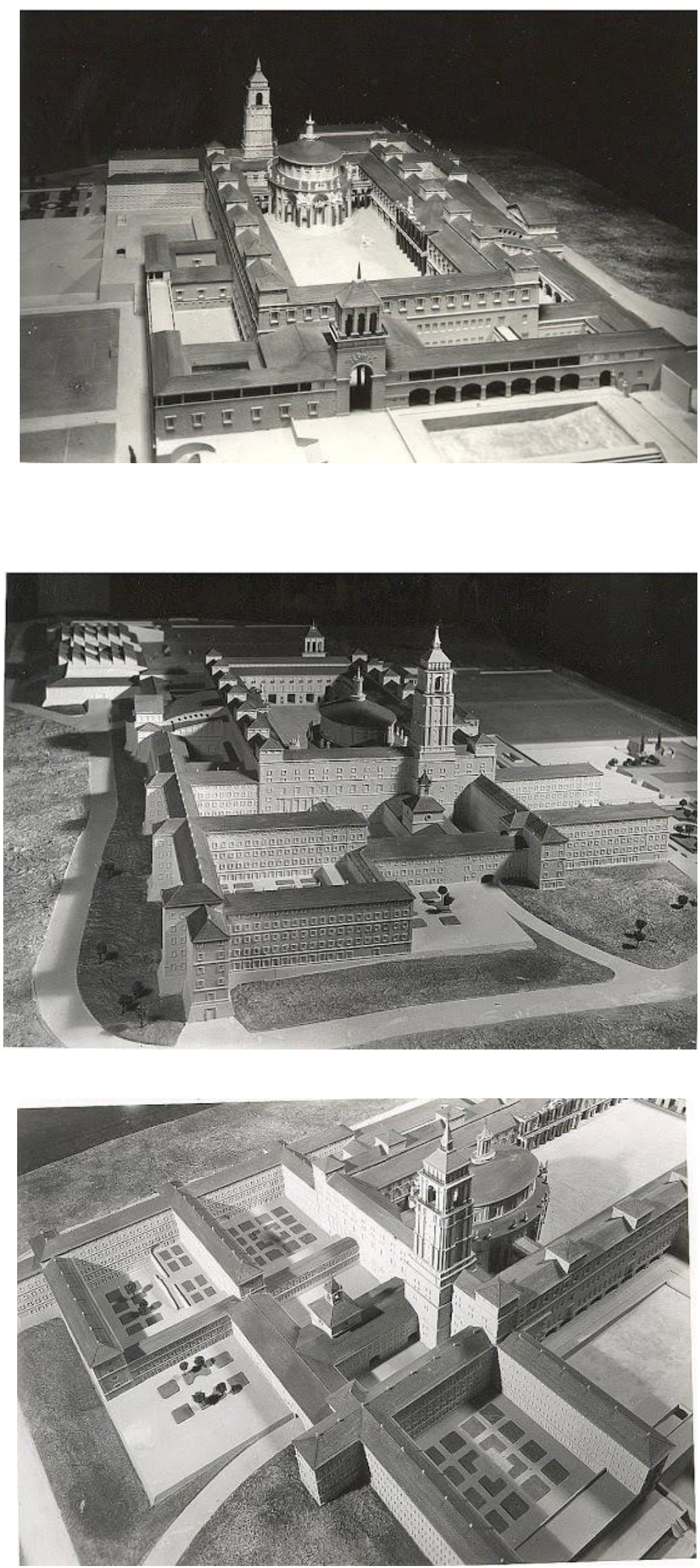

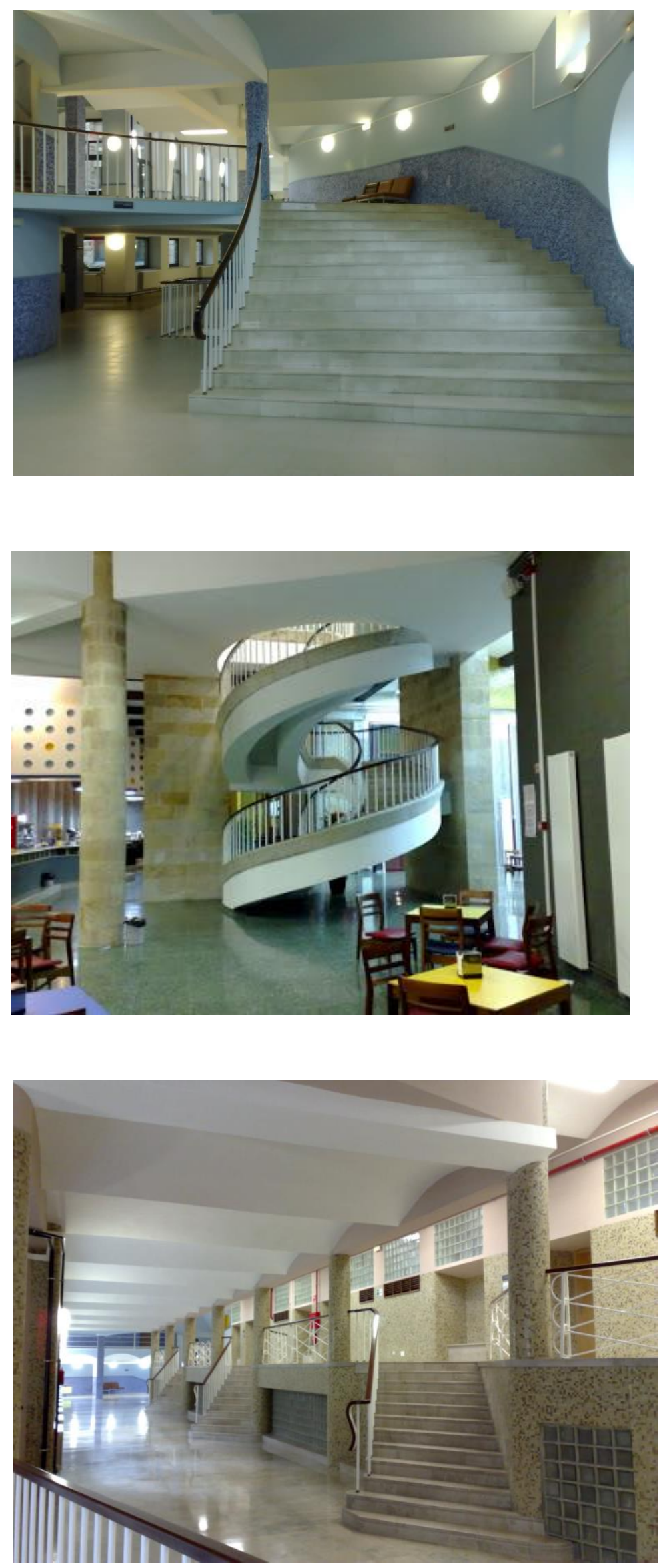

Imágenes: 39, 40 y 41: : Espacios interiores de zonas comunes de cafetería y pasillos $d$ acceso a las dependencias privativas. 


\section{LA UNIVERSIDAD LABORAL DE CULLEREDO (1962)}

La Universidad Laboral "Crucero Baleares" de A Coruña está situada en Acea da Ama, parroquia de Santiago de O Burgo, término municipal de Culleredo, en plena Ría de O Burgo, limítrofe con la capital provincial de A Coruña.

La idea inicial de construir una Universidad Laboral en A Coruña se produjo en 1960, previa solicitud de la Diputación Provincial a mediados de los años 50. Su ubicación se determina en el término municipal de Culleredo y se lanza la convocatoria de un concurso de anteproyectos para la construcción de las instalaciones.

Los ganadores del concurso son los arquitectos Luis Laorga Gutiérrez y José López Zanón. Al concurso concurrieron varios arquitectos, de los que cabe destacar la presencia del equipo formado por Javier Carvajal Ferrer, José Antonio González Gutiérrez, Ramón Vázquez Molezún y Alejandro de la Sota.

En la propuesta de los ganadores, la metodología del movimiento moderno más ortodoxo está presente en la precisa definición de las áreas funcionales, las cuales están compuestas por células extandarizables, ya sean aulas y talleres en el caso del área de aprendizaje o dormitorios en el caso del área residencial.

El conjunto está formado por la interrelación de piezas semiindependientes, en cada pabellón conformante del conjunto cada una de las funciones se expresa como tal, coordinada con las demás para formar un grupo de edificios primero y una ciudad después.

Por otro lado, cabe destacar el carácter o la metáfora naval que los autores querían imprimir a esta Laboral y el cual está presente en la materialización de esta institución moderna.

"Ingenieros anónimos, mecánico metidos entre la grasa y el hierro de la fragua, han construido esas casas formidables que son los paquebotes. Nosotros, habitantes de tierra firme, carecemos de los medios de valoración y sería una suerte que para que aprendiéramos a descubrirnos ante las obras de la "regeneración", se nos brindase la oportunidad de recorrer los kilómetros que representa la vista de un paquebote ${ }^{60}$.

En estas palabras de Le Corbusier introduce su reflexión acerca de la configuración espacial de los barcos para el transporte de pasajeros dentro del capítulo IV de "Hacia una arquitectura", titulado "Ojos que no ven"...: "Una época acaba de comenzar", "existe un espíritu nuevo", "Nuestra época fija cada día su estilo"61 ... sin embargo, nuestro ojos todavía no son capaces de discernirlo. 
La arquitectura naval ha estado presente en varios arquitectos en los inicios de la etapa moderna, no sólo Le Corbusier hace referencias a los caracteres navales, como señala Stanislaus Von Moos ${ }^{62}$.

Para esta Universidad Laboral se escoge la ubicación en el margen de la Ría de Burgo a unos 7 km de la dársena de A Coruña. Se sitúa en una posición central en la costa gallega, en el Golfo de Ártabro, un entorno de importante tradición marinera. Forma junto con el Puerto de A Coruña la principal estructura laboral vinculada al mar de Galicia $^{63}$

El mástil que domina la plaza de entrada contribuye a reforzar el ambiente marítimo de la propuesta. Planteado desde el proyecto de concurso, mientras se realizaba la obra fue levantado por expertos de la Escuela Naval Militar de Marín y se convirtió en el perfecto contrapunto a la horizontalidad de los edificios, al tiempo que se erige como un elemento representativo de las enseñanzas que se imparten en el centro y señala la presencia del mismo entorno.

Teniendo en cuenta que la enorme operación de construcción de esta universidad no puede permitirse derroche alguno, los modelos existentes se someten a exámenes funcionales y constructivos, optando los autores por una organización en pabellones con una materialización rápida y económica. A este aspecto colaboró el hecho del desarrollo experimentado por la industria ligera británica durante la guerra ${ }^{64}$. Nuevamente la huella de la máquina está presente. Los avances en sistemas de ensamblaje, prefabricación, laminados plásticos, perfilerias de aluminio y estructuras ligeras de acero, encontraron un enorme campo de aplicación en la arquitectura escolar de la década de los 60 y, especialmente, en las Universidades Laborales del segundo periodo; entre 1960 y 1965.

En el año 1966, José López Zanón colabora en la Enciclopedia de la Nueva Educación de la editorial Apis, con un ensayo titulado "El edificio Escolar". En esta publicación recoge, además de criterios organizativos para la proyección de escuelas, una serie de referentes europeos y americanos entre los que aparecen los colegios californianos del despacho de Falk \& Kump y los de Alfred Roth o Josef Furrer en Zurich.

" En construcciones de planta baja las ordenaciones son sencillas y brillantes. Por lo general, se resuelven en galerías, ya por alineaciones de aulas, por variantes en espina de pez o agrupamientos en damero. EN todas ellas puede mantenerse con facilidad la iluminación bilateral y aireación transversal, aplicable también a pasillos y vestíbulos" ${ }^{\prime 65}$ 
No se puede obviar la escala urbana que poseían estas propuestas que, desde los primeros casos, como el anterior visto de Gijón, se pueden entender como auténticas ciudades de aprendizaje. Con la aplicación de los principios modernos en la Universidad laboral de Coruña, éstos se pueden leer también aplicándolos a gran escala.

La ciudad puede ser considerada como de los principales y fundamentales proyectos urbanos de la arquitectura moderna española. Uno de los ejemplos, a nivel europeo,, ha sido el que se ha estudiado en el capítulo de la Cité, en bloque anterior, donde se ilustra la visión urbana de Le Corbusier en el pabellón Suizo, donde el solar se extiende por debajo del edificio y éste se separa del soporte mediante pilotis, enfocando el vestíbulo de entrada y el salón de estar, los cuales se constituyen como continuación del terreno inmediato. En este caso, la conexión de los tres espacios principales, el salón de actos, el comedor y la capilla, con el entorno asegura el entendimiento entre soporte y edificio al tiempo que se remarcan la escala urbana del edificio por medio de la plaza que configuran. Una plaza que no se puede entender sin pensar en su relación directa con el mar. En origen se trataba de un gran espacio urbano abierto a la ría, de un modo similar a la plaza del Comercio de Lisboa. A partir de la plaza, que es lugar de acceso, pero también de reunión, reforzada con la colocación del mástil como elemento simbólico, las circulaciones se distribuyen siguiendo una retícula, que define las pautas, como se ha dicho anteriormente, de crecimiento y posee unos límites edificados que acotan la ciudad.

En el año 1962, Laorga y Zanón ganan el concurso de una Nueva Universidad Laboral, en este caso para Madrid. En su propuesta remarcarán aún más la idea del edificio entendido como una ciudad. Las exigencias del proyecto servirían para definir los condicionantes de un sistema urbano:

"La Universidad estará e continua evolución, con una renovación constante de medios y sistemas. La Universidad ha de crecer de manera continua y orgánica, permaneciendo completa en cada uno de sus estados intermedios de crecimiento. Tendrá una gran flexibilidad en cuanto a su funcionamiento ("Universidad laboral en Madrid" en: Arquitectura 42 (1962), p. 2)

Nunca llegará a construirse. En su lugar reciben el encargo de la Universidad Laboral de Huesca, cuyo salón de actos, único elemento simbólico que se erige en un nuevo tapiz horizontal, es una gran pirámide que recuerde a la que Luis Moya proyecta en Gijón. 
Esta Universidad Laboral deja paso a una nueva institución moderna caracterizada por la diferenciación del conjunto en varias piezas semiindependientes. Cada una de las funciones se expresa como tal, y luego se coordina con las demás para formar un grupo de edificios. Esta Laboral está conformada por una serie de piezas, todas con su identidad particular, al tiempo que están interconectadas para formar una totalidad. Así es como la planta libre se transfiere desde la escala de la vivienda a la escala semiurbana en la que varios edificios se relacionan entre sí con el entorno.

Ocupa una superficie de $50 \mathrm{Ha}$, unos $500.000 \mathrm{~m}^{2}$. Ocupando las construcciones una superficie $30.000 \mathrm{~m}^{2}$. Las obras se iniciaron en 1962, terminándose el 12 de noviembre de 1964 .

Todas las edificaciones responden a un sentido utilitario y eficaz, dentro de una moderna simplicidad de líneas y elementos.

El conjunto se concibe como un desarrollo eminentemente horizontal en dos zonas claramente segregadas: por un lado, la zona docente, con predominio de la planta baja, y por el otro la zona de residencia, en la que destacan los dormitorios de estudiantes, en pabellones de tres plantas de altura, además, están situados en la parte más alta del terreno. Los talleres se sitúan en la zona más baja de la parcela, donde su impacto visual es menor, y en cierta manera, ajenos a la estructura general de la propuesta. Tanto es así, que en un principio, fueron los únicos elementos que salían de la ortogonalidad de la malla generadora. El conjunto de pabellones, aulas, talleres y residencias se articulan a través de corredores cubiertos.

Con posterioridad, en una segunda fase (1967-1973), se construyeron otros dos talleres y una nueva zona deportiva que no siguen la trama reguladora inicial del conjunto, lo que le confiere un carácter extraño sin relación formal con el resto de pabellones.

Formalmente, la solución cuenta con cubiertas a un agua de grandes dimensiones, jugando con los volúmenes y caídas de faldones, todo ello pretendiendo "plegarse o adaptarse a la topografía".

El esquema general es un esquema de peine, verdaero leit motiv del concurso, permite un crecimiento natural de la propuesta, tanto hacia el norte con las aulas de los pabellones de docencia, como hacia el sur con los elementos de la residencia. Este hecho hace que el conjunto se reconozca con unidad, evitando una posible fragmentación en un esquema de este tipo. 
El proyecto, propone por tanto un sistema de crecimiento modular ordenado y con una clara ley de desarrollo horizontal, pero al mismo tiempo, con elementos que son unidades en sí mismos. Los diferentes pabellones funcionan de forma autonóma, creando células que se van sumando por adición, mediante unos elementos de comunicación que los van enhebrando y haciendo que funcionen en conjunto. Las premisas sobre las que trabjaron los dos arquitectos autores fueron principalmente tres:

- La escala, el tamaño y las proporciones, así como la modulación, son serían acordes con la dedicación docente del edificio y la edad del alumnado, nunca ajeno a las condiciones del lugar de asentamiento.

- La integración en el paisaje, tomando la opción por la forma abierta y presencia de la naturaleza como fundamentos de esa sensación.

- La flexibilidad debía marcarse en la planta como consideración fundamental, en la idea de acomodaciones económicas a las condiciones futuras, presumiblemente cambiantes.

La universidad se distribuye en un con conjunto de pabellones formados por tres colegios-residencias. Los espacios residenciales están provistos de salas de estar y estudios. La capacidad de cada colegio-residencia es de 104 alumnos, son considerados los internos, mientras que en la universidad cursan estudios 700 alumnos en régimen de mediopensionistas y otros 300 son totalmente externos.

En este caso, en la residencia de estudiantes, la habitación es el elemento mínimo de agregación y a través de su agregación se compone el pabellón residencial.

También hay residencia destinada a personal de servicio.

Las dependencias comunes las forman el comedor universitario, el salón de actos, cocina enfermería.

En la zona central están las dependencias generales y comunes. El gran vestíbulo de recepción lo cubre un techo de pino rojo del Báltico en forma de quilla de barco que se prolonga al amplio salón de actos. Allí se encuentran el rectorado, la administración y las oficinas.

La capilla está cubierta por un entramado reticular de barras de acero, que forman pirámides, y de cuyos vértices se proyecta la iluminación. 
En las posibles influencias, en esta obra se pueden reflejar de modo nítido las siguientes influencias: el funcionalismo de la Bauhaus de Walter Gropius, producto de la formación de López Zanón; la impronta de la High School del New Deal americano de los años 40, mundo en el que profundizaron los dos arquitectos a través de la colaboración con el consultor americano E.J. Kump (autor de la High Scholl La Fayete, de Palo Alto en California), entre 1955 y 1958, mientras realizaban las viviendas para las bases americanas de Torrejón y Madrid; y la arquitectura escolar de Arne Jacobsen, teniendo como modelo la escuela de Munkegaards, 1951 en Copenhague.

Frente a la primera solución de Luis Moya que se puede considerar "antimoderna", considerando como antimoderno el concepto de Antoine Compagnon que lo define para arquitectos que son modernos pero en contra de su voluntad, esta Universidad Laboral ofrece un nuevo planteamiento que se puede entender del distanciamiento de lo clásico en materiales y lenguaje, donde todos los elementos conformantes gozan de la misma entidad. La capilla deja de tener la presencia singular de modelos anteriores, donde, en la de Moya por ejemplo, es el elemento principal y articulador. 

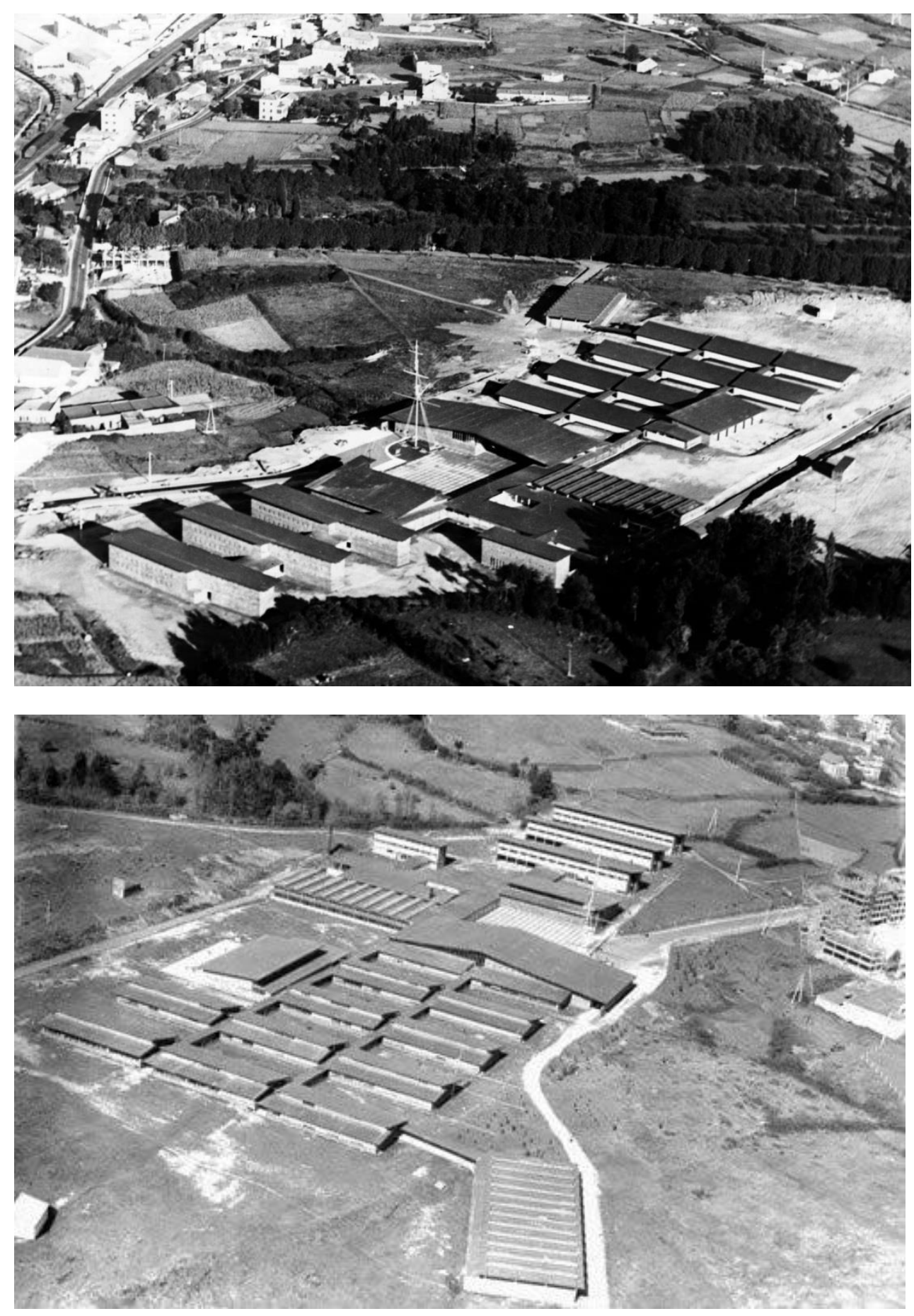

Universidad laboral de Culleredo

Imágenes 42 y42: Vistas generales del

conjunto 


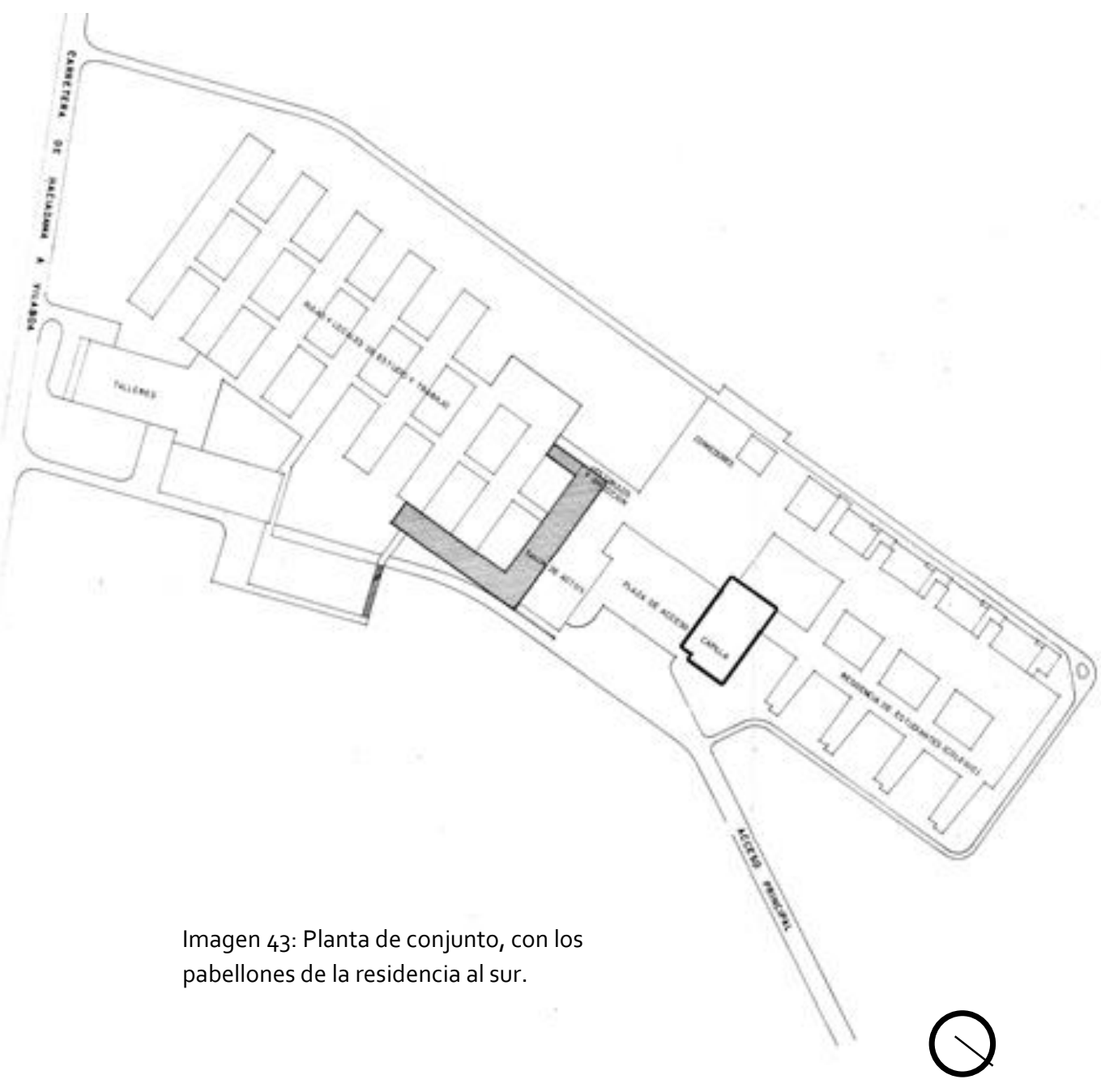




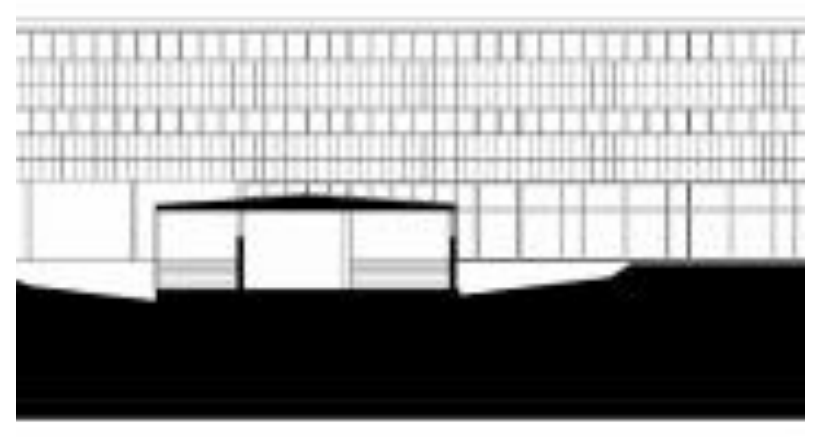

Imagen 44: Sección por los corredores cubiertos que dan acceso a los pabellones de residencia.

Imagen 45: Planta de conjunto con la zona de la residencia remarcada.

Imagen 46: detalle en planta de un pabellón residencial

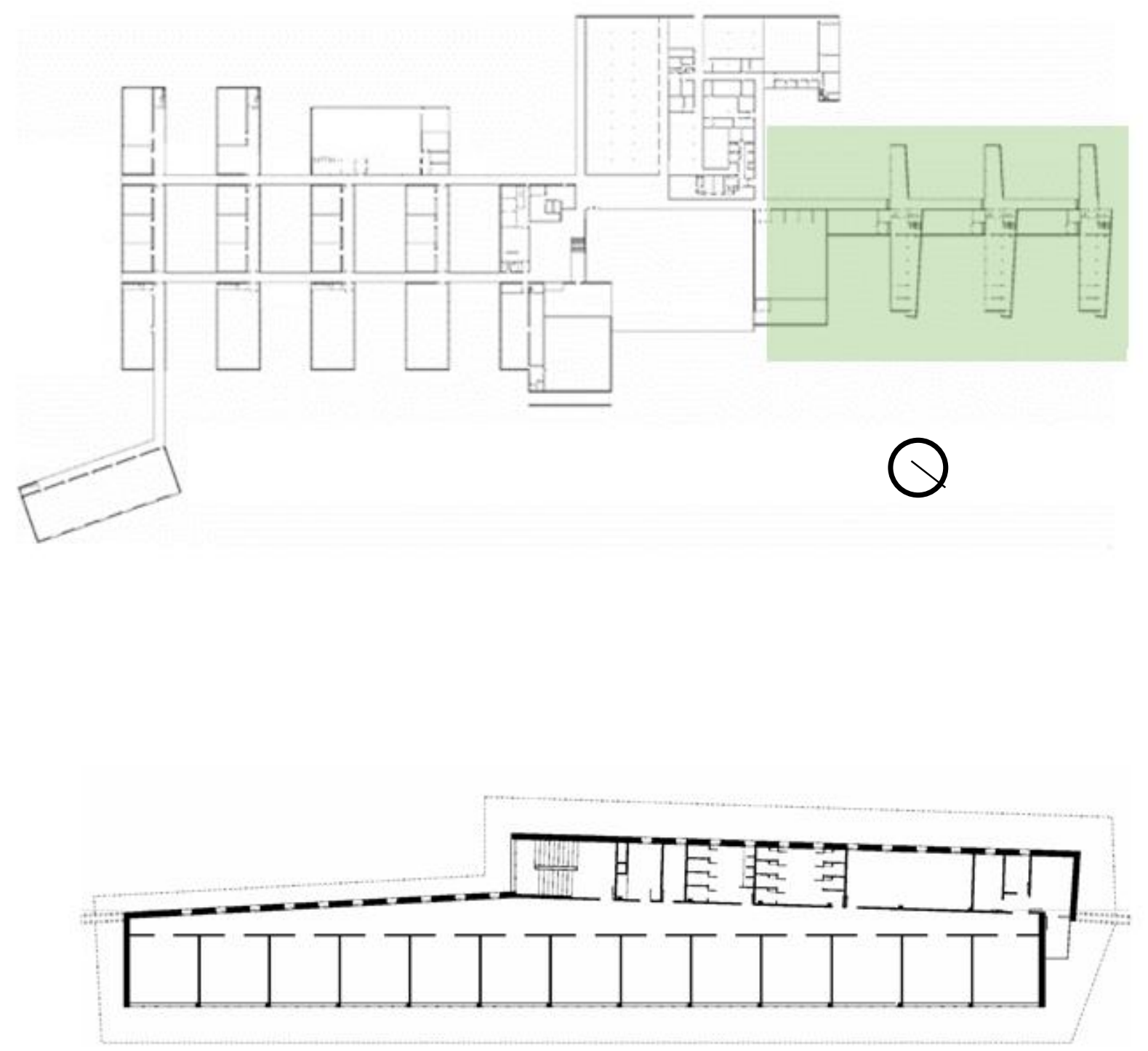




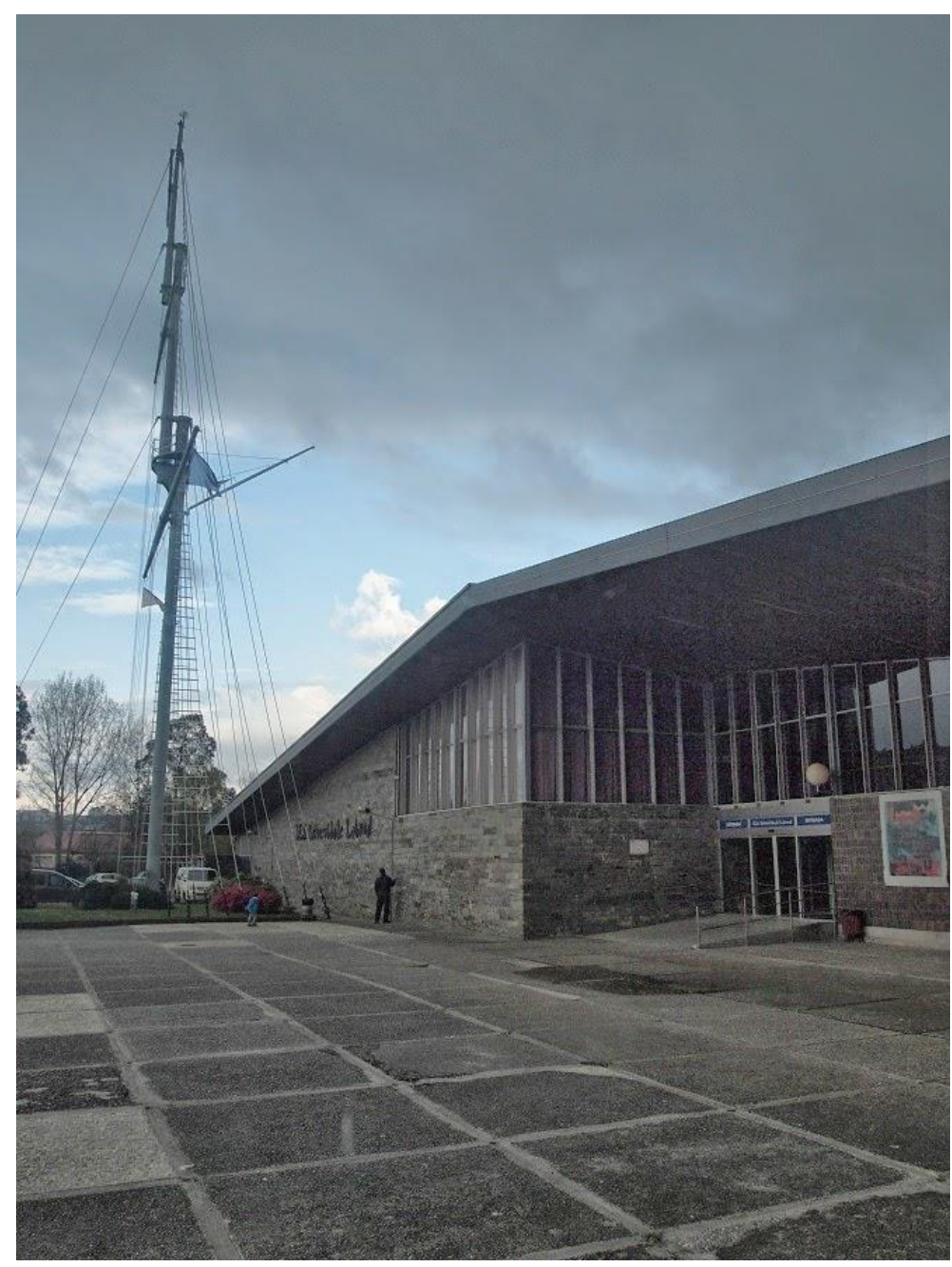

Imágenes 47 y 48: Vista del acceso principal, donde se puede el carácter marítimo con la figura del mástil de barco.

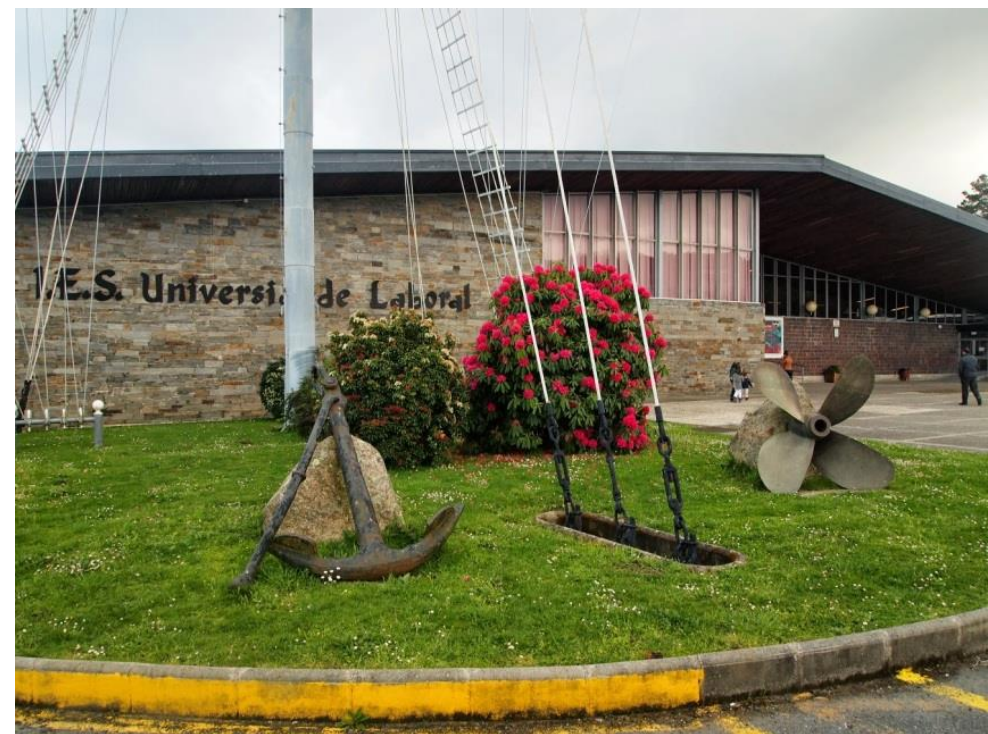




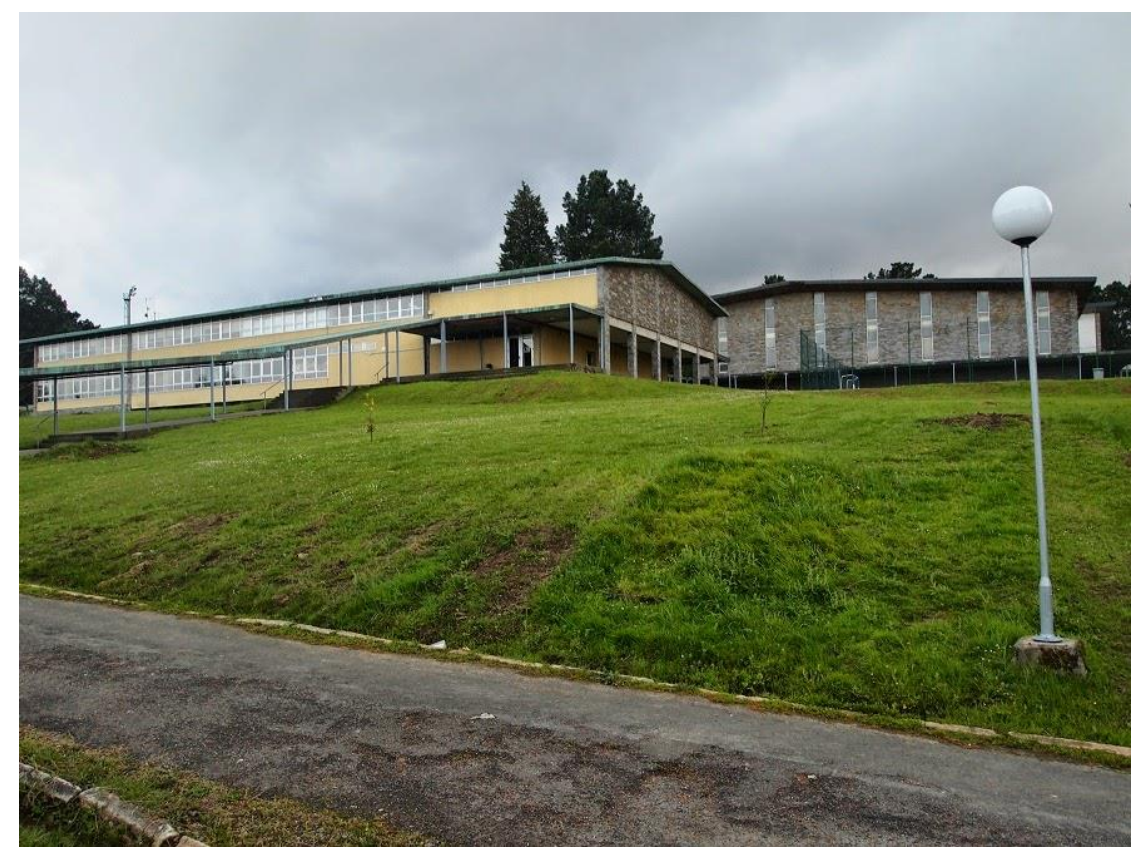

Imagen 48: Vistas del de los

pabellones residenciales

Imagen 49: Vista de los talleres

de trabajo y aularios.

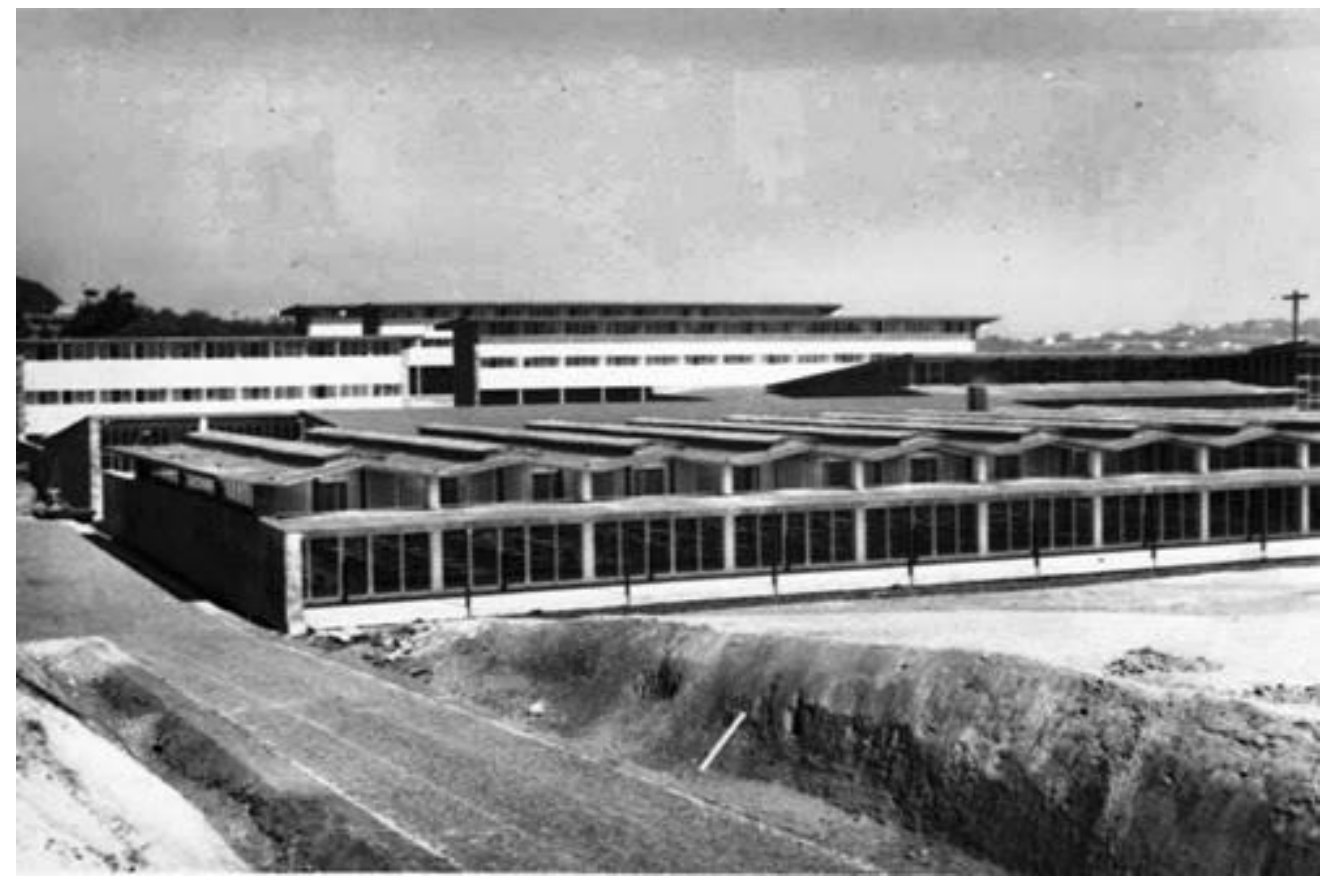



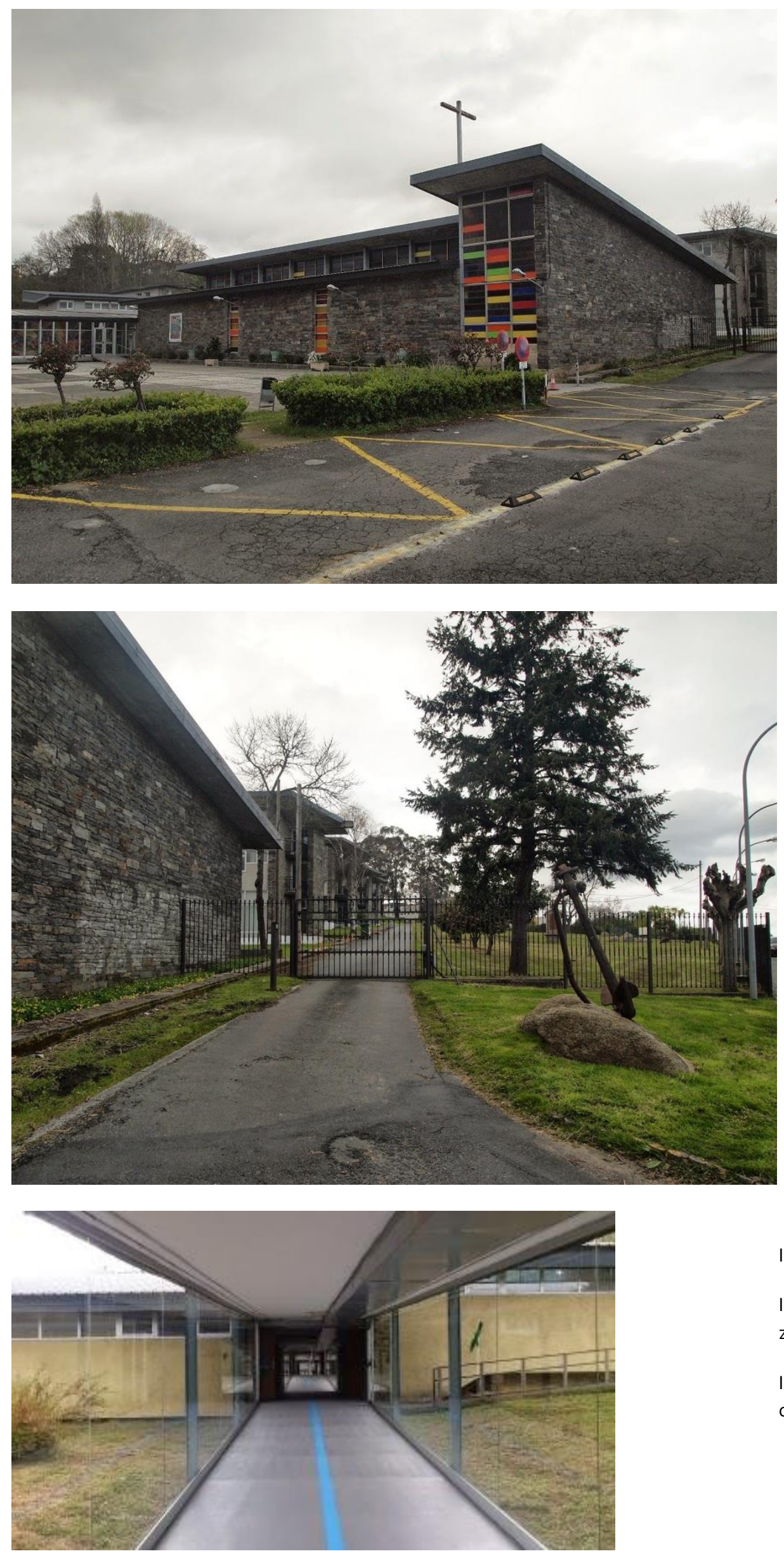

Imagen 50: Vistas de la capilla Imagen 51: Acceso lateral a la zona residencial

Imagen 52: Vista de los corredores cubiertos 


\section{LA UNIVERSIDAD LABORAL DE CHESTE (1969)}

Existió un proyecto previo donde la ubicación era distinta dentro de Valencia, se disponía en unos terrenos situados en el Saler. Se trataba de una parcela de $243.700,00 \mathrm{~m}^{2}$, propiedad del Ayuntamiento que cedía gratuitamente, situada entra las carreteras de El Saler, de El Palmar y de La Albufera, en las cercanías de la denominada "Mata del Fang" dentro de la partida "Racó de l'Olla"67.

La organización del proyecto inicial, adaptada a un terreno prácticamente plano, lógicamente era lineal y el autor aplicó un criterio de zonificación según las diferentes funciones del centro docente, siguiendo un eje longitudinal de norte a sur que partía de un salón de actos dejando en situación lateral el edificio de rectorado. La zona docente se disponía en el centro, teniendo a la derecha la zona residencial y de dormitorios, mientras a la izquierda se emplazaban comedores y servicios; el fondo se reservaba para zonas de expansión y deportiva.

Como bien describe Carmen Jordá: el solar no era del gusto del arquitecto y desde el primer momento Moreno Barberá advierte sobre la escasez de espacio para cumplir con el ambicioso programa que se le encargaba. En este caso la superficie por alumno era inferior al del resto de laborales y ni siquiera cumplía los requisitos mínimos exigidos por las normas docentes. Moreno Barberá afirmaba que, si se atendían criterios racionales de arquitectura moderna, el conjunto de sus edificios se concentraba excesivamente, incluso para un suelo urbano. Las aulas, en bloques de cinco plantas, estaban tan próximas que no permitían la entrada de sol en invierno en los pisos inferiores. Por otra parte, el terreno llano, carente de perspectivas, obligaba a una solución donde unos edificios ocultaban las vistas de los otros. También, la mala calidad de terreno de esta ubicación, obligaba a ejecutar una cimentación a base de pilotes que era muchísimo más cara que otra cimentación de tipo convencional ${ }^{68}$.

Ante tantos inconvenientes, el Ministerio de Trabajo decidirá buscar una nueva ejecución para el nuevo centro docente. La propuesta del Ayuntamiento de Cheste fue la ganadora del concurso convocado por el Ayuntamiento de Valencia para la ubicación de los nuevos terrenos.

Para la adaptación del proyecto de El Saler a la nueva topografía se construyó una maqueta con curvas de nivel marcando el relieve real del terreno, realizándose modelo $s$ a escala de los edificios e instalaciones deportivas ya definitivamente proyectados ${ }^{69}$. Éstos se 
fueron situando sobre la maqueta con el criterio de producir el mínimo movimiento de tierras, la buena orientación y la organización funcional del conjunto, conservando en la medida de lo posible los valores paisajísticos originales ${ }^{70}$.

La organización está distribuida según funciones y se concreta en las siguientes zonas ${ }^{71}$ :

-Zona Pública, que comprende salón de actos, edificio de dirección, administración, recepción y cafetería.

-Zona de comedores, cocinas y servicios.

-Zona docente, con aulas, talleres y edificio de departamentos.

-Zona residencial

-Zona deportiva

-Zona de servicios médicos y oratorio.

Acotando el estudio a la zona residencial, el criterio básico, anteriormente nombrado, del proyecto de la Universidad laboral de Cheste de evitar la sensación de masificación adquiere aquí su máximo sentido para resolver el problema de alojamiento del alumnado, es decir, para 4.800 estudiantes internos. La primera decisión adoptada por el arquitecto, consiste en decidir dicho programa, la misma opción que es seguida en otras dependencias como aularios y comedores.

Las residencias son el edificio de mayor volumen de todo el conjunto, a excepción del paraninfo. De ahí su visibilidad como remate territorial en la zona más elevada del emplazamiento y la importancia de su imagen desde el paisaje desde la lejanía.

La parte residencial se compone de 4 grandes edificios que disponen, además de áreas comunes, con importante superficie y presencia definiendo un espacio de relación que, tratado unitariamente y aprovechando el nivel topográfico, actúa también como un mirador. La composición general se basa en oponer a una edificación de una sola planta, a modo de plataforma extendida horizontalmente, el ritmo vertical de los 4 edificios de dormitorios.

La organización residencial, a partir de la premisa de evitar la masificación, fue subdividida en 4 edificios albergando cada uno de ellos a 1.200 estudiantes, distribuidos en 6 plantas. En cada uno de ellas se alojarían 600 estudiantes, que se constituían en una unidad o "colegio", según la denominación oficialmente adoptada por el 
complejo docente, de forma que cada uno de éstos presenta una gran autonomía y entidad propia.

Cada una de las plantas posee una escalera independiente, es decir, que cada edificio tiene seis escaleras $y$, por tanto cada una de ellas sólo sube a un piso, así se refuerza el carácter de autonomía. EN planta baja y junto a cada escalera se encuentran las salas de estar y de juego de cada colegio, tan comunes ya en estas universidades laborales y posiblemente importadas de Estados Unidos, también se encuentran los despachos de los educadores y director del colegio.

De esta disposición, se hace eficiente la manera de no mezclar la circulación de alumnos de diferente colegio, teniendo las zonas comunes de planta baja como espacios de relación. Junto a las seis escaleras de acceso de alumnos se disponen, además, otras dos de servicio en los extremos de cada uno de los bloques, una de ellas con montacargas para facilitar el cambio de ropa de camas y la otra para agilizar la evacuación de personas en caso de emergencia.

Se puede afirmar que el conjunto de condiciones que representaba esta intrincada red de accesos y conexiones, lejos de llegar a ser un grave problema de complicada solución, se convertitía gracias a la habilidad de Moreno Barberá en una aportación singular a la tipología residencial ${ }^{72}$.

Todas las escalera son abiertas, sin carpinterías, y sus petos son altos y de hormigón armado. Entre los peldaños y entre las barandillas y el piso de la meseta, se construyó una ranura para facilitar tanto la limpieza como la salida del agua de lluvia.

A diferencia de lo que ocurre en la zona residencial de la Universidad Laboral de Gijón, el autor no contempla la reiteración de pequeños huecos en muros planos de fachada, sino que opta por una composición con un cierto dinamismo gracias a su relieve perimetral, que lo aprovecha para individualizar las ventanas. El volumen de este conjunto, construido en ladrillo $y$, en líneas generales, de predominio horizontal, contrasta con el cuerpo anexo de hormigón armado correspondiente a las escaleras cuya composición alcanza valores de gran plasticidad con su especial ritmo de huecos y macizos o con el juego que genera de luces y sombras ${ }^{73}$.

Los bloques residenciales, a pesar de emplazarse en la zona de menor pendiente, la gran longitud de los edificios hace que se eleven en uno de sus extremos, por lo que esta disposición facilita la añadidura de de sótanos y muros de contención que servirán para instalar las salas de gimnasia, transformadores y aseos, una solución 
de programa similar a la optada por Walter Gropius en la Residencia de la Bauhaus de Dessau. Por otra parte, la cubierta de estas dependencias se convirtió en transitable para aumentar la superficie de expansión de los alumnos $y$, precisamente, este espacio a cubierto con bancos y amplias vistas, constituye el inmenso mirador sobre el valle desde el que se accede a las residencias ${ }^{74}$.

Bajo el mirador existen una serie de aulas que complementan la dotación de los edificios destinados a aularios.

Las zonas comunes de planta baja donde están situadas lo que Carmen Jordá denomina zonas recreativo sociales, con una distribución abierta, dando a numerosos patios donde se colocaron árboles cuyas copas pueden percibirse desde el exterior. Además de la de servicio, cada una de las 6 entradas independientes de cada colegio conduce o a la escalera y los dormitorios o a las salas de estar. Cerca de cada entrada se dispone una unidad de dirección y administrativa, con dependencias para el director, el sacerdote y los cuatro educadores del colegio. Estos despachos volcaban a un pequeño patio privado. Los locales de estancia y las salas de juego de los alumnos volcaban también a un patio, pero ninguno de los colegios tenia ventanas al patio del otro, asegurando siempre una independencia total de las unidades residenciales. La iluminación proveniente de los pequeños patios de luces se complementa con la ofrecida por los lucernarios que había dispuestos en estancias de planta baja.

Además de los servicios privativos de cada uno de los colegios, se proyectaron otros de carácter general, como peluquería, kiosko y vicerrectorado de residencia, incluyendo sala de espera, secretaría, despacho del vicerrector con guardarropa, sala de juntas para 50 personas con iluminación cenital y club de educadores.

Desde el exterior $y$, en cada uno de los cuatro bloques residenciales, se agrupan cuatro de los seis accesos con otro de servicio, cada uno de ellos con sus puertas independientes, formándose una zona de recepción que se retranquea respecto a la línea de planta baja, recibiendo iluminación natural por un amplio hueco en los porches. El juego de las cubiertas se desarrolla con un recurso simple, colgando de barras metálicas dos de los tramos de su forjado de hormigón, que descienden sobre el resto de la estructura evidenciando el acceso. En los extremos de cada planta baja se sitúan los dos accesos restantes.

En el interior de las plantas para dormitorios se dispusieron camas para 1200 estudiantes, con la particularidad de que éstos no podían acceder durante horario matinal diurno ${ }^{75}$. El acceso a estas piezas se 
produce por pasillo central y se proyectan divididas en cabinas sin pared interior, con capacidad para ocho literas con ocho armarios y un banco. Con posterioridad se independizaron los dormitorios del corredor central mediante la incorporación de puertas recayentes al pasillo.

Cabe destacar, que se proyectó una ventilación forzada mediante chimeneas y rejillas situadas junto al pavimento para establecer en los dormitorios una pequeña corriente de aire.

En la actualidad únicamente dos de los edificios residenciales se siguen utilizando para actividades diversas, estando cerrado otro, mientras que el último se encuentra prácticamente abandonado y en estado ruinoso.

Viviendas de directivos.

Se encuentran semiocultas entre los árboles. Son 6 viviendas adosadas, diseñadas por Moreno Barberá, para los directivos y jefes de mantenimiento del centro docente. Están colocadas, al igual que ocurre en la Residencia de Estudiantes de Dessau con las viviendas de los profesores, desplazadas, con cierto grado de aislamiento, con respecto al resto del conjunto. Las 6 viviendas se encuentran a la altura del conjunto de los comedores y edificio de servicios. Lo primero que anuncia su existencia en el exterior es la presencia de un pequeño pabellón para aparcamiento de coches, construido con el singular ladrillo de Cheste y una cubierta plana de hormigón visto.

El acceso peatonal aparece en un lateral en forma de senda $y$, al avanzar por ésta, se descubre entre la vegetación el conjunto de viviendas, que se adosan de forma escalonada frente a un estrecho camino pavimentado. 

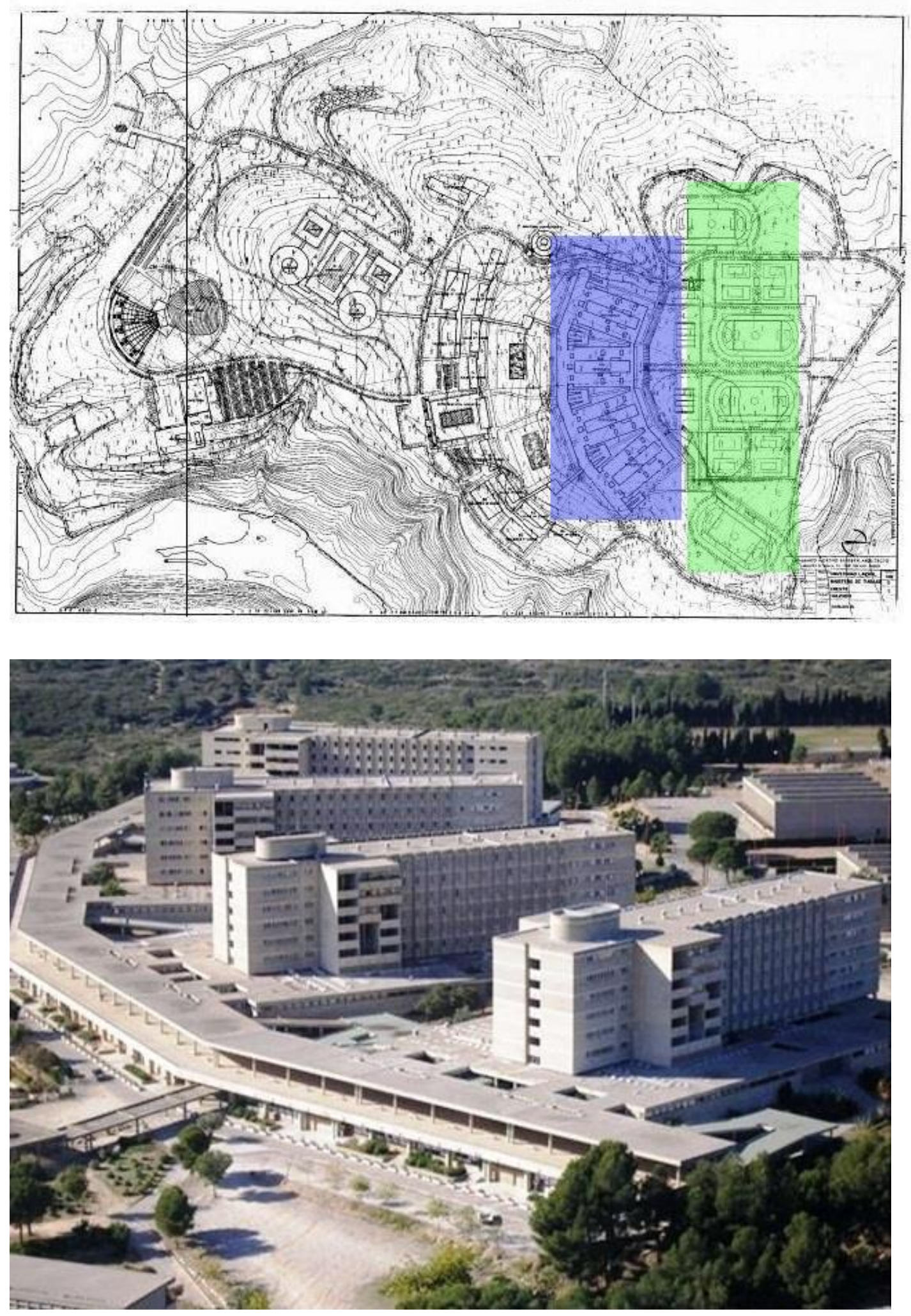

Imagen 53: Plano general de conjunto, donde se marcan los bloques de residencias, a la izquierda, vinculados a la zona deportiva, a la dercha.

Imagen 54Residencias de estudiantes 


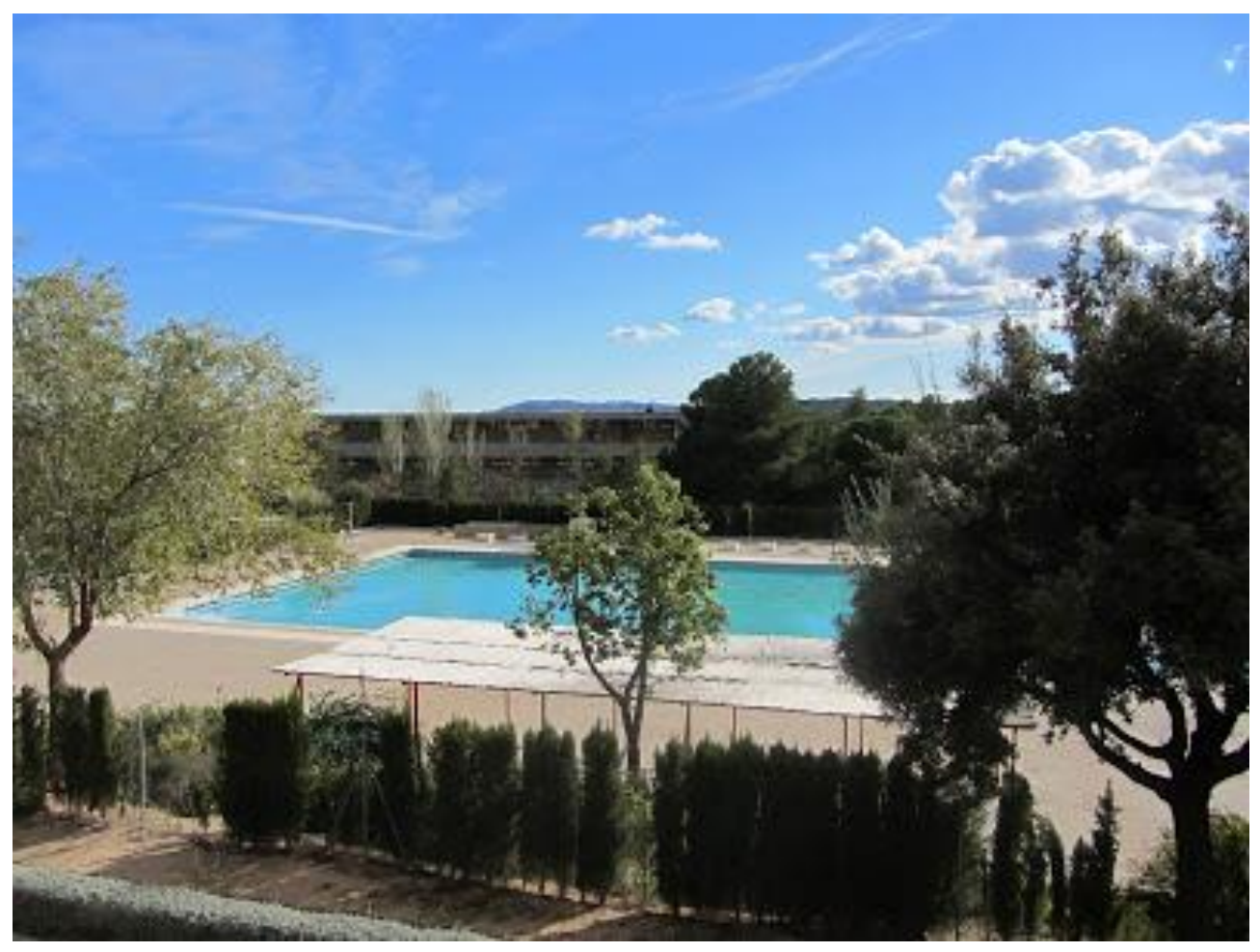

Imagen 54: Plano general de conjunto, donde se marcan los bloques de residencias, a la izquierda, vinculados a la zona deportiva, a la derecha.

Imagen 55: Bloque de residencias de estudiantes, donde se aprecia el núcleo de escaleras separado, en volumen, del bloque de habitaciones.

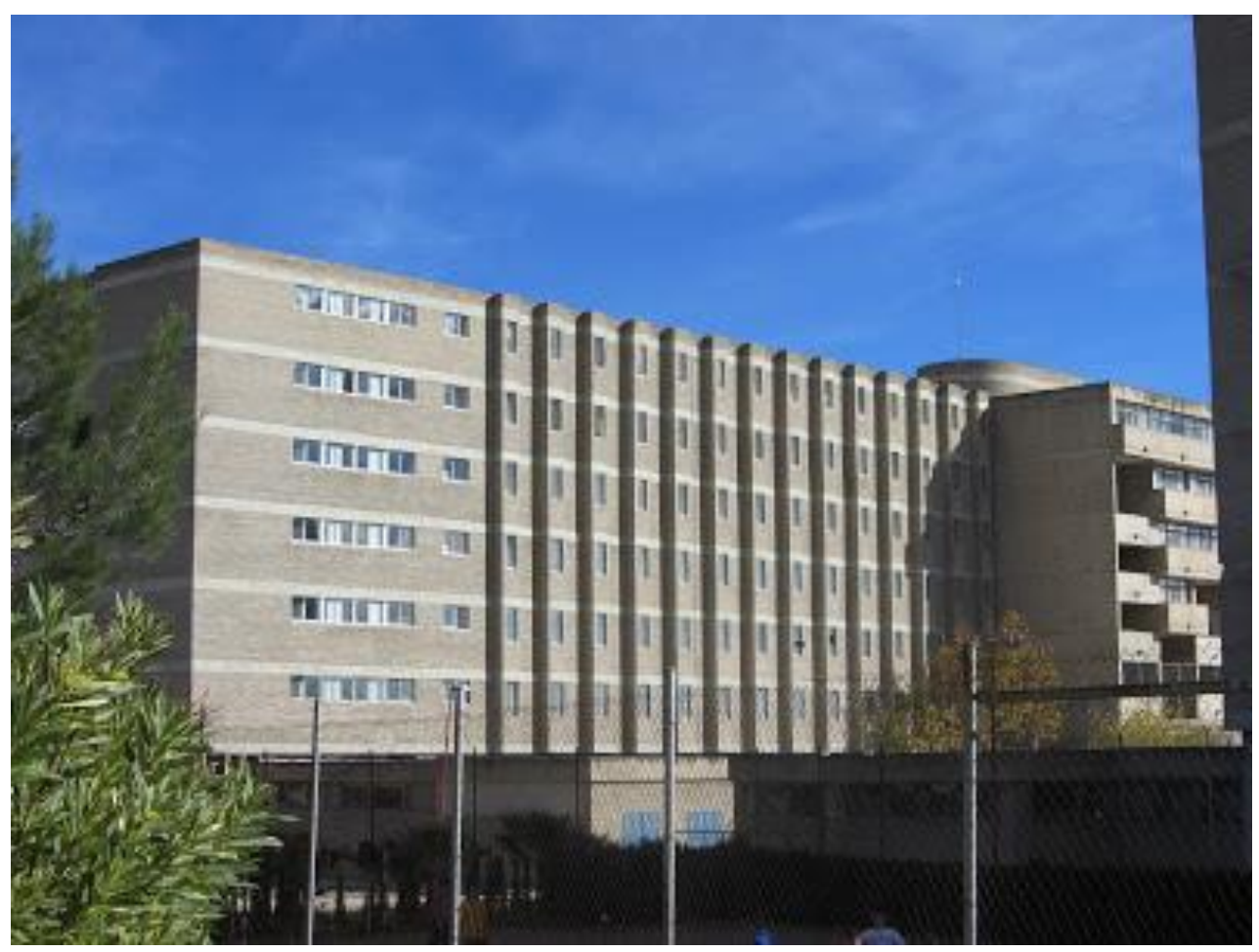




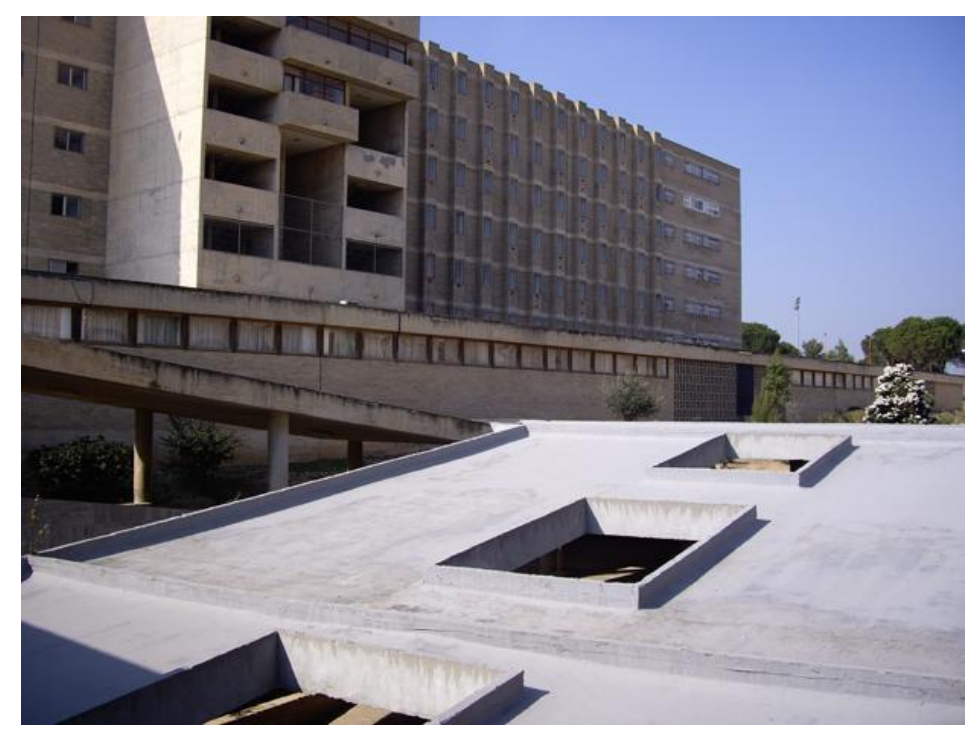

Imagen 56: Conexión de los bloques residenciales con las zonas comunes, ubicadas en un volumen de menor altura.

Imagen 57: vista de las escaleras con la barandilla de hormigón armado.

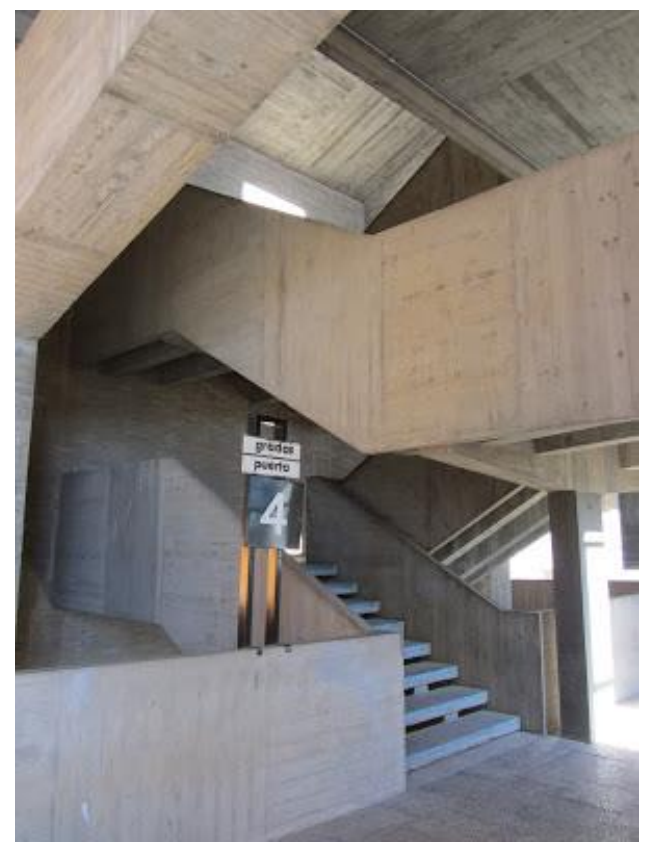




\section{NOTAS Y REFERENCIAS BIBLIOGRÁFICAS (RESIDENCIAS UNIVERSITARIAS EN ESPAÑA, GENERADORA DE CIUDAD)}

1. La arquitectura del Movimiento Moderno 1925-1965. Fundación DOCOMOMO IBÉRICO. Felipe Díaz-Miranda y Marías en LIÑO 15. Revista anual de Historia del Arte, 2009.

2. VENTURI, Robert, "Complejidad y Contradicción en la Arquitectura". Ed. Gustavo Gili. Barcelona 1972 pp. 26,39.

Venturi propone los términos inclusivo y exclusivo como opuestos en la arquitectura. Entiende por arquitectura inclusiva aquella que admite y hace suyas todo tipo de posibles sugerencias, principalmente las ofrecidas por la Historia de la Arquitectura, pasada o presente.

Entiende por arquitectura exclusiva aquella que, mirándose a sí misma rechaza toda sugerencia exterior, para lograr un máximo grado de autonomía: " LAunidad difícil de la inclusión en vez de la unidad fácil de la exclusión. Más no es menos.

3. Luis Lacasa, Escritos 1922-1931. (Introducción de Carlos Sambricio) Madrid COAM. 1976. Carlos Sambricio, "Garcia Mercadal, Pretexto/Calembourg, GATEPAC G.C.", en Cuando se quiso resucitar la arquitectura, Murcia, Galeria Yerba, 1983.

4. En relación de los escritos publicados por los arquitectos de estos años en diarios y en revistas profesionales, casi la mitad del total tiene como autor a Mercadal. Véase la bibliografía contenida en las notas de Carlos Sambricio en "Pretexto/Calembourg, GATEPAC G. C. op. Cit, y en Fuentes hemerográficas: "artículos de arquitectos" en Juan Antonio Cortés, El Racionalismo Madrileño. Casco Antiguo y Ensanche. 19251945. Madrid, COAM, 1992.

5. Incluido en eel libro Luis Lacasa, Escritos 1922-1931 op. cit, pp 128-131.

6. "Intentemos seguir con la imaginación el proceso de la creación de un proyecto racionalista. Vemos en primer lugar la erie de condiciones intrínsecas al caso concreto: el problema de su funcionamiento. Lo más profundo de la arquitectura actual es la solución del problema del funcionamiento". Luis Lacasa, "Arquitectura impopular", Arquitectura, año XII, num. 129, enero 1930, pp. 9.

Escritos como éste muestran la preocupación de Lacasa y del grupo de arquitectos de Madrid citados para encontrar el sentido del racionalismo arquitectónico en términos de funcionalidad.

7. Luis Lacasa. "Escritos" 1922-1931. Op cit, pp. 75-96.

8. Ibid, p. 95 . 
9. Carlos Flores López, "La primera fase de la Ciudad Universitaria de Madrid. Ambiente cultural y obra realizada" en AAVV. La Ciudad Universitaria de Madrid, Tomo I. Ed. COAM y Universidad Complutense de Madrid, 1988. Pp. 101-124.

10. La Institución Libre de Enseñanza fue fundada en $\mathbf{1 8 7 6}$ por Francisco Giner de los Ríos y otros catedráticos, como Gumersindo de Azcárate o Nicolás Salmerón, que habían sido separados de la Universidad por defender la libertad de cátedra. Para proseguir su tarea educadora, crearon una institución privada, orientada primero a la enseñanza universitaria y, después, a la educación primaria y secundaria. En el proyecto participaron numerosas personalidades comprometidas en la renovación educativa, cultural y social, entre las que destaca Manuel Bartolomé Cossío, continuador de la obra de Giner, y también Joaquín Costa, Augusto González de Linares, Rafael Altamira, Adolfo Posada, Segismundo Moret, Fernando de los Ríos, Julián Besteiro o Antonio Machado, entre otros muchos.

11. CASTILLEJO, J. "Guerra de ideas en España: Filosofía, Política y Educación" Ed. Siglo XXI, 2009.

12. SUBIRÁ, J. "Una gran obra de cultura patria. La Junta para la Ampliación de Estudios". Nuestro Tiempo, XXIV, 301, enero 1924, 304, abril 1924. 305, mayo 1924, p. 23.

13. PÉREZ-VILLANUEVA TOVAR, Isabel, "La residencia de Estudiantes: grupos universitario y de señoritas". Ed. Centro de Publicaciones, Ministerio de Educación y Ciencia, Madrid, 1990, p. 10.

14. PIJOAN, J. "Mi Don Francisco Giner (1906-1910). Ed. Alsina. San José de Costa Rica, 1977. P. 19.

15. TREND, J. B. "The origins of Modern Spain". Ed. The University Press. Cambridge, 1934. Pp. 78 y 80.

16. Véase Castillejo, J.R., "Guerra de Ideales en España. Filosofía, Política y Educación. Revista de occidente. 1976, p 94.

17. Véase Castillejo J.R., "La educación en Inglaterra". Ed. La Lectura. Madrid, 1919. Pp. 292-295 Y $483-493$.

18. Manuel Bartolomé Cossío fue becario del Colegio del Colegio español de Bolonia durante 1879-1881. Véase Jiménez Landi Martínez, "A Manuel Bartolomé Cossío, una vida ejemplar" (1857-1935). Ed. Instituto de Cultura "Juan Gil Albert". Alicante, 1989. Pp. 25-29. El interés institucionalista por este colegio queda expresado, por ejemplo, en COSTA, J, "Maestro escuela y patria. Biblioteca Costa, Madrid, 1916. Pp. 232-233 y 349; y en GINER DE LOS RIOS, H. "El Colegio de Bolonia", Boletín de la Institución Libre de enseñanza, V, 102, 17 de Mayo de 1881. Pp67-68.

19. CASTILlejo, J. "Guerra de ideas en España" op. Cit. P. 108.

20. Jiménez, A. "Ocaso y Restaurción, op cit pp.171-172. 
21. Ibid. Pp. 227 y 240.

22. GARCÍA MORENTE, M. "La Universidad" en Escritos Pedagógicos. Ed Espasa Calpe. Madrid, 1975. Pp. 48-50.

23. JIMÉNEZ, A."Ocaso y Restauración", op cit pp 214 y 219.

24. Véase BRANDIS, D., "El paisaje residencial en Madrid. Ed. Ministerio de Obras Públicas y Urbanismo, Madrid, 1983. p. 100.

25. El hotel de Ruperto Besga, edificado entre 1921 y 1924 en la calle de Miguel Ángel $n^{\circ} 11$, con vuelta al Paseo del General Martínez Campos, contituye un buen ejemplo del tipo de construcción ajardinada imperante en la zona, (Archivo de la Villa de Madrid, expediente24.313-8)

26. Véase Avery, I., «Relación entre la Institución Libre de Enseñanza y el Instituto Internacional para Señoritas en España», .en AAVV, En el centenario de la Institución Libre de Enseñanza, op.cit., p. 115.

27. ZULUETA, C. de, "Misioneras, fenunistas. educadoras. Historia da! Instituto Internacional". Ed. Castalia Madrid, 1984, p. 145.

28. Ibid 146 .

29. Avery, I., «Relación entre la Institución Libre de Enseñanza y el Instituto Internacional para Señoritas en España»,op. cit., p. 113.

30. Archivo de la Villa de Madrid, expediente 17.424-29. El proyecto inicial sufrió diversas modificaciones: se suprimió la cúpula que, como observatorio astronómico, debía haber rematado d torreón, que pasó además de circular a cuadrado, y se convirtió en piso habitable la zona alta abuhardillada; posteriormente se modificó de nuevo, tras solicitud de autorífación de 20 de ¡unió de 1906, el piso de cubiertas.

31. En la antigua Cuesta del Zarzal, hoy calle de Menéndez Pidal, se conserva todavía como propiedad familiar la finca comprada por Castillejo, así como la casa que construyó a comienzos de los años veinte; recientemente se ha constituido una Fundación para preservarla de alteraciones y favorecer la realización de actividades de orden cultural. Su condición de olivar, vegetación propia del antiguo núcleo de Chamartín de la Rosa, y las características de la casa ponen de manifiesto los gustos y el modo de vida, de indudable raíz institucionista, del Secretario de la Junta. También se conserva, cuidadosamente restaurada, la vecina casa de Menéndez Pidal, sede de la Fundación dedicada a la memoria del que durante laníos años lúe Presidente del Comité directivo de la Residencia de Estudiantes.

32. "El rey en la Residencia de Estudiantes". Diario ABC, 20 de febrero de 1911, p. 6.

33. Jiménez, A., "Ocaso y Restauración", op. cit.. pp. 2 19-220. La sala y la biblioteca fueron posteriormente dormitorios y «salas do recibir» del eenti o residencial al ocuparlo el grupo de señoritas ("El 14", Residencia, I, t, enero-abril 1926, P- 74).

34. Documentación del Archivo J.A.E. I. C. (CSIC)

35. JIMENEZ, a., "Ocaso y Restauración, op.cit, p. 220.

36. Documentación del Archivo J.A.E.I.C. (C.S.I.C.)- El comedor antiguo quedó unido desde entonces al construido en el nuevo pabellón. 
38. Memoria J.A.E.I.C., años 1912 y 1913, p. 331.

39. Ibid, pp. 331, años 1914 y 1915, p. 311.

40. Jiménez, A., Occiso y restauración, op. cil., p. 242. El llamado «Canalillo», que se abastecía del sóbrame de las aguas del Luzoya que llegaban a Madrid, ora un simple canal de riego. Manuel de Terán recuerda que el lugar, limitado a un lado por la calle de Lorie.1, de Hoyos y de otro por una zona llamada Ojo del Lagarto, de una altura cercana a los 700 metros, era en realidad una «loma alargada» de "barro y arcilla", "un islote alargado embarrancado en todos sus frentes"; el acceso era difícil por el lado este al 1 Lindarse la Residencia ya que la calle de Serrano, a partir de López, de Hoyos, no estaba todavía abierta (Terán, M. de, "Recuerdos de los primeros tiempos", en AAVV, Sesenta aniversario del Instituto-Encueta, Madrid, Asociación de Antiguos Alumnos del Instituto-Escuela, I97S, pp. 11-12)

41. Juan Ramón Jiménez denomina, en efecto, al lugar "Cerro del Viento" (véase "Visita nocturna a la colina", en Jiménez, J. R., "Antolojía jeneral en prosa"., p. 984); Alfonso Reyes señala que la colina era llamada por "los viejos" el "Ceno del Aire" ("La Residencia de Estudiantes", op. cit., p. 187); y, por su parte, José Moreno Villa dice que se la "conocía por el nombre de "Cerro del Viento", "La Residencia", op. cit., p. 24).

42. Memorias J.A.E.I.C, años 1912 y 1913, p. 3 11, años i 914 V 1915. p. 311.

43. Jiménez, A., Ocaso v restauración, op. cit., p.219-20

44. Memoria J.A.El.C, años 1912 v 1913, p. 325.

45. PÉREZ- VILLANUEVA TOVAR, Isabel, "GRUPOS UNIVERSITARIO Y DE SEÑORITAS. Ed. Ministerio de Cultura. MADRID, 1910-1936 p. 81.

46. Ibid p. 378 .

47. Memoria J.AE/.C, años 1910 y 1911, p. 214.

48. Archivo J.A.E.I.C. (Archivo General de la Administración), legajo 13.609-1

49. Documentación del Archivo J.A.E.I.C. (C.S.I.C.)

50. Memoria J.A.IU.C. años 1916,v 1917, p. 272

51. Giner ele los Ríos, B., Cincuenta años ile arquitectura española (1900-1950). T Q, Madrid, Adir, 1980, pp. 88-89. Hay que hacer notar, sin embargo, que en $1 \mathrm{ji}$ transcripción que se conserva de ia intervención de Gropius en la Residencia de Estudiamos no hay la menor alusión a los pabellones residenciales Ju la calle del Pinar (véase «Arquitectura funcional. Conferencia de Walter Gropius en la Residencia de Estudiantes de Madrid». Arquitectura, XJH, 142, Febrero 1931, pp. 51-62.

52. JIMENEZ, A. "Ocaso y Restauración, op. Cit. Pp. 253.

53. En el Archivo J.A.E.I.C. (C.S.I.C.) queda constancia de la vinculación de Carlos Arniehes al conjunto residencial desde el 21 de octubre de 1927, fecha en la que la Junta le solicita un presupuesto para efectuar reparaciones en los edificios de Fortuny y Ralael Calvo.

54. CAPITEL, Antón, "La construcción de la Colina de los Chopos" en Madrid. (de Antonio Flórez a Miguel Fisac). Ed. Arquitectura, Madrid, 1959, p. 18-21. 
55. Javier de Winthuyssen, es Inspector Nacioanl de Parques y Jardines artísticos.

56. Ramón Ortiz Ferrer, es Jardinero Mayor del Ayuntamiento de Madrid.

57. MONTES SERRANO, Carlos. "Clasicismo, Licencia y Retórica en la Arquitectura de Luis Moya" en A propósito del 50 aniversario de la arquitectura de Luis Moya. Revista de Arquitectura, n 3. Ed. Servicio de Publicaciones de la Universidad de Navarra, 1999, p. 7 .

58. MOYA, Luis, "Tradiciones, funcionalistas y otros", La arquitectura cortés y otros escritos. Ed. Colegio Oficial de Arquitectos de Madrid. Madrid, 1993, p. 74.

59. Ibid. P. 76 .

6o. LE CORBUSIER. "Vers une architecture". París: Crès, 1924, p.70

61. Ibíd, p.67

62. MOOS, Stanislaus von. "Le Corbusier". Ed. Lumen. Barcelona, 1977, p. 85

63. RÍO VAZQUEZ, Antonio. Tesis Doctoral "La recuperación de la modernidad en la arquitectura gallega", Director: José Ramón Alonso Pereira Departamento de Composición arquitectónica. Universidad de La Coruña " Op cit p. 145

64. Ibíd p. 146

65. LÓPEZ ZANÓN, Op cit, p. 491.

66. NORBERG-SCHULZ, Christian, "Los principios de la arquitectura moderna", ed. Reverté. Barcelona, 2005, p. 144.

67. CODINA BAS, Juan Bautista: PENALBA GUILLÉN, Francisco, "De Centro de Organización de Universidades Laborales a Complejo Educativo. 1969-1994", Comisión Organizadora del XXV Aniversario del Complejo Educativo de Cheste; Valencia, 1994, p.18.

68. JORDÁ SUCH, Carmen, "Universidad Laboral de Cheste 1967-1969". Colegio Oficial de Arquitectos de Almería, Almería, 2005, p. 36.

69. Ibíd, p. 39

70. Ibid, p. 39

71. Ese listado de zonas proviene del proyecto reformado, pero hay que advertir que todavía existe otra zona de carácter más privado que no suele aparecer en la documentación oficial. Únicamente está grafiada esquemáticamente, como un rectángulo formado formado por seis cuadrados iguales, en un plano general, tratándose en la realidad de viviendas para los directivos de la Universidad Laboral de Cheste, que allí residen.

72. JORDÁ SUCH, Carmen, "Universidad Laboral de Cheste 1967-1969". Op. Cit, pag 103.

73. Ibíd, p.105.

74. Ibíd, p. 105.

75. Ibid, p. 106. 
434| RESIDENCIAS UNIVERSITARIAS EN ESPAÑA, GENERADORA DE CIUDAD 
COLEGIOS MAYORES DE LA CIUDAD UNIVERSITARIA DE MADRID Y LA AROUITECTURA MODERNA

\section{BLOQUE IV}

\section{IV.1 DIMENSIÓN URBANÍSTICA}

El emplazamiento colegial en la primera Ciudad Universitaria de Europa.

El Colegio Mayor Ximénez de Cisneros. Luis Lacasa y Javier Barroso. Hacia la segregación funcional especializada.(1942) 
436| COLEGIOS MAYORES DE LA CIUDAD UNIVERSITARIA DE MADRID Y LA ARQUITECTURA MODERNA 


\section{EL EMPLAZAMIENTO COLEGIAL EN LA PRIMERA CIUDAD- CAMPUS UNIVERSITARIO DE EUROPA.}

La Ciudad Universitaria de Madrid constituye en sí misma uno de los capítulos más importantes de la transformación urbana de una ciudad. Desde el punto de vista de la modernización que se operó en España durante el siglo $X X$ es uno de los elementos más significativos $y$ trascendentes ${ }^{1}$.

El concepto de "ciudad universitaria" se puede establecer desde muchas ópticas. Por ejemplo, el recinto que alberga las dependencias del Colegio de San Ildefonso en Alcalá de Henares, como se ha visto en capítulos anteriores, pretendía por el Cardenal Cisneros convertirse una ciudad universitaria, o cualquier ciudad que albergue en su trazado un recinto universitario puede ser considerada como tal. El concepto de ciudad universitaria se aborda desde un concepto de ciudad integral universitaria, importado del campus estadounidense, y donde se muestra la evolución del equipamiento residencial universitario a través de la figura del Colegio Mayor.

Se estudia la evolución tipológica del Colegio Mayor entre 1932 y 1970. El proceso se canaliza en tres escalas urbanísticoarquitectónicas bien diferenciadas, con el propósito de observar la transición entre planeamiento, forma urbana y edificación singular. Atendiendo al criterio de lo general a lo particular, las escalas serían: la urbanística, la edilicia y la social.

La Ciudad Universitaria es considerada desde el primer momento como la "nueva Atenas", la Ciudad Platónica del saber, el templo de la Sabiduría. ${ }^{2}$

Se encuentra situada en uno de los parajes naturales de Madrid, a la salida de la ciudad en un bosque frente a la velazqueña sierra de Guadarrama. Muchos de los autores que sobre ella han escrito han ponderado sus excelentes condiciones para instalar allí los distintos edificios dedicados al estudio, a la enseñanza y a la residencia.

El director de la Residencia de Estudiantes, Alberto Jiménez Fraud, que al advenimiento de la República formó parte de la Junta de la Ciudad Universitaria de Madrid, en su libro sobre la Historia de la Universidad Española, al hablar del emplazamiento en la Moncloa de las Facultades y nueva Residencia de Estudiantes hace un elogio del "emplazamiento maravilloso de los terrenos" y la enorme extensión dedicada a la edificación fuera de la ciudad, en pleno campo. A sus ojos merece un verdadero elogio la "enorme empresa" que 
constituye esta ciudad dado que tiene óptimas condiciones higiénicas y favorables para el estudio concebido.

Históricamente, frente a los antiguos conventos y caserones que rehabilitados habían servido de albergue a las Facultades Universitarias y sobre todo respecto a las antiguas y poco confortables pensiones del casco antiguo donde se alojaban los estudiantes, la Ciudad Universitaria supone una mejora cuantitativa y cualitativa indiscutible y casi inconcebible para la época.

Con este nuevo recinto universitario se inaugura en España un tipo novedoso de Universidad, el del campus tipo norteamericano, diferente a las universidades europeas instaladas en pleno centro urbano o concebidas de forma compacta en reducidos recintos.

La novedad del campus constituyendo una unidad o conjunto, fue directamente importada de Estados Unidos. En gran parte, la concentración de edificios colegiales de Salamanca hace que una parte de la ciudad pueda considerarse casi por entero dedicada a la docencia y a la residencia. Como se ha visto en el capítulo de Alcalá de Henares, esta ciudad plantea una concentración de edificios escolares y residenciales sometidos a una planificación previa a su construcción. Como se ha visto en el bloque II, al adquirir el Cardenal Cisneros para su fundación una gran cantidad de terrenos libres al este de la población existente, lo hizo de forma consciente, pensando en la ordenación de un conjunto que funcionaría como ciudad del estudio. Establecido su plan de antemano, hizo que se trazasen amplios rectángulos relativamente regulares. A la vez ejerció un control sobre el patrimonio inmobiliario urbano de gran pare de la ciudad, que desde la creación de la Universidad hasta el siglo XIX, cuando se trasladó esta última a Madrid, fue casi exclusivamente dedicada a tareas docentes y la vida estudiantil. En realidad, la nueva Ciudad Universitaria madrileña es una forma moderna de retomar la tradición alcalaína perdida.

En la génesis de esta ciudad universitaria, hay que tener en cuenta varios factores determinantes. En primer lugar la disposición de Alfonso XIII de modernizar España proporcionándole la grandeza que le correspondía a una nación de su rango. A la vez de recuperar para ella su papel preponderante dentro del concierto de los países hispanos. Consejeros y amigos del Rey, como el odontólogo Florestán Aguilar, fueron decisivos a la hora de llevar a cabo una realización que en principio podía parecer utópica. Florestán Aguilar (1872-1934), ennoblecido por el Rey con el título de Vizconde de Casa Aguilar4, inauguró en España en 1869 una profesión nueva; su formación la había realiado en el extranjero, en especial en Estados 
Unidos. Sobrepasado el traumas del 98 con el desastre colonial de la pérdida de Cuba y Filipinas, la influencia de lo norteamericano era cada día de mayor fuerza en España, como se puede comprobar en la labor llevada a cabo en Madrid por Instituciones como el Instituto Internacional de Bostón, la introducción de tecnologías nuevas a través de los ingenieros o el interés que despertó en el mundo de la arquitectura la vuelta o "revival" de lo hispano por influencia de lo californiano. Florestán Aguilar, que en su casa había reunido un archivo sobre centros universitarios de libros y folletos con los planes de enseñanza, vistas y planos de edificaciones, y que conocía de visu las principales universidades del mundo. Fue quien guió a la Comisión de estudio que visitó los campus universitarios de Estados Unidos que podían servir de modelos para la Ciudad Universitaria de Madrid. El Dr. Aguilar acostumbraba a realizar frecuentes viajes al extranjero: asiduo visitante de Estados Unidos, había estableciso contactos con Instituciones como la Rockefeller o la Carnegie, logrando interesarles a éstas en el tema universitario madrileño. La primera ya había convocado un concurso para la realización de un Instituto de Física y Química en Madrid ${ }^{6}$ y resultaba obvio que su llegada a España no obedecía al desinterés, y que coincidía con la introducción en nuestro país de las primeras multinacionales. Las obras de la Ciudad Universitaria se beneficiaron de la ayuda estadounidense, pero a cambio firmaron convenios de diversa índole que compensaron con creces esta ayuda; bastaría citar, por ejemplo, que el mobiliario de los laboratorios se construyó en España pero según modelos y patentes norteamericanos ${ }^{7}$.

La formalización y creación de la Junta Constructora de la Ciudad Universitaria se concretó el 17 de mayo de $1927^{5}$, coincidiendo con la celebración del XXV aniversario de la jura de la Constitución de Alfonso XIII. EI Real Decreto de creación de la Junta fue redactado de manera tal que pudiera facilitar el rápido desarrollo del proyecto ${ }^{8}$, la Ciudad Universitaria fue dotada de amplísimas retribuciones, y el proyecto disfrutó desde el principio de la categoría superior y autónoma de "ciudad", el cual hacía presagiar que sería susceptible de futuras ampliaciones.

La Junta de la Ciudad Universitaria quedó constituida, de forma mayoritaria, por miembros de una ideología tradicionalmente monárquica, que ocupaba cargos de importancia en la administración pública o poseedores de un cierto prestigio social ${ }^{9}$. Resulta inevitable que su pensamiento y educación fueran a menudo coincidentes, pero aún se podría matizar si se establecen unos subgrupos por actividades afines; por ejemplo, el primero englobaría 
a las personalidades del mundo de la enseñanza. La elección resulta obvia puesto que a ellos respondería la redacción de los programas de necesidades en cada rama de los estudios, que posteriormente se deberían materializar en respuestas arquitectónicas completas. A este grupo, entre otros, pertenecía Modesto López Otero, director de la Escuela de Arquitectura y Luis Landecho.

Estos arquitectos son los primeros responsables en materializar los criterios arquitectónicos de la Junta, y la formación de los mismos, definitoria de sus estilos es:

Luis Landecho y Urríes se definió como continuador de la tradición de Viollet-le-Duc, que llegara a España a través de Segundo de Lema y Madrazo; con éste colaboró en el Palacio de Zabalburu (1876), y de él aprendió la simplicidad del ladrillo rojo visto, la piedra, el vidrio y el metal ${ }^{10}$. A Landecho se deben, entre otras obras madrileñas: El Ateneo (1882-84, realizado con Enrique Fort y Guyenet), unas viviendas de la CL. Sagasta, no 33 y 35 (1902) y la Escuela de Matronas en la CL. Odonell (1918). Era un hombre de gran prestigio y avanzada edad al crearse la Junta. Por razones de salud, tuvo que renunciar a realizar los viajes de estudios previos a la redacción de Proyecto de la Ciudad Universitaria, y fue el mismo quien propuso a López Otero para sustituirle ${ }^{11}$, ya que a su juicio éste poseía una gran capacidad y una extraordinaria preparación.

López otero era más joven, titulado en 1910, pertenecía a una de las últimas promociones de arquitectos formada en el tradicionalismo y el academicismo. Su postura conservadora se manifiesta en la adopción de un estilo ecléctico ${ }^{12}$. Como muestra de sus obras en Madrid se puede citar: El edificio de la Unión y el Fénix situado en la CL. Peligros no 2, (1928-30), el Hotel Gran Vía, (1919-25), anteriormente citado en el apéndice contemporáneo de la Cité Universitaire, el Hotel Nacional en la CL. Paseo del Prado n० 48 (1919) y el Colegio de Chamartín en la Plaza Duque de Pastrana no 5.

El Doctor Florestán Aguilar, prosigue de manera incansable su propaganda en el extranjero, a través de su correspondencia con la Fundación Rockefeller de Nueva York consigue la visita de uno de sus técnicos de la oficina de Asuntos Médicos, el Doctor Alan Greg ${ }^{13}$. Este trajo el ofrecimiento de su colaboración $y$, lo que es más importante, propuso a la Junta la visita de Universidades ya consolidadas de Europa y Estados Unidos.

La intervención americana cambió radicalmente los planteamientos de los primeros meses de la Junta. El viajar al extranjero cerró, rápida y definitivamente, la fase de gestación de la idea universitaria, que en el enfoque de la misma había sido limitada a la óptica de una 
minoría de arquitectos españoles. A partir del primer viaje, se sucederían otros, que amplían y enriquecen notablemente la configuración urbanística de la Ciudad Universitaria.

Cabe destacar algunos detalles de estos viajes.

La proposición de realizar un viaje asesorados por la Fundación Rockefeller fue inmediatamente aceptada. Se formó una Comisión formada por José Casares Gil, Catedrático de Química y Decano de la Facultad de farmacia; Antonio Simonena Zabalegui, Catedrático de la Facultad de Medicina; Julio Palacios Martínez, Catedrático de la Facultad de Ciencias; y Modesto López Otero, Director de la Escuela de Arquitectura. Durante aproximadamente dos meses permanecieron visitando universidades europeas y norteamericanas.

En Europa visitaron las Universidades de Leiden, Amsterdam, Utrech, Estrasburgo, Colonia, Lyon; Hamburgo y Berlín. Después embarcaron en Santander, en el barco "Manuel Armús", con rumbo a Nueva York; en esta segunda etapa por Estados Unidos y Canadá, visitaron los centros universitarios y de Yale, Harvard, Boston, Toronto, Michigan, Rochester, Washington, Baltimore, Nueva York y la Universidad de Montreal.

El diario de viaje de López otero es muy interesante, y reproduce las características de las Universidades referentes a "su emplazamiento, urbanización, servicios generales, agrupación de edificios y, además, a cuantos detalles afectan a la parte constructiva de los mismos ${ }^{\prime \prime 25}$.

Se pueden resumir algunas conclusiones que afectan a la estructuración urbanística:

- Las universidades norteamericanas se debían en su mayoría a la iniciativa particular, y consecuentemente poseían una completa autonomía, tanto económica como pedagógica. Las que no se apoyaban en los presupuestos estatales, se mantenían con las matrículas de los alumnos y los espléndidos donativos de sus benefactores.

- La génesis de las universidades era variable; las fundadas hace algún tiempo solían poseer un núcleo principal de edificios administrativos y pedagógicos, distribuidos en torno a un "campus"; por datar sus construcciones de épocas diversas, y responder a necesidades y recursos disponibles, no obedecían en general a un plan urbanístico previo, pero mantenían sus situación en torno a un gran espacio de relación. Las más modernas sí que obedecían a un plan preconcebido, respondiendo a una tendencia innovadora: la acumulación de 
dependencias de una facultad en un edificio único; esto llevado al extremo podía incluso llegar a agrupar la Universidad completa en un bloque único ${ }^{17}$.

Las Universidades se destinaban a la formación integral del estudiante, proporcionándole todo lo necesario para completar su educación religiosa, intelectual, física y moral. Por este motivo se disponía en un mismo conjunto, de edificios de carácter pedagógico ${ }^{18}$, de carácter administrativo, viviendas para el

personal empleado (básicamente para profesores), residencias para estudiantes ${ }^{19}$, teatros, capillas, restaurantes, instalaciones deportivas ${ }^{20} \ldots$

- La centralización de infraestructuras y servicios era un dato importante; y de ellas, las "Power Houses" o centrales, se destinaban al suministro de calefacción a todos lo sedificios universitarios mediante galerías subterráneas visitables que alcanzaban los lugares más remotos del recinto.

Al visitar Harvard, López Otero reconoció:" Para la vida colectiva hay en cada residencia de estudiantes un comedor y una sala de tertulia. Los dormitorios son individuales, pero cada dos estudiantes tienen en común el cuarto de estudio y el baño. Todo ello es más lujoso y confortable que un departamento en un hotel de primera categoría"23.

Cabe destacar, que por aquellos tiempos, Estados Unidos disponía de 530 instituciones universitarias, incluidos más de un centenar de campus con diez mil estudiantes ${ }^{24}$. En comparación, en España sólo existen, en esta época, apenas una docena de universidades y en las antípodas del concepto del concepto norteamericano de campus.

La Junta quedó fuerte y favorablemente impresionada por las conclusiones de los viajes y resolvió desde estos primero días del mes de diciembre de 1927, dar un giro radical a la marcha de la Ciudad Universitaria, ampliando, en un primer paso, el programa básico de construcciones, que quedaría organizado de la siguiente forma:

- En un primer grupo de construcciones "necesarias" se incluyeron las Facultades de Medicina, farmacia y Ciencias, el Hospital Clínico con capacidad para 1.500 camas, las Facultades de Filosofía y Letras y Derecho, la Gran Biblioteca Universitaria, las Residencias de Estudiantes y Profesores, la zona de Deportes; edificios de 
representación del Gobierno y servicios de la Universidad, y además, una Escuela Militar Universitaria. En el resto de fases se procederían a construir, por ejemplo, la Escuela de Arquitectura y otras Facultades como la de Bellas Artes.

Este programa presentado en el mes de enero de 1928 no fue tampoco definitivo. Diversas presiones, entre las que se podrían citar las de algunos miembros de la Junta, contribuirían a modificarlo, incluyendo en la primera fase, por ejemplo, las Escuelas de Arquitectura y Odontología, lo cual era lógico, puesto que estaban apadrinadas por López Otero y Florestán Aguilar respectivamente.

Paralelamente a la necesidad de ampliar el programa, se plantearon otros dos imperativos:

- En primer lugar, el solar disponible resultaba escaso a las nuevas pretensiones; el Gobierno, que ni podía ni debía mantenerse al margen de la iniciativa universitaria, resolvió finalmente ceder a la Junta de la Ciudad Universitaria los terrenos de la Finca de la Moncloa.

- En segundo lugar, se acordó ganar tiempo y poner en manos de técnicos competentes, controlados por la Junta, la redacción del proyecto y su realización inmediata. Para lograr este efecto, se nombró a López Otero "Arquitecto Director de las Obras y Proyectos de la Ciudad Universitaria", por iniciativa de Landecho²5, y acuerdo tácito del resto de la Junta ${ }^{26}$.

La elección de López Otero implicaba la autorización de elegir y emplear al personal auxiliar que estimara necesario. Igualmente se le daba un voto de confianza en el plazo de entrega de los trabajos ${ }^{27}$ y en la forma de redactarlos. Obviamente, la opción de convocar concurso quedó eliminada.

..."Después de repetidos estudios parciales, el Sr. Landecho dijo creía llegada la hora de comenzar los trabajos y planos, acordando por unanimidad la Junta, ser ella misma quién los hiciera, encomendándole al Sr. López Otero la alta dirección de los mismos. El Sr. López otero puso a la Junta ciertos reparos sobre la trascendencia del encargo, pero clamorosamente la Junta dijo que no quería el concurso y que allí se haría mediante la aportación de las ideas de todos los miembros, que una oficina técnica dirigida por el Sr. López otero trataría de armonizar, y éste tendría la responsabilidad de los trabajos y del personal a sus órdenes"... ${ }^{28}$.

Aprobada la libertad de Modesto López Otero para elegir a sus colaboradores, éste explica que "sintió el escrúpulo de que el procedimiento pudiera no parecer a la clase correcto", y por ello 
procedió a consultar a las personalidades de la profesión y a seleccionar a aquéllos arquitectos "que tuvieran en su carrera antecedentes de trabajos similares", por lo que recurrió al reciente concurso de la Institución Rockefeller en Madrid ${ }^{29}$. Esto le condujo a elegir a Luis Lacasa y Manuel Sánchez Arcas, galardonados con el primer premio, y al equipo Agustín-Aguirre - Miguel de los Santos, que habían obtenido el segundo premio. Poseían, pese a su juventud, un buen currículum.

En las primeras propuestas urbanísticas de la Ciudad Universitaria de Madrid, se puede constatar un nuevo concepto de vida universitaria, pionero en Europa y que implica a la residencia universitaria en el campus, en el que se busca un equilibrio entre la formación intelectual y la vida deportiva.

El resultado es un diseño constituido por amplios recintos académicos; presencia destacada de la naturaleza; proyectos unitarios y monumentales; y planificación de espacios abiertos. Estas ideas rompen, de forma clara, con la configuración de las viejas universidades españolas y europeas, de raíces claustrales.

A partir de aquí nos centramos en los que fueron los primeros proyectos residenciales de la Ciudad Universitaria de Madrid, pasando, posteriormente, a estudiar un conjunto de obras elegidas.

La implantación urbana de los modelos seleccionados obedece a una planificación integral de conjunto, que se deriva de un Plan Director ideado por una Junta Constructora que encabezaba, como se ha dicho en líneas anteriores, López Otero. Este Plan Director es el instrumento de coordinación, articulación y anticipación de un recinto tratado como un organismo unitario, el cual integra a los Colegios Mayores como elemento único en su función residencial. Para la ubicación de los mismos se destina un terreno de gran atractivo paisajista, rodeado en un frente por una destacada presencia de la naturaleza y, por el otro, zonas verdes e instalaciones deportivas, adaptando el modelo de campus norteamericano al enfoque madrileño y a los condicionantes de emplazamiento de los terrenos de Moncloa.

La composición se organiza segregando el conjunto, constituyendo unidades menores separadas entre sí por áreas ajardinadas $y_{\text {, }}$ simultáneamente, creando todo un "archipiélago residencial" en la zona suroeste de la Ciudad Universitaria. 
Se establece el criterio compositivo de la edificación abierta, que más tarde sería muy habitual según la idea moderna de urbanismo. El equilibrio entre la formación intelectual, la vida deportiva y la residencia conformaría un nuevo concepto de vida universitaria, pionero en Europa y que implica de forma directa al Colegio Mayor en el campus.

Aparece una nueva concepción urbanístico-arquitectónica que, en palabras de López Otero, mitigará la falta de espacio, de aire puro y de silencio. Los edificios se extienden de un modo armónico configurando el espacio urbano como elementos activos del mismo, lo que supone una transformación transgresora en el criterio organizativo que tanto la universidad española como la europea habían tenido hasta entonces.

Antes de comenzar el análisis con el Colegio Mayor Ximénez de Cisneros, conviene citar un pequeño apunte sobre la primera implantación de carácter residencial en la Ciudad Universitaria, cuyo proyecto, como se ha citado en líneas anteriores, se hizo en paralelo a las primeras trazas de la Ciudad Universitaria. La Fundación del Amo (1928-1929), cuyo proyecto realizaron los arquitectos Blanco Soler y Bergamín.

Emplazado entre el Parque del Oeste y el antiguo Instituto de Higiene, en la zona destinada a residencias universitarias para estudiantes, se levanta este conjunto cuyo proyecto incluía, junto al edifico principal, dos campos de tenis y una piscina, separados por un pequeño pabellón longitudinal, así como una construcción, también rectangular para dos garajes.

El edificio está configurado, salvo en planta baja, mediante una disposición tipológica en $\mathrm{H}$ y presenta exteriormente una diferenciación en tres cuerpos, siendo: planta baja, plantas dela primera a la tercera y, por último, un ático.

La planta baja se destaca del resto tanto por una mayor ocupación de superficie, principalmente dedicada a la sala de conferencias y proyecciones, como por su remate en una fina línea de cornisa, la terraza con pórticos antepuesta a la entrada principal, el pórtico de carruajes en la fachada lateral y los ventanales y puertas vidrieras con arcos medio punto, realizados, ambos, con perfiles especiales de acero estirado ${ }^{30}$ con soldadura eléctrica. En esta planta se alojan los servicios generales, es decir, salas de estar, biblioteca, comedor, cocinas y administración.

El resto de las plantas se halla destinado a dormitorios de los estudiantes, donde en su mayoría son hispanoamericanos. Las 
habitaciones son individuales y dobles, y cuentan con una sala de estudio intermedia, al igual que ocurría en las residencias universitarias de Harvard. Cada piso se subdivide en seis secciones independientes con sus correspondientes servicios. Las escaleras se sitúan en el centro de cada uno de los tres cuerpos de la $H$, disponiéndose la principal en el eje horizontal. Los planos de fachada están perforados con huecos individualizados según un ritmo uniforme, remarcándose tan sólo con un estrecho alféizar. Únicamente las bajantes de pluviales rompen a intervalos la perfecta horizontalidad que se consigue en el conjunto, junto con el ventanal rasgado que se corresponde con la vertical del hueco de la escalera principal.

La estructura de hierro y ladrillo, se cierra con paramentos recubiertos de piedra, a base de placas de bateig de $4 \mathrm{~cm}$ de espesor, y se corona con una cubierta inclinada, de escasa pendiente, cuya terminación es a base de teja árabe, contribuyendo a la sensación de horizontalidad.

Este edificio se puede considerar como de los primeros ejemplos dentro del racionalismo madrileño, y posee la característica, común a otros edificios de esta época, de tener el diseño por los arquitectos autores de los diversos elementos de mobiliario (butacas, mesas, barandillas, pasamanos, jardineras...). 


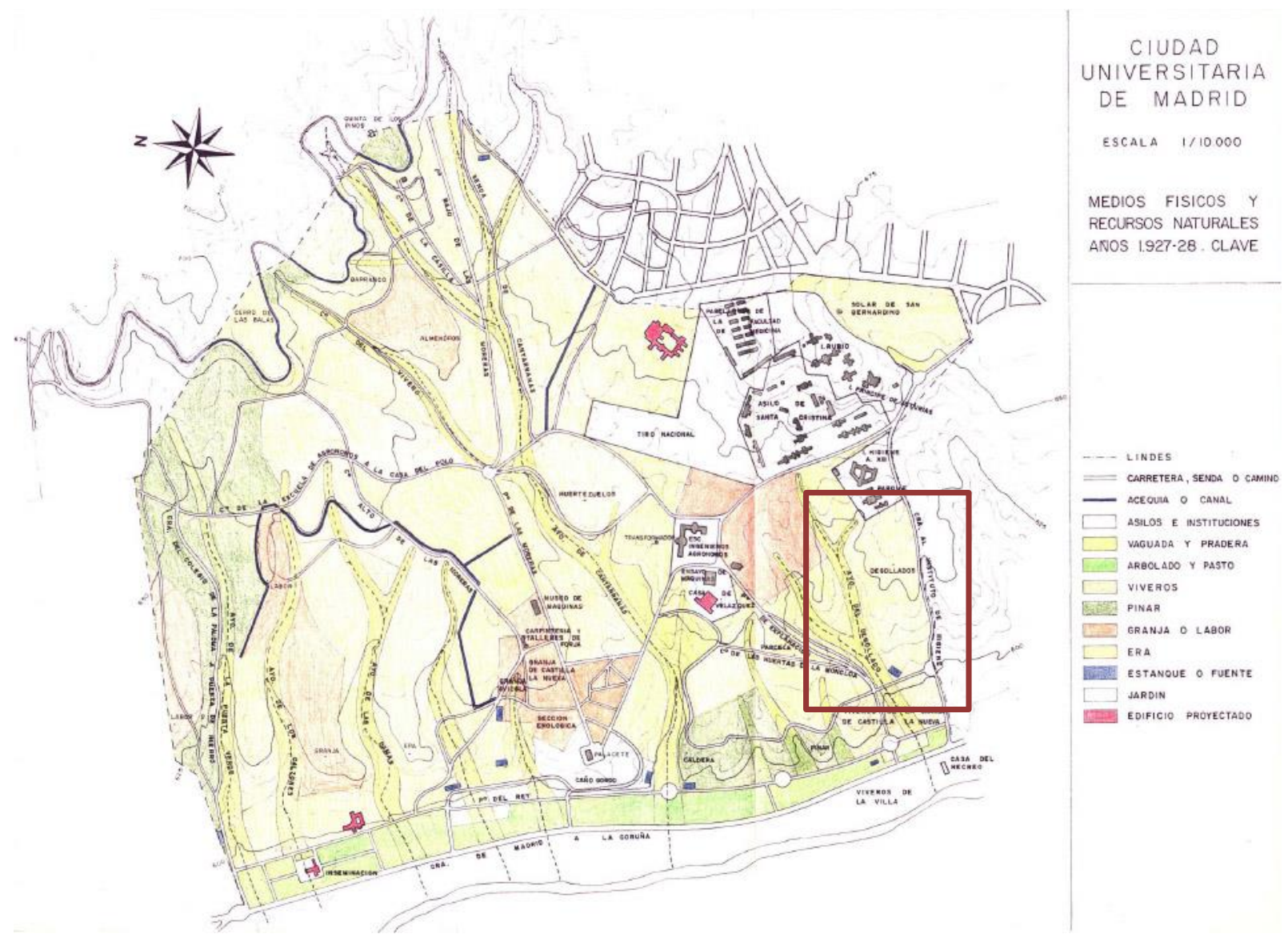

\section{Ciudad Universitaria de Madrid}

Imagen 1: Plano de Medios Físicos y Recursos Naturales. La ubicación de la zona residencial se ubica en la zona perimetral sur.

Imagen 2: Acta de la constitución de la primera Junta Constructora de la Ciudad Universitaria de Madrid.

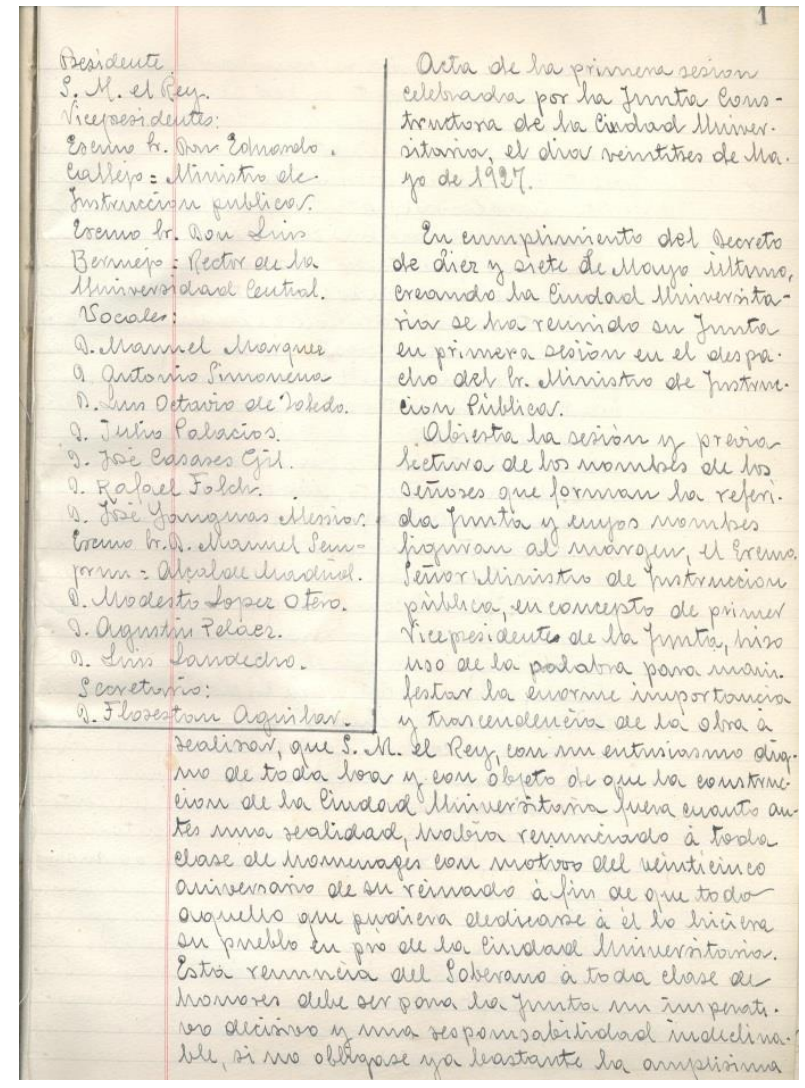



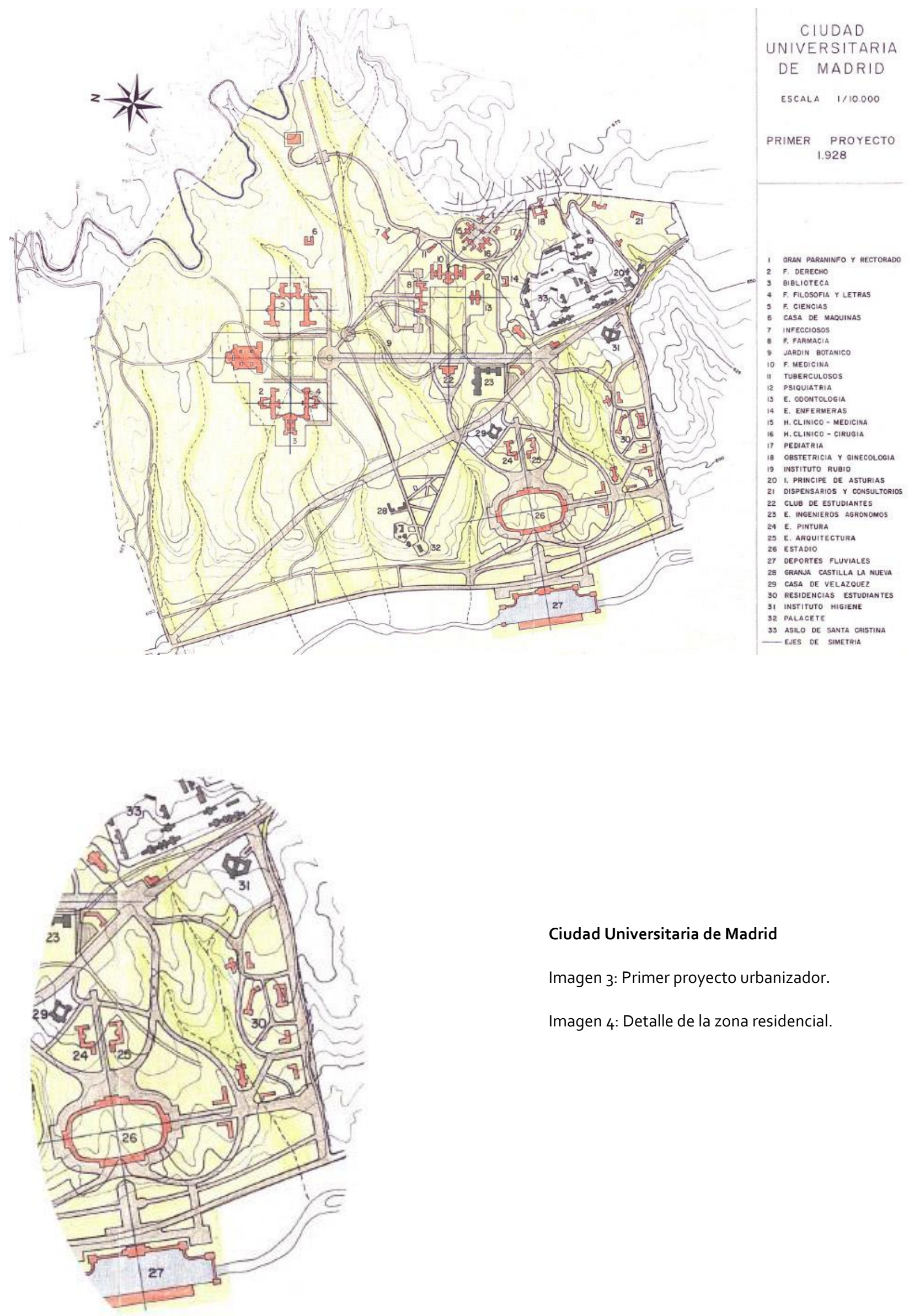

Ciudad Universitaria de Madrid

Imagen 3: Primer proyecto urbanizador.

Imagen 4: Detalle de la zona residencial. 


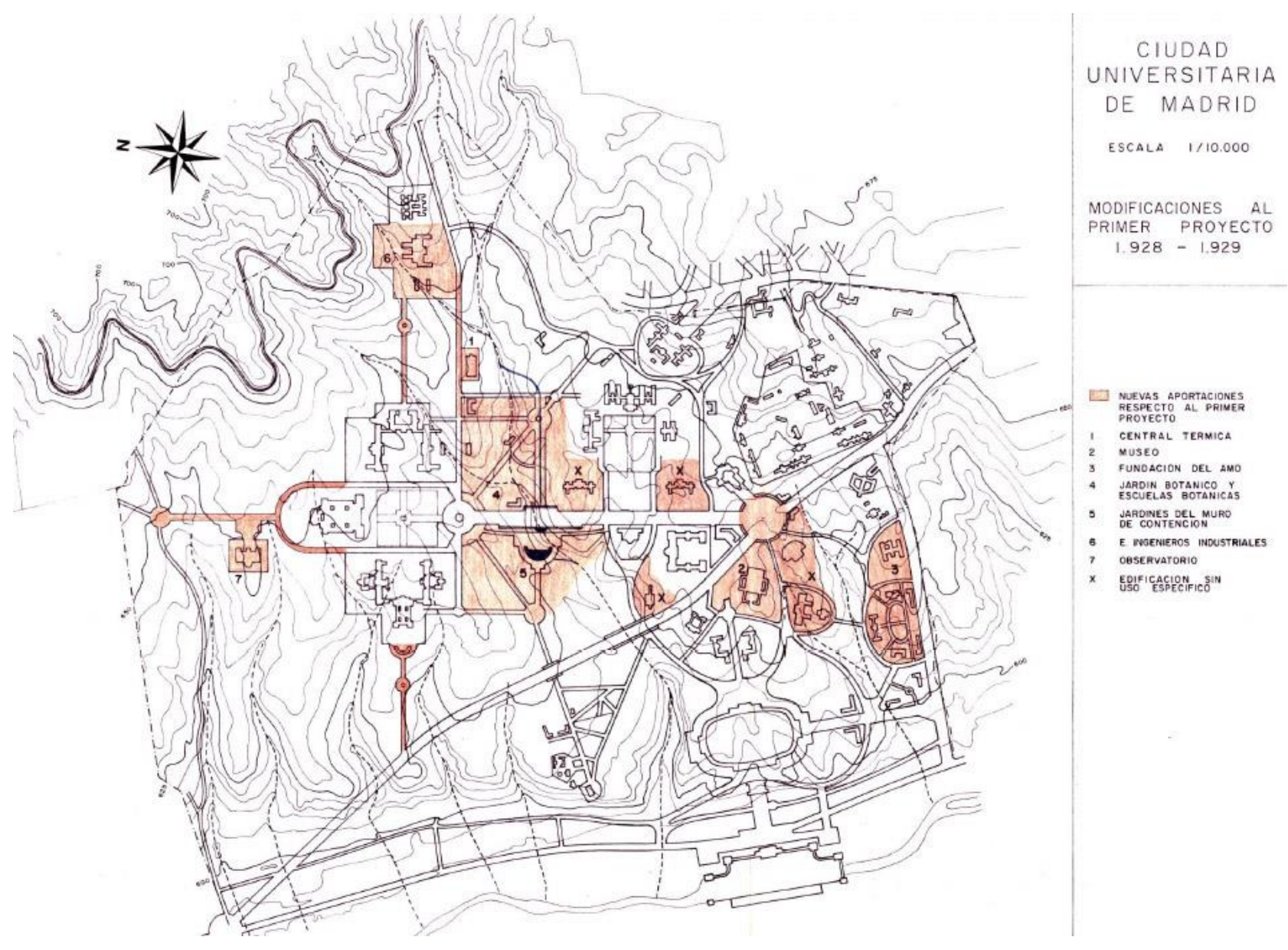

Imagen 5: Modificaciones al primer proyecto urbanizador. Se aprecia la situación de La Fundación del Amo en el número 3.

Imagen 6: Plano en planta de la Fundación del Amo donde se puede ver el esquema en $\mathrm{H}$.

Imagen 7: Vista fachada principal de la Fundación del Amo, primer proyecto residencial en la Ciudad Universitaria.
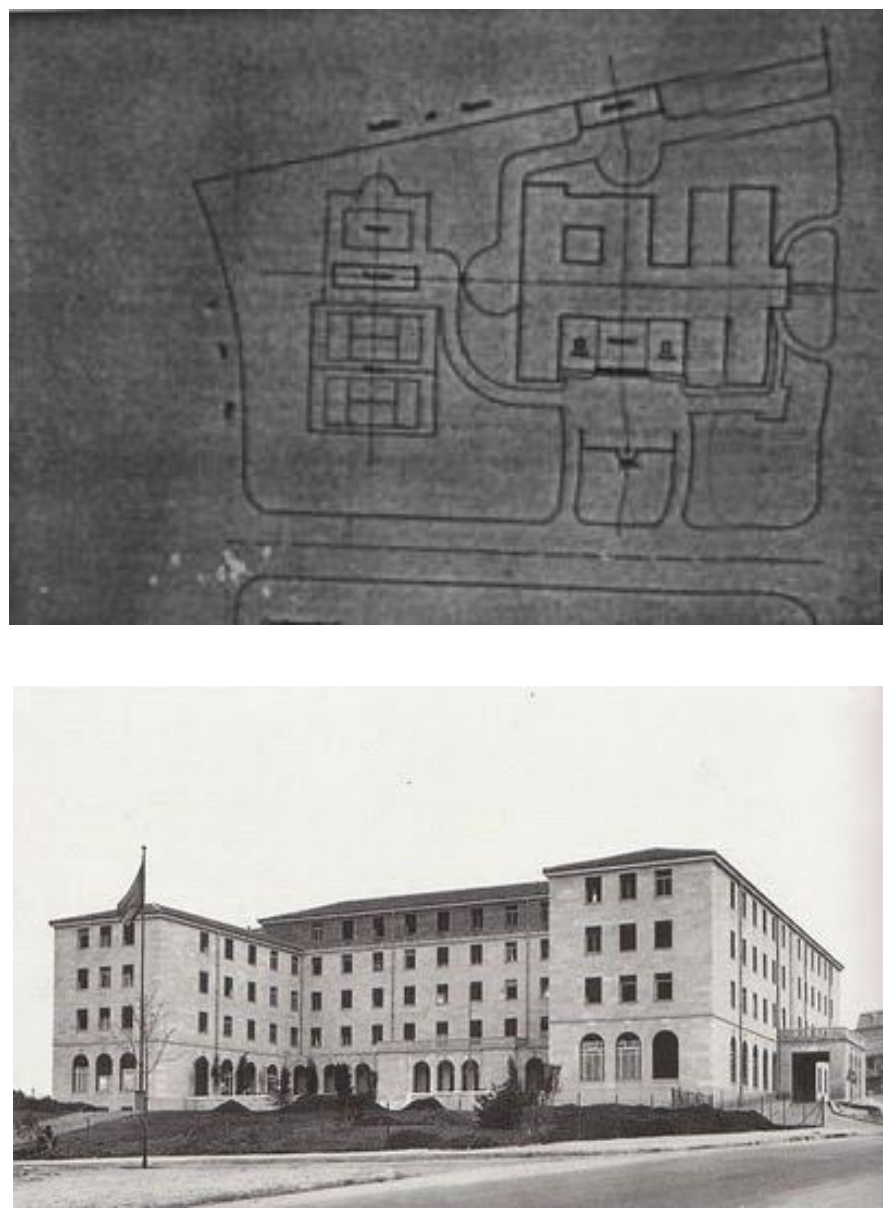

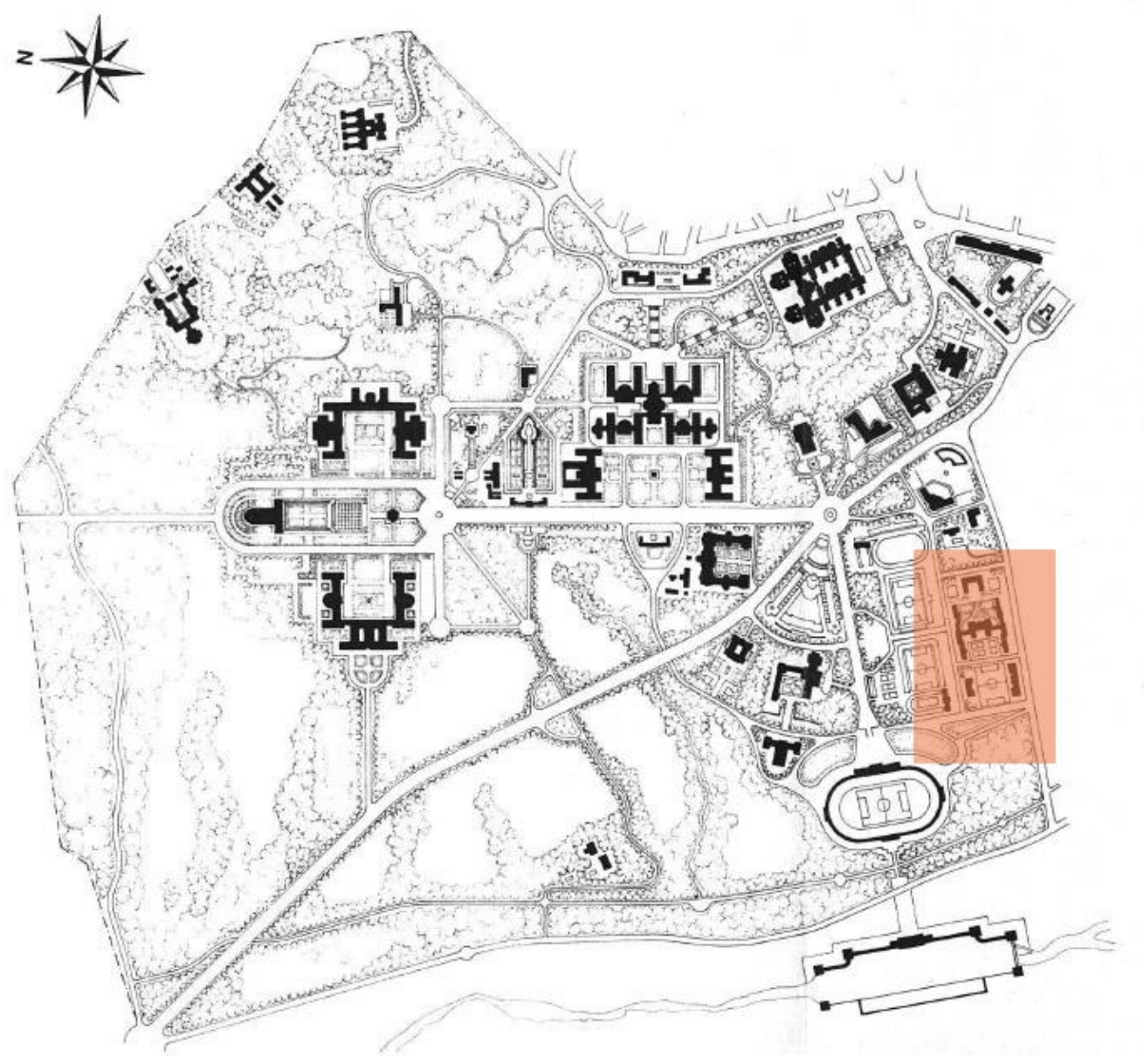

CIUDAD

UNIVERSITARIA

DE MADRID

ESCALA $1 / 10.000$

PLAN DE CONUUNTO 1943

Zona residencial

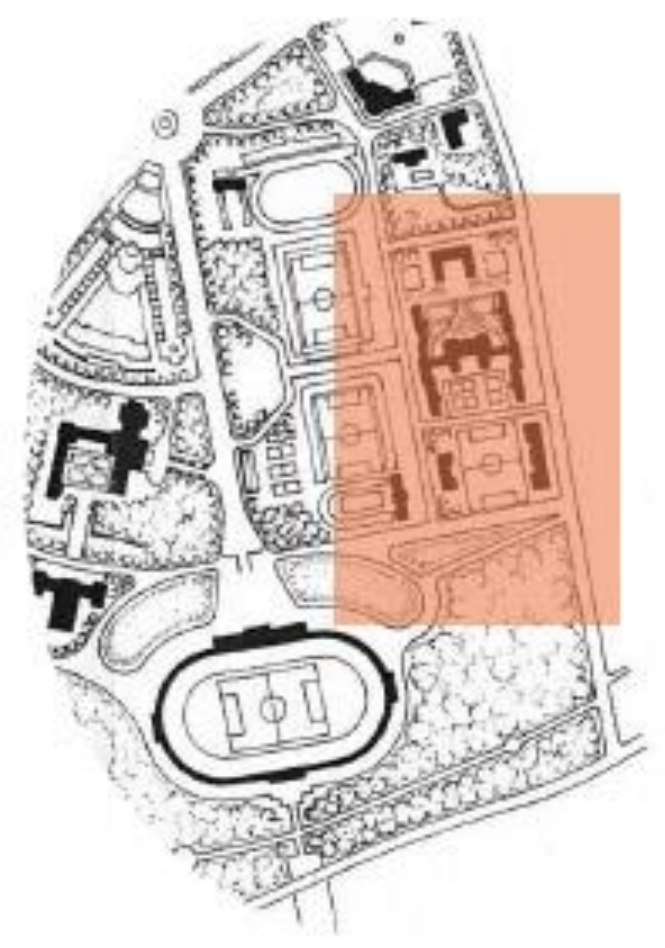

Imagen 8: Plan General de Conjunto de la Ciudad Universitaria en 1943.

Imagen 9: Detalle ampliado de la implantación de la nueva sede de La Residencia de Estudiantes proyecta por Luis Lacasa. 


\section{EL COLEGIO MAYOR XIMÉNEZ DE CISNEROS. LUIS LACASA Y JAVIER BARROSO. Hacia la segregación funcional especializada (1942)}

Este es un complejo formado por los Colegios Mayores Nebrija, Cisneros, Menéndez Pelayo y Covarrubias. Son el resultado del desdoblamiento de la antigua sede de La Residencia de Estudiantes proyectada por Luis Lacasa.

Son los primeros Colegios Mayores, junto con la Fundación del Amo, que se proyectan en la Ciudad Universitaria. Su situación viene condicionada por el planeamiento de López Otero, que dispuso esa zona para las residencias universitarias, como se ha visto en las zonificaciones anteriores, por su proximidad y buena comunicación con el casco urbano madrileño. Después de la guerra, con la destrucción del Instituto de Higiene, la zona se amplió hacia el suroeste ${ }^{31}$.

El proyecto original de Luis Lacasa incluía en su programa dos grupos de dormitorios y unos pabellones centrales con servicios comunes y vivienda independiente para el director. Todo ello estaba acabado en 1935, pero la destrucción de la guerra apenas dejó en pie la estructura de los bloques de dormitorios, pues ambos pabellones centrales quedaron tan dañados que inevitable su casi total derribo.

Javier Barroso retomaría el proyecto en 1941 y haría sobre él unas sustanciales variaciones. Dicho proyecto queda terminado en 1943. Hoy el conjunto son los colegios Mayores Cisneros, Nebrija Covarrubias y Menéndez Pelayo que se reparten cada uno la mitad de los dos antiguos pabellones centrales y el ala de dormitorios correspondiente.

Entretanto, la Residencia de Estudiantes pasa a llamarse Residencia "Jiménez de Cisneros", estando aún en la sede de la calle Pinar de Madrid.

El conjunto conserva el aire racionalista del proyecto original de Lacasa, muy en consonancia con los edificios llevados a cabo en la Ciudad Universitaria durante el periodo republicano.

Los dormitorios se alojan en dos grandes bloques de desarrollo longitudinal que en el proyecto primitivo se distribuían en un esquema de doble crujía, con pasillos al norte y habitaciones al sur. En la reconstrucción de Barroso se optó por sacrificar la orientación ideal adoptando el sistema de pasillo central y habitaciones a ambos lados. Otra innovación, por parte de Barroso, son las galerías de paso que comunican bloques de dormitorios y pabellones centrales, 
con el objeto de que los estudiantes no tengan que salir al aire libre para utilizar los servicios comunes.

Todos los edificios son de ladrillo visto y guardan la mayor sencillez de líneas. La decoración de fachadas se reduce a las impostas que marcan la horizontalidad y a los recercados de las ventanas. 

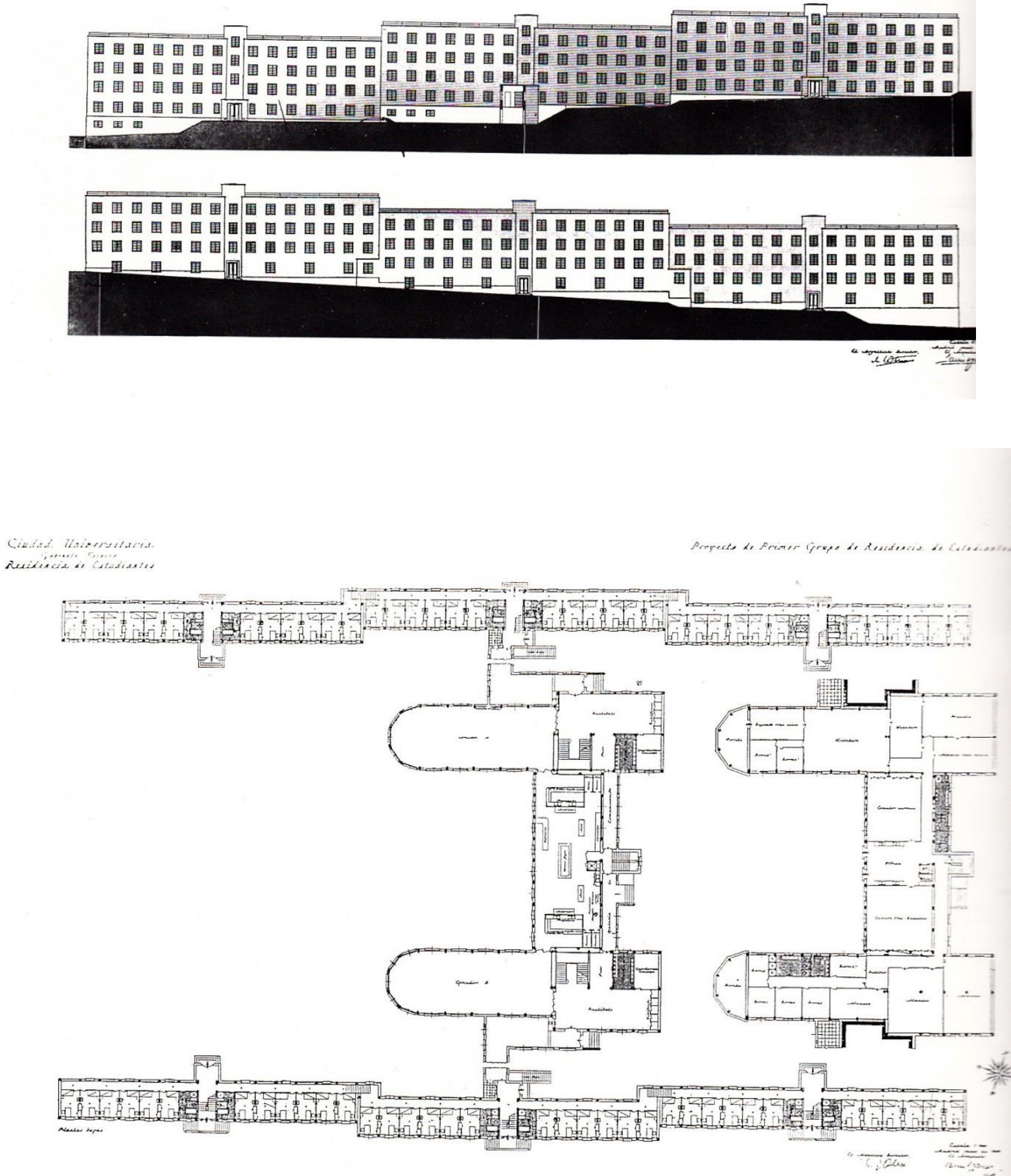

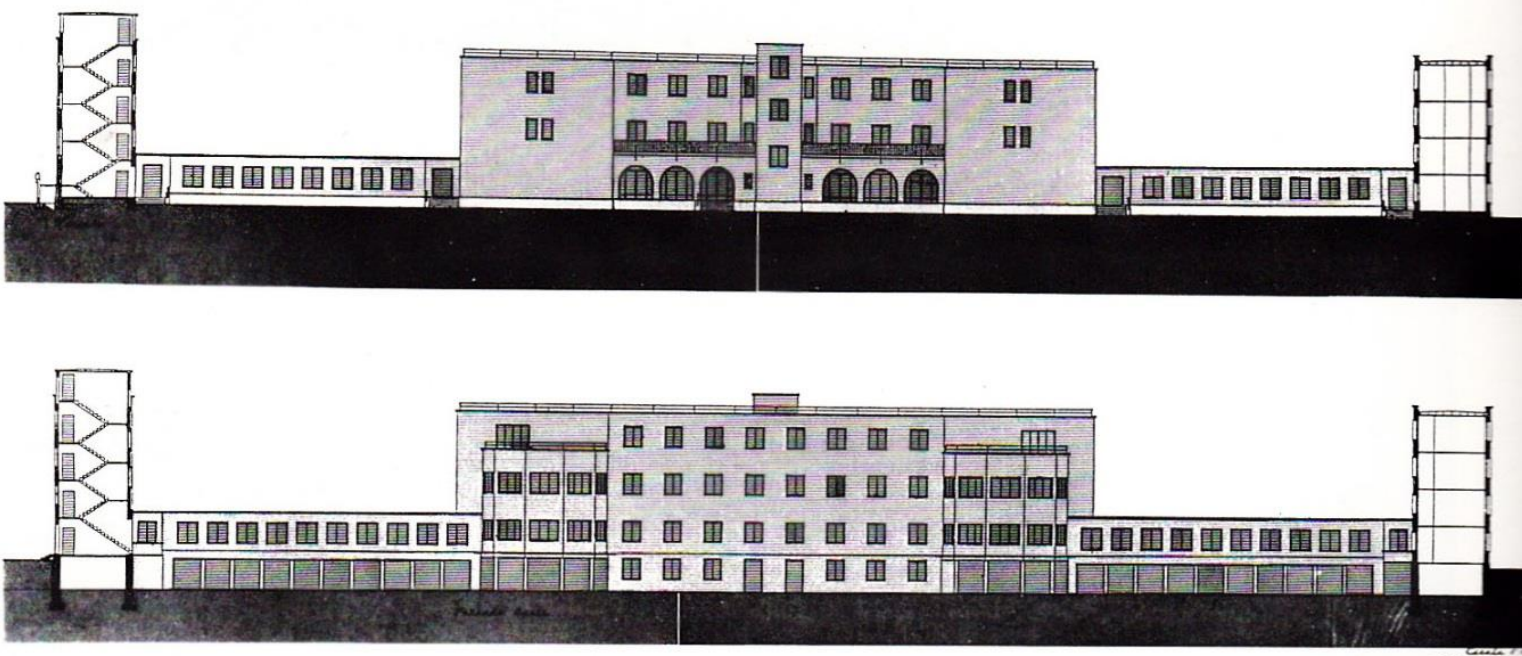

arritam

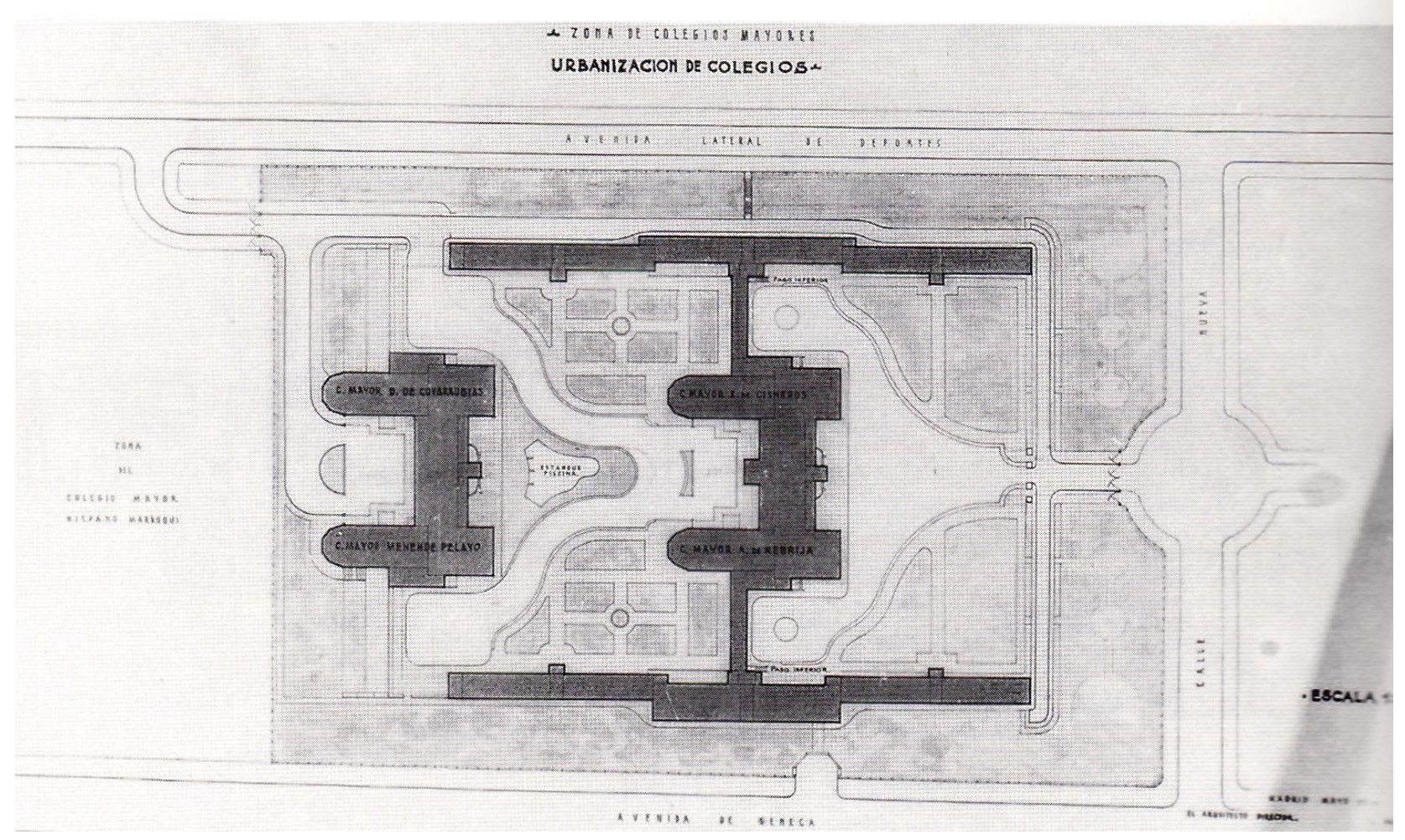

Imagen 12: Sección transversal del conjunto

Imagen 13: Planta de la urbanización de los Colegios Mayores Covarrubias, Menéndez Pelayo, Cisneros y Nebrija. Se aprecia la inclusión en proyecto del tratamiento de las zonas exteriores como espacios de relación 


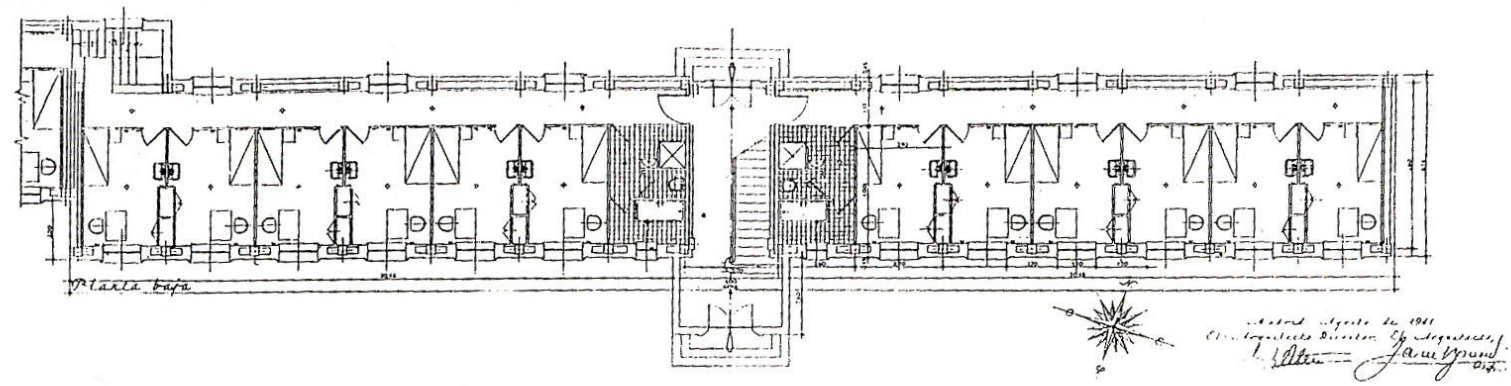

Ciudad Universitaria

Retidescia de Eicrico
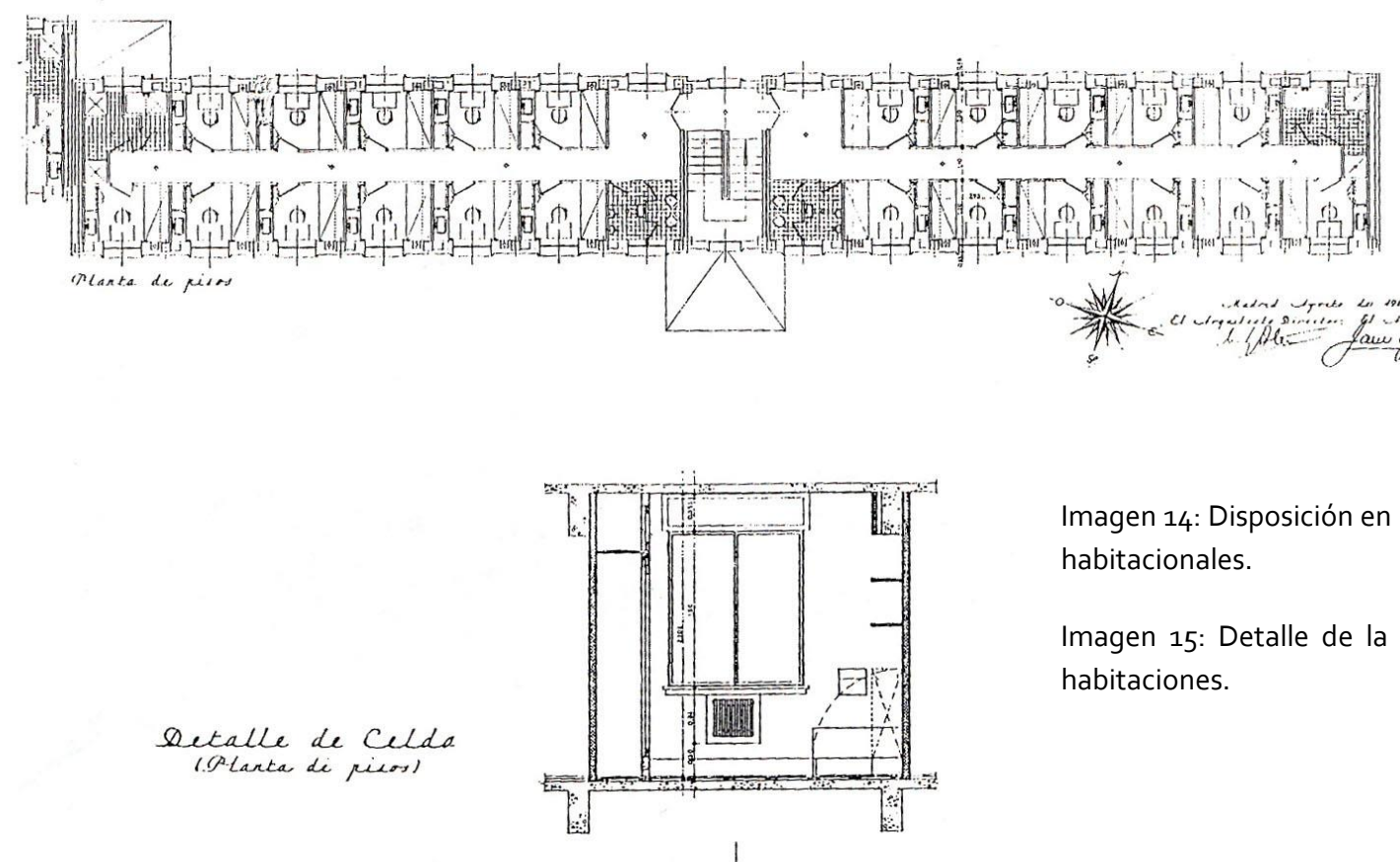

Imagen 14: Disposición en planta de los bloques habitacionales.

Imagen 15: Detalle de la configuración de las habitaciones.
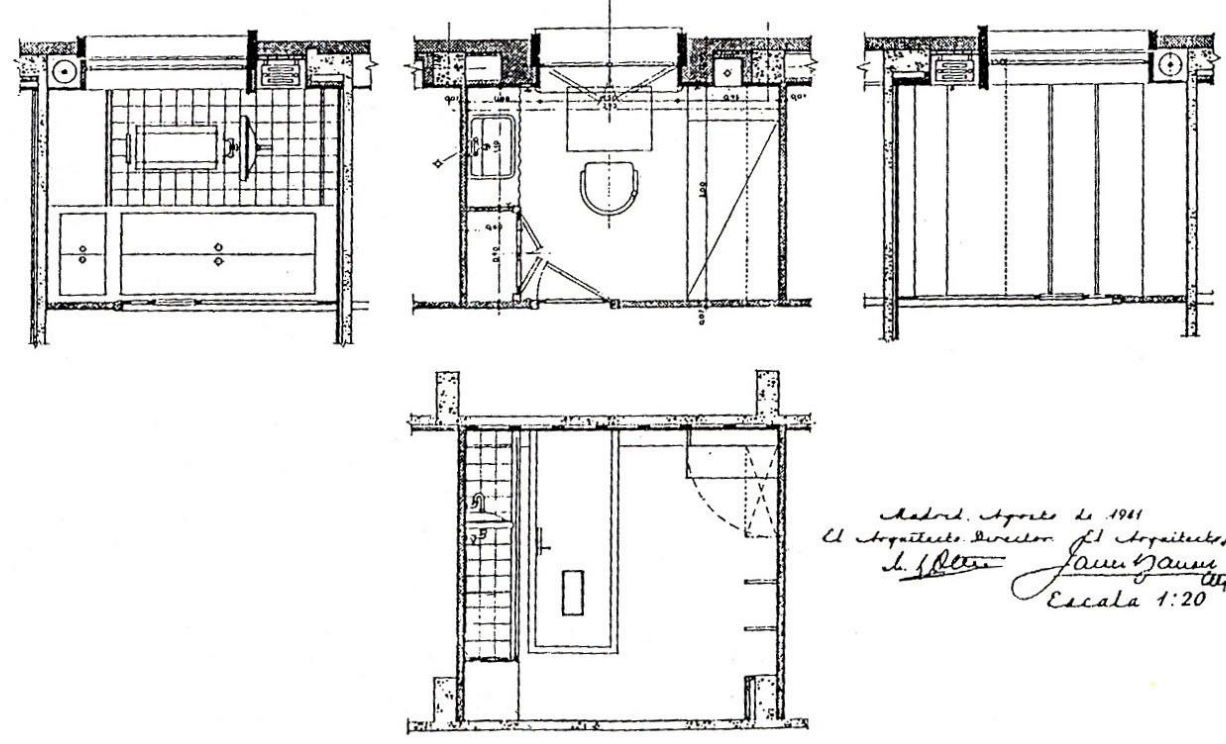

chend trate 4 sol

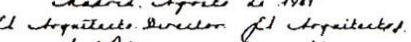
L.1Rer Oam Samm 

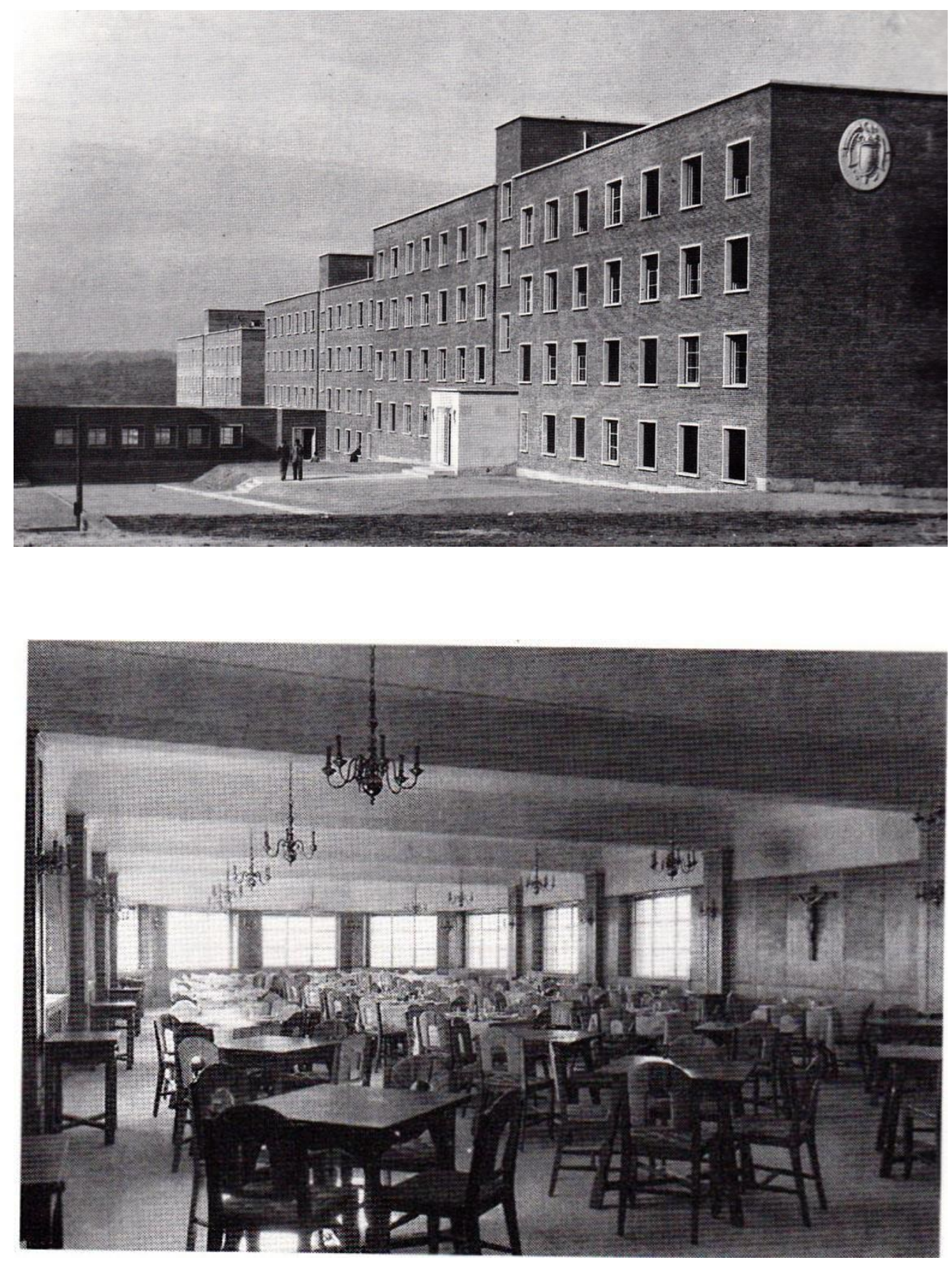

Imagen 16: Residencia de Estudiantes después de su reconstrucción.

Imagen 17: Residencias de Estudiantes. Colegio Mayor Cisneros. Comedor en los años cuarenta. 


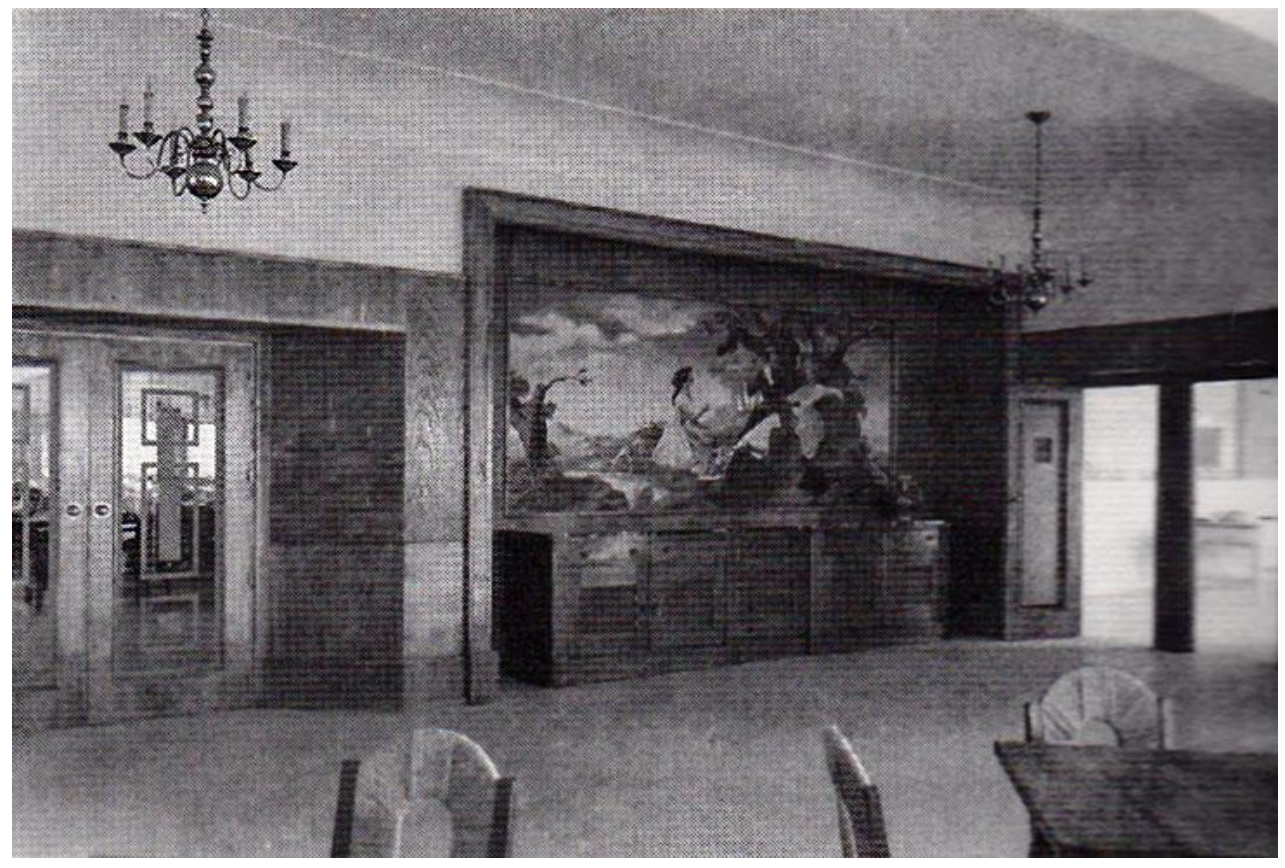

Imagen 18 : Residencias de estudiantes. Colegio Mayor Cisneros. Comedor en los años cuarenta.

Imagen 19: Vista actual de las edificaciones, donde se puede ver la pasarela unión de los bloques.

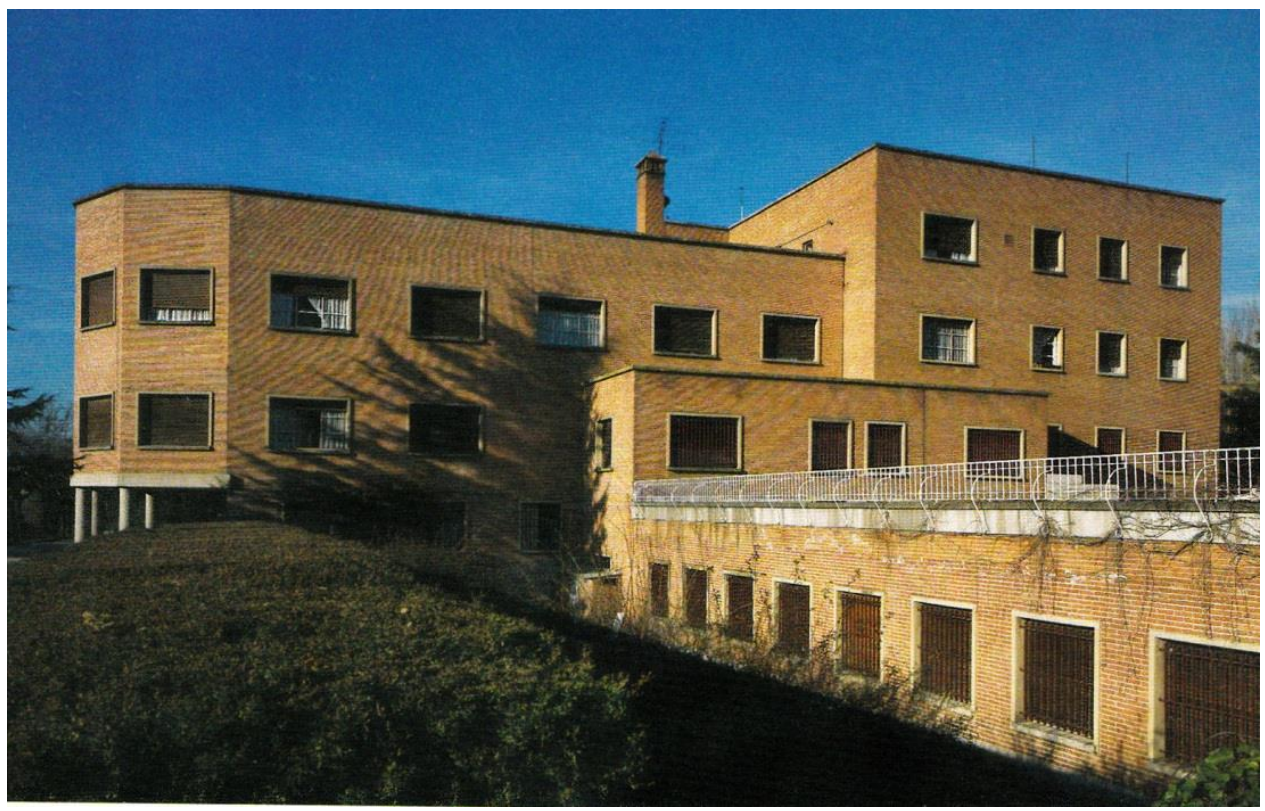


458| COLEGIOS MAYORES DE LA CIUDAD UNIVERSITARIA DE MADRID Y LA ARQUITECTURA MODERNA 
COLEGIOS MAYORES DE LA CIUDAD UNIVERSITARIA DE MADRID Y LA AROUITECTURA MODERNA

\section{BLOQUE IV}

\section{IV.2 DIMENSIÓN URBANO-EDILICIA.}

El emplazamiento colegial en la primera Ciudad Universitaria de Europa.

El Colegio Mayor Ximénez de Cisneros. Luis Lacasa y Javier Barroso. Hacia la segregación funcional especializada.(1942) 
460| COLEGIOS MAYORES DE LA CIUDAD UNIVERSITARIA DE MADRID Y LA ARQUITECTURA MODERNA 


\section{COLEGIO MAYOR NUESTRA SEÑORA DE GUADALUPE. LUIS FEDUCHI. Entre el historicismo y la modernidad (1947)}

Cuando terminó la reconstrucción del Colegio Ximénez de Cisneros, visto en el capítulo anterior, la Ciudad Universitaria tuvo su reestreno el 12 de octubre de 1943, en una conmemoración especial del Día de la Raza"32.

El Colegio Mayor Nuestra Señora de Guadalupe fue creado por fundación 33 , tal y como ocurría en los antiguos colegios españoles de la edad media. Gozaba del patrocinio de una institución ajena a la Universidad. En este caso el patrocinador fue un organismo del Estado Español, el Instituto de Cultura Hispánica, creado expresamente para dirigir la política de acercamientos con Hispanoamérica y estrechar los lazos culturales que unían a la comunidad iberoamericana (entonces llamada hispánica).

La primera sede, de forma provisional, se estableció en las proximidades de la Plaza de la Moncloa, pórtico de entrada a la Ciudad Universitaria, donde se realizaban los trabajos de reconstrucción tras devastación sufrida por todo el complejo durante la Guerra Civil. Concretamente en la calle Donoso Cortés, número 65. Se situó en uno de los dos edificios gemelos de viviendas sitos en esta calle. Éste tuvo que ser adaptado a su nuevo uso y acondicionados para crear una capacidad de go plazas habitables, más la vivienda del Director. El arquitecto encargado de dicha rehabilitación es Luis Martínez Feduchi. El otro edificio, el número 63, fue destinado a residencia de estudiantes procedentes de Europa del Este ${ }^{34}$, desplazados de sus países desde que habían caído bajo la influencia comunista, con el nombre de Colegio Mayor Santiago Apósto 35 .

Los procedimientos para dotar al Colegio de un edificio propio en la Ciudad Universitaria de Madrid, en la que es su actual sede, comenzaron prácticamente desde su fundación. El Ministro de Asuntos Exteriores, como presidente del Patronato del Instituto de Cultura Hispánica, solicitó a la Junta de la Ciudad Universitaria una parcela para ese fin $^{36}$. El Rector de la Universidad, en nombre de la Junta, concedió un terreno de 9.000 metros cuadrados entre la antigua de la Fundación del Amo (destruida durante la Guerra Civil) y el futuro Colegio José Antonio. Estando esta parcela situada en la franja destinada a residencias universitarias del proyecto urbanístico primigenio. Inicialmente, sin embargo, los dirigentes de la institución de este colegio habían previsto reservar una parcela para cuatro colegios mayores hispanoamericanos en los terrenos que se 
encuentran entre las sedes del Instituto de Cultura Hispánica, del Museo de América y el Hospital Clínico, de manera que se creara en esa esquina de la Ciudad Universitaria un conjunto arquitectónico compacto y dedicado íntegramente a resaltar los vínculos culturales e intelectuales con Hispanoamérica ${ }^{37}$.

El nuevo edificio se situaría finalmente en la zona sur, donde se empieza a constituir un verdadero "archipiélago residencial" dentro de la Ciudad Universitaria.

Este proyecto es encargado de nuevo a Luis Martínez Feduchi.

El esquema del edificio es rectangular, existiendo un patio interior de forma claustral, sobresaliendo dos pabellones en la fachada principal. En el eje principal de la planta baja, se dispone el vestíbulo de entrada, el salón de actos y la capilla; en uno de los lados se distribuye la cocina y un amplio comedor, y en el otro, las salas de espera y seminarios. Uno de los pabellones se destinó a vivienda, y el otro a los servicios de administración y secretaría. En las plantas superiores se sitúan los dormitorios para los estudiantes.

La fachada principal consta de cinco alturas. La parte frontal de planta baja se realiza en piedra, y se accede a ella a través de una triple puerta, situada en el centro, que presenta un dovelaje muy marcado. A ambos lados, las seis ventanas forman un conjunto con la entrada, además tienen el mismo tratamiento en cuanto a forma y material. Las plantas segunda, tercera y cuarta, presentan un tratamiento a base de ladrillo rojo. Éste, sólo se interrumpe en la ventana de la balconada principal, al remarcarla con pilastras y frontón partido, motivo que puede resultar un tanto manierista. En el proyecto de Martínez Feduchi, este motivo se repetía también en las ventanas en las ventanas laterales del primer piso, pero no se llegaron a hacer así. Por último, la planta quinta es abuhardillada, y en ella se vuelve a utilizar la piedra como material de revestimiento.

La obra se puede describir como una arquitectura sobria, con una planta racional y una meticulosa organización, que se puede dar a entender que pretende aunar tradición y modernidad. 


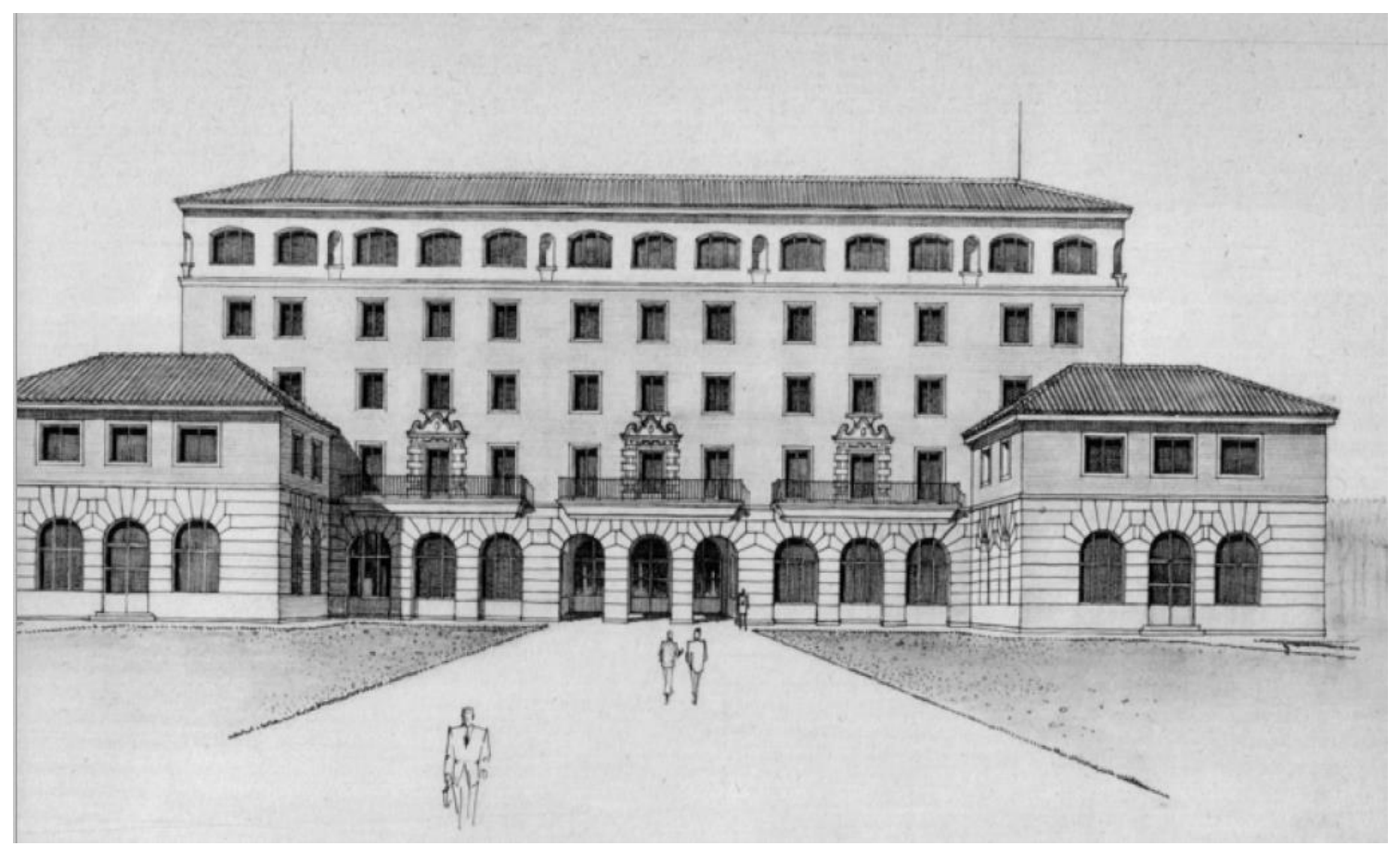

Imagen 20 : Vista alzado del Colegio Mayor Nuestra Señora de Guadalupe.

Imagen 21: Planta del Colegio. Responde a un tipo rectangula/claustral más propio de épocas préteritas.

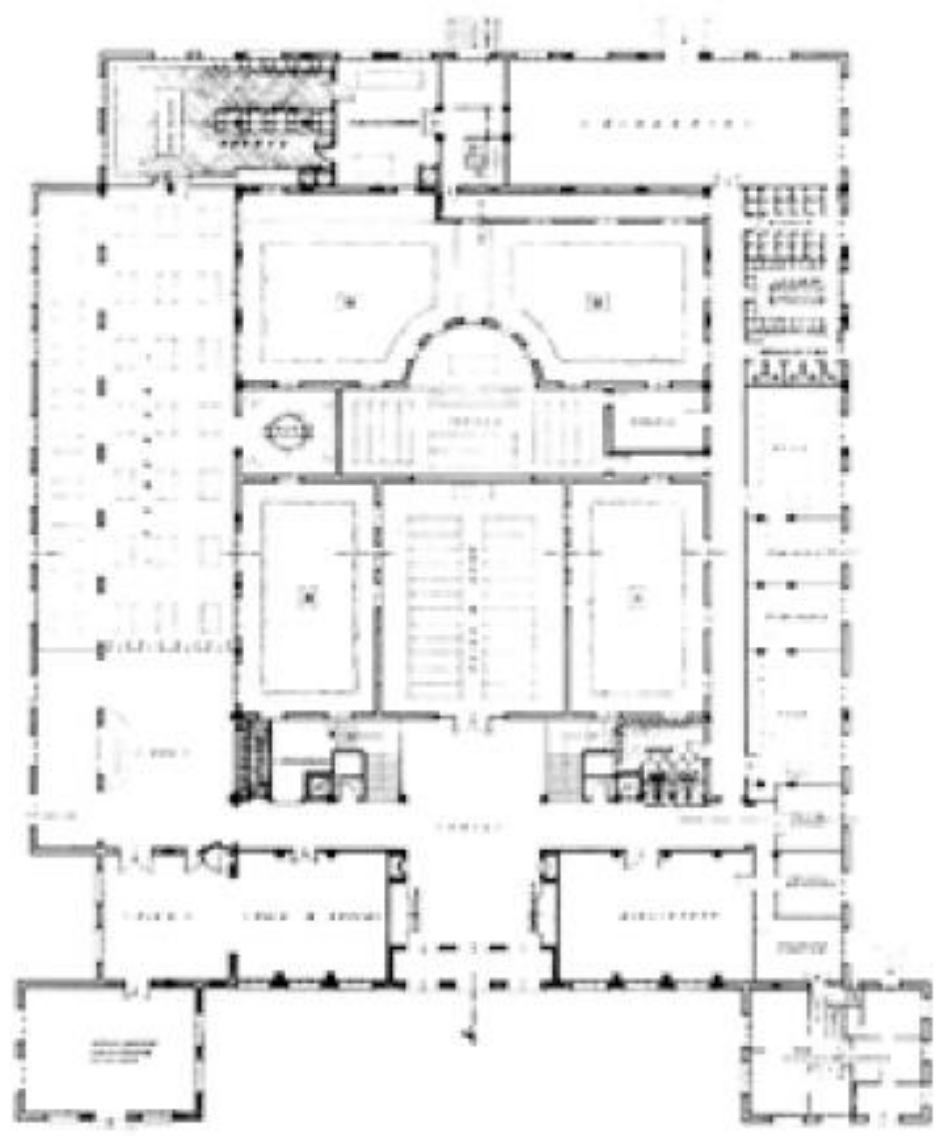



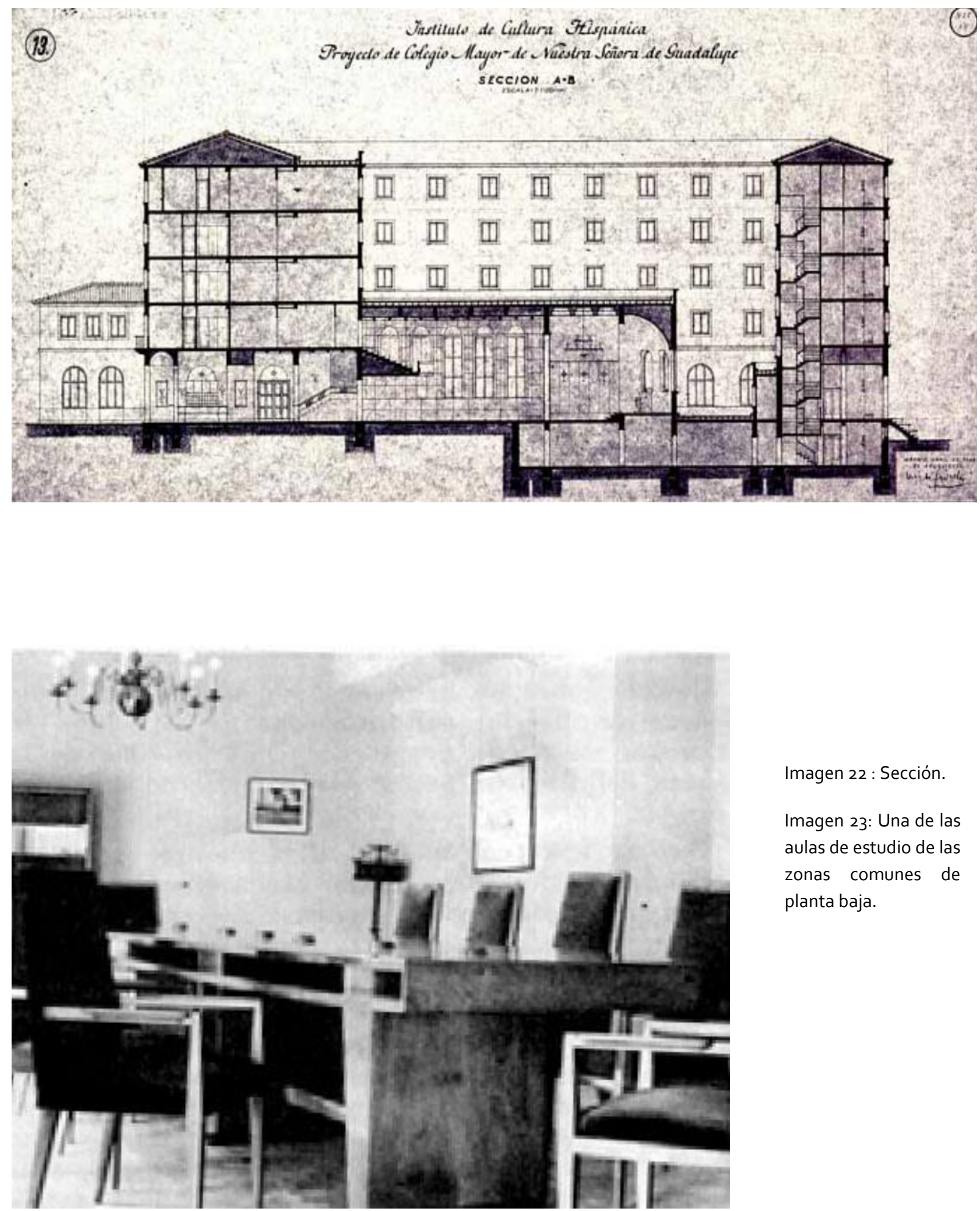

Imagen 22 : Sección.

Imagen 23: Una de las aulas de estudio de las zonas comunes de planta baja. 

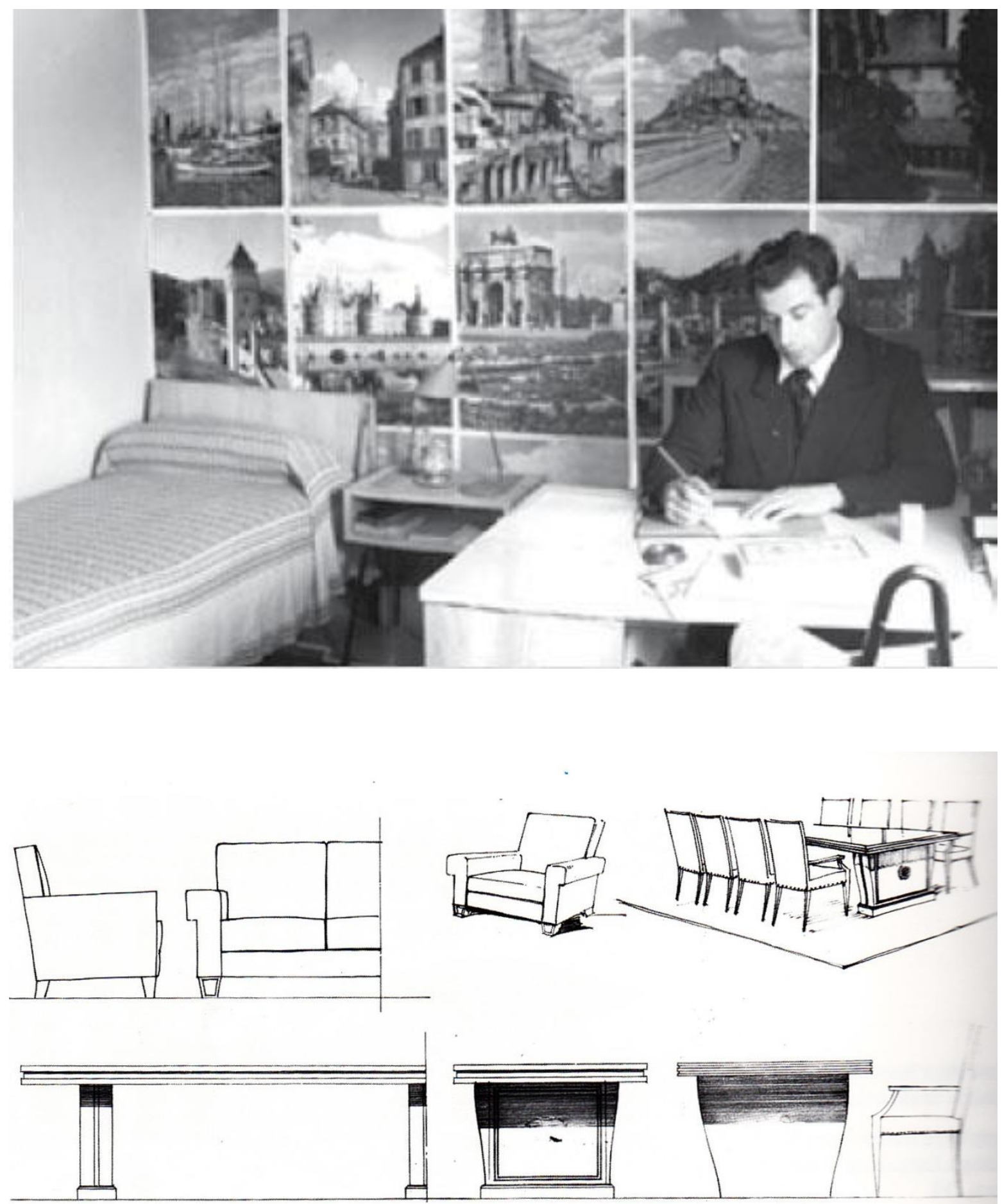

Imagen 24 : Habitación de estudiante.

Imagen 25: Mobiliario creado y diseñado por Luis Martínez Feduchi para el Colegio. 


\section{COLEGIO MAYOR AQUINAS. JOSÉ MARÍA GARCÍA DE PAREDES}

Y RAFAEL DE LA HOZ ARDERIUS. Premio de Arquitectura al

desglose espacial en plataformas (1957)

Constituye la primera etapa de un complejo programa de edificios que constituían el Instituto Angelicum de los dominicos: un centro universitario de investigación, capilla, pabellón de servicios generales, instalaciones deportivas y club universitario.

El plan de repoblación a que fue sometida la zona, proporciona al conjunto una especial integración en el paisaje que suaviza la posible dureza de la formulación arquitectónica ${ }^{3}$. Esta integración se extiende a los interiores, en los que parece que se tiende siempre a buscar grandes cerramientos de cristal.

Construido sobre una ladera bien pronunciada en dirección norte-sur y siguiendo el hilo conductor del "diálogo con el entorno" es diseñada cada una de las partes que conforman el edificio. Éste es representativo de la culminación de la segregación plena del programa según funciones, que cabe interpretar como influencia directa de la Bauhaus. Formado por varios pabellones interrelacionados y rodeados de jardines, resueltos a base de plataformas, se compone de: residencia universitaria y religiosa, capilla, servicios generales e instalaciones deportivas, con lo que se consigue un clima universitario de convivencia y trabajo. La arquitectura del Aquinas es fruto de una estrecha colaboración entre los arquitectos y los dominicos encargados de configurar la vida del Colegio Mayor. El objetivo esencial del proyecto era lograr que el edificio respondiera a dos ideas fundamentales; la primera, de clara caracterización miesiana, supone la creación de espacios diáfanos, capaces de ambientar el espacio de convivencia y apertura que debe caracterizar la vida del estudiante residente. A la realización de este primer propósito se destinaron las dos primeras plantas del edificio.

El bloque vertical es el elemento principal y está destinado a la residencia de los alumnos. Tiene una planta dentada con espacio abierto continuo. Los espacios comunes de planta baja, en los que se encuentra el hall y cafetería, se abren al horizonte de la Dehesa de la Villa a través de un cerramiento continuo de cristal. La segunda idea consistía en conseguir de la arquitectura una colaboración eficaz para la creación de un espíritu de concentración y trabajo conforme a las características propias de la vida universitaria.

Sin embargo, las galerías de acceso, lugares de paso y conversaciones ruidosas no son el medio más idóneo para conseguir un ambiente de silencio e independencia en las habitaciones. Esto unido a la conveniencia de una equitativa orientación en lo que a luz 
y sol se refiere, darían origen al peculiar esquema que caracteriza la obra. Un plano situado en el eje heliotérmico se pliega sobre sí mismo, orientando así los planos parciales resultantes hacia el punto de máxima incidencia de la luz. La única escalera central se abre directamente a un paso exterior, traducción actual del clásico corredor de las casas de vecindad madrileñas, que da acceso a las habitaciones. La disposición de la fachada se ordena formando ángulos rectos, en uno de cuyos planos se encentra la puerta de acceso a la habitación y un gran ventanal por el que la luz invade el lugar de trabajo. El otro plano corresponde a un muro de cerramiento que aísla la habitación, dándole su habitual independencia. Esta estructuración arquitectónica y el ambiente de sobria y cómoda sencillez del interior acogen y favorecen el estudio, que junto con la convivencia constituyen el nervio de la vida colegial, objetivo de la nueva tendencia moderna donde la "escala social" empieza a cobrar una cierta importancia.

El conjunto mereció el premio nacional de Arquitectura del año 1956 y resulta una obra de especial repercusión en un momento en el que las corrientes de la arquitectura de vanguardia vuelven a manifestarse en la Ciudad Universitaria. 

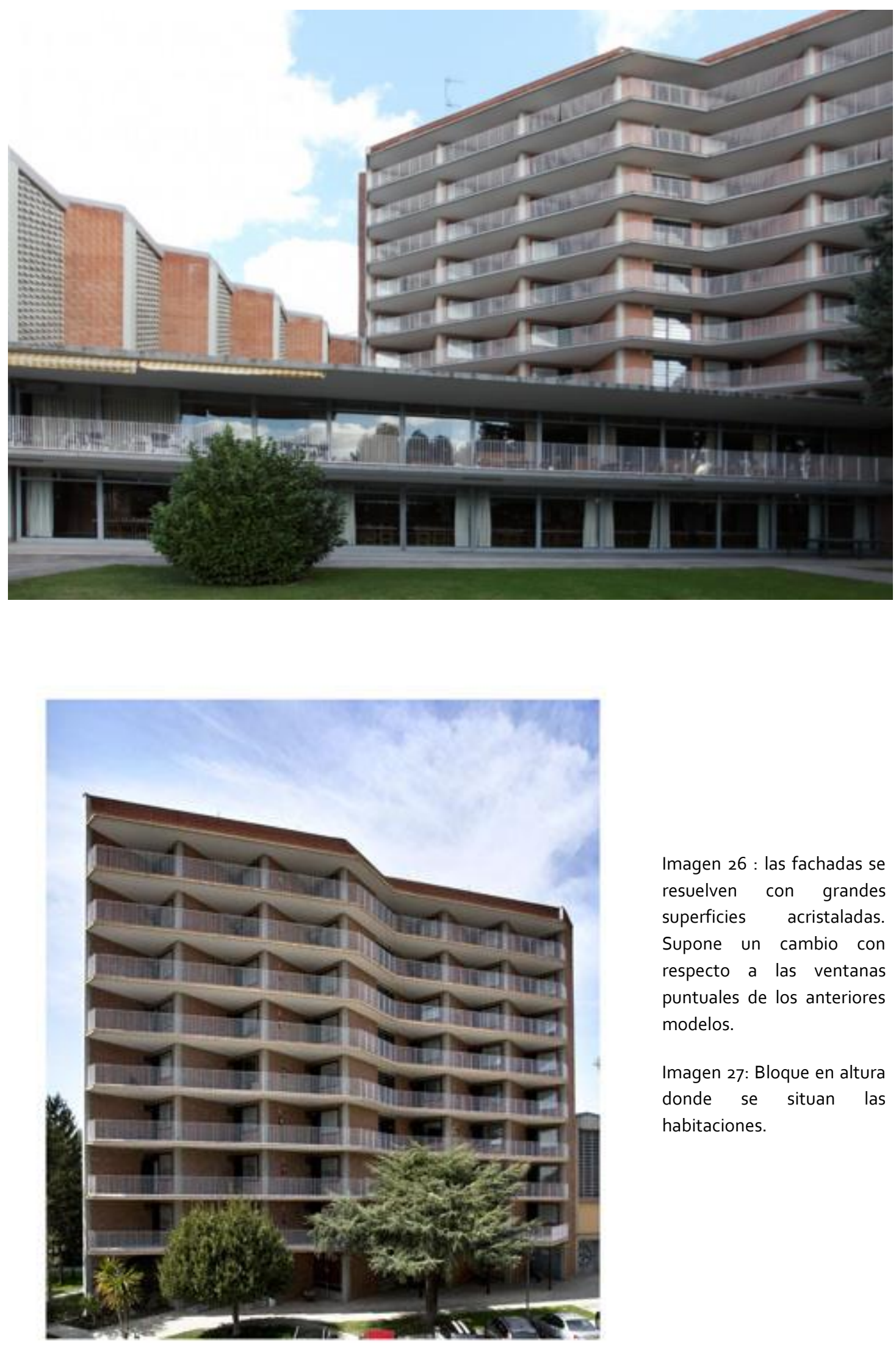

Imagen 26 : las fachadas se resuelven con grandes superficies acristaladas. Supone un cambio con respecto a las ventanas puntuales de los anteriores modelos.

Imagen 27: Bloque en altura donde se situan las habitaciones. 

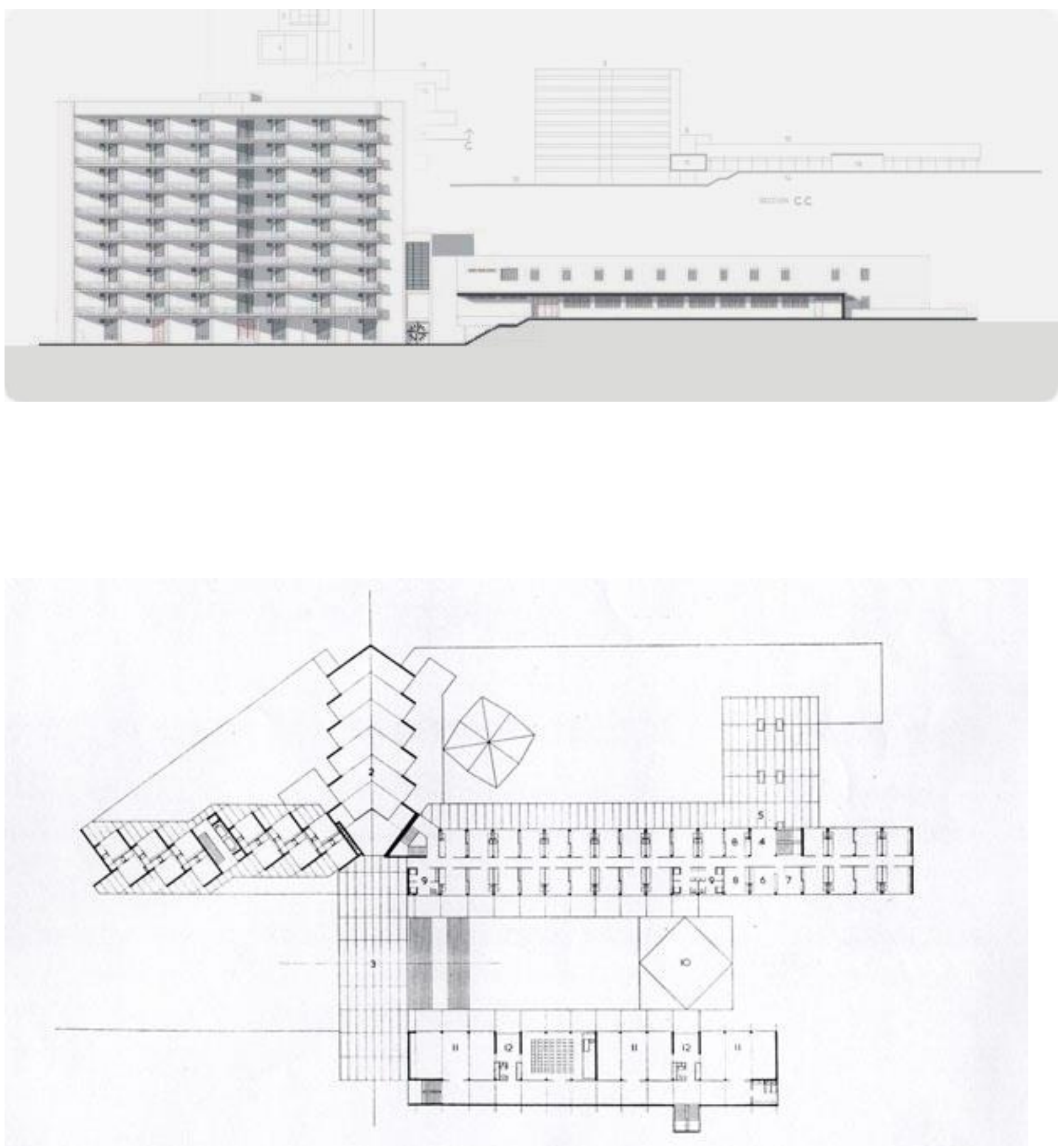

Imagen 28 : Alzado de la fachada principal.

Imagen 29: Planta del conjunto donde se puede apreciar la segregación plena según funciones.

Imagen 30: Modulo de habitación con baño.

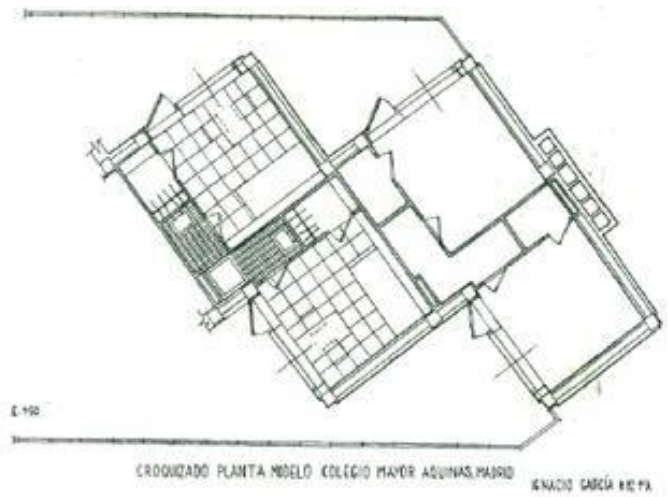



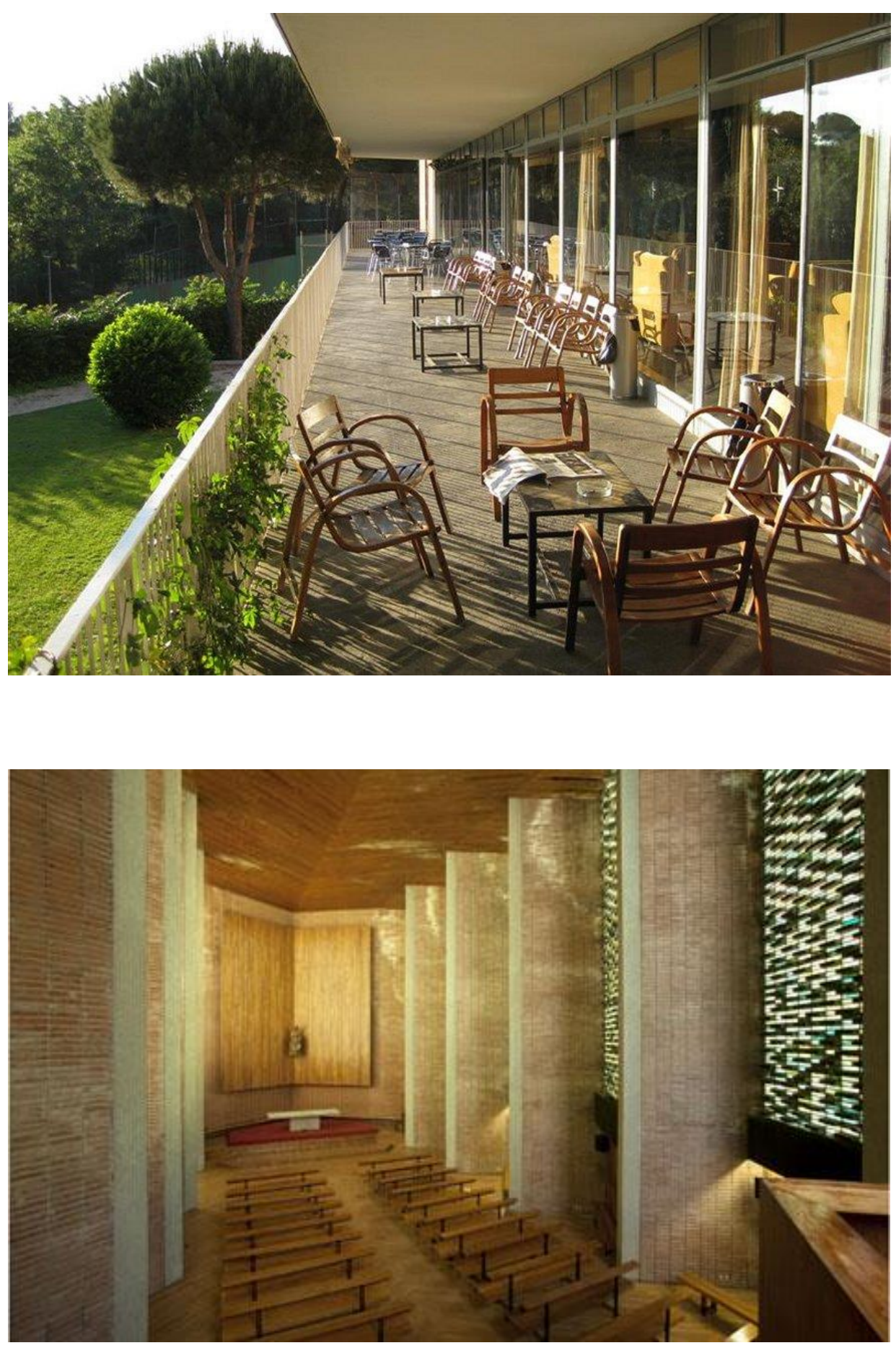

Imagen 31: Colegio Mayor Aquinas. "Diálogo" de los espacios interiores con el entorno natural exterior circundante a través de superficies acristaladas de suelo a techo.
Imagen 32 : La capilla es un cuerpo totalmente diferente del resto en cuanto a volumen y forma. La iluminación se produce por grandes superficies de vidrio. El escalonamiento de los paramentos verticales y el techo enfatiza la proyección de la mirada hacia el altar . 


\section{COLEGIO MAYOR JORGE JUAN. ALBERTO LÓPEZ DE ASIAÍN S. Y ALBERTO LÓPEZ DE ASIAÍN M. Rasgos nórdicos (1958)}

Con este colegio comienza la época desarrollista de colegios mayores dentro de la Ciudad Universitaria de Madrid.

Se realiza por encargo del Patronato de Casas de la Armada del Ministerio de Marina con objeto de dotar a los hijos de los marinos de guerra de un colegio donde residir durante sus estudios universitarios.

El programa incluye 120 plazas en habitaciones individuales.

La forma consiste en un bloque curvo de cuatro plantas con semisótano con vestíbulo y escaleras en el centro, del que parte un pasillo que distribuye la circulación hacia las dos alas. Adosado a la parte trasera de la zona de escaleras destaca el bloque casi ciego de la capilla y el salón de actos que, al disponerse sus entradas en las mesetas intermedias de la escalera, amplían su capacidad gracias a una solución tanto ingeniosa como económica.

En el sótano se concentran garaje, cocinas, almacenes y demás servicios del edificio. En la planta baja se localizan los servicios comunes, con amplio salón y comedor en el ala derecha que desbordan la línea del bloque traspasándolo de manera diáfana. Ambos están apenas separados por la galería de tránsito, pero desde todas partes son visibles los dos grandes ventanales con vistas al Parque del Oeste, a la casa de Campo y al jardín posterior.

Las habitaciones se distribuyen en las tres plantas superiores: todas ellas cuentan con un pequeño balcón y por medio de una cortina es posible separar la zona de la mesa de estudio de la del dormitorio propiamente dicho, que durante el día puede transformarse en un pequeño cuarto de estar gracias a los divanes convertibles en camas.

La curvatura del bloque obedece al hecho de buscar el sol naciente en las habitaciones de la fachada posterior, que de no haberse situado allí habrían obligado a doblar la longitud del edificio o el número de plantas. Esta solución, de curvar el edificio para buscar una orientación determinada, recuerda a la adoptada por Alvar Aalto en la Baker House en el campus de Harvard.

Las fachadas, que manifiestan claramente el módulo, son de ladrillo visto y planchas de fibrocemento blanco sujetas por armaduras metálicas, y en todo el diseño se ha cuidado de subrayar bien la linealidad del edificio y su limpieza de volúmenes. 
Este edificio, forma parte del grupo de construcciones que desde la segunda mitad de los años cincuenta empiezan la recuperación de la tradición moderna para la arquitectura de la Ciudad Universitaria. 


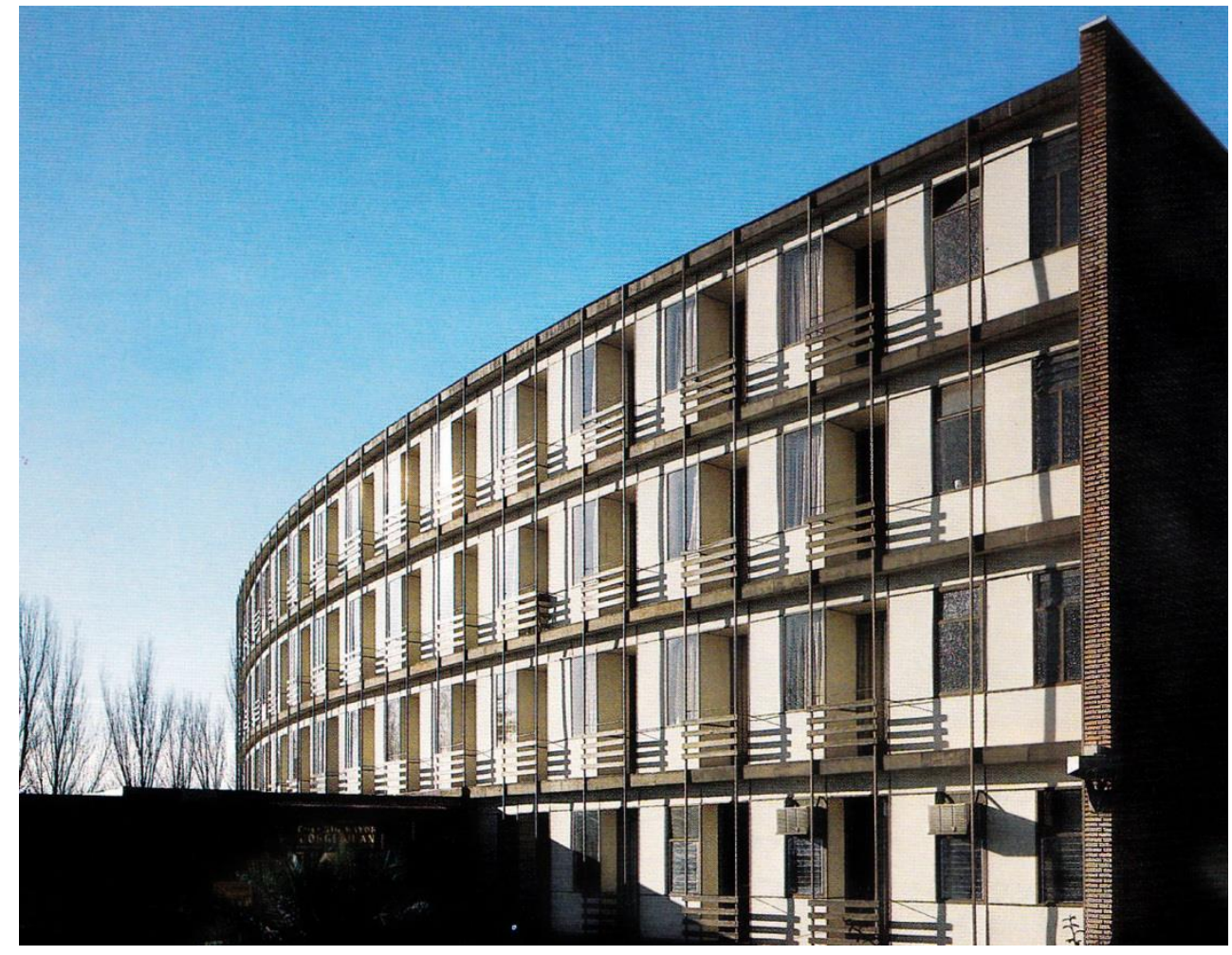

Imagen 33 : Fachada principal del colegio.

Imagen 34: Fachada posterior. En esta se encuentra el acceso al semisótano.

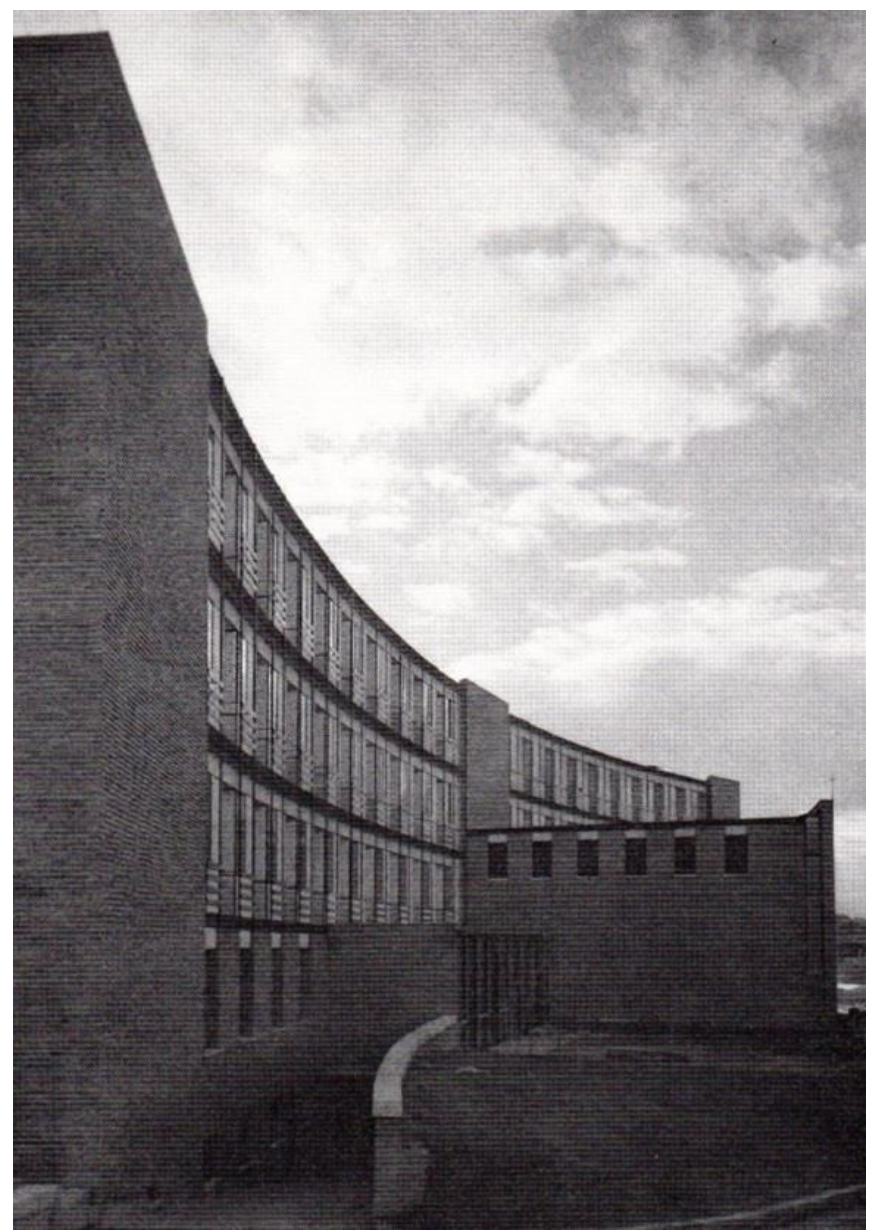



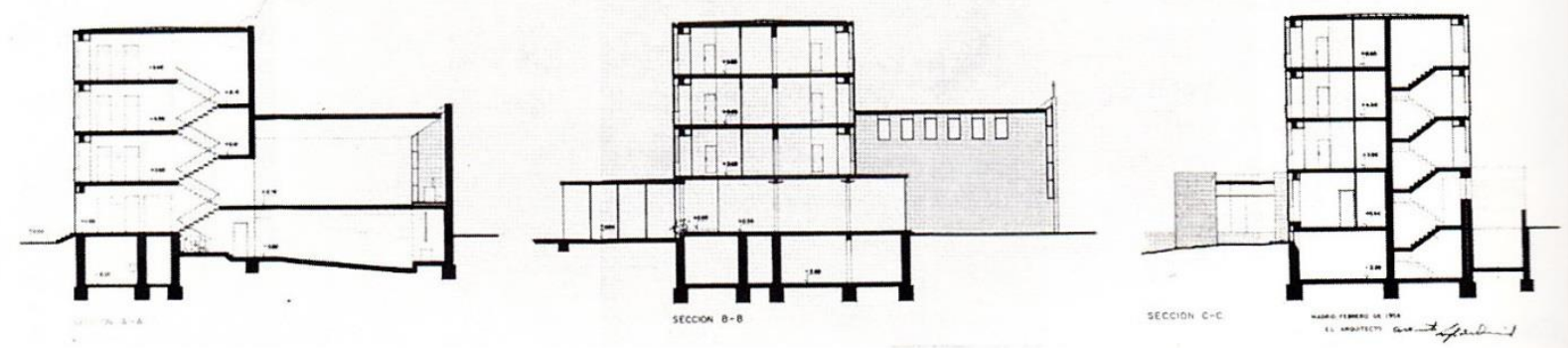

Imagen 28: Secciones del conjunto.

Imagen 29: Alzado principal.

Imagen 30: Vista del conjunto.
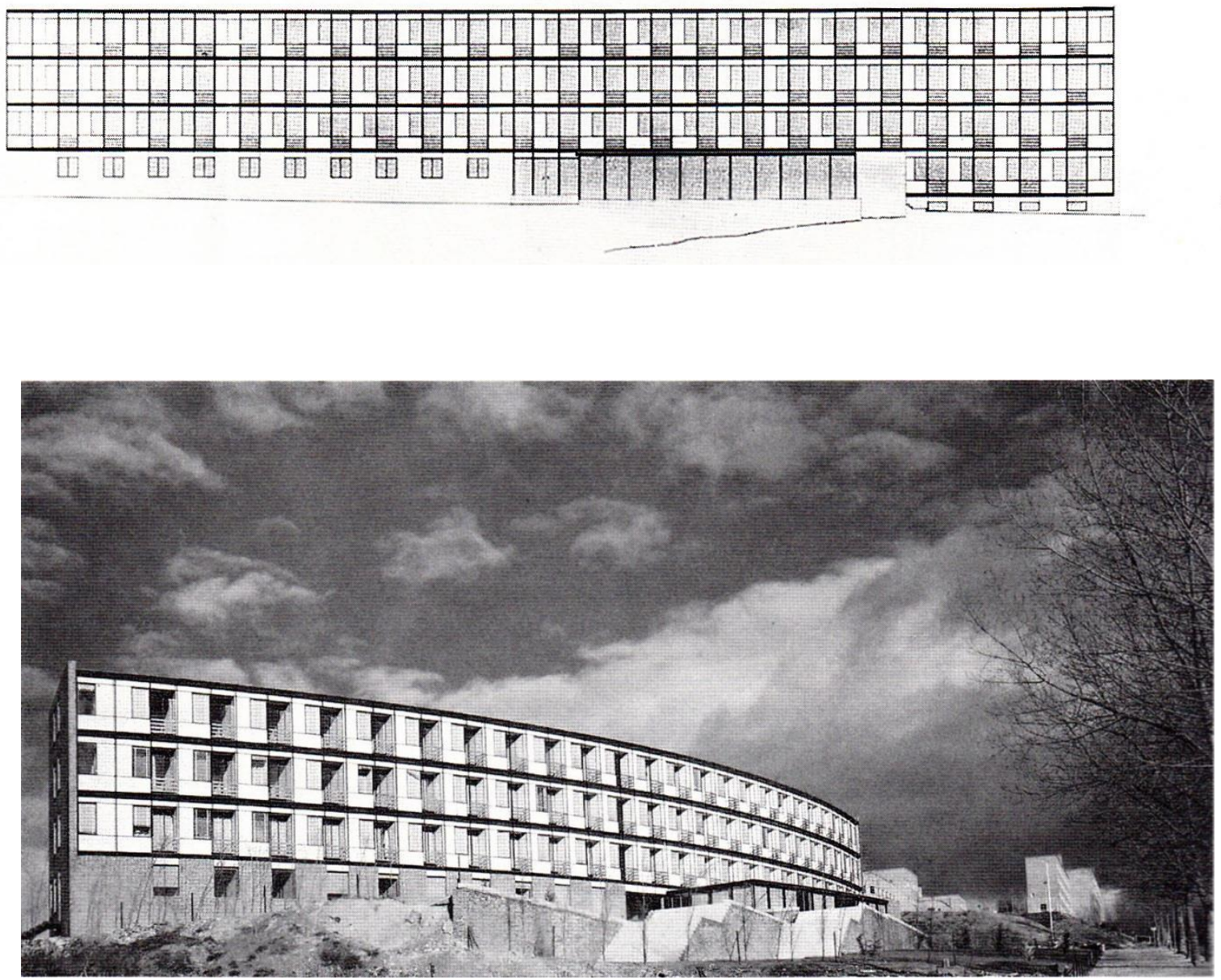


\section{COLEGIO MAYOR SAN AGUSTÍN. FRANCISCO DE ASÍS \\ CABRERO. La tradición retomada (1962)}

Se trata de un edificio característico del estilo de su autor que comparte casi todos los rasgos de eficacia y sencillez que distinguen su obra. Consecuentemente con ello, el propio Cabrero lo ha definido como "ejemplo de arquitectura social utilitaria"39.

Se compone de dos grandes núcleos. En el primero de ellos, de planta rectangular, se agrupan casi todos los servicios comunes del colegio y en él predominan los dos grandes espacios de la capilla y el salón de actos. En el segundo, un bloque longitudinal de cuatro plantas compuesto por cuatro rectángulos sucesivos y levemente escalonados, están los dormitorios, dispuestos en cada planta a ambos lados de un pasillo que atraviesa todo el bloque siguiendo los ejes longitudinales de cada uno de los rectángulos que lo integran.

Los núcleos de comunicación vertical se sitúan uno de los rectángulos extremos y cabe destacar, dentro de un esquema de distribución tradicional, el sutil juego del desplazamiento de los ejes del pasillo y su correspondencia con el movimiento de fachada ${ }^{40}$.

Esta correspondencia entre interior y exterior es característica de todo el edificio, y en general, en muchas de las obras de este autor, como eledificio del Periódico de Arriba ; y algunas posteriores, como el Pabellón de Cristal o la Escuela Nacional de Hostelería, ambos en Madrid.

Las cubiertas son de fibrocemento ${ }^{41}$ y todo el conjunto participa del estilo austero y racionalista del autor, muy en consonancia con la orientación estilística que, con sus diversas variantes, se da en muchos de los edificios que se están construyendo dentro del complejo residencial de la Ciudad Universitaria. 

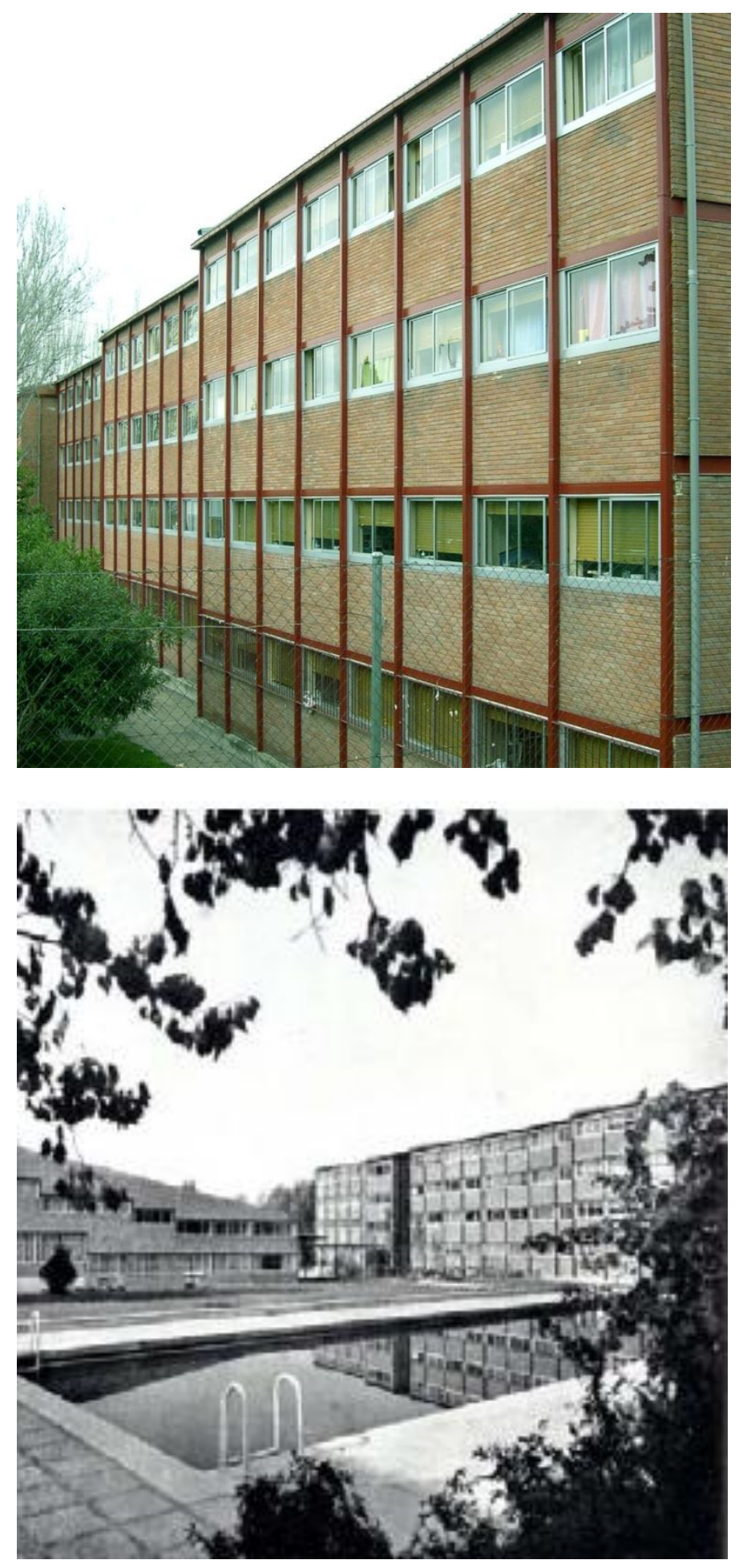

Imagen 35 : Fachada interior del Colegio San Agustín. Uso Tradicional de la fachada de ladrillo

Imagen 36: Espacio interior, donde se ubican las instalaciones deportivas.. 

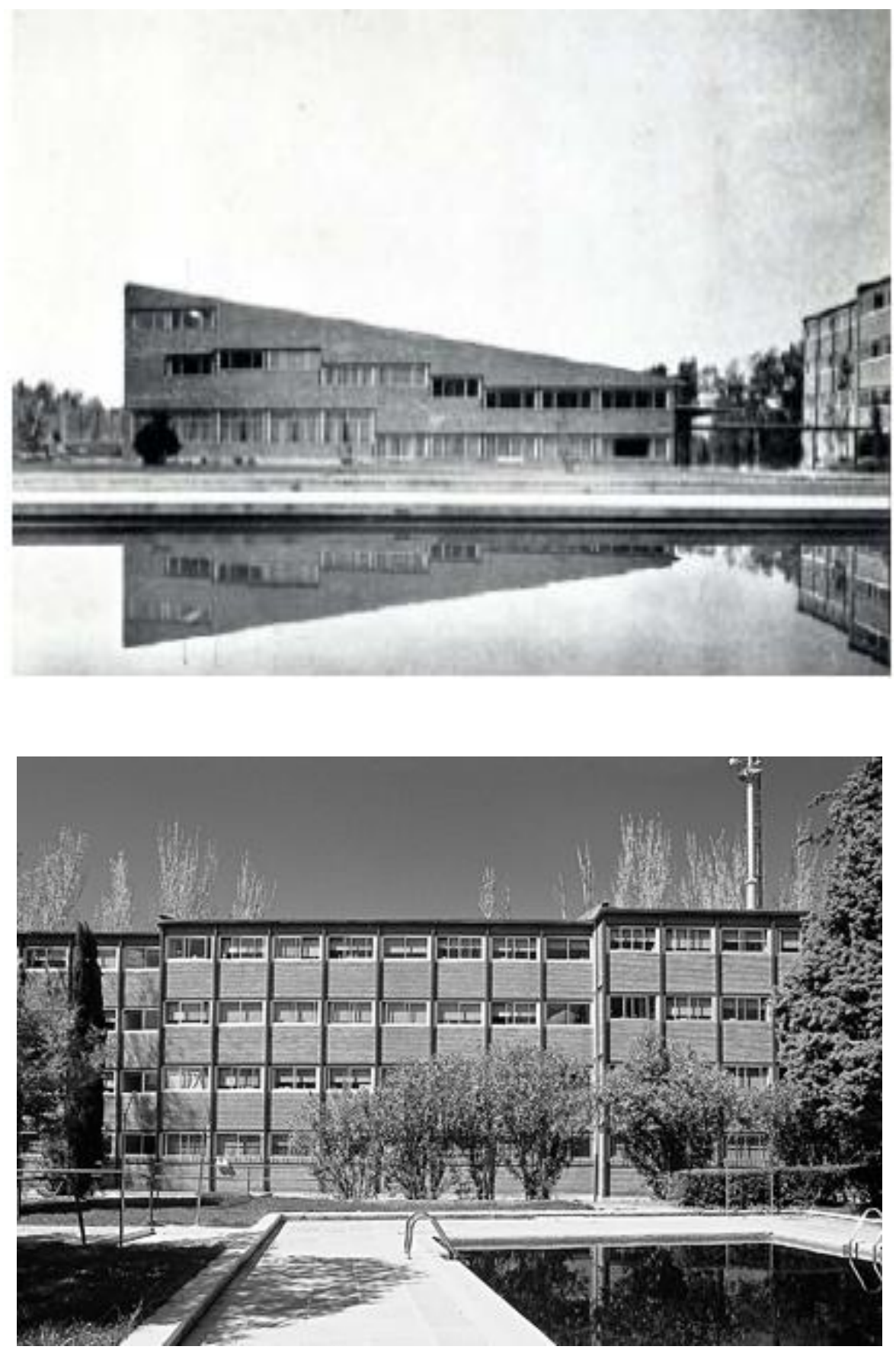

Imagen 37 : Bloque escalonado de dormitorios. En planta baja se crea una rasgadura de vidrio de forma continua.

Imagen 38: Se aprecia en esta vista la repetición del módulo que organiza las fachadas, todas resueltas con fábrica de ladrillo vista. 

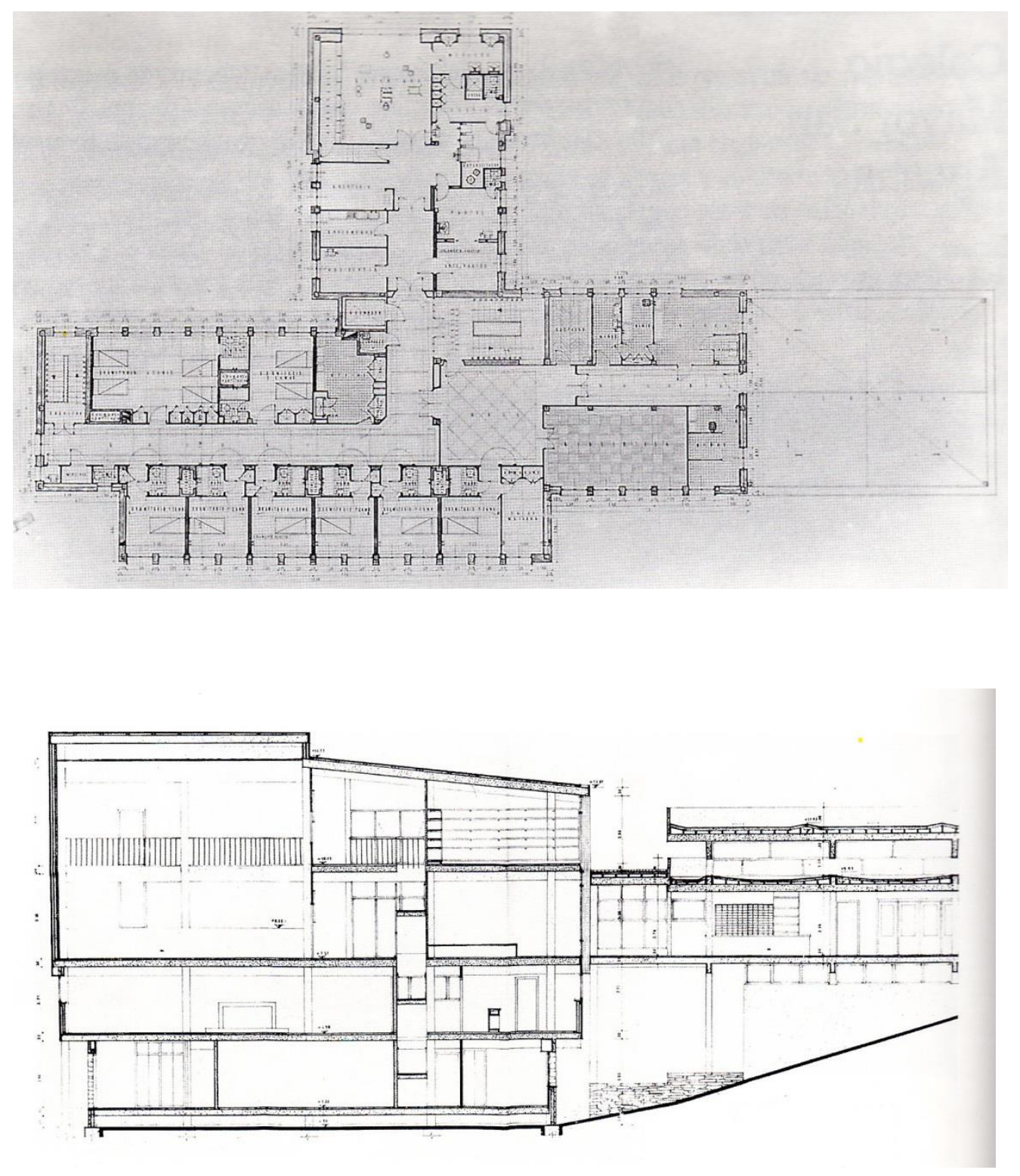

Imagen 39: Planta del conjunto..

Imagen 40: Sección transversal por el bloque de acceso al conjunto. 


\section{COLEGIO MAYOR CHAMINADE. LUIS MOYA BLANCO. Un ensayo racionalista (1965)}

El terreno donde se encuentra ubicado es aproximadamente rectangular y la planimetría es descendiente desde la fachada hacia el fondo de la parcela. Debido a este desnivel, el proyecto se resuelve mediante dos plantas bajas.

La planta baja inferior está dedicada a las instalaciones, almacenes y garaje, así como a gimnasio y a locales para actividades diversas promovidas por los alumnos ${ }^{42}$, que cuando el tiempo lo permite, actúan también en el patio octógono situado en este nivel.

La planta superior se encuentra a nivel de calle, es la principal. Esta organizada a lo largo de un eje norte-sur que forma un ángulo aproximado de $45^{\circ}$ con los límites irregulares del terreno. En este eje se suceden la capilla, un claustro con jardín, el salón de actos y el mencionado patio octógono. A cada lado se encuentran situadas unas salas de estar y comedor, correspondiente a las dos secciones en que está dividido el colegio. Completan la planta el vestíbulo con sus anejos, la dirección y administración, un aula grande para usos múltiples, la biblioteca, dos comedores pequeños, el bar y la cocina, con los offices para los cuatro comedores mencionados.

Sobre el basamento que forman estas dos plantas se elevan dos pabellones alargados paralelos al eje norte-sur. Uno de tres plantas y otro de cuatro.

Las habitaciones individuales, situadas a ambos lados de un pasillo central, tienen huecos al este $o$ al oeste con el objetivo de que todas reciban sol, pero cada una recibe su dosis de iluminación a horas diferentes, como es natural debido a la diferente orientación. Las ubicadas en el pabellón este tienen los servicios comunes, por ello, el módulo de composición es diferente en ambos.

Al extremo del edificio existe un pequeño pabellón de dos plantas para el personal de servicio.

Hay que destacar que es de los pocos que su estructura es metálica, y las fachadas son de ladrillo visto con la disposición de ventanas de carpintería de aluminio. El racionalismo se aprecia sobretodo en la distribución de las funciones en planta y en la utilización de nuevos materiales. Se puede apreciar una evolución con respecto a los materiales y disposiciones empleados diez años antes en la Universidad Laboral de Gijón. 

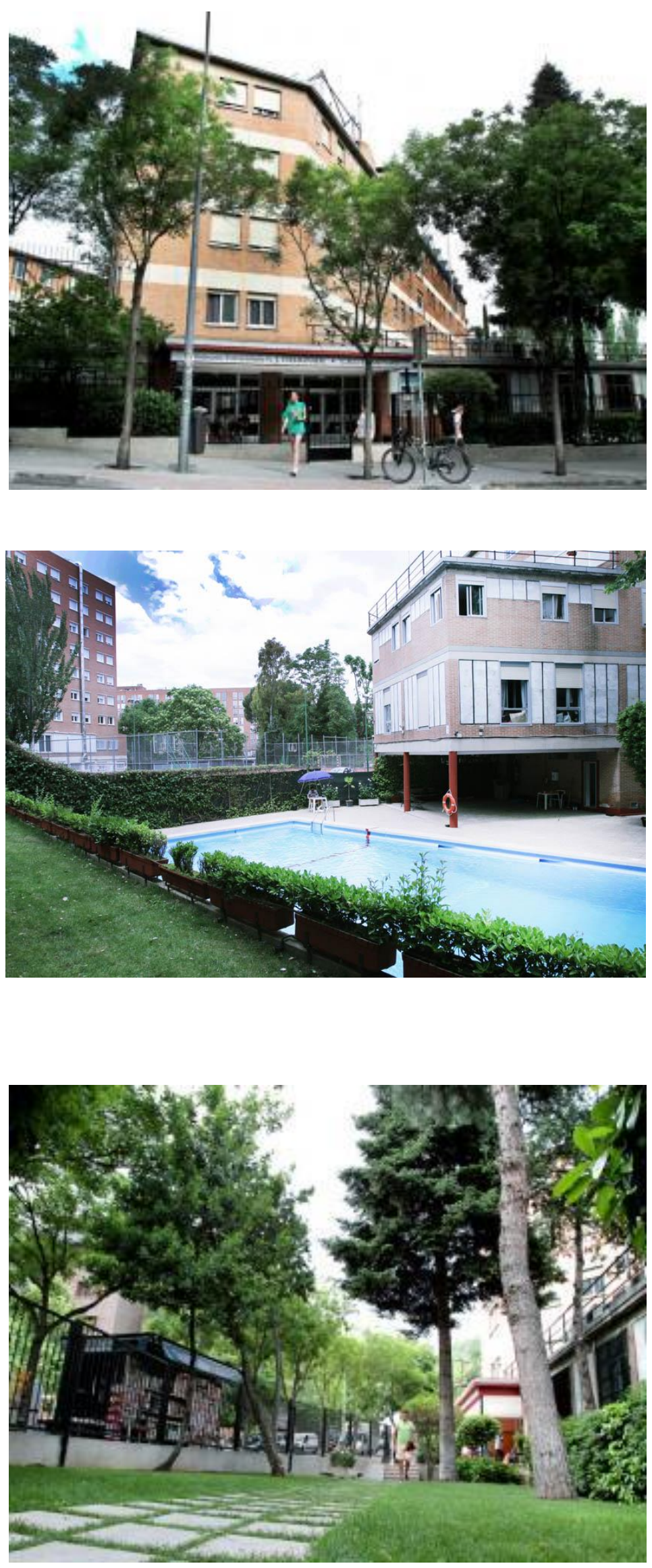

Imagen 41: Fachada principal.

Imagen 42: En este proyecto, utiliza la planta elevada sobre pilotis, siendo éstos de estructura metálica.

Imagen 43: La vegetación y los espacios de relación exteriores ajardinados son un denominador común en todos los colegios de la Ciudad Universitaria. 


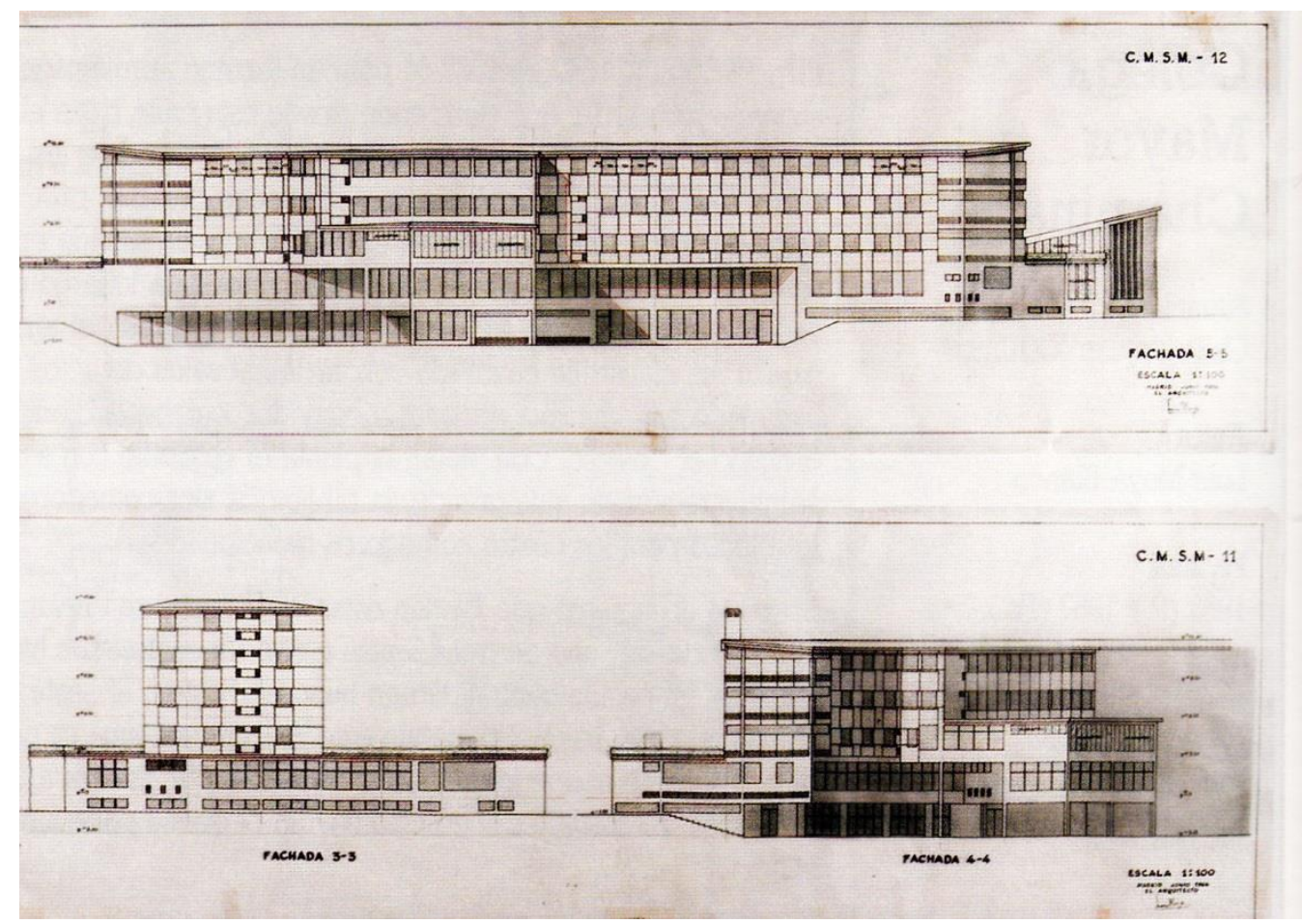

Imagen 44: Fachadas del conjunto.

Imagen 45: Planta baja del conjunto. Donde se puede apreciar la solución de ubicar esos patios, el primero claustral y el segundo ortogonal. Es de resaltar el encaje que realiza Luis Moya para ubicar todas las funciones albergantes.

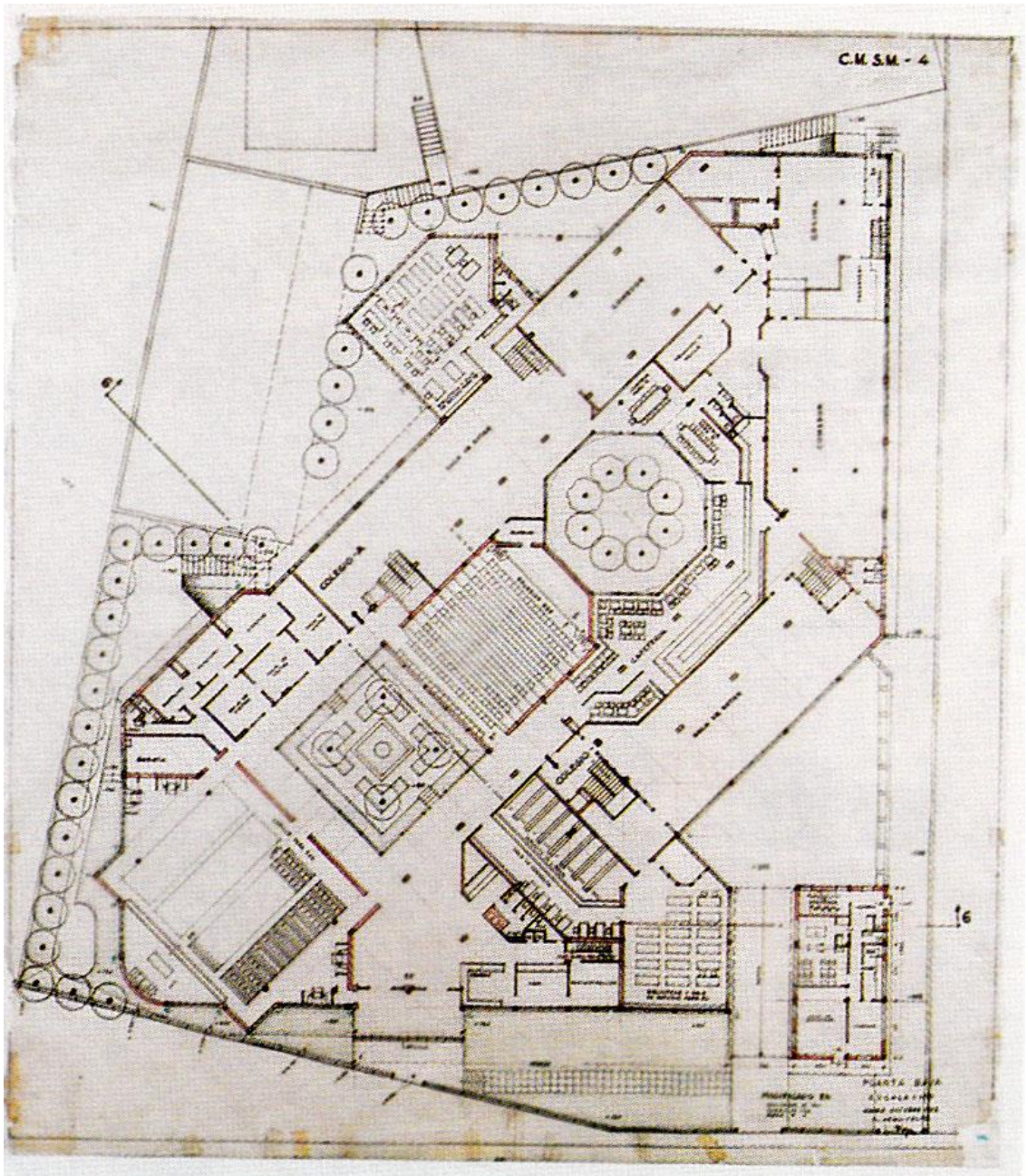



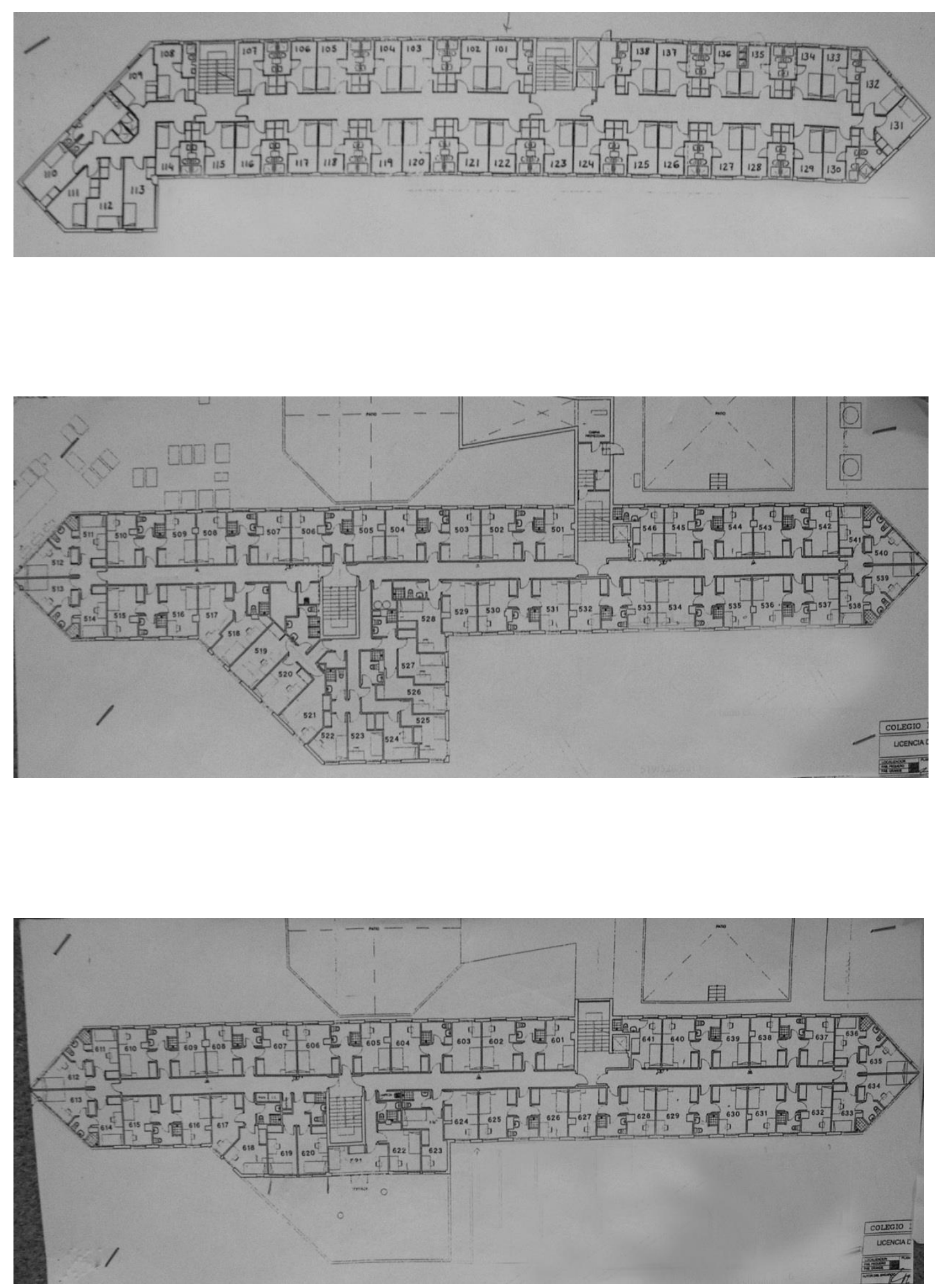

PLANTAS DE DISTRIBUCIÓN DE LAS HABITACIONES

Imagen 46: Plantas de la 1 a la 5 del bloque de mayor longitud..

Imagen 47: Planta 5

Imagen 48: Planta 6. 


\section{COLEGIO MAYOR JAIME DEL AMO. LUIS BLANCO SOLER PÉREZ. Rompiendo la ortogonalidad (1967)}

Debido a la desaparición, como se ha comentado ya, del edificio de la Fundación del Amo en 1937, Jaime del Amo, hijo de Gregorio del Amo, encargó nuevamente en 1964 otra residencia al mismo arquitecto. Éste quiso continuar la obra emprendida por sus padres y decidió crear un colegio Mayor que llevara el nombre de su padre. Jaime murió inesperadamente sin ver terminado el colegio el 8 de noviembre de 196643 .

El estilo cambia totalmente con respecto al anterior proyecto. EI edificio ve su diseño muy condicionado por las características de la parcela donde se ubica. El solar se encuentra en una zona caracterizada por fuertes pendientes y por tener un pequeño bosque de pinos y abetos en su parte posterior. Así, dispuesta la construcción en la zona más elevada del terreno, se configura, lo mismo en planta que en altura, como dos cuerpos proyectados perpendicularmente aunque formando una unidad.

En la planta baja se articulan a su vez los locales que utilizarán tanto los residentes, como aquellos que no formen parte del colegio. De esta manera, a la derecha del vestíbulo se sitúan el auditorio, cuya traducción formal exterior en zig-zag se individualiza respecto del conjunto. También se sitúan, con acceso directo exterior la capilla y la vivienda del director. A la izquierda, se dispone la cocina, el comedor, el bar y la administración. $Y$ en el ala transversal se encuentran situados el salón, la zona de juegos y la biblioteca.

La escalera principal, tiene un desarrollo en forma semicircular y esta convenientemente ubicada en la zona donde se conectan las tres partes.

Este colegio tiene 103 habitaciones, entre las cuales se van disponiendo los estudios, de forma que lo comparten cada dos habitaciones (un sistema muy americano). Se distribuyen a través de las cinco plantas del pabellón perpendicular, el cual se va curvando ligeramente, a medida que avanza hacia la naturaleza, sobre los jardines y la piscina, rompiendo paulatinamente esa perpendicularidad, y cuya planta baja, que corresponde al sótano del cuerpo bajo, en donde se ubica la zona de servicios y locales dependientes de los deportes, queda exenta, solamente interrumpida por el ritmo de los pilares, con lo que el arquitecto consigue enlazar la mencionada zona verde de jardines con las instalaciones deportivas que discurren al otro lado. 
Al igual que ocurre en el Colegio Mayor Aquinas, cada función no sólo está segregada, sino que se representa con un volumen diferente dentro del conjunto, marcando la diferenciación tanto en planos verticales como horizontales. Esto se consigue con la utilización de distintos materiales, alternando la fábrica de ladrillo visto con el aplacado de piedra y con paños continuos de vidrio.

La utilización de la carpintería metálica, cubriendo incluso paños ciegos (antepechos y forjados) anejos a las grandes superficies de vidrio, recuerda a una disposición miesiana. Este paño situado en el bloque de mayor altura en la fachada principal, sirve para marcar el acceso al edificio.

Mucho ha cambiado el estilo, desde la primera Residencia a este Colegio Mayor, donde se incorporan los criterios de forma inequívoca del Movimiento Moderno. 

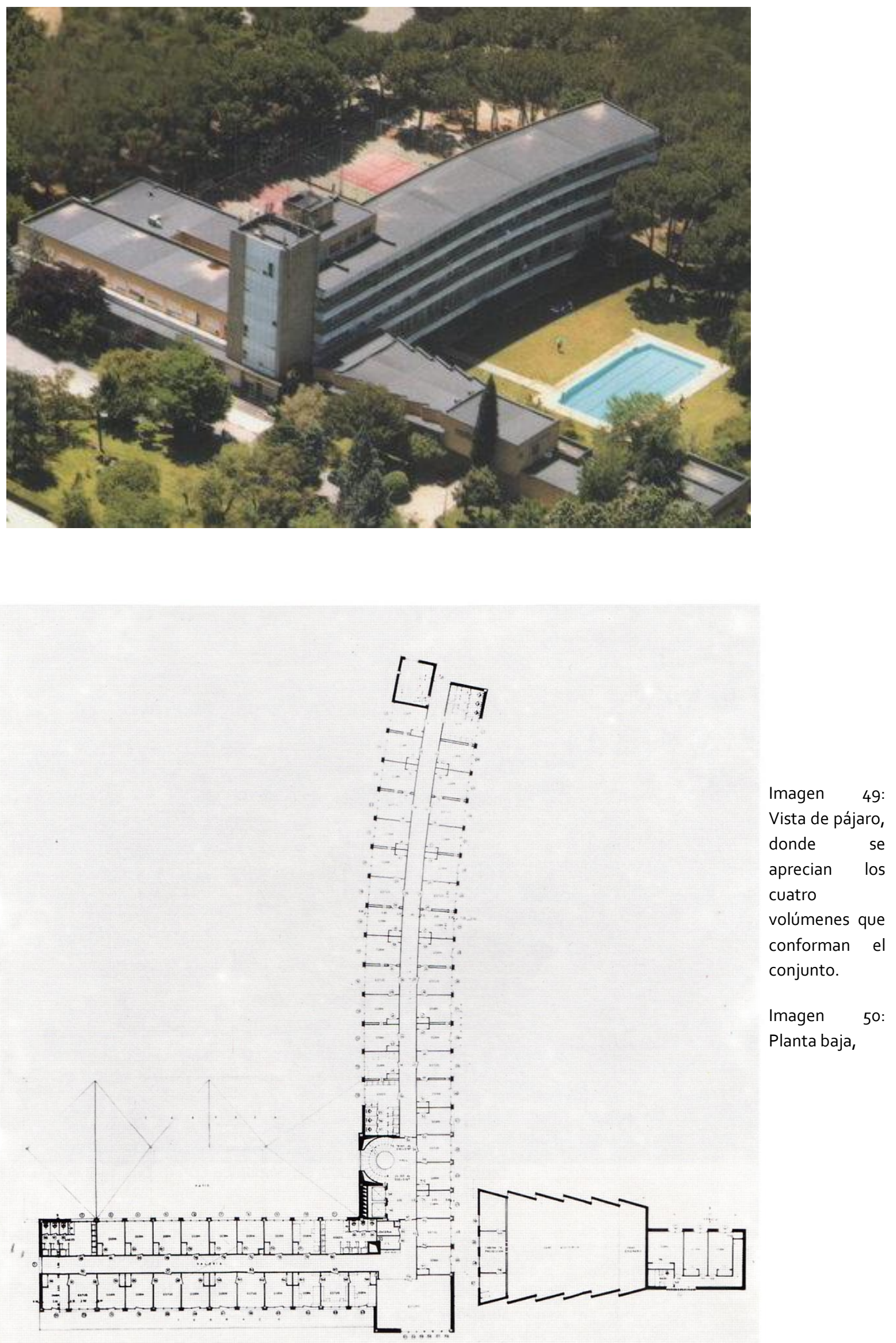


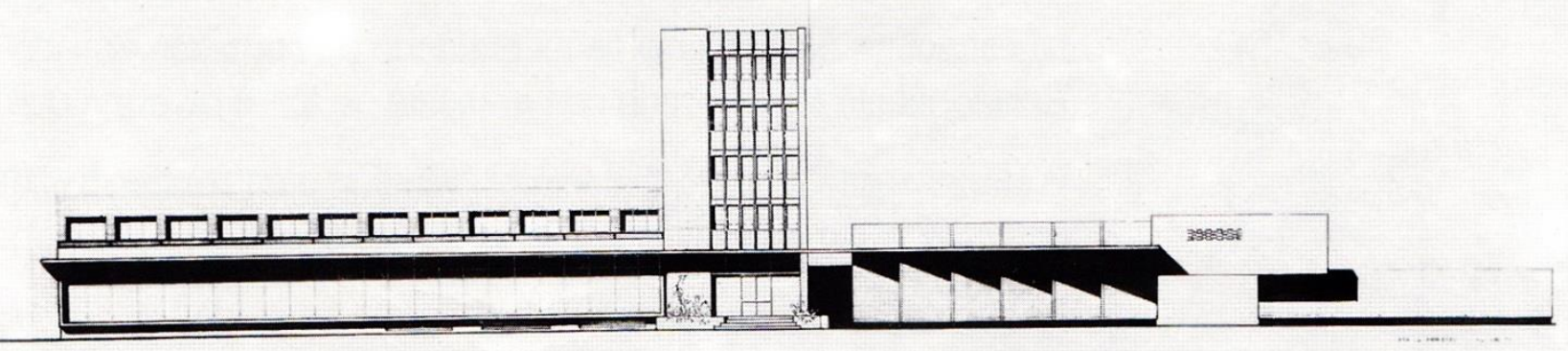

FACHADA PQINCIPAL

furdacior DEL AMO

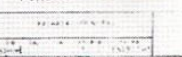

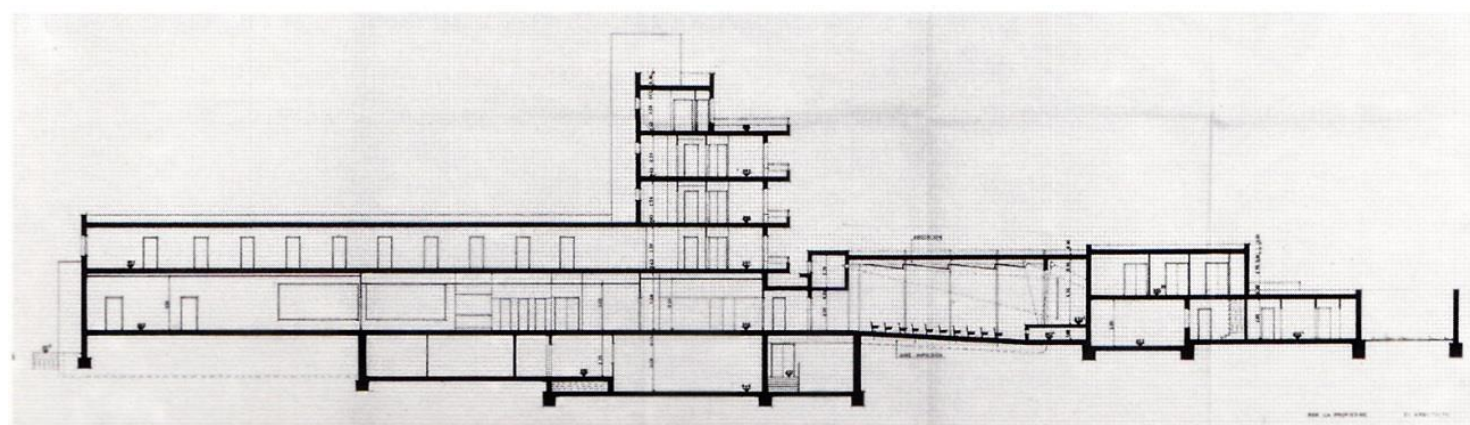

seccion A-A
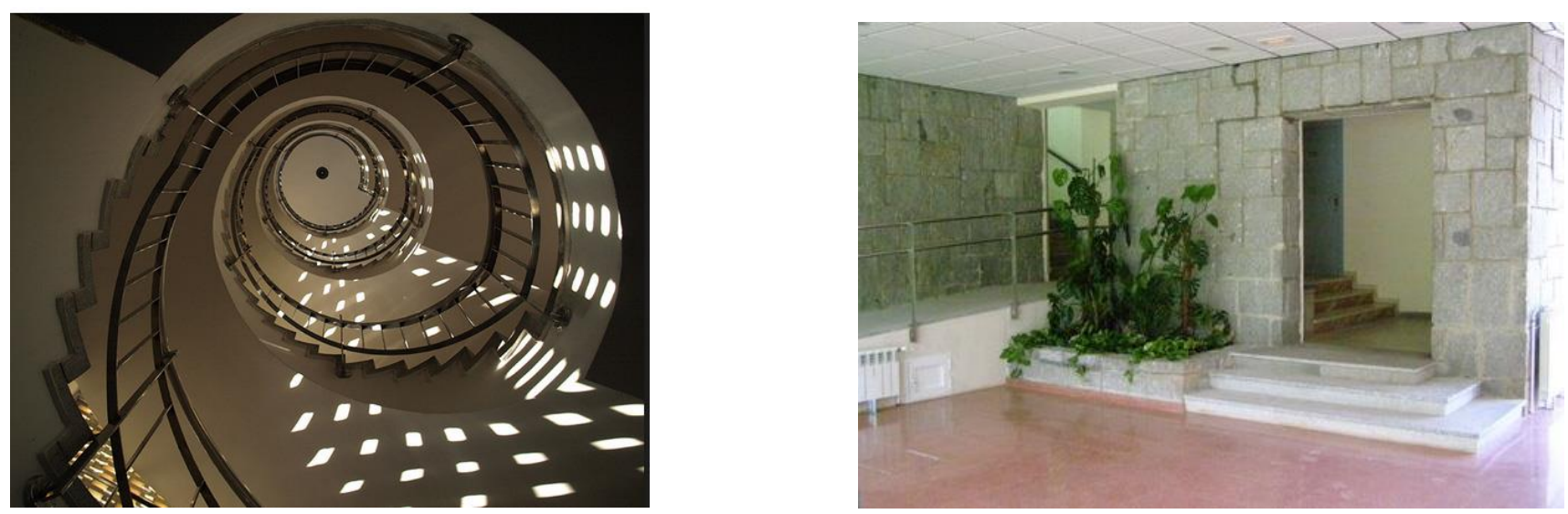

Imagen 51: Alzado principal

Imagen 52: Sección longitudinal.

Imagen 53: Escalera semicircular

Imagen 54: Entrada a la biblioteca, el revestimiento de piedra la sustantiva con respecto a otros espacios 

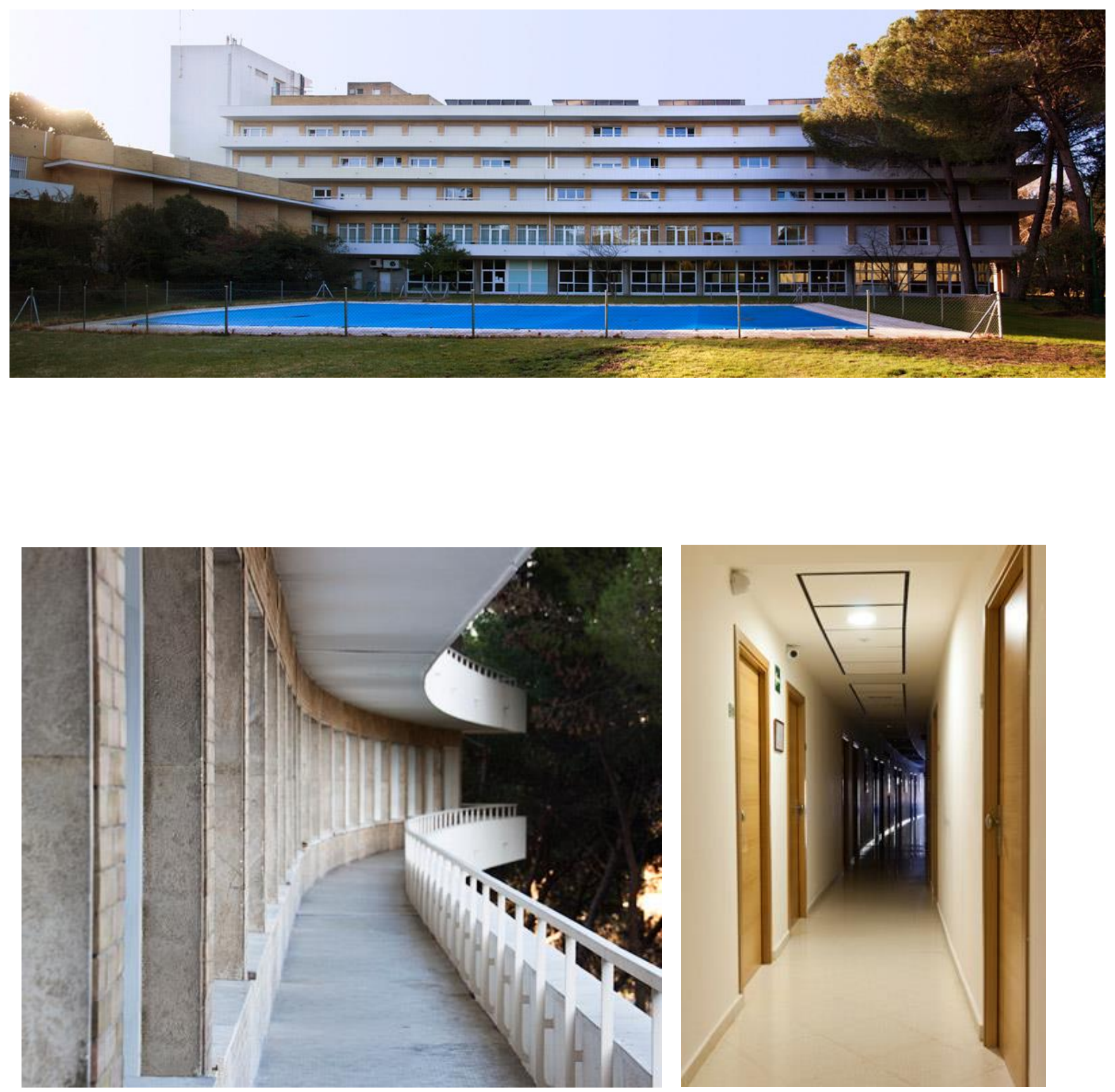

\section{PLANTAS DE DISTRIBUCIÓN DE LAS HABITACIONES}

Imagen 55: Bloque de los dormitorios

Imagen 56: Detalle de los corredores-terraza a los que vuelcan las habitaciones. Se aprecia la curvatura o pérdida de ortogonalidad.

Imagen 57: Detalle de los pasillos interiores donde también se aprecia la curvatura. 
COLEGIO MAYOR NUESTRA SEÑORA DE GUADALUPE.CARMEN CÓRDOVA Y HORACIO BALIERO Arquitectura y paisaje (1969)

Éste Colegio Mayor acoge estudiantes argentinos en Madrid y su origen en un concurso resuelto en Argentina en 1964 del que salieron ganadores $^{44}$ los arquitectos argentinos Horacio Baliero y Carmen Córdova ${ }^{45}$. En la construcción, la dirección de obra corrió a cargo de Javier Feduchi.

El emplazamiento inicial era el después es destinado al Colegio Mayor Casa DO Brasil, por lo que en 1977 los autores revisaron el proyecto ganador del concurso para adaptarlo a su nueva ubicación.

Esta revisión tuvo que ser también con la toma de contacto con los materiales y sistemas constructivos de España ${ }^{46}$. A pesar de ello, la adaptación consiguió mantener en lo esencial la imagen y características generales del proyecto inicial. La labor de los arquitectos no se limitó al proyecto del edificio, sino que incluyó también el diseño de mobiliario.

Adaptándose a la topografía del terreno, el edificio se desarrolla en cinco niveles, de forma curva, siguiendo un arco de cuarto de círculo. La distribución se hace a partir de un eje central muy destacado en planta, en el que se colocan los núcleos de comunicación vertical y del que parten las galerías de circulación hacia las dos alas. El tercer nivel es el que corresponde a la fachada de acceso, y en él se han situado todos los servicios comunitarios. En los dos niveles inferiores se sitúan los dormitorios individuales, la zona de servicios y la vivienda del director con acceso independiente. En los dos niveles superiores están las habitaciones dobles y algunas pequeñas zonas de estudio y trabajo, que los autores denominan "ateliers" 47 . Todas las habitaciones están dotadas de cuarto de aseo y pequeña zona de trabajo y se resuelve el tema del soleamiento mediante la disposición de terrazas.

El edificio se levanta sobre una estructura de hormigón armado con cerramientos de ladrillo visto. Merece destacar el ajardinamiento del recinto interior, para lo cual se ha movido el terreno formando una especie de hoya central $4^{8}$ que aisla todo el conjunto de las parcelas colindantes.

Además de las dependencias necesarias para sus fines residenciales, contaba con salón de actos, biblioteca y dos aulas. El proyecto es una respuesta firme a los condicionantes del solar y del programa y el edificio se amolda perfectamente a la envolvente topográfica vegetal en multitud de texturas. Es preciso destacar el cuidado de las 
superficies que relacionan el interior con el exterior enfatizando la idea de continuidad, lo cual se materializa en los pavimentos continuos que atraviesan las zonas comunes y las habitaciones y que a la vez forman las terrazas del edificio. El espacio interior muestra una gran riqueza, especialmente en el acceso, con las escultóricas escalera y chimenea, el contraste de materiales y el mobiliario diseñado por los propios arquitectos. La forma curva del edificio, de sugerentes rasgos nórdicos cercanos a Jacobsen y Aalto, recoge el jardín, que se repliega para cerrarse al exterior. El Colegio dispone de terrazas con tersas superficies inclinadas de cerámica, que contrastan con los grandes volúmenes de ladrillo opacos. El proyecto es un ejemplo de estrategia espacial y paisajística, con recursos similares a los utilizados en el Colegio Mayor Jorge Juan del arquitecto Alberto López de Asiaín. 

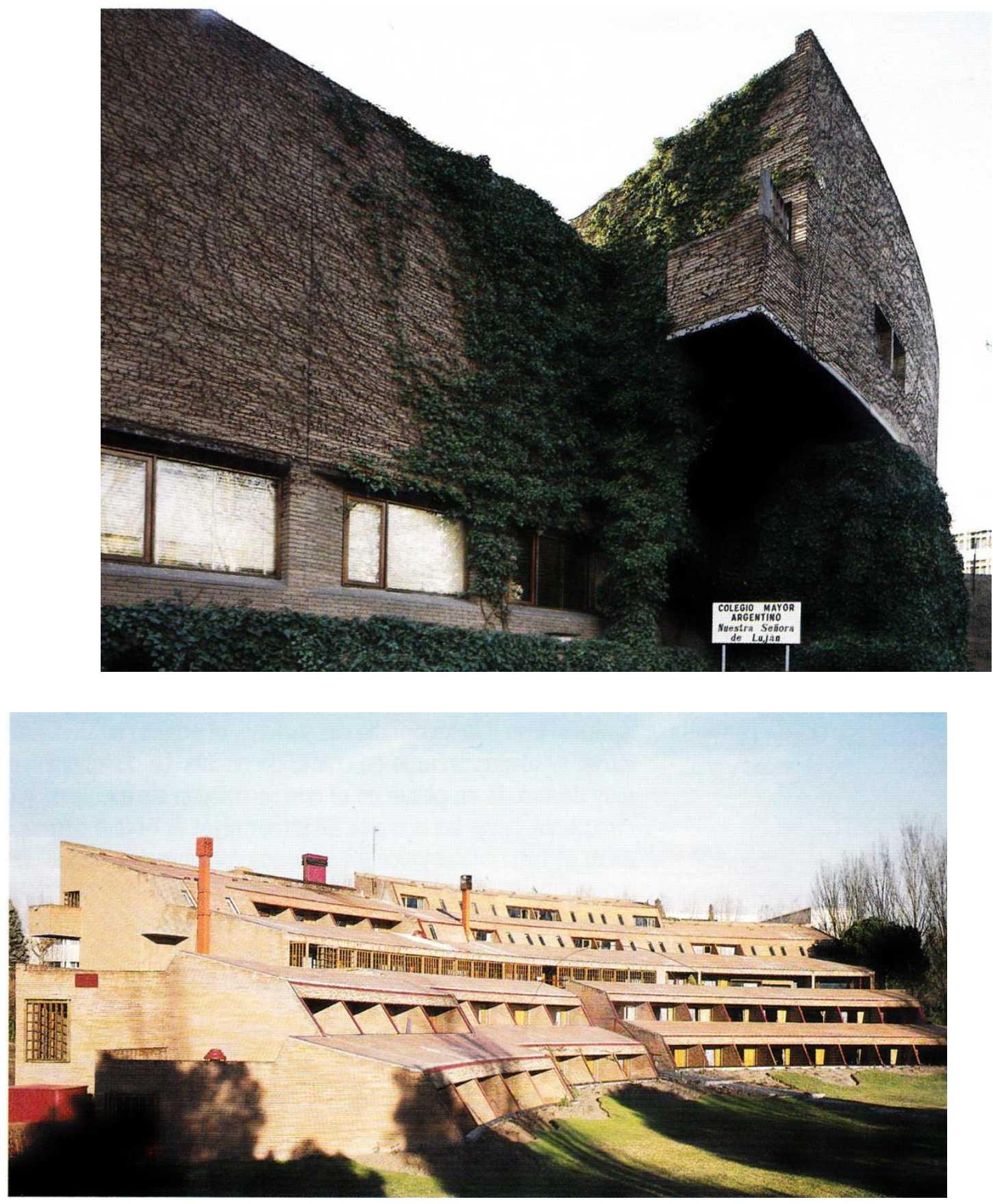

Imagen 58: Entrada al Colegio Nuestra Señora de Luján.

Imagen 59: Vista de la implantación. Todas las habitaciones vuelcan al paisaje posterior. 

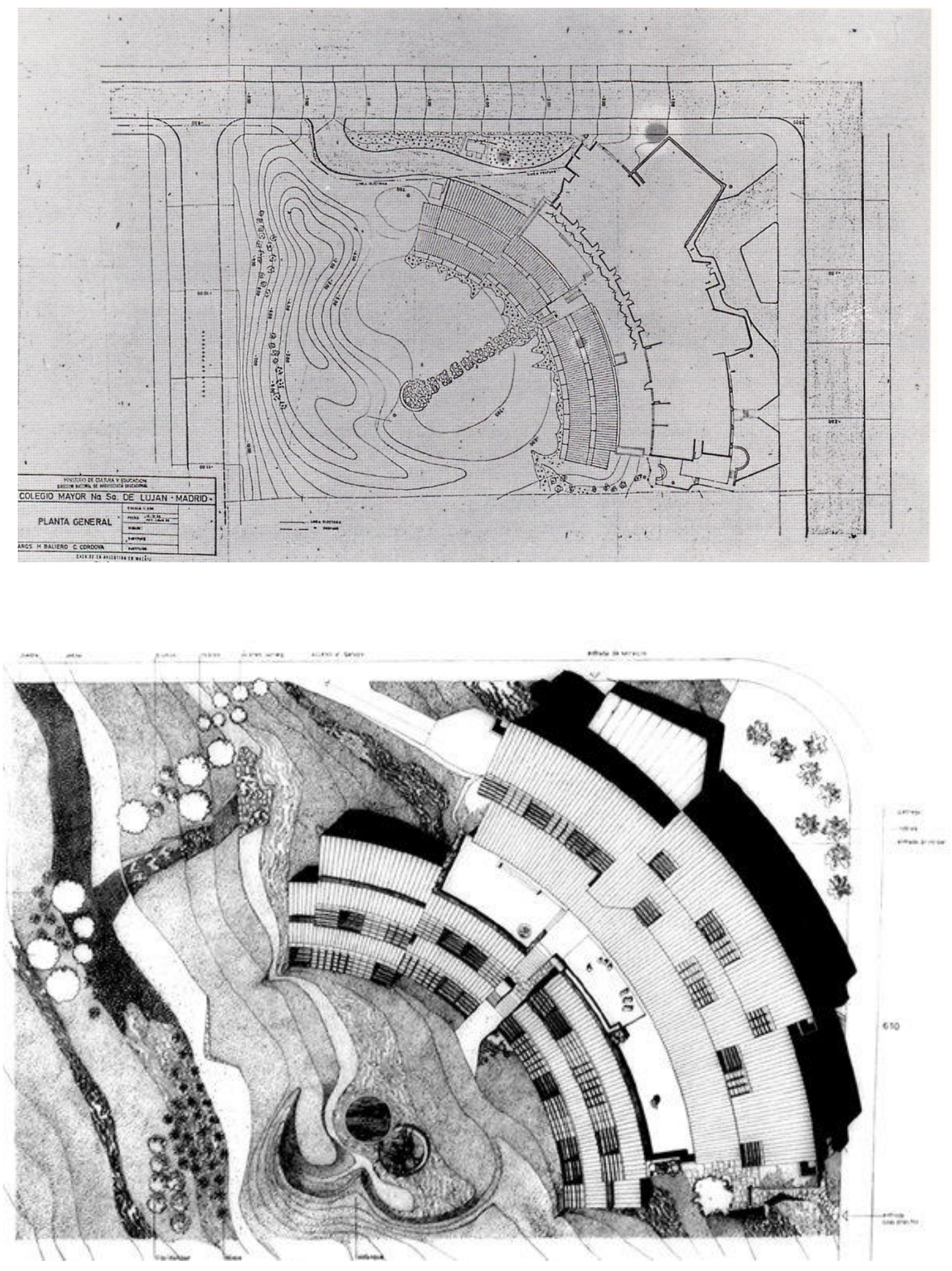

Imagen 6o: Plano de curvas de nivel. El conjunto de "amolda" al terreno.

Imagen 61: Planta de cubiertas. Todas las habitaciones de los estudiantes vuelcan sobre el mismo paisaje. 


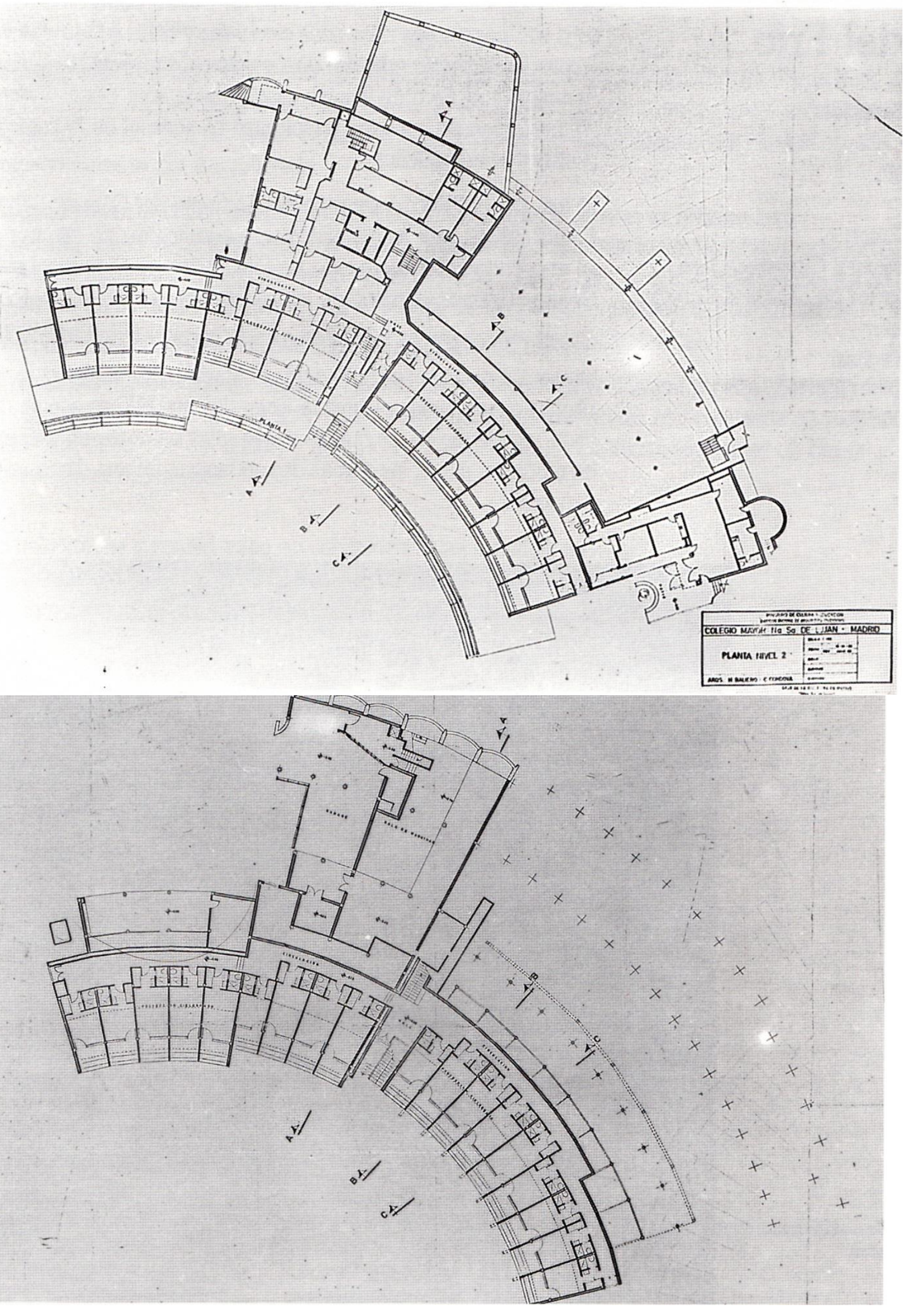

Imagen 62: Panta segunda.

Imagen 63: Planta primera 


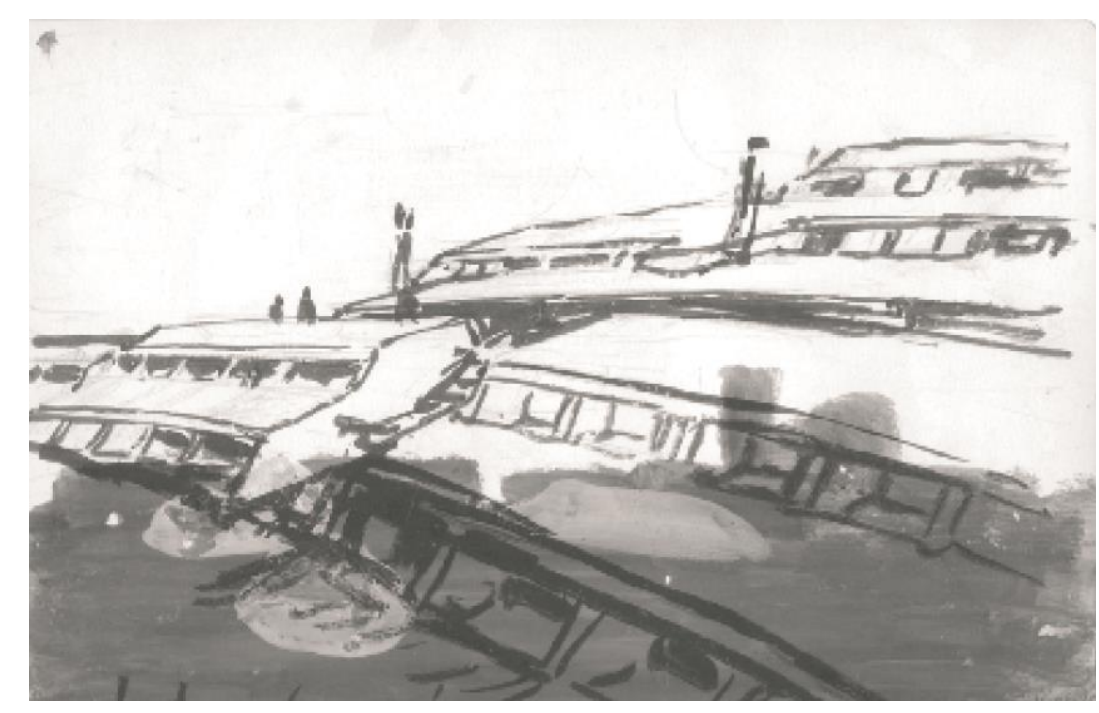

Imagen 64: Boceto de los autores. Forma parte de la documentación que presentaron al concurso.

Imagen 65: Vista del edificio desde el paisaje al que pretende volcarse.

Imagen 66: Mediante La utilización de materiales iguales en interiores y exteriores refuerza la sensación de continuidad.
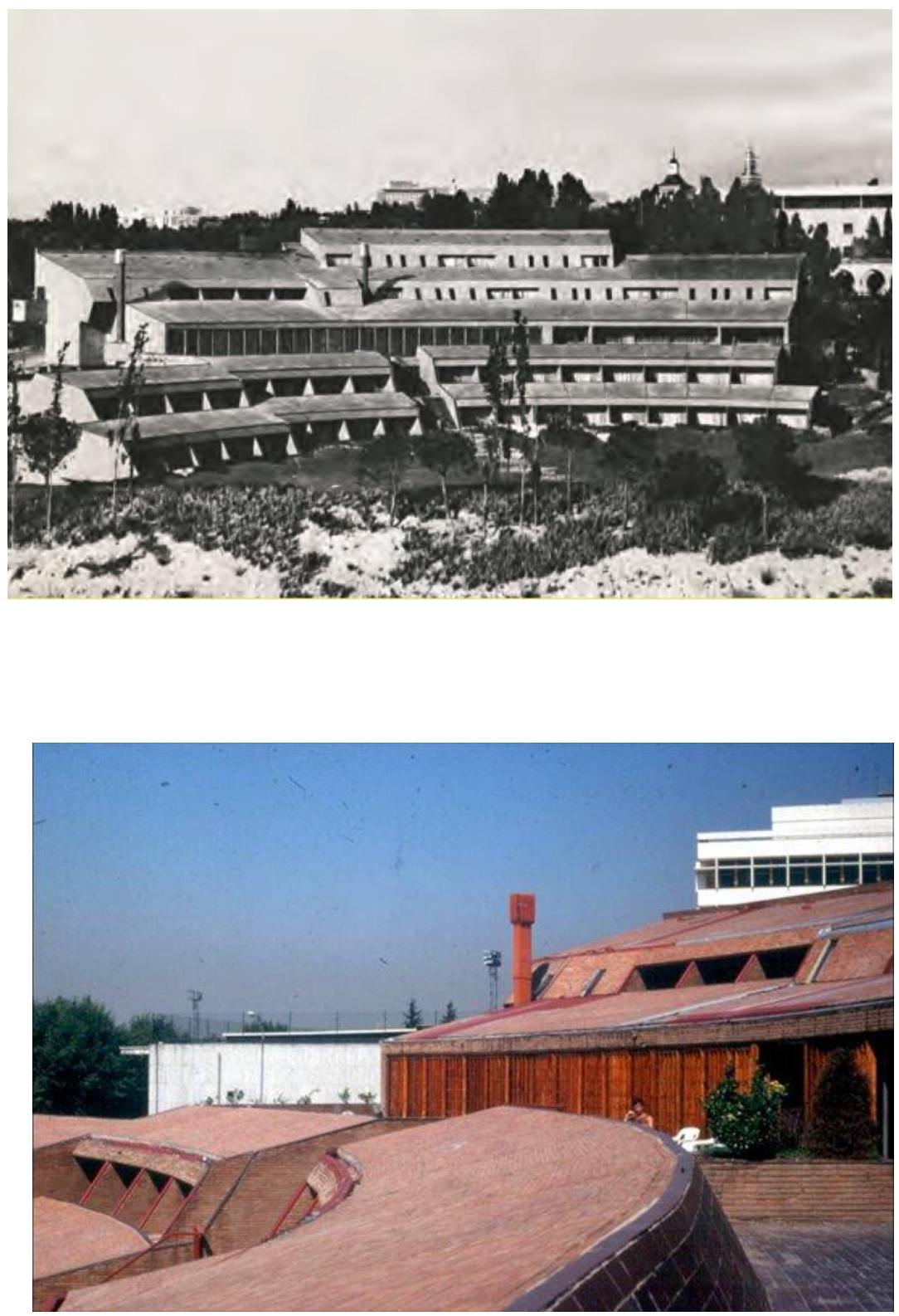

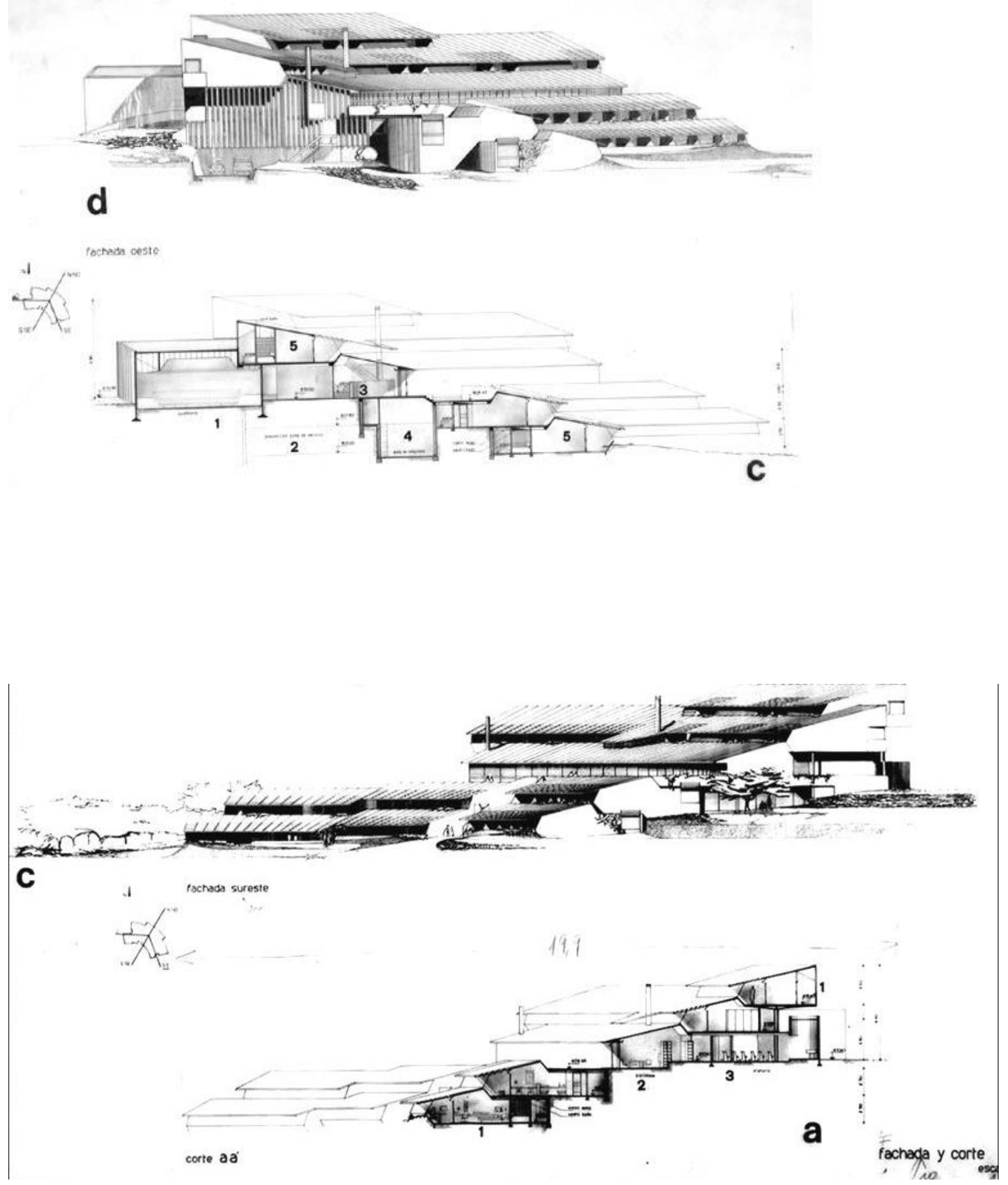

Imagen 67 y 68: Secciones del conjunto, donde se aprecia la adaptación del conjunto al terreno. 
COLEGIOS MAYORES DE LA CIUDAD UNIVERSITARIA DE MADRID Y LA ARQUITECTURA MODERNA

\section{BLOQUE IV}

\section{IV.3 DIMENSIÓN SOCIAL}

Colegio Mayor César Carlos. Alejandro de la Sota. Experimentando con el tipo (1970)

El Colegio Mayor Casa do Brasil. Alfonso d'Escagnolle. Un bloque atemporal (1962) 


\section{COLEGIO MAYOR CÉSAR CARLOS. ALEJANDRO DE LA SOTA. Experimentando con el tipo (1970)}

El nuevo concepto de Colegio Mayor ha evolucionado hacia una doble dualidad. De un lado, la persona se realiza tanto individual como colectivamente y, del otro lado, el Colegio Mayor se desdobla en sus aspectos tanto formativos como residencial. Estos cuatro factores se relacionan y coordinan orgánicamente sin que exista interferencia entre ellos en el Colegio Mayor César Carlos ${ }_{L}$ de Alejandro de la Sota.

El arquitecto plantea en este edificio una de las soluciones más originales dentro de la tipología del Colegio Mayor.

La arquitectura de esta obra genera su programa libre de cualquier influencia que se aleje de su función específica. Cada bloque es un espacio interrelacional. Se evita la masificación dividiendo y dividiendo los grupos humanos hasta llegar al grupo cuyo número facilite la relación directa entre personas. Esto dentro de un hipotético crecimiento indefinido que no deshumanice las relaciones.

Por otra parte, se genera una serie que puede dar origen a una forma urbana longitudinal encerrada entre dos peines encontrados, uno que distribuye los accesos y otro entrelaza la arquitectura con el espacio exterior. Con este Colegio se pretende posibilitar la vida en común sin interferir la intimidad en los núcleos de habitación y, a su vez, esta individualidad no quede aislada de los espacios interrelacionales. Por esto las circulaciones son la pieza capital, donde es necesaria una dualidad entre ambiente y servicio, consiguiéndose una armonía entre individuo y colectividad. Los materiales empleados, fruto del avance de la técnica, son cinco: hormigón, hierro, ladrillo, cristal y plástico; están subordinados a la unidad y simplicidad del diseño constructivo, cuya plástica responde a un criterio compositivo de masas rectangulares.

En planta, el conjunto consiste fundamentalmente en dos bloques o torres simétricas, en las que se distribuyen las habitaciones de los colegiales en torno a un núcleo de escaleras y ascensores. Las habitaciones están diseñadas según un tipo en "L" que pretende resolver la zonificación de estos espacios distinguiendo a las simples de las dobles. Las dos torres de habitaciones están unidas están unidas entre sí por un gran elemento central que contiene dos servicios comunes: la biblioteca y el gimnasio, los cuales, asu vez, tienden dos puentes, por la zona superior y la inferior, entre los dos bloques. 
El conjunto cobra así un aire monumental, pudiendo evocar un gran arco del triunfo que impregna de marcado simbolismo una estructura que responde a exigencias, como se acaba de apuntar, muy concretas, como son la de resolver el problema de los largos pasillos que normalmente dan acceso a las habitaciones en los colegios mayores, creando problemas de ruidos y molestias.

A este primer elemento se conecta un segundo cuerpo posterior, unido al primero por una galería subterránea. En él se sitúan, distribuidos en dos plantas y un semisótano, los restantes servicios comunes: comedor, bar, salas de estar y aulas, y los equipamientos de almacenes, cocinas y demás instalaciones.

El resultado es un peculiar énfasis de los elementos centralizadores y sociales ${ }^{49}$, siendo éstos el arco que forman las piezas del cuerpo central, y a parte, la galería subterránea, produciéndose una sutil jerarquización de núcleos mediante un rico sistema de tensiones e integraciones en planta.

El edificio es una pertinente combinación entre el racionalismo de la ordenación espacial y el organicismo de las circulaciones y de la textura; todo ello bajo la premisa de la modernidad. 
Imagenes 69, 70 y 71: Vista de la parte del conjunto que corresponde a los bloques en altura.
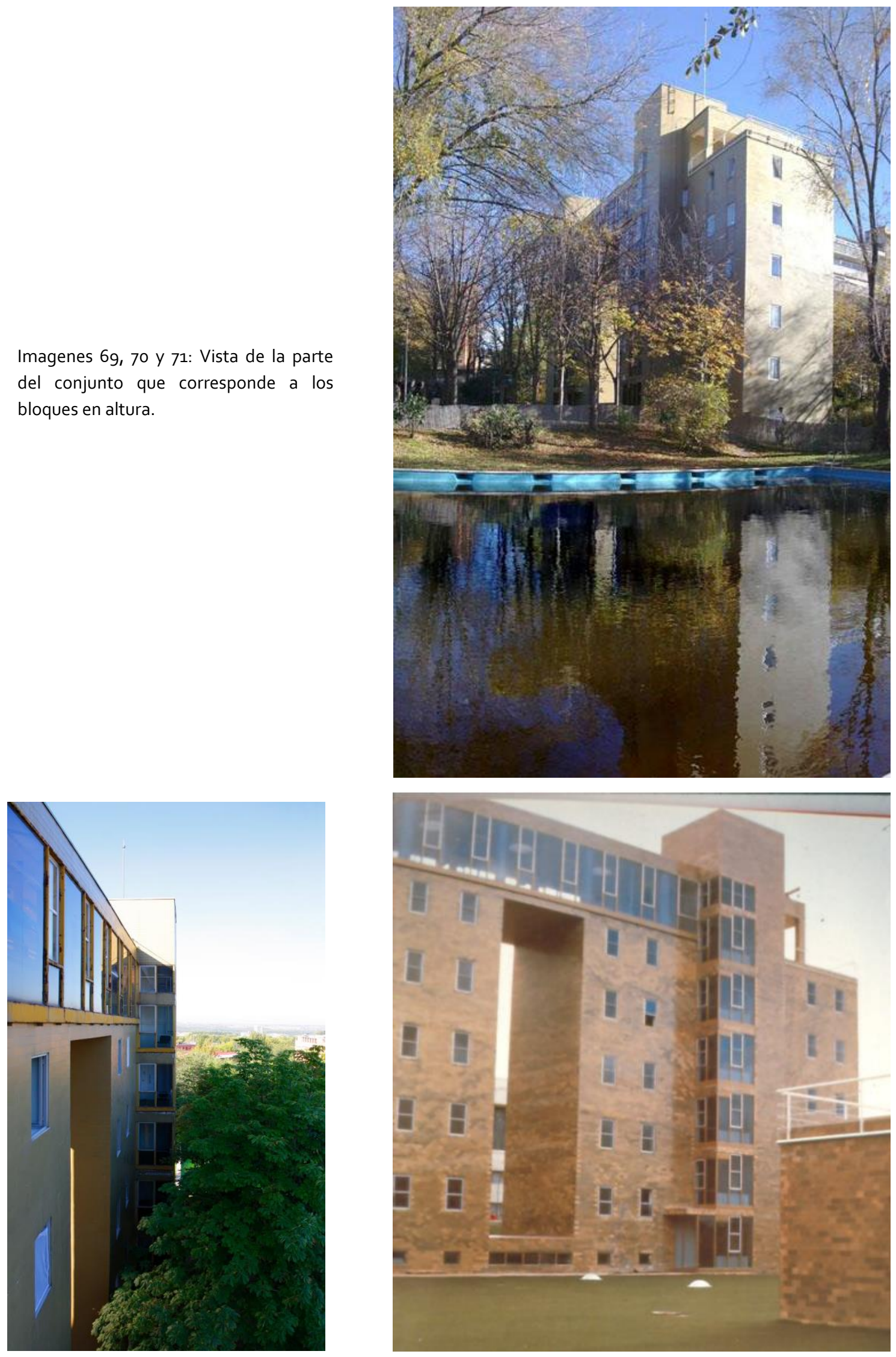
BOCETOS DEL AUTOR
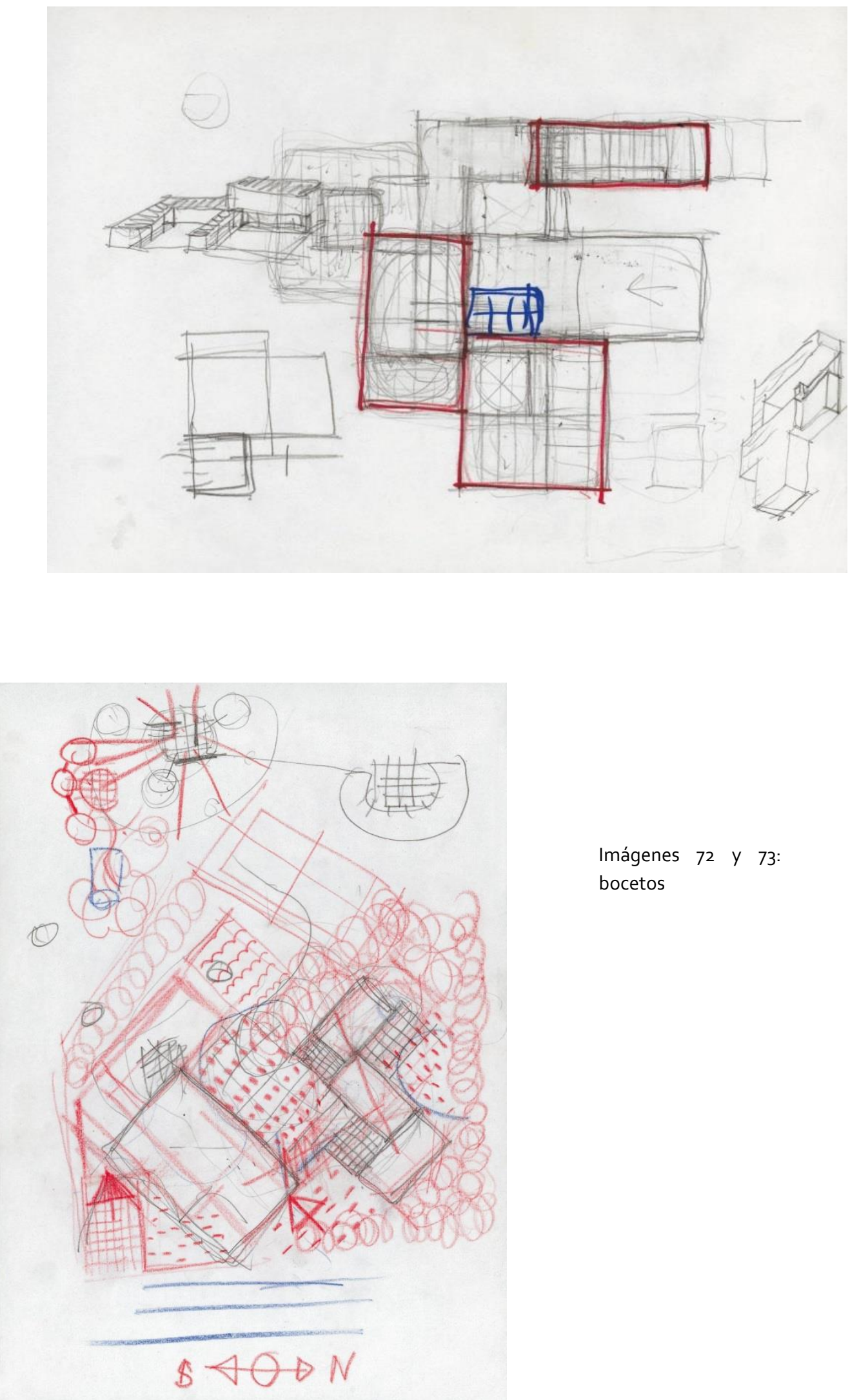

Imágenes 72 y 73 :

bocetos 

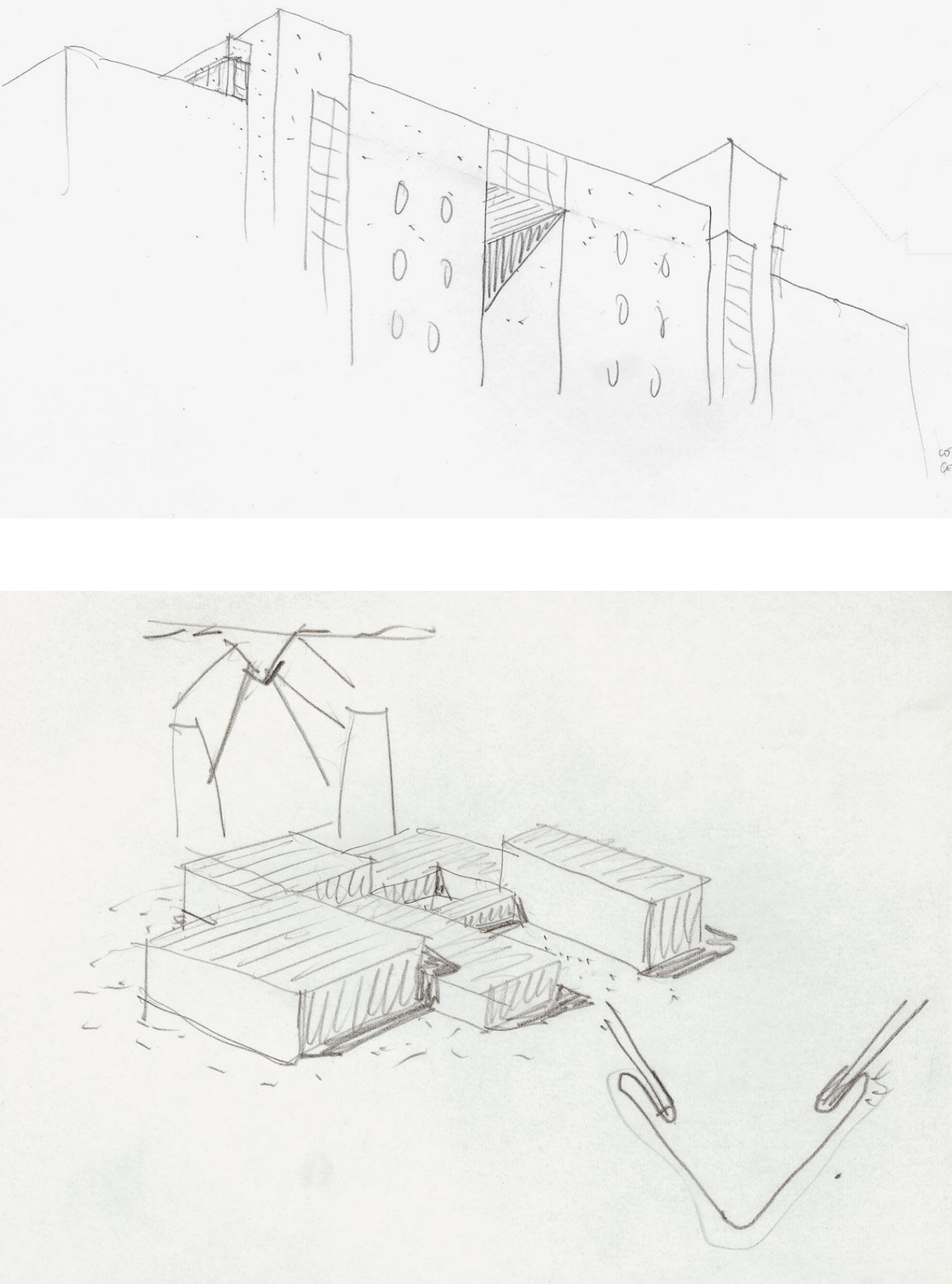

Imágenes 74 y 75 : bocetos 

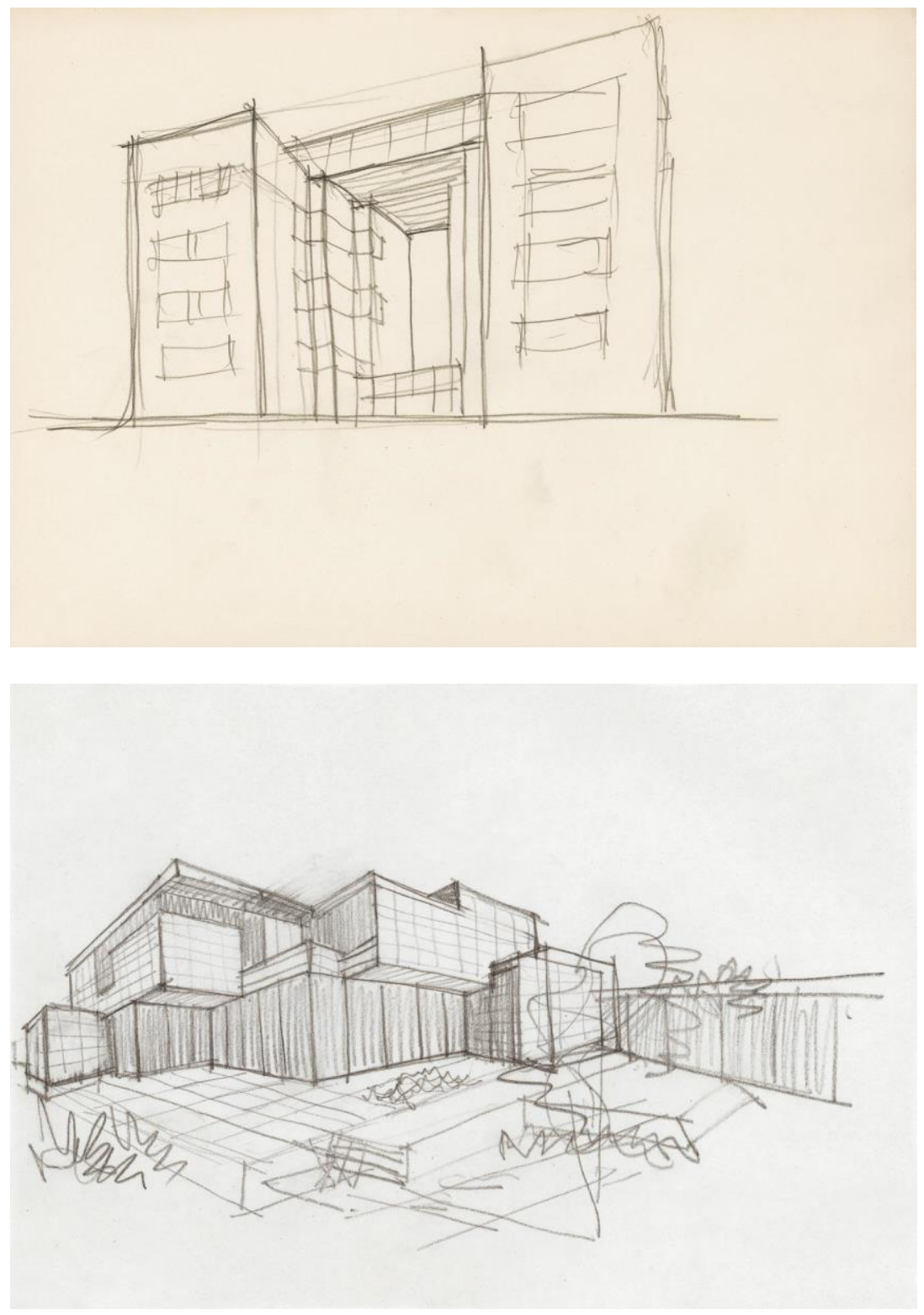

Imágenes 76,77 y 78 : bocetos

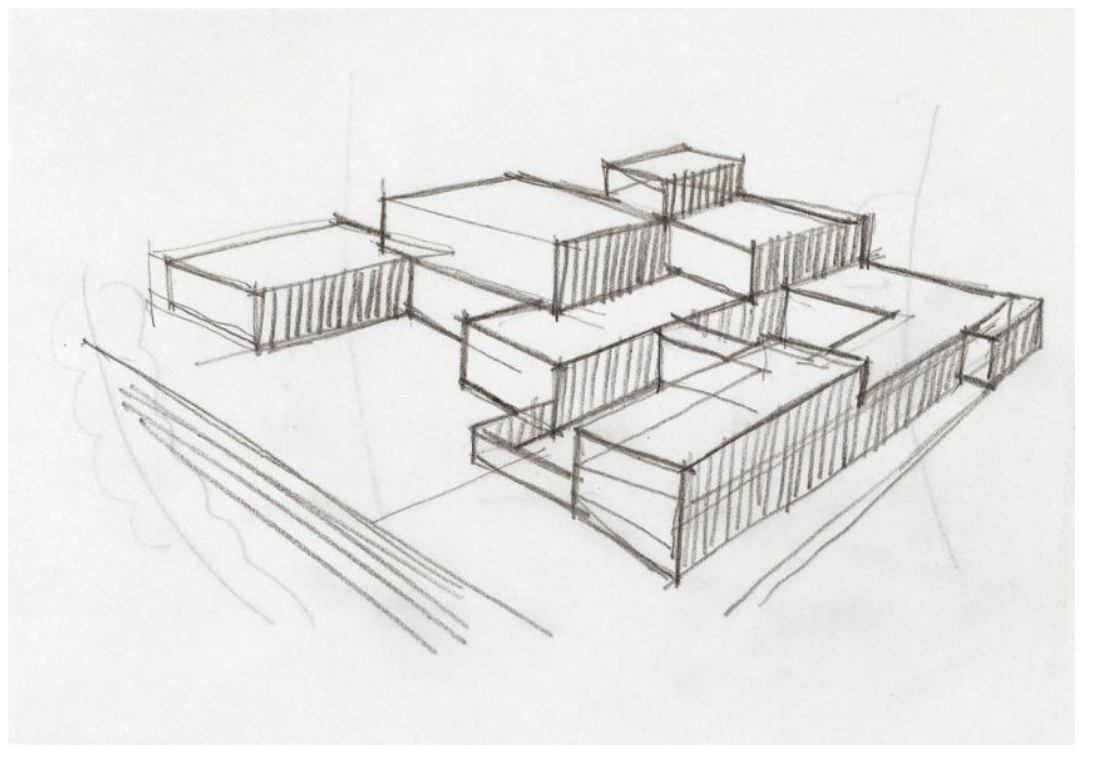


Imágenes 79: boceto.

Imagen 80: Boceto sobre los espacios interiores
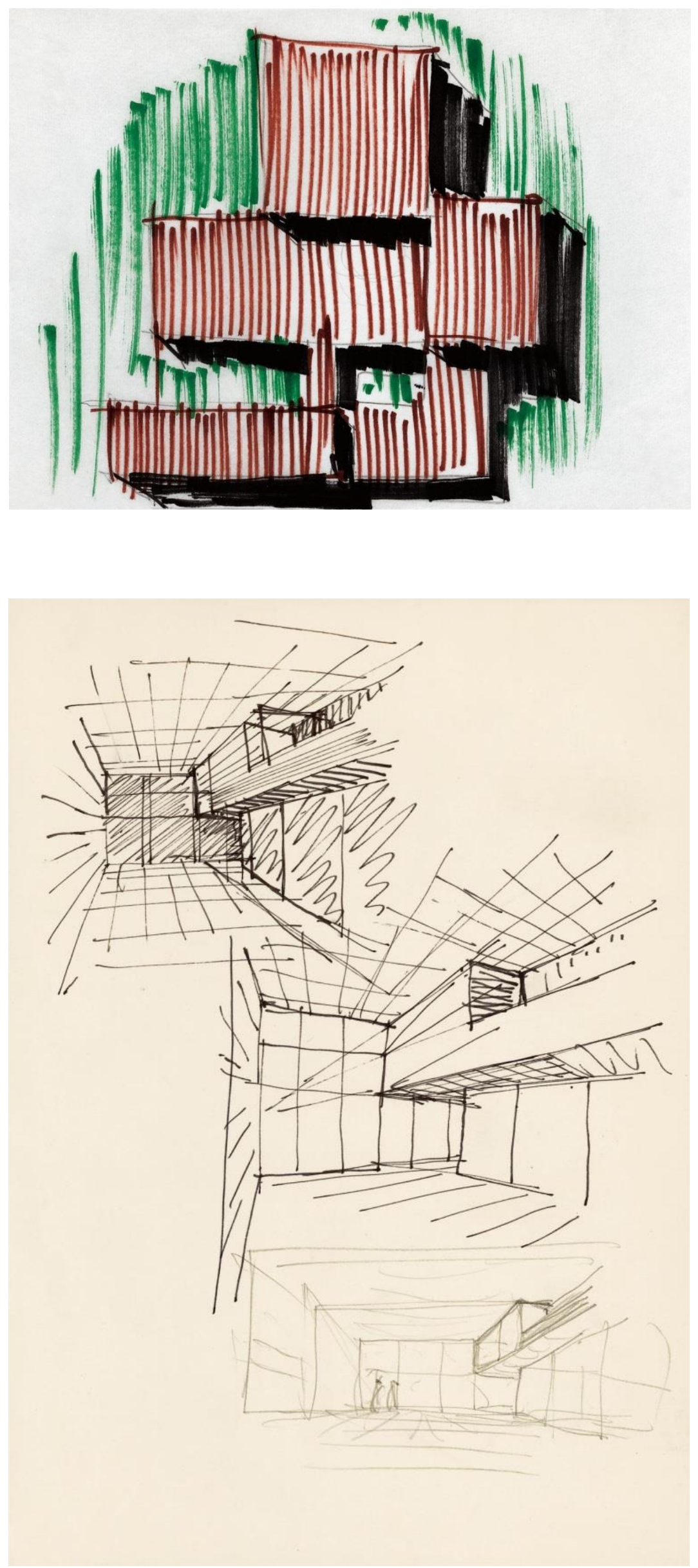


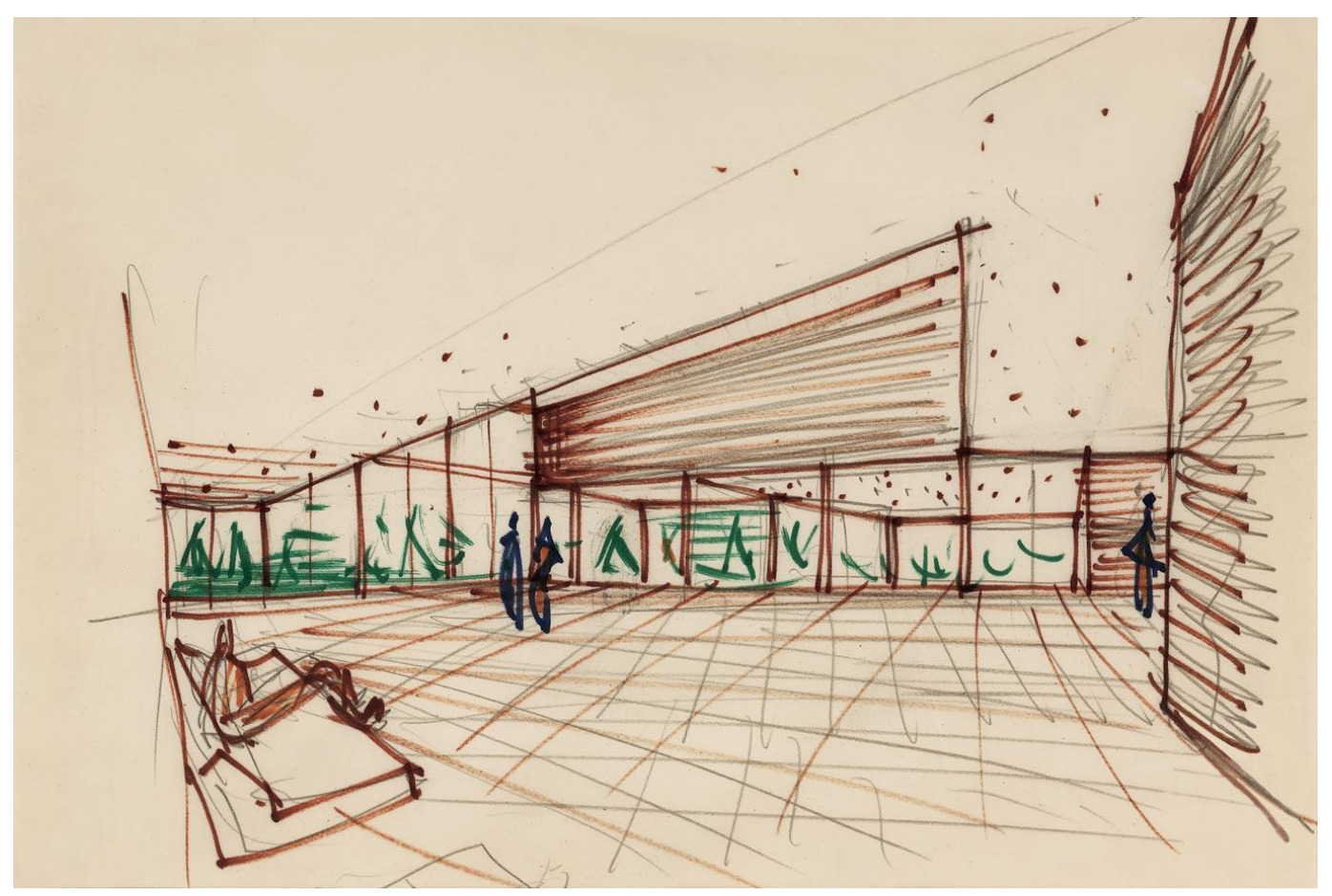

Imágenes 80 y 81: El planteamiento de la dimensión social, es tenido en cuenta por el autor desde los bocetos.

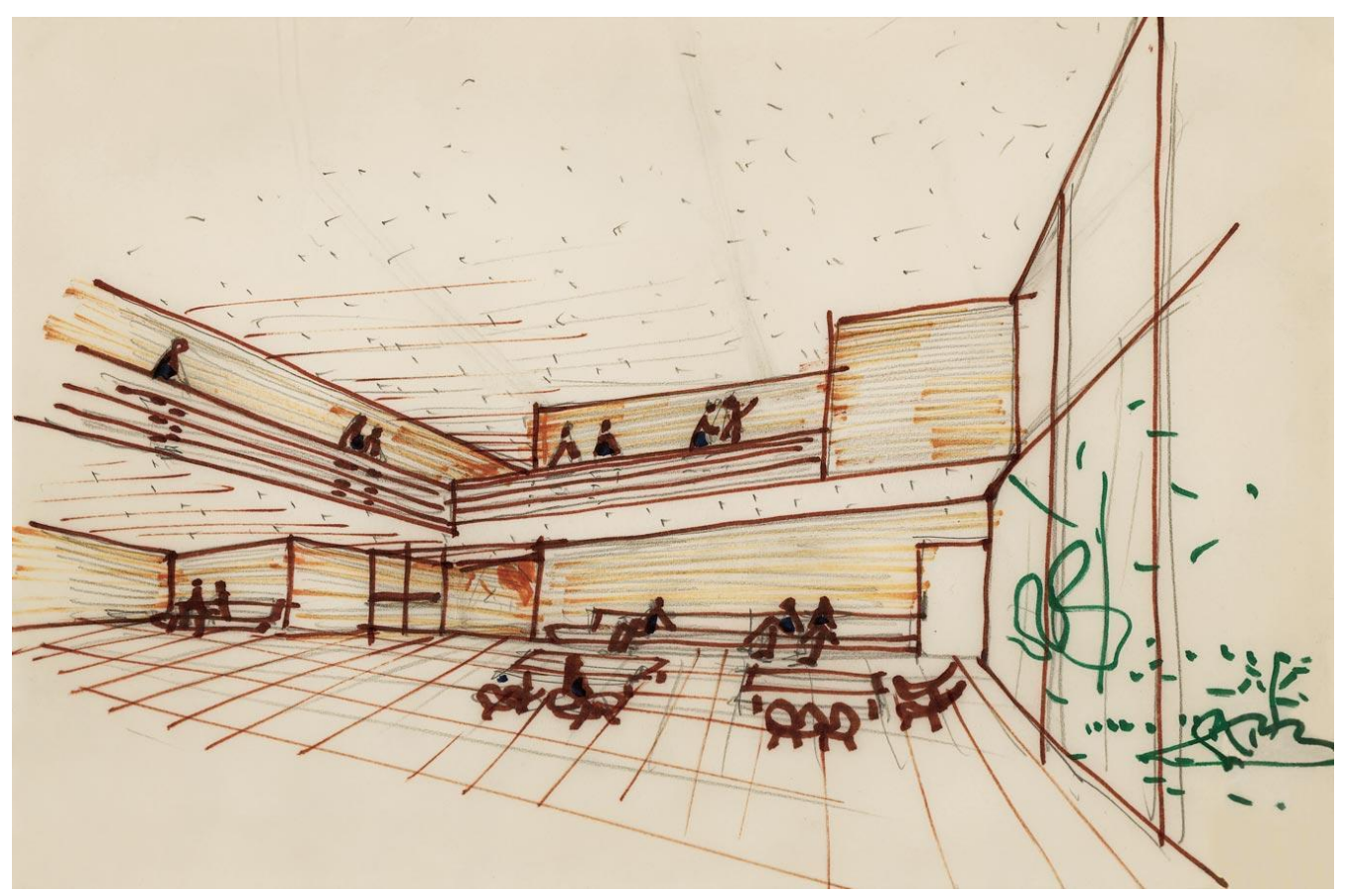


Imagen 82: Zonificación del Colegio Mayor César Carlos. Edificación abierta como implantación urbana y segregación plena según funciones.

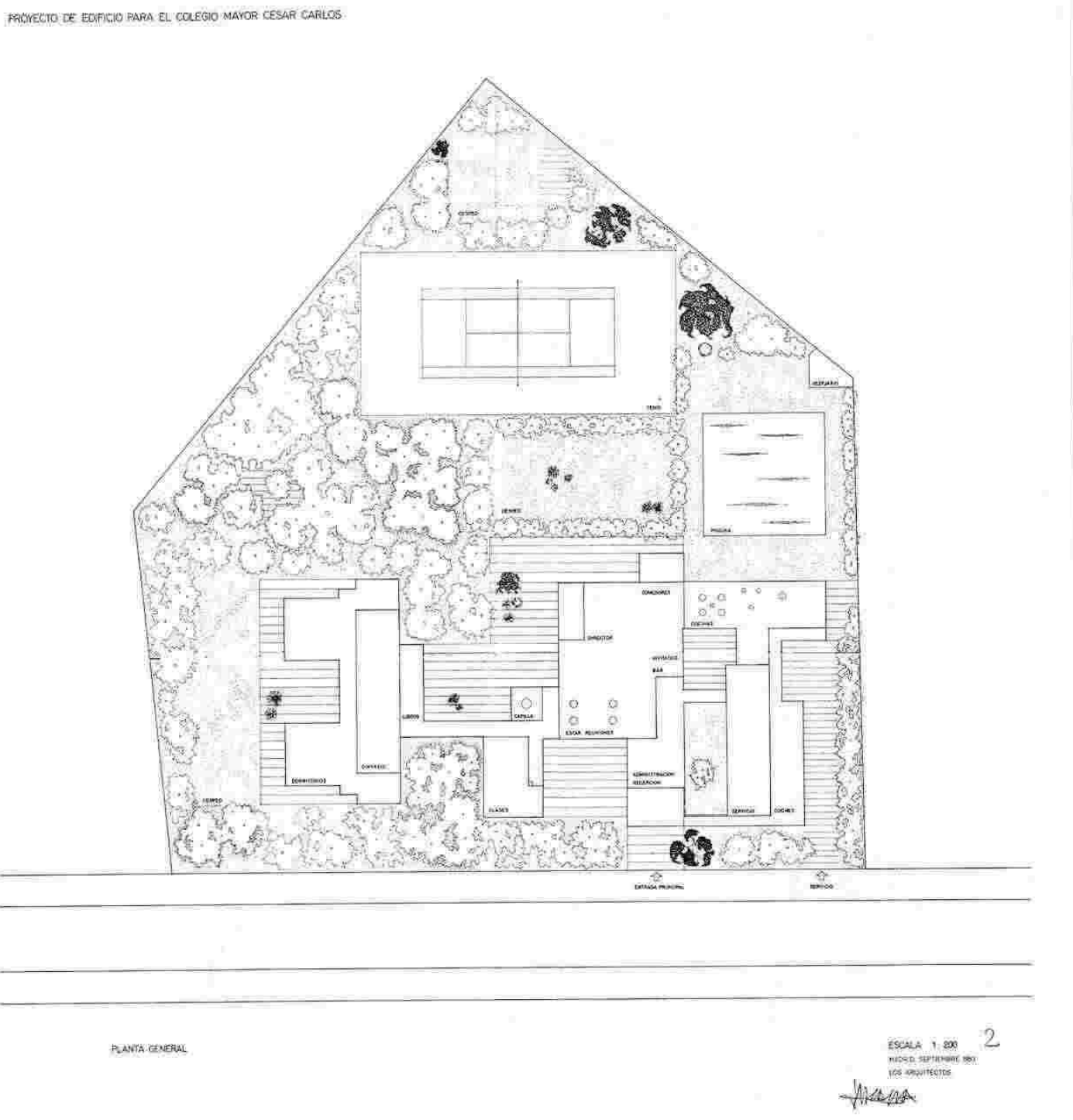




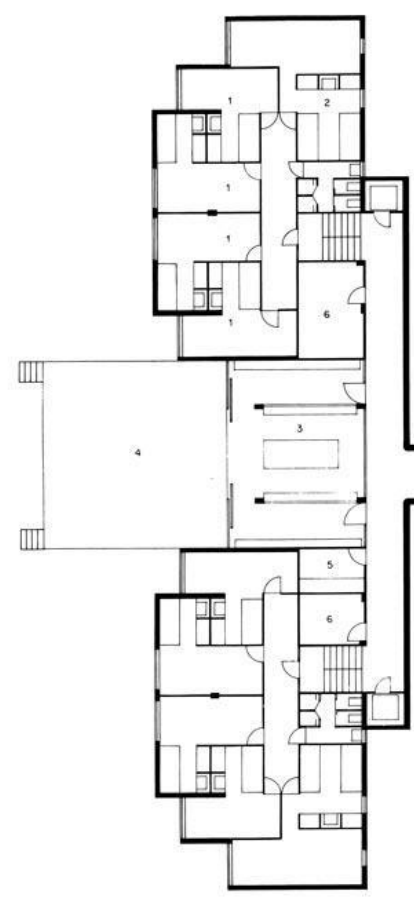

Imágenes 83: Planta pasarela subterránea:

1 DORMITORIO SENCILLO; 2 DORMITORIO DOBLE; 3 BIBLIOTECA; 4 TERRAZA; 5 CAFETERIA; 6 ALMACÉN 7 PASAJE SUBTERRÁNEO; 8 ALMACÉN; 9 INSTALACIONES; 10 PATIO SERVICIO;11 ALMACÉN SERVICIO
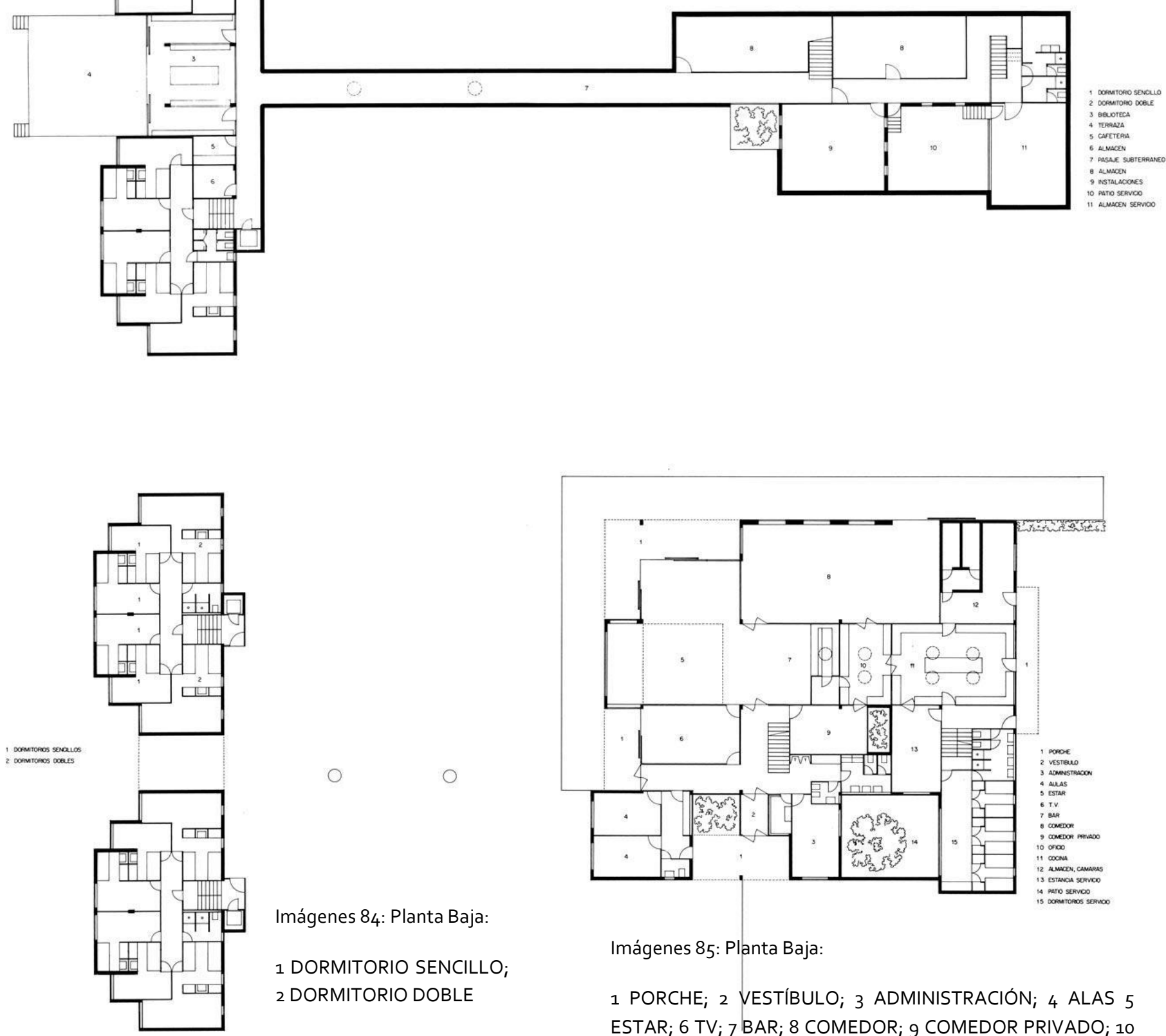

Imágenes 84: Planta Baja:

1 DORMITORIO SENCILLO; 2 DORMITORIO DOBLE

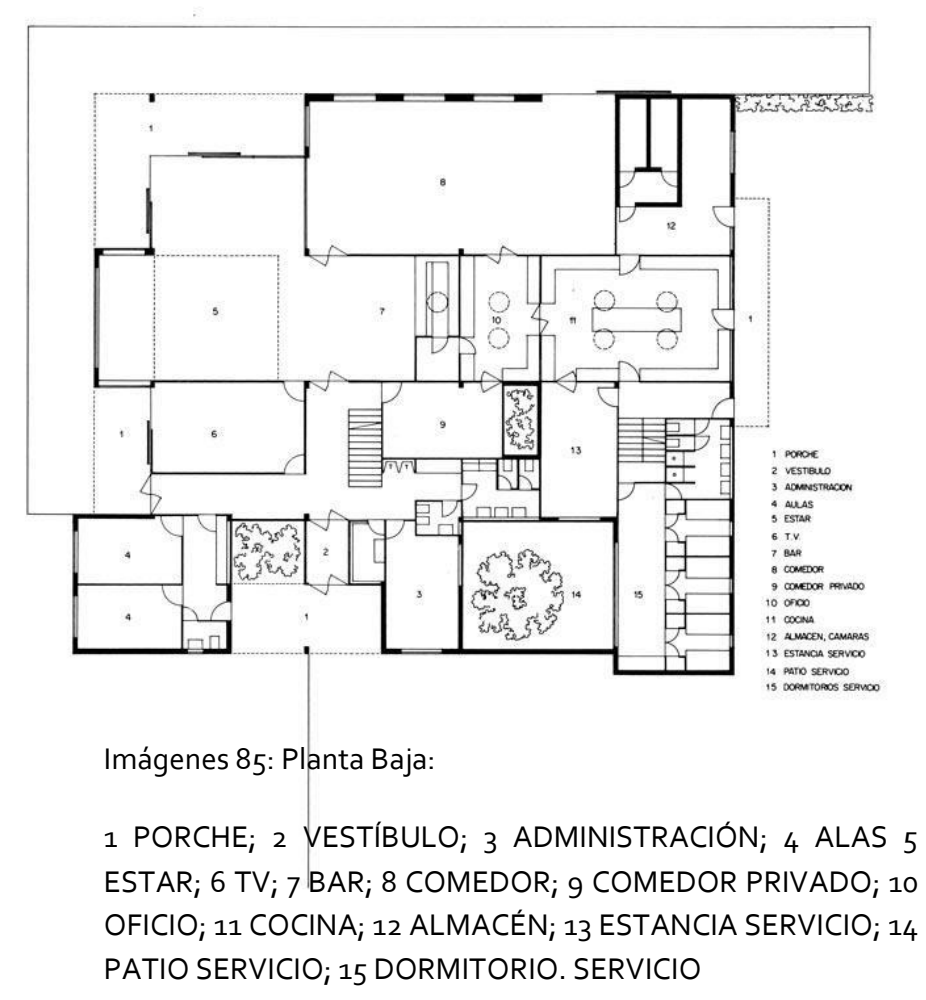

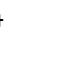



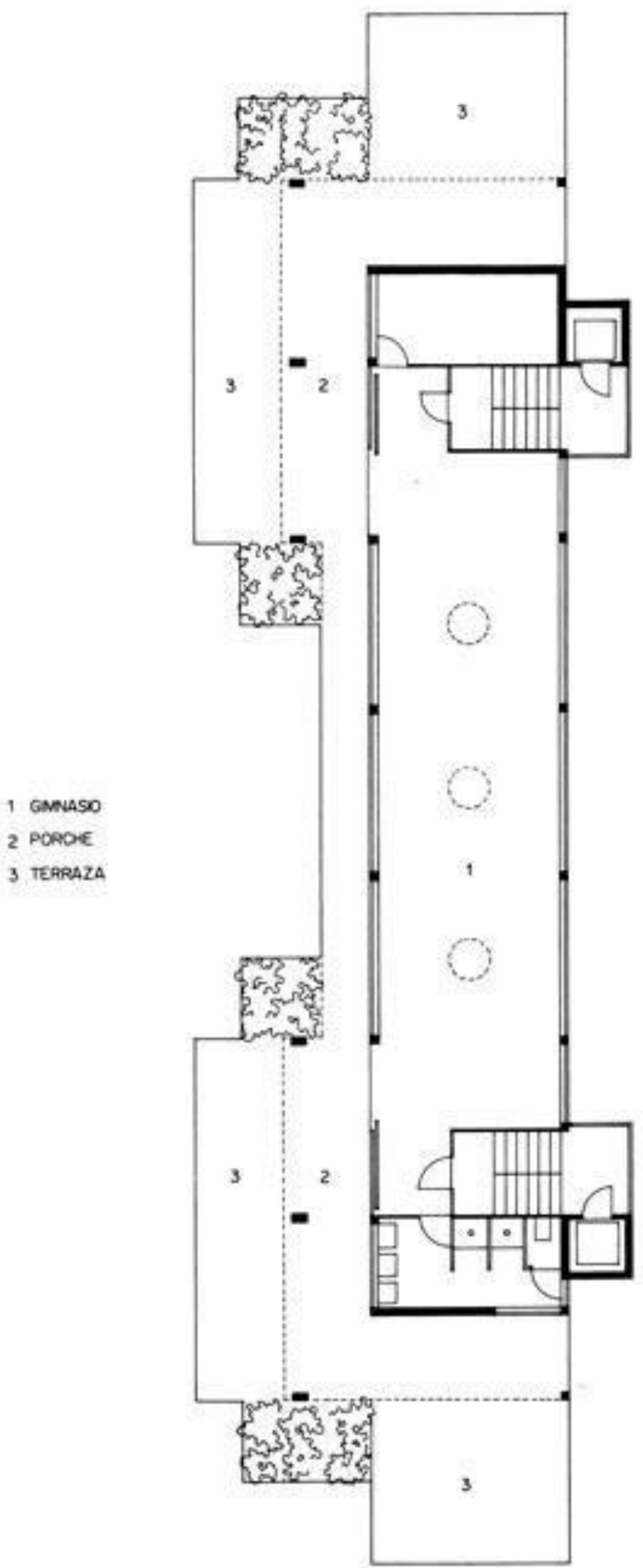

Imágenes 84: Planta Puente. 


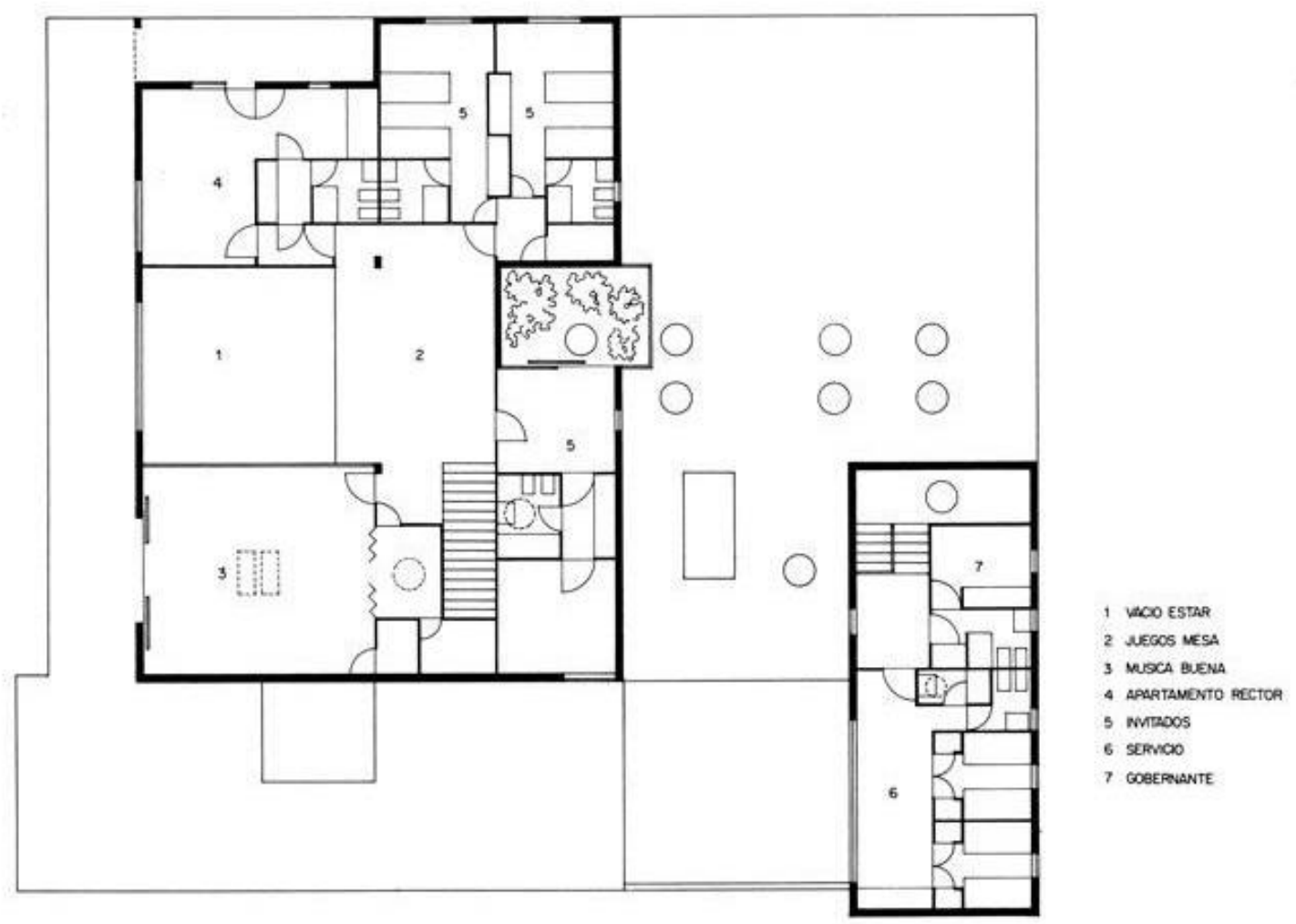

Imágenes 85: Planta 2. Zona de

servicios comunes y ocio.

Imagen 86: Alzado principal y Alzado posterior

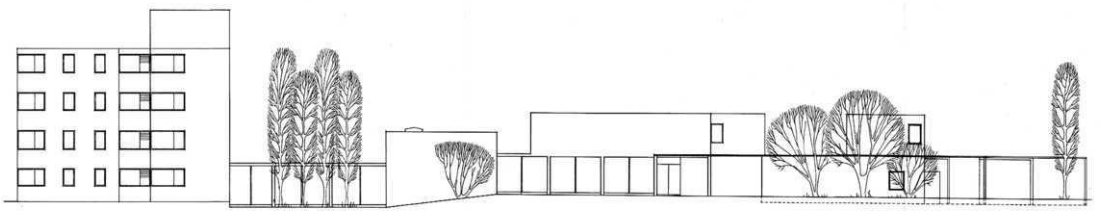

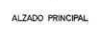

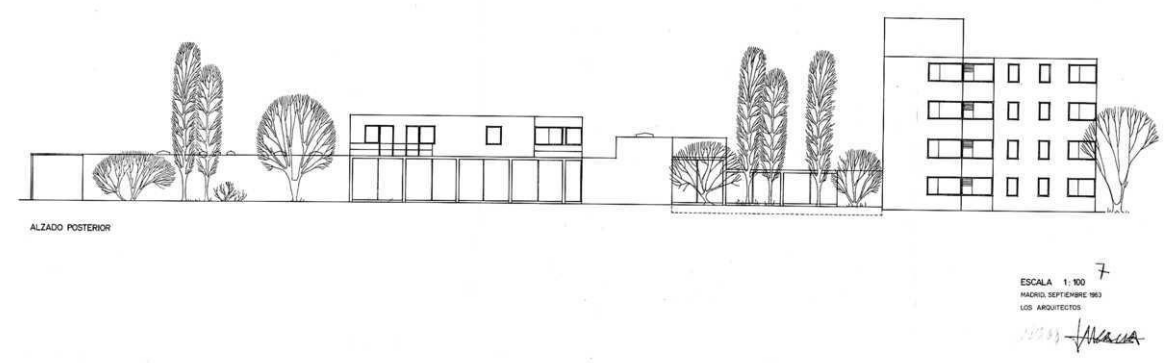



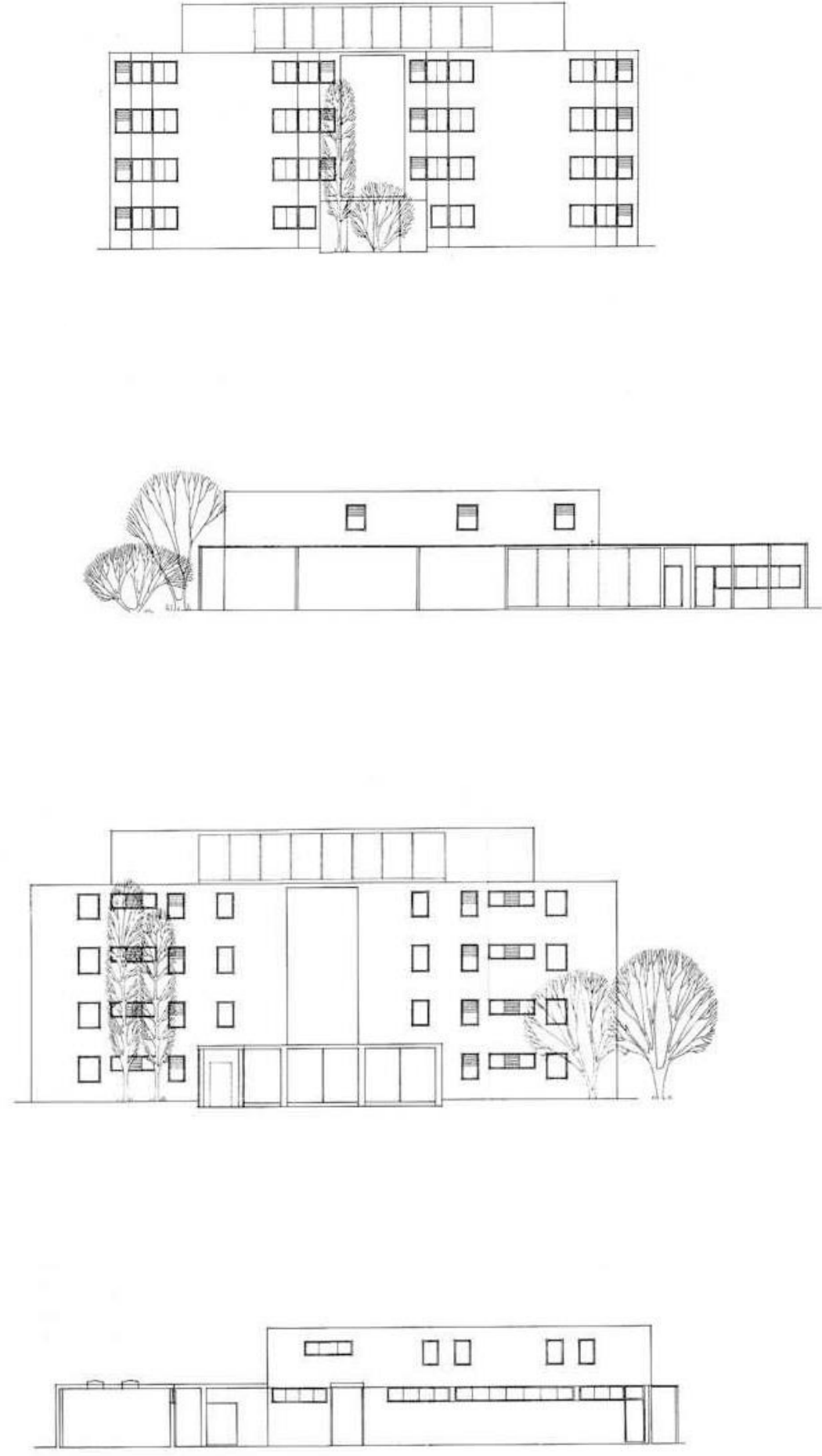

$$
\begin{aligned}
& \text { ESCALA , } 100 \\
& \text { Masho, seprieunat } \\
& \text { Hosten }
\end{aligned}
$$

Imagen 86: Alzado posterior del pabellón de dormitorios

Imagen 87: Alzado de la zona de servicio

Imagen 88: Alzado principal del pabellón de dormitorios.

Imagen 89: Sección y alzado interior d ela zona de servicio 

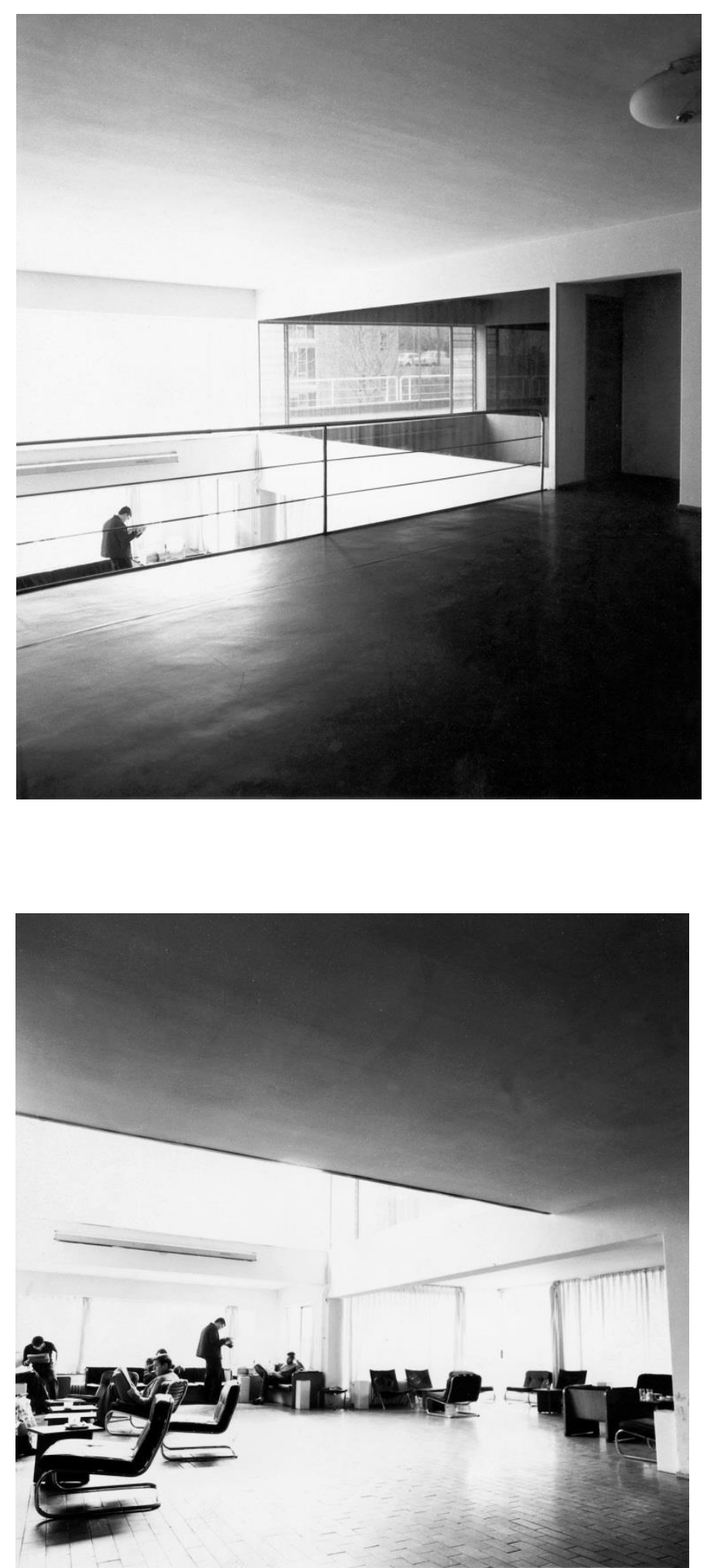

Imagen 90 y 91: Vistas interiores donde se ve potenciada la dimensión social y humana a través de los espacios. 


\section{COLEGIO MAYOR CASA DO BRASIL. ALFONSO d'ESCRAGNOLLE. Un bloque atemporal (1962)}

Para concluir, aparece situado al este de la zona residencial del primer proyecto de urbanización de la Ciudad Universitaria el Colegio Mayor Casa do Brasil, de Alfonso d'Escragnolle y, cuya dirección de obra fue llevada a cargo de Fernando Moreno Barberá.

La idea de la construcción de una Casa de Brasil en Madrid surgió con ocasión de la visita hecha a la capital española por el Dr. Juscelino Kubitschek de Oliveira, en aquél entonces Presidente electo de Brasil, que al recibir a los estudiantes de su país que ampliaban en Madrid sus estudios, apreció la necesidad de tal iniciativa cultural.

La escala social, al igual que El Modulor de Le Corbusier, se muestra de forma patente en este conjunto que guarda semejanza con las residencias parisinas de este arquitecto y también con la tendencia arquitectónica que Niemeyer y Costa ensayaban en la ciudad de Brasilia.

De acusada horizontalidad, está formado por varios volúmenes prismáticos unidos entre sí por pasadizos y se sustenta sobre una terraza apoyada sobre pilotes para salvar las irregularidades del terreno. La planta baja es libre, diáfana y está marcada por espacios a doble altura comunicados por escaleras en voladizo. El bloque de dormitorios se sitúa en un lugar de preferencia paralelo a la avenida del Arco de la Victoria. En las habitaciones se parte el estudio de una planta tipo que se va repitiendo indefinidamente.

El aspecto exterior está configurado por la fachada libre y la celosía como solución moderna para establecer las relaciones directas entre interior-exterior. Aspectos como la orientación, la iluminación y la acústica condicionan los materiales de la construcción, con lo que el bloque de dormitorios, paralelo a la avenida, presenta una fachada ciega con bandas continuas de celosía enmarcadas por la orla de piedra para protegerlo del ruido. Para filtrar la luz se utilizan parasoles.

El hormigón armado forma el contorno de las "cajas", que cada una de ellas, con tamaño diferente se reparten las funciones que alberga el colegio.

En el interior del edificio en la planta baja, la concepción del espacio también va a resultar libre, va a ser otra de las características de este edificio, con grandes espacios a dos alturas cuyo desnivel se salva mediante dos escaleras voladizas que se incluyen dentro del mismo 
espacio interior. Este espacio tiene una gran similitud con el Pabellón Suizo de Le Corbusier, donde el tratamiento de la escalera sirve para jerarquizar e identificar espacios según sean comunes o más privados.

Se hace patente la similitud de recursos constructivos empleados con los de Moreno Barberá en la Universidad Laboral de Cheste, tales como el tratamiento del hormigón visto y los pasadizos cubiertos. Asimismo aparece el ladrillo visto como material secundario, enfatizando la continuidad espacial al revestirse en espacios interiores como exteriores.

Esta obra aparece como un bloque atemporal, congregando, salvo la terraza ajardinada, los puntos de arquitectura de Le Corbusier, convirtiéndose en un emblema de la Arquitectura Moderna española de esta época. 


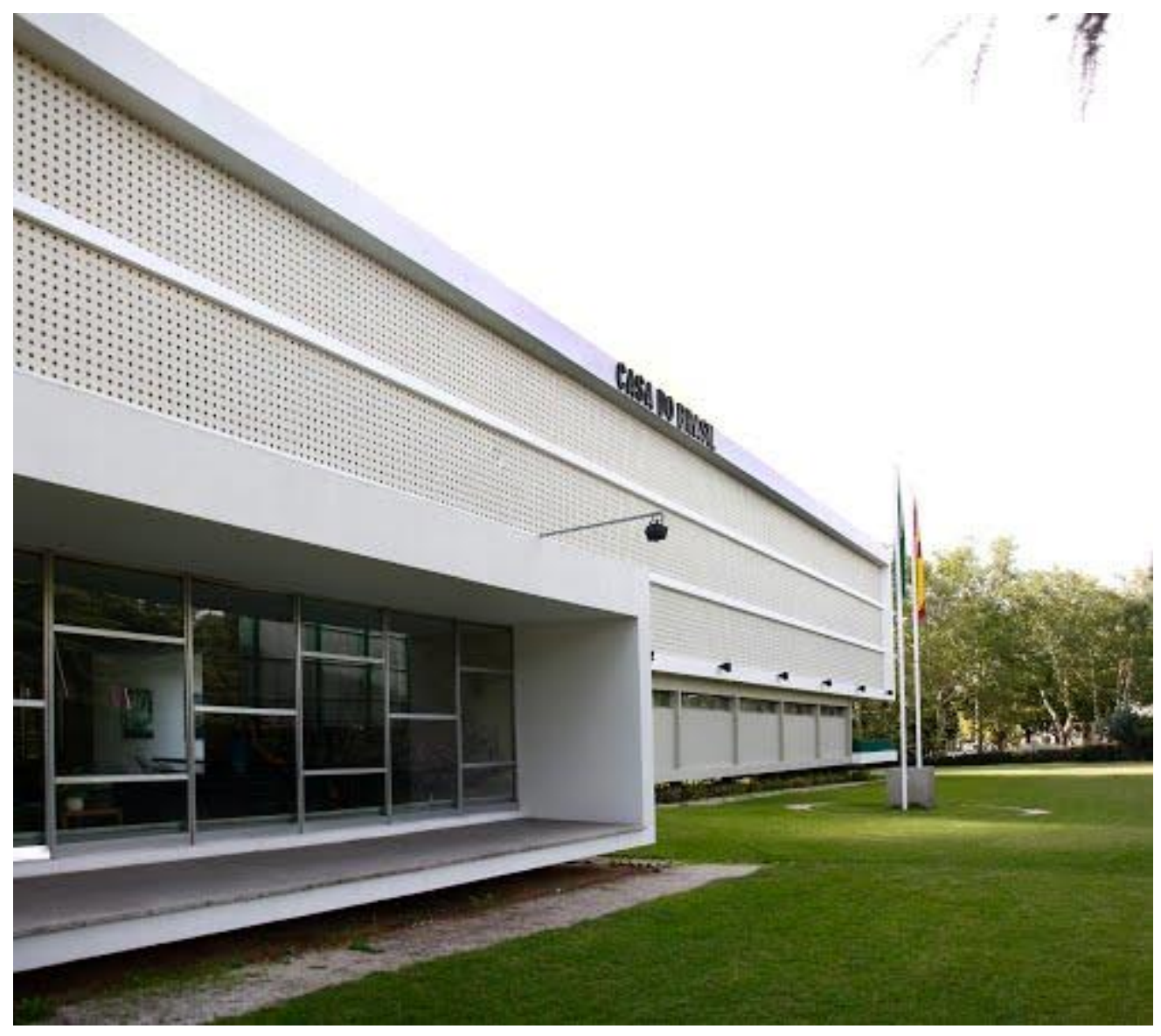

Imagen 92 y 93: Vista este del conjunto, se aprecia la celosía de forma continua en los tres niveles.

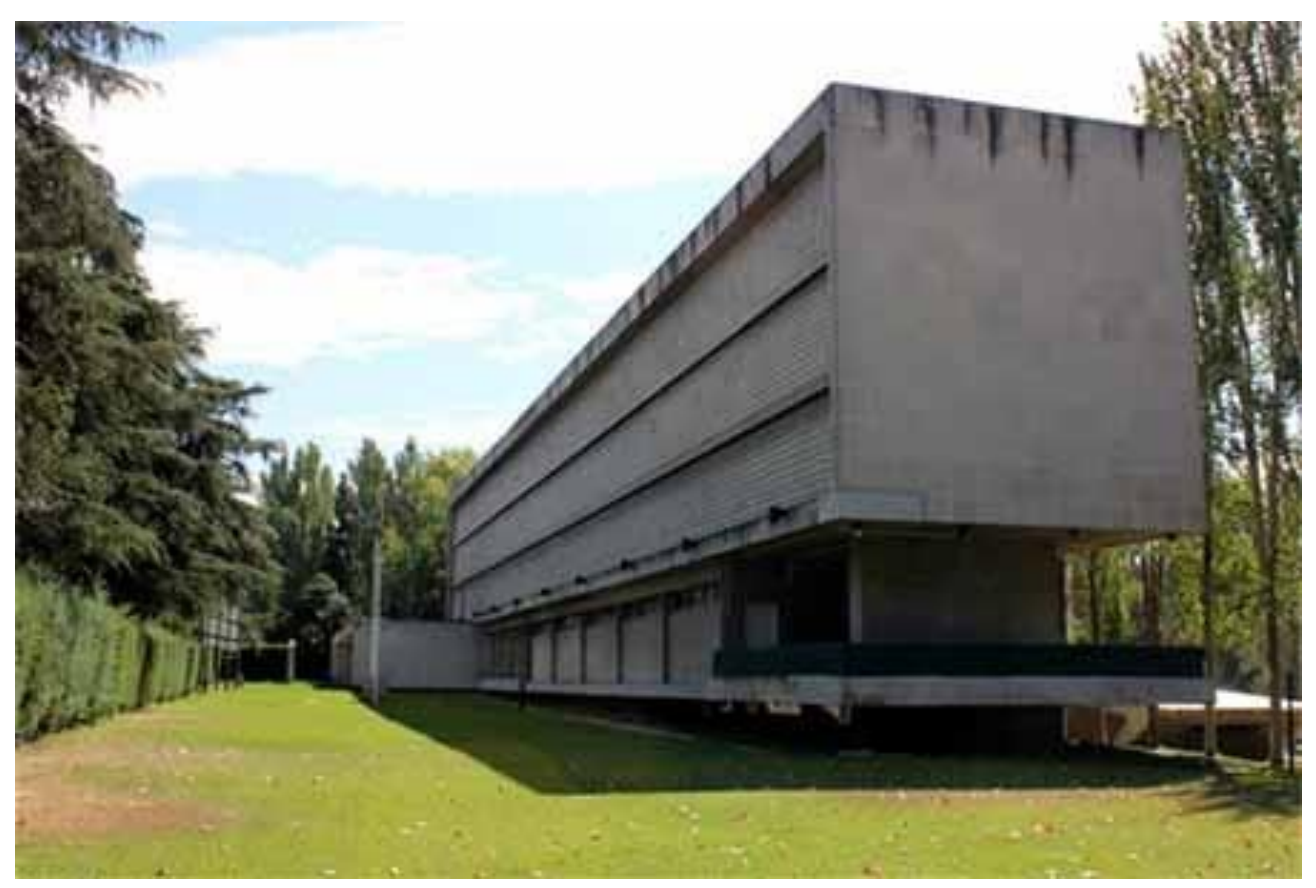




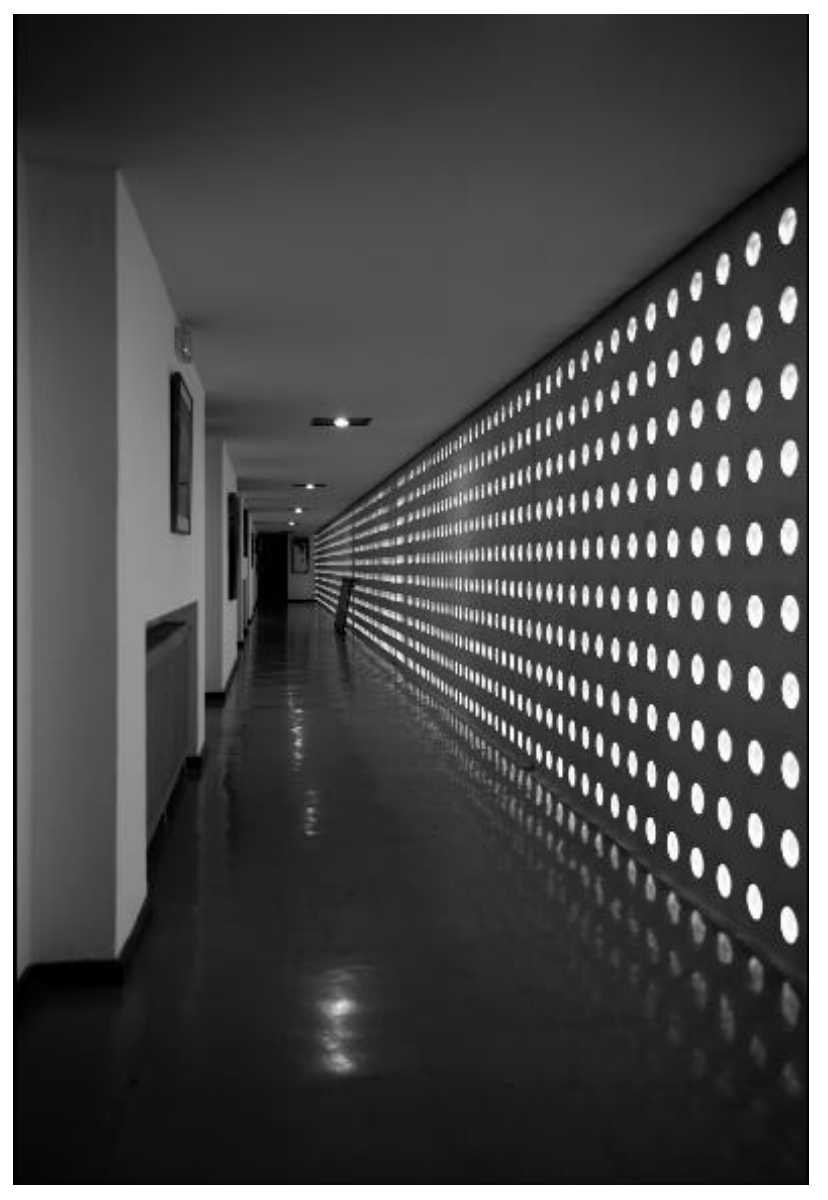

Imagen 94 y 95: Fachada libre y celosía como solución moderna interior-exterior

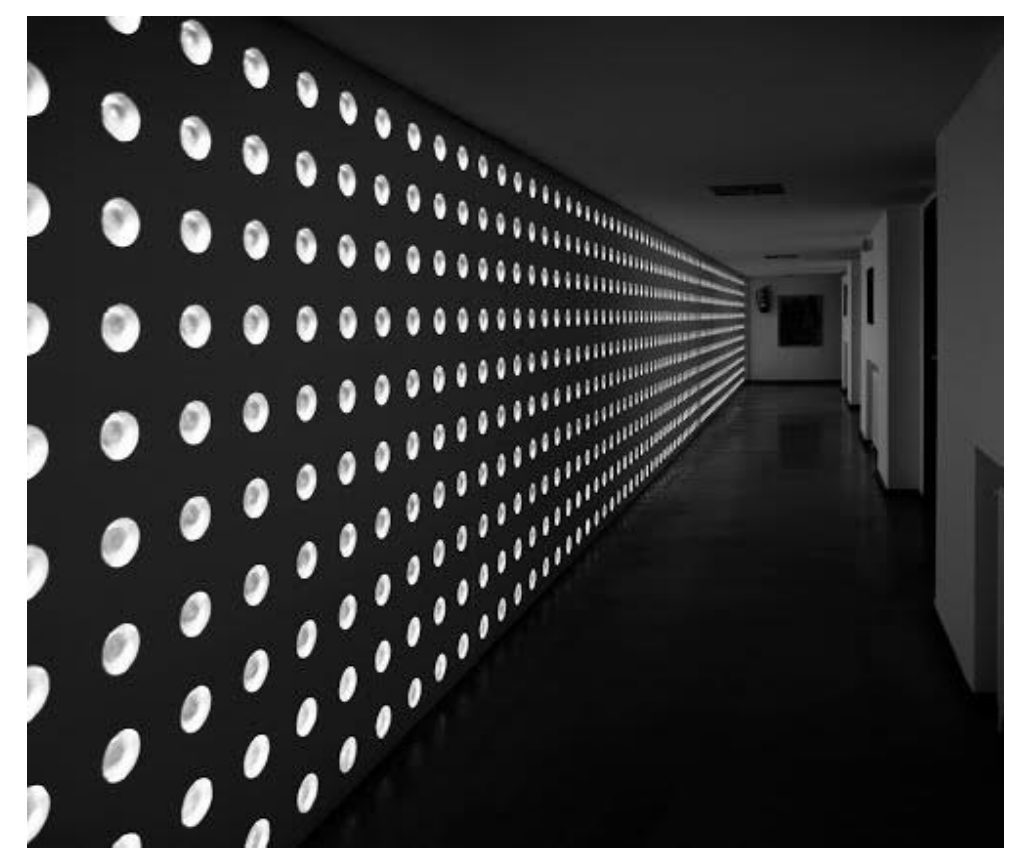




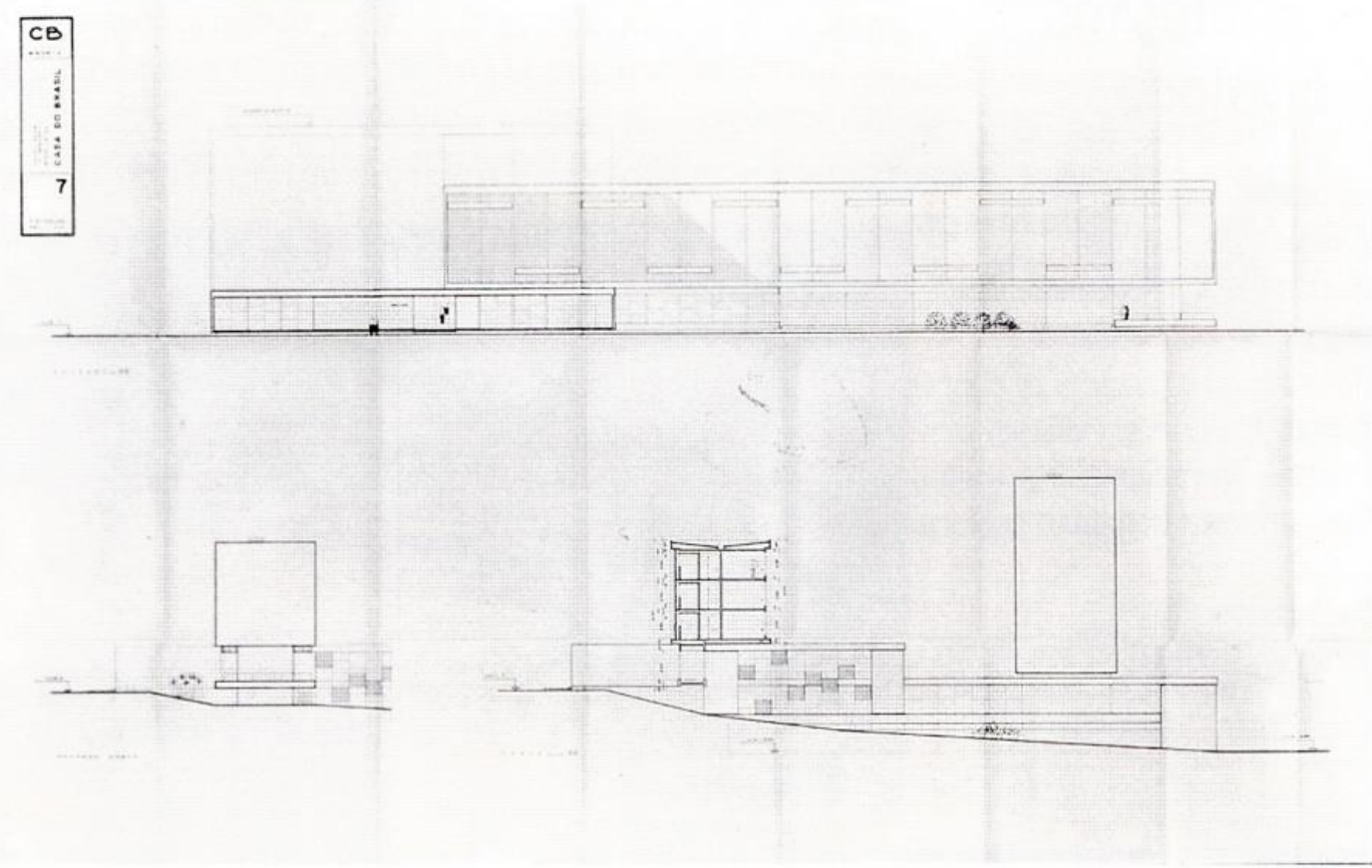

Imagen 96 y 97: Alzados y planta del proyecto original.

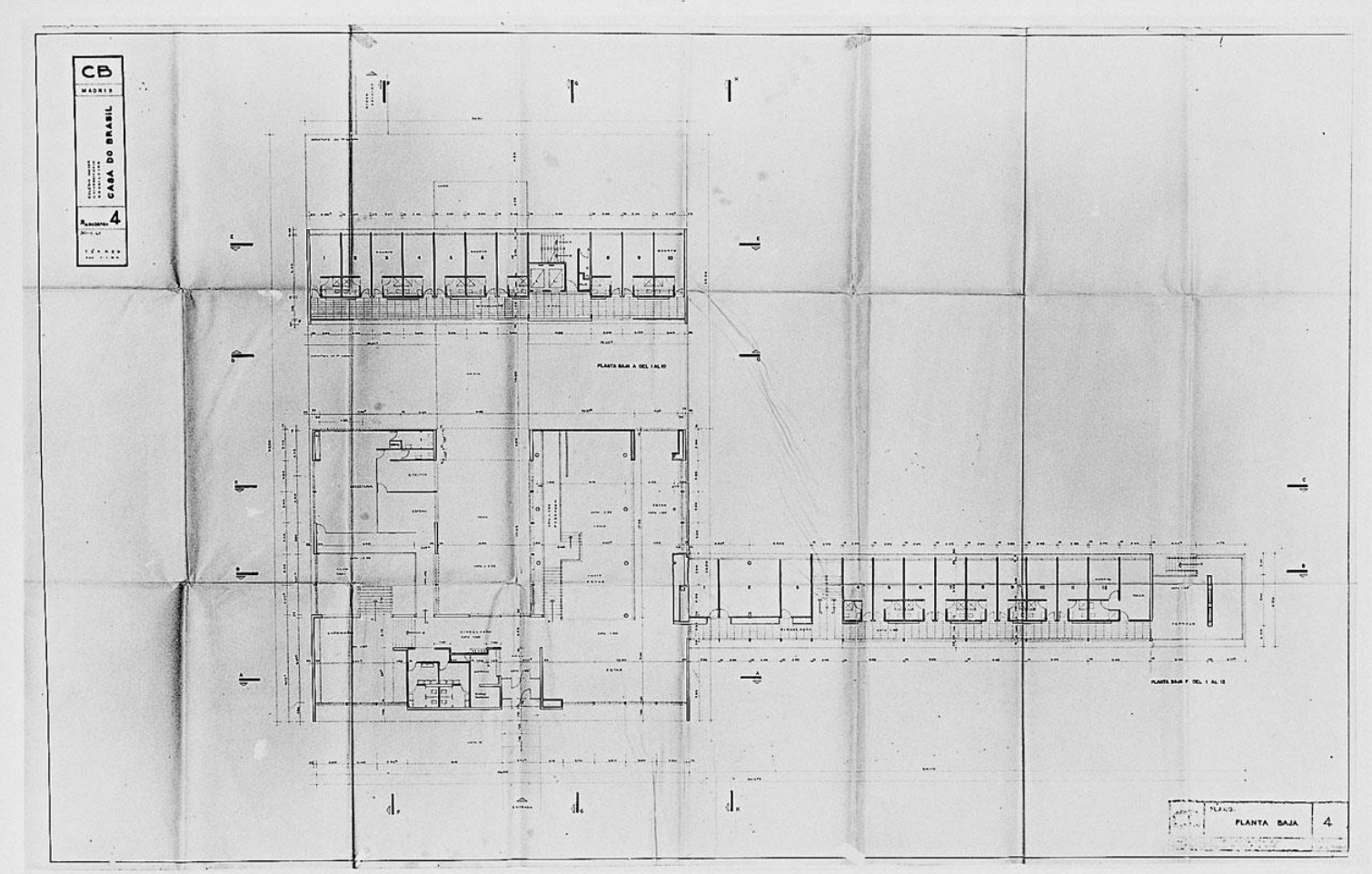




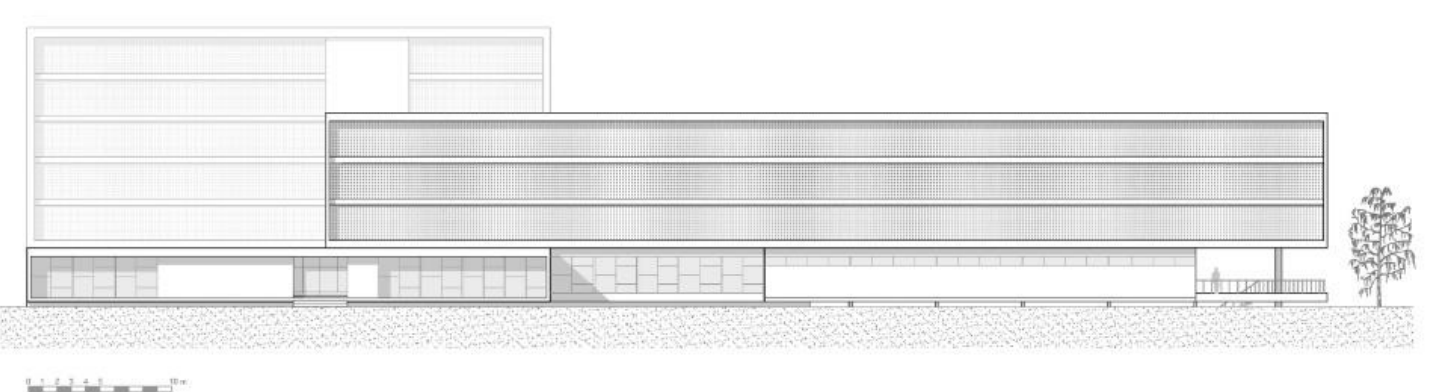

Imagen 98: Alzado este
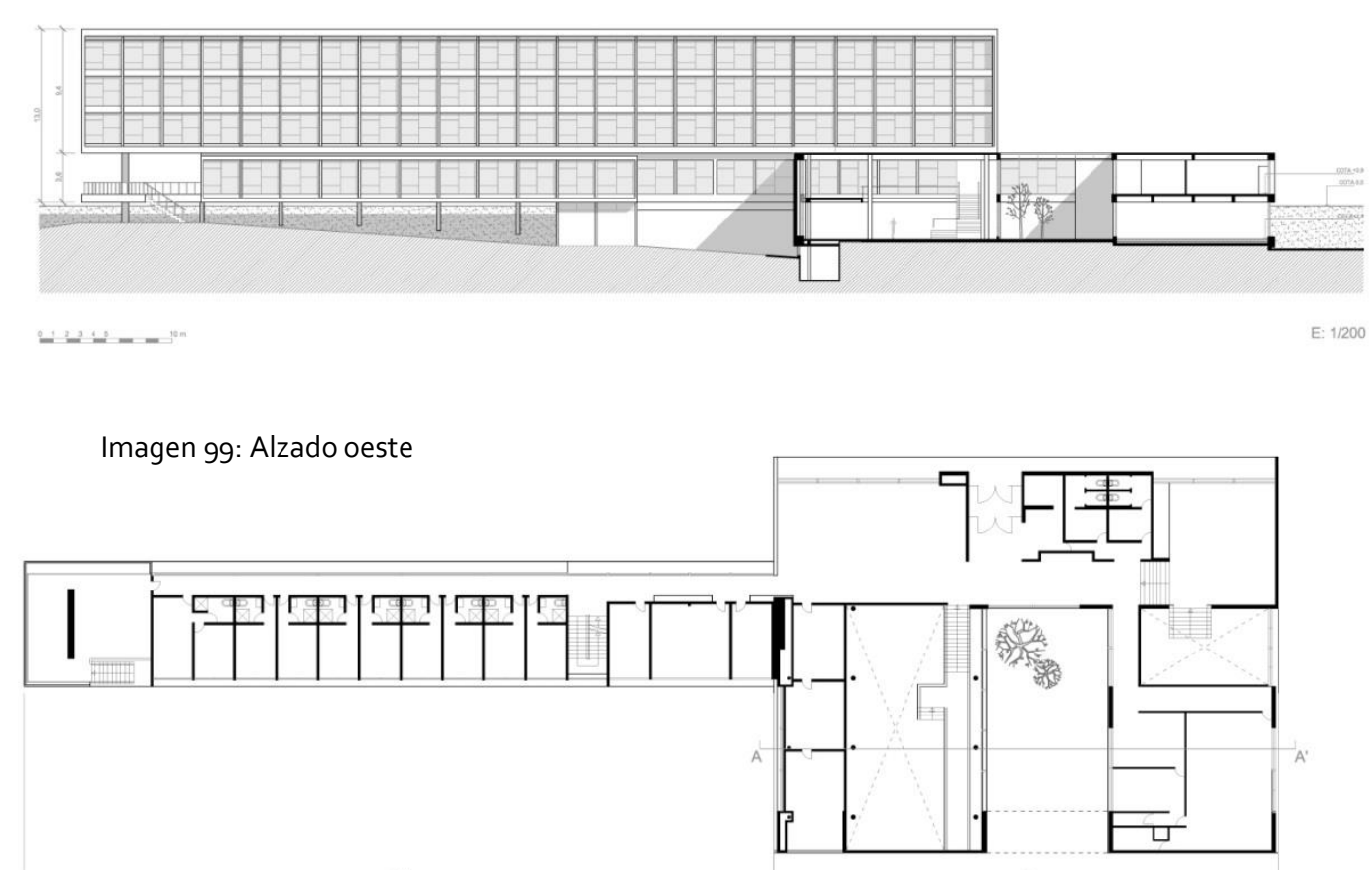

Imagen 100: Planta baja

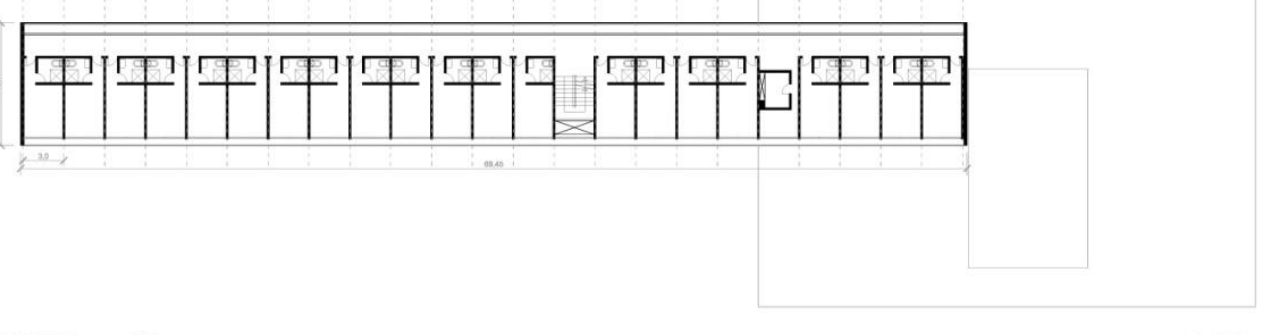

Imagen 100: Planta primera,

segunda y tercera 

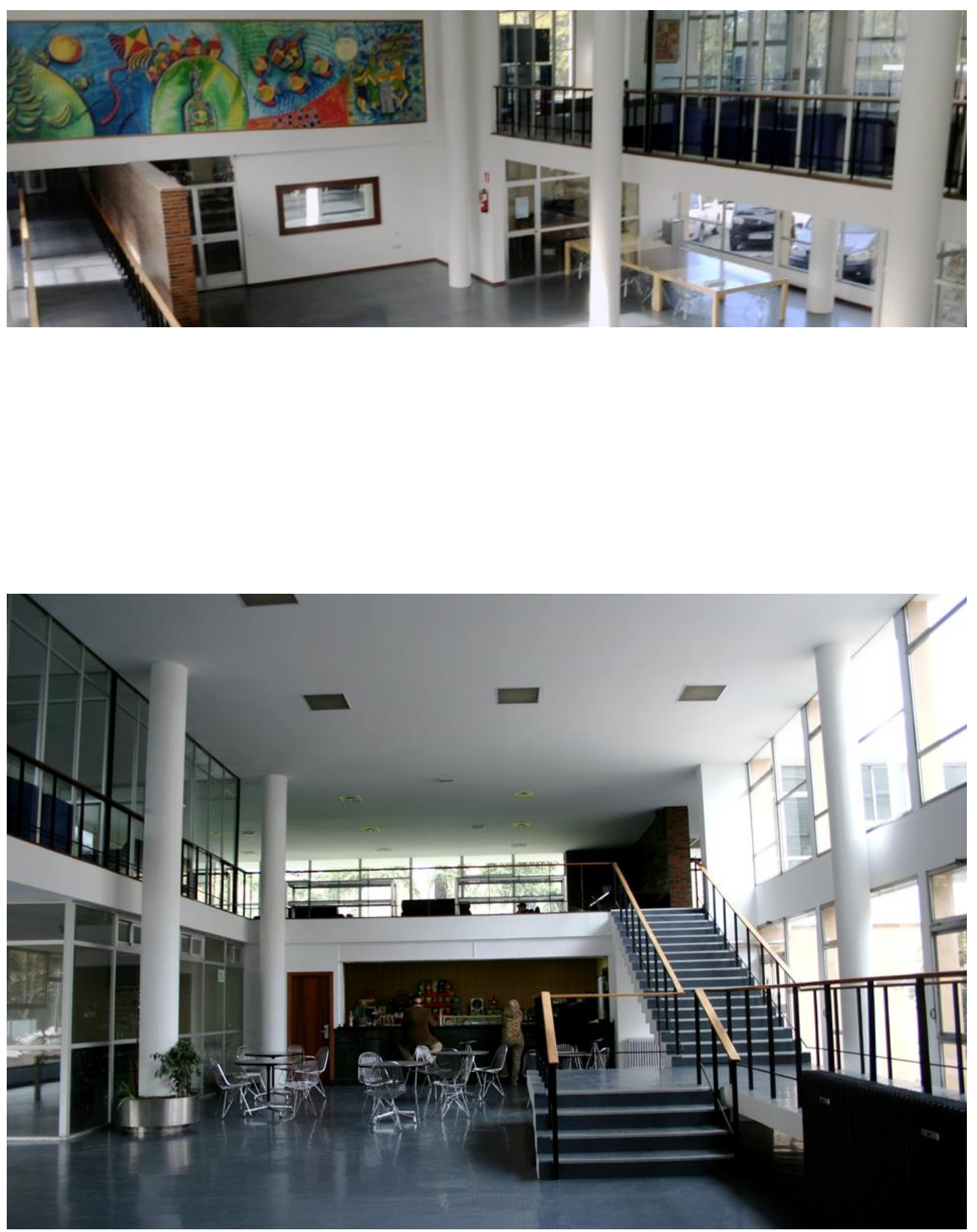

Imagen 101 y 102: Planta baja diáfana, independización de la estructura con respecto a la fachada. Solución moderna que permite los grandes tanto los grandes acristalamientos como la celosía. 


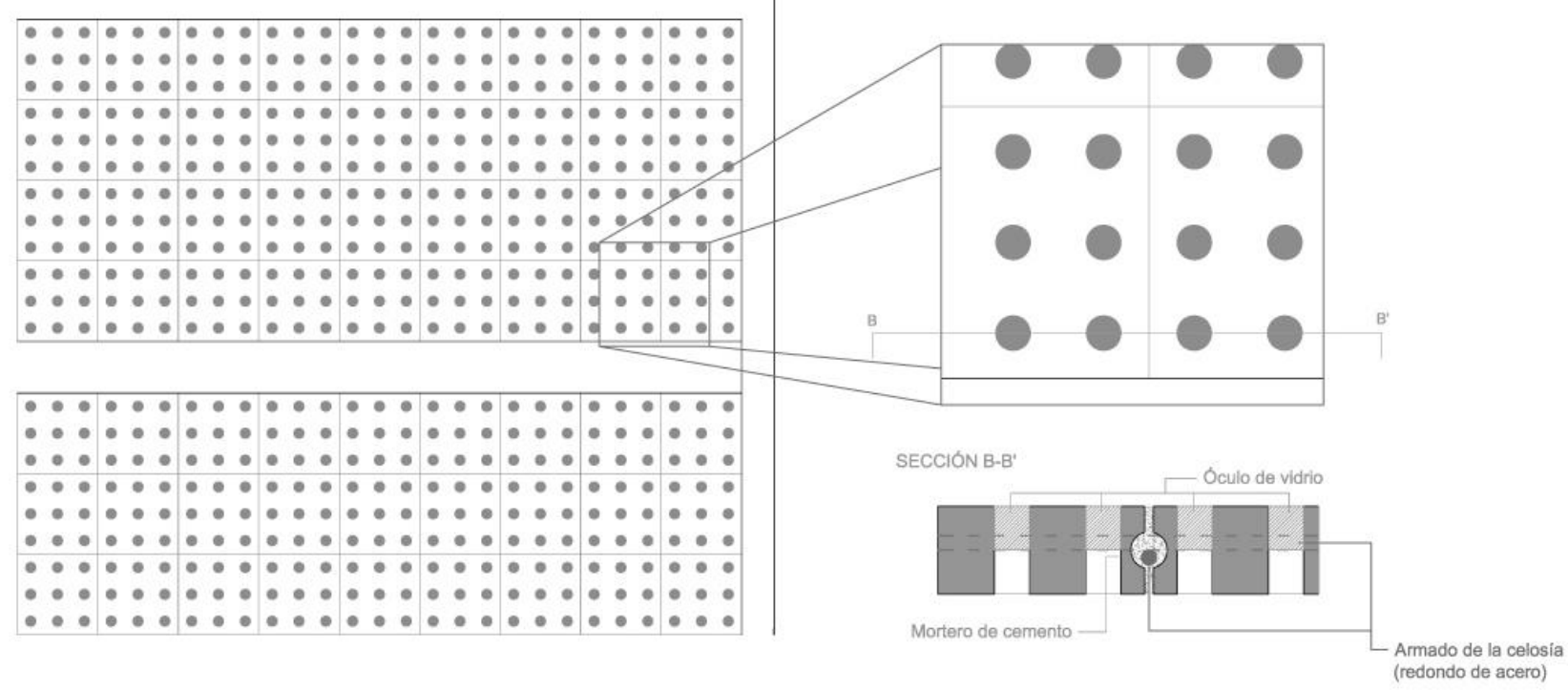

\section{ANCLAJE SUPERIOR}

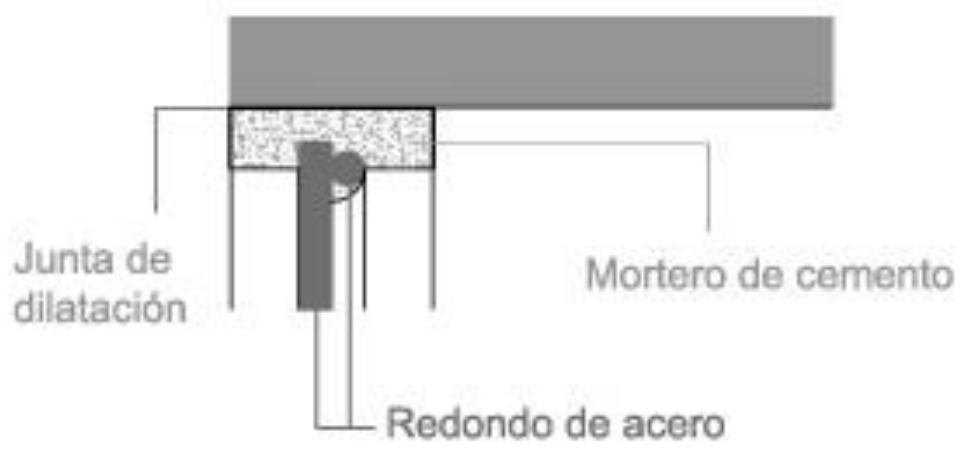

ANCLAJE INFERIOR

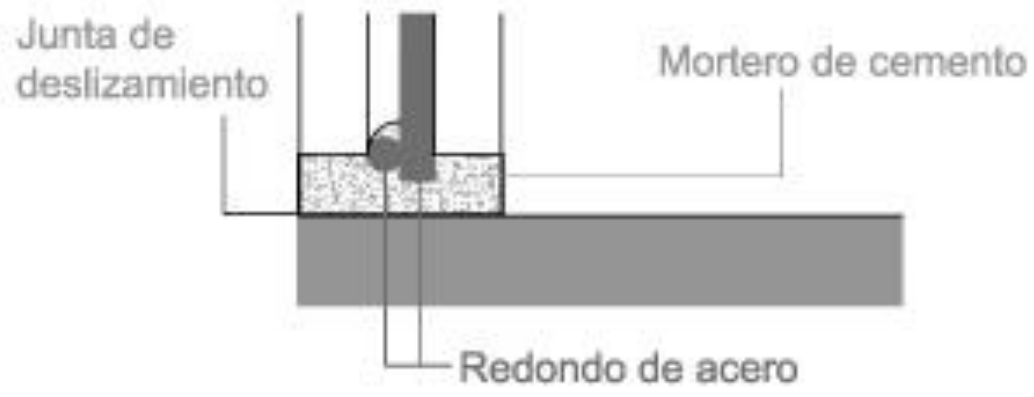




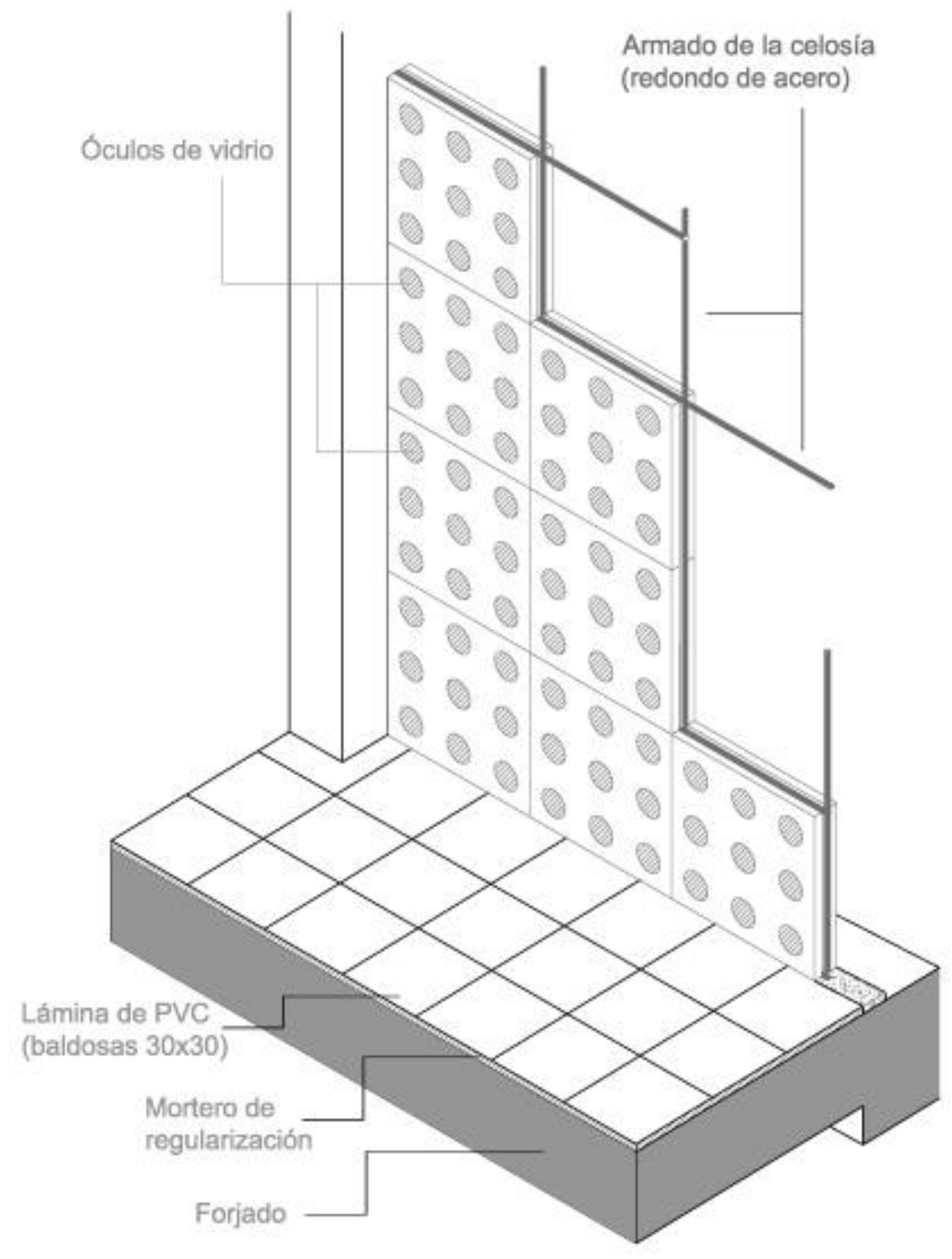




\section{NOTAS Y REFERENCIAS BIBLIOGRÁFICAS (COLEGIOS MAYORES DE LA CIUDAD UNIVERSITARIA DE MADRID Y LA AROUITECTURA MODERNA)}

1. BONET CORREA, Antonio, " La Ciudad Universitaria de Madrid: Realidad y utopía de un proyecto para la modernización cultural de España" en La Ciudad Universitaria de Madrid, volumen I. Ed. Colegio Oficial de Arquitectos de Madrid y Universidad Complutense de Madrid, 1998, p.1.

2. Ibíd, p. 1.

3. Ibid, p.5.

4. Elenco de Grandezas y Títulos Nobiliarios Españoles. Instituto "Salazar y Castro", C.S.I.C.

5. La Junta se creó por Real Decreto de 17 de mayo de 1927.

6. El concurso de la Institución Rockefeller de la CL. Serrano de Madrid se encuentra profusamente publicado, así como su construcción; por ejemplo en la Revista Obras no 7 , abril 1932.

7. ChÍAS NAVARRO, Pilar. "La Ciudad Universitaria de Madrid". Tesis Doctoral. Universidad Politécnica de Madrid, febrero de 1983. Madrid, 1983. p. 22.

8. $A B C, 24$ de mayo de 1927. p. 12.

9. Bajo la presidencia del Rey se agrupaban:

- como vicepresidente: el ministro de Instrucción Pública y el Rector de la Universidad Central;

- como secretario, Florestán Aguilar.

- como tesorero, Agustín Peláez(síndico de los agentes de Bolsa)

- como arquitecto director (desde el 24 de bril de 1928, puesto que antes era vocal por su condición de director de la Escuela de Arquitectura: Modesto López Otero;

- vocales: el Alcalde de Madrid; Decanos de las facultades de Medicina, farmacia, Filosofía y Letras y Derecho; y los catedráticos de las mismas Sres. Simoena, Palacios, Folch y Asín Palacios.

- $\quad$ Asesor Jurídico; Yanguas Messía;

- Delegado de ja Junta Facultativa de Construcciones Civiles: Luis Landecho.

10. ChÍAS NAVARRO, Pilar. "La Ciudad Universitaria de Madrid" Op. Cit. P. 25. 
11. Acta de la sesión extraordinaria celebrada en la Sociedad Central de Arquitectos, el 25 de abril de 1928.

12. ..."Vivian (los arquitectos de 1875 a 1910) un ambiente densamente histórico. Reunían el alma plena de tradición, a lo que debe añadirse su formación académica y el peso de la opinión local, tan arraigada en nuestros viejos escenarios urbanos, lo que explica su cautela ante cualquier novedad"... "Tales arquitectos, que pueden clasificarse como eclécticos en cuanto al estilo, poseedores de las novedades técnicas, diestros en la práctica profesional, buenos dibujantes, y con un especial equilibrio entre sus acopios científicos y su estabilidad artística, dominada por una entrañable adhesión a su arquitectura original y a sus característicos monumentos, a los que apasionaban apasionadamente..."

Texto extraído de la conferencia pronunciada por López Otero en la sesión inaugural de la Cátedra Ricardo Magdalena en Zaragoza, 1960.

13. ChÍAS NAVARRO, Pilar. "La Ciudad Universitaria de Madrid" Op. Cit. P. 35.

14. CAMPOS CALVO SOTElO, Pablo, "El viaje de la Utopía". Ed. Complutense, Madrid, 2002. p.

15. "Las Universidades norteamericanas", apuntes de viaje de López otero.

16. La Universidad de Harvard, por ejemplo, llevaba recibidos en 1926, más de 76 millones de dólares "para fines generales y para dotar a sus diferentes instituciones".

17. Se refiere a la tendencia de la Universidad de Montreal. Una de las visitadas en el periplo por estados Unidos y Canadá.

18. Los "halls" y los destinados a fines especializados: Laboratorios, clínicas, museos, bibliotecas, hospitales...

19. Viene apuntado por López Otero con su nombre en inglés: "Dormitories" y "Fraternities".

20. Incluían las escuelas militares y multitud de instalaciones para la práctica de diversos deportes como football americano, tenis, squash, natación, regatas, golf...

21. Destinada a preparar a los estudiantes para el servicio militar. Esta idea se recogerá en la inmediata posguerra.

22. La cesión se verificó por Real Decreto Ley no 2.246 de 3 de Diciembre de 1928; la intención de realizarla se conoció mucho antes, como reflejarán los sucesivos trabajos del equipo de López Otero.

23. CAMPOS CALVO-SOTELO, "EI Viaje de la Utopia". Op. Cit. 107-115

24. Ibid, p. 107-115. 
25. Del acta de la sesión celebrada el día 25 de abril de 1928, se extraen los siguientes párrafos:

..."El vocal Sr. Landecho propone que por las circunstancias de preparación y extraordinaria capacidad profesional del Sr. López Otero, la Junta, prescindiendo de convocar concurso alguno para formar el proyecto de conjunto de las construcciones de la ciudad universitaria, debe encomendar dicho trabajo a dicho Sr. D. Modesto López Otero, designándole Arquitecto Director de la Ciudad Universitaria"...

26. El citado acuerdo continúa:

..." S.M. el rey manifiesta que el Sr. López Otero conoce mejor que nadie las necesidades de las diferentes facultades, que en sus viajes de estudio se ha capacitado especialmente para esta labor y ha demostrado ante la Junta su laboriosidad y preparación, haciéndose acreedor de la absoluta confianza de la misma y debe ser por tanto, encargado de la dirección suprema del proyecto"... "el Sr. Somonena manifiesta que, en su opinión, el mejor y único preparado para confeccionar el proyecto es el Sr. López Otero, sumándose a esta opinión los Sres. Yanguas y Bermejo"...

27. Ver "Construcción Moderna", 30 de mayo de 1928.

28. Extracto de acta de la sesión extraordinaria de la Sociedad Central de Arquitectos del 18 de julio de 1928.

29. Ibid.

30. AA VV, "La Ciudad Universitaria de Madrid", volumen II. Ed. Colegio Oficial de Arquitectos de Madrid junto con Universidad Complutense de Madrid. Madrid, 1988. P.24.

31. CHÍAS NAVARRO, Pilar. "La Ciudad Universitaria de Madrid" Op. Cit. P. 72.

32. NAVARRO, Concepción y NIÑO, Antonio, "La casa matriz del sueño hispánico. El Colegio Mayor Hispanoamericano Nuestra Señora de Guadalupe. 1947-2009" p. 14

33. Ibid, p. 39.

34. Ibid, p. 59 .

35. Fue creado por la Universidad Madrileña, pero la iniciativa y la dirección correspondía a la Obra Católica de Asistencia Universitaria, un organismo dependiente de Pax Romana. En la época franquista era comunes este tipo de iniciativas para ayudar a los emigrados del bolchevismo.

36. NAVARRO, Concepción y NIÑO, Antonio, "La casa matriz del sueño hispánico. El Colegio Mayor Hispanoamericano Nuestra Señora de Guadalupe. Op. Cit. P. 89. 
37. LASCARIS MORENO, Constantino, "Colegios mayores". Ed. Ediciones de Cultura Hispánica, Madrid, 1952.

38. AA VV, "La Ciudad Universitaria de Madrid", volumen II. Op. Cit. P. 103.

39. Ibid, p. 121.

40. Ibid, $\mathrm{p} 121$.

41. Ibid, p. 121.

42. Ibid p. 147

43. SEOANE, Carlos, "Gregorio del Amo: un mecenas desconocido", Ed. Gaceta Complutense, Madrid, 2000.

44. TABERA ROLDÁN, Andrés y TÁRRAGO MINGO, Jorge. "El concurso del Colegio Mayor Nuestra Señora de Luján de 1964. Política, viajes y encuentros, dibujos. Ed. Universidad de Navarra. El presente texto se enmarca dentro del proyecto de investigación "El siglo XX: España y Latinoamérica a través d la Arquitectura: Exilios, ayudas y dependencias mutuas: triunfos y fracasos. Los casos de Argentina y México subvencionado por el Ministerio de Ciencia e Innovación del Gobierno de España (Ref. HAR2009-13381).

45. Horacio Baliero (Buenos aires, 15 de marzo 1927-26 de marzo de 2004) y Carmen Córdova (Buenos aires, 28 de diciembre 1929-01 de febrero de 2011). Se conocen en el taller del pintor argentino Emilio Pettoruti en 1948. Junto con otras personalidades que marcan su formación universitaria y primeros años de profesión (Francisco Billrich, Alfredo Hlito, Tomás Maldonado) fundan el grupo OAM (Organización para la arquitectura moderna). Siempre vinculados a la vanguardia local, forman parte de un conjunto de intelectuales argentinos disconformes con el pensamiento conservadurista del gobierno Peronista. Son miembros fundadores de la Editorial Nueva Visión en 1950, resultado de las reflexiones contrarias a los valores políticos y sociales del momento y en donde el concepto de arquitecto comienza a vincularse a otros campos artísticos como la música, la danza, la pintura...

46. AA VV, "La Ciudad Universitaria de Madrid", volumen II. Op. Cit. P. 155.

47. Ibid, p. 155 .

48. Ibid, 156 .

49. Ibid, p.185. 


\section{EPÍLOGO - CONCLUSIONES}

\section{¿Fin de una época?}

¿Cómo se implantan y evolucionan distintos modelos de residencia universitaria a lo largo de su historia? Estas conclusiones tratarán de aproximar algunas respuestas simplificadas a estos interrogantes. Partiendo de la base de que, en cualquier investigación, siempre hay que pensar que, las conclusiones son y se deben interpretar como provisionales.

El establecimiento de unos límites es necesario para acotar el contenido, desde qué punto empieza y hasta donde finaliza el trayecto investigador. En este caso, el comienzo se establece con el nacimiento de las universidades, ya que está muy relacionado con el origen de las residencias universitarias. Por otra parte, la terminación de este trabajo se hace coincidir con un final de siglo, el $X X$, en el que, posiblemente, se empieza a producir un punto de inflexión dentro de las tendencias arquitectónicas que afectan al tema principal. Tras finalizar el análisis realizado, se ha estimado conveniente pensar en la fecha de 1965, haciéndola coincidir con la establecida por el Registro DOCOMOMO IBÉRICO en España, que es la estipulada como finalización del periodo de arquitectura moderna por nuestros territorios.

Tras establecer el punto de partida en la época medieval, comienza la línea de investigación a través de las residencias universitarias objeto de análisis. Cada una de las edificaciones se ha estudiado atendiendo a su localización, periodo cronológico y contexto arquitectónico. Se ha realizado una selección de obras para identificar cuáles han sido capaces de, entre otros conceptos, configurar un arquetipo, resistir o no el paso del tiempo, repercutir influencia en casos posteriores, provocar una evolución de programas, funciones y/o materiales, es decir, las que han logrado convertirse en algún patrón arquitectónico.

La arquitectura de residencias universitarias ha ido cristalizando en diferentes estructuras en función del espacio, tiempo y lugar. Produciéndose y creando un dinamismo en el que los factores de referencia son la universidad y la ciudad, además de la propia residencia. Cada uno de los modelos seleccionados representa una identidad dentro de la continuidad, mostrando unas señales capaces de definir el espíritu social de los tiempos, correspondientes a cada periodo estudiado, lógicamente. 
El origen de la residencia universitaria, al estar vinculado al de las universidades, se produce en distintas zonas geográficas y, a su vez, en unos periodos de tiempo próximos pero diferentes. Las primeras tipologías arquitectónicas que establecen patrones se producen en Bolonia, París, Oxford y Cambridge. Todas ellas han sido herederas del espacio claustral como sistema de organización espacial, cuyo precedente se encuentra en el esquema del Monasterio de Saint Gall en Suiza.

En las tres primeras ciudades, se empieza adaptando construcciones existentes al uso docente y residencial universitario. Las primeras construcciones de nueva planta adoptan un esquema cuadrangular, donde los espacios, aunque tienes aperturas al exterior, vuelcan totalmente sobre el patio interior, buscando cerrarse al mundo exterior y garantizando una plena autonomía. Albergan tanto a profesores o maestros como a estudiantes.

En París se produce la adaptación de edificios existentes en el núcleo urbano de la ciudad, tales como hospederías convertidas en colegios universitarios. El de mayor trascendencia y repercusión es el Colegio de Sorbon. No obstante, en París, cuando se produce la ejecución de un edificio de nueva planta, se dispone también un patio central al que vuelcan las estancias, tal es el caso del Colegio de Navarra. Los colegios posteriores van creciendo en las proximidades de los precursores, pero de una forma desordenada, constituyendo el alojamiento de los estudiantes el primer problema de desarrollo urbano que las universidades tenían que resolver. Se empezó agrupando a los estudiantes en "naciones", según la provincia o el país de origen del que procedían. Con el paso del tiempo, esta tendencia marcará el leit motiv de agrupación en los colegios de la Cité Universitaire de París, aparecen unas de las primeras obras modernas de colegios universitarios, destacando el Pabellón Suizo de Le Corbusier.

En los ejemplos británicos, o colleges, se formula la disposición claustral a través de la formación de patios, normalmente con un elemento verde en la zona central. Estos patios se denominan cuadrángulos (quadrangles). Este hecho puede indicar una voluntad de integración, dentro del patio, parte de los grandes pastos verdes que rodean a estas instituciones. Este modelo continúa siendo autónomo y no participante del espacio exterior. Se integra en el tejido urbano existente, creciendo en función de la adición de espacios claustrales de forma ordenada.

En el programa común de los colleges están siempre presentes los siguientes elementos: capilla, salón-refectorio, aulas docentes y 
habitaciones de los estudiantes, ubicándose estas últimas en las plantas superiores $y$, mediante una disposición de corredor, se va accediendo a cada una de las habitaciones.

Hoy, estos colleges de Oxford y Cambridge han conservado buena parte de sus características originarias. Implantados en ciudades de un tamaño mediano, han marcado a lo largo del tiempo el paisaje de éstas y constituyen un parámetro de identidad. Especial mención merece la particular adaptación a la modernidad del college que se observa en el Florey Building de James Stirling.

En Bolonia, la residencia universitaria aparece en una tipología claustral compacta, ubicada dentro del núcleo urbano de la ciudad. La primera aportación aparece en el Colegio San Clemente de los Españoles en 1369, donde se configura el modelo colegiouniversidad y se crea el primer tipo europeo en materia de residencia universitaria.

Este modelo se conforma a través de un patio compuesto por galerías porticadas, donde alrededor del mismo se sitúan los espacios del programa. El esquema general es similar a los anteriores, presentando únicamente alguna pequeña novedad: capilla, espacios comunes de aprendizaje, archivo, y aunque también con un espacio dedicado a uso deportivo, como la sala de esgrima y gimnasia.

La conjugación del uso residencial del edifico y la distribución de sus ambientes hacen de este colegio un hito en la arquitectura residencial universitaria, teniendo una dilatada influencia en la arquitectura colegial universitaria española, donde los primeros colegios mayores importan este modelo para configurar sus instituciones.

Contemplando ahora el continente y a partir del siglo XVII, debido a las influencias de los colonizadores británicos se desarrolla una implantación de la residencia universitaria basada en los colleges ingleses. Se inicia un debate entre los partidarios de una ubicación intraurbana y aquellos que se inclinan por un emplazamiento periférico. La segunda opción desemboca en la construcción de residencias en contacto con la naturaleza y conformando parte del nuevo campus. La importancia de la naturaleza es tal que se fragmenta el modelo edicilio del college, dejando espacio para que la naturaleza penetre dentro del conjunto universitario. Empiezan como elementos compactos, el Harvard Hall en las inmediaciones de Boston, o el Colegio William and Mary en Virginia. Poco a poco va separándose, volumétricamente, la función residencial del espacio docente, apareciendo el modelo de pabellón. 
También en Estados Unidos, aparece la irrupción de la residencia en bloques de gran altura. Tal es el caso del Hartley y Livingston Hall en el Campus de Columbia, aportando también innovaciones en el programa, como la aparición de zonas dedicadas al ocio. Hay que destacar el Peabody Terrace de José Luis Sert en Boston, combinando espacios de gran altura donde se alojan los espacios más privados, con espacios de baja altura donde sitúa los espacios comunes.

Volviendo a Europa, la experiencia de la Bauhaus a través de la Residencia Universitaria de Dessau es decisiva para el linaje posterior de los colegios mayores españoles. El marco geográfico final de esta Tesis, se sitúa en España y, más concretamente en la Ciudad Universitaria de Madrid. Como se ha señalado, la etapa inicial del Movimiento Moderno, se cifra en los años 20 y 30 del siglo $X X$, haciendo su entrada a través de una mirada hacia las vanguardias europeas y teniendo una importante sede de difusión en la Residencia de Estudiantes de Madrid, con Fernando García Mercadal como personaje relevante.

En este periodo, los ejemplos de residencia universitaria alcanzan su estado más interesante de aceptación plena de la modernidad arquitectónica. La nueva sede de la Residencia de Estudiantes de Madrid, de Luis Lacasa, en la Ciudad Universitaria, constituye sólo un preámbulo, mientras que el Colegio Mayor Nuestra Señora de Luján de Carmen Córdoba y Horacio Baliero se puede tomar como ejemplo de las nuevas ideas y preferencias de los arquitectos.

En el tramo autárquico, los modelos intentaban luchar y romper con la política nacionalista, costándole a algún arquitecto la inhabilitación. En este contexto se puede entender el discurso historicista de Luis Moya en la Universidad Laboral de Gijón, donde su residencia de estudiantes presenta una tipología claustral.

Hacia la mitad de siglo se recupera dinamismo coincidiendo con el auge de los Colegios Mayores, cuya máxima expresión se materializa en ejemplos como El Colegio Mayor Santo Tomás de Aquino de José María García de Paredes y Rafael de la Hoz o como el Colegio Mayor César Carlos de Alejandro de la Sota y José Antonio López Candeira. Es una época de aceptación social creciente de los modelos modernos, como se ha reiterado. Se generaliza una actitud y un sistema basado en la racionalidad del espacio a la par de la introducción de las técnicas en vías de industrialización.

Con el inicio del llamado High-Tech, surgen ciertas actitudes discordantes o revisionistas en el panorama internacional, sugiriendo alguna crítica a los modelos modernos que, de alguna manera, ya 
están socialmente aceptados. La etapa posmoderna se está anunciando.

La señal de término, de un posible fin de ciclo, viene implícita en dos publicaciones: La Arquitectura de la Ciudad de Aldo Rossi, y Complejidad y Contradicción de la Arquitectura de Robert Venturi.

El límite cronológico establecido en el año 1965 responde a este argumento y coincide tanto la fecha de edición de los dos célebres libros como con el término de ejecución del último Colegio Mayor estudiado: Casa do Brasil de Alfonso d'Escragnolle y Fernando Moreno Barberá. Su modernidad, plenamente desarrollada, refleja que se ha materializado la integración de la arquitectura en las corrientes coetáneas más interesantes y productivas. Es decir, el punto de inflexión con su correspondiente interrogante ifin de una época?, significa que la arquitectura española, con independencia de las particularidades políticas del país, se reconcilia con su tiempo a través de los equipamientos universitarios $y$, dentro de ellos, la residencia universitaria desvela que en 1965 ya es una tipología asimilable a las innovaciones que ofrece el Movimiento Moderno. 
530| EPÍLOGO - CONCLUSIONES 
AA VV. "La España de Alfonso X. Cuadernos Historia 1681". Ed. Información e Historia.Madrid. 1997.

AGUADÉ NIETO, Santiago. "Universidad, Cultura y Sociedad en la Edad Media". Ed. Universidad de Alcalá. Alcalá de Henares.1994.

ARNALDI, Gilolano (a cura di). "Le originidell' Universitá". Ed. II Mulino, Bologna. 1974.

BARCALA MUÑOZ, Andrés. "Las Universidades Españolas durante la Edad Media". Ed. Anuario de Estudios Medievales 15. Barcelona. 1985.

BARTOLOMÉ MARTÍNEZ, Bernabé. "El Colegio-Universidad en el Burgo de Osma y su tiempo". 1550-1840. Soria. 1988.

BELLET, C. ; GANAN, J. "Ciudad y Universidad". Ed. Milenio. 2006.

BORN, Ernst; HORN, Walter. "The Plan of saint Gall: A study of the Architecture and Economy of, \& Life in a Paradigmatic Carolingian Monastery". Ed. University of CaliforniaPress. 1979.

CAMPOS CALVO-SOTELO, Pablo. "Arquitectura y Universidad en la sociedad contemporánea: innovación abierta y aprendizaje activo en las cuatro escalas espaciales" Ed. Universidad San Pablo CEU. Madrid.2010.

CAMPOS CALVO-SOTELO, Pablo. "España-Campus de Excelencia Internacional". Ed. Ministerio de Educación. Secretaría General de Universidades. Madrid. 2010.

CAMPOS CALVO-SOTELO, Pablo."Urbanismo y Arquitectura en las universidades de la Comunidad de Canarias".Ed. Gobierno de Canarias. Consejería de Educación, Universidades, Cultura y Deportes". Gran Canaria. 2010.

CANTÓ, Antonio. "La pizarra de Yuri". Historias de Ciencia al calor del fuego. Ed. Silente ediciones. Madrid. 2011.

CARDINI, Franco y FUMAGALLI, M.T."Universidades de Europa. Raíces culturales del Viejo Mundo". Ed. Anaya. Milán. 1991. 
CASTREJÓN DÍEZ, Jaime."El concepto de Universidad". Ed. Trillas. Mexico D.F. 1990.

COBBAN, A. B."The Medieval Universities: Their Development and Organization. Ed. Medieval Academy of America. Cambidge. 1980.

DE RIDDER-SIMOENS, Hilda. "Las Universidades en la Edad Media" voll. De la Historia de la Universidad de Europa. Ed. Universidad del País Vasco. Bilbao. 1994.

ECO, Umberto. "El Nombre de la Rosa".Ed. RBA. Madrid. 1993.

GARCÍA GARCÍA, M. "El Colegio Universidad de Santa Catalina. Ed. Celtiberia. Soria. 1959.

GARCÍA MARSILLA, Juan Vicente (director); MANCHO, Carles; RUIZ DE LA PEÑA, Isabel. "Historia del Arte Medieval". Ed. Universidad de Valencia. Valencia. 2012.

GENESTHER, Philippe. "L'Université et la cité". Espaces et Sociétés. Ed. Eres L'Hartaman. París. 1996.

HASTINGS RASHDALL, M.A. "The Universities in the Middle Ages".Ed. Clarendom Press. Oxford. 1895. Reeditada y anotada por F.M. Powicke y A.B. Emden en 1958.

HENRIQUEZ UREÑA, Pedro. "Universidad y Educación". Ed. UNAM. México. 1969.

HOMER HASKINS, Charles. "The rise of Universities".Ed. Cornell Paperback.Itaca, New York. 1957.

HUFF, Toby E. "The Rise of Early Modern Science: Islam, China and the West". Ed. Cambridge UniversityPress. Cambridge, Massachusetts. 2003.

JIMÉNEZ, Alberto. "Historia de la Universidad Española". Ed. Alianza. Madrid. 1971.

KOSCHATER, Paul. "Europa y el Derecho Romano". Ed. Ediciones de derecho privado. Madrid. 1955

OLLERO PINA, José Antonio. "La Universidad de Sevilla en los siglos XVI y XVII". Ed. Universidad de Sevilla. Sevilla. 1993. 
PEVSNER, Nikolaus. "Historia de las tipologías arquitectónicas". Ed. Gustavo Gili. Barcelona. 1979.

PILZ, Anders. "The World of Medieval Learnig".Ed. BasilBlackwell. Oxford. 1981.

RÁBADE, M. a del Pilar. " Las Universidades en la Edad Media". Ed. Arco Libros. Madrid. 1996.

RELANCIO, Alberto. "Las Universidades Medievales". Comunicación en Actas Seminario Orotava de Historia de la Ciencia. Años VIII y X. Fundación Canaria Orotava de Historia de la Ciencia. Canarias. 2007.

RUBIO SÁNCHEZ, María Soledad. "El colegio-universidad de Osuna (Sevilla) 1548-1826". Ed. Universidad de Sevilla.Sevilla. 1972.

SEAGAL, EdwarA."Monastery and Plan of Saint Gall".Dictionary of the middle ages.Volume 10.Ed. Oxford University Press. Oxford. 1989.

TEJERINA, Fernando (ed. Principal). "La Universidad, Una historia ilustrada". Ed.Turner Banco Santander. Madrid. 2010.

TORREMOCHA HERNÁNDEZ, Margarita."El Estudio General de Palencia. Historia de los ocho siglos de la Universidad española". Ed. Universidad de Valladolid. Valladolid. 2012.

TÜNERMANN BERNHEIM, Carlos. "Universidad, Historia y Reforma". Ed. UCA. Nicaragua. 1992.

WTERUSZOWSKI, Helene. "The Medieval University: Masters, Students, Learning". Ed. Van Nostrand Reinhold. New York. 1966. 


\section{BIBLIOGRAFÍA LA RESIDENCIA UNIVERSITARIA EN LA HISTORIA}

ALONSO PEREIRA, José Ramón."El Colegio de los españoles en París como punto de inserción arquitectónico entre las ciudades universitarias de París y Madrid". Liño no 19. Revista anual de Historia del Arte. Universidad de Oviedo. Oviedo. 2013.

BALADRO PACHÓN, Arturo. "Excavaciones arqueológicas en la Capilla de los Reyes de la Catedral de Palencia: nuevos datos sobre el origen de la Pallantia romana". Santuola $n^{\circ} 15$. Revista del Instituto de Prehistoria y Arqueología Sautuola. Santander. 2009.

BELTRÁN DE HEREDIA, V. "Primeros Estatutos del Colegio Español de San Clemente de Bolonia". Hispania Sacra no 11 . Revista española de historia eclesiástica. Madrid. 1958.

BELTRÁN DE HERDIA, Vicente. "Los orígenes de la Universidad de Salamanca". Ed. Ediciones Universidad de Salamanca. Salamanca. 1999.

CÁNOVAS DEL CASTILLO, Antonio. "El cardenal Albornoz". Ed. Tipografía de El Universal. Sevilla. 1894.

COHEN, Jean Louis. "Le Corbusier 1887-1965 El Lirismo de la Arquitectura en la era mecánica". Ed. Taschen. Colonia. 2004.

COHEN, Jean Louis. "Architecture du zoe siècle en France. Modernité et continuité". Ed. Hazaneditions. Paris. 2014.

DE LA FUENTE, Vicente. "Historia de las universidades, colegios y demás establecimientos de enseñanza en España". Imprenta de la viuda e hija de Fuentenebro. Madrid. 1884.

GAULTIER DALCHÉ, Jean. "Historia Urbana de León y Castilla en la Edad Media". Ed. Siglo XXI de España S.A. Madrid. 1979.

GINER DE LOS RÍOS, Hermenegildo y BORRAJO Y HEREDIA, Pedro. "El Colegio de Bolonia: Centón de noticias relativas a la Fundación Hispana de San Clemente por los excolegiales Pedro Borrajo y Heredia y Hemenergildo Giner de los Ríos". Ed. NabuPress. Madrid. 2010.

GONZÁLEZ -VARAS IBAÑEZ, Ignacio. "Dietroil muro del Collegio di Spagna". Ed.Clueb. Cooperativa Universitaria EditriceUniversità di Bologna. Bolonia. 1998.

GONZÁLEZ GONZÁLEZ, Enrique y PÉREZ PUENTE, Leticia. "Permanencia y cambio en las universidades hispánicas". Ed. Universidad Autónoma de México. Ciudad de México. 2001. 
HILTON, Rodney. "Las ciudades en la sociedad feudal inglesa, Conflicto de clases y crisis del feudalismo". Ed. Oxford UniversityPress. Barcelona. 1988.

LARIO RAMIREZ, Dámaso de. "La Universidad de Bolonia y el Colegio de España en el tránsito de los siglos XVI alXVII". Estudis no 8. Revista de historia moderna. Valencia. 1979-80.

LARIO RAMIREZ, Dámaso de. "Mecenazgo de los Colegios Mayores en la formación de la burocracia española (siglos XIV-XVIII) en Universidades Españolas y Americanas". Ed. CSIC. Valencia. 1987.

MADRUGA JIMÉNEZ, Esteban. "Crónicas del Colegio Mayor Arzobispo Fonseca de Salamanca" en "Historia de La Universidad de Salamanca. Estructuras y flujos". Volumen II. Ed. Universidad de Salamanca. Salamanca. 1953.

MARTI, Berthe. "The Spanish college at Bolonia in the fourteenth century".Edition and translation of its statutes with introduction and notes.Ed. University of Pennsylvania Press. Filadelfia. 1996.

MARTÍNEZ ARCONADA, L.T. "Orígenes de la Universidad en España: Palencia, del Estudio General a la Universidad". Ed. Universidad de Salamanca. Salamanca. 1991.

NAVASCUÉS PALACIO, Pedro. "El Colegio Mayor Fonseca y su arquitectura". Ed. Departamento Composición Arquitectónica, ETS Arquitectura Madrid. Madrid. 1993.

KAGAN, Richard. "Universidad y Sociedad en la España Moderna". Ed. Tecnos. Madrid. 1981.

REPRESA RODRÍGUEZ, Armando. "Palencia: breve análisis de una formación urbana durante los siglos XI-XIII en la España medieval". Ed.Universidad Complutense de Madrid. Madrid. 2014.

RODRIGUEZ CRUZ, Águeda. "Historia de la Universidad de Salamanca". Ed. Fundación Areces y Congregación de Santo Domingo. Salamanca. 1990.

RODRIGUEZ-SANPEDRO BEZARES, Luis E. y POLO RODRIGUEZ, Juan Luis. "Universidades Hispánicas: Colegios y Conventos Universitarios en la Edad Moderna". Ed. Universidad de Salamanca. Colección Aquilafuente. Salamanca. 2011.

ROGGERO, Marina. "I collegiuniversitari in etá moderna" en "Lúniversitá in Italia fraetá moderna e contemporánea: aspetti e momenti", Ed. Clueb. Cooperativa UniversitariaEditriceUniversità di Bologna. Bolonia. 1991. 
RUIPÉREZ ALMAJANO, Nieves. "Urbanismo de Salamanca en el siglo XVIII". Ed. Salamanca delegación del Colegio Oficial de Arquitectos de León. León. 1992.

RUIPÉREZ ALMAJANO, Nieves. "EIColegio de San Bartolomé o de Anaya". Ed. Universidad de Salamanca. Salamanca. 2003.

SERRA DESFILIS, Amadeo. "MatteoGattapone, arquitecto del Colegio de España". Ed. Publicaciones del Real Colegio de España en Bolonia. Bolonia. 1992.

SERRA DESFILIS, Amadeo y COLOMER, Josep Lluis. "España y Bolonia: siete siglos de relaciones artísticas y culturales". Cooeditado CEEH y Fundación Carolina. Madrid. 2006.

SERRA DESFILIS, Amadeo. "Bolonia y la definición de un tipo en la arquitectura universitaria europea". Miscelánea Alfonso IX. Ed Universidad de Salamanca. Salamanca. 2013.

TORREMOCHA HERNÁNDEZ, Margarita. "La matriculación estudiantil durante el siglo XVIII en la Universidad de Valladolid". Ed. Investigaciones Históricas. Valladolid. 1986.

TORREMOCHA HERNÁNDEZ, Margarita. "Los estudiantes, los estudios y los grados" en PALOMARES IBAÑEZ, Jesús María "Historia de la Universidad de Valladolid". Ed. Universidad de Valladolid. Valladolid. 1990.

TORREMOCHA HERNÁNDEZ, Margarita. "Las noches y los días de los estudiantes universitarios(posadas, mesones y hospederías) en Valladolid". Ed. Universidad de Alicante, Departamento de Historia Medieval, Historia Moderna y Ciencias y Técnicas Historiográficas. Alicante. 1991.

URQUIJO, Maria José. "Archivo Histórico Provincial y Universitario de Valladolid: Guía del investigador". Ed. Universidad de Valladolid. Valladolid. 1994.

VELASCO Y HEREDIA, Salvador Silvestre de. "Compendio de la fundación y privilegios del Colegio Mayor de San Clemente de los españoles en Bolonia, fundado por el cardenal Carrillo de albornoz". Imprenta de Blae. Sevilla. 1695.

VICENTE Y GUERRERO, Guillermo. "Los inventarios de documentación del Archivo Histórico de Zaragoza". Ed. Dykinson, Universidad Carlos III de Madrid. Madrid. 2003.

VIDAL Y DÍAZ, Alejandro. "Memoria Histórica de la Universidad de Salamanca". Imprenta de Olva y Hermano. Salamanca. 1869. 
538| BIBLIOGRAFÍA LA RESIDENCIA UNIVERSITARIA EN LA HISTORIA 


\section{BIBLIOGRAFÍA LA RESIDENCIA UNIVERSITARIA EN ESPAÑA, GENERADORA DE CIUDAD}

AALTO, Alvar. "The technology review" en L'Architecture D'aujour d' hui, nº 191. París. 1977.

AA VV, "Luis Moya Blanco, arquitecto: 1904-1990", Centro de Publicaciones, Secretaría General Técnica, Ministerio de Fomento. Madrid. 2000.

AA VV, "Luis Moya Blanco: arquitecto: 1904-1990". Ed. Electa España. Madrid. 2000.

ALLUÉ SALVADOR, Miguel. "Las Residencias de Estudiantes en España". Universidad . Revista de Cultura y Vida Universitaria (Zaragoza). II, 1, enero-marzo 1925.

ALONSO DE ARMIÑO PÉREZ, LUis; JORDÁ SUCH, Carmen y VIDAL VIDAL, Vicente. "Fondo Documental de arquitectura y espacios públicos del siglo XX". Comunidad Valenciana. Ed Generalitat Valenciana, Instituto Valenciano de la Edificación y Colegio oficial de Arquitectos de la Comunidad Valenciana. Valencia. 2000.

ALONSO PEREIRA, José Ramón. "Cincuenta años de vida colegial. Crónica y análisis de medio siglo de historia del Colegio de León, Asturias y Galicia". Ed. Colegio Oficial de Arquitectos de Asturias. Oviedo. 1982.

ALONSO PEREIRA, José Ramón, (coord). "Modernidad y contemporaneidad en la arquitectura de Galicia". A Coruña: Grupo de Investigacion en Historia de la Arquitectura. Ed. Universidad de A Coruña. Coruña. 2012.

ARNICHES MOLTÓ, Carlos. "Nuevo pabellón en la residencia de señoritas estudiantes en Madrid". Nuevas Formas n 6 . Revista de arquitectura. Madrid. 1935.

ARTIGAS, Miguel y otros. "Una poderosa fuerza secreta: La Institución Libre de Enseñanza". Ed. Editora Española, S.A. San Sebastian. 1940.

ASENJO, Carmen y ZAMORA BONILLA, Javier. "Caminos de ida y vuelta: Ortega en la

Residencia de Estudiantes", en Revista de Estudios Orteguianos n 7. Madrid. 2003.

ASÍN VERGARA, Rafael."Rafael Altamira (1866-1951)". Ed. Instituto de Estudios Juan Gil Albert, Diputación Provincial de Alicante. Alicante. 1987. 
AZCÁRATE, Pablo de. "Notas sobre el origen de la Institución Libre de Enseñanza". Boletín de la Real Academia de la Historia, núm. 161. Madrid. 1967.

BALDELLOU, Miguel Ángel, CAPITEL, Antón,"Arquitectura española del siglo XX". Ed. SummaArtis, Vol. XL Espasa Calpe. Madrid. 2001.

CACHO VIU, V. "La JAE, entre la Institución Libre de Enseñanza y al generación de 1914", en SÁNCHEZ RON, José Manuel, coord."19071987. La Junta para Ampliación de Estudios e

Investigaciones Científicas 80 años después" . Ed. Consejo superrior de investigaciones científicas. Madrid. 1989.

CAPEL, Rosa M. "Estudiar e investigar: la enseñanza de la mujer en la política educativa de la Junta para Ampliación de Estudios". Boletin de la Institución Libre de Enseñanza n 63-64. Madrid. 2006.

CAPITEL, Antón, "La Universidad Laboral de Gijón o el poder de la arquitectura", en

Arquitecturas Bis no 12 . Marzo de 1976.

CAPITEL, Antón. "La arquitectura de Luis Moya Blanco".Tesis dirigida po Ra. Universidad Politécnica de Madrid. Madrid. 1979.

CAPITEL, Antón, "La Arquitectura de Luís Moya Blanco", en "Monografías 3", Comisión de

Cultura. Servicio de Publicaciones del Colegio Oficial de Arquitectos de Madrid, 1982.

CAPITEL, Antón y WANG, Wilfried. "Arquitectura del siglo XX. España". Ed. Tanais. Madrid. 2000.

CODINA BAS, Juan Bautista y PENALBA GUILLÉN, Francisco. "De Centro de orientación de Universidades Laborales a Complejo Educativo. 1969-1994". Comisión organizadora del XXV Aniversario del complejo educativo de Cheste. Valencia. 1994.

COLOMER SENDRA, Vicente (dir). "Registro de Arquitectura del siglo XX". Comunidad Valenciana, Generalitat Valenciana, Instituto Valenciano de la Edificación y Colegio Oficial de Arquitectos de la Comunidad Valenciana. Valencia. 2002.

DÍEZ-PASTOR, Concha. "Carlos Arniches y Martín Domínguez, arquitectos de la generación

del 25". Ed. Mairea. Madrid. 2005.

FERNANDEZ ALBA, Antonio (ed.). " Ideología y enseñanza de la arquitectura en la España Contemporánea". Ed. Tucar. Madrid. 1975.

FERNÁNDEZ COBIÁN, Esteban. "A Coruña. Guía de Arquitectura". Ed. Colegio Oficial de Arquitectos de Galicia. A Coruña. 1998. 
FERNÁNDEZ MANERA, R. "Record de edificación en España", en Obras. Revista de construcción, nº 115. 1971.

FLORES LÓPEZ, Carlos. "Arquitectura Española Contemporánea" (Tomos I y II). Ed. Aguilar. Madrid. 1989.

FLORES LÓPEZ, Carlos. "Sobre arquitecturas y arquitectos". Ed. Colegio Oficial de Arquitectos de Madrid. Madrid. 1994.

FREIXA JANARIZ, Jaume, "Obra amercana de José Luis Sert", Tesos Doctoral, dirigida poEmili Donato Folch. Universidad Politécnica de Catalunya. Escola Técnica Superior d'Arquitectura de Barcelona. 1993.

GAMERO MERINO, Carmela "Un modelo europeo de renovación pedagógica: José Castillejo". Ed. Consejo Superior de Investigaciones Científicas. Madrid. 1988.

GARCÍA-VELASCO, José. "La Junta para Ampliación de Estudios, la Institución Libre de Enseñanza y la modernización de la cultura española". Boletin de la Institución Libre de Enseñanza no 63-64. Madrid. 2006. Boletin de la Institución Libre de Enseñanza n 63-64. Madrid. 2006.

GARCÍA-VELASCO, José y LÓPEZ COBO, Azucena. "Un proyecto compartido de modernización cultural: Ortega y Gasset y la Residencia de Estudiantes" en AA VV, "El Madrid de José Ortega y Gasset", Publicaciones de la Residencia de Estudiantes SECC, Madrid, 2006,"Liberalismo y Europeísmo: la política cultural de la Residencia de Estudiantes", en BILE 63-64. diciembre de 2006.

GINER DE LOS RÍOS, Bernardo. "Cincuenta años de arquitectura española II (1900-1950)". Ed. Adir. Madrid. 1980.

GUERRERO, Salvador. "Arquitectura moderna y significado cultural: actitudes y criterios en cuatro intervenciones en la arquitectura de Carlos Arniches y Martín Domínguez", en LANDROVE, Susana. "¿Renovarse o morir?: experiencias, apuestas y paradojas de la intervención en la arquitectura del Movimiento". Ed. Fundación DOCOMOMO Ibérico. Barcelona. 2007.

GUERRERO, Salvador. "La Colina de los Chopos: un campus para la pedagogía y la ciencia modernas en la España del primer tercio del siglo XX", en AA VV "Tiempos de investigación: JAE-CSIC, cien años de ciencia en España". Ed. Consejo Superior de Investigaciones Científicas. Madrid. 2007.

JIMÉNEZ FRAUD, Alberto. "Ocaso y restauración. Ensayo sobre la Universidad Española Moderna" en Historia de la Universidad Española. Ed. Alianza Editorial. Madrid. 1971. 
JIMÉNEZ FRAUD, Alberto. "La Residencia de Estudiantes". Ed. Ariel. Barcelona. 1972.

JIMÉNEZ FRAUD, Alberto. "Residentes. Semblanzas y recuerdos". Prólogo de Alberto Adell. Ed. Alianza Editorial. Madrid. 1989.

JIMÉNEZ-LANDI, Antonio. "La Institución Libre de Enseñanza y su ambiente", 4 Tomos: I. Los orígenes de la Institución; II. Período para universitario; III. Período escolar 1881-1907; IV. Período de expansión influyente. Ed. Complutense. Madrid. 1996.

JIMÉNEZ-LANDI, Antonio. "Breve historia de la Institución Libre de Enseñanza". Coeditado por la Consejería de Educación y Ciencia de la Junta de Andalucia y la Fundación El Monte. Sevilla. 1998.

JORDÁ SUCH, Carmen. "Arquitectura Valenciana: itinerarios de la historia reciente". Geometría no 13 . Revista de arquitectura y urbanismo. Málaga. 1992.

JORDÁ SUCH, Carmen(dir.). "20x20. Siglo XX. Veinte obras de arquitectura moderna" (Catálogo de exposición itinerante).Ed. Generalitat Valenciana, Conselleria d'Obres Públiques, Urbanisme i Transports y Colegio Oficial de Arquitectos de la Comunidad Valenciana, Valencia. 1997.

JORDÁ SUCH, Carmen. "Comunidad Valenciana", en María José Aguaza y Raúl Rispa (eds), Guía de Arquitectura. España 1920-2000. Ed. Ministerio de Fomento y Tanais. Madrid. 1998.

LANDROVE BOSSUT, Susana. "Lugares públicos y nuevos programas, Registro DOCOMOMO Ibérico, 1925-1965". Cooeditado Fundación DOCOMOMO Ibérico/Fundación Caja de Arquitectos. Barcelona. 2010.

LANDROVE BOSSUT, Susana (ed.). Actas del VII Seminario DOCOMOMO Ibérico, Barcelona: Fundación DOCOMOMO Ibérico, 2012

MORENO BARBERÁ, Fernando. "Centro de Orientación de Universidades Laborales Jesús Romero, Cheste, Valencia". Arquitectura nº 142. Revista. Madrid. 1970.

MOYA BLANCO, Luis. " La obra arquitectónica del Orfelinato Minero de Gijón". Ed. Fundación José Antonio Girón. Gijón. 1948.

MOYA BLANCO, Luis. "Madrid 1904 : su obra en la exposición "Arquitectura para después de una guerra 1939-1949"', en Cuadernos de Arquitectura y Urbanismo 121, enero de 1977.

MUT, José Andrés. "Yo estuve en Cheste". Ed. Diálogo S.L. Valencia. 2003. 
ORTIZ-ECHAGÜE RUBIO, César. "Cincuenta años después". Ed. T6 Ediciones. Pamplona. 2001.

OTXOTORENA ELIZEGI, Juan Miguel. "Arquitectura y proyecto moderno". Ed.Universidad de Navarra. Pamplona. 1991.

PÉREZ-VILLANUEVA TOVAR, Isabel. "La residencia de Estudiantes". Ed. Centro de Publicaciones, Ministerio de Educación y Ciencia. Madrid. 1990.

PÉREZ-VILLANUEVA TOVAR, Isabel. "La residencia de Estudiantes". Ed. Centro de Publicaciones, Ministerio de Educación y Ciencia. Madrid. 1990.

PESET, M. y J. L. "La Universidad española (siglos XVIII y XIX)". Ed. Taurus. Madrid. 1974.

PIZZA, Antonio. "Guía de Arquitectura del siglo XX. España". Ed. Electa. Milán. 1997.

POZO MUNICIO, José Manuel (ed.). "Los brillantes 50. 35 proyectos". Ed.T6 Ediciones. Pamplona. 2004.

PRELLEZO GARCÍA, José Manuel. "Francisco Giner de los Rios y la Institución Libre de enseñanza. Bibliografía (1876-1976)". Ed Las y Central Catequística Salesiana. Roma. 1975.

ROVIRA, Josep, "José Luis Sert (1902-1983)". Ed. Electa Spa. Florencia. 2003.

SAENZ DE LA CALZADA, Margarita. "La Residencia de Estudiantes 1910-1936". Ed. Consejo Superior de Investigaciones Científicas. Madrid. 1986.

VEGA, Rafael de la. "Francisco Giner y la Introducción de la ciencia Moderna en España". Ed. Cuadernos para el Diálogo. Madrid. 1965.

VV.AA."Centenario de la Institución Libre de Enseñanza". Ed. Tecnos. Madrid. 1977.

VV.AA."Homenaje a la Institución Libre de Enseñanza". Estudios turísticos no 83. Revista del Instituto Español de Turismo. Madrid. 1984 .

ZAFRILLA TOBARRA, Ricardo. Tesis doctoral "Universidades Laborales. Un proyecto educativo falangista para el mundo obrero, 1955-78". Universidad de Castilla la Mancha. Cuenca. 1998. 
544| BIBLIOGRAFÍA LA RESIDENCIA UNIVERSITARIA EN ESPAÑA, GENERADORA DE CIUDAD 
BIBLIOGRAFÍA COLEGIOS MAYORES DE LA CIUDAD UNIVERSITARIA DE MADRID Y LA AROUITECTURA MODERNA

AA VV. "Conversaciones sobre la Ciudad Universitaria". Arquitectura n 162. Madrid. 1972.

AA VV. "Guía de arquitectura y urbanismo de Madrid, I: Casco antiguo". Ed. COAM. Madrid. 1982.

AA VV. "Guía de arquitectura y urbanismo de Madrid, II: Ensanche, periferias y crecimiento actual". COAM. 1984.

BALDELLOU, Miguel Ángel y CAPITEL, Antón. "AummaArtis: Arquitectura española del siglo XX". Ed. Espasa Calpe. Madrid. 2001.

BARREIRO P.; MURO, F. y RIVAS, P.: "Análisis de la Ciudad Universitaria de Madrid". Ed.COAM. Madrid. 1985.

BARREIRO PEREIRA, P. "El templo de la Hispanidad en la nueva Atenas madrileña. El Madrid no construido". Ed. COAM. Madrid. 1986.

BERGAMíN, R. y BLANCO SOLER, L. "Proyecto de Residencia de Estudiantes. Fundación del Amo, en Madrid". Memoria, pliego de condiciones. Madrid. 1929.

BOHIGAS, Oriol. "Arquitectura española de la Segunda República". Ed. Tusquets Editor. Barcelona. 1970.

BONET CORREA, A. (coord.). "Arte del Franquismo". Ed. Cátedo. Madrid. 1981.

BRAVO REMIS, Restituto: "De Luis Lacasa a Alejandro de la Sota: la interpretación del modelo de ciudad jardín y el problema de las residencias para estudiantes en la Ciudad Universitaria de Madrid" en "Equipamientos en infraestructuras culturales 1925-1965". Actas del Tercer Seminario DOCOMOMO ibérico. Oporto.2001.

CAMPO BAEZA, Alberto. "La arquitectura racionalista en Madrid". Tesis doctoral dirigida por Javier Carbajal Ferrer. Escuela Técnica Superior de Madrid, 1982.

CAMPOS CALVO-SOTELO, Pablo. "El viaje de la Utopía". Ed. Complutense. Madrid. 2002.

CASTILLO OREJA, M.A.. "Alcalá de Henares. Ciudad de la Reforma" en Ponencia en el II Simposium de Urbanismo e Historia Urbana. Ed. Universidad Complutense. Madrid. 1985. 
CASTILLO OREJA, M.A. "Alcalá de Henares, un modelo de la España moderna". Ed. Comisión de Cultura. Alcalá de Henares. 1982.

CHÍAS NAVARRO, Pilar. "El proceso de planificación urbanística de la Ciudad Universitaria de Madrid". Ciudad y Territorio n ${ }^{\circ} 56$. Madrid. 1983.

CHÍAS NAVARRO, Pilar. "La Ciudad Universitaria de Madrid. Génesis y realización". Ed. Universidad Complutense. Madrid. 1986.

CIUDAD UNIVERSITARIA: "La Ciudad Universitaria de Madrid". Revista Nacional de Arquitectura nº 6 y 7. Madrid. 1941.

CIUDAD UNIVERSITARIA. "Ciudad Universitaria. Esquema del trabajo realizado por el Ministerio de Educación Nacional sobre las ruinas heroicas". Imprenta Samaran. Madrid. 1942.

CIUDAD UNIVERSITARIA. "Madrid, Secretaría de la Junta de la Ciudad Universitaria". Ed. Gráficas Universidad. Madrid. 1947.

COSTA, Xavier y LANDROVE, Susana. "Arquitectura del movimiento moderno: registro DOCOMOMO Ibérico, 1925-1965". Ed. Fundacío Mies Van der Rohe/DOCOMOMO Ibérico. Barcelona. 1996.

CURTIS, N.C. "ArchitecturalComposition". Ed J.H. Jansen. Cleveland. 1926.

DE LA SOTA, Alejandro. "Colegio Mayor César Carlos". Archivo digital personal. Fundación Alejandro de la Sota

DIÉGUEZ PATAO, Sofía. "Nueva Política, nueva Arquitectura". Arquitectura nº 199. Madrid. 1976.

DIÉGUEZ PATAO, Sofía "La Moncloa". Ed. Espasa Calpe. Madrid. 1979.

DIÉGUEZ PATAO, Sofía. "Urbanismo de Madrid, 1939-1951", tesis doctoral inédita leída en la Facultad de Geografía e Historia. Julio, 1983.

DOMENECH, Lluis "Arquitectura de siempre. Los años 40 en España". Ed. TusquetsEditores. Barcelona. 1978.

DREXLER, Arthur. "The Architecture of the Ecole des Beaux Arts".Ed. Museum of Modern Art. Londres. 1977.

FARGA, Manuel Juan. "Universidad y democracia en España (30 años de lucha estudiantil)". Ed. Era. México. 1969.

FERNÁNDEZ ALBA, A, " La crisis de la Arquitectura española, 193972". Ed. Edicusa. Madrid. 1972. 
FLORES, C. "Arquitectura española Contemporánea". Ed. Aguilar. Madrid. 1961.

FLORES, C. y AMANN, E. "Guía de Arquitectura de Madrid". Ed. Artes Gráficas Ibarra. Madrid. 1967.

GARCÍA ESCUDERO, J.M. "Historia política de las dos Españas". Ed. Editora Nacional. Madrid. 1975.

GIMÉNEZ CABALLERO, E. "Madrid nuestro". Ed. de la Vicesecretaría de Educación Popular. Madrid. 1944.

GINER DE LOS RÍOS, Bernardo. "Cincuenta años de arquitectura española". Ed. Patria. México. 1952.

GONZÁLEZ CAPITEL, A. "La arquitectura de Luis Moya Blanco". Ed. COAM. Madrid. 1982.

GUERRA DE LA VEGA, R. "Madrid. Guía de arquitectura 1800-1919". Ed. del autor. Madrid. 1980.

GUERRA DE LA VEGA, R. "Madrid. 1920-1980. Guía de Arquitectura Contemporánea". Ed. del autor. Madrid. 1981.

JORDÁ SUCH, Carmen:" Los equipamientos en España" en" Equipamientos I. Lugares públicos y nuevos programas, 1925-1965. registro DOCOMOMO ibérico". Ed. Fundación Caja de Arquitectos/Fundación DOCOMOMO Ibérico. Barcelona. 2010.

JUNTA CONSTRUCTORA DE LA CIUDAD UNIVERSITARIA. "Estudio de proyecto de Empréstito para la construcción de la Ciudad Universitaria". Imprenta de la Junta Sindical. Madrid. 1929.

JUNTA DE RECONSTRUCCIÓN DE MADRID. "Memoria de Ordenación General de Madrid" Ed. J.R.M. Madrid. 1942.

JUNTA DE LA CIUDAD UNIVERSITARIA. "La Ciudad Universitaria de Madrid". Ed. Junta constructora de la Ciudad Universitaria de Madrid. Madrid. 1947.

JUNTA DE LA CIUDAD UNIVERSITARIA: La Ciudad Universitaria de Madrid, Valencia, Tip. Moderna, 1961.

LACASA, Luis. "Escritos 1922-1931". Ed. COAM. Madrid. 1976.

LAHUERTA, M. "Liberales y Universitarios: La Universidad de Alcalá en el traslado a Madrid". Ed. Alcalá de Henares. Alcalá de Henares. 1986.

LASSO DE LA VEGA ZAMORA, Miguel (dir). "Arquitectura de Madrid. Madrid: Fundación". Ed. COAM. Madrid. 2003. 
LÓPEZ OTERO, M. "Alfonso XIII, Santander y la Ciudad Universitaria de Madrid". Conferencia pronunciada el 22 de abril de 1959 en la Delegación de Santander del Colegio Oficial de Arquitectos (Archivo Marín-López Otero).

LÓPEZ OTERO, M. "Las universidades americanas, apuntes de viaje" (Archivo Marín-López Otero).

LÓPEZ OTERO, M. "Conferencia pronunciada en la sesión inaugural de la Cátedra de Ricardo Magdalena". (Archivo Marín-López Otero). Zaragoza. 1960.

LÓPEZ OTERO, M. "La Ciudad Universitaria y la Arquitectura Biotécnica". Notas inéditas, años cincuenta (Archivo Marín-López Otero).

LÓPEZ-PELAEZ, J.M. "Sedes Sepientiae. Apuntes desde la Ciudad Universitaria de Madrid". Arquitectura n 255. Madrid. 1985.

LORITE KRAMER, J. "Informe sobre el Plan General de Extensión del año 1931, Ayuntamiento de Madrid". Ed. Artes Gráficas Municipales. Madrid. 1932.

LUQUE, Javier: "La Ciudad Universitaria de Madrid. Notas críticas". Imprenta Góngora. Madrid. 1931.

MONEO, Rafael: "Madrid: los últimos veinticinco años (1940-1965)" en "Madrid: cuarenta años de desarrollo urbano: 1940-1980". Ayuntamiento, oficina Municipal del Plan. Ed. COAM. Madrid. 1981.

ORTEGA Y GASSET, J.: "Misión de la Universidad" en "Obras completas, tomo IV". Revista de Occidente. Madrid. 1930.

ORTIZ MUÑOZ, Antonio. "La Universidad Complutense y los Colegios Mayores". Imprenta Provincial. Madrid. 1960.

PARDO CANALIS, Enrique. "La Ciudad Universitaria". Ed. Instituto de Estudios Madrileños. Madrid. 1957.

PARDO CANALIS, Enrique. "La Ciudad Universitaria". Ed. Instituto de Estudios Madrileños. Madrid. 1959.

PARDO CANALIS, E.: La Ciudad Universitaria, Madrid, Instituto de Estudios Madrileños. Madrid. 1970.

PEREZ- VILLANUEVA TOVAR, Isabel. "La Residencia de Estudiantes 1910-1936. Grupo universitario y residencia de señoritas". Ed. Residencia de Estudiantes de Madrid. Madrid.2011.

RICO PÉREZ, F. "Alfonso XIII y la Ciudad de Hispanoamérica". Ed. Fundación Ramos de Castro. Zamora. 1982. 
SÁNCHEZ RON, José Manuel (coord). "La Junta para Ampliación de Estudios elnvestigaciones Científicas 80 años después 1907-1987" 2 vols. Ed. CSIC. Madrid. 1988."SERVICIO HISTÓRICO, Fundación Arquitectura COAM: "Comunidad de Madrid" en "Equipamientos I. Lugares públicos y nuevos programas, 1925-1965". Registro DOCOMOMO Ibérico. Ed. Fundación Caja de Arquitectos/Fundación DOCOMOMO Ibérico. Barcelona. 2010.

SOTA MARTíNEZ, Alejandro de la. "Alejandro de la Sota. Escritos, conversaciones, conferencias". Ed. Gustavo Gili. Barcelona. 2002.

TABERA ROLDÁN, Andrés y TÁRRAGO MINGO, Jorge: "El Concurso del Colegio Mayor Nuestra Señora de Luján de 1964. Política, viaje y encuentros, dibujos". Comunicación de Congreso. Escuela Técnica Superior de Arquitectura. Universidad de Navarra. 2012.

TAMAMES, Ramón. "Historia de España, Alfaguara VII: La República. La era de Franco". Ed. Alianza Universidad. Madrid. 1979.

TERÁN, Fernando. "Notas para la historia del planeamiento de Madrid: de los orígenes a la Ley Especial de 1946". Ciudad y Territorio nº 23. Madrid. 1976.

TERÁN, Fernando. "Planeamiento Urbano de la España contemporánea". Ed. Gustavo Gili. Barcelona. 1978.

UCHA DONATE, Rodolfo. "Cincuenta años de Arquitectura española I 1900-1950". Ed. Adir. 1980.

ZULUETA, Carmen de y MORENO, Alicia. "Ni convento ni college. La Residencia de Señoritas". Ed. Residencia de Estudiantes. Madrid. 1993. 
